\title{
A TECHNOLOGY \\ ASSESSMENT \\ OF GEOTHERMAL \\ ENERGY RESOURCE \\ DEVELOPMENT
}

\author{
Prepared for \\ NATIONAL SCIENCE FOUNDATION \\ Contract-C-836
}

by

THE FUTURES GROUP

124 Hebron Avenue

Glastonbury, Connecticut

06033

April 15, 1975 


\section{DISCLAIMER}

This report was prepared as an account of work sponsored by an agency of the United States Government. Neither the United States Government nor any agency Thereof, nor any of their employees, makes any warranty, express or implied, or assumes any legal liability or responsibility for the accuracy, completeness, or usefulness of any information, apparatus, product, or process disclosed, or represents that its use would not infringe privately owned rights. Reference herein to any specific commercial product, process, or service by trade name, trademark, manufacturer, or otherwise does not necessarily constitute or imply its endorsement, recommendation, or favoring by the United States Government or any agency thereof. The views and opinions of authors expressed herein do not necessarily state or reflect those of the United States Government or any agency thereof. 
This report deals with some potential futures for geothermal energy in the United States, evaluates these, and makes recommendations based on these evaluations which can help policy-makers capture the desirable aspects of this energy source while avolding 1ts pitfalls. Because such considerations of ten involve a high level of uncertainty, the conclusions of this work necessarily depend on assumptions and judgments; therefore, the report documents the assumptions which were involved, separates opinion from fact.

Many people were Involved in this study. The methodo1ogy which was employed drew heavily on interviews with experts in geothermal energy and its potential social, environmental, political, and economic effects. Participants in these interviews are identifled in the report with their permission; but particular statements are not attributed, in accordance with our understanding with these contributors. An Oversight Committee made extremely valuable suggestions to the study team. Numerous consultants were employed. Bechtel Corporation, the major study subcontractor, furnished most of the material dealing with potential technological impediments, environmental aspects, and resource development. The Futures Group is responsible for the work as a whole, and in particular, the social, economic, political, and legal material, some technical and environmental material, and the development of the simulation model. And, finally, The Futures Group is responsible for the definition and assessment of impacts and for the framing of recommendations.

The Futures Group team consisted of Theodore J. Gordon, Frank Maslan, Lillian Deitch, David Weinstein, John Stover, and Elthu Fein. Theodore J. Gordon was the study director and Frank Maslan was assistant director. The Bechtel team consisted of Meir Carasso, Larry Beaulaurier, Michael Gallagher, and Jerome Hankin. Me1r Carasso headed the Bechtel effort.

Speclal thanks must also be given to reviewers of the original manuscript and to Joseph Coates, the National Science Foundation study monitor, who, through artful inquiry, helped the study team sharpen 1ts views. 


\section{DISCLAIMER}

Portions of this document may be illegible in electronic image products. Images are produced from the best available original document. 
Chapter

1. INTRODUCTION

1.1 Study Objectives and Framework References

1.2 An Overview of Geothermal Energy References

1.3 Overall Study Design References

1.4 Study Conclusions and Recommendations Overall Potential 13 Impacts of Development $\begin{array}{ll}\text { Impact on Interest Groups } & 19\end{array}$ Policies Which Stimulate Exploration and Development Policies Which Will Lead to the Required Technological
Developments References

2. STATE OF THE GEOTHERMAL ART

2.1 Geothermal Resources: Identification, Development, and Use 26 References

2.2 Geothermal Technology: Special Considerations Geopressured Water As An Energy Resource $\quad 40$ Power Extraction from the Hot Dry Rock Geothermal Resource 41 Hot Water Total Flow As An Energy Source $\begin{array}{ll}\text { Geothermal Power Cycles Analysts } & 48\end{array}$ Economics of Production in Geothermal Power Plants Dual Fuel Cycle (Geothermal-Fossil Fuel Combined Cycle) References

2.3 Institutional Considerations Federal Government Agencles Other Federal Organizations

State Governmental Agencles

Geothermal Industry

Residents and Environmentalists

Forelgn Institutions References

2.4 Laws and Regulations Applying to Geothermal Development 72 References

2.5 Overview of Environmental Considerations 97 References

3. HOW GEOTHERMAL ENERGY MAY EVOLVE IN THE UNITED STATES

3.1 The Technical Inquiry

3.2 The Social and Political Inquiry

3.3 Technical, Social, Polltical, and Economic Impediments 119 References.

3.4 A System Dynamics Model of the Electric Utility Deciston Process 135 References 
TABLE OF CONTENTS (Cont.)

3.6 Some Policles and Their Anticlpated Effects

3.7 Sensitivity of the Model to Input Assumptions

4. PRIMARY AND HIGHER ORDER IMPACTS OF GEOTHERMAL ENERGY $\begin{array}{ll}\text { References } & 156\end{array}$

4.2 Effects on Businesses Relevant to Geothermal Energy 157 References

4.3 Macroeconomic and Macrosocietal Impacts $r$ 170 Effects on the Regional Economy 175 $\begin{array}{ll}\text { Macrosocietal Effects } & 176\end{array}$ $\begin{array}{lr}\text { References } & 179\end{array}$

4.4 Effects on a National Electrical Grid 181 $\begin{array}{ll}\text { References } & 197\end{array}$

$\begin{array}{llr}4.5 & \text { Regulatory and Institutional Impacts } & 198\end{array}$ 203

4.6 Effects on Regions, Cities, and Buildings 204 References $\quad 216$

4.7 Impacts on International Relations 217 $\begin{array}{ll}\text { References } & 227\end{array}$

4.8 Effects on the Environment 228 Vapor-Dominated Systems $\quad 229$

Liquid-Dominated Systems $\quad 233$

Hot Dry Rock Systems $\quad 236$

Magma Systems $\quad 240$

$\begin{array}{ll}\text { References } & 242\end{array}$

5. EVALUATION OF IMPACTS 243

Appendices

A. THE TECHNICAL INQUIRY 251

B. TECHNOLOGICAL RELEVANCE TREES 285

1. The Geothermal Relevance Tree 286

2. The Energy Relevance Tree 330

c. SOCIAL AND POLITICAL INTERVIEWS AND FINDINGS 356

D. A RELEVANCE TREE OF PRIMARY AND SECONDARY IMPACTS 370

E. THE ELECTRIC UTILITY MODEL

F. TREND IMPACT ANALYSIS $\quad 485$

G. THE VALUE MATRIX $\quad 489$

H. STATE AIR QUALITY STANDARDS FOR STATES WITH GEOTHERMAL POTENTIAL 493

I. UNITED STATES GEOTHERMAI STEAM ACT $1970 \quad 496$

J. GEOTHERMAL ENERGY RESEARCH, DEVELOPMENT, AND DEMONSTRATION ACT 501 OF 1974 


\section{INTRODUCTION}

\subsection{Study Objectives and Framework}

Geothermal energy, energy derlved from the intrinsic heat of the earth, may become an Important element of the energy inventory of the United States and throughout the world over the next few decades. In some of Its earliest applications, it has proven to be relatively economic, and if not completely "pure" environmentally, then at least relatively acceptable. How important it w111 become, and what effects it w111 have on the nation, the economy, the enviromment, and people, depends on many factors, including the extent of the resource and the length of time any particular field will last when tapped. Estimates of the extent of the resource vary widely. Participants at the Hickel Geothermal Resources Research Conference [1] estimated the developable potential as $132,000 \mathrm{MW}$ of electric power by 1985. (For comparison, the Federal Power Commission anticipates a demand of about 930,000 Me for the United States in 1985.) The National Petroleum Counc11 [2] on the other hand estimated that the level of power generated from geothermal sources would range between 3500 .MW and 19,000 MW by 1985 . These estimates, separated by almost two orders of magnitude, indicate that by 1985 geothermal energy may be able to supply between 0.4 percent and 14 percent of the power consumed in the United States. With the lower estimate geothermal energy would be interesting; with the higher estimate it would be extremely Important.

For the most part current geothermal installations in the United States and elsewhere exploit resources relatively near the surface of the earth in the form of natural steam or hot brine. In many places, however, it appears that deep geological formations exist which have abnormally high heat content. These formations are known as "hot dry rock"; these formations exist because they are relatively Impervious to meteoric or magmatic waters which, if present, would provide a cooling heat transport mechanism. Such formations may exist within 20,000 feet of the surface in the wester United States; in the East their depth may be on the order of 40,000 feet. In addition, very extensive deep $(5,000-20,000$ feet) zones of hot pressurized water with widely varying salinity have been found to exist in the northern Gulf of New Mexico basin along the Texas, Loulsiana, and Mississippl coasts, and beneath the Gulf Continental Shelf. If technology can be developed to utilize these deep resources safely, geothermal sources could we11 satisfy a large portion of the energy demand of the United States before the year 2000 .

Energy derived from geothermal sources must be bought by a relatively narrow set of users: In most instances, the electric utility. industry and other users of heat. The potential buyers of geothermal energy w111 view the resource in context with other resources. Are they cheaper? Do they have advantage by virtue of their lesser environmental Impact? Are they rellable? Has that rellability been proven? Does geothermal energy, more than other energy sources, promlse abundance and relative independence of supply interruption caused by natural or political events?

Clearing institutional and political hurdles in the Identification and development of geothermal resources is a particularly complex problem. Most Known Geothermal Resource Areas (KGRA) [3] exist on federal lands and a leasing program has recently been established by the U.S. Department of the Interior. The industry which w11 pursue the development and sale of these resources is only now being formed and 1 ts interface wth the body of $1 \mathrm{aw}$ and practices largely established for other purposes must yet be clarified.

Most environmental impacts of geothermal installations have seemed relatively innocuous. However, for certain types of wells, some experts have felt that the environmental impacts may include land subsidence. In addition, It has been suggested that when geothermal installations involve injection or removal of fluids near active fault lines, selsmictty must be considered.

Certainly there are a host of other issues: to what degree will geothermal resources be useful in providing fresh water supplies and minerals? The technology for removing or preventing some kinds of scale formation in high salinity hot water fields is not yet well known; can 1 t be developed effectively? Is the required deephot drilling technology 1 ikely to be avallable to exploit "hot dry rock" energy resources? If the high resource estimates are correct, can a new Industry with 1 ts concomftant demand for capital, manpower, and materials be put into place fast enough?

Out of this mix of scientific, technological, social, economic, and political issues emerges these considerations: there is a potential for geothermal energy to provide an appreciable portion of our energy needs; 1ts growth may be shaped by institutional pollcles; and Its impacts may affect not only those who provide and service the new Installations and those who live nearby, but essentlaliy all people who use energy. The central objectives in this study were to determine the plausible levels of energy which can be produced using the intrinsic heat of the earth, the effects on soclety of doing so, and the consequences of policles avallable for modulating the evolution of the technology and Its impacts.

Fundamental to this work is the notion that not only can man shape his future, but he has the obligation to do so, both to avoid stumbling into a potentially disastrous situation and to gain the best of what is possible.

More specifically, the objectives of this study were to:

1. Identify potential constraints to the development of geothermal power, including technological constraints, and should the source be found potentially beneficlal, develop action options which can be helpful in removing the constraints.

2. Determine technologically feastble levels of geothermal energy resources development in the United States in the 1973-2000 time period.

3. Determine the Impacts of the wide use of geothermal energy on the nation as a whole as well as on the energy industry and other groups which would be Importantly affected.

4. Analyze the soclal, political, economic, and environmental impacts assocfated wh possible future geöthermal energy developments before this source comes Into wide use in this country. Both favorable and unfavorable effects are Included in the term "Impact." .

5. Provide an understanding of. the interplay of environmental consequences with prospective pollcy actions and resource development.

6. Provide input to the policy process regarding this technology and its impacts so that the chances of achieving 1 ts intrinsic benefits are improved and Its disfunctional aspects avoided, to the greatest extent possible. 
7. Foster development and application of systemat1c technology assessment methods for potential use in other policy-related studies.

Over the past year these objectives have been pursued by a study team composed of members of the staff of The Futures Group and Its major subcontractor, the Bechtel Corporation. The study team was ably assisted by distinguished consultants whose sk111s ranged from geology to urban design, and an oversight committee which not only reacted to ideas presented by study team members but also provided advice and furnished much needed information throughout the study period. The contribution of both the consulting group and the oversight commlttee is gratefully acknowledged; part1clpants are listed in Figure 1.1.1.
3. With a plausible range of geothermal energy in In the United States defined, the study next mover to inquire about the potential primary and high order impacts of this evolution, including effec on the economy and society, cities and dwellings, environment, and on the institutions which are $11 \mathrm{kely}$ to serve and be served by the new energy source. These impacts are evaluated in terms of their percelved desirability from the standpoint of various interest groups. Finally, conclusions and recommendations are stated.

Throughout, 1t has been the intent to make assumptions explicit and, where possible, to test conclusions for sensitivity to these assumptions. Numerical and methodological detail is included in a series of Appendices to this report.

\section{REFERENCES}

\begin{tabular}{|c|c|}
\hline MEMBERS OF OVERSIGHT COMMITTEE & CONSULTANTS \\
\hline $\begin{array}{l}\text { DAVID ANOERSON } \\
\text { CALIFORNIA OIVISION OF } \\
\text { OIL E GAS } \\
\text { GERALO GUNNING } \\
\text { VICE PRESI OENT } \\
\text { ECONOMICS DEPARTMENT } \\
\text { CHASE MANMATTAN BANK } \\
\text { WALTER HAMILTON, PHD } \\
\text { VICE PRESIOENT } \\
\text { THE CONFERENCE BOARD } \\
\text { LELAN SILLIN, JR. } \\
\text { CHAIRMAN } \\
\text { NORTHEAST UTILITIES } \\
\text { JOSEPH SWIOLER } \\
\text { CHAIRMAN } \\
\text { NEW YORK PUBLIC SERVICE } \\
\text { COMMISSION } \\
\text { JOSEPH WILSON } \\
\text { MANAGER OF LANDS } \\
\text { UNION OIL CGMPANY }\end{array}$ & $\begin{array}{l}\text { DAVIO O, BLACKWELL, PHO } \\
\text { SOUTHERN METHOOIS: UNIVERSITY } \\
\text { HERBERT H. KLEI, PHD } \\
\text { UNIVERSITY OF COHNECTICUT } \\
\text { PAUL KRUGER, PHD } \\
\text { STANFORD UHIVERSITY } \\
\text { A.D.K. LAIRD, PHD } \\
\text { UNIVERSITY OF CALIFORNIA } \\
\text { AT BERKELEY } \\
\text { SIDNEY LAW } \\
\text { DIRECTOR OF RESEARCH AND } \\
\text { SYSTEMS STUDIES } \\
\text { NORTHEAST UTILITIES } \\
\text { FRITZ LUNDE } \\
\text { ARCHITECT S PLANNER } \\
\text { WARPIER, BURNS, TOAN, LUNDE } \\
\text { TSVI MEIDAV, PHD } \\
\text { GEONOMICS, INC. } \\
\text { EOWARD M. PAWLAK } \\
\text { STEVE E WEBSTER MANAGEMENT } \\
\text { CONSULTANTS } \\
\text { JAMES SMITH } \\
\text { DIRECTOR OF NORTHEAST PLANNING } \\
\text { WESTERN MASS. ELECTRIC COMPANY }\end{array}$ \\
\hline
\end{tabular}

[1] Denton, J. C. (ed.), Geothermal Energy, A Specia1 Report by Walter J. Hickel (Fairbanks, Alaska: Unfversity of Alaska, 1972), p. 95.

[2] Committee on U. S. Energy Outlook, A Summary Report of the National Petroleum Council (National Petroleum Counc11, Washington, D.C., 1972), p. 52.

[3] KGRA is defined in the Geotherma1 Steam Act of 1970 as "an area in which the geology, nearby discoveries, competitive interests, or other indicia would, in the opinion of the Secretary of the Interior, engender a belief in men who are experienced in the subject matter that the prospects for extraction of geothermal steam or associated geothermal resources are good enough to warrant expenditures of money for that purpose.")

F1gure 1.1.1

The presentation of the material in this report 18 divided into three major segments:

1. After the Introductory sections, which describe study objectives and study design, the report concentrates on a description of the geothermal state-of-the-art including geothermal resources, technology, and institutional, legal, and environmental considerations.

2. With this information in hand the report describes how geothermal energy may evolve in the United States; a series of plausible scenartos and the factors and policies which control the rate of growth of the resource are described. 


\subsection{An Overview of Geotherinal Energy}

In terms of systematic commerclal exploitation of geothermal resources for general societal benefit, the chemical plant at Lardere1lo (Tuscany), Italy, which was producing bortc acid in 1818, predates all others. In 1904 the first attempt to generate electrical energy from geothermal energy was made on a small scale. By 1913 a capactey of $250 \mathrm{kWe}$ had been insţalled. Durlng World War II, a large part of the Larderello plant was destroyed by the retreating German Army; however, the plant has been fully restored and 1 ts capacity expanded to 1 ts present $384 \mathrm{MWe}$

In the $1930^{\prime} \mathrm{s}$ the Hungarlans began using geothermal water from Margit Sziget Island (In the Danube) for district heating in Budapest.

The Icelanders began heating of a few of their homes and greenhouses with geothermal hot water in 1925. They started drilling for steam in 1928, but it was not until December 1943 that a hot water pipeline to Reykjavik and a distribution system were commissioned for district heatIng (which is now provided to almost the entire city). The Icelanders currently have a 3 MWe unit in operation and are studying the possibłlity of generating electric power from their resource on a large scale.

In New Zealand the commerclal development of geothermal resources started in 1955 when the Tasman Pulp and Paper Company, Ltd. undertook using geothermal steam to provide process heat and to drive a $10,000 \mathrm{kWe}$ generator at their Kawerau paper mi11. This was followed In March 1960 by the commisstoning of 69 MWe of geothermal electric generating capacity by the State Electricity Department, which has since been increased to 192 MWe. A much greater potential exists and further expansion continues.

The Soviet Union has pursued a vigorous geothermal exploration program for the past decade or more, and currently has two operating geothermal electric generation plants of $440 \mathrm{kWe}$ (net) (Paratunka, 1967) and 5 MWe (Pauzhatka, 1967), respectively. The former is the only geothermal plant in the world operating on a binary cycle (steam/freon). Thousands of homes and commercial facilities are space-heated by district heating systems in several areas of the Soviet Union.

The Mexican Government has been conducting an intense exploration program for approximately 20 years, which has culminated in the recent completion of a $75 \mathrm{MWe}$ flashed steam plant (2-37.5 MWe unfts) at Clerro Prieto.

In Japan private interests have developed electric power generation from geotherma1 resources. A 20 MWe unit at Matsukawa (Honshu I) was commlssioned in Séptember-1966 and a 7 MWe unit at Otake (Ryushu I) was. commissioned in 1972. The Japanese are also using theilr geothermal resources for district heating, desalInation, agricultural heating, and Industrial process heat. Because of the extreme sensftivity of the Japanese economy to energy availabillty and the heavy dependence of Japan on Imported o11, the Japanese are embarkIng on a major: research enterprise designed to achleve as much energy as possible from Indigenous geothermal sources.

The PhIllppine Government has had a-3 Me inft producing electric power at reduced capactity for some four to flve years at their Tiwl Hot Springs, Bicol District, Tizon Island, which is currently being followed by an aggressive drilling, testing, and feasibility program. The government is now planning a larger commerclal capacity station.
The Turkish Government, assiated by the United Nations, is currently conducting evaluative studies and physical tests of their Kizildere Field, with the stated intention of using it for electric power production.

Explorations, test and production driling, and feasibility studies, some under the auspices of the United Nations, are also being conducted in Kenya, Ethiopla, Afar and Issa Territorles (East Africa), Indonesia, New Hebrides, Algerlá, Greece, Israel, Yugoslavia, ChIle, Columbla, Guatemala, N1caragua, El Salvadore, and India.

At The Geysers, Californ1a, a well was drilled in 1921 (by J. D. Grant of Healdsburg, California) for the purpose of generating electrlc power; however, large-scale production of electric power from this resource did not occur until 1960 when the Pacific Gas \& Electric Company commissioned their Unit No. 1 (12.5 Me). Total installed capacity of this installation 18 now 396 MWe (net), with an additional $110 \mathrm{MWe}$ (net) under construction, and an additional 406 MWe (net) committed for construction. Magma Power Company and Thermal Power Company, developers, and the Union 011 Company, which operates the fleld, are increasing The Geysers' production capacity at a rate equivalent to 100 MWe yearly. The Paciflc Energy Corporation and the Burmah 011 \& Gas Company have, under separate agreements, also contracted to supply The Pacific Gas \& Electric Company with steam. The total capacity scheduled for installation at The Geysers is 900 MWe by 1976. [1]

In the three years following issuance of the Geothermal Steam Act of 1970, the U.S. Department of the Interior prepared an environmental impact statement for the geothermal leasing program. With this statement, lssued In December 1973, leasing of federal lands for geothermal exploration began in January 1974. The first competitive lease sale was held by the Bureau of Land Management on January 22, with 52,000 acres of land in California put up for bid in three Known Geothermal Resource Areas (KGRA)-The Geysers, Mono-Long Valley and East Mesa in Imperial County. Bids were higher than expected in the already proven Geysers area and all unita offered there drew compet1tive bids from several compantes. In the Mono-Long Valley KGRA, three out of the seven units offered recelved bids and in the East Mesa KGRA, five out of fourteen. The 23,000 acres leased brought in $\$ 6,813,000$ in h1gh b1ds at an average b1d per acre of $\$ 290$. The average bid per acre in The Geysers was $\$ 631$.

Monthly bidding on a non-competitive basis for approximately 57 million acres of federal lands designated as Potential Geothermal Resource Areas (PGRA's) also began In January 1974. The Department of the Interior defines a Potential Geothermal Resource Area as "an area containing an Inferred geothermal reservolr with1n a geothermal resource. province which has not been determined to be a Known Geothermal Resource Area." As of the end of February, b1ds had been filed for over 6 million acres, with heaviest concentrations in Callfornia, Oregon, and Nevada. These bids must now be assessed for overlapping claims, which according to law constitute competitive interest, and may entall reclassification of the tract in question as a KGRA, requiring competitive bidding.

Worldwide, the total installed electric generating capacity deriving from geothermal sources at the present time is about $1100 \mathrm{MWe}$. Th1s is approximately the same as one large nuclear generating untt. 


\section{Resource Base}

Geothermal energy can be defined in the broadest terms as heat emanating from the earth. The major source of this heat is belleved to be the gradual decay of radioactive elements within the earth. [2] Temperatures in the earth Increase with depth, and range from about 400$1800^{\circ} \mathrm{F}$ at the base of the Continental crust, $80,000-$ 160,000 feet deep. [3] At the center of the earth, at a depth of some 21 million feet, the temperature range ts approxtmately $6500-8000^{\circ} \mathrm{F}$. [4] Nevertheless, the rate of outward flow of heat at the earth's surface is so thinly dispersed (low heat flux) that in most locations it is of no practical value. [5] However, highly localized thermal anomalles exist at many sites where high heat flows are produced near the earth's surface by geologically recent intrugive flows of molten rock or magma through massive fractures in the earth's crust. As the magma solidifles, its heat 18 conducted to the surface through the overlying geological formation. This often results in the heating of groundwaters which are sometimes ejected through surface vents to form thermal springs, geysers, fumaroles, or mud pots. By their very nature these phenomena are closely assoclated with selsmic and volcanic activity and are widely distributed over the earth's surface. An example of this close-relationship is the consistency with which geothermal activity is found along the volcanism belt (so-called Ring of Fire) that surrounds the Pacific Ocean. This accounts for the fact that the preponderance of geothermal surface manifestations in the United States occurs in the western states. Similarly, geothermal manifestations in Kenya, Ethiopia, Afar and Issa territories closely follow the Great Rift Valley of East Africa.

Geothermal resources can be classifled In accordance with their geological, hydrological, and thermodynamic characteristics in the following manner:[6]

1. Vapor-dominated: Naturally occurining primar1ly single-phase thermodynamically saturated or super-heated steam. To date only six major vapor-dominated reservoirs have been located. These are The Geysers, Callforn1a; Larderello, Italy; Matsukawa, Japan; Ontkobe, Japan; The Monte Amiata Region, Italy,

2. Liquid-dominated: A naturally occurring twophase mixture of liquid water (or brine) and steam at an elevated temperature and corresponding saturation pressure. Most hydro-thermal sites throughout the world are of the 11quiddominated type, perhaps twenty times as many as vapor-dominated sites. [7]

3. Hot Dry Rock: A geologlcal formation having an abnormally high heat content but not containing meteoric or magmatic waters to act as a heat transport medium.

Due to volcantsm and tectonic activity, there are excellent prospects for finding enormous amounts of hot dry rock, particularly in the western United States. Vast amounts of energy stored in this form have been discovered in such locations as The Crater of the Moon, Idaho, and Marysville, Montana.

4. Geopressured: Very extensive deep (5000-20,000 feet) zones of pressurlzed water with widely varying salinity, the pressure in which exceeds the corresponding hydrostatic pressure of the fluld at depth. This is caused by the weight of the overlying higher density geological formation on the trapped fluld. Fluld temperatures in the reservolr have been measured in the range from approximately $140-360^{\circ} \mathrm{F}$. Corresponding fluld pressures vary from about $3000 \mathrm{psig}$ to 14,000 paig. [8]

At present, the most extensive known geopressured zones in the United States exist in the Northern Gulf of Mexico Basin which 11 es along the Texas, Loulstane and Mississippl coasts, and beneath the Gulf Continental Shelf. There are also other geopressured zones of lesser extent In the Unfted States such as the Anadarco Basin of Oklahoma and Texas, the Rocky Mountain Basin, and the Los Angeles Basin.

5. Magma: Formations comprising molten rock in the range of approximately $1000^{\circ} \mathrm{F},-3000^{\circ} \mathrm{F}$. Although magms systems exist at levels that are accessible to current drilling equipment in active volcanic areas such as the western United States, Hawali, and Alaska, very deep drilling, 100,000 feet or more, w111 be required to reach these resources in most regions of the continental. United States.

\section{Resource Estimates}

Section 2.2 of this report summarizes in detail the avallable estimates of geothermal resources throughout the world and in the United States in particular. Uncertainty about the extent of geothermal resources is very great. Figure 1.2.1 displays some estimates of electricity production through the use of geothermal energy which have been made in the recent 11terature. Note that the estimates range over almost two orders of magnitude by 1985 .

$$
\text { ESTIMATES OF ELECTRICITY }
$$

WHICH COULD BE PRODUCED BY GEOTHERMAL ENERGY

(1000 MWE)

\begin{tabular}{|l|c|c|}
\hline \multicolumn{1}{|c|}{ SOURCE } & 1985 & 2000 \\
\hline ROBERT REX - SENATE HEARINGS, 1972[9] & -- & 400 \\
BUREAU OF MINES, 1972 [10] & 4 & 40 \\
DEPARTMENT OF THE INTERIOR, 1972[10] & 19 & 75 \\
NATIONAL PETROLEUM COUNCIL, CASE 1, 1972[12] & 19 & -- \\
NATIONAL PETROLEUM COUNCIL, CASE IV, 1972[11] & 3.5 & -- \\
W. HICKEL, GEOTHERMAL ENERGY, 1972[12] & 132 & 395 \\
DR. O. L. RAY - ENERGY POLICY OFFICE, 1973[13] & 20 & 80 \\
& & \\
\hline
\end{tabular}

PIgure 1.2 .1

\section{Exploration}

Historically, geothermal sites have been located from obvious surface manifestations, such as hot springs, fumaroles, mud pots, geysers, and the 11ke, or through accidental discovery while exploring or drilling for other natural resources. This approach is rapidly being replaced by more scientific and productive prospecting methods, such as remote infrared sensing, detection of anomalies in the earth's magnetlc and gravity fields, and electric resistivity of strata. Earth noise emanating from microseismlc activity is also recorded and correlated with data from the above sources. If a natural effluent is apparent at the surface, its chemlcal composition (constituents and concentrations) can be analyzed relative to the potential thermal and chemlcal productivity. Boring test-holes to production depths. (3000-8000 feet) is an expensive proposition, but in the final analysis it is necessary to establish quantitatively a fleld's potential. As the drilling proceeds, core samples are recovered from the hole for logging and for physical and chemical analysis. 
Temperature profiles are measured (top to bottom of hole) and where natural effluents occur, the bottomof-hole static pressure and wellhead static pressures (over a range of flow rates) are recorded. From the latter data, the energy potentlal of the well can be inferred, and to a lesser extent, the field potential. To fully explore a field in an attempt to determine its geographical limits (both horlzontally and vertically) is a protracted and expensive affair, of ten requiring years to accomplish with present methods. Even then, the anticipated longevity of the field remains a speculative matter.

\section{Dr11ling}

The basic techniques used in drilling for geothermal resources are essentially those employed in the petroleum business and, in fact, they were developed by and borrowed from that long established industry. While the hazards of fire and hydrocarbon gas explosions generally do not exist, great care must be exercised in securely anchoring (cementing) the well casings into the upper geological formation in order to withstand high pressures, severe mechanical vibrations, and thermal cycling. Drilling rates can vary greatly, depending on the hole dtameter, frequency of sampling, and formation hardness, density, and temperature. Drilling costs can vary from $\$ 20 / \mathrm{ft} .-\$ 60 / \mathrm{ft}$. , exclusive of mobilization and moving on and of the site.

\section{Hypothetical Energy Recovery Methods}

Similar to the practice employed in the oil fields, it has been widely suggested that by artificialiy fracturing a heat bearing formation (wet or dry) it may be possible to realize a more favorable release of geothermal energy by creating channels through which a heat recovering medium (water) can flow. Hydrofracturing, a procedure coumon to the petroleum industry which consists of pumping very high pressure water into the formation to fracture the rock, has been suggested as one method of field stimulation. Deep underground detonation of chemical or nuclear explosives to achieve the same purposes has also been suggested, but is not currently in favor. It has been hypothesized that subsequent to fracturing, energy recovery could be accomplished either by a natural effluent, or by injecting water into a hot, dry formation through one or more riser shafts. AEC Los Alamos Laboratorles have begun an experiment with this design, which should be operative in four years. Others have proposed an interesting but untried method of heat recovery in which a long double-pipe, concentric heat-exchanger, having a closed outer envelope, is embedded in the heat bearing fórmation. A designer's chotce working flutd would then be pumped down the center pipe, emerging at the bottom into the closed outer pipe and rising back to the surface in the annular space between the two pipe walls. Heat exchange between the working fluid and the surrounding formation is intended to occur at a sufficiently high rate to fustify the installation. Ore obvious advantage of this method, if it can be proven to be practical, is the fact that the working fluid would remain uncontaminated with deposit-forinfing dissolved solids, and would not bring polluting constituents to the surface because it would never come in direct contact with the geological formation.

\section{Electric Power Generation}

At present there are three power sites in the world which produce saturated or superheated steam (single phase; no 1iquid). The best known sites are Larderello,
Italy, The Geysers, Callfornia, and Matsukawa, Japan. In all three cases the steam is fed directly from the wellheads to steam turbines, with only minor pretreatment to remove particulate matter and occasional slugs of water. These plants employ relatively simple, low pressure Rankine steam cycles to drive the electric generators. In the case of the much more common wells which issue hot water (or brine) mixed with steam (two phase), such as at Cerro Prieto, Mexico, or Watrakei, New Zealand, steam $1 \mathrm{~s}$ produced by flashing the hot 1 iquid at a reduced pressure, separating the two phases, and feeding the steam to a turbine. When effluent is fed directly to the turbine the process is commonly referred to as the direct process. In contrast to this, the binary process employs a designerselected secondary working flufd which circulates through the turbine (producing mechanical work) and passes through a heat exchanger in which it absorbs heat from the natural well effluent (steam and/or water), without becoming contaminated by the effluent 1tself. Although the binary process requies a more complex plant, it has the advantage of protecting the turbine from the corrosive, erosive, deposit forming constituents of natural well effluents. Only one such plant has been constructed in the world to date, namely the USSR Paratunka plant (Kamchatka Peninsula) of $440 \mathrm{kWe}$ capactty, which was commissioned in September 1967. This plant employs Freon 12 as the secondary working fluid.

At least two proprietary binary processes are present1y being advanced by thelr proponents in the Unfted States. These are the "Magmamax" process by Magma Energy Corporation of Los Angeles, California, and the "HutchingonHolt" process by the Ben Holt Engineering Company of Pasadena, Callfornia. Detalls of the latter have not been made public. Both of these processes are in the developmental state at the present time.

A number of proprletary novel heat engines have been proposed for directly converting the geothermal energy in a two-phase effluent into shaft work without separation. One of these is the "Keller Rotary Osclllating Vane" (KROV) engine by the Keller Corporation of Fort Worth, Texas, and another concept is the "Helical Screw Expander" offered by the Hydrothermal Power Company Ltd. of Pasadena, California. In addition, a bladeless turbine is under development. Prototype models of these engines have been built and are currently undergoing evaluative performance tests.

Present heat rejection systems for geothermal power plants are essentially the same as for fossil fueled plants, with certaln important differences. In nearly all cases the condenser cooling water mixes intimately with the condensate and both return to efther a natural water course or a cooling tower. For all geothermal plants employing evaporative coollng towers, the amount of water produced from the wells exceeds the water requirements of the cooling tower, thus imposing no demand on local water supplles for make-up. In the case of The Geysers plant, the excess is approximately 25 percent of the effluent rate.

The steam and/or liquid effluent from geothermal we1ls always contains varying percentages of entralned or dissolved non-condensable gases (NCG) of varying composition. These gases continuously flow into the condenser and must be removed by a gas ejector or vacuum pump at rates much higher than in a fossil fueled plant, in order to preserve minimum.discharge pressure for the turbines.

As with fossil fueled or nuclear plants, the cooling system can be based on use of evaporative cooling towers, cooling ponds, or In certain cases, once-through flow.

Due to the relatively low avallable pressure and temperature of geothermal effluents, power plants energized by them are 
InherentIy low efficiency conversion.systems, having overall plant efficiencies of 10-14 percent.

All presently operating geothermal power plants produce waste products of varying toxicity and nuisance effect. The residual 1iquid fractions usually are charged with a high concentration of dissolved solids which preclude discharge of the liquids into natural water courses. Consequently, reinjection of the liquid back into the formation is presently being used as a disposal method, and in many cases appears to be the only practical available method. Gaseous emissions of the $\mathrm{H}_{2} \mathrm{~S}$, and to a lesser degree, ammonia, are commonly associated with geothermal effluents. Historically, these have been discharged directly to the atmosphere since they were regarded as of minor consequence. Recent1y, however, due to statutory and public opinion pressures, control treatments are being developed to maintain emissions at legally acceptable levels. Disposal of large volumes of solld wastes, such as the chloride salts in the Imperial Valley, pose a problem at the present time,

Control of solids deposition (carbonates, silicates, etc.) In the production bore-holes and in plant piping and equipment is a major design problem in geothermal plants. One patented procedure, the "EEP System" by Rogers Engineering Company of San Francisco, proposes infection of $\mathrm{CO}_{2}$ gas into the effluent stream deep in the well to inhibit precipitation of calcium carbonate in the system; this scheme is theoretical only at this point and has not yet been proved physically. Above ground, long established techniques of chemical cleanIng and mechanical chipping or reaming to remove deposits from pipe, separators, heat exchangers, turbine casings, and other equipment are readily avallable. Practical techniques for refuvenating deposit plugged production wells are not yet well developed.

Because of the Inherent inertia of a geothermal power plant (relatively long start-up and shut-down time) and its low operating costs (no fuel), it is economically and technica1ly advantageous to operate the plant base-loaded. Integrating the plant into the power network may require construction of extensive transmission Iines; otherwise, the electrical characteristics are the same as for any other power plant.

Time required to develop sufficient producting and reserve wells (In an already explored fleld) to energize a 150 MWe plant presently requires from 18-24 months.

Figure 1.2.2 presents energy cost compartsons for geothermal installations which have appeared in the 1iterature and Figure 1.2.3 presents a comparison of geothermal costs with the costs of generating electrical energy using other primary energy sources as reported to the FPC in 1974. Because accounting systems vary, these figures should be utilized only as a general indication of the price range of geothermal electricity.

\section{REFERENCES}

[1] Pacific Gas and Electric Week (August 24, 1973).

[2] Rex, R.W., Investigation of Geothermal Resources, Imper1al Valley, and Their Potential Value for Desalination of Water and Electricity Production (Riverside, Callf.: University of California, June $1,1970)$. See also E. Bullard, "Basic Theories -Geothermal Energy," UNESCO, Earth Science, Vo1. 12 (1973).

[3] Lachenbruch, A.H., "Crustal Temperature and heat Production--Investigations of the Linear Heat Flow
ENERGY FROM GEOTHERMAL RESOURCES

\begin{tabular}{|c|c|c|c|c|}
\hline POWER PLANT TYPE & $\begin{array}{l}\text { PLANT } \\
\text { SIZE } \\
\end{array}$ & $\begin{array}{l}\text { CAPITAL } \\
\text { COST }\end{array}$ & \begin{tabular}{|c|} 
THERNAL HEAT \\
COST
\end{tabular} & $\begin{array}{r}\text { CENERATI } \\
\text { COST }\end{array}$ \\
\hline & Mive & S/kwe & & 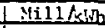 \\
\hline $\begin{array}{l}\text { Geysers, Californla unle No. } \\
11 \text { under construction [14] } \\
\text { No. } 14 \text { on line } 1976 \text { [15]. } \\
\text { Larderello, Italy [16] }\end{array}$ & $\begin{array}{r}106 \\
110 \\
25\end{array}$ & $\begin{array}{l}132 \\
148\end{array}$ & $\begin{array}{l}2.7 \mathrm{mil1} / \mathrm{kth} \\
4.8 \mathrm{~m} 111 / \mathrm{kWh} \\
3.2 \mathrm{c} / \mathrm{MQBCu}\end{array}$ & $\begin{array}{l}5.71 \\
8.35 \\
2.96\end{array}$ \\
\hline $\begin{array}{l}\text { Hot Brine - Operational } \\
\text { Cerro Prieto, Mexico } 1973 \\
\text { [17] } \\
\text { Otake, Japan 1970 [18] } \\
\text { Valrake1, New Zealand } \\
\text { 1970 [19] } \\
\text { Rotorua, New Zealand, } \\
\text { d1strict heat, 1970 } \\
\text { [19] } \\
\text { Reykjavik, Iceland, dis- } \\
\text { trict heat, 1970 [19] }\end{array}$ & $\begin{array}{r}75 \\
30 \\
192\end{array}$ & $\begin{array}{l}264 \\
288\end{array}$ & $\begin{array}{l}6.9 \mathrm{c} / \mathrm{MABtU} \\
3.36 \mathrm{c} / \mathrm{MBBtu} \\
7.5-14 / \mathrm{MMB} \text { tu }\end{array}$ & $\begin{array}{l}8.00 \\
6.50 \\
5.14\end{array}$ \\
\hline $\begin{array}{l}\text { Hot Brine - Estimates } \\
\text { Arwstead 1970 [19] } \\
\text { Green \& Laird 1973 [20] } \\
\text { Austin, Higgins, Howard } \\
1973 \text { [2I] } \\
\text { Stanford Research Institute } \\
1973 \text { [22] } \\
\text { Esufman, } 1973 \text { [23] }\end{array}$ & $\begin{array}{l}100 \\
20-42 \\
220 \\
215 \\
260\end{array}$ & $\begin{array}{l}270 \\
330- \\
297 \\
180 \\
.\end{array}$ & 4-5c/MBtu & $\begin{array}{c}3.90 \\
12.77- \\
4.77 \\
3.20 \\
7.75- \\
9.35 \\
9.00\end{array}$ \\
\hline $\begin{array}{l}\text { Hot Dry Rock Estimates } \\
\text { Brown, Satth, Potter, } \\
1973 \text { [24] } \\
300^{\circ} \mathrm{C} \text {, dual cycle } \\
175^{\circ} \mathrm{C} \text {, 1sobutane cycle } \\
\text { Battelle Northwest } 1973 \\
{[25]}\end{array}$ & $\begin{array}{l}100 \\
100 \\
200\end{array}$ & $\begin{array}{l}186 \\
316\end{array}$ & & $\begin{array}{r}4.70 \\
8.00 \\
6.87\end{array}$ \\
\hline $\begin{array}{l}\text { Ceopressure } \\
\text { Durham, } 1973 \text { [26] }\end{array}$ & 45 & 380 & $1.25 \mathrm{ml111} / \mathrm{kmh}$ & \\
\hline
\end{tabular}

Figure 1.2.2

Relation," Journal of Physical Research, Vo1. 75, No. 17 (1970), Pp. 3291-3300.

[4] Muffler, L.P.J., "Geothermal Resources," U.S. Geological Survey, Professional Paper 820 (1973).

[5] White, D.E., "Geothermal Energy," U.S. Geological Survey C1rcular 519 (1965).

[6] Hicke1, W.J., Geothermal Energy--A National Proposal for Geothermal Resources Research (Alaska: University of Alaska, 1972). See a1so D.E. Wh1te, "Characteristics of Geothermal Resources," in Kruger and Otte (eds.), Geothermal Energy (Stanford, Callf.: Stanford University Press, 1973).

[7] White, D.E.,"Geochemistry Applied to the Discovery, Evaluation, and Exploitation of Geothermal Energy Resources," Geothermics, Speclal Issue 2, Vo1. 1 (1970).

[8] Jones, P.H., "Hydrodynamtes of Geopressure in the Northern Gulf of Mexico Basin," Journal of Petroleum Technology (July 1969). See also P.H. Jones, "Geothermal Resources in the Northern Gulf of Mexico Basin," Geothermics, Special Issue 2, Vol. 2, Part 1 (1970). 
ESTIMATED COSTT OF ELECTRIC ENERGY GENERATION IN DIFFERENT TYPES OF POWER PLANTS, JULY $1974^{5}$

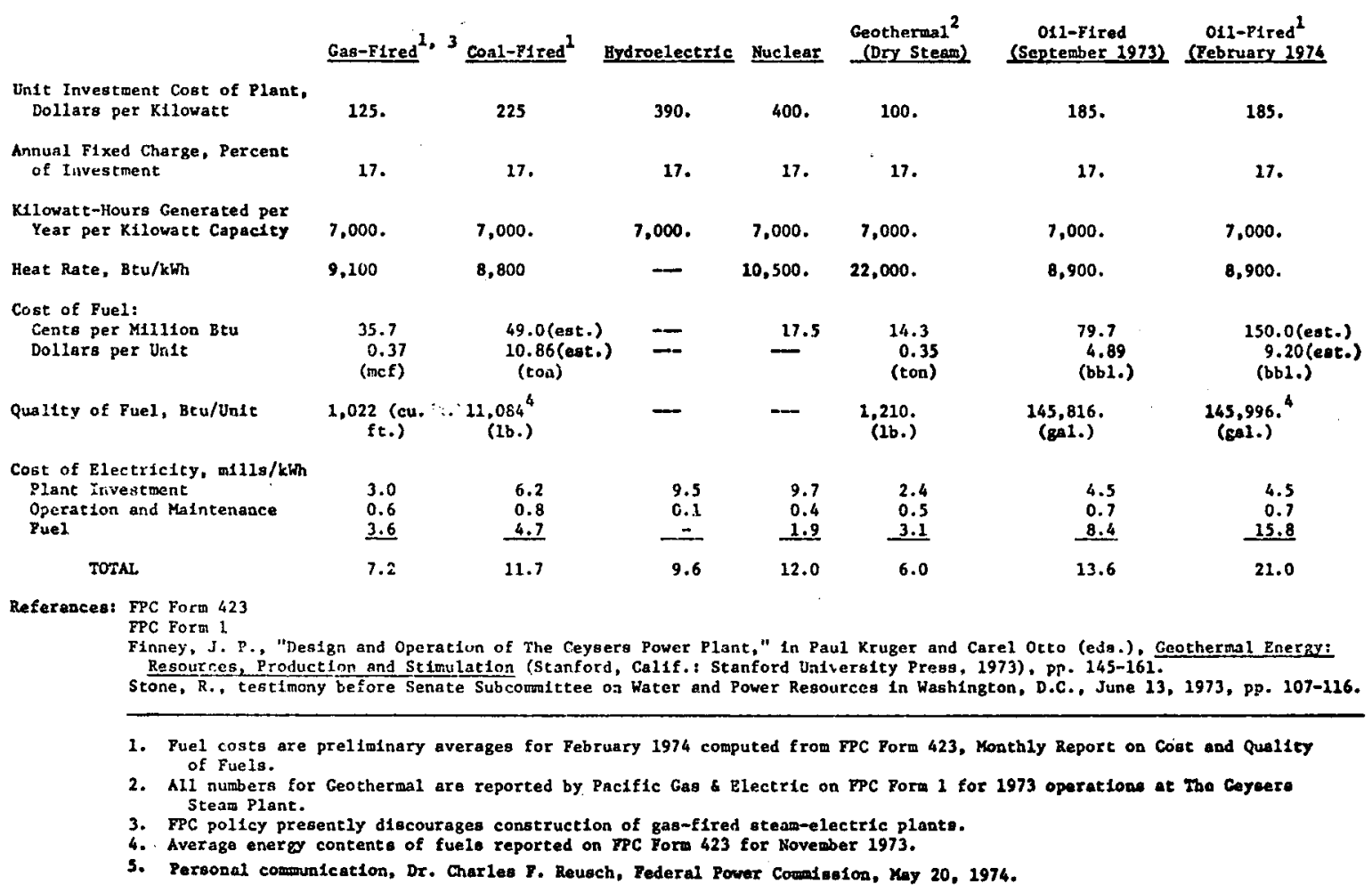

Figure 1.2.3

[9] U.S. Senate Committee on Interlor and Insular Affairs, Hearings on the Role of Geothermal Energy Resources in our Nation's Future Energy Economy, June 15 and 22, 1972 (92nd Congress, 2nd session).

[10] U.S. Dept. of the Interior, Final Statement for the Geothermal Leasing Program, Weshington, 1973.

[11] U.S. Energy Outlook, A Summary Report of the Natura1 Petroleum Counc11; Wash1ngton, December 1972 .

[12] Hickel, W. J., Geothermal Energy (Alaska: University of Alaska, 1972).

[13] The Nation's Energy Future, A Report to Richard M. N1xon, President of the U.S., submitted by $\mathrm{Dr}$ D1xy Lee Ray, Chalrman U.S. Atomic Energy Commisston, December 1973.

[14] Pacific Gas and Electric Company, "App11cation Before the Public Utilities Commission of the State of Callfornia, Untt 11 at The Geysers Power Plant."

[15] Pacific Gas and Electric Company, "Application Before the Public Utilities Commission of the State of California, Unit 14 at The Geysers Power Plant," July 1973.

[16] Armstead, H.C.H., "Geothermal Iconomlcs," GeoThermal Energy, UNESCO, Review of Research and Development (1973).

[17] Paredes, S., Superintendent Planta Geotermoelectrica, Comission Federal de Electricidad, speech
E1 Centro, Californta, October 17, 1973.

[18] Hayashida, T., "Cost Analysis on Geothermal Power," Geothermics, Special Issue 2, Vol. 2, Part 1 (1970).

[19] Armstead, H.C.H., "Geothermal Econom1cs," Geothermal Energy, UNESCO, Review of Research and Development (1973).

[20] Green, M.A., and A.D.K. Laird, "Comparison of Elementary Geothermal--Brine Power--Production Processes," Report LBL-2102 (University of Callfornia, Lawrence Berkeley Laboratory, August 2, 1973).

[21] Austin, A.L., G.H. Higgins, and J.H. Howard, "The Total Flow Concept for Recovery of Energy from Geothermal Hot Brine Deposits," UCRL-51366, TID-4500, UC-51, Apr11 3, 1973.

[22] "MeetIng California's Energy Requirements 1975-2000," SRI Project ECC-2355 (Stanford Research Institute, May 1973).

[23] Kaufman, A., Letter to Congressman Mike McCormack, Chairman, Subcominittee on Energy, U.S. House of Representatives, December 6, 1973.

[24] Brown, D.W., M.C. Smith, and R.M. Potter, "A New Method for Extracting Energy from Dry Geothermal Reservoirs," LA-DC-72-1157 (Los Alamos Sclentiflc Laboratory, July 1, 1973). 
[25] American 0i1 Shale Corporation, Battelle Northwest, Westinghouse Electric Corporation, and U.S. Atomlc Energy Commission, "A Feasibility Study of a Plowshare Geothermal Power Plant," April 1971.

[26] Durham, C.0.,Jr., Louisiana State University, Statement on "Proposed Geopressure Energy Invest1gation" on the Geothermal Energy Research,

Development, and Commercial Demonstration Act of 1974 , H.R. 11212. 


\subsection{Overall Study Design}

Technology assessment may be defined as "the systematic study of effects on soclety that may occur when a technology is introduced, extended, or modified, with spectal emphasis on the impacts that are unintended, indirect, and delayed...technology assessment is a policy generation and analysis or declsion orlented tool. Its alms, techniques, and methods are best conceived as ylelding systematic inputs into the larger political economic decision process."[1]

There is no codified set of techniques which can be followed to satisfy these objectives. The methods of technology assessment which have been used in past studies have been drawn from many different disclplines, including, most prominently, economics, soctal poychology, statistics, engineering, and operations research. The cholce of the approprlate technique depends on the fudgment of the researcher as well as the nature of the problem and the level of funding of the project. As Joseph F. Coates of the National Science Foundation recently put 1t:

Technology assessment is an art form.... It is separate, distinct, different from [existing disciplines] and as in any other art form, implies both a degree of creativity as well as the use of techniques. It also implies that not everyone is talented in undertaking or understanding the art forms. [2]

Martin V. Jones, in an early set of technology assessments performed for the Office of Sclence and Technology, defined seven major steps in making a technology assessment. These steps included:

1. Defining the assessment task, in which relevant 1ssues and major problems are discussed, project ground rules estab11shed, and the scope of the Inquiry is set.

2. Describing relevant technologies including not only the technology being assessed, but other technologies supporting or competing with the technology under study.

3. Developing state of soclety assumptions, involving the identification and description of major non-technical factors which could influence the application of the technology.
4. Identifying the impact areas, that 1s, socletal characteristics that will be most influenced by the technology.

5. Making preliminary impact analysis: tracing and Integrating the process by which the assessed technology makes its societal influence felt.

6. Identifying possible action options through the development and analysis of varlous programs for obtaining public advantage of the technology.

7. Completing the Impact analysis through study of the ability of each action option to alter the previously established socletal impacts. [3]

Most technology assessments go somewhat further than these seven steps. The Identification of interest groups is an important facet of most studies. It is not enough simply to Identify impact areas; the questions of who is affected, when, and how, must also be addressed. In addition, the study of action options and state of socity assumptions must include at least macro-level alternatives to the technology under study. A technology assessment of geothermal energy, for example, should probe not only the means for producing and using geothermal energy and the effect of this technology on society as a whole and groups within 1t, but also whether geothermal energy or some other energy form is more appropriate, as well as the consequences of reducing energy demand.

Given the objectives of technology assessment and the major elements of such studies, a logic flow chart such as that shown In Figure 1.3 .1 can be prepared.

Beginning at the left of the diagram:

Task 1. State-of-the-Art. The state-of-the-art is defined first. In this task, the major question is, "What do we know about the technology or problem under study?"

Task 2, Other Condttions. Here the focus is on other aspects of change. which Impinge on the subject under Investigation. For example, this task may address concomitant technologies which, if successful, would Iimtt or in some way amplify the basic technology. In addition, this task might center on external social

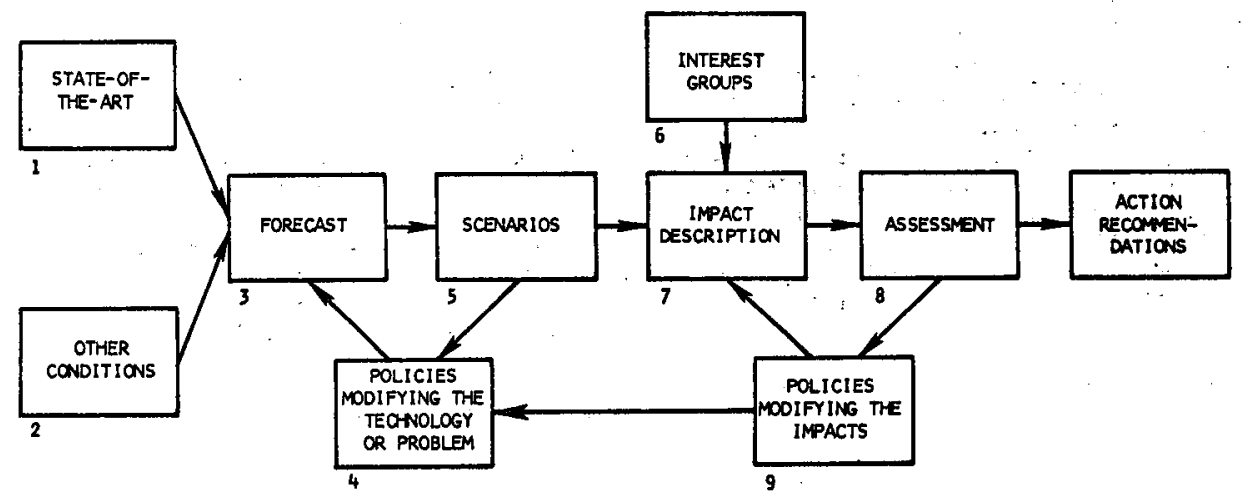

F1gure 1.3.1 TECHNOLOGY ASSESSMENT LOGIC FLOW 
conditions which could change the impacts of the technology or the values by which the Impacts are to be judged.

Task 3. Forecast. Th1s task 1nvolves generating an Image or set of Images of the future of the technology under study. How might it evolve? What are the most Important breakthroughs? When might they occur? What paces them?

Task 4. Pollcies for Modifying the Technology or Problem. In this task, policies are nominated and defined which might change the time scale or nature of the technology. Typically, the definition of a policy might Include Identification of the agency which could perform the action, the cost of the polfcy, 1ts timing, and its intended consequences. Note that the output of Task 4 provided an 1nput to Task 3; that 1s, the policies generated here are designed to amend the technological forecast.

Task 5. Scenar108. In this task, forecasts are grouped Into self-consistent sets, alternative futures depicting the evolution of the technology or problem under study in the presence of pollctes considered in Task 4. In effect, the output of Task 5 is a statement of what the world might be like in the particular domaln of the assessment. The remainder of the analyBis is devoted to an Identification of the consequences of these alternative worlds and means for improving them.

Task 6. Interest Groups. Here the groups likely to be affected by the emerging technology or problem are Identified.

Task 7. Impact Descript1on. Given the Interest groups and the alternative futures produced in Tasks 6 and 5, respectively, this task defines and estimates specific impacts. Thus, at this point in the study, an array can be constructed of Interest groups, how they are likely to be affected in the varlous worlds depicted by the scenarios, each scenario having been determined by a particular technological or problem-orlented pollcy set.

Task 8. Assessment. Now the problem 1s: Are the forecasted impacts likely to be seen as good or bad? of course, such judgments are value-laden and mult1dimensional. An Impact seen as good for one group might be bad for another. Furthermore, "good" and "bad" can be defined only in terms of a value framework. Yet despite these difficulities, the assessment accomplished in this task necessarily must deal with these issues.

Task 9. Modifying the Impacts. The object of Task 9 Is to Invent policies which seem likely to Improve the future state of affalrs, that 1s, the conditions Identified in Task 8 . Nominated policies are fed back to Tasks 7 and 3. The loop to Task 7 is designed to test policles which are supposed to modify the technology itself. When pollcies have been found which produce the "best" world for the interest groups and soclety as a whole, they form the basis for action recommendations.

In accomplishing the geothermal technology assessment, both conventional and relatively novel analysis techniques were used. L1terature searches were employed in reviewing the state-of-the-art of geothermal energy and other potentially competing sources of energy, such as coal, natural gas, petroleum, nuclear, and solar. As in the two preceding sections, 1.1 and 1.2 , the bibllography of sources reviewed to listed at the end of the section.

Technological forecasts, information about constraints to technological progress, and suggestions of means for removing those constraints were obtained in interviews and in responses to questionnaires by technological experts. This portion of the study was conducted by Bechtel Corporation personnel.

Briefly, the interviews involved careful preparatory steps, including:

1. Description of the content of geothermal technology down to the component level, using relevance tree techniques (the relevance tree is presented in Appendix B). A relevance tree 18 a hierarchical structure in which lower levels, in the aggregate, completely describe the higher levels to which they are connected, in some particular respect.

2. Compilation of an Initial 1ist of Impediments to the evolution of geothermal technology; this 11st was checked and extended later by comparison against the completed relevance tree. Impediments to technological developments are described in Section 3.3 .

3. Identification of respondents with expertise needed to span the spectrum of disiplines-from geology to rotating machinery-relevant to the picture of geothermal technology. In a11 28 experts participated.

The members of the panel were interviewed in person, by mail, and by telephone. They responded about their view of technological impediments to identifying geothermal resources, bringing them to the surface of the earth, and converting them to electricity. In recognition of the fact that government actions by way of choosing directions, goals, and financial support levels directly affect the timing and magnitude of technological capabilities, responses were solicited from the panel members for two research and development program scenarios, defined as follows:

1. "Norma1 Development Program: Geothermal technology continues to develop on the same basis that is presently developing, without additional externally-applfed stimuli."

2. "Crash Development Program: Geothermal techology develops under the stimulus of a declared national policy and massive government support, in which case cost is virtually no Impediment."

Information produced by this interview sequence included independent assessments of technologically feastble levels of 1dentified resources and levels of electricity production, as well as information on the nature of the associated technological impediments, and how and under what conditions the impediments could be removed, for each of the five types of geothermal resources and for the two research and development program scenarios.

The detalled technology forecasts produced by these interviews were synthesized into overall technology forecasts, quantitative energy system flow diagrams, and resulted in estimates of technologically feasible levels of development of geothermal energy for normal and crash program scenarios. The design and results of this portion of the study are summarized in Sections 3.1 and 3.3 and are provided in detall in Appendix A. 
Having produced forecasts based on techological feas1bility it was then necessary to consider and synthesize non-technological factors to arrive at an overall picture of the likely evolution of geothermal energy in the United States.

Several approaches were utilized. In the first, the study team added soclo-political developments suggested In the 1iterature to the two scenarios used previously in the technical interviews.

While these scenarios seemed intultively consistent, a more structured approach was felt necessary to synthesize the avallable data and to provide a systematic basis for comparing the consequences of contemplated policies. A model was constructed to fill this need; It is described in deta1l in Appendix $\mathrm{E}$ and its operatIon 18 summartzed in Section 3.4 .

There are subtle benefits which often flow from the construction and use of such simulation models. First of all, a discipline is imposed which requires that the system being described be broken down into its elemental components. The interaction among these components should be understood in order to be simulated well. When used in a "futures" mode, modeling requires an explicit consideration of potential forces which can make a difference. In policy analysis applications, analysts can often define the range of control which actually can be exerted and can learn the range of outcomes which may result from actions or inactions.

The model used here involves many assumptions about relationships and the values of varlous initial parameters. As a forecasting tool, the model produces results which reflect and depend on these assumptions. In this study the assumptions and values of inftial input parameters were largely based on judgments of The Futures Group with inputs from the 11terature and consultants; therefore, the model output reflects those judgments.

Basically, the model described the rate of growth of geothermal electricity production in the United States besed on a simulation of utility company decision-

making. It was capable of describing factors such as:

A. The amount of electricity produced from geothermal sources in both the eastern and western United States.

B. Total capital costs required for geothermal activities.

C. Installed capacity in both the East and West in coal, petroleum, and nuclear power plants.

The assumptions on which the model was based could be tested by varying them one at a time. In this way, the assumptions to which the output of the model was most sensitive could be identified. In addition, polictes designed to improve or diminish the rate of introduction of geothermal energy could be tested, at least wthin the framework of the simulation.

Interest groups were Identified through review of the 11terature, Informal discussions with the Oversight Committee members, and, most important1y, through a careful review of comments submitted in response to the U.S. Department of the Interior Ehvironmental Impact statement of 1973. The Interest groups are summarized in Sections 2.3,2.4, and Section 5 .

Given the scenar1os, It now became necessary to Identify the Impacts wich might result. A primary tool here was, once again, a series of carefully structured intervlews. Now the respondents were selected because of their interest and expertise in the socio-political, environmental, or economic implications of geothermal energy. In all, 17 people were interviewed. These people included utility company executives, environmentalists, geothermal advocates, affected land owners and homeowners, local government officials, etc. They were first asked to comment on the scenarlos and correct them where they felt necessary. In the second part of the interview, they were presented with a set of prospective impacts of geothermal evolution; they were asked to fudge the relative significance and probabillty of these impacts and to add to the set other Impacts which they felt should be included. These newly added Impacts were also judged for Importance and probability. Finally, for the important impacts, each respondent was asked to invent policies which they felt could mitigate adverse Impacts or help assure the positive impacts which they saw.

Emerging from the interviews was a set of impacts of varying probabilities and relative significance which had to be assembled into a cohesive structure before assessment could be performed. The Impact statements were carefully reviewed and organized into a second set of relevance trees.

EIght primary impact areas were identified; the relevance trees depicted how secondary and tertiary impacts might flow from these primary impacts. The impact relevance tree is contained in Appendix D; the impacts themselves are described in detall in Section 4.

Now given the results of the second set of Interviews and a structure for displaying the "impact space," the question remained: How can one assess the impacts? The study team utilized three approaches. The first was a conventional comparison of costs and benefits. For example, In determining the consequences of the evolution of geothermal energy on the economy, estimates were made of the capital investments required, and these were compared to expected Improvements in import/export ratio.

The second approach, Trend Impact Analysis, was used where it was important to describe the potentlal development of some particular parameter.

Trend Impact Analysis is a new forecasting method that permits extrapolations of historical trends to be modifled in view of expectations about future events which could. Influence the trends. This technique permits including and systematically examining the effect of posstble future events which are belleved to be Important on trends which deplct the consequences of the technology being assessed. The events may be technological; political, social, economic, or.valueorlented changes.

After making surprise-free extrapolations; a list of potentially important and relevant unprecedented future events is prepared. These events are plausible and potentially powerful in impact. The source of this list of events was the ilterature search, the two sets of interviews, and recomendations from consultants.

The TIA program combines impact and event-probability Judgments with the results of the surprise-free extrapolation to produce an adjusted extrapolation, plus estimates of upper and lower quartile 1imits. The expected value of the combined impacts is computed by summing the products of the probabilities of the impacting events for each year in which they are possible with the magnitude of their expected impacts, 
taking into account the specified impact 1ags. The TIA program is described in detail in Appendix $F$; the forecasted parameters are included in Section 4.

A third tool was used in the assessment task. Whereas conventional analysis and Trend Impact Analysis were useful in describing future conditions 1ikely to affect various interest groups, it remalned to describe how the various groups would percelve the changes brought about by the evolution of geothermal energy and pol1cles Implemented to shape it.

To analyze potentlal group Impacts, a serles of "value matrices" were contructed in which interest groups were 1isted along the abscissa of a matrix deplcting geotherma1-induced changes and developments important to the interest groups were listed on the ordinate. Each cell of the matrix contained a number deplcting the relative importance, either positive or gegative, of the development. By summing the products of the development probability and the cell entries, along a row, the relative importance of each of the developments could be established. By summing in the colum, Impact of the technology on the Interest group could be deduced. Statistical analysis of these data could be used to Indicate relative agreement or disagreement among groups. Furthermore, when impact shaping policles were tested, these matrices could Indicate whether turmoll or tranquility was likely to be promoted. This portion of the analysis is included in section 5.

When apparently inappropriate impacts were discovered, policies suggested in the interviews or invented by the study team were introduced in an effort to change the evolutionary scenarlo and 1ts impacts. These policles were tested in the simulation model produced in Task 5 , in the impact descriptions produced in Task 7, and by changing factors involved in the cost/benefit, trend impact and value matrix analyses. From the three Iterative loops. involved, a sertes of potentlally desirable policles emerged. These polictes were related to the evolution of the technology, as well as to means for mitigating impacts. They ranged from suggestlons for needed research to auggestions for modifyIng the Institutional arrangements by which geothermal energy would be pursued. The action recommendations are described in Section 1.4 of this report.

\section{REFERENCES}

[1] Coates, Joseph F., "The Identification and Selection of Candidates and Prioritles for Technology Assessment," Technology Assessment (February 1974).

[2] Coates, Joseph F., "Inst1tutional and Technical Problems in Risk Analys1s," Proceedings of a Conference. on Bulk Transportation of Hazardous Materials by Water in the Future, sponsored by the Committee on Hazardous Materials, College Park, Maryland, July 9-10, 1973.

[3] Jones, Martin V., A Technology Assessment Methodology, MITRE MTR6009, 7 vols. (McLean, Va.: The Mitre Corporation, 1971). 
1.4 Study Conclusions and Recommendations [1]

\section{Overall Potential}

Geothermal energy can be a relatively important energy source in the United States by the year 2000 . It could supply on the order of 185,000 to $250,000 \mathrm{MWe}$, or more, compared to an expected U.S. total capacity of 2 million MWe. (For comparison, the State of California currently has a total generating capacity of 37,000 MWe.) At these levels, by 2000 geothermal sources will be contributing more to our energy supply than hydroelectric sources (Section 3.5).

Because geothermal sources are located primarily in the western part of the United States, the effects of geothermal energy will be considerably greater there than elsewhere in the United states. For example, total expected electricity generation capacity in the western part of the United States is expected to reach about 480,000 MWe by the year 2000; geothermal sources can constitute 25 percent or more of the total supply in that region (Section 3.5 ).

There is a great deal of uncertainty about the true extent of the total resource and the relative potential of 1 ts varfous forms (vapor-dominated, 1iquid-dominated, hot dry rock, geopressured, and magma). During the study, experts were asked to express their opinions about the likely extent of identified resources, resource development, and the level of energy conversion which could be realized in various years, constrained only by technology (Section 3.1). Ranges of estimates of identifled resources were the widest, varying for the year 2000 from the lowest level of $50,000 \mathrm{MWe}$ to almost Infinite supply. The higher level was predicated primarily on the potential discovery of large quantitles of hot dry rock resources. The mid-range of opinions of participating experts about the level of technologically feasible utilization of these resouxces for the generation of electricity was between 55,000 and $200,000 \mathrm{MWe}$ in a normal program, and 270,000 and 800,000 Me if a program unlimited by costs were implemented (Section 3.1).

The contribution of geothermal resources to U.S. energy supplies seems likely to increase continuously; by 1985 it is reasonable to expect that geothermal sources will be producing 7000 to 20,000 MWe or so out of a total of about 1 milition MWe in the United States. After 1985, growth could be more rapld (Sections 3.1 and 3.5 ).

\section{Impediments to Development}

To achieve a high level of geothermal energy development, certain technological, institutional, and polit1cal issues will have to be resolved (Section 3.3). The timing of the actions which resolve these issues wi11 determine the pace and the extent of utilization of geothermal energy.

\section{Technological Issues}

The present state of knowledge of the extent, distribution, and quality of geothermal resources in the United States is fragmentary, uncoordinated, and, on the whole, undeveloped. This fact is a major impediment to the rapld development of an energy industry based on the use of geothermal resources (Section 3.1).

Development of vapor-dominated reservoirs and liquiddominated reservoirs of moderate salinity has reached the level of large-scale energy production. However, energy extraction methods have not yet been demonstrated on a large scale for high-salinity brines, nor for hot dry rock, geopressured, or magma resources. Serious experimentation is being conducted on energy recovery techniques for high-salinity brines and for hot dry rock. However, little or no experimentation is being conducted on energy recovery from geopressured zones and magma (Section 2.1).

Technology for conversion of geothermal energy from vapor-dominated and moderate salinity 11quid-dominated geothermal systems is fairly well in hand. However, conversion processes and equipment for high salinity systems and moderate to low temperature systems are still experimental. Conversion processes for hot dry rock have not yet been developed, but will probably be similar to vapor- or liquid-dominated geological systems. Processes for geopressured resources are only conceptual at this time. The possibility of extracting and converting energy from magma is so remote that little or no serlous thought has been given to this problem (Section 2.1).

Figure 1.4.1 summarizes the most important currently perceived technological issues and indicates whether they are expected to exist as developmental impediments as late as 1985 (Sections 3.1, 3.3, and Appendix A).

The technological problems 11sted in Figure 1.4 .1 seem amenable to solution.

The environmental issues deserve particular mention. Some of these issues have important local but temporary significance and others have potentially lasting oignificance (e.g., contamination of groundwater supplies, seismicity, and subsidence). The extent of the potentially irreversible environmental impacts is not known with precision; however, similar activitieg in the ofl and gas industries have proven manageable. Clearly, research and development, incentives and sanctions are necessary in this area (Sections 2.6, 4.5, and 4.8). Such incentives and sanctions are discussed later in this section.

\section{Non-Technical Issues}

A number of regulatory and institutional impediments to the development of geothermal energy also exist. None of these seems 11kely to prevent the development of this energy source, but in the aggregate, they will pace its growth as certain1y as the technological 1ssues (Sections 3.3 and 4.5). The Issues are assoclated with the encouragement of explóration and development, assuring a market for geothermal steam or hot water, and accomplishing the required research and development in a timely manner (Section 4.5). These 1ssues are summarized in Figure 1.4.2.

\section{Impacts of Development}

The development of geothermal energy in the UnIted States at the level described above is apt to cause both favorable and unfavorable, though manageable, impacts which can be grouped into elght major areas.

1. It will change the electric ut1lity fuel mix by substituting for nuclear and coal generating plants (Section 4.1). The development of geothermal resources could lead to (by 2000) fewer nuclear plants (about 100,000 to $150,000 \mathrm{Me}$ could be saved) and fewer coalfired plants (about 90,000 to 120,000 MWe could be saved). For comparison, a modern nuclear plant generates about 


\begin{tabular}{|c|c|c|c|c|c|c|c|c|c|c|c|}
\hline \multirow[b]{2}{*}{ ISSUE } & \multicolumn{2}{|c|}{ TIMING } & \multicolumn{4}{|c|}{ DEVELOPMENT PMASE } & \multicolumn{5}{|c|}{ RESOURCE } \\
\hline & $\bar{z}$ & $\stackrel{\sim}{\sigma}$ & 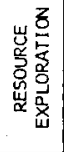 & 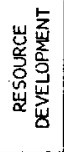 & 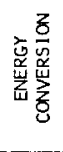 & 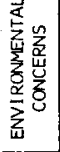 & $\begin{array}{l}\frac{0}{0} \\
\frac{1}{3}\end{array}$ & $\stackrel{9}{\frac{9}{g}}$ & 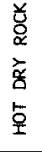 & 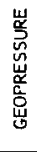 & $\frac{\sqrt[\pi]{5}}{\substack{5 \\
\frac{\pi}{2}}}$ \\
\hline $\begin{array}{l}\text { LACK OF INFORMATION ON THE EXTENT, DISTRIBUTION, } \\
\text { AND QUAL ITY OF GEOTHERMAL RESOURCES IN THE } \\
\text { UNITED STATES. }\end{array}$ & $x$ & $x$ & $x$ & & & & $x$ & $x$ & $x$ & $x$ & \\
\hline $\begin{array}{l}\text { LACK OF A PRACTICAL TECHNIQUE FOR CONDUCTING } \\
\text { GROSS EXPLORATION (II.E., REMOTE THERMAL I.R. } \\
\text { [INFRARED] SCANNING FROM EARTH RESOURCES } \\
\text { SATELLITE). }\end{array}$ & $x$ & & $x$ & & & & $x$ & $x$ & $x$ & & $x$ \\
\hline $\begin{array}{l}\text { LACK OF GEOTHERMAL DATA INFORMATION CENTER } \\
\text { DESIGNED TO RECEIIVE,' STORE, PROCESS, AND } \\
\text { DISSEMINATE EXISTING AND FUTURE RESOURCE AND } \\
\text { RESERVOIR DATA (GEOLOGICAL, GEOPHYSICAL, } \\
\text { GEOCHEMICAL, ETC.) WHICH IS IN THE PUBLIC } \\
\text { DOMAIN FOR USE IN RESOURCE APPRAISAL, RESOURCE } \\
\text { DESIGN, AND MANAGEMENT. }\end{array}$ & $x$ & $x$ & $x$ & & & & $x$ & $x$ & $x$ & $x$ & $x$ \\
\hline $\begin{array}{l}\text { NEED FOR IMPROVEMENT IN PROCEDURES, EQUIPMENT, } \\
\text { AND DATA INTERPRETATION OF THE VARIOUS } \\
\text { GEOPHYSICAL EXPLORATION AND APPRAISAL TECHIQUES. }\end{array}$ & $x$ & & $x$ & & & & $x$ & $x$ & $x$ & & $x$ \\
\hline $\begin{array}{l}\text { LACK OF DEMONSTRATED METHOD FOR CONTINUOUS } \\
\text { RECOVERY OF ENERGY FROM HOT DRY ROCK RESERVOIRS. }\end{array}$ & $x$ & & $x$ & & & & & & $x$ & & \\
\hline $\begin{array}{l}\text { PRESENT ACUTE SHORTAGE OF TUBULAR GOODS (DRILLL } \\
\text { STEEL. AND WELL CASING) WHICH ARE ESSENTIAL TO } \\
\text { DRILLING AND CASING OPERATIONS. }\end{array}$ & $x$ & $x$ & & $x$ & & & $x$ & $x$ & $x$ & $x$ & $x$ \\
\hline $\begin{array}{l}\text { LIMITED AVAILABILITY OF DRILL RIGS FOR DEEP TO } \\
\text { VERY DEEP DRILLING (I.E., BELOW } 25,000 \text { FT.) AND } \\
\text { VERY HOT DRILLING (I.E., GREATER THAN } 800^{\circ} \mathrm{F} \text { ). }\end{array}$ & $x$ & $x$ & & $x$ & & & $x$ & $x$ & $x$ & $x$ & $x$ \\
\hline $\begin{array}{l}\text { LACK OF LONG-TERM CASE HISTORY DATA ON WHICH } \\
\text { FIELD LONGEVITY PREDICTIONS CAN BE BASED. }\end{array}$ & $x$ & & & $x$ & & & $x$ & $x$ & $x$ & $x$ & $x$ \\
\hline $\begin{array}{l}\text { NON-EXISTENCE OF A DEMONSTRATED, PRACTICAL DOWN- } \\
\text { HOLE HEAT EXCHANGER OF SUFFICIENT CAPACITY TO } \\
\text { BE USEFUL IN LARGE-SCALE ENERGY EXTRACTION } \\
\text { OPERATIONS. }\end{array}$ & $x$ & & & $x$ & & & & $x$ & & & \\
\hline $\begin{array}{l}\text { NON-EXISTENCE OF A LARGE-SCALE DEMONSTRATION } \\
\text { ELECTRIC POWER PLANT FOR LIQUID-DOMINATED } \\
\text { RESOURCES TO MEDIUM- TO LOW-THERMAL QUALITY. }\end{array}$ & $x$ & & & & $x$ & & & $x$ & & $x$ & \\
\hline $\begin{array}{l}\text { NEED FOR DEMONSTRATION ELECTRIC POWER PLANT FOR } \\
\text { CONVERSION OF ENERGY FROM HEAVY BRINE RESERVOIRS. }\end{array}$ & $x$ & & & & $x$ & & & $x$ & & $x$ & \\
\hline $\begin{array}{l}\text { LACK OF DEMONSTRATION ELECTRIC POWER PLANT FOR } \\
\text { CONNERSION OF ENERGY FROM HOT DRY ROCK. }\end{array}$ & $x$ & & & & $x$ & & & & $x$ & & \\
\hline $\begin{array}{l}\text { LACK OF A PROVEN PRIME MOVER CAPABLE OF. } \\
\text { CONTINUOUS OPERATION ON A PREDOMINANTLY } \\
\text { LIQUID TWO-PHASE FLUID. }\end{array}$ & $x$ & & & & $x$ & & & $x$ & $x$ & $x$ & \\
\hline $\begin{array}{l}\text { LACK OF AN EFFECTIVE METHOD FOR PREVENTING } \\
\text { SCALE DEPOSITS ON INTERNAL SURFACES OF } \\
\text { MECHANICAL EQUIPMENT, I.E., HEAT EXCHANGERS, } \\
\text { PIPES, TURBINES, ETC. }\end{array}$ & $x$ & & & & $x$ & & $x$ & $x$ & $x$ & $x$ & \\
\hline $\begin{array}{l}\text { LACK OF DEMONSTRATION ELECTRIC POWER PLANT FOR } \\
\text { CONVERION OF ENERGY FROM GEOPRESSURED ZONES. }\end{array}$ & $x$ & & & & $x$ & & & & & $x$ & \\
\hline $\begin{array}{l}\text { NECESSITY FOR DEVELOPING PRACTICAL TECHNIQUES } \\
\text { FOR PREVENTING GROUNDWATER CONTAMINATION. }\end{array}$ & $x$ & & & & & $x$ & & $x$ & & $x$ & \\
\hline $\begin{array}{l}\text { NECESSITY FOR DEVELOPING TECHNIQUES OF } \\
\text { EFFECTIVEY CONTROLLING HARMFUL OR NUISANCE } \\
\text { CASEOUS EMISSIONS. }\end{array}$ & $x$ & & & & & $x$ & $x$ & $x$ & & $x$ & \\
\hline $\begin{array}{l}\text { NECESSITY FOR DEVELOPING BROADLY APPLICABLE } \\
\text { TECONIQUES FOR LIQUID AND SOLID WASTE DISPOSAL. }\end{array}$ & $x$ & & & & & $x$ & $x$ & $x$ & & $x$ & \\
\hline $\begin{array}{l}\text { NECESSITY FOR DEVELOPING PRACTICAL AND EFFECTIVE } \\
\text { TECNIQUES FOR NOISE CONTROL DURING INITIAL } \\
\text { DRILLING AND TESTING OPEERATIONS, AS WELL AS } \\
\text { DURING OPERATING LIFE OF THE PLANT. }\end{array}$ & $x$ & & & & & $x$ & $x$ & $x$ & & $x$ & \\
\hline $\begin{array}{l}\text { LACK OF CONFIRMED UNDERSTANDING OF CAUSE/EFFECT } \\
\text { RELATIONSHIP BETWEEN FLUID INUECTION INTO THE } \\
\text { FORMATION AND. THE OCCURRENCE OR SUPPRESSION OF } \\
\text { EARTHQUAKES, WITH RESPECT TO ENWIRONMENTAL } \\
\text { EFFECTS ON THE SURROINDING AREA AND POPULACE. }\end{array}$ & $x$ & $x$ & & & & $x$ & $x$ & $x$ & $x$ & $x$ & \\
\hline $\begin{array}{l}\text { NECESSITY OF DEVELOPING PREDI CTIVE, I PREVENTIVE, } \\
\text { AND CORRECTIVE TECHNIQUES FOR DEALING WITH LAND } \\
\text { SUBSIDENCE CONSEQUENT TO GEOTHERMAL FLUID } \\
\text { WI THORAWAL. }\end{array}$ & $x$ & & & & & $x$ & $x$ & $x$ & & $x$ & \\
\hline
\end{tabular}

Figure 1.4.1 TECHNOLOGICAL ISSUES 


\begin{tabular}{|c|c|c|c|c|c|}
\hline \multirow[b]{2}{*}{ ISSUE } & \multirow[b]{2}{*}{ DESCRIPIION } & \multicolumn{4}{|c|}{ DEVELOPMENT PHASE } \\
\hline & & 岁矢 & 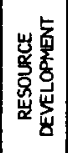 & 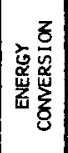 & 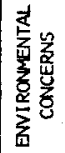 \\
\hline $\begin{array}{l}\text { CLASSIFICATION OF GEOTHERMAL } \\
\text { RESOURCES-MINERAL RESERVATIONS }\end{array}$ & $\begin{array}{l}\text { VARIOUS HOMESTEAD ACTS RESERVE MIINERAL } \\
\text { RIGHTS TO THE WNITED STATES; DEFINITION } \\
\text { OF THE RESOURE CCNTAINED IN CURRENT LAWS } \\
\text { DOES NOT CARIFIFY THE RIGHTS OF LND OWNERS } \\
\text { AND THE UNITED STATES. }\end{array}$ & $x$ & $x$ & & \\
\hline $\begin{array}{l}\text { CASSIFICATION OF GEOTHERHAL } \\
\text { RESOURCES-ACQUISITION OF RIGHTS }\end{array}$ & 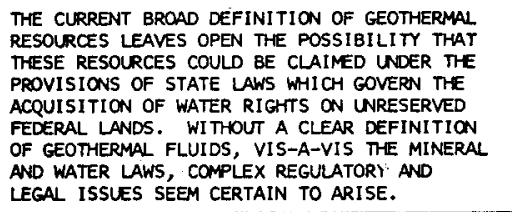 & $x$ & & & \\
\hline $\begin{array}{l}\text { CLASSIFICATION OF GEOTHERMAL } \\
\text { RESOURCES-TAX TREATMENT }\end{array}$ & 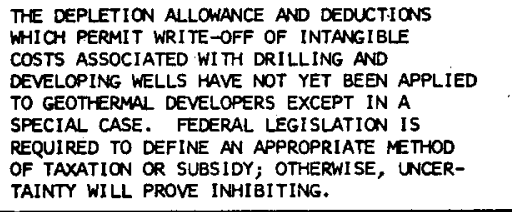 & $x$ & $x$ & & \\
\hline $\begin{array}{l}\text { AVAILABILITY OF LANDS FOR } \\
\text { DEVELOPMENT--EXCLUDED LANDS }\end{array}$ & 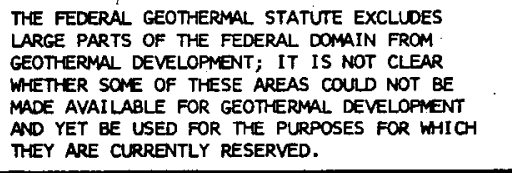 & $x$ & $x$ & & \\
\hline $\begin{array}{l}\text { AVAILABILITY OF LANDS FOR } \\
\text { DEVELOPMENT--ACREAGE LIMITATIONS }\end{array}$ & $\begin{array}{l}\text { THE GEOTHERMAL STATUTE LIMITS EACH LESSEE } \\
\text { TO } 25,000 \text { ACERS. IT IS NOT YEAT CLEAR } \\
\text { WHETHER THIS LIMITATION WILL PROVE TO } \\
\text { BE A SUSTANIAL BARR IER TO DEVLOPWET, } \\
\text { OR HHETHER COOPERATIVE CONTROL AMONG } \\
\text { LESSEES WILL SUOVERT THE INTENT OF THE } \\
\text { STATUTE. }\end{array}$ & $x$ & $x$ & & \\
\hline $\begin{array}{l}\text { AVAILABILITY OF LANDS FOR } \\
\text { DEVELPPENT-AODINISTATIVE } \\
\text { DISCRETION TO WITHDRAW LANDS FROM } \\
\text { GEOTHERMAL DEVELOPNENT }\end{array}$ & $\begin{array}{l}\text { THE SECRETARY OF THE INTERIOR AND OTHER } \\
\text { ACENCIES RESPONSIBLE POR MANAGENENT OF } \\
\text { FEDERAL LAND HAVE VIRTALLY WNRESTRICTED } \\
\text { DISCRETION TO WITHDRAN LANDS FROM } \\
\text { DEVELOPVENT; THE INHIBITING AFFECT OF } \\
\text { THIS PROVISION IS UNKNOWN. }\end{array}$ & $x$ & $x$ & & \\
\hline $\begin{array}{l}\text { AVAILABILITY OF LANDS FOR } \\
\text { DEVELOPMENT-MULTIPLE USES OF } \\
\text { PWLLIC LANDS }\end{array}$ & 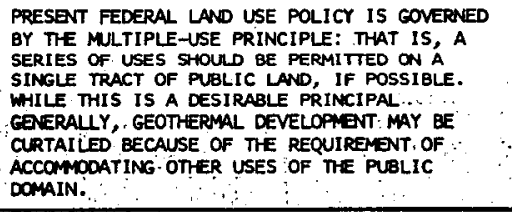 & $x$. & & & \\
\hline 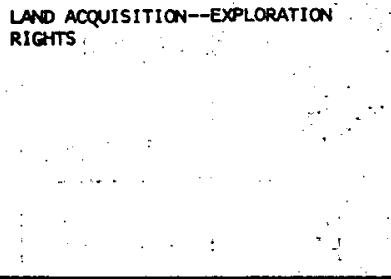 & 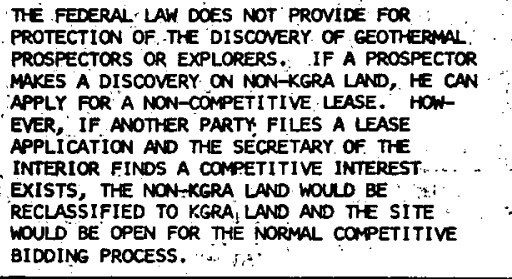 & $x$ & & & \\
\hline LAND ACQUISITION--BONUS BIDOING & 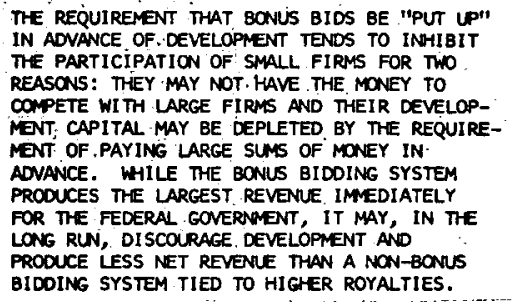 & $x$ & $x$ & & \\
\hline
\end{tabular}

F1gure 1.4.2 NON-TECHNOLOGICAL ISSUES 


\begin{tabular}{|c|c|c|c|c|c|}
\hline \multirow[b]{2}{*}{ ISSUE } & \multirow[b]{2}{*}{ DESCRIPTION } & \multicolumn{4}{|c|}{ DEVELOPMENT PHASE } \\
\hline & & 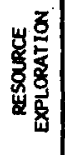 & 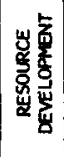 & 充焉 & 夏 \\
\hline $\begin{array}{l}\text { LAND ACQUISITION-PUBLIC VS. } \\
\text { PRIVATE DEVELOPMENT }\end{array}$ & $\begin{array}{l}\text { THE FEDERAL GOVERNENT SHOULD CONSIDER } \\
\text { WMETHER THERE ARE TO BE DIFFERENT POLICIES } \\
\text { REGARDING THE DEVELOPMENT OF PUBLICLY } \\
\text { OWNED RESOURCES BY PRIVATE OR PLBLIC } \\
\text { ORGANIZATIONS. }\end{array}$ & $x$ & $\mathbf{x}$ & $x$ & \\
\hline SECURITY OF TENURE--LEASE TERMS & $\begin{array}{l}\text { THE LEASE TERMS ESTABLISHED BY THE FEDERAL } \\
\text { STATUTE ARE RELATIVELY SHORT AND IN MANY } \\
\text { INSTANCES, SHORTER THAN STATE LEASE TERMS. } \\
\text { THE SHORT TIME PERIOD WAS INTENDED TO } \\
\text { ENSURE THAT GEOTHERML LAND WOULD BE PUT } \\
\text { INTO PRODUCTION AND NOT HELD BACK FOR } \\
\text { SPECULATION. IT IS TOO EARLY TO TELL } \\
\text { WHETHER THE PRIMARY LEASE TERM IS TOO SHORT. }\end{array}$ & & $x$ & $x$ & \\
\hline $\begin{array}{l}\text { SECURITY OF TENURE--RENEGOTIATION } \\
\text { RIGHTS }\end{array}$ & $\begin{array}{l}\text { THE SECRETARY OF THE INTERIOR HAS RIGHTS } \\
\text { TO RENEGOTIATE BOTH LEASE TERMS AND } \\
\text { CONDITIONS AS WELL AS RENTS AND ROYALTIES; } \\
\text { THE POSSIBILITY OF OISPUTE ANO TERMINATION } \\
\text { IN THE NEGOTIATION PROCESS MAY INHIBIT } \\
\text { PERSONS FROM INVESTING SUBSTANTIAL. AMOUNTS } \\
\text { OF CAPITAL. }\end{array}$ & $x$ & $x$ & $x$ & \\
\hline $\begin{array}{l}\text { ENVIRONMENTAL CONCERNS-- } \\
\text { TRADE-OFFS WITH DEVELOPMENT }\end{array}$ & $\begin{array}{l}\text { ENVIRONMENTAL REGULATIONS SHOULD RECOGNIZE } \\
\text { THAT ENVIRONMENTAL IMPACTS ASSOCIATED WITH } \\
\text { GEOTHERMAL DEVELOPMENT CAN BE DIVIDED INTO } \\
\text { TWO CATEGORIES: THOSE WHICH HAVE IMPORTANT } \\
\text { LOCAL AND TEMPORARY SIGNIFICANCE, AND THOSE } \\
\text { WHICH HAVE POTENTIALLY LASTING SIGNIFICANCE. } \\
\text { IN THE CASE OF TEMPORARY IMPACTS, CONTROLLING } \\
\text { MECHANISMS COULD RANGE FROM INDEMNIFICATION } \\
\text { BY THE GOVERNENT FOR DAMAGES CAUSED BY } \\
\text { GEOTIERMAL EXPLORATION AND DEVELOPMENT, TO } \\
\text { SELF-INSURANCE BY THE GEOTHERMAL OPERATORS. }\end{array}$ & & & & $x$ \\
\hline $\begin{array}{l}\text { ENIROMENTAL CONCERAS -- } \\
\text { ADMINISTRATIVE COMPLEXITY }\end{array}$ & $\begin{array}{l}\text { ADHINISTRATION IN THE AREAS OF LAND USE, } \\
\text { ENVIRONENTAL AFFAIRS, AND THE PRODUCTION } \\
\text { AND DEVELOPMENT OF GEOTHERMAL RESOURCES } \\
\text { SEEMS TO BE OVERLY COMPLEX AND REDUNDANT. } \\
\text { EFFORTS MUST BE MADE TO COORDINATE VARIOUS } \\
\text { REGULATORY RESPONSIBILITIES BOTH AT STATE } \\
\text { AND FEDERAL LEVELS TO ENSURE THAT THE } \\
\text { IMPORTANT VALUES EMBODIED IN THE REGULATORY } \\
\text { PROCESS ARE PRESERVED AND TO REDUCE THE } \\
\text { BURDEN ON THE GEOTHERMAL DEVELOPER TO } \\
\text { OBTAIN THE APPROVALS NECESSARY TO INITIATE } \\
\text { AND CONTINUE WITH DEVELOPMENT PROUECTS. }\end{array}$ & $x$ & $x$ & $x$ & $x$ \\
\hline $\begin{array}{l}\text { EFFECTS ON TME ELECTRIC UTILITIES-- } \\
\text { INCENTIVES FOR THE PURCHASE OF } \\
\text { STEAM }\end{array}$ & $\begin{array}{l}\text { GEOTFERMAL ENERGY WILL BECOME AN IMPORTANT } \\
\text { SOURCE OF ENERGY IN THE UNITED STATES IF } \\
\text { TEE UTILITY COMPANIES BUY IT. A MANOR } \\
\text { OBSTACLE IN THEIR ACCEPTANCE OF THIS } \\
\text { RESOURCE IS THE UNCERTAINTY ABOUT THE } \\
\text { LENGTH OF TINE WHICH A GIVEN FIELD WILL } \\
\text { BE PRODUCTIVE. PARTICULARLY POWERFUL } \\
\text { INCENTIVES WOULD BE TO PROVIDE "RESOURCE } \\
\text { INSURANCE" AND "RELIABILITY INSURANCE", } \\
\text { THAT IS, INSURANCE AGAINST THE RISK OF } \\
\text { EARLY OEPLETION AND LACX OF CONTINUITY } \\
\text { OF SUPPLY. }\end{array}$ & $x$ & $\mathbf{x}$ & $x$ & \\
\hline $\begin{array}{l}\text { EFFECTS ON THE ELECTRIC UTILITIES-- } \\
\text { IMPACTS ON TRAMSMISSION }\end{array}$ & $\begin{array}{l}\text { GEOTHERMAL RESOURCES ARE OFTEN LOCATED } \\
\text { OUTSIDE OF A MAJOR UTILITY'S AREA AND A } \\
\text { LARGE DISTANCE FROM EXISTING LOAD CENTERS. } \\
\text { THE PATTERNS OF JOINT OWNERSHIP OF TRANS- } \\
\text { MISSION LINES HAVE TO BE ESTABLISHED. NEW } \\
\text { INSTI TUTIONAL PROBLEMS WILL ARISE IF GEO- } \\
\text { TEERMA ENERGY IS TRANSPORTED FROM WEST TO } \\
\text { EAST IN THE FORM OF ELECTRICITY OVER } \\
\text { TRANSCONTINENTAL LINES. THE ALTERVATIVE } \\
\text { INSTITUTIONAL FORMS INCLLDE: COOPERATIVE } \\
\text { ARRANGEMENTS AMONE UTILITIES, A FEOERAL } \\
\text { AGENCY, A PRIVATE VENTURE (ANALAGOUS TO } \\
\text { TEE GAS PIPELINE COMPANY, AND A QUASI- } \\
\text { PLBLIC ORGANIZATION MODELED AFTER THE } \\
\text { COMMNICATIONS SATELLITE CORPCRATION. }\end{array}$ & & & & $x$ \\
\hline
\end{tabular}

F1gure 1.4.2 (Cont.) 


\begin{tabular}{|c|c|c|c|c|c|}
\hline \multirow[b]{2}{*}{ ISSUE } & \multirow[b]{2}{*}{ DESCRIPTION } & \multicolumn{4}{|c|}{ DEVELOPMENT PHASE } \\
\hline & & 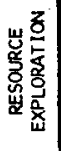 & 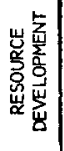 & 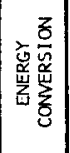 & 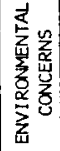 \\
\hline $\begin{array}{l}\text { EFFECTS ON THE ELECTRIC UTILITIES-- } \\
\text { DIVERSIFICATION }\end{array}$ & $\begin{array}{l}\text { IN SOME INSTANCES, UTILITIES MAY WISH TO } \\
\text { PARTICIPATE IN GEOTHERMAL DEVELOPMENT } \\
\text { THROUGH DIRECT INVESTMENT. IF THE UTILITY } \\
\text { IS CLASSED AS A UTILITY HOLDING CONPANY, } \\
\text { SEC REGULATIONS PROBABLY WOULD NOT PERMIT } \\
\text { THE COMPANY TO DEVELOP GEOTHERMAL RESOURCES } \\
\text { FOR SALE TO OTHERS. FURTHERMORE, THE. CASE } \\
\text { IS CERTAIN TO ARISE IN WHICH A GEOTHERMAL } \\
\text { DEVELOPER WISHED TO UT ILIZE THE RESOURCE } \\
\text { FOR THE GENERATION OF ELECTRICITY RATHER } \\
\text { THAN SELLING STEAM. THESE SITUATIONS } \\
\text { WILL CHALENGE THE EXISTING REGULATING } \\
\text { STRUCTURE. }\end{array}$ & $x$ & $x$ & $x$ & \\
\hline $\begin{array}{l}\text { EFFECTS ON GOVERNAENT--PENDING } \\
\text { LEGISLATION }\end{array}$ & $\begin{array}{l}\text { THERE ARE A NUMBER OF LEGISLATIVE PROPOSALS } \\
\text { PENDING WHICH WILL HAVE IMPACT ON GEOTHERMAL. } \\
\text { ENERGY DEVELOPMENT. THESE IMPACTS INCLUDE, } \\
\text { MOST PROMINENTLY, THE ESTABLISHMENT OF A } \\
\text { NATIONAL PROGRAM FOR RESEARCH, DEVELOPMENT, } \\
\text { AND DEMONSTRATION IN FUELS AND ENERGY. }\end{array}$ & $x$ & $x$ & $x$ & $x$ \\
\hline $\begin{array}{l}\text { EFFECTS ON GOVERUMENT--R \& D } \\
\text { PLANIING }\end{array}$ & $\begin{array}{l}\text { SHOULD A CENTRAL FEDERAL AGENCY BE } \\
\text { ESTABLISHED FOR ENERGY RESEARCH AND } \\
\text { PLANNING, THE CURRENT FEDERAL INTER-AGENCY } \\
\text { PANEL RESPONSIBLE FOR GEOTHERMAL R \& D } \\
\text { WOULD UNDOUBTEDLY BE REPLACED. THE PERIOD } \\
\text { OF TRANSITION COULD INVOLVE UNNECESSARY } \\
\text { DELAYS. }\end{array}$ & $x$ & $x$ & $x$ & $x$ \\
\hline EFFECTS ON FINANCIAL INSTITUTIONS. & $\begin{array}{l}\text { LOAN GUARANTEES BY THE FEDERAL GOVERNMENT } \\
\text { WILL ENCOURAGE CAPITAL INVESTMENT IN } \\
\text { GEOTHERMAL DEVELOPMENT. }\end{array}$ & $x$ & $x$ & $x$ & $x$ \\
\hline
\end{tabular}

Figure 1.4.2 (Cont.) 
$1200 \mathrm{MWe}$. In total, these savings amount to about 15 percent of the country's coal and nuclear generation capacity by the end of the century; thus, while geothermal development has an important effect on these generating sources, it is by no means pre-emptory.

These shifts in fuel mix are likely to bring a number of secondary impacts, such as reduction in the number of nuclear and coal-fired generation sites, reduction In the amount of radioactive material to be stored, reduced need. for mining of coal for use in electrical generation, and so on.

2. Two busines's sectors w111 be stimulated by geothermal development (Section 4.2). These are businesses involved in the exploitation of geothermal energy and businesses which can uniquely utilize geothermal resources.

- The total investment in geothermal development (materials, land, equipment, and so on) could be on the order of $\$ 95$ bilition by the year 2000 .

- The businesses affected by the advent of geothermal energy will be largely those which can utilize geothermal heat directly.

While the following applications are interesting, they are not likely to be of great economic importance. These applications include:

(a) Agriculture (e.g., utilizing geothermal heat for soil warming, hothouse heating, treatment of animal wastes, drying, soil sterilization, and so on).

(b) Process heat for certa1n classes of manufacturing (e.g., paper production, lumber drying, and so on).

(c) Desalination, in which geothermal heat serves as an energy source for distillation.

A business which utilizes low grade geothermal heat is, in effect, utilizing hot water. Hot water can come from many other sources (e.g., power plant effluent); thus, development of a technology which permits the use of waste heat is directly applicable to geothermal fluids. Businesses which utilize geothermal electricity could, as we11, utflize electricity from other sources; one kllowatt is indistinguishable from another. The effect on such businesses will be only that realized as the result of increased avallability of electricity.

A major consequence of direct use of geothermal heat will be to bring certain Industrial plants near the source of geothermal heat. Flowing from this impact will be a host of higher order impacts assoclated with land use, demographic shifts, regional economics, and so on. Since the extent of geothermal resources is not yet clearly known, and since it is apparent that the first major use of geothermal energy will be for the production of electricity, it is difficult to project the intensity of these impacts; however, the effect of these impacts probably will not be large when viewed on a national scale. From the standpoint of the affected localities, however, impacts could be similar to those associated with mild industrialization and therefore could be vlewed by various interest groups as being benefictal or detrimental as a result of changing land use patterns, Increasing population density, creation of the need for new public services, increasing the tax base, increasing the number of jobs, and so on.
3. Macroeconomfc and socfetal factors will be affected (Section 4.3), It seems certain that the demand for electrictty will increase; development of geothermal energy provides a way of helping to meet that demand. However, since geothermal sources may furnish about 10 percent of the total demand for electricity by the end of the century, the effect of its price "dilution" wi11 be small.

Most of the specific societal impacts flowing from the development of geothermal energy w111 evolve from significant characteristics: the small size of ptimum installations and the location of the resources which, in most cases, are In outlying areas.

Federal royalty income from geothermal development could amount to $\$ 1$ billion per year by 2000 , and local governments could realize about $\$ 475$ million per year from local taxes by 2000 . These sums are helpful but not overwhelming; for comparison, federal tax revenues in 1971 were $\$ 137$ b1111on and local tax revenues, $\$ 43$ billion.

4. The development of geothermal energy will encourage the development of a national electrical grid

(Section 4.4). Using preliminary estimates of the cost of constructing and operating a transcontinental high voltage DC transmission line, electricity derived from geothermal sources in the West can probably be supplied to the Mid-West and eastern portion of the United States at a cost of about 25 mills (1973 dollars) per kWh in 2000. Based on considerations of reliability, continued supply, diversity, and capital requirements, it is plausible to expect mid-western and eastern utility companies to purchase on the order of 56,000 we (out of a demand of 1.6 million MWe in the East) of geothermally-generated electriclty from western sources by the year 2000 .

Transportation of electrical energy from west to east could take advantage of intercontinental lines which may be in place in support of coal minemouth generation plants. The important secondary impacts flowing from this development include increased R\&D development in the flelds of high efflctency, high capacity transmission lines, and esthetic effects which seem likely to arouse conflict. Cost considerations seem to preclude placing transmission lined underground; however, the use of hydrogen produced from electrolysis of geothermal electricity may be an economic alternative to high voltage DC transmission.

5. Institutional arrangements w11l be affected (Section 4.5$)$. It is essential that certain institutional arrangements change if the development of geothermal energy is to be accelerated. Currently, federal, state, and local regulations, particularly environmental regulations, overlap and cause delays.

At the federal level, research and development and programatic planning is being accomplished by an Interagency Panel for Geothermal Energy Research composed of the National Sclence Foundation, the Department of the Interfor, the Department of Defense, and the Atomic Energy Commission. As the geothermal program develops, these groups may have some divergent and conflicting interests; the implementation of an energy $R \& D$ agency (ERDA) will also make this panel obsolete.

The geothermal law, as presently constituted, encourages the participation of large companies and discourages small companies. For this reason a significant inst1tutional impact is expected to be the Increasing particlpation in geothermal development of major petroleum companies. 
Arrangements developed in the past for selling other forms of energy may not be adaptable to this form and Indeed may hinder its development. As the system is presently constituted, utility companies are the only major buyers of geothermal energy.

6. Geothermal development will affect regtons, citles, and buildings (Section 4.6). The impacts on reglons and cities stem from Industrialization resulting from the development of the geothermal resource itself and from the potential influx of businesses which support geothermal development and which can utilize the heat and mineral content of the geothermal flulds. At the secondary level this results in changing population levels, population density, and land use patterns. However, these changes also bring an increased tax base, a potentially cleaner environment, and increased employment. Cittes near geothermal resources will have the opportunity to develop district heating and cooking; Rekjavik, Iceland, which now supplies almost all of Its residents with inexpensive geothermal heat, can serve as an example. District cooling systems have not yet been attempted anywhere in the world, but cooling of a tourlst hotel in New Zealand using geothermal heat as an energy source establishes the feas1bility of such an approach, at least on a small scale.

7. Geothermal energy will affect international relations (Section 4.7). At least 70 countrles have geothermal potential. Some of these countries have already developed a portion of their geothermal resources; others have not. Development of geothermal technology in the Untted States will not only create the opportunity for technological ald, particularly to countries with relatively low GNP per capita, but it w111 lead to the creation of new markets throughout the world. Technological ald and geothermal markets can be expected to develop as early as the late $1970^{\prime} \mathrm{s}$. When forelgn countries develop indigenous geothermal resources, their demand for imported fuel will diminish. Simllarly, as the United States develops geothermal energy, fuels which might have been used for the generation of electriclty can be put to other uses (or not mined or Imported at al1). The impact is significant: Geothermal energy could "free up" enough coal for export to bring into the United States a total of between $\$ 13$ and $\$ 20$ billion (cumulative) by the year 2000 .

8. Geothermal energy will have certain environmental Impacts (Section 4.8). Environmental impacts can be classed Into two general categorles: those of. local or short-term importance, and those of regional' lasting aignificance. In the former category fall local nolse, gaseous emissions, and blowouts. These impacts: have some danger associated with them and will undoubtedly be offensive to nearby residents. Good engineering. practice can reduce these impacts. Regulations should clearly Impose penalties for not adhering to $: 8 u c h+8 t a t e-$ of-the-art practices.

There are three important potentially 1rreversible environmental impacts: contamination of groundwater, selsmicity, and subsidence. The extent of these environmental impacts is not known today except by inference from activities similar to geothermal explottation currently being puraued in the petroleum and gas industry. There such problems have proved manageable; in the case of geothermal energy, they will probably respond to research and development and a growing body of geophysical knowledge.

\section{Impact on Interest Groups}

Detailed assessment of selected potential impacts indicates that the Interest groups in soclety most likely to support geothermal development because of the benefits it provides are the financial community, the U.S. Government, businesses that supply the geothermal. Industry, the geothermal industry 1tself, and the new research communitylinvolved in geothermal research. The groups 1ikeiy to react to the threats of geothermal energy are environmentalists, the Environmental Protection Agency, groups of homeowners near geothermal installations, and the utility companies affected by the transcontinental grid. The policles likely to be viewed most desirable (that 1s, policles which increase the perceived positive consequences, minimize the perceived detriments, and promote agreement among the groups involved) are those which address the environmental implications of the use of the resource and help to resolve potential land use conflicts (Section 5).

\section{Pollcy Recommendations}

Policy 18 defined as "a definite course of action adopted for the sake of expediency, facllity, etc.; prudence, practical wisdom....". This definttion brings several questions immediately to mind: How can the best definitive courses of action be identified from among the myriad alternatives? By what dimensions can a course of action be defined? Policies which appear "prudent" to one group may appear reckless to another: How can such value questions be handled?

Because of such basic philosophical 1ssues, it is inportant to define the frame of reference to be used.

In the discussion which follows,

- Recommended policles are those which, on the bas1s of analyses conducted by The Futures Group or, where necessary, judgments seem the "best" answer to issues 1dentified during the study.

- The dimensions involved in defining a recommended policy are:

What is to be done?

By whom is $1 \mathrm{t}$ to be done: What level of government, the private sector, citizen groups?

When would $1 \mathrm{t}$ be best to do $1 \mathrm{t}$ ?

Why is it being done?

What Is it 1ikely to -cost?

What are the consequences of not dolng 1 t?

- The value orientation to be employed in the use of the term. "best"." or "prudent" w111, for the most part, be that of a national: planner seeking to ensure and Improve the economic conditions and quality of life of people in the country. - Where conflict exists between these dual objectives, or when conflict exists between the national orientation and the orientation of specific groups within the country, this will be identifled if at all possible.

The key polfcy 1ssue is whether or not the development of geothermal energy should be encouraged in the United 
States. On the basis of this research, we belfeve it will be useful and important to the United States to encourage the expeditious development of indigenous geothermal resources; not only for. the generation of electricity. but to explo1t the heat, and possibly the water anc mineral potential of the resource, as well. We expect that development of geothermal resources could, under prodent polfcies, provide about 10 percent of the cointry's total generation capacity by the end of the century.

The aggregate expenditures for geothermal power through the remainder of the century, including capital, operating costs, taxes, and royalties, are likely to be on the order of $\$ 95$ bilition; if the amount of electricity ant1cipated from geothermal sources were to be generated by petroleum, cumulative expenditures for fuel alone would amount to at least $\$ 100$ billion by 2000 , assuming an average cost of oil of $\$ 10 / \mathrm{bbl}$.

If the coal which geothermal energy can reolace is exported, it will improve the import-export balance by a total of more than $\$ 13$ billion over the next two and a half decades; diminish by 100-150 the number of new 1000 MWe nuclear reactors required; diminish by $90-120$ the number of new 1000 MWe coal-fired generators required; and provide new opportunities for international cooperation leading toward economic improvement of certain developing nations. These benef1ts will not be achieved without cost or conscientious effort. There are important uncertainties still connected with this resource fncluding, most partfcular1y; 1dentifying the extent of the resource and the length of time over which particular Installations could operate; solving the remaining problems of scaling when utilizing. high salinity twophase geothermal fluids; and handling potential environmental effects such as the potential for subsidence and seismic effects in some instances, and the possibility of groundwater contamination which could result from improper operations. Land use issues will also be vexatlous. Incentives wili be necessary to encourage ut1lity companies to buy geothermal energy. before field longevity is accurately known. Pilot plants will be required to help resolve some of these technical uncertainties as well as to develop operating experience. Government R\&D programs must be introduced to help resolve these uncertainties. Certain crucial defects in federal regulations must be corrected if the development is to be encouraged in favorable directions.

We belleve, further, that after a period of federal involvement in the development phase and after the necessary regulatory changes are accomplished, the development and use of the resource is 1tkely to prove attractive enough economically to private. Investors so that normal market mechanisms will bring geothermal energy into prominence.

Recomended policies are discussed in the remainder of this section. These policies are divided into the following mafor categories:

- Those which stimulate exploration and development.

- Those which provide incentives to potential users of the resource.

- Those which will lead to the required technological developments.

Figure 1.4.3 summarizes the recommended policies. $\frac{\text { Policies Which Stimulate Exploration }}{\text { and Development }}$

Legal Classification of the Resource

The appropriate legal classification of geothermal resources for some purposes is as yet unclear: Are these resources minerals, water, or should they be considered sui generis (i.e., a new area of law)?

Geothermal resources are encumbered by legislation developed for other purposes. The lack of clear definition particularly impedes geothermal development by perpetuating uncertainty of treatment under income tax and public land laws. Investors do not have any assurance that they will be entitled to tax incentives similar to those provided for the 011 and gas industry. These incentives currently include depletion allowances and deduction of intangible drilling costs. There is uncertainty as to the effect of mineral reservation in past federal deeds and land grants.

We believe that it is appropriate to consider geothermal energy as sui generis and therefore to define a body of law appropriate to this field. In particular, consideration should be given to stimulating exploration and development since the analytic work of this study has tended to show that reducing the uncertainty about the level of identified resource will be an important stimulant to the overall development of geothermal resources. It is recommended that a spectal subcommittee of the American Bar Assoclation be formed, in confunction with approprlate congressional representatives, within the next year, to review the current legal issues associated with geothermal energy and to make recommendations to Congress for appropriate legislation.

\section{Land Availability}

Are current provisions of the federal geothermal statute with respect to the avallability of federal lands for leasing apt to encourage geothermal development?

There are two 1mportant restrictions in the law which limit the avallability of federal land for leasing. One provision removes federal lands used for a variety of other purposes from the leasing process. The other limits the acreage which any one developer can hold in a single state. Taken together, these provisions have the effect of (a) removing large biocks of the federal domain from geothermal development and (b) discouraging the formation of large-scale concerns which could economically exploit the geothermal resources.

At present, given the state of knowledge about the location, exploitation, and practicality of using geothermal energy, it is probably unwise to open up more land to geothermal development than is presently planned. However, as the program progresses, Congress should reconstder some of the restrictions it has placed upon use of the public domain. Similarly, it Is not clear whether the acreage limitations in the geothermal statute are too large or too small. Since the thrust of the rest of the statute is to encourage competitive bonus bidding and perhaps thereby encourage large firms to dominate the geothermal development Industry, the acreage limitation may not be sensible. It may be that for energy development purposes it would 


\begin{tabular}{|c|c|c|}
\hline POLICY AREA & RECOMPEDEC POLICY & RESPONSIBLE ACENCY \\
\hline $\begin{array}{l}\text { 1. STIMULATION OF EXPLORATION } \\
\text { AO DEVELPMENT-CLASSIFICATION } \\
\text { OF RESOLCE }\end{array}$ & $\begin{array}{l}\text { CONSIDER GEOTHERMAL AS SUI } \\
\text { GENENIS (A NEW AREA OF LAW'). }\end{array}$ & $\begin{array}{l}\text { CONGPESS ANO AMERICAN } \\
\text { BAR ASSOCIATION }\end{array}$ \\
\hline $\begin{array}{l}\text { 2. STIMULATION OF EXPLORATION } \\
\text { AND DEVELOPVENT--LAND } \\
\text { AVAILABILITY }\end{array}$ & $\begin{array}{l}\text { RECONSIDER RESTRICTIONS ON } \\
\text { USE OF PULLIC DCMAIN AND ON } \\
\text { ACREAGE LIMITS. }\end{array}$ & CONGRESS \\
\hline $\begin{array}{l}\text { 3. STIMELATION OF EXPLORATION } \\
\text { ANO DEVELOPMENT--LAND TEWIRE }\end{array}$ & $\begin{array}{l}\text { MODIFY LAW TO ELIMINATE } \\
\text { WNREASONABLE ARBITRARY } \\
\text { GOVERNWENT ACTION AND TO } \\
\text { INTROOUCE LEASE NEGOT IATION } \\
\text { PROCEDURES, POSSIBLY RE- } \\
\text { QUIRING ARBI TRATION. }\end{array}$ & COnGeress \\
\hline $\begin{array}{l}\text { 4. STIMMLATION OF EXPLORATION } \\
\text { AND DEVELOPMENT-BIDOING } \\
\text { SYSTEM ON KGRA }\end{array}$ & $\begin{array}{l}\text { A. DETERMINE WETKER IT IS IN } \\
\text { TEE NAT IONAL INTEREST FOR } \\
\text { LREE COPANANIES TO DOMINATE } \\
\text { GEOTHERML DEVELOPRENT. } \\
\text { B. CONSIDER A ROYALT BIDOING } \\
\text { SYSTEM FOR ENCORAGING THE } \\
\text { SMALLER ENTREPRENELR. }\end{array}$ & $\begin{array}{l}\text { CONERESS } \\
\text { CONGRESS }\end{array}$ \\
\hline $\begin{array}{l}\text { 3. STIMLATION OF EXPLORATION } \\
\text { ANO DEVELOPIENT--PROTECTION } \\
\text { OF EXPLORERS AND PROSPECTORS }\end{array}$ & $\begin{array}{l}\text { AMEND STATUTES TO PROTECT RIGHTS } \\
\text { OF EXPLORERS ON NON-KCRA LANDS. }\end{array}$ & CONCRESS \\
\hline $\begin{array}{l}\text { 6. STIMLLATION OF EXPLORATION } \\
\text { MO DEVELOPMENT-ADMINISTRATIVE } \\
\text { COPLEXITY }\end{array}$ & 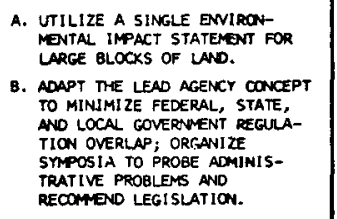 & $\begin{array}{l}\text { CONERESS } \\
\text { FEDERAL, STATE, ANO LOCAL } \\
\text { AGENCIES; NSF; AND EPA }\end{array}$ \\
\hline $\begin{array}{l}\text { 7. STIMLLATION OF EXPLORATION } \\
\text { AO DEVLOPMENT--CAPITAL } \\
\text { AVAILABILITY }\end{array}$ & $\begin{array}{l}\text { MONITOR CAPITAL AVAILABILITY; } \\
\text { IF LIMI TED, STRENGTIEN LOAN, } \\
\text { GLARANTEES ANO INI TIATE OTHER } \\
\text { INCENTIVES. }\end{array}$ & FEA, CONGRESS \\
\hline $\begin{array}{l}\text { 8. INCENTIVES TO RESOLRCE USERS-- } \\
\text { PURCHASE OF GEOTHERAL STEAM; } \\
\text { INPROVENENT IN RELIABILITY }\end{array}$ & 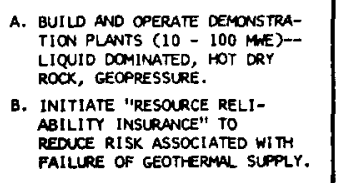 & $\begin{array}{l}\text { NSF, AEC } \\
\text { OONGRESS }\end{array}$ \\
\hline $\begin{array}{l}\text { 9. INCENTIVE TO RESOARCE USERS-- } \\
\text { ASSURING LONGEVITY }\end{array}$ & $\begin{array}{l}\text { INITIATE "RESOURCE LONGEVITY } \\
\text { INSURANCE" TO MINIMIZE RISK } \\
\text { OF EARLY FIEL DEPLETION. }\end{array}$ & Concress \\
\hline $\begin{array}{l}\text { 10. RESEARCH AND OEVELOPNENT-- } \\
\text { CEVERAL CONS IDERATIONS }\end{array}$ & 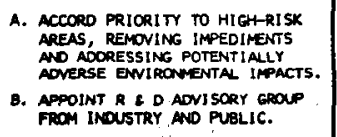 & $\begin{array}{l}\text { NSF, AEC, DOt } \\
\text { NSF }\end{array}$ \\
\hline 11. RESEARCH AD DEVELOPYENT- & 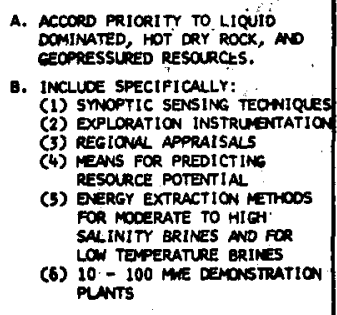 & . \\
\hline $\begin{array}{l}\text { 12. RESEARCH ANO DEVELOPMENT- } \\
\text { DATA BANK }\end{array}$ & 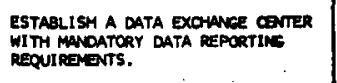 & uses \\
\hline $\begin{array}{l}\text { 13. RESEARCH AND DEVELOPAENT- } \\
\text { GNIBOHENTAL CONCERNS }\end{array}$ & 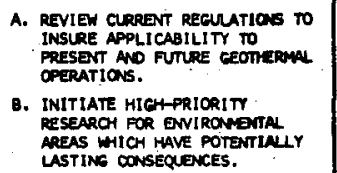 & $\int_{\text {NSF }}^{\text {EPA }}$ \\
\hline
\end{tabular}

FIgure 1.4.3. Summary of Recommended Pollcies 
be better to encourage a much larger scale of development by fewer firms and attempt to deal with a monopoly situation created thereby to regulation. Again, congress has made a consclous pollcy of attempting to encourage some competition in the geothermal industry. It is too early to tell whether this is the correct decision or not.

\section{Tenure}

Are provisions in the federal geothermal statute relating to security of tenure adequate?

Geothermal development, especially if it is to be devoted to the generation of electric power, requires that the developer and producer of geothermal energy have enough security of tenure to be willing to make long-term investments. Electric generating companies, for example, normally require at least 20 to 30 years of active production before they w111 commit themselves to the construction of power plants. Against the required security for the developer one must welgh the need to keep geothermal land in production and out of the hands of speculators. It is not yet possible to tell whether the lease renewal and renegotiation periods spectfied in the law are long enough to give the geothermal developer the kind of security he will require to develop the resources. Several of the state laws are, however, somewhat more generous in this regard than is the federal law.

Of particular concern is the power of the Secretary of the Interior to renegotiate lease terms and conditions after a 35-year interval. If the geothermal developer refuses to accept the Department of the Interior's offered renegotiated condition, then the Department of the Intertor may terminate the lease. This, in essence, gives the Department of the Interior the right to terminate the lease since 1t may 1mpose such conditions on the developer that he cannot reasonably agree to.

The law and regulations in this regard should be modifled to make clear that the geothermal developer or producer w1ll not lose his lease if the Department of the Interior at tempts to 1mpose unreasonable conditions upon him. Provision for forced arbitration may be required in the statute. This will at least offer the geothermal producer or developer protection against arbitrary administrative action. On the other hand, it would seem reasonable that there should be some right to renegotiate lease terms and conditions as well as rents and royalties, since, over a 35-year period, there may well be considerable changes in both the energy situation, the economic situation, and attitudes with respect to use of pub1ic lands which would require that the United States reconsider its position. It should not be possible, however, to have terms and conditions change without adequate justification and due process.

\section{The Bldding System}

Is the bidding system now in effect for geothermal lands appropriate?

The federal thrust toward competitive bonus bidding gives firms with access to relatively large amounts of capital an advantage. The results may be betterfinanced development by firms with more ski11s and better equipment but perhaps less aggressive exploration if large companies begin to dominate géothermal resource development process. In an era in which the largest firms are beginning to dominate many phases of energy extraction and production, it may not be desirable to add geothermal energy to the list of resources they control. Firms which are engaged in the development of many energy sources may tend to concentrate on developments which are the most profitable at the moment. If geothermal energy is not in the optimum mix, it may not be developed as rapidly or as completely as one would desire.

To encourage the small entrepreneur, it would be necessary to move toward non-competitive leasing of lands and to eliminate the bonus-bidding system with respect to competitive lands. Appropriate amendment to the definftion of KGRA would be to follow the state statutes by defining a KGRA in purely physical terms and eliminating the "competitive interest" provision. As an alternative to the bonus-bidding system, some kind of varlable royalty bidding system might be considered. That firm which offered the highest royalty combined with an adequate work plan might be awarded the geothermal lease without the necessity of depositing the cash bonus in advance. The funds that might otherwise be tied up in the cash bonus would be aval1able for geothermal development. In the short run, this policy may contradict the Department of the Interior's established goal of obtalning the largest inmediate cash resources in exchange for public land; In the longer run, a higher variable royalty without a bonus-bidding might produce greater revenues for the United States.

Furthermore, the notion that monies collected through leasing and royalties should flow to general revenues may be obsolete; in this instance it may be more approprlate to use these funds for geothermal research, indemification, data collection, etc., at least until the Industry is firmly in place.

\section{Protection of Explorers and Prospectors}

How can the protection given to geothermal explorers or prospectors be made more adequate?

Under federal law the explorer or developer who does not first acquire a geothermal lease is not protected. If other persons file applications for the same land, then, according to the Department of the Interfor policy, the land will be classified as a KGRA and therefore it w111 become subject to competitive bidding. State law does, in some instances, offer the prospector more protection. Since the explorer is not protected under federal law, 1t will be incumbent upon all persons who wish to protect thelr rights to first secure a lease to lands which they wish to explore. This will require an inftial investment in a non-competitive geothermal lease with a risk that at any time during the lease application process the land could be declared a KGRA and therefore subject to competitive bidding.

The study team recommends that consideration be given to amending the federal geothermal statute so as to provide explicit protection for prospectors or "wildcatters" working on non-RGRA lands.

\section{Administrative Complexity}

How can the current overlap of regulatory jurisdictions among varlous levels of government which control geothermal resources be eliminated without sacrificing important values?

Federal, state, and local governments have not yet sorted out their respective responsibllities with 
respect to geothermal development. Estimates are that in California it may take up to one year to obtain necessary pproval before geothermal land can be developed. Not only is the processing time long, but the cost is high. The developer and the regulatory agency are both faced with the necessity of preparing environmental impact statements for federal and state governments if federal lands are involved and also complying with a variety of state and local regulatory requirements with respect to air and water quality and land use.

Since each leasing operation has been determined to be a major action requiring an environmental impact statement or environmental report, the process of preparing such statements or reports is repeated over and over again as the geothermal leasing process progresses. A provision should be made for a single environmental impact statement to cover large blocks of land, requiring only that each developer report to the regulatory agency concerning any additional impact on the environment that his developmental activities will create. In the long run the goal should be "one-step" administrative clearance. Ideally, the agencies which are responsible for regulating various aspects of environmental control and geothermal development on federal, state, and private lands should agree that one agency w111 be the lead and that lead agency will be responsible for ensuring that the proposed geothermal developer or explorer complies with all applicable regulations of all agencies. This process will be difficult and will probably involve federal legislation eventually. The process might be started, however, through a serles of symposia involving affected governmental agencles. These symposia could be organized by NSF or EPA.

Is adequate capital available for geothermal development?

Probably not, as things stand, because geothermal development is viewed as high rlsk, and in general, has a long time to pay off. Federal loan guarantees which are included in recent legislation; however, should ease this situation considerably. Furthermore, as geothermal development accelerates, its potential to attract capital will improve. We recommend that cap1tal avallability be monltored continuously and should capital avallability be 1 imiting, loan guarantees should be strengthened and other incentives such as direct subsidies to explorers and developers should be considered. [2]

Pollcles Which Provide Incentives to Potential Users of the Resource

Why should a utillty company choose to purchase geom thermal steam as an energy input?

There are likely to be two primary concerns on the part of the utility companies when they face the dectsion about whether or not to buy geothermal steam. These are reliability and longevity of the supply. Without assurance thet the supply is reliable and that it will last at least over a 20-30-year time perlod, ut1litles w11 look elsewhere for primary energy inputs. Since the ut1lity company is the primary customer for geothermal. steam, these concerns must be taken very serlously.

Confidence In operational rellability can be Improved through the use of demonstration plants. Denonstration plants operating at a level of about 10-100 MWe, using high salinity 11quid-dominated resources, hot dry rock resources, and geopressured resources, seem to be quite appropriate. These plants would provide test beds for new technology as well as rellability demonstration vehicles.
In addition, the government should consider "resource reliability insurance" which would compensate utility companies for extra losses incurred as a result of their decision to utilize geothermal resources, in the event of fallure of geothermal supply.

With respect to longevity, it is 1mpractical to plan on demonstration plants which illustrate the length of time that a 'field will be productive. Rather, scientific research programs which include the development of geophysical models and data collection systems to enable the prediction of field lifetime and maximum heat extraction rates should be supported

Furthermore, the government should initiate "resource longevity insurance" which would help minimize the risk to utility companies which choose to buy geothermal steam as a primary energy source. This insurance could take the form of expedited depreclation in the event of resource depletion, reimbursement of additional expenses incurred as a result of early field depletion, or other similar mechanisms.

\section{Pollcies Which W11l Lead to the Required Technological Developments}

Government vs. Private Technologlcal Development

Should the government intervene in the process by which geothermal technologles are developed?

Government pollcies could range from laissez falre (as in the case of innnovation in the petroleum industry) to complete government development of new geothermal technology (as in the case of the early nuclear Industry).

Although the study team belleves that geothermal energy w1ll become economlcally attractive and selfsupporting, government intervention in several technological areas seems warranted. Three specific areas are:

- Technologies which are pivotal to further development.

- Technologies which, If avallable, would remove currently discernible impediments.

- Technologies.required to remove potentially adverse environmental impacts.

Priority for government development in such technological areas should be increased if the technology under consideration is intrinsically high risk, but in the national interest because of long-term and Indirect desirable national effects.

As In other areas of goverment-sponsored research, there are two dangers which should be consldered: FIrst, government-sponsored research may cause private f1rms to avold engaging in similar research because of concern about thelr ability to compete with the government. Second, potential users of the research may olmply walt unt1l government programs are complete before Initlating programs. which could have utilized somewhat more primftive technology--thus producing a slower growth than might have otherwlse been the case.

Private Industry performs research because of the promise of a competitive advantage and economic return which it brings. If the government research program removed this promise, then the government would find itself performing almost all of the required R\&D. 
Clearly, the government has a battery of tools ava11able to stimulate geothermal research in the private 3ector; these tools include expedited write-off of R\&D, contracts which do not require public disclosure of proprietary Information, patent protection, and so on.

Because of the need for government sponsorship of high risk technological research and the programatic pitfalls which might accompany 111-chosen research agendas, the study team concurs with the present government intention to form an advisory group composed of representatives from electric utilities (perhaps through the Electric Power Research Inst1tute), the resource extraction industry, the supply and services industry, agriculture, mining, financial Institutions, state and local governments, and regulatory agencles. This group should have the authority to help formulate and review the government's research agenda. The group will bring to government research planning an industry and operational orientation which might otherwise be absent; such an orlentation is necessary to ensure a rapld and efficlent transfer of government developed technology to the user. While the study team does not belleve it is necessary to provide this group w1 th veto power, they should be able to publish reports of their findings which might be useful in governmental planning and budgetary processes.

\section{The Research Agenda}

Specifically, what pivotal technologies and technological impediments should form the focus of the government's research and development program?

The cholces are quite broad: The research agenda might concentrate on a single resource type, or could cover high r1sk issues in all resources simultaneously. Fur thermore, the range of possible targets within the domain of each resource 1s very large. We bellieve a phased program should be established which concentrates Intitially on the parallel development of energy extraction methods and conversion processes for moderate to high salinity brines and for low temperature brines, and which would lead to the identification of the extent, distribution, and quality of geothermal resources in the United States as soon as possible. Most geothermal sites throughout the world are of 1iquiddominated type; perhaps as many as twenty times as many 11quid-dominated sites exist as vapor-dominated sites.

The potential of hot dry rock and geopressured resources is also extremely large. Therefore, research prlority should also be accorded these resource types. While magma resources are also. likely to be very large, environmental and technical problems suggest that research priority should be placed elsewhere. (Note that magma applications in Hawal1 may be a spectal case.)

More spectfically, the research agenda should probably Include:

- Development of synoptic remote sensing techniques.

- Development of geochenical, geological, geophysical instrumentation for the identification of geothermal resources.

- A systematic and well planned serles of regional appraisal designed to 1dentify the extent of geothermal resources in the western states, Including Hawal1 and Alaska, first, followed by the central and eastern states.

- Development of methods for predicting the energy potential of specific reservolrs, including, at lower priority, deep geothermal reservolrs.

- Development of energy extraction methods and energy conversion processes and equipment for moderate to high salinity brines and of low temperature brines. This work would involve solving problems of scalling of pipes and heat exchangers which contain geothermal flulds.

- Initlating a series of demonstration plants (10-100 MWe) for moderate to high salinity. IIquid-dominated resources; hot dry rock resources; and geopressured resources to develop and demonstrate new technology and to improve levels of confidence in the reliability of these energy sources.

The current federal program seems to be moving generally in these directions. However, whether a cohesive, efficlent, and fast moving program can be maintained by an Interagency panel (Section 4.5 ) remains to be seen.

\section{Information Data Bank}

Respondents in the technological interview endorsed the idea of establishing a geothermal data exchange center for the dissemination of existing and future resource and reservolr data obtained from both governmental and industrial programs. The concept of this data exchange center as an instrument for stimulating resource exploration and geothermal development was first proposed at the National Science Foundation seminar conducted under W. J. Hickel. [3] Such a data exchange center would have the following functions:

- Providing up-to-date information in the public domain about reservoli location and qual1ty.

- Collecting and publishing operation data, particulariy concerning field longevity, accidents, and environmental effects of geothermal operations.

- Acting as a repository for all environmental Impact statements and comments about the statements.

- Complling and making publicly avallable all detalled Information about the status of federal leases, including, for example, published bids, lessees, and the status of leased federal property.

- Publishing bulletins about new technologies avallable to meet specific problems and government research plans and results.

The data exchange center would serve two primary purposes: a focus of Information for public review and a reference center for professionals in the fleld. Having such information readily available, communtcations in the field would be Improved, the process of "reinventing the wheel" would be diminished, and the development process would be expedited. Many of the functions defined for the data exchange center are already being performed by the United States Geological Survey. It Is suggested that their role be expanded to include all of the elements listed above. [4]

\section{Environmental Technologies}

What research and development programs should the 
government initiate in order to minimize potential ad"erse environmental impacts of geothermal energy?

belleve that current environmental regulations, both at the federal and state level, should be reviewed with special attention to areas likely to be affected by geothermal operations, and extended where necessary. Specifically, selsmic effects, subsidence, and potential contamination of ground and surface water by geothermal fluids should be considered. In paralle1, the government should Initlate research programs tallored particularly to the various geothermal media to determine the potential for damage and means for exploring, developing, and operating with minimum damage. This program should be high priortty and should focus on the following objectives:

- Develop and demonstrate practical techniques for preventing ground and surface water contamination by geothermal fluids.

- Obtain an understanding of the cause/effect relationship between fluid infection into a rock formation and earthquake occurrences.

- Develop predictive, preventative, and corrective techniques for dealing with land subsidence consequent to geothermal fluld withdrawal.

In addition, this environmental research program should include certain other prfority objectives:

- Develop technology for effectively controlling potentially harmful or nuisance gaseous emissions such as hydrogen sulfide or ammonta.

- Develop practical effective techniques for notse control during geothermal drilling and plant operation.

- Reconclle design of surface geothermal power systems with preservation of local esthetic values.

- Develop a design safety code dealing with hazards to workers and to the public which is specific to the geothermal industry.

The successful accomplishment of these objectives may be key to the development of certain vapor- and 11quiddominated, hot dry rock, and geopressured resources in the Inited States. In addition, this environmental technology may be an important element of international technology transfer programs.

\section{REFERENCES}

[1] The estimates of the future geothermal generating capacity are sensitive to a number of assumptions about the extent of the resource, technological developments, and removal of socio-economic impediments, which are described in detail in later sections of this report.

[2] Following completion of this section of this report Congress, on September 3, 1974, adopted the Geothermal Energy Research, Development and Demonstration Act of 1974 (P.L. 93-410). The Act (reproduced in Append1x J) provides for guldance of geothermal R\&D by a Geothermal Energy Coordination and Management
Project composed of one presidential appointee and representatives of NSF, Department of Interior, NASA, $A E C$, and FEA. The project was assigned "overall responsibility for the provision of effective management and coordination with respect to a national geothermal energy research, developtent, and demonstration program" (P.L. 93-410, Section 101). The Project is also responsible for administering a loan guarantee and interest assistance program. The legislation directs that the Project be transferred to a permanent energy $R \& D$ agency when one is created.

The R\&D program is to be carried out through the constituent agencies with the Project acting as overall coordinator. Its elements include: comprehensive program definition of an integrated effort and comitment for effectively developing geothermal energy resources; resource inventory and assessment; technical and environmental research and development; information collection and dissemination; scientific and technical education; and pilot and demonstration projects.

A loan guarantee may cover up to 75 percent of the aggregate cost of any program for which it is made. Interest payments may be made by the federal guarantor if the borrower cannot do so and the project is worth continuing. Guarantees are limited to $\$ 25,000,000$ for a single project and $\$ 50,000,000$ for a single borrower. A Geothermal Resources Development Fund was created for carrying out the loan guarantee and interest assistance program.

[3] Hickel, W. J., Geothermal Energy--A National. Proposal for Geothermal Resource Research (Alaska: University of Alaska, 1972).

[4] P.L. 93-410 mandates an inventory of geotherma1 resources and publication of maps, etc. It also encourages development of state geothermal resources clearing houses. 
2.1 Geothermal Resources: Identification, Development, and Use

\section{Resource Exploration and Appratsal}

As mentioned in Section 1.2, geothermal sites have usually been Identified from obvious surface manifestations such as hot springs, fumaroles, mud pots, and geysers, or through accidental discoveries while exploring or drilling for other natural resources. Figure 2.1.1 on the following pages illustrates the location of KGRA's in the western United States. This approach is rapidly being replaced by more scientific prospecting methods and techniques for appraising the volumetric extent as well as the physical and thermodynamic properties of the reservoir. Development of these techniques has emanated from established disciplines such as geology, geochemistry, geophysics, and hydrology. A great amount of further research and development work, is needed in these areas as well as in drilling, well logging and testing, and modeling in order to simplify and speed up the process of exploration and appraisal. Since each prospective geothermal formation has unique characteristics which differ over a wide range, a number of different techniques are normally employed and the data obtained are correlated to form the final result. A logical progression of steps or phases has been recommended for exploration with each step being more sophisticated and/or expensive [1]. Such a progression might begin with a literature search for existing information and then progress to airborne surveys, geologic and hydrologic surveys, geochemical surveys, geophysical surveys, and finally to drilling.

The various techniques for exploring and appralsing geothermal sites are described below under the major categories involved:

Geological. Geological studies consist of fleld work, aerial surveys, and subsurface investigations. Field work involves mapping the rock types and their distribution as well as any thermal manifestations and performing petrological studies $[2,11]$. Structural maps and subsurface cross sections which identify the reservolr are prepared from structural and fracture analyses of the formation. Aerial surveys are made using visible light, infrared, and microwave photography. These are used for geological mapping, structural analysis, and topographic mapping. Cores or cuttings from wells are ldentifled as a function of depth and serve to refine the structural model developed from surface data.

Geochemical. In prospecting for geothermal flelds, geochemical analyses provide a guide to selecting specific drilling sites. They are used to determine the physical and thermodynamic properties of the reservolr flulds and the origins of these flulds $[1,3,4,5,6]$. Information on water drainage, storage and recharge is also obtained from geochemical techniques. To obtain this information, analyses are performed on solid, Ilquid, and gaseous samples obtained from surface manifestations during exploration and later from downhole and effluent samples obtained during the drilling phase. In analyzing the solids, rocks are age dated, bulk and trace elements are delineated, 1sotope studies are performed, and the mineralogical composition is determined. This Information 18 used in modeling the geology of the reservolr that is being evaluated. Analysis of liquids and gases includes 1sotopic studies which yleld information on the origin of the water and regional patterns of water circulation. An estimate of the reservoir temperature at depth can be obtalned from a determination of the constituents or ratios of constituents dissolved in the effluent. This technique of geochemical analysis has been termed geothermometry.

The chemical composition of $11 q u i d s$ and gases in the reservoir fluld is a major factor in determining appropriate uses for geothermal resources from a given reservoir and in designing the spectflc processes and equipment to be employed. For instance, the fluids may contain large amounts of dissolved solids that would precipitate and obstruct the flow when its thermodynamic state is altered, by such means as expansion or temperature decrease, during a particular process. On the other hand, it may be economically advantageous to recover these minerals. Equipment must be designed to handle non-condensable gases and methods for controling corrosion and erosion must be included. Solid, liquid, and gaseous waste materials must be disposed of in an environmentally appropriate manner. Geochemical analyses provide the basis for such evaluations.

Geophysical. Most geophysical methods measure varlous physical parameters at depth, such as temperature, electrical conductivity, the propogation velocity of elastlc waves, density, and magnetic susceptibility, primarily by Indirect means $[1,7,8]$. These methods may be used for prospecting, for selecting drilling sites, for mapping the geothermal reservolr, and for predicting the thermodynamic properties of the resource.

Heat flow measurements provide a direct means for predicting the reservolr temperature and for determining the three-dimensional extent of the reservolr. These measurements involve drilling, measuring the temperature gradient in the drill hole, and measuring the thermal conductivity of rock samples taken at various depths. Heat flow is the product of temperature gradient and thermal conductivity.

Electrical and electromagnetic reconnaissance techniques measure electrical conductfvity at depth. In interpreting the results of such surveys, care must be taken to include factors other than temperature, such as porosity, fluld salinity, and clay content, which also affect resistivity. The primary electrical method used to date has been DC resistivity. ThIs involves placing electrodes in contact with the ground in prescribed arrays, such as linear or dipole-dipole. Other electrical methods include self-polarization, Induced-polarization, and telluric. Electromagnet1c methods used to date Include a two-loop method (the EM gun), a longwre source with a loop detector, and an audiofrequency magneto-telluric system. Selomic surveys, both active and passive, are useful in locating faults and delimiting fractured and permeable zones. Active selsmic methods, both reflective and refractive, use explosives to produce elastic waves. Passive selsmic techniques involve recording elther naturally generated micro-earthquakes or acoustic nolse patterns within prescribed frequency ranges.

Thermal infrared surveys from atrcraft $[9,10]$ or satellites may be used to map surface temperature anomalles. However, care must be taken in 


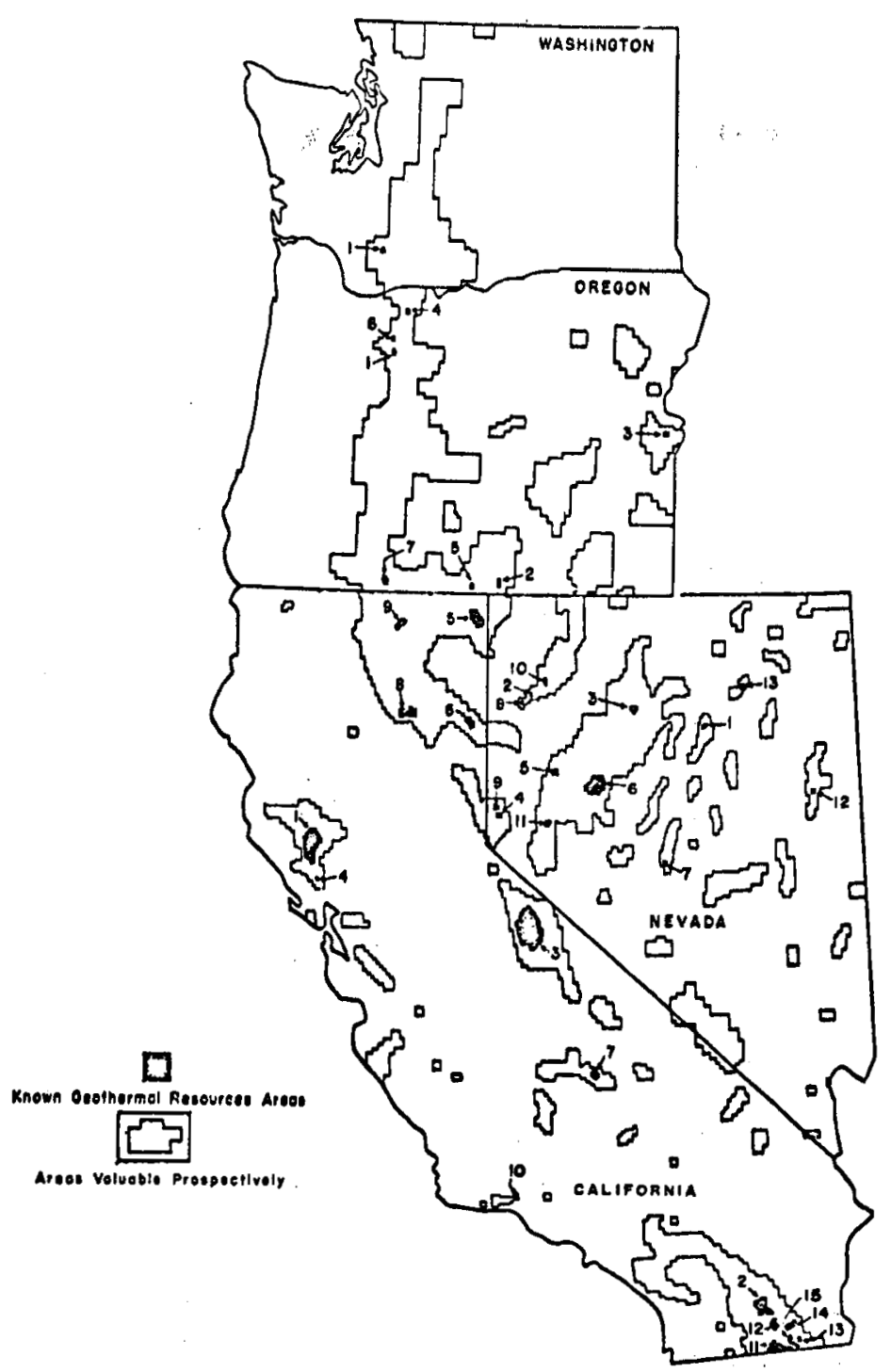

Source: U.S. Department of the Interior, Final Environmental Statement for the Geothermal Leasing Program, 1973 (Hereafter called FInal Environmental Statement, 1973)

Figure 2.1.1 KNOWN GEOTHERMAL RESOURCE AREAS IN THE WESTERN UNITED STATES 


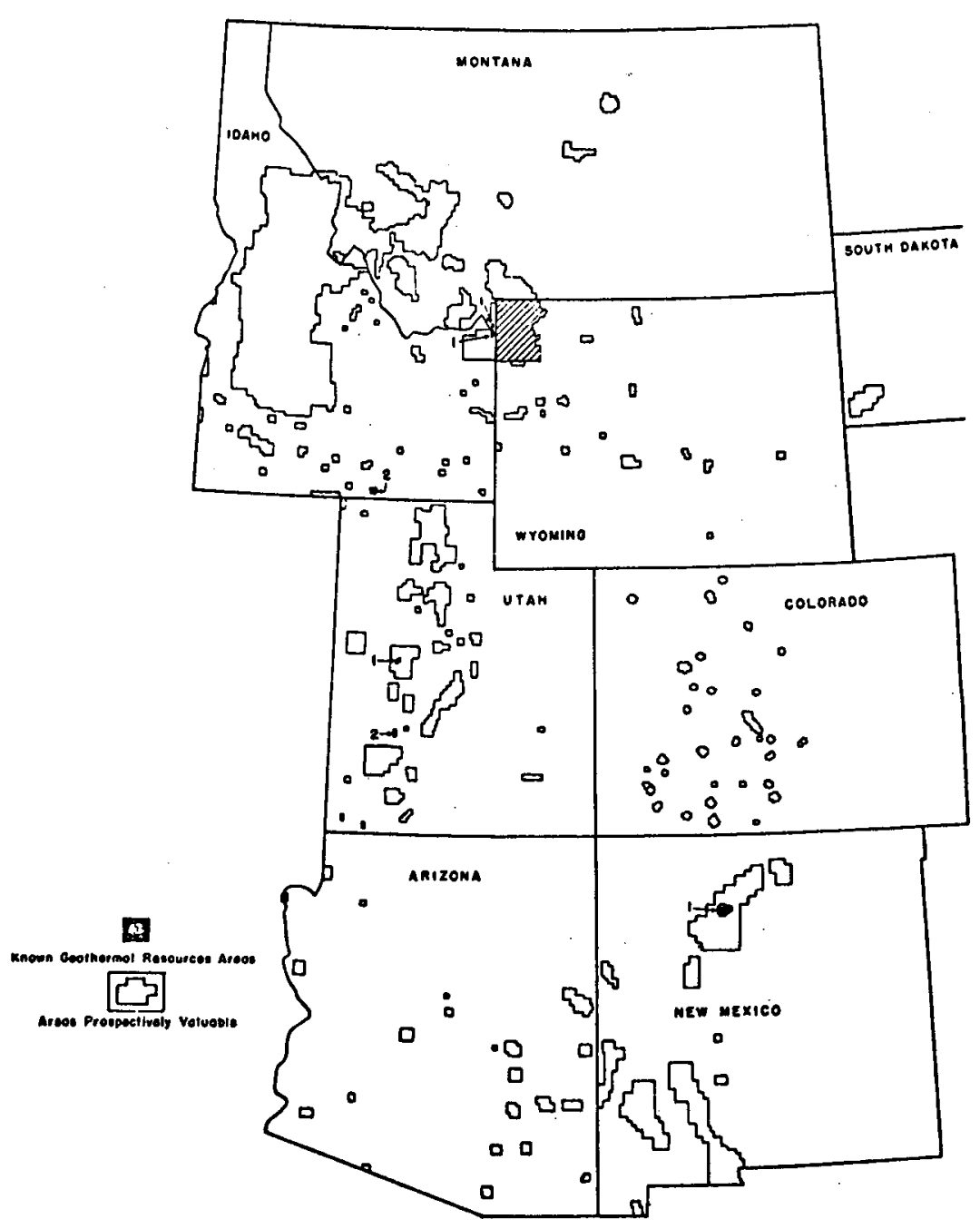

Source: U.S. Department of the Interior, Final Environmental Statement, 1973.

Figure 2.1.1 (cont.) KNOWN GEOTHERMAL RESOURCE ARRAS IN THE WESTERN UNITED STATES 


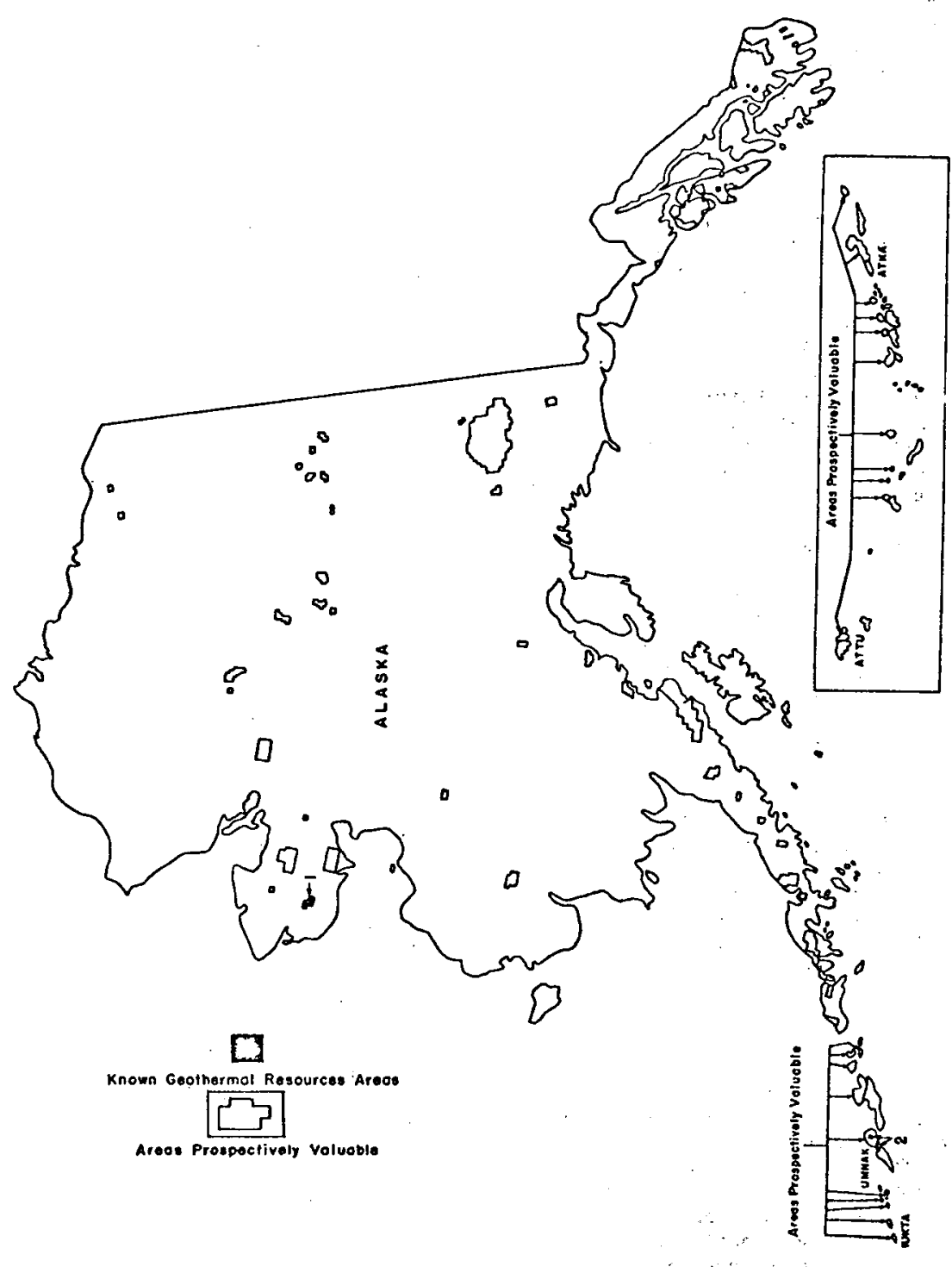

Source: U.S. Department of the Interfor, Final Environmental Statement, 1973

Figure 2.1.1 (cont.) KNOWN GEOTHERMAL RESOURCE AREAS IN-THE WESTERN UNITED STATES 
Interpreting the data since such apparent anomalies can be caused by many factors other than geothermal heat flow. Other frequencles, primarily microwave, have been used to improve results by increasing the depth of penetration into the earth: - Magnetic and gravimetric surveys aid in interpreting structural features.

Hydrological. Surface hydrological investigations are normally carried out during the early stages of exploration along with geological field studies [1, 11]. Recharge and discharge studies are made by investigating the movement of surface waters. This includes estimating the discharge rates from springs as we 11 as studying the drainage patterns in rivers, lakes, and watersheds. Water temperature is measured and samples are collected for chemical analysis. Water table studies are made from measurements in extsting wells. As the exploration program proceeds to the drillIng phase, subsurface hydrological investigations are made. These include studies of subsurface water flow which 'give information on local aquifers. The porosity and permeab11Ity of rock at various depths are measured. These properties control the flow of water, which is the heat transport medium. Water temperature and water chemistry, at depths are useful in evaluating the thermal characteristics of the reservolr and chemical reactions that occur in the formation.

Drilling. Geothermal wells are currently drilled with the standard rotary rigs that are used in the oil and natural gas industries. Research is being conducted on a number of novel drilling methods in order to increase drilling rate, decrease cost, and Increase the ultimate depth attainable. The current method, as well as novel ones, employs one or a combination of four basic mechan 1sms for excavating rock. These include mechantcally induced stresses, thermally Induced stresses, fuston and vaporlzation, and chemical reactions [12]. Mechanically induced stresses may be produced by equipment such as standard rotary drills, explosive drills, and ultrasonic drills. These methods induce mechanical stresses by impact, abrasion, or exosion. Brittle fracturing or plastic ylelding occurs when these stresses exceed the tensile or shear strength of the rock. Thermally induced stresses may be produced by forced-flame drills, microwave drills, Induction drills, etc. These devices generate thermal stresses that fracture rock by producing differential thermal expansion. Rocks may be fused or vaporized by applying heat at a sufficiently rapid rate to produce local temperatures that exceed the melting temperature or vaporization temperature of the rock. This principle is employed by techniques such as electric heater drills, electron beam drills, and laser drills. Chemical drills use highly reactive chemicals to dissolve rock. Chemicals may also be used to alter rock hardness in order to increase the drillIng rate of mechanical methods.

Well Logging and Testing. Well logging refers to measurements that are made as a function of depth during and after the drilling operation. Measurements normally included are temperature and pressure, bore Inclination, sonic logs to Investigate cement bonding to the casing, and radioactivity, electrical and gravimetric surveys to ald in the study of the formation $[13,14]$. After comple- tion of the well, the the rmodynamic properties and chemical compositton of the fluid are determined at various depths. Flow tests are conducted to determine the effluent mass flow rate as a function of wellhead pressure, and the thermodynamic properties of the fluid at the wellhead as a function of flow rate $[15,16]$. These tests are conducted over a period of time, normally several months, in order to evaluate the effect on reservoir lifetime. During flow testing, the chemical composition of the effluent is monitored and materials testing is conducted to determine the corrosion, erosion, and scaling properties of the fluld.

Modeling. Regional and national models of geothermal resources are needed as the first step in appraising the total resource. These models would map geological and geophysical data, such as temperature gradients or heat flow [17]. The data must be complled by statistical analysis after belng gathered by systematic methods. Statistical analyols is needed to ellminate erroneous or false data while treating a very large sample and to eliminate false thermal anomalies [18].

A different class of models is used to describe the dynamic behavior of a specific reservoir during its utilization.- These models describe the heat source, unsteady-state heat and mass transport, and single and two-phase flow through porous and fractured media. They also describe the relationships between pressure and temperature at depth and at the wellhead and the rates of fluid discharge, Injection or reinjection, and recharge (In-flow of cold ground water to the reservoir). The models may take the form of theoretical ana1yses having relationships in any conventent form such as curves, matrices, tables, or equations. Alternatively, the models may conslst of computer programs, elther digital or analog. Although a considerable amounc of work has been accomplished in simulating reservoir dynamics $[19,20,21,22$, $23,24,25,26$ ] further effort is needed to fully define all necessary parameters. Reservoir models are used to appralse the capacity and predict the longevity of a fleld. They are also important in several aspects of developing and managing reservolrs, such as determining well spacing and investigating the effects of fluid production and reinjection on the formation.

\section{Reservo1r Development and Operation}

The development and operation of a reservoir is discussed below in terms of reservoir design, production well design, drilling and construction, well stimulation, the design and construction of the gathering system, and engineering and management during the years of production.

Reservolr Design. A reservolr is designed to provide a certain thermal energy production rate for a specific number of years. Generally, the criterion is that the fleld longevity must be at least long enough to amortize the capital expenditure for the fleld and plant. To accomplish this, studies are made of fluid production, reinjection, and recharge rates and fleld layout. These studies include production and reinjection well diameter and depth, reservoir recharge rate, and watermineral reactions that may occur in the formation and adversely affect the system porosity and, consequently, the effluent flow rate. Input 
information to these studies 18 dertved from production well test data and from reservolr models which include hydrological, geological, geochemical, and geophysical test data. After these studies have been completed, the next task is to lay out the field. This involves, primarily, the arrangement ot production and reinjection wells. The number of wells, well spacing, and amount of reserve area to be set aside for future drilling are site dependent and are determined from such considerations as expected flow rates and therodynamic conditions of the effluent from the wells to be drilled, and from system requirements including the production rate of thermal energy and field and plant lifetime. In determining specific well locations, such considerations as terrain, access roads, and underground pipe or cables that are in existence or planned are taken into account. In some instances, a given field may have multiple owners. In this case, provision must be made for. cooperative reservolr development.

Production Well Design, Drilling and Construction. To date, geothermal wells have been drilled with conventional drill rigs that are normally used for oil or gas wells $[14,17,29,31,33,35]$. Speclal high-temperature drilling "mud," water, or compressed air circulation is used to cool the b1t and remove solid particles from the bore hole $[30,32]$. Although directional drilling has been well developed in ofl field practice, vertical drilling is far less expensive and, therefore, normally employed. Safety equipment includes blow-out preventers at the wellhead, an adequate supply of cooling water for quenching, and also gas detection equipment and gas masks since gas emitted may contain poisonous hydrogen and arsentc sulphides [13]. Future drill rigs using advanced techniques, such as described above-under Resource Exploration and Appraisal, may Increase the depths that are economically attainable.

Well casing design normally calls for steel casing with diameters that decrease as depth increases $[15,28]$. The production zone may be bare- (no casing), have a slotted liner, or the solid liner may be perforated after setting in place. The casing is cemented to the formation to prevent vibration, to Insure that steam and/or hot water do not erupt in the annulus between the casing and the drill hole, and to prevent the casing from being ejected from the drill hole. Special high-temperature cements, and in speclal cases acid resisting cements, are used. At the vellhead, a concrete collar or pad is normally poured before drilling commences. In special instances, where the surface of the formation is not well consolidated, grout may be injected into the ground in the area of the drilling site [34]. Equipment attached to the top of the well casing includes the varlous shut-off and bleed valves.

We11 Stimulation. Well stimulation techniques may be used to increase the flow in hydrothermal systems or to create cracks in impermeable hot dry rock formations. Stimulation techniques may prove beneficial in hydrothermal systems that have inftially poor formation permeability or those that have decreased in production during use because of solids deposition. In the formation [36]. Stimulation techniques include the use of hydraulic fracturing, chemical solvents, chemical explosives, and nuclear explosives. Hydraulic fracturing, or hydrofracturing, is common practice in oil and gas flelds. It involves pumping water down the well with a sufficlently high presaure to produce cracks in the rock at the bottom of the well [37]. These cracks extend as pumping continues.

In hot dry rock, controlled hydrofracturing creates a system of cracks that resembles a pancake on edge [38]. By injecting water into this pancake shaped system of cracks, or an array of such systems through one or more wells and recovering hot water through one or more other wells, heat may be extracted from hot dry rock formations. Although the cracks created by hydraulic fracturing may extend for several thousand feet, they are only about one-half Inch wide and tend to close when the hydraulic pressure is removed. Propping material, such as sand, is injected in order to maintain the cracks in an open position.

After a period of production, a hydrotherma1 system may. decrease in flow because of sollds deposition in the formation which decreases permeability. Injection of chemical solvents through the well may be effective in desolving these solids and restoring the well to its original rate. Chemical and.nuclear explosives may prove useful in creating rubble chimneys in hydrothermal systems to improve fluid flow to a well or produce an artificial reservoir in impermeable hot dry rock formations $[39,40]$.

Gathering Systems. The piping network that transmits hot fiuld from the wells to the point of use Is called a gathering system. "In a commercial size operation, the: gathering system normally. collects flutd from a number of wells and manifolds it to the plant. $[15,34,4142]$. . The system consists primarily of insulated piping; suitably anchored to the ground and having expanston loops or bellows. It also. contains cyclone separators, screens, and filters to remove rock particles and In the case: of vapor-dominated reservolrs, slugs of water that occasionally are emitted from the well. Mufflers, safety valves, and steam traps are also installed. In designing a gathering system, the objective is to maximize the flow and minimize cost and heat loss. These objectives are somewhat opposed, since large diameter piping wI11 decrease pressure loss and maximize flow, but will also increase the surface area. for heat 108s, as well as pipe cost [15]. Instrimentation useful in operating a fleld would include flow meters, fluid sampling equipment, and instruments for measuring the thermodynamic properties of the fluid such as temperature, pressure, and enthalpy.

An alternative to transporting heat to the surface by extracting fluid from the reservoir 18 the use of downhole heat exchangers, heat pipes; or di- $\because$ rect energy conversion devices. A downhole heat exchanger consists of a long concentric double pipe with the outer pipe closed at the bottom and the Inner pipe open. A working flutd; probably water, would be pumped down the center pipe and rlse back to the ourface in the annular space between the two.pipes. Heat from the formation would be transferred to the fluld as it rises in the annular space of the heat exchanger.: $A$ heat pipe consists of a closed pipe containing a sinall amount of volatile flutd which would absorb heat and vaporize at the bottom of the well, then rise to the top. where it would condense, transfer Its heat, and return to the heat source region by gravity. A direct energy conversion device, such as a thermoelectric:converter, would produce electrical energy when inserted in a hot geothermal 
we11. Although simple downhole heat exchangers made of U-shaped tubes (not concentric pipes) have been successfully used in shallow wells for space heating [43], neither the downhole heat exchanger, the heat pipe, nor the direct energy conversion devices have been commercially demonstrated for electric power production.

Production Engineering and Management. After the wells: have been drilled and the gathering system and utilization plant have been constructed; the field must be operated in a manner that will ensure a uniform flow of hot fluid having consistent propertles over a perfod of time that is at least long enough to amortize the capital investment. Operating procedures coverIng start-up, production,' and shut-down must be developed for the weils and the gathering system. These procedures are important in avolding the entrainment of particulate matter In the geothermal fluid and subsequent transmission of particles to the turbine or other processing equipment in the plant.. They are also designed to prevent thermal shock in the formation, the: well casing and the gathering system.. Implementation of these procedures requires close communication and cooperation between the personnel operating the field and those operating the plant [15].

As a field is being produced, a number of measurements must be continuously or periodically made and corresponding records maintained [44]. Typically these should include mass flow rate, wellhead pressure, thermodynamic and chemical properties of the fluid delivered to the plant, the net mass withdrawal from the fleld, and any ground subsidence that may occur. Accumulation of: such information in a central data bank would be of mutual benefit to all field operators as well as to the geothermal industry in general. Pooling of this information may, however, be restrained because of proprietary considerations.

In order to effectively manage the operation of a field, studies of the effect of exploitation on fleld behavior and avallable reserves should be made periodically... Such possible effects as pressure decline, depletion of fluid, and changes in the chemical composition of the fluid would be evaluated. Reservoir models describing the availability and distribution of energy at a given point in time, as weli as the overall system dynamics during steady operation, would be most useful to these studies. Based upon the results of the studies, decisions may be made'regarding the discharge rate from Individual wells, reinjection of cooled fluids, and possible recharge of the reservoir from ground water sources.: of course, in the case of a hot dry rock reservolr, groundwater must be initially injected before hot fluid can be produced. $\therefore$ If a field has multiple users, there must be some agreement between them on : such matters as the rates of fluld discharged from and infected into the formation, since the operation' of each w1ll affect all others.

Flutds discharged from geothermal wells contain minerals and noncondensable gases which vary in amount over a wide range between geothermal sites. - These cause corrosion and scale deposition which must be controlled by the proper selection of construction materials and maintenance operations such as well workover
$[45,46,47,48,49,50]$. Other maintenance operations would include ensuring that abandoned wells are safely secured, and drilling and constructing new wells in reserve areas.

Figures 2.1.2 and 2.1.3 summarize locations within the United States where governmental or commercial geothermal development is taking place.

\section{Resource Utilization}

Since hot fluids cannot be transported economically by pipeline over long distances, geothermal energy must be converted to electric energy. or otherwise utilized at sites that are in close proximity to geothermal reservoirs. In most instances, geothermal fields are remote from population centers. For this reason the primary utilization of geothermal energy has been to generate'electrical energy which can be transmitted to locations that require energy. However, in some regions geothermal provinces exist near population centers and have been successfully used for space heating and air conditioning. Other applications of geothermal resources, such as process heating and mineral extraction, are reported in the literature. Depending upon the chemical and thermodynamic properties of the geothermal flufd and the site location, it may be economically advantageous to construct a multipurpose plant. For instance, geothermal fluid from a given field could be used to generate electricity and also provide process heat, desalinated water, and salable minerals.

Electrlc Energy. Several different processes are currently being used to commercially produce electrical energy from geothermal energy. Still other processes are in the experimental or theoretical stage of development. The process selected for a particular site will depend upon the chemical and thermodynamic properties of the effluent. For instance, a different process must be considered for a liquid-dominated reservoir that produces a mixture of steam and hot brine than for a vapordominated site that produces only steam. In order to introduce a new technology such as geothermal energy, the most prudent first step would be the construction and operation of a demonstration scale plant for each of the bastc conversion processes. This would normally be required before a utility company or other user would invest in a commercial scale plant.

Several conversion processes are shown schematically in Figure 2.1 .4 on a following page. The first shown 18 a direct single-phase flow of steam from the well to the turbine which turns a generator to produce electrical energy $[45,51,52,53]$. Vapor dominated sites which produce single-phase saturated or superheated steam without liquid are presently producing electrical energy on a commerical scale In the United States, Italy, and Japan. These plants employ relatively simple low pressure Rankine steam cycles and require only minor pretreatment of the steam to remove particulate matter and occasional slugs of water. Although steam could be exhausted from the turbine to the atmosphere, a condenser is normally employed which substantially increases the turbine efficiency. Heat refection systems such as cooling towers provide cooling water for the condenser. Ejectors or vacuum pumps are used to remove noncondensable gases from the condenser.

In the case of liquid dominated reservoirs which Issue hot water (or brine) mixed with steam (twophase), steam is produced In a separator by flashing 
LOCATION OF SELECTED NON-GOVERMENTAL GEOTHERMAL DEVELOPLENTS

\section{CALIFORNIA}

The Geysers

-Current power output - 396 MWe

-PG\&E plants scheduled for operation - total

of 908 MWe by late 1976

-Exploration and test wells (Union 011, Pacific Energy, Magma, Geothermal Kinetics, Burmah Oil and Gas (SIgnal Co.), Shell 011, Sun 011/ Aquitalne

Mono-Lake - Casa Dlablo

-I0 MWe generating plant planned for 1975 (Southern California Edison \& Magma)

Surprise Valley (northeastern corner of California)

-Exploration (Magma, Gulf 011, American Thermal Resources, Hunt Oil)

Imperial Valley

-Production test wells, binary system development (Chevron, Magma, San Diego Gas \& Electric)

-25 MWe power plant planned (San Diego Gas \& Electric)

-50 MWe power plant planned (San Diego Gas \& Electric)

-Tests on brine reinfection systems (Phillips

Petroleum, Southern Cal. Edison)

ARIZONA

-2 test wells (Geothermal Kinetics)

-Test well (Nix Drilling Co.)

NEVADA

-Test we11 (Chevron and American Thermal

Resources)

-Test well (PhIllips Petroleum and Southern

Pacific Land Co.)

-Test wel1 (Union 011, Magma)

NEW MEXICO

-12 wells drilled since 1960

-Baca 11 , planned, power capacj.ty of $6.5 \mathrm{MW}$ OREGON (Union Oil)

-Test well (Gulf 011)

-2 greenhouses ut $111 z$ ing geothermal heat under construction (Bolse Cascade)

UTAH

-Test well (Geothermal Kinetics and Utah Power and Light)

-Test well (N1x Drilling Co.)
LOCATION OF GOVERMMENT GEOTHERMAL DEVELOPMENT

U.S. GEOLOGICAL SURVEY - exploration and research evaluation techniques

Clear Lake - Geysers, Callfornia

Long Valley, Callfornia

Imperial Valley, Callfornia

Northwest Nevada

Southwestern Oregon

Yellowstone National Park

Jemez Mountain Area, New Mexico

Southern Idaho

ATOMIC ENERGY COMMISSION

Los Alamos, New Mexico - hot dry rock experiment

Nevada - field exploration leading to hot water pilot plant (high temperature - low salinity)

Imperial Valley - equipment deslgn and testing at Lawrence LIvermore Lab, Cal. leading to hot water pllot plant (high temperature - high salinity)

Raft River Valley, Idaho - exploratory drilling leading to hot water pllot plant (moderate temperature - low salinity)

NATIONAL SCIENCE FOUNDATION

New Mexico - heat flow measurements Hawaf1 - nature and extent of resource Imperlal Valley, California - nature and extent of resource

Montana - hot dry rock evaluation

Nevada - delineation of reservoirs

(does not include basic research not geographically or Lented)

U.S. BUREAU OF RECLAMATION

Imperial Valley, California - pllot desalination plant

U.S. NAVAL WEAPONS CENTER

China Lake, Californta - exploration and drilling

Figure 2.1.2 
the hot 11quid at a reduced pressure and separating the two phases [35]. The steam is then fed to 3 a turbine. If the flrst flash pressure is sufficlently high, the remaining liquid can be economIcally flashed again, producing steam at a secondary pressure which can be fed to a lower pressure turbine or a lower-pressure stage of the same turbine. This system also employs a Rankine steam cycle and, since the natural effluent 18 fed directly to the turbine, it is referred to as a direct process (Flgure 2.1.4). Commercial plants are currently operating with this type of process In Mexico, New Zealand, Japan, Iceland, and the USSR.

In contrast to direct processes, the binary process (F1gure 2.1.4) employs a designer-selected secondary working fluid, such as isobutane or freon, which expands through the turbine and passes through a heat exchanger in which it absorbs heat from the natural well effluent (steam and/or water), without becoming contaminated by the effluent itself [54]. The binary process is potentially more efficient than the single-stage flashed steam process where the wellhead temperature 18 less than about $400^{\circ} \mathrm{F}$. Since the great majority of known hydrothermal reservoirs fall into this class, the binary process appears important to the utilization of this large source of energy.

Although research and development effort has been devoted to the development of binary processes by private Industry and universities in the United States, only one binary plant, a demonstration scale plant located in the USSR [55], has been constructed in the world to date.

Several proprletary novel heat engines have been proposed for directly converting the geothermal energy in a two-phase effluent into shaft work w1 thout separation (Figure 2.1.4). Engines of th1s type such as the "rotary osclllating vane," the "helical screw expander," and the "bladeless turbine" are being developed in the United States by private industry [56].

Although it is possible to directly convert geothermal energy to electrical energy by inserting such devices as thermoelectric converters into walls, there are many technical problems associatè with the production of a sufficient amount of electrical energy to make a commercial plant of this type economically viable. For this reason, direct energy conversion of geothermal resources has recelved little attention to date.

The effluent from geopressured resources contains a sufficlent amount of natural gas to separate and burn in a power plant to produce electrical energy. This can be done with equipment such as modifled gas turbines or steam turbines powered by boilers.

Another energy extraction process using a low grade two-phase fluid has been suggested. Suppose the fluld were simply heated (after appropriate treatment) in a conventional boiler. The amount of energy required to raise the temperature of the fluid to high quality steam would clearly be less than the case in wich cold water was used. This possibility is evaluated further in section 2.2 of this report $[68]$.

Process Heat. Geothermal energy currently provides process heat for industry and agriculture in a number of countries [57, 58, 59]. Present processes include the production of paper, the evaporation of sea water to produce salt, and the production of diatomite. Agricultural applications involving the heating of greenhouses and soil warming in the open are of major Importance in several countries. Add1tionally, the warm waters from geothermal sources have been widely used for bathing, recreational, and therapeutic purposes for many years. Undoubtedly, a great many additional commerclal processes could operate with geothermal energy. Suggested uses include sugar processing, heavy water production, mining and upgrading of minerals, ice melting, refrigeration, and freeze drying.

\section{GEOTHERMAL CONVERSION PROCESSES}

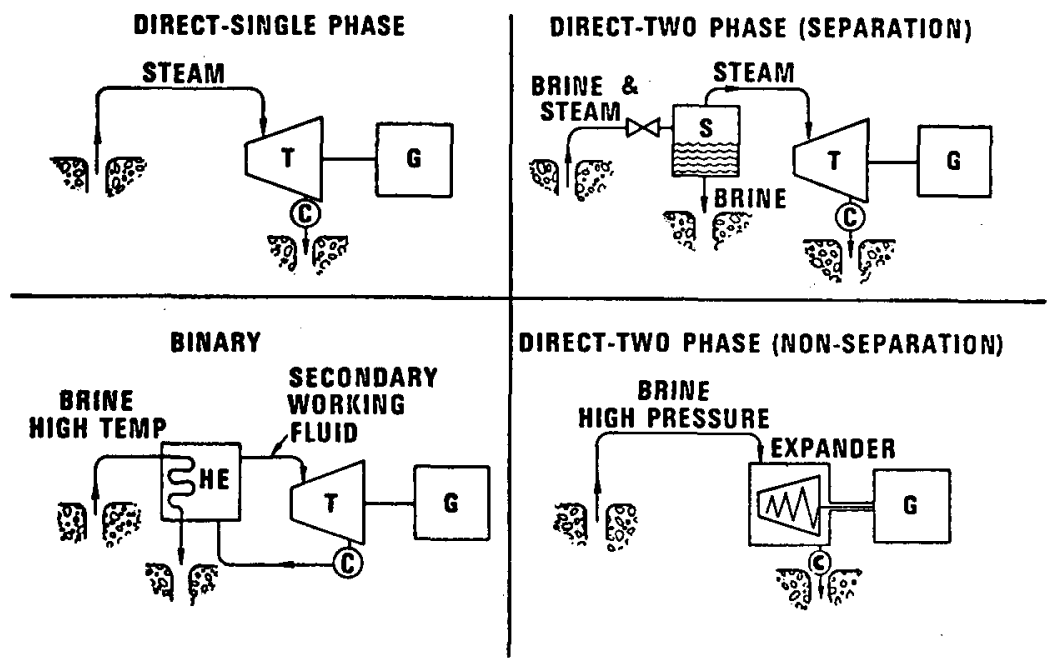

F1gure 2.1.4 
The appropriateness of using geothermal energy for process heat in a particular process depends upon the temperature as well as the other thermodynamic and chemical properties of the effluent fluid. It is quite feasible to extract process heat from single-phase flow of steam, two-phase flow with flash separation, two-phase total flow, and heat exchange with secondary fluid, using the same processes and equipment as described previousiy in this section under Resource Utilization, Electric Energy. In addition to these, singlephase hot water which is too low in temperature to flow up the well by flashing may also be used for industrial and agricultural purposes by inserting deep well pumps. It is not considered economically feasible to produce electrical energy from water at this low temperature.

Space Heating and Alr Conditioning. In areas where geothermal resources exlst in close proximity to population centers, the natural energy from the earth has been successfully extracted for space heating and alr conditioning [60]. Largescale use of geothermal energy is currently being made for this purpose in Iceland, Hungary, the USSR, New Zealand, Japan, and the United States. Heating may be accomplished with single-phase flow (either steam or hot water), two-phase flow with flash separation, two-phase total flow, or heat exchange with secondary fluid, as described above in Resource Utilization, Electric Energy and Process Heat. Alr conditioning to date has been produced with absorption cooling units. Steam fet (vacuum) cooling units are also theoretically applicable. It is also feasible to decrease fuel consumption by using geothermal heat in conjunction with heat pumps and either direct or reversed mechanical refrigeration cycles.

Desalinated Water. The mineral content of water In hydrothermal reservotrs varies over a wide range from site to site and may be ouffictently pure for drinking, industrlal, or agricultural purposes. On the other hand, it may contain up to ten times the salt content of sea water. Self-desalination of geothermal brines $[61,62]$ is considered in this section. The application of geothermal energy to desalinate sea water or other bracklsh water 18 considered to fall into the category of process heat. Electric energy produced from geothermal energy may, simtlarly be used at remote locations to desalinate sea water. Membrane desalting is more appropriate than distillation when electrical energy is applied.

In an electric generation plant, condensate from the steam turbine may be used as a source of fresh water. Two well-known conventional methods for desalting water are multiple-effect distillation and multistage flash. E1ther of these methods may be used to desalt geothermal brines and no fuel will be required.

Reported1y, geothermal resources provide a great potent1a.1 supply of desalted water [63, 64]. The U.S. Department of the Interior. Is currently operating a geothermal desalination plant in the Imperial Valley, Callfornia [65]

Mineral Extraction. Generally, the tecinology for recovering minerals from geothermal fluids exists. Methods for extracting minerals such as potassium, 11thlum, and calclum have been described $[57,58$,

$66,67]$. Geothermal brines contain large amounts of such minerals. They may be recovered by precipitation which requires clarifying tanks and chemicals to increase the rate of this process or simple evaporation in ponds or evaporators. From 1810 to 1966 large amounts of boron were produced from geothermal resources in Italy. Also, calcium chloride was successfully produced in the Imperial Valley, California, but this operation was discontinued for economic considerations.

Natural Gas Extraction. Flulds from geopressured reservolrs commonly contain 10 . to 16 standard cubic feet of natural gas per barrel of geothermal fluid, and concentrations as high as 30 standard cubic feet per barrel have been reported. Since each geopressured well will produce perhaps a million standard cubic feet of natural gas per day, recovery of these dissolved hydrocarbon gases would be a valuable by-product [64]. These gases could be recovered in standard fractioning towers. other classes of geothermal reservolrs do not contain sufficient quantities of natural gas to make their recovery economically viable. However, all classes may contain noncondensable gases such as argon, helium, and carbon dloxlde that may prove to be valuable by-products and, therefore, their recovery should be considered. The natural gas recovered from geopressured reservolrs could be pipelined to load centers or burned at the site to produce electrical energy, provide process heat, or space heating and air conditioning.

\section{REFERENCES}

[1] Combs, J., and L. P. J. Muffler, "Exploration for Geothermal Resources," in Kruger and Otte (eds.), Geothermal Energy (Stanford, Calif.: Stanford University Press, 1973).

[2] Healy, J., "Pre-Investigation Geological Appra1sal of Geothermal Fields," Geothermics, Special Issue 2, Vol. 2, Part $1(1970)$.

[3] Tonan1, F., "Geochemical Methods of Exploration for Geothermal Energy," Geothermics, Spectal Issue 2, Vo1. 2, Part I (1970).

[4] El11s, A. J., "Quant1tative Interpretation of Chemical Characteristics of Hyrothermal Systems," Geothermics, Speclal Issue 2, Vo. 2, Part 1 (1970).

[5] Fournter, R. 0., and A. H. Truesde11, "Chemical Indicators of Subsurface Temperature Applied to Hot Spring Waters of Yellowstone National Park, Wyoming, U.S.A.," Geothermics, Special Issue 2, Vol. 2, Part 1 (1970).

[6] Sigvaldason, G. E., "Geochemical Methods In Geothermal Exploration," Geothermal Energy, Vol. 12 (1973).

[7] Banwe11, C. J., "Geophysical Methods in Geothermal Explorat1on," Geothermal Energy, Vol. 12 (1973).

[8] Grose, L. T., "Geothermal Energy: Geology, Exploration, and Developments," Mineral Industries Bullet1n, Vo1. 14, No. 6 (November 1971).

[9] Hodder, D. T., "Application of Remote Sensing to Geothermal Prospecting," Geothermlcs, Speclal Issue 2, Vo1. 2, Part 1 (1970). 
[10] Valle, R. G., "Photogeologic and Thermal Infrared Reconnaisance Surveys of the Los NegritosIxlan de Los Hervores Geothermal Area, Michoacan, Mexico," Geothermics, Special Issue 2, Vol. 2 Part 1 (1970).

[11] McNitt, J. R., "The Role of Geology and Hydrology In Geothermal Exploration," Geothermal Energy, Vo1. 12 (1973).

[12] Maurer, W. C., Novel Drilling Techniques (E1msford N.Y.: Pergamon Press, 1968).

[13] Matsuo, K., "Dr111ing for Geothermal Steam and Hot Water," Geothermal Energy, Vol. 12 (1973).

[14] U.S. Department of Interior, Bureau of Reclamat1on, Geothermal Resource Invest1gations, Imper1al Valley, California (Washington, D.C.: U.S. Government Printing Office, Pebruary 1973).

[15] Budd, C. F., Jr., "Steam Production at The Geysers Geothermal Field," In Kruger and Otte (eds.), Geothermal Energy (Stanford, Calif.: Stanford University Press, 1973).

[16] Dench; N. D., "We11 Measurements," Geotherma1 Energy, Vol. 12 (1973).

[17] Blackwe11, D. D., "The Thermal Structure of the Continental Crust," Geophysical Monograph Series, Vol. 14, American Geophysical Unton (1971).

[18] Kehle, R. 0., R. J. SchoeppeI, and R. K. Deford, "The AAPG Geothermal Survey of North America," Geothermics, Special Issue 2, Vo1. 2, Part 1 (1970).

[19] Donaldson, I. G., "The Simulation of Geothermal Systems with a Simple Conductive Model," Geothermics, Spectal Issue 2, Vol. 2, Part 1 (1970).

[20] Nogucki, T., K. Nishikawa, T. Ito, and K. Ushifima, "Some Theoret1cal Considerations on Hydrotherma1 Systems Due to Cracks," Geotherm1cs, Special Issue 2, Vol. 2, Part 1 (1970).

[21] Mundry, E., "Mathematical Estimation Concerning the Colling of a Magmatic Intrusion" Geothermics, Spec1al Issue 2, Vol. 2, Part 1 (1970).

[22] Marsha11, D. C., "Development of a Theory of the Wairakei Geothermal Field by the 'Simplest Cases First' Technique," Geothermics, Special Issue 2, vol. 2, Part 1 (1970).

[23] Donaldson, I. G., "The Estimation of Subsurface Flows and Permeabilities from Temperature Pressure Data," Geothermics, Special Issue 2, Vol. 2, Part 1 (1970).

[24] Whiting, R. L., and H. J. Ramey, Jr., "Application of Material and Energy Balances to Geothermal Steam Production," Journal of Petroleum Technology (July 1969).

[25] Miller, F. G., "Theory of Unsteady-State Influx of Water in Linear Reservoirs," Journal of the Inst1tute of Petroleum, Vo1. 48, No. 467 (November 1962)

[26] Miller, F. G., "Steady Flow of Two-Phase SingleComponent Flulds Through Porous Media," Petroleum Transactions, AIMR, Vol. 192 (1951).
[27] Cromling, J., "How Geothermal Wells are Drilled and Completed," World O11 (December 1973).

[28] Stilwell, W. B., "Drilling Practices and Equipment in Use at Wairake1," Geothermics, Spectal Issue 2, Vo1. 2, Part 1 (1970).

[29] Cirnf, U., and A. Glovannon1, "Planning Methods in Geothermal Drilling," Geothermics, Special Issue 2, Vol. 2, Part 1 (1970).

[30] Fabbri, F., and M. Vidal1, "Drilling Mud in Geothermal We1ls," Geothermics, Special Issue 2, Vol. 2, Part 1 (1970).

[31] Brunett1, V., and E. Mezzett1, "On Some Troubles Most Frequently Occurring in Geothermal Drilling," Geothermics, Special Issue 2, Vo1. 2, Part 1 (1970).

[32] Cigni, U., "Completion of Producing Geothermal Wells," Geothermics, Special Issue 2, Vol. 2, Part 1 (1970).

[33] "Larderello and Monte Amiata: Electric Power by Endogenous Steam," Ente Nazionale per 1'Energia Elettrica (ENEL).

[34] New Zealand Electricity Department, "Power from the Earth: The Story of a Wairakel Geothermal Project."

[35] Otte, C., "Productions and D1sposal Technology in Salton Sea Geothermal Area, Imperial County, California," presented to the Geothermal Resources Board of the State of Californta in the Imperial Valley geothermal hearings, October 22-23, 1970.

[36] EwIng, A. H., "Stimulation of Geothermal Systems," In Kruger and Otte (eds.), Geothermal Energy (Stanford, Callf.: Stanford University Press, 1973).

[37] Smith, M., "Introduction and Growth of Fractures in Hot Rock," In Kruger and Otte (eds.), Geothermal Energy (Stanford, Calif.: Stanford University Press, 1973).

[38] Smith, M., "Geothermal Resources," Hearings before the Subcommlttee on Water and Power Resources of the Committee on Interior and Insular Affa1rs, U.S. Senate (June 13, 1973).

[39] Burnham, J. B., and D. H. Stewart, "Recovery of Geothermal Energy from Hot Dry Rock with Nuclear Explosives," In Rruger and Otte (eds.), Geothermal Energy (Stanford, Calif.: Stanford University Press; 1973).

[40] Ramey, H. J., Jr., P. Kruger, and R. Raghaven, "Explosive Stimulation of Hydrothermal Reservolrs," In Kruger and Otte (eds.), Geothermal Energy (Stanford, Calif.: Stanford University Press, 1973).

[41] Pollastr1, J., "Design and Construction of Steam Pipelines," Geothermics, Special Issue 2, Vo1. 2 Part 1 (1970)

[42] Armstead, H. C. H., "Geothermal Economlcs," Geothermal Energy, Vol. 12 (1973).

[43] Peterson, N. V., and E. A. Groh, "Geothermal Potentlal of the Klamath Palls Area, Oregon," The Ore Bin, Vol. 29, No. 11 (November 1967). 
[44] Bolton, R. S., "Management of a Geothermal Field," Geothermal Energy, Vol. 12 (1973).

45] Finney, J. P., "Design and Operation of The Geysers Power Plant," in Kruger and Otte (eds.) Geothermal Energy (Stanford, Calif.: Stanford University Press, 1973).

[46] Ham, W. C., "Materials and Corrosion, Geysers Geothermal Power Plant," presented at the National Association of Corrosion Engineers Western Regional Conference, San Francisco, Callf., October 3-5, 1972.

[47] Krikorian, O. H., "Corrosion and Scaling in Nuclear-Stimulated Geothermal Power Plants," in Kruger and Otte (eds.), Geothermal Energy (Stanford, Calif.: Stanford University Press, 1973).

[48] Marsha11, T., and W. R. Brafthwaite, "Corrosion Control in Geothermal Systems," Geothermal Energy, Vol. 12 (1973).

[49] Ricci, G., and G. Viviani, Maintenance Operations in Geothermal Power Plants, Geothermics, Special Issue 2, Vol.2, Part 1 (1970).

[50] Allegrini, G. and G. Benvenuti, "Corrosion Characteristics and Geothermal Power Plant Protection," Geothermics, Special Issue 2, Vol. 2, Part $\overrightarrow{1}(1970)$.

[51] Corti, R., et al., "New Trends in the Planning and Design of Geothermal Power Plants," Geothermics, Special Issue 2, Vol. 2, Part 1 (1970).

[52] Da1 Secco, A., "Turbocompressors for Geotherma1 Plants," Geothermics, Special Issue 2, Vol. 2, Part 1 (1970)

[53] Clap1ca, I., "Present Development of Turbines for Geothermal App1ication," Geothermics, Special Issue 2, Vo1. 2, Part 1 (1970).

[54] Anderson, J. H., "The Vapor-Turbine Cycle for Geothermal Power Generation, "In Kruger and Otte (eds.), Geothermal Energy (Stanford, Calif.: Stanford University Press, 1973).

[55] Hibben, S. G., Soviet Geothermal Electric Power Engineering, Report 2 (Informatics Inc., 1972).

[56] Geothermal Energy Magazine, Vol. 1, No. 1 (August 1973).

[57] Muffler, L. P. J., "Geothermal Resources," Professional paper 820 (Waghington, D.C.: U.S. Geological Survey, 1973).

[58] Lindal, B., "Industrial and Other Applications of Geotherma1 Energy," Geothermal Energy, Vol. 12 (1973).

[59] Komagata, S., "The Status of Geothermal Utilization In Japan," Geothermics, Special Issue 2, Vo1. 2, Part 1 (1970).

[60] Einarsson, S. S., "Geothermal Distric Heat1ng," Geotherma1 Energy, Vol. 12 (1973).

[61] Laird, A. D. K., "Water from Geothermal Resources," in Kruger and Otte (eds.), Geothermal Energy (Stanford, Calif.: Stanford University Press, 1973).
[62] Wong, C. M., "Geothermal Energy and Desalination: Partners in Progress," Geothermics, Speclal Issue 2, Vol. 2, Part $1(1970)$.

[63] Rex, R. W. Investigation of Geothermal Resources, Imperial Valley and their Potential Value for Desalination of Water and Electricity Production (Riverside, Calif.: University of California, June $1,1970)$.

[64] Hickel, W. J., Geothermal Energy--A National Proposal for Geothermal Resource Research (University of Alaska, 1972).

[65] "Will Geothermal Steam Projects Sizzle or Fizzle?" Chemical Week (August 22, 1973).

[66] Lindal, B., "The Production of Chemicals from Brine and Sea Water Using Geothermal Energy," Geothermics, Special Issue 2, Vol. 2, Part 1 (1970).

[67] Glassett, J. M., "Mineral Recovery from Concentrated Brines," R\&D Progress Report 593 (Washington, D.C.,: U.S. Department of the Interior, December 1970).

[68] Joseph Coates, NSF Study Director, suggested this concept 


\subsection{Geothermal Technology:} Special Considerations

\section{Introduct Ion}

This section describes in more detall than in Section 2.1 , some specific geothermal technologies and the economics of production in geothermal plants. The technologies discussed in this section are geopressure power, hot dry rock power, hot water total-flow concept, and geothermal power cycles. While the technology of commercialized geothermal power from steam is not discussed here because $1 \mathrm{t}$ is described adequately in other sections of this report, the economics of production are examined in detail. Finally, the concept of dual geothermal-foss 11 fuel power plants is described.

Geopressured Water as an Energy Resource

\section{Formation of Geopressured Water}

Water in geopressured strata zones is one of the 1mportant geothermal energy sources described in this report. In the United States the only major known geopressured area is in the northern Gulf of Mexico basin. As shown In Figure 2.2.1 there are two main areas of geopressured strata, south Texas and southern Loulsiana, extending into the offshore in both areas. Figure 2.2.1 also shows the depths at which geopressures generally occur in each of these two areas. [1] Geopressured strata have also been reported In Mississippi.

Very large bodies of sand and shale containing saline waters under high pressure have long been known to exist along the northern shore of the Gulf of Mexico. Drillers, exploring for oll, have encountered the "geopressured zones" in an area stretching from Texas to Florida and extending from approximately $100 \mathrm{miles}$ inland to the edge of the continental shelf. Due to extensive ofl exploration along the Texas and Loulsiana coasts, a great deal of data concerning the nature of the zones in this area is available and has been studied extensively; unfortunately, much of this information is proprletary.

The geology of the Gulf Coast, particularly from Brownsville to New Orleans, Is predominantly that of a sedimentary geosyncline. $[2,3,4]$ Sediment transported from the eastern flanks of the Rocky Mountains. by ancestral Rio Grande and Mississipp1 rivers and the intervening sister streams within the past 40 million years has resulted in roughly one million cublc miles of deposits, mainly sand and clay, in the northern Gulf basin. As these deposits in the form of river deltas grew to massive proportions, they eventually slid off into the deeper waters of the Gulf, carrying with them the entrapped saline water plus the water of hydration of the primarily montmorillonite clay. This movement along planes (referred to as "growth faults") resulted in the sealing off of sand zones and the entrapment of the contained waters.

Continued deposition and subsidence brought more and more welght upon the earlier layers. With the water unable to escape, the normal compaction of the sands could not occur and the water became the load-bearing element of the formations, resulting in the high pressure known as "geopressure."

Heat continually rising from the earth's interior has been absorbed by the waters of these geopressured zones as a result of the low thermal conductivity of water as compared to normal sands and clays. Thus the temperatures of these waters are much higher than normal for their depth of occurrence. [5]

Another interesting property of these waters is their much lower than normal salinity. [6] (Figure 2.2.2.) A total dissolved solids content of 3 to 6 percent is normal in the geopressured zone sands, while in normal zones immediately above, 15 to 20 percent solids is the rule. No Intentional production of these geopressured waters has been attempted, but the geopressured strata

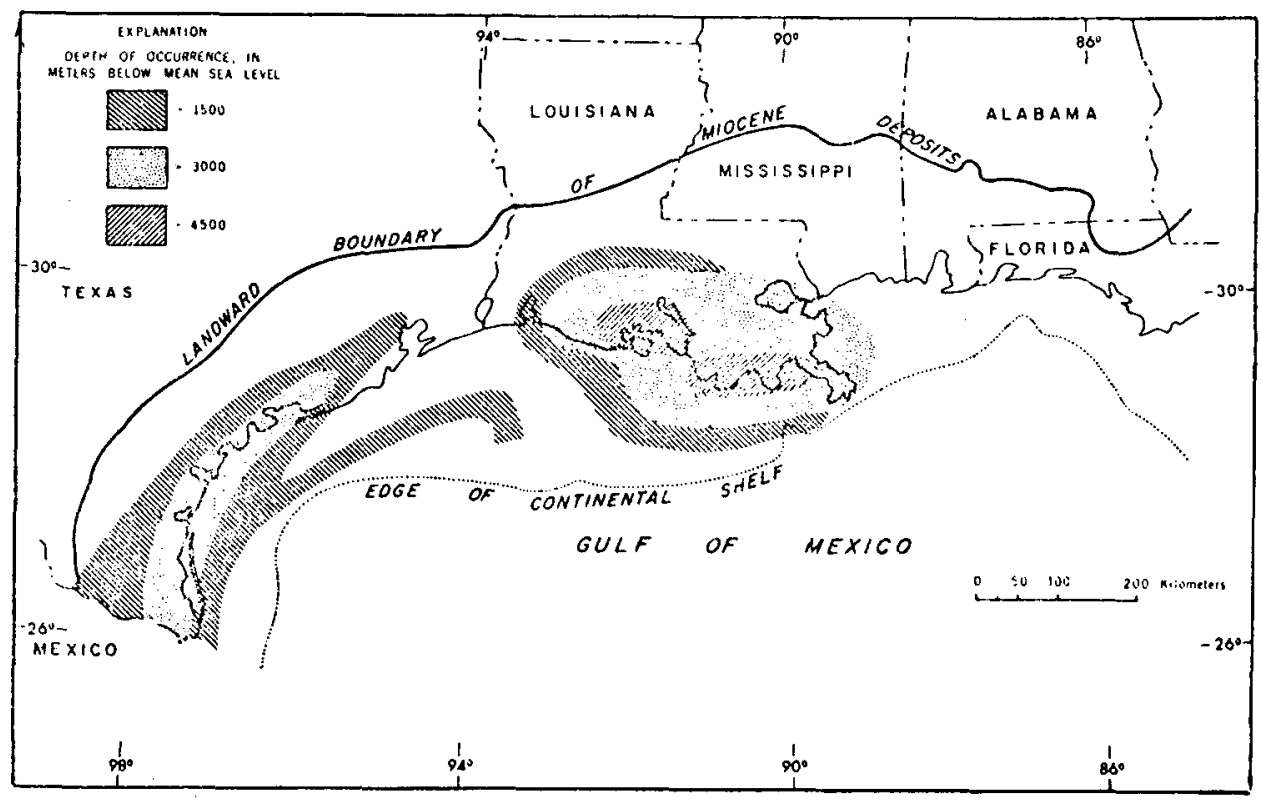

Figure 2.2.1 LOCATION AND DEPTH OF OCCURRENCE OF GEOPRESSURES IN THE NORTHERN GULF OF MEXICO BASIN (AFTER JONES, 1969) [1] 


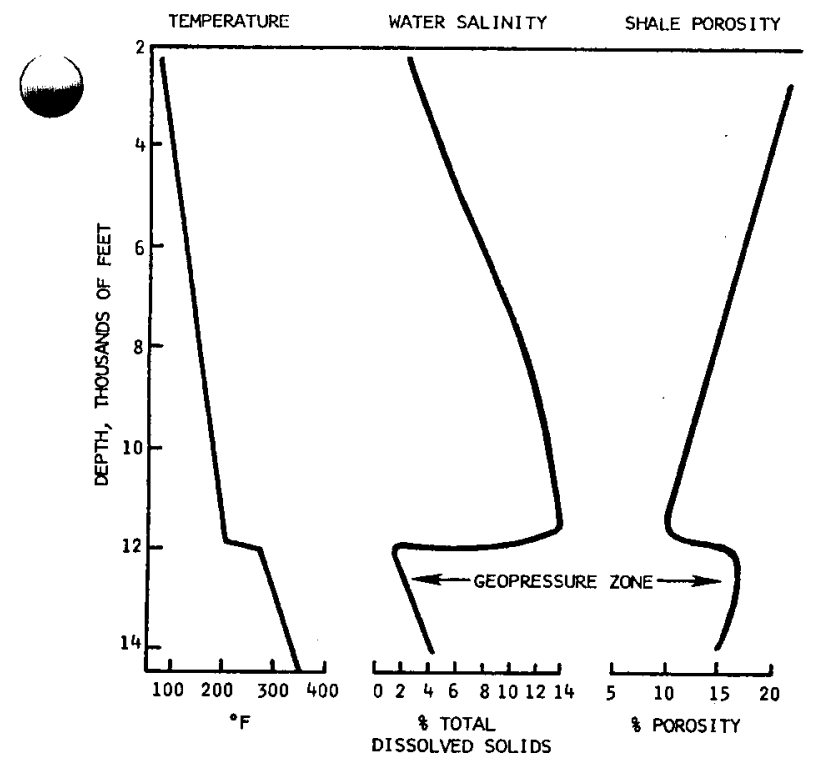

SOURCE [ 2 ]

Figure 2.2.2 CHARACTERISTICS OF THE GEOPRESSURED ZONE

have been accidently tapped numerous times. Continued flow has resulted in a steady decrease in salinity [7] with puritles approaching that of fresh water on occasion. It appears that as the water contained in the sand is withdrawn, it is replenished by water from the surrounding clay layers. These clays, under the influence of the Increased temperatures, have undergone diagenesis to shale, releasing much of the bound water. They are now composed of 30 to 40 percent (by volume) free water which can migrate into the sands. Th1s water appears to be of very low salinity due to the membrane qualities of the shale which acts as a reverse osmosis membrane to desalinate the water.

The migration and desalination of the shale waters is very important because the hot water resource then becomes that of both the sands and the shales and makes possible high rates of production over many years.

A second significant feature of these waters is the presence dissolved hydrocarbons. Many hundreds of analyses have indfcated that they are in general saturated with natural gas. [2] The gas content may be expected to be in the range of 10 to 40 standard cubic feet of gas per barrel of water. [2] This gas is recoverable. On the basis of 30 cubic feet per barrel, a 3000 gallon per minute well would yield 2.5 million cuble feet of gas per day. This materlally increases the incentive to bring these waters into production. If the flulds are hotter than $450^{\circ} \mathrm{F}$, the natural gas is 1ikely to be absent and carbon dioxide and hydrogen sulfide are likely to be found.

Thus there are uncompacted zones of and and shale of high, hot, and gas-bearing water content stretching some 800 miles along the Gulf Coast. [1] The top of these zones vartes from as shallow as 4000 feet to as deep as 16,000 feet, while the bottom is known to exceed 25,000 feet. These exist in elght parallel belts. corresponding to elght ancient shorelines or tertiary deposit episodes of which seven are major deposits. by the faults and become geopressured, are Individually large but are discontinuous and occur at various levels. [8] 011 well data Indicate that these zones occur almost everywhere in the area at some depth and overlay one another In most cases.

High temperatures (up to $500^{\circ} \mathrm{F}$ ) occur as well as high pressures. High well flow rates ( 4000 gallons per minute) have been observed [10] but no long-term flows have been demonstrated. Sustalned flow requires continued migration of water from the thick shales into the broad sand layers and this remains to be tested.

\section{Producing Energy}

Three kinds of energy may be obtained from water produced from geopressured strata: (a) geohydraulic energy from the high pressure water arriving at the surface at pressures in excess of 2000 psig; (b) natural gas dissolved In the water; and (c) geothermal energy from the heat in the produced water. Figure 2.2 .3 shows sahematically a proposed surface energy recovery system based on a medfum temperature aquifer which is described In Figure 2.2.4.

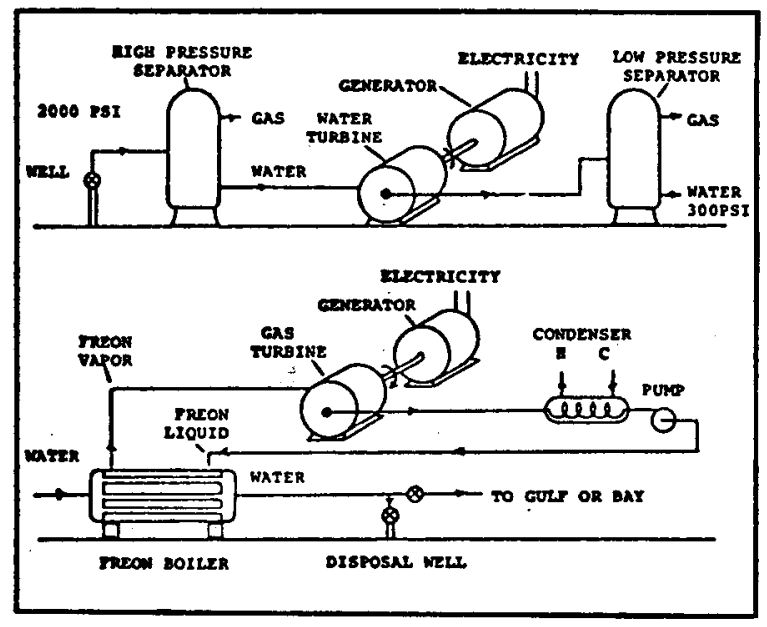

Figure 2.2.3 SCHEMATIC OF SURFACE INSTALLATIONS USED TO CAPTURE ENERGY FROM GEOPRESSURED WATER WELLS [10]<smiles>[Li]</smiles>

SORCE: [10]

F1gure 2.2.4 WELL AND AQUIFER DATA 
Water leaves the well at $2000 \mathrm{psig}$ and $260^{\circ} \mathrm{F}$, after which some gas is removed by the high pressure separator. H1gh pressure water then runs a water turbine to generate electricity, after which the remainder of the solution gas 18 removed by the low-pressure separator. Th1s water, st111 near $260^{\circ} \mathrm{F}$, is then passed through a Freon boller which generates Freon "steam" to run a gas turbine, generating more electriclty. The Freon emerging from the turbine 18 cooled, liquefied, and rectrculated to the boller. Water leaving the botler is relnfected into shallow normally-pressured sands; or, where possible, released to the Gulf of Mextco.[10]

There 18 much that 18 not known about waters in the geopressured strata. One important unknown is the amount of dissolved gas in the water. Figure 2.2.5 shows that water at $260^{\circ} \mathrm{F}$ at 8000 to $10,000 \mathrm{ps} 1$ can hold about 30 cublc feet of gas in solution in each barrel of water. There is general consensus among petroleum engineers that geopressured water is saturated with natural gas but data supporting this opinion are somewhat Ifmited. Other unknowns are (a) the extent and interconnection between geopressured water-bearing reservolrs and (b) the rates at which wells can be expected to produce.

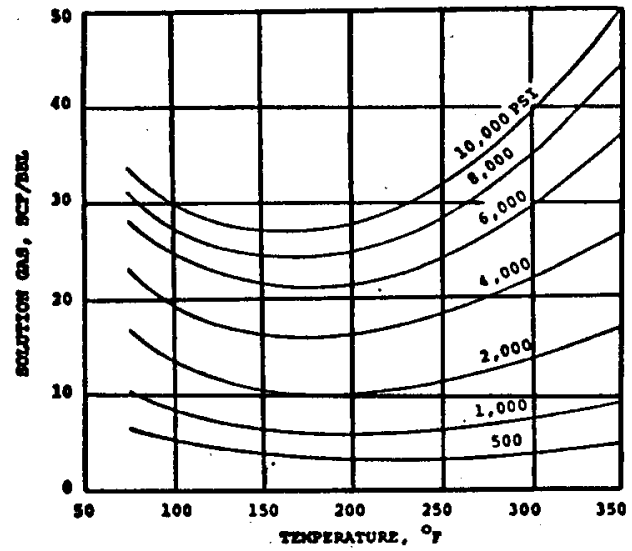

Figure 2.2.5 SOLUBILITY OF METHANE IN WATER (AFTER CULBERSON AND MCKETTA, 1951) [10]

Uaing well and aquifer data given In Figure 2.2.4, Parmiglano [10] predicts the performance of a typical Gulf Cosst geopressured water well as shown in Figure 2.2.6. As indicated, such a well w111 flow at 80,000 barrels per day, or more, and at surface pressures above 2000 palg for a pertod of 15 years. It w111 flow for at least another 30 years at 80,000 barreli per day but at surface pressure below 2000 psig as the aquifer gradually loses pressurlzation. These data (summarized in F1gure 2.2.7), were used by Durham [10] to estimate the we11 power production; a summary of his findings $1 \dot{s}$ presented in Figure 2.2.8. This figure 11lustrates the three kinds of energy which one well could produce, a total. of 15 megawatts, as suming all forms are converted into electricity. In preparing Figure 2.2.8 it was assumed that all of the energy would be used to produce electriclty, and the conversion efficiencles have been based on this premise.

FIgures 2.2.9 and 2.2.10 present estimated data on the economics of producing electriclty from geopressured water. For the data in Figure 2.2.9 it was assumed that three geopressure energy wells can be located in a cluster; these wells terminate in three different

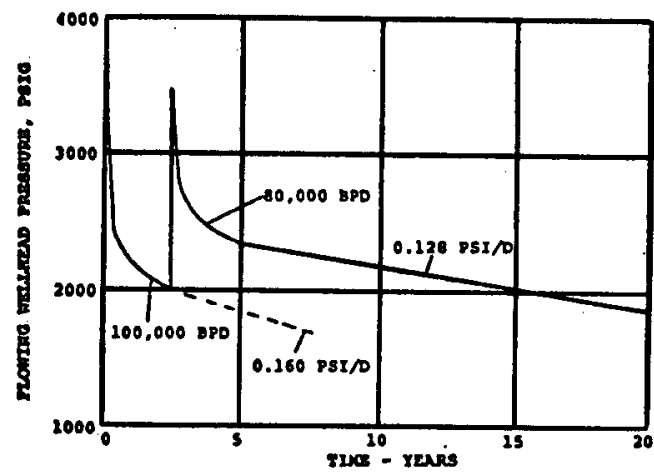

FIgure 2.2.6 SURFACE PRESSURE AND FLOW RATE HISTORY PREDICTED FOR A GEOPRESSURED WELL [10]

\begin{tabular}{lc}
\hline WELL FLOW RATE & $80,000 \mathrm{BWPD}$ \\
FLOWING SURFACE PRESSURE & $2,000 \mathrm{PSIG}$ \\
WELLHEAD WATER TEMPERATURE & $260^{\circ} \mathrm{F}$ \\
NATURAL GAS CONTENT OF WATER & $30 \mathrm{SCF} / \mathrm{BBL}$ \\
GAS PRODUCTION RATE & $2,400 \mathrm{MCF} / \mathrm{DAY}$ \\
GAS HEATING VALUE & $1,000 \mathrm{BTU} / \mathrm{SCF}$ \\
WATER TEMPERATURE AT DISCHARGE & $100^{\circ} \mathrm{F}$ \\
\hline
\end{tabular}

FIgure 2.2.7 DATA FOR POWER PRODUCTION ESTIMATE [10]

\begin{tabular}{|l|c|c|}
\hline KIND OF ENERGY & $\begin{array}{c}\text { CONVERSION } \\
\text { EFFICIENCY } \\
\text { (PERCENT) }\end{array}$ & $\begin{array}{c}\text { ELECTRIC } \\
\text { POWER } \\
\text { (MEGAWATTS) }\end{array}$ \\
\hline MATURAL GAS & 25 & 7.5 \\
GEOHYORAULIC & 75 & 1.5 \\
GEOTHERMAL & 11 & $\underline{6.0}$ \\
TOTAL & & 15.0 \\
\hline
\end{tabular}

FIgure 2.2.8 POWER PRODUCTION ESTIMATE [10]

ASSUME 3 WELLS FOR A PLANT $=45$ MEGANATTS
3 WELLS AND DISPOSAL FIELD $=\$ 10,000,000$
SURFACE POWER STATION $=\$ 7,000,000$
TOTAL COST
COST PER KW

F1gure 2.2.9 GEOPRESSURE INSTALLATION ECOWOMICS [10] 
geopressure reservoirs (total of 45 megawatts). It 1 s estimated that the geopressure source wells and a disvsal well field will cost some $\$ 10,000,000$. The cost the surface facillties is estimated at $\$ 7,000,000$, Which is approximately equal to the cost of a 45 megawatt generating plant designed to burn natural gas. The design of the geopressure plant would be considerably different, but much of the electrical machinery would be similar to a conventional power plant. Based on these concepts, the installed cost of a geopressure facility to generate electricity is about $\$ 380$ per installed kilowatt. This compares favorably with costs for nuclear power in the $\$ 350$ to $\$ 700$ per kilowatt range.

Figure 2.2.10 presents an estimate of operating costs for a geopressure power installation. For the purposes of comparison, the geopressure energy source is treated as a "fuel" for the electrical generating plant. On this basis 1 t is estimated that the geopressure energy sources will cost about $1.25 \mathrm{mils} / \mathrm{kWh}$ as compared to an expected cost of fuel for nuclear power on the order of $1.5 \mathrm{mils} / \mathrm{kWh}$. [10] In summary, it would appear that geopressure energy for electricity generation is economically competitive with nuclear power. If environmental factors (discussed in Section 4.5) require the use of additional equipment when using this energy source, costs could be higher than those presented above.

$$
\begin{array}{ll}
\begin{array}{l}
\text { OPERATING COST FOR } 3 \text { SOURCE } \\
\text { WELLS PLUS DISPOSAL FIELD }
\end{array} & =\$ 500,000 / Y R \\
\text { RAW POWER PRODUCED } & \text { 口 } 400 \times 10^{6} \mathrm{KW}-\mathrm{HR} / \mathrm{YR} \\
\text { RAW POWER COST (FUEL COST) } & =1.25 \mathrm{MILS} / \mathrm{KW}-\mathrm{HR}
\end{array}
$$

\section{Figure 2.2.10 GEOPRESSURE OPERATING ECONOMICS}

$$
\text { [10] }
$$

Figures 2.2.11 and 2.2.12 add additlonal perspective to the amount of energy that might be avallable from geopressured water. F1gure 2.2.11 shows a comparison of the natural gas production possible and provides a comparison with current production for Louisiana and the United States. Figure 2.2.12 shows a comparison of the electrical power potentially available from geopressure sources with present power consumption in Loufsiana and the United States.

\begin{tabular}{|lcc|}
\hline 500 WELLS & .447 TCF/YR \\
TOTAL GAS OVER 15 YR. LIFE $=6.50 \mathrm{TCF}$ \\
TOTAL GAS OVER 30 YR. LIFE $=13.00 \mathrm{TCF}$ \\
COMVENT IONAL SOURCES & $\cdot$ &. \\
& $\begin{array}{c}\text { PRODUCTION } \\
\text { RATE } \\
\text { (TCF/YR) }\end{array}$ & $\begin{array}{c}\text { RESERVES } \\
(1-1-72) \\
(T C F)\end{array}$ \\
$\begin{array}{l}\text { STATE OF LOUISIANA } \\
\text { (INC. OFFSHORE) } \\
\text { UNITED STATES }\end{array}$ & 8 & 80 \\
\hline
\end{tabular}

Figure 2.2.11 NATURAL GAS FROM GEOPRESSURE WATER [10]

Maasberg and Osborn [2] have also made an estimate of geopressure power development. The known geopressured Gulf Coast area covers 150,000 square miles. If only one-third, or 50,000 square miles, ts assumed productive and sites consisting of ten wells each are assumed,

\begin{tabular}{|c|c|c|}
\hline & $\begin{array}{l}\text { MEGAWATTS } \\
\text { OF POWER } \\
\end{array}$ & $\begin{array}{l}\text { CUBIC FEET OF } \\
\text { GAS PER DAY }\end{array}$ \\
\hline ONE WELL & 9 & 1.6 MILLION \\
\hline ONE POWER SITE & 90 & 16.0 MILLION \\
\hline 500 POWER SITES & 45,000 & 8.0 BILLION \\
\hline \multicolumn{3}{|l|}{ ASSUMPTIONS } \\
\hline \multicolumn{3}{|c|}{ - 1600 GAL/MINUTE/WELL } \\
\hline \multicolumn{3}{|c|}{ - 450 $\mathrm{F}$ WATER } \\
\hline \multicolumn{3}{|c|}{ - 30 CU.FT. OF GAS/BARREL } \\
\hline \multicolumn{3}{|c|}{ - 20 YEAR PRODUCTION PERIOD } \\
\hline
\end{tabular}
then some 500 sites are practical. Using the assumptIons for a well performance given in Figure 2.2.13,

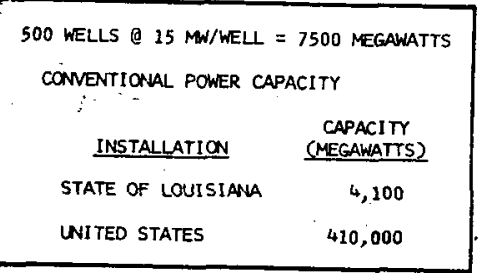

FIgure 2.2.12 GEOPRESSURE POWER [10]

Figure 2.2.13 ENERGY POTENTIAL OF THE GULF COAST GEOPRESSURE ZONE [2]

they calculated a power potential of 9 MWe and gas production of 1.6 million cubic feet per day per well. This gives an estimated total production potential of 45,000 MWe and 8 billion cublc feet gas per day for at least 20 years.

Durham [10] In his estimate ( $7500 \mathrm{MWe}$ ) did not claim his total as a maximum possible for the Gulf coast. Using either his estimate or the estimate of Masberg and Osborn $(45,000 \mathrm{MWe})$, the potential of the resource is clearly very high: and of potentially great importance to the national energy capability. Interestingly, the estimates for the year 2000 given by experts interviewed In this study for the geopressure potential (Section 3.1) agree closely with Maasberg and Osborn.

Power Extraction from the Hot Dry Rock Geotherma1 Resource

In many places, such as in the western United States, Alaska, and Hawaii, useful hot rock is close enough to the earth's surface to be easily accessible using conventional: drilling techniques.

At present, however, geothermal energy from this source, is used only. in the relatively few places where here the natural circulation of groundwater in permeable reservolrs overlaying the basement hot rock causes the heat to be conducted upward and then to be trapped in the form of steam.

However, the reservoir of geothermal energy contained by hot dry rock is so vast, so broadly distributed, and in many accessible places so hot that it constitutes a geothermal reservolr deserving very serious technical attention. Based on many recent heat flow measurements, the Los Alamos Atomic Energy Laboratory [11,12] and the Battelle Pacific Northwest Laboratory [13] have started research profects aimed at extracting and utilizing this geothermal heat. 
Studies by Potter $[14,15]$ and Blackwell [16] based upon measured heat flow data and temperature versus depth data, have been used to estimate in a semi-statistical fashion the probability of finding a given temperature at a given depth. Using this technique, Figure 2.2.14 was calculated, listing the estimated probability, in the form of a percentage distribution, of a given temperature range for two specified depths, 5 and $6 \mathrm{~km}(16,400$ and 19,700 feet), for the 13-state western region being considered. In making this calculation, a mean depth to basement rock of $2.5 \mathrm{~km}$ ( 8200 feet) was used, along with the appropriate thermal conductivity values for sedimentary and crystalline basement rock.

\begin{tabular}{|c|c|c|c|}
\hline $\begin{array}{l}\text { PROBABLE } \\
\text { AREAL } \\
\text { DISTRIBUTION }\end{array}$ & $\begin{array}{l}\text { HEAT FLOW } \\
\text { RANGE } \\
\text { HFU: }\end{array}$ & $\begin{array}{l}\text { RESERVOIR TEMPERA } \\
\text { TO A DRILLED HOLE } \\
5 \mathrm{KM}(16,400 \mathrm{FT})\end{array}$ & $\begin{array}{l}\text { ATURE RANGE CORRESPONDING } \\
\text { DEPTH (DEEPER HOLE) OF: } \\
\text { (6 KM(19,700 FT) }\end{array}$ \\
\hline $20 \%$ & $<1.6$ & $\begin{array}{l}<158^{\circ} \mathrm{C} \\
\left(316^{\circ} \mathrm{F}\right)\end{array}$ & $\begin{array}{l}<180^{\circ} \mathrm{C} \\
\left(356^{\circ} \mathrm{F}\right)\end{array}$ \\
\hline 308 & $1.6-2.1$ & $\begin{array}{c}158-203^{\circ} \mathrm{C} \\
\left(316-397^{\circ} \mathrm{F}\right)\end{array}$ & $\begin{array}{c}180-233^{\circ} \mathrm{C} \\
\left(356-451^{\circ} \mathrm{F}\right)\end{array}$ \\
\hline 338 & $2.1-2.6$ & $\begin{array}{c}203-248^{\circ} \mathrm{C} \\
\left(397-478^{\circ} \mathrm{F}\right)\end{array}$ & $\begin{array}{c}233-285^{\circ} \mathrm{C} \\
\left(451-545^{\circ} \mathrm{F}\right)\end{array}$ \\
\hline 108 & $2.6-3.1$ & $\begin{array}{c}248-293^{\circ} \mathrm{C} \\
\left(478-560^{\circ} \mathrm{F}\right)\end{array}$ & $\begin{array}{c}285-337^{\circ} \mathrm{C} \\
\left(545-639^{\circ} \mathrm{F}\right)\end{array}$ \\
\hline 78 & $>3.1$ & $\begin{array}{l}>293^{\circ} \mathrm{C} \\
\left(560^{\circ} \mathrm{F}\right)\end{array}$ & $\begin{array}{l}2337^{\circ} \mathrm{C} \\
\left(639^{\circ} \mathrm{F}\right)\end{array}$ \\
\hline
\end{tabular}

F1gure 2.2.14 PROBABLE DISTRIBUTION OF HOT ROCK RESERVOIR TEMPERATURES FOR THE WESTERN THIRD OF THE UNITED STATES (BASED ON A MEAN SEDTMENTARY TH ICKNESS OF $-2.5 \mathrm{~km}$ OVERLYING THE TOP OF THE CRYSTALLINE BASEMENT ROCK [17]

From an examination of Figure 2.2.14 1t may be concluded that a hot rock reservoir temperature level in excess of $290^{\circ} \mathrm{C}\left(550^{\circ} \mathrm{F}\right.$ ) (a very appropriate reservolr temperature level for surface electrical power generating power plant) can be achleved by drilling to a depth of about $5 \mathrm{~km}$ anywhere within a 95,000 square mile broadly distributed region of the western United States, Alaska, and Hawali. This area is over 30 times greater than the present total KGRA area 1isted by the USGS for potential geothermal hot water and steam development.

Hot dry rock contains a vast amount of heat energy. Morton Smith [12] gives an example of this by considering a quantity of this rock four miles by five miles in horizontal area and two miles thick. This 40 cubic miles of granite, when cooled from 290 to $90^{\circ} \mathrm{C}$, a $\Delta \mathrm{t}$ of $200^{\circ} \mathrm{C}$, would give $6.8 \times 10^{16} \mathrm{Btu}$. This is the total amount of energy used for all energy purposes in the United States in 1970. obviously, if a practical and economical method for extracting energy from these known reservotrs of hot dry rock can be developed, then this geothermal resource is very, very large.

\section{Power Plant S1te}

Both the Los Alamos Atomic Energy Laboratory and Battelle Pacific Northwest Laboratory are developing hot dry rock power plant concepts which are similar and are 11lustrated by F1gure 2.2.15. Such a power site would probably be developed in the following manner.

The accessible and avallable land near a spectfled load center would be surveyed for sultable near surface heat

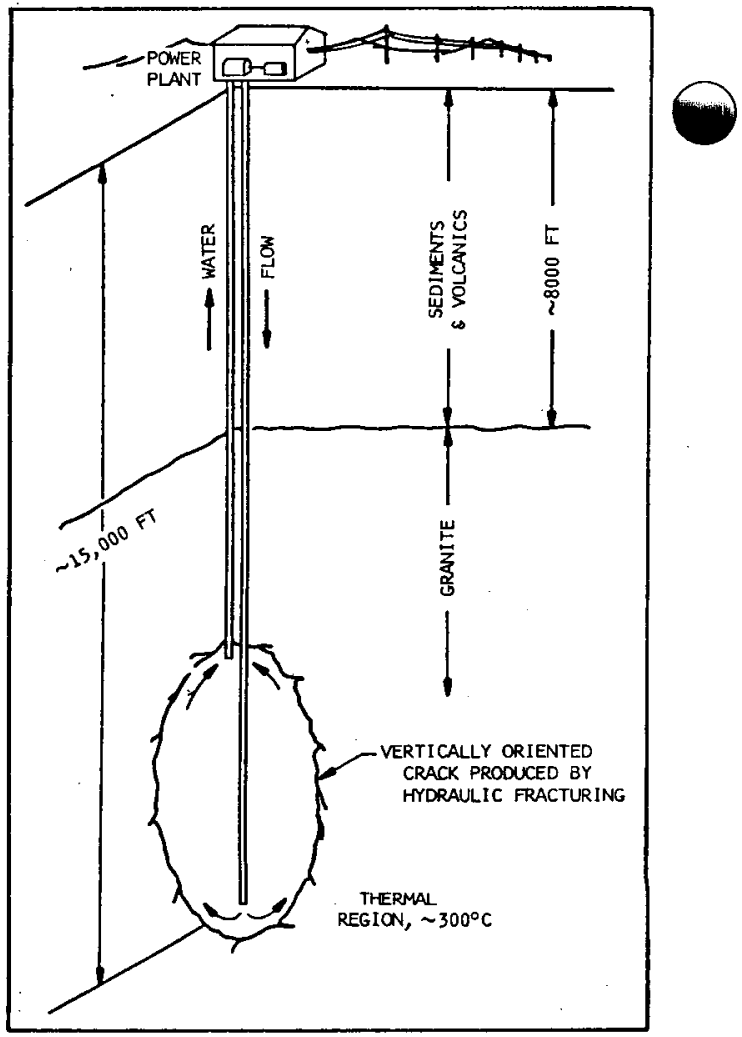

FIgure 2.2.15 TYPICAL DRY-ROCK GEOTHERMAL-ENERGY SYSTEM PRODUCED BY DRILLING AND HYDRAULIC FRACTURING [17]

flow and favorable geology. From a geological standpoint, it would be desirable for the potential power plant site to be in an area free of major active faults or other obvious geologlcal structural complexitles, and with reasonably competent rock at the projected reservoir depth. Having done this, the first hole (the deeper one) would be drilled with a diameter of 9 to 12 inches to the projected depth of about 15,000 feet. Since this rock would be elther granite or basalt, the drilling will be much tougher than the conventional oil well drilling which is usually in sedimentary rocks such as IImestone and sandstone. Nevertheless, the testing which has been done so far Indicates that conventional diamond drilling techniques can be used in the hot dry granite and basalt even though the drilling rate is onethird to one-fourth that for sedimentary rocks. [17]

After completing the drilling of the first hole, a large hydraulic serles of fractures would be formed at or near the botton of this hole using methods that are common in the ofl well service industry. This is done, using a high pressure pump at the surface, by pumping water down a high pressure line extending through a seal Inserted just above the bottom of the hole. Fleld experience and mathematical analysis Indicate that the resulting series of fractures would be in the form of thin vertically orfented discs of eliptical cross section as shown in Figure 2.2.15. Diagnostic measurements obtained during the hydraulic fracturing operation w111 be used to determine the orlentation of the fracture system. It 1s possible to obtain hydraulic fracture cracks 4000 feet away from the bottom of the hole. 
The second hole will be drilled several hundred feet away from the first (deeper) hole. This second hole ill be on a line perpendicular to the orientation of he fracture system formed at the bottom of the first hole. This hole will be the same diameter as the first hole but several thousand feet shallower. It will be drilled parallel to the first hole unttl adjacent to the upper portion of the fracture system, and then slanted (whipstocked) to Intersect the fracture system using directlonal drilling techniques.- After suffictent connection has been established through the fracture system connecting the two vertical drill holes, the entire fracture system will be enlarged to 1ts final dimensions by pumping additional quantitles of high pressure water.

Following this final fracturing operation, the two wells will be connected at the surface with high pressure plpIng, thus forming a complete flow loop. Circulation would be initiated with an auxiliary pump down the deeper hole through the fracture system up. the shallower hole, through the surface heat transfer system, and finally back down the deeper hole. Once a moderate temperature difference has been established between the ascending and decending legs of the loop, the auxlliary pump will not be requixed due to the density difference between the hot and cold water legs whlch w111 create a natural flow system.

A pressure of approximately 200 psla will be maintained at the surface of this flow system and obviously the pressure at the bottom will be considerably higher. Th1s high pressure water offers a very large heat transfer capability in extracting thermal energy from the thin cracks in the hot rock and gives a high heat transport rate through the pipe to the surface heat transfer equipment.

One of the critical parameters which has yet to be determined in a full-scale test is the heat transfer characteristics through the surrounding hot dry rock to the cracks and then into the pressurized hot water The present experimental data and analysis Indicate that the thermal conductivity of the surrounding rocks is high enough so that the hot water loop can draw on heat contalned in the rock as far as two miles away from the base of the deeper hole.

\section{Hydraulic Fracturing}

Hydraulic fracturing is a very common production stimulation technique used in the oil Industry to improve reservoir flow characteristics by creating a set of cracks in the producing formations adjacent to the we11 bore. Although there does not appear to be any depth. IImitation, hydraulic fracturing heretofore has been done in sedimentary rock; "However, a series of rock mechanics experiments recently completed at the Los Alamos Sclentific Laboratory has demonstrated that... hydraullc fracturing works equally well In 1 gneous and metamorphic rock. [12] morphic rock were of the order of the corresponding :overburdened compressive stress (about 1 psi per foot of depth). The resulting fractures are essentlally vertical, and more importantly, capable of containing pressurized water with little if any observed leak-off at the desired pressure levels. Therefore, this data Indicate hydraulic fracturing offers a method of producing a large crack surface area in the hot dry rock for heat transfer, and is relatively Inexpensive.

\section{Thermal Stress Cracking}

Extraction of heat from the rock penetrated by the hydraulic fractures w11 create thermal contraction stresses that should eventually be sufficlent to extend the initial crack system in three dimensions. Initially, the cooler rock next to the fracture surfaces will be restrained from contracting by the adjacent hot rock. These restraints w111 cause tensil stresses to be developed which after sufflclent cooling has occurred will exceed the tensil : strength of the rock; new cracks will then form along the surfaces of the initial hydraulic fracture system which w111 probably propagate far beyond the initlal cooled reglon. Both the amount of heat transfer surface and the total amount of heat available to the pressurized water circulating through the crack system should therefore increase continuously as heat is withdrawn from the geothermal reservoir. Calculations done on a typical well system show the varlation of geothermal power with time as given in Figure 2.2 .16 . [17]

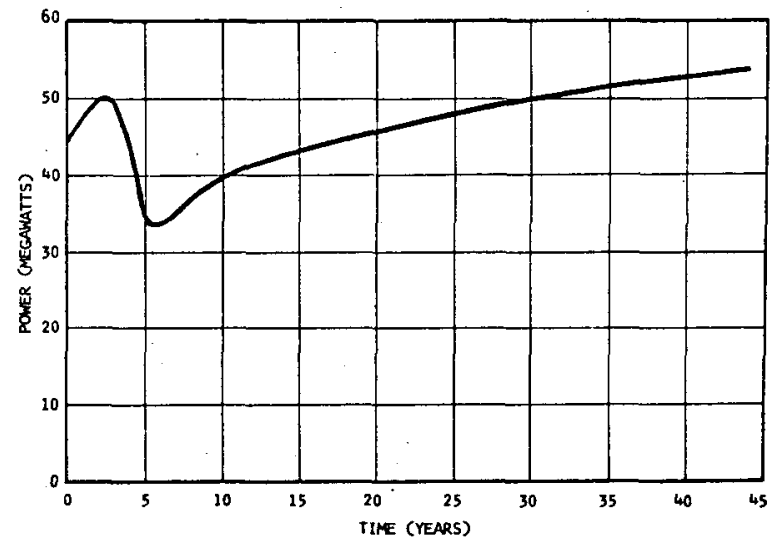

FIgure 2.2.16 POWER VS. TIME AT CONSTANT CALCULATION RATE [17]

\section{Hot Dry Rock Commerclal Power Plant Concept}

A concept for a hot dry rock geothermal energy system 18. shown 1n. Figure $2,2.17$. [12]. The Los Alamos group has selected a dual cycle power generating system as most appropriate. This uses a conventional steam cycle for the higher temperatures and an isobutane vapor cycle for the lower temperatures. Also, due to the shortage of cooling water in the West, the plant 18 shown using air cooled condensers. Figure. 2.2.17 gives the heat and material.balances for the system. Th1s Indicates a total. net power production of $50.7 \cdot \mathrm{MW}$ at a net effictericy of 18.8 percent.

\section{Electrlcity Production Economics}

The economics of an electrical power generating system In the western. United States based on this hot dry rock geothermal energy concept appear to be very favorable based on preliminary analysis. However, it should be remembered that no dual cycle power plant has been bullt so that the estimated costs given are speculative. On the other hand, geothermal power generating plants operating at a turbine inlet steam condition somewhat lower than those shown In FIgure 2.2.17 are now operating at The Geysers. In the United States and at Cierro Prieto in 


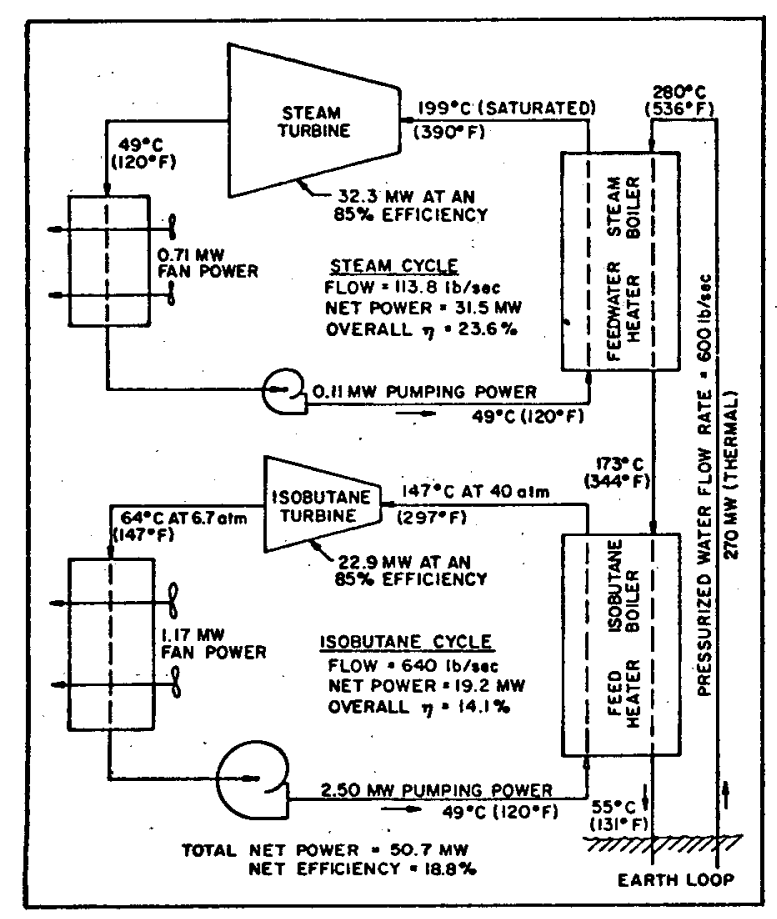

Figure 2.2.17 POSSIBLE DUAL-CYCLE POWER GENERAT ION SYSTEM [17]

Mexico. The capital costs of the surface power plant for both of these Installations was about $\$ 110$ per kWe Installed capacity (1974).

Al though no actual cost data are available for organic vapor cycle power generating plants, estimates have been made. These estimates give a profected capital cost for a 100 Me plant size of $\$ 125$ per kWe installed capacity (1970 dollars). [17] Using these data the estimated capital cost for a 100 MWe dual cycle hot dry rock power plant are estimated at $\$ 185$ per $k W$ for a unft coming on-line in 1975 . The associated drilling and fracturing costs for two pairs of holes is estimated to be $\$ 6.2$ million, giving an overall cap1tal cost of $\$ 247$ per $\mathrm{kWe}$, as shown in Figure 2.2.18. The holes would be drilled to depths of $4.2 \mathrm{~km}(13,000$ feet) and $5 \mathrm{~km}(16,400 \mathrm{feet})$, respectively. The est1mated overall electricity generating costs for this system are $6.3 \mathrm{mflls}$ per $\mathrm{kWh}$ as calculated by the Los Alamos group. This $1 \mathrm{~s}$ a low figure and very competitive with the electricity generating costs by other methods such as nuclear and coal. Indeed, even if the actual cost is twice this, 12 mills per $\mathrm{kWh}$, the cost would still be competitive.

\section{Environmenta1 Problems $[11,12]$}

In drilling the holes for a hot dry rock system, the same precautions normally taken in drilling for ofl and gas should result in no contamination of groundwater in the rocks and soil above the granite. Therefore, the pressurized water energy system will be completely contained and should be entirely non-polluting.

Since the energy extraction loop is relatively narrow, deeply burled in strong, competent rock, and always full of water under a pressure at least equal to the pore pressure of any fluid originally in the reservoir, it should produce no subsidence of the earth's surface either during operation or even after abandonment.

Sma11 earthquakes have been stimulated in the Denver and Rangely areas of Colorado by the injection of large volumes of pressurized water into active fault systems. However, there have been no earthquakes in these areas when the fluld was injected into the same formation at places short distances away from the active faults. Therefore, the evidence is good that by simply avoiding active faults, seismic risk associated with a manmade hot dry rock geothermal power system can be reduced to essentially zero. However, the geothermal system should be continuously monitored.

\section{Hot Water Total Flow as an Energy Source}

The geothermal research group at Lawrence Livermore Laboratory [18] has proposed a "total flow" concept for recovering the energy from the hot concentrated brines of the Imperial Valley, California. These brines are very corrosive and contain 5 to 30 percent dissolved salts. These adverse conditions have prevented the use of a Walrakef, New Zealand type steam flash system so far because of numerous problems assoclated with scaling, corrosion, plugging, and concomitant low efficiency.

The proposed method consists of allowing the brine to expand to the surface as is now being done at Walrake1 and at Cerro Prieto, and then expanding the total fluid stream through a convergent/divergent nozzle. The kinetic energy of the entire fluld stream would then be used in a corrosion-resistant impulse turbine, modeled after typical hydroelectric devices, to drive an electrical generating system. Theoretically, this method should produce about 1.6 times as much power from a given well as either the flashed steam system or the binary fluid system. Since fewer mechanical components are required at the surface, capital costs should be less, despite the need to protect against corrosive brines.

The enthalpy drop is calculated by subtracting the enthalpy at the nozzle exit from the inlet enthalpy (562 Btu/1b. and $360 \mathrm{psia}$ ). The exit value is found by assuming an isentropic expansion to the turbine operating pressure, which is get by the condensing temperature. For the wellhead conditions shown in Figure 2.2.19, the ideal velocity is about $2400 \mathrm{fps}$ for a condenser temperature of $120^{\circ} \mathrm{F}$ at $3.5 \mathrm{In.} \mathrm{Hg.} \mathrm{The} \mathrm{1deal} \mathrm{power} \mathrm{output}$

\begin{tabular}{|c|c|c|c|c|}
\hline & POWER PLANT TYPE & $\begin{array}{l}\text { POWER PLANT } \\
\text { SIZE } \\
\text { MWE }\end{array}$ & $\begin{array}{l}\text { SYSTEM } \\
\text { CAPITAL COST } \\
\text { DOLURS/KN }\end{array}$ & $\begin{array}{l}\text { GEERATING } \\
\text { COST } \\
\text { MILS/KNH }\end{array}$ \\
\hline \multicolumn{5}{|c|}{ 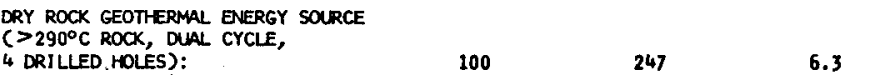 } \\
\hline BASIS: & \multicolumn{4}{|c|}{$\begin{array}{l}\text { 0.17 ANWALL CAPITAL CHARGE RATE. } \\
\text { USE FACTOR }=808 \text { OF RATED CAPACITY. }\end{array}$} \\
\hline
\end{tabular}

Figure 2.2.18, ESTTMATED PLANT AND GENERATING COSTS FOR THE YEAR 1975 [17] 


\begin{tabular}{|c|c|}
\hline PRESSURE, $P$ & 360 PSIA \\
\hline VOLIME, $\mathbf{v}$ & $0.259 \mathrm{FT} 3 / \mathrm{LB}$ \\
\hline TEMPERATURE, $T$ & $434{ }^{\circ} \mathrm{F}$ \\
\hline ENTHALY, $\mathrm{b}$ & 562.5 BTU/LB \\
\hline QuALITY, $x$ & 0.189 \\
\hline DEPTH & $5100 \mathrm{FT}$ \\
\hline FLOW RATE, W/A & $500 \mathrm{LB} / \mathrm{SEC} / \mathrm{FT}^{2}$ \\
\hline VELOCITY, $v=w / A$ & $130 \mathrm{FT} / \mathrm{SEC}$ \\
\hline VAPOR VOLUNE/LIQUID VOLURE, $v_{v} / v_{L}$ & 16 \\
\hline
\end{tabular}

Figure 2.2.19 WELLHEAD PRODUCT CHARACTERISTICS [18]

In terms of $\mathrm{MW} / \mathrm{ft}^{2}$ of wellbore area is a function of condenser pressure. For a backpressure of $3.5 \mathrm{In}$. Hg at $120^{\circ} \mathrm{F}-\mathrm{a}$ practical value for this application--the ideal power output $1863.1 \mathrm{MW} / \mathrm{ft}^{2}$. For other wellhead conditions, the ideal power output will, of course, have other values.

The point is that the thermal energy in the entire wellhead product is converted to kinetic energy which is then converted to electrical energy by an impulse turbine. The advantage of this method 18 that most of the thermal energy 1s used for power production. In comparison, the flashed steam system uses only the energy contained in the flashed vapor to drive a turbine, with the remalning energy discarded with the separated hot brine.

The ideal power output of $63.1 \mathrm{MW} / \mathrm{ft}^{2}$ assumes a perfect turbine and an isentropic nozzle. The actual power output, however, will be less because of non-1deal flow in the nozzle and losses in the turbine. The wheel eff1clency should be about 0.9 (nozzle coefficlents of about 0.9 are not unreasonable even for the two-phase flow, In which the mass of vapor is 20 percent of the total). Hence an overall efficlency value of $0.73 \mathrm{is}$ a reasonable design goal and would lead to an expected power output of $46.0 \mathrm{MW} / \mathrm{ft}^{2}$ of well cross section.

Figure 2.2.20 shows the expected power output $/ \mathrm{ft}^{2}$ of well cross section area. The total flow system is compared to a steam flash system (Wairake1) and to a binary flutd (1sobutane). system. All three systems were estimated on the same inlet well conditions as given in Figure 2.2.19. The system efficlency in Figure 2.2.20 is defined as the ratio of the electric energy generated to the recoverable energy from the wellhead product. Thus, 60 percent more power is likely to be avallable from a given well using the total flow system than from either alternate system.

\begin{tabular}{|l|l|c|c|}
\hline SYSTEM & $\begin{array}{c}\text { IDEEL POWER } \\
\text { OW/FT2) }\end{array}$ & $\begin{array}{c}\text { EXPECTED } \\
\text { PWER } \\
\text { (MW/FT2) }\end{array}$ & $\begin{array}{c}\text { ESTIMATED PRACTICAL } \\
\text { SYSTEM EFFICIENCY }\end{array}$ \\
\hline FLASTED STEAM & 39.5 & 27.7 & 11 \\
EINARY FLUID & 40.4 & 28.3 & 11 \\
TOTAL FLOW & 63.1 & 44.2 & 18 \\
\hline
\end{tabular}

P1gure 2.2.20 EXPECTED POWER OUTPUTS [18]
This Increased power is expected because the total flow system uses the entire mass flow and, hence, gives a higher conversion efflclency. The flashed steam aystem uses only 29 percent of the mass as ateam to drive the turbine while discarding the remalning as hot brine at $338^{\circ} \mathrm{F}$. The two-fluld system refects all of the brine at $300^{\circ} \mathrm{F}$. Reinjection of the hot brine 18 possible with all systems, so part of the rejected energy is returned to the reservolr.

\section{Turbine Choice}

While there 18 a wde variety of turbines, they generally can be divided into two classes. In an impulse turbine thermal energy is converted to kinetic energy by a pressure drop through a nozzle only. The fluid's kinetic energy is then converted to rotational energy when the steam 1mpinges on a vane or bucket attached to a wheel. There 18 almost no pressure drop through the rotating components. The reaction turbine, usually used to recover energy from high pressure gases, operates by allowing the gas to expand as it passes through the rotating vanes, and this expansion is accompanted by a pressure drop. Very close tolerances are used between the vanes and housings or stators to prevent the fluid from bypassing the rotating components.

Therefore, there are two possibilities for recovering energy from, the full fluld stream: expanding the twophase mixture through a nozzle to obtain h1gh velocity fets that are used to drive an impulse turbine, with the entire pressure drop occurring in the nozzle, or expandIng the two-phase mixture through a reaction turbine where both a velocity change and a pressure drop occur. An axial flow reaction turbine has a higher efficiency, normally operates at higher speeds, requires multiple stages, and is generally more complex requiring very small clearances to maintain the pressure drop/stage. But a multi-stage turbine cannot be expected to function rellably when driven directly by a mixture of vapor, brine, silica, and, probably, sand and other extraneous materials.

This nature of the geothermal working fluid requires that the turbine be almple and easily maintained; the impulse turbine therefore appears to be the better cholce. The most common impulse turbine is the axial flow configuration in which the fluld is fed through a serles of nozzles located around the wheel pertphery. Blade friction, leakage past the blade, turbulence, and fanning will reduce efficlency. In addition, large axial forces can be developed, and control of vibration is always a serlous factor in axlal flow turbine deslgn.

Other Impulse turbine alternatives include radial and tangential flow configurations, and these appear to be most promlaling for the brine application. They are shown schematically in Figure 2.2.21. The radial flow device shown 18 simllar to the Francis hydraulic turbine except that nozzles are used in place of inlet gulde vanes. Proper selection of the rotor inlet and outlet vane angles w111 direct the exit fluld radially inward with no tangentlal velocity component (whirl). In principle, the blade efficlency for this condition can be 100 percent. This 1s unlikely, however, since turbulence losses will occur, and it may be necessary to select vane angles to give some whirl to the extt fluld. The advantages of the radial flow impulse turbine are high efficlency, reduced fanning losses, flexibility in cholce of nozzle angle, reduced 108 ses by fet dispersal, and minimal vibration problems. There are $f e w$ vibration problems because the nozzles lie in the plane of the wheel, producing low axial forces.

The tangential flow turbine shown in Figure 2.2 .16 is modeled after the Pelton wheel. Although it has only 


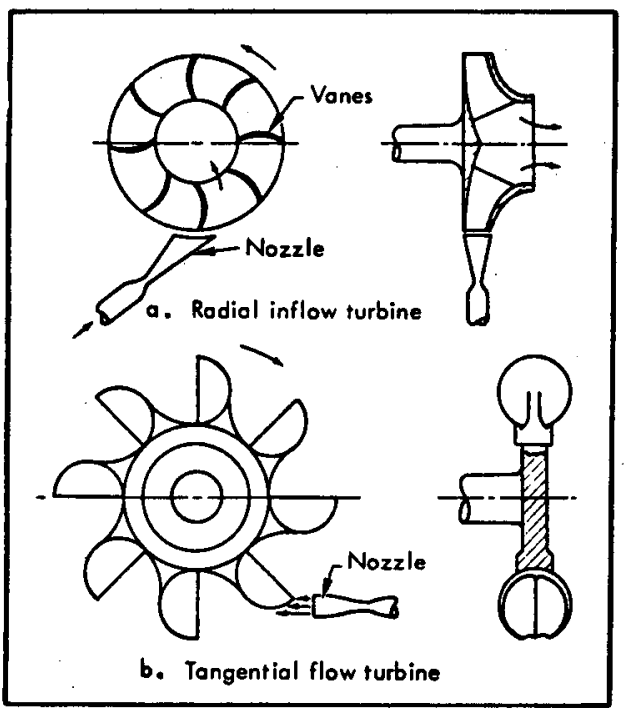

Figure 2.2.21 TOTAL FLOW IMPULSE TURBINE CONCEPTS [18]

been used as a hydraulic turbine, there is no fundamental reason why it cannot be operated with a twophase fluid. This device can have an efficiency as hIgh as 95 percent, depending on bucket splitter angle and exit angle. Blade friction, of course, may be important, but the major losses (and disadvantages) w11 probably result from fanning and jet dispersal, since the nozzles must be placed some distance away from the buckets. The major advantages, however, are inherent high efficiency, simpliclty of fabrication (and resultant low cost), low potentlal for vibration, and ready maintenance of the buckets. This latter point may be very important since the working fluid may be very corrostve.

Typically, hydraulically-operated devices of these types exhibit wheel efflciencies greater than 90 percent. No data exist for operation in the two-phase flow regime, and $1 \mathrm{t}$ is not possible to report efficlencies for this operating condition. Nevertheless, there is no fundamental reason why gross differences should exist, so it seems reasonable that a two-phase total flow turbine could be developed which ylelds on the order of 90 percent efficiency. The efficlencies reported for the impulse turbines do not include the nozzle efficiency. Hence, nozzle efficlency is a critical factor. For wet steam, the nozzle coefficlent may be low because of the difference in velocitles of water droplets and vapor. Some data have been gathered for low quality steam flowing through a converging-diverging nozzle. The results Indicate that mixtures containing 20 percent vapor can be expanded with nozzle coefficlents of about 0.9 . Hence, it appears possible to achieve high nozzle coefficients $(0.9)$ by careful experimentation and testing to determine the optimum nozzle configuration. Therefore, it is reasonable to expect that impulse turbines could be constructed for two phase brine which will have an overall efficlency of about 80 to 85 percent.

\section{The Concept [18]}

To 1llustrate the nature of the design problem, one particular system is examined in some detall. It should be recognized that this example is intended only for illustrative purposes, and is not necessarily an optimum design. Figure 2.2.22 is an elevation view of an Installation with a radial inflow turbine. A nozzle coefficient of 0.9 is assumed, with wellhead conditions taken from Figure 2.2.18 as the input data for calculating nozzle exit conditions. For a condensing temperature of $120^{\circ} \mathrm{F}$ at 1.7 psia, Figure 2.2.23 describes the exlt conditions from nozzle to turbine and from turbine to condenser.

\begin{tabular}{|c|c|c|c|c|c|c|}
\hline $\begin{array}{c}\text { ExIT } \\
\text { CONDITION }\end{array}$ & $\stackrel{p}{p}$ & $(\xi)$ & $\stackrel{\mathrm{h}}{(\mathrm{BTU} / L \mathrm{~B})}$ & $\left(F T^{3} / L B\right)$ & $\begin{array}{c}\mathbf{v} \\
\text { (FPS) }\end{array}$ & $\underset{\left(F T^{2}\right)}{A}$ \\
\hline WELLEEAD & 360 & 0.19 & 562.5 & 0.26 & 130 & 1 \\
\hline NOZZLE OUTLET & 1.7 & 0.37 & 465.7 & 75.2 & 2205 & 17.1 \\
\hline TRBINE OUTLET & 2.7 & 0.37 & 465.7 & 75.2 & 965 & 17.1 \\
\hline
\end{tabular}

Figure 2.2.23 EXIT CONDITIONS FROM NOZZLE AND TURBINE [18]

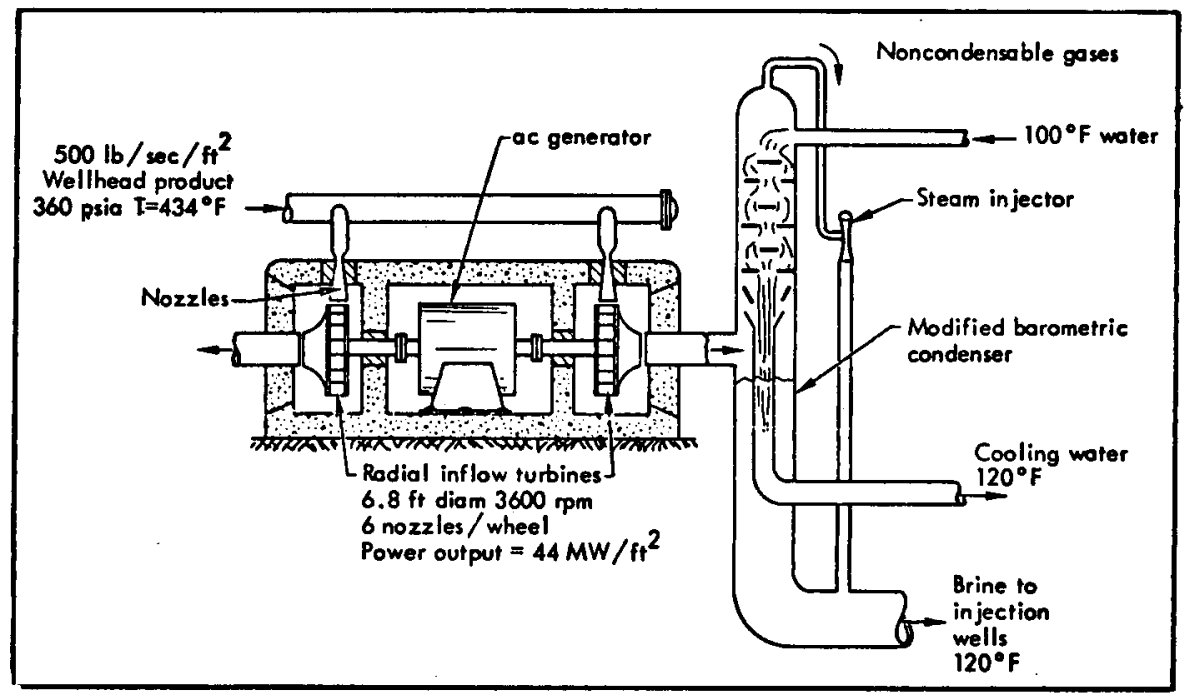

F1gure 2.2.22 SCHEMATIC OF A TOTAL FLOW SYSTEM 
Since the fet area is 17 times the inlet area, multiple ozzles and/or wheels w11 be necessary. The particutar system chosen for this example is a single generator operated by two turbines with six nozzles per wheel. In this case the turbines have a diameter of 6.8 feet, rotate at $3600 \mathrm{rpm}$, contain nine equally spaced vanes, and (with an assumed turbine efficlency of 90 percent) produce about $44 \mathrm{MW} / \mathrm{ft}^{2}$ of wellbore area. Hence, this power output requires two $9-5 / 8 \mathrm{in}$. $1 . d$. wells, each flowing at $250 \mathrm{lb} / \mathrm{sec}$.

This is not a large system compared to conventional hydraulic installations; however, the peripheral wheel opeed is much higher than usual and will result in high stress levels, somewhere between 50,000 and 70,000 ps 1 for a steel wheel. The stresses would scale down linearly with desntiy for lighter materials, but it may prove more effective to develop design alternatives that elther use lower mass flow rates per turbine or smaller nozzle angles or require pressure staging as a means of lowering peripheral wheel veloc1ty. A twostage device, for example, would reduce the peripheral velocity enough to lower the stress to 40 percent of its former value, but this requires a mare complex and possibly less efficient system. Nevertheless, many alternatives exist, and arriving at an optimized system should be a fundamental goal of a research and development program.

The barometric condenser can do the cooling (see Figure 2.2 .22 ) and could be modifled as indicated to allow return of the cooling water without excessive contamination by the exhaust brine. The cooling water can be fed through elther a cooling tower or a spray pond. Calculations indicate that for a cooling range of $20^{\circ} \mathrm{F}$, each 44-MW module (500-1b/sec flow) requires about 9000 $\mathrm{lb} / \mathrm{sec}$ of cooling water flowing between the condenser and pond. ThIs includes $170 \mathrm{lb} / \mathrm{sec}$ added from the condensed vapor. The evaporative cooling loss is calculated to be $172 \mathrm{lb} / \mathrm{sec}$. Depending on drift losses, there w11l be either a small net gain or loss in coolIng water flow. Disposal of the concentrated brine outflow from the barometric condenser will be accomplished by injection through a number of wells equal to the number of production wells and extending to about the same depth.

\section{Cost Estimates}

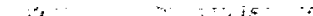

Estimating costs of an operating geothermal total fiow system is difficult, since nelther the materials nor machine design problems are solved and the optimum cooling aystem 1s unknown Nevertheless, it is desirable to make a crude economic evaluation to determine the relative range of geothermal costs.:

Assumptions
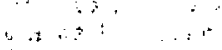

Assume the plant module is served by ten producing vells of 9-5/8-in. nominal production diameter driving 3 to 5 alternators, each with 2 turbines. In case the radial flow machine is used, each turbine would be driven from one well and 2 turbines could be used to drive one alternator, so there would be 5 turbine $\therefore$. alternator combinations in the module. With the tangential flow turbine, each wheel would be driven by one we11, with 4 wheels for each aiternator. Peak capacity of the module would be $220 \mathrm{MW}$ and with a load factor of 80 percent, the annual power production,. 1.53 billion $\mathrm{kWh}$.

\section{Capital Costs}

The major capital requirements include the production and reinfection wells, powerhouse and plant that houses and services the wells and turbo-generators, the turbine-alternators, and a high voltage substation. A hole loss factor of 0.2 has been assumed; that 18 , it is assumed that during drilling one of each five at tempts to complete a hole will be unsuccessful. These lost holes were distributed against the drilling costs of the completed wells at a value equal: to 75 percent of the base drilling cost without the completion tubing. The well 1ife is assumed to be 20 years. The estimates are shown below in Figure 2.2.24.

\begin{tabular}{|c|c|}
\hline $\begin{array}{l}\text { ORILLING AND CASING } 20 \text { WELLS, } \\
5000 \text { FT EACH } @ \$ 20 / F T\end{array}$ & $\$ 2,000,000$ \\
\hline $\begin{array}{l}\text { LOST HOLE ALLOWANCE, } \\
20,000 \mathrm{FT} \text { Q } \$ 15 / \mathrm{FI}\end{array}$ & 300,000 \\
\hline $\begin{array}{l}\text { SPECIAL TUBING, } 100,000 \mathrm{FT} \\
\text { a } \$ 22 / \mathrm{FT}\end{array}$ & $2,200,000$ \\
\hline CONTINGENCY If 158 & 675,000 \\
\hline SUBTOTAL & $\$ 5,175,000$ \\
\hline
\end{tabular}

F1gurë 2.2.24[18]

The capital investment for the remalnder of the factlity was estimated from New Zealand experience, approximately inflated to 1973. Note that all these costs (Figure 2.2.25) are higher than current fossil fired plants.

\begin{tabular}{|c|c|}
\hline $\begin{array}{l}\text { POWER HOUSE AND PLANT FACILITY } \\
\text { ( } \$ 49.50 \mathrm{~kW}\end{array}$ & $\$ 10,791,000$ \\
\hline $\begin{array}{l}\text { TURBINE AND GENERATOR } \\
\text { C } \$ 56.54 / \mathrm{KW} \text {. }\end{array}$ & $12,325,700$ \\
\hline COOLING SYSTEM @ $\$ 17.62 / \mathrm{KW}$ & $3,841,100$ \\
\hline $\begin{array}{l}\text { HIGH VOLTAGE SUBSTATION } \\
\text { \$11.11/KW }\end{array}$ & $2,421,900$ \\
\hline CONTINGENCY $15 \%$ & $4,406,900$ \\
\hline & $\$ 33$, \\
\hline
\end{tabular}

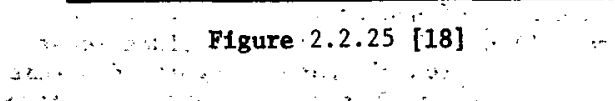

he drilling costs totaling $\$ 51.75 /$ ft compare favorably with the costs in New Zealand, which are $\$ 51.10 / \mathrm{ft}$ when Inflated to 1972-1973 dollars. F1gure 2:2,26 shows the total captal costs. Note that tubing costs-are highly uncertaln. However, even if these costs were-multiplied fivefold, the total capital costs increase to only.\$214/ $\mathrm{kW}$, which 18 st111 less than current systems. All capital construction costs- Include architect and enginee fees; land, iutilities, and services.

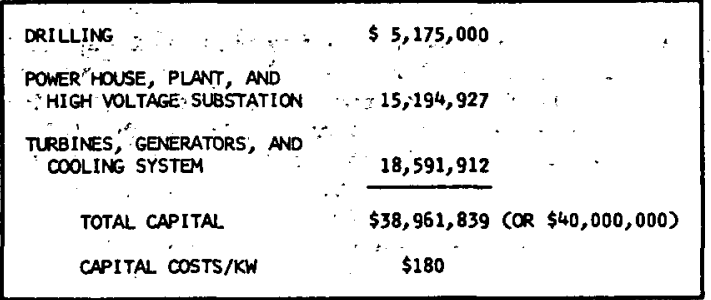

F1gure 2.2.26 CAPITAL COST SUMMARY [18] 


\section{Operating Costs}

A well production 11fe of 20 years was assumed, but replacement of the production tubing was assumed every 5 years. This tubing cost was allocated by using an annual cost equal to 20 percent of the initial capital cost of production tubing. Maintenance was estimated at 1 percent per year of original capital cost of the power house, plant, and high voltage substation, and a 5 percent per year for the units subject to corrosion: turbines, generators, and cooling systems. To calculate operating labor and supervision, it was assumed that two operators would be required on each shift and that there would also be two craftsmen required on each weekday shift. A 30 percent supervision cost was added. State and local taxes were. calculated as 5 percent of the assessed valuation, which was estimated at 25 percent of the depreclated capital value of the whole facility. This is shown in the cost summary for the average year at 0.625 percent of the inftial capital cost. Insurance 18 shown as 1 percent of the inftlal capital cost and a contingency of 30 percent is included because of the gross method used in calculating maintenance and operating expenses. Corporate management is Included in the maintenance costs. Figure 2.2.27 summarizes the operating costs.

\begin{tabular}{|lc|}
\hline PRODUCTION WELL MAINTENANCE & $\$ 506,000$ \\
POWER HOUSE, PLANT, AND SUBSTATION & 151,949 \\
MAINTENANCE & \\
TURBINES, GENERATORS, AND COOLING & 929,596 \\
SYSTEM MAINTENANCE & 190,362 \\
LABOR AND SUPERVISION & 243,511 \\
STATE AND LOCAL TAXES & 389,618 \\
INSURANCE & 723,310 \\
CONTINGENCY @ 30\% & $\$ 3,134,346$ (OR $\$ 3,000,000)$ \\
\hline
\end{tabular}

FIgure 2.2.27 ANNUAL OPERATING COST SUMMARY [18]

\section{Cash Flow and Profitability}

There are a number of uncertainties that prevent a rigorous cash flow analysis. These include lease royalty rate, depletion allowance, regulated permissible rate of return, method of financing, and corporate tax structure for calculating federal income tax. Assumed In this example were: an 80 percent load factor; lease royalties of efther 12.5 percent or 5 percent of gross sales; internal flnancing; and a computed internal rate of return as a function of power sales price.

Figure 2.2.28 shows the cash flow using $6 \cdot \mathrm{mills} / \mathrm{kWh}$, 12.5 percent royalty, no-depletion allowance, and 48 percent federal income tax.

Figure 2.2.29 shows the rate of return on investment for vartous power sales prices. The upper curve. Is calculated wth 5 percent royalty and no federal income tax; the lower curve is calculated with 12.5 percent royalty, no depletion allowance, and 48 percent federai Income tax. Depreciation has been calculated as straight:1ine for 20 years and the Investment and plant 1ife are assumed to be 20 years, with no recoverable value at the end of the $20 \mathrm{th}$ year. The actual profitability, should fall between these two curves.

\begin{tabular}{|c|c|}
\hline POWER SALES \& \$0.006/KWH & $\$ 9,180,000$ \\
\hline ROYALTY @ 12.58 & $1,147,500$ \\
\hline COST OF SALES & $3,134,347$ \\
\hline GROSS PROFIT & $\$ 4,898,153$ \\
\hline DEPRECIATION & $\$ 1,948,092$ \\
\hline $\begin{array}{l}\text { NET PROFIT BEFORE FEDERAL } \\
\text { INCOME TAX }\end{array}$ & $2,950,061$ \\
\hline FEDERAL INCONE TAX & $1,416,029$ \\
\hline NET PROFIT AFTER TAXES & $1,534,032$ \\
\hline TOTAL CASH FLOW & $3,482,124$ \\
\hline YEARS TO RETURN INVESTMENT & 11.9 \\
\hline INTERNAL RATE OF RETURN & $=6.48 \ldots$ \\
\hline
\end{tabular}

Figure 2.2.28 CASH FLOW [18]

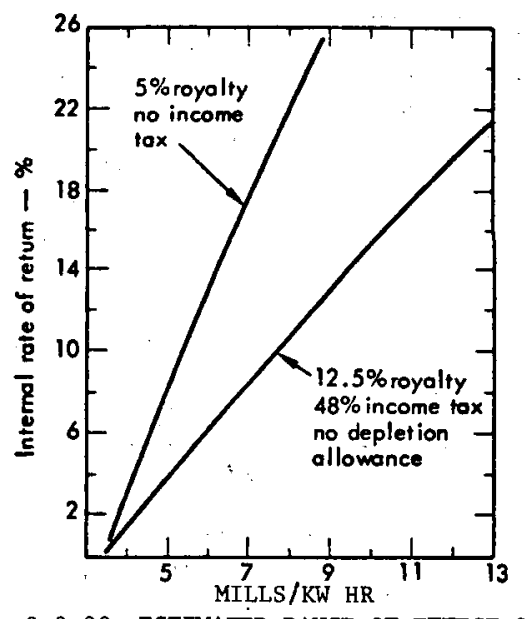

F1gure 2.2.29 ESTIMATED RANGE OF EFFECT OF POWER SALES PRICE ON INTERNAL RATE OF RETURN [18]

Figure 2.2.29 shows that this system can provide a rate of return of 7.5 percent or greater for power prices greater than $6.5 \mathrm{mills} / \mathrm{kWh}$.

The method for converting brines to electrical power using the whole fluld stream appears to be technically reasonable and economically attractive. An experimental program is needed to select materials that will withstand the corrosive brines, to find the best form of production tubing and well operation, to identify acceptable turbines, and to demonstrate comerclal feasibility of a power plant. None of these problems seem intractable, although few if any of the conventional methods and materials appear to be workable.

$$
\text { Geothermal Power Cycles Analys1s }
$$

\section{Introduction}

A number of power cycles have been proposed for extracting thermal energy from geothermal medium and high temperature brine resources, such as those of the Imperial Valley, Callfornla. Differences in these processes result from attempts to increase efficlency, reduce costs, or avold one or another of the gevere corrosion, erosion, and solids deposition problems assoclated with processIng high salinity brines. The geothermal power study 


\begin{tabular}{|c|c|c|c|}
\hline optian & DVATTAOES & DI SLPWHTTGES & OEVLLORENT PC:ETHIT:- \\
\hline $\begin{array}{l}\text { 1. STEAM TUREINE OPEPATIHG } \\
\text { ON STEAM FLSSHED FROM } \\
\text { THE BPISE. }\end{array}$ & 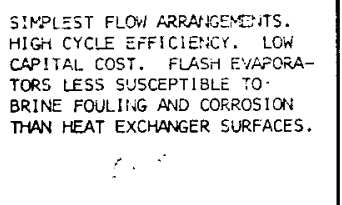 & 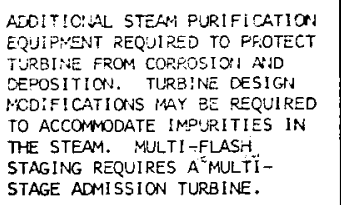 & $\begin{array}{l}\text { HIGH DEVELOPAEPT POTENATIAL } \\
\text { WITH LOW DEVELOPMENT FISKS. }\end{array}$ \\
\hline $\begin{array}{l}\text { 2. STEAM TURBINE OPERATING } \\
\text { ON CLEAN STEAM GENERATED } \\
\text { BY A SECONDARY BRINE-TO- } \\
\text { STEAM HEAT TRANSFER } \\
\text { SYSTEM. }\end{array}$ & $\begin{array}{l}\text { TURBINE SEES ONLY CLEAN STEAM. } \\
\text { CONVENTIONAL STEAM CLEAN-UP } \\
\text { EQUIPMENT IS ADEQUATE. }\end{array}$ & $\begin{array}{l}\text { FOUL IHG AND CORROSION PRESENTS } \\
\text { A PROBLEM IN TUBULAR STEAM } \\
\text { GENERATOR. LOWER TURBINE } \\
\text { THROTTLE TEMPERATURE AND } \\
\text { PRESSURE THAN OPTION } 1 . \\
\text { INCREASED CAPITAL COST DUE TO } \\
\text { SECONDARY STEAM GENERATOR } \\
\text { LOOP. SURFACE CONDENSER } \\
\text { REQUIRED. LARGER CAPITAL COST } \\
\text { AND LOWER POWER CAPABILITY. } \\
\text { THAN OPTION 1. }\end{array}$ & $\begin{array}{l}\text { HIGH DEVELOPMENT POTENTIAL } \\
\text { WITH LOW DEVELOPMENT RISK. } \\
\text { DEVELOPMENT RISK IS } \\
\text { PROBABLY LOWER THAN } \\
\text { OPTION 1, BUT ECONOMICS } \\
\text { ARE LESS FAVORABLE. }\end{array}$ \\
\hline $\begin{array}{l}\text { 3. ISOBUTANE TURBINE, } \\
\text { FLASHED STEAM TO ISO- } \\
\text { BUTANE HEAT TRANSFER } \\
\text { SYSTEM. }\end{array}$ & $\begin{array}{l}\text { POTENTIALLY SMALLER (AND } \\
\text { LOWER COST) TURBINE THAN } \\
\text { STEAM CYCLES. }\end{array}$ & $\begin{array}{l}\text { ALL OF OPTION } 2 \text { (EXCEPT TUR- } \\
\text { BINE THROTTLE PRESSURE) PLUS: } \\
\text { LARGER STEAM GENERATORS DUE } \\
\text { TO POOR THERMAL CONDUCTIVITY } \\
\text { OF ISOBUTANE. LARGE I SORITANE } \\
\text { PUMPS ANU FUMT POWER. HIGH } \\
\text { WORKING PRESSURES INCREASE } \\
\text { HEAT EXCHANGER COSTS. DEVEL- } \\
\text { OPMENT OF LARGE SECONDARY } \\
\text { FLUID TURB INE REQUIRED. }\end{array}$ & $\begin{array}{l}\text { HAS ALL OF THE DEVELOPMENT } \\
\text { PROBLEMS OF OPTION } 2 \text { PLUS } \\
\text { LNAVAILABILITY OF ISOBUTANE } \\
\text { TURBINES IN THE DESIRED } \\
\text { SIZE RANGE. }\end{array}$ \\
\hline $\begin{array}{l}\text { 4. N-BUTANEE TURBINE, } \\
\text { FLASHED STEAM-TO-N- } \\
\text { BUTANE HEAT TRANSFER } \\
\text { SYSTEM. }\end{array}$ & $\begin{array}{l}\text { POTENTIALLY SMALLER TURBINE } \\
\text { THAN STEAM CYCLES. }\end{array}$ & $\begin{array}{l}\text { ALL OF OPTION } 3 \text { PLUS LOWER } \\
\text { POWER CAPABILITY. }\end{array}$ & LOW. \\
\hline $\begin{array}{l}\text { 5. FREON-TURBINE FLASHED } \\
\text { STEAM-TO-FREON HEAT } \\
\text { TRANSFER SYSTEM. }\end{array}$ & $\begin{array}{l}\text { POTENTIALLY SMALLER TURBINE } \\
\text { THAN BUTANE OR STEAM CYCLES. }\end{array}$ & $\begin{array}{l}\text { ALL OF OPTION 3. FREON } \\
\text { DECOMPOSITION MAY LEAD TO } \\
\text { CORROSION. }\end{array}$ & LOW. \\
\hline $\begin{array}{l}\text { 6. AMMONIA TUREINE, FLASHED } \\
\text { STEAM-TO-AMMONIA HEAT } \\
\text { TRANSFER SYSTEM. }\end{array}$ & POTENTIALLY SMALLEST TURBINE. & ALL OF OPTION 3. & LOW. \\
\hline 7. TOTAL FLOW CONCEPT. & $\begin{array}{l}\text { ELIMINATES SEPARATORS, FLASH } \\
\text { EVAPORATORS, AND STEAM GENERA- } \\
\text { TORS. USES RUGGED TURBO- } \\
\text { MACHINERY WITH REPLACEABLE } \\
\text { PARTS. HIGH EFFICIENCY. } \\
\text { POTENTIALLY A SIMPLE, LOW- } \\
\text { COST SYSTEM. }\end{array}$ & $\begin{array}{l}\text { MORE SEVERE CORROSION/EROSION } \\
\text { FOULING PROBLEMS THAN OPTIONS } \\
1 \text { AND } 2 \text {. REQUIRES DEVELOP- } \\
\text { MENT OF NOVEL TURBO-MACHINERY } \\
\text { CONCEPTS AND DEVELOPNENT OF } \\
\text { BASIC ANALYSIS METHUDS FOR } \\
\text { HIGH-VELOCITY, TWO-PHASE } \\
\text { BRINE FLOW. }\end{array}$ & $\begin{array}{l}\text { DEVELOPMENT POTENTIAL } \\
\text { UNCERTAIN. REQUIRES } \\
\text { FURTHER ANALYTICAL } \\
\text { EVALUATION. }\end{array}$ \\
\hline $\begin{array}{l}\text { 8. ISOBUTANE TURBINE, } \\
\text { FLASHED STEAM-TO- } \\
\text { ISOBUTANE PLUS BRINE- } \\
\text { TO-ISOBUTANE HEAT } \\
\text { EXCHANGER. }\end{array}$ & $\begin{array}{l}\text { RELATIVELY SIMPLE FLOW } \\
\text { ARRANGEMENT, SINGLE FLASH } \\
\text { VESSEL AND NO DOWNHOLE PLMP. } \\
\ldots \\
.\end{array}$ & $\begin{array}{l}\text { ALL OF OPTION } 3 \text { PLUS SCALE } \\
\text { DEPOSITION ON TUBES OF BRINE } \\
\text { HEAT EXCHANGER. }\end{array}$ & $\begin{array}{l}\text { LOW DEVELOPMENT POTENTIAL } \\
\text { DUE TO SCALE DEPOSITION } \\
\text { PROBLEMS. }\end{array}$ \\
\hline $\begin{array}{l}\text { 9. ISOBUTANE TURBINE AND } \\
\text { DOWNOHLL PUMP, TOTAL } \\
\text { WELL FLOW TO ISOBUTANE } \\
\text { IEAT TRANSFER SYSTEM. }\end{array}$ & $\begin{array}{l}\text { SIMPLE FLOW ARRANGEMENT, STEAM } \\
\text { SEPARATOR NOT REQUIRED. HIGH } \\
\text { EFFICIENCY POSSIBLE. SCALE } \\
\text { DEPOSITION IN WELL IS } \\
\text { MINIMIZED. }\end{array}$ & $\begin{array}{l}\text { ALL OF OPTION } 3 \text { PLUS DEPOSI- } \\
\text { TION ON HEAT EXCHANGER TUBES. } \\
\text { LARGE EXPENSIVE ALLOY HEAT } \\
\text { EXCHANGER REQUIRED DUE TO } \\
\text { LOW COEFFICIENTS AND } \\
\text { CORROSIVENESS OF BRINE. }\end{array}$ & $\begin{array}{l}\text { LOW DEVELOPMENT POTENTIAL } \\
\text { DUE TO SCALE DEPOSITION } \\
\text { PROBLEMS. }\end{array}$ \\
\hline 10. DOWNHOLE HEAT EXCHANGER. & $\begin{array}{l}\text { TURBINE SEES ONLY CLEAN } \\
\text { STEAM. MAY EASE HEAT EX- } \\
\text { CHANGER CORROSION AND FOULING } \\
\text { PROBLEMS. } \\
\therefore \\
\quad .\end{array}$ & $\begin{array}{l}\text { THERMAL REFLUXING PROBLEM WITH } \\
\text { CONCENTRIC TUBE IN WELL CASING, } \\
\text { I.E. COLD DOWNSTREAM MUST BE } \\
\text { THERMALLY INSULATED FROM HOT } \\
\text { IPSTREAM. UNCERTAIN KNOWLEDGE } \\
\text { OF HEAT EXTRACTION MECHANI SM } \\
\text { FROM GEOTHERMAL DEPOSITS. } \\
\text { OUTSIDE SCALING OF CASING AND } \\
\text { PLUGGING OF FORMATION MAY. BE } \\
\text { A PROBLEM. }\end{array}$ & DEVELOPMENT POTENTIAL IS \\
\hline $\begin{array}{l}\text { 11. INJECTED HYDROCARBON } \\
\text { INTO HOT BRINE WITH } \\
\text { VAPOR PASSED TO MIXED } \\
\text { VAPOR TURBINE. }\end{array}$ & $\begin{array}{l}\text { SIMPLE FLOW ARRANGEMENT. } \\
\text { HIGMER HYDROCARBON TEMPERA-, } \\
\text { TURE THAN } 3 \text {. MAY EASE WELL } \\
\text { CASING CORROSION AND/OR SCALE } \\
\text { DEPOSI TIO\& PROBLEMS. }\end{array}$ & $\begin{array}{l}\text { REMOVAL OF. BRINE DROPLETS FROM } \\
\text { MIXED HYOROCARBON-STEAM VAPOR } \\
\text { PRESENTS PURIFICATION PROBLEMS. } \\
\text { THERMAL REFLUXING IN WELL. } \\
\text { LARGER FLUID FLOW REQUIREMENTS } \\
\text { IN WELL.. REQUIRES SPECIAL } \\
\text { TURBIME DEVELOPMENT. LOSS OF } \\
\text { HYDROCARBON WITHS BRINE, CONN- } \\
\text { DENSATE, AND INC:-CO WENISABLE } \\
\text { GAS STREAMS. }\end{array}$ & $\begin{array}{l}\text { REQUIRES FLRTHER EVALUATIOHS } \\
\text { TO ESTABLISH DEVELOPMENT } \\
\text { POTENTIAL. }\end{array}$ \\
\hline
\end{tabular}

Figure 2.2.30 COMPARISON OF ALTERNATIVE GEOTHERMAL POWER OPTIONS [19] 
group at Atomics International, Inc. [19] has conducted a a preliminary study of a number of alternative approaches to geothermal power generation. The merits of several proposed systems relative to each other with respect to thermodynamic performance, current development problems, and potential for future growth were analyzed.

A tabulation of the various options is given in Figure 2.2.30. This figure summarizes a qualitative evaluation of the technical problems and Indicated economice for each of these concepts.

Seven baslc power production cycles were analyzed by Atomics International: These cycles incorporate direct steam turbine operation or heat exchange between . flash steam and a secondary fluid (including pure water). These performance analyses consider both single- and multi-stage flashing of the brine. Uniform wellhead and heat sink temperatures are assumed for all cycles in order that comparisons would be independent of other influences. The wellhead conditions used In these studies are shown in FIgure 2.2.31. The seven cycles considered in the analysis are 11sted In Figure 2.2.32.

\begin{tabular}{|lc|}
\hline STEAM FLOW & 494,000 LB/HR \\
BRINE FLON $\cdots$ & $2,326,000$ LB/HR \\
BRINE TEMPERATURE & $426^{\circ} \mathrm{F}$ \\
BRINE PRESSURE & 265 PSIA \\
SALT CONCENTRATION & 270,000 PPM $(327,000$ IN BRINE FRACTION $)$ \\
\hline
\end{tabular}

F1gure 2.2.31 WELLHEAD CONDITIONS USED IN THE CYCLE STUDIES [19]

1. STEAM TURBINE OPERATING ON STEAM FROM THE FLASHED BRINE.

2. STEAM TURBINE OPERATING ON CLEAN STEAM GENERATED:BY A SECONDARY FLASHED STEAM-TO-WATER HEAT TRANSFER SYSTEM.

3. ISOBUTANE TURBINE WITH A STEAM-TO-ISOBUTANE MEAT TRANSFER SYSTEM.

4. TOTAL FLOW CONCEPT IN WHICH THE SATLRATED BRINE SOLUTION IS EXPANDED TO HIGH VELOCITY THROUGH A' CONYERGING-DIVERGING NOZZLE AND THEN IS USED TO DRIVE A HYDRAULIC IMPULSE TURBINE.

5. ISOBUTANE TURBINE WITH A BRINE-TO-ISOBUTANE HEAT TRANSFER SYSTEM.

6. DOWNDLE HEAT EXCHANGER.

7. DOWNHOLE, DIRECT-CONTACTING HYDROCARBON VAPOR GEVERATION WITH MIXED VAPOR TURBINE.

F1gure 2.2.32 CYCLES CONSIDERED IN ANALYSIS [19]

The results of the cycle performance studles are summarized in Figures 2.2 .33 and 2.2 .34 .

The direct steam cycle shows the highest performance of ali the cases considered. Somewhat surprisingly, the steam-to-steam cycle shows a performance capability approximately equal to that of the 1sobutane cycle. If the difference in pump work between these two systems is considered, as shown in the last column of F1gure 2.2.34, even the h1gh temperature and pressure 1sobutane cycle $\left(380^{\circ} \mathrm{F}, 1050 \mathrm{psia}\right)$ shows little

\begin{tabular}{|c|c|c|c|}
\hline \multirow{2}{*}{ CYCLE } & \multicolumn{3}{|c|}{ GROSS GENERATOR OUTPUT, MW } \\
\hline & 1 STAGE & 2 STAGE & 3 STAGE \\
\hline DIRECT STEAM, WET TOWER & 42.9 & 49.0 & 54.7 \\
\hline DIRECT STEAM, DRY TOWER & 34.6 & 41.0 & 45.8 \\
\hline STEAM-TO-WATER, WET TOWER & 35.0 & 42.9 & 47.0 \\
\hline STEAM-TO-WATER, DRY TOWER & 30.2 & 37.4 & 41.3 \\
\hline STEAM-TO-ISOBUTANE, 600 PSI SYSTEM & - & 38.0 & 42.0 \\
\hline STEAM-TO-ISOBUTANE, 1050 PSIA SYSTEM & - & - & 49.0 \\
\hline STEAM-TO-N BUTANE & 30.6 & - & - \\
\hline STEAM-TO-FREON 114 & 30.8 & - & - \\
\hline STEAM-TO-AMTONIA & 27.0 & - & - \\
\hline TOTAL FLOW CONCEPT, 908 EFFICIENCY & 62.0 & - & - \\
\hline 858 EFFICIENCY & 57.0 & - & -- \\
\hline
\end{tabular}

F1 gure 2.2.33 SUMMARY OF CYCLE STUDTES (POWER PRODUCTION FROM 2,820,000 1b/hr WELL FLOW) [19]

\begin{tabular}{|c|c|c|c|c|}
\hline \multirow{3}{*}{ creif } & \multicolumn{4}{|c|}{ REQUIREMENTS } \\
\hline & \multirow{2}{*}{$\begin{array}{l}\text { WELL PRCOUCTION } \\
\text { IDS LB/HR }\end{array}$} & \multicolumn{2}{|c|}{ COOLING WATER } & \multirow{2}{*}{$\begin{array}{l}\text { POWER CYCLE } \\
\text { FLUID PUPPING } \\
\text { MW }\end{array}$} \\
\hline & & $\begin{array}{c}\text { CIRC. } \\
106 \text { LB/HR }\end{array}$ & $\begin{array}{c}\text { MAKEUP } \\
10^{6} \mathrm{LB} / \mathrm{MR}\end{array}$ & \\
\hline \multicolumn{5}{|l|}{ DIRECT STEAM, WET TOWER } \\
\hline 1 STACE & 6.6 & 120.0 & 1.6 & - \\
\hline 2 STAGE & 5.8 & 123.3 & 1.7 & - \\
\hline 3 STAGE & 5.2 & 111.1 & 1.5 & - \\
\hline \multicolumn{5}{|l|}{ DIRECT SIEAM, DRY TCUER } \\
\hline 1 STAGE & 8.2 & - & -- & - \\
\hline 2 STAGE & 6.9 & - & - & - \\
\hline 3 STAGE & 6.2 & - & - & - \\
\hline \multicolumn{5}{|l|}{ STEAM-TO-KATER, WET TOUER } \\
\hline 1 STAGE & 8.1 & 150.9 & 2.1 & 0.15 \\
\hline 2 StAGE & 6.6 & 139.9 & 1.9 & 0.25 \\
\hline 3 STAGE & 6.0 & 130.4 & 1.8 & 0.30 \\
\hline \multicolumn{5}{|l|}{ STEIAH-TO-WATER, DQY TOWER } \\
\hline 1 STACE & 9.3 & - & - & 0.17 \\
\hline 2 STACE & 7.5 & - & 一 & 0.29 \\
\hline 3 STAGE & 6.8 & 一 & - & 0.36 \\
\hline \multicolumn{5}{|l|}{ STEALTO-I SCBUTANE } \\
\hline 2 STACE - 600 PSIA & 7.4 & 162.1 & 2.3 & 13.32 \\
\hline 3 STACE - 600 PSIA & 6.7 & 263.1 & 2.3 & 13.38 \\
\hline 3 STACE - 1050 PSIA & 5.8 & 125.0 & 1.8 & 21.27 \\
\hline STEAM-TON BUTANE & 9.2 & 190.5 & 2.7 & 7.78 \\
\hline STEAY-TO-FREON 114 & 9.2 & 189.3 & 2.6 & 19.45 \\
\hline STEAM-TO-AMPONIA & 10.3 & 218.3 & 3.1 & 13.85 \\
\hline
\end{tabular}

Figure 2.2.34 COMPARISON OF POWER CYCLE REQUIREMENTS (BASIS 100 MW GROSS ELECTRICAL OUTPUT) [19]

or no performance advantage over the steam-to-steam cycle. Taking into account the higher capital costa due to $h 1$ gher pressure pipes and heat exchanger tubes, the larger pump requirements, the considerably higher mass flow rates (which entalls larger pumps and pipes), the substantially larger heat transfer surface requirements due to the poor thermal properties of 1sobutane, 
and the unavailability of a proven turbine design in the size range required for geothermal plants, it belomes difficult to consider selecting the lsobutane system In preference to a proven stean-to-steam or direct steam cycle. However, a developed 1sobutane turbine should be appreclably lower in cost than a low pressure steam turbine operating over the same temperature range because of the much smaller volume of 1sobutane vapor involved. All of the other binary cycles show relatively poor performance capability and do not yet appear to warrant more serfous consideration.

Important technical features of the cycles analyzed in Figures 2.2.33 and 2.2 .34 are discussed in the following paragraphs.

\section{D1rect Steam Cycles}

In these cycles the steam turbines operate on steam flashed directly from the brine. Highly efficient separators and steam purifiers are required, since even a minor carry-over of high salinity brine accelerates corrosion and leads to deposition of solids on the turbine blades. Non-condensable gases present in the flashed steam also contribute to corrosion and result in the requirement for non-condesable gas removal from the steam condenser. Some minor modifications in turbine design, such as elimination of crevices and labyrinth seals between stages, can ease some of the problems resulting from impurfties in the steam.

Saturated steam turbines have to deal with increasing molsture content in the expanding steam. This problem is reduced somewhat with mult 1 -admission turbines because the steam introduced into the lower pressure stages does not expand to as $\mathrm{hlgh}$ a moisture content. Molsture separator stages can be considered if necessary to keep wetness within manageable limits.

Another approach which should be considered for multiadmission turbines is the superheating of low pressure steam using a portion of the higher pressure steam for the purpose. Molsture content is not a problem with isobutane and Freon cycles since the vapor does not expand into the wet region in the turbine.

Special designs must be developed for multiple inlet turbines when two or three stage flashing is applied. Discussions with turbine designers indicate this is not a problem. They feel that as many as four inlet stages are feastble. A potential limitation is the large Inlet ducts required for the lowest pressure stage. In some cases, separate turbines for each pressure may be the best compromise.

\section{Indirect Steam (Steam-to-Water) Cycles}

In these cycles steam flashed from the brine in one or more flash stages is condensed in tubular heat exchangers in which pure water is heated and bolled to produce pure steam. This permits the use of "conventional" low piressure steam turbines operating on pure steam. In order to maintain the purity of the secondary steam circuit, direct contact condensers using cooling tower water are not practical and it is necessary to provide surface condensers to separate the recycled pure water and cooling water streams. The two sets of heat exchangers (steam generators and condensers) decrease the temperature range of the steam-to-water cycles compared to direct steam cycles and thereby cause a decrease in efficiency.

Although the 1mpure flashed steam is kept out of the turblne, it must be handled in a large heat exchanger.
$\mathrm{H}_{2} \mathrm{~S}, \mathrm{CO}_{2}$, ammonia, borlc acid, and other corrostve constituents of the brine. It must also be designed for ease of cleaning because of the possibility of fouling on the flashed steam side.

A further source of Inefficlency in indirect cycles is the need to pump the feedwater from the condenser to the steam generator. Such pumps are not required in direct steam cycles.

\section{Steam-to-Secondary Fluid Cycles}

These cycles are very similar to the steam-to-water cycles described above and many of the same considerations apply. The difference is that a second fluld is selected which has thermodynamic properties particularly well suited to the temperature interval available. Specific criteria are a reasonable pressure at the top temperature (e.g., less than 2000 psi) and a vapor pressure slightly over atmospheric at the temperature of condensation. Other requirements are a low cost and high level of stability. After reviewing a number of candidates, four were selected in the Atomics International study for detalled analysis: 1sobutane, Nbutane, Freon 114, and ammonta.

Steam generators and heat exchangers between the flashed steam and working fluid must be designed to accommodate cleaning. The drop in temperature of any brine droplets carried by the steam can lead to prectpitation of chemicals and scaling of the brine-side heat transfer surface. This problem is compounded in the 1sobutane and Freon systems because of their substantlally larger heat transfer areas relative to the allsteam system.

Turbines for 1sobutane and the other secondary fluids In the size required for geothermal power are beyond the state-of-the-art as developed to date. Designs can be extrapolated from existing smaller units, but the lack of a successful long-time operating history for units of this size introduces a degree of uncertainty in the application of such units to geothermal power.

Expansion turbines for lsobutane and other secondary fluids have been dfscussed with a major manufacturer who claims that there is no basic size limitation. They have built hundreds of units; most are In the 1000 to 2000 hp range. These units have included six frame sizes; the largest being $12,000 \mathrm{hp}$ (8-9 MW). One more step would, they feel; take them to a size equivalent to a $50 \mathrm{MW}$ generator. They see no problem dolng this; only a demand 18 required. The b1gger turbines w111 turn at lower speeds, and thus, actually be easier to design and operate. They favor the $50 \mathrm{MW}$ as the initial geothermal power unit size. It would turn at 3600 rpm and therefore match avallable two pole generators.

Efficiencies are as good or better than steam turbines82 to 85 percent. Expansion rates of $1: 2$ or $1: 2-1 / 2$ are quite good; $1: 3$ is acceptable if a few percent efficlency loss can be tolerated. For greater expansions, two or three stages (usually separate machines) can be used.

\section{Total Flow Concepts}

In the total flow concept, the entire output of a geothermal well is expanded through a prime mover which is used to drive a generator. Several prime mover concepts have been proposed including Pelton wheels, radial inflow turbines; bladeless turbines, hellcal screw expanders, and rotary-osc1llating vane machines. 
It appears that the adaption of turbine concepts already developed in large sizes for hydraulic power generation would require a less extensive development ef fort than the development of radically new concepts.

Although hydraulic Impulse turbines for the total flow concept are within the present state-of-the-art with respect to size, a substantial development effort. w111 be required to adapt these to the erosive-corrosive scaling environment of high velocity, two-phase hot brine solutions. Multi-staging of Pelton wheels or radial inflow turbines introduces unique hydrodynamic design problems which are compounded in two-phase flow systems. Lack of an analytical model for two-phase brine flow in the turbine buckets and nozzles compounds the experimental problems and increases the development time and development costs.

The development program would require a supporting experimental study of the dynamic corrosion of materials under flashing flow before a turbine design can be attempted. Also, the dynamic properties of flash1ng brine solutions are not known, and probably would be required before the nozzle and turbine designs could be optimized. Preliminary studies of exit nozzle velocities and peripheral wheel speeds Indicate a need for at least a two-stage hydraulic turbine. This could present a difficult design problem since bucket and radial inflow impulse hydraulic turbines are Inherently single-stage machines. Nevertheless, because of the potential for achieving high performance at low cost, the total flow energy recovery device deserves further consideration. A more detailed discussion of this concept appeared previously in this section.

\section{Brine-to-Secondary Fluld Cycles}

The 1sobutane turbine plus downhole pump concept permits total well flow of the brine to an lsobutane heat transfer system. It is a simple flow arrangement since steam separators are not required. High cycit efficiency is possible and scale deposition in the well is mintmized. A once-through heat exchanger can be considered.

However, severe corrosion and scaling problems may occur in the tubular heat exchangers. Certainly silica deposition will be a problem and the downhole pump and lsobutane turbine need to be developed.

The hybrid 1sobutane turbine with a flashed steam plus brine heat transfer system does not need a downhole pump. However, it retains the deposition and corrosion problems associated with tubular brine heat exchangers. Isobutane turbine development is also required.

\section{Downhole Heat Exchanger}

One downhole heat exchanger wh1ch has been studied has a concentric tube arrangement in which injection water is carried down the wellhole through a central pipe and hot steam is brought up in the annular space between the pipe and the well casing. In this concept, 1t is desirable to minimize thermal refluxing between the infection water and the process steam which lowers the avallability of the steam at the wellhead. The effectiveness of the concept depends on malntaining refluxing to a low'level.

A number of typical designs were evaluated in the Atomlcs International study using infection pipe diameters of 4,6 , and 8 inches, with and without thermal Insulation. Injection pipe lengthe of 4000 and 6000 feet were considered to estab11sh the effect of pipe length of refluxing. The temperature of the well bottom was assumed to be $600^{\circ} \mathrm{F}$, and the injection water was assumed to enter the well at a temperature of $100^{\circ} \mathrm{F}$. A flow rate of $300,000 \mathrm{lb} / \mathrm{hr}$ was assumed. The results of the analyses are shown in Figure 2.2.35.

\begin{tabular}{|c|c|c|}
\hline $\begin{array}{l}\text { PIPE DIAMETER } \\
\text { (INCHES) }\end{array}$ & $\begin{array}{l}\text { PIPE LENGTH } \\
\text { (FEET) }\end{array}$ & $\begin{array}{l}\text { WELLUHEAD EXIT } \\
\text { STEMM TEMPERATURE } \\
\text { (F) }\end{array}$ \\
\hline 4 & 4000 & 332 \\
\hline 6 & 6000 & 384 \\
\hline 6 & 4000 & 259 \\
\hline UNINSULATED & 4000 & 129 \\
\hline $\begin{array}{l}1 / 2^{\prime \prime} \text { INSULATION } \\
\left(K=0.08 \text { BTU/FT-HR- }{ }^{\circ} \mathrm{F}\right)\end{array}$ & 4000 & 562 \\
\hline 1.0" INSULATION & 4000 & 581 \\
\hline \multicolumn{3}{|c|}{$\begin{array}{ll}\text { NOTES: } & \text { WELL-BOTTOM TEMPERATURE }=600^{\circ} \mathrm{F} \\
& \text { WELHEAD INJECTION TEMPERATURE }=100^{\circ} \mathrm{F} \\
& 300,000 \text { LB/HR FLOW } \\
& \text { SPECIFIC HEAT STEAM } / \text { SPECIFIC HEAT WATER }=0.7\end{array}$} \\
\hline
\end{tabular}

Figure 2.2.35 THERMAL REFLUXING IN A DOWNHOLE HEAT EXCHANGER [19]

For the case of an uninsulated 4-Inch diameter injection pipe 4000 feet long, the exit steam temperature 1s calculated to be $332^{\circ} \mathrm{F}$. The degradation in temperature at the wellhead due to 108 s of heat from the hot steam to the cold water was $600-332=268^{\circ} \mathrm{F}$. This produces a 53 percent reduction in heat flow from the well. A 6-1nch pipe of the same length would produce steam at a temperature of $259^{\circ} \mathrm{F}$, resulting in a 68 percent $10 s s$ in heat flow from the well. The ef fect of applying a small amount of thermal Insulation between the hot and cold streams is significant. One-half inch of thermal insulation reduces the heat loss to less than 2 percent. A suitable Insulation materlal probably can be found for application to the inside of the downcomer plpe where 1t sees only relatively pure water. However, the structural integrity of the insulation and its resistance to spalling with a $500^{\circ} \mathrm{F}$ temperature differential needs evaluation.

A more serious problem with the downhole heat exchanger concept is the uncertainty assoclated with the mechantsms by which the heat is transported from the geothermal strata to the well casing in the absence of large-scale mass transport of the hot brine to the production zone. The only known mechanism avallable for driving the brine toward the casing is thermal convection of the brine through the geothermal rock or sand formation. The driving heat that can be provided by small density differences is small compared to that generated by vapor pressure or hydrostatic 1iquid heat. It does not appear that the large flow requirements of the well can be established by small density differences generated by temperature gradients. In any event, these will be significant only in the Immediate neighborhood of the well casing.

There 1s also the problem of scale formation on the outside of the casing and its deleterious effect on well production. A $1 / 2-1$ nch thick deposit $(k=0.5 \mathrm{Btu} / \mathrm{ft}-\mathrm{hr}-$ OF) on the outside of a 12-1nch dlameter well casing w111 transfer $2 \times 10^{7} \mathrm{Btu} / \mathrm{hr}$ for each 1000 feet of casIng with a $300^{\circ} \mathrm{F} \Delta \mathrm{T}$ between the geothermal brine and the wall of the casing. Ten production wells (2000 ft 
casing) would therefore produce about $40 \times 10^{7} \mathrm{Btu} / \mathrm{hr}$ and $300^{\circ} \mathrm{F}$ water temperature. Comparing this to the $124 \times 10^{7} \mathrm{Btu} / \mathrm{hr}, 420^{\circ} \mathrm{F}$ brine used for the previous cycle analysis studies in this section, it indicates that significantly more production wells would be required in the downhole heat exchanger system.

The precipitation of silica, both as a scale on the casing and as colloidal particles which may plug the formation is quite possible. A thorough stidy of the potential flow and scaling problems which can arise with this concept is advisable.

\section{Direct Contact Hydrocarbon Vapor Generation}

The direct contact cycle vaporizes the hydrocarbon by injecting it into the hot brine, either in the well or in a high pressure vessel. The mixture of steam and hydrocarbon vapor then passes through a steam purification system to remove the brine droplets that have been entrained by the vapor. If the contacting is done outside the we11, the brine must be compressed to the hydrocarbon vapor pressure, assumed to be 1sobutane at 100 to $600 \mathrm{psia}$, before it can enter the pressure vessel.

This concept does not show any potential performance advantages over the direct steam cycle. All of the technical problem areas external to the well still remain. A high performance mixed vapor purification system is required to remove the brine droplets before the vapor can enter the turbine. The purlfication problem will be magnifled only if a few percent of brine blows out of the well with the mixed vapor. Binary turbine development must consider the flow of mixed vapors through the turbine.

The infection pipe, which must be insulated to limit thermal refluxing area limitations in the well hole, may present a flow problem. The isobutane process calculations show that $4.5 \times 10^{6} \mathrm{1b} / \mathrm{hr}$ of isobutane are required for the turbine system as compared to $2.82 \times 10^{6} \mathrm{lb} / \mathrm{hr}$ of brine and steam from the well. If the isobutane were introduced directly into the we11, the downcomers would have to flow $4.5 \times 10^{6} 1 \mathrm{~b}$ of liquid down into the well and the annular upcomer space would have to flow $4.5 \times 10^{6}$ ib of 1sobutane vapor out of the wel1. Thus, the mass flow requirements for each casing would increase by at least a factor of four relative to a brine-steam flow. The economic effect of an increase in well costs needs to be evaluated.

Availability of suitable hydrocarbons for this app1ication may be limited. The well bottom temperatures of 500 to $600^{\circ} \mathrm{F}$ are well above the permisstble operating Iimit of Freon and well above the destrable operating temperature for ammonia vapor. Hydrocarbons that are suitable for the well may not be effective for the turbine.

\section{Inert Gas Injection at Bottom of Well}

As an alternative to infection of an immiscible volatile fluld, gas injection has been proposed as a means of bringing geothermal brine out of a well while maintaining pressure (and temperature). The object of such an approach would be to minimize flashing and thereby mintrifze brine cooling and consequent silica deposition in the well.

At ordinary rates of production, flashing occurs about half way to the surface in geothermal wells. As a result, the fluid in the upper half of the well welghs much less than pure liquid, and hydrostatic pressure in the formation at the bottom drives the brine out. The rate stabilizes when wellhead, pressure, plus the weight of the fluid in the well, plus friction losses in well and formation equal formation pressure.

With the proposed technique, a small amount of gas (e.g., nitrogen) is injected at the very bottom of the well. The bubbles of gas and water vapor decrease the density of the entire fluld column in the well. If the production flow rate is kept sufficiently low so that the frictional losses do not mask the effect of density reduction, an increase in pressure (and temperature) should be seen at the wellhead. The nitrogen and water vapor mixture would be separated from the hot brine, recompressed, and reinjected. Probably some heat would be extracted first to decrease the volume being compressed.

It appears that the injection of an inert gas at the bot:tom of a geothermal brine well may permit the production of a higher temperature brine and thereby inhibit scale formation in the well. Another benefit could be the avallability of some of the heat at a relatively high teraperature which may increase conversion effictency and permit steam superheating to be practiced. The disadvantages of such a system include higher capital and operating costs (due to the gas compression step), possibly higher well corrosion (due to elevated temperatures near the surface), and greater scale formation in surface equipment. The concept represents an interesting poss1bility and may warrant a simple test or additional study.

Economics of Production in Geothermal. Power Plants

Al though geothermal power plants have been built for some years, their size continually increases as the demand for power becomes more pressing. Generally, the economy of scale should make the unit costs decrease by some exponential factor as size increases. However, with geothermal systems, the piping and steam gathering costs can become more important in the larger systems and tend to make larger plants more costly. In an effort to Identify an optimum plant size, the capital and electrical production costs were computed for a range of power plant sizes. In performing this computation, assumptions had to be made about geothermal field life, well IIfe, and the probability of drilling a successful well. Until more data are on hand in these areas, cost projections must be considered quite preliminary.

\section{Dry Steam We1ls}

The calculation of the capital fnvestment for a geothermal producing site is outlined in the top section of Figure 2.2.36. Four bas1c blocks of information were needed to sum together for the required capital investment. They are turbine and generator costs, exploration costs, well costs, and piping costs.

Turbine and Generator Costs. Some turbine-generation ccist information for steam producing wells is avallable for The Geysers installations. $[20,21,22,23]$ The Geysers fleld has been expanded several times, each time adding on larger units.. The Geysers plant cost 18 plotted in Figure 2.2.37 indicating a scale-up factor of .085 which agrees with the assimption of Armstead. $[20,24]$ The line through The Geysers' data was used in succeeding calculations rather than the higher cost curve of Armstead. This cost is assumed to include everything located at the plant site, principally the generators, turbines, transformers, and cooling towers. Once the capacity of the plant 18 assumed in MW, then the turbine-generator costs can be calculated. 


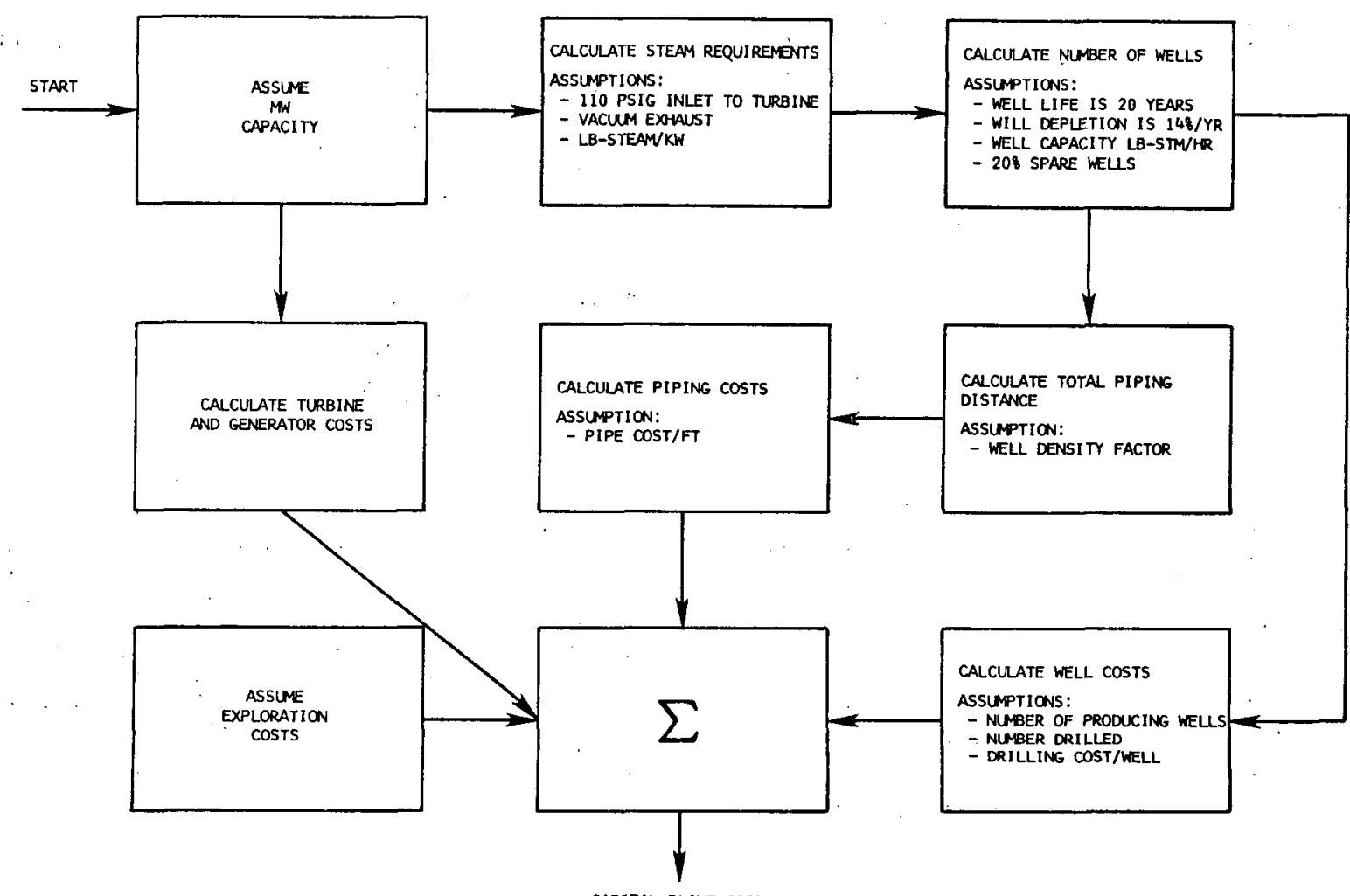

Figure 2.2.36 CALCULATION FLOW SHEET

Well Costs. To determine well costs, of course, the number of wells must be first determined and this number is governed by many unknown factors about which certain assumptions must be made. The steam requirements of the plant must first be calculated. For this system, 110 psig steam is assumed to be available at the turbine inlet, while the turbine exhaust is under vacuum. The amount of steam required from The Geysers field is $2,000,000 \mathrm{lb} / \mathrm{hr}$ per $110 \mathrm{MWe}$ or $18.2 \mathrm{lb} / \mathrm{kWe}$. This value 18 within the general range of 15 to $20 \mathrm{lb} /$ kWe reported from steam wells. After the steam requirements are determined, a number of assumptions regarding the well must be made, the two most important of which are well production capacity and well placing density. The steam production rate from The Geysers field varles between $40-300,000 \mathrm{lb} / \mathrm{hr}$ per well at about $125 \mathrm{psig}$. For this system, $110,000 \mathrm{lb} / \mathrm{hr}$ per well was assumed, thus giving a well energy yleld of $5.5 \mathrm{MWe}$ per well. A reserve capacity of 20 percent in the number of wells was assumed.

The output of two Geysers wells [25] with t1me were plotted on semi-log paper, and the we11s' output was found to decrease at 14 percent per year. Therefore the reserve would be used up within the first year, necessitating a constant drilling of new wells at the rate of 14 percent per year. The well life is assumed to be 20 years, after which the output would have become negligible.

The inftial number of wells is,

$$
\mathrm{N}=\frac{\text { capacity, } \mathrm{MW}}{5.5 \mathrm{MW} / \text { wel1 }} \times 1.20
$$

The total number over 20 years 1s,

$$
\mathrm{N}_{\mathrm{T}}=\frac{\text { capab11.tty, MW }}{5.5}(2.8+1.20)
$$

After the number of wells has been determined, the inttial well cost becomes

$$
\text { Well cost }=\frac{N(\text { cost } / \mathrm{dr} 111 \mathrm{ed} \text { well) }}{\text { \#producing wells/\# drilled }}
$$

Assuming a cost of $\$ 200,000 /$ wellhole and 80 percent success of drilling a producing well,

$$
\text { We11 cost }=\$ 250,000 \times \mathrm{N}
$$

Piping Costs. It is assumed that as new wells are needed they are drilled at the perimeter of the existing field. In addition, it is assumed that the wells are drilled at a density of one we11/40 acres, which is typical for The Geysers fleld. (A grid network for wells in a typical fleld 1s shown in Figure 2.2.38). Therefore the piping cost will increase for the later wells and as the capacity of the plant increases. This increase will work to the disadvantage of larger plants.

The distance of each well from the station as well as the cumulative distance of all wells to the station are given in Figure 2.2.39. The distance of each well from the central turbines was predicted by circular geometry to be

$$
\mathrm{N}=\operatorname{area} \times \frac{\text { number }}{\text { area }}
$$




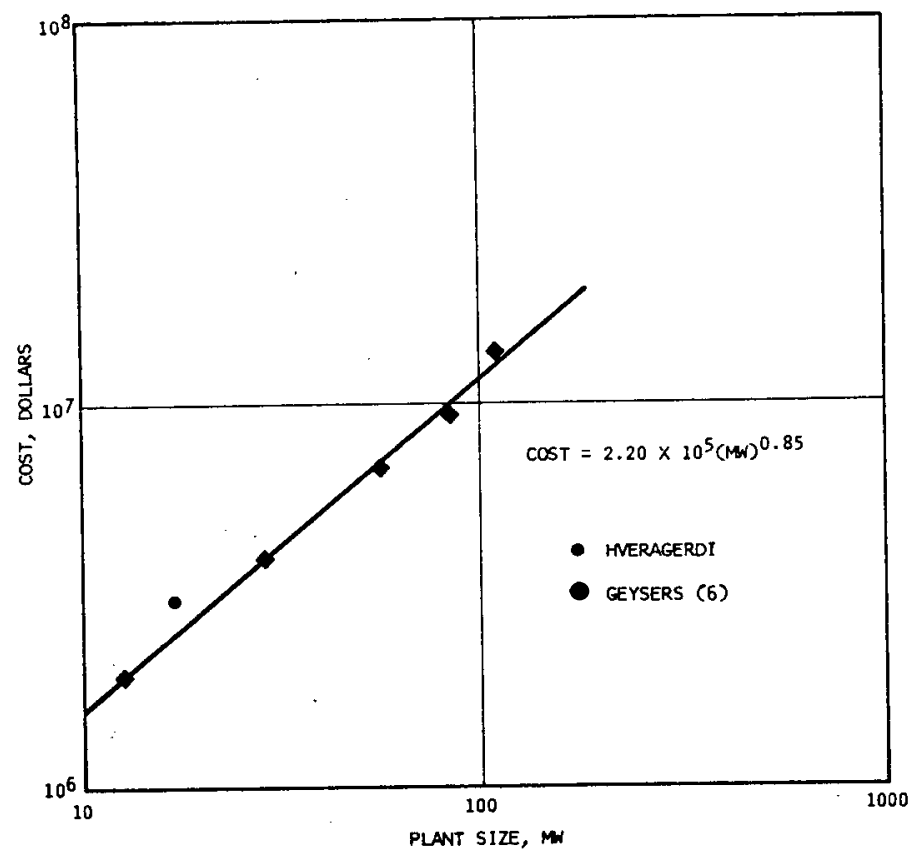

Figure 2.2.37 CAPITAL COSTS FOR DRY STEAM TURBINE-GENERATOR ELECTRICITY GENERATING PLANT

\begin{tabular}{|c|c|c|c|c|c|}
\hline & (21) & (17) & $\stackrel{(19)}{ }$ & (27) & \\
\hline (22) & (9) & (6) & $\stackrel{(8)}{\bullet}$ & (14) & (30) \\
\hline (16) & (5) & (1) & (3) & (11) & (24) \\
\hline (18) & (8) & (2) & (4) & (15) & $(28)$ \\
\hline (25) & (13) & (10) & (12) & (20) & \\
\hline & (29) & (23) & (26) & & \\
\hline
\end{tabular}

\10 ACRE PLANT SITE

- well site (Well no.) (IN ORDER OF INCREASING DISTANCE FROM PLANT SITE) EACH SQUARE $=40$ ACRES

F1gure 2.2.38 GRID FOR WELL PLACEMENT

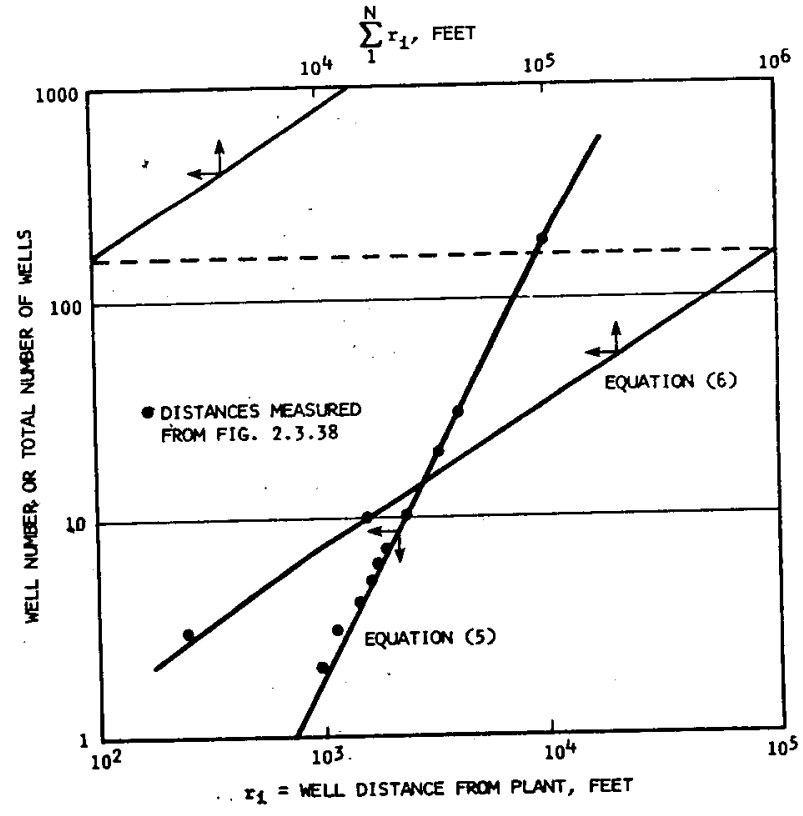

Figure 2.2.39 WELL DISTANCES FROM POWER STATION 


$$
\begin{aligned}
& =\pi r^{2} \times \frac{1}{40 \times 43,560} \\
& =1.80 \times 10^{-6} r^{2}
\end{aligned}
$$

Equation (5) gives the radius of the circle necessary to contain the $\mathrm{N}$ wells, or the distance out to the Nth well. As seen in Figure 2.2.39, the line has a slope of 2 on the log- $10 \mathrm{~g}$ paper as predicted from the above equation, where the points are the measured distances on Figure 2.2.38.

The cumulative distance may be obtained by solving Equation (5) for $r$

$$
\begin{aligned}
r_{1} & =745 \sqrt{n_{i}} \\
\sum_{1=1}^{N} r_{1} & =745 \sum_{i=1}^{N} \sqrt{n_{i}} \\
\sum_{i=1}^{N} r_{1} & =745\left(\frac{2}{3} N^{3 / 2}+\frac{\sqrt{i}}{2}-0.245\right)
\end{aligned}
$$

Equation (6) is plotted in Figure 2.2.39 and the sum of the well distances approached $1 t$ closely for $\mathrm{N} 4$.

The pipe mains were assumed to be 30 -inch diameter and to service four wells at full capacity. The laterals from the well to main were assumed to be $16-$ Inch

diamter. The 30-inch pipe was assumed to be installed at a cost of $\$ 88 / \mathrm{ft}$ while the 16 -inch pipe was $\$ 43 / \mathrm{ft}$. It was also assumed that 200 feet of 16-inch pipe was needed per well to connect to the 30-1nch main. The pipes' cost becomes

$$
\text { Piping cost }=\$ 22 \times \sum_{1=1}^{N} r_{1}+(\$ 43 \times 200)
$$$$
\mathbf{x} \mathbf{N}
$$

These cost figures are averages for reported piping costs. $[20,24,26,27,28]$

Field Exploration Costs. The cost for developing a field is relatively constant at between 0.5 and 1.25 million dollars $[28,29,30]$, a1though one reference [20] quotes several U.N. studies at 3.0 million dollars. The $\$ 1.25$ mfllion figure was chosen since it represents costs more in line with The Geysers field. Since the exploration costs are fixed and must be written off against the producing wells, it becomes a major capital 1 tem in small plants.

\section{We11 Plow Characteristics}

Since the well has a performance curve simllar to a centrifugal pump, it may be approximated by

$$
{\frac{\mathrm{H}}{\mathrm{H}^{\mathrm{o}}}}^{\mathrm{n}}+{\frac{\mathrm{G}}{\mathrm{G}^{\mathrm{o}}}}^{\mathrm{n}}=\mathrm{k}
$$

where $\mathrm{H}^{\circ}=$ wellhead pressure at no flow

$G^{\circ}$ a well flow rate at atmospheric pressure

$n$ a exponent characteristic of a particular we11, $1.5 \leq n \leq 1.85 ; n=1.7$ for Geysers

If the well is located auficiently far from the turbines, it is possible that the wellhead pressure could be sufficiently above the $110 \mathrm{ps} 1 \mathrm{~g}$ at the turbines to cause an appreciable decrease in flow rate below the assumed $100,000 \mathrm{lb} / \mathrm{hr}$. Taking $\mathrm{G}^{\circ}=110,000$ $1 \mathrm{~b} / \mathrm{hr}$ and $\mathrm{H}^{\circ}$ at $480 \mathrm{psig}$, by differention:

$$
\begin{aligned}
\frac{\mathrm{dG}}{\mathrm{dH}} & =-\left(\frac{\mathrm{G}^{\circ}}{\mathrm{H}^{\circ}}\right)^{\mathrm{n}} \cdot\left(\frac{\mathrm{H}}{\mathrm{G}}\right)^{\mathrm{n}-1} \\
& =-88 \mathrm{lb} / \mathrm{hr} / \mathrm{psig}
\end{aligned}
$$

For a 16-inch pipeline carrying $100,000 \mathrm{lb} / \mathrm{hr}$ of steam the pressure drop at $110 \mathrm{psig}$ is about $0.25 \mathrm{psig}$ per 100 feet of pipe. Considering lengths of 10,000 feet to be the maximum distance from a well, the maximum pressure drop between well and plant becomes $25 \mathrm{psig}$. Therefore, from Equation (8), the maximum drop in capacity for a well is $88 \times 25=22001 \mathrm{~b} / \mathrm{hr}$ or about 2 percent, which is assumed to be negligible.

Total Cap1tal Costs for Dry Steam. The capital investment for $N$ wells to satisfy the first year production is shown in Figure 2.2.40. The required capital investment continues to decrease over the capacity range of 10-400 However, it is very insensitive to capacity over the range of 100 to $400 \mathrm{MW}$, reaching a plateau of $\$ 180 / \mathrm{kWe}$. Therefore, there is very little incentive to expand to larger scale plants above $100 \mathrm{MWe}$. It should be emphasized that these figures are the capital investment for only the first year of operation, after which the well capacity should be expanded by 14 percent per year and that these additional wells will be further from the turbines and hence more expensive than the wells they replace. Therefore, if $\mathrm{N}_{\mathrm{T}}$ wells are considered, the required total capital investment over 20 years is summarized in Figure 2.2.41. Here we have a minimum between 50 and $100 \mathrm{MW}$ in contrast to the previous case where no minimum occurred.

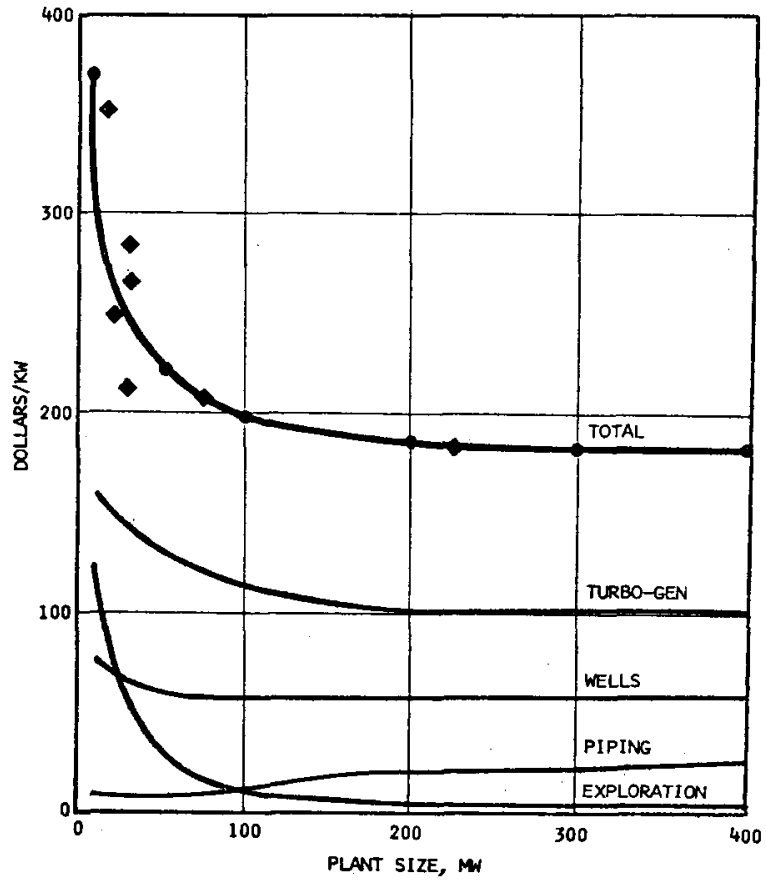

- ory steam (Gersers)

- hOT BRINE

FIgure 2.2 .40 INITIAL CAPITAL COST

There are several ways to budget future capital investments reserved for the new we11s, [30] They can be treated as an operating expense and charged against production costs in the year in wich they were spent. They also can be discounted to give their present worth 


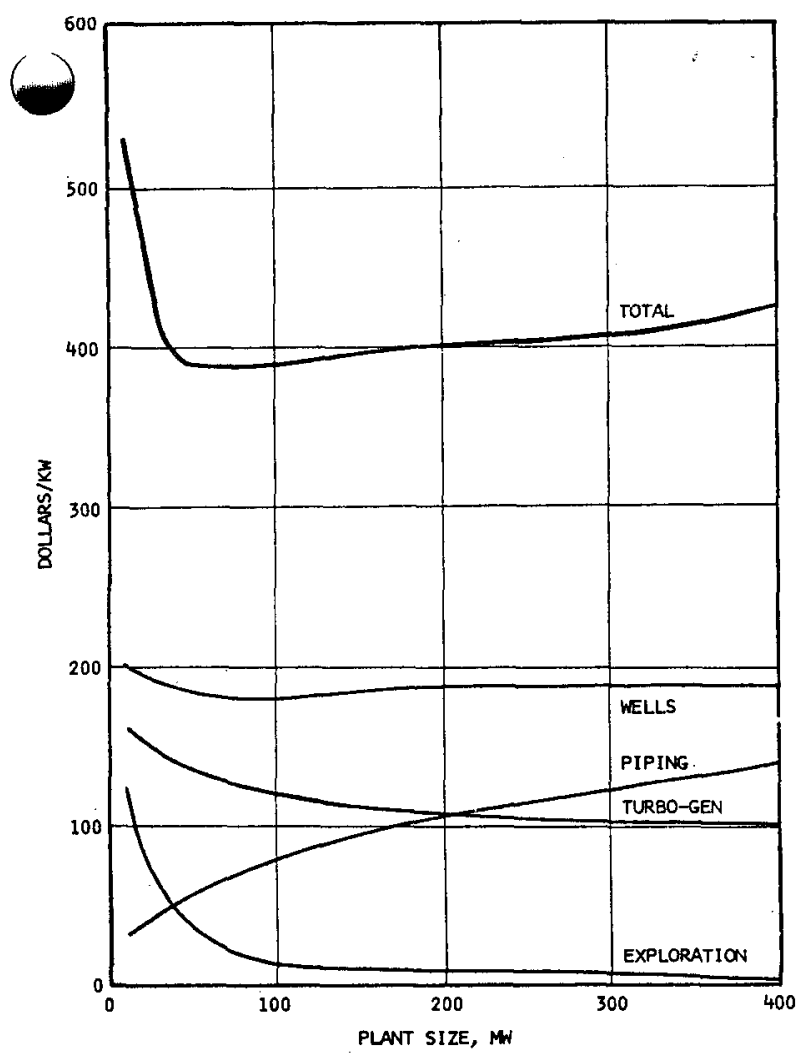

Figure 2.2.41 TOTAL CAPITAL INVESTMENT FOR 20 YEARS STEAM PRODUCING WELLS (GEYSERS)

and the discounted value can be added to the Initial amount. This study utilized the latter method. If the discount factor is taken to be 8 percent, the total capital cost of the plant over the future 20 years in present dollars 1s given by Figure 2.2.41. It is interesting to note that after several scale-ups, Pacific Gas and Electric Company (PGSE) has settled on module units of 100 to $110 \mathrm{MW}$ for several additional units through 1976 which would indicate that they are designIng near the optimum.

Production Costs for Dry Steam. Current profections of future production costs and methods of accounting for them are outlined in the application of PG\&E to the Public Utilities Commission of the State of California, dated July 24, 1973, for Unit No. 14 at The Geysers. [22] Their costs are based upon purchasing the steam. necessary to run the turbine-generators and therefore the well and piping costs must be accounted for in the manufacturing cost analysis of a grass roots plant. F1gure 2.2.42 gives the calculated manufacturing cost of electricity at the generation site for a $110 \mathrm{MW}$ plant running at a 90 percent operation factor. The cost of electricity is largely determined by the required capital investment per kflowatt, and as such, only one production cost is necessary near the minimum 1n F1gure 2.2.41, of $110 \mathrm{MW}$. (Th1s 1s the same size as in the PG\&E application.)

The projected cost of $6.33 \mathrm{mill} / \mathrm{s} / \mathrm{kWh}$ compares with that of $8.35 \mathrm{mills} / \mathrm{kWh}$ from the PG\&E application. The difference between the two figures is due to the method of calculating the steam cost to the generators. The cost of steam to PG\&E 1s set by contract to fluctuate w1th The price of crude oll, and may bear no direct relationilp to the cost of steam production in the fleld. The recent rise in crude oll prices may have been antict-
BASIS: 110 MN PLANT WITH $90 \%$ OPERATION FACTOR

1. TOtal capital investMent

$\$ 21.45$ MILLION

2. DIRECT COSTS
A. installation OF NEW wellos
B. EFFLUENT DISPOSAL (0.5 MILL/KWH)
C. ADDITIONAL DEPRECIATION OF INITIAL WELLS (10 YEAR-STRAIGHT LINE)

3. FIXED CHARGES ( $\%$ OF CAPITAL INVESTMENT, [7])
A. RETURN AND DEPRECIATION
9.79
B. TAXES AND INSURANCE
2.22
C. PROPERTY TAXES
2.03
D. INSURANCE
$\frac{0.09}{14.13}$
3.035

4. GENERAL, (THOUSAND \$) $\begin{array}{ll}\text { A. OPERATION } & 55 \\ \text { 8. MAINTENANCE } & 80 \\ \text { C. GENERAL. EXPENSE } & 40 \\ & 175\end{array}$

TOTAL ANWAL COST
5. PRODUCTION COST FOR GENERATED POWER $=6.33 \mathrm{MILLS} / \mathrm{KWH}$

Figure 2.2.42 CALCULATED PRODUCTION COST FOR DRY STEAM WELLS

pated in PG\&E's application. In Figure 2.2.42, the steam costs are 11 sted under Direct Costs as covering the installation of new wells, as well as the depreciation of the initial wells over a 10-year period. A charge for effluent waste disposal is also included. Since the amount of depreciation under (3a) of Figure 2.2 .42 is based upon a 29 year life, the additional depreclation over ten years of the Initial wells was included in line (2c) to more truly reflect the useful 11fe of the well. If a company owns its own wells, the cost of electricity should be in the 6-7 mill range instead of the 8-9 mill range profected by PG\&E. In any case, these costs are well below the 1980 projected costs for all sources of power except enriched urantum fuel, where costs of $5.1 \mathrm{mllls} / \mathrm{kWh}$ are projected. As a result, geothermal power will be very competively priced relative to other energy sources.

\section{Hot Brine We1ls}

The chances of discovering a hot brine fleld as opposed to a dry steam field (e.g., Geysers) are estimated at $20: 1$ and therefore, they represent a larger source of potential geothermal energy. Unfortunately, the corrosion and scaling of equipment by the hot brines have seriously 1imited their utilization. In order to extract the energy from the hot brines, three general recovery methods have been considered: flashing the brine to obtain 20-30 percent of the brine water as steam, heat transfer to a secondary fluld such as 1sobutane or Freon for use in the power cycle; and the total flow of the flashed steam and hot brine to a turbine capable of hand1Ing the two-phase flow. Since the basic elements of capital cost in all of these processes is simllar to that for the dry steam un1ts and power output characterlstics are similar (P1gure 2.2.43), the effect of size on cap1tal Investment should be similar and should plateau out around the 100 to $200 \mathrm{MW}$ range. The Initial capital investment required for the geothermal plants with brine wells are comparable to that for the dry steam wells as seen In Figure 2.2.40. 


\begin{tabular}{|l|c|c|c|}
\hline \multicolumn{1}{|c|}{ LOCATION } & $\begin{array}{c}\text { FLASHED STEAM } \\
\text { (LB/HR) }\end{array}$ & MN/WELL & REF. \\
\hline $\begin{array}{l}\text { IMPERIAL VALLEY, CALI FORNIA } \\
\text { (21,000 BRINE BBL/DAY } \\
\text { @ 12S PSIG) }\end{array}$ & 118,000 & & 31 \\
WAIRAKEI, NEW ZEALAND & 43,700 & 3.2 & 32 \\
CERRO PRIETO, MEXICO, & 110,000 & 5.0 & \\
GENERAL & & 3.8 & 34 \\
" & 100,000 & 5.0 & 20 \\
GEYSERS, CALIFORNIA & 96,800 & 5.3 & 20 \\
CORY STEAM WELL--FOR \\
OOMPARISON)
\end{tabular}

F1gure 2.2.43 POWER OUTPUTS FROM BRINE WELLS

Several detalled cost estimates have been prepared for those three brine methods and are summarized in Figure 2.2.44. The reports referenced in this figure assume wide range of depreclation rates and hence a range of production costs were found for similar size plants. However, the electric generation costs for all schemes was below that predicted for the dry steam wells, primarily because the brine wells to date have not decreased the1r output with usage. In the dry steam wells, the production has been observed to decrease about 14 percent per year, while the rate of brine flow has remained constant. This decreased replacement cost can show up directly as lower electrical energy costs. The amount of flashed steam available per well from brine wells is very close to that found in the dry steam. flelds, such as The Geysers, Callfornia.

\section{Hot Dry Rock We11s}

Methods to extract energy from hot dry rock are largely centered around the method proposed by the Los Alamos Sclent1f1c Laboratory. [36] Two holes are to be drilled into the hot rock regions of the earth's crust, and the region between the holes will be hydrofractured, a common practice in the ofl industry. Water will be pumped down one hole, permeate through the hot rock, and exit the other hole heated to about $300^{\circ} \mathrm{C}$. The pressurized water would be heat exchanged with efther steam or 1sobutane in secondary cycles with the secondary fluld sent to the same type of turbine-generator system as for a dry steam plant. If a secondary fluid is not desired, the hot water could be flashed, and the steam sent to the turbine generators. Since no hot rock wells have been drilled and operated, it is difficult to project power costs using this method. The well depths are projected to be between 20,000 and 60,000 feet, about 4 to 10 times the depth of present dry steam or brine wells. The present IImit to drilling technology is about 30,000 feet and therefore poses some constraint on reglons of the country to be examined. In addition, 1ittle is known about the heat recharge rate to such a rock formation which will sustain a steady removal of heat from 1t. Recognizing these uncertaintles, some projections of hot rock power costs have been made, nevertheless, and are given in Figure 2.2.45.[36] Capital and electrical generating costs are comparable to both the dry ateam and hot brine systems. Until actual hot rock wells are drilled and evaluated, a large degree of uncertainty w111 govern hot rock costs.

\begin{tabular}{|l|c|c|c|}
\hline TYPE & $\begin{array}{c}\text { PLANT SIZE } \\
\text { MWN }\end{array}$ & $\begin{array}{c}\text { CAPITAL COST } \\
\text { S/KW }\end{array}$ & $\begin{array}{c}\text { GENERATING } \\
\text { COST } \\
\text { MLLLS/KWHR }\end{array}$ \\
\hline $\begin{array}{l}300^{\circ} \text { C ROCK, STEAM } \\
\text { AND ISOBUTANE CYCLES, } \\
4 \text { HOLES } \\
\begin{array}{l}175^{\circ} \mathrm{C} \text { ROCK, ISOBUTANE } \\
\text { CYCLE, 10 HOLES }\end{array}\end{array}$ & 100 & 186 & 4.7 \\
\hline
\end{tabular}

Figure 2.2.45 POSSIBLE ELECTRICAL COSTS FROM HOT ROCK GEOTHERMAL PLANTS [10]

\section{Conclusions}

1. The Initial capital investment required for dry steam geothermal plants changes little from $\$ 180 /$ 200-kW for plants above $100 \mathrm{MW}$. Therefore, there is no economic advantage to installing larger units.

2. When the total investment in replacement we1ls over 20 years 18 added to the initial capital investment, the total reaches a minimum for plants between 50 and $100 \mathrm{MW}$.

\begin{tabular}{|c|c|c|c|c|c|}
\hline PROCESS & SIZE, MW & $\begin{array}{c}\text { CAPITAL INVESTMENT } \\
\$ / K W\end{array}$ & $\begin{array}{c}\text { OPERATING } \\
\text { COSTS } \\
\$ / Y R\end{array}$ & $\begin{array}{l}\text { PRODUCTION } \\
\text { COSTS } \\
\text { MILLS/KWHR }\end{array}$ & REF. \\
\hline BRINE FLASH & & & & & \\
\hline $\begin{array}{l}\text { BRINE } 6000 \text { BTU/LB } \\
\text { BRINE } 6000 \text { BTU/LB } \\
\text { BRINE } 550 \text { BTU/LB } \\
\text { BRINE } 9510 \text { BTU/LB }\end{array}$ & $\begin{array}{l}28 \\
22.6 \\
192 \text { (WAIRAKEI) } \\
75 \text { (CERRO PRIETO) } \\
30 \text { (OTAKA) }\end{array}$ & $\begin{array}{l}214 \\
251 \\
208 @ 178 \text { OVERHEAD } \\
288\end{array}$ & $\begin{array}{r}677,000 \\
838 \\
1,427,000\end{array}$ & $\begin{array}{l}2.8 \\
4.77 \\
5.14 \\
8.0 \\
6.53\end{array}$ & $\begin{array}{l}35 \\
23 \\
20\end{array}$ \\
\hline $\begin{array}{l}\text { SECONDARY FLUID } \\
\text { BRINE O } 600 \text { BTU/LB } \\
\text { THO-PHASE TURBINE }\end{array}$ & 14.1 & 354 & 761,000 & 6.82 & 23 \\
\hline $\begin{array}{l}\text { BRINE @ } 600 \text { BTU/LB } \\
\text { BRINE @ } 562 \text { BTU/LB }\end{array}$ & $\begin{array}{r}28 \\
220\end{array}$ & $\begin{array}{l}264 \\
180\end{array}$ & $\begin{array}{l}1,050,000 \\
3,134,000\end{array}$ & $\begin{array}{l}4.70 \\
3.30\end{array}$ & $\begin{array}{l}23 \\
34\end{array}$ \\
\hline
\end{tabular}

Figure 2.2.44 GEOTHERMAL BRINE ENERGY COSTS 
3. Since the amount of flashed steam per well obtained from hot brine wells is close to that obtalned from dry steam wells, and their inftial capital investments are the same, conclustons 1 and 2 also hold for hot brine we1ls.

4. Since the level of capital investment determines 80 to 90 percent of the electrical production costs, electrical production costs are a minimum for plants around 100 MWe in size.

5. The electrical production cost for a $110 \mathrm{MW}$ plant is between 6 and $8 \mathrm{mills} / \mathrm{kWh}$ fọ both dry steam and hot brine systems.

6. The hot rock well systems are projected to have electrical costs between 4 and $8 \cdot \mathrm{mills} / \mathrm{kWh}$, although these costs are largely conjecture.

\section{Dual Fuel Cycle (Geothermal-Fossil} Fuel Combined Cycle)

It has been suggested by Joseph Coates [37] and others $[38,39]$ that the geothermal energy resource in the form of hot water can be combined. wh fossil fuel energy into an efficient combined cycle. Flements of this general concept have been studied by James [38] and by Armstead. [39]

James, In a study of the Wairakei installations investigated superheating the geothermal steam in order to improve the power system. It was found that the optimum turbine pressure was $50 \mathrm{psig}$, and at this condition about 300 MWe could be generated at the total field fluid draw rate. If this saturated 50 psig steam.were superheated with oll to $1000^{\circ} \mathrm{F}$. before entering the turbine, the power output could be boosted from 300 MWe to about 500 WWe for the same geothermal field output conditions. Th1s would give a 67 percent increase in power capacity.

Another benefit would be improved turbine conditions. Because of superheating at low pressure, the turbine steam would never become wet at the final row of blades, hence, problems associated wh wet steam erosion vanish and the speed of the turbine may be increased from $1500 \mathrm{rpm}$ to $3000 \mathrm{rpm}$. All of this would give a less costly turbine. On the other hand, of course, a superhester has to be included In the cost of the plant, and this would about counterbalance the savings. James [38] made a cost analysis of all the additional equipment required for an oil superheating unit added onto the geothermal unit. He concluded that an examination of the thermodynamic cycle Ind 1cates that the thermo effictency of the fuel-fired fraction of the unit would be in the range of 33 to. 37 percent, depending on the superheater's efficlency, and 18 therefore not greater than that of a modern thermal plant. whtch is in the range of 40 percent. Therefore, fuel costs are about the same for a dual geothermal-oil superheat system as for separate geothermal and o1l fuel fired atations of equivalent . total power. However, becaube of reduced capital investment, the dual compostte system has apparently lower total generating costs. James emphasizes that this analysis is only for the Waralkel fleld. - He believes that since every geothermal fleld is unique, the concept of an oll fuel fired superheating of geothermal steam w111 have to be analyzed for every separate field in order to determine the economica.

In the cycle suggested by Armstead [39], the geothermal steam power plant is used for base loading, and peak system demand is satisfled by superheating the geo- thermal steam in a ofl superheater before sending it to the turbines. Geothermal steam power plants normally use steam that is elther saturated, as in 1iquid fields, or only slightly superheated, as in steam fields. By adding superheat from a fossil fuel, the cycle efficiency can be improved, as pointed out above, and a larger number of kllowatts, can therefore be generated from a given quantity of steam. For example, steam at 100 psig could yield about 25 percent more power per pound of steam when superheated to $650^{\circ} \mathrm{F}$, than when saturated at $338^{\circ} \mathrm{F}$. Hence, a base-load plant deslgned to carry 80 percent of the maximum system load with saturated steam at 100 psig could also carry the full peak load of 20 percent more if the steam were superheated to a maximum of $650^{\circ} \mathrm{F}$. To achieve this, it would be necessary to add 162 Btu per pound of steam when the turbine Is carrying the full peak load. As the perlod of peak load demand (over 80 percent of the peak) would be only a few hours per day, only a small amount of fossil fuel (ol1 or coal) would be required ordinarily to provide the superheat.

In evaluating this dual fossil fuel-geothermal steam power plant, Armstead found that the capital costs of adding an ofl-fired superheater for peak load purposes to a base load geothermal steam plant gives a lower capital cost than a stralght expansion of the geothermal power plant. On the other hand, the cost of the o1l is greater than, the cost of the geothermal steam. In the cases which he examined, which were based largely on the geothermal field In New Zealand, it was shown that an oll-fired superheater would give slightly lower overall electrical generating costs than straight expansion of the geothermal plant. He points out that all that can be concluded from these samples is that ofl-fired superheating can sometimes be an economic method of supplying peak loads in combination with a base-loaded geothermal power plant. However, each case will have to be examined carefully to determine 1ts Individual characteristics and merits.

It might well be asked: Why not feed the two-phase brinesteam mixture from a liquid geothermal field directly to the boiler of a fossil fuel fired plant? The answer is that the tubes would scale up in a very short time, thus stopping operation of the boller. This corrosion problem has been discussed previously in this section and in the previous section. It is well known that the water in a steam boller must be very pure.

This leads to another concept; that: 1s to use the geothermal hot water as a heating medium for bolling pure boller feedwater in a special heat exchanger or for preheating the boller feedwater. of a fossil fuel boller. This concept has been examined silghtly by several groups in the geothermal power business. They found that it is extremely difficult and expensive to design a heat exchanger to withstand the scaling and corrosion of the hot brines. So far, attempts to build economic un1 ts of th1s kind have been stymied.

The derivation of successful plant operating economics for a dual cycle geothermal-fosoll fuel power plant will depend a great deal on a colncidence of location of geothermal-and-foss 11 fuel resources. 011, of course, can be transported falrly easily to certain geothermal fields:In the Untted States. For example, this could be done falrly eas1ly for the Imperfal Valley area. On the other hand, transportation of coal 18 much more expensive and it would be destrable to have coal fields near the geothermal fields. The maps given in a later section (Section 4.4) show that in many western areas, e.g., Wyoming and Utah, coal flelds are very close to promlsing geothermal resource areas. 
Therefore, the possibility of developing a combined cycle utllizing these western coal and geothermal resources should be examined further to determine their possible merits.

In conclusion, the concepts of dual cycle power plants combining the good features of geothermal and fossil fuel power cycles show some potential. However, at present only a small amount of study has been given to these concepts. The results to date indicate that further study is well justifled.

\section{REFERENCES}

[1] Jones, P. H., "Geothermal Resources of the Northern Gulf of Mexico Basin," Geothermica, Speclal Issue 2, Vo1. 2, Part 1 (1970).

[2] Maasberg, A. T., and 0. Osborn, "Statement on the Geotherma1 Energy Research, Development and Commercial Demonstration Act of 1973

H.R. 11212" (Midland, Mich.: The Dow Chemical Company, February 4, 1974).

[3] Burst, J. F., Jr., "Postdlagenetic Clay-Mineral Envirommental Relationships in the Gulf Coast Eocene," Earth Science, Vol. 2 (1959), pp. 327 341.

[4] Jones, P. H., Hydrology of Neogene Deposits in the Nor thern Gulf of-Mextco Basin, Loulsians Water Resources Research Institute Bulletin GT-2 (Baton Rouge, La.: Loulsiana State Un1versity, 1969).

[5] Schoeppe, R. J., and S. Gilarranz, "Use of Wel1 Log Temperatures To Evaluate Reg1onal Geothermal Gradients," Journal of Petroleum Technology, Vo1. 18 (June 1966), PP. 667-673.

[6] Schmidt, G. W., "Interstitial Water Composition and Geochemistry of Deep Gulf Coast Shales and Sandstones," American Association Petroleum Geol. Bulletin, Vol. 57, No. 2 (February 1973), pp. 321-337.

[7] Wallace, W. E., "Water Production from Abnormally Pressured Gas Reservolrs in South Loulslana," Journal of Petroleum Technology Vol. 21 (August 1969), pp. 969-983.

[8] Jones, P: H., "Hydrodynamics of Geopressuxe In the Northern Gulf of Mexico Basin," Journal of Petroleum.Technology, Vo1. 21 (July 1969), pp. 113-125

[9] A Feasibility Study of Power Production from Overpressured ..Reservoirs, ARPA Contract 72-2395 (Department of Geological Sclences, Southern Methodlst University, n.d.).

[10] Durham, C. D., "Proposed Geopressured Energy Investigation, :Statement on the Geothermal Energy Research " Development and Commerclal Demonstration Act of 1973 H.R. 11212," Director, School of Geosclence (Baton Rouge, La.: Loulsiana State University, February 4, 1974).

[11] Sm1th, M. C., "Geothermal Energy,".LA-5289-MS (Los Alagmos, N.M.: Los Alamos Sclentific Laboratory of the University of Callfornia, May 1973).

[12] Smlth, M. C., "The Potential for the Production of Power from Geothermal Resources," LA-UR-73-
926 (Los Alamos, N.M.: Los Alamos Scientific Laboratory of the University of Californta, June 13, 1973)

[13] Burnham, J. B., and D. H. Stewart, "Recovery of Geothermal Energy from Hot Dry Rock with Nuclear Explosives," In Paul Kruger and Carel Otte (eds.); Geothermal Energy, Resources Production, Stimulation (Stanford, Calff.: Stanford Untversity Press, 1973).

[14] Potter, R. M., "Geothermal Resources Created by Hydraulic Fracturing in Hot Rock," paper presented at the Geothermal Research Conference (sponsored by the National Sclence Foundation through a research grant to Walter J. Hickel, UnIversity of Alaska) (Washington, D.C.: Battelle Seattle Research Center, September 1972).

[15] Potter, R. M., "Assessment of Some of the Geothermal Resources of the Eastern United States" (Los Alamos, N.M.: Los Alamos Scientific Laboratory, 1973)

[16] Blackwe11, D. D., "The Thermal Structure of the Continental Crust," Geophysical Monograph Serles Vol. 14 (1971), p. 169 .

[17] Brown; D. W: "The Potential for Hot-Dry-Rock Geothermal Energy in the Western United States," LA-UR-73-1075 (Los Alamos, N.M.: Los Alamos Scientific Laboratory, University of California, July 25, 1973).

[18] Austin, A. L., G. H. Higgins, and J. H. Howard, "The Total Flow Concept for Recovery of Energy from Geothermal Hot Brines Deposits," UCRL-51366 (Livermore, Calif.: Lawerence Livermore Laboratory, Untversity of California, April 3, 1973).

[19] Power Generation from Imperial Valley Geothermal Brine--Preliminary Cycle'Screenlng (Canoga Park, Cal1f.: Rockwell International Corp., Atomics International Division; 1974).

[20] Armstead, H. C. H., "Geothermal Economics," Geotherma1 Energy (Paris: UNESCO, 1973), Pp 161-174.

[21] Kaufman, A., "The Economics of Geothermal Power In the United States," Geothermics, Special Issue 2 (1970), p. 967 .

[22] Application of the Paciffc Gas and Electric Company before the Public Utilities Comission of the State of California for Unit 14 (1973).

[23] Green, M. A., and A. D. K. Latrd, Compartson of Elementary Geothermal-Brine Power-Production Processes, Report LBL-2102 (Berkeley, Callf.: Lawrence Berkeley Laboratory of the Untversity of California, 1973).

[24] Armstead, H. C. H., "Geothermal Power for NonBase Load Purposes, Geothermics, Spectal Issue 2 $(1970)$, P. 936.

[25] Budd, C. F., in Paul Kruger and Carel Otte (eds.), Geothermal Energy (Stanford, Calif.: Stanford Untversity Press, 1973), p. 129.

[26] Hayashida, T., "Cost Analysis in the Geothermal Power," Geothermics, Special Issue 2 (1970), p. 950 .

[27] Smlth, J. H., "Collection and Transmission of Geothermal Fiuids," Geothermal Energy (Paris: 
[28] Grefder, R., "Economic Constderations for Geothermal Exploration in the Western Unfed States," Bulletin, Geothermal Resources Councll, Dav1s, Calif., May/ June 1974.

[29] Reed, M. J., "The Economics of Geothermal Exploration, presented at the Geothermal Short Course in Sacramenta, Calif., May 9, 1973.

[30] Gretder, R., excerpt from seminar on geothermal energy held at Un1ted Nations Headquarters, January 1973.

[31] Dtte, Carel, "Drilling, Production and Disposal Technology in Salton Sea Geothermal Area, Imperial County, Callfornia," presented to the Geothermal Resources Board of the State of Californla, October 22-23, 1970.

[32] Walrake1, Commisstoner, Ministry of Energy Resources, Wellington, New Zealand.

[33] Paredes, S., Superintendent Planta Geotermoelectrica, Comission Federal de Electricidad, speech presented at EI Centro, Calffornia, October 17, 1973.

[34] Austin, A. L., G. H. Higgins, and J. H. Howard, The Total Flow Concept for Recovery of Energy from Geothermal Hot Brine Deposits, Report UCRL51366 (Livermore, Calif, : Lawrence Iivermore Laboratory, University of California, n.d.).

[35] Ranking Research Problems on Geothermal Development, R\&D Progress Report 711 (Washington, D.C.: U.S. Department of the Interior, office of Saline Water, 1971).

[36] Brown, D. W., M. C. Smith, and R. M. Potter, A New Method for Estimating Energy from "Dry". Geothermal Reservolrs, Report LA-DC-72-1157 (Los Alamos, N.M.: Los Alamos Scientific Laboratory, 1972).

[37] Coates, Joseph, private communication, December 1973.

[38] James, R., "Power Station Strategy," Geothermics, Spectal Issue 2, Vol. 2, No. 2 (1970), P, 1676.

[39] Armstead, H. C. H., "Geothermal Power for NonBase Load Purposes," Geothermics, Special Issue 2, Vol. 2, Part 1 (1970), p. 936. 


\subsection{Institutional Considerations}

\section{Introduction}

The exploration, development, exploitation, use, and regulation of geothermal energy has involved a host of institutions, government and corporate, formal and informal. These institutions sometimes support one another, but more of ten than not overlap in their functions; they act elther in their own interest or in a manner which they view as representing the broad social interest; they are carving out their areas of responsibility or have had them.defined by law. Out of this complex mix will come the future geothermal Industry, its constituents, and Its public. The purpose of this section is to review the groups and institutions with interest in geothermal energy and the nature of their interests.

The relationship of the Institutions involved in the development of geothermal energy is 11lustrated in Figure 2.3.1. Each of the primary functions of land ownersh1p, resource exploration, resource development, energy distribution, and energy consumption involve several different institutions, some of which have primary and active roles, and others, secondary and passive. The institutions discussed are mafor federal government agencles, other federal organizations, the geothermal industry, residents and environmentalists, and foreign institutions. The more important of these institutions and the nature of their involvement is described below. [1]

\section{Federal Government Agencles}

W1thin the Federal Government, the main agencles involved in the evolution of geothermal energy are: the U.S. Geological Survey, which has the responsibility for the Identification and leasing of geothermal resources; the National Sclence Foundation, which has embarked on a broad and important program of research and which 18 currently serving as lead agency within the government; and the Atomic Energy Commission, which has initiated certain crucial geothermal research projects.[2]

\section{The U.S. Geological Survey}

This is the Department of the Interior's lead bureau in geothermsl energy atudles. The major elements of their program Include exploration methodology, resource appraisal, reservoir development, utilization technology and environmental monftoring. The Depertment hes carried out cooperative studies with private Industry focused on the geochemistry and petrology of the hydrothermal system. Such studies have been going on In the Salton Sea geothermal fleld since 1963. In 1966, the Geological Survey began a major Investigation of all aspects of the geology of Yellowstone National Park, Including intensive studies at the Hot Springs area. Several other hot springs systems in the western United States have been Investigated by the Survey, Including Sulfur Bank on Clear Lake, Callfornia, and the Lake CIty area. With increased appropriations in 1971, the Geological Survey expanded 1ts geothermal program. Projects were started at The Geysers, Clear Lake, and Long Valley, Californla, using detalled geologic and geophysical, geochemical, and hydrologic techniques. Recomalsaance geologic, geochemica1, and hydrologic surveys were started in northwest Nevada and southeastern Oregon, and a program was begun for developing and testing new geophysical techniques.
The USGS is responsible for the superviston of operathions under all federal geothermal leases, including approval of exploration and development plans; .Inspec tion of operations, and collection of royalties due the government.[2]

\section{Nationa1 Science Foundation}

The major effort of the Foundation in geothermal energy is the funding of research on 1iquid-dominated and hot dry rock systems. The Foundation has several exemplary projects underway, one being an effort by the New Mexico Institute of Mining and Technology to investigate the thermal regime of the Rio Grande rift system In New Mexico; another project Involves the study of the hydrothermal systems of the KIlauea Volcano on the Island of Hawail under the direction of the Colorado School of Mines; while a third project, Initlated last year, is using electrical methods to desalinate geothermal reservoirs. A major area of investigation sponsored by the Foundation Involves the evaluation of the geothermal resources at the Imperfal Valley in cooperation with the state of California. $[2,3]$

Research into the stimilation of geothermal aquifers is also being subsidized. Thts research has three major objectives: (1) development of experimental and numer1cal data to evaluate optimum performance of explosion stimulated geothermal aquifers; (2) development of a geothermal steam reservoir model to evaluate the thermal phystcal hydrodynamic and chemical parameters Involved; and (3) development of a laboratory model of an explosion-produced chimey to produce experimental data on the processes of Inplace bolling, moving. flash fronts, and two-phase, flow in high porous media: The Foundation has embarked on a research effort on hot dry rock geothermal systems in Marysville, Montana. Here, research teams from Southern Methodist University, Batelle Memorial Institute; and several other research centers are completing a geological survey of the area. Plans are to drili a test hole to develop appropriate technology as a model for exploration of simflar hot dry rock formations and to ultimately develop this particular area to an economic productive source.

\section{The Atomlc Energy Commission}

This Commission's research and development authority was revised in 1971 by a statutory amendment to the Atomic Energy Act of 1954. This amendment authorizes the AEC to conduct research and development activities related to "...the preservation and enhancement of a viable environment by developing more efficient methods to meet the nation's energy needs." In particular, this means that the AEC's efforts in R\&D are no longer 11mited to the nuclear area.[2]

Studies were undertaken, In 1970 and 1971 , at Bate1le Northwest Laboratory, American Shale Company, Westinghouse Electric Company, the Lawrence Livermore Laboratory, and the Los Alamos Sclentific Laboratory of the ARC. These studies concerned the technical and economic feasibility of extracting thermal energy from relatively dry geothermal reservolrs through the use of nuclear explosives to fracture the rocks and the subsequent injection of water to provide a carrier of heat.

A particularly promiaing profect currently is the possib1ilty of developing hot rock geological systems. Th1s project will be carried out at LOB Alamos Sclentific Laboratory, where plans call for drilling into hot rock in the Jemez Plateau of New Mexico and developing a pilot profect plant. The major research work will concentrate on thermal, mechanlcal, and chemical behavior of rock to demonstrate the feasibility of such a manmade system. The AEC has requested $\$ 4.7$ million for 1974 to finance this profect. [3] 


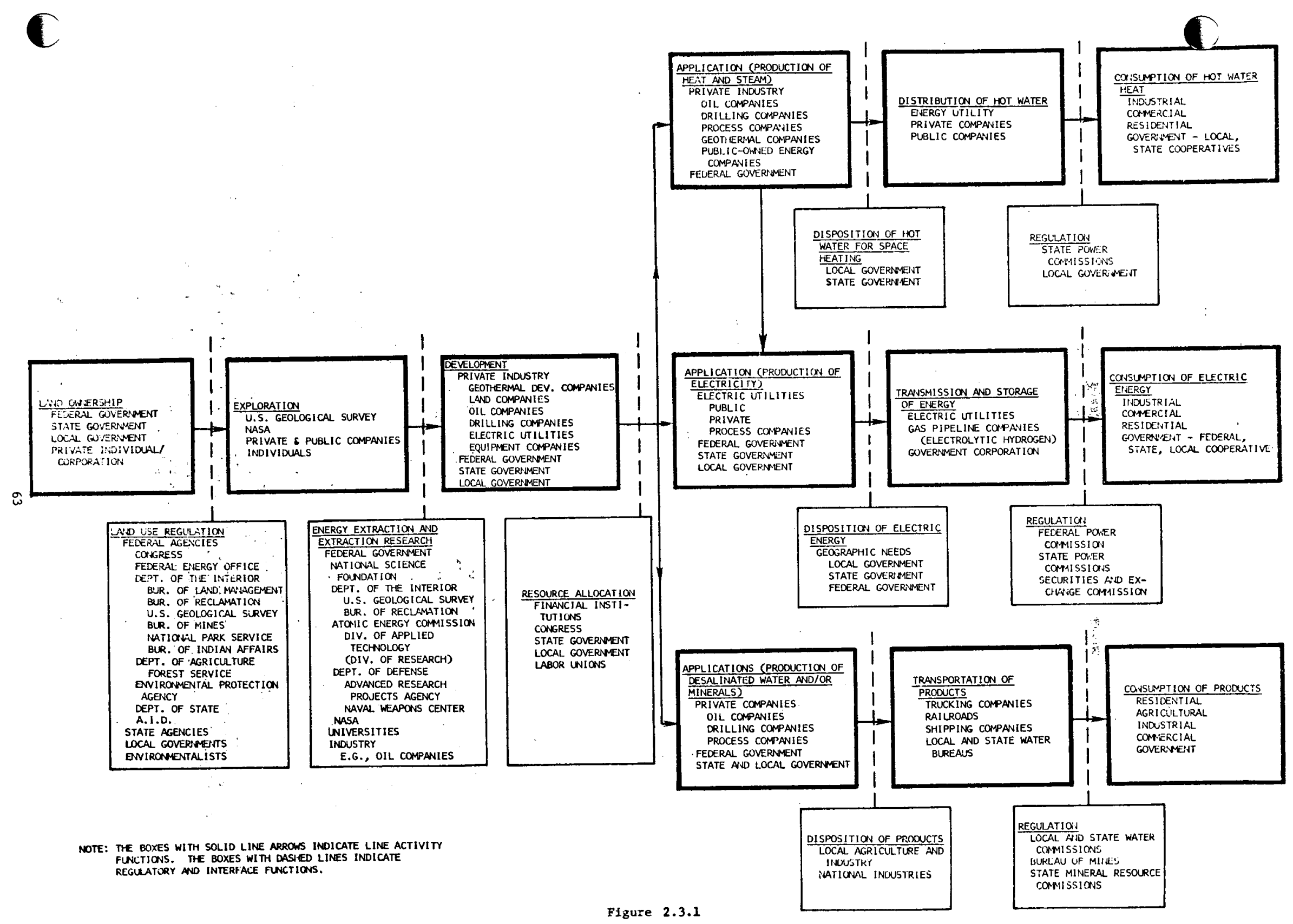


The LOB Alamos Sclentific Laboratory is developing a thermal dxill using electrically generated heat. A prototype of the drill has been successfully tested in the laboratory in the field.

The AEC has recommended three different. paths that may be followed in a government industry geothermal development program. The first, a phased approach, would be one in which the inttlal research effort would be predominantly governmental as in the development of the hot dry rock concept at Los Alamos. The second could Involve joint funding in management over the life of a program. The third could be a joint government industry program taking the form of government operated test facilities where varlous industrial equipment components might be Installed for the development of long-term operational experiments. Such techniques, of course, have been applied successfully to the commerclalization of reactor technology.

\section{Other Federal Organizations}

\section{Bureau of Land Management}

As manager of the public 1and, the Bureau of Land Management is responsible for leasing of federallyowned geothermal resources. The Bureau Identifles potential geothermal leasing tracts based on geological aurveys and on information provided by the U.S. Geologic Survey and the Bureau of Mines, as well as their own data and evaluation. Lands to be withdrawn, offered for competitive bidding, and marked for non-competitive leasing, are Identifled by the Bureau of Land Management.

The Bureau of Land Management recommends to the Secretary of the Interfor exemption of those lands from leasing where the 1ssuance of the lease might be contrary to the public interest. Such areas are those (a) administered under the national park system; (b) within a national recreation area; (c) In a fish hatchery administered by the Secretary, a wildife refuge, wlldlfe range, game range, wildlife management area or water fowl production area, or for lands acquired or reserved for the protection and conservation of fish and wildilfe which are threatened with extinction; and (d) Individually owned Indian trust or restricted lands within or without the boundaries of Indian reservations. The Slerra Club has already Indicated their bellef that the provision for exempted areas falls short and should Include, In addition: (1) the national wilderness preservation system; (2) unfts of the aystem of national wild and scenic rivers; (3) unfts of the national tralls system; (4) areas reserved by the Secretary of the Interlor or the Secretary of Agriculture for ecologlcal, scenic, natural wlldife, geological, educational, historical, or sclentific value, Including primitive areas, roadless areas, back country areas, natural areas, and ploneer areas; (5) areas of de facto wilderness under study by the Secretary of the Interfor or the Secretary of Agriculture for reservation as part of the national w1lderness preservation systems; and (6) areas within one mile of the exterfor boundaries of geothermal pools, hot springs, geysers, fumaroles, and mud pots [4]. It 18 quite apparent that should the iseue be pressed, the larger pollcles addressed w111 probably go beyond the Department's confines and may require further legislative acts.

\section{National Aeronautics and Space Administration}

For several years NASA has carried out cooperative regearch with the U.S. Geological Survey in remote sensing of geothermal areas. In this program, data from the geologic survey fleld and laboratory studies and aerial photographs were augmented by infrared scanning data and high altitude aerlal photographs provided by NASA. [2]

\section{The Bureau of Reclamation}

The Bureau of Reclamation has the statutory respons1bility to Investigate alternate water supplies to supplement the Colorado River and to desalinate the river water. Under the Colorado RIver Basin Project Act (P.L. 90-537, 82 Stat. 885, September 30, 1968); the Bureau began an extensive, ambitious, 20-year project in 1971. [5]

First, the Bureau is to investigate the technological and economic feastbility of producing fresh water from the saline brine contained in the liquid-dominated systems of the Imperial Valley (East Mesa), California. Extensive geological, geophysical, geohydrological, and water chemistry investigations w111 be undertaken to fully evaluate those regions. Deep test wells will be drilled for both production and reinjection, and a major portion of the research effort will be in the evaluation of geothermal desalting techniques and the most feasible desalting processes. These studies may culminate in the construction of prototype desalting plants which would be operated in confunction with the appropriate pre-treatment and waste disposal systems.

The components of the Bureau of Reclamation's geothermal program are (1) exploration, (2) production and infection wells, (3) research and development, and (4) appralsal. The exploration program is currently designed to secure estimates of the quantity and quality of geothermal resources in the Imperfal Valley on reclariation withdrawn land. These estimates will be needed at an early date for a declsion on the source of replacement water to prevent subsidence due to fluid withdrawal. If the resource proves to be large, the most economical source may be the ocean. In the case of large scale Importation of replacement water from the ocean, the entire resource might be developed as a foint venture by federal and non-federal interests. If the source 18 moderate or small, local replacement water from such sources as near surface groundwater, the Salton Sea, and the Welton-Mohawk Draln would be used.

Finally, if the resource is found to be large and saltwater is therefore piped in from the Pacific for replacement, the Bureau has further plans. The Imported saltwater can be distilled and, 11ke the desalinated geothermal water, be piped on to the Colorado River. Since the full implementation of this plan would produce $2,500,000$ acre feet of fresh water per year, very large quantities of steam and pumping power would be required. The Bureau expects to be able to contribute an amount of fresh water equal to approximately 25 percent of the present Colorado RIver flow at the Imperial Dam. In addition, with this throughput at the East Mesa Installation, the Bureau studies Ind1cate that 10,500 MWe could be developed fointly. About 2000 MWe would be required for water production and conveyance pumpIng, and the balance of 8500 MWe could be avaliable to sell to the Pacific Southweat. [5]

As 1t proceeds with 1ts project, the Bureau w11 also estimate environmental aspects of geothermal development, including effects such as selomlc activity, subsidence, and air pollution.

The development of the Colorado RIver and 1 ts water quallty are both national and international problems. The Federal Government (and, In particular, the Bureau of Mines) is bound by treaty to guarantee Mexico 1.5 
million acre feet of Colorado RIver water per year. The government is also morally bound to supply this water at reasomble quality. With the gradual deterioration of qual ity of water avallable from the lower Colorado River, the multi million dollar agricultural Industry in Coache1la, Imperial, and Mexicali Valleys is at stake. The water supply is essentially fully utilized at the present time, and unless augmented by external sources as may be derived from geothermal development, only a modest increase in the amount of irrigated acreage can be expected in the future.

\section{The Office of Saline Water}

This office began a seven-year geothermal program in 1972 aimed at developing technology necessary to the desalting of geothermal brine. Their program included research on brine chemistry, materlals of construction, process analysis and testing, environmental effects of the desalting processes, and effluent disposable techniques. Particular attention was directed towards finding economical and rellable materials of construction for the potentially corrosive geothermal fluid, a hot, acidic brine containing sulf1de or carbonic gases. Funds were not requested for 1974 and it appears that the program has been terminated as part of a general dismantling of the department's desalination activities. The work in the Imperial Valley will shift entirely to the Bureau of Reclamation, as described above. [2]

\section{Bureau of Mines}

The major emphasis of the Bureau of Mines' activities centers on the recovery of minerals and gases found dissolved in geothermal fluid. The Bureau's program consists of five elements: (1) developing a system for evaluating brines to determine constituents of potential economic value; (2) developing methods for recovering the constituents found; (3) developing methods for separating non-commerclal constituents and for their disposal; (4) determining criterla for selecting materials of engineering construction needed in the handling of hot, concentrated brines; and (5) finding new metallurgical processing uses for residual brine.

Research investigation will concentrate on the geothermal fluids of the Imperial Valley in addition to other promising geothermal resource areas. If research indicates the presence of mineral and gas constituents of sufficient economic value in the brines, a pilot plant for their recovery may be built in close proximity to a desalination plant in order to receive and process the plant effluents. [2]

\section{The Department of State}

Besides being involved in treaty negotiations with Mexico over the development of the Colorado River, the Department of State has a two-part program of its own with respect to geothermal power: The first is a series of informal exchanges between scientists in the United States and overseas. For example, through this program the Department of State has entered into a cooperative development program with Japan. Beyond information and scientific exchange, the State Department has a provision for direct assistance in developing countries through the Agency for International Development. Th1s program has flnanced, for example, a preliminary reconnaissance of geothermal energy resources in the Dlang Plateau of Central Java. AID is also assisting in the planning of a small pilot geothermal project in southern Luzon in the Philippines. The development of geothermal resources w111 become of increasing Importance to certain underdeveloped countrles which have sparse supplies of fossil fuels. [2]
The Advanced Research Project Agency of the Department of Defense

Th1s agency is conducting studies of potential application of geothermal sources for specific military needs. Applications of concern to the military include (1) providing a primary source of relfable power at remote locations, (2) an emergency or back-up power source in the event that conventional power sources are disrupted, and (3) a self-contained standby power source for hardened, underground or underwater facilities capable of providing space heating and cooling and potable water, as well as electric power. While the ARPA effort is limited to the definition of Department of Defense needs, their work w111 be appropriate to the technological development of a sma11 geothermal power station. [2]

\section{The Bureau of Sport Fisherles and Wildlife}

A division of the U.S. Fish and Wildiffe Service (Department of the Interior), the Bureau's objectives Include the perpetuation, use, understanding, and enjoyment of sportfish and widlife resources in the United States. The Bureau operates over $100 \mathrm{f} 1 \mathrm{sh}$ hatcherles and stocks public waters and farm fish ponds. Wildlife programs are designed to protect and enhance the values of the nation's wildlife species.

The Bureau studies environmental impact statements proposed by federal or private agencies in order to assess the effects on fish and wildlife resources, and recommends appropriate measures for their conservation and development. Thus, it would be the role of the Bureau to evaluate the effects of brine, siltation, and subsidence in freshwater ponds and lakes near geothermal extraction operations. It may also advise in the placement of power lines, taking into account bird nesting, feeding, and migratory patterns. In addition, the Bureau may assist in the relocation of displaced ranges and hunting grounds. The Bureau presently maintains a fishery research station on Hot Creek, a tributary of the Owens River in Long Valley, California. Development of that region for geothermal power resources may lead to relocation of this station or perhaps its monftoring role could be expanded to assess the impact of geothermal development on the fish in that particular area.[4]

\section{The Bureau of Outdoor Recreation (Department of the} Interior)

This Bureau is responsible for the malntenance of public parks, recreation areas, and wildlife and waterfow1 refuges. In some instances, geothermal power plant installations may lead to closing down some of these areas to ensure the public's safety. The Bureau might play a significant role in relocating the wildlife and waterfowl refuges which have been displaced and for providing alternate parks and recreat ion areas to the public in the affected region. The Bureau reviews proposed transportation projects for the possible adverse effects on parks; recreation areas, and wildlife and waterfowl refuges. Under the National Environmental Policy Act; the Bureau also reviews all projects having an impact on outdoor recreation. Geothermal leasing in areas designated as wild or wilderness areas must be compatible with the designation and purpose of these areas. However, under the Wilderness Act, these areas are not excluded from development of power projects or transmission lines if such use or uses are determined by the President to better serve the interests of the United States than would denfal of such use. [4] 
Environmental Protection Agency

EPA was established in the executive branch as an independent agency in 1970. Its role is to maintain water and air quality standards throughout the United States. It sets standards for major types of afr purity in order to protect public health, as well as soll, water, vegetation, materials, animals, weather, visibllity, and personal comfort and well-being. EPA has the role of enforcing environmental quality standards; this Includes the gathering and preparing of evidential data and conducting enforcement proceedings. This agency made several significant comments in response to the Department of the Interior's draft environmental impact statement. EPA was concerned that dewatering active faults may result in a lessenting of seismic frequency but an increase in the magnitude of severity when earthquakes do occur. They also mentioned that long-term subsidence control in the Imperial Valley trough (the areas between the Sea of Cortez in the Gulf of California and the Salton Sea) may be needed. [4]

The EPA suggested further examination of the possible radiological hazards resulting from geothermal fluids and the dangers of asbestos dust. It also commented that the environmental 1mpact statement should address itself to the problem of clearance, debris disposal, and clean-up operations.

\section{State Governmentai Agencies}

Within each state and locality there are numerous agencies originally constituted for other purposes which exert control over patterns of geothermal exploration, development, and use.

A flow chart of agencies involved in California is presented in Section 3.3. "Some of the agencies involved are utility commisstons, land zoning boards, water comissions, environmental agencles, mineral resource commisstons, securtty and exchange boards, parks and recreation agencles, and so on. Some speciflc problems associated with this multiplicity of regulating agencles are redundant requirements, overlapping jurisdictions, and conflicts resulting from differing federal; state, and local regulations.

These problems are discussed in: detat1 in Legal Considerations, Section 2.4 .

\section{State Agencles Concerned with Appraisal and Research}

In Calffornta the State Geothermal Resources Board presently disseminates Information about geothermal. resources through publication, conferences, and discussions. Represented on the Callfornla Geothermal Resources Board are the federal agencles, in particular the Bureau of Land Management, the Bureau of Reclamation, and the U.S. Geological Survey, Coordination is provided for geothermal activities where they bear upon the jurisdiction of the Division of 011 and Gas, the State Water Resources Control Board, and the State Land Commission. (About 45 percent of the land in California is government owned. Government ownership is high in all of the western states, and the percentage of geothermal resources on state owned land is, of course, much smaller than on land owned by the Federal Government.) [6]

Natural resource agencles of many western states are currently engaged in geothermal research studies. The Division of Mines, as well as the Department of Water Resources and the DIvision of 011 and Gas in the State of Callfornia, have been appraising the state's resources and conducting geologic Investigations of the producing field at The Geysers and several other promising areas in the state for many years The Oregon Department of Geology and Mineral Industries and the New Mexico Bureau of Mines and Mineral Resources have conducted geothermal programs, as have the Nevada Bureau of Mines and Geology, the Idaho Bureau of Mines and Geology, and the natural resources agencies of Alaska, Arizona, Colorado; Montana, Utah, and Washington. While the effort up to now has been relatively modest and primarily aimed at resource appraisal, Interest in resource exploitation may grow to the point where joint ventures with private industry may be undertaken to develop promising resources on state land.

A recent report prepared by the Geothermal Resources Board of the State of Callfornia emphasizes research on the state level. While primarily directed at exploration. and economic analysts of geothermal resources in California, this research $1 \mathrm{~s}$ seen as providing "the basis for a sound development of geothermal resources as well as the basis for prediction of revenues to be derived from leases and royalties on state lands."

With the need increasing for wise management of natural resources, it becomes more necessary that research into geothermal, resources be better coordinated. Several state-supported institutions, including the state university and the state college systems, are presently engaged in basic research in several phases of geothermal exploration and development . [6]

\section{Response to Environmenta1 Impact Statement}

Several state agencles commented on the Department of the Interior's environmental impact statement. A review of their comments indicates some of their specific interests.

The State of California: Calffornia asked that federal geothermal leases Include provision for power plant and transmission line construction without the requirement of a separate peralt. The multiplicity of permits and approvals required is a continuing problem (see Section 3.3).

The California State Water Resources Contro1 Board. This board has Jurisdiction over the western Colorado River basin. Among the water quality indicators they are concerned with are: color, turbidity, bottom deposits, floatables, ofl and greases, odors, pesticides, pH level, blostimulants, coliform bacterla, toxiclty, radloactivity, temperature, dissolved oxygen, and dissolved solids. Their monitoring of the river basin could interact with geothermal exploration and development.

The California Department of Fish and Game. A trout hatchery on Hot Creek, a tributary of the Owens RIver (Long Valley), is maintained by the department. The hatchery depends on constant temperature cold water springs for water supplies. Should thermal pollution, siltation, or other adverse environmerital impacts on the creek take place from geothermal development, the trout hatchery could be affected.

The Oregon Environmental Council. The Council responded to the Impact statement by pointing out that issuance of standards for erosion control, noise control, waste disposal, wildiffe protection, and others on a site-tosite basis could result in, cases of permissive standards. This raises the issue of whether or not state regulations (In many cases far more restrictive than federal standards) are applicable to federal properties. The OEC also requested mandatory public hearings be held prior to any approval of unitization. Such hearings 
are now at the discretion of the Director of the Bureau of Land Management.

he state of Colorado. Colorado objected to a USGS supervisor determining what measures are necessary to protect wildlife and wildlife habitat. The state feels that the USGS supervisor is not a professional wildiffe man and the decision should be made by the Bureau of Sport Fisheries and WIIdife in cooperation with state wildife agencies.

Oregon and Washington. Both states submitted that officlally classifled wild and wilderness areas should be excluded from proposed leasing programs, along with wildlife or game range areas. They felt that leases should not be issued in recreational areas, near national wild and scentc rivers, national trail systems, or primitive, roadless, or national ploneer areas.

\section{Geothermal Industry}

\section{Field Development at The Geysers}

The Geysers, California, is the only U.S. geothermal installation producing electricity. Its production is expected to grow from 400 MWe in 1974 to 908 MWe in 1977. In 1974 The Geysers contributes 5-6 percent of the electric capacity of the Paclfic Gas and Electric Company; by 1977 this will increase to 10 percent. But, as mentioned earlier, like most infant industries, geothermal development at The Geysers had a slow, faltering beginning.

The Geysers' development began with the ploneering of Barkman C. McCabe, a Los Angeles stockbroker, and a friend of his, Dan McMillan. In 1955 they purchased about 5500 acres of property in Southern California, and after drilling several successful test wells, pursuaded Pacific Gas and Electric to set up a pllot generating plant using an old $12,000 \mathrm{~kW}$ generator. Their efforts resulted in the creation of two firms, Magma Power, in Los Angeles, and Therma1 Power, in San Francisco.

The most difficult technological hurdle they encountered was that of proving the potential of the field. The utility company was reluctant to bulld a generating plant unless assured of sufficient steam to run the plant for at least 30 years. Until recentiy, this meant that all the wells in the field had to be drilled and tested over roughly a flve-year perlod before orders would be placed for the generating equipment. Generation began in 1960. The major breakthrough came, when the Paciflc Gas and Electric Company dectded to accept reserve estimates based on criterla devélóped for natural gas flelds. Dr. Carel Otte, a geologist who heads Union O11's geothermal division, has observed that it was the acceptance of the principles of gas reservolr engineering applied to an underground steam fleld which provided the breakthrough for estimating the 11 fettme of The Geysers. [7]

\section{Profits, Leasing, and Joint Ventures}

Can geothermal development for electric1ty sat1sfy. corporate demand for profits? Some observers say yes. They point to the venturesone efforts of Magma Power Company and Thermal Power Company, and proprietary interests at The Geysers who sel1 to utility companies such as Pacific Gas and Electric Company.

In 1971, when $192,000 \mathrm{kilowatts}$ were being generated at The Geysers, Thermal showed a loss of 18c per share and Magma, 3c per share. In 1972, the joint venture ylelded $37 c$ a share for Thermal [7] and $7 c$ a share for Magma. With the addition of another 110,000 kilowatts of power in mid-1973, earnings were forecast by the brokerage firm, Henry F. Swlft \& Company, to be $60 c$ a share for Thermal and $85 \mathrm{c}$ for Magma in 1974.

Negotlation for a $\$ 13.4$ million straight bank loan with the Welles Fargo Bank of San Francisco is held as proof of the increasing stature of geothermal activities in California. Of this, some $\$ 4$ mtlilon are slated for further expansion and drilling development in the Geysers field, and some half a million dollars set aside for other exploration. [7]

However, the story of the successful rise of these two firms should not be given without some cautions. The Geysers have proven to be a particularly fertile geothermal resource area; other areas may not prove as useful. Furthermore, certaln hazards become apparent with time. One is the risk of subsidence and the other, reduced longevity of the fleld.

Magma and later Thermal Power became the holders of leases on geothermal land. Pure 011 Company, which later merged with Union 011 , entered into a joint venture with Magma and Thermal in 1967. Under this arrangement, Unton 011 performs all the required drilling. Costs and profits are shared under a formula whereby the first 200,000 kilowatts of generating capacity belong ta Magma and Thermal on a 50/50 basis, the second 200,000 k1lowatts is shared equally by all three partners, and the third 200,000 kllowatts belongs entirely to Union, everything beling shared equally again in excess of that. Steam sold to Pacific Gas and Electric is tied to the utility's other fuel costs and is thus not controlled by the supplies of steam. The utility, having accepted assurance of the productivity of the wells for a 30-year perfod, is, of course, attracted by the low cost of electric production. [7]

Magma and Thermal holdings, together with those of Union 011, in The Geysers amount to about 13,000 acres. other compantes have now bought up leases in the area, including Signal Company, holding a large tract in lake country northeast of The Geysers; Pactfic Energy Corpora tion, a subsidlary of Hughes Aircraft, which has 1120 acres to the southwest; and Geothermal Kinetics Systems Corporation, owned by a Canadian mining firm, United Cisco Mines Ltd., which has a 409-acre tract lying between Joint venture property and that of Pacific Energy. In addition to these companies, there are a number of smaller concerns which are entering the geothermal development area actively, including American Thermal" Resources, Incorporated, of Bakersfleld, California, and Calvert Exploration Company, of Tulsa, oklahoma. Calvert has bought leases on over 100,000 acres In New Mextco, Including 2000 acres of known geothermal resource areas known as the Valles Caldera. Geothermal KInetics has drilled two successful wells. near Phoenix, Arizona, which are now being tested and evaluated. Geothermal Kinetics appears to be one of the most active of the Independents; they have taken out leases on some 100,000 acres and are currently negotlating for conslderably more acreage.[7]

In addition to Pacific Gas and Electric, other utilities have begin to take geothermal energy serlously. In 1971, San Dlego Gas and Electric, in a joint venture with Magma, dug. two wells. In 1972 the utility let contracts for the design of a $\$ 3$ mililon pilot plant, though at this point corrosion problems have postponed construction unt1l procedures can be developed to cope with them. A consortium, including Southern California Edfoon and Southern Pacffie and Phillips Petroleum Corporation, together with Union and S1gnal, are seriously exploring the possibility of developing geothermal 
resources'for feeding electricity into Southern Californla's grid, and New MexLco: and Utah public utilities have Indicated interest in buying steam or hot water from Geothermal Kinetics. [7]

\section{Geotherma1 Development by Utilities}

The development of geothermal resources by private entrepreneurs rather than by the utilities who will be the major customers for geothermal energy, is due, in large part, to utility economics and utility regulation. An electric utility concerned with raising large sums of money for 1ts expansion relles upon the stability of its rate of return to secure its long-term debt. The uncertainties of geothermal development make it a venturesome business, and, therefore, probably unattractive from the point of utility investment. While its product is, of course, of vital interest to utility growth, the uncertainties of development will probably keep utilities in the role of purchasers of steam from proven flelds.

Utilities are also limited by regulation in the services that they can perform. The development of multi-purpose utilization of geothermal resources would present problems to a utility, particularly one regarded as a utility holding company under SEC regulations. The structure of a utility as an organization marketing a single product would be significantly altered should the utility engage in the marketing of minerals produced from geothermal resources, for example. The profitability of the utility. In terms of its investment is controlled by the regulation of revenues as a function of the utility rate base. The utility is non-competitive; should it engage in the competitive marketing of products, the relation of these activities to its non-competitive sale of electricity might prove difficult to balance.

The prospective role of the publicly owned utility, however, may be somewhat different from that of the privately owned utility. In the testimony pertalning to the Department of the Interlor's geothermal leasing program, states and municipalities asked for preference In the issuing of leases. These leases, presumably, could be passed on to publicly owned utilities, a situation similar to the preference provisions for hydroelectric site permits as established in the Federal Power Act. The broad powers inherent in publicly owned utilities and their relative freedom from regulation might allow them to pursue geothermal resource development directly, rather than as purchasers of steam from privately developed resources. In those states heavily dependent upon hydroelectric power, the percentage of generation by publicly owned electric utilities is very high, being over $90^{\circ}$ percent In Washington, over 70 percent in Oregon, and almost 30 percent in California. In Oregon, for example, the powers of a People's Utility District are very broad, Including that of eminent domain, permitting even acquisition of property outside the District if that property is needed to serve the D1strict. A People's Utility District may enter into contracts with the U.S. Government or with the State of Oregon, or with any other state, munlelpality, or util1ty district. In Washington, a first-class district is a public utility district which may obtatn a license from the Federal Power Commission to construct major hydroelectric projects. Precedent $1 \mathrm{~s}$ set, therefore, in several western states for active participation of publicly owned utilities in the generation of electricity.

\section{Federal Government Involvement}

As described prevlously, through the Bureau of Reclamation the Federal Government runs the project at East Mesa in the Impertal Valley of California. [5] Other federal profects could be forthcoming if the government chooses to upgrade an entire area through geo- thermal development: This could be a TVA-1ike undertaking, an integrated land/river project committed or a reglonal scale to the development of low-cost powe as an essential motivation for industrial expansion. within the area. In the case of the TVA, which is primarily a wholesaler of power; preference is given to municipalities and cooperatives.

\section{Residents and Environmentalists}

The visual and olfactory impact of geothermal energy manifestations can be unpleasant. When William Bell E1llott was hunting grizzly bears in 1847 and stumbled upon the fumaroles at The Geysers, he thought he had arrived in Hades. It $1 \mathrm{~s}$ generally acknowledged that the geothermal area near Larderello, Italy, was the Inspiration for the Inferno segment of Dante's Divine Comedy of 1310. And in 1973, some of the residents in areas near geothermal sites were voicing similar complaints.

\section{Resident Complaints During Ear1y Development}

In many ways, these residents are more fortunate than those located near other energy sources. Geothermal energy is relatively "clean" energy. It does not produce atmospherfc particulate pollutants and does not require fuel to be mined or transported, handled or consumed. For the most part, the primary environmental effects are local. Yet the adverse environmental impacts may alter the quality of 11 fe for nearby residents. Such impacts are described in more detall in Section 4.8. In summary, during the exploration phase of geothermal development, envilronmental damage may result from field parties moving across access roads, generating dust, nolse, and vehicular pollution. Vegetation 1s often lost resulting in patchy areas of dirt across the terrain. During the exploration, work forces must be housed and supported locally. Sometimes new public facilities are bullt to house large numbers of workers. After construction is completed, these fac111ties can be utilized for recreation and tourist needs, although their proximity to wells and drilling equipment may render them unsultable for that purpose.

If exploration proves encouraging, test drilling is begun. This stage of development is often sald to be the worst by many homeowners. The atmosphere becomes more polluted by cars, trucks, and other vehicles for transporting men and equipment. Diesel-powered trucks and drili rigs intensify the problem. The movement of vehicles on untreated or unsurfaced roads generates a considerable amount of dust. The settling of this particulate matter on plant 11 fe in the surrounding area may affect their growth and survival.

Blowouts, or uncontrolled release of the hot water and steam to the atmosphere, are extremely noisy, contaminate the air with gases, and may pollute surface and groundwater resources. The 1957 blowout at The Geysers in Callfornia has emitted more than 9 million tons of steam, about 4000 tons of hydrogen sulf 1 de, 5000 tons of anmonia, and 6000 tons of methane to the atmosphere. In August 1972, three we11s in Beowawe, Nevada were dymamited by vandals. Fortunately, the water efected was of low salinity and has been successfully routed for use in pasture irrigation. [4]

In the third stage of development, production testing, non-condensable gases and vapors are released whtch may pose a health hazard to employees and disagreeable odors to residents. Asbestos is used as an insulation materlal around plpes; the fibers can be inhaled by workers.

Wells are vented into the alr for pertods up to 24 
hours to ayold turbine blade damage from amall rocks otones witch may be present in the steam. The vere nolse level is a local nulsance and may present a health hazard. At a distance of 25 feet, the noise level reaches 126 dB. Barkman McCabe, President of Magma Power Company and Magma Energy Company, is partlally deaf from working around "those banshees." In addition, nolse from trucks and other vehicles and racking of drill pipe contributes to the problem. Besides being hazardous and objectionable to residents and visitors, this nolse could disturb wildife distribution and breeding patterns. [4]

The land is physically modified during this third phase of development. Roads and ponds are constructed. Drill sites are leveled. Erosion from this construction can lead to coverage of flsh spawning and feeding areas and shallowing of streams. Wildlife directly within the area of development is either physically altered or removed completely: Releases of heated effluents to aquatic habitat could alter 1t by creating intolerably high temperatures and/or fostering the growth of nuisance algae.

In addition to the environmental and aesthetic results, there may be a reduction of hunting, angling, and camping opportunities on the land. Plant siting can affect mining and mineral operations, timber production, grazing, fish and wlldilfe habltat, and outdoor recreation. These effects may be especially objectionable in a resort or recreational communty dependent upon the surrounding unspoilt beauty for 1 ts economic survival.

\section{Res1dent Complaints During Fins1 Development}

The last three stages of geothermal development are fleld development, power plant and powerline construction, and full-scale operations, Now access roads are Improved and service and living quarters constructed. The beneficlal economic effects for the community include increased tax montes, royalties and rental fees, and some spending by construction workers, drilling crews, and employees.

Nevertheless, negative impacts are felt; complaints are voiced during these later development stages. I1sted below are some specific examples of how these developmental steps may impinge on communtties.

Members of the Anderson Springs (Californta) Homeowners Association, located $100 \mathrm{miles}$ northwest of San Francisco in Lake county, have complained of notse, odor from hydrogen sulfide ("ame1ls 1ike rotten eggs"), threats to the creek, f1sh and wildlife, and water pollution.[4]

Clear Lake 18 the largest and most Important warm water f1shery lake in Callfornia. Angling is estimated at : 200,000 man-days per year. Although the effect of :geothermal development on the lake is not clear yet, any disturbance of this fishery would foster further regulation of power plant development and siting. [4]

Posalble Future Resident Complaints. . Some towns are expecting development problems. One such town ig Lee Vining, the only town in the Mono Lake-Long Valley area. The population 18 approximately 400 . Residents are concerned that development by Geothermal Resources International, Inc. will bring an Influx of people and equipment. These newcomers will be associated with contractual firms of varlous kinds involved in the drilling and development of the geothermal reservoir, its operation and maintenance, and the construction of a power-generating station. Most of these people would be temporary residents but would increase the short-term use of utilities, housing, and so on. [4]
The Town of Cedarville, Californte is located on the western slope of Surprise Valley. This area is known for its hunting, fishing, camping, vacationing, and range land attractions. Should a geothermal plant be installed here, there is the possibility of a high nolse level until the electric generating plant is completed, noxious odors of hydrogen sulfide, steam blown to the alr causing certain damage to plant $11 f e$, and drilling activities generating some dust. [4]

01ancha, California, population 150, is located near the south end of Owens Lake Basin in Inyo County. Getty oil Corporation is prospecting for geothermal resources there. Presently, cour1sm and recreation-orlented services form the economlc base of this community; geothermal development may Impinge upon this or may offer an acceptable means of augmenting the economic base.[4]

\section{Concerns of Interested Groups}

Varlous groups, of course, volce concern over posstble geothermal development. Following are the responses some groups gave to the Department of the Interfor's draft environmenta1 impact statement. [4]

The Sterra Club. Members sald that the statement treats the scenfe impact and posstble solutions too lightly. This is a particularly difficult issue to come to grips with because of the lack of we11-defined paradigms like those in alr pollution.

Trout Unlimited. The Nevada Chapter wrote that provislons should be made to protect flsh habitat from thermal pollution and detrimental dissolved solids. Maintenance of fish habitat is primarlly their concern, but it $1 \mathrm{~s}$ also Important that this be done in its "natural" setting so as to allow the fisherman or recreationer other aesthetic pleasures.

The Cal1fornla Farm Bureau Federation. The concern of the Federation was that the tone of the statement was negative and could result in unnessary delay of the resource. Clearly, this group is concerned that this source of additional irrigation water be developed and Implemented.

The Audubon Soclety. The Society felt that transmlssion IInes and destruction of natural habitat may result in unnecessary deaths, changing patterns of bird migration, and restriction of related bird watching and photography activities.

The comments of utility companies who responded to the U.S. Department of the Interior geothermal environmental impact statement are oummarized below.

The Pacific Gas and Electric Company. PG\&E commented that if the estimated level of 1000-2000 MW at The Geysers field is not achleved, the company would be obligated to generate the equivalent.power by other means. It mentloned that subsidence was not a demonstrated problem at The Geysers and that the 1ssue depends on the underlying rock types. PG\&E was concerned that the power vested with the Department of the Interior officials is so restrictive as to discourage entrepreneurlal geothermal resource development. Another suggestion was that federal geothermal leases should include provision for power plants and transmission line construction without requiring separate permits. And the company commented that noise level standards should be applied only to certain locations (e.g., residentlal areas) to be spectfled by PG\&.

The company responded to the environmental impact statement by stating that the danger of microearth- 
quakes from fluid. Injection has been overemphasized. They also mentioned that the statement should emphasize tectonic setting of geothermal areas; much subsidence could be naturally occurring due to dynamic crustal processes.

\section{Foreign Institutions}

The development of geothermal resources in most countries other than the United States has been elther a governmental undertaking or a joint undertaking between government and industry.

New Zealand $[8,9,10,11,20]$

An example of this governmental involvement is found in the control of the Walrakei Stations by the Electricity Department. This department is also respons1ble for all government-owned power stations and for distributing electricity through the national grid to electricity supply authoritles in various centers. The Ministry of Works is in charge of the overall administration of construction on the Walrakei profect. Th1s department is charged with investigating and developing geothermal areas in which the government is directly interested, and performs all drilling and associated field work.

The Department of Sclentific and Industrial Research is called on by the Ministry of Works to provide scientific services, mainly in geology, geophysics, chemistry, physics, and metallurgy. Actual construction has been done almost entirely by contract with consuldting engineers aiding in design and supervision of the construction of the power stations and of the steam collection and transmission systems.

New Zealand Industry has thus far been slow to develop and use geothermal energy, according to J. H. Smith, formerly chief geothermal engineer in the Miniatry of Works. [8] Th1s is partly due to the location of geothermal fields, which are remote from sources of raw materials, centers of consumption, or ports. The t1mber Industry in the central region of North Island is a potential mafor user; other minor uses being currently Investigated are geothermal heat for crop drying and the extraction of sulfur by the Frasch process (Section 4.2).

The Geothermal Energy Act (1953) In New Zealand orig1nally provided for a rental payable to the government proportional to the value of the benefit derived from the uses of geothermal energy. Smith has observed that th1s has proved unworkable because of the difficulty in assessing the value of the benefit relative to other resources of energy. The basis was changed therefore to a charge of $2.5 \mathrm{New}$ Zealand cents (approxdmately 3 U.S. cents) per million Btu in excess of ten thousand mililon Btu per 12 months. The rate was kept low in order to promote exploitation. At present, there is no rental payable for domest1c use, and the only user which exceeds the exempted amount is a paper and pulp company. [10]

The City of Rotorua in the Wairakel area has been empowered by the Rotorua City Geothermal Energy EmpowerIng Act (1967) to grant author1ty for 11 censing and control of geothermal energy in the clty and for the sinking of bores for the purpose of obtaining geothermal energy in the clty. Hot water is provided for space heating, bathing pools, for comnercial heating in hotels, hospitals and offices, and some for Industrial uses. This has required close association with the local authority regarding the control of possible problems arising from the discharge of hot waters and atmospheric pollution and noise arising from operation of the we11s. [11]

\section{Iceland $[12,19]$}

Iceland has ploneered in the use of hot water for municipal heating since the $1930^{\prime} \mathrm{s}$. Approximately 50 percent of the 200,000 population recelves geothermal heating, and this is to rise to over 60 percent in this decade. Nine out of ten homes in Reykjavik, the nation's capital, recelved geothermal water for home heating distilled by the Reykjavik Municipal District Heating Service (Section 4.6).

\section{Italy $[18]$}

In Italy at the Larderello fields generating capacity has now grown to over 390,000 kflowatts. In Italy, Ente Nazionale per 1'Energia Elettrica (ENEL) is the sole national agency which has been entrusted by law with the exploitation of geothermal energy for generation of electricity. An agreement; however, has been established between ENEL and the National Research Council of Italy for cooperating in the basic research of geothermal resources.

\section{Japan $[13,14,15,16,17]$}

The Japanese have a major program in geothermal development; the National Natural Resources Committee has reported that it 18 possible to develop geothermal energy in Japan in a range between 30,000 and 50,000 megawatts, and perhaps up to $60,000-140,000$ megawatts (Section 4.7). [13]

An interesting example of the private exploitation of geothermal resources in order to develop cheap electric power may be seen in the case of the Japan Metals and Chemicals Company of Morloka, Japan. Plans for a large thermal power station, which had included an electrochemical works as a joint project were abandoned in the face of the projected high costs for electricity. Consideration of other methods of power led the Japan Metals and Chemicals Company to choose to develop power from the hot springs in the Matsubawe area. Since 1952, hot water from these springs had been used as a health center built by Matsuo village for 1 ts inhabitants. Cooperative atudies were begun in 1956 by both the company and the Geological Survey of Japan. By 1966, $9500 \mathrm{~kW}$ were belng generated; today, $20,000 \mathrm{~kW} 18$ being consumed at full load operation. Present plans call for the construction of an additional $40,000 \mathrm{~kW}$ by $1975 .[14]$

\section{Mexico [21]}

Mexico has pushed the development of geothermal resources vigorously. Under the National Electricity Authority, a 75 MWe power plant at Clelro Prleto (northwest Mexico) was successfully completed in October 1973. It is being doubled in size now. Geothermal areas in other parts of the country are being explored for futare exploitation.

\section{Other Nations}

Research is reported from the Somall Democratic Republic where plans are underway to commence drilling operations in the geothermal areas of Afars and Issas in order to provide geothermal power for Djibouti, and in order to stimulate the development of local industry. In India, a planned project is to start in late 1973 and will concentrate on exploration of favorable areas in the northwestern Himalayan region and western India, areas where alternative power shcemes are considerably more expensive than in other parts of the country. 
The United Nations and the government of Nicaragua are fointly studying a project to rebulld the ruined city

Managua with geothermal heating and alr condition8 , as well as electriclty.

\section{REFERENCES}

[1] The Geothermal Energy Research, Development and Demonstration Act of 1974 (P.L. 93-410) adopted after this section was written, redefines the responsibilities of NSF, Department of Interior, NASA, AEC, and FEA. It establishes a Project Comnittee to manage and coordinate research and development efforts. Under P.L. 93-410, Department of Interior is assigned responsibility for evaluation and assessment of the resource base, including development of exploration technologies. NASA is charged with overall program definition as wel1 as contract management, resource evaluation and assessment, and development of technologies. AEC has technology development responsibilities and NSF is charged with basic and applied research and technical and scientific education. These delegations are not exclusive and all agencies may participate in the pilot and demonstration projects.

[2] Hearings on Geothermal Energy Resources and Research, U.S. Senate Committee on Interfor and Insular Affairs, Washington; D.C., June 15 and 22,1972 , p. 86 .

[3] Ray, D. L., The Nation's Energy Future--A Report to Richard M. Nixon, President of the United States, WASH-1281 (Washington, D.C.,: United States Atomic Energy Commission, December 1 , 1973).

[4] Final Environmental Statement for the Geothermal Leasing Program, Vol. IV (Washington, D.C.: U.S. Department of the Interior, 1973); pp: 1-134.

[5] Geothermal Resource Investigations--Imperial Valley, California--Developmental Concepts (Washington, D.C.: U.S. Bureau of Reclamation, January 1972).

[6] The Economic Potential of Geothermal Resources on California (Sacramento; Calif.: The Geothermal. Resources Board, JJanuary 1971), pp:' 29-30.

[7] Baron's (September 15, 1973), p. 3.

[8] Smith, J. H., private communication, Wellington, New Zealand, January 10, 1974.

[9] New Zealand Electricity. Department, Wa1rake1Power from the Earth (1970).

[10] Statutes of New Zealand, "The Geothermal" Energy. Act 1953" and "Geothermal Energy Amendment Act 195.7," Vo1. 5; p. 637. "An Act To Amend the Geothermal Energy Act 1953," No. 50 (October 19, 1966).

[11] Statutes of New Zealand, "An Act To Enable the Rotorua City Council To Make Provisions for the Control of the Tapping and Use of Geothermal Energy in the City of Rotorua," No. 2-Local, 1967.
[12] City of Reykjavik, A Smokeless City, Report on the Reykjavik city geothermal district heating system (May 1972). National Energy Authority, "Recent Geothermal Developments in Iceland," Geothermics, Vo1. 2 (March 1973), p. 38

[13] Japan Agency of Industrial Science and Technology, "Sunshine Project". (May 1974). Japan National Natura1. Resources Committee, "Geothermal Development In. Japan," Geothermics, Vol. 2 (March 1973), p.:-39.

[14] Japan Geothermal Energy Association, Annual Information on Development and Utilization for Geothermal Energy in Japan--1971, Denkikyokai Building, 1-3 Yurakucho Chiyoda-ku, Tokyo.

[15]. Mori, Y., "Recent Plans of Geothermal Exploitation," Geothermics, Special Issue 2, Vol. 2, Part $2(1970)$, P. 1150 .

[16] Sato, K., "The Present State of Geothermal Deve1opment in Japan," Geothermics, Special Issue 2, Vol. 2, Part 1 (1970), P. 155.

[17] Komagata, S., I. Iga, H: Nakamura, and Y. Minohara, "The Status of Geothermal Utilization in Japan," Geothermics, Special Issue 2, Vol. 2, Part 1 (1970), p. 185 .

$$
\because x
$$

[18] Cataldi, R. P. Ceron, P. Di Mario, and T. Leardini, "Progress Report on Geothermal Development in Italy," Geothermics, Special Issue 2, Vol. 2, Part $1(1970)$, p. 77 .

[19] Palmason, G., and J. Zoega, "Geothermal Energy Developments in Iceland 1960-1969," Geothermics. Spectal Issue 2, Vol. 2, Part 1 (1970), p. 73.

[20] Smith,. J.H., "Geothermal Development in New Zealand," Geothermics, Special Issue 2, Vol. 2., Part 1 (1970), p. 232 .

[21] Banwe11, C. J., and R. G. Valle, "Geothermal Exploration in Mexico 1968-1969," Geothermics, Special Issue 2, Vo1. 2, Part $1(1 \overline{970), ~ p . ~} 27$.

[22] Kaya, S., Chafrman, Industrial Technology Council to $Y$. Nakosone, Minister of International Trade and Industry, "On Ways To Promote Development of New Energy Technology," ITC, No. 44 (December 18, 1973). 


\subsection{Laws and Regulations Applying} to Geothermal Development

\section{Introduction}

Ideally, the legal structure for regulation of geothermal resource development should be logically and explicitly related to the nature of the resource and the Institutional arrangements most appropriate to its development. Unfortunately, the legal reglime not been as rationally structured as one might desire. The legal aspects of geothermal resource development today are a product of the past history of state and federal minting, mineral leasing, mineral disposal, water resources, environmental, and pub11c.land laws. The attempt to fit geothermal resource development into legal structures created for other purposes has inhibited its full exploitation:

This section of the study examines from an historlcal perspective the legal context in which geothermal resource development has taken place and efforts that have been made to develop a more rational legal foundatIon for future development. It includes a review of the history of minerai and water laws, 1imitations encountered in applying, these laws to geothermal development, the development of new state and federal regulatory regimes, and the remalning legal barriers to geothermal resource exploitation. Other sections discuss what new legal incentives might be created to accelerate geothermal development while maintainIng other important values.

\section{Historical Context}

While Interest in the development of geothermal resources is of comparatively recent origin, laws dealing with the development of mineral and water resources have existed for many years. These laws differ somewhat depending on the location of the resources and whether private or public lands are involved.

If the resources are located upon private lands then the law is relatively clear: the owner of the surface of the land owns all that is under 1t. W1th respect to hard rock minerals, the owner is free to exploit these minerals as he sees fit subject to only the byoadest restrictions such as those against creating a nulsance which injures his neighbor's lands.

With respect to underground water resources the surface owner is subject to additional restrictions especially in the arid western states. The use and enfoyment of resources underlying $\mathrm{hts}$ land are often tempered by the requirement that he not trespass upon or unreasonably interfere with his nelghbor's enjoyment of their underground water resources. The "law of capture" of a common underground water source which holds that one could use what one could take has been qualified by the doctrine that adjoining users have some "correlative rights" which limit one's ability to Interfere with a nelghbor's use.

In the arid West, early law relating to underground waters was further modified if the exploitation of underground resources interfered with the flow of surface waters. In such a case the surface owner's use of underground waters was limtted by the rights of persons who had previously acquired rights in the flow of the surface waters.

As the West became more populated, the state governments assumed an even larger role in the development and use of water resources. Today in most western states the surface owner must obtain state permission to explott the water resources underlying his lands. The extent to which state water regulations govern geothermal resource development is explored below.

\section{The Mineral Resources Mode1}

In the earliest period of the development of the West, there was no comprehensive legislation dealing with mineral resource development. A variety of state, terr1torial, and private "miners" laws governed. In 1872 Congress passed the General Mining Law [1] governing the extraction of minerals. Intended to apply primarily to hardrock or metallic minerals, the 1872 Mining Law permitted:

1. Open exploration of the federal domain.

2. Acquistition of rights to minerals on public lands by discovery and filing of a claim.

3. Acquisition of title to the surface by acquisition, for a nominal sum, of a federal deed known as a "patent."

4. Production of minerals without a patent and without payment of any rents or royalties.

The size of the claims was limfted to 20 acres. For a varlety of reasons this system was not appropriate to all types of minerals.

A second system was estabilished in 1920 when specific minerals were removed from the General Mining Law's "location-patent" system and placed under a leasing plan. Under the Mineral Leasing Act of 1920 [2] and subsequent related legislation, oil, gas, ofl shale, phosphate, sulfur (In two states), potassium, sodium, native asphalt, and solid and semisolid bitumen and bltuminous rock (e.g., tar sands) on public lands were made subject to leasing by competitive or noncompetitive bid. The competitive bidding system applied when minerals were known to exist inworkable deposits. With respect to ofl and gas, the test was whether or not the land sought to be leased was within a "known geologic structure" of a producing oil or gas fleld.

Under the competitive bidding system, appropriate notice is given and all interested parties are invited to submit bids. Sales of leases are made on the basis of royalty bidding: The highest. cash bonus wins the bid. With respect to offshore oll and 898 leases, the lump-sum bonus bidding system has generated billions of dollars in federal revenues.

Non-competitive leases are generally awarded to the first qualifled applicant on a first-come, first-served basis except in certain circumstances in which a drawIng is used to resolve competing claims. With the exception of ofl and gas, exploration permits are issued for leasable minerals on a first-come, firstserved basis and carry with them the right to lease minerals once a discovery has been made.

More recently Congress has provided for outright sale of certain minerals. The Materlals Act of 1947 [3] authorizes sale of common materials, such as sand and gravel, usually by competitive bidding.

Much of the early congressional debate about the most approprlate legal arrangements for development of geothermal resources involved discussion of which of these three systems of mineral rights acquisition should apply to geothermal resources. As the debate progressed it became Increasingly apparent that the three systems 
were deficient even in the contexts in which they rere being applied and needed significant modifica(mon prior to application to geothermal resources.

The location-patent and leasing systems per se were criticlzed by the prestiglous Public Land Law Review Commission in its final report [4].

The Commission found with respect to the 1872 General Mining Law that:

1. It permitted Individuals not primarily interested in mineral development to acquire rights in the public domain.

2. Inadequate f1ling procedures prevented federal land managers from locating clatms.

3. Inadequate controls permitted filing of millions of claims, many of which were dormant and remained as clouds on title.

4. There were no revenues to the government except the nominal fee for acquisition of a patent.

5. The claims were too small in size and the re was Inadequate provision. for acquisition of land for mining-related purposes.

6. There were no provisions by which the Federal Government could control environmental impacts.

7. There was no certainty of tenure prior to a discovery even if large expenditures were made and no certainty as to what constituted a discovery.

8. The claim holder was required to show actual possession of the claim or be subject to the rights of third parties.

9. The clatm holder had to comply with state laws regarding location and maintenance of a claim.

10. The law was only applicable to speclfically defined public lands and lands could be withdrawn administratively for other uses thereby upsetting mining claims.

Some Commission members were so unhappy with the location-patent system that they urged its replacement with a leasing system for all minerals. While the majortty would not go this far, the Cormission did recommend substantial modification of the system to provide for better filing procedures for claims; gystematic review and granting of exploration permits; limitations on exploration rights; environmental regulation; development and production rights; patents to minerals only; payment of fair market value for the land surface; payment of royalties: for minerals; uniform federal requirements for location and maintenance of claims; and elimination of dormant claims.

The work of the Public Lavi Land Review Commission postdated some of the debate over the legal structure to govern geothermal resource development. Its objection to the location-patent system of mineral exploitation were, however, widely shared and undoubtedly influenced the Congress' decision to seek an alternative system for geotherma1 resources.

One such system was that of the Materials Act, which provided for outright sale of certain materials. This system was at one time considered by the Department of Interior to be applicable to geothermal resources. This position was soon reversed and the outright sale of geothermal resources was viewed as inappropriate to the complicated geothermal exploration and development process.

The ultimate cholce narrowed, then, to selection of some sort of leasing system for geothermal resources. The most closely related resources were 011 and hydrocarbon gas, so most Congressional attention focused on how the leasing system applicable to these resources should be modified to apply to geothermal resources.

Two basic sets of 1 ssues faced the Congress in selecting a workable leasing plan. The first related to the deficlencies in the Mineral Leasing Law itself, and the second related to the peculiar nature of geothermal resources. The Public Land Law Review Commission found the mineral leasing system to be inadequate in a number of ways [5].

The provisions for competitive sale of gas and oil exploration permits and leases were a major area of concern. The law provides that competitive bidding (In the case of ofl and gas) need take place only when the area in question is within the known geologic structure of a producing oil or gas fleld. The Commission wanted to broaden competitive bldding to include cases in which: (1) the land 18 in the general area of a producing we11; (2) the land is covered by relinquished or forfeited leases or permits; or (3) where past activity and general knowledge suggest reasonably good prospects for success. The purely physical test of a "known geologic structure" would be eliminated in favor of the more flexible testa listed.

A second set of deficiencies in the leasing system involved granting of exploration permits. The Comission in its report recommended:

1. Limiting the area covered by a single exploration lease or permit and the aggregate acreage held by any one explorer.

2. Specifying the time perlod for which the exploration right is granted.

3. Establishing performance requirements de+ signed to ensure diligent exploration.

These recommendations were designed to encourage compet1tion and prevent lands from belng held for speculation. 011 and gas: leases, for example, have only limited performance requilrements.

Another recommended modification designed to encourage competitive bidding was the modification' of the cash. bonus system. The requirement of deposit of a percentage of the cash bonus serves to ellminate small developers without signiffcant capital." The Commlssion recomended that federal authortties have the discretion to employ a combination of bonus, royalties, and rentals to encourage bidding by smaller firms.

Another problem wth the leasing system was the ability of administratorg elther to withdraw lands from leasing or modify lease and operational conditions. The Commission recognized that excessive discretion led to lack of confidence In the developer's tenure. The resultant 
Insecurity led, in turn, to an inability to raise investment capital and/or an unwlilingness to invest available capital in ventures which were viewed as uncertain. The Commission recommended that unilateral authority to modify operational and payment requirements be limited under guldelines to be spectfled by Congress.

Another area of concern was environmental protection: The Commission recomended that administrators operatIng under congressional guidelines establish environmental controls for protection of surface values. They recommended that the controls cover all phases of development from exploration through development and production to restoration and rehabilitation of the land after cessation of extraction operations.

A closely related issue is the use of conservation measures to protect development of the resource itself. The Commission came down strongly in favor of having federal law alone, rather than federal and state law together or, state law alone govern conservation activities.

\section{The Water Resources Mode1}

The foregoing discusston has assumed that one of the three major systems of. mineral exploitation should serve as the model for geothermal development. There is, however, another possible mode1-water resource development. The elusive nature of the geothermal resource has led some to urge that geothermal resources be regulated as a water resource [6]. The argument is that geothermal energy is found, in nature, in an exploitable form only in association with water in its liquid or gaseous, forms.

If geothermal resources in the federal domain are to be treated as water for regulatory purposes; then several unique problems arise. With respect to the eleven arid western states, Congress, In the Desert Land Act [7], decreed that state water laws would determine rights to use of all surplus unappropriated waters "upon the public lands." This grant of authority to the states was tempered by a mafor exception. The term "public lands" has a speciallzed meaning. refers to lands , that have not been reserved or withdrawn by the federal government. for public purposes. Following a reservation no further rights to water can be obtalned under state law whlch are superior to federal rights [8].

If geotherma1 resources were. "water", within the meanIng of appllcable federal:- statutes, then prior to federal reservation 1t would be posatble for a private cltizen to acquire rights to such "water."

In.the early $1960^{\prime}$, s some persons began to assert claims to geothermal resources on the federal pub11c domain under state water laws. The Department of the Interfor resolved these clalms in two ways. First, it claimed that the lands in question had prevlously been "reaerved" by President: Hoover In 1930-under the authority of the Pickett Act [9] (governing reaervations) and the Mineral and Hot Springs Act of 1925.[10] (governing leasing of hot springs). Second, 1t proceeded to execute, extensive withdrawals of potential geothermal lands and resources from public acquisition. The rellance on President Hoover's reservation is somewhat doubtful since he purported to withdraw "springs"! and not untapped heated waters or steam obtainable only-by drilling.
Another argument which could have been made is that state water law governed acquisition of rights. to waters "upon" the public lands. Since'geothermal waters or stean are beneath the surface they would not be subject to appropriation under state law. At least one state court rejected this argument with respect to "arteslan waters" which may explain the Federal Government's reluctance to rely on this argument [11].

The fallure to agree on the nature of geothermal resources has given rise to yet another conflict. In making the public domain avallable for private settlement under varlous homestead and related acts, the federal government reserved the right to minerals in the lands conveyed to private persons. In due course, the question arose as to whether or not the federal government had reserved to 1tself the rights to geothermal resources. The Department of Interfor ruled that reservation. of minerals did not include reservation of waters. "It concluded that geothermal steam is essentially fust subterranean water heated to a high temperature and, therefore, rights to it passed to the land owner and were not held by the federal government.

One of the arguments the Department of the Interior made was that geothermal steam is primarily the product of meteorfc rather than connate or magmatic waters. Such latter waters are not only non-renewable and, hence, are. "mineable," but they also tend to have a high mineral content. The result of this federal ruling may be that the waters belong to the land owner but that the mineral by-products in them belorig to the Federal Government:

The present ederal geothermal resource leasing act does not 'resolve this uncertalnty.

The statute does, however, authorize test 11tigation to clear up the question of the mineral reservation. One such case has been declded by a United States District Court in the Northern District of California [12]. The court there held that a mineral reservation under the Stock Ralsing Homestead Act [13] d1d not include geothermal water or steam. The land owner is therefore free to use or dispose of geothermal resources whout fear of any auperseding federal rights. The court decided the case on the grounds that accepted definitions and past federal interpretation indicated that water. Is not a mineral. This case is presently upon appeal in the U.S. Court of Appeals.

Geothermal Steam Act of 1970 (Reprinted In Appendix I.)

Beginning in the early $1960^{\circ} \mathrm{s}$ Congress attempted to construct a rational leasing scheme for geotherwal resources. The early efforts culminated in passage of legislation by the Congress in 1966. The b111 was vetoed by President Johnson on November 13, 1966. He found the legislation to be deficlent in a number of waye: (1) It gave over1y generous "grandfather rightg" to early geothermal prospectors; (2) It provided for maximum lease acreages of 51,200 acres which was too extensive; (3) It provided for royalties only on steam sold or utilized, thereby encouraging waste; (4). It falled to give the government clear authority to readfust lease terms and conditions; (5) it provided for perpetual leases to developers of steam produced In commercial quantities; (6) it gave the developer 20 years to begin production and thereby encouraged holding land for speculative purposes. 
The Congress returned to the drafting process and sucessfully resolved these and other pressing 1ssues. 1970 President Nixon signed into law the federal othermal Steam Act [14]. This Act, which remalns on the books in its original form, resolved a number of open questions about geothermal energy development on federal lands but left some issues unresolved. This section reviews the legislation and some of the issues which require further resolution.

Defintition of Geothermal Resources. The initial task facing the Congress was to produce an acceptable definition of geothermal resources. As the discussion above reveals, the particular legal regime to be applied to geothermal resources could depend on the definition of the physical character of the resource. Congress defined "geothermal steam and associated resources" to include all products of geothermal activity, Including steam, water, gases, brines, heat, and assoctated energy in geothermal formations; energy from artificially injected fluids was also covered. By-products derlved from the above were included in the definftion.

By adopting such a broad definition the Congress intended the federal leasing statute to supersede other leasing or mineral exploitation arrangements which might be applicable to geothermal resources. Ne1ther the location-patent nor other mineral leasing systems would, henceforth, apply to geothermal resources.

What the definition did not do, however, is resolve all the questions as to how other aspects of mineral and water law applfed to geothermal resources. By not stating explicitiy that geothermal resources are either minerals, water, or sui generis, Congress left open several issues which from the developer's perspective might better have been resolved.

One such issue concerns mineral reservations by the Un1ted States in patents (deeds) issued under the various homestead acts. The definition does not clarify the respective rights of landowners and the Unt ted States with respect to geothermal resources under lands patented by the United States subject to mineral reservations. Indeed, Congress, in Section 21(b) of the Act instructed the Attorney General to institute appropriate proceedings in the courts to test out the scope of such mineral reservations. A noted above, one such suft has been Instituted and the court held that the mineral reservations in the patents did not include geothermal resources. Thto case (and possibly others) w111 have to proceed through the courts until an "authoritative judic1al determination" of the issue is recelved. In the meantime uncertalnty will exist as to who has the rights to geothermal resources on land formerly owned by the United States. The Act does make clear that future patents and land restrictions will include reservations of geothermal resources as well as minerals (Section 23).

A second major uncertalnty not resolved by the deffinition is the degree of applicability of state water laws to geothermal resources on federal lands. By not clearly excliuding geothermal resources from waters. "upon the public lands," Congress left open the poss1bility that some persons might claim to have perfected rights to geothermal resources inder the provistons of the Desert Land Act [15] which perimits state laws to govern acquisition of water rights on unreserved federal lands. Congress clouded the 1ssue in Section 22 of the Act by providing that "nothing in the Act shall constitute an express or implied claim or denial on the part of the Federal Government as to 1ts exemption from State water laws." But in Section 23 it made 1ts
Intent clear that "rights to develop and ut1lize geothermal steam and associated resources underlying lands owned by the Un1ted States may be acquired solely in accordance with provisions of this Act."

This section may be sufficient to overcome the equivocal statement with respect to state water laws in the preceding section. In any event the Secretary of Interior has undertaken to withdraw lands from the public domain which might contain geothermal resources. Under prior case law this withdrawal should effectively prevent use of state water laws to perfect geothermal rights.

The 1nclusion of "by-products" in the definition of geothermal resources raises several questions. The first concerns the rights to non-leasable minerals subject to location under the mining laws. The geothermal lessee, upon termination of his lease, is given the rights to locate under the mining laws all minerals which are not leasable and which would constitute a byproduct if commerclal production or utilization of geothermal steam continued (Section $6(\mathrm{e})$ ). The geothermal lessee must complete the location of mineral claims within 90 days after termination of his lease. While the lessee is producing geothermal steam, the minerals would constitute a "by-product" subject to leasing under the Act.

These provisions would seem to protect the geothermal lessee. There is, however, one ambiguity in this section (and other sections of the Act). Section $6(e)$ refers only to "geothermal steam" leases and production. There is no reference made to "associated geothermal resources." As the section now reads a lessee of "hot waters" or "hot brines" would not have the same rights to file mineral claims as would the lessee of "geothermal steam." It is doubtful that Congress intended to treat lessees differently depending on the form of the geothermal resources underlying their lands, but this may be what has occurred.

A second possible problem ares concerns the rights to locatable minerals lylng within the land covered by the geothermal lease which are not by-products associated with geothermal steam and assoclated geothermal resources, and hence are subject to acquisition under the mining laws. The geothermal lessee is given no preference to such minerals. This means that another person could obtain rights to minerals on the same tract held by the geothermal lessee. The possible conflict between the parties would have to be resolved under the principles of the Multiple Mineral Development Act [16], poss1b1y to the detriment of the geothermal lessee.

A related set of losues arises with respect to minerals subject to leasing under the general Mineral Leasing laws. During production of geothermsl resources rights to leasable minerals which constitute a "byproduct" belong to the geothermal lessee. When geothermal resource production is no longer commerclally feasible, the geothermal lessee may convert hls geothermal lease to a mineral lease under the appropriate act. Such leases are subject to such terms and conditions as normally apply to the particular leasable mineral (Section $6(3))$.

These provisions do not, however, apply to oil, hydrocarbon gas, and hellum. Section 2(d) exp11citly excludes them from the definition of geothermal resources and byproducts. Section 27 of the Act reserves to the United States the ownership and right to extract these leasable minerals. The exerclse of such rights probably will not, in most instances, interfere with production of geothermal steam and associated resources; except, however, complications may arlse in the case of geopressured resources where it is not uncommon to extract large 
quantities of dissolved natural gas with the geothermal flutds.

The definttion of the term "by-product" raises one other potential problem. A by-product is any mineral or minerals associated with "geothermal steam" and which have value of less than 75 percent of the value of "geothermal steam" or, are not, because of quantlty, quality, or technical difficulties in extraction or production, of suffictent value to warrant extraction and production by themselves. This definition refers only to "geothermal steam." Since the more valuable byproducts are likeiy to be found in association with hot brines, there is some question as to whether or not the lessee of hot brines owns the rights to the byproducts. Second, if market conditions change during the course of a lease so that the extractable minerals are worth more than 75 percent of the value of the geothermal steam or are worth extracting alone, who owns the rights to them? They are, by definition, no longer "by-products," therefore, they must be elther leasable or locatable minerals under the mining or mineral leasing laws. The geothermal lessee may, under certain circumstances, have to perfect additional rights to these minerals.

Lands Available for Leasing. The availability of federal lands for geothermal leases was a subject of continuous debate before the Congress in the hearings assoclated with the Geothermal steam Act. Producers and potential developers urged broad avallability; persons concerned with conservation and environmental matters argued for restrictions on avallability of certaln federal lands. The final resolution was to remove from leasing: the National Parks; nationa1 recreation areas; flsh hatcherles; wlldlife refuges; wildilfe ranges; game ranges; wildlife managenent areas; water fowl production areas; and lands acquired or reserved for the protection and conservation of fish and wildilfe that are threatened with extinction. Tribally or Individually-owned Indian trust or restricted lands, within or without the boundaries of Indian reservations, were also removed by Congress from geothermal leasing (Section 15(c)).

Lands withdrawn or acquired in atd of a function of the Department of Agriculture (e.g., National Forest 1ands) can only be leased with consent of the head of that department. Lands subject to Federal Power Commission jurisdiction can only be leased with consent of that commission and subject to conditions concerning its use for power and related purposes.

A major 1ssue in the congressional hearings was the degree to which the Secretary of Interlor might use his discretionary powers to withdraw other lands potentially valuable for geothermal development. Industry spokesmen urged that this discretionary power be IImited; they feared that investment in exploration would be limited because lands of interest would be removed from active development and production.

Competitive and Non-Competitive Bidding. One of the single biggest issues faced by Congress in establishing the geothermal legislation was definttion of a competit1ve bldding system for geothermal resources. Industry representatives argued that competitive leasing would discourage exploration and deny security of tenure to those persons who made investment in the exploration and discovery of geothermal resources. The Department of Interior argued consistently for a wholly competitive geothermal leasing system. Its representatives opposed any non-competitive leasing syatem. Congress, In Section 4 of the Act, adopted a bifurcated system wh1ch has elements of both competitive and non-competitive leasing. The key factor in determining whether or not geothermal lands will be leased on a competitive basis is whether or not the lands to be leased are within a "known Geothermal Resource Area" (KGRA). If the land's are within such an area, they can only be leased to the highest responsible qualified bidder by competitfve bidding. If lands are not within a known Geothermal Resource Area, the qualified person first making application for the lease is entitled to a lease of such lands without competitive bidding.

The key dectsional variable, then, is whether or not lands are within a "Known Geothermal Resource Area." Section 1(e) of the Act defines a KGRA as "one in which the geology, nearby discoveries, competitive interests, or other Indicia would, In the opinion of the Secretary of the Interfor, engender a belief in men who are experienced in the subject matter, that the prospects for extraction of geothermal steam or assoclated geothermal resources are good enough to warrant expenditures of money for that purpose."

As adopted, the definition of known Geothermal Resource Area, unlike the definition of a "known geologic structure" in the oil and gas leasing system, is not purely a question of geology. Rather, in addition to geology, one must consider factors such as nearby discoveries, competitive interests, or other factors that indicate that people are willing to spend money to develop geothermal resources. The net effect of this definition is to push all geothermal leasing toward competitive bidding. The regulations adopted by the Department of Interior make even clearer the thrust toward compet1tive bidding. Nearby discoveries are defined in these regulations as "any well deemed to be capable of producing geothermal resources in commerclal quantities" and where the geological structure 18 not known, "nearby will be constdered to be 5 miles or less from any such discovery." Hence, lands near new discoveries will be classifled as KGRA's unless geological surveys determine that the lands are on a different geologic structure from the discovery. "Competitive Interest" is defined to extst if at least one-half of the land covered in an application for a geothermal lease is also covered by another application which was filed during the same application filing period. Therefore, if one puts these definttions together 1t would appear that if two or more persons file for the same parcel of land, a competitive interest can be found to exist and competitive bidding w111 be required. This procedure should be contrasted with the procedures under the oil and gas leasing regulations which indicate that when there is a competitive flling the lessee will be selected by lot.

of special concern to the Industry was the revision that permitted the Secretary of Interfor to determine that a Known Geothermal Resource Area existed when men exper1enced in geothermal development determined that prospects were good enough to warrant expenditure of money for that purpose. Th1s proviston gives the Secretary of the Interior considerable discretion to put areas which are subject to exploration and investment in the category of Known Geothermal Resource Areas, thereby prompting competitive bidding.

Since the thrust of the Act and enabling regulations is toward competitive bidding, the net effect will be to discourage "wIldcat" exploration. The wildcatter may not be protected if he makes a discovery, and some other person, within the same filing period, also files with respect to those lands. (In this case this land would be clasglfled as a KGRA and compet1tive bidding would follow.) The premtum will be on secrecy, so that a developer can have some securfty that his investment in exploration w111 lead to a geothermal lease and not to competitive bidding. 
Tese provisions will undoubtedly discourage small independent companies from the geothermal leasing process, in part because they may not be rewarded for their exploration activities, and in part because the bonus bidding system used to award competitive leases discriminates against small firms which do not have the capital to put up before the award of the lease. The Act itself is silent as to the bidding system which shall be used. It merely provides that lands shall be leased to the highest responstble, qualifled bidder by competitive bidding under regulations formulated by the Secretary of Interior. In his regulations the Secretary of Interior has provided that each bidder must submit with his bid a certified or cashier's check, bank draft or money order, or cash, in the amount of one-half the amount bid. Upon award of the lease the bidder.must pay the first year's rental and the balance of the bonus bid. This means that the bidder must submit, in cash, before he has started his work the entire amount of the first year's rental and the entire amount of his bonus cash bid. This system operates to favor those who have available cash to invest in bonus bids.

There is some question whether the bonus bidding system is properly applicable to geothermal resources as it is to other resources whose characteristics and market are known. The offshore oil leasing system produces billlons of dollars in bonus revenues for the Department of Interlor. With respect to the recent geothermal bids in a known geothermal resource in California, the highest amount bid for a single lease was only about $\$ 350,000$. The revenues to the federal government through the bonus bidding system appear small when compared to the potential value of development of the geothermal resource. The net result, however, is that the major of 1 companies tend to be the winning bidders for the largest and potentially most valuable tracts of land in the California KGRA's which were opened up for intitial bidding. If these recent bids established a trend, then one would belleve that the major energy producers, be they oil compantes or others, will tend to dominate the geothermal industry. If one wishes to open up this infant industry to more independent talent, then some change in the bidding system will probably be required.

Conversion Rights. Section 4 of the Act carved out a major exception to the bidding system outlined above. A number of so-called "ploneers" had explored federal lands potentlally valuable for geothermal leasing, and had attempted to establish claims under federal mining and leasing statutes. The Department of Interior consistentiy opposed the validity of any claim for geothermal resources based on mineral leases or mining claims. The Department argued that these statutes were limited to minerals specified therefn or resources which qualified as intnerals. The Department argued that geothermal resources did not qualify as minerals within the meaning of the General Mining Act, and, therefore, were not subject to location under that act:

Congress, however, felt that some consideration should be given to the go-called ploneers, and, therefore, provided that persons holding mineral leases; ining permits or applications, or mining clatms, could convert these leases, permits and claims, or applications for leases and permits, Into geothermal Ieases or appl1cations for such leases, respectively. The conversion. right 1 s conditioned on a showing that the person who wished to convert had made substantial expenditures for exploration, development, or production of geotherimal steam on the lands for which the lease is sought or on adjoining, adfacent, or nearby federal or non-federal

lands. Conversion rights are limlted to 10,240 acres.

if there were more than one claimant for a particular piece of land, that claimant who filed first had priority. September 1965 was used as the cutoff date. It was the congressional intent that claims filed after September 7, 1965, would not ${ }^{7}$ have priority, presumably because the claimant was on notice that the federal government intended to restrict the development of geothermal resources under a new leasing statute.

There was an exception stated for lands within any Known Geothermal Resource Area whIch were subject to a right to convert to a geothermal lease. Section 4 (f) of the Act provides that a competitive geothermal lease shall be issued to the person owning the right to conversion if he makes payment in an amount equal to the highest bona fide bid for the lease in the Known Geothermal Resource A:rea. Therefore, the Act requires competitive bldding for geothermal leases in such areas but permits the holder of prior rights to convert his right to a geothermal lease if he matches the highest b1d. The recent leases in Californla covered some lands for which there were conversion rights. It fs not clear whether any of the applicants choose to exerclse their right to meet the highest bid.

While the question of a "grandfather" clause absorbed considerable time and energy in the congressional hearings on the geothermal leasing statute, such conversion rights will probably be of minor importance in years to come, since out of the militions of acres of federal land potentially avaflable for geothermal development, only about 80,000 acres were subject' to-converston rights. However, in the short run, these conversion rights may be important since they may apply to lands of the highest potential which had been explored early.

Rents and Royalties. Section 5 of the Act provides that there be a royalty of not less than 10 percent nor more than 15 percent of the value or amount of steam or any form of heat or energy derived from production under a geothermal lease and sold or utilfzed by the lessee or reasonably susceptible to sale or utilization by the lessee. Some Industry spokesmen argued that with respect to a resource whose characteristics were unknown that it would be unwise for congress to estabIish any fixed royalty or, at least, peg it at a rate so high that the producer could not make a profit. other industry spokesmen urged congress to establish a royalty so that the producers would not be subject to the uncertain discretion of the Secretary of Interior to fix royalties? As the statute present $1 y$ reads the? royalty applies to the amount or value of steam or other form of heat or energy sold or ut 11 ized by the lessee or reasonably susceptible to sale or utilization by the lessee. "It should be noted that even if the lessee does not engage in commercial production or sale of geothermal resources, he is still subject to payment of the royalty for any resources which are utillzed by him; presumably at the site, or wilch he reasonably could have utIllzed or sold." This "language removes one of the grounds for the presidential" veto of the : 1966 bill. The net effect of this provision is to encourage lessees to engage in comerctal production. and sale, because they will have to pay the royalty whether' or not they, In fact, sell the resource. In addition, lessees-will have to be very sure that they have customers for their steam?

$$
\text { custome }
$$

The royalty on by-products derived from production under the lease and sold or utllized or reasonably susceptible of sale or utillzation by the lessee is set at 5 percent of the value. There is an exception, however, for any by-product which is a mineral named in the Mineral Leasing Act: "The rate of royalty is the same as that provided in that statute. 
The Act does not address the question of royalties. on commercialify demineralized water. The regulations do, however, specify that the royalty on commerclally demineralized water shall be at a rate of not more than 5 percent for value of guch water which has been sold or utilized by the lessee or is reasonably susceptible to sale or utilization. However, no payment of the royalty is required if the water is used for plant operation, for cooling, or in the generation of electrical energy.

The regulations provide that in no event shall a royalty, on any producing lease for any lease year be less than $\$ 2$ per acre, or fraction thereof, after the commencement of. production in commerctal quantities. This mintinum royalty in lieu of rental is payable at the expiration of each lease year.

Section 5(c) of the Act also provides for payment of annual rental for lands leased under the Geothermal Steam,Act. The rental is payable in advance at a rate of not less than $\$ 1$ per acre or fraction thereof for each year of. the lease. If there is no producing well on the land, then the failure to pay the rental on or before the anniversary day terminates the lease by operation of law. The Secretary of the Interior has been given some discretion to continue the lease if payment is deficient but there is adequate fustification for fallure to pay on a timely basis. The lessee may pay, 1n ifeu of rent, a minimum royalty of $\$ 2$ per acre, or fraction thereof, at the explration of each lease year for each-producing lease, commencing after the production of geothermal resource in commercial quantities.

The Secretary is given the right. to determine the value of any geothermal steam and by-products used by the lessee and not sold and reasonably susceptible to sale. He is mandated to take into consideration the cost of exploration and production and the economic value of the resource in terms of its ultimate utilization. Here, again, the valuation question and the discretion which resides with the Secretary of Interlor to establish value has troubled Industry representatives. They feel that they are dealing in the dark with respect to value of steam not sold but which may be reasonably susceptible to sale. Economic decisions are made on the basis of production expectations which can be upset by the -Secretary of Interior determining that the resources have been utilized or are reasonably susceptible to sale and then establishing a value for those resources upon which the royalty must be based.

The regulations contain a provision not in the statute for escalating rental rates. They state that to encourage orderly and timely development. of geothermal resources all leases issued pursuant to the regulations w111 provide that beginning with the sixth year and for each year thereafter unt 11 the lease year beginning on or af ter commencement of production of geothermal resources in commerclal quantities, the rental will be set by the authorized off 1 cer as the amount of rental for the preceding year plus an additional rental of $\$ 1$ per acre. The authorized officer may, upon a showing of sufficient fustification by the lessee, waive the payment of any or all of the portion of additional rental. The intent of this section is to encourage production by continually escalating the rental rate. For the first five years, the lessee can engage in development activities at a fixed rate. Beginning with the sixth year and uniti commercial production, he must .pay rental at an escalating rate... Therefore, it is. In h1s interest to get to commercial production as soon as possible so that the lands themselves will. begin to cover the cost of operation and the developer w1 11 not be forced to finance them out of pocket.
Lease Term and Renewal. The term of the lease and periods of renewal and discretion to alter terms upo renewal were another serles of 1ssues which once agal divided industry spokesmen and the Department of the Interfor. The Department of Interfor wanted optimum flexibility in terms of lease term and conditions. Predictably, industry spokesmen wanted long fixed term and IImited governmental discretionary powers. Section 6 (a) of the act was a compromise. It provides that geothermal leases extend for a primary term of ten years. If geothermal steam is produced or utilized in commerclal quantities within the ten-year period, the lease continues for so long thereafter as geothermal steam is produced and ut1lized in commercial quantities, but not to exceed an additional 40 years. Establishment of the 10-year and 40-year time periods was to permit the developer adequate time to develop the resource, and then ensure him some measure of security of investment In those resources.

Many industry spokesmen appearing before Congress argued against the leasing system and for outright transfer of title to geothermal land to developers on the model of the location-patent system. Once Congress determined that geothermal leasing rather than outright sale would be the mode of exploitation of geothermal resources, then the Industry spokesmen shifted their argument and trled to get as long a primary term as possible and automatic renewals not subject to renegotlation. Many producers argued that the ten-year primary term was too short and that it was unrealistic with respect to a resource whose location and characteristics were not well known to expect commerclal production withIn ten years after commencement of the lease. On the other hand, the Department of. the Interior argued that longer than a ten-year primary term would permit lessees to withhold land from production and to slow down developmental activites. The Department of the Interior also argued that the renewals should not be automatic but should be subject to appropriate renegotfations between the Secretary of Interfor or his representatives and the lessee. The Department wanted to protect the public domain and federal revenues where appropriate. The producers wanted as much security as possible.

The 40-year time period seems to be a reasonable compromise between the two objectives. The statute does not provide for renegotiation of terms and conditions at the end of the ten-year period. Therefore, the lessee is entitled to continuation of the lease on the same terms and conditions subject to other sections of the act which provide for renegotiation of lease terms.

The regulations stated that if at the end of 40 years, geothermal steam is "produced or utilized in commercial quantities" and the lands are not needed for another purpose, then the lease will be renewed upon renegotlation of terms and conditions. Production or utilization of steam in commercial quantities is defined to include the completion of one or more wells producing or capable of producing geothermal steam in commercial quantities and a bona fide sale of such geothermal steam for delivery to or utilization by a facility or facilities not yet installed but scheduled for installation not later than 15 years from the date of commericement of the primary term of the lease. Th1s proviston which appears in Section 6 (d) of the act is to deal with the case In which the geothermal producer has entered into negotiations with an electric utility for utilization of his steam but because of the lead times involved in construction of electric power generating facilities, the facility cannot be completed at the end of the tenyear primary term. The lessees are given the right, If they have achieved production, to renew for a second 40-year term. However, this renewal ts subject to such 
terms and conditfons as the Secretary of the Interior then deems appropriate.

tion $6(d)$ of the Act provides for extension of leases for land on which or for which, under an improved cooperative or unit plan of development or operation, actual drilling operatlons were commenced prior to the end of 1ts primary term and which are being diligently prosecuted at the end of the primary term: The lessee is entitled to five-year extensions but not morethan 35 years total as long as geothermal steam is produced or utilized in commercial quantities. This proviston was necessary because an individual lessee may not be able to show production under an approved cooperative or unit plan of development or operation, since the actual development may be taking place on adjoining property.

Area of Geothermal Leases. Of particular concern to geothermal developers, both large companies and independents, was the area which a geothermal lease may embrace. An 1mportant related question was the amount of land which could be under the control of any single developer. The major companies argued that geothermal leases should be of large size and that a developer should be able to control hundreds of thousands of acres as under the ofl and gas leases. The independents and, also, the Department of the Interfor; which was interested in promoting some competition within the geothermal industry, argued that leases should be sma11, relatively speaking, and that no person or assoctation should be able to monopolize the industry. President Johnson's veto of the earlier version of the Act was based, in part, on the fact that the Act permitted too large an acquisition by a single developer.

The compromise which resulted is embodied in Section 7 of the Act. It provides that a geothermal lease shall embrace a reasonably compact area of not more than 2560 acres, except where there is an irregular subdivision. No individual or corporation, except as otherwise provided in the act, can hold or control directly or indirectly more than 20,480 acres, including conversion leases. At any time after 15 years from effective date of the Act, the Secretary of the Interior, after public hearing, may increase the maximum holding in any one state to an area not to exceed 51,200 acres.

At this stage of development it is not yet clear whether these acreage limltations are too large or too small. In a single state, 20,480 acres is a fairly significant holding considering that the producing geothermal leases in The Geysers area: of Californla encompass no more than a few thousand acres. However, unt1l more is known about the nature and location of the resource, and its general aval1ability, it will not be possible to draw a definitive judgment as to whether or not these acreage limftations are too large or too small: "It may well be that Congress, by authorlzing use of the bonus bidding systen, has limited active participation to well financed energy protucers; the refore, the acreage Iimitation may not be an effective way of encouraging competition.

Readjustment of Lease Terms and Conditions. Of particular concern to Industry personnel is the amount of discretion given to the Secretary of the Interior. One area in which there was particular objection to the Secretary's discretion is the readjustment' of lease terms and conditions. Industry spokesmen argued that if the Secretary of the Interior were given broad powers to reduce or otherwise adjust the terms and onditions, he would use that power to the detriment the producers
This, in turn, would reduce the security of tenure and, therefore, the willingness to make investments. The Secretary of the Interior argued that he needed authority to modify lease conditions as the character of the industry changed and more Information was obtained about the exact nature of the geothermal development process.

Section 8 (a) of the Act, which was a compromise between these positions, provides that readjustment of lease terms may be done at not less than ten-year Intervals beginning ten years after geothermal steam is produced. The lessee is given the option of filing objections to any proposed lease terms and conditions. If the lessee Iles objections and an agreement cannot be reached between the authorized officer and the lessee within a period of 60 days; the lease may be terminated by elther party subject to provisions of the law.

The Act is somewhat more stringent with respect to readjustments of rents and royalties as distinguished from other terms and conditions of the lease. It provides, in Section $8(\mathrm{~b})$, that the Secretary may readjust the rents and royalties of any geothermal lease at not less than 20-year intervals beginning 35 years after the date that geothermal steam is produced. In the event of any such readjustment, neither the rent nor royalty may be increased by more than 50 percent over the rental or royalty paid during the preceding period, and in no event shall the royalty exceed $22-1 / 2$ percent. The lessee may object and if his differences with the Secretary of Interior are not resolved, he may lose his lease. Because of the longer time perlods for readjuatment of rents and royalties and the upper celling on royalty payments, these provisions are probably not going to be a major factor in upsetting investors' expectations:

Section 12 of the Act also provides that the leases may be terminated outright by the Secretary of the Interior for any violation of the regulations or lease terms after appropriate notice and opportunity for the lessee to correct any defaults. The lessee is given the right to a hearing on any clatmed violation or proposed termination of the lease provided he requests the same. Again, this'section offeris the' lessee some limited protection. However; it does give the Secretary of Interior considerable discretion to determine what is a violation of the lease and then to act after hearing on that violation. It gives the lessee no recourse rights with respect to the Secretary's termination of the lease because of an alleged violation.

$$
\text { A.: }
$$

Miscellaneous Lease Provistons.- There are also a number of sections of the Act which deal with various lease provisions. For example, Section 10 permits the holder to relinquish the lease if he determines that he no longer wishes to continue with development or production of geothermal resources. However, he imist make a11 payments of accrued rents and royalties and act to restore the surface lands prior to complete relinquishment.

Compatibility of Multiple Uses of Land. A continuing problem with respect to all mining and mineral leasing statutes is the question of what princlples should govern the use of land and resources when multiple uses are possible. - Section 17 of the Act adopts the general principle that the Geothermal Steam Act shail allow for coexlstence of other leases of the same lands for deposits of minerals under the laws applicable then, for location and production of claims under the mining $1 \mathrm{aw}$, and for other uses of the areas covered by them." The net result of this provision is that there 18 really no set of priorities established other than that the leases or uses of land shall not unreasonably interfer with each other: This, again, raises the question of administrative discretion, since the Secretary of the Interior, who is responsible for' administration of this Act, may find 
that there is some conflict of uses and subordinate the geothermal development to the development of other resources. This could endanger the lessee's use of the lease premises for géothermal development. It does not give priority to development of geothermai resources, and, therefore, does not offer the lessee complete security in its tenure.

Cooperative or Unit Plan and Drilling Agreements. Section 18 of the Act replaces the law "of capture" with a more rationa1 system of development of geothermal resources in a pool, fleld or area where there are more than one lessee or land owner. This section provides that for the purpose of properly. conserving the natural resources of any geothermal poo1, field or area, or part thereof, lessees and their representatives may unite fointly or separately with other' in collectively developing, adopting, and operating under a cooperative or unit.plan of development. The Secretary of the Interior may in his discretion and with consent of the holders of the leases Involved establish," alter, change, or evoke and make such regulations with reference to such cooperative leases as he deems necessary or proper to secure reasonable protection of the public interest. He may even include in geothermal leases a provision requiring the lessee to operate under such a reasonable cooperative or unit plan, and may prescribe such a plan. The compulsory unitization of leases again places the Secretary of the Interior in a key role in determining the linvestment and production decisions of private parties. Compulsory unitization may result in protection of individual lessees and of the resource pool, but possibly at the expense of delaying the development process, for, now, a bureaucratic chain of decisions may be included in the private investment decision.

Section 18 also provides that when separate tracts cannot be Independentiy developed and operated in conformity with an established well spacing or development program, any lease or portion there of may be pooled with any other land whether or not owned by the United States under a communitization or drilling agreement providing for apportionment of production or royalties among the separate tracts of land comprising the drilling or spacing unit. The Secretary may require such communitization or drilling agreements if the lessees cannot voluntarlly agree among themselves. In this section, interestingly enough, the Secretary is given the power to apportion production of royalties among separate tracts of land including lands which are not federal lands and not subject to geothermal leasing under the Act. It 18 not clear how this provision relates to state laws which purport to give state ofl and gas or geothermal officers the power to regulate drilling.

The Act does provide as a "bonus" to lessees that leases operated under an approved operating, drilling or development contract, and unitization or cooperative agreement; shall not be counted in determining maximum allowable holdings under other provtstons of the Act. This-provision of the law encourages lessees to engage in cooperative activities rather than competing activities if they are close to holding the maximum allowable lands in any single state.

Administration of the Act. The Act also contains a number of administrative provisions, the most important of which 18 contalned in Section 24 : the Secretary shall prescribe such rules and regulations as he may deem appropriate to carry out provisions of the Act. The scope of the regulations is large, including provisions for prevention of waste, development and conservation of geothermal and other natural resources, protection of the public interest, assignments, segregation, extension of terms, relinquishment of leases, development contracts, unitization, pooling and driliIng agreements, compensatory royalty agreements, suspension of operations of production and suspension or reduction of rents or royalties, filing of surety bonds, use of the surface by the lessee, maintenance by lessee of an active development program, protection of water and other environmental qualities.

Section 23. of the Act provides that all leases shall be subject to conditions: the lessee will, in conducting his exploration development and producing activities, use all reasonable precautions to prevent waste of geothermal steam and associated resources in the leased land. Section 21 provides that within 121 days after effective date of the Act the Secretary shall cause to be published in the Federal Register a determination of all lands which were Included within any known geothermal resource area on the effective date of the act and shall add such determination in the Federal Register from time to time as he specifies.

Section 19 of the Act provides that upon request of the Secretary, other federal departments and agencies sha11 furnish him with any relevant data then in their possession or knowledge concerning or having bearing upon fair and adequate charges to be made for geothermal steam produced or to be produced for conversion to electric power or other purposes: the data so provided shall be confidential.

Exploration Rights. The federal Act is silent with respect to granting of exploration rights. The Secretary of Interfor, in accordance with his rule-making authority, has established a procedure whereby persons who wish to search for geothermal resources upon the public lands must file, a notice of intent to engage in exploration operations. The notice of intent gives the holder the right to engage in non-exclusive exploration for geothermal resources. The explorer gains no preferential rights to geothermal resources or any lease. There are requirements with respect to bonding, environmental maintenance, and the like. The way that the exploration process is presently structured, a person coming upon the public domain does so at his own risk. All expenditures for geothermal exploration may be vitiated efther by a prior filing of a non-competitive lease application by another person or by a declaration by the Secretary of Interior that the lands explored are within a KGRA and therefore subject to competitive bidding.

The net result of this provision will be to discourage independent exploration of the public domain for geothermal resources. The investor would do so at his own risk. Those persons who wish to protect their investment will first have to obtain a geothermal lease. These procedures should be contrasted with those under state law, where in California, for example, a geothermal explorer can obtain an exploration permit from the State of California for exploration on state land and, therefore, have a preferentlal right to a geothermal lease if geothermal resources are. discovered as a result of the exploration operation.

\section{State Geothermal Leasing Laws}

Nine states, Wyoming, California, Arizona, Alaska, Oregon, New Mexico, Utah, Montana, and Idaho, have adopted geothermal laws. Figure 2.4.1 summarizes the current laws and Append $1 x$ I contains an analysis of air quality standards in thirteen states. Only three of these states, Callfornla, Alaska, and New Mexico, have specific geothermal leasing statutes with respect to state lands. 


\begin{tabular}{|c|c|c|c|c|c|c|c|}
\hline Stace & 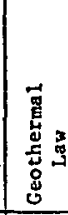 & 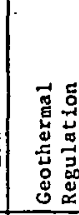 & 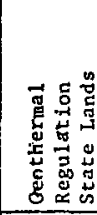 & 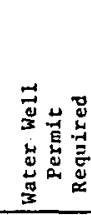 & 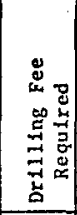 & 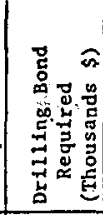 & 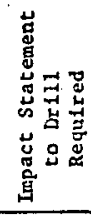 \\
\hline Alaska & Yes & No & $\begin{array}{r}\text { Yes } \\
1972 \\
\end{array}$ & Yes/No & $\$ 100$ & Yes 15 & No \\
\hline Artzona & \begin{tabular}{|l|} 
Yes \\
1972 \\
\end{tabular} & $\begin{array}{r}\text { Yes } \\
1972 \\
\end{array}$ & Yes & No & $\$ 25$ & Yes 15 & No \\
\hline Callfornia & \begin{tabular}{|l|} 
Yes \\
1965 \\
\end{tabular} & $\begin{array}{l}\text { Pend: } \\
\text { (1973) }\end{array}$ & $\begin{array}{r}\text { Yes } \\
1967 \\
\end{array}$ & No & $\begin{array}{r}\$ 25 \\
1,000 \\
\end{array}$ & Yes 15 & No \\
\hline Colorado & No & No & No & UD & UD & UD & UD \\
\hline Hawa 11 & No & No & $\begin{array}{c}\text { No } \\
\text { Pend. }\end{array}$ & Yes & Nom. & & Yes \\
\hline Idaho & \begin{tabular}{|l|} 
Yes \\
972 \\
\end{tabular} & $\begin{array}{r}\text { Yes } \\
(1973)\end{array}$ & $\begin{array}{r}\text { Yes } \\
1972 \\
\end{array}$ & Yes & $\$ 500$ & Yes 110 & \\
\hline Montans & \begin{tabular}{|c|} 
Yes \\
(ii73)
\end{tabular} & $\begin{array}{c}\text { Yes } \\
(7 / 73)\end{array}$ & $\begin{array}{c}\text { Yes } \\
(7 / 73) \\
\end{array}$ & Yes & \begin{tabular}{|c|} 
Yes \\
\$75-150
\end{tabular} & Yes 15 & Cond, \\
\hline Nevada & No & No & No & Yes & $\$ 25+$ & No & No \\
\hline New Mexico & \begin{tabular}{|l|} 
Yes \\
$(6 / 73$
\end{tabular} & $\begin{array}{r}\text { Yes } \\
\times 6 / 73)\end{array}$ & $\begin{array}{r}\text { Yes } \\
1967\end{array}$ & Yes & UD & UD & No \\
\hline Oregon & \begin{tabular}{|l|} 
Yes \\
1971 \\
\end{tabular} & \begin{tabular}{|r|} 
Yes \\
1971 \\
\end{tabular} & $\begin{array}{r}\text { Yes } \\
1972 \\
\end{array}$ & Yes & $\begin{array}{l}\text { Yes } \\
\$ 25\end{array}$ & Yes 15 & No \\
\hline Utah & \begin{tabular}{|l} 
Yes \\
1973 \\
\end{tabular} & No & Yes & Yes & $\$ 10+$ & & No \\
\hline Washington & No & No & No & UD & UD & UD & No \\
\hline Wyoming & $\begin{array}{l}\text { Yes } \\
\text { k/73 }\end{array}$ & No & No & Yes & $\$ 2$ & No & No \\
\hline
\end{tabular}

Source: State of California, Division of $0 i 1$ and Gas, Department of Conservation, Apr11 1973 (Updated)

Figure 2.4.1 OVERVIEW OF GEOTHERMAL LAWS AND REGULATIONS IN THE WESTERN UNITED STATES

Wh1le these statutes are modeled on the federa1 statutes, they do differ in some respects. California's statute was adopted prior to enactment of the federal law and therefore served as a model for several other states. The statutes are adminlstered by a variety of state agencies--illustrating the uncertainty about the nature of geothermal resources. In California, for example, the supervisor is the State $0 i 1$ and Gas supervisor. In Artzona, it 18 the 011 and Gas Conservation Commissioner. In Alaska, it is the Director of the Division of Lands and Department of Natural Resources; In Oregon, the state geologist; in New Mexico, the Commissioner of Public Lands; and in Idaho, the Director of the Idaho Department of Water Administration.

Generally, these statutes are written so as to govern all leasing of state lands for geothermal purposes. All the statutes draw a distinction between competitive and non-competitive bidding lands, and basically paralle1 the federal statute in this regard.

Definition of G eotherma1 Resources. The state statutes use differing definitions of geothermal resources. of particular Interest are the Arizona and Oregon statutes wh1ch explicitly recognize that geothermal, resources include energy resulting from artifictal stimulation or Induction of fluids into geothermal formations. Oregon also, perhaps in order to resolve some conflict with its water laws, Indicates that geothermal resources include hot waters which have a bottom hole temperature of more than $250^{\circ} \mathrm{F}$. Idaho indicates in its statute that geothermal resources are declared to be sut gener1s, nefther a water resource nor a mineral resource, but the legislation goes on to indfcate that they are also found and declared to be closely related to and possibly affected by water and mineral resources in many instances; Th1s tag clause appears to leave some uncertainty with respect to the nature of geothermal resources in Idaho.

Definition of geothermal Resource Area. The nine states which have adopted geothermal statutes have in five cases defined "geothermal resource area" or "Known Geothermal Resource Area." It is interesting that the states which have so defined these areas have used what appears to be, in essence, a physical definition. That is, they refer to surface areas which are underlatd or reasonably appear to be underlaid by geothermal resources. This definition should be distinguished from the federal statutory definition which indicates that a KGRA is an area which 1s, in effect, sultable for investment purposes. The use of a purely physical definition removes some discretion from the state administrative of ficers with respect to classification of lands, and thereby encourages non-competitive leasing of state lands, whereas the federal statute has the distinct tendency to encourage competitive leasing of lands.

Prospecting Permits. Calffornia and Alaska have dealt explicitly with the problem of exploration and prospecting for geothermal resources on lands which are not classified as geothermal resource areas. The first qualified applicant, upon payment of a fee of $\$ 1$ per acre or more, may obtaln the right to an exclusive prospecting permlt for lands not classified as a KGRA. If before the permit is issued the lands are classifled as a KGRA, the application will be denled. If the permit is awarded, the prospector has an exclusive three-year period of prospecting which may be extended administratively for an additional two years. Th1s prospecting permit includes a preferential right to lease lands. If wh1le the prospecting permit is still valid and, in effect, the state authoritles reclassify lands in a KGRA, the permittee is given a preferential right to lease the lands. Permits are subject to cancellation for non-performance or faflure to use diligence and care in prospecting and development. Any single person, assocfation, or corporation may obtaln a prospecting permit for an area of not more than 25,600 acres within the California state domain. California, interestingly enough, provides for preferential rights for the surface owner with respect to prospecting. In lands sold to private persons by the state with a mineral reservation in the state, the owner may, If any other person applies for an application for a prospecting permit, himself file an application within six months and obtain preferentlal rights. The fallure to apply terminates the landowner's rights and the original applicant is permitted to proceed with his application.

State Leasing Provisions: State leasing provisions are very similar to those in the federal law. They do, however, differ in some particulars. For example, in Callfornia the primary leasing term is 20 years and renewals of up to 99 years are permitted as long as there is commerctal production of geothermal resources. This should be contrasted with the federal law which has a ten-year primary term and 40-year renewal perlods. Alaska has a ten year primary term and 40-year renewals up to a total of 99 years. New Mexico provides for a 5-year primary term and 5-year renewals thereafter as long as the resources are produced in commercial quant1ties. The developer would appear to have more security In Calffornia than under the federal statute, but more under the federal statute than he would in New Mexico. The rental provisions are similar to the federal law with roughly $\$ 1$ per acre required at a minimum. The 
royalty provisions differ somewhat. California provides for 10 percent of gross revenue on steam and brine, and between 2 and 10 percent on gross revenue of other resources found in geothermal fluids. This should be contrasted with the federal law which provides for a royalty of from 10 to 15 percent for steam, 5 percent or less on by-products, and 5 percent or less on commercially deminerallzed water. Alaska provides for royalties of 10-15 percent of gross revenue from sales of steam and brine, and 2-10 percent of gross revenues of minerals and chemfcals sold. Oregon puts the authority for setting royalties in the Division of State Lands and has no statutory maximum or minimum. New Mexico is similar to California and Arizona, but does, however, provide for a royalty of 8 percent of net revenue from energyproducing plants; and 2-10 percent of gross revenue for use of lands for recreational purposes. The state statutes also have provisions with respect to termination of leases; suspension; transfer ability; and waiver, suspension and reduction of rents and royalties which are similar to the federal statute. The state laws have provisions for adjustment of rents and royalties and terms and conditions of the lease which are basically the same as the federal statute, although Callfornia does provide for readjustment of terms and conditions after 20 years, whereas the federal statute provides for readjustment of terms and conditions at ten-year intervals beginning ten years after commerclal production.

Protection of Resources and Environment. The state statutes, as well as the federal statute, provide for prevention of waste and safeguarding of $11 \mathrm{fe}$, health, property and the environment. The terms of conservation and waste prevention provisions are essentially similar to those in the federal statute. California, Alaska, and New Mexico also provide that where land is used for some other state purpose, the state lease requires the consent of the agency which has reserved the land for Its own purposes. The state statutes provide that in future leases the state authorities have the right to reserve minerals or geothermal resources in the leasing and selling of state lands. State statutes have provisions for cooperative development and drilling agreements to conserve the resource pool; the emphasis here 1s on conservation of the resource and protection of the public interest in those resources.

\section{Overlapping Regulatory Jurisdictions [17]}

A problem which is going to plague the geothermal resource Industry in years to come is the sorting out of overlapping regulatory jurisdictions with respect to acquisition of rights to geothermal resources, exploration, drilling, development, production, and utilization of those resources. Federal, state, county, and local governments are involved with respect to regulat1on of private lands, state lands, and federal lands. Figure 3.3.1 depicts schematically the complex regulatory system in California.

\section{Federal Lands}

In order to obtain rights on federal 1and the prospective geothermal developer must pass through a series of procedures established by regulatory agencles. First, the lands must be made avallable for leasing by the Bureau of Land Management of the Department of the Interfior. Sacondly, prior to a lease sale, the Bureau of Land Management must prepare an environmental impact statement which must then 1tself go through a series of review processes.
Following avallability of lands for leasing and acceptance of the environmental impact statement (which may include 11tigation by persons opposed to geothermal development in a particular area), the bidder must then determine whether or not the lands are available for competitive leasing or non-competitive leasing. If the lands are avallable for non-competitive leasing, and the potential developer wants to go upon the lands prior to development or bidding, he must file a notice of intent to engage in geothermal resource exploration. Th1s notice of Intent is filed in the office of the Bureau of Land Management for the district in which the lands are located. The prospector must also obtain a bond. Assuming that the developer is reasonably confident there are geothermal resources under the land and wishes to engage in exploratory drilling, he must do so after obtaining administrative approvals from the USGS conservation division and the applicable office of the Bureau of Land Management. He must not only have appropriate bonds but he must give appropriate assurances that he will not affect the environment adversely or will restore the land if he will have such an effect. As noted earlier, this exploratory drilling is solely at the developer's risk, since he may find that the lands are reclassified as a KGRA or he may find that the lands are withdrawn from leasing at any time prior to granting of a non-competitive lease to $\mathrm{him}$.

If the developer wishes to proceed with a non-competitive lease, he mist file an application and provide a year's rent in advance. If the land is not classifled as a KGRA and he is the only applicant, he will in due course recelve such lease unless the Department of the Interior determines otherwise. If the land is reclassified as a KGRA, then the developer must engage in a competitive bidding process. He stands a substantial risk that persons with more capital will, because of his exploratory work, feel free to invest larger sums of money than he can afford to obtain a competitive lease to the land. The risk is particularly great for the small developer since the Bureau of Land Management uses the cash bonus bidding system for the development of geothermal lands.

If an environmental 1rapact statement has not previously been filed with respect to those lands, then the law seems to require that such a statement be produced, a1though it is less clear with respect to non-competitive lands than 1t 18 with respect to competitive lands. In addition to filing an application for a non-competitive lease, the applicant must file a proposed plan, consisting of a map and a narrative statement. The statement must describe the operation the developer Intends to conduct, the method he Intends to use, and the way in which he will protect the environment, wildilfe, and other natural resources.

If after this process, the developer is able to acquire a lease to promising land, he is then in a position to engage in developmental drilling. This drilling process requires, according to applicable regulations, clearances by the U.S. Geological Survey with respect to all drilling plans and proposals. The developer must comply with a number of production and drilling regulat1ons. It appears (but is by no means completely clear) that the developer must in addition comply with state regulations pertaining to exploration, exploratory drilling and developmental drilling on federal land. Callfornla state law, for example, purports to bring actions on federal lands under California jurisdiction. The Bureau of Land Management has Indicated that it intends to comply to the extent possible and consult with state regulatory agencies. However, it has not taken the step of firmly committing itself to state or local regulation.

Once a developer gets into the development stage, he 
must concern himself about additional regulations with spect to resource production and utilization. The deral regulations require that the developer take a number of steps with respect to soll and resource conservation and production on leased land as determined by the supervisor of the USGS. These steps include safe reinjection of fluids, monttoring of land for subsidence, and precautions that will facllitate the restoration of disturbed lands to their original condition. The production regulations also require the developer to ftle perfodic monthly production and financial reports and obey all geothermal resource operational orders issued by the supervisor of the USGS.

At the production stage, the developer may efther voluntarily or upon order of the supervisor have to enter into a unft or cooperative drilling arrangement with other developers in the area. The extent to which these arrangements will be required will depend upon experience with development of geothermal resource pools.

If the resource is to be used for production of electricity, the Federal Power Commission enters the picture. The Commission must grant a permit before a power plant is constructed on federal land or transmission ifnes are developed over navigable waters. The extent to which this provision will be used is not yet clear since there has been no actual production on federal land. If the developer should produce valuable mineral by-products, then he is subject to additional regulations w1th respect to the use and disposition of those by-products.

\section{State Lands}

California, which is the only state in which there 18 active production and utilization of geothermal resources for the generation of electriclty, provides a model for other states with respect to state regulation of geothermal activity on state lands. In order to conduct exploration operations on lands owned by the State of Calffornia, the prospective developer must apply to the State Lands Commission for a prospecting permit. The permit must include a description of the land as well as statements of the methods proposed for developing deposits, the quality and use of underlying groundwaters and adfacent surface waters, and waste disposal methods. Fees, deposits, and bonds are required at this stage. Additional information is required by the permittee before drilling any exploratory wells.

The State Land Commission must grant permlssion before any exploratory drilling commences. There are also' provisions for environmental protection of fioh and wlldife resources, and relmbursement to the state for t1mber damaged and destroyed: state law requires that the permittee comply with all valid ordinances of cltie and counties applicable to his operation, and to submlt perlodic reports and logs showing hls developmental activities.

Before exploratory drilling can begin, the developer must apply to the 011 and Gas Supervisor of the DIv1sion of 011 and Gas of California's Department of Conservation. He must submit a work program and appropriate bonds which comply with the rules and regulations of that department. H1s Intent must be filed before any driling is actually commenced. The Division of 011 and Gas is directed by 1 aw to enforce varlous operating standards, including standards with respect to casing and safety devices and environmental protection. Abandonment of a well also requires state ( proval and restoration of lands. Overseeing these exploratory and developmental activities is the Callfornia Geothermai Resources Board of the Division of Conservation which has general oversight of all agency activities dealing with geothermal resources development in the state.

In accordance with the Californfa Environmental Quality Act of 1970, an environmental impact report must be prepared before any geothermal exploration projects on state lands can be undertaken. The State Land Commission must prepare an approprlate environmental report before grantIng a prospecting permit. The developer must cooperate in preparation of that report:. The environmental 1mpact report is also required at other stages of the development process. It must, under California law, Include a description of the environment in the vicinity of the profect, an account of the direct and indirect impacts of the proposed project on the environment; it should include specifics with respect to the area resources Involved, physical changes, alteration of ecological systems and changes introduced into population distribution, population concentration, human uses of land, and other aspects of the natural resource base such as water, scentc quality, and public services. Avoidable environmental impacts must be described and mitigation measures Imposed. The statement must contain a description of the relationship between the local short-term uses of man's environment and the malntenance and enhancement of long-term productivity and any irreversible environmental changes which could result.

In addition to the state environmental impact statement, the developer must also obtaln a permit from the appropriate local or regional atr. pollution control board. If the operation intends to discharge waste waters from the we11, the operator must also file a report with the local regional water quality control board. Operations, of course, must not violate air or water control provisions.

With respect to leasing, the California system is similar to the federal law, except that no leases at a11 are granted upon non-KGRA lands--only prospecting permits are allowed. Lands must be converted to a KGRA before the permittee can obtain a lease. However, the prospecting permittee may obtain a lease without competitive bldding if the land is so classified. The State Land Commission must prepare an environmental impact report before it grants any leases for geothermal development. Once a geothermal lease has been obtained and developmental drilling 1 s contemplated, the developer must go through substantially the same procedures for developmental drilling as are required with respect to explora-. tory drilling. The same types of information and clearances are required. The Division of 011 and Gas has generai regulatory jurlsdiction over both developmental drilling and exploratory drililing.

In California, the State Land Commission plays an active role In regulating resource production and utilization: on state lands. It can determine the rate of development in production of weils to promote their maximum. economic recovery and conservation of resources in each resource basin. All sales of geothermal resources must be approved in advance by the State Land Commission. There must be state approval of generating plants, buildIngs, structures, production equipment, metering system, pipeline, and roads prior to installation. The Commission has the authorlty to require production of by-products. Monthly reports must be submitted to the Division of oil and Gas.

If a developer Intends to enter Into a contract or construct a power generating plant; additional approvals must be obtained from the Callfornia Public Utilities Commission. The applicable statutes and regulations also require an environmental impact report when the plant is 
to produce more than 50 megawatts of electric power. Reglonal or local A1r Resource Control Boards and Regional Water Quality Control Boards must also give their permission when any power plant or other plant is likely to emit air contaminants or water contaminants. If the power plants on state lands come under FPC regulation, then they will also have to obtain Federal Power Commission permission. This could occur if they sell power across state Ilines or sell Into a federal power net.

Local government is also involved in regulating those stages of geothermal development likely to present land use problems. California counties, for example, are authorized to minimize the effects that geothermal operattons will have on other economic activities and on recreation. They w111 also check to see that noise is not produced near businesses and homes. 'It 18 not clear whether counties will be able to regulate federal lessees operating within their jurisdicitonal 1imits. It appears 1ikely that this matter w11 have to be worked out by consultation between state, federal, and local authorities.

In some instances county regulations are quite extensive. For example, in Imperial county, the county requires a permit for geothermal exploration activities if they Involve drilling a well. The county requires indemnity bonds and 1lability insurance. If the development is to be near populated areas or other areas of exlating deve1opment, then more stringent regulations are imposed, including the use of sump ponds, nolse level limitations, and participation in a subsidence detection program. Minimum distance criteria exist which control well sitings with respect to residences, schools, hospita1s, and the 1ike. The closer that the development activity is to existing residences, businesses, or other land uses, the lighter the level of regulation with respect to noise, sound, esthetics, and other possible environmental impacts.

The county also requires permits with respect to bulldIngs upon lands within the county and facilities to produce, process, transport, and sell geothermal resources. The county also has other areas of regulatory jurisdiction. For example, they can regulate the location of power 1ines, the restoration of environment, the location of collection and sewage pipes, and so on. A summary and comparison of state and federal regulations is presented In Figure 2.4.2.

\section{Private Lands}

The leasing of private lands 18 essentially an individual transaction between the developer and the owner of the land. However, public bodies still play a significant role. The Division of 011 and Gas in California's Department of Conservation has been given power to regulate geothermal operations on private lands. The state sees Its role as safeguarding life, health, property, and the public welfare, and encouraging maximum economic recovery of the resource. The regulations issued by the Division of 011 and Gas concerning development on private lands are simflar to those applicable to state lands. While no environmental impact statement is required with respect to private lands; these lands are nonetheless subject to jurisdiction of the Air Pollution Control Board and the Reglonal Water Quality Control Boards in the area. County land use regulations also apply to development on private property.

It 18 not yet clear how federal and state officlals intend to deal with resource pools which underlle state, federal, and private lands at the same time. It appears that some consensus wili be required to obtaln unitization or drilling agreements with respect to these joint1y underlaid lands. It 18 Interesting to note that the federal regulations provide that when leased lands are being drained of geothermal resources due to activitifi of developers on non-federal lands, the lessee of the federal lands $1 \mathrm{~s}$ required to drill and produce all weils necessary to protect the leased land from drainage, or in lieu. of such drilling may pay a compensatory royalty. It is generally conceded to be undesirable that individual federal, state, and private lessees engage in competitive activity, therefore it is anticipated that some resolution of this problem will be worked out on a cooperative basis. State regulations with respect to utility reguiation also apply to creation and operation of electric generating facllities on private lands.

Conflicting Regulatory Jurisdiction. State, county, and federal regulations overlap in several areas, and there are several areas of uncertainty with respect to regulatory jurisdiction. Federal lands, of course, lie within both state and county boundaries, but 1 is is not clear that the county or state governments have any authority to bind the Federal Government. California state law purports to exert jurisdiction over federal lands. It is not yet clear that the Federal Government will accept such furisdiction.

Within the state, there is a comparable problem since it is not clear the extent to which county regulation can overrule conflicting state regulation. Unt1l geothermal development occurs on federal lands, the debilitating effect of overlapping and confilcting regulatory jurisdictions w111 not be known. At the very least, it appears that the regulatory processes w111 be quite time consuming, expensive, and to all but the most persevering, discouraging.

\section{Tax Treatment of Geothermal Resources}

The taxation of geothermal resources is a problem which has not yet been resolved. Geothermal developers would 1ike to obtain the favorable tax treatment both under federal and state law which is given to hydrocarbon, o11, and gas developers. 011 and gas companies may deduct a percentage (currently 22 percent) of thelr gross income as a depletion allowance. This allowance Is not related to the rate at which the resources are being used up; rather, it is in the nature of a subsidy for the producer. The ofl and gas people are also entitled to deduct in a single year intangible costs of drilling and developing wells. These intangible drilling and development costs include the cost to operators of any drilling or development work (excludIng amounts payable only out of production and amounts properly allowable to cost of depreclable property) done for them by contractors under any form. of contract, including "turnkey" contracts. It is to the advantage of the developer to be able to deduct these so-called intanglble costs in a single year rather than have to depreclate them over the IIfe of the resource. In 1969 precedent was established In a significant tax case, Relch vs. U.S. [18]. The taxpayers in that case had participated in ventures to develop geothermal resources at The Geysers. They had taken the depletion allowance and intangible drilling expense deductions applicable to hydrocarbon of 1 and gas.

The court was faced with several different questions. First, it had to determine whether the resource was classified as one of the substances for which the depletion allowance was applicable. In practlcal terms this meant that the resource had to be classified as a "gas." Secondly, the resource could not be one for which a depletion allowance was spectfically denied by the Internal Revenue Code, and, third, the resource had to be one which is exhaustible as provided in the Internal Revenue Code regulations. 


\begin{tabular}{|c|c|c|c|c|c|c|c|}
\hline $\begin{array}{c}\text { TOPIC: } \\
\text { OPERATIONS }\end{array}$ & FEDERAL & CALI FORNIA & ARIZONA & ALASKA & OREGON & NEW MEXICO & IDAHO \\
\hline $\begin{array}{l}\text { SUPERVISOR's } \\
\text { DUTIES (in some } \\
\text { cases, title is } \\
\text { different, e.g., } \\
\text { director, super- } \\
\text { voor) }\end{array}$ & $\begin{array}{l}\text { E mpowered to re- } \\
\text { gulate operations } \\
\text { and to perform } \\
\text { other duties; } \\
\text { approval of plans, } \\
\text { operations, etc. }\end{array}$ & $\begin{array}{l}\text { Supervise drilling } \\
\text { operation, mainten- } \\
\text { ance of well in a } \\
\text { manner calculated } \\
\text { to achieve state } \\
\text { objectives. Also, } \\
\text { to supervise owners, } \\
\text { operators of well } \\
\text { so as to best ex- } \\
\text { tract geothermal } \\
\text { resources. }\end{array}$ & $\begin{array}{l}\text { Approves of opera- } \\
\text { tion plan bearing } \\
\text { in mind objectives } \\
\text { of resource deve1- } \\
\text { opment, and gen- } \\
\text { eral environmental } \\
\text { protection. }\end{array}$ & $\begin{array}{l}\text { Commissioner's } \\
\text { dut les are passive, } \\
\text { approves or dis- } \\
\text { approves of opera- } \\
\text { ton plans. }\end{array}$ & Same as Callfornda & $\begin{array}{l}\text { Commissioners can } \\
\text { prescribe develop- } \\
\text { ment program, for } \\
\text { best reallzing } \\
\text { state 1nterests } \\
\text { wh1le producing } \\
\text { resource, to } \\
\text { leasee. }\end{array}$ & $\begin{array}{l}\text { Basicaliy same as } \\
\text { California. Objec- } \\
\text { t1ves gimliar; } \\
\text { duties start } \\
\text { earller since fur- } \\
\text { isdiction atarts } \\
\text { from moment appli- } \\
\text { cant applies for } \\
\text { permit. }\end{array}$ \\
\hline DISTRICT DEPUTY & -- & $\begin{array}{l}\text { Gathers Informa- } \\
\text { tion for proper } \\
\text { supervision of } \\
\text { operations. }\end{array}$ & -- & -- & - & -- & - \\
\hline $\begin{array}{l}\text { SUPERVISOR'S } \\
\text { AUTHORITY TO } \\
\text { ORDER }\end{array}$ & $\begin{array}{l}\text { Can regulate } \\
\text { operations. }\end{array}$ & $\begin{array}{l}\text { Imp1led in duties } \\
\text { the rlght to order } \\
\text { particular methods }\end{array}$ & $\begin{array}{l}\text { Can change approval } \\
\text { in emergency, } \\
\text { basically a pas- } \\
\text { sive supervisor } \\
\text { role. }\end{array}$ & $\begin{array}{l}\text { Can suspend or ter- } \\
\text { minate for cause, } \\
\text { can disapprove of } \\
\text { operation plans. }\end{array}$ & Same as Callfornis & $\begin{array}{l}\text { Implied that in ore- } \\
\text { scribing program, } \\
\text { power lo similar to } \\
\text { supervisor's la } \\
\text { Callfornla, can } \\
\text { suspend production, } \\
\text { or terminate for } \\
\text { cause. }\end{array}$ & $\begin{array}{l}\text { General } \\
\text { supervision. }\end{array}$ \\
\hline $\begin{array}{l}\text { CONTENTS OF } \\
\text { NOI ICE OF INTENT } \\
\text { TO DRILL }\end{array}$ & $\begin{array}{l}\text { A. Location of } \\
\text { well by survey. } \\
\text { B. Altitude of } \\
\text { ground \& derrick. } \\
\text { C. Plan of opers- } \\
\text { t1ons, "detalls } \\
\text { of work." }\end{array}$ & $\begin{array}{l}\text { A. Location \& ele- } \\
\text { vation of floor of } \\
\text { derrick. } \\
\text { B. Identification } \\
\text { \& designation of } \\
\text { well. } \\
\text { c. Estimated depth } \\
\text { for production. } \\
\text { D. Any further in- } \\
\text { formation that } \\
\text { supervisor way } \\
\text { require. }\end{array}$ & $\begin{array}{l}\text { Commisaton } \\
\text { spectfies infor- } \\
\text { mation tt wants. }\end{array}$ & - & Same as Callfornia & - & $\begin{array}{l}\text { A. Namea of Inter- } \\
\text { ested parties. } \\
\text { 8. Particulars of } \\
\text { incorporation if } \\
\text { necessary. } \\
\text { c. Location of well } \\
\text { by survey. } \\
\text { D. Operation plan } \\
\text { In entirety. } \\
\text { E. Purpose of } \\
\text { drillig. } \\
\text { F. Any further 1n- } \\
\text { formation requested }\end{array}$ \\
\hline
\end{tabular}

Figure 2.4.2 GEOTHERMAL REQUIREMENTS IN SIX STATES COMPARED WITH FEDERAL REQUIREMENTS 


\begin{tabular}{|c|c|c|c|c|c|c|c|}
\hline TOPIC & FEIJERAi & CALIFORNLA & ARIZONA & ALASKA & OREGON & NEW MEXICO & $\begin{array}{l}\text { IDАно } \\
\ldots\end{array}$ \\
\hline INTENT TO DRILL & $\begin{array}{l}\text { Must firat apply } \\
\text { to oupervisor for } \\
\text { a peralt to drill. }\end{array}$ & $\begin{array}{l}\text { Must not1fy deputy } \\
10 \text { days prior of } \\
\text { Intent to dr111 }\end{array}$ & $\begin{array}{l}\text { Shall notify com- } \\
\text { missioner prior to } \\
\text { drilling. }\end{array}$ & 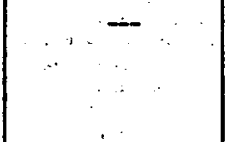 & $\begin{array}{l}\text { Must notify ouper- } \\
\text { visor prior to } \\
\text { drilling,'redrf11- } \\
\text { lng, or widening } \\
\text { well. }\end{array}$ & - & $\begin{array}{l}\text { Must apply to dept. } \\
\text { for geotherwal } \\
\text { resource well. } \\
\text { pernit. }\end{array}$ \\
\hline $\begin{array}{l}\text { FLES FOR DRILLING } \\
\text { NEW WELL } \\
\text { N. }\end{array}$ & - & $\begin{array}{l}\$ 25 \text { or } \$ 200 \text { or } \$ 500 \\
\text { or } \$ 1000 \text {, depending } \\
\text { on superviston } \\
\text { required. }\end{array}$ & $\$ 25.00$ & - & $\begin{array}{l}\$ 25 \text { flling fee } \\
\text { with every notice } \\
\text { except for } \\
\text { prospect well. }\end{array}$ & - & $\begin{array}{l}\text { Flling feea: } \\
\$ 500 \text { for vell } \\
\$ 50 \text { for lajection } \\
\text { vell } \\
\$ 50 \text { to asend }\end{array}$ \\
\hline $\begin{array}{l}\text { PREVENTION OF } \\
\text { FIRES AND } \\
\text { EXPLOSIONS }\end{array}$ & 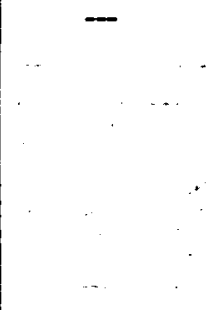 & $\begin{array}{l}\text { Where well is oper- } \\
\text { atcd in area of } \\
\text { high of unknown } \\
\text { pressure, casings } \\
\text { of-sufficlent } \\
\text { strength will be } \\
\text { used, as approved } \\
\text { by supervisor. } \\
\end{array}$ & $\begin{array}{l}\text { Basicallý same es } \\
\text { Cal1fornia }\end{array}$ & $\begin{array}{l}\text { General duty to } \\
\text { conduct operations } \\
\text { In a manner calcu- } \\
\text { lated to protect } \\
\text { environment, avold } \\
\text { waste pollution. }\end{array}$ & Same caltfornta & - & $\begin{array}{l}\text { In applying for } \\
\text { perwit, spec's } \\
\text { must be given on } \\
\text { casing and methods } \\
\text { used (to be) for } \\
\text { best real1zing } \\
\text { combination of } \\
\text { prod. of geother- } \\
\text { mal resources } \\
\text { whlle prevent Ing } \\
\text { waste s environ- } \\
\text { mental dasage of } \\
\text { all kinde. }\end{array}$ \\
\hline $\begin{array}{l}\text { WhTERPROOFING } \\
\ldots, \ldots\end{array}$ & $\begin{array}{l}\text { Nust meet Federal } \\
\text { and State stand- } \\
\text { ards on water } \\
\text { quality oafety. }\end{array}$ & $\begin{array}{l}\text { Casing shall be } \\
\text { watertight o ade- } \\
\text { quate to prevent } \\
\text { environment \& } \\
\text { agricultural } \\
\text { damage. }\end{array}$ & $\begin{array}{l}\text { Bastcally same as } \\
\text { California. }\end{array}$ & - & $\begin{array}{l}\text { Basleally ame as } \\
\text { Callfornls. }\end{array}$ & , & - \\
\hline \begin{tabular}{c} 
REMEDLAL WOPK \\
$\vdots ;$ \\
\hdashline \\
\hdashline
\end{tabular} & $\begin{array}{l}\text { Lessee wust pro- } \\
\text { vide for restora- } \\
\text { tlon of disturbed } \\
\text { lands. }\end{array}$ & $\begin{array}{l}\text { Supervisor shall } \\
\text { require tests \& } \\
\text { remedlal work to } \\
\text { meet objectives of } \\
\text { geothermal pollcy. }\end{array}$ & - & Same as California & $=$ & - & $\begin{array}{l}\text { Dept. way order } \\
\text { correctlon of } \\
\text { practlces that } \\
\text { might cause damage } \\
\text { to life, property, } \\
\text { under, on, snd/or } \\
\text { above ground. }\end{array}$ \\
\hline $\begin{array}{l}\text { STATEMENT OF } \\
\text { PRODUCTION }\end{array}$ & $\begin{array}{l}\text { Must f1le in } \\
\text { duplicate each } \\
\text { month, last day } \\
\text { of, quantley of } \\
\text { production and } \\
\text { any by-products } \\
\text { obtalned. }\end{array}$ & $\begin{array}{l}\text { Shall file with } \\
\text { supervisor a state- } \\
\text { ment of production } \\
\text { on loth day of each } \\
\text { month. }\end{array}$ & $\begin{array}{l}\text { Snall file a } \\
\text { statement of pro- } \\
\text { duction on } 25 \text { th } \\
\text { day of each wonth. }\end{array}$ & $\begin{array}{l}\text { Lesses must Install } \\
\text { measuring devices } \\
\text { to ensure propex } \\
\text { measurement of } \\
\text { production. }\end{array}$ & Same callformla & - & - \\
\hline
\end{tabular}

Figure 2.4.2 (Cont.) 


\begin{tabular}{|c|c|c|c|c|c|c|c|}
\hline $\begin{array}{c}\text { TOPIC: } \\
\text { OPERATIONS }\end{array}$ & FEDERAL & CALIFORNLA & ARIZONA & ALASKA & ORSGON & NEW YEXICO & IDAHO \\
\hline $\begin{array}{l}\text { REMOVAL OF } \\
\text { CASING }\end{array}$ & $\begin{array}{l}\text { May not make cas- } \\
\text { ing tests or } \\
\text { alter casing } \\
\text { after completion } \\
\text { of well without } \\
\text { first getting } \\
\text { approval of plans } \\
\text { from supervisor. }\end{array}$ & $\begin{array}{l}\text { Supervisor must } \\
\text { have } 5 \text { days notice } \\
\text { for written ap- } \\
\text { proval. Fallure } \\
\text { to respond - } \\
\text { approval. }\end{array}$ & - & - & Same as Callfornia & - & -- \\
\hline $\begin{array}{l}\text { WELL LOCATION AS } \\
\text { PUBLIC NUISANCE }\end{array}$ & - & $\begin{array}{l}\text { Within } 100 \mathrm{ft} \text {. of } \\
\text { outer boundary, or } \\
100 \mathrm{ft} \text {. of public } \\
\text { road, street, or } \\
\text { highway, built } \\
\text { prior to well com- } \\
\text { mencement, 1s } \\
\text { public nuisance. }\end{array}$ & - & -- & - & -- & --- \\
\hline $\begin{array}{l}\text { ABANDONMENT } \\
\text { OPERATIONS }\end{array}$ & $\begin{array}{l}\text { Lessee pust plug } \\
\text { \& abandon useless } \\
\text { or unused wells. } \\
\text { plans, reasons } \\
\text { for, proof of } \\
\text { reasons for aban- } \\
\text { donment, must } \\
\text { first be submitted } \\
\text { to supervisor. }\end{array}$ & $\begin{array}{l}\text { Supervisor must be } \\
\text { satisfled that } \\
\text { underground } \delta \text { gur- } \\
\text { face waters will } \\
\text { not be endangered } \\
\text { for 1rrigatlon, } \\
\text { that fluids will } \\
\text { not egcape to } \\
\text { surface. } \\
\text { 5-day notice of } \\
\text { intent. }\end{array}$ & - & $\begin{array}{l}\text { Implied that aban- } \\
\text { donment operation } \\
\text { must return area } \\
\text { to a "proper con- } \\
\text { dition." }\end{array}$ & $\begin{array}{l}\text { Basica11y same as } \\
\text { California. } \\
\text { 24-hour notice. }\end{array}$ & - & $\begin{array}{l}\text { 5-day notice to } \\
\text { director, must be } \\
\text { approved, with a } \\
\text { plan giving con- } \\
\text { ditlon of gight. } \\
\text { Must comply with } \\
\text { objective of avoid- } \\
\text { ing waste, damage, } \\
\text { property, and } \\
\text { natural resources. }\end{array}$ \\
\hline $\begin{array}{l}\text { REPORT BY } \\
\text { SUPERVISOR, ETC. } \\
\text { ON PROPOSED } \\
\text { ABANDONMENT }\end{array}$ & $\begin{array}{l}\text { Supervisor must } \\
\text { first approve } \\
\text { manner \& method } \\
\text { of abandonment. }\end{array}$ & $\begin{array}{l}\text { Supervisor, before } \\
\text { proposed commenced } \\
\text { abandonment, will } \\
\text { furnish owner or } \\
\text { operator a report } \\
\text { giving: } \\
\text { A. approval or } \\
\text { B. necessary steps } \\
\text { to gain approval } \\
\text { c. request for in- } \\
\text { formation nec- } \\
\text { essary to gain } \\
\text { approval. }\end{array}$ & $\ldots$ & - & Same as Callfornla & - & $\begin{array}{l}\text { Department may } \\
\text { approve or d1s- } \\
\text { approve orally or } \\
\text { writted, fa part } \\
\text { or in whole, on } \\
\text { proposed operation. }\end{array}$ \\
\hline
\end{tabular}

Figure 2.4.2 (Cont.) 


\begin{tabular}{|c|c|c|c|c|c|c|c|}
\hline $\begin{array}{c}\text { TOPIC: } \\
\text { OPERATIONS }\end{array}$ & TEDERAL & CALIFORNLA & ARIZONA & ALASKA & OREGON & NEW MEXICO & IDAHO \\
\hline $\begin{array}{l}\text { DESIGNATION OP. } \\
\text { AGENT FOR CONTACT } \\
\text { FROM SUPERVISOR } \\
\text { OR COMMISSION, } \\
\text { ETC. }\end{array}$ & $\begin{array}{l}\text { Supervisor may } \\
\text { require designa- } \\
\text { tlon of agent, } \\
\text { local, empowered } \\
\text { to recelve notices } \\
\text { b orders of } \\
\text { supervisor. }\end{array}$ & $\begin{array}{l}\text { Omer or operator } \\
\text { shall deslgnate } \\
\text { agent, state res1- } \\
\text { dent, for recelpt } \\
\text { of orders, notlces, } \\
\text { processes, etc. }\end{array}$ & - & $-\infty$ & Same as California & - & Same go Callforn1n \\
\hline $\begin{array}{l}\text { CENERAL LOCS AND } \\
\text { RECORDS }\end{array}$ & $\begin{array}{l}\text { Lesses ghall keep } \\
\text { log records } 6 \\
\text { h1atory. }\end{array}$ & $\begin{array}{l}\text { Owner or operator } \\
\text { shall keep core s } \\
\text { log record, vell } \\
\text { listory. }\end{array}$ & $\begin{array}{l}\text { Commission may } \\
\text { require any infor- } \\
\text { mat1on necesaary } \\
\text { to supervise. }\end{array}$ & $-\infty$ & Same as Callfornia & $\begin{array}{l}\text { Comonissloner may } \\
\text { require report, } \\
\text { samples, logs, } \\
\text { assays, or cores } \\
\text { as necessary for } \\
\text { adminlstration. }\end{array}$ & $\begin{array}{l}\text { Logs, records, and } \\
\text { historles way be } \\
\text { required by } \\
\text { director. }\end{array}$ \\
\hline $\begin{array}{l}\text { LOG RECORD } \\
\text { PARTICULAR }\end{array}$ & $\begin{array}{l}\text { Geologic informa- } \\
\text { tion, formatton } \\
\text { samples, electric } \\
\text { logs, temperature } \\
\text { surveys, water, } \\
\text { steam analysia, } \\
\text { heat flow tests, } \\
\text { etc. }\end{array}$ & $\begin{array}{l}\text { Character \& depth } \\
\text { of formation passed } \\
\text { through, size } \\
\text { welght of casing, } \\
\text { location, depth, } \\
\text { temperature of } \\
\text { water bearing } \\
\text { strata, chemical } \\
\text { characteristlcy of } \\
\text { fluids encountered. }\end{array}$ & - & 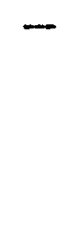 & Same as Callfornia & - & -- \\
\hline CORE RECORD & - & $\begin{array}{l}\text { Depth, character, } \\
\text { \& fluid content of } \\
\text { cores obtalned. }\end{array}$ & $\rightarrow$ & $\rightarrow$ & Same as California & - & - \\
\hline HISTORY & - & $\begin{array}{l}\text { Location omount } \\
\text { of sidetracked } \\
\text { casing, tools, other } \\
\text { materinl, depth \& } \\
\text { quantity of cement } \\
\text { in plugs, dynamite } \\
\text { usage, production, } \\
\text { tests, o completion } \\
\text { data. }\end{array}$ & - & - & Same ae Callfornia & -- & \\
\hline $\begin{array}{l}\text { PROGRUNINC OP } \\
\text { PROSPECT WELLS: } \\
\text { INFORYATION IN } \\
\text { PLAN }\end{array}$ & - & $\begin{array}{l}\text { Wells numbers, } \\
\text { locations } 6 \text { eleva- } \\
\text { tlons, geological } \\
\text { lnterpretation of } \\
\text { area, data required } \\
\text { by supervibor. }\end{array}$ & m & - & - & - & - \\
\hline
\end{tabular}

Figure 2.4.2 (Cont.) 


\begin{tabular}{|c|c|c|c|c|c|c|c|}
\hline ( TOP IC: & FEDERAL & CALIFORNLA & ARIZONA & ALASKA & ORBGON & NEW MEXICO & IDAHO \\
\hline FEES & -- & $\begin{array}{l}\$ 25 \text { per we } 11 \text {, } \\
\$ 250 \text { per program, } \\
\text { wh1chever } 18 \text { less. }\end{array}$ & - & $\cdots$ & - & $\cdots$ & -- \\
\hline $\begin{array}{l}\text { APPROVAL BEFORE } \\
\text { COMMENCEMENT }\end{array}$ & --- & $\begin{array}{l}\text { Supervisor or dis- } \\
\text { trict deputy must } \\
\text { flrst approve. } 10 \\
\text { days of no response } \\
\text { equals approval. }\end{array}$ & - & - & - & -- & -- \\
\hline $\begin{array}{l}\text { FILING OF LOGS, } \\
\text { CORE RECORD, } \\
\text { HISTORY, ON COM- } \\
\text { PLETION, ABANDON- } \\
\text { MENT, SUSPENSION, } \\
\text { ETC. }\end{array}$ & $\begin{array}{l}\text { Within } 30 \text { days } \\
\text { af ter completion } \\
\text { of each well. }\end{array}$ & $\begin{array}{l}\text { Within } 60 \text { days } \\
\text { after completion, } \\
\text { abandonment, sus- } \\
\text { pension of well, } \\
\text { must file data with } \\
\text { district depucy. }\end{array}$ & $\begin{array}{l}\text { Must file within } \\
30 \text { days of com- } \\
\text { pletton. }\end{array}$ & -- & $\begin{array}{l}\text { Basically same as } \\
\text { California. 20- } \\
\text { day limit to file. } \\
\text { Suspension to } \\
\text { apply here must } \\
\text { have been for } 6 \\
\text { months. }\end{array}$ & -- & $\begin{array}{l}\text { Director may re- } \\
\text { quire such data } \\
\text { withla reasonable } \\
\text { time after well } \\
\text { completion. }\end{array}$ \\
\hline $\begin{array}{l}\text { FILING OF LOGS, } \\
\text { CORE RECORD, } \\
\text { HISTORY ON } \\
\text { REQUEST }\end{array}$ & --- & $\begin{array}{l}\text { Supervisor or dis- } \\
\text { trict deputy can } \\
\text { request such data } \\
\text { be furnished by } \\
\text { personal notice or } \\
\text { by registered mall. }\end{array}$ & $\begin{array}{l}\text { Commisstoner } \\
\text { specifles inter- } \\
\text { vals at which } \\
\text { data must be } \\
\text { supplied. }\end{array}$ & - & $\begin{array}{l}\text { Basically same as } \\
\text { Californla. }\end{array}$ & $\begin{array}{l}\text { As necessary for } \\
\text { adminiatration of } \\
\text { Act. }\end{array}$ & $\begin{array}{l}\text { Basically oame as } \\
\text { New Mexd co }\end{array}$ \\
\hline $\begin{array}{l}\text { REQUEST FOR ORDER, } \\
\text { SUPERVISOR'S } \\
\text { ORDER, APPEAL }\end{array}$ & - & $\begin{array}{l}\text { If given written } \\
\text { direction, owner } \\
\text { or agent can re- } \\
\text { quest definfte } \\
\text { order be given } \\
\text { within } 5 \text { days for } \\
\text { purpose of appeal. } \\
\text { (Seeming confilct } \\
\text { \$3743, \$3762. }\end{array}$ & - & -- & Same as Callfornla & -- & $\begin{array}{l}\text { Can appeal order } \\
\text { within } 30 \text { days. }\end{array}$ \\
\hline $\begin{array}{l}\text { COMMENCEYENT OF } \\
\text { WORK ORDERED; } \\
\text { APPEAL }\end{array}$ & $\begin{array}{l}\text { Within } 30 \text { days } \\
\text { after order, ad- } \\
\text { versely effected } \\
\text { party may appeal. }\end{array}$ & $\begin{array}{l}30 \text { days after } \\
\text { order. } 10 \text { days } \\
\text { after affirmation } \\
\text { of appealed order. }\end{array}$ & - & -- & $\begin{array}{l}\text { Order of super- } \\
\text { visor must be } \\
\text { complled with } \\
\text { (commencement of) } \\
\text { or appealed withln } \\
5 \text { days. }\end{array}$ & -- & - \\
\hline
\end{tabular}

Figure 2.4.2 (Cont.)

\begin{tabular}{|c|c|c|c|c|c|c|c|}
\hline $\begin{array}{c}\text { TOPIC: } \\
\text { SUSPENSION }\end{array}$ & FEDERAL & CALIFORNIA & ARIZONA & ALASKA & OREGON & NEW MEXICO & IDAHO \\
\hline $\begin{array}{l}\text { CAUSE FOR } \\
\text { SUSPENSION }\end{array}$ & $\begin{array}{l}\text { By application of } \\
\text { lessee to secre- } \\
\text { tary, secretary } \\
\text { can suspend for } \\
\text { conservation } \\
\text { reason. }\end{array}$ & -- & - & $\begin{array}{l}\text { Application of } \\
\text { lessee, conserva- } \\
\text { tion 1nterests. }\end{array}$ & $\begin{array}{l}\text { Application in } \\
\text { good cause by } \\
\text { permittee. }\end{array}$ & $\begin{array}{l}\text { Application of } \\
\text { lessee, on motion } \\
\text { of commissioner in } \\
\text { interest of conser- } \\
\text { vation. }\end{array}$ & - \\
\hline EFFECT ON LBASE & $\begin{array}{l}\text { Where supervisor } \\
\text { approves, rentals } \\
\text { or minimum roya1- } \\
\text { tes shall be } \\
\text { suspended. }\end{array}$ & $-\cdots$ & $\begin{array}{c}-\cdots \\
\cdots \\
\cdots \\
\cdots\end{array}$ & $\begin{array}{l}\text { Lease may be ex- } \\
\text { teaded for pertod } \\
\text { of suspension; } \\
\text { rental o royaltios } \\
\text { may be rediced or } \\
\text { walved. }\end{array}$ & $=$ & -- & - \\
\hline $\begin{array}{l}\text { EXTENSION OF } \\
\text { SUSPENSION }\end{array}$ & -- & $\cdots$ & $\ldots$ & - & $\begin{array}{l}\text { If, before suspen- } \\
\text { ston time is up, } \\
\text { permittee can get } \\
\text { extenston by appli- } \\
\text { cation and show of } \\
\text { good cause. }\end{array}$ & - & $\cdots$ \\
\hline $\begin{array}{l}\text { EFFECT OF PAILURR } \\
\text { TO RESUME OPERA- } \\
\text { TIONS }\end{array}$ & - & $\begin{array}{l}\text { If, after suspend- } \\
\text { ing operations for } \\
6 \text { months, drilling } \\
\text { operat1ons are not } \\
\text { resumed or applica- } \\
\text { tion for extension } \\
18 \text { made, primg } \\
\text { facie case of de- } \\
\text { sertion } 18 \text { created. }\end{array}$ & - & $-\cdots$ & \begin{tabular}{|l|} 
Pallure to resume \\
operation vith1n \\
6 months after \\
suspension ended \\
or suspending \\
production for 6 \\
months vithout \\
proper application \\
rafse presumption \\
of unlaufful aban- \\
domment.
\end{tabular} & - & - \\
\hline
\end{tabular}




\begin{tabular}{|c|c|c|c|c|c|c|c|}
\hline $\begin{array}{c}\text { TOPIC: } \\
\text { ADMINISTRATION }\end{array}$ & FEDERAL & CALIFORNIA & ARIZONA & ALASIKA & OREGON & NEW ARRICO & IDAHO \\
\hline $\begin{array}{l}\text { COMPLAAINTS, } \\
\text { REPORT \& ORDER }\end{array}$ & $\cdots$ & $\begin{array}{l}\text { Upon recetpt of } \\
\text { specifled coor- } \\
\text { plaint, supervisor } \\
\text { or district deputy } \\
\text { must nvestigate } \\
\text { and make a report. }\end{array}$ & - & - & - & - & $\cdots$ \\
\hline $\begin{array}{c}\text { EFFECT OF REPORT } \\
.\end{array}$ & - & $\begin{array}{l}\text { Report may d1smiss } \\
\text { complaint or state } \\
\text { order for correc- } \\
\text { tive measurea. }\end{array}$ & - & - & - & - & - \\
\hline $\begin{array}{l}\text { DELIVERY OR ORDER } \\
\text { PURSUANT TO } \\
\text { COMPLAINT }\end{array}$ & -- & $\begin{array}{l}\text { If corrective } \\
\text { measures are nec- } \\
\text { essary, owner, } \\
\text { operators, or } \\
\text { agents 1n charge } \\
\text { of wells will be } \\
\text { delfvered each a } \\
\text { copy of sald order. }\end{array}$ & - & - & - & - & - \\
\hline
\end{tabular}

Figure 2.4 .2 (Cont.)

\begin{tabular}{|c|c|c|c|c|c|c|c|}
\hline $\begin{array}{c}\text { TOPIC: } \\
\text { CANCELLATION OR } \\
\text { TERMINATION }\end{array}$ & FEDERAL & CALIFORNIA & ARIZONA & ALASKA & OREGON & NEW MEXICO & IDAHO \\
\hline $\begin{array}{l}\text { REPORT BY OWNER/ } \\
\text { OPERATOR AFTRR } \\
\text { ABANDNMENT IS } \\
\text { COMPLETED }\end{array}$ & -- & $\begin{array}{l}\text { Within S days after } \\
\text { completion of aban- } \\
\text { donment operations } \\
\text { on work are done. }\end{array}$ & - & - & Same as California & - & Same as Callfornin \\
\hline $\begin{array}{l}\text { REPORT BY SUPER- } \\
\text { VISOR, ETC. AFTER } \\
\text { ABANDOMENT IS } \\
\text { COMPLETED. }\end{array}$ & -- & $\begin{array}{l}\text { Within } 10 \text { days } \\
\text { at fer owner/opera- } \\
\text { for report glving } \\
\text { either approval or } \\
\text { disapproval with } \\
\text { reasons. }\end{array}$ & - & - & Same as Californ1a & - & - \\
\hline $\begin{array}{l}\text { CANCELLATION AND } \\
\text { TERMINATION } \\
\text { CAUSES }\end{array}$ & $\begin{array}{l}\text { Unexcused fallure } \\
\text { to pay rent, vio- } \\
\text { lation of regula- } \\
\text { tions and fatlure } \\
\text { to timely correct. } \\
\text { Supervisor deems } \\
\text { operations unsafe } \\
\text { or dangerous to } \\
\text { environment. }\end{array}$ & $\begin{array}{l}\text { Fallure to exer- } \\
\text { c18e diligence } \\
\text { aearch for re- } \\
\text { sources and devel- } \\
\text { oppent and fatlure } \\
\text { to t1mely correct } \\
\text { violat lons of } \\
\text { lease terms. }\end{array}$ & - & $\begin{array}{l}\text { Violation of lease } \\
\text { or peralt and } \\
\text { fallure to t1mely } \\
\text { correct. Fallure } \\
\text { to pay rent when } \\
\text { no well is produc- } \\
\text { ing. Well where } \\
\text { voliationg do not } \\
\text { exlst unaffected. }\end{array}$ & - & $\begin{array}{l}\text { Non-payment of } \\
\text { rents, royalties; } \\
\text { violation of lease } \\
\text { terms or conditions }\end{array}$ & -- \\
\hline $\begin{array}{l}\text { REMOVAL OF } \\
\text { MATERIALS AFTER } \\
\text { TERMINATION }\end{array}$ & $\begin{array}{l}\text { Must be with1n } 90 \\
\text { days after ter- } \\
\text { mination (any } \\
\text { materials, tools, } \\
\text { structures, etc. } \\
\text { except for } 1 \text { - } \\
\text { provement needed } \\
\text { for productng } \\
\text { wells). After } 90 \\
\text { days, lessor may } \\
\text { claim property } \\
\text { left. }\end{array}$ &. & - & $\begin{array}{l}\text { Reasonable time to } \\
\text { remove equipment } \\
\text { omed or operated } \\
\text { by lessee or } \\
\text { permittee. }\end{array}$ & - & $\begin{array}{l}\text { Can remove all } \\
\text { equipment \& 1m- } \\
\text { provements as long } \\
\text { as rents \& royal- } \\
\text { ties have been } \\
\text { pald and premises } \\
\text { are not damaged. } \\
\text { 2 years for } \\
\text { removal. }\end{array}$ & - \\
\hline
\end{tabular}




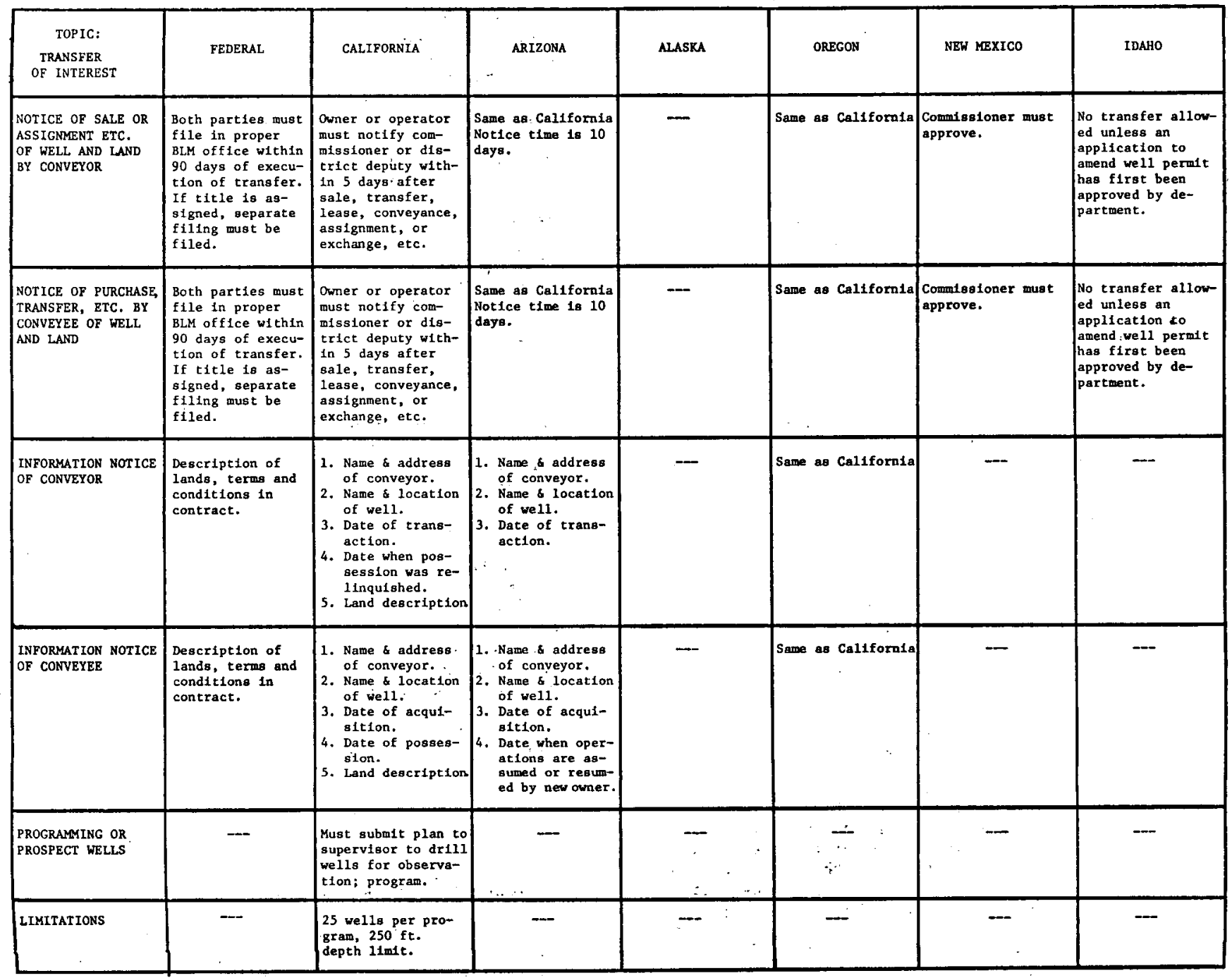

Figure 2.4.2 (Cont.) 
The opinion of the court dealt largely with the physical nature of the resource. It determined that with respect to The Geysers area the resource existed in the ground as superheated steam and at no time was in a liquid water form. This was an important determination since the Internal Revenue Code explicitly prohibited a depletion allowance for water. The court held that water was intended to have its common meaning of 11quid $\mathrm{H}_{2} \mathrm{O}$ rather than its chemical meaning of $\mathrm{H}_{2} \mathrm{O}$ in all states. The court therefore held that the steam In The Geysers was not water and, second1y, that it was a gas and, therefore, if the third condition were met, entitled to a depletion allowance.

The third condition is that the resource be exhaustible. The argument was made by the U.S. Government that The Geysers steam reservoir was constantly being replenlshed by groundwater and that the heat of the earth was turning this water into steam, and as long as the heat of the earth remained, the resource was, in essence, Inexhaustible. The taxpayers argued that at The Geysers there existed, underground, a steam reservoir which through a slow geologic process had become sealed off and incapable of replenishment. They also argued there was no water in this reservolr so that the steam was being taken from a closed volume and was gradually being depleted. There was evidence as to reduction of pressure of steam at The Geysers offered on behalf of the taxpayers.

The Court agreed with the taxpayers' contention and concluded that with respect to the facts of the situat1on at The Geysers, that the resource was exhaustible and was a gas, and therefore the developer was entitled to a deduction of 22 percent depletion allowance and was entitled to deduct his intangible drilling costs in a single year rather than amortizing them over the Iife of the project.

The Reich case was limited to its own facts by the Court of Appeals. That is to say it does not apply generally to all geothermal resource developers. The Court relied heavily on the specific geologic structure of The Geysers area and the fact that it contained a closed volume of steam. The finding would not, for example, apply to an area where there is a wet basin characterized by an active groundwater system. The result of the case has been that developers of geothermal resources in an area other than The Geysers are not certafn at this time whether they may, in fact, claim the depletion allowance and deduct their intangible drilling expenses in a single year. Because of the limitation of the case to its own facts, it is anticipated that there will be considerably more 11tigation with respect to depletion allowance and expense deduction with respect to geothermal resource development, and, second, there w111 be considerable pressure on Congress to define an approprlate scheme of tax or other subsidy to the infant geothermal resource development industry [19].

The problem is not limited to the federal tax laws. There are state, business, Income, and franchise taxes which also depend upon the characterization of the resource as a gas. These taxes should also be re-examined in light of the economic and institutional necessities for development of the geothermal resource industry and appropriate rules adopted.

\section{An Experlence With the Leasing Process}

In order to become more famtliar with the leasing process, in practice as well as in theory, Michael Belzer, a third-year student at the University of Connecticut School of Law, was asked to submit a lease bid in the January 1974 competition and to write a description of his experiences. His report followe

On January 22, 1974 , I bid $\$ 1394$ for a tract of land In California known as "Geysers KGRA, Lease Unit" which had been released for competitive bidding by the Bureau of Land Management in Sacramento, California.

The bidding process was really quite simple since all that was required was the filling out of a simple form, bidding at least the minimal amount acceptable per acre, and submitting a certified check for one-half the amount bid. Under the Federal Rules and Regulations, no filing or application fee was required. Moreover, I was able to submit my bid by mall. Thus, the dollars and cents cost of bidding was $\$ 1.82$ for the registered letter, plus the interest value on $\$ 697$, from the time the certified check was made out, approximately January 18, 1974, until the check came back, on March 1, 1974. This convenience would seem to encourage participation in the bidding system, since a qualified bidder can submit his bid from any place on earth as long as it arrives at the proper Bureau of Land Management office in time.

I should note that I did not expect to win the bid. When William Buckley ran for mayor of New York, he was asked what he would do if elected. He supposedly replied that he would ask for a recount. If my bid had carried the day, my sentiments would have been quite similar. At any rate, to ensure against winning the bid, I bid the absolute minimal amount permitted on a piece of land which I knew had the Interest of another party, since it was subject to socalled "grandfather" conversion rights. In the notice of the lease bidding, descriptions of each lease unit were given. Under some of the land descriptions, names of people or corporations were given which owned conversion rights on that particular unit. As will be discussed, that interest would have had great significance if $I$ had chosen to submit a truly competitive bid. The owner of the right to convert to a geothermal lease would have had 30 days to match a higher bid. Doing so would give him the right to the lease if otherwise qualified.

As 1t was, my bid of $\$ 1394$ on the 697 acres lost to Signal 011 and Gas Company, which b1d $\$ 56,666$.

Interestingly, the bid was taken and opened on January 22, 1974 with all the other bids, and while I learned through second-hand sources that I had been out-bid, I did not get direct word from Californla unt11 March 1, 1974, when my check was returned along with a letter informing me as to who made the winning bid and how much was the winning bid. This represented 41 days, during which funds were tied up. In my case, this represented no great hardship since the amount bid was relatively sma11. A bid of larger magnitude, say, several hundred thousand dollars or more, w11l increase the cost of subuitting a bid; perhaps making it a olgnificant factor.

I should note here, and will discuss later, once a bid has been accepted, all other bids are considered rejected. However, the officer reviewing the bids has the right to reject any 
or all bids. This could have considerable Impact on the bidder whose bid came in second.

While my experience represented a starting point, in many senses it just scratched the surface. It did not cover non-competitive leasing, it did not cover all aspects of competitive bidding, nor did it cover all aspects of the matter on conversion rights.

F1gure 2.4.3 summarizes the results of the competitive bidding In January 1974.

\section{FEDERAL GEOTHERMAL LEASE SALE \\ JanUaRY 22,1974 \\ BIDDING RECAP}

Total Money Exposed (all areas)

$\$ 12.499,494.60$

Total of High Bids (all areas)

6.812 .679 .79

AVERAgE BID/ACRE (ALL AREAS)

290.54

AVERAGE BID/ACRE GEYSERS K.G.R.A.

631.00

AVERAge BID/ACRE Mono-Long Valley K,G.R.A. $\quad 115.00$

Average bid/ACre East Mesa K.G.R.A.

71.00

FEDERAL GEOTHERMAL LEASE SALE

JANUARY 22, 1974

MaJor BidDers

SHELL OIL

THERMOGENICS. INC.

UNION OIL

SignaL OIL \& GAS

Occidental Petroleum Corporation

Chevron Oil company

GetTY OIL COMPany

Mono PoWer COMPany

Republic Geothermal

Figure 2.4.3

Several statements are required by the applicant for a lease. They include a statement of citizenship and that the applicant's interests, direct or Indirect, in federal geothermal leases does not exceed the acreage Iimitations out1ined in S3201.2 of the lease. Violation of this regulation could result in automatic refection of the bid, or eventual forfelture of the lease(s) which brought the applicant over the limit $(20,480$ acres in any state, 10,240 acres through conversion of mineral leases, permits, applications or claims).

Additionally, an association or corporation must show with 1ts application (1) authority to hold a geothermal lease; (2) authorlzation of the officer executing the lease application; (3) state of incorporation along with the names and addresses of 10 percent-plus stockholders, owners, and interests in the corporation; (4) a statement from each person owning or controlling 10 percent, plus, giving his holding and citizenship.

Requirement (4) above raises the possibility of a minority stockholder thwarting the majorlty wishes of the stockholders and owners by refusing to give a statement. Even if the corporate by-laws dealt with the matter, one could prevent the corporation from making the bid in a timely manner.

A municlpality or governmental unit application must Include (1) authorlty to hold leases,

(2) authority of officer executing application, and (3) a copy of the regulation by which the government unit authorized such action.

Primarily, land can be leased on two bases: non-competitive and competitive.

An application for a non-competitive lease (one that does not involve RGRA) must be filed in duplicate at the BLM (Bureau of Land Management) for public lands, and In triplicate for acquired lands.

Figure 2.4.4 summarizes the non-competitive lease applications on federal land through January 31, 1974.

\section{FEDERAL GEOTHERMAL HON-COAPETITIVE LEASE APPLICATIONS}

period ending January 31,1974

\begin{tabular}{|c|c|c|c|}
\hline STATE & $\begin{array}{l}\text { NUNBER OF } \\
\text { APPLICATIONS }\end{array}$ & $\begin{array}{l}\text { NUMBER OF } \\
\text { APPLICANTS" }\end{array}$ & ACREAGE \\
\hline CALIFORNIA & 528 & 200 & 1.071 .277 \\
\hline OREGON & 458 & 61 & $1,003.691$ \\
\hline Mevada & 433 & 58 & 907.248 \\
\hline New Mexico & 274 & 50 & 637.073 \\
\hline IDAHO & 265 & 83 & 582.590 \\
\hline Utah & 207 & 30 & 453,548 \\
\hline WASHINGTOM & 151 & 41 & 344.000 \\
\hline COLORADO & 64 & 14 & 125,906 \\
\hline Montana & 55 & 8 & 105,444 \\
\hline ARIZONA & 18 & 3 & 42.783 \\
\hline \multirow[t]{2}{*}{ HYOMING } & 3 & 3 & 6.973 \\
\hline & 2.456 & & $5,280,534$ \\
\hline
\end{tabular}

-INCLUDES OIL COMPANIES, geothermal companies, a STATE university, RURAL ELECTRIC COOPERATIVE, AND A NUMBER OF INDIVIDUALS, haNY HAV

Figure 2.4 .4

The application is submitted In a sealed envelope with the following information on It:

1. "Application for lease pursuant to 43CFR 3210."

2. Name and address of applicant. On the application the following: name and address of the applicant, statement of citizenship, and qualifications.

3. An accurate description of the land from a survey, or if not avallable, by metes and bounds.

4. A plan Including maps, makeup of land, topography, pertinent land conditions, narrative on proposed exploration, and steps to be taken to prevent damage to the environment. 
5. Statement of citizenship.

6. Compliance with acreage limits.

One will note that, whereas a competitive bid requires little more than the bid 1tself, a non-competitive application for a lease requires much advance preparation.

Not that a non-competitive lease is a sure thing! First of all, the earliest application in the filing period ( 30 days) will have prior1ty. Moreover, if the land area applied for $1 \mathrm{~s}$ overlapped by one half or more, a competitive interest is created which in effect causes the overlap to be treated constructively as a KGRA, and, thus, not subject to a non-compet1tive application.

In an application Including a KGRA; an opportunity to amend to Just non-KGRA is allowed with priority assigned according to the original lease date.

An application submitted simultaneously to another for the same land is decided by a public draw.

One can withdraw his application provided the request to the BLM arrives before the application has been signed on behalf of the United States.

If land applied for properly is not included In the lease for any reason, and later becomes avallable, the origina 1 lease w111 automat1cally amend to include that land unless a withdrawal is first submitted or the land is KGRA. Th1s would seem important where a lessee, having given up on lessing a tract of land, reallocated his resources not used on the land he did recelve, only to find hImself later "stuck" with a plece of land he no longer wants nor can properly develop.

The issuance of a lease cannot be made before considering (1) prior application(s), (2) subsequent applications based on preferential rights, and (3) petition for renewal or reinstatement of an existing or former lease.

Finally, before a lease is 1ssued, a final determination as to whether a KGRA is involved. RGRA parts of the application are refected, as are applications on lands reclassifled as KGRA between the time of filing and 1ssuance. NonKGRA parts of application retain validity.

Another type of non-competitive leasing involves the releasing of land formerly leased. The BLM must give notice in the Federal Registrar when such lands become avallable: (1) a listing of the units, (2) time for application, and (3) place to apply, terms, and conditions. For this type of lease, only one lease untt per application is allowed.

W1th1n 15 days of acceptance the app11cant must furnish a plan of operation. The application period is 30 days; all applications submitted within that period are treated as simultaneous.

The application envelope must be marked "Application for a lease pursuant to $43 \mathrm{CFR}$ subpart 3211." Here, a \$50 application fee, service charge for each unit bid for, is included. While a plan is not inimediately required, the accepted applicant must pay his advance rental within 15 days or else the applicant with the next highest priority gets consideration.

Competitive leases involve bidding on lands which have been determined to be KGRA. This can happen by several ways. The Geological Survey, a federal agency, can declare certain lands to be KGRA on the basis of evaluating the 1and. As mentioned before, a competitive interest on a plece of land originally of fered non-competitively as a non-KGRA can create a KGRA. Also, before 1ssuance of a lease on a non-competitive land, a final determination as to whether a KGRA is involved is made.

The leasing process on a RGRA is very simple. The process goes into motion when the Secretary of Interior (or h1s agent) based on information given him by the Geological Survey and other government agencles, decides to offer KGRA for competitive bid leasing.

The Secretary gives notice by publication in a newspaper, published in an area near the RGRA, the following information:

1. Time and place of bidding.

2. Manner of b1dding.

3. Description of land.

4. Terms and conditions of sale.

5. Proper BLM to which bids should be submitted.

6. Notice that a proposed plan of operation is necessary before the lease will be fisued.

7. Where applicable, after each unit description, the names and addresses of those holding conversion rights (to be discussed) of mineral lesses on the land.

On the envelope for the bidding must be "B1d for Geothermal Resources Lease In (name of KGRA)." Inside the envelope must be a description and Identification of the lease unit bid upon; only one lease untt can be bid for in any one envelope. A statement of citizenship and qualifications to hold a lease is included in the bidding form. The amount of the bid must be Indicated along with a certified or cashier's check, bank draft payable to the BLM, or cash or money order equaling one-half the amount bid.

At the same time specified in the notice, all bids are broken open and the highest qualified bidder gets the lease except where conversion rights permit the owner of those rights 30 days in which to match the highest qualifled bid.

The authorized officer has 30 days during which he can refect any or all bids. Once a bid 1s accepted, though, all other bids are rejected for a11 intents and purposes. If the accepted bidder fails to comply with the rules and regulations (1.e., execution of lease, advance payment of rental and balance of bid, file bonds, 
submit operation plan), he forfeits. The land hen goes back to the status of a KGRA, possibly o be reoffered in the future.

Summing the above up, it would seem that unt11 the highest bid is accepted as being made by a qualified bidder and no other extenuating circumstances crop up, all the other bids remain in contention. Once a bid is accepted, the losers no longer have to think about the matter; their deposits are returned eventually and they can start making new plans.

At times, I have mentioned the phrase, "conversion rights." This is an 1mportant phrase and can be explained in its several aspects without too much difficulty. When I bid on the piece of property in California, that piece was subject to the conversion rights of the Signal 0il Company. In my case, it meant that, even if mine had been the highest qualified bid, the owner of the conversion rights would have had 30 days to match my bid, and, thus, get the bid.

Conversion rights involve leases, permits, and applications valid on September 7,1965 , issued under the Mineral Lease Act of 1920, 30U.S.C. $181-287,351-358$

If someone applied for a mineral lease under the 1920 act on or before September 7, 1965, he could convert the application to one for a geothermal lease and get prlority by having it dated by the original application date. This would not help where a KGRA was involved but for a non-competitive bid, this could be decisive.

Where someone actually owned a lease, on September 7,1965 , on a piece of property classifled as a KGRA, his rights would not hold off a bid. He would have 30 days, if needed and wanted, to top the highest bid. The lease owner must bid if he wants the geothermal lease conversion. Even if no one else bids, if he does not, he forfeits his conversion rights.

Those who wanted to convert their leases of applications had to apply on or before June $22,1971$.

Where a non-KGRA is involved, the owner of a convertible mineral lease only has to apply, and if qualified to hold, his lease becomes a geothermal lease.

In choosing land for leasing, knowledge of conversion rights owners should have a high priority, especially where a KGRA is involved since here you could have your funds tied. up for a considerable time. . For example, your bid is read, let's say, on January 22, 1974. The owner of the conversion lease right can wait 30 days and then top your bid. Then the officer who evaluates the bid could take up to 30 days to decide if the bid is acceptable. Finally, the losing bids must be processed and returned. In other words, one could have a lot of money tied up for over two months with absolutely nothing to show for 1 .

REFERENCES largely In 30 U.S.C., Sec. 21 et seq.

[2] Mineral Lands Leasing Act, 41 Stat. 4371, now codifled with amendments in 30 U.S.C., Chs. 2 and 3.

[3] Mater1als Act of 1947, 61 stat. 681, as amended 30 U.S.C. 601 et seq.

[4] U. S. Public Land Law Review Commission, One Third our Nation's Land (Washington, D.C.: U.S. Government Printing office, 1970).

[5] U. S. Public Land Law Review Commission, One Third our Nation's Land (Washington, D.C.: U.S. Government Printing office, 1970), pp. 121-138.

[6] A smal1 number of articles and papers have addressed the legal aspects of geothermal resource development including those applicable to water and mineral law. The following is the bulk of the small 11terature on the subject:

Allen, Donald, "Legal and Policy Aspects of Geothermal Resource Development," Water Resources Bulletin, Vol. 8, No. 2 (Apri1 1972), pp. 250255 .

Brooks, John W., Jr., "Legal Problems of Geothermal Industry," Natural Resources Journal, Vol. 6 , No. 4 (October 1966), pp. 511-541.

01pin, Owen, "The Law of Geothermal Resources," Rocky Mountain Mineral Law Inst1tute, Vo1. 14 (1968), pp. 123-165.

Note, "Acquisition of Geothermal Rights," Idaho Law Revlew, Vo1. 1, No. 1 (1964), pp. 49-67.

Abbott, George W., Address to Rocky Mountain Minerals Conference, Soclety of Mining Engineers of AIME, Salt Lake City, Utah, September 11-13, 1963.

[7] Desert Land Acts, 43 U.S.C., Sec. 321 et seg.

[8] FPC v. Oregon, 349 U.S. 435 (1955).

[9] P1ckett Act, 16 U.S.C., Sec. $471 ; 43$ U.S.C. Sec. 141 et seq.

[10] Mineral and Medicinal Springs Act of 1925, Act of March 3, 1925, 43 Stat. 1133, 43 U.S.C. 971, implemented by Executive Order No. 5389 , July 7 , 1930.

[11] State Ex. Rel. Bless v. Dor1ty, 55 N.M. 12, 225 P.2d1007 (1950), App.dism. 341 U.S. 924 (1951).

[12] U.S. v. Union OI1 Co. of California, U.S. District Court, Northern District of Californta (October 1973; civ11 No. 72-1866 GBH)

[13] Stock Raising Homestead Act, 43 U.S.C., Sec. 291 et seg.

[14] Geothermal Steam Act of 1970, 30 U.S.C., Sec. 530, 1001 et seq. (Hereafter referred to as the Act.) Al1 text references are to section numbers of the original Act appearing in 84 Stat. 1566 et seg.

[15] Desert Land Acts, 43 U.S.C., Sec. 321 et seg.

[16] Multiple Use Law, 30 U.S.C., Sec. 521 et seg.

[17] This section was drawn directly from a paper pre- 
pared by Thomas H. Cahrman entitled "The Interrelationship between Federal, State and Local

Regulatory Agencies on the Development of the

Geothermal Resource In California," which was

presented at a geothermal conference in California

in Apri1 1973. In some instances, direct quo-

tations were made-from this paper, but the quota-

tIon marks were eliminated to preserve continuity

of the text. Full indebtedness to Mr. Cahrman

is acknowledged.

[18] U.S. v. Re1ch, 52 Tax Court 700 aff'd 454 F2d1157 (9th Cir., 1972).

[19]. H. R. 13856, introduced on Apr11 1, 1974, would amend the Internal Revenue Code to extend the deductions for intanglble drilling and development expenses and for depletion to geothermal resources. 


\subsection{Overview of Environmental Considerations}

he technical aspects of alleviating the environmental Impacts that result from the commerclal development of geothermal resources are summarized in this section in terms of land use, gaseous emissions, waste disposal, groundwater contamination, heat rejection, land subsidence, notse emissions, induced earthquakes, safety, fog plumes and aesthetics $[1,: 2]$. More thorough and quantitative discussion of the potential environmental Impacts which may result from the development of geothermal resources is contalned in Section 4.8 of this report.

Land Use. In terms of land surface area occupled, the geothermal power plants themselves use no more space than other types of power plants. However, the wells may be widely scattered, requiring an extensive gathering system of feeder plpes and trunk lines to convey the effluent (steam and/or water) to the plant. It is feasible to use the land occupied by the wells and gathering systems for compatible types of agriculture such as orchards, or animal grazing; this is being done in the geothermal fields at Larderello, Italy. A necessary adjunct to any electric power generation station is the electric transmission lines leading to the load centers, which occupy dedicated rights-of-way. Apart from the land surface occupled, the question of conflict of land use has arisen from time to time. Geothermal reservoirs are often located in remote or primitive areas which have historically been used for recreational purposes. Introduction of an Industrial plant into such an area is a marked departure from the preexisting land usage and, in general, does not enhance the recreational value of the region.

Gaseous Emissions. Geothermal effluents carry a variety of noncondensable gases, elther in solution in the 11quld phase, or as a gas mixed with the steam. The most common and abundant spectes are carbon dioxide $\left(\mathrm{CO}_{2}\right)$, hydrogen sulfide $\left(\mathrm{H}_{2} \mathrm{~S}\right)$, amonia $\left(\mathrm{NH}_{3}\right)$, and methane ${ }^{2}\left(\mathrm{CH}_{4}\right)$. Release of $\mathrm{CO}_{2}$ to the atmosphere is relatively harmiless. However, $\mathrm{H}_{2} \mathrm{~S}$ diluted by the atmosphere can be a slgnif1cant nuisance because of its objectionable odor, and a potential danger to human and animal life when in high concentration. Methods are currently being developed for chemically oxidizing the $\mathrm{H}_{2} \mathrm{~S}$ while in solution and disposing of it as a solid precipitate. However, this approach is being developed specifically for The Geysers plant and may not be transferable to other sites. Incineration of the $\mathrm{H}_{2} \mathrm{~S}$, posstbly at each wellhead, has also been proposed as a possible solution, but its practicality has not yet been demonstrated. Methane is in solution in substantial amounts in the liquids of most geopressured zones, and bolls out of solution when the pressure is released. Methane is an energy source itself $(21,120 \mathrm{Btu} / \mathrm{lb})$, and it has been proposed in some cases that it be burned, possibly in a gas turbine, as an adjunct to the geothermal energy conversion process: Radon 223 has been detected in very small quantities in isolated cases.

L1quid and Solid Waste D1sposal. 'In general, 11quid wastes from geothermal plants are charged with dissolved solids such as sodium chloride, calcium chloride, potassium chloride, boron, arsenic, and other chemicals in a wide range of combinations and concentrations, which in most instances preclude direct disposal into natural water bodles or water courses. Presently, the most acceptable and commonly used disposal method is to reinject the liquid waste back into the geological formation at a depth and stratum which, hopefully, will not permit contamination of surface and groundwaters. Disruption of the integrity of groundwater aquifers can permit migration of higher-pressured saline fluids into zones of sweet groundwater, producing cross-contamination of one aquifer by another. Much Investigation and experimentation remalns to be done to develop construction and operating methods as well as monitoring techniques to assure that groundwater contamination does not occur. Although the sale of mineral salts would be an ideal method for disposing of such solid wastes, their extraction has not proved economical to date. Mineral extraction would require construction of processIng equfpment, storage facilities, evaporation ponds, and other ancillary facilities. Landfill disposal of insoluble precipitates has been proposed, but this does not appear to be a viable solution for readilysoluble chloride salts. No universally acceptable method for disposal of solid wastes, such as precipitated salts and chemically precipitated sulfur (from $\mathrm{H}_{2} \mathrm{~S}$ ), has been identified.

Surface and Groundwater Contamination. Surface and groundwater contamination would result from geothermal operations in which solid wastes or mineral-charged 11quid wastes were discharged into natural water courses or water bodies. Avoidance of these problems is often a matter of good housekeeping practices during drilling operations and provision for adequate disposal of liquid and solid wastes. Liquid wastes can be reinjected deep into the formation. Disposal of solid wastes has not yet been fully solved; appropriate solutions are dependent upon the particular constituents involved. A thorough knowledge of the formation in which the dri11ing is being conducted and well-engineered casing and cementing operations are required to prevent interaquifer contamination.

Heat Rejection. Heat rejection is an essential feature of al1 thermodynamic power cycles, including those used in geothermal power plants. Any of the conventional heat refection methods can be applied, but the most common method used to date has been the evaporative cooling tower. Because of their inherently low overall conversion efficiency, geothermal power plants reject a higher percentage of heat than do fossil-fueled or nuclear plants. Typical overall plant efficlencies for geothermal power plants have been in the range of 10-14 percent, due to the relatively low initial temperatures and pressures of the steam and/or hot water. It should be noted that vapor dominated plants such as The Geysers in California and Larderello in Italy produce all the water required by their evaporative cooling towers by condensing steam and do not draw upon local water sources. However, hot dry rock or magma plants may require a continuous supply of water unless effective dry cooling towers can be designed.

Land Surface Substdence: "Land surface subsidence has been noted in some oll and gas flelds. Where it occurred, it was due to massive withdrawal of gas and crude petroleum without application of approprlate preventive measures. Land surface subsidence can also be caused by massive withdrawal of geothermal flulds from liquiddomfnated.systems. This has occurred at Walrakef, New Zealand. 'Presumably, it could occur in a similar manner In geopressured zones. On the other hand, subsidence has not been observed at vapor-dominated sites such as The Geysers, Calffornia and Larderello, Italy [3].

Subsidence is a long-term phenomenon which does not occur suddenly. Reinjection of waste liquids or substitute 11quids (such as bracklsh water) on a one-forone volume basis has been proposed as a preventive measure. - In the case of geopressured zonès, reinjection would have to be Into aquifers of relatively shallow depths and low pressure, otherwise there would be no net gain of extracted energy. Extraction of heat from a hot dry rock formation will cause a gradual temperature decline of the formation and, therefore, a thermal contraction of the rock. It is not known at this time whether subsidence can be caused by this effect. Mon1toring and detection of subsidence is accomp11shed by setting up a system of precise leveling benchmarks 
within the affected area and reference controls outside the affected areas. Periodically, sets of leveling measurements are made to determine the degree and extent of any settlement or horfzontal movement.

Noise. No1se emisstons from geothermal operations are most serious and prevalent during drilling of vapordominated wells, wh1ch are usually drilled with compressed air as the drilling fluid (Instead of drilling "mud"). When the well is being blown for cleanout, there is sudden release of compressed air and natural steam, resulting in very, intense noise. Specialized muffling devices are being developed to hold these noise emissions within acceptable limits. Compounded "drilling muds" are used for washing out the cuttings when drilling liquid-dominated wells and the same noise problem does not exist. Under normal operating conditions, noise emissions from the geothermal power plants themselves are no different than from any other steam power plant, and are, within acceptable limits.

Induced Earthquakes. Minor earthquakes have been triggered in a number of instances by infection of high pressure flulds into the geological formations [4]. These occurrences were not. assoclated in any way with geothermal developments. However, the implication is clear that a problem may result from reinjection of 11quid wastes, reinjection to control land surface subsidence, or injection of liquids to exploit a hot,dry rock field. Recent experimental work by Dr. Barry Raleigh of the USGS near Rangely, Colorado, indicates that injection may trigger minor earthquakes if there is hydraulic comminication with an active fault zone.[5] Although additional investigation and confirmatory work are needed, it is fairly clear that reinjection operations should avold active faults.

Safety. Problems of public safety and safety. of geothermal workers are moderate to minimal, in comparison with other similar industries. In general, these operatlons are subject to federal and state Industrial safety codes. One problem peculiar to geothermal operations is the possibility of a well blowout, which is a-fallure of the well casing and attendant valving to contain the pressure, resulting in the casing being blown out of the well. It is expected that adherence to long-established safe drilling, casing, and cementing practices will virtually preclude this type of accident.

Fog Plumes. Evaporative cooling towers assoclated with geothermal power plants, like all evaporative cooling towers, will develop fog plumes under certain conditions of atmospheric temperature and humidity. For geothermal plants this poses no problem except possibly one of aesthetics, where the cooling towers are not large and are widely dispersed. Minor weather modification is of some concern where dense clustering of cooling towers over a sizeable region is contemplated.

Aesthetics. The problem of preserving the aesthetic values of an area in which an industrial facility is being constructed is essentially the same for a geothermal plant as for any other type of plant. In this respect, problems peculiar to geothermal plants would include the appearance of an extensive piping system for gathering geothermal steam and water and for returning the reinjected liquid wastes. It is technically feasible to bury these insulated pipes and their valving and thermal expansion loops; however, this would greatly increase the capital costs.
[1] Muffler, L.P.J., "Geothermal Resources," U.S. Geological Survey, Professional Paper 820 (1973).

[2] Bowen, R.G., "Environmental Impact of Geotherma1 Development," In Kruger and Otte (eds.), Geothermal Energy (Stanford, Calif.: Stanford University Press, 1973). (Hereafter called Bowen, 1973.)

[3] Bowen, 1973.

[4] Healy, J.H., et al., "The Denver Earthquakes," Science, Vo1. 161 (1968), pp. 1301-1310.

[5] Raleigh, C.B., "Earthquakes and Fluid Infection;" Underground Waste Management and Environmental Implications, Memolr 18 (American Association of Petroleum Geologist8, 1972). 
3. HOW GEOTHERMAL ENERGY MAY EVOLVE IN THE UNITED STATES

\subsection{The Technical Inquiry}

The geothermal energy industry is in 1ts Infancy in the United States. Forelgn experfence, operating data collected at The Geysers, engineering estimates for other systems, and informed speculation all indicate that the infant industry may well have an important, perhaps vital, future in furnishing energy in the decades ahead. The study began by defining the nature of the technology on which this industry depends, the technological impediments which, If uncorrected, might block its growth, the means available to overcome the impediments, and the range of energy production levels which might possibly be expected from this source. Several analytic tools were employed in the pursult of these objectives:

1. A technical relevance tree was constructed depicting in detail the elements of geothermal technology. The purpose of this activity was to help assure that all 1mportant subsystems and components were considered.

2. A set of sequenced interviews Involving a broad spectrum of well-1nformed individuals throughout the geothermal industry was conducted to solfcit opintons about the seriousness of individual impediments, forecasts about when the impediments could be substantially removed, and the types and quantities of inputs (in terms of capital, manpower, or material resources) which would be required to effect the removal of the impediments.

3. Energy system diagrams were produced to help synthesize judgments about technologically feasible levels of geothermal resources development as functions of time, resource type, and research and development programs.

These elements of the technological inquiry are discussed in more detall below and in Appendix A.

\section{The Technological Relevance Tree}

A relevance tree is a hierarchical structure; at each level in the structure, mutually exclusive elements are displayed whlch, in the aggregate, completely define the next higher level. In effect, a relevance tree 18 merely an outline, and it should conform to the same rules of development. A relevance tree, properly accomplished, requires that the analyst explore alternative ways of making the structure of his topic explicit and in doing so helps assure that the topic itself is defined. to the appropriate level of detall. In this case, the relevance tree formed a systematic, visual framework for describing geothermal technology, and alded in identifying impediments to the development and utilization of geothermal energy. The relevance tree whIch was produced In this task is displayed in Appendix B.

The relevance tree was ifmited to the technologles Involved In exploration, development, utilization; and environmental aspects of. geothermal systems, and at Its lowest leve1, specifled major system components such as steam turbines or spectfic techiniques such as resistivity measurements used in exploration. While the inquiry Included consideration of process heating, space heating and air conditioning, water desalination, and mineral extraction, the emphasis was on electrical energy production.

The relevance tree consists of six levels, with each sucLeeding level describing the preceding one in greater detail. These levels were built by answering the six questions shown in Figure 3.1 .1 below.
RELEVANCE INTERROGATION

$\begin{array}{ll}\text { LEVEL I } & \text { WHAT NATURAL RESOURCES ARE AVAILABLE? } \\ \text { LEVEL II } & \begin{array}{l}\text { WHAT PRIMARY ENERGY FORMS CAN BE DEVELOPED FROM } \\ \text { THESE NATURAL RESOURCES? }\end{array} \\ \text { LEVEL III } & \begin{array}{l}\text { WHAT MAJOR TECHNOLOGIES ARE ASSOCIATED WITH THE } \\ \text { DEVELOPMENT OF THESE ENERGY FORMS? }\end{array} \\ \text { LEVEL IV } & \begin{array}{l}\text { WHAT APPLIED TECHNOLOGI ICAL AREAS ARE INVOLVED IN } \\ \text { THESE MAJOR TECHNOLOGIES? }\end{array} \\ \text { LEVEL } V & \begin{array}{l}\text { WHAT SYSTEMS, PROCESSES, OR METHOOS ARE INVOLVEO } \\ \text { IN THESE APPLIED TECHNOLOGICAL AREAS? }\end{array} \\ \text { LEVEL VI } & \begin{array}{l}\text { WHAT MAJOR COMPONENTS COMPRISE THESE SYSTEMS AND } \\ \text { PROCESSES, OR WHAT SPECIFIC TECHNIQUES ARE USEO } \\ \text { IN THESE METHOOS? }\end{array}\end{array}$

Figure 3.1 .1

Geothermal energy Itself comprises level one. At level two, flve classes of geothermal resources are 1dent1fled: vapor-dominated, IIquid-dominated, hot dry rock, geopressured, and magma. At the next level, each class of resource branches into four major subsystems of the technology: resource exploration and appraisal, reservoir development and operation, resource utilization, and environmental systems. Figures 3.1 .2 through 3.1 .5 on the following page 111 ustrate one particular branch of the tree (components involved in field surveys, aerial surveys, and subsurface investigations germane to geologic methods of resource exploration and appraisal of vapor-dominated resources).

The work involved in bullding such a structure is a task which requires much time and the strenuous mental effort of a group of technical people. However, the explicitness and organizational thinking demanded by this task led to a level of precision and completeness In later work which would have been difficult to achieve in other ways. At level six, the questions could be asked: Where do we stand with respect to these components? What Impediments are Ifkely to develop as the technology moves forward?

As technical impediments to geothermal development and utilization were identified, they were assigned speciflc numbers which were cross-referenced to the relevance tree.

\section{Interview Sequence}

This task began with the formulation of a preliminary impediment 11st. In this context, an "Impediment" Is defined as any technical condition or deffciency which w11 materlally 1mpede the development of geothermal. resources in the United States to 1ts fullest potential within the next 25 years or so. An example of an Impediment would be lack of adequate definition of the location, distribution, energy content and class segregation of, the natural resource, or lack of a demonstrated method for continuous recovery of thermal. energy from hot dry rock reservolrs. It should be noted that the impediments considered In this portion of the Inquiry dealt only with technical problems and were not concerned wth legal, Institutional, socletal, or other apects of technology; these questions are treated elsewhere In the study.

The preliminary impediment 11st was compiled from inputs of consultants to the study team, members of the team 1tself, and a detalled review of the literature. The relevance tree provided an important means of checking the impediment 11st. Th1s preliminary 11st formed a major Input to the technical Interviews. In essence, the geothermal consultants were asked to modify and 


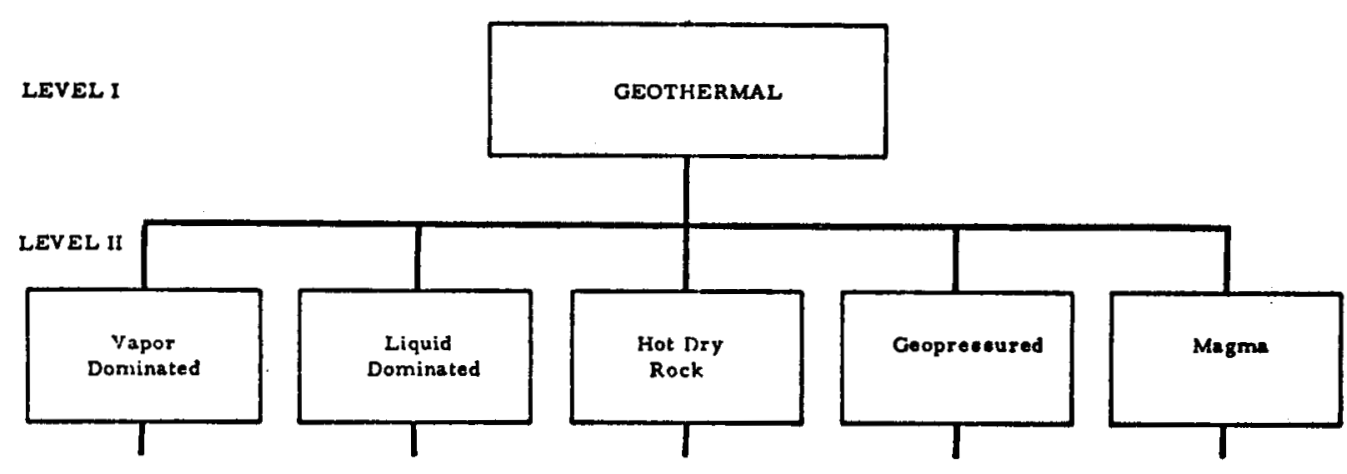

(A)

F1gure 3.1 .2

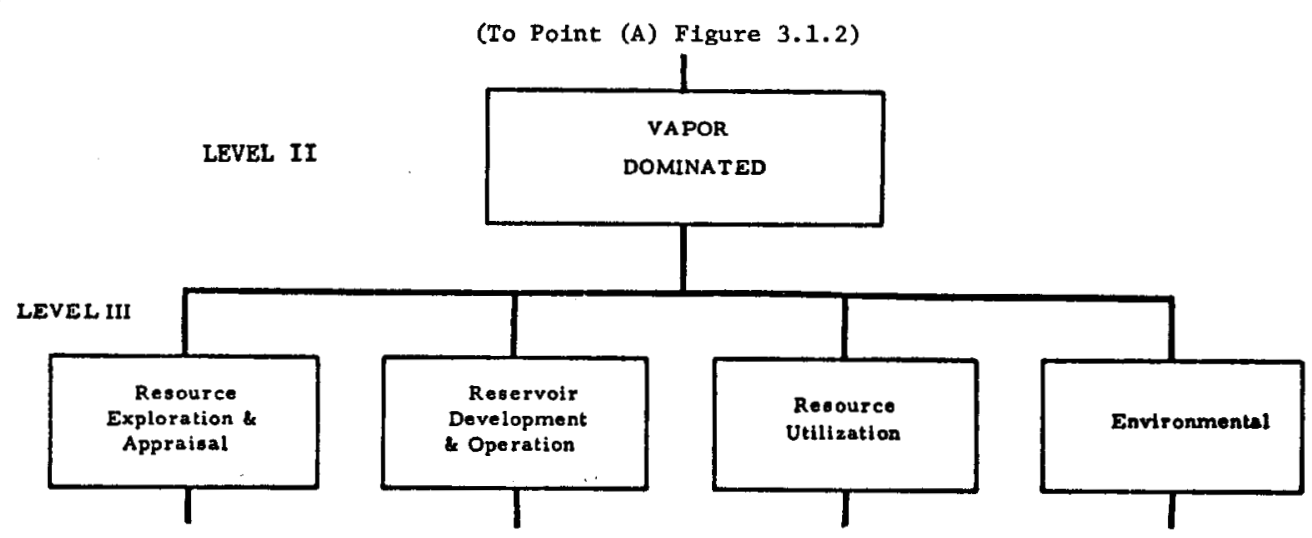

(A)

Figure 3.1.3

(To Point (A) Figura 3.1.3)

LEVEL III
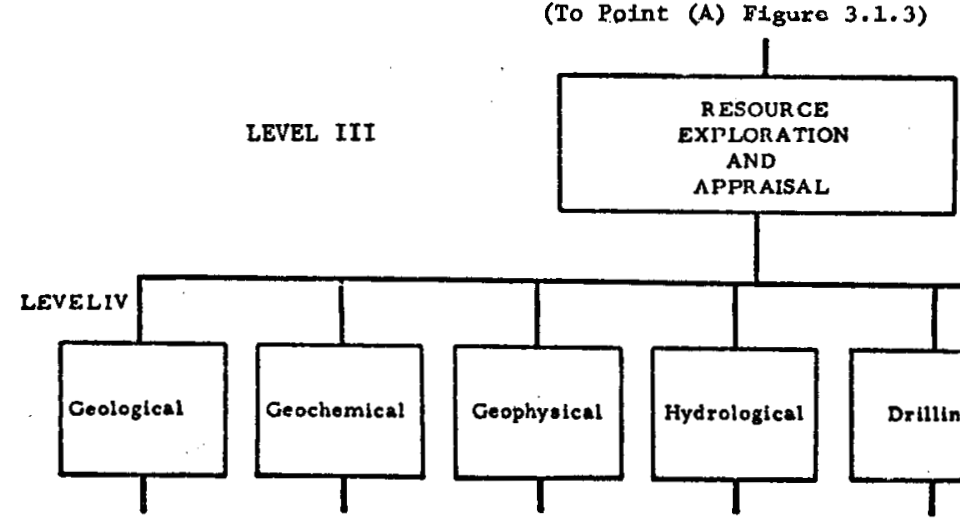

(A)

Figure 3.1 .4 


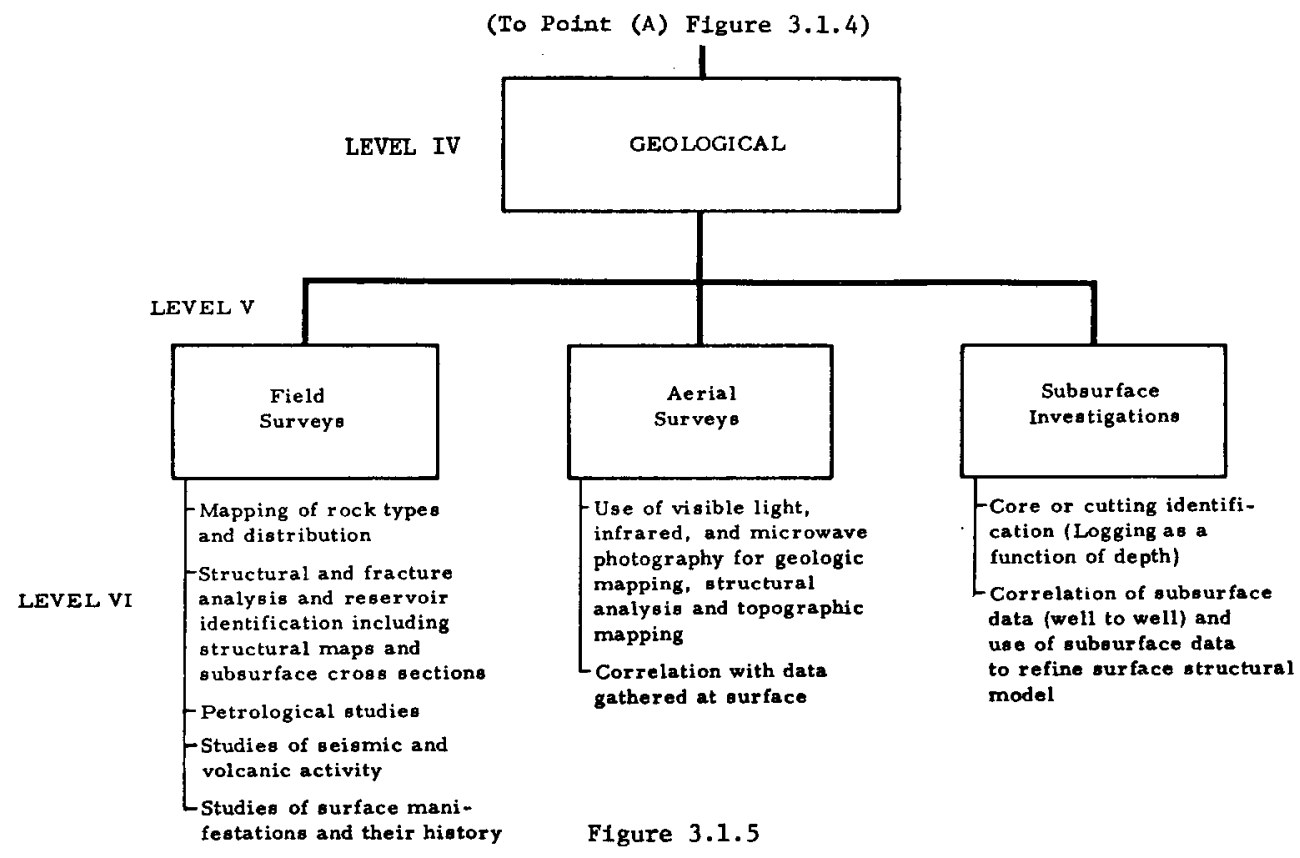

extend the list and to contribute ideas as to how the Impediments which were elther provided to them or which they themselves added might be overcome.

Early in this task, the Impediment list was divided into four categories, called subsystems, as follows:

1. Resource exploration and appraisal.

2. Reservo1r development.

3. Energy conversion.

4. Environmental technology.

The first of these included all identified impediments associated with gross and locallzed exploration, and exploratory driling and data gathering for the purpose of discovering and appralsing the extent of a reservoir in the energy content, quality, and distribution.

The second category included all impediments relating to the commercial development of Identified reservolrs, including production driling, formation fracturing, fluid infection, Installation of well casing and wellhead valving, and gathering gystems.

The third category included the technical impediments which Inhibit the manufacture and construction of all above-ground facllities from the gathering system: discharge forward through the energy conversion or mineral recovery plants.

The fourth category encompassed the technical impediments to the alleviation of the adverse environmental effects which may follow from exploration for utilization of geothermal resources.

These Impediments were revlewed in interviews by a selected group of experts in geothermal technology and the geothermal industry.
Candidate Interviewees were chosen because of their widely-recognized knowledgeabllity about one or more of the 1mpediment areas. The criteria for "knowledgeability" in this context were the extent to which an individual had published on a particular topic related to one or several impediments, or whether the Individual was known to be actively engaged in a particular segment of industry which put him in a "position to know" with respect to forecasting the status of given impediments. Figure 3.1.6 on the following page summarizes the particlpants and their affillations.

Prospective participants were first contacted by telephone. The initial response, in every case, was favorable and of ten reflected considerable enthusiasm. Of the 31 prospective interviewees solicited, only one declined (conditionally) at the outset, and six additional Individuals who originally agreed to act as interviewees efther declined subsequently or fafled to respond. Consultants to Bechtel Corporation in this portion of the study also acted as interviewees on certain specific Impediments.

\section{Interview Procedure}

After ascertaining that the prospective interviewee would, In fact, 1ike to participate, a selected group of questlonnalres was malled, accompanied by an introductory cover letter and a supplementary sheet which defined the essential terms and presented an example of the types of answers desired. (Appendix $A$ includes examples of these documents.) The cover letter included an approximate date by. which the Interviewee would be recontacted for the purpose of discussing the questionnalre and solicitIng replles. During the course of the inftial phone contacts, the study team promised to supply all participants with a summary of the results of all of the interviews. Th1s inducement to participate was confirmed in the cover letter. Additionally, each prospect (also confirmed in the cover letter) was assured that their contribution would remain anonymous, If they 80 desired; that 1s, no 


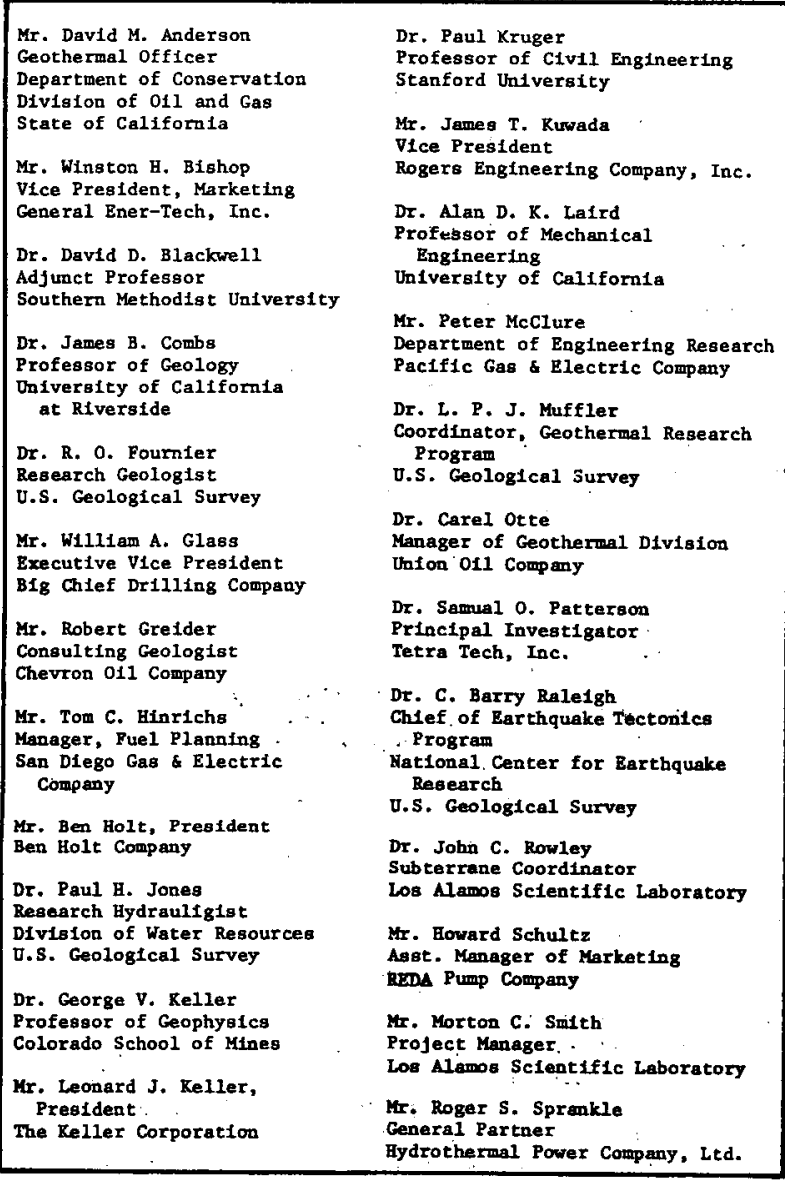

F1gure 3.1.6 THE TECHNICAL PANEL

specific comment would be attributed to any particular individual, without prior authorization.

In general, the method of responding to the questionnaire was determined by the preference of the interviewee; 1.e., by mall, phone, or person-to-person. The process of receiving and recording phoned replies was usually a protracted affair, requiring from 45 minutes to an hour and a half per Interview to complete. As expected, person-to-person interviews were less burdensome and usually more productive of desired information. (A later task in the study required that a similar set of interviews be conducted, but in this case, focusing on social, political, and economic factors. Almost all of these later interviews were conducted person-to-pierson.)

Individual questionnaires were prepared for each of the first three subsystems. The basic intent of these questionnaires was to solicit the intervlewees' forecasts of what geothermai developments they thought could be accomplished in terms of what was percelved as technically possible; political, competitive; regulatory, and environmental considerations notwithstanding.

In essence, the questionnatre was divided into two major parts. The first dealt with specific Individual impediments; most respondents were given a number of impedimen to address. The second dealt with the more general ques tions of resource appraisal, reservoir develop.nent, and resource conversion. The comprehensiveness of these general questions, the request for quantitative replies, and general low state of knowledge about these 1ssues, made the questions rather difficult ones to answer and limited the possible number of respondents. The respondents were asked not only to complete these questionnalres, but also to contribute, in view of their own experience and judgment, other impediments which they felt might have been omitted.

For each impediment the questionnaire sought judgments as to:

1. Present status of the 1mpediment.

2. Future status (In 1985 or 2000 under the assumption of either a "normal" or "crash" program) in terms of performance, avallability, and policles which might be necessary to overcome the impediment belng considered.

\section{Overview of Interview Findings}

The results of the technical interview sequence were utilized as inputs to almost all later tasks in the study. The interviews produced information on attitudes and expectations of various experts about technological impediments which could, if uncorrected, pace the development of geothermal energy. The Impediments which they defined, the areas to which those impediments applied, and the expected schedule of the resolution, are presented in Figures 3.1 .8 through 3.1.15. Detailed discussion generated in the interviews about each of these impediments 1s Included in Appendix A; Section 3.3 discusses these Impediments in more detail and, in particular, probes their implication for the accelerated evolution of geothermal energy in the United States.

\section{Energy System D1agrams}

The purpose of this activity was to integrate the forecasts produced in the technological interviews to produce estimates of the amount of geothermally-generated electricity which is, in the minds of the respondents, technologically feasible under. various program definitions between the present time and the end of the century. It should be noted in the discussion which follows that other estimates were produced later in the study of the amount of electricity produced from geothermal sources. These later estimates were, in general, more conservative than the estimates produced by the technical panel. This is reasonable since the technical panel was answering the question: How much electricity could be produced if only technological impediments paced either a "normal" or "crash" program?

In order to provide a uniform basis on which impediment questions could be answered, it was necessary to define essential terms used in the questionnafre. Important terms used in.this portion of the study are defined in Figure 3.1 .7 on the following page.

Any of the first three subsystems may limlt the electric power potential of a geothermal energy resource. Consistent with the search for technical feasibility levels, rather than economic viability, the level of identified resources (as opposed to reserves) has been used to determine the upper limit on technically feasible levels of geothermal energy which can be extracted and converted to electric energy:- It was assumed that-field lifetime is 25 years, and identified resources are adequate to support a given reservoir development capability if 


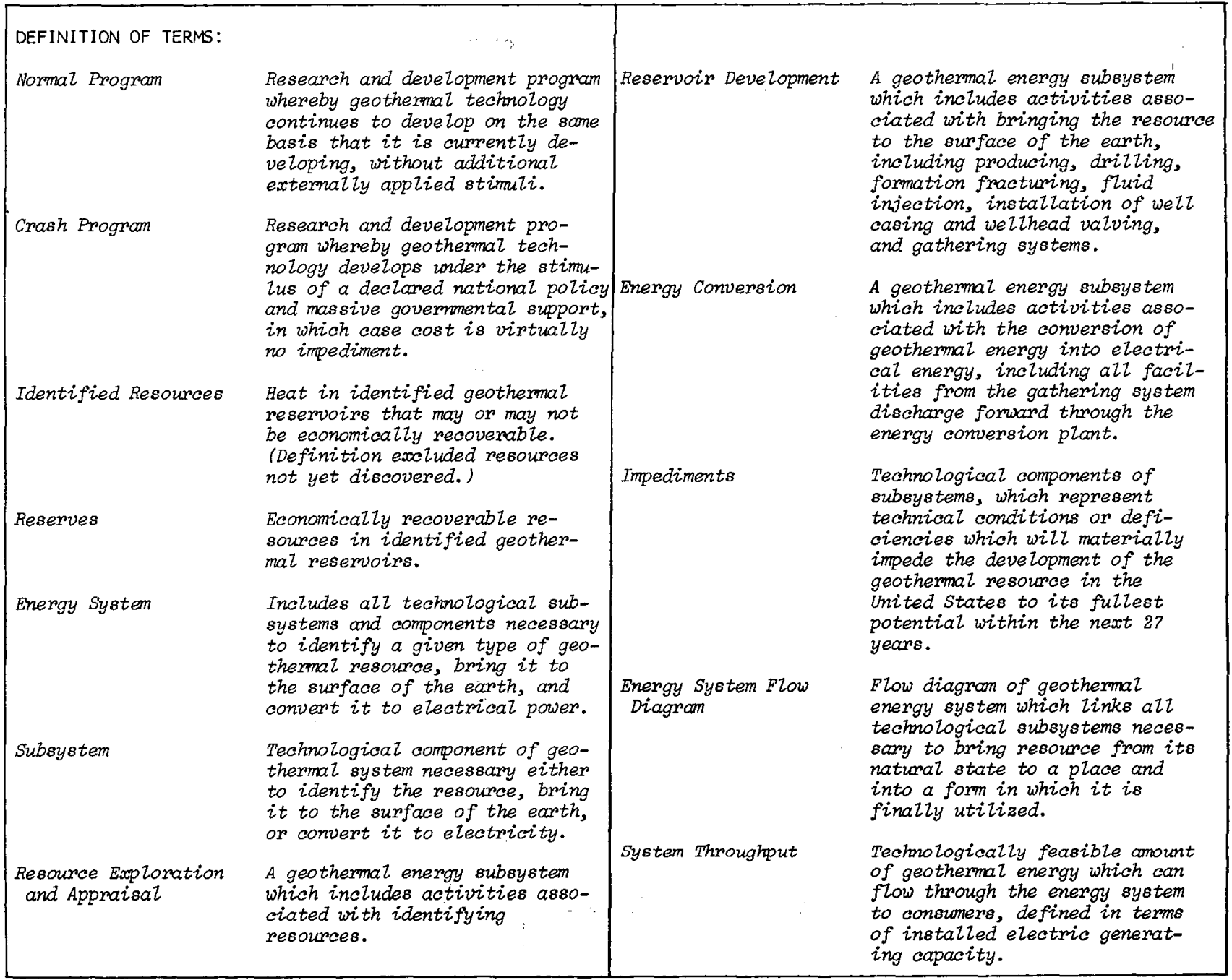

Figure 3.1.7 DEFINITION OF TERMS 
A. RESOURCE EXPLORATION AND APPRAISAL

(ABBREVIATED STATEMENT OF IMPEDIMENTS)

A1 DOMNOLE SAMPLING TECHNIQUES AND DEVICES

A2 GROSS EXPLORATION TECINIQLES

A3 CORRELATION OF GEOPHYSICAL DATA

A4 SIGNIFICANCE OF GEOCHEMICAL DATA

A5 DATA BANK FOR INFORMATION POOLING

A6 DYNAMIC RESERVOIR MDDELS

A7 IMPROVED GEOPHYSICAL TECHNIQUES AND EQUIPMENT

A8 DEEP DRILLING RIGS

A9 REGIONAL GEOLOGICAL MOOELS

Figure 3.1.8 IMPEDIMENT LIST

\begin{tabular}{|c|c|c|c|c|c|c|c|c|c|c|c|c|c|c|c|c|c|c|c|c|c|c|c|c|c|c|c|c|c|c|c|c|c|c|}
\hline \multirow{2}{*}{ TIME FAAME } & \multicolumn{7}{|c|}{ VAPOFDOMINATED } & \multicolumn{7}{|c|}{ LOUID-DOMINATED } & \multicolumn{7}{|c|}{ HOT ORY ROCK } & \multicolumn{7}{|c|}{ GEOPAESSUREO ZONES } & \multicolumn{6}{|c|}{ Magma } \\
\hline & 1 & 3 & 4 & 5 & $\theta$ & 7 & - & 1 & 2 & 34 & 5 & - & 10 & 9 & 12 & 3 & 1 & B & - & 7 & 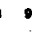 & 1 & 2 & 31 & $B$ & $\bullet$ & , & - & 2 & 4 & 5 & 17 & 7 & - \\
\hline $\begin{array}{c}\text { PAESENT } \\
1973\end{array}$ & 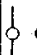 & & & & & & & & 1 & & 1 & 1 & & 1 & & & & & $\oint$ & & & 1 & $\phi$ & & $\downarrow$ & & & 1 & 1 & & 1 & & 1 & \\
\hline$\underset{1985}{\text { MORMAL }}$ & & 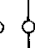 & & & & & & & 8 & & & 0 & & 0 & 1 & 8 & & & 0 & $\oint$ & 8 & & 8 & $\phi$ & & & & & 8 & 8 & & & i & \\
\hline$\underset{2000}{\text { MOAMAL }}$ & & & & & & $\phi$ & & & 8 & & 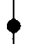 & & 0 & & C & & & & & 00 & & & 8 & & & & & & 8 & & & 8 & & \\
\hline$\underset{1995}{\text { CAASH }}$ & S & & & & & & & & 8 & & & & & & 8 & & & & & & 8 & & $\phi$ & & & & & & 8 & & & & 0 & \\
\hline $\begin{array}{c}\text { CFASH } \\
2000\end{array}$ & & & & & & & & & & & & & & & & & & & & & & & & & & & & & & & & 1 & & \\
\hline
\end{tabular}

LEGEND

:- MINOR IMPEDIMENT

MO MOMPEIMENT

Figure 3.1.9 FORECASTS OF TECHNICAL IMPEDIMENTS IN RESOURCE EXPLORATION AND APPRAISAL 


\begin{tabular}{|c|c|}
\hline & $\begin{array}{l}\text { B. RESERVOIR DEVELOPMENT } \\
\text { (ABBREVIATED STATEMENT OF IMPEDIMENTS) }\end{array}$ \\
\hline B1 & VERY DEEP DRILLING TECANIQUE \\
\hline B2 & TUBULAR GOODS SHORTAGE \\
\hline B3 & ENERGY RECOVERY METHOD FOR HOT DRY ROCK \\
\hline B4 & ENERGY RECOVERY METHOD FOR MAGMA \\
\hline B5 & DOWNHOLE HEAT EXCHANGER \\
\hline B6 & SOLIDS DEPOSITION IN FORMATION AND CASING \\
\hline 87 & DEEP-WELL PUMPS \\
\hline B8 & RESERVOIR FLUID RECHARGE \\
\hline Bg & FIELD STIMULATION METHOOS \\
\hline B10 & REINJECTION OF LIQUID WASTES \\
\hline B11 & THEPAMLL STRESS INDUKED IN HOT DRY ROCK \\
\hline 812 & RELATIONSHIP BETWEEN FLUID INJECTION AND EARTHQUAKES \\
\hline 813 & AVAILABILITY OF DRILL RIGS FOR DEET DRILLING \\
\hline B14 & PORTABLE TIO-PHASE FLOW METER \\
\hline B15 & DYNAMIC RESERVIIR MODELS \\
\hline B16 & CASE HISTORY DATA FOR FIELD LONGEVITY PREDICTIONS \\
\hline
\end{tabular}

FIgure 3.1.10 IMPEDIMENT LIST

\begin{tabular}{|c|c|c|c|c|c|}
\hline & VAPOMOOMIMATED & LQUTODOMUNATED & NOT DAY MOCK & GEONULSEUREO ZOWES & mamn \\
\hline & 12348670910112131418 & 1 & 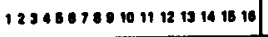 & [ & | 12348070010111213141818 \\
\hline $\begin{array}{l}\text { PAEEENT } \\
\text { Pa73 }\end{array}$ & 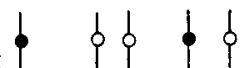 & 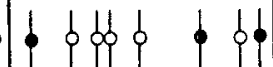 & Het & 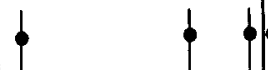 & 1 \\
\hline$\underset{1098}{\text { NogmaL }}$ & 0 & & 0 & & \\
\hline$\underset{2000}{\text { normat }}$ & 9 & \%. & 9 & & \\
\hline$\underset{1 S O S H}{\text { CARH }}$ & 0 & 0. & 9 & & 00 \\
\hline CRASH & & & & & $\$ \%$ \\
\hline
\end{tabular}

8: : MMENOA IMPEDMENT

: MOLOR MPREOMENT

F1gure 3.1.11 FORECASTS OF IMPEDTMENTS IN RESERVOIR DEVELOPMENT 
C. ENERGY CONYERSION

(ABBREVIATED STATEMENT OF IMPEDIMENTS)

CI DEMONSTRATION POWER PLANT FOR LIQUID-DOMINATED RESERVOIR OF MEDIUM TO LOW THERMAL: QUALITY

C2 DEMONSTRATION POWER PLANT FOR HEAVY BRINE RESERVOIRS

C3 PRIME MOVER FOR TWO-PHASE FLUID

C4 SCALE DEPOSITION

C5 EMPIRICAL DATA FOR SELECTION OF PLANT MATERIALS

CG DEMONSTRATION POWER PLANT FOR GEOPRESSURED ZONES

C7 DEMONSTRATION POWER PLANT FOR MAGMA

C8 DEMONSTRATION POWER PLANT FOR HOT DRY ROCK

F1gure 3.1.12 IMPEDIMENT LIST

\begin{tabular}{|c|c|c|c|c|c|c|c|c|c|c|c|c|c|c|c|c|c|c|c|c|c|c|c|c|c|c|c|c|c|}
\hline \multirow{2}{*}{ time faAme } & \multicolumn{4}{|c|}{ VAMOMDOMINATED } & \multicolumn{7}{|c|}{ LIQUID-DOMIMATED } & \multicolumn{6}{|c|}{ HOT DAY ROCX } & \multicolumn{7}{|c|}{ GEOPRESSURED ZONEE } & \multicolumn{5}{|c|}{ maQma } \\
\hline & 123 & 4 & $6 \times$ & 10 & 1 & 2 & $\mathbf{3}$ & 4 & - & - 7 & $\bullet$ & 2 & 2 & 4 & B & 7 & - & 1 & 2 & 2 & 4 & - & , & - & 12 & , & 4 & - & - \\
\hline$\underset{\text { Pagsent }}{\text { PRES }}$ & & 1 & & & 1 & 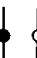 & & & & & & & 8 & 1 & & & 1 & & 1 & 1 & & 1 & & & & & $\phi$ & $\phi$ & \\
\hline$\underset{10003}{\text { NOAmeal }}$ & . & & & & & & & & & & & & & & & & & & & & & & & & & & & 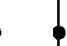 & 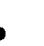 \\
\hline$\underset{2000}{\text { NORMAL }}$ & & & & & & & & & & & & & & & & & & & & & & & & & & & & & \\
\hline $\begin{array}{c}\text { CFASH } \\
1906\end{array}$ & & & & & & & & & & & & & & 8 & & & & & & & & & & & & & & & \\
\hline $\begin{array}{c}\text { CRASH } \\
2000\end{array}$ & & & & & & & & & & & & & & & & & & & & & & & & & & & & & 8 \\
\hline
\end{tabular}

LEGEND

8- MiNo impeorment

- MaNof IMPEDMM

F1gure 3.1.13 FORECASTS OF TECHNICAL IMPEDTMENTS IN ENERGY CONVERSION 
D. ENVIRONMENTAL TECINOLOGY (ABBREVIATED STATEMENT OF IMPEDIMENTS)

DI GROUNOWATER CONTAMINATION

D2 GASĖOUS EMISSIONS

D3 LIQUID AND SOLID WASTE DISPOSAL

D4 NOISE EMISSIONS

D5 EARTHQUAKE INDUCTION

D6 SAFETY CODES

D7 LAND SUBSIDENCE

D8 AESTHETICS

FIgure 3.1.14 IMPEDIMENT LIST

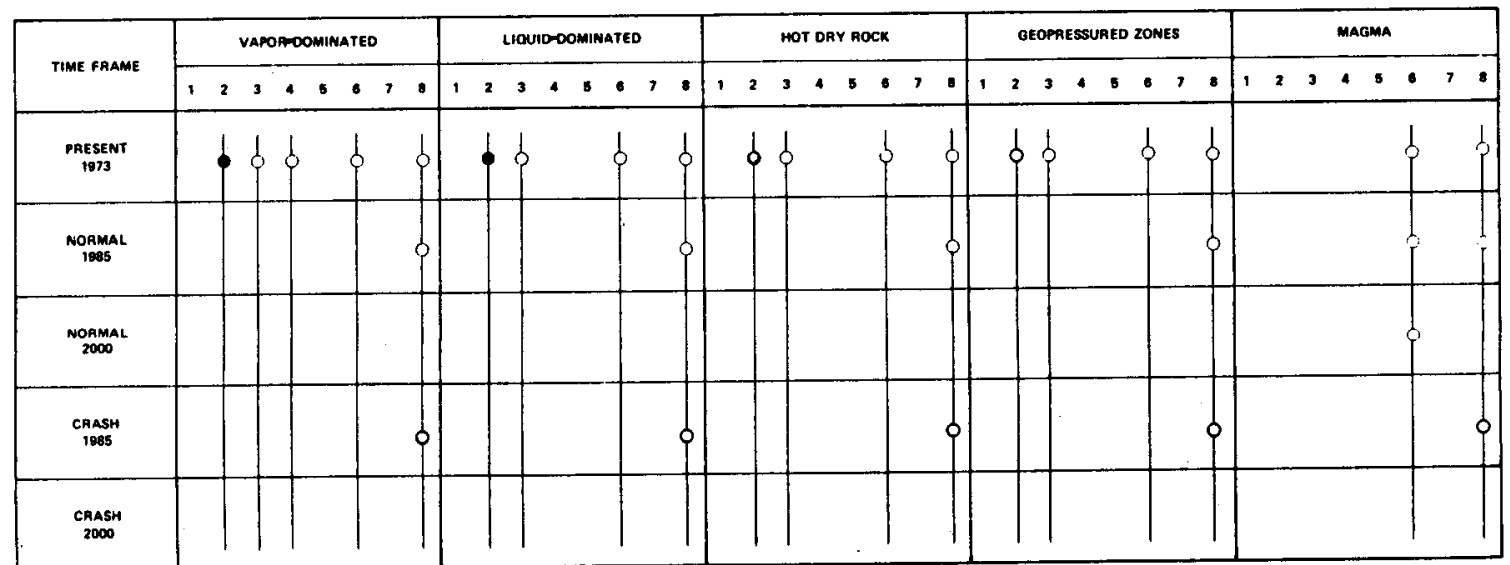

LEGEMD

- Minof mPEEDiment

MO MPPEDMENET

Figure 3.1.15 FORECASTS OF TECHNICAL IMPEDIMENTS

IN ENVIRONMENTAL TECHNOLOGY 
they are greater than or equal to the amount of geothermal resources which would be extracted in 25 years by the reservoir development capability estimate. Using this convention the potential of each geothermal resource in terms of added installed electric capacity was computed as follows:

The technologlcally feastble level of geothermal energy resources development which flows into the energy conversion subsystem is the lower of the two subsystem capabilities for (a) 1dentification of resources and (b) reservolr development: The technologically feasible geothermal energy development level determined from resource and reservolr development considerations is adequate to support a given energy conversion capability if it is greater than or equal to the amount of thermal energy which could be converted to electric energy at a 10 percent conversion effictency.

Thus, the technologically feasible level of installed electric power capacity which flows from the energy system (system throughput) is the minimum of the three subsystem capabilities:

(1) "Resource equivalent,"* defined as the amount of electrical generating capacity which can be supported by the forecasted level of identified resources for 25 years, assuming 10 percent overall conversion efficiency.

(2) "Reservoir development equivalent," defined as the amount of electrical generating capacity which can be supported by the forecasted level of reservoir development capability, assuming 10 percent overall conversion effictency.

(3) Energy conversion capability.

*This definition of resource equivalent assumes that all Identifled resources would be depeleted in 25 years if they were developed at the resource equivalent rate. However, no value judgment has been made as to the advisability of this procedure as a national policy, and It is a relevant concern only in those cases when resource equivalent is a more limiting subsystem than reservoir development equivalent or energy conversion capab11ity.

The resource information requested during the interviews can be summarized as follows:

1. "What do you think could be the level of identifled resources in MWt-years?" Th1s question was asked for 1985 and 2000, for "normal" and "crash" development programs and for five resource types ( 20 questions).

2. "What do you think could be the level of developed geothermal reservolrs within the entire United States in MWt?" (For 1985 and 2000, "normal" and "crash" programs, five resource types; 20 questions.)

3. "What do you think could be the Installed geothermal electric generation capacity within the entire United States in MWe?" (For 1985 and 2000, "normal" and "crash" programs, five resource types; 20 questions.)

of the set of 24 respondents, 14 were asked to respond to these questions; 8 were asked to provide resource estimates; 6 were asked for reservolr development capability forecasts; and 3 for energy conversion capability forecasts.
The quality of the responses generally met expectations In view of the comprehensive and difficult nature of the subsystem questions and the state of knowledge. In $s$ cases, the respondents querled elther falled to respor or falled to give quantitative forecasts. In addition, some interviewees responded only to a portion of the questions asked (for example, some respondents discussed fewer than all five resource types or a regional section of the entire United States) as their expertise dictated. An overview of the responses is given In FIgure 3.1.16.

\begin{tabular}{|c|c|c|c|}
\hline RESPONOENT & $\begin{array}{l}\text { RE SOURCE EXPLORATION } \\
\text { ANO APPRAISAL }\end{array}$ & $\begin{array}{c}\text { RESERVOIR } \\
\text { DEVELOPMENT }\end{array}$ & ENERGY CONVERSION \\
\hline 1 & $x$ & & \\
\hline 2 & $x$ & & \\
\hline 3 & QUALITATIVE & & \\
\hline 4 & QUALITATIVE & & \\
\hline 5 & QUALITATIVE: & QUAL ITATIVE: & $x^{*}$ \\
\hline 6 & $\mathrm{x}$ & QUALITATIVE & $x$ \\
\hline 7 & & $x$ & $x$ \\
\hline B & & $x$ & \\
\hline 9 & & 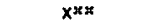 & \\
\hline 10 & & & QUALITATIVE \\
\hline
\end{tabular}

XONE RESOURCE TYPE ONLY.

*:'REGIONAL SUBSECTION OF UNITED STATES.

KEY $X$ = QUANTITATIVE FORECAST OF TECHNICALLY FEASIBLE LEVEL, QUALITATIVE = QUALITATIVE FORECAST OF TECHNICALLY FEASIBLE LEVEL.

FIgure 3.1.16 OVERVIEW OF RESPONSES TO SUBSYSTEM-LEVEL QUESTIONS

During the course of the interview sequence, it became apparent that the majority of respondents found it difficult to isolate reservoir development capability estimates from energy conversion capability considerations and vice-versa, and that the Independent forecasts obtalned for these two technological capabilities would be more representative of the respondents' state of information if they were considered as forecasts of the combined reservolr development and energy conversion capability of industry. Accordingly, the energy system flow diagrams have been modified to include only two Independent forecasts for geothermal energy systems, one for the level of identified resources, and one for the reservolr development and energy conversion capability of Industry. Thus, the technologically feastble level of geothermal energy resources development was determined from the energy system flow diagrams as the minimum of the two numbers for:

(1) Resource equivalent (GWe)

(2) Reservolr development and energy conversion (GWe)

and the forecasts provided by the respondent were aggregated as shown in Figure 3.1.17 on the following page. As can be seen from the figure, only 3-4 estimates for level of Identified resources and 3-5 estimates for reservolr development/energy conversion capability were obtained. Clearly, these data cannot be given any stat1stical significance; the value accorded them is derived solely from the high level of expertise of the contributors. FIgure 3.1.18 11lustrates the process which was followed.

Analysis of results from the Interview sequence Indicates that any attempt to achleve a consensus in describing the potential of geothermal energy by a single deterministic value would have probably falled, with the exception of a few specific cases. A range of forecasts has been obtalned both for the technological subsystems and for electric power throughput from geothermal energy systems. In the treatment of results, this range of throughput 


\begin{tabular}{|ccc|}
\hline RESPONDENTE & RESOURCE EXPLORATION AND APPRAISAL & $\begin{array}{c}\text { RESOURCE DEVELOPMENTI } \\
\text { ENERGY CONVERSION }\end{array}$ \\
\hline 1 & $x$ & \\
2 & $x$ & \\
3 & $x^{*}$ & $x * \times$ \\
4 & $x$ & $x$ \\
5 & & $x$ \\
6 & & $x * \%$ \\
7 & & \\
\hline
\end{tabular}

IRESPONDENTS NUMBERED 1-7 HERE DO NOT CORRESPOND TO TMOSE NUMBERED 1-7 IN

FIGURE 3.1.16 PRECEDING.

HLOWER LIMIT ONLY FOR ONE RESOURCE TYPE ONLY.

XXONE RESOURCE TYPE ONLY.

XXYFOR ONE REGIONAL SECTION OF THE COUNTRY ONLY.

F1gure 3.1.17 INDEPENDENT QUANTITATIVE FORECASTS

forecasts w111 be presented in varlous forms:

(1) full range (al1 data)

(2) midrange, calculated by eliminating forecasts which led to extreme points of full range, and

(3) median, calculated by Integrating median subsystem forecasts

The median values are calculated for convenience of results presentation only; the range and midrange forecasts reflect the present state of knowledge.

The fullrange regource estimates are presented in Figures 3.1 .19 and 3.1 .20 on the following page. Figure 3.1.21 summarizes the results for fullrange, midrange, and median estimates.

Some general trends are reflected by the median forecasts. The present installed geothermal electric generating capacity is 0.396 GWe (1973). The technically feasible level of geothermal energy resources development is forecasted to be 10 GWe In 1985 and 200 GWe in 2000 (median forecasts), under normal program conditions. If a crash program is implemented, the corresponding values are 35 GWe in 1985 and 770 GWe in 2000.

The potential relative contribution of each of the various types of geothermal resources to electric power supply is illustrated by F1gures 3.1 .22 and 3.1.23, which plot the median forecast for each resource for 1985 and 2000 , respectively. Additional analysis indicates that hot dry rock and Ifquid-dominated resources are relatively abundant, whereas vapor-dominated and to a lesser degree geopressured zone resources are relatively scarce. Accordingly, the year 2000 results indicate small contributions from the two resource-limited types. On the other hand, It is the technology associated with the development of the hot dry rock resources, rather than a resource limitation, which w111 cause the development of this resource to $\mathrm{lag}$ behind that of the 11quid-dominated resources, according to most experts. The technological problems assoclated with development of magma resources restrict their utilization to negligible amounts.

Results of the analysis also Indicate that the greatest 1mpact of a crash development program, in terms of potential additions to the national fuel supply mix, w11 be on increased development of liquid-dominated and hot dry rock resources, due primarily to the fact that resources for these two types are abundant and can support greater exploitation.

A strategy suggested by these results for allocating crash program R \& D efforts to geothermel programs would be to concentrate on programs related to development of liquid-dominated and hot dry rock resources. The degrèe of success of this effort, both in terms of mapping of the resource and appraisal of its qualities, should yield data for required $R \& D$ efforts in reservoir development and power conversion technology. In the case of hot dry rock, concentration of R\&D effort on development and conversion technologies should yleld data on the technological feasibillty of large-scale development of the resource.

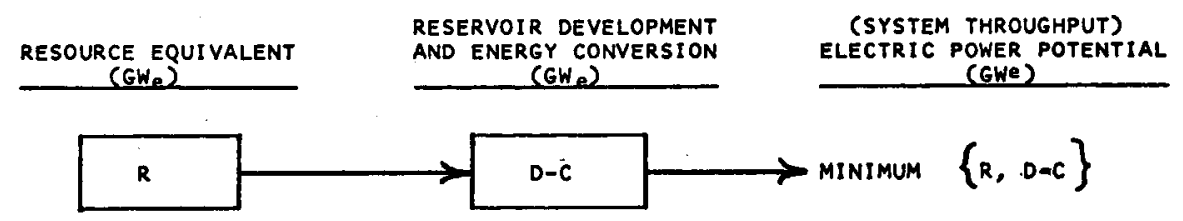

NOTATION: $\quad R=$ FORECAST FOR RESOURCE EQUIVALENT, AMOUNT OF ELECTRICAL GENERATING CAPACITY WHICH CAN BE SUPPORTED BY FORECASTED LEVEL OF IDENTIFIED RESOURCES FOR 25 YEARS, ASSUMING 108 OVERALL CONVERSION EFFICIENCY, FOR RESOURCE TYPE PROGRAM TIME

D-C = FORECAST FOR RESERVOIR DEVELOPMENT AND ENERGY CONVERSION CAPABILITY FOR RESOURCE TYPE PROGRAM TIME

FIgure 3.1.18 SAMPLE ENERGY SYSTEM FLOW DIAGRAM 


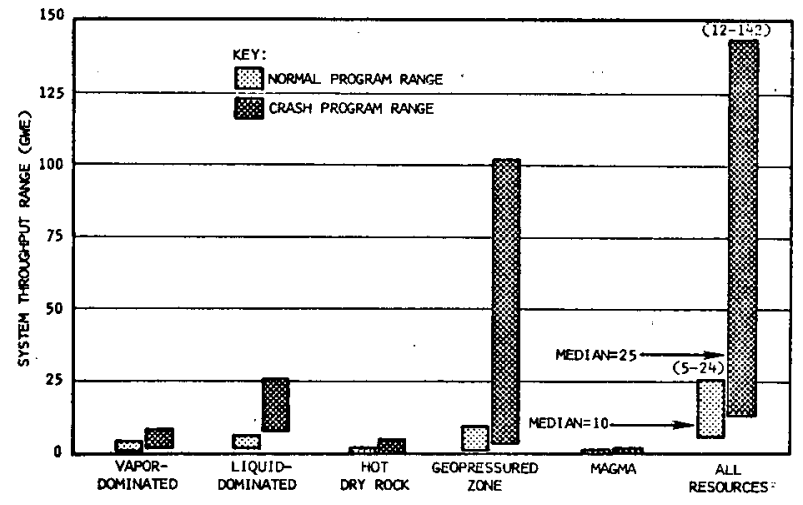

RESOURCE TYPE

Figure 3.1.19 SUMMARY OF SYSTEM THROUGHPUT RANGES, YEAR 1985

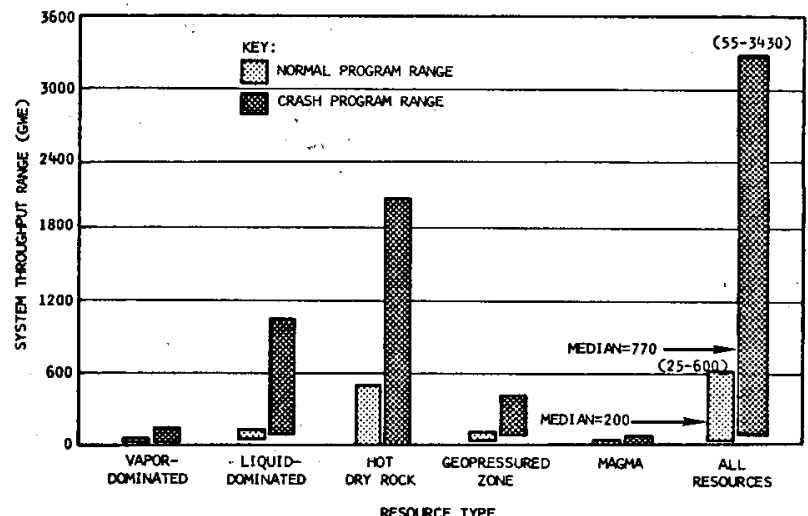

F1gure 3.1.20 SUMMARY OF SYSTEM THROUGHPUT RANGES, YEAR 2000

\begin{tabular}{|c|c|c|c|c|}
\hline \multirow[b]{2}{*}{ Year } & \multirow{2}{*}{$\begin{array}{c}\text { Level of } \\
\text { Development } \\
\text { Program } \\
\end{array}$} & \multicolumn{3}{|c|}{$\begin{array}{c}\text { Technologically Feasible Electric } \\
\text { Power Capac1ty (GWe) } \\
\end{array}$} \\
\hline & & Range (a11 data) & Midranget & Median* \\
\hline 1973 & - & 0.396 & & 0.396 \\
\hline 1985 & Normal & $5-24$ & $9-11$ & 10 \\
\hline & Crash & $12-142$ & $27-40$ & 35 \\
\hline 500 & Norma1 & $25-600$ & $55-200$ & 200 \\
\hline & Crash & $55-3430$ & $270-800$ & 770 \\
\hline
\end{tabular}

+ Calculated by eliminating two forecasts which. led to low and high extremes of range forecats.

- Median values are glven here for convenlence. The range of forecasts reflect better the present state of knowledge.

Figure 3.1.21 GEOTHERMAL TECENOLOGY FORECASTS (ALL RESOURCES) 
MEDIAN: FORECASTS OF GEOTHERMAL POTENTIAL, YEAR 1985

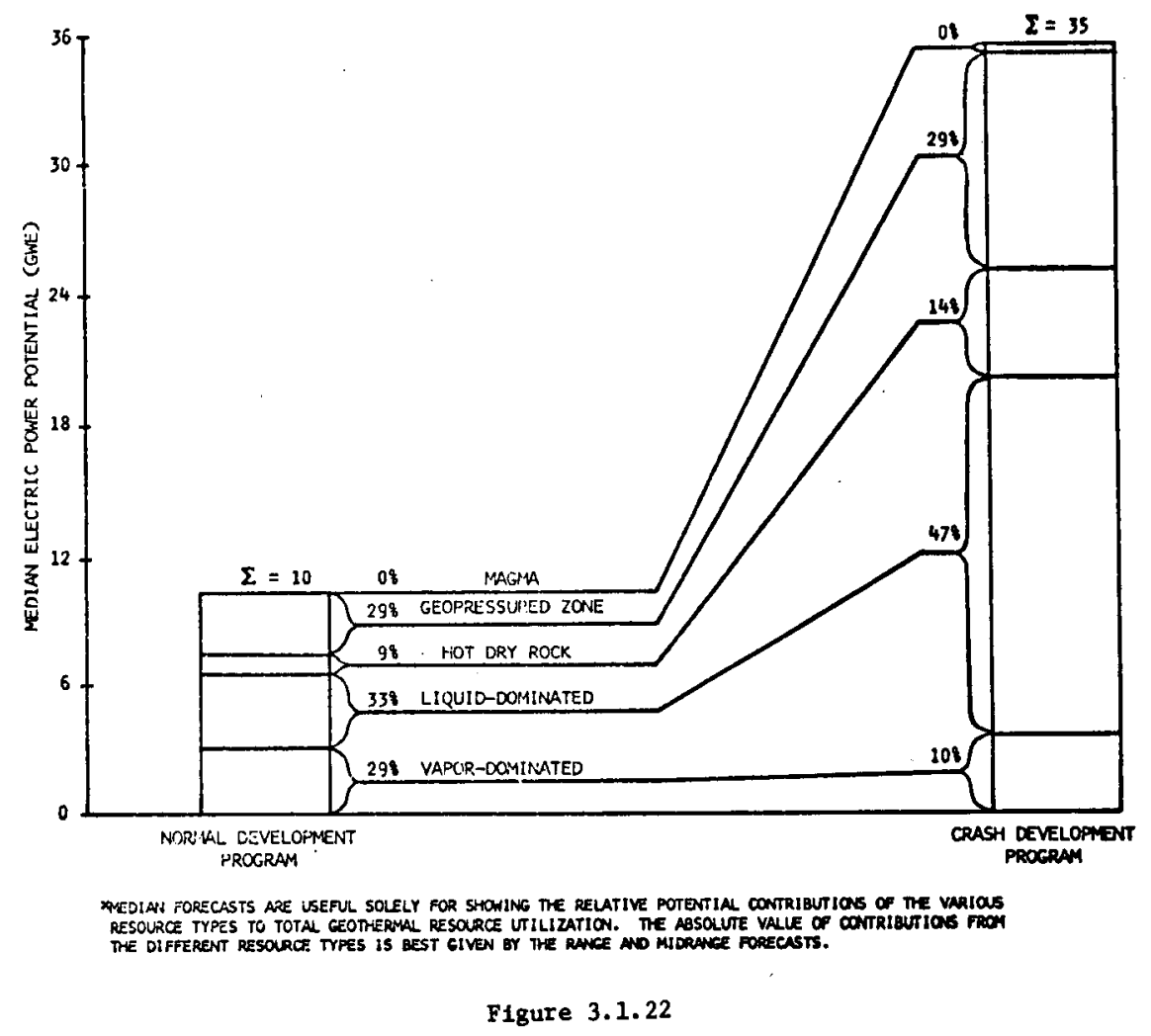

MEDIAN: FORECASTS OF GEOTHERMAL POTENTIAL, YEAR 2000

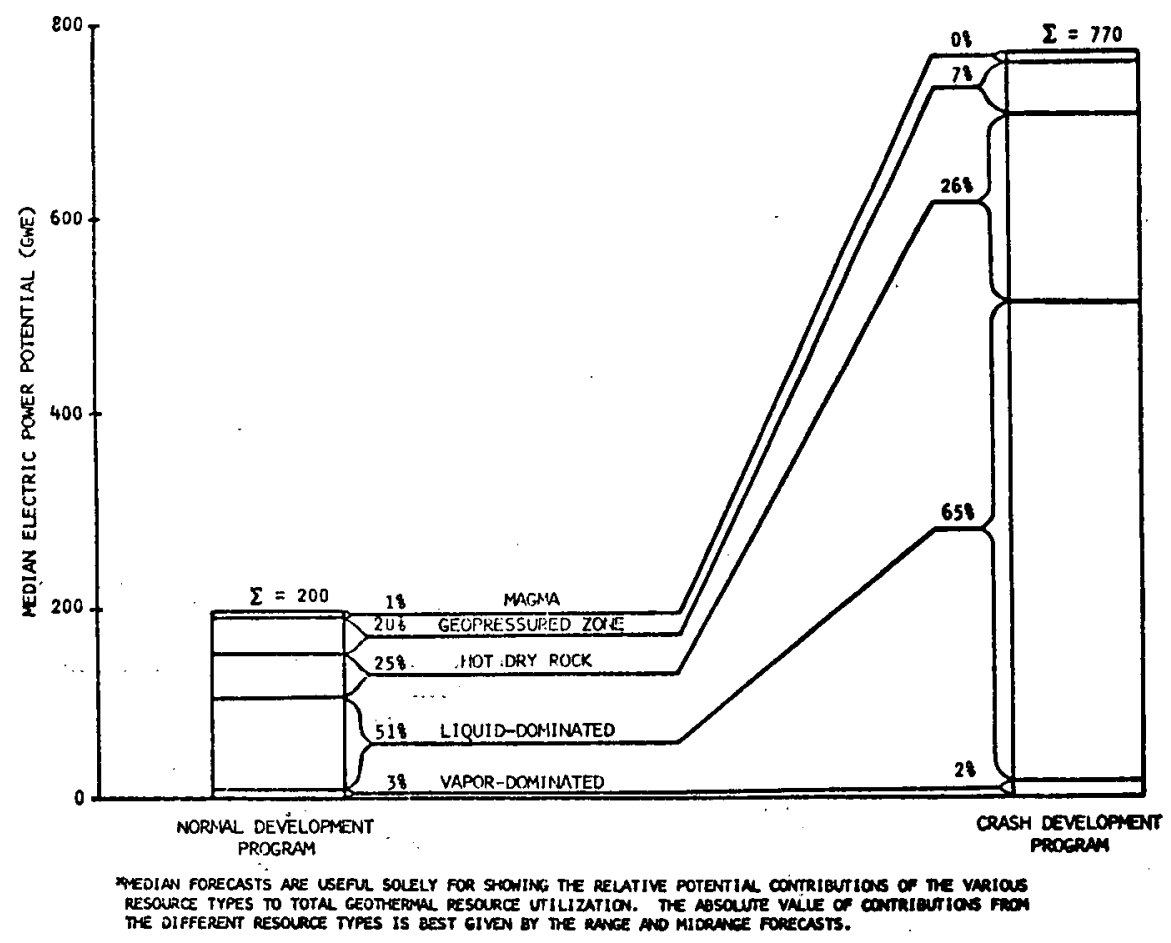

P1gure 3.1.23 


\subsection{The Soctal and Politlcal Inquiry}

\section{The Role of the Interview}

As described in Section. 1.3, the basic logic flow of the study required that technological capacities be addressed first. Having described what seemed possible, recognizIng technological constraints, the study then focused on the nature of the impacts likely to emerge from the evolution of geothermal energy. Using the technological forecast as a quantitative framework generated in Section 3.1, background material in the geothermal and general energy 1iterature was synthesized to construct scenarios depicting potentlal evolutionary paths of geothermal energy development. These scenarios were then used as interview springboards to elictt from representatives of varlous interest groups their opinions about the probable future course of geothermal development and the Impacts which could be expected as a result of this development on their spectific group, on other interest groups, and on the netion as a whole. In addition, this phase of the study was designed to identify and detine various policies which might be implemented to mitigate or Improve potential impacts of geothermal development.

Seventeen experts were selected for in-depth intervlews from groups interested in various aspects of geothermal energy and representing a broad range of attitudes and opintons. Included were representatives of federal agencles and leglslative bodies, state agencies, research Institutions, oll companies, commercial geothermal deverlopers, public utilities, environmental organizations, land developers, and financial institutions. F1gure 3.2.1 summarizes the participants and their backgrounds.

\begin{tabular}{|c|c|}
\hline PARTICIPANT & AFTIIATION \\
\hline Nr. Joseph Aldiln & Counsel, Magma Power Company \\
\hline Mr. Daniel Beard & $\begin{array}{l}\text { Environmental Pollcy Speciallat } \\
\text { LAbrary of Congreas }\end{array}$ \\
\hline Mr. R1chard Bowen* & $\begin{array}{l}\text { Economic Geologist } \\
\text { Oregon Department of Geological } \\
\text { and Mineral Industries }\end{array}$ \\
\hline Dr. R. D. Doctor & Rand Corporation \\
\hline Mr. Daniel Dreyfus & $\begin{array}{l}\text { Staff Profegsional } \\
\text { U.S. Senate Interior Committee }\end{array}$ \\
\hline Professor Hamiliton Bess & $\begin{array}{l}\text { Oafverstty of San Francisco and } \\
\text { sierra Club }\end{array}$ \\
\hline Mr. Donald Everitts & Cailfornia State Lande Div. \\
\hline Mr. W1211 monger & S1gnal 011 Gas Company \\
\hline Mr. Alvin Raufman & $\begin{array}{l}\text { Director, office of Rconomic } \\
\text { Research } \\
\text { Iew York State Public Service } \\
\text { Coumlasion }\end{array}$ \\
\hline Mr. Owen Malone & $\begin{array}{l}\text { Legialative Assistent to } \\
\text { Senator Bible of Nevada }\end{array}$ \\
\hline Mr. Carl McCulloch & $\begin{array}{l}\text { Cnlef Goologist } \\
\text { Southern Pac1fle Land Co. }\end{array}$ \\
\hline Dr. Patrlek Muffler & v.s. Geological Survey \\
\hline Mr. Nlex Raden & $\begin{array}{l}\text { General Manager } \\
\text { Amortcan Public Povar } \\
\text { Asooctation }\end{array}$ \\
\hline Mr. Pred searles & $\begin{array}{l}\text { Commarcial Development Dept. } \\
\text { Bechtel Corporation }\end{array}$ \\
\hline Wr. Barton W. Shackelford & $\begin{array}{l}\text { Vice President-P1anning } \\
\text { Pacielc Gas \& Electric co. }\end{array}$ \\
\hline Itr. C. Melote Sutaney & $\begin{array}{l}\text { Manser, Energy Rasources Group } \\
\text { Southern Callforrile Bd1son Co. }\end{array}$ \\
\hline Mr. Joseph Wilsoo & $\begin{array}{l}\text { Kenager of Landa } \\
\text { Ceothermal Diviaion } \\
\text { Datos } 011 \text { Company }\end{array}$ \\
\hline
\end{tabular}

Telaphone Interview

Figure 3.2.1 SOCIO AND ECONOMIC PANEL
A modified Delphi interview approach developed by The Futures Group was employed to obtain the desired infor mation in a face-to-face meeting of 2-3 hours. The $b$ Delph1 technique, used extensively in forecasting since the mid-60's, attempts to crystallize group judgments of experts unidentified to each other through use of written questionnarles in an iterative process. The modified approach used in this study substitutes interviews for written questionnatres.

There are at least five advantages to this alternative: (1) the Information is gained in a much shorter time; (2) personal contact with the respondents makes 1t possible to obtain a first-hand sense of their confidence and competence in handing the questions; (3) the interview sequence can be modified readily to accommodate the thought process of the respondents; (4) the personal Interest shown on the part of the Interviewers tends to enhance the cooperativeness of the panelists (th1s 1s, If the study is important enough to warrant sending professional researchers to gather the information, the panelists generally feel a stronger obligation to take the questions serfously;) and (5) the interviewers have the opportunity to learn at first hand about the respondents' organizations, to observe their actual dayto-day environment, and to see their answers more fully In the context of this environment.

\section{Interview Procedure}

Coples of the "normal" and "crash" scenar1os (Figures $3.2 .2,3.2 .3,3.2 .4$, and 3.2 .5 ) were sent to each respondent prior to the interview when time permitted.

\section{HORHAL SCEMARIO}

PRESENT TREND OF GEOTHERMIAL GRONTH CONTINUED.

MODERATE GOVERNMENT RRD FOR EXPLORATION AND OPERATIONS TECHNOLOGY. GRADUAL DEVELOPMENT OF INVESTMENT INCENTIVES, GRADUAL DEVELOPMENT OF REGULATORY COOPERATION.

\section{CRASH SCEHARLO}

NATIONAL COMMITMENT TO INTENSIVE GEOTHERMAL DEVELOPMENT. GREATLY INCREASED GOVERNIENT RGD,

GOVERHIIENT FUNDING OF PILOT AND DEMONSTRATION PLANTS. INTENSIVE EFFORT TO ELIMINATE REGULATORY DELAYS , GOVERNMENT PROVISION OF TAX INCENTIVE AND CAPITAL GUARANTEE PROGRAMS. PRONOTION OF CROSS-COUNTRY TRANSMISSION LIMES.

\section{FIgure 3.2.2 SCENARIO DEFINITION}

If not, they were presented on arrival. The levels of Installed geothermally derived power Included In these scenarios correspond to estimates obtained in the technical interviews; the events included in the scenarios were meant to deplct a potentially plausible sequence of steps leading to the power estimates. Each participant was asked to comment on their content in general and/or In detall, and to present his own appralsal of the course of development and his underlying assumptions. Where relevant, the Interviewer directed the discussion to aress of the respondent's expertise or particular Interests.

The respondent was then presented with a set of 36 cards, each a possible impact of the development of geothermal energy. These Impact statements are listed in Figure 3.2.6 later in this section. The objective of this part of the interview was to have the respondents evaluate these impacts as to their percelved desirability and their probability of occurring under the pattern of geothermal development which the respondents believed most 
The energy cr:ats of 1973 necessitates a changing pattern of input fuels for electricity generation. Shortages of low-sulfur ofl and natural gas preclude the continuing substitution of these fuels for coal. Nuclear energy supplies are less than anticlpated because of siting problems and long lead times involved in nuclear plant problems and long lead times involved in nucleax plant
construction. Appropriate environmental accommodations construction. Appropriate environmental accommodations additional nuclear plants become operative by the :mid1980 's. By the early 1980's oll supplies are availeble from shale, tar sands, and Alaska, but are primarlly used for transportation, heating, and petro-chemicals rather than for electricity generation.

By 1974 intensive prospecting for geothermal resources is underway, spurred by the open leasing of federal land. Supported by venture capital, utility development funds and governmental pllot projects, exploration for geothermal steam and hot water resources begins in the western regions. Th1s exploration, spurred by new developments for assessing the resource longevity of fields, indicates that most identified geothermal resources are liquid-dominated hot water systems. Potential development of these hot water resources, however, is slowed due to difficulties with high brine content. It is 1978 before any commerclally viable plants ut1lizIng hot water are operative.

Legal and institutional impediments are gradually removed during the mid- to late $1970^{\prime} \mathrm{s}$. By $1980 \mathrm{geo}-$ thermal resources are treated as unique and statutes are clear regarding what can be developed and in what manner. Specific guidelines are Instituted to assure that the physical sites of geothermal systems are developed in a manner compatible with existing land use patterns.

Due to the large risk factor, substantial capital outlay involved, and long lead times which characterize geothermal developments, it becomes evident that private thitiat developments, it becomes evident that private programs (tallored depreciation allowances, Investment guarantees, and/or production subsidies). Federal and state pollcies regarding geothermal resource development are coordinated and most conflicts resolved.

As hot water systems are being developed, work commences on possible ut1lization of hot rock resources. In the $1970^{\prime} s$ research efforts focus on hydraulic fracturing and also on possible seismic effects of fluid injection into hot dry rock.

By 1985 there is an electrical output capabllity of about 7500 megawatts from geothermal energy in the West. Of this total 3000 is from stean, 3500 from hot water, and 1000 from hot dry rock. This accounts for. 6 percent of the generating capacity of the West. The only other significant geothermal production is on the Gulf coast where geopressured fields produce some 3000 megawatts.

The utilization of geothermal resources proceeds rapid1y since it has cost and environmental advantages over coal and in many instances over nuclear powered plants as well. The growth of nuclear development slows somewhat in the West as geothermal power is clearly demonstrated as a practical energy source.

As the year 2000 approaches geothermal energy is a major factor in the factor in the West and a minor, though significant, facto
in the Gulf states. Prospecting for geothermal reserves in the East begins, spurred by new advances in drilling and resource locating technology.

By the year 2000 geothermal resources supply over one-third of the generating capacity of the West. Of this total of 140,000 megawatts, 6000 are from steam, 100,000 from 140,000 megawatts, 6000 are from stean, 100,000 from
hot water, and 34,000 from hot dry rock. Plans to export hot water, and 34,000 from hot dry rock. Plans to export
electrfelty from western reglons awalt the development of electrictiy from western reglons await the development of
additlonal capacity and adequate transmission technology.

Other uses of geothermal energy being implemented on a relatively large scale Inciude space heating and air conditioning, supplying irrigation water from desalinated wastes, and provision of minerals recovered from fluld wastes, and provision of minerals recovered from fluid
wastes. Some geothermal systems are multi-purpose comwastes. Some geothermal systems are multi-purpose con-
bining electrical generation with one or more of the bining electrical gener
After the opening of federal lands for leasing in 1974 interest in geothermal energy intensifies. Congress, spurred by an awareness of private industry interest, acts to stimulate geothermal development through a variety of measures. By 1975 and 1976 legislation 1s passed wh1ch coordinates federal research and development activities on geothermal energy; and in addition, funding and guarantees for new programs are passed. Sfnce it has been demonstrated that private industry is unable or unwilling to bear all early risks of geotherma1 development, the federal government funds entire projects for mapping, exploration', and the development of hot water, hot rock and geopressure technology. To hasten the development of commerclally feasible resources (steam and hot water), the Federal Government utilizes loan guarantees to private industry and actually particlpates with some utilities and municlpalftes in joint pilot projects.

The comblned actions of federal, state, and local agencies are successful in preventing duplication of effort by estab1ishing standardized procedures regarding the development and definition of geothermal resources. A national data bank for geothermal information is established by 1977 to facilitate orderly research and exploration.

These programs, plus additional federal activity in granting depreciation allowances and instituting manpower trafing projects, have a significant effect on the pace of development of steam, hot water, and geopressure resources. Exploratory techniques advance rapidiy and the scale deposit problem is solved by 1980 .

Most major technical impediments to the development of hot water reservoirs have been removed by 1985 . In addition, hot dry rock and geopressure technology is developing rapidly, especially in the area of deep drilling techniques (commerclal rigs are available for depths up to 30,000 feet and temperatures of $800^{\circ} \mathrm{F}$ ). Despite the lack of adequate field longevity data some regional utilities have been encouraged through federal incentive programs to base a large part of their new capacity on geothermal energy. This increased utilization is encouraged since geothermal energy has been shown to have cost and environmental advantages over coal and in many instances over nuclear powered plants as wel1. Production has reached a level of 35,000 megawatts: 3500 in steam, 16,500 in hot water, 5000 in hot dry rock, and 10,000 in geopressure.

While further development of steam and geopressure resources is lint ted by the extent of these resources, hot water and hot rock resources have been identified in very substantial quantities. Whether these resources are to be fully developed depends on the possibility of exporting excess electricity from the West to other regions. In other areas increased demand for electricity is being met through the construction of additional nuclear plants since fossil and synthetic fuels are largely reserved for other uses. As the use of nuclear power increases so do the perceived environmental problems of siting, safety, and wastes: In dealing with these problems the cost of nuclear power Iises and it becomes cost-competitive to transport electricity from geothermal developments via high voltage transmission lines from the West to the rest of the country.

After a prolonged national debate which weighs the advantages of more abundant energy versus possible environmental damage, Congress proclaims a national policy to promote this transmission of geothermal electriclty. In addition. legislative action provides funding and incentives to minimize any undesirable environtental and economic effects of this policy.

By the year 2000 the geothermil industry 1s a major source of Income in western regions. Formerly lsolated areas are now populated as jobs open at geothermal plants and surrounding industries. Geothermal generating capacity in the West totals 660,000 megawatts: 10,000 in steam, 500,000 in West totals 660,000 megawatts: 10,000 in steam, 500,000
hot water, and 150,000 in hot dry rock. The Gulf coast hot water, and 150,000 in hot dry rock. The Gulf cosst
states are supplied with 50,000 megawatts from geopressured resources; whlle hot rock resources ut 111 zed for space heating provides the equivalent of 50,000 megawatts in other reglons. Th1s erash program, which has ellminated mafor constraints and accelerated geothermal development, results in geothermal energy supplying about one-third of the electrictiy produced in the United States. 


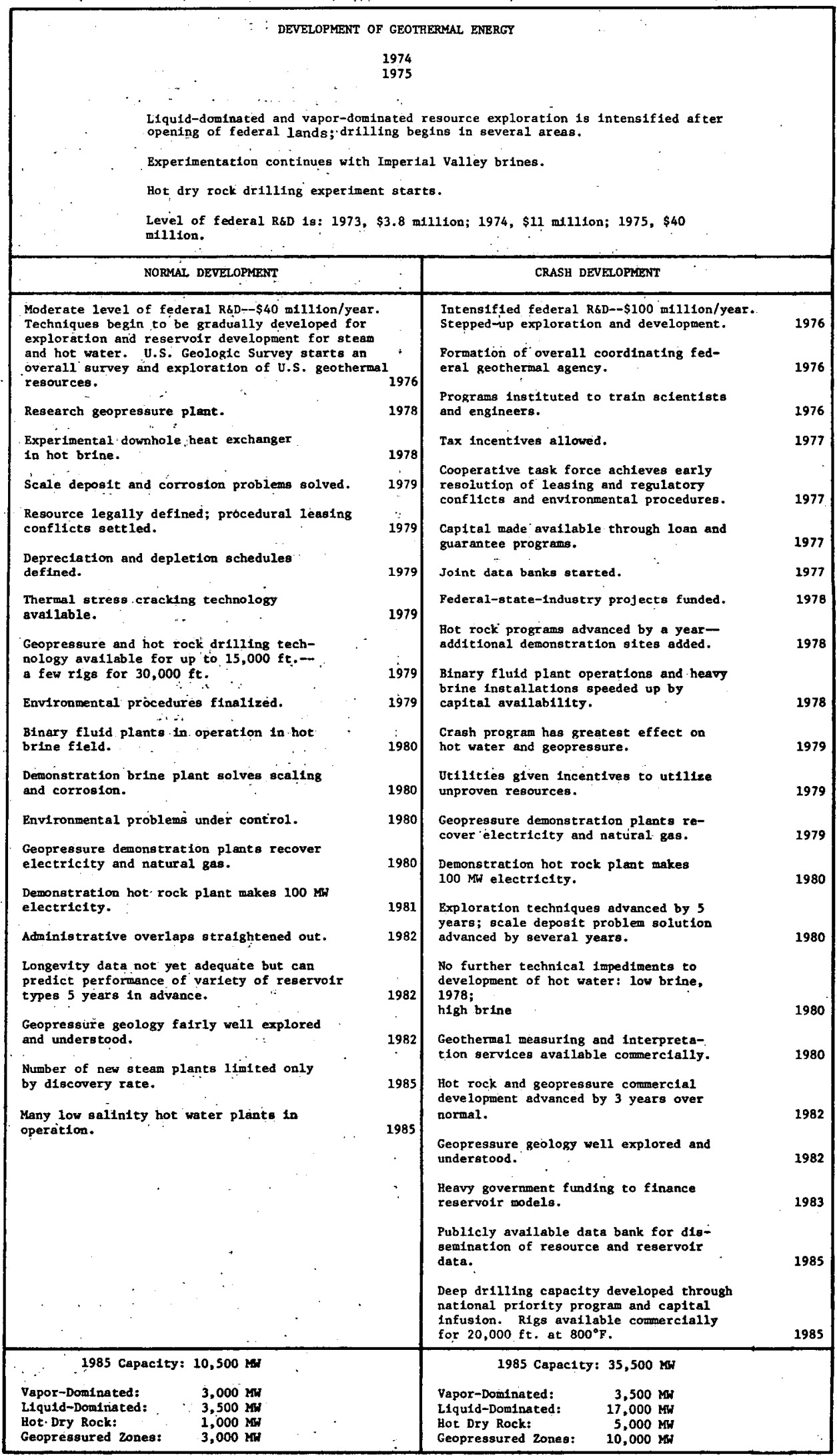

F1gure 3.2.5 CHRONOLOGICAL AND QUANTITATIVE SCENARIOS 


\begin{tabular}{|c|c|}
\hline $\begin{array}{l}\text { NORMAL DEVELOPHENT } \\
\text { BY } 2000\end{array}$ & $\begin{array}{l}\text { CRASH DEVELOPMIENT } \\
\text { BY } 2000\end{array}$ \\
\hline 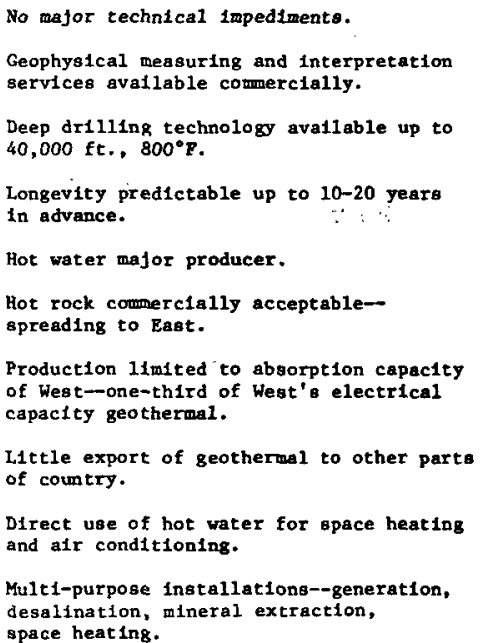 & $\begin{array}{l}\text { Congress making national pollcy to export } \\
\text { geothermal energy from West to the rest of } \\
\text { the country via cross-country transmission } \\
\text { grid. } \\
\text { Western states allowing geothermal production } \\
\text { to increase for export. } \\
\text { Geothermal an important weans of producing } \\
\text { electricity for the whole country. } \\
\text { Hot rock furnishing lncreasing amounts of } \\
\text { energy in eastern areas. } \\
\text { Multi-purpose Installations basis of new } \\
\text { population centers. }\end{array}$ \\
\hline 2000 Capac1ty: 200,000 & 2000 Capac1ty: $770,000 \mathrm{MW}$ \\
\hline $\begin{array}{lr}\text { Vapor-Dominated: } & 6,000 \mathrm{MW} \\
\text { Lqquid-Dominated: } & 100,000 \mathrm{MW} \\
\text { Hot Dry Rock: } & 50,000 \mathrm{MW} \\
\text { Geopressured zones: } & 40,000 \mathrm{MW}\end{array}$ & $\begin{array}{lr}\text { Vapor-Dominated: } & 10,000 \mathrm{MH} \\
\text { L1quid-Dominated: } & 500,000 \mathrm{MW} \\
\text { Hot Dry Rock: } & 200,000 \mathrm{MW} \\
\text { Geopressured Zones: } & 54,000 \mathrm{MW}\end{array}$ \\
\hline
\end{tabular}

Figure 3.2 .5 (cont.) CHRONOLOGICAL AND QUANTITATIVE SCENARIOS

likely to unfold. A matrix was physically laid out through the use of heading cards, with the desirability scale as the abscissa and the probability scale as the ordinate, as shown in Figure 3.2.7. The respondent was asked to place each of the impact statement cards at the matrix intersection which he considered appropriate. He was instructed to make his judgment from the point of view of the national interest, and was encouraged to comment on the reasons for his choices, particularly for those impacts seen as "very desirable" or "very undesirable."

If time permitted, the scale of desirability alone was laid out and the respondent was asked to reclassify the impact cards from the point of view of his own self--or group-interest as contrasted to the national interest assumed above. An alternative approach ut1lized was to ask if there was any area of Impact which, if judged from the respondent's own or professional point of view, might be in conflict with any judgments made from a national polnt of view.

As the final point of the interviews, the respondent was asked to suggest any additional 1mpacts of geothermal development which he could foresee and polficies which he would like to see implemented. This question usually resulted in a summing up of the respondent's overall attitudes and projections.

\section{Overview of Interview Findings}

The results of the socio-political interview sequence were utilized as inputs to the impediment definition (Section 3.3), 1mpact definition (Section 4), and Impact evaluation and policy assessment (Section 5). The interviews produced Information on attitudes and expectations of the various interest groups and on specific current activities in the field. The format was designed to encourage free discussion and the respondents were able to concentrate on their particular area of expertise in commenting on the scenartos and possible impacts. Appendix $C$ contains a compilation of individual responses to each impact question along with additional comments made to clarify the matrix placement. Figure 3.2.7 fllustrates the format used to present the judgments about each impact considered.

The major area of agreement among respondents was that the normal scenario represented a much more $11 \mathrm{kely}$ level of development than the crash scenarlo, which was judged far too optimistic. Although the pattern of the normal scenarlo was in general thought to be falrly realistic through 1985, a number of respondents considered it to be at too high a level for 2000 . Some emphasized uncertainties as to the extent of resources and the possibility of their utilization at the projected levels (particular1y for hot dry rock) within the given time frame.

An underlying theme appeared to be that geothermal energy will evolve. as a supplementary source of power, playing a role perhaps comparable to that of hydroelectric power. As such, it could help provide an Important portion of the energy input for electrical generation and thus help possibly avert both electricity shortages and shortages of fuels replaced by geothermal energy.. Several respondents felt that the electrical load growth would be so great that all available energy resources would have to be developed to thelr fullest, and that only in the case of a hot dry rock breakthrough would geothermal development Impinge on development of other resources. References were made in many cases to ant1c1pated nuclear bottlenecks, and one researcher advanced the thesis that strict conservation of electrical energy combined with use of geothermal resources could drastically cut the need for nuclear power plants in the West.

There was a general agreement that the cost of geothermal steam at present 18 competitive with other fuels used to generate electricity. A utflity source felt that by the 
POSSIBLE IMPAC": OF GEOTHERMAL DEVELOPMENT

1. Air pollution due to electric generation in western regions reduced.

2. Land subsidence disrupting agricultural production.

3. Nolse from geothermal systems disrupting land use patterns (i.e., wildlife habitation, residential, agricultural, etc.).

4. Increased selsulc activity in western regions due to fractures and fluld withdrawal.

5. Localized cllmatic modification in areas where vapor-dominated geothermal systems are developed.

6. Development and construction of nuclear power plants slowed markedly in western regions.

7. Contamination of water tables in many localtites by geothermal wastes.

8. Prevlously 1naccessible areas opened for recreational use.

9. The development of agriculture in previously unfarmed areas stimulated by the availability of Irrigation water from desalinated geothermal wastes.

10. Revitallzation of the drilling Industry.

11. Other primary energy sources (o11, coal, and natural gas) freed for use other than the generation of electricity.

12. Bxclusion of small firms from geothermal development.

13. Large Integrated companies dominating the development of geothermal resources.

14. Reduced needs for Imported petroleum improving the U.S. balance of trade.

15. The construction of transcontinental transmission lines requiring new rights of wav.

16. Tax revenues and royalties from geothermal developments providing the basis for tax reductions in municipalities and states in western regions.

17. Increased Industrial development due to the avallability of low-cost electricticy.

18. Implementation of ant1-poverty programs based upon municipal development and administration of geothermal resource areas.

19. Alteration or modification of home construction techniques to utilize geothermal potential for space heating.

20. The construction and development of new towns near geothermal resource systems.

21. Commercial market for minerals and mineral salts extracted from geothermsl 11quids.

22. Eastern electrle1ty demand met in part by electric1ty exported from western geothermal developments.

23. Improved living standards.

24. Energy 1ntensive Industries located in the East migrating to western regions.

25. Real GNP growth higher than it might have been without geothermal power.

26. Population migration from East to West atimulated.

27. Shortage of skilled manpower.

28. Slowdown in the growth of the aynthet le fuel industry.

29. Increased government regulation of resource development by private enterprise.

30. Despollation of land by coal strip mining essentially terminated.

31. Recreational space in western states reduced.

32. The state of geological sctence advanced markedly.

33. Mult1-purpose Industrial/agricultuṛal complexes developed in the West.

34. Natural gas supplies Increased.

35. Creation of tax sheiters for Investment in geothexmal developments.

36. Formation of many new federal, state, and munfcipal agencies to oversee geothermal resource development.

Figure 3.2.6 POSSIBLE IMPACTS OF GEOTHERMAL DEVELORMENT 


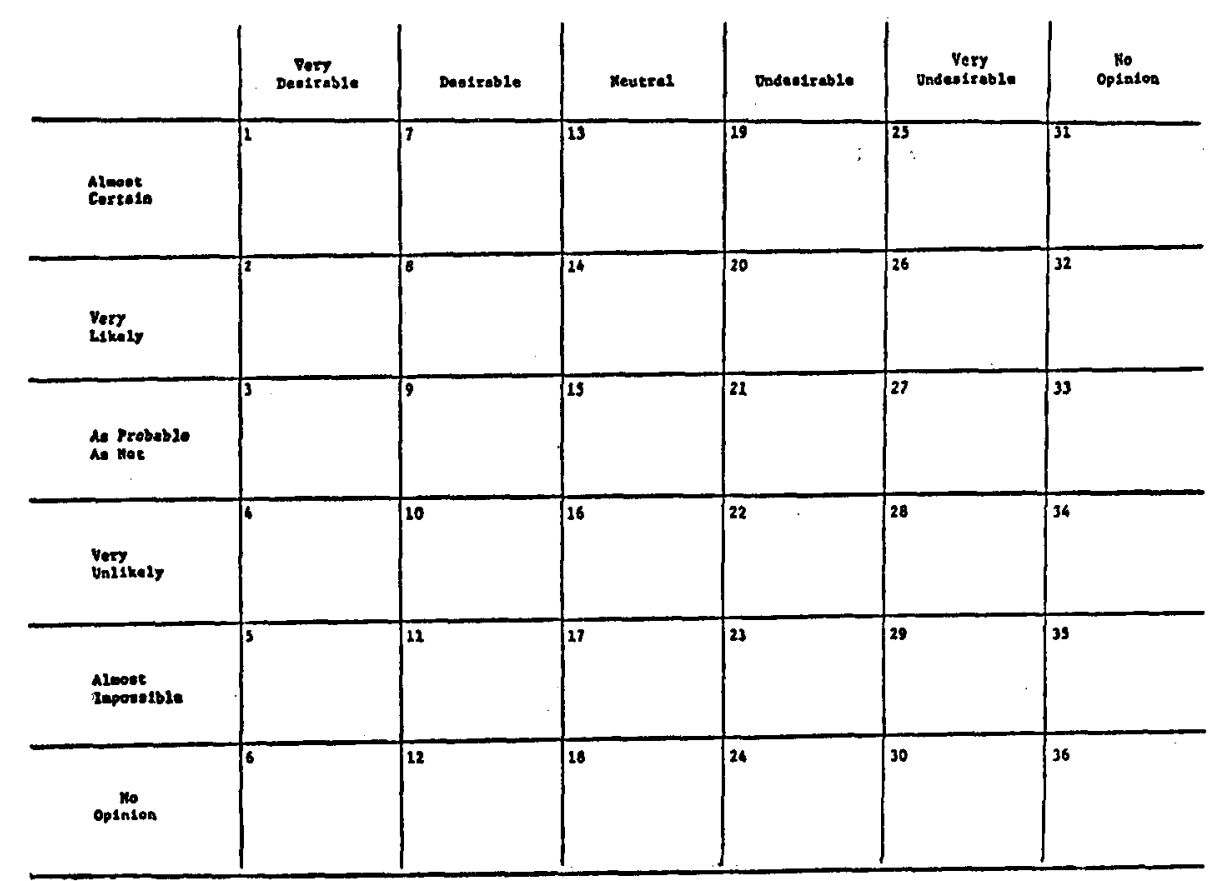

Figure 3.2.7 IMPACT CLASSIFICATION MATRIX

$1980^{\prime} 8$ steam costs could be in the same range as nuclear costs because of additional envirommental protective equipment. Although the use of hot water resources will inevitably cost more than steam, it also was genera1ly projected to be competitive unless very serious problems develop. One operator pointed out that each hot water reservolr will have a different fluld composttion and consequently will require individually designed plants. Under these circumstances, costs from plant to plant could differ by a factor of two or three. Several respondents criticized the present arbitrary method of pricing geothermal steam by tying its cost to other fuels, stating that this provides economic incentive to utilize geothermal resources. It was suggested that pricing be based Instead on the cost of production plus a reasonable rate of return.

Opinions on other aspects of development were wideranging. For Instance, one respondent involved in field operations considered the brine problem of hot water resources almost solved, while another stated it might be insoluble for up to ten years. Federal legislative experts see the basic problem as financing of development, while a representative of an operating company stated that government ald was not needed to finance exploration and should be 11mited to true, research and development. One respondent felt that utilization of minerals from geothermal brine would be of great commercial importance, but most did not think that desalination elther for minerals or water would prove practical.

Pessimism generally prevalled on the possibllity of coordination and simplification of government regulatory procedures. Particulariy singled out for criticism were leasing procedures, complexity of permita. and duplication of emvironmental impact statements.
One official of a development company strongly emphasized his view that the principal obstacle to development lies in the circumscribed nature of the electricity market, where, by law, there can be only one buyer of energy, the local franchlsed utllity.

Assessments of the 11st of possible 1mpacts by the respondents depended, of course, on their view of how the development scenario would unfold. Their perception of the degree of Impact on other energy sources, for Instance, varied with the level of geothermal energy expected to be utilized. Opinions varied as to whether a slowdown in bullding of nuclear plants was desirable and whether geothermal development seemed $11 \mathrm{kely}$ to cause this to happen. The majorlty thought that the use of other geothermal energy would free other fuels, particularly petroleum, for uses other than the production of electricity, but all agreed that geothermal development would not cause a slowdown in the synthetic fuel industry or the cessation of strip mining. There was a wide range of views about whether imports of petroleum and the balance of trade would be affected.

Several respondents emphasized that Industries would be attracted more by the avallability of process heat than by electricity. There was a diveraity of views on the possibility of development of new towns. Most respondents did not expect a noticeable impact on national GNP or living atendarda. Environmental Impacts were generally viewed as locally controllable.

Almost all respondents considered the exclusion of small firms from geothermal development undesirable, but most felt there was a likelihood of this happening. There was also a general expectation of increased government regulation of private Industry and establishment of new geothermal agenc1es, but different views on the desirabillty of this development. 
Most respondents agreed that transcontinental transmission lines would be built in the future but disagreed as to whether the development of geothermal energy would be a causal factor. About half thought there was an even or greater probability that eastern electricity demand would be met by the export of geothermal-generated electricity. One participant theorized that only the development of hot dry rock regources could cause an excess of electricity in the West; but if hot dry rock technology were per-

fected it could be ut1lized in the East, even though it Involved deeper drilling. Eastern development would thereby eliminate the need for transcontinental transmission.

Several important additional impacts of geothermal development were suggested by the participants. These Included a change in the character of management and ownership of electrical systems, a change in the electricity marketing structure, and the effect on electriflcation of rallroads.

Representatives of the varying interest groups offered suggestions as to goverment policles which they would like to see implemented. Among the recommendations were preference for: publicly-owned power compantes in geothermal leasing; establishment of a federal geothermal development corporation to serve as an economic barometer; elimination of bonus payments of leases 1 favor of royalties; government loan guarantee programs; government allocation of pipe casing and drilling rigs; allowance of more rapid plant amortization; government pllot programs to ameliorate present environmental problems; and limitation of government afd to cover only basic research and development.

Figure 3.2.8 summarizes the interview results and Appendix $C$ presents the findings in more detall.

In addition to the structured in-depth interviews discussed here, at least 50 telephone interviews of varying lengths were conducted with informed persons on various specific topics. These conversations were inftiated at varlous points throughout the course of the study when expert opinion or unpublished information on a particular aubject was needed. Those contacted included, among others; utllity officlals, government administrators, suppliers of geothermal equipment, researchers in geothermal and allied scientific flelds, and representatives of trade associations. Their particular inputs are referenced in the sections of the report in which they appear.

DFTERVIEW PANBL ETALUATION OF GEOTHEPQAL DFPACTS

\begin{tabular}{|c|c|c|c|c|}
\hline & DESIRABLE & NEUTRAL & DNDESTRABLE & $\begin{array}{l}\text { DISAGREMIGTI } \\
\text { ON DESIRABILITY }\end{array}$ \\
\hline 2IKELY TO OCCUR & $\begin{array}{l}\text { 1. Reduction In air } \\
\text { pollution } \\
\text { 11. Other energy sources } \\
\text { freed from use for } \\
\text { electricity } \\
\text { 32. Geological sclence } \\
\text { advanced } \\
\text { 33. Mult1-purpose con- } \\
\text { plexes developed }\end{array}$ & & $\begin{array}{l}\text { 13. Large integrated } \\
\text { companies dominate } \\
\text { development }\end{array}$ & $\begin{array}{l}\text { 29. Increased goveriment } \\
\text { regulation of pri- } \\
\text { vate development } \\
\text { 36. Formation of new } \\
\text { government agencles }\end{array}$ \\
\hline $\begin{array}{l}\text { EVEN CHANCE } \\
\text { OF OCCURRENCE }\end{array}$ & $\begin{array}{l}\text { 21. Commercial martet } \\
\text { for mlneralo } \\
\text { 6. Nuclear planţs olowed }\end{array}$ & & & \\
\hline $\begin{array}{l}\text { UNLIKELY TO } \\
\text { OCCUR }\end{array}$ & \begin{tabular}{|l} 
18. Implementation of \\
anti-poverty based on \\
developrsent of geo- \\
the rmal regource \\
23. Improved l1ving \\
standards
\end{tabular} & \begin{tabular}{|l} 
24. \\
Energy-1ntensive \\
Industries migrating \\
to West \\
20. Construction of new \\
towng \\
26. Population migration \\
to Weat \\
35. Geothermal tax shelters
\end{tabular} & $\begin{array}{l}\text { 2. Land subsidence } \\
\text { 4. Increased selomic } \\
\text { activity } \\
\text { 7. Contamination of } \\
\text { water tables } \\
\text { 31. Recreation space } \\
\text { reduced }\end{array}$ & $\begin{array}{l}\text { 28. Slowdown in growth } \\
\text { of oynthet1c fuelo } \\
\text { 30. Strip-mining despoil } \\
\text { ation terminated } \\
\text { 16. Geothermal tax } \\
\text { revenues permit re- } \\
\text { duction of mulcipal } \\
\text { tax }\end{array}$ \\
\hline $\begin{array}{l}\text { DISAGREEMENT ON } \\
\text { OCCURRENCE }\end{array}$ & 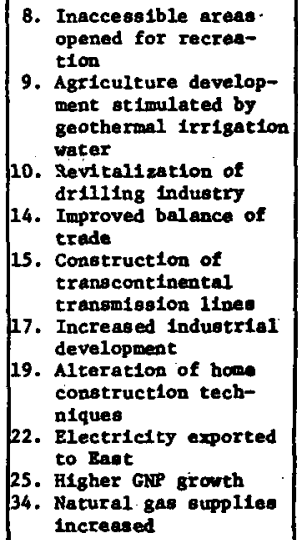 & 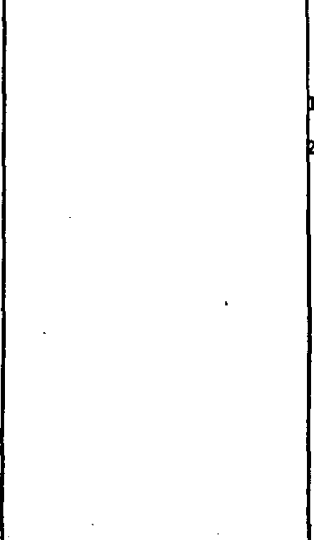 & $\begin{array}{l}\text { 3. Holse discupting } \\
\text { land use patterns } \\
\text { 5. Localized climatic } \\
\text { modifleation } \\
\text { 12. Exclusion of mall } \\
\text { f1rms } \\
\text { 27. Shortage of akilled } \\
\text { manpower }\end{array}$ & - \\
\hline
\end{tabular}

F1gure 3.2.8 INTERVIEW PANEL EVALUATION OF GEOTHERYAL IMPACTS 
3.3 Technical, Social, Polltical, and Economic Impediments

The purpose of this section is to summarize and record critical problems and technical unknowns which may act to varying degrees as constraints on the development of geothermal energy. This list of critical factors was developed from literature in the field and data collected in the two interview sequences described in Sections 3.1 and 3.2. The listing almost certainly will be modifted as experience grows. Nevertheless, it represents a compendium of issues which currently constrain the development and use of geothermal energy.

The impediments are summarized below by principal categorles, and are then repeated in more extended form with a detalled discussion of each issue and its significance in the pattern of geothermal development.

\section{Technical Issues--Summary}

A. Resource Exploration and Development

1. Need for developing more sophistlcated deep sampling techniques and devices.

2. Lack of a practical technique for conducting gross exploration.

3. Lack of understanding of the correlations between sets of geophysical data.

4. Lack of understanding of a geochemical profile.

5. Lack of geothermal data exchange center.

6. Lack of coherent, verified, dynamic reservoir models.

7. Need for improvement in geophysical exploration and appraisal techniques.

8. Limited availability of deep drilling rigs.

9. Lack of generalized, coherent static geological models.

\section{B. Reservo1r Development}

1. Lack of practical technique for very deep and very hot drilling.

2. Present acute shortage of tubular goods.

3. Lack of demonstrated method for recovery of energy from hot dry rock.

4. Lack of demonstrated method for recovery of magma.

5. Non-existence of a demonstrated downhole heat exchanger of sufficlent capacity.

6. Lack of effective method for inhibiting and correcting solids deposition in the formation.

7. Non-existence of proven high-temperature deep-we11 pumps.

8. Unknown effects of reinjection on the producing formation.
9. Lack of knowledge of thermal stress-field inducted in a hot dry rock formation by massive injection and withdrawal of cold water.

10. Lack of confirmed understanding of cause/effect relationship between fluid injection into the formation and the occurrence of earthquakes.

11. Limited availability of drill-rigs for deep to very-deep drilling.

12. Lack of coherent, verified, dynamic reservofr models.

13. Lack of long-term case history data needed for field longevity predictions.

C. Energy Conversion

1. Need for demonstration electric power plant for liquid-dominated moderate temperature resources.

2. Need for demonstration electric power plant for heavy-brine reservoirs.

3. Non-existence of a proven prime mover on a predominatly 11quid two-phase fluid capable of continuous operation.

4. Lack of effective method for preventing scale deposits on internal surfaces of equipment.

5. Lack of demonstration electric power plant for geopressured zones.

6. Lack of demonstration electric power plant for hot dry rock.

\section{Environmental Technology}

1. Need to prevent groundwater contamination.

2. Need to control harmful gaseous emissions.

3. Need to dispose of 11 quid and solid wastes.

4. Need for noise control.

5. Need to understand relationship between fluid injection and earthquake induction.

6. Need for developing techniques for dealing with land subsidence.

Non-Technical Issues--Summary

A. Lack of Uniform Definition of Geothermal Resource And Consequent Tax and Other Uncertalnt les

1. Need for classification as water, mineral, or sul gener1s.

2. Need for clarification of income tax treatment.

3. Need to define allowable depreciation schedules.

B. Land Use Problems Ar1sing from Private Development of Public Lands 
1. Lack of certainty as to use of federal land and operation of leasing regulations.

2. Need to resolve problems arising from patchwork of government and private lands.

3. Need to resolve question of bonus bidding vs. greater emphasis on royalties.

C. Overlaps in Administrative and Environmental Regulations

1. Need for simplification of costly and delaying regulatory maze resulting from multiplic1ty of agencies at many government levels.

2. Necessity to provide assurance to developers of proceeding to production stage.

3. Need for clarification of which level of government's regulations are binding on federal and state lands.

D. Reluctance of Private Financial Institutions, Utilities, or Investors to Back Projects Entailing High Risks, Long Wait's for Return, or Unproven Resources

1. Lack of incentive to encourage investment in inherently high-risk, long-walt geothermal projects.

2. Lack of legal right to include geothermal exploration and development in utility rate base.

E. Commercial Institutional Arrangements

1. Lack of institutional flexibility in producing and marketing electricity.

2. Lack of provision in current utility regulations for multi-purpose geothermal complexes.

F. Availability of Materlals, Manpower, and Capital

1. Present shortage of drill rigs and tubular goods.

2. Need for geothermal experts and trained drill crews.

3. Difficult geothermal competitive position in high-interest, tight capital market.

\section{G. Previous Commitment of Ut1lities to Other Fuels}

Need to evaluate long-term expansion demand for electricity relative to lead-time for plant construction.

H. Conflicting Local, Reglonal, and Federal Interests

Need for cost/benefit trade-offs in environmental areas.
Technica1 Issues--Discussion

A. Resource Exploration and Development

1. Need for developing more sophisticated sampling techniques and devices which are capable of retrieving unaltered representative samples of solids, liquids, and gases at depth. Sampling procedures are divided into two basic groups: those conducted during drilling operations and those conducted after well completion.

Sampling during drilling can be partially characterized as follows:

a. Solids samples (cores) can most conventently be retrieved during drilling. These are required to determine physical varlations in rock types (such as porosity and permeability).

b. Bulk chemical composition is often difficult to determine because soluble fractions and clays are usually washed away by the drilling fluid (water or drilling mud).

c. "Slim holes" (2-3" diameter) yleld more useful data because they do not disturb the sample to nearly the same extent as production drilling. Slim holes are practical to an approximate maximum depth of $3000 \mathrm{ft}$.; their sole purpose is to gain information. S11m hole technology was developed for minerals exploration.

Sampling after well completion can be partially characterized as follows:

a. Solids sampling is almost impossible to perform after well completion because the well casing prevents it and present samplers are not capable of scoopling solid samples from the wall of an unlined hole.

b. Liquid sampling of groundwater at moderate depths is conducted in order to acquire baseline data against which to compare future composition of groundwater in order to monitor possible contamination.

c. Samplers can be sent to the bottom of a hole to retrleve an in-situ liquid sample under no-flow conditions, or a "grab" sample can be taken at the wellhead while the well is flowing.

d. One falrly-effective in-situ liquid sampler has been developed which 18 capable of going to approximately $1000 \mathrm{ft}$.

e. A small submersible pump has been suggested as an effective sampling device.

2. Lack of a practical technlque for conducting gross exploration (1.e., remote thermal I.R. (1nfrared) scanning from Earth Resources Satellite. 
Knowledge of the location of geothermal sources is important to growth in the use of the resource. If reliable synoptic methods for remote identification could be developed, KGRA's could be spectfied and development encouraged: The present thermal infrared scanning instruments appear to be ineffective for the purpose of conducting gross geothermal exploration. The minimum heat flow that can be detected is at least 10 times greater than the necessary minimum value for exploration. Instrumentation explicitly for this purpose is not currently included in the Earth Resources Satel11te Program. Micro-earthquake location techniques may be an alternate synoptic exploration candidate. Certainly, ambitious but potentially useful would be the compllation of a comprehenstve set of geologlcalheat-flow/surface manifestation maps of the entire United States, based on existing uncorrelated data; these data would be expanded by further extensive surface and sub-surface physical measurements.

3. Lack of understanding of the correlation between sets of data obtained from the numerous geophysical measurement techniques. Geophysical measurement techniques include electric surface resistivity, selsmology, magnetic, gravimetric, magneto-telluric, deep electrical resistivity and heat flow measurements. Each has been used to greater or lesser extent in surveying for geothermal sources. There is no clear and general understanding of the degree to which data produced by the varlous methods correlate with each other and with geologic structure at depth.

4. Lack of understanding of the inferential $\mathbf{s i g -}$ nificance of a geochemical profile (identification and concentration of constituents).

A chemical profile $1 s$ needed to predict important characteristics of a particular formation. It 18 important in determining the hydrology and porosity, and can be used to determine the expected levels of produc1bility. The avallability of accurate geochemical profiles would also hold the key to assessing the economically recoverable mineral values. The geochemical profile for each field should be determined before the conversion system 18 designed. In terms of downhole solution chemlstry, measuring pressure, as well as temperature; 18 critical. Much more research is required in order to relate quantitatively the geochemlat analysis to the geothermal resource characteristics.

5. Lack of geothermal data 1nformation center destgned to recelve, store; process, and disseminate existing and future resource and réervolx dața (geologlcal, geophysicai, geochemical, etc.) which is in the public domain for use In resource appraisal, reservolr design and management:

Much data are gathered by private compantes and are not avaflable for public release because of the proprietary nature of the data. The industry urgently needs feedback of data from exploration programs (both successes and fallures) to a centralized data bank so $1 t$ w11l be available for general public dissemination and correlation. Subatantial incentIves will probably be necessary to compensate for the proprietary value of data. Also much of the effort will have to be made by government agencies such as the U.S. Geological Survey and National Sclence Foundation.

6. Lack of coherent, verifted, dynamic reservoir models. To date there are no simulation models avaflable which allow accurate prediction of dynamlc reservolr behavior-with increased driliIng data, the formation of such models will become more practical. Models predicting behavior of reservolis will be useful in determining the optimum rate of heat extraction and reservoir Iffetime.

7. Need for improvement in procedures, equfpment, and data interpretation of the various geophysical exploration and appraisal techniques. The presently available techniques for making geophysical measurements are essentlally laboratory methods which have been adapted to fleld use, and they are often cumbersome, time-consuming, and require the use of highly trained personnel. Therefore, acquisition of data is an expensive and drawnout affair. Greatly improved techniques, procedures, and Instruments are needed which will reduce both required time and costs.

8. Limited avallabilfty of drill rigs and knowledge for deep to very deep dr1lling $(25,000 \mathrm{ft}$. and greater).

Geothermal drilling to date has not exceeded the $10,000 \mathrm{ft}$. depth: The few extsting ultra-deep wells are natural gas wells. Experience in planning and drilling deep, hot, igneous, widediameter geothermal wells is lacking. There are only eight to twelve ratary drill rigs. In the United States today that are capable of drilling to depths greater than $25,000 \mathrm{ft}$. The geothermal drilling industry can expect strong and increasing competition from the deep ofl and gas well drilling industry. Production lead time for this type of drill rig is currently three to five years. Geothermel drilling requires speclally modified petroleum industry equipment. At the present time there is a short-term shortage of tratned persomel, an acute shortage of tublar goods (drill steel and well casing), and keen competition for drill rigs of all capabilitles. The geothermal industry occupies a poor competitive position because of present lack of continuity of the driling work (The Geysers is an exception), 1.e., no. long-term drilling contracts of two to three years in the same general location. This situation can be changed by instituting an organized geothermal. drillitis program.

There are rtgs avallable today which can penetrate to $30,000 \mathrm{ft}$; but what will be most needed are Investors and/or sponsors for more regearch. $A$ thorough systems analysis and planning of all the components of deep geothermal development appears to be needed.

9. Lack of generallzed, coherent, regional geotherma1 geologica1 models (static)."

Reglonal geologic; geophysical, hydrologic, and geochemical studies can pleld maps indicative of resource dispersion throughout a particular region. Such maps could provide insight into the formation of three-dimensional underground models deplcting heat and water flow. If models of this sort were avallable, forecasting the extent of the resource, avallable reserves, and disposal well 
location and projecting the consequence of fluid removal, would all become more feasible and precise.

\section{B. Reservoir Development}

1. Lack of practical, broadly-applicable technique for very deep drilling (1.e.; below $25,000 \mathrm{ft}$ ) or to temperatures above $800^{\circ} \mathrm{F}$ for the following reasons:

a. Compounded drilling fluids ("mud") begin to break down chemically and physically at about $600^{\circ} \mathrm{F}$. Unt11 now, there has been no compelling reason to break through this temperature limit.

b. The water in casing cements boils out of the cement at $600^{\circ} \mathrm{F}$. A $700^{\circ} \mathrm{F}$ setting cement is now being developed.

c. Data measuring and recording instrument packages (logging tools) generally fafl when subjected to temperatures above $500^{\circ} \mathrm{F}$.

Research should be directed toward the temperature and depth goals, proof-ofconcept experiments (POCE), and field demonstrations.

Eventually sources will be required for dr111 b1ts and associated heavyduty drill rigs capable of making holes to depths of $40,000 \mathrm{ft}$. Into formations having temperatures greater than $800^{\circ} \mathrm{F}$. Availability, will be shown by one demonstration in the field.

First demonstration of the energy extraction technology for hot dry rock as a practical energy resource will be at the lower temperature levels $\left(430^{\circ} \mathrm{F}\right)$. Then the potential of very hot rock resources $\left(800^{\circ} \mathrm{F}\right)$ for expanded electric power production will generate the impetus for the development of a high-temperature drilling technology to the state of commercial fleld equipment.

2. Present acute shortage of tubular goods (drill steel and well casing) wh1ch are essential to drilling and casing operations.

Geothermal drilling operations must compete with oll and gas drilling operations, both domestic and foreign, for tubular goods (1.e., for drill steel and well casing). Fabrication plants have been able to keep up with the demand until recently. However, the shortage has now become acute, and is due to a rapid1y increasing domestic and forelgn demand. Forelgn buyers prefer U.S. casing and dr 111 pipe because it is cheaper than foreign fabricated tubular goods because of the devaluation of the U.S. dollar. This situation was exacerbated under Phase IV since price controls prevented ralsing of the domest1c prices; therefore, a very substantial fraction of the supply flowed out of the country.
In the United States alone, there are 85-100 offshore drill rigs being bullt at any one time. Each of these requires approximatel $40,000 \mathrm{ft}$. of drill steel (two complete strt...)

Prior to development of the shortage, normal delivery time was 30-60 days from date of placement of order, with a present slippage rate of 2-3 months per calendar month. The Industry believes this situation is temporary and will return to normal in about two years.

3. Lack of demonstrated method for continuous recovery of energy from hot dry, rock reservoirs. The recovery of energy from hot dry rock is an unproven concept. While large-scale technological problems remain yet to be solved, inttial results from the laboratory and field experiments are very encouraging.

If the present funding is expanded and the research programs are continued until 1985, commercial feasibility may be demonstrated with a 50-100 Me power plant. Within five years from now, demonstrated continuous energy recovery for the western Untted States is possible.

Hot dry rock is ublquitous and therefore development of practical methods for its utilization will be extremely significant for the whole country.

4. Lack of demonstrated method for continuous recovery of energy from magma reservolrs.

The use of this resource is extremely speculative and of low prlority. Potential applications may be found in Alaska and Hawa11 near active volcanoes, but the technology required is 111 defined and very poorly understood.

5. Non-existence of a demonstrated, practical downhole heat exchanger of sufficient capacity to be useful in large-scale energy extraction operations.

Within two years, a downhole heat exchanger system (Van Huisen concept) will be full-scale tested in the Imperial Valley, California. If this system is proven to be feasible many units will be Installed in the Imperial Valley. The approach w11l require an adequate source of cooling water, or other satisfactory heat rejection schemes.

Control of deposition of dissolved solids on the exterfor of the heat exchanger may be achleved by judicious management of well production.

6. Lack of effective methods for inhibiting and correcting solids deposition in the producing formation and in the production casing.

Presently the hydraulic, chemical and thermal mechantsms of deposition are understood but are difficult to deal with and to control. Deposition of calcium carbonate and calclum sulfate 18 a major problem. Silica deposition 18 a problem at temperatures of $240^{\circ} \mathrm{C}$ and higher, and is a major problem at $280^{\circ} \mathrm{C}$ and above. No information is available on silica or calcium carbonate deposits in the formation. Fleld otudies and laboratory studies on the kinetics and 
solubilities are much needed, as well as on methods of inhlbiting scale formation.

Close control of well production rate is required to avold well draw-down, causing flashing and subsequent salt deposition in the formation which may be irreversible, or at least expensive to correct. The effects of mechanical pumping must be well-understood and carefully applied.

A good possfbility exists for a breakthrough within six years. Work will be done to determine effects on the formation, as this is much needed. A required input for solving the silica deposition problem will be good fleld studies with strong laboratory support. For the calctum carbonate deposition problem, the work will parallel that for silica.

7. Non-existence of proven deep-well pumps (for geothermal applications at $500-700^{\circ} \mathrm{F}$.

Electric cable and motor windings are presently available for $300^{\circ} \mathrm{F}$ operation on a routine basis, but at reduced useful $11 \mathrm{fe}$ and increased maintenance costs. Electric insulation 18 temperature-1imited. One experimental aircooled electric motor has been operated autocontinuously at $500-700^{\circ} \mathrm{F}$. Experimental work in the next few years is expected to improve the technology. Requirements for production w111 include: a strong demonstrated demand; development of improved lubricants, such as silicones, etc.; development of high-temperature electric insulation for cables and motor windings; and development of high-temperature bearings and seals.

Hydraulic pumps for this high temperature duty are also beling researched. The main problems are finding a longlife high temperature hydraulic fluid, a lubricant, and a workable mechanical design.

A third suggested pump is a steam driven centrifugal. The most apparent basic problems are mechantcal destgn, seal design, and lubrication.

The development of these three types of h1gh temperature deep well pumps w111 be difficult, expensive, and require much Innovative research.

8. Unknown effects on the producing formation resulting from reinjection of solids-bearing liquid wastes (cooling tower blowdown or flash tank liquid).

Damage to the producing formation from this cause, if any, has not been investigated and therefore 18 essentially unknown. Liquid wastes can be cleaned up (pretreatment) on the surface before disposal or reinjection. It 1 s esseritial to know the geochemical profile of the liquid wastes, the undisturbed liquids in the formation, and the solids in the reinjection zone, especially with respect to calclum carbonate, sllica, clays, zeolites, and sulfate Ions. There is too little thermochemical data presently avallable to permit prediction of the effects on the formation caused by reinjection. The small amount of available data 18 not well characterized with reference to temperature and pressure. It will be necessary to collect much new thermochemical data, and to develop new computer models with inputs which characterize the varfous geological systems, i.e., the chemical composition of liquids and solids which are already in place. Modeling of solution-solution reaction dynamics is also required. Experimental drilling should be conducted in which core sampling is done before reinjection and some years after reinjection, to assess the extent of buildup on the formation. It may be necessary to pretreat before reinjection.

9. Lack of knowledge of thermal stress-fields induced in a hot dry rock formation by massive injection and withdrawal of cold water.

The successful operation of a geothermal hot rock resource depends on the scientific understanding of the behavior of the formation when subjected to infection and flow of colder water. The presence of the cold water w1ll set up temperature gradient fields in the surrounding rock. In turn, this will cause the formation of differential thermal stress-flelds. Very little is known about the hot dry rock characteristics and how it will act under the conditions of the proposed operation.

Laboratory experiments with cast concrete have begun and are yielding some important results. Further laboratory work w1th Igneous rock (granite) similar to that found in actual rock formations is required. This should be followed by proof-of-concept experiments (POCE) at selected field sites.

This successful research is vital to the effective engineering of a hot dry rock power system. A good engineering understanding of the rock thermal mechanics can be used in rock fracturing and creation of the required heat transfer surface and channels. The entire concept can only be proven in a full scale fleld test.

10. Lack of confirmed understanding of cause/effect relationship between fluid injection into the formation and occurrence of earthquakes with respect to possible damage or destruction of the wells, gathering system, power plant or surround ing land.

Th1s mechanism is better understood than 18 generally belleved, and is presently being studied Intensively by the U.S. Geological Survey. Field experiments are very advanced at this time. State-of-the-art of locating earthquakes is also far advanced, 1.e., with a network of Inexpensive sefismic stations. A present Imped1ment 18 the Inability to predict the magnitude of earthquakes. Based on results of recent field experiments by Dr. B. C. Raleigh (USGS) in the oll fleld near Rangely, Colorado, triggering earthquakes by infection of fluids into the formation can be avolded by not injecting where the pressurized fluid can communicate with active selomic faults.

11. Limited availability of dr111-rigs for deep to very deep drilling ( $1 . e .$, below 25,000 ft.) and 
very hot drilling (1.e., greater than $800^{\circ} \mathrm{F}$ ).

Geothermal drilling must compete with oll and gas drilling operations for the avallable drill rigs, skilled personnel, and tubular goods (dr111 steel and well casing). At present, there is a shortage of trained personnel, an acute shortage of tubular goods, and keen competition for drill rigs of all capabilities. Present geothermal drilling technology depends completely upon the ofl and gas Industry developed drilling equipment. Deep drilling requirements 1mply an extended geothermal drilling development beyond present trends which today require only relatively shallow (approximately 5000-10,000 fi.) steam and hot water wells. There are only eight to ten drill rigs in the United States capable of drilling to depths greater than 25,000 ft. Current dr $111 \mathrm{rig}$ production lead time is three to five years. The geothermal industry has a poor competitive position because of present lack of continuity of the drill work, 1.e., it cannot provide long-term drilling contracts of two to three years in the same general location.

The three largest rigs available in the United States today were developed in response to U.S. AEC drilling requirements.

The near-term situation is strongly influenced by the general demand for gas and ofl in the Unt ted States and the foreign value of the U.S. dollar. In terms of performance, drill rig capability can be expected to extend to 40,000 ft. with ability to handle normal geothermal gradient temperature problems (1.e., less than $390-520^{\circ} \mathrm{F}$ ). Present trends in oll and gas exploration and production Indicate that deeper capabilities w111 evolve but it is I1kely that very few drill rigs of this capabillty will extst. Avallabllity of drill rigs, trained crews, and tubular goods for geothermal w111 depend on the geothermal industry's ability to stimulate these essential Items with higher prices and long-term contracts. Among the Incentives which should be consldered are: (a) Government established priorities for drilling equipment; (b) depletion allowance for geothermal steam; (c) means of assuring continulty of work (1.e., two to thiree year drilling contracts), or the ability to pay premium prices for a one- or two-hole drililing effort.

12. Lack of coherent, verifled, dynamic computer reservolr models to understand and manage field development. A concerted, wellfinanced sclentific program should be instituted to obtain data on which to base sufficient dynamic reservoir models.

Private companies probably w111 not initiate the necessary programs of scientific data recovery because $1 t$ is difficult to demonstrate that this kind of Investment is either recoverable, or profitable. Nevertheless, geothermal reservoir models are badly needed now and in the future in order to effectlve1y understand and manage fleld development. A government supported research program could make computer programs and data pubifcly avallable. These w111 be a valuable and necessary tool in the rational development. of geothermal energy.

13. Lack of long-term case h1story data on which fleld longevity predictions can be based. There is a sertous need to correlate geophysical signatures with reservoir characteristics at depth and to develop test methods that allow prediction of reservolr longevity without waiting unt11 the fleld is exhausted. The only data avallable at present $1 \mathrm{~s}$ on The Geysers, Wairake1, and Larderello. Declines in pressure and fluld discharge rates have been noted, but no information about the ultimate significance of these changes is yet at hand.

This situation is likely to be serious because ten years or more of data may be required to form a good Idea of field performance. This will lead, hopefully, to the ability to predict the behavior of a variety of types of fluid reserves for at least five years in advance.

\section{Energy Conversion}

1. Non-existence of a large-scale demonstration electric power plant for 11quid-dominated resources of medium to low thermal quality.

There are no plants now operating on medium to low temperature brines (hot water). Since large quantities of geothermal resources of this type are avallable, there is a great incentive for overcoming this impediment. The problem really has two parts: (1) the plant thermodynamic efficiency, and (2) the brine corrosion, scaling, and deposition due to dissolved salts.

The plant thermodynamic efficlency tends to be low and is limited by the temperature of the brine. The present high temperature brine power cycle (Mexico and New Zealand) which only uses the single flashed steam and discards the remaining hot water is not usable simply because not enough energy is contained in the small amount of flashed steam. Most of the heat will remain in the discarded water, so a cycle 18 required which will use more of the heat in the initial brine. Two general methods are now proposed to do this.

In the first method, the inlet brine is flashed successively, two or three times, at decreasing pressures and each flash is sent through an optimum turbine stage. Such a system would recover most of the avallable energy and have a fatrly good efficiency. Some of the equipment for this cycle will have to be developed. The low pressure steam turbine design will be a problem but probably can be solved. This cycle avoids most of the scale and corrosion problems as the inlet dissolved salts remain in the portion of brine which does not flash and is sent to waste.

The second method is also potentially capable of an economically viable plant efficiency (10-15 percent) because it would use all of the available energy contained in the inlet brines. In this cycle, the inlet hot brine Is sent through a heat exchanger in which 1sobutane or freon $1 \mathrm{~s}$ bolled as the cycle working fluld. Th1s 1sobutane vapor, of 
course, is at an elevated pressure and temperature. This is then sent through a turbine generator to make electricity.

There are a series of problems to be overcome in developing this cycle. First, a heat exchanger must be developed which has a good efficiency and does not scale up. Second, an efficient large size turbine design must be developed for the isobutane or Freon. It does not exist now. Third, and finally, severe scaling and corrosion caused by the inlet brine in the heat exchanger, pumps, pipe, and other equipment, must be controlled.

When all of this is accomplished, medium to low temperature geothermal brines may be ut1lized to generate very large amounts of electricity and space heat.

2. Need for demonstration electric power plant (of any size) for conversion of energy from heavy-brine reservoirs.

While no technical impediments are known to exist in buflding 50-100 MWe plants using the binary process, no expander of this size has yet been built for a geothermal application. The major technical impediment is knowledge of how to control (or 1ive with) the heat exchanger scaling problem. Possibly scaling can be overcome by multi-stagè flash and steam clean-up processes. Employing multi-stage flash systems will permit construction of binary plants of any size. Control of scaling in heat exchangers has yet to be demonstrated. Plans exist (e.g., Magmamax process in the Valley) for a small-scale demonstration plant to be built in five years, plus three years of testing, for a total of elght years.

3. Lack of a proven prime mover capable of continuous operation on a predominantly liquid two-phase fluld.

The liquid dominated brines are essentially two-phase systems, vapor-1lquid at the turbine inlet temperature-pressure conditions. Since a conventional turbine cannot withstand 11quid material without breaking, new design machines are required. This new machine must be capable of converting the energy in the vapor-liquid brine at elevated pressure and temperature to mechanlcal work and then to electriclty. Thermodynamicaliy, this is an adiabatic Isentropic expansion of the entire geothermal vapor-11quid mass. of course, the process and machine must operate continuously. Such an energy conversion machine (turbline) does not exist now. A large research effort is required to solve this problem and build a reliable machine. At present there is a small industry effort to develop a machine capable of handling a two-phase fluld. A prototype KROV (Reller Rotating Osclllating Vane) engine 18 presentiy being built. Test plans call for a full range of mechanical and performance tests by persomel from M.I.T. Hydrothermal Power Company has accumulated approximately 1000 hours of operational experience on a machine which functions directly on high-energy brine, employing a helical-screw type expander. Considerable development expertence has been accumulated by General Ener-Tech, Inc., in bladeless turbines utilizing superheated steam, and also In varlous hot gas applications in ranges from 3-1600 hp. Add1tionally, General Ener-Tech has developed several two- and three-phase pumps in performance ranges to $1000 \mathrm{gpm}$ which also utilize this princtple. Currently undergoing development testing is a $250 \mathrm{hp}, 300 \mathrm{gpm}, 500 \mathrm{psig}$ geothermal reinjection pump which is scheduled for testing on a geothermal weil in the Imperial Valley, Callfornia.

4. Lack of effective method for preventing scale deposits on intemal surfaces. of mechanical equipment, 1.e., heat exchangers, pipes, turbines, etc.

Hot saline brines are we 11 known for their corrosiveness. However, there are some reasonably good methods and materials for dealing with low salinity water. These methods are for 10,000 ppm dissolved salts and for fairly lowsulfate ions and dissolved silica. A combination of selected non-corrosive metals and design methods can be used to give a successful geothermal unit. However, hot saline brines containing large amounts of salts, such as those of the Imperial Valley, Californda $(300,000 \mathrm{ppm})$ present a very difficult set of problems. The only known non-corrosive materials of construction are expensive and must be used in combination with improved engineering design in order to make: the plant economical. Such designs will have to be developed, as well as improved with less costly metals.

The fouling and scaling. of the internal surfaces is mainly due to the deposition of calclum * sulfate and silica. . This is a set of problems, not just one. New techniques will have to be developed to control the water chemistry, the heat transfer, the mass transfer, and the eng $1-$ neering design. This set of problems is formidable. They have been attacked slowly and piecemeal in the past. A well thought-out coordinated research program is now required to solve this critical problem.

5. Lack of a demonstration electrtc power plant of any size for conversion of energy from geopressured zones.

The geopressured resource is extensive but relatively little is known about environmental and technological issues assoclated with its use. Most important among environmental concerns is the posstbility of land aubsidence; ..prominent among technical issues are techniques for reinfection of waste fluids, recovery of the mechantcal energy from the pressurized fluid, and, finally, efficient conversion of the low temperature heat to electrical energy of $\because$

6. Lack of a demonstration electric power plant of any size for conversion of energy from hot dry rock.

A 10 MWe demonstration plant will be built at the Los Alamos Sclentific Laboratory test site, posstbly by 1978. Among the Important problems yet to be resolved in the use of this potentially important energy source are:

a. Determining the rate at which heat can be extracted from the heat source.

b. Developing effective methods of increasing the heat transfer surface through hydrofracturing and other means. 
c. Ascertaining the effect of this energy extraction form on selsmicity.

d. 'Determining the available heat resource contained in the surrounding rock strata.

e. Researching, developing, and demonstratIng the whole' system of machinery required to continuously circulate water through the rock fractures, extract heat, carry it to the /surface power plant heat exchangers, boll the turbine working flutd, and convert it to mechanical and then electrical energy.

\section{Environmenta1 Technology}

1. Necessity for developing practical techniques for preventing groundwater contamination. The importance of this Issue w111 be a functIon of the type of geothermal reservolr, Its hydrological setting, and the means employed for fluld recharge or disposal of geothermal fluids.

Rejsearch is needed to show whether it $1 \mathrm{~s}$ possible to recharge an underground reservolr at an acceptable rate at the approprlate depth and stratum and still prevent contamination of any groundweter aquifers which are likely to be used as 'a water supply source.

2. Necessity for developing techniques of. effectively controlling harmful or nulsance gaseous emisstons. $\left(\mathrm{H}_{2} \mathrm{~S}, \mathrm{CH}_{4}\right.$, ammonia, etc.).

Hydrogen sulfide 18 present in very small amounts in both steam and hot water we1ls. Research to control $\mathrm{H}_{2} \mathrm{~S}$ emissions from power generating units with an open cycle, wet cooling tower, and with dry steam, as at The Geysers, is falrly well understood. Demonstration at the prototype and operational. levels is scheduled for 1974 . Control of $\mathrm{NH}_{3}$ and $\mathrm{CH}_{4}$ emissions 18 not necessary at The Geysers and therefore should be the subject of future research, although neither presents much of an environmental problem.

3. Necessity for developing broadly applicable techniques for liquid and solid waste disposal.

Disposal of liquid waste brine by reinjection has already been demonstrated and 18 commerclally reliable at The Geysers. Means of disposal of solid waste products are now being invest1gated at The Geysers and $a$ solution 18 expected during 1974.

Techniques for disposal of both 11quid and solld wastes must be fully developed and commerclally rellable. Disposal of solid wastes may require landfill sites.

However, IIquid waste brine disposal otill is a very formidable problem In liquid geothermal ffelds such as the Imperial Valley, California. Extensive research 18 required to solve the many problems assoclated with

chemlatry, corrosion, pumps, geochemistry, geophysics, reservolr engineering, and environmental chemistry, among others. The solution of these problems will require a large effort:
4. Necessity for developing practical and effective techniques for noise control during initial drilling and testing operations, as well as during operating life of the plant.

A noise problem exists for high-pressure steam wells during drilling and clean-out blow, which is due to the use of compressed afr as a drilling fluld, and the uncontrolled release of the natural steam. At present, drilling mufflers are in an experimental stage of development. A clean-out blow lasts from 6-48 hours, depending on the characteristics of the well. For hot water systems, nolse is not a problem at the well during drilling, because drflling mud is used instead of compressed air, and there is no uncontrolled release of the geothermal fluid.

During operation there are several places in a field at which some steam is blown off, creating a considerable nolse. This, of course, is localized. Research is required to develop good functional sound muffilng equipment.

5. Lack of confirmed understanding of cause/effect relationship between fluid injection into the formation and occurrence or suppression of earthquakes, with respect to environmental effects on the surrounding area and populace.

Dr. B. C. Raletgh (USGS) has demonstrated in the ofl fields near Rangely, Colorado that earthquakes can be triggered as a result of infection of fluids into regions which contain active selsmic faults. Clearly a requirement for geothermal operations will be the avoidance of active seismic faults. When deep wells, either primary or reinjection, are utilized it may prove difficult to Identify faults a priorl. Therefore, what is required is a more basic understanding of the mechanism by which fluid injection relates to earthquakes; and a means of more positively ldentifying the course of faults, particularly deep faults.

6. Necessity of developing predictive, preventive, and corrective techniques for dealing with land subsidence consequent from geothermal fluid withdrawal.

Subsidence is of most concern in the use of geopressured zones and shallow hot water resources. In the latter case, reinjection of fluids after heat removal should virtually eliminate any potential subsidence threat. (However, if the fluids which are removed are used to supplement local water supplies, and the net amount returned is less than the amount extracted, subsidence may result.) In the case of geopressured resources, the situation is more complex. The under surface flulds exist at very high pressure, therefore, reinfection in the same strata would require high pumping pressures and, therefore, could potentially eliminate an appreciable portion of the advantages which might accrue to the use of this energy source.

Much more research in geophysics and geology is required to understand the phenomena involved in subsidence and reinjection of water into rock strata. At this time very little is actually known, In a sclentific sense, about the factors involved and their interrelat Ionships. 
Non-Technical Issues--Discussion

Ack of Uniform Legal Definition of Geothermal Resources and Consequent $\mathrm{Tax}$ and 0 ther Uncertaintles

1. A state of uncertainty exists as to whether geothermal resources should be legally classified as water, minerals, or sui generis. The Geothermal Steam Act of 1970[1] (see also Appendix K) clarifies this matter to some extent. It does, however, leave to be settled the question of whether reservation of minerals to the United States in prior land grants and patents included the geothermal resources. Ownership of resources is therefore in ques$t$ ion in many cases. No unique legal definition of geothermal resources has been provided by Congress and current conflicts must now be settled through iftigation.

2. The lack of clear definition particularly impedes development by perpetuating uncertainty of treatment under income tax laws. Investors do not have any assurance that they w111 be entitled to tax incentives similar to those provided for the oil and gas industry. These incentives include the depletion allowance and deduction of intang1ble drilling costs. The Reich case [2]. in 1969 established that steam produced at The Geysers in California could be classified as a "mineral gas" for tax purposes. Consequent$1 y$, participants in drilling ventures in that area are entitled to deduct the depletion allowance from gross income recelved from steam production and to expense the intang1ble costs of drilling and developed wells. Tax treatment is still uncertain, however, for steam in other places and for non-steam resources. The question remains whether they are depletable resources or continually renewable. Depreciation schedules have also not been defined to fit special geothermal conditions.

3. It is probable that the present situation will lead to time-consuming court cases turning on the definition question. Research into legislation which could be recommended to speed up the process could result in earlier removal of this impediment. Studies are also needed to evaluate the effects of various tax treatments and depreciation schedules, and to expedite their adoption so that private developers will be able to proceed with greater assurance.

B. Land Use Problems Arlsing From Private Development of Public Lands

1. About $60-70$ percent of geothermal resources are on government-owned land, and in many promising exploratory areas a patchwork of public and private land exists, "These conditions :" have led inevitably to a number of conflicts and uncertainties. The most basic difficulty centers around which land can be developed. The opening of federal lands for leasing in 1974 removed the greatest obstacle to explora$t$ ion, but some aspects of the leasing law have been subject to criticism. or remain to be clarified.

Including the element of "competitive interest" in the definition of a KGRA, it is claimed by some private developers[3], will inhibit acquisition of leases in areas not currently designated as KGRA's by allowing the Secretary of the Interior the option of reclassification for competitive bidding if more than one bid is recefved in an area with more than 50 percent overlap. In contrast, if this type of situation occurs on federal land in non-competitive 011 and gas areas, the choice is made solely by order of application or by lottery. The criterion is purely physical, i.e., whether the land is within a known geological structure. Reduction or elimination of this administrative discretion and redifinition of KGRA's on a purely scientific basis would clarify this situation. Other ambiguous ttems in the leasing regulations are provisions for duration and renewability of leases and the definition of land subject to leasing because of environmental factors. This.latter definition may take a number of years because of the necessity to balance the diverse interests involved.

2. A related 1and-use problem is the need for joint development of areas where governmentowned land, elther federal or state (or both), are intermingled. There is provision in the leasing law for unit or cooperative agreements for such areas, but questions remain as to whether federal, state, or local land-use regulations would govern such developments.

3. There has been some criticism of the use of the bonus bid system for competitive leasing on the grounds that. It favors larger companies over the small operator who does not have the financial capability to tie up a large amount of money prior to production. Emphasis. on larger royalty payments rather than prepald bonuses would also, tend to maxtmize long-term rather than short-term income to the government.

Ambiguities in the leasing law can be clarified by amendment or by changes in regulatory action, but studies are. needed to determine what type of emphases (e.g.; competitive vs. non-competitive bldding, or bonus vs. increased royalty payments) would best serve the needs of the Industry and the public.

$$
\cdots \cdots
$$

\section{Overlaps In Administrative and Environmental} Regulations

1. A multiplicity of agencies with some responsibliftes in the development and use of geothermal energy exist on the federal, state, county, and local level, each with its own standards, requirements, and time schedules. This situation 18 compounded by confusion as to the nature of the resources and by the involvement of vartous types of regulatory bodles on all levels. These include agencles with jurisdiction over public lands, geothermal resources per se, oll and 8 as, water, bullding inspection, public work, public utilities, and spec1-

* fic environmental areas such as land planning, air pollution, f1sh and, game, and forestry. Figure 3.3.1 (on the following page) charts the regulations which must be met in California for each phase of the development.

2. Different regulations must be complied with at each stage of exploration and drilling, and there is no assurance that the developers will 


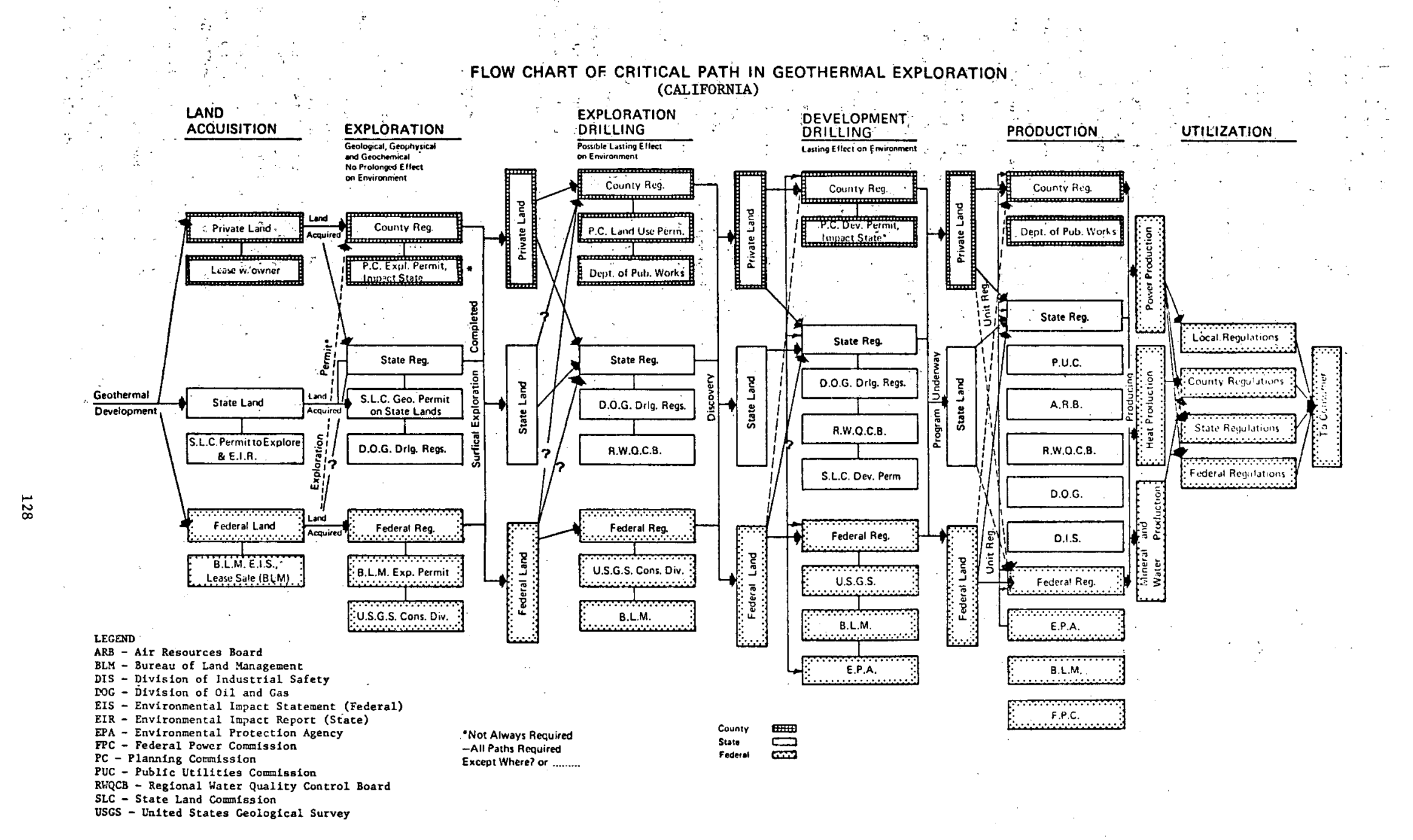

Source: David Anderson, Division of 011 and Gas, State of California. 
be able to continue on to production. As many as three environmental impact statements can be required for each project. It is difficult for developers to be aware of all required procedures, and the necessary compliance involves costly duplication of effort and time delays. There is also a lack of administrative finality in the environmental area. [4]

3. In addition, there is the problem of what regulations are binding on what land; that 1s, if state regulations can apply on federal land, and county zoning and environmental regulatIons on state and federal land.

As more exploratory drilling is done and environmental knowledge of the resource is augmented, necessary standards will become more clearly defined and duplications may be able to be gradually ellminated, although all levels of government will malntain their concern. Immediate measures to enlist the cooperation of all agencies and interests involved could speed up the simplification process. Study teams could datermine the best way for this to be accomplished. Statewide geothermal regulatory clearing houses could be established for instance, to work for standardization of laws and regulations, coordinate processing of forms and public hearings, dissemtnate information to developers, and encourage counties to establish land use and zoning plans which give developers some assurance that their profects can be carried to completion. Californla has made a start in coordination of federal and state agencles through 1 ts Geothermal Resources Board.

An additional possibility for simplified requirements is amendment of the National Environmental Protection Act to allow one Impact statement for all levels of government. This could still allow local input, since present statements are not generally conflicting, but repetitive.

This one statement might be more extensive than any of the former separate ones because of the need for some different information by different levels of government. It has been auggested that some 11mitations be put on rights of appea1 in order to ensure some degree of administrative finallty, but some political conflict can always be expected to exist in this area.

Another contribution to unraveling the regulatory maze could be made through establishment of multilevel commissions to prepare model laws and standard operating procedures for states. In addition to streamlining procedures, such measures could enable developers to operate In different states without having to become familiar with entirely different regulations.

Although it will be possible through coordinated efforts of all involved to make regulatory procedures more clearly defined and easier to fulfill, a large number of regulations wIIl always have to be met in order to accommodate the interests of all levels of the public.
D. Reluctance of Private Financial Institutions, Utilities, or Investors To Back Projects Entalilng High Risks, Long Waits for Return, or Unproven Resources

1. Even after basic research has shown that a process can be commerclally viable, financing may be difficult to obtain. Especially in the high-interest capital market which prevalls today, with many competing demands for money, high risk and long-term projects are hard to finance. These high risk and long walt factors are inherent in geothermal development. Several years can elapse between the time a producing well is drilled and the time purchase contracts are negotlated with utilities and generating plants are bullt. Developers, particularly smail operators with limited resources, are being constrained by these conditions.

2. Ut11ities are also discouraged from undertaking investment in geothermal field exploration, appratsal, and development, and equipment and process research and development because of uncertainties as to whether utility commissions w111 allow costs of these activities to be included in utility rate bases.

W1thout some sort of government incentive programs, these investment factors will be major constraints on development. [5] Development would at first be limited to those few projects which would be judged to have an immediate chance for commerclal success. Any steam resources found would be most easily financed because of their proven capability. At least several years of production and convincing geological evidence that the resource would continue might be necessary before a utility would comit itself to utilize a hot water resource. Hot dry rock and geopressured resources, because of their greater uncertainties, would probably require a longer time to attract venture capital.

Several proposals have been advanced in Congress to provide utility and investor assurance, though none has been yet enacted. Title II of S1283 [6] authorizes a loan guarantee for geothermal development. It guarantees banks or other financial institutions against loss of princ1pal or interest on loans to acquire rights in geothermal resources and to perform exploration, development, and construction and operation of commerclal production facllities. The guarantee extends up to 75 percent of the cost of the project, up to $\$ 25$ million for any project, and up to $\$ 30 \mathrm{~m} f 111$ ion for any borrower. The government is authorized to pay the interest if the borrower is unable to do so. The bi11 authorizes up to $\$ 50$ million to be appropriated to a Geothermal Resources Development Fund . [7]

Another approach is contalned in Title I of S1283, applying to all energy research. It provides for federal purchases or price guarantees for products of demonstration plants. Another possibility is for local governments to declare a moratorfum on property taxes between the time a well $18 \mathrm{dr}$ illed and returns are realized. 
An additional avenue is for uttlities to offer loans for development drilling, wh th utility commissions permitting the costs to be included in rate base formulation. In return, the utility could recelve an option to purchase steam. Utilities presently use thts method with the o11 and gas industry.

\section{E. Commercial Institutional Arrangements}

1. One of the most fertile areas for innovative research lies in the area of institutional arrangements for marketing the products of geothermal energy, both electrical and nonelectrical. Arrangements developed in the past which were suitable for utilization of other forms of energy may not be adaptable for this form and may indeed hinder its development.

The primary area of concern is the structure of the electric utility Industry and its transmlssion network. Privately held public utilities are granted monopoly status in their areas and are closely regulated by public utflity commissions. They are generally allowed to sell no product other than electricity, gas, or water, and no competing firm may operate in their franchised territory. Transmission lines are owned by the companies and are not common carriers. (In publicly-owned systems, such as exist in the Pacific Northwest, transmission lines are common carriers.)

Any private geothermal company which develops a geothermal resource therefore has only one customer for his product-the local utility. Selling it to another utility would require permission to use the local utilities transmission system or building of new lines. A recent Supreme Court decision (Otter Ta11 vs. U.S., February 1973), [8] may modify this situation. The court in this case ruled that a power company 18' not exempt from antitrust regulation and cannot refuse to "wheel" (transfer) wholesale power from another producer to another consumer. Unt1l the precedent 18 well established, however, this factor may deter development.

2. The possibility of multiple uses of geothermal energy may also pose a problem. [4] If chem1cals or desalinated water are developed from geothermal resources along with electrical power in a multi-purpose complex, the utilities may not be allowed to sell the non-electrical product. Conversely, an industrial company developing such a complex would not be allowed to sell electricity. Use of geothermal water for district heating and cooling or for industrial process heat might involve simflar institional problems.

As the capability for such 1nstallation grows, It must be accompanied by investigation of legal changes necessary to permit effictent marketing methods.

\section{F. Ava1lability of Materials, Manpower, and Capital}

Even though an estimated level of geothermal capacity may be attainable technologically and 1nstitutionally, its feastbility must still be judged on a production basis. Materials, manpower, and capital must be avallable to implement the projections.
1. Major considerations in materfals needs for geothermal development are the avallability of drill rigs and tubular goods (well casing and drill steel). These materials are essentially the same as are used in the oil industry. At the present time, there is an intensification of exploratory oil drilling. For a number of years, this drilling has been in a down-trend, but the recent higher prices for crude oil triggered a surge in activity. The total number of wells drilled ts expected to rise from an estimated 26,600 in 1973 to 30,500 in 1974 (Figure 3.3.2).

NUMBER OF GAS AND OIL WELLS DRILLED IN THE UNITED STATES

\begin{tabular}{|ll|}
\hline 1974 & 30,500 (EST.). \\
1973 & 26,596 \\
1972 & 28,755 \\
1971 & 27,300 \\
1970 & 29,464 \\
1969 & 34,853 \\
1968 & 32,914 \\
1967 & 33,818 \\
1956 & 58,000 \\
\hline
\end{tabular}

SOURCE: AMERICAN PETROLEUM INSTITUTE

DRILLING RIGS IN USE IN THE UNITED STATES

\begin{tabular}{|ll|}
\hline 1974 & 1,600 (EST.) \\
1973 & 1,435 \\
1972 & 1,376 \\
1971 & 1,235 \\
1970 & 1,506 \\
1969 & 2,074 \\
1968 & 2,110 \\
1967 & 2,308 \\
1956 & 4,845 \\
\hline
\end{tabular}

SOURCE: WORLE OIL

\section{Figure 3.3.2}

With this rise in drilling has come a scramble for materials. Although the supply of rigs is tight, the major constraint on current activity is a shortage of tubular goods. According to officials of equipment supply and drilling assoclations, $[9,10]$ this shortage may be a shortterm one, stemming primarily from distortions of steel price relationships and probiems of allocation which particularly affect independent drillers.

Steel executives predict general steel shortages in the United States for at least two to three years before additional capacity can meet overall demand. However, they anticipate a greater supply of oll country goods (comprising certain types and grades of pipe) resulting from diversion of production from cold rolled sheet production, which is down because of decreased demand from the auto Industry. [11] Stee1 companies have assured the government that shipments of oll country tubular goods will increase by 25 percent in 1974. In addition, steel inports from Europe increased approximately 25 percent over the previous year during the first 
five months of 1974 , although prices were 2530 percent above domestic levels.[12] Thus, it appears that by the time geothermal development enters an intensive phase, an easing of material shortages can be expected; although current operations are being delayed by the limited avallability of casings.

In the next few years, probably around 15-20 drilling rigs w111 be required for geothermal exploration and production wells, with about 200 MWe per year being added to production capacity. This assumes a combination of a 10 percent success rate for wildcat wells and a 90 percent success rate for development and production wells, an average production of $5 \mathrm{MW}$ per well, and a drilling rate, including downtime, of four 6000-ft. wells per year per rig. After 1985, assuming the rate of expansion of geothermal capacity has gradually increased to about 2000 MWe a year, and the installed capacity is about $7000 \mathrm{MWe}$, approximately 150 rigs will be needed; in the early 1990's, assuming expansion averaging 5000 MWe a year, about 375 rigs a year; and by 2000, when capacity has reached $190,000 \mathrm{MWe}$ and expansion is proceeding at 20,000 MWe a year, about 1500 rigs will be required.

By comparison, there are currently approximately 1600 drill rigs operating in the United States [13] and about 100 additional rigs are being produced annually.[9] In the 1950 's, however, there were several years where over 4800 were in use. The historical pattern for tubular goods parallels that for drill rigs. In 1956, over 2.3 million tons of oil country goods were sold to the oil industry, 50 percent above the current market.[10] A condition of excess capacity existed in the industry for 15 years unt 11 the energy crisis reactivated exploration.

The estimated expansion of about 10 percent above current levels by 1985 in drill rigs and accompanying materials to meet geothermal requirements and 100 percent by 2000 would seem to be within the long-term capacity of supply industries. The consensus of equipment industry spokesmen is that if a geothermal market is defined and there is reasonable expectation that demand for equipment will last for at least flve years to provide an adequate amortization period, probably normal geothermal demand could be' met along with the expanding needs of the o11 industry. $[9,10]$

Although the accelerated level of drill rig production and the necessary accompanying production of tubular goods seems within longrange feasible limits, government incentive or guarantee programs, plus some sort of allocation program might be required for shorter-term expansion. As mentioned above a market must be defined with a reasonable expectation of sustained demand before manufacturers can be expected to increase their output. Tax incentives or low interest loans to expand capacity for geothermal materials would speed up the free market process. In addition, an allocation program could ensure that geothermal developers, especially those with no historical records of purchases, could recelve their share of tight supplies. This provision would be of particular benefit to independent operators, espectally those with no connection to the oll industry.
2. It has been estimated that there are in the country today only about 50 trained geothermal explorers and 50 engineers with direct experience in the development and utiliza$t$ Ion of geothermal power. [14] There are, however, earth scientists and engineers in other fields whose skills are adaptable to this area, and a large pool of college students who could be directed into the field. Past experience in development of other new technologies indicates that the supply of scientific manpower increases to meet the demand if well-paying jobs are avaflable.[15] When the aeronautical field opened up, for instance, there were no specifically trained engineers, but mechanical engineers switched to the field. Similarly, at the inception of the nuclear industry, many chemical engineers chose this new opportunity. If good salaries and opportunities are available in geothermal enterprises, the same type of change-over can be expected to occur. If other industries are simultaneously experiencing shortages of scientific personnel and competition is keen, the worst that can be expected is a four-year lag to allow colleges to produce the needed manpower. A recent M.I.T. study of engineering manpower [16] concludes that the supply of new entrants to engineering is highly responsive to economic conditions. These conditions were measured by starting salaries and by vartous factors that determine job opportunities, salaries, and the state of the market.

The Bureau of Labor Statistics[17] projects a record number of college graduates through the mid-1980's. The available supply is estimated at 15.3 million from $1972-1985$, about 750,000 above projected job requirements, even after including the assumption that there will be an increasing trend toward specifying college graduates for jobs formerly filled by lesseducated workers. The gap will be greatest in the latter part of the perlod, 1980-1985, because of projected slowdowns in the growth rate of the economy in those years. The BLS does not project unemployment for college graduates, but rather conditions of underemployment at occupational levels lower than anticipated and consequent job dissatisfaction and increasing occupational mobility. In the face of this situation, avallability of engineering and geological job openings w111 certainly induce college students to prepare for them. Declines in engineering enrollment in recent years were attributed to the perceived lack of opportunities rather than to any shortage of scientifically inclined students. According to the College Placement Council, 59 , percent of all business and industry fob offers to 1974 B.A. graduates were made to engineers, who comprise only 5 percent of total graduates.[18] The Scientific Manpower Commission recommends that a program be set up to assess. long-term scientific manpower needs to avold the successive pertods of shortages, and oversupply, which have existed In the recent past

Some outside stimulation may be required to accelerate the process of developing scientific personnel. Programs could be instituted to alert colleges and professional groups to geothermal opportunities more quickly. Examples are government grants for seminars to spread geothermal information, grants to universities for work involving graduate students, and provision of student internships on geothermal profects. In addition, premium pay scales 
might be necessary to immediately attract ta1ent from allied flelds.

There is currently a shortage of trained manpower for operating ofl drilling rigs. This appears to be a short-range condition, however, precipitated by the sudden surge in drilling activity brought on by the energy'crisis. It takes four to five months to train a crew member, according to the International Association of Drilling Contractors, and intensified trainIng programs are now underway. In addition, some workers who were lald off during the perlod of declining oll well drilling activity from 1968-1973 can be expected to return to this occupation if it appears to offer continuing opportunities. The trend towards more highly automated equipment also reduces the former need for crew members of unugual. strength or stamina.

At an average of 17 workers per crew for each drilling rig, the $150 \mathrm{rigs}$ estimated to be needed around 1985 for an expansion rate of 2000 MWe per year could require about 2500 workers, and the 1500 rigs in the year 2000 , about 25,000 .

Labor has historically been attracted to areas where job opportunities offering good pay are avallable, and can be expected to move in from outside the area if it is not avallable in the West. In addition, California, the expected site of a large proportion of geothermal activity, has its climatic advantages to offer. From 1960-1970, the population of California Increased by over 4 million persons. In relation to this growth, additions of $2,500-25,000$ geothermal workers to the labor force of the whole West area by 2000 are minimal.

In addition to drilling crews, of course, workers will be required to operate the production facilities and the electrical generating plants. These can be considered as transfers from other types of plants which would be operated in the absence of geothermal facilities, however, and would not exert any net additional demands on the labor market.

3. Capital markets are highly competitive today, and will continue to be so into the foreseeable future. "Shortages of energy and a number of basic materials point to the need for expanded capacity." Manufacturers Hanover Trust Company projects annual capital spending by American industry of $\$ 147$ b111ton from now through 1985 as compared to $\$ 90$ b11lion in 1973 (in 1971 dollars). Electric utility requirements are particularly heavy both in absolute and percentage terms $[19,20]$ since growth in electricity consumption has in recent years been almost double the real growth rate of the economy as a whole. Electrical World forecasts a total of $\$ 266$ billion needed for Investment in electricity generation alone (excluding transmission and distribution fac1l1ties) from 1973-1990.[21] Profecting this ten years further gives a total of $\$ 506$ billion needed from 1973-2000. On a proportional basis, about $\$ 100$ billion of this sum would be required for electrical generation in the western regions. If it $1 \mathrm{~s}$ assumed that geothermal energy will replace other fuels for electrical generation and that costs will be comparable or less, then total expenditure needs would not be increased by geothermal development. As a practical matter, however, geothermal projects have to compete in the capital marke place with more traditional forms of investment at a time when it seems 1mprobable that all capital demands can be met. At the present time, a number of utilities which had planned to finance facilities through sale of common stock have deferred new issues because of unfavorable stock market conditions and have switched to debt funding instead. This has led to sluggish sales of recent $1 y$. issued bonds.

As discussed in Section 3.5, a level of 190,000 MWe of geothermal capacity in 2000 would require a cumulative investment of: $\$ 95$, bilition. (Th1s figure is not comparable with the Electrical World forecast above since it includes exploration and drilling expenditures as

well as investment in generating facilities.) In order to recelve the necessary financing, either from financial. institutions or individual investors, geothermal investment veh1cles will have to be made as or more attractive than competing forms. Since exploration is a high-risk enterprise and development dr1ling, though less risky, is still unproven, elther high rates of return must be expected or government guarantees provided to reduce risk of default. High prevailing interest rates can destroy the economic viabllity of a project if there is a long lead time between exploration and production, and since this is a common situation in geothermal development, government subsidization of Interest payments may be necessary. Government subsidized loans are provided for geothermal development in Title II of S1283, as described in Section D. 2 above, and if a measure of. this type is passed, it will greatly expand the funds available.

Ralph Saul, Chairman of the First Boston Corporation, describes new methods for utility financing, [22] which appear to be applicable to geothermal development. He points out that traditional methods cf financing will no longer be adequate in the face of massive need for capital. Utilities will have to finance fuel sources or even assume ownership of production facilities and finance long-distance transportation of fuel. They will form folnt ventures to further these projects, with several methods of financing described which could be used for geothermal profects. In the,first, the partic1pating companies will guarantee the debt incurred by the foint company. Another method 1s the "take-or-pay" contract, in which each utility commits itself to purchase a specific percentage of the output and pay the same percentage of the costs. Alternatively, the project company can lease the facilities from the financial institution providing the funds.

In addition to funds raised through federal government guarantee programs and innovative private investment approaches, there may be some local government financing provided for geothermal development. The C1ty of Burbank, in confunction with a private developer, has already leased federal land for exploration.

\section{G. Previous Comitment of Utilities-to Other Fuels}

Demand for electricity will double every ten years if recent historical growth rates continue. The National Power Survey of the Fede 
Power Commission projected an increase in national capacity from 390,000 MWe in 1970 to 1.26 billion MW in 1990 in order to meet demand.[23] Projecting this curve at the same rate would give a level of about 2.5 billion YWe in 2000. In light of recent emphasis on conservation, it seems appropriate to reduce these demand estimates by 10 percent or 80 to account for energy-saving measures. Some may argue that 10 percent is not enough, that conservation will be much more powerfu1. Perhaps so, but there are also forces 11kely to come into prominence which will tend to increase electricity consumption, most notably the drive toward selfsufficiency. This objective leads inevitably to increasing relative use of coal and urantium, probably in the form of electricity.

Using the FPC estimates, generating capacity in the west region, comprised of 11 states, would increase from 64,900 MWe in 1970 to over 400,000 MWe in 2000 , even with the 10 percent reduction. Using these assumptions, utilities will have to plan for enormous expansion.

Because of shortages of natural gas and oll, the choice for new facilities appears to lie between coal and nuclear. The pollution problems of coal, both in the mining stage and in the generating stage, indicate that nuclear facilities will be deemed by many utility companies to be the long-range desirable alternatives. Industry forecasts made by Electrical World indicate that nuclear power plants wil1 rise from about a quarter of the new capacity coming on line in the mid$1970^{\prime} \mathrm{s}$ to close to one-half in the $1980^{\prime} \mathrm{s}$. [23] The FPC estimates that nuclear energy will supply half the total U.S. generation by 1990. [23]

Since nuclear plants presently require lead times of seven to ten years because of siting and licensing problems, the question arises of whether utilities would be able to absorb geothermal energy when avallable if their needed capacity additions are already comitted. This lead-time factor may be modified somewhat in the near future by the adoption of standardized nuclear plants requiring less individualized design time. However, installation of nuclear plants is now about five years behind projected schedules, and, in some cases, crash installation of alternative fossil-fueled generation has been necessary.

The Atomic Industrial Forum recently announced that a record number of orders for nuclear reactors were placed in 1973 and that U.S. ut111ties now have a total commitment for 213 reactors for a total capacity of 204,470 MWe. [24] It added, however, that a number of nuclear plant construction and licensing schedules have continued to sIIp, and that there is also a shrinking inventory of acceptable power plant sites. According to the Federal Power Commission, 42 of 47 nuclear plants planned for operation in 1974-1978 are behind schedule by an average of 25 months. [25]
In the west region, the FPC estimated that about 25,000 MWe of nuclear power would be on-1ine by 1980. At the present time, however, according to Electrical World, only 11,500 MWe of nuclear capacity is committed for that area for installation by 1982 , in addition to the currently existing 1628 MWe. It does not seem feasible, then, considering the lead times involved, that the projected levels can be met.

In the West, at least, geothermal energy may come on line in some instances as a stop-gap for slipping nuclear schedules. It is unreasonable to expect utilities to drop current and near future nuclear commitments in favor of geothermal sources. If the resources are present, and utilities are convinced of the resource's reliability, cost, and longevity, geothermal sources can provide in the next decade a partial augmentation, easing the impact of slipping nuclear schedules in the West.

\section{H. Conflicting Local, Regional, and Federal Interests}

These problems are just beginning to develop and will grow increasingly severe, particularly if a crash geothermal policy is followed. In opening federal lands for leasing, for instance, there are the questions of which land to open f1rst and which should not be opened at all. Some local areas may want development and others may be against it for environmental reasons. Even though a whole area may need power, a particular locality may not wish to be chosen as its site. When it comes to a question of providing energy for other areas of the country, one region may not want to bear the environmental costs:

Areas of conflict are also becoming apparent in the case of geothermal water, particularly in the Imperial Valley. Several states plus Mexico use the waters of the Colorado River; and, if desalinated water is used to reduce the salinity of the river as planned, there will be questions of where to introduce the new water and who will reap the greatest benefits.

Transportation of geothermal energy may engender the greatest conflicts of interest. Since geothermal resources are in scattered areas, ut1l1zation other than at the site will require transmission networks, and the localities on the way to load centers may not wish to be transversed. Interstate and cross-continental transmission can be expected to engender even more controversy.

Land and water problems will probably be gradually ironed out through 11tigation and negotiated agreements. Environmental siting problems and transmission rights may involve extensive public hearings, with federal, regional, and state planning commissions or other bodles arbitrating conflicts of -interest. Acceptance of local undesirable effects may be encouraged by consideration of the alternative effects of nuclear siting. In the last analysis the decisions made w11 be polftical and governed by a trade-off of cósts and benefits among varlous areas of the country. 
REFERENCES

The Technical and Social Interview Panels as listed in Sections 3.1 and 3.2 provided extensive materials for this section in addition to the references 11 sted below.

[1] Geothermal Steam Act of 1970, 30 U.S.C., Sec. 530, 1000 et seg.

[2] U.S. v. Relch, 52 Tax Court, 700 aff'd 454 F 2nd 1157 (9th C1r.1972).

[3] Finn, Donald F. X., private papers, 1974.

[4] Proceedings, Nationa1 Conference on Geothermal Energy (Riverside, Calif.: University of Californla, August 1973).

[5] The Potential for Energy Production from Geothermal Resources, Report of the Subcomittee on Water and Power Resources, Committee on Interlor and Insular Affairs (Washington, D.C.: U.S. Government Printing Offlce, December 1973).

[6] S. 1283, Nationa1 Energy Research and Deyelopment Policy Act of 1973, 93 rd Cong., lst Sess. Passed Senate December 7, 1973.

[7] See p. 25 for a discussion of the Geothermal Energy Research, Development and Demonstration Act of 1974 (P.L. 93-410, Append Ix J), which enacted a loan guarantee and Interest assistance program.

[8] Otter Tail Power Co. v. U.S., 410 U.S. 366, 35 L. Ed 2d 359, 93 S Ct. 1022 (1972).

[9] Private communication, Warren L. Baker, International Association of Drilling Contractors, 1974.

[10] Private communication, W1lliam J. Sallans, Petroleum Equipment Supplies Associates, 1974.

[11] "A Grim Forecast for Steel Users," Business Week (May 11, 1974).

[12] Farnsworth, Clyde H., "Europe Se11s More Steel Here," The New York Times (June 20, 1974).

[13] Private communication, World 011 Magazine (1974).

[14] Fuchs, Robert L., and W. Westphal, World O11 Magazine (December 1973).

[15] Private communication, Alan. E. Harger, Center for Policy Alternatives, Massachusetts Institute of Technology, 1974.

[16] Freeman, R. B., Changes in Englneering Manpower, 1948-1972 (Cambridge, Mass .: Massachusetts Inst1tute of Technology, Center for Pollcy Alternatives, September 1973).

[17] Johnston, Denis F.," "The U.S. Economy in 1985-Population and Labor Force Projections," Monthly Labor Review (December 1973).

[18] Vetter, Betty M., "Assessing the Demand for Scientists and Engineers," Science, Vol. 184, No. 4132 (Apri1 5, 1974).

[19] Archbold, Pamela, "Utilitles Money Shortage," The New York Times (March 17, 1974).

[20] "Ut1lities Face Pricing Dilemma," Business Week (February 2, 1974).

[21] Electrical Wor1d, 1974 Annual Stat1st1cal Report (March 15, 1974).
[22] Saul, Ralph, "Energy and the Capltal Markets, Public Ut1lities Fortnightly (January 31, 1974).

[23] The 1970 National Power Survey (Washington, D.C.: Federal Power Commission, December 1971).

[24] Sm1th, Gene, "Industry' Report Asserts Nuclear Power 'Came into Own' in 1973," The New York Times (January 16, 1974).

[25] Schorr, Burt H., "Bottlenecks Hinder U.S. Plans To Boost Supplies of Energy," Wall Street Journal (May 9, 1974).

The following are other references, not numbered in the text, used as background for this section.

Private communication, Robert Platte; American Iron and Steel Institute, 1974.

Private communication, David Anderson, California Division of 011 \& Gas, 1974.

U.S. Senate, Hearings on S. 2465 before the Subcommittee on Water and Power Resources of the Committee on Intertor and Insular Affairs, 93rd Congress, Washington, D.C.; November 7, 1973.

U.S. Senate, Hearings on S. 2465 before the Subcomittee on the Potential for the Production of Power from Geothermal Resources, 93rd Congress, Washington, D.C., June $13,1973$.

U.S. Senate, Hearings before the Committee on Interior and Insular Affairs, 92nd Congress, on the role of geothermal energy resources in our nation's future energy Washington, D.C., June 15 and $22,1972$. 
3.4 A System Dynamics Model of the Electric Utility Decision Process

\section{Introduction}

One of the major determinants of the rate of growth of geothermal energy in the United States is whether or not the utility companies will wish to buy energy from this source. If they do there will be a "pul1" on the development of the resource; if they do not, there wi11 be little economic incentive to pursue the enterprise. Therefore, it is important to ask about the factors likely to be involved in the utility company dectsion process, how these factors may change with time, and when geothermal energy sources seem likely to measureup to competing energy sources.

Imagine a situation in which a utility company executive Is faced with a decision about what type of generation capacity to add to his system. He sees a gap between presently avallable generation capacity and projected demand. Suppose there are several alternative systems from which he might choose. What factors would enter his decision process? The ilterature in the fleld, informal discussion with a number of utility company executives, and the socio-economic interviews suggest that competing systems might be compared on the basis of:

Rellab1lity: (Is the rate of unplanned repair and malntenance 11kely to be higher for one than the other?)

Environmental Hazards: (Clearly systems must comply with environmental regulations; nevertheless it may be easier to do so with one than with the other.)

Fuel Availability: (Is fuel likely to be equally available for both syatems over Its anticipated 1ife?)

Capital Costs: (Is one system likely to be 1 ess
expensive than the other?)

Operating Costs: (Is the manufacturing cost of electricity higher for one system than the other?)

Construction Time: (Is the planning and construction process more lengthy for one system than the other?)

The relative importance of these factors has changed somewhat with time. For example, economists Harvey Averch and Leland Johnson assumed and demonstrated in a widely discussed theoretical paper in $1962[1,2,3,4]$ that utilities with regulated rates of return would find it to their stockholders ' advantage to oyercap1talize. Whether this was done in the past is not clear. $[2,5]$ However, the current inflationary climate, lagged regulatory action, and conditions in the capital markets, in which utilities are hard-put to ralse needed money by elther equity or debt financing, appear to have made the "A-J B1as" thesis currently untenable:

Decisionmaking in the utility industry has been the focus of a recent study.'[5] Th1s shows that plant investment has usually been gulded by a'judicious evaluation of the 11sted factors. There-seems to be little doubt that criteria are changing; and all the factors in the list presented above are now of primary concern in the selection of generation facilities.

Geothermal energy could be evaluated on the basis of any of the factors in the 1ist; how it will fare depends not only on the state of prior development but on perceptions about its performance vis-a-vis competing energy sources.

Th1s statement of the problem suggested that a model could be constructed to simulate the utility company dectsionmaking process. (See Appendix E.) Such a model was developed and used to explore sensitivity of geothermal development to prospective policies designed to Influence the rate of development and to initial assumptions. It is worth repeating the caveat presented In Section 1.3:

The model used here Involves many assumptions about relationships and the values of vartous in1tial parameters. As a forecasting tool, it produces results which reflect and depend on these assumptions. In this study the assumptions and values of Intial input parameters were largely based on judgments of The Futures Group and its consultants; therefore the output reflects those judgments.

The model is not expected to serve as a substitute for other forms of detailed analysis. Although it necessarfly produces estimates of the consumption of coal, nuclear, solar, and other energy forms used in generating electricity in the United States, these should be regarded only as artifacts of the Input assumptions. Nevertheless, the model was useful in several ways: It resulted in the development of a coherent set of assumptions concerning those factors apt to influence the rate of growth of geothermal electrical generation systems and, based on those assumptions, it provided a means for beginning the analysis of the consequences of contemplated policies. It also provided a means for exploring the sensitivity of certain conclusions to changing Input assumptions.

Simulation modeling is one of the most useful of policy analysis techniques. The general concept behind mathematical models is simply that the model can serve as a surrogate for the real system. A mathematical model is a detailed, mathematical description of the relationships among the most important variables within a specifled system. Thus, given values of these variables at one point in time (the condition of the system at that time), the state of the system at some later time can be calculated. The usefulness of mathematical models stems from the fact that human judgment 18 not capable of relfably determining how complex systems are apt to change with time or tin response to external influences. Although a person may have detalled knowledge about particular parts of a syatem, the number of interactlons taking place may be too large to handle on an aggregated judgmental bag1s. Mathématical modeling assumes that by using human judgment to specify the parts of the system and the nature of their interactions (a simpler task with fewer varlables Involved) a model can be constructed that will display the behavior of the system in a more rellable manner.

System dynamics is one method of mathematical simulation. It was developed during the $1950^{\prime} \mathrm{s}$ by Professor Jay $W$. Forrester of the Massachusetts Institute of Technology. This technique is based on Information feedback within closed systems. An example of a simple information feedback loop in a closed system ls a television cameraman who views a scene through the eyeplece of the camera. Using this Information, he makes a decision about how to move the camera to bring the acene into the center of the plcture. If he overshoots, the projected scene conveys this information and corrective action is taken. Of ten many such simple loops interact with each other, producing complex gystems. 
Figure 3.4.1 depicts one of the feedback loops in the electric utlifty model. Projected electrical demand is compared with present generating capacity to determine the need for new capacity. This leads to new plants being planned. After planning and construction delays, present capacity is increased by the completion of these new plants.

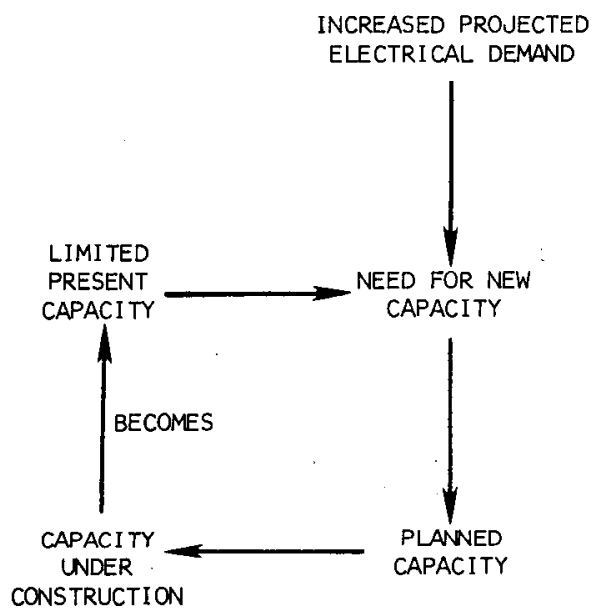

Figure 3.4 .1

When system dynamics modeling is applied to a spectfic problem, the first task $1 \mathrm{~s}$ to identify the feedback loops that appear to have bearing on the problem. The next step is to study these feedback loops to determine the decision points and, once these are Identified, to. describe the decision process, including the information used In these decisions. Bullding on this information, a simulation model 18 defined and tested by comparing its behavior with actual historical system behavior. The model may be refined unt11 it appears to represent the real system accurately. This model is then used as a tool for experimentation to identify methods of 1mproving the system behavior which can then be studied in more detall before introduction.

\section{The Electric Ut1lity Model}

The electric utility simulation model developed in this study is primarily a model of the decision mechanism involved in the construction of new central station generating capacity. Given a certain level of future demand and Information concerning future costs and other characteristics of the varlous generating alternatives, the model calculates on-line capacity for each alternative through the year 2000. Separate calculations are made for the western region of the United States (as defined by the Federal Power Commisalon) and the remainder of the country.

Figure 3.4.2 11lustrates the calculation of the need for new capacity. Demand for electricity is supplied to the model as an input. FPC projections [6] have been used through 1990 and extrapolations of those trends have been used to simulate demand projections through 2010. These profections are presented in Figure 3.4.3. In the model, profected demand 18 read from the table, ten years in the future.

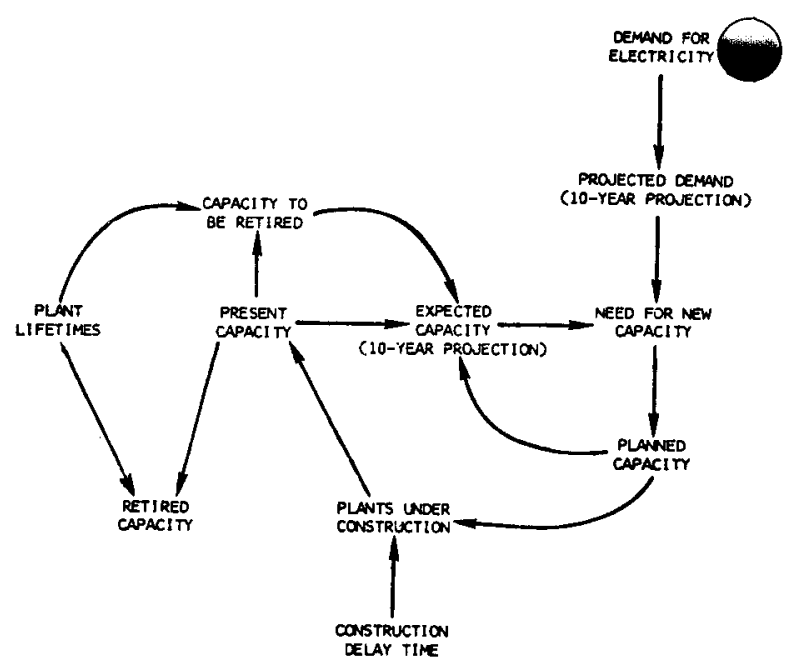

F1gure 3.4.2 Determination of Present Capacity and Need for New Capacity

\begin{tabular}{|c|c|c|}
\hline YEAR & EAST & WEST \\
\hline 1970 & 109 & 44 \\
1975 & 374 & 94 \\
1930 & 536 & 129 \\
1985 & 710 & 181 \\
1990 & 1005 & 255 \\
1995 & 1281 & 340 \\
2000 & 1558 & 406 \\
2005 & 2045 & 533 \\
2010 & 2532 & 060 \\
\hline
\end{tabular}

Figure 3.4.3 Demand for Electrical Capacity (1000 Me)

The need for new capacity is the difference between projected demand and expected capacity, the capacity that w1ll be on-1ine in ten yeara if no new capacity 18 planned. Expected capacity is found by subtracting the capacity of plants that will be retired during the next ten years from present capacity and adding the capacity of plants that are already planned or under construction. The Initial values of present and planned capacity are shown In Figure 3.4.4. The amount of new capacity that is needed to meet projected demand 18 then allocated among the various genersting alternatives as planned capacity which, after construction and planning delays, becomes on-1ine capacity. 


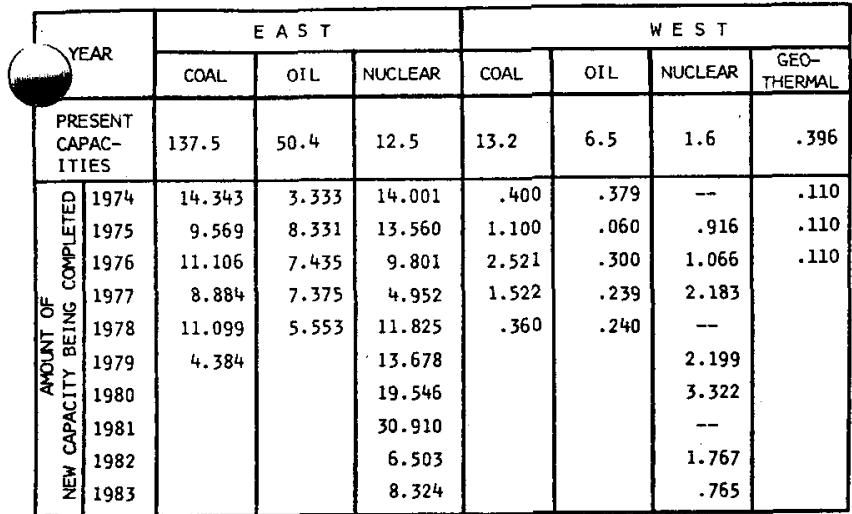

SOURCE: NEW CAPACITY ADDITIONS PLANNED OR IN CONSTRUCTION AS OF JUNE 1 , 1973 COMPILED BY ELECTRICAL WORLD (NEW YORK: MCGRAVI HILL, 1973).

Figure 3.4.4 Present and Planned Capacities Used As Initial Model. Values (1000 MWe)

The process by which needed capacity is allocated to the various alternatives is shown in Figure 3.4.5. The alternative generating plants included in the model are coal, ofl, nuclear, geothermal, solar, natural gas, hydroelectric and, for the East only, imports of energy from the West via a transcontinental grid. Natural gas and hydroelectric capacities are input to the model, following National Electric Reliability Council [7] and FPC projections, and do not enter into the allocation process. Figure 3.4.6 presents the projections used.

The decision value for each alternative is a measure of the perceived desirability of that alternative to the ut1lity. It is assumed that the desirabilfty is based

\begin{tabular}{|c|c|c|c|c|}
\hline \multirow{3}{*}{ YEAR } & \multicolumn{2}{|c|}{ E A S T } & \multicolumn{2}{c|}{ WE S T } \\
\cline { 2 - 5 } & $\begin{array}{c}\text { NATURAL } \\
\text { GAS }\end{array}$ & $\begin{array}{c}\text { HYDRO- } \\
\text { ELECTRIC }\end{array}$ & $\begin{array}{c}\text { NATURAL } \\
\text { GAS }\end{array}$ & $\begin{array}{c}\text { HYDRO- } \\
\text { ELECTRIC }\end{array}$ \\
\hline 1970 & 55 & 22 & 22 & 30 \\
1975 & 43 & 21 & 19 & 35 \\
1980 & 37 & 23 & 16 & 42 \\
1985 & 30 & 25 & 13 & 47 \\
1990 & 24 & 27 & 10 & 52 \\
1995 & 20 & 30 & 9 & 55 \\
2000 & 16 & 32 & 7 & 58 \\
2005 & 14 & 34 & 6 & 61 \\
2010 & 12 & 36 & 5 & 64 \\
\hline
\end{tabular}

SOURCES: PROGRESS REPORTS OF THE REGIONAL ORGANI ZATIOASS TO TTEE EXECUTIVE EOARO OF NATIOOAAL ELECTRIC RELIABILITY COLNCIL (PRIACETÓN, N.J.: NERC, APRIL 1973); FEDERAL PONER COMMISSION.

F1gure 3.4.6 Profected Natural Gas and Hydroelectric Capactites (1000 MWe)

on the six criteria previously listed:

1. Perceived reliability.

2. Percelved environmental hazards.

3. Percelved fuel avallability.

4. Percelved capital costs.

5. Perceived operating cost of electricity (at the busbar).

6. Perceived construction time.

Initially, the selection of the factors themselves, the welghts accorded them and the other judgmental inputs to the model were provided by the study team. As mentioned earlier the study team was strongly guided in these choices by the literature and informal

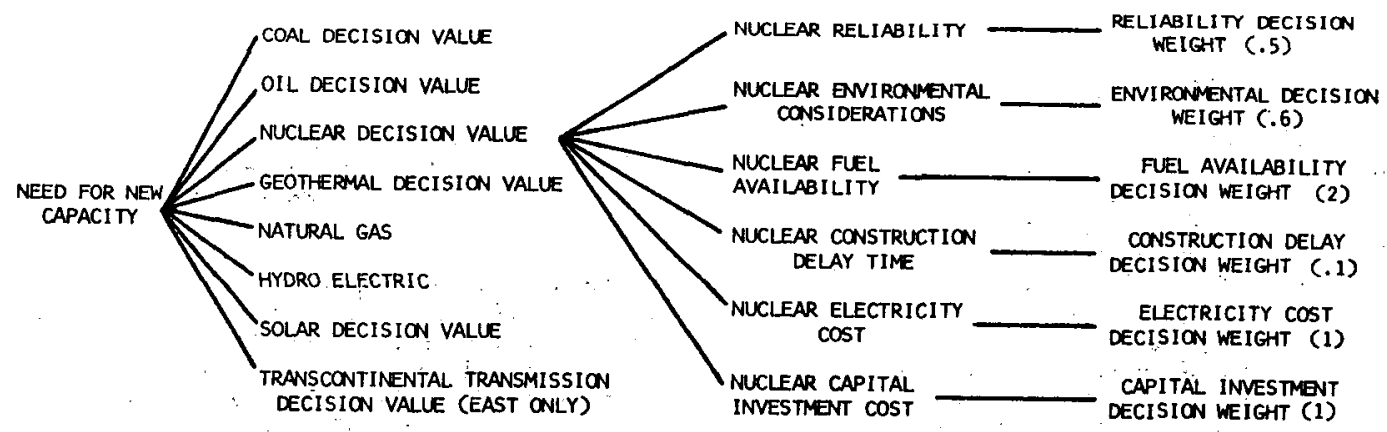

NOTE: DECISION FACTORS ARE SHOWN FOR NUCLEAR ONLY; CONSIDERATIONS ARE SIMILAR FOR COAL, OIL, GEOTHERMLL, SOLAR, AND TRANSCONTINENTAL TRANSMISSION; HYDRO AND NATURAL GAS CAPACITIES ARE EXOGENOUS INPUTS.

Figure 3.4.5 Allocation of New Capac1ty 
discussions with utility company executives. Early runs of the model were conducted with only these inputs. When it appeared that the model could indeed serve a useful purpose in the study, a small panel of experts familiar with or Involved in utility company decisionmaking was assembled to provide the required judgments. [8]

Total decision values for particular alternatives were found by multiplying the weight for each decision factor by the perceived value of that factor for that alternative and suming the products for all six decision factors. (ThIs is shown for nuclear only in Figure 3.4.5.)

For example, the total decision value for nuclear in 2000 is found by summing the following products:

Perceived nuclear reliability (.9) x rellability decision weight $(.5)=.45$

Percelved nuclear capital cost factor (.43) $x$ capital cost decision weight $(1)=.43$

Percelved nuclear environmental impacts (.9) $\mathrm{x}$ environmental decision welght $(.6)=.54$

Percelved nuclear electrical cost factor (.56) $\mathrm{x}$ electrical cost decision weight $(1)=.56$

Perceived nuclear fuel availability (.95) $\mathrm{x}$ fuel availability decision weight $(2)=1.90$

Percelved nuclear construction delay factor (.5) $\mathrm{x}$ construction delay decision weight $(.1)=.05$

Total: 3.93

The sum of these products, 3.93 , is the total decision value for nuclear in 2000. Dividing the value by the total decision value for all fuels in the year 2000

(this figure is 14.32) yields the amount of new capacity needs that will be met by new nuclear plants. In this case 27 percent of the capacity gap would be filled with new nuclear plants.

Thus, the most important factor in the decision is fuel availability, with capital investment and electricity costs also having high importance.

The values of the decision factors for the varlous alternatives are expressed as numbers from zero to one, with one denoting the most desirable. The actual estimates used for each alternative are presented in Figures 3.4.7 through 3.4.11. The estimates for environmental impact, rellability, and fuel availability are expressed directly as numbers from zero to one. Estimates for capital costs, electricity costs, and construction delay time are expressed in real units. These values were converted to numbers from zero to one by dividing the value (of electrictty costs, for example) for a particular alternative into the value (of electricity costs) for the least expensive alternative. Thus, if nuclear electricity costs are $32 \mathrm{mills} / \mathrm{kWh}$ in 2000 and the least expensive alternative $1 \mathrm{~s}$ geothermal at $18 \mathrm{mills} / \mathrm{kWh}$, the nuclear electricity cost factor would be $18 / 32$ or 0.56 .

In the estimates of percelved reliability (Figure 3.4.7) the transcontinental grid is assumed to be the most reliable since it is connected to a number of different plants. The rellability of coal plants is assumed to decline somewhat as complicated pollution abatement equipment is added.

\begin{tabular}{|c|c|c|c|c|c|c|}
\hline YEAR & COAL & OIL & NUCLEAR & $\begin{array}{c}\text { GEO- } \\
\text { THERMAL }\end{array}$ & SOLAR & $\begin{array}{c}\text { TRANS- } \\
\text { CONTI } \\
\text { NENTA } \\
\text { GRID }\end{array}$ \\
\hline 1973 & .8 & .9 & .6 & .7 & -- & 1 \\
\hline 1985 & .7 & .9 & .9 & .7 & .55 & 1 \\
\hline 2000 & .7 & .9 & .9 & .8 & .65 & 1 \\
\hline
\end{tabular}

Figure 3.4.7 Estimates of Perceived Plant Reliability (The scale is from 0 to 1 , with 1 denoting the most rellable plants.)

Capital cost profections (Figure 3.4.8) were prepared by using actual englneering estimates through 1982 and escalating at 1.5 percent per year (constant December 1973 dollars) thereafter.[9] Solar central station capital costs in the West were based on estimates by the Axthur D. Little Company study team conducting a technology assessment of solar energy. [10] Solar central station capital costs in the East were assumed to be double those in the West because of a lower incidence of solar energy per square mile and higher land costs.

\begin{tabular}{|c|c|c|c|c|c|c|c|}
\hline YEAR & COAL & OIL & NUCLEAR & $\begin{array}{c}\text { GEO- } \\
\text { THERMAL }\end{array}$ & $\begin{array}{c}\text { SOLAR } \\
\text { EAST }\end{array}$ & $\begin{array}{c}\text { SOLAR } \\
\text { WEST }\end{array}$ & $\begin{array}{c}\text { TRANS- } \\
\text { CONTI- } \\
\text { NENTAL } \\
\text { GRID }\end{array}$ \\
\hline 1973 & 240 & 220 & 354 & 264 & - & - & - \\
1975 & 359 & 260 & 385 & 272 & -- & -- & - \\
1980 & 550 & 299 & 615 & 292 & - & -- & - \\
1985 & 615 & 332 & 734 & 315 & 3000 & 1500 & 467 \\
1990 & 662 & 358 & 791 & 339 & 2667 & 1334 & 503 \\
1995 & 713 & 386 & 852 & 365 & 2334 & 1167 & 542 \\
2000 & 768 & 416 & 918 & 394 & 2000 & 1000 & 583 \\
2005 & 882 & 447 & 989 & 424 & 2000 & 1000 & 629 \\
2010 & 892 & 482 & 1065 & 456 & 2000 & 1000 & 677 \\
\hline
\end{tabular}

FIgure 3.4.8 Cap1tal Cost Projections (1973 dollars $/ \mathrm{kW})$

Percelved environmental impacts (Figure 3.4.9) assume that the transcontinental grid will have the least negative impact on the environment. Coal, o11, and geothermal are all assumed to Improve with time as the introduction of new technologies reduces the impact of these fuels on the environment.

\begin{tabular}{|c|c|c|c|c|c|c|}
\hline YEAR & COAL & OIL & NUCLEAR & $\begin{array}{l}\text { GEO- } \\
\text { THERMAL. }\end{array}$ & SOLAR & $\begin{array}{l}\text { TRANS- } \\
\text { CONTI- } \\
\text { NENTAL } \\
\text { GRID }\end{array}$ \\
\hline 1973 & .5 & .7 & .9 & .75 & .8 & 1 \\
\hline 2000 & .8 & .85 & .9 & .9 & .8 & 1 \\
\hline
\end{tabular}

Figure 3.4.9 Environmental Impacts (The scale is from 0 to 1 , wh 1 denoting the least impact on the environment. 
Electricity costs (Figure 3.4.10) were prepared by using actual engineering estimates through 1982. [10] Estimates past 1982 were based on capital cost increases of 1.5 percent per year and average fuel cost escalations of 3 percent per year (constant December 1973 dollars).

\begin{tabular}{|c|c|c|c|c|c|c|c|}
\hline YEAR & COAL & OIL & NUCLEAR & $\begin{array}{c}\text { GEO- } \\
\text { THERMLL }\end{array}$ & $\begin{array}{c}\text { SOLAR } \\
\text { EAST }\end{array}$ & $\begin{array}{c}\text { SOLAR } \\
\text { WEST }\end{array}$ & $\begin{array}{c}\text { TRANS- } \\
\text { CONTI- } \\
\text { NENTAL } \\
\text { GRID }\end{array}$ \\
\hline 1973 & 12 & 21 & 12 & 7 & & & 14 \\
1975 & 18 & 23 & 18 & 8 & & & 16 \\
1980 & 21 & 27 & 19 & 9 & & & 18 \\
1985 & 23 & 30 & 21 & 10 & & & 19 \\
1990 & 26 & 33 & 23 & 12 & 196 & 98 & 21 \\
1995 & 29 & 37 & 25 & 13 & 180 & 90 & 23 \\
2000 & 32 & 42 & 27 & 14 & 180 & 90 & 26 \\
2005 & 35 & 47 & 29 & 16 & 180 & 90 & 28 \\
2010 & 39 & 53 & 32 & 18 & 180 & 90 & 31 \\
\hline
\end{tabular}

Figure 3.4.10 Cost of Electricity (Mills/kWh)

Percelved fuel availability (Figure 3.4.11) represents the likelihood that a particular fuel will be aval1able for the lifetime of a new plant ( 30 to 40 years). Coal, nuclear, and solar are assumed to be the most abundant energy sources. Importation of electricity via a transcontinental grid is also assumed to be based on abundant resources. Initial uncertainty about the lifetime of geothermal reservoirs leads to lower estimates for this source before 1985. In the case of oil, it was assumed that without major breakthroughs in recovery technology and with rapidly increasing world demand, the perceived availability of petroleum in the United States for long term planning (30 to 40 years) will drop to very low levels by 2000 . (For example, a plant buflt in 1990 would require petroleum until about 2030.)

\begin{tabular}{|c|c|c|c|c|c|c|}
\hline YEAR & COAL & OIL & NUCLEAR & $\begin{array}{c}\text { GEO- } \\
\text { THERMAL }\end{array}$ & SOLAR & $\begin{array}{c}\text { TRANS- } \\
\text { CONTI- } \\
\text { NENTAL } \\
\text { GRID }\end{array}$ \\
\hline 1973 & .95 & .75 & 1 & .75 & 1 & 1 \\
\hline 1985 & .95 & .4 & .95 & .75 & 1 & 1 \\
\hline 2000 & .95 & .2 & .95 & .95 & 1 & 1 \\
\hline
\end{tabular}

Figure 3.4.11 Projected Perceived Fuel Avallability

Construction delay times were assumed to be the following:

$\begin{array}{ll}\text { Coal } & -6 \text { years } \\ \text { Petroleum } & -5 \text { years } \\ \text { Nuclear } & -10 \text { years in } 1973, \\ & \text { decreasing to } 6 \text { years } \\ & \text { by } 2000 \\ \text { Geothermal } & -3 \text { years } \\ \text { Solar } & -8 \text { years } \\ \text { Transcontinental Grid } & -6 \text { years }\end{array}$

There are four other considerations that may limit the development of any alternative. First, some alternatives (such as central station solar plants) are not yet technically feasible. Thus, they become generating alternatives only at some future time when the technology is sufficiently developed. In the base run of the model, the first year that solar plants begin to come on-1ine is assumed to be 1995. (The first plants are actually planned, eight years earlier, in 1987.)

Second, the percelved value of one of the six decision factors may be sufficiently undesirable for a particular alternative that no new capacity will be allocated to that alternative no matter how desirable it otherwise appears.

For example, if a continued supply of petroleum were to become unlikely, no new petroleum-fired plants would be constructed. The threshhold value in the case of fuel avallability was assumed to be .5 Thus, when percelved petroleut avallability drops below .5 , as it does in 1985, no new petroleum plants are planned. A IImitation on the cost of electricity generated is also included.

The third limitation simulates a "learning process" in the introduction of new generating alternatives. It is assumed that when new generating alternatives become available there is inftial hesitation on the part of the industry to choose that new alternative until some initial use has been demonstrated by a few ploneering utilities. The model includes the effects of this learning process through the use of a learning curve multiplier which reduces the total decision factor for the generating alternative in question by a factor which rises from $1 / 10$ in the first year that the alternative becomes technologically available to 1 in the tenth year. This learning process affects geothermal in the West (beglnning in 1970), geothermal in the East (beginning in 1985) and solar, East and West, (beginning in 1987).

The fourth restriction is a limitation that applies only to geothermal. The total amount of potentlal resources that will be avaflable is based on the technologically feasible capacity described in Section 3.1. If at any particular time more geothermal energy is called for by the model than is actually available, geothermal development is limited to the resources available and the shortfall is made up by coal, oil, and nuclear plants.

The amount of geothermal energy potentially available is a key input assumption. The median estimates of the technologically feasible level of geothermal power, derived in the technology interviews, were used as this assumption. Figure 3.4 .12 presents these estimates (divided by The Futures Group between East and West). As will be recalled, these estimates represented the levels of geothermally derived electricity viewed as possible by the technology and resource experts, given only technological constraints. The model has the effect of adding other consultants' opinions.

\begin{tabular}{|c|c|c|c|c|}
\hline \multirow{2}{*}{ YEAR } & \multicolumn{2}{|c|}{ BASE PROGRAM CASE } & \multicolumn{2}{c|}{ CRASH PROGRAM CASE } \\
\cline { 2 - 5 } & EAST & WEST & EAST & WEST \\
\hline 1985 & 3,000 & 7,000 & 10,000 & 25,000 \\
\hline 2000 & 40,000 & 160,000 & 54,000 & 716,000 \\
\hline
\end{tabular}

Figure 3.4.12 Resources Available Estimates (MWe) 
To illustrate some of the model calculations the model output for the year 1979 can be used. In this year installed capacity in the West is about 101,000 MWe. The demand for electricity in ten years, 1989, is projected to be 240,000 MWe. The present capacity of 101,000 MWe, minus plants that will be retired over the next ten years, yields a value for that portion of present capacity which is expected to be on-line in ten years of $98,000 \mathrm{MWe}$. Currently planned capacity additions (all of which will be on-1ine in ten years) equal 122,000 MWe. Thus, the sum of these two represents the amount of capacity expected to be on-line in ten years, or $220,000 \mathrm{MWe}$. Comparing this figure with projected demand, $240,000 \mathrm{MWe}$, yields the amount of new capacity that must be added in order to meet demand, in this case 20,000 MWe. This needed capactty will be allocated among the various alternatives: coal, petroleum, nuclear, and geothermal (solar is not available for planning in 1979). The decision values for each of the alternatives determine the amount to be allocated to each. The decision value for coal (which is the result of considerations of relfability, environmental factors, construction time, fuel availability, electriclty costs and capital costs) is calculated to be 3.64. The values for nuclear and geothermal are 3.84 and 4.25 , respectively. The decision value for petroleum is only 1.33. This low value is a result of a perceived fuel availability that is very low. (Were it not for a low fuel avallability the decision value would have been about 3.3.) The decision value for all four alternatives is 13.06. The percentage of needed capacity that w111 be allocated to coal is found by dividing the coal decision value by the total decision value: $3.64 / 13.06$ or 28 percent. New coal plants are then assumed to be 28 percent of the projected capacity gap, or 5,600 MWe. Calculations are similar for the other alternatives. In the case of geothermal, however, not enough resources are available to supply the demand for geothermal.

The model tests desired geothermal additions against resource availability 3,6 , and 10 years in the future. In the case described here, this $11 \mathrm{mlt}$ was reached 6 years in the future, in 1985 . In 1979,2800 MWe of geothermal power were installed and an additional 4340 MWe were planned to be available by 1985. The computation in 1979 called for a further addition of 2000 MWe by 1985, yielding a total of $9140 \mathrm{MWe}$. This figure exceeded that expected to be avallable. Thus no new geothermal plants are planned for that year, of course, plants planned earlier can still be built in that year since resources have already been allocated to those plants. The geothermal shortfall is distributed among the other alternatives according to their respective decision values.

As mentioned earlier, a detailed discusstion of model equations and assumptions is presented in Appendix E.

\section{REFERENCES}

[1] Averch, H. and L. Johnson, "Behavilor of the Firm under Regulatory Constraint," The American Economic Review, Vol. 52, No. 5 (December 1962).

[2] Baumal, W., and A. Klevalch "Input Choice and Rate of Return Regulation: An Overview of the Discussion," The Bell Journal of Economics and Management Science, Vo1. 1, No. 2 (Autumn 1970).

[3] Bailey, Elizabeth E., and Roger D. Coleman, "The Effect of Lagged Regulation in an Averch-Johnson Mode1," The Bell Journal of Economics and Management Sclence, Vo1. 2, No. 1 (Spring 1971).
[4] Spann, R. M., "Rate of Return Regulation and Efficiency in Production: An Empirical Test of the Averch-Johnson Thesis," The Bell Journal of Economics and Management Science, Vo1. 5, No. 1 (Spring 1974).

[5] Gray, John E., "A Study of Energy Industry Decision-Making," Draft Report, Ford Foundation Energy Study Project, 1973.

[6] The 1970 National Power Survey (Washington, D.C.: Federal Power Commission, 1970).

[7] Estimated Fossil Fuel Requirements for the Electric Utility Industry of the United States 1973-1982, National Electric Reliability Council, February 12 , 1974.

[8] The following people were involved: Mr. Sidney Law, Director of Research and System Studies, Northeast Utilities Service Company; Mr. James Smlth, Director of New England Planning, Western Mass. Electric Company; and Mr. Edward Pawlak, Stone \& Webster Management Consultants.

[9] A Study of Base Load Alternatives for the Northeast. Utilities System (Cambridge, Mass . : A.D. Little, Inc., July 1973).

[10] A Technology Assessment of Solar Energy, Preliminary Report (Cambridge, Mass.: A.D. Little, Inc. 1974). 
A profection of the rate of growth of geothermal energy, varlous hydrocarbon and nuclear fuels, and other energy sources was made using the model described in the previous section. This profection had several uses in this study:

1. It provided a basis for exploring the relative Importance of the assumptIons Included in the model which can affect electricity generation fuel $\mathrm{mix}$.

2. The model served as a means for testing the potentlal effect of some candidate policies and established, within the initations of Its assumptions, the levels of some impacts.
The results of the run based on the assumptions outIined in the previous section are presented in Pigure 3.5.1 and 3.5.2. In essence, the model output can be considered a scenario. In which assumptions and projections are consistent.

There are several important observations to be made about this scenario:

1. Petroleum ut1lization in the generation of electrictty. peaks in the early $1990^{\prime}$ $(227,000 \mathrm{MWe})$ as a result of uncertainty about continued supply.

2. Indigenous geothermal energy sources in the East (which are not tapped until early

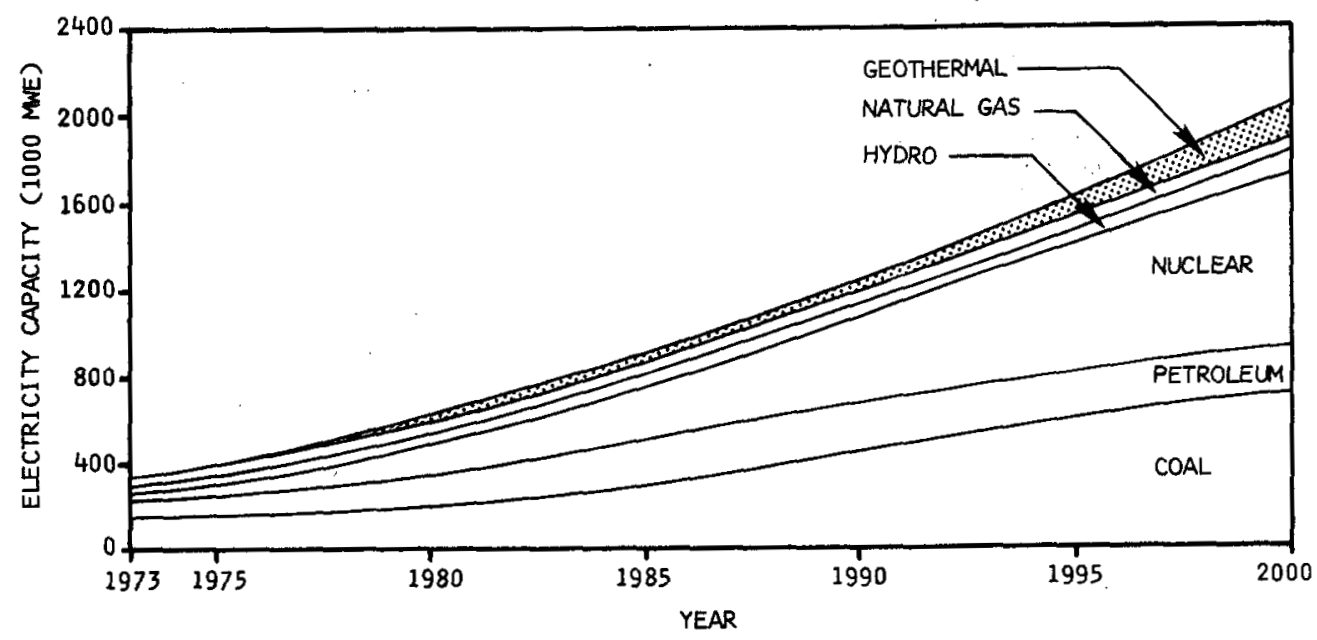

F1gure 3.5.1 ELECTRICITY FUEL MIX - TOTAL U.S.

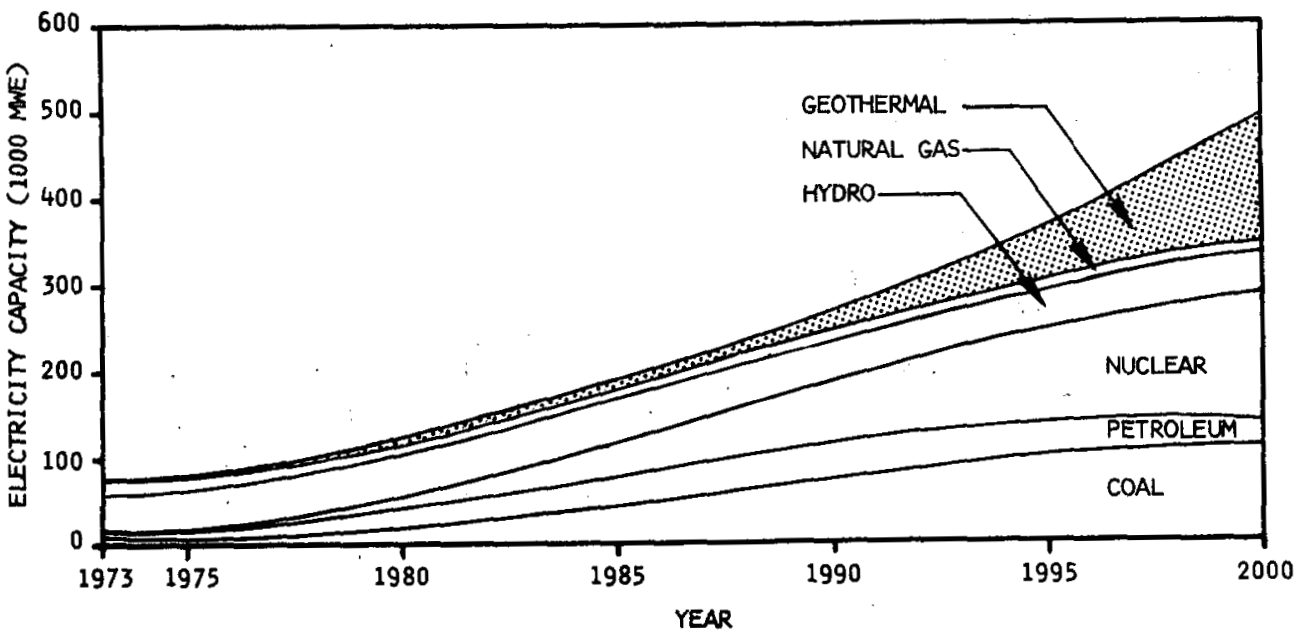

F1gure 3.5.2 BLECTRICITY MIX - KESTERN U..S. 
in the 1990's) account for 40,000 MWe of installed capacity by 2000 .

3. In the West, however, geothermal sources: are more significant, yielding 147,000 MWe out of a total of 495,000 MWe in the year 2000 , or about 30 percent of the Installed capacity. By: 2000, geothermal energy equals the contribution of the other primary energy sources in the West: coal and nuclear.

4. In both the East and the.West, nuclear energy provides more power than other: sources after about 1990 :

5. In the early $1990^{\prime} \mathrm{s}$, geothermal energy Is transported from the West to the East and is distributed with energy generated by other means; by 2000 , 56,000 MWe is handled in this way.

Validation of this kind of model is quite difficult. of course, it can duplicate historical data if model coefficients are chosen so as to fit these data, hence a "match to history" offers 11ttle in the way of confidence. With respect to projected future cond1tlons, the absolute accuracy of the model need not be great in order for it to be quite usefui in testing the expected effects of simulated policies or the sensitivity of conclusions to changing initial conditions, since in both instances overall system behavior and differences from the base run are used to form conclusions. Nevertheless, the projections provided by the model seem quite plausible for several reasons:
1. The input assumptions about decision criteria, on which the model depends, are consistent with judgments provided by :utility company executives and utility regulators. These judgments agree. qualitatively with recent research performed by John Gray in his work in the Ford Foundation Energy Policy Study. [1]

2. The profections obtained, assuming zero geothermal development, were compared with forecasts prepared by the Federal Power Commission in the 1970 National Power Survey. [2] As shown in Figure 3.5.3 the two estimates are in relatively close agreement.

\section{REFERENCES}

[1] Gray, John, "A Study of Energy Industry Decision Making," Draft report to the Ford Foundation Energy Policy Project (1974).

[2] Federal Power Commisston, The 1970 National Power Survey 3822 (Washington, D.C.: December 1971).

[3] National Petroleum Council, U.S. Energy Outlook (Washington, D.C.: December 1972).

[4] Office of Planning and Analysis, Nuclear Power 1973-2000 (Washington, D.C.: Atomic Energy Commission, December 1972).

[5] Bureau of Mines, An Energy Model for the United States (Washington, D.C.: Department of the Interior, July 1968).

[6] Assoclated Universities, Inc., Reference Energy Systems and Resource Data for Use in the Assessment of Energy Technology (New York: Upton, 1973).

YEAR $=1980$

\begin{tabular}{|c|c|c|c|c|c|c|c|}
\hline SOURCE & $\begin{array}{l}\text { TOTAL } \\
\text { ELECTRICAL } \\
\text { CAPACITY }\end{array}$ & COAL & PETROLEUM & $\begin{array}{l}\text { NATURAL } \\
\text { GAS }\end{array}$ & NUCLEAR & $\begin{array}{l}\text { HYDRO } \\
\text { ELECTRIC }\end{array}$ & GEOTHERMAL \\
\hline MODEL BASE RLN & $584.6 \%$ & 229.0 & 120.8 & 53.3 & 113.5 & 65.0 & 3.1 \\
\hline $\begin{array}{l}\text { MODEL NO FURTHER } \\
\text { GEOTHERMAL }\end{array}$ & $584.6 *$ & 229.7 & 121.4 & 53.3 & 113.5 & 65.0 & 1.8 \\
\hline FPC (2) & $598.0 \%$ & 231.7 & 80.0 & 78.4 & 140.0 & 68.0 & 0 \\
\hline NPC (3) & 672.0 & 288.6 & 81.8 & 78.5 & 153.0 & 65.3 & 2.5 TO 10.3 \\
\hline $\operatorname{AEC}(4)$ & $-\infty$ & $-\infty$ & -- & $\therefore$ & 131.6 & $m$ & --- \\
\hline $\begin{array}{l}\text { DOI - BUREAU } \\
\text { MIPIES (5) }\end{array}$ & $523.0^{-}$ & --- & TAL OF 377 & $\therefore--$ & 69.7 & 75.8 & 0 \\
\hline
\end{tabular}

\begin{tabular}{|c|c|c|c|c|c|c|c|c|}
\hline SOURCE & $\begin{array}{c}\text { TOTAL } \\
\text { ELECTRI CAL } \\
\text { CAPACI TY }\end{array}$ & COAL & PETROLEUM & SOLAR & $\begin{array}{l}\text { NATURAL } \\
\text { GAS }\end{array}$ & NUCLEAR & $\begin{array}{l}\text { HYDRO } \\
\text { ELECTRIC }\end{array}$ & GEOTHERMAL \\
\hline MODEL BASE RUN & $2022.6^{2}$ & 695.9 & 180.7 & 3.5 & 23.2 & 841.1 & 90.0 & 188.1 \\
\hline $\begin{array}{l}\text { MODEL NO FURTHER } \\
\text { GEOTHERMAL }\end{array}$ & $2048.9 *$ & 787.2 & 183.1 & 5.5 & 23.2 & 958.7 & 90.0 & 2.2 \\
\hline FPC (2) \& AU (6) & $1964.1^{3}$ & 704.5 & 138.1 & 0 & 95.0 & 829.0 & .98 .0 & 0 \\
\hline AEC (4) & 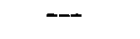 & -- & -- & -- & -- & 1200.0 & - & $-\cdots$ \\
\hline
\end{tabular}

"EXCLUDES PUMPED STORAGE IMDRO, INTERNAL COMBUSTION, 'AND GAS TURBINES.

HEFPC ESTIMATES FOR ' 1990 PROJECTED TO 2000 BY AU TREND.

F1gure 3.5.3 A COMPARISON OF FORECASTS OF ELECTRICAL GENERATING CAPACITY IN THE UNITED STATES (1000 MTe) 
3.6 Some Policies and Their Anticipated Effects

An important use of the model described in section 3.4 is to test sensitivity to policy; to explore and illustrate the effects of certain policies designed to control the rate of introduction of geothernal energy, within the limits of accuracy of the simulation. A systematic attempt was made to define a range of activities designed to influence geothermal development and to understand their significance and power by testing them with the mode1. FIgure 3.6.1 lists the policies considered and the means employed to simulate them. The paragraphs which follow describe the candidate polictes in more detail.

\begin{tabular}{|c|c|}
\hline POLICY & METHOD OF SIMULATING \\
\hline $\begin{array}{l}\text { 1. GEOTHERMAL RESOURCES NOT } \\
\text { DEVELOPEO. }\end{array}$ & $\begin{array}{l}\text { GEOTHERMAL OPTION REMOVED } \\
\text { FROA MOOEL DECISION } \\
\text { SIMULATION. }\end{array}$ \\
\hline $\begin{array}{l}\text { 2. GEOTHERMAL RESOURCES NOT } \\
\text { EXPORTED FROM WEST TO } \\
\text { EAST. }\end{array}$ & $\begin{array}{l}\text { IMPORTATION OPTION REMOVED } \\
\text { FROM MODEL EAST DECISION } \\
\text { SIMULATION. }\end{array}$ \\
\hline 3. BASE RUN. & $\begin{array}{l}\text { TECHNOLOGICALLY FEASIBLE } \\
\text { GENERATION CAPACITY (FROM } \\
\text { TECWNOLOGICAL INTERVIEWS) } \\
\text { PER "NORMAL" PROGRAM. }\end{array}$ \\
\hline $\begin{array}{l}\text { 4. INCENTIVES CREATED TO } \\
\text { REDUCE PERCEIVED RISK } \\
\text { ASSOCIATED WI TH FIELD } \\
\text { DEPLETION RATE. }\end{array}$ & $\begin{array}{l}\text { PERCEIVED AVAILABILITY } \\
\text { FACTOR FOR GEOTIERMAL } \\
\text { INCREASED TO } 1 .\end{array}$ \\
\hline $\begin{array}{l}\text { 5. GOVERNMENT-FUNDED HOT } \\
\text { DRY ROCK DEVELOPMENT } \\
\text { PROGRAM. }\end{array}$ & $\begin{array}{l}\text { TECHNOLOGICALLY FEASIBLE } \\
\text { GENERATION CAPACITY (FROM } \\
\text { TECHNOLOGICAL INTERVIEWS) } \\
\text { FOR HOT DRY ROCK. "CRASH" } \\
\text { PROGRAM USED WI TH "NORMAL" } \\
\text { CAPACITY ESTIMATES FOR } \\
\text { OTHER RESOURCE TYPES. }\end{array}$ \\
\hline $\begin{array}{l}\text { 6. TECHNICAL "CRASH" } \\
\text { PROGRAM. }\end{array}$ & $\begin{array}{l}\text { TECHNOLOGICALLY FEASIBLF } \\
\text { GENERATION CAPACITY (FROM } \\
\text { TEONOLOGICAL INTERVIEWS) } \\
\text { PER "CRASH" PROGRAM. }\end{array}$ \\
\hline $\begin{array}{l}\text { 7. ACCELERATED (TECHNICAL } \\
\text { AND NON-TECHN CAL } \\
\text { "CRASH'") PROGRAM WHICH } \\
\text { INCLUDED: } \\
\text { - STEAM COST SUBSIDY. }\end{array}$ & $\begin{array}{l}\text { AS IN } 4 \text { AND } 6 \text { ABOVE PLUS: } \\
\text { - STEAM COST REDUCED TO } \\
25 \% \text { OF ITS INITIAL } \\
\text { LEVEL. }\end{array}$ \\
\hline $\begin{array}{l}\text { - DEMONSTRATION PLANTS. } \\
\text { - ENVIRONMENTAL } \\
\text { PROGRAMS. }\end{array}$ & $\begin{array}{l}\text { - PERCEIVED GEOTHERMAL } \\
\text { RELIABILITY FACTOR } \\
\text { INCREASED TO UNITY. } \\
\text { - PERCEIVED ENVIRONMENT } \\
\text { FACTOR INCREASED TO } \\
\text { UNITY. }\end{array}$ \\
\hline
\end{tabular}

Figure 3.6.1 POLICIES STUDIED USING STMULATION MODEL

Geothermal Resources not Developed. This case is designed to simulate a program which cuts off all further geothermal development. This simulation involves removing the option of deciding to purchase geothermal steam from the present through the year 2000 . This option is included to produce estimates of how load would be met without geothermal energy so that the effect of geothermal development on fuel mix can be estimated.

Geothermal Resources Not Exported from West to East. As explained in Section 3.4, the model includes an option for the simulated East Coast utility decisionmaker to develop geothermal energy in the East and to buy geothermal energy transported from the West via transcontinental transmission 1ines. In this pollcy simulation, the importation option is removed from the mode1; however, the possibility of developlng both ast coast and west coast geothermal resources is etained.
The Base Case. This case is identical to the run described in the previous section. Estimates of the geothermal energy available were derived from the technological interviews and were equivalent to the levels of power judged to be technologically feasible by the panel under "normal" circumstances; that is, no additional political action to create development incentives, and technology evolving as a result of private initiative and a plausible conservative continuation of government technolozy programs currentiy in effect.

Depletion Uncertainty Removed. This case simulated a situation in which incentives were created to reduce the perceived risks assoclated with geothermal field depletion. Such incentives might take the form of guarantees to utility companies which would reimburse them for losses incurred should a geothermal resource on which they depended for energy be depleted before an arbitrary cut off time, say 25 years. In order to simulate this pollcy the factor associated with percelved availability was increased to unity.

Government Funded Hot Dry Rock Development Program. This case was designed to simulate a set of policies intended to expedite the development of hot dry rock resources. Among the specific actions included here might be the increase in the tempo of exploration, vigorous funding of R\&D programs associated with hot dry rock drilling and utilization and early hot dry rock proof-of-concept plants. These actions were simulated by increasing the avallable resource level from the base case values to levels which corresponded to the hot dry rock "crash" program identified in the technological interviews.

Technical "Crash" Program. This case assumed that all possible effort was placed on the technical development of geothermal technology. It was simulated by employing the technologically feasible generation capacity corresponding to a "crash" program as defined by the technological interviews. It did not include non-technical actions which might have been viewed as pacing.

Accelerated Technical and Non-technical "Crash" Program. Th1s case was intended to represent a situation in which all reasonable action which could be taken was in fact initiated. It included not only the technological factors of the case listed above, but also simulated other actions such as the initiation of a steam cost subsidy, the construction of demonstration plants, and the inttlation of a set of environmental programs. The subsidization of the purchase of steam would presumably be an inducement to the utility company since 1 ts cost would be artificlally reduced through federal programs. This pollcy was simulated by reducing steam costs to 25 percent of their initial level. Demonstration plants would be designed to improve perceptions of rellability and to expedite the development of appropriate technology. This policy was simulated by increasing the percelved geothermal reliabllity factor to unity. The environmental programs were simulated by Increasing the perceived environmental factor in the model to unity. In the remainder of this report, this program 18 called "Case 7" or "the accelerated program."

The results of the runs using the simulated policies as well as the base case described in the previous section and a no geothermal case are presented in Figure 3.6.2. 


\begin{tabular}{|c|c|c|c|c|c|c|c|}
\hline POLICY & NO GEOTHERMAL & $\begin{array}{l}\text { NO IMPORTS } \\
\text { TO EAST }\end{array}$ & BASE RUN & $\begin{array}{l}\text { DEPLETION } \\
\text { UNCERTAINT IES } \\
\text { REMOVED }\end{array}$ & $\begin{array}{l}\text { HOT DRY ROCK } \\
\text { DEVELOPMENT }\end{array}$ & $\begin{array}{l}\text { TECHNICAL } \\
\text { CRASH }\end{array}$ & ACCELERATED \\
\hline $\begin{array}{l}\text { GEOTHERMAL } \\
\text { EAST }\end{array}$ & $\therefore \quad 0$ & 43.4 & 41.3 & 40.2 & 41.3 & 54.8 & 57.0 \\
\hline $\begin{array}{c}\text { GEOTHERMAL } \\
\text { WEST . }\end{array}$ & 2.2 & 90.04 & $\$ 46.8$ & 148.2 & 155.6 & 181.1 & 192.2 \\
\hline $\begin{array}{l}\text { IMPORTED } \\
\text { BY EASTT }\end{array}$ & 0 & 0 & 56.4 & 56.0 & 57.5 & 57.5 & 57.2 \\
\hline
\end{tabular}

FIgure 3.6.2 EFFECT OF SELECTED POLICIES ON THE LEVEL OF GEOTHERMAL DEVELOPMENT IN YEAR 2000 - 1000 MWE

Some observations about these policles are:

1. If all of the simulated technical and non-technical policies designed to expedite geothermal. development are implemented simultaneously, the amount of electricity produced from this source could be increased about 30 percent over a "normal program" of geothermal deve1opment $(249,000 \mathrm{MWe}$ vs. $188,000 \mathrm{MWe}$ in 2000).

2. The policies which seem most effective in stimulating the development of geothermal energy are those which improve the level of available technologically feasible development.

3. As the amount of geothermal energy is increased by vartous policies, the other electricity sources which are most affected are nuclear energy and coal. Figure 3.6.3 compares, for example, the power generated by various sources in 2000, under the base case assumptions and under accelerated program assumptions. Comparing the technical policy crash case to the no-geothermal case, some 51,000 MWe of coal generation and $62,000 \mathrm{MWe}$ of nuclear generation would be replaced in the West. Generating sources using petroleum are 11mited by uncertainty about the continued avallabllity of oil and, thus, are little affected by geothermal growth. Solar energy from central generating plants becomes available too late in the simulation to be much affected by geothermal before 2000 .

\begin{tabular}{|c|c|c|c|c|c|c|c|c|c|c|c|c|c|c|c|}
\hline \multirow{2}{*}{ 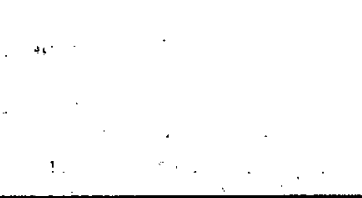 } & \multicolumn{8}{|c|}{ E A S T } & \multicolumn{7}{|c|}{ WES T } \\
\hline & $\frac{1}{8}$ & 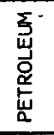 & $\begin{array}{l}\text { 岁 } \\
\text { 岁 } \\
\text { žz }\end{array}$ & 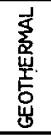 & $\begin{array}{l}\text { 号 } \\
\end{array}$ & $\underset{z}{\stackrel{8}{z}}$ & 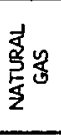 & $\begin{array}{l}\text { 咅 } \\
\text { 高. }\end{array}$ & $\underset{8}{8}$ & 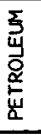 & 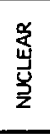 & 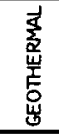 & 営 & $\begin{array}{l}\frac{0}{0} \\
\grave{c}\end{array}$ & $\frac{1}{\frac{5}{3}} \frac{5}{5}$ \\
\hline NO GEOTHERMAL (CASE 1) & 640 & 150 & 777 & 0 & 2.9 & 32 & 16 & 0 & 147 & 33 & 181 & 2.2 & 2.6 & 58 & 7 . \\
\hline ACCELERATED (CASE 7) & 576 & 151 & 691 & +57 & 1.7 & 32 & 16 & 57 & 96 & 28 & 119 & 192 & 1.2 & 58 & 7 \\
\hline DIFFERENCE (CASE 1 - CASE 7) & 64 & -1 & 86 & -57 & 1.2 & 0 & 0 & -57 & 51 & 5 & 62 & -190 & 1.4 & 0 & 0 \\
\hline
\end{tabular}

Figure 3.6.3 EFFECT OF GEOTHERMAL DEVELOPMENT ON OTHER FUELS IN 2000 (1000 MWE)
4. A run was made in which petroleum aval1ability was increased by 10 percent; the amount of electricity from that source by 2000 almost doubled over the base case; neither coal-fired nor nuclear generation develop as rapidly as before. Geothermal slightly.

The reason that petroleum was affected to such a large extent by a relatively small change in perceived fuel avallability is that, in the base run, the perceived availabllity drops so low that petroleum ceases to be considered a viable alternative after 1985. Increasing the percelved avallability by 10 percent resulted in petroleum existing as a viable alternative a few years longer, which, when coupled with rapidly growing demand, resulted in a large increase in new petroleum generation capacity.

5. The amount of geothermal energy exported from the West to the East is not affected significantly by the policies considered. and solar development were affected only 
3.7 Sensitivity of the Model

to Input Assumptions

The assumptions which form the basis for the model were described in previous sections. It is possible to vary these assumptions systematically to determine Input points at which large changes in output can be induced. When such points are discovered they can suggest particularly effective policles, the need for increasing confidence about input assumptions (which might in turn be reflected as research projects), or parameters to be monitored as the geothermal program progresses in order to 1mprove the accuracy of such simulations and the quality of the decision-analysis process.

In the paragraphs which follow; the spectfic variations tested and the results achieved are described. In general the variations in model assumptions could be grouped into six major categorles:

- The decision weights

- The level of technologically feasible geothermal development

- The demand for electricity

- Electricity and capital costs

- Availability of petroleum

- Parameters associated with the introduction of solar energy.

\section{Deciston Welghts}

As explained in Section 3.4 ; a "decision" about which type of generating capacity to butld was reached each year of the simulation. The amount of generation capacity was based on a ten year projection of load and a set of six decision factors.

- Capital Investment

- Environmental criteria

- Cost of electricity

- Percetved fuel avallability

- Reliability

- Construction time

These factors did not contribute equally to the decision; rather welghts were assigned to each factor. In the first set of sensitivity runs, the weights assigned to these factors were systematically varled. For example, in the first run, reliablilty weight was doubled; In the second run rellability weight was halved; in the third run capital Investment welght was doubled; and so on. It, was found that the model was quite insensitive to changes of this magnitude in the assumed weighting. The most extreme fluctuations in this series of runs amounted to only about three per-. cent of the total amount of geothermal energy expected in the year 2000 .

The Level of Technologically Feasible Geotherma1 Development

In testing the sensitivity of the model to assumed level of resources, two iruns were made. The first : assumed a factor of two increase in technologically feastble resources and the second assumed that resources were only one-half as great. as the base case. The results achleved in the-first run are shown in Figure 3.7 .1 and the second, 3.7.2. Clearly, this is a major point of sensitivity of the model. It suggests that early polfcles be concentrated on Identifying the proven resources.

\begin{tabular}{|c|c|c|c|c|}
\hline \multicolumn{2}{|c|}{ CONDITION } & $\begin{array}{c}\text { GEOTHERMAL } \\
\text { WEST }\end{array}$ & $\begin{array}{c}\text { GEOTHERMAL } \\
\text { EAST }\end{array}$ & $\begin{array}{c}\text { GEOTHERMAL } \\
\text { IMPORTS } \\
\text { EAST }\end{array}$ \\
\hline \multirow{2}{*}{$\begin{array}{l}\text { BASE } \\
\text { CASE }\end{array}$} & 1973 & 0 & 0 & 0 \\
\cline { 2 - 5 } & 1985 & 7 & 0 & 0 \\
\cline { 2 - 5 } & 2000 & 145 & 40 & 56 \\
\hline \multirow{2}{*}{$\begin{array}{l}\text { RESOURCES } \\
\text { DOUBLED }\end{array}$} & 1985 & 14 & 0 & 0 \\
\cline { 2 - 5 } & 2000 & 158 & 73 & 57 \\
\hline
\end{tabular}

Figure 3.7.1 EFFECT OF DOUBLING RESOURCES

\begin{tabular}{|c|c|c|c|c|}
\hline \multicolumn{2}{|c|}{ CONDI TION } & $\begin{array}{c}\text { GEOTHERMAL } \\
\text { WEST }\end{array}$ & $\begin{array}{c}\text { GEOTHERMAL } \\
\text { EAST }\end{array}$ & $\begin{array}{c}\text { GEOTHERMAL } \\
\text { IMPORTS - } \\
\text { EAST }\end{array}$ \\
\hline \multirow{2}{*}{$\begin{array}{l}\text { BASE } \\
\text { CASE }\end{array}$} & 1973 & 0 & 0 & 0 \\
\cline { 2 - 5 } & 1985 & 7 & 0 & 0 \\
\cline { 2 - 5 } & 2000 & 145 & 40 & 56 \\
\hline $\begin{array}{l}\text { RESOURCES } \\
\text { DIMINISHED } \\
\text { BY } 5\end{array}$ & 1985 & 3 & 0 & 0 \\
\cline { 2 - 6 } & 2000 & 80 & 20 & 23 \\
\hline
\end{tabular}

F1gure 3.7 .2 EFFECT OF HALVING RESOURCES

\section{The Demand for Electricity}

A serles of runs was conducted to explore the effect of changing assumed levels of electricity demand. The base case used a level of demand projected by the Federal

Power Commission In 1970. Five variations on the FPC assumption were tested: demand Increased by 25 percent; demand increased by 50 percent; demand Increased by 50 percent with resources assoclated with the "Technological Crash" case (case 6--Section 3.6); demand decreased by 25 percent; and change in the demand growth curve which presumed no growth after the year 1990. The results of these runs are presented in Figures 3.7.3 through 3.7.7. The effect of demand is relatively important. Figure 3.7.8 shows how effective demand is in stimulating the development of geothermal energy and in changing importation levels of geothermal energy by the East. As demand Increases, the amount which can be furntshed from geothermal sources is constrained by the amount of resources avallable. Comparison of Figures 3.7 .4 and 3.7 .5 also makes this point. In the former case demand-1ncreased by 50 percent but resources were Iimited to the level assumed in the base run. In the latter case, resources were ralsed to the "crash" program level and the amount of geothermal energy utilized was about 50 percent more than the resource-constrained, high-demand example. 


\begin{tabular}{|c|c|c|c|c|}
\hline \multicolumn{2}{|c|}{ CONDI TION } & $\begin{array}{c}\text { GEOTHERMAL } \\
\text { WEST }\end{array}$ & $\begin{array}{c}\text { GEOTHERMAL } \\
\text { EAST }\end{array}$ & $\begin{array}{c}\text { GEOTHERMAL } \\
\text { IMPORTS - } \\
\text { EAST }\end{array}$ \\
\hline \multirow{2}{*}{$\begin{array}{l}\text { BASE } \\
\text { CASE }\end{array}$} & 1973 & 0 & 0 & 0 \\
\cline { 2 - 5 } & 1985 & 7 & 0 & 0 \\
\cline { 2 - 5 } & 2000 & 145 & 40 & 56 \\
\hline \multirow{2}{*}{$\begin{array}{c}\text { DEMAND } \\
\text { BNCREASED 1.25 }\end{array}$} & 1985 & 6 & 0 & 0 \\
\cline { 2 - 6 } & 2000 & 155 & 40 & 60 \\
\hline
\end{tabular}

F1gure 3.7.3 EFFECT OF INCREASING DEMAND BY $25 \%$

\begin{tabular}{|c|c|c|c|c|}
\hline \multicolumn{2}{|c|}{ (1000 MWE) } \\
\hline \multirow{3}{*}{\begin{tabular}{c} 
CONDI TION \\
\multirow{2}{*}{\begin{tabular}{c} 
CASE \\
\cline { 2 - 5 }
\end{tabular}}
\end{tabular}} & $\begin{array}{c}\text { GEOTHERMAL } \\
\text { WEST }\end{array}$ & $\begin{array}{c}\text { GEOTHERMAL } \\
\text { EAST }\end{array}$ & $\begin{array}{c}\text { GEOTHERMAL } \\
\text { IMPORTS } \\
\text { EAST }\end{array}$ \\
\cline { 2 - 5 } & 1985 & 0 & 0 & 0 \\
\cline { 2 - 5 } & 2000 & 145 & 40 & 56 \\
\hline $\begin{array}{l}\text { DEMAND } \\
\text { INCREASED } \\
\text { BY 1.5 }\end{array}$ & 1985 & 6 & 0 & 0 \\
\cline { 2 - 6 } & 2000 & 160 & 40 & 52 \\
\hline
\end{tabular}

F1gure 3.7.4 EFFECT OF INCREASING DEMAND BY 50\%

\begin{tabular}{|c|c|c|c|c|}
\hline & & \multicolumn{3}{|c|}{ (1000 MNE) } \\
\hline \multicolumn{2}{|c|}{ CONDITION } & GEOTHERMAL & GEOTHERMAL & $\begin{array}{l}\text { GEOTHERMAL } \\
\text { IMPORTS - }\end{array}$ \\
\hline \multirow{3}{*}{$\begin{array}{l}\text { BASE } \\
\text { CASE }\end{array}$} & 1973 & 0 & 0 & 0 \\
\hline & 1985 & 7 & 0 & 0 \\
\hline & 2000 & 145 & 40 & 56 \\
\hline \multirow{2}{*}{$\begin{array}{l}\text { DEMAND } \\
\text { INCREASED BY } \\
1.5 \text { AND } \\
\text { RESOURCES } \\
\text { EQUIVALENT } \\
\text { TO "CRASH" }\end{array}$} & $1985^{\circ}$ & 26 & 0 & 0 \\
\hline & 2000 & 264 & 55 & 86 \\
\hline
\end{tabular}

Figure 3.7.5 EFFECT OF INCREASING DEMAND BY $50 \%$ RESOURCES AVAILABLE EQUIVALENT TO "TECHNOLOGICAL CRASH"

\begin{tabular}{|c|c|c|c|c|}
\hline \multicolumn{2}{|c|}{} & \multicolumn{3}{c|}{ (1000 MWE) } \\
\hline \multirow{3}{*}{ CONDI TION } & $\begin{array}{c}\text { GEOTHERMAL } \\
\text { WEST }\end{array}$ & $\begin{array}{c}\text { GEOTHERMAL } \\
\text { EAST }\end{array}$ & $\begin{array}{c}\text { GEOTHERMAL } \\
\text { IMPORTS } \\
\text { EAST }\end{array}$ \\
\hline \multirow{2}{*}{$\begin{array}{c}\text { BASE } \\
\text { CASE }\end{array}$} & 1973 & 0 & 0 & 0 \\
\cline { 2 - 5 } & 1985 & 7 & 0 & 0 \\
\cline { 2 - 5 } & 2000 & 145 & 40 & 56 \\
\hline $\begin{array}{l}\text { DEMAND } \\
\text { DECREASED } \\
\text { BY.25 }\end{array}$ & 1985 & 7 & 0 & 0 \\
\cline { 2 - 5 } & 2000 & 116 & 40 & 43 \\
\hline
\end{tabular}

Figure 3.7.6 EFFECT OF DECREASING DEMAND BY $25 \%$

\begin{tabular}{|c|c|c|c|c|}
\hline \multicolumn{2}{|c|}{ CONDITION } & $\begin{array}{c}\text { GEOTHERMAL } \\
\text { WEST }\end{array}$ & $\begin{array}{c}\text { GEOTHERMAL } \\
\text { EAST }\end{array}$ & $\begin{array}{c}\text { GEOTHERMAL } \\
\text { IMPORTS } \\
\text { EAST }\end{array}$ \\
\hline \multirow{3}{*}{$\begin{array}{l}\text { BASE } \\
\text { CASE }\end{array}$} & 1973 & 0 & 0 & 0 \\
\cline { 2 - 6 } & 1985 & 7 & 0 & 0 \\
\cline { 2 - 6 } & 2000 & 145 & 40 & 56 \\
\hline \multirow{2}{*}{$\begin{array}{l}\text { No DEMAND } \\
\text { GROWTH AFTER } \\
1990\end{array}$} & 1985 & 7 & 0 & 0 \\
\cline { 2 - 6 } & 2000 & 80 & 11 & 8 \\
\hline
\end{tabular}

Figure 3.7.7 EFFECT OF LIMITING DEMAND TO NO GROWTH AFTER 1990

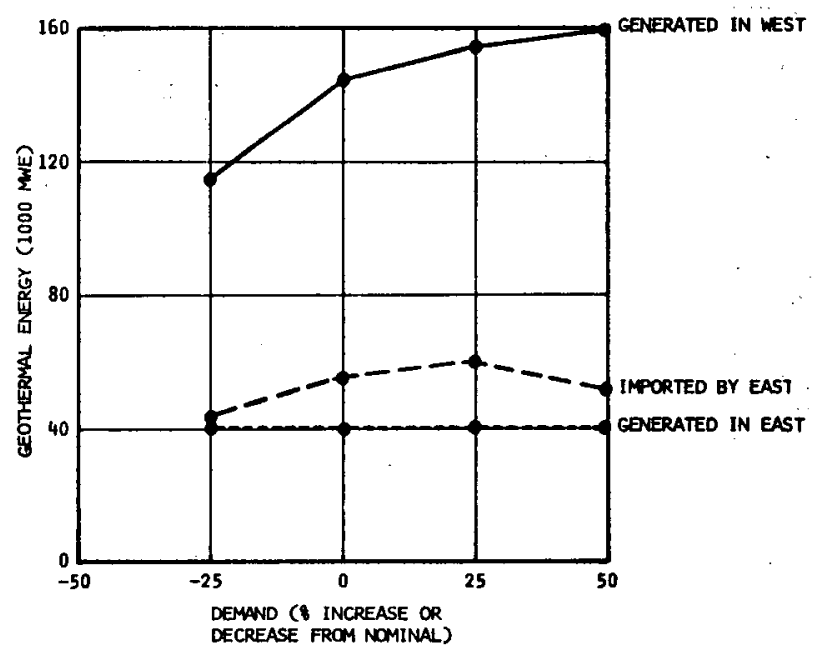

FIgure 3.7.8 VARIATION IN GEOTHERMAL ENERGY PRODUCED IN 2000 AS A FUNCTION OF DEMAND (WITH CONSTRAINED RESOURCES) 
The demand 11mited example, which assumed no growth

ifter 1990 (FIguxe 3.7.7) produced some very Interest-

ing results. The demand assumptions Involved in both the base case and the "no growth" case are shown in Figure 3.7.9. Using these assumptions, the model forecasted significantly lower demand for ail fuels involved in the generation of electricity. Figure 3.7.10 summarizes this effect. The energy source affected the least is petroleum since, In the decision sector of the model, a relative uncertainty about continuous supply became less important for this fuel, and demand was

lower. Geothermal is affected greatly because of the fact that, in the base case, most of the geothermal development takes place after 1990. In the no growth case the only opportunity for geothermal development after 1990 is in replacing retired capacity, thus its growth is severely restrained.

\section{Electricity and Capital Costs}

A serles of twelve simulation runs were made in which the costs of electricity associated with various fuels and capital costs assoclated with the use of various fuels were increased and decreased by 50 percent compared to the base run. The simulated situations were as follows:

- Coal electriclty costs increased by 50 percent

- Coal electricity costs decreased by 50 percent

- Coal electricity and capital costs Increased by 50 percent

- Coal electricity and capital costs decreased by 50 percent

- Nuclear electricity costs increased by 50 percent

- Nuclear electricity costs decreased by 50 percent

- Nuclear electricity and capital costs increased by 50 percent

- Nuclear electricity and capital costs decreased by 50 percent

- Geothermal electricity costs increased by 50 percent

- Geothermal electricity costs decreased by 50 percent

- Geothermal capital costs increased by 50 percent

- Geothermal capital costs decreased by 50 percent
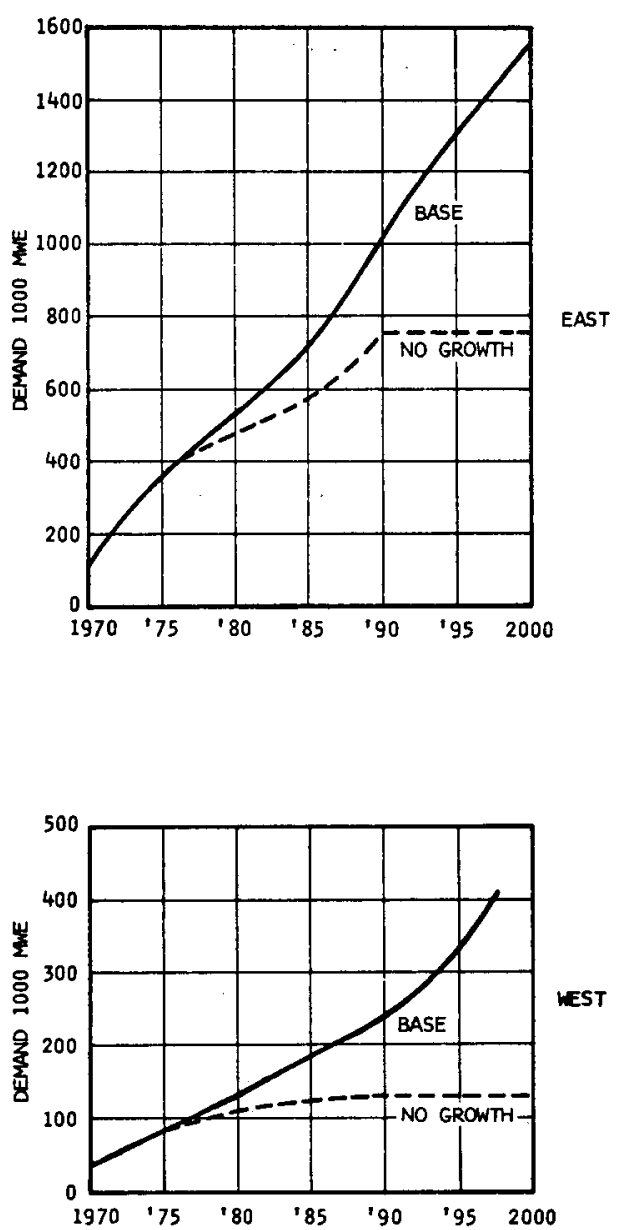

Figure 3.7.9 DEMAND ASSUMPTIONS

\begin{tabular}{|c|c|c|c|c|c|c|c|c|c|c|c|c|}
\hline \multirow{2}{*}{\multicolumn{2}{|c|}{$R \cup N$}} & \multicolumn{5}{|c|}{ WE S T } & \multicolumn{6}{|c|}{ E A S T } \\
\hline & & COAL & PET. & NUC. & GEO. & SOLAR & COAL & PET. & NuC. & GEO. & SOLAR & MPORT \\
\hline \multirow{3}{*}{ BASE } & 1973 & 13 & 6 & 2 & 0 & 0 & 137 & 50 & 12 & 0 & 0 & 0 \\
\hline & 1985 & 45 & 32 & 39 & 7 & 0 & 262 & 163 & 220 & 0 & 0 & 0 \\
\hline & 2000 & 112 & 29 & 141 & 145 & 2 & 582 & 145 & 708 & 40 & 2 & 56 \\
\hline \multirow{2}{*}{$\begin{array}{l}\text { CONSTRAINED } \\
\text { DEMAND }\end{array}$} & 1985 & 27 & 16 & 22 & 7 & 0 & 207 & 113 & 164 & 0 & 0 & 0 \\
\hline & 2000 & 78 & 14 & 97 & 80 & 1 & 231 & 99 & 275 & 11 & 0 & 8 \\
\hline
\end{tabular}

FIguxe 3.7.10 SENSITIVITY TO DEMAND GROWTH CONSTRAINTS (1000 MNe) 
These runs showed that the amount of geothermal energy generated in the year 2000 was not sensitive to changes In cost assumptions; within the range tested the maximum fluctuation was on the order of 6 percent. Figure 3.7.11 summar1zes these runs. Changing the cost factors assoclated with coal had the effect of changing the amount of coal capacity installed in the expected direction; the same effect was noted for nuclear generation capacity. This shift with changing costs was not observed to any large extent for geothermal energy because the constraint on development In the model was primarily the level of resources assumed to be avallable.

\begin{tabular}{|c|c|c|c|c|c|c|c|c|c|c|c|}
\hline \multirow{2}{*}{$R \cup N$} & \multicolumn{5}{|c|}{ WES T } & \multicolumn{6}{|c|}{ EAS T } \\
\hline & COAL & PET. & NUC. & GEO. & SOLAR & COAL & PET. & NuC. & GEO. & SOLAR & IMPORT \\
\hline BASE & 112 & 29 & 141 & 145 & 2 & 583 & 146 & 708 & 40 & 2 & 56 \\
\hline $\begin{array}{l}\text { COAL ELECTRICITY COSTS } \\
\text { INCREASED BY } 50 \text { PERCENT }\end{array}$ & 109 & 29 & 143 & 245 & 2 & 570 & 147 & 718 & 40 & 2 & 56 \\
\hline $\begin{array}{l}\text { COAL ELECTRICITY COSTS } \\
\text { DECREASED BY } 50 \text { PERCENT }\end{array}$ & 120 & 28 & 136 & 142 & 2 & 617 & 141 & 681 & 40 & 2 & 56 \\
\hline $\begin{array}{l}\text { COAL ELECTRICITY AND CAPITAL } \\
\text { COSTS INCREASED BY } 50 \text { PERCENT }\end{array}$ & 106 & 30 & 145 & 146 & 2 & 556 & 149 & 730 & 40 & 2 & 56 \\
\hline $\begin{array}{l}\text { COAL ELECTRICITY AND CAPITAL } \\
\text { COSTS DECREASED BY } 50 \text { PERCENT }\end{array}$ & 129 & 27 & 131 & 139 & 2 & 652 & 137 & 652 & 40 & 2 & 56 \\
\hline $\begin{array}{l}\text { NUCLEAR ELECTRICITY COSTS } \\
\text { INCREASED. BY } 50 \text { PERCENT }\end{array}$ & 114 & 30 & 138 & 146 & 2 & 594 & 147 & 695 & 40 & 2 & 56 \\
\hline $\begin{array}{l}\text { NUCLEAR ELECTRICITY COSTS } \\
\text { DECREASED BY } 50 \text { PERCENT }\end{array}$ & 107 & 28 & 151 & 140 & 2 & 551 & 141 & 745 & 40 & 2 & 56 \\
\hline $\begin{array}{l}\text { NUCLEAR ELECTRICITY AND CAPITAL } \\
\text { COSTS INCREASED BY } 50 \text { PERCENT }\end{array}$ & 116 & 30 & 135 & 146 & 2 & 604 & 149 & 684 & 40 & 2 & 56 \\
\hline $\begin{array}{l}\text { NUCLEAR ELECTRICITY AND CAPITAL } \\
\text { COSTS DECREASED BY } 50 \text { PERCENT }\end{array}$ & 103 & 27 & 159 & 137 & 2 & 528 & 137 & 772 & 40 & 2 & 56 \\
\hline $\begin{array}{l}\text { GEOTHIERMAL ELECTRICITY COSTS } \\
\text { INCREASED } 8 Y 50 \text { PERCENT }\end{array}$ & 112 & 29 & 142 & 141 & 3 & 581 & 145 & 709 & 40 & 4 & 57 \\
\hline $\begin{array}{l}\text { GEOTHERMAL ELECTRICITY COSTS } \\
\text { DECREASED BY } 50 \text { PERCENT }\end{array}$ & 111 & 29 & 140 & 146 & 0 & 584 & 147 & 707 & 40 & 1 & 56 \\
\hline $\begin{array}{l}\text { GEOTHERMAL CAPITAL COSTS } \\
\text { INCREASED BY } 50 \text { PERCENT }\end{array}$ & 114 & 30 & 141 & 142 & 2 & 585 & 150 & 703 & 40 & 2 & 57 \\
\hline $\begin{array}{l}\text { GEOTHERMAL CAPITAL COSTS } \\
\text { DECREASED BY } 50 \text { PERCENT }\end{array}$ & 110 & 28 & 141 & 145 & 2 & 580 & 140 & 715 & 40 & 2 & 56 \\
\hline
\end{tabular}

F1gure 3.7.11 EFFECT OF CHANGING COST ASSUMPTIONS (YEAR 2000--1000. MWe) 


\section{Availability of Petroleum}

base model assumed that petroleum availability will be perceived as diminlshing significantly through the turn of the century. A sensitivity run was conducted in which it was assumed that the current petroleum availability would be malntained. Figure 3.7.12 1llustrates that increasing petroleum avallability has a relatively minor effect on the amount of geothermal energy developed. However, this change has a major effect on the petroleum generating capacity itself and on the generating capacity using other fuels. The effect is a major one: as petroleum generating increases, coal and nuclear diminish significantly.

\section{Parameters Associated with the Introduction of Solar} Energy

The sensitivity of geothermal development to different assumptions about solar energy was also tested because of the great uncertainty about the amount of central station solar generating capacity that might be installed by 2000 . The base run has assumed that the solar option could be included in the dectsion process after 1987. The four sensitivity runs were:

- The solar option is avallable after 1982.

- The solar learning process is accelerated (solar gains widespread acceptability four years after first introduction rather than ten years).

- The solar option is available after 1982, the learning process is accelerated, and perceived reliability is increased to unity.

- The solar option is avallable after 1980, the learning curve is accelerated (to inmediate acceptance), reliability is increased to unity, capital costs are halved, and the cost of solar electricity is halved.
These runs are summarized in Figure 3,7,13. These runs are not intended to be forecasts of central station solar development. They do show, however, that the amount of geothermal that is developed is not very sensitive to the level of solar development. Solar substitutes for coal and nuclear, primarily.

\section{Conclusions}

The level of geothermal energy projected by the model is quite sensitive to assumptions about available geothermal resources and insensitive to decision weights and costs assumptions within the range tested.

Increasing or decreasing the level of assumed demand affects all fuels; as demand increases, the amount furnished by geothermal sources is restricted by the assumed level of resources avallable.

Changing the leve1 of percelved petroleum availability has little direct effect on geothermal capacity; however, it has a very large effect on petroleum generating capacity by the year 2000 .

The level of geothermal use is relatively insensitive to changing assumptions about solar central station capacity; a simulated vigorous solar development program leads to the substitution of solar-generated electricity mainly for coal- and nuclear-generated electricity sources, rather than for geothermalgenerated electricity.

\begin{tabular}{|c|c|c|c|c|c|c|c|c|c|c|c|}
\hline \multirow{2}{*}{$R \cup N$} & \multicolumn{5}{|c|}{ WE S T } & \multicolumn{6}{|c|}{ E A S T } \\
\hline & COAL & PET. & NuC.: & GEO. & SOLAR & COAL & PET. & NuC. & GEO. & SOLAR & IMPORT \\
\hline BASE & 112 & 29 & 141 & 145 & 2 & 583 & 145 & 708 & 40 & 2 & 56 \\
\hline IMPROVED PETROLEUM AVAILABILITY & 93 & 89 & 117 & 123 & 1 & 465 & 423 & 569 & 40 & 1 & 53 \\
\hline
\end{tabular}

FIgure 3.7.12 EFFECT OF INCREASEING PETROLEUM AVAILABILITY (YEAR 2000--1000 MWe) 


\begin{tabular}{|c|c|c|c|c|c|c|c|c|c|c|c|}
\hline \multirow{2}{*}{$R \cup N$} & \multicolumn{5}{|c|}{ WES T } & \multicolumn{6}{|c|}{ E A S T } \\
\hline & COAL & PET. & NUC. & GEO. & SOLAR & COAL & PET. & NuC. & GEO. & SOLAR & IMPORT \\
\hline BASE & 112 & 29 & 141 & 145 & 2 & 583 & 145 & 708 & 40 & 2 & 56 \\
\hline $\begin{array}{l}\text { THE SOLAR OPTION IS AVAILABLE } \\
\text { AFTER } 1982 \text {. }\end{array}$ & 111 & 29 & 141 & 144 & 3 & 581 & 145 & 707 & 40 & 4 & 56 \\
\hline $\begin{array}{l}\text { THE SOLAR LEARNING PROCESS IS } \\
\text { ACCELERATED (SOLAR GAINS WIDE- } \\
\text { SPREAD ACCEPTABILITY FOUR } \\
\text { YEARS AFTER FIRST INTRODUC- } \\
\text { TION RATHER THAN TEN YEARS). }\end{array}$ & 112 & 29 & 141 & 144 & 3 & 582 & 145 & 707 & 40 & 4 & 56 \\
\hline $\begin{array}{l}\text { THE SOLAR OPTION IS AVAILABLE } \\
\text { AFTER 1982, THE LEARNING } \\
\text { PROCESS IS ACCELERATED, AND } \\
\text { PERCE IVED RELIABILITY IS } \\
\text { INCREASED TO WNITY. }\end{array}$ & 111 & 29 & 140 & 144 & 5 & 580 & 145 & 706 & 40 & 7 & 56 \\
\hline $\begin{array}{l}\text { THE SOLAR OPTION IS AVAILABLE } \\
\text { AFTER 1980, THE LEARNING CURVE } \\
\text { IS ACCELERATED (TO IMMEDIATE } \\
\text { ACCEPTANCE), RELIABILITY IS } \\
\text { INCREASED TO UNITY, CAPITAL } \\
\text { COSTS ARE HALVED, AND THE COST } \\
\text { OF SOLAR ELECTRICITY IS HALVED. }\end{array}$ & 104 & 29 & 131 & 135 & 23 & 565 & 145 & 688 & 40 & 34 & 56 \\
\hline
\end{tabular}

F1gure 3.7.13 EFFECT OF VARYING ASSUMPTIONS ABOUT SOLAR ENERGY (YEAR 2000--1000 MWe) 
4. PRIMARY AND HIGHER ORDER IMPACTS

OF GEOTHERMAL ENERGY

\subsection{Effect on Electric Utility Fuel Mix}

"Fuel mix" refers to the distribution of energy sources used in the generation of electricity. Today, the fuel mix includes primarily nuclear (uranium), petroleum, coal, hydroelectric, natural gas, and geothermal energy sources. The introduction of geothermal energy on the scale suggested in earlier sections of this report will have the effect of changing the fuel $\mathrm{mix}$ used by utilities and this changing mix w111 trigger downstream consequences, as we11. Figure 4.1 .1 presents the top levels of the impact relevance tree; Appendix D presents the relevance tree in detail.

\section{Outlook for Electricity}

The consumption of primary fuels for the generation of electrictty was about 25 percent of the tota1 national energy input in 1970 and may reach 30-50 percent by the year 2000. [1] This increasing role for electrlcity has several implications. First, since the generation of electricity involves conversion from primary energy sources and this conversion necessarily involves losses, increasing relative use of electricity will result in rapid growth in the use of primary fuels. In other words, relative growth of electricity generation results in consumption of larger portions of the total energy supply as conversion losses. Of course,

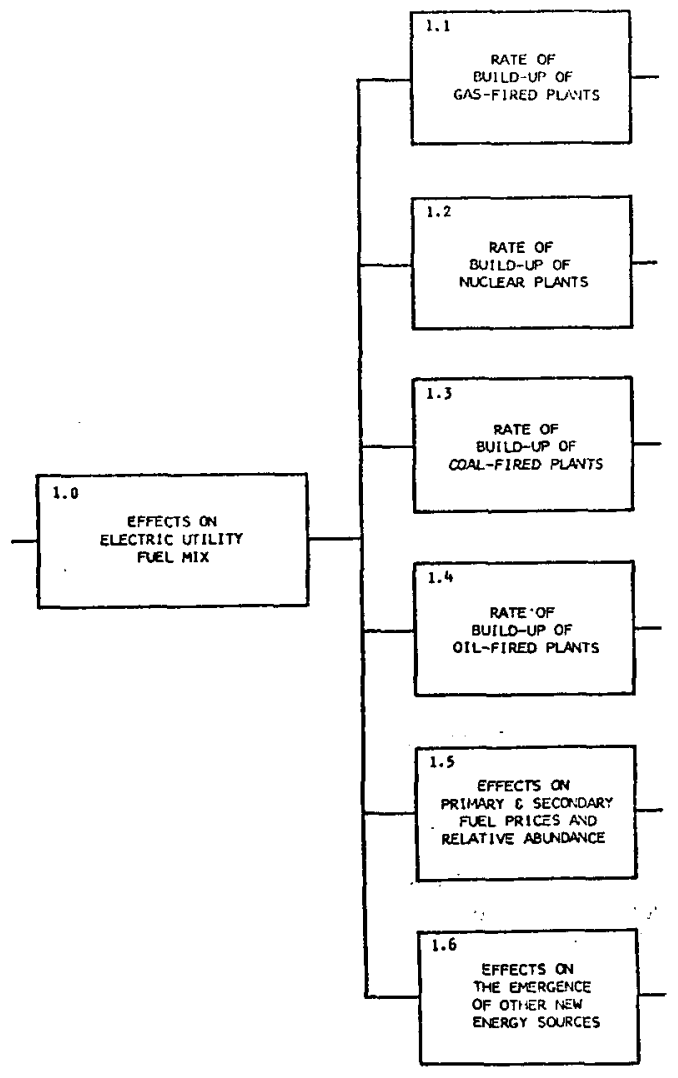

Figure 4.1.1 the magnitude of the conversion losses depends heavily on the absolute levels of electricity generated, the state of generation technology, the fuel mix, and other factors. A recent study can provide an example of the magnitude of energy losses involved. The Ford Foundation Energy Policy Project projected conversion losses of 18.4 percent of total energy input in 1975; by 2000 these losses were projected to be 31 percent of total energy consumption. [2]

The second implication of the increasing relative use of electricity is that otherwise unusable energy sources can be more fully employed. For example, uranium, hydroresources, solar, geothermal, coal, and residual oil can enter the overall fuel mix in the form of inputs to electricity generation; scarce fuels such as natural gas and petroleum remain available for direct use. Furthermore, the primary energy sources useful in the generation of electricity are, for the most part, indigenous; therefore, the increasing relative use of electricity moves the country towards energy independence from foreign supply with all of its associated political-financial headaches.

The Hudson-Jorgenson energy polfcy model represents a recent sophisticated attempt to project the rate of growth of consumption of varlous fuels and electricity. [2] The model is based on an integration of econometric modeling and input/output analysis. The input/output portion of the model included demand for inputs and supply for nine aggregated industrial sectors; the econometric portion of the model involved consideration of business and household sectors, as well as investment, capttal, and labor. For electricity, this model projected a growth rate of 5.2 percent per year between 1975 and 2000. (By comparison, the Federal Power Commission has projected that electricity consumption will grow at an average rate of over 7 percent per year between 1970 and 1990 , and that by 1990 , electricfty will have increased its share of total energy consumption to about 41 percent.) [3]

The rate of growth peaks in the $1975-1980$ period at 5.5 percent; by 2000 , the rate of growth has diminished to 5 percent. Within the electricity sector, personal consumption is projected to grow at the fastest rate: 6.9 percent per year over the perlod 1975-2000. This rate is somewhat less than that of the recent past due to "different price behavior, the new awareness in energy conservation, the Introduction of more energy efficient capltal such as heat pumps and thermal insulation, and the approach to saturation of such heavy electricity users as home air conditioning, dishwashers, laundries, ranges, and so on."[2] However, a number of technological and social trends suggest that the role played by electricity may be greater than that expected. These possibilities include: increased home heating by electricity, the advent of electric autotoobiles, the use of electricity in desalination, increasing mechanization of production, and the introduction and acceptance of new appllances.

\section{Projected Fuel Mix Requirements}

Almost all studies deallng with projected electrlcty supply indicate a diminishing role for fossil fuels and a greatly expanded role for nuclear sources. Figure 4.1 .2 presents the results of a recent study illustrating this point.

Interfuel competition has long existed within the fossil fuel sector. Among the factors involved in this competition are: 


\begin{tabular}{|c|c|c|c|c|c|}
\hline \multirow{2}{*}{ YEAR } & \multirow{2}{*}{ TYPE OF PLANT } & \multicolumn{2}{|c|}{ INSTALLED CAPACITY" } & \multicolumn{2}{|c|}{$\begin{array}{c}\text { ELECTRICAL } \\
\text { ENERGY }\end{array}$} \\
\hline & & $\left(10^{3} \mathrm{MWE}\right)$ & $q$ & $\left(10^{9} \mathrm{KW}-\mathrm{HR}\right)$ & $q$ \\
\hline 1969 & $\begin{array}{l}\text { HYDROPOWER } \\
\text { GAS TURBINE AND I-C } \\
\text { GAS-STEAM } \\
\text { OIL-STEAM } \\
\text { COAL-STEAM } \\
\text { LWR } \\
\end{array}$ & $\begin{array}{r}53 \\
14 \\
78 \\
40 \\
143 \\
4 \\
332\end{array}$ & $\begin{array}{r}16.0 \\
4.2 \\
23.5 \\
12.0 \\
43.1 \\
1.2 \\
100.0\end{array}$ & $\begin{array}{r}246 \\
15 \\
368 \\
150 \\
761 \\
13 \\
1553\end{array}$ & $\begin{array}{r}15.8 \\
1.0 \\
23.7 \\
9.7 \\
49.0 \\
0.8 \\
100.0\end{array}$ \\
\hline 1977 & $\begin{array}{l}\text { HYDROPOWER } \\
\text { GAS TURBINE AND I-C } \\
\text { GAS-STEAM } \\
\text { OIL-STEAM } \\
\text { COAL-STEAM. } \\
\text { LWR } \\
\end{array}$ & $\begin{array}{r}53 \\
36 \\
81 \\
61 \\
203 \\
90 \\
524\end{array}$ & $\begin{array}{r}10.1 \\
6.9 \\
15.5 \\
11.6 \\
38.7 \\
17.2 \\
100.0\end{array}$ & $\begin{array}{r}246 \\
25 \\
392 \\
293 \\
980 \\
514 \\
2450\end{array}$ & $\begin{array}{r}10.0 \\
1.0 \\
16.0 \\
12.0 \\
4.0 \\
21.0 \\
100.0\end{array}$ \\
\hline 1985 & $\begin{array}{l}\text { HYDROPOWER } \\
\text { GAS TURBINE AND I-C } \\
\text { GAS-STEAM } \\
\text { OIL-STEAM } \\
\text { COAL-STEAM } \\
\text { LWR } \\
\\
\text { TOTAL. }\end{array}$ & $\begin{array}{r}55 \\
57 \\
79 \\
78 \\
250 \\
258 \\
777\end{array}$ & $\begin{array}{r}7.1 \\
7.3 \\
10.2 \\
10.0 \\
32.2 \\
33.2 \\
100.0\end{array}$ & $\begin{array}{r}257 \\
40 \\
367 \\
364 \\
1175 \\
1469 \\
3672\end{array}$ & $\begin{array}{r}7.0 \\
1.0 \\
10.0 \\
9.9 \\
32.0 \\
40.0 \\
100.0\end{array}$ \\
\hline 2000 & $\begin{array}{l}\text { HYDROPOWER } \\
\text { GAS TURBINE AND I-C } \\
\text { GAS-STEAM } \\
\text { OIL-STEAM } \\
\text { COAL-STEAM } \\
\text { LWR } \\
\text { LMFBR TOTAL }\end{array}$ & $\begin{array}{r}72 \\
86 \\
90 \\
112 \\
447 \\
407 \\
422 \\
1636\end{array}$ & $\begin{array}{r}4.4 \\
5.3 \\
5.5 \\
6.8 \\
27.3 \\
24.9 \\
25.8 \\
100.0\end{array}$ & $\begin{array}{r}320 \\
60 \\
400 \\
500 \\
2000 \\
2320 \\
2400 \\
8000\end{array}$ & $\begin{array}{r}4.0 \\
0.8 \\
5.0 \\
6.3 \\
25.0 \\
29.0 \\
30.0 \\
100.0\end{array}$ \\
\hline 2020 & $\begin{array}{l}\text { HYDROPOWER } \\
\text { GAS TURBINE AND I-C } \\
\text { GAS-STEAM } \\
\text { OIL-STEAM } \\
\text { COAL-STEAM } \\
\text { LWR } \\
\text { LMFBR } \quad \text { TOTAL }\end{array}$ & $\begin{array}{r}86 \\
142 \\
86 \\
62 \\
1070 \\
443 \\
1739 \\
3628\end{array}$ & $\begin{array}{r}2.4 \\
3.9 \\
2.4 \\
1.7 \\
29.5 \\
12.2 \\
47.9 \\
100.0\end{array}$ & $\begin{array}{r}360 \\
100 \\
360 \\
260 \\
4500 \\
2520 \\
9900 \\
18000\end{array}$ & $\begin{array}{r}2.0 \\
0.5 \\
2.0 \\
1.4 \\
25.0 \\
14.0 \\
55.0 \\
100.0\end{array}$ \\
\hline $\begin{array}{l}\text { PPOST } \\
\text { PLAN } \\
\text { PLAN } \\
\text { IN 1 } \\
\text { FACT }\end{array}$ & $\begin{array}{l}969 \text { CAPACITIES ARE DE } \\
\text { FACTORS OF } 0.08 \text { FOR G } \\
\text { THE PLANT FACTOR O } \\
7 \text { AND DECREASES THERE } \\
S \text { FOR } 1977 \text { AND } 1985 \text {. }\end{array}$ & $\begin{array}{l}\text { VED FROM TH } \\
\text { TURBINE A } \\
\text { OOSSIL FUEL } \\
\text { EER TO APPR }\end{array}$ & $\begin{array}{l}\text { POWER G } \\
\text { I-C PLA } \\
\text { STEAM } \\
\text { IMATE T }\end{array}$ & $\begin{array}{l}\text { RATION FIGURE } \\
\text { AND } 0.65 \text { FOR } \\
\text { NTS IS TAKEN } \\
\text { OVERALL SYSTE }\end{array}$ & $\begin{array}{l}\text { USING } \\
\text { UCLEAR } \\
0.55 \\
\text { LOAD }\end{array}$ \\
\hline
\end{tabular}

SOURCE: OFFICE OF SCIENCE AND TECHNOLOGY, AOVISORY PANEL, "AN ASSESSMENT OF NEW OPTIONS IN ENERGY RESEARCH AND DEVELOPMENT," REPORT AET(UPTON, N.Y.: ASSOCIATED UNIVERSITIES, INC., NOVEMBER 1973).

Figure 4.1.2 INSTALLED CAPACITY AND GENERATION FOR CENTRAL STATION POWER PLANTS (INCLUDES INDUSTRIAL SELF-GENERATION) 
...the cost of fuel (and) such considerations as plant site and cooling water avallabllity, fuel

avallabllity over a perfod of time, characterfstics of the fuel supply market, magnitude and nature of fuel demand, proximity to transportation routes, reglonal varlations in plant construction costs, transmission costs and avallability of transmission rights-of-way, local tax structures, Import restric-

tions, and environmental quality considerations... [4]

Many of these considerations, of course, are quite simtlar to those employed in the dectsion factors used in the simulation model described in Section 3.4 .

Interfuel competition has led to significant changes in fuel $\mathrm{mix}$ over the past few years, Figure $4.1: 3111 \mathrm{ug}-$ trates the swing from coal to ofl over the last decade; this change was prompted primarily by environmental and economic considerations.

\section{Effect of the Introduction of Geothermal Energy on}

\section{Fuel Mix}

In projecting the effect of geothermal energy on fuel $\mathrm{mix}$, three runs of the simulation model are of interest:

- No Geothermal

- Base case

- Accelerated case

Figure 4.1 .4 presents the generation capacity for each of the fuels of interest for both the western portion of the United States and for the United States as a whole. Th1s figure shows that before 1985 geothermal energy has little effect on the total capacity of generating plants using other fuels. By 2000, however, the effect is significant: Geothermal installations substitute primarily for coal and nuclear plants. This substitution is illustrated in Figure 4.1.5. The most important effects of these substitutions are described below.

\section{Effect on Electricity Costs}

Even in the simulation of the accelerated program, geothermal energy sources represent only 12 percent of total generation capacity by 2000 . If the cost of geothermal electricity were 75 percent of the average cost of electricity from all other sources, the net effect on average electricity costs would only be a reduction of 3 percent. Therefore, the introduction of geothermal energy is not likely to change electricity costs to any great extent.

\section{Number of Power Plants Required}

If the average size of new coal or nuclear plants is taken to be $1000 \mathrm{MWe}$, then the substitutions described in Figure 4.1.5 for the accelerated case would imply, by the year 2000:

- 151 fewer nuclear plants in the UnIted States

- 116 fewer coal-fired plants in the United States

- 62 fewer nuclear plants in the West

- 52 fewer coal plants in the West

Without geothermal energy the simulation model Indicates that approximately 1811000 Me nuclear plants w111 be required in the West by the year 2000; with an accelerated geothermal program, this number would be reduced to about 119. This reduction in the number of nuclear plants will probably ease ofting problems to some extent because of the limited number of coastline locations avallable in the West, and the relatively high density of population near avallable cooling water supplies.

\section{Effect of the Introduction of Geothermal Energy on} Water Use

The Federal Power Comission has recently conducted studies of the consumption of fresh water required in

\begin{tabular}{|c|c|c|c|c|c|c|}
\hline \multirow{2}{*}{ REGION } & \multicolumn{2}{|c|}{ COAL } & \multicolumn{2}{|c|}{ GAS } & \multicolumn{2}{|c|}{ OIL } \\
\hline & 1960 & 1969 & 1960 & 1969. & 1960 & 1969 \\
\hline NEW ENGLAND & 58 & 23 & 5 & 2 & 37 & 75 \\
\hline MID ATLANTIC & 78 & 57 & 8 & 9 & 14 & 34 \\
\hline E. N. CENTRAL & 96 & 93 & 4 & 6 & - & 1 \\
\hline W. N. CENTRAL & 47 & 55 & 52 & 44 & 1 & 1 \\
\hline S. ATLANTIC & 77 & 70 & 15 & 13 & 8 & 17 \\
\hline E. S. CENTRAL & 92 & 89 & 8 & 11 & 0 & 0 \\
\hline W. S. CENTRAL & 0 & 0 & 100 & 100 & 0 & 0 \\
\hline MOLNTAIN & 26 & 55 & 66 & 42 & 8 & 3 \\
\hline PACIFIC & 0 & 0 & 68 & 83 & 32 & 17 \\
\hline U.S. AVERAGE & 66 & 58 & 26 & 29 & 8 & 13 \\
\hline
\end{tabular}

SOURCE: FEDERAL POWER COMMISSION, 1970 NATIONAL POWER SURVEY.

Figure 4.1.3 FOSSIL FUEL USE FOR ELECTRIC POWER GENERATION BY REGION (\% OF TOTAL BtU) 


\begin{tabular}{|c|c|c|c|c|c|c|c|c|c|}
\hline & \multirow{3}{*}{ FUEL } & \multicolumn{4}{|c|}{1985} & \multicolumn{4}{|c|}{2000} \\
\hline \multirow[b]{2}{*}{$\therefore$} & & \multicolumn{2}{|c|}{ WEST } & \multicolumn{2}{|c|}{ TOTAL } & \multicolumn{2}{|c|}{ WEST } & \multicolumn{2}{|c|}{ TOTAL } \\
\hline & & $\begin{array}{l}1000 \\
\text { MWE } \\
\end{array}$ & $\because$ & $\begin{array}{l}1000 \\
\text { MiNe }\end{array}$ & 咅 & $\begin{array}{l}1000 \\
\text { MNEE }\end{array}$ & 3 & $\begin{array}{l}1000 \\
\text { MNE } \\
\end{array}$ & 8 \\
\hline \multirow[t]{2}{*}{$\begin{array}{l}\text { NO } \\
\text { GEOTHERMAL }\end{array}$} & $\begin{array}{l}\text { COAL } \\
\text { PETROLEUM } \\
\text { NUCLEAR } \\
\text { GEOTHERMAL } \\
\text { HYDRO } \\
\text { NAT. GAS }\end{array}$ & $\begin{array}{r}47 \\
36 \\
41 \\
0 \\
47 \\
13 \\
\end{array}$ & $\begin{array}{r}25.5 \\
19.6 \\
22.3 \\
0 \\
25.5 \\
7.1 \\
\end{array}$ & $\begin{array}{r}307 \\
202 \\
258 \\
0 \\
72 \\
43 \\
\end{array}$ & $\begin{array}{r}34.8 \\
22.8 \\
29.2 \\
0 \\
8.2 \\
4.9 \\
\end{array}$ & $\begin{array}{r}147 \\
33 \\
181 \\
0 \\
58 \\
7 \\
\end{array}$ & $\begin{array}{r}34.5 \\
7.8 \\
42.5 \\
0 \\
13.6 \\
1.6 \\
\end{array}$ & $\begin{array}{r}787 \\
183 \\
959 \\
0 \\
90 \\
23 \\
\end{array}$ & $\begin{array}{r}38.5 \\
9.0 \\
47.0 \\
0 \\
4.4 \\
1.1 \\
\end{array}$ \\
\hline & TOTAL & 184 & 100.0 & 882 & 100.0 & 426 & 100.0 & 2042 & 100.0 \\
\hline \multirow[t]{2}{*}{$\begin{array}{l}\text { BASE } \\
\text { CASE }\end{array}$} & $\begin{array}{l}\text { COAL } \\
\text { PETROLEUM } \\
\text { NUCLEAR } \\
\text { GEOTHEWAL } \\
\text { HYDRO } \\
\text { NAT. GAS }\end{array}$ & $\begin{array}{r}44 \\
34 \\
39 \\
6 \\
47 \\
13 \\
\end{array}$ & $\begin{array}{r}24.0 \\
18.6 \\
21.3 \\
3.3 \\
25.7 \\
7.1 \\
\end{array}$ & $\begin{array}{r}305 \\
201 \\
255 \\
6 \\
72 \\
43 \\
\end{array}$ & $\begin{array}{r}34.6 \\
22.8 \\
28.9 \\
.7 \\
8.1 \\
4.9 \\
\end{array}$ & $\begin{array}{r}112 \\
30 \\
139 \\
147 \\
58 \\
7 \\
\end{array}$ & $\begin{array}{r}22.7 \\
6.1 \\
28.2 \\
29.8 \\
11.8 \\
1.4 \\
\end{array}$ & $\begin{array}{r}695 \\
181 \\
841 \\
188 \\
90 \\
\quad 23 \\
\end{array}$ & $\begin{array}{r}34.4 \\
9.0 \\
41.7 \\
9.3 \\
4.5 \\
1.1 \\
\end{array}$ \\
\hline & TOTAL & 183 & 100.0 & 882 & 100.0 & 493 & 100.0 & 2018 & 100.0 \\
\hline \multirow[t]{2}{*}{$\begin{array}{l}\text { ACCELERATED } \\
\text { CASE }\end{array}$} & $\begin{array}{l}\text { COAL } \\
\text { PETROLEUM } \\
\text { !UCLEAR } \\
\text { GEOTHERMAL } \\
\text { HYDRO } \\
\text { NAT. GAS }\end{array}$ & $\begin{array}{l}43 \\
32 \\
38 \\
19 \\
47 \\
13 \\
\end{array}$ & $\begin{array}{r}22.4 \\
16.0 \\
19.8 \\
9.9 \\
24.5 \\
6.8 \\
\end{array}$ & $\begin{array}{r}303 \\
200 \\
254 \\
19 \\
72 \\
43 \\
\end{array}$ & $\begin{array}{r}34.0 \\
22.5 \\
28.5 \\
2.1 \\
8.1 \\
4.8 \\
\end{array}$ & $\begin{array}{r}95 \\
28 \\
119 \\
192 \\
58 \\
7 \\
\end{array}$ & $\begin{array}{r}19.0 \\
5.6 \\
23.8 \\
38.5 \\
11.7 \\
1.4 \\
\end{array}$ & $\begin{array}{r}671 \\
177 \\
808 \\
249 \\
90 \\
23 \\
\end{array}$ & $\begin{array}{r}33.3 \\
8.8 \\
40.0 \\
12.3 \\
4.5 \\
1.1 \\
\end{array}$ \\
\hline & TOTAL & 192 & 100.0 & 891 & 100.0 & 499 & 100.0 & 2018 & 100.0 \\
\hline
\end{tabular}

Figure 4.1.4 FORECAST GENERATION CAPACITY OBTAINED FROM SIMULATION MODEL

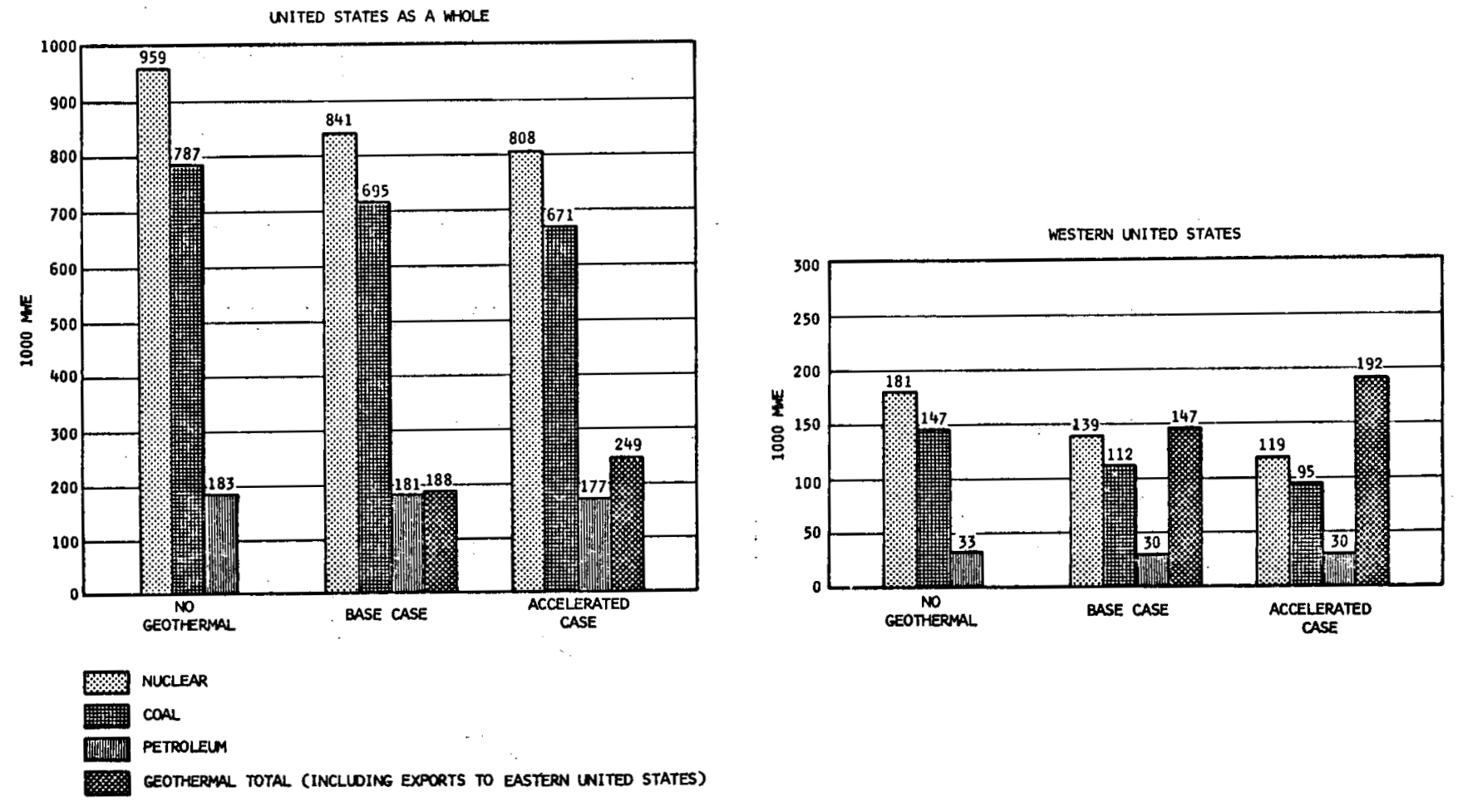

Figure 4.1.5 GEOTHERMAL SUBSTITUTION FOR OTHER PLANTS (1000 MWe--YEAR 2000) 
the operation of steam-electric power plant cooling sys'ms. If it is assumed that essentially all electric uerating plants will require a cooling pond or an -vaporative cooling tower (unless they utilize water from the ocean with a long outfal1), approximately 14,700 cubic feet per second of fresh water w111 be consumed in the process of power plant cooling in 1990. [5] Th1s is equivalent to the average annual runoff at the mouth of the Potomac River. The introduction of geothermal energy, to the extent defined by the accelerated case, will reduce surface fresh water demand for the generation of electriclty on the order of 10 percent by the end of the century. More important, it w111 do this in the West where water is already critically short. Therefore, development of the western geothermal resource will significantly help the development of western coal and ofl shale for national use.

Effect of the Introduction of Geothermal Energy on Reduction in the Amount of Coal Mined

If coal were to be used as a substitute for geothermal energy in the generation of electric power, it is estimated that an additional 1,000 tons of coal per day would be required to replace each 100 MWe of geothermal generating capacity. [9] A Government estimate of uranium and coal requirements by the year 2000 is given in Figure 4.1.6. [10]

\begin{tabular}{|c|c|c|}
\hline \multicolumn{3}{|c|}{$\begin{array}{l}\text { Fuel Resources Committed For Electrical } \\
\text { Generation -- Year } 2000 \\
\text { (Including Cumulative Usage and For Commitments) }\end{array}$} \\
\hline & $\begin{array}{l}\text { Case A } \\
\text { LMFBR } \\
\text { and LWR }\end{array}$ & $\begin{array}{c}\text { Case B } \\
\text { LWR }\end{array}$ \\
\hline $\begin{array}{l}\text { Uranium (millions of short } \\
\left.\text { tons } \mathrm{U}_{3} \mathrm{O}_{8}\right)\end{array}$ & 1.7 & 2.0 \\
\hline Coal (billions of short tons) & 32.0 & 32.0 \\
\hline Oll (billions of bbl.) & 9.0 & 9.0 \\
\hline
\end{tabular}

Figure 4.1 .6

Therefore comparing the no-geothermal case to the accelerated case leads to an estimate of 4.7 billion tons of coal (cumulative) which would not have to be mined

should geothermal energy be developed in accordance with the accelerated program.

"The existing 298 MW Geysers generating capacity would be equivalent to approximately 3,000 tons of coal per day. An estimated 10,000 to 21,000 tons of coal per day would be required to replace the 1,000 or 2,000 Mh power potential of The Geysers. In the West approximately 45 billion short tons of the recoverable resources could be extracted by open pit mining methods. At present, a.very large open pit coal mine may produce 5 million short tons of coal per year. Very large underground mines may produce 2 million short tons per year per mine. The replacement impact of coal-fired power plants would thus range from a scale-up of existing facilities to the development of large underground coal mines or very large surface coal mines or a combination of both types of mining. Coal production of this magnitude could have a significant impact on the environment. For example, if such volumes were to be produced by surface mining methods, the estimated areas that would be disturbed annualiy at alternative geothermal power level could be as shown in Figure 4.1.7."[9]

After World War II, coal lost much of its market to ofl and natural gas because of environmental difficulties, transportation costs, and handling complexity. Experts doubt whether coal production can be expanded fast enough now to meet the goals of Project Independence. [7] $\mathrm{Re}-$ cent legislation pertaining to stripmining, decling productivity, stringent safety requirements, and uncertainties in the technology required to remove sulfur, gasify or liquefy coal, make this resource less certain than it would otherwise seem. To the extent that geothermal energy substitutes for coal, these difficulties are amellorated.

Effect of the Introduction of Geothermal Energy on Reduction in the Amount of Uranium Mined

As for uranium, about 7500 tons per year of $\mathrm{U}_{3} \mathrm{O}_{8}$ were required in 1970; well over 100,000 tons per yearr would be required in 1990 assuming no recycle of plutanium. The Government estimates for cumulative uranium requirements in Year 2000 for two cases are given in Figure 4.1.6. In the $1990^{\prime} \mathrm{s}$ the breeder reactor is scheduled to produce significant amounts of plutonium-239 fuel usable in nuclear plants. In its substitution for nuclear plants, geothermal energy lessens demand for uranium by 0.32 million tons (accelerated case) by 2000 and tends to delay the need for added full processing facilities and the breeder reactor. $[8,10]$

Effect of the Introduction of Geothermal Energy on Atmospheric Pollutants

In 1968 fossil fuel steam electric power plants produced an estimated 16.8 million tons of sulfur oxide, 4 million

LAND REQUIRED FOR SURFACE COAL MINES

\begin{tabular}{|c|c|c|c|c|c|c|}
\hline $\begin{array}{l}\text { Coal Bed } \\
\text { Thickness } \\
\text { (ft.) }\end{array}$ & $\begin{array}{l}\text { Militons of Tons of Cosi } \\
\text { Avallable Per Sq. Mile e } 80 z \\
\text { Recovery (1800 ton/acre ft.) }\end{array}$ & $1,000 \mathrm{MH}$ & $\begin{array}{l}\text { Annual Ar } \\
2,000 \mathrm{MW}\end{array}$ & $\begin{array}{l}\text { as Disturb } \\
7,000 \mathrm{MW}\end{array}$ & $\begin{array}{l}\text { d (Acres) } \\
20,000 \mathrm{MW}\end{array}$ & $10,0,000 \mathrm{MW}$ \\
\hline 10 & 9.2 & 256 & 525 & 1,811 & 5,216 & 26,080 \\
\hline 20 & 18.4 & 128 & 262 & 902 & 2,611 & 13,055 \\
\hline 30 & 27.6 & 83 & 173 & 602 & 1,741 & 8,705 \\
\hline 40 & 36.1 & 64 & 134 & 461 & 1,331 & 6,655 \\
\hline 50 & 46.1 & $s 1$ & 102 & 358 & 1,043 & 5,215 \\
\hline
\end{tabular}

F1gure 4.1 .7 
tons of nitrogen oxide, and $5.6 \mathrm{million}$ tons of particulate matter. $[6,11]$ These amounts represented quite significant levels of pollution: The sulfur oxides emitted by electric power generating plants were 50 percent of all such pollutants released in the United States; the nitrogen oxıdes, 20 percent; and particulates, 20 percent. [6] The atr pollutants which can be released by fossil fuel plants are the result of combustion; and therefore their control requires intervention in the combustion cycle. For example, the fuel can be modified (e.g. the removal of sulfur); bollers can be modified to reduce the temperature of hot spots (and thereby control nitrogen oxides); and the products of combustion can be modified (e.g., through the removal of sulfur compounds and particulate matter). The cost of atmospheric pollution control devices ranges from \$50-125 per kflowatt. [11]

If the accelerated program were realized, geothermal energy would substitute for about 15 percent of the otherwise required coal-fired plants in the United states by 2000 . This substitution will result in a commensurate decrease in the amount of atmospheric pollutants released to the atmosphere, and in the costs expended for pollution control devices. This will give the savings shown in Figure 4.1.8.

From an Accelerated Geothermal Program Substitut fng For 116,000 MWe Coal-fired Power Plants in Year 2000

\section{Pollutant}

Sulfur Oxide

Nitrogen Oxides

Particulate solids

Capital Cost. Savings,

Cumulative (1973 dollars) $\$ 5.8$ billion $\$ 29$ billion

Note--Pollutant calculatlons based on data In Reference [10]. Current EPA emission standards for new coalfired power plants is assumed-- $\mathrm{SO}_{2}$ and particulate removal equipment is installed.

Figure 4.1 .8

\section{REFERENCES}

[1] Starr, Chauncey, "Energy and Power," Sclentific American (September 1971), p. 44

[2] Hudson, Edward A., and Dale W. Jorgenson, U.S. Energy Policy and Economlc Growth, 1975-2000 (Cambridge, Mass.: Harvard University and Data Resources, Inc. [part of the Ford Foundation Energy Policy Profect], June 1974).

[3] The 1970 National Power Survey, Part I (Washington, D.C.: The Federal Power Commission, December 1971) p. I-1-13. (Hereafter called The 1970 National Power Survey.)

[4] The 1970 National Power Survey.

[5] The 1970 National Power Survey, p. I-10-16.
[6] The 1970 National Power Survey, p. I-11-2.

[7] Walsh, John, "Problems of Expanding Coal Produc tion," Science (Apr11 1974), p. 336.

[8] The 1970 National Power Survey, p. I-6-11.

[9]. Final Environmental Statement for the Geothermal Leasing Program, Vol. 1 (Washington, D.C.: U.S. Department of the Interior, December 1973); $p$ IV-61.

[10] Environmental Statement Liquid Metal Fast Breeder Reactor Program, Vol: 1 (Washington, D.C.: U.S. Atomic Energy Commission, March 1974), p. I-11-10.

[11] Hotte1, H. C., and J. B. Howard, New Energy Technology--Some Facts and Assessments (Cambridge, Mass.: The MIT Press, 1971), pp. 70-80. 


\subsection{Effects on Businesses Relevant} to Geothermal Energy

\section{Introduction}

Any change in energy source, in an economy as complex as ours, can have ripple effects throughout a broad spectrum of industry. Businesses which utilize the new source of power can be affected, as well as businesses which supply goods and services for its production. Changing requirements in these categories result in secondary and tertiary impacts which are by no means limited to economic or operational areas: There may also be effects on the environment, on inst1tutional arrangements, on research policy, on industry location. Some of these Impacts may be expected to be pronounced; others so minor or diffuse as to be unnoticeable. This section will attempt to define the major areas of impact on particular businesses resulting from the development of geothermal energy.

\section{Effects on Businesses that Utilize Geothermal} Energy: Businesses that Need Electricity

Most businesses need electricity, although the requirements of Individual firms differ drastically. To the extent that geothermal-generated electriclty merely substitutes for electricity produced by another energy source, it would have no perceptible general effect on users other than through possible cost variations. [1] But if it alleviates a shortage of electricity which might otherwise occur, the use of geothermal electricity would allow industrial growth to continue rather than to be limited in the future. Th1s overall impact on the economy is discussed in Section 4.3 under macroeconomic effects.

More spectifically, it is possible that the use of geothermal energy for electrical generation can have sizeable impacts on Industrles which have unusually heavy electrical needs and on the areas in which they are located. Figure 4.2.1 shows the fuel consumption of Industries with the highest energy needs. The production of aluminum is quite energy-intensive; large plants are located in the Pacific Northwest, drawn there by the avallability of hydroelectric power. Unt1l recently power supply seemed assured, but drought conditions in the past few years have made it apparent that alternate or additional energy sources are needed in the area. Some industrial plants were forced to cut power usiage by up to one-third during the shortages, and in a few cases, complete shutdowns were necessitated.

\begin{tabular}{|c|c|c|c|c|c|}
\hline INOUSTRY GROAP & $\operatorname{coses}$. & MATURAL & $\begin{array}{l}\text { PETROLEUN } \\
\text { PROOUCTS }\end{array}$ & ELECTTRICITY & $\begin{array}{l}\text { TOTAL } \\
\text { ENERGY }\end{array}$ \\
\hline PRIMARY METAL INOUSTRIES & 2,838 & 863 & 306 & $.1,291$ & 5,298 \\
\hline OMEMICALS AND ALIIED PROOUCTS & 666 & $1: \quad 1,219$ & 1,426 & $\therefore 1,626$ & 4,937 \\
\hline $\begin{array}{l}\text { PETROLEUM REFINING, ANO } \\
\text { RELATED INDUSTRIES }\end{array}$ & & $\cdot \quad+1,012$ & 1,589 & 225 & 2,826 \\
\hline FOOO AND KINORED PROOUCTS & 263 & 593 & 134 & 338 & 1,328 \\
\hline PAPER AND ALLIED PROOUCTS & 467 & 341 & 212 & 280 & 1,299 \\
\hline $\begin{array}{l}\text { STONE, CLAY, GLASS, AND } \\
\text { CONCRETE PROOUCTS }\end{array}$ & 406 & $\begin{array}{r}.449 \\
\end{array}$ & 87 & 280 & 1,222 \\
\hline SUETOTAL & 4,640 & $4,477=$ & $\therefore \quad{ }^{2} 3,753$ & $4,040^{\circ}$ & 16,910 \\
\hline ALL OTER INDUSTRIES & $976^{\circ}$ & $\cdot \quad+4,781$ & 721 & $\therefore 1,572^{\circ}$ & 8,050 \\
\hline TOTAL & 5,616 & 9,258 & $4,47,4$ & 5,612 & 24,950 \\
\hline
\end{tabular}

SOURCE: STANFORD RESEARCH INSTITUTE USING BUREAN OF MINES DATA, AS PEPRINTED IN TME POTENTIAL FOR ENERGY CONSERYATION, DEECUTIVE

FIgure 4.2.1 INDUSTRIAL FURL CONSUMPTION BY MAJOR USERS (TRILLION BTU)
Prospects for hydroelectric expansion are limited because major sites have already been exploited, and consequently metals companies are actively seeking other energy sources.[2] The existence in the Northwest of a large power grid acting as a common carrier provides the opportunfty to transport and trade power which does not exist In many other parts of the country. Power can be fed into the grid at any point and removed elsewhere on an exchange basis. Aluminum companies located on the coast, for instance, are now looking into coal sources in Wyoming and would be. receptive to the use of any available geothermal energy. Amax Corporation has started geothermal exploration on private land in Callfornia, Oregon, and other western areas to find energy for its metallurgical operations, and has no doubt that private utilities as well as the public system would utilize any facilities they might develop.[3]

Certaln chemical processes also require unusually large amounts of electrical power, and chemical companies are In the forefront of industrial interest in geothermal development. Dow Chemical Company, which needs an assured source of electrfcity supply for its Washington plant, has bought an interest in Magma Power Company and also is investigating geopressured resources in the Gulf area. [4]

There are other locallties of geothermal potential where chemical companies could also be benefitted by add1tional power sources. The phosphate industry of southeastern Idaho, for Instance, needs additional power to produce fertilizer and phosphorlc acid from phosphate rock [5], and southern Nevada has a cluster of energyintensive chemical (chlorine-caustic) and metallurgical plants, [6] based on Hoover Dam.

The avallability of geothermal power can be an important factor in keeping existing heavy electrical users In an area and in Influencing the location of new capacity. If a particular industry brings with it pollution problems or changes the desired character of an area, these adverse effects might offset to some degree the beneficial local economic effects. On the other hand, the companies themselves and their customers would be benefitted by the assured production levels made possible by adequate and reliable energy supplies. The cost of the products would not necessarily be lower, however, since in some instances production of energy intensive industries has depended on inexpensive, government-subsidized hydro-electric power

Avallability of geothermally-generated-electricity could also have an Impact on the transportation system of the west. European rallroads have long been electrifled, but In this country the avallability of cheap foss11 fuel (diesel oil) did not encourage-electrification. In fact, the number of electric locomotives in the United States declined from 827 in 1950 to 255 in 1971. Rapldiy rising costs of diesel fuel; which now powers almost all U.S: railroads, may. cause a reversal in this trend in the next ten years.

The Southern Paciflc Rallroad Company 18 Investigating possibllities : of using geothermally-generated electricity.[7] Planners envision a line of geothermal plants roughly paralleling the rallroad, feeding in power at varlous points. Institutional and marketing difficulties might stand In' the way of tmplementing such a plan, however. A proprletary transmission system might be required if approprlate arrangements could not be made with local utilities, but this might entail duplicate facilities. In addition, since geothermal power is base-loaded, extra power would, at 
times, be avallable to be sold at elther end of the transmission lines, with the local utility the only legal customer. (See Section 4.5, Effects on Institut1onal Arrangements.)

Depending on the location of geothermal resources sultable for generating power and their distance to population centers, growth of electrified mass transit systems could be influenced by geothermal developments. Greater avallability of electricity would reinforce the interest in commuter lines now increasing due to potential auto gasoline shortages. Such a development would in turn affect levels of local air pollution and population mobility patterns.

\section{Businesses that Need Heat}

Although interest in U.S. geothermal resources has focused primarily on thelr use for electrical power production, it is possible that direct use of heat from the earth for space heating and Industrial and agriculturai processing may emerge as a very sizeable energy factor. The limiting constraint on this type of utilization is its site-dependency. It is 11kely that moderate temperature water-dominated reservolrs suitable for a large number of direct uses w111 be Identified in many areas of the West, but the hot fluid must be utilized within a few miles of the geothermal field because of the expense of piping and the 1088 of heat in transmission. Therefore, the extent of development-w111 depend upon the location of the resource with respect to prospective users and the consuming market, as well as upon the particular temperature and chemical composition of the geothermal water at the site.

A most 1mportant characteristic of the use of geothermal energy $1 \mathrm{~s}$ its potential for a multiplicity of complimentary and auxtliary uses in the same installa tion. Water remaining after steam has been flashed for electric power production could be utilized for many of the same purposes as direct geothermal fluid, depending on temperatures, composition, and the need for relnjection. Concurrent production of desalinated water and/or chemicals along with electrical power is the subject of current investigations. [8] In the case of utilization of direct geothermal fluid alone, once the resource is made avallable for a prime user, other secondary uses are likely to follow. Therefore, there is a good possibility that industrial-agricultural complexes could evolve near a geothermal resource, combined possibly with power production and/or residential space heating. Such a development could effect major changes in local economles and draw population to formerly 1solated areas.

Lindal [9] has compiled suggestions made by scient1sts from many different countries for the use of direct geothermal heat. In some few cases practical applications are already in existence; in most the proposals are merely in the conceptual stage. Poss1ble categor les of use include process and space heating, drying, distillation, refrigeration, de-icing and tempering in mining operations, production of alumina from bauxite; production of heavy water through the hydrogen sulfide-water lsotope exchange process, greenhouse heating, fish farming, and soilwarming. Specific absorption refrigeration processes include those in the production of synthetic rubber, ammonia, protein, vitamins, freeze-drled food, and in metallurgical plants. The feasibility of these varlous uses, of course, differs in varlous parts of the world according to prevalling Industrial costs. energy, and climatic conditions. Figure 4.2.2 shows the approximate geothermal fluid temperatures re- quired for various uses. The minimum temperature is the limiting factor, since too high a temperature usually can be easily adjusted.

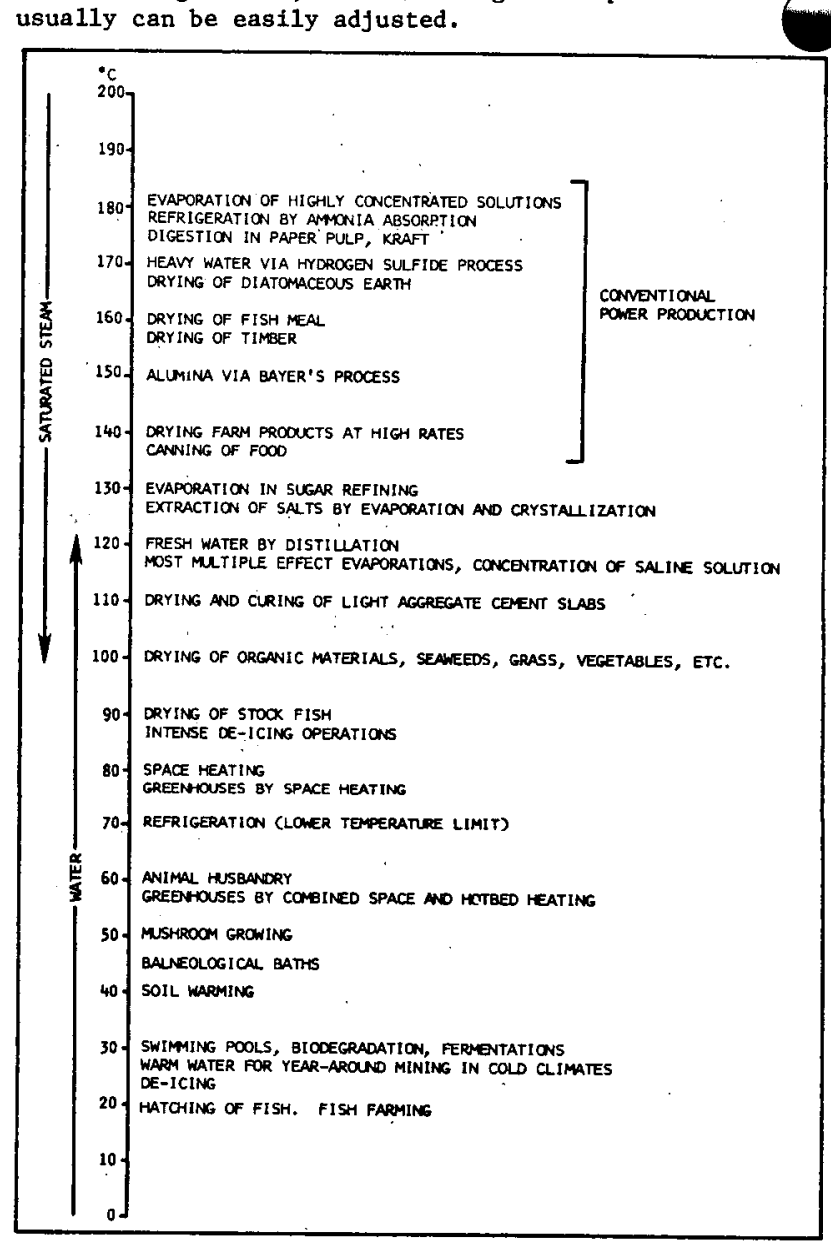

SOURCE: LINDAL, B., "INDUSTRIAL AND OTHER APPLICATIONS OF GEOTHERMAL

ENERGY, UNESCO, PARIS 1973 .

F1gure 4.2.2 THE REQUIRED TEMPERATURE OF GEOTHERMAL FLUIDS (APPROXIMATE)

A range of spectfic lindustrial processes which utilize steam and the amount of steam required per dollar of product value are shown in Figure 4.2.3. Although the figures for steam consumption are based on foss 11 fuel and are not necessarily directly applicable to geothermal steam, they indicate in which processes the cost of steam is a major consideration. IIndal [9] draws an analogy with power-consuming industries, where the cost of electrical power becomes an important factor In plant location when it accounts for more than 10 percent of the value of the product. In the case of steam, if steam cost $1 \mathrm{~s} \$ 1.75$ per ton of steam consumed, the 10 percent level would be reached by the use of 128 pounds of steam. per dollar value. Therefore, Industrles engaged in the ten processes 11sted In the figure with over 128 pounds of steam per dollar value might be prime candidates for moving to any cheaper source of steam supply, and those with somewhat lesser though substantial needs would also probably be Interested in its utilization. For example, natural sodium sulfate $(688,000$ tons, 1971) and natural sodium carbonate $(2,878,000$ tons, 1971) are mined in very large quantities in California and Wyoming. [10] Geothermal fields may be exploited near some of these mining areas. 


\begin{tabular}{|c|c|c|c|}
\hline & $\begin{array}{c}\text { STEAM } \\
\text { REQUIRENENTS }\end{array}$ & $\begin{array}{l}\text { PRUDUCT } \\
\text { VALUEE }\end{array}$ & $\begin{array}{l}\text { STEAMA PER UAIT } \\
\text { PROCUCT VALUE }\end{array}$ \\
\hline PROCUCT AND PROCESS & LE STEAM/La & CCONTS,LB & $\begin{array}{l}\text { LB STENOW } \\
\text { I VNUEE }\end{array}$ \\
\hline HEAVT WATER BY HYOROGEN SULFIOE PROCESS & 10,000 & 3,000 & 333 \\
\hline ASCOPBIC ACID & 250 & 250 & 100 \\
\hline VISCOSE PAYOA & $70^{1}$ & 75 & $\therefore 93$. \\
\hline LACTOSE & $40 \ldots$ & 14 & 286 \\
\hline ACEIIC ACID FROM WOJO VIA SUIDA PROCESS & 35 & 10 & 350 \\
\hline ETHYL ALCOHOL FROM SULFITE LIQUOR & 22 & 7 & 314 \\
\hline ETHYL ALCONOL FROM WOOO WASTE & 19 & 7 & 271 \\
\hline ETHTLENE GLYCOL VIA OHLOFOMYDRIN" & 13 & 13 & 100 \\
\hline CASEIN $\cdots$ & 13 & - 56 & 23 \\
\hline ETHYLERE OXIOE- & 11 & $15 \div$ & 73 \\
\hline EASIC MG CARBONATE & 9 & II & $: \quad .82$ \\
\hline 35\% HYDROGEN PEROXIDE & 9 . & 18 & $\cdots 50$ \\
\hline 854 HYCROGEN PEROXIDE FROM $358 \mathrm{H}_{2} \mathrm{O}_{2}$ & $43 / 4$ & - & $\overline{-}$ \\
\hline SOLID CAUSTIC SODA VIA DIAPHRAGM CELLS & g & 3 & 266 \\
\hline ACETIC ACIO FPOM WOOD VIA SOLVENT EXTRACTIOHA & $71 / 2$ & 10 & 75 \\
\hline ALLMINA VIA BATERS PROCESS & $7^{2}$ & 3 & 234 \\
\hline ETHYL ALCOKOL FROM MOLASSES & 7 & $?$ & 100 \\
\hline BEET SLCAR & $53 / 4$ & 10 & 58 \\
\hline SOOIUA CHLORATE & $53 / 2$ & 9 & 61 \\
\hline KEAFT PULP & $41 / 5$ & 6 & 70 \\
\hline DISSOLVING PULP & $41 / 5$ & -- & -- \\
\hline SULFITE PULP & $31 / 2$ & 6 & 58 \\
\hline ALUMINIM SULFATE & $31 / 2$ & 2 & 175 \\
\hline SWNTEETIC ETHYL ALCOHOL & 3 & 7 & 43 \\
\hline CALCILM HIPOCHLORIDE, HIGH TEST & $31 / 3$ & 3 & 111 \\
\hline ACETIC ACIO FROM WOOO VIA OTHER PROCESS & $2,3 / 4$ & 10 & 28 \\
\hline AMTONIA CHLCRIDE & $23 / 4$ & 6 & 46 \\
\hline BORIC ACID : & $21 / 4$ & 5 & 45 \\
\hline SOOA ASH VIA SOLVAY PROCESS & 2 & $11 / 2$ & 133 \\
\hline COTION SEED OIL & 2 & 10 & 20 \\
\hline NATLRAL SODIUM SULFATE & $14 / 5$ & $1 \mathrm{~L} / 2$ & 120 \\
\hline CANE SUCAR PEFINING & $12 / 3$ & 10 & 17 \\
\hline AMONIA N:TRATE & $12 / 2$ & $31 / 2$ & 43 \\
\hline AMIONIA SULFATE & $1 / 6$ & $11 / 2$ & 11 \\
\hline FRESH WATER FROM SEA WATER BY DISTILLATIIN & $1 / 12$ & $1 / 60$ & .500 \\
\hline
\end{tabular}

ISHREVE (1956) QUOTES 150 LB STEAM PER PC'ND.

2 HAS DECLIMED IN PECERT YENAS IN MOST CASES.

SOURCE: LINDAL, B., "INUUSTRLAL ANO OtTER APPLICATICNS OF GEOTERMAL ENERGY," CEOTHERMAL ENERTY, UESCO, 1973.

Figure 4.2.3 THE SPECIFIC CONSUMPTION OF STEAM AND THE STEAM USED PER DOLIAR VALUE IN SOME ESTABLISHED PROCESSES

In this country there are a number of industries in promising geothermal areas which can be identifled as prospects for use of direct heat. The lumber, paper and pulp, and food processing Industries in the Northwest current1y use large amounts of: low grade heat. This is provided primarily by natural gas, but the gas companies are no longer offering firm supply contracts. [4] Geothermal fluid at a minimum of $230^{\circ} \mathrm{F}$ could provide this type of heat. The chemtcals industry makes extensive use of process heat at from $200^{\circ}$ to $450^{\circ} \mathrm{F}$, now provided by ofl and gas, Greenhouses, flsh farming, animal husbandry, and other agricultural applications are also potential utilizers of geothermal resources:

Most companies in these Industries are not exploration-. oriented and would not risk drilling for themselves, Development companies and/or government entities, would probably have to estab1ish the resource and guarantee the supply for any large-scale utilization. Local 1mpacts of such projects would be pronounced, particularly In rural areas, if they, stimulated growth of existing industry or attracted new companies to the area. There would be effects on the economy, the tax base, and the size and character of the population.

Although 11ttle research has been done in this country on the use of geothermal process heat, there has been Investigation in an allied area, use of thermal effluents from power plants. TVA, in conjunction with the Oak RIdge National Laboratories; has several projects underway to determine beneficial uses of waste heat. [11] These include use of condenser cooling water for catfish production in power plant water raceways, soil heating to extend the growing season of horticultural and field crops, and environmental control in greenhouses. There are also plans to study the use of hot water in heating and cooling livestock facilities and in recycling nutrients from livestock wastes. A number of utilities are also experimenting with possible uses of warm water discharged from power plants. The effluents from a Long Island. Lighting $C o$, power plant are used by Long Island Oyster Farms to accelerate oyster breeding [12], and Northern States Power Co. In Minnesota recently started a one-year demonstration project to test whether warm water discharge could be used to heat and cool greenhouses. [13] This project is being conducted in confunction with the -University of Minnesota Agricultural Experiment Station, which is also Investigating the use of warm water for soll-warming and fish farming. [14] The temperature of water circulated through power plant cooling towers normally ranges from $60^{\circ}$ to $115^{\circ} \mathrm{F}$, lower. than generally expected geothermal fluld temperatures.. Since higher temperatures can be adjusted, however, or in many cases, as described below, may prove more effective, the power plant research currently being conducted will be useful in Ident1fying geothermal app11cations.

The following paragraphs will discuss in greater detall, by Industry, the prospects for Industrial and agricultura1 use of geothermal heat. Space heating and cooling w111 be treated in Section 4.6.

Greenhouses $[4,14,15,16,17,18,19,20,21,22,23]$

The advent of titerest in geothermal energy colncides fortultously with a trend toward greater use of controlled environments in agriculture. There is increasing demand for off-season, greenhouse-grown products, and some scientists have envisioned the possibility of creating artificlal microclimates over large areas using geothermal resources as the heat source. [8] Technology exists to grow super-size vegetables and grains under controlled conditions, although the commercial stage has not yet been reached. In the past, heating costs in conventional greenhouses in Illinols, Ohio, and Southern. Ontario have represented 25 to 30 percent of total operating costs [21]. Recent Increases in fuel prices have, of course, Increased this percentage. Heating costs are high because of the difficulty in . insulating transparent panels... Even mote important, reduced fuel allocations: for hortlcultural production during the energy crisis helghtened the risk of crop 1oss. - Just, $a$ : $f$ ew degrees change in temperature for even a few minutes can precipitate disaster under hothouse conditions, and therefore reliability of fuel supply is a paramount consideration. Under-today's energy supply conditions, the use of heating water from on-site geothermal wells becomes increasingly attractive for greenhouse use. Although investment costs for equipment and piping would probably be higher than for some conventional systems, the fuel savings and increased rellability of geothermal sources may be of sufficient. attractiveness to warrant their use In many applications.

Numerous examples of geothermal usage for greenhouses exist throughout the wor1d.[9] In Hungary, use for both hothouses and animal husbandry has been rapidly increasing in recent years. . In Iceland, the greenhouse Industry showed tremendous growth from 1940 to 1960 until the market became saturated, and has since remained on a high plateau with 70 percent of the acreage in vegetables and 30 percent in flowers. Japan has some geotherma1ly heated horticultural hothouses and In New Zealand mushrooms are grown in propagation houses with the heat also 
being used to sterilize the soll. The USSR has experim mented with geothermal greenhouses, some surrounded by so11-warming areas. In the Un1ted.States, there are a few greenhouses heated by geothermal flulds in Cal1fornla, Idaho, and Oregon.

A new trend to accelerate the growth of tree seedilngs In greenhouses is currently stimulating geothermal exploration in the Northwest. Most.timber companies are interested In greenhouses, and the abundance of geothermal resources in the area make this form of heating a promising alternative to other fuels.- Bolse Cascade corporation 18 buliding two seedling greenhouses in Oregon adjacent to a hot spring in order to ut1lize its $85^{\circ} \mathrm{F}$, hot water for growing half a million seeding conifers a year. The growth rate is expected to be two to three times greater than in conventional ground beds. Weyerhauser Company is starting to explore for geotherwial resources for space heating and greenhouses.

Forty percent of the country's. flower' and nursery stock growers are located on the west coast. The horticultural part of the greenhouse industry had particular fuel problems during the energy shortage because they were not classifled as agriculture and dd not get full fuel allocations. The classification has been recently changed, but uncertaint1es linger and the Industry would probably be quick to take advantage of established geothermal resources. Location is not a particular problem, since more nurserles are speclalizing today and shipping products greater distances by truck and plane. Ohio has more horticultural and vegetable greenhouses than any other part of the country.

Vegetables grown in greenhouses in remote geothermal areas might have prohibitive transportation costs to population centers. However, as heating costs rise, the lower costs of geothermal energy might offset transportation charges. An interesting sidelight which might contribute to relocation 18 the fact that many existing greenhouses, originally on the edge of town, are now in the middle of high-valued land. It might therefore be economic for some growers to sell their existing facilities and rebulld. In more remote area. In addition, development of plastic greenhouses has reduced Inttial investment costa.

Vegetable growing in greenhouses could be a particularly important application of geothermsl energy in Alaska. Fresh vegetables are more expensive there because of the very short growing season. Alaskan greenhouses also need a 11 ght source for the long Arctic winters. Th1s may be obtained from fluorescent lights ut111aing geothermal electricity. Thus, the Alaskan greenhouse could use two attributes of geothermal energy, heat and electric1ty. [22.]

The TVA waste heat research greenhouse at Muscle Shoals, Alabama, is currently testing the use of power plant thermal discharge in growing tomatoes, cucumbers, and lettuce, wh1ch account for 93 percent of greenhouse vegetable production In the United States. The preIIminary economic evaluation [21] points out that refinements are needed for greater commerclal potential. One of the suggested Improvements ls use of higher temperature water which could be made avallable if power plants go to closed-loop cooling. Thls would lower capital and operating costa through, for example, lower waterflow rates or smaller heat exchangers. Warmer water would also maintain lower humidty and thus reduce the cost of disease contro1. This research would seem to Indicate that the higher temperatures generally avallable in geothermal fielda would be more efflclent than power plant thermal discharges for greenhouse use. Other disadvantages of power plant waste heat deacribed by IVA which would not exist in geothermal use are the variation of water temperature with generating load and, of great Importance; the problem of temporary plant shutdown causing sudden temperature reductions.

other power plant research also indlcates that low temperature is the mafor constraint. Russell v. Stansfleld, Administrator of Warm Water Utilization for Northern States Power Co., has stated, "The biggest obstacle to using power plant warm water for heating and cooling is that the temperature of the water 1880 close to that of the desired greenhouse temperature that the equipment needed to transfer that heat from the water to the afr must be very large."

\section{So11-Warming}

TVA is currently conducting experiments in the use of warm water for Irrigating and heating the soll for vegetable crops In open fields at Muscle Shoals, Alabama.[11] Beds are underlain with electric heating cables to simulate underground warm water pipes, and are subirrigated with porous plastic pipes. Ylelds of string beans and sweet corn are almost doubled, sumer squash yields are increased only during the early production period, and tomatoes show little response. More elaborate experiments are belng planned to extend both the early and late growing seasons.

Whether geothermal water can prove economically feastble for th1s type of soll-warming probably depends on the climate in which it is found and utilized. The University of Minnesota has conducted field studies of heating soll to remove frost in order to extend the growlng season. Preliminary conclustons are that it may not be practical because it requires a coldtolerant crop, and there are no high income cold tolerant crops. [14]

\section{F1sh Farming $[23,24,25,26,27,28]$}

It has been predicted that by 1990 about half of all fish consumed will be grown by cultivation methods because of declines in the natural catch. The catfish farming Industry, which did not exist ten years ago, grew 25 percent a year from 1968 to 1972 and 10 percent $a$ year for the past two years. Sixty thousand acres. are now in production, mostly in the South. Developmental profects are also underway for growing shrimp, oysters, salmon, and crayfish. In 1972, fish farms provided about 90 million pounds of f1sh, two percent of domestic fish production. [30]

Geothermal fluids may be useful in marlculture. The growth of almost all cold-blooded animals can be accelerated by increased temperatures, and in general, for flsh, the warmer the water the greater the growth, up to the 11mit of tolerance. Optimum temperatures for economlc breeding can range from $65^{\circ}$ to $90^{\circ} \mathrm{F}$. In Iceland, geothermal water 18 used for tempering pond water in fish breeding stations and at least one salmon breeding station uses the warm water directly. Eels are bred in Japan in ponds where geothermal water $1 \mathrm{~s}$ mixed with river water. [9] In the UnIted States several projects are now underway using thermal effluents from nuclear power plants to Increase shellfish growth and to breed catfish.

The main problem to be faced in utilizing geothermal fluids for marlculture lo water quality. Geothermal water is low in dissolved oxygen, may be too alkallne, and may contain trace elements and $h \mathrm{~h}_{\mathrm{gh}} \mathrm{H}_{2} \mathrm{~S}$ wh1ch would be harmful to fish. Flowlng water is needed to remove fecal matter and for aeration, and a flow of 20 cubic 
feet per second is needed for raising fish that swim t the same time, a high concentration of fish is heeded to make an operation profitable. At least one pound of fish flesh per cublc foot per year must be produced. To maintain this density, the water must be fairly clean, since disease is a hazard under such crowded conditions. Big fish exhaust oxygen especially quickly.

Each geothermal field would have to be analyzed fndividually to determine its fish-raising potentialities with respect to temperature, chemical composition, possibility of mixing with other waters, and proximity to markets and transportation. Aeration problems could probably be solved by running the water over a three to four foot waterfall. This could be done up to three times within a mile to maintain sufficient oxygen levels.

The use of geothermal water for fish-ralsing has one highly desirable advantage over use of power plant effluents--constant temperature. If the plant is temporarfly shut off, Inlet water temperature can swing wildly, with extremely harmful effects on the flsh. Geothermal water would remain at constant temperature. In addition, as artesian water, it is bacterla-free.

Some of many species which might be investigated for cultivation in or with the mixture of geothermal fluids include trout, catflsh, crayfish, carp (for fish meal), salmon, fresh water crawfish, and fresh water shrimp. Some experimentation has been done in Galffornia on the use of geothermal water to breed talapia and brine shrimp. It is possible that fish which are now confined to southern waters could be grown in warm water further north if the mineral content could be tolerated.

A TVA experiment in using heated water for raising catfish in concrete raceways found that growth rates were significantly enhanced by heated water and that the growing season was lengthened.[11] The project was not able to proceed to commercial operation because of several problems not yet overcome. Feed loss and mortality rates were high and the state imposed requirements for secondary treatment of the used water because of substantial quantities of waste materials. At the University of Minnesota, Investigators are using an existing commercial operation to determine if catfish can be kept growing in the winter with the addition of warm water.

Accelerated development of mariculture through use of geothermal water could not only provide additional input to a fish market currently characterized by frequent shortages of particular species and high prices; but would also have a beneficial impact on the balance of trade. The percentage of total fish consumed in the United States which were Imported increased from 32.5 percent in 1955 to 65.8 percent in 1972 . The total value of edible fish imports in 1972 was $\$ 1,205$ militon [10], almost 20 percent of all food imports. Any part of this which could be replaced by cultivation methods would contribute to the domestic economy.

\section{Pulp and Paper; Wood Processing}

The Tasman Pulp and Paper Co. of New Zealand is the first major Industrial user of geothermal steam in the world. [31] It was located specifically for this purpose and uses 400,000 pounds of natural steam per hour for processing cellulose pulp out of wood by the Kraft process, The wells produce wet steam, which is flashed before transmission by pipeline. Some of the steam is used directly and some is fed into steam generators for producing clean steam, The energy is used for timber-drying, log-handling equipment, pulp digestion, and black liquor evaporation. In addition to this major use, timber is seasoned by natural heat in various parts of the world.

U.S. geothermal applications in the lumber and paper industry appear particularly promising since almost 60 percent of lumber production in this country is in the Mountain and Pacific areas, where geothermal resources are belleved to be abundant. Kiln drying of lumber is a standard industry procedure and geothermal hot water would be suitable in many instances. [32]

\section{Food Processing}

The food processing industry uses large amounts of heat for freezing and canning fruits and vegetables and for producing sugar from sugar beets. These functions could be implemented by geothermal resources in areas such as the Imperial Valley of Callfornia, a major agricultural area, and the Oregon-Idaho border, a foodprocessing area for potatoes, beets, peas, and other vegetables. $[4,33]$

Greater avallability of energy resources for processing may increase agricultural production in a particular area, and will very likely supplement a growing greenhouse industry based on the use of geothermal heat if the range of products grown under controlled conditions increases. As in the case of all other applications of process heat, the temperature of discovered resources and their location will play a major part in determining the extent of use.

Crop drying is another application of geothermal heat, and already has small scattered applications. Most wheat, corn, and soybeans must be dried before long term storage to prevent rotting. It has also been suggested that natural heat could be used in the dairy industry for production of dried milk, casein, and sucrose. [9]

\section{Animal Husbandry}

In a number of countries, geothermal heat is used in the livestock and poultry industries. In Hungary, it is used for heating cattle stalls, milking rooms, pigstles, and chicken houses; in Japan for hatching eggs and raising poultry; and in New Zealand for biodegradation of wastes from pigsties and for washing and drying of wool. [9, 22] All of these applications are on a small scale at present.

TVA plans to build an experimental feedlot and poultry house heated by hot water as part of 1 ts program to develop uses for power plant thermal effluent. Research has shown that feed conversion and efflciency are improved. for livestock and poultry within certain ranges of moderate temperatures:[11]. In connection with this profect, a study of techniques for recycling nutrient from livestock wastes is also planned; It would involve producing algae by utilizing nutrients from manures in a serles of heated lagoons and ponds. The algae could then be harvested and processed into a high-protein feed source, although this is a difficult and expensive project. "The results of this exper1ment w11l probably be applicable for geothermal research, particularly since the Mountain states have both geothermal resources and a sizeable cattle industry. 


\section{Mining}

Geothermal energy has proven useful in mining operations in some parts of the world. In Northern Iceland, it is being used for recovery and drying of diatomaceous earth which was not able to be economically ut1lized by other means. Research is being conducted in the USSR on the use of geothermal waters in mining in permafrost regions. Possibilities for usage there are for ore flotation and for heating and humidification of ore air.

Whether any mining applications will be found in the United States is not yet known.

\section{Chemical By-Products and Desalinization}

Some high temperature geothermal fluids tend to contain high percentages of minerals, and also contain the energy potential for self-evaporation. Figure 4.2.4 shows the chemical components of high saline brines in the Salton Sea area in California as compared with fluids of much lower salinity at Cerro Prieto and Arizona. Sodium chloride is the most abundant compound, but although extraction of salt has proven feasible in some other parts of the world, it is not currently competitive in this country because of adequate, less costly, deposits and considerable transportation costs that would be 1nvolved if geothermal sources were utilized. Potassium and magnesium appear to have the greatest commercial potential, but the costs of production are not yet clearly economic.

\begin{tabular}{|c|c|c|c|c|c|}
\hline ELEVENT & $\frac{\text { NLLAND }}{\text { WELLL } 39}$ & $\begin{array}{c}\text { SALTON S } \\
\text { WELL } 36\end{array}$ & $\begin{array}{l}\text { EA AAEA) } \\
\text { WELLL } 57\end{array}$ & $\begin{array}{l}\text { CERRO } \\
\text { PRIETO } \\
M 3\end{array}$ & $\frac{\text { ARIZONA }}{\text { MUSGROVE } 1}$ \\
\hline soolum & $50,400^{\circ}$ & 53,000 & 10,600 & 5,610 & 141": \\
\hline POTASSILM & 17,500 & 16,500 & 2,250 & 1,040 & --- \\
\hline CALCIUM & 28,000 & 27,800 & 1,130 & 320 & 148 \\
\hline LITHIUM & 215 & 210 & 40 & 14 & - \\
\hline MGESEIUM & 54 & 10 & 74 & $* x$ & 43 \\
\hline STRONTIIMM & 400 & $4+0$ & 85 & 27 & - \\
\hline QARIUM & 235 & 250 & 3 & 57 &.- \\
\hline RUEIDIUM & 135 & 70 & - & $x=$ & - \\
\hline CESIUM & 14 & 20 & - & $x$ & -- \\
\hline IRON & 2,290 & 2,000 & 0.7 & $x$ & - \\
\hline MANCANESE & 1,400 & 1,370 & 6.4 & $x=x$ & - \\
\hline LEAD & 102 & 80 & - & $\mathbf{x x}$ & - \\
\hline ZINC & 540 & 500 & - & $x$ & - \\
\hline SILVER & $x$ & $\infty$ & - & 0.05 & - \\
\hline COPPER & 8 & $\mathbf{x x}$ & - & 0.09 & - \\
\hline SILICA & 400 & 400 & 120 & $m$ & 18 \\
\hline CMLORIDE & 155,000 & 155,000 & 19,700 & 9,694 & 188 \\
\hline BORON & 390 & 390 & 100 & $12=2=x$ & - \\
\hline FLUORIDE & 15 & $x^{x x}$ & 1 & 0.88 & - \\
\hline SIM Or' SULFUR & $x \times$ & 30 & - & $\approx 10$ & - \\
\hline DISSOLVED SOLIOS & 258,973 & 259,000 & 34,800 & $\approx 17,000$ & 1,000 \\
\hline $\begin{array}{l}\text { XINCLUDES POTASS } \\
\text { XINOT REPRTE } \\
\text { OOXXEECALCOLATED FRC }\end{array}$ & $\mathrm{H}_{3} \mathrm{BO}_{3}$ & & & & \\
\hline
\end{tabular}

Figure 4.2.4 ANALYSES OF WATER FROM GEOTHERMAL WELLS AT SALTON SEA GEOTHERMAL AREA (IMPERIAL VALLEY), CERRO PRIETO (MEXICO), AND YUMA, ARIZONA VICINITY (PARTS PER MILLION)

Some efforts have been made in the past in the Imperial Valley to extract minerals from geothermal brine but these proved uneconomic because the minerals carried the full cost of development. [34] If power, minerals, and possibly desalinated water could be produced concurrently, the costs might be brought down to a commer ctal level. Demonstration plants will be necessary fo this concept to be tested, Geothermal fluid is complex and each field differs just as solid ore deposits differ. Equipment would have to be tailored for each particular location.

If chemical extraction proves feasible using proprietary power, an Industrial base could be added to the present agricultural economy of the Imperial Valley and thus reduce the currently high level of unemployment. The crucial element is not necessarily comparative costs for metals today, but those future ones which will prevail at the time a multipurpose geothermal complex could be implemented. Growing scarcities and rising prices of metals may make extraction from geothermal fluid economically viable. U.S. demand for potassium fertilizer in 1985 is projected at 6.85 million short tons ( $K$ equivalent), with a value of over $\$ 200$ million at current prices, as compared to projected domestic production of 3.66 million. Demand for manganese is estimated at 1.77 million short tons in 1985 with no domestic production. [35] Manganese is almost entirely imported today, at an annual cost of $\$ 34$ million. [10] A competitive means of production here could not only contribute to the local economy, but could help improve the balance of trade.

Desalination of geothermal fluld in the Imperial valley is being investigated by the Bureau of Reclamation, but there is yet 1ittle knowledge of the economics involved. [36]. Two test wells have been drilled, but desalting is not yet actually underway, Physical data must be obtained before commercial possibilities can be ascertained.

The objective of the Bureau's long-range program is to determine the compatibility of concurrent production of electricity and fresh. water, in order to augment the the Colorado River. [34] Within a time-frame of 20 years and depending on the results of research and development steps, 2,5 million acre-feet of desalted water per year could be produced with 10,500 MWe of electricity, of which about 2,000 MWe would be used for processing and pumping.

The major operational and cost problem is the need for substitution of other water for reinjection in order to replace the desalinated fluid. This reinjection is necessary to prevent subsidence in the geothermal fleld. Several alternatives have been proposed: the use of Salton Sea or other local waters or the 1mportation of water from the Pacific by aqueducts. Only a combination of multi-purpose development plus an urgent need for water is likely to make such an elaborate project economically feasible.

If implemented, however, the impacts would be sizeable. The Colorado River has become increasingly saline, and this condition may threaten the viability of the canal system which now irrigates $5,000,000$ acres of land in the Imperial valley. There are also international implications, since the United States is obligated to furnish Mexico with water from the Colorado River and the deterforating quality has become an issue of dispute.

\section{Un1que Geothermal Applications}

The applications of geothermal process heat described above are primarily adaptations and extensions of existing technologies. There are other possibilities for more futuristic uses of the earth's heat which can be envisioned. If geothermal wells were bored into the ocean floor in strategic locations, it is 
concelvable that the upwelling of hot water could create elerated growth areas for ocean nutrients and fish. her contribution to the food chaln would be to ed single cell animals and plants in geothermally heated ponds. When dry hot rock drilling is developed, it is possible that a means will be found to leach out minerals by dissolving them in acidic water circulated in pairs of deep wells bored Into deep strata. These epeculations serve as fllustrations of types of applications which may emerge as new geothermal teĉ̉hnology develops.

Effects on Businesses That Supp1y or Support Geothermal Industries

\section{Summary of Development Requirements}

Extensive business activity will be engendered by the heavy capital investment needed to yield the rate of geothermal growth projected by the model described in Section 3.5. Figure 4.2 .5 presents a summary of some of the demands which will be placed on the emerging geothermal industry if it is to reach a producing level of about 7,000 MWe in 1985 and 190,000 in 2000. From reported experience at The Geysers, Cerro Prieto, and Wairakei, and from estimates made in the literature, it is possible to project roughly the number of wells, rigs, men, and capital necessary to sustain the postulated development rate. By 2000 , some 40 million feet of wells will have to be drilled annually, assuming average depths of 6000 feet, production of 5MWe per well, one disposal well for two producing wells, a wildcat drilling success rate of 1 well in 10 , and a development and production success rate of 9 in 10. (See figure note for hot dry rock modifications.) In the mid-elghties, the model yearly expansion rate of 2000 MWe would require about 150 drilling rigs operating per year, assuming a dr1lling rate of 24,000 feet a year, including downtime. By 2000 , the expansion rate would rise to 20,000 MWe per year, requiring 1,500 rigs. Manpower requirements for rig crews, at the present rate of 17 men for round-the-clock shifts, would total 2,500 in 1985 and rise to 25,000 in 2000. As discussed in Section 3.3, these long-range requirements seem attainable, even in the presence of a vigorous and expanding program of petroleum exploration and development, although spectal government allocation and incentive programs might be required in periods of rapid expansion.

By 2000 , about $\$ 2,800$ million per year would be required for drilling, assuming that present estimated costs of $\$ 50$ per foot have escalated to $\$ 70$ per foot in constant 1973 dollars because of deeper and more difficult drilling attempted. These development and production expenditures will, in general, be net additions to the regional economy and stimulate a wide range of local businesses as well as material supplies. The power plant building stage, in contrast, will substitute for other types of generating plant investments, although it will change the localized impact within the region.

Cumulative geothermal investment, including all drilling and power plant costs, is projected at $\$ 95$ billion by 2000 . This estimate assumes that present average Investment costs of around $\$ 250$ per installed k1lowat will gradually rise to about $\$ 500$ in constant 1973 dollars by the end of the century as more expensive technologies and labor are employed to utillze highsalinity brines, lower temperature fluids, geopressured resources, and hot dry rock in an environmentally acceptable way. The effects of these factors causing increased costs will more than of $f$ set economies affected by exploration, drilling, and equipment design 1mprom inents.
This estimate of $\$ 500$ per kilowatt in 2000 was derived through Trend Impact Analysis (TIA), a computer program for combining trend extrapolation with human fudgment on the probabilities of certain events occurring which would divert the trend, (See Appendix F.) Figure 4.2.6 1ists forecasted events which could be expected to impact on the current approximate geothermal cost of $\$ 250$ per kilowatt, the probabilities of their occurrence by 1995, the t1me for the maximum 1mpact to be felt if the event occurs, and the maximum percentage impact on the base trend. (The program also includes probabilities for earlier years.) Figure 4.2 .7 shows the range of costs which could occur depending on where the forecasted events come into effect. The most significant result of the analysis is that despite the discrepancy between the posstbility of costs as high as almost $\$ 600$ and as low as $\$ 250$ in the $1990^{\prime} s$, depending on the timing of the impacts, all three trend lines are converging on the central estimate of $\$ 500$ by the year 2000 as almost all events have exerted their maximum Impact on the base trend.

Even at $\$ 500$ per kilowatt, geothermal electricity is 1ikely to be less expensive than other energy sources; capital costs of Installations utilizing other fuels are expected to rise commensurately because of increased costs of construction materials, equipment, labor, capita1, pollution control, and siting, thereby preserving the cost advantage which geothermal resources currently present.

For example, nuclear power plants which cost $\$ 200$ per kilowatt in 1966 are profected to cost about $\$ 750$ per kilowatt by the mid-eighties, and will continue to rise thereafter about 1.5 percent per year (constant 1973 dollars). About 85 percent of these capital costs represent construction materials, equipment, and labor together with the financial charges of the long construction schedule. [37]

The following sections detall the many enterprises which will participate in and benefit from this heavy spending program. The process starts with the developer. continues through the exploration and drilling stage, and culminates in power production.

\section{Exploration and Drilling Phase}

The pioneers in geothermal development, as in the oil and gas Industry, have been small entrepreneurlal companies which took early leases on private lands. As bellef in the potentiality of the resource became more widespread, however, and the ofl crisis spurred the search for energy in any form, large oil companies began to show interest in acquiring a stake in the geothermal industry. Several of the developmental efforts now being made on private lands are joint profects of small geothermal developers or land companies, which held the original leases, and major ofl companies, which have more extensive financial resources and which may also hold adjacent leases.

Unitization of adjoining lands in a geothermal field is usually necessary for economic viability of the profect. Since the energy must be sold on the spot, competing nearby wells are wasteful. Greatest efficiency and profit can be made by planning the least number of wells necessary to develop a whole field and using a single management. The Geothermal Steam Act permits such unitization, and proposed Congressional leglslation for geothermal financial incentives encourages 1t. Therefore, it appears that as commercialIzation of the resource accelerates, the market may be increasingly dominated by large enterprises or 
SUMARY OF GEOTHERMAL DEVELOPMENT PARAMETERS:

\begin{tabular}{|c|c|c|}
\hline PARANETERS & 1985 & 2000 \\
\hline NUMBER OF FEET DRILLED/YR. (1000'S) & 4,000 & 40,000 \\
\hline NUMBER OF RIGS/YR. & 150 & 1,500 \\
\hline MANPOWER IN DRILLING (MEN/YR.) & 2,500 & 25,000 \\
\hline DOLLARS NEEDED FOR DRILLING/YR. (MILLIONS) & 200 & 2,800 \\
\hline CUMNLATIVE NUMBER OF WELLS DRILIED & 2,500 & 68,000 \\
\hline CLMLLATIVE GEOTHERMAL INVESTMENT (BILLIONS) & 2.2 & 95.0 \\
\hline RESOURCE DEVELOPMENT RATE (MWE/YR.) & 2,000 & 20,000 \\
\hline CUMULAT IVE RESOURCES DEVELOPED & 7,000 & 190,000 \\
\hline RESOURCES AVAILABIE FOR DEVELOPMENT & 10,000 & 200,000 \\
\hline
\end{tabular}

JARESORCE DEVELOPMENT FIGURES ARE OUTPUT OF MODEL DESCRIBED IN SECTION 3. DRILLING AND INVESTMENT ESTIMATES ARE DERIVED FROM OPERATING EXPERJENCE IN STEAM AND HOT WATER PLANTS FROM ECONOMIC ANALYSES IN THE LITERATURE, AND FROM TREND IMPACT ANALYSIS. ONLY CONJECTURES CAN BE MADE AT THIS TIME ON DRILLING PARAMETERS FOR HOT DRY ROCK. IT IS ASSUMED THAT MEGAWATT CAPACITY PER WELL WILL. BE MIGHER THANI FOR HOT WATER BUT THAT DRILLING WILL BE DEEPER, SLOWER, AND MORE EXPENSIVE.

Figure 4.2 .5

\begin{tabular}{|c|c|c|c|c|c|}
\hline FORECAST & ESTIMATE & $\begin{array}{l}\text { BABILITYY } \\
\text { IOWN }\end{array}$ & $\begin{array}{l}\text { YEARS TO } \\
\text { FIRST IMPACT }\end{array}$ & $\begin{array}{l}\text { YEARS TO } \\
\text { MAXIMMM IMPACT }\end{array}$ & $\begin{array}{l}\text { MUXIMUM INPACI } \\
\text { (PERCENTAGE) }\end{array}$ \\
\hline $\begin{array}{l}\text { EXPLORATION, DRILLING, AND EQUIPMENT } \\
\text { DESIGN IMPROVEMENTS DIMINISH COSTS BY } 208 .\end{array}$ & .80 & 1995 & 0 & 3 & -10 \\
\hline $\begin{array}{l}\text { AVERAGE DRILLING DEPTH INCREASES BY A } \\
\text { FACTOR OF } 1.5 \text {. }\end{array}$ & .50 & 1995 & 0 & 1 & 15 \\
\hline $\begin{array}{l}\text { TIME TO INSTALL GEOTHERMAL PLANTS } \\
\text { INCREASES BY } 30 \% \text {. }\end{array}$ & .60 & 1995 & 0 & 1 & 15 \\
\hline $\begin{array}{l}\text { COST INDEX OF FINISIED EQUIPMENT AND } \\
\text { MATERIALS DOUBLES. }\end{array}$ & .90 & 1995 & 0 & 3 & 15. \\
\hline $\begin{array}{l}\text { IIJCREASINGLY SEVERE ENVIRONENTAL } \\
\text { REQUIREMENTS ADD } 208 \text { TO CAPITAL COSTS. }\end{array}$ & .50 & 1995 & 0 & 3 & 20 \\
\hline $\begin{array}{l}\text { LABOR COSTS INCREASE TO } 1.25 \text { OF CURRENT } \\
\text { VALUE. }\end{array}$ & .80 & 1995 & 0 & 3 & 25 \\
\hline $\begin{array}{l}\text { AVERAGE RESOURCE QUALITY DIMINISHES TO } \\
758 \text { OF CURRENT VALUE. }\end{array}$ & .40 & 1995 & 0 & 1 & 25 \\
\hline
\end{tabular}

FIgure 4.2.6 EVENTS USED IN TREND IMPACT ANALYSIS OF CAPITAL COSTS OF GEOTHERMAL OPERATIONS

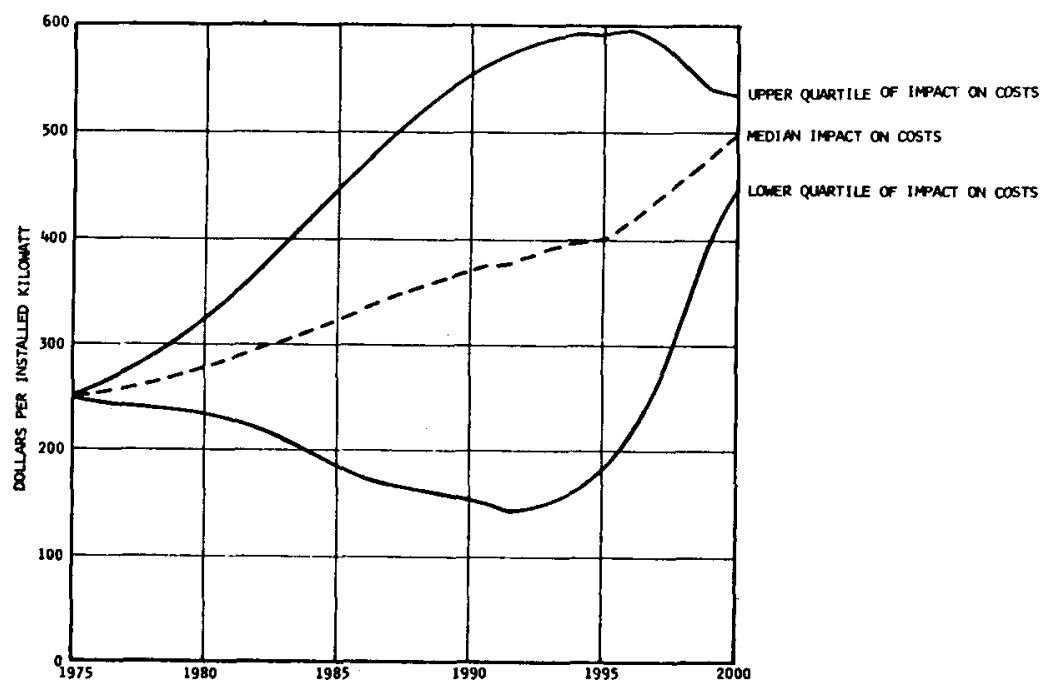

Figure 4.2.7 PORECAST OF CAPITAL COSTS OF GEOTHERMAL OPERATIONS (IN 1974 DOLLARS PER KILOWATT) 
consortia, As the prime example of this, The Geysers ld is unitized with Unton 011 Company managing perty owned by Unton, Magma Power Co, and Thermal Power Co.

The bonus bidding aystem, by requiring prepayment, also acts in favor of larger, better financed companies. In the recent competitive bidding for KGRA units in California, six out of nine successful bidders were large ofl companies. Non-competitive lease applications, however, show a wider range of particlpants. Included among the first month's (January 1974) app11cations were oll companies, geothermal companies, a State university, a rural electrical cooperative, and a number of individuals. As in the oll industry, there w1ll probably always be a place for the omall wildcatter who is willing to explore in less proven or smaller areas.

As developers enter the exploration and driling phase, they utilize the resources of a large number of contractors and suppliers. In some cases the activities and materials used in geothermal development and In the ofl and gas industry are Identical; in othera, some modifications are required; but in general, the same support companies service both geothermal and oil and gas operations. [38]

For Instance, there are now about a half dozen compantes offering geophysical services, all of whom had prior mining or ofl expertence. Shailow-well drillers engaged in exploratory activities are interchangeable with the ofl Industry, and laboratories utilized for geothermal chemical analyois are already existing enterprises. The effect, therefore, is not the creation of a large number of new companies, but expanded opportunities for those in allied fields. Regulatory requirements lead to employment of many specialists such ss enviromental impact consultants and, of course, staffs for government regulatory agencies.

Major drilling contractors hired after the shallow exploratory stage are also interchangeable with the oll Industry. For this reason, the supply of rigs and materlals avallable for geothermal drilling will be affected by demand in the oll industry, and vice versa. The recent surge in 011 and gas exploration has caused shortages of tubing and casings which are a delaying factor in geothermal drilling. As geothermal development accelerates, it can be expected to contribute to the demand for rigs and materials. Th1s may extend short term material shortages, although in the"longer term, the additional requirements of geothermal activities 11e within reasonable industry expansion potential if sufficlent incentive is percelved.

There are today about $1600 \mathrm{dr} 111$ rigs operating in the 011 and gas Industry. About a ten percent expansion over this total level would be required by 1985 to accommodate geothermal demand, and almost 100 percent by 2000 . In terms of current production, about a 15 percent annual increase over today's production level of 80 to $100 \mathrm{r} 1 \mathrm{gs}$ a year would be necessary to acconinodate the additional geothermal demand by 1985, and doubled production would be necessary in ensuing years.

A commensurate increase would be required in materials production. Higher prices may be necessary to encourage this production, but as the market $1^{\mathrm{s}}$ defined and proven, fleld oupplies can be expected to be forthcoming. Imports of casing and tubing from Burope have recent1y been etimulated, for Instance, by w11linginees of customers to pay prices higher than those charged by domestic ateel mills. Continuation of this trend in the absence of adequate domestic capacity, however, would adversely affect the balance of trade.
The growing utilization of 1 igs for geothermal driliing w11l contribute to the growing prosperity of the independent drilling industry, Unt11 revitalized by the sudden surge in ofl prices, the industry had been in a downtrend since 1956. Many former workera had left the occupation because of limited opportunities. Drillers are now conducting crew training programs and the geothermal demand will add to employment in the fleld. Around 2500 persons can be expected to be employed in geothermal drilling in the mid-elghties and up to 25,000 by 2000 . These w111 be transient crews for the most part, except for those permanently employed in drilling replacement wells at establlshed largescale flelds. Therefore their impact on the economy of a particular location will be temporary, although sizeable, particularly in rural areas

Many auxiliary suppliers and services will also benefit from the drilling phase of development. Manufacturers of bits, valves, drilling muds, control devices, and other drililng equipment and supplies will feel increased demand along with compantes making drill pipe and line pipe. Well logging services will be utilized. A number of spectalty services will also be needed, ouch as magnaflux teams"to coat casing with powder. In this stage some devices w111 be required which are unique to geothermal activities, such as new types of wellhead sound mufflers. R\&D activities will be engendered for these specific Items and for improvements in varlous aspects of deep drilling at $\mathrm{h} i \mathrm{gh}$ temperatures.

Local and reglonal services will be temporarily affected by large-scale drilling. Grading contractor will be heavily involved, as well as vacuum truck companies to haul materials and waste. Craft unions will enter the picture through needs for carpentry and plumbing. A wide range of services will be called upon, such as printers, motel operators, airlines, and rental cars.

Robert Greider of Chevron 011 Company has prepared an economic analys1s; shown in Figure 4.2.8, of the costs assoclated with developing a 250-275 MNe hot water geothermal field.[39] He considers this size the minimum which can support the exploration risk, the fleld development Investment, and the charges for time value of capital Invested while walting for revenue to be generated. In his example, total exploration costs amount to $\$ 8$ militon. This figure is based on the assumptions that one out of four land areas of interest acquired w11l be judged worthy of drilling, that only one out of four of the exploratory wells drilled will show enough promise to run pipe and complete for more extensive testing, and that in turn, only one out of four of these completed wells will locate a field of the minimim aize to be commercially viable. To develop a producing fleld with 50 producing wells and 25 Infection disposal wells will cost up to $\$ 15$ million, bringing the total surface and subaurface cap1tal investment coste to a range of $\$ 21$ to $\$ 24$ m1111on. F1gure 4.2.9 shows Grelder's model of how such an Investment could generate a rate of return of 13.7 percent with a payment perlod of 7.3 years $1 f$ the purchaser of the geothermal energy pays 4.8 mills per kllowatt hour. He emphasizes that a higher rate of return 18 necessary for geothermal exploration and development than for more conventional fuels because of greater uncertainties and higher rlake tnvolved. 


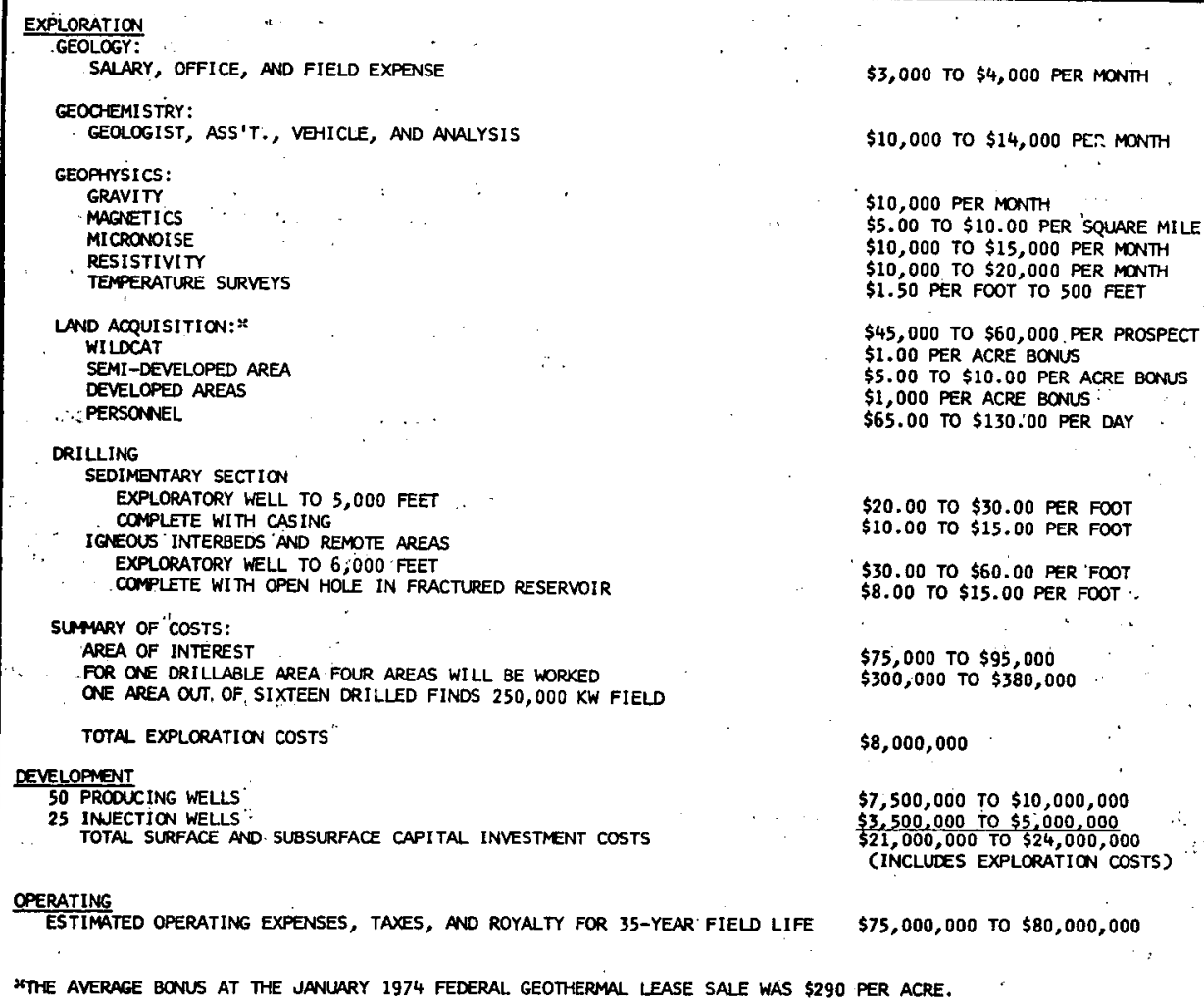

ESTIMATED OPERATING EXFENSES, TAXES, AND ROYALTY FOR 35-YEAR FIELD LIFE $\$ 75,000,000$ TO $\$ 80,000,000$

$\$ 3,000$ TO \$4,000 PER MONTH

$\$ 10,000$ TO $\$ 14,000$ PES MONTH

$\$ 10,000$ PER MONTH

$\$ 5.00$ TO \$10.00 PER 'SQUARE MILE

$\$ 10,000$ TO $\$ 15,000$ PER MONTH

$\$ 1.50$ PER FOOT TO 500 FEET

$\$ 45,000$ TO \$60,000. PER PROSPECT

$\$ 1.00$ PER ACRE BONUS

$\$ 5.00$ TO $\$ 10.00$ PER ACRE BONU

$\$ 65.00$ TOR ACRE BONUS:

$\$ 20.00$ TO $\$ 30.00$ PER FOOT
$\$ 10.00$ TO $\$ 15.00$ PER FOOT

$\$ 30.00$ TO $\$ 60.00$ PER FOOT

$\$ 8.00$ TO \$15.00 PER FOOT.

75,000 TO $\$ 95,000$

300,000 TO $\$ 380,000$

$\$ 8,000,000$

$\$ 7,500,000$ TO $\$ 10,000,000$

$\$ 3,500,000$ To $\$ 5,000,000$

CINCLUDES EXPLORATION COSTS

SOURCE: GREIDER, ROBERT, "ECONOMIC CONSIDERATIONS FOR GEOTHERMAL EXPLORATION IN. THE WESTERN UNITED STATES," GEOTHERMAL RESOURCES COUNCIL BULLETIN, VOL. 3, NO. 3 (MAY/JUNE 1974).

FIgure 4.2.8 ESTIMATED COSTS FOR EXPLORING AND DEVELOPING A 250,000 kW GEOTHERMAL HOT WATER FIELD

$$
\begin{gathered}
\text { ECONOMIC MODEL } \\
\text { EXPLORATION PROGRAM THROUGH PRODUCTION } \\
275 \text { MW FUEL SUPPLY }
\end{gathered}
$$

INCLUDES ALL GEOLOGICAL, GEOPHYSICAL, AND LAND EXPENDITURES REOUIRED FOR DRILLING SIXTEEN PROSPECTS TO DISCOVER ONE FIELD THAT CAN MEET THE REQUIREMENTS FOR THIS SIZE OF PRODUCTION.

1. PRODUCTION RATE WILL BE THE AVERAGE OF COMPLETED WELLS AT CERRO PRIETO, MEXICO.

2. PRODUCING WELLS SPACED 10 ACRES APART. INUECTION WELLS ON FIELD PERIPHERY.

3. TEN PRODUCING WELLLS AND FIVE INJECTION WELLS REQUIRED FOR EACH $55 \mathrm{MW}$ TURBINE.

4. 808. PLANT FACTOR, $90 \%$ PRODUCING WELL FACTOR, AND $20 \%$ STANDBY CAPACITY.

5. 108 MAXIMUM ROYALTY EXPENSE.

6. MINERAL AND PRODUCTION TAXES ARE 68 OF GROSS WORKING INTEREST INCOME.

7. 22 DEPLETION CREDIT.

DEVELOPMENT TO 275 MN

INVESTMENT ( $\$ 000)$

OPERATING EXPENSE, TAXES, \& ROYALTY $(\$ 000)$

YEARS TO COMPLETE PAYOUT

RATE OF RETURN

NET PROFIT. PER YEAR AFTER PAYOUT $(\$ 000)$

THE PAYOUT TIME MAY BE DECREASED TO 6.4 YEARS, AND RATE OF RETURN INCREASED TO 178, IF (1) THE PRICE OF FUEL IS INCREASED TO 5.6 MILS PER KWH GENERATED, (2) THE DRILLING SOHEDULE OF THE FIELD is ADUUSTED TO ACTLAL MODUIE GENERATING PLANT COMPLETION, AND (3) MINERAL AND PRODUCTION TAXES ARE HELD TO $5 \%$ OF INCOME.

SOURCE: GREIDER, ROBERT, "ECONOMIC CONSIOERATIONS FOR GEOTHERMAL EXPLORATION IN THE WESTERN UNITED STATES," GEOTHERMA RESOLRCES COUNCIL BULLETIN, VOL. 3, NO. 3 (MAY/JINE 1974).

Figure 4.2.9 


\section{Generating Stage}

drilling phase of development in general brings a increase to the regional economy and to the equipment, contracting, and service firms involved. In contrast, the production and generating stage is probably in large part a substitution for other forms of generation and equipment. It does, however, requifre more equipment unique to the resource and tallored to the specific requirements of each producing area. It will involve expanded research and development on concepts, materials, and equipment to utilize fluids or steam of varying temperatures and composition.

The pattern which has been set at The Geysers is for the developing and/or producing companies to sell steam energy to the utillty company on a royalty basis for units of heat supplied. The utility builds and operates the steam-electrical generating facllities. Unless public utility regulations are changed to allow other types of companies to sell electricity, this pattern will probably be followed in future developments.

The actual construction of the plant and transmission IInes will provide temporary business for a vartety of contractors and their suppliers. This work can be considered a substitute for construction of other types of power plants to use other fuels, although it will probably be in a different location and built in smalier units of 50 to $150 \mathrm{MW}$. It is probable that some of the same large regional contractors would be involved, but smaller local businesses, depending on their avallability in the area, would probably benefit.

Sales of generating equipment to utllize geothermal heat will, in general, substitute for provision of conventional types of equipment, and will probably transfer business from one division to another of large equipment manufacturers or create new business for specialty manufacturers. To the extent that geothermal heat powers capacity that would not otherwise be built, there would be an increase in equipment sold. The extent of economic gains or losses will depend on comparative costs of the competing equipment.

Unt1l recently, turbines used at The Geysers were of Japanese manufacture, but a new 60 and a 135 MWe turbine will be furnished by General Electric Company. [40] The policy followed by domestic manufacturers appears to be to wait until commercial utilization is assured before developing specific geothermal equipment. Steam equipment is now in that category but hot water, hot dry rock, and geopressure are not. Only after sma11 experimental plants are built to test custom equipment and the process appears economically feastble can U.S. manufacturers be expected to produce geothermal equipment on a commerclal scale.

As this commercial development evolves, forelgn markets are likely to offer promise along with the domestic one and may eventually turn out to be larger. . American manufacturers are not expected to compete heavily in Common Market countries or In Japan, but instead in third world countries which do not have equipment manufacturers of their own. [41] The Philippines, for instance, are now in the process of taking bids for geothermal equipment and Iceland is considering buildIng a geothermal electrical plant. Thus the overall worldwide development of geothermal resources is

likely to result in a net increase in business for domestic generating equipment manufacturers.
Summary of Buginess Impacts

The categories of impact discussed in this section are displayed in Figures 4.2.10, 4.2.11, and 4.2.12. These present the top two levels of the relevance tree section on the impacts of geothermal energy on business. The lower levels of the tree are included in Appendix D.

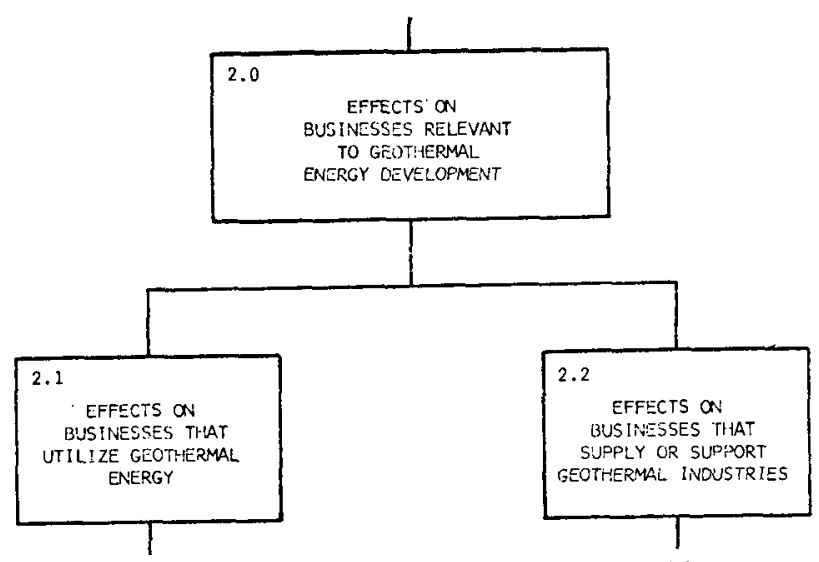

(A)

(B)

Figure 4.2.10

To Point (A) In Figure $4,2.10$ 1

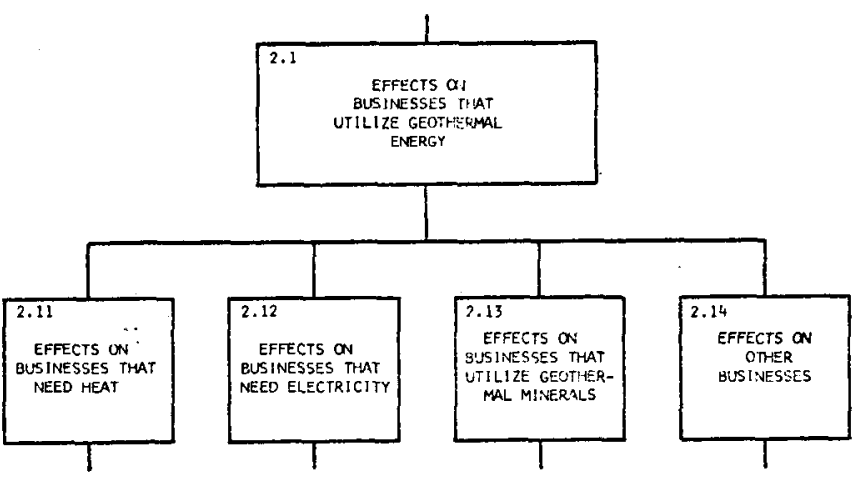

F1gure 4.2.11 


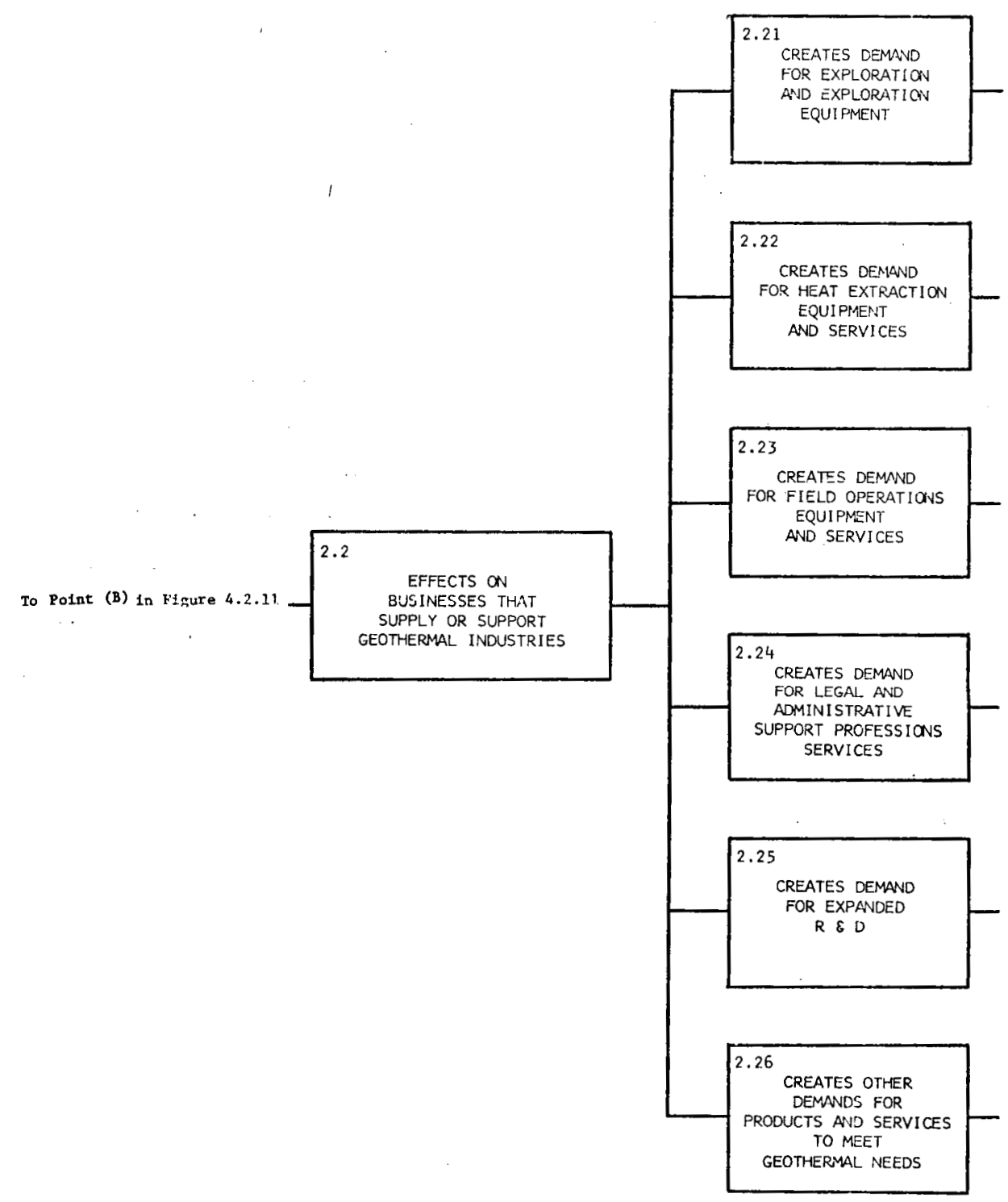

Figure 4.2.12

\section{REFERENCES}

[1] Schurr, Samue1 H., et al., Energy in the American Economy (Baltimore, Md.: Johns Hopkins Press, 1960).

[2] Personal communication, William Pritsky, the Aluminum Association, New York, N.Y., 1974.

[3] Personal communtcation, B. Caldwell, Amax Corporation, New York, N.Y., 1974.

[4] Personal communication, Richard Bowen, Oxegon Department of Geology and Mineral Industries, 1974.

[5] Ross, S. H., "Geothermal Potential of Idaho," Geothermics, Special Issue 2 (1970).
[6] Personal Commun1cation, Noel Clark, Nevada Public Service Corporation., 1974.

[7] Personal Communication, Carl McCulloch, Southern Pactfic Land Company. San Francisço, California, 1974.

[8] U.S. Department of the Interior, Geothermal Resource Invest1gations, Nevada, 1973.

[9] Lindal, Baldur, "Industrial and Other Applications of Geothermal Energy," Geothermal Energy (Paris: UNESCO, 1973).

[10] U.S. Department of Commerce, Stat1stical Abstract of the U.S., 1973.

[11] Bond, B. J., et al., "TVA Profects--Beneficlal Uses of Waste Heat," paper presented at the National Conference on Complete Water Re-use, Washington, D.C., Apri1 23-27, 1973. 
[12] Personal comnunication, Ralph Pitman; Long Island Oyster Farms, Inmont Corp., New York, N.Y., 1974.

[13] Personal communication, L. C. Weber, Research Department, Northern States Power Company, Minneapolis, Minnesota, 1974.

[14] Personal communtcat1on, Dr. Leonard Boyd, Agr1cultural Experiment Station, Universtty of Minnesota, St. Paul, Minnesota, 1974.

[15] Personal communication, Leonard Bettinger, Natlonal Greenhouse Assoclation, 1974.

[16] Personal communtcation, B. J. Bond, Division of Agriculture Development, TVA, Muscle Shoals, Alabama, 1974.

[17] Personal communication, A. E. Mercker, Vegetable Growers Assoc of America, Washington, D.C., 1974.

[18] Personal communication, Pat Redding, Horticultural Research Institute, Washington, D.C. , 1974.

[19] Personal communication, Russell V. Stansfield, Warm Water Ittilization, Northern States Power Company, Minneapo11s, Minnesota, 1974.

[20] Personal communication, Dr. Charles Wilson, Shadetree and Ornamental Plant Lab, ARS, U.S. Department of Agriculture, Delaware, Ohio, 1974.

[21] Bond, B. J., et a1., "Uses of Power Plant Discharge Water in Greenhouse Production," paper presented at the conference on the Use of Wastewater in the Production of Food and Fiber, Oklahoma City, Oklahoma, March 5-7, 1974.

[22] Personal communication, W1111am Ogle, geothermal consultant, Anchorage, Alaska, 1974.

[23] Personal communication, Edwin Schlender, Raft River Electric Cooperative, Malta, Idaho, 1974.

[24] Personal communication, Porter Briggs, Catfish Farmers of Amer1ca, Little Rock, Arkansas, 1974.

[25] Personal communication, Michael Costagna, V1rginia Marine Institute, Newport News, Va., 1974.

[26] Personal communication, Paul Kueser, Westinghouse Electric Company, Pittsburgh, Pennsylvania; 1974.

[27] Personal communication, Dr. Robert Shlesser, Bodega Marine Labs, Univeraity of California, Bodega Bay, California, 1974.

[28] Personal communication; Everett A. Tolley, She11fieh Institute of North America, Wash., D.C. 1974.

[29] Forecasts from the Japanese Delph1, Report 21-0104 (Glastonbury,' Conn.: The Futures Group, 1971).

[30] "Down on the Fish Farm: A Protein Industry Goes Into Production," New York Times (December 9, 1973).

[31] EInarsson, Svelnn S.,, "Geothermal District Heating," Geotherma1 Energy (Paris: UNESCO, 1973).

[32] Personal communication, Eric Shuster, Department of Natural Resources, State of Washington, 1974.

[33] Personal communication, Dr. Jay Kunze, Reactor Technology and Geothermal Project Branch, Aerojet Nuclear Company contract under USAEC, Idaho Falls, Idaho, 1974.
[34] U.S. Department of the Interfor, Geothermal Resource Investigations (Washington, D.C.: Bureau of Reclamation, 1972)

[35] Cameron, Eugene (ed.), "The Mineral Position of the United States, 1975-2000" (Madison, Wisc.: University of Wisconsin Press, 1973).

[36] Personal communication, M. K. Fulchur, Bureau of Reclamation, Boulder City, Nevada, 1974.

[37] Keat, M. F., "Let Us Be Realistfc About Our Energy Future," Public Ut1lities Fortnfghtly (June 6 , 1974).

[38] Personal communtcation, David Anderson, California Division of 011 and Gas, Sacramento, Californta.

[39] Grelder, Robert, "Economic Considerations For Geothermal Exploration in the Western United States," Geothermal Resources Council Bulletin, Vol. 3, No. 3 (May/June 1974).

[40] Personal communication, John Finney, Pacific Gas and Electric Company, San Francisco, Calif., 1974.

[41] Personal communfcation, R. W. Snyder, Market Development, General Electric Company, Lynn, Massachusetts, 1974.

The following are other references, not numbered in the text, used as background for this section.

Robson, Geoffrey R.; "Geothermal Electricity Production," Sclence, Vol. 184 (Apr11 19, 1974).

"Development and Use of Geothermal Energy," Geothermics, Vol. 2 (March 1973).

Shcherbakov, A. V., and V. I. Dvorov, "Thermal Waters as a Source for Extraction of Chemicals," Geothermics, Special Issue 2 (1970).

Patterns of Energy Consumption in the U.S., Office of Sclence and Technology, Executive OFflce of the President, Washington,. D.C., January 1972.

Barnea, Joseph, speech, Proceedings of the National Conference on Geothermal Energy (Riverside, Calif.: Unfversity of Calffornia, 1973).

Austin, A. L., et al., The Total Flow Concept for Recovery of Energy from Geothermal Hot Brine Deposits, (LIvermore, Calif.: University of Callfornia, Lawrence Livermore Laboratory, 1973).

"A Gr1m Forecast for Steel Users," Business Week (May 11,1974 ).

Geothermal Hot Line, Division of 011 and Gas, State of Calffornia, Apri1 1974 .

Personal communlcation, W. H: Seaman, Southern Californ1a Edison Company, Rosemead, Cal1fornia, 1974. 


\subsection{Macroeconomic and Macrosocietal Impacts}

\section{Introduction}

This section will deal with net economic and societal effects of geothermal development at the national level and with regional and local effects as well. Figures $4.3 .1,4.3 .2$, and" 4.3.3 show the top two levels of the relevance tree pertaining to this impact category.

The influence of the development of geothermal energy on the national economy and soctety will be channeled In large part through substitution effects engendered by regional and local impacts. Since capital and materials markets are generally national in scope and American labor is highly mobile, energy-induced changes in one particular region in these factors, along with the attendant social consequences, affect the national picture, albelt with a diluted and often time-lagged impact.

\section{Effect on the National Economy}

In order to assess the impact of alternate geothermal development programs on the national economy, it is necessary first to place them within the framework of the overall energy supply-demand situation and then to relate this energy balance to national economic indicators. It has been the usual procedure in making projections which are related to economic factors to assume a basic continuing growth in Gross National Product (GNP), usually at about the 4 percent level. Historical data show a close connection between GNP and energy consumption, however, and $1 \mathrm{t}$ is apparent that recent disruptions and shortages in the energy market have the potential of limiting future GNP growth. Therefore, rather than relying on an exogenous assumption as to GNP growth, this section attemps to estimate the relationship of energy availability to GNP growth and the extent to which different levels of development of geothermal energy could affect any energy-connected Iimitations on growth.

As the foundation for this procedure, it was necessary to employ some sort of projection model of energy variables to test the effect of differing assumptions or policies pertalning to geothermal development on the overall economy. As this study began; no really comprehensive model existed which could link energy avallability to economic variables, a1though a proliferation

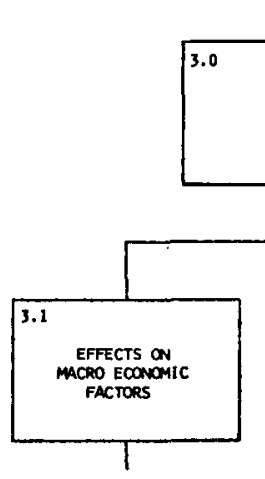

(A)

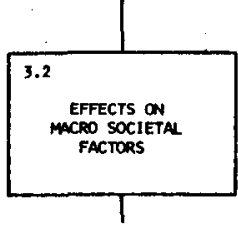

(B)
Figure 4.3.1 of such studies was underway. Most avajlable models reviewed for possible use[1-13] covered only limited spectal-purpose domains: some dealt with only one fo of energy, such as oll or electricity; others covered only particular geographical areas. Demand is the factor most commonly covered; fewer models include the supply side, with many merely assuming that the amount demanded will be available. Only a few models consider supplydemand interaction, particularly from the point of view of any dynamic relationship or with consideration of the effect of regulatory controls, and only a few include interfuel competition. A most important omission in most existing energy forecasting tools is the role of price.

Modeling approaches used in the various energy studies include input-output, econometric,.11near programing, and structural methods, and, in a number of cases, combinations of these. Structural models do not use formal econometric or optimizing techniques but instead develop a set of procedures with which to evaluate the results of alternative sets of initial assumptions over a simulated time interval. This approach tis best typified in the widely used energy report of the National Petroleum Counci1 [3].

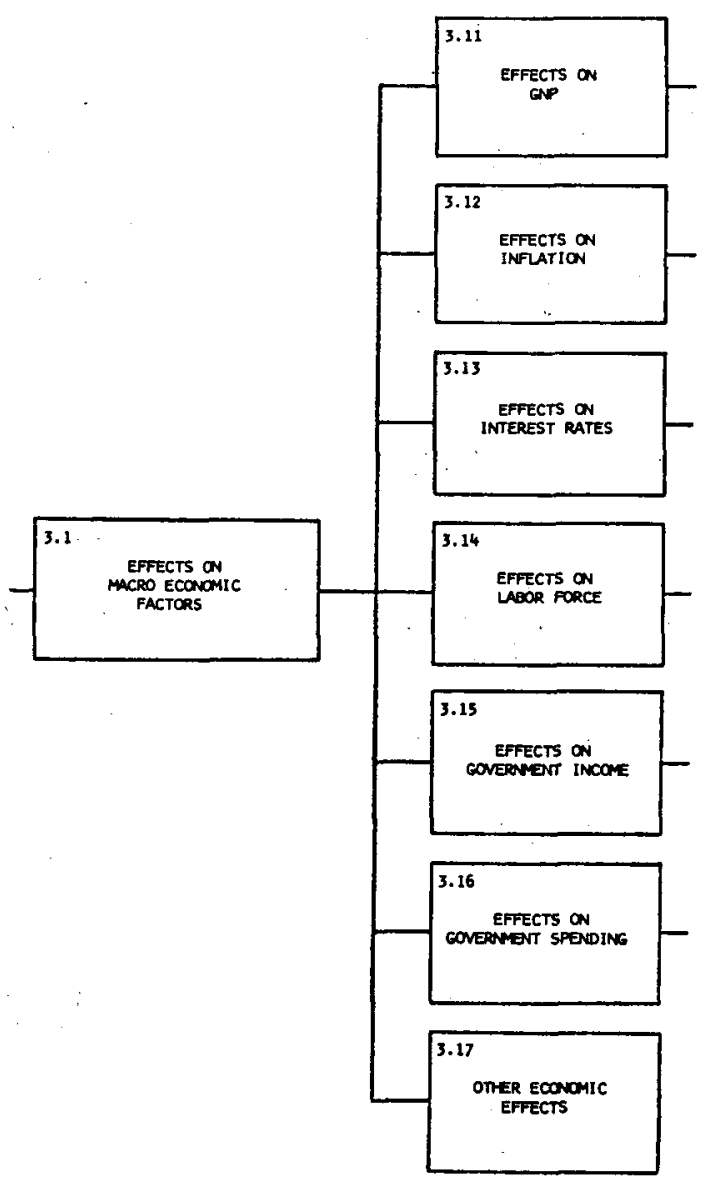

Ffgure 4.3 .2 


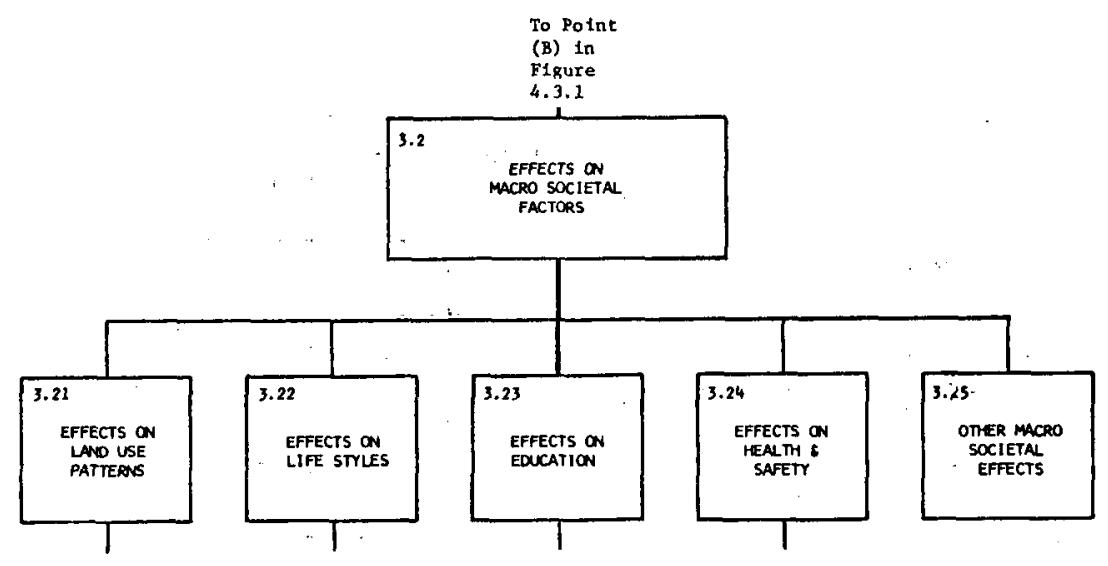

FIgure $4 \cdot 3 \cdot 3$

It was decided, in the absence of any approprlate operational energy mode, to utilize a structural approach in assessing the macroeconomic consequences of vartous levels of geothermal energy developments, assuming that they constituted net additions to the nation's energy supply. As will be explained in detall below, a level of sustainable growth in GNP was estimated for several hypothetical levels of energy avallability through the use of an algorithm. The algorithm was based on historfcal and projected data pertaining to the ratio of energy consumption to GNP. The results of this analysis are not designed to provide forecasts of absolute levels, but rather to show the macroeconomic consequences of alternative assumptions about geothermal energy avallability.

Relationship of Energy Consumed to GNP. Throughout the world, there has been a pronounced positive correlation between GNP growth and energy consumption. The ratio of Btu consumed per dollar of output, however, varies from country to country. The United States is on the high end of the distribution, with a ratio about 17 percent above the mode.

Changes in the energy/GNP ratio have an important bearing on the future of energy consumption. A rising ratio means that energy consumption is increasing at a faster rate than GNP, while a falling rat1o indicates that it is Increasing at a lesser rate. Since the early. $1920^{\prime} s$ the U.S. energy/GNP ratio has been in a falling trend, as more intensive use of energy was offset by increased technical efficiency. [14] From 1966 through 1970 the trend reversed 1 tself and the ratio moved steadily upwards. This had alarming implications for the future, and there has been much speculation, that if the rise continued $1 \mathrm{t}$ would lead to even more drastic energy shortages than have been predicted. In 1971 and 1972 , however, the ratio resumed 1ts downward direction.: Both. the National Petroleum Counctl and the Bureau of Mines of the U.S. Department of the Interfor [4] anticipate that the ratio w111 continue to fall in the future.

If the energy/GNP ratio could-be projected, it would be possible to arrive at an upper level of GNP for any assumed level of energy avallabllity... Trend Impact Analysis (Appendix F) was used to project the energy/GNP ratio based on the historical trend of the energy/GNP ratio from 1947 through 1972 and the set of speculative future events shown in Figure 4.3.4. The judgments shown were provided by the study team. The curves produced are shown in Figure 4.3.5. The median is somewhat below projections made by the Bureau of Mines before the 1973 energy crisis, probably because of the energylonserving effects of the forecasted events.
If the ratio presented in Figure 4.3 .518 divided into the level of geothermal energy expressed In Btu, the marginal effect of geothermal energy on GNP can be approximated. Figure 4.3 .6 presents this estimate. Assume for a moment real GNP grows at just 3 percent per year; in this case GNP in 1985 will be $\$ 1612$ b11Iion and GNP in 2000 will be $\$ 2510$ billion expressed in constant 1970 dollars. Figure 4.3.6 indicates that the energy available from geothermal sources could "swing" an energy-1imited 1985 GNP by $\$ 5$ to $\$ 18$ b1111on, or up to about one percent, and an energy-11mited 2000 GNP by $\$ 156$ to $\$ 231$ billion, or 6 to 9 percent.

Relationship of Unemployment to GNP. It 1s very difficult to derive estimates of components of the economy by working backwards from a given level of GNP. Econometric models of the economy are constructed of interrelated equations involving a number of exogenous variables and there are an almost infintte number of combinations of variables which can result in the same total GNP. In the same way, differing levels of unemployment can exist with the same total GNP, depending on such factors as the size and structure of the labor force, differing growth rates of varying sectors of the economy, and the types of labor required.

Although it is impossible to assign an absolute unemployment rate to a given level of GNP, a relationship can be 1dentified between-rates of change of GNP and unemployment. By conducting a simple regression analysis, a falrly high correlation from 1947 to the present was demonstrated between the annual percentage change in GNP and the annual percentage point change in the unemployment rate. Th1s-1inear trend line is defined by the following equation:

Percentage point change in unemployment -

$1.392-(.344 \times$ percentage change of GNP)

The equation has an $x^{2}$ of .73 , Indicating that about three-quarters of the variations in unemployment are explained by the percentage change in GNP. The standard error of: estimate 18. 62 ; meaning that two-thirds of the estimated unemployment rates will be w1thin a range of plus or minus. 62 percentage point of the actual rate, and 95 percent within a range of 1.24 points. Figure 4.3.7 compares actual unemployment rates, the rates generated by applying the equation to the 1947 rate and proceeding from there, and the rates generated by applying the equation to each actual previous year's unemployment. 


\begin{tabular}{|l|c|c|c|c|c|}
\hline \multicolumn{1}{|c|}{ EVENT } & \multicolumn{2}{|c|}{ ESTIMATED PROBABILITY BY YEAR } & $\begin{array}{c}\text { YEARS TO } \\
\text { FIRST } \\
\text { IMPACT }\end{array}$ & $\begin{array}{c}\text { YEARS TO } \\
\text { MAXIMMM } \\
\text { IMPACT }\end{array}$ & $\begin{array}{c}\text { MAXIMUM } \\
\text { IMPACT } \\
\text { (PERCENTAGE) }\end{array}$ \\
\cline { 2 - 5 } GENERAL ACCEPTANCE OF A CONSERVATION ETHIC \\
REDUCES DEMAND FOR ENERGY BY 158.
\end{tabular}

Figure 4.3.4 EVENTS USED IN TREND IMPACT ANALYSIS OF ENERGY/GNP RATIO

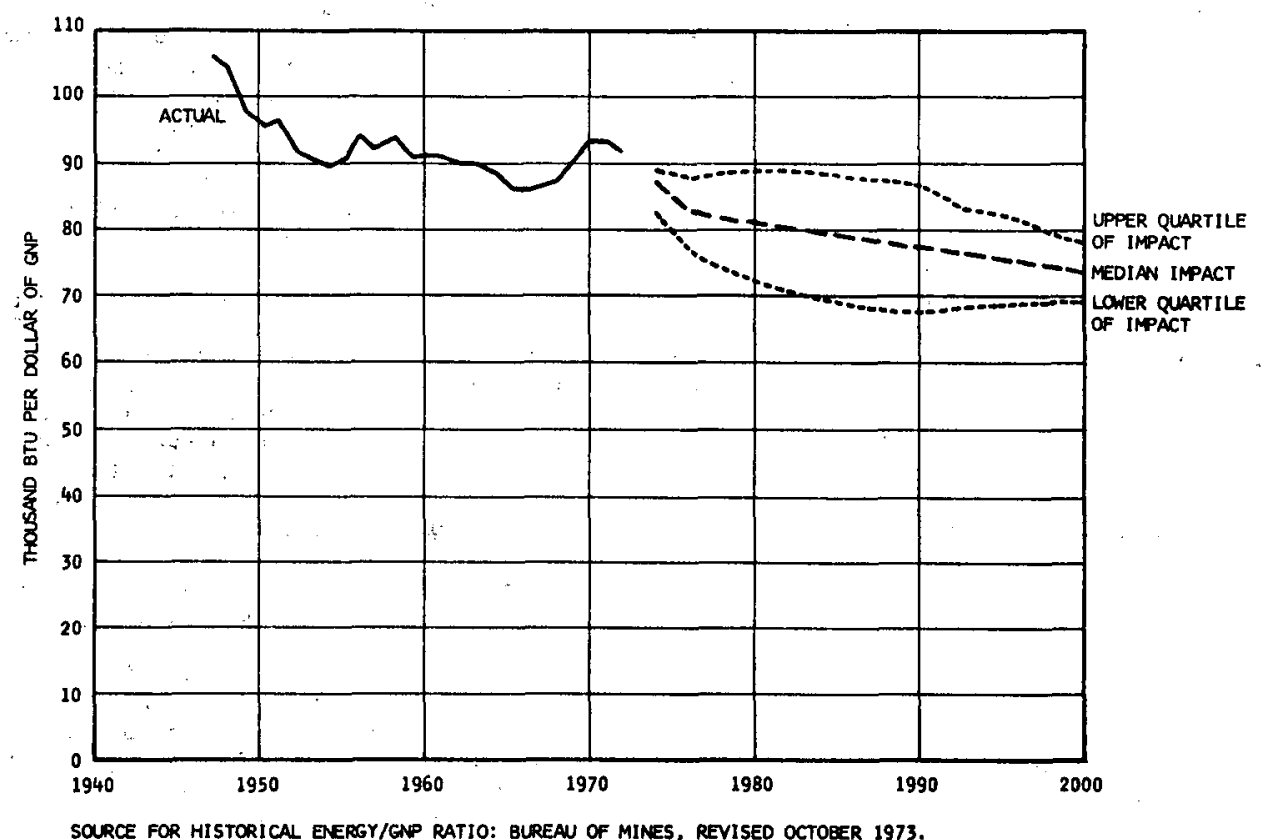

FIgure 4.3.5 FORECAST OF U.S: ENERGY/GNP RATIO 


\begin{tabular}{|c|c|c|c|c|c|c|c|c|c|c|c|}
\hline \multirow{3}{*}{ YEAR } & \multicolumn{2}{|c|}{$\begin{array}{l}\text { GEOTHERMAL ENERGY } \\
\text { (1012 BTU) }\end{array}$} & \multirow{2}{*}{\multicolumn{3}{|c|}{ THOUSAND BTU/\$ GNP }} & \multicolumn{6}{|c|}{$\begin{array}{l}\text { MARGINAL EFFECT OF GEOTHERMAL ON GNP } \\
\text { (BILLIONS OF DOLLARS) }\end{array}$} \\
\hline & \multirow{2}{*}{$\begin{array}{l}\text { BASE } \\
\text { PROGRAM }\end{array}$} & \multirow{2}{*}{$\begin{array}{l}\text { ACCELERATED": } \\
\text { PROGRAM }\end{array}$} & & & & \multicolumn{3}{|c|}{ BASE PROGRAM } & \multicolumn{3}{|c|}{ ACCELERATED PROGRAM: } \\
\hline & & & LOW & MEDIAN & HIGH & LOW & MEDIAN & HIGH & LOW & MEDIAN & HIGH \\
\hline 1980 & .26 & .38 & 72.9 & 81.4 & 88.7 & 3.6 & 3.2 & 2.9 & 5.2 & 4.7 & 4.3 \\
\hline 1985 & .42 & 1.25 & 69.4 & 79.5 & 88.2 & 6.1 & 5.3 & 4.8 & 18.0 & 15.7 & 14.2 \\
\hline 1990 & 1.34 & 3.33 & 67.8 & 77.5 & 86.1 & 19.8 & 17.3 & 15.6 & 49.1 & 43.0 & 38.7 \\
\hline 1995 & 4.47 & 7.51 & 68.5 & 75.7 & 82.2 & 65.3 & 59.0 & 54.4 & 109.6 & 99.2 & 91.4 \\
\hline 2000 & 12.17 & 15.97 & 69.0 & 74.0 & 78.1 & 176.4 & 164.5 & 155.8 & 231.4 & 215.8 & 204.5 \\
\hline
\end{tabular}

rACCELERATED PROGRAM IS ONE IN WHICH VIRTLALLY ALL TEONOLOGICAL AND NON-TEONOLOGICAL IMPEDIMENTS ARE REMOVED.

Figure 4.3.6 MARGINAL EFFECT OF GEOTHERMAL AVAILABILITY ON ENERGY-LIMITED GNP

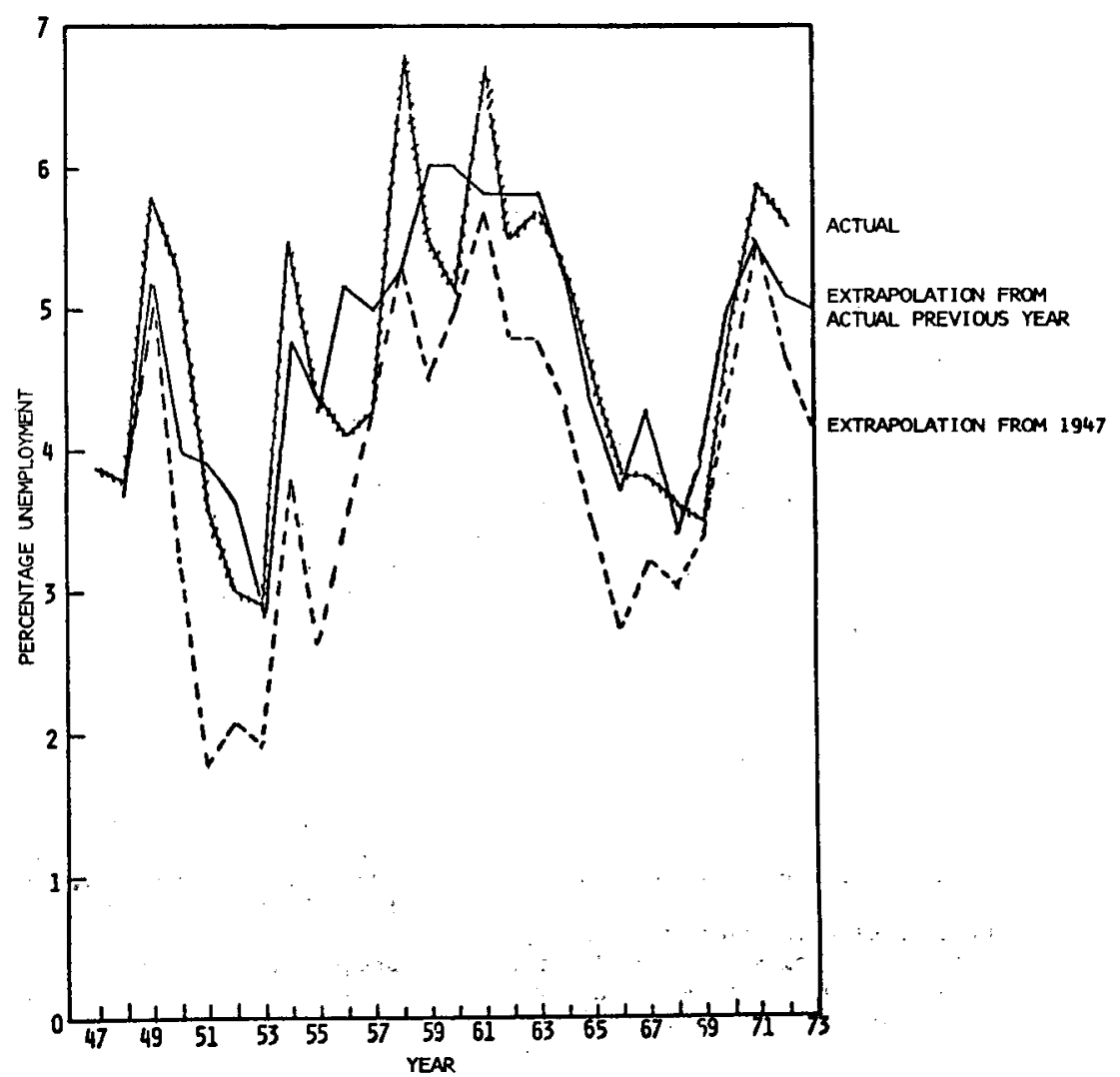

FIgure 4.3.7 UNEMPLOYMENT RATE BY YEAR (1947-1972)

(ACTUAL, BY TREND EXTRAPOLATION FROM

1947, BY TREND EXTRAPOLATTON FROM

ACTUAL PREVIOUS YEAR) 
This equation is presented graphically in Figure 4.3.8. $\bar{I} t$ indicates that a 4 percent increase in GNP produces a 0.2 increase in the unemployment rate. For instance, if we already have a level of 5 percent unemployment, a yearly rise of 4 percent in GNP will increase unemployment to 5.02 percent. This would seem to be compatible with a recent study by the Stanford Research Institute [15] showing that a 4.2 percent yearly increase in GNP is necessary to keep unemployment at or below 5 percent.

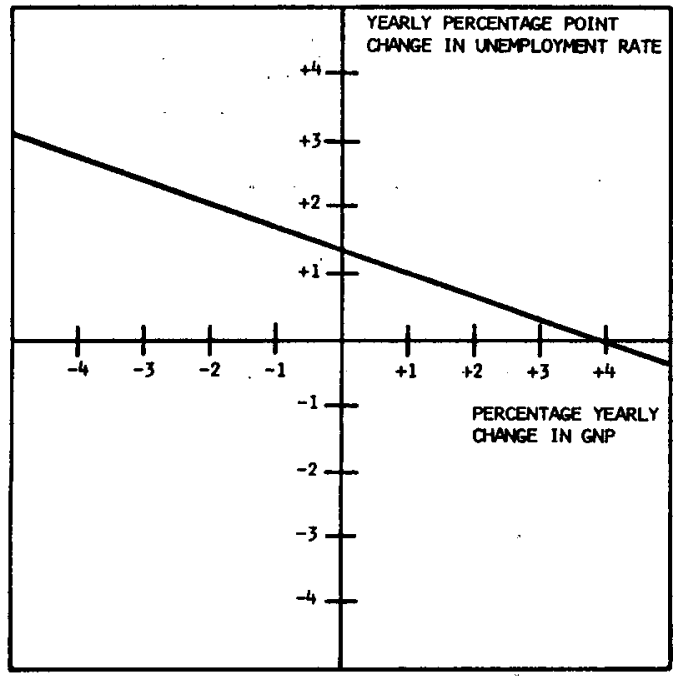

F1gure 4.3.8 RELATIONSHIP BETWEEN PERCENTAGE CHANGE IN GNP AND PERCENTAGE POINT CHANGE IN UNEMPLOYMENT

The slope of this curve can be obtained by differentlating the regression equation:

$\frac{\text { (change in unemployment) }}{\text { (change in GNP) }}=-.344$

Working with the data of Figure 4.3.6, it is possible to compute the marginal effect of geothermal energy on unemployment through 1ts impact on raising the limits of GNP growth. This is shown in Figure 4.3.9. In utilizIng the unemployment equation, the assumption must be made that the labor force will continue to grow at rates simflar to those prevalling in recent years. The Bureau of Labor Statistics has recently estimated [16] that the labor force through 1980 will continue to grow at an annual rate of about 1.7 percent, about the same as the average annual rate for the $1960^{\prime} \mathrm{s}$. After 1980 , the rate 18 expected to drop to 1.0 percent a year, which may make the unemployment estimate derived from the equation slightly high relative to GNP change.

The conclustons from the analysis are as follows:

- The development of geothermal energy is 1ikely to have only a relatively slight impact in raising the limits to GNP growth Imposed by energy restrictions and on accompanying unemployment levels until the mid $1990^{\circ} \mathrm{s}$, when effects could become significant.

- If conservation measures are relatively unsuccessful, as Implied by a higher energy/GNP ratio, a base line geothermal program would furnish energy for $\$ 156$ billion of a $\$ 2500$ billion GNP (1970 dollars) by the year 2000; this increment is equivalent, in an energyIfmited economy, to an unemployment level lower by about 2 percentage points than could otherwlse be the case. An accelerated program would furnish $\$ 204$ billion, equivalent to a lowered unemployment level of about 3 percentage points.

If conservation measures are relatively successful, as implied by a lower energy/GNP ratio, a base 11ne program would furnish energy for $\$ 176$ billion of a $\$ 2500$ billion GNP by the year 2000 . This increment of GNP is equivalent to an unemployment rate lower by about 2 percentage points In an energy-11mited economy. An accelerated program would furnish $\$ 231$ billion, equivalent to an unemployment level lower by about 3 percentage points.

As th1s report was being prepared, an energy model designed by Dale Jorgenson and Edward Hudson for Data Resources, Inc., under grants from the Ford Foundation Energy Policy Project and the National Sclence Foundation, became available[17]. This model takes a new approach in quantitative analysis of U.S, energy policy. It combines econometric modeling and input-output analysis to model the interplay between energy demand and supply and relates it to economic growth. Price, omitted In most other models, plays the dominant role. As energy prices rise, high price elasticities become evident and other production factors are substituted for energy. In order to incorporate the role of price, the traditional fixed input-output coefficients, which represent technological production patterns, are varied according to the prices of the production factors. Price increases are shown to Induce energy conservation and substitution measures, and therefore GNP 1s not affected by energy shortages to the degree implied in the process described above which is based on a more static energyGNP ratio. The major conclustion of the Hudson-Jorgenson model is that the economy is flexible enough to adapt to changing resource avallabilities as defined through the price system and that therefore substantial reductions in energy use can be achleved without major damage to the economic growth rate. The validity of this thesis will hinge in large part upon current data still to be complled on the actual effect of energy price rises on demand. The effect of price on energy consumption is not yet clear.

Effect on the Federal Budget. Another aspect of the effect of geothermal development on the national economy 1s the net Impact on the federal budget, a major determinant of GNP. The proposed National Geothermal Energy Research Program submitted to the office of Management and Budget in June 1974 by the Interagency Panel for Geothermal Energy Research[18] proposes spending $\$ 430.2$ million in the five years through 1979 . The objective is to accelerate commerclal geothermal production by the private sector through federally funded programs in resource exploration and asssessment, environmental, legal and institutional research, experimental research plants, and advanced research and technology.

Rough estimates can be made to ascertain the monetary return to the Federal Government as the result of commerclal geothermal development. Some income has already been generated by the bonus b1dding for KGRA tracts in Callfornia in January 1974 and in Oregon in June 1974. The California sale brought $\$ 6.8$ million at an average of $\$ 290.54$ an acre and the Oregon sale (of one small tract) brought in $\$ 13,000$ at $\$ 10.26$ an acre. Three distinct geographical areas were involved in the california bidding, and brought markedly different 


\begin{tabular}{|c|c|c|c|c|c|c|c|c|c|c|c|c|}
\hline \multirow{3}{*}{ YEAR } & \multicolumn{6}{|c|}{$\begin{array}{l}\text { CHANGE IN UPPER LIMIT } \\
\text { OF GNP, IN PERCENTAGE }\end{array}$} & \multicolumn{6}{|c|}{$\begin{array}{l}\text { UNEMPLOYMENT CHANGES IN } \\
\text { PERCENTAGE POINTS }\end{array}$} \\
\hline & \multicolumn{3}{|c|}{ BASE PROGRAM } & \multicolumn{3}{|c|}{ ACCELERATED PROGRAM } & \multicolumn{3}{|c|}{ BASE PROGRAM } & \multicolumn{3}{|c|}{ ACCELERATED PROGRAM } \\
\hline & LOW & MEDIAN & HIGH & LOW & MEDIAN & HIGH & Low & MEDIAN & HIGH & LOW & MEDIAN & HIGH \\
\hline 1980 & .3 & .2 & .2 & .4 & .3 & .3 & -.1 & -.1 & -.1 & -.1 & -.1 & -.1 \\
\hline 1985 & .4 & .3 & .3 & 1.1 & $1 \% 0$ & .9 & -.1 & -.1 & -.1 & -.4 & -.3 & -.3 \\
\hline 1990 & 1.2 & .9 & .8 & 2.6 & 2.3 & 2.1 & -.4 & -.3 & -.3 & -.9 & -.8 & -.7 \\
\hline 1995 & 3.0 & 2.7 & 2.5 & 5.1 & 4.6 & 4.2 & -1.0 & -.9 & -.9 & -1.8 & -1.6 & -1.4 \\
\hline 2000 & 7.0 & 6.6 & 6.2 & 9.2 & 8.6 & 8.1 & -2.4 & -2.3 & -2.1 & -3.2 & -3.0 & -2.8 \\
\hline
\end{tabular}

Figure 4.3.9 COMPUTATION OF MACRO IMPACT OF GEOTHERMAL ENERGY ON UNEMPLOMMENT

prices per acre. At The Geysers, land brought $\$ 631$ per acre, but tracts in Mono-Long Valley brought $\$ 115$ and at East Mesa, $\$ 71$. If we assume that future sales attract average bids of $\$ 25$ to $\$ 50$ an acre (with the Oregon sale indicating that bidders pay considerably less away from proven areas), the approximately 1.8 million acres of land currently identified as KGRA's could generate $\$ 45$ to $\$ 90$ million in bonus payments. This is equivalent to about one year's spending. In the government research and development program.

When the commercial level is reached, however, royalty payments can be expected to exceed considerably the developmental expenditures. Working with the system dynamics model base projection of around $25,000 \mathrm{MWe}$ capactty in the early $1990^{\prime} \mathrm{s}$, and 190,000 MWe by 2000 , a 12-1/2 percent federal royalty on value of energy sold could range from $\$ 130$ million a year early in the decade to over $\$ 1$ billion annually by 2000 . These estimates assume that: ( 1 ) about 70 percent of the development will be on federal land; and (2) energy will be sold at 15 mills per kilowatt hour (other energy costs can be expected to rise commensurately). Rent of $\$ 1$ per acre per year will also be collected on all leased federa1 land for the first five years of a lease and an additional $\$ 1$ per acre for each of the next flve years. (Note that in addition. to the 1.8 million acres of KGRA's, there are 58 milition acres of Potential Geothermal Resource Areas with leasing potential.) A1though not included in the estimates, any by-products, such as chemicals or desalinated water, would also be subject to royalty payments. Furthermore, income tax. revenues will be augmented as corporations and individuals are benefited by increased geothermal activity. Thus in the long run, geothermal expenditures. w111 result in a net surplus return to the Federal Government, resulting in an overall deflationary effect. It should be noted, however, that this net return would be reduced by losses to the government resulting from any decreased fossil fuel and uranium production on federal lands and connected income taxes.

National capital markets may also be benefited by substitution of geothermal energy for other sources. Since geothermal capital costs are expected to be lower than for alternate energy sources, demands for investment capital; w11 decrease. For example, if the difference between the capital costs of geothermal and nuclear plants is $\$ 250 / \mathrm{KW}$ by the year 2000 and, as Indicated in Section 4.1, 117,000-149,000 MNe of nuclear power is displaced, capital savings of 29-37 billion dollars (1973 dollars) will result.

\section{Effects on the Regional Economy}

The effect of geothermal development on the economy will be much greater at the regional level than at the national level. Between the present and 2000 most geothermal activity will be concentrated in the eleven western states, the Gulf states if geopressured resources are tapped, and Alaska and Hawail. If the relationship between GNP and energy postulated in our structural model continues, the avallability of geothermal power In a region can help to prevent economic growth from being dampened by energy shortages. Even though in the national model a substitution effect was assumed, with the existence of geothermal energy in the West releasing other fuels for use in the remainder of the country, the region, and particularly its energy-intensive industries, will benefit from the easler accessibility and probably lower cost of a native source of energy. The nor thwestern states especially have become accustomed to abundant hydropower, but few hydro-expansion sites remain and the recent drought of 1973 pointed up the need for alternate fuels. Callfornia has encountered numerous nuclear power plant siting problems, and an indigenous energy source would make it easier to fulf 111 demand for electricity and maintain economic growth. Some areas in the mountain states. are on the fringes of the power network emanating from population centers and experience intermittent outages. Rellab1l1ty of service could be improved in these areas by a local geothermal generating station.

Although the reglonal economy would be benefited in this way by more abundant energy, the major discerntble impacts will be in the nature of transfer benefits. This w11l be especially true in the case of power plant construction when geothermal installations substitute for fossil fuel. or nuclear plants. The optimum size of a geothermal plant 18 around 100-200 Me (although clusters totaling at least 250 Me may be necessary to justify exploration costs) while the newer fossil fuel and nuclear plants typically have 1100 MWe capacity. Because geothermal plants are smaller and geothermal areas are often 1solated, these installations w111 be widely dispersed.

In contrast to power plant construction, exploration and drilling activity and the support activities they stimulate will bring a net increase to the regional economic product, since regional production of geothermal resources can be expected to exceed any loss in reglonal production of the fossil fuels and uranium whose use it replaces. 
Process heat applications will probably be a plus factor in the regional economy. Although some direct uses of geothermal heat will merely substitute for use of scarcer or more costly fuels, other uses will encourage expansion of existing industries or attract new businesses to the area, as discussed in Section 4.2. Thus new capital investment, plus the additional business generated through the multiplier effect, will contribute to the growth of regional GNP.

The development of geothermal energy will impact on the overall regional employment level most importantly through its salutary influence on energy availability, maintenance of economic growth, and attraction of new or expanded industries. Its specific additions to the working force will be heaviest toward the end of the century with respect to drilling manpower. As estimated in Section 4.2 , drilling crew requirements to reach capacity of 190,000 MWe by 2000 should peak at about 25,000 men per year. Production and plant operating manpower requirements are minimal. The generating units at The Geysers are highly automated and currently employ under 40 persons. This number is expected by the utility to increase very little as additional. units are added.[19] At any rate, power plant personnel are not net additions to regional employment since comparable numbers would be employed in other power plants in the absence of geothermal energy utilization.

Regional government income can be expected to show a net increase as geothermal development progresses. State government will collect rent and royalties on resources developed on state lands, and possibly roya1ties on private lands on which they have reserved mineral rights if court cases now pending rule that geothermal resources are mineral. State income taxes w11. be augmented through geothermal-connected business increases, and excise and sales taxes will be collected on material and equipment. The largest category of tax collection generated by geothermal activity within the region will be local ad valorem taxes on land and possessory interest in land, tangible assets; and steam or heat rights. A substantial part of these will not represent a net increase, but a transfer to geothermal areas of tax income from areas where fossil fuel or nuclear plants would have been built instead.

The Impact of these dispersed tax collections w111 be great at the local level. Local tax bases in rural areas could be increased dramatically by geothermal activity on either private or public land. Since possessory interest on federal and state lands is subject to local property tax, counties or towns in effect can obtain the same income from installations on these lands as from those on private property. Thus areas which previously received no income from government land will be able to add them to their tax base.

The Geysers is now the largest single taxpayer in Sonoma County. In the 1974 fiscal year, taxes totaled approximately $\$ 1$ million. [20] This averages out to $\$ 2500$ per megawatt of production, and extrapolation would indicate that 190,000 MWe geothermal capacity by 2000 could result in returns in the neighborhood of $\$ 475$ million per year to local governments. This would be reduced to the extent that the generating plants are owned by non-taxable, publicly-owned utilities. In addition, areas with process heat applications would recelve additional income from taxes on new Industries or on Increased land values occastoned by the availability of geothermal heat.

\section{Macrosocietal Effects}

On the macrolevel, the societal effects of geotherma development parallel the impact on GNP. If the geothermal contribution to energy supply helps to malntain economic growth, then as a corollary it helps to maintain current life styles based on abundant energy. These overall life styles are not discernably affected by whether the electric power on which they are so highly dependent is furnished through fossil fuel, nuclear, solar, or geothermal resources; it is the fact that abundant power is available which permits the existing standard of living to continue. A case can be made, of course, that this current standard is wasteful and that cutting energy usage could actually improve the quality of life. It must be recognized, however, that curtailment of energy either through limitation of use or higher prices could have a serious impact on lowerincome groups who have fewer luxuries to eliminate and can least afford increased costs. [21]

There appears to be ample reason to expect that the relative rate of growth of electricity will be higher than the growth of energy as a whole. This is because any effort to reduce dependency on imported fuels will move the United States toward conservation measures and relatively greater usage of indigenous fuels: uranlum and coal, primarily. These are most expeditiously utilized in production of electricity. Furthermore, many advanced energy systems are electricity-related: e.g. breeder, solar, fusion, and magnetohydrodynamic (MHD). The development of geothermal resources will promote this shift to electricity since it is also an indigenous resource and it helps to make electricity more abundant and, to a small degree, less costly. The potential macrosocietal impacts of this situation include: maintenance of mobility patterns through growth of electrified rallroads and mass transit; improved potential for electric automobiles; growth of electric space heating; and continued growth in electric motor usage for thousands of tasks.

Aside from its general contribution to the standard of living, most of the specific societal impacts of the development of geothermal energy will evolve from the two significant characteristics previously mentioned: the small size of optimum installations and the location of resources in most cases in outlying areas. Figure 4.3.10 superimposes KGRA's upon a population density map of the eleven western states. With only a few exceptions, the geothermal areas are all located in countries with population densities of under 50 persons per square mile.

Development of geothermal sites will mean that a number of formerly Isolated areas or small towns will have an Increased industrial and tax base accompanied by only a small increase in population, since geothermal power installations and most process heat applications are not labor Intensive. This can make smaller towns more viable by improving community services and providing enough opportunities to prevent loss of population. Except In the few cases where unusually large resources are found and major industrial complexes are established, the impact will probably not be substantial enough to attract large numbers of strangers and change prevalling mores.

The transfer of generating facilitles from large concentrated fossil fuel or nuclear plants to smaller, scattered units w11l avold some of the political and environmental problems encountered in planning and siting 


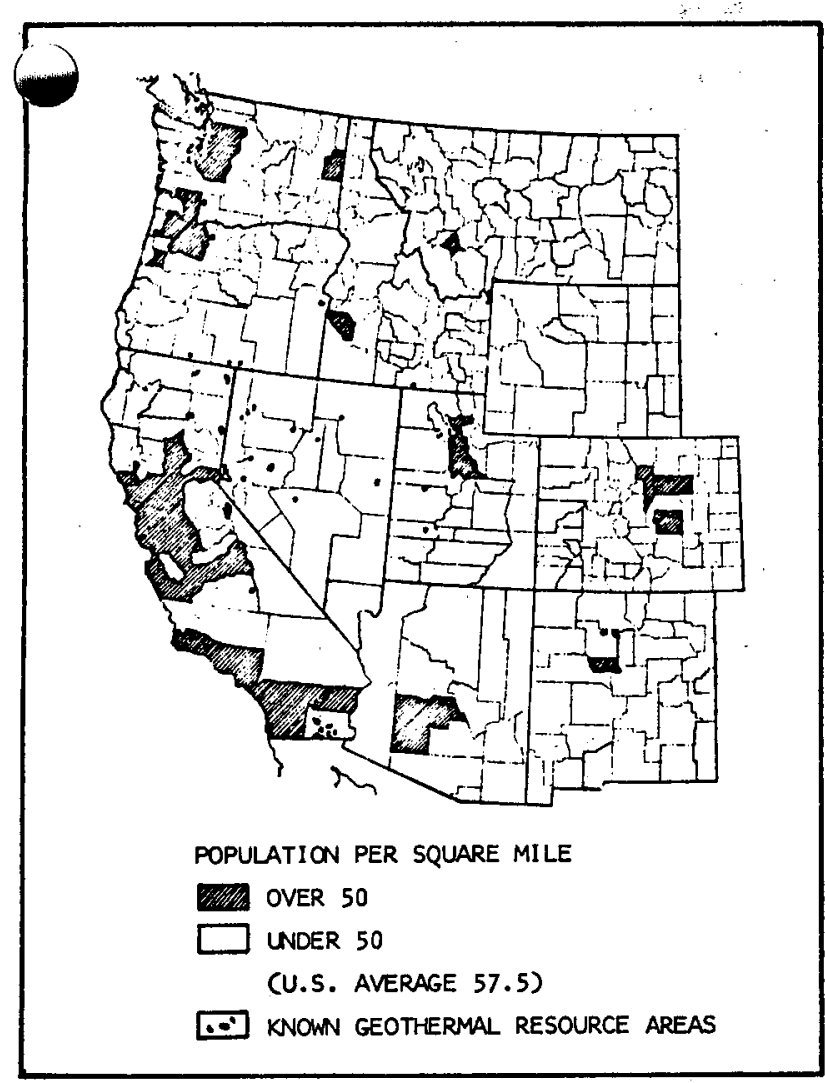

SOURCE: U.S. DEPARTMENT OF COMMERCE, BUREAU OF THE CENSUS; AND U.S. DEPARTMENT OF THE INTERIOR.

F1gure 4.3.10 KGRA'S IN RELATION TO POPULATION DENSITY

large installations. It thus could help reduce soctal conflict and health hazards from pollution in areas where these plants would have been built. Because of lower capital requirements of the smaller plants, small private or publicly-owned utilities could be the purchasers of geothermal steam, rather than larger systems; this would contribute to local control of industrial growth.

There are a number of secondary demographic and cultural effects which may stem from the dispersed nature of the resource. Young people who might previously have moved to the cities may be motivated to remain by the moderate expansion of local community activitles. The presence of opportunities for relatively Inexpensive geothermal space heating and possibly the revival of interest in therapeutic bathing may provide an attraction for establishment of retirement communfties.

It is also 11 kely that health. care may Improve in geothermal areas as increased local government income makes possible greater contributions to regional hospitals. A similar effect will be felt on local and regtonal school systems since the school population will increase less, proportionately, than the tax base. Better heslth and school systems will be on element in retaining and attracting population and improving the quality of 11fe.

In areas ut1lizing geothermal space heating, personal rafety w111 be enhenced by the absence of conventional heating system fire hazards. Personal safety may be somewhat diminished, however, by the increased opportunities for crime which accompany any economic expansion. These could range from Increases in petty thievery accompanying gains in population to the more remote possibilities of sabotage by blowing up a geothermal well.

As an 11lustration of the changes which could be wrought in the life of a smali town by the nearby discovery of a useful hot water geothermal fleld of moderate size, a hypothetical example was constructed of such a place. [22-25] This will not be a major geothermal installation or a new town, but a typical small-scale user. Assume that the town, population 2000 , is located in an agricultural area producing sugar beets, potatoes, corn, wheat, w1th some cattle and da1ry farms. A small greenhouse on the edge of town utilizes an old geothermal well, once the site of a health spa, to grow flowering plants. About 100 people are employed in several produce-crating, companies, and about 300 in retail stores and businesses servicing the surrounding area. Another 50 are employed by the town, county, and school district. The tax rate is one of the highest in the county because of the low tax base of $\$ 10$ million. The county collects $\$ 30$ per thousand of valuation (at 100 percent assessment) and returns $\$ 9$ of this to the town on the basis of 1 ts assessed valuation and the size of its budget. The remalnder goes for the support of the school district, the county administration, the regional hospital, and the community college.

When, through test wells, the potential of the geothermal field at the edge of town is evaluated to have at least the capability of supporting a 100 MWe power plant, there is some fear volced by local Inhabitants that the character of their rural life will be damaged by an influx of strangers. The prevalent view, however, is that the discovery will immediately benefit the town and provide needed tax revenue. It turns out, however, that nefther opinion is entirely accurate. The full impacts of the discovery are not felt at once; it Is ten years before they fully evolve.

Although the field is discovered in 1975, it is two years before the extent of the resource is proven by exploration and geological measurements to the satisfaction of the regional privately-owned utility. It then contracts with the geothermal developer to buy enough hot water on a m-lll per kflowatt hour generated basis to operate a $100 \mathrm{MWe}$ plant. The generating plant is to be built in two 50 Me stages. Plant construction takes three years and the facility itself is within the town limits although the large producing field is not.

During this time period drilling and construction activities bring anywhere from 20 to several hundred workers at one time into town temporarily. Some commute the fifty miles from the nearest.city and others live in transient camps. Local retallers benefit from the business, although residents complain of construction noise, dirt, and traffic, and for the first time begin to lock their doors.

Since the largest part of the producing field is not within the corporate 11 mits, Its taxes go directly to the county, but the town reaps the generalized benefits of 1mproved county and school district services. When the power plant is completed, about $\$ 12,000,000$ is added to the tax base of the town 1tself, more than doubling 1t. At the same time, overall land values in town begin to Increase along with improved business activity and anticipation of further geothermal development. This optimism proves fustified when a large foodprocessing company, Impressed by the performance of 
the power plant and evidence of long-lasting resources, announces that 1 plans to utilize geothermal heat in new $\$ 10$ million canning plant employing 100 persons. Meanwhile, the existing greenhouse bullds an addition and an enterprising local motel owner dectdes to cap1tallize on his location near the old spa by refurbishIng his accommodations and bullding therapeutic bathing facilities plus a geothermally-heated swimming pool. Property very close to the producting field has lost some of 1 ts value, however, and owners of this property are leaders of the group of townspeople who want further development stopped. They c1te the notse and odor of the Installation, the changing character of the region, and the environmental consequences of improperly disposed-of geothermal fluids.

If these objectiong can be answered satisfactorily, the overall effect on the town could be quite beneficlal. Trend Impact Analysis (Appendix F) shows how these events could affect the growth of the town'tax base through 2000. Figure 4.3.11 lists these events and essumptions about their probabilities of occurrence; Figure 4.3.12 shows the medien forecast and the ranges of the upper and lower quartile. By 1985 it is likely that the tax base w11I triple, and then continue to rise slowly through 2000, assuming no other improvements are : Introduced.
In social terms this means that the town, by 1985 , could offer more economic opportunitles and more munity amenities and services to its residents. The rise In town expenditures would be far behind the rise in revenues, since the 1ncrease in employment would not have been large enough to bring in sizable numbera of new residents with additional children or new homes requiring municipal services. Rather, local people would probably have been able to find work more easily and not as many young people would have left the area. The total tax rate would drop to $\$ 20$ per thousand, with both the town and county rates reduced. The county, profiting from 1 ts taxes on the geothermal fleld, could have moved to improve the local communtty college and hospital. Electric heating has gradually taken over as residents phased out their natural gas furnaces and there are plans afoot to utilize.diatrict geothermal heating and cooling for a new shopping mall. A feeling of optimism is prevalent, and although some of the townspeople are against any further development, the majority have voted to contribute town funds to a County Development Agency to attract new industries using geothermal process heat to the area.

This is an optimistic scenario, but one which is plaus1ble, and given appropriate policles and favorable research results, likely. The experiences of Rotorua, New Zealand, Klamath Falls, Oregon, and Reykjavik, Iceland (see Section 4.6) serve as precursor examples.

\begin{tabular}{|c|c|c|c|c|c|c|}
\hline \multirow{2}{*}{ FORECAST } & \multicolumn{3}{|c|}{ ESTIMATED PROBABILITY BY YEAR } & \multirow{2}{*}{$\begin{array}{l}\text { YEARS TO } \\
\text { FIRST } \\
\text { IMPACT }\end{array}$} & \multirow{2}{*}{$\begin{array}{l}\text { YEARS TO } \\
\text { MAXIMMM } \\
\text { IMPACT }\end{array}$} & \multirow{2}{*}{$\begin{array}{l}\text { MAXIMUM } \\
\text { IMPACT } \\
\text { (PERCENTAGE) }\end{array}$} \\
\hline & 1980 & 1985 & 1990 & & & \\
\hline $\begin{array}{l}100 \text { MWE PLANT BUILT, ASSESSED AT } \\
\$ 12,000,000 \text {. }\end{array}$ & .75 & .99 & .99 & 0 & 1 & +120 \\
\hline $\begin{array}{l}\text { FOOD PROCESSING PLANT BUILT TO UTILIZE } \\
\text { DIRECT HEAT, .-ASSESSED AT } \$ 10,000,000 \text {. }\end{array}$ & .20 & .90 & .95 & $\mathbf{0}$ & 2 & +100 \\
\hline RESIDENTIAL PROPERTY BASE INCREASES BY 108. & .50 & .95 & .99 & 0 & 0 & +10 \\
\hline $\begin{array}{l}\text { EXISTING GREENHOUSE BUILOS } \$ 250,000 \\
\text { ADDITION. }\end{array}$ & .30 & .80 & .90 & 0 & 0 & +2.5 \\
\hline $\begin{array}{l}\text { OLD HEALTH SPA REVIVED AT COST OF } \\
\$ 250,000 \text {. }\end{array}$ & .30 & .50 & .80 & 0 & 0 & +2.5 \\
\hline $\begin{array}{l}\text { RESIOENCES CLOSE TO PRODUCING FIELDS } \\
\text { LOSE VALUE TOTALING } \$ 200,000 \text {. }\end{array}$ & .90 & .90 & .90 & $\mathbf{0}$ & 0 & -2 \\
\hline
\end{tabular}

F1gure 4.3.11 EVENTS USED IN TREND IMPACT ANALYSIS OF GEOTHERMAL TOWN TAX BASE 


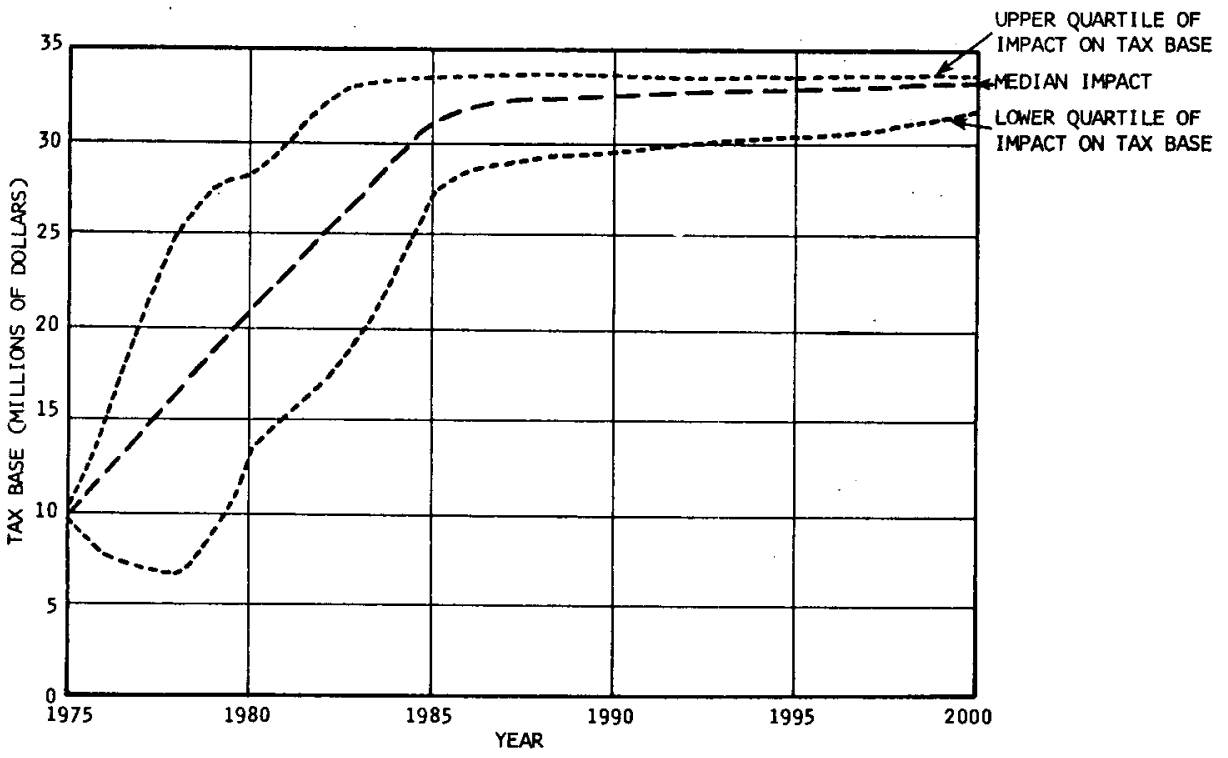

Figure 4.3.12 FORECAST OF TAX BASE FOR GEOTHERMAL TOWN

REFERENCES

[1] Quantitative Energy Studies and Models, A State of the Art Review (Jenkintown, Pa.: Decision Sciences Corporation, 1973).

[2] Searle, Milton F., Energy Modeling-Art-SciencePractice, Resources for the Future (Washington, 1973).

[3] U.S. Energy Outlook, National Petroleum Council (Washington, 1972).

[4] Dupree, W. and R. West, U.S. Energy Through Year 2000 (Washington: U.S. Department of the Interior, December, 1973).

[5] Total Energy Resource Analysis (TERA) (Jenkintown, Pa.: Decision Sciences Corporation, 1973).

[6] Herendeen, Robert A., An Energy Input-Output Matrix for the U.S. 1963; User's Guide (Champaign, Ill.: University of Illinois, Center for Advanced Computation, 1972).

[7] EPA Energy Qual1ty Model (Columbus, Ohio: Battelle Memorfal Institute, 1973).

[8] Reardon, W. A., An Input-Output Analysis of Energy Use Changes from 1947 to 1958 and 1958 to 1963 (Hanford, Washington: Battelle Pacific Northwest Laboratorfes, 197.4 ).

[9] Baughman, Martin L., Energy System Dynamics Mode1 for Interfuel Competition (Cambridge Mass.: MIT, February, 1973).

[10] Reference Energy Systems and Resource Data for Use In the Assessment of Energy Technologies (Assoctated UnIversittes, Upton, N.Y.: April 1972).
[11] Debanne, J. G., A Pollution and Technology Sensitive Model for Energy Supply - Distribution Studies (University of Ot towa, 1972).

[12] Hof fman, K. C., A Linear Programming Mode1 of the Nation's Energy System (Upton, N.Y.: Brookhaven National Laboratory, February, 1973).

[13] Mooz, W. E., Projecting California's Electrical Energy Demand (Santa Monica, Calif.: Rand Corporation, 1972).

[14] National Economic Research Associates, Inc., Energy Consumption and Gross National Product in the United States (New York: 1971).

[15] "Energy Supply and Demand Situation in North Amerlca to 1990," visual presentation (Menlo Park, Calif.: Stanford Research Institute, November 1973).

[16] Johnston, Devis F., "The U.S. Economy in 1985 Population and Labor Force Projections," Monthly Labor Review (Washington: December 1973).

[17] Hudson, Edward A., and Dale Jorgenson, U.S. Energy Pollcy and Economic Growth, 1975-2000 (Cambridge, Mass.: Harvard University and Data Resources, Inc. [part of the Ford Foundation Energy Policy Project], June 1974).

[18] "A Report to the Office of Management and Budget by the Interagency Panel for Geothermal Energy Research," unpublished report. (Washington, D.C.: National Science Foundation, June 1974).

[19] Personal communication, David Cohen, Pacific Gas and Electric, San Francisco, Calffornia, 1974.

[20] Personal communication, Earnest Comalli, County Assessor, Sonoma County, California, 1974. 
[21] Berman, M.B., M.J. Haumer, and D.P. Tihausby, The Impact of Electric1ty Price Increases on Income Groups: Western United States and Callfornia (Santa Monica, Calif.: Rand Corporation, November 1972).

[22] Final Environmental Statement for the Geotherma1 Leasing Program (U.S. Department of the Inter1or, Washington, 1973).

[23] Bratton, Oscar B., Statement of Taxes (Malhem County, Oregon: 1973-1974)

[24] Personal communication, Howard Ego, Town Manager, Vale, Oregon.

[25] Personal communtcation, J. Schneider, Town Manager, Nyssa, Oregon. 


\subsection{Effects on a National Electrical Grid}

U.S. electric utility industry w111 continue to be challenged by two demands which are inextricably bound to each other: the need to develop adequate generation facilities and the need to transport electrical energy from points of generation to points of consumption. These two needs must be satisfied under the constraints of system reliability, a rational fuel $\mathrm{mix}$, and environmental impact. It has become apparent to many utilities that because their problems are common, solutions are best found by reglonal and national planning for the growth of facilities. As the result of such planning, the electrical interconnections between utilities have grown at an accelerated rate during the past few years, and it is expected that this growth will continue for the next several decades. [1]

The development of the transmission grid, by permitting the flow of power among neighboring electric systems, secures several primary benefits: [2]

1. Power may be transferred between systems to meet power shórtages on both an emergency and planned basis.

2. Through the planned exchange of power and energy between regions, important reductions in cost of energy production can be achieved.

3. Scheduling of bulk energy transfer over tle lines takes advantage of energy cost differentials between areas.

4. Power exchanges are made possible by differing load characteristics due to seasonal patterns, time zones, and weather.

5. Sharing of operating reserves permits scheduling of different types of generation and through this, improvement in overall system efficiency.

6. Improvement in translent system power stability results from a greater degree of system flexibility.

A further benef1t, particularly important in the future, is the ebility to transfer power over the grid from sources remote from load centers. In the case of geothermal energy, accelerated development in the West may raise the possibility of sending power eastward. In effect, the Weat would be "exporting" geothermal energy in the form of electricity; the situation would be analogous to Loulsians exporting an Indigenous energy resource, natural gas, to users elsewhere in the United States. If the transcontinental grid 18 developed first for transmission of electricity from remotely located nuclear plants and coal/ mine-mouth generators, the geothermal application would be a marginal addition.

\section{Plans of the Electrlcal Industry for a National Elec-} tricity Grid

Overhead transmission lines in the United States, with voltages of $230 \mathrm{kV}$ and above, totaled approximately 65,000 clrcult miles in 1970; by 1990, this total is expected to reach 160,000 circuit miles Currently, with the exception of a major portion of the electrical systems in Texas, all of the larger utilities in the United States are interconnected. There are places, however, where the interconnecting os have limited capacity, and therefore cannot

ure continuous and reliable operation. This is particularly true of the East-West connections in the Rocky Mountain area. It has been strongly recommended by both the National Electrical Rellability Council (NERC) and the Federal Power Commission that interregional and transregional transmission lines be strengthened. [1] It is expected that future developments will strengthen the varlous weak polnts in the national transmission grid. Continual strengthening of the interconnected networks of the United States is essentlal if an acceptable level of reliability is to be maintained. The installation of transmission links, not solely as generation outlets but as inter-area and interregional ties with adequate power transfer capability, is required.

An order by the Federal Power Commission (Order 383-3) required the reglonal electrical counctis to submit dlagrams showing possible transmission patterns for the year 1992. Generally, these diagrams were developed without detailed engineering or economic studies, but they do represent, on a broad conceptual basis, the current thinking of those engaged in long-range planning for the various power systems within the United States.

A composite of these NERC transmission diagrams submitted in September 1973, is shown in Figure 4.4.1 on the following page [1]. A map of the regional areas of the NERC is shown in Figure 4.4.2. Generally, the transmission system expansion patterns are extensions of the existing Extra High Voltage (EHV) network; it also includes new U1tra High Voltage (above 800,000 volts, UHV). It is significant that in this particular plan, more than 4500 miles of UHV and 2500 miles of EHV DC are envisioned for the year 1992. The diagram does not show any of the spectal lines required for the proposed coal mine-mouch or geothermal projects discussed in this section.

\section{The Development of Geothermal Electricity West of the} Rocky Mountains

The development of large amounts of geothermal electric power in the West by the year 2000 ralses the posstbility of feeding this electricity into the various consuming centers of the West Coast and the entire region of the United States east of the Rocky Mountains.

F1gure 4.4.3 presents forecasts and selected assumptions included in the base case model simulation (Section 3.5); this run suggests that about 147,000 megawatts of geothermal energy will be produced west of the Rocky Mountains by the year 2000. Of th1s, the model forecasts transmission of 56,000 megawatts east of the Rocky Mountains to the mid-western consuming centers. The national grid, as described above, does not antictpate the transmission of such a large quantity of power over long distances. If geothermal electric power is used at points far from the geothermal resources, not only will the U.S. electrical transmission grid be affected, but several other impacts will be realized as well. These impacts Include Institutional issues particularly assoclated with management and operation of the grid, and environmental issues assoclated with Its aesthetics and effects on land use.

As described previously in this study and shown in FIgure 4.4.4, geothermal power sources are located primarily west of Rocky Mountains. [3] It 1s now reasonably clear that geothermal energy w111 be generated in dispersed plants ranging from 100-1000 megawatts in size. The consuming centers west of the Rocky Mountains are quite a distance from many of the good geotherma1 locations. Therefore, the power will be probably first gathered locally from one or more 


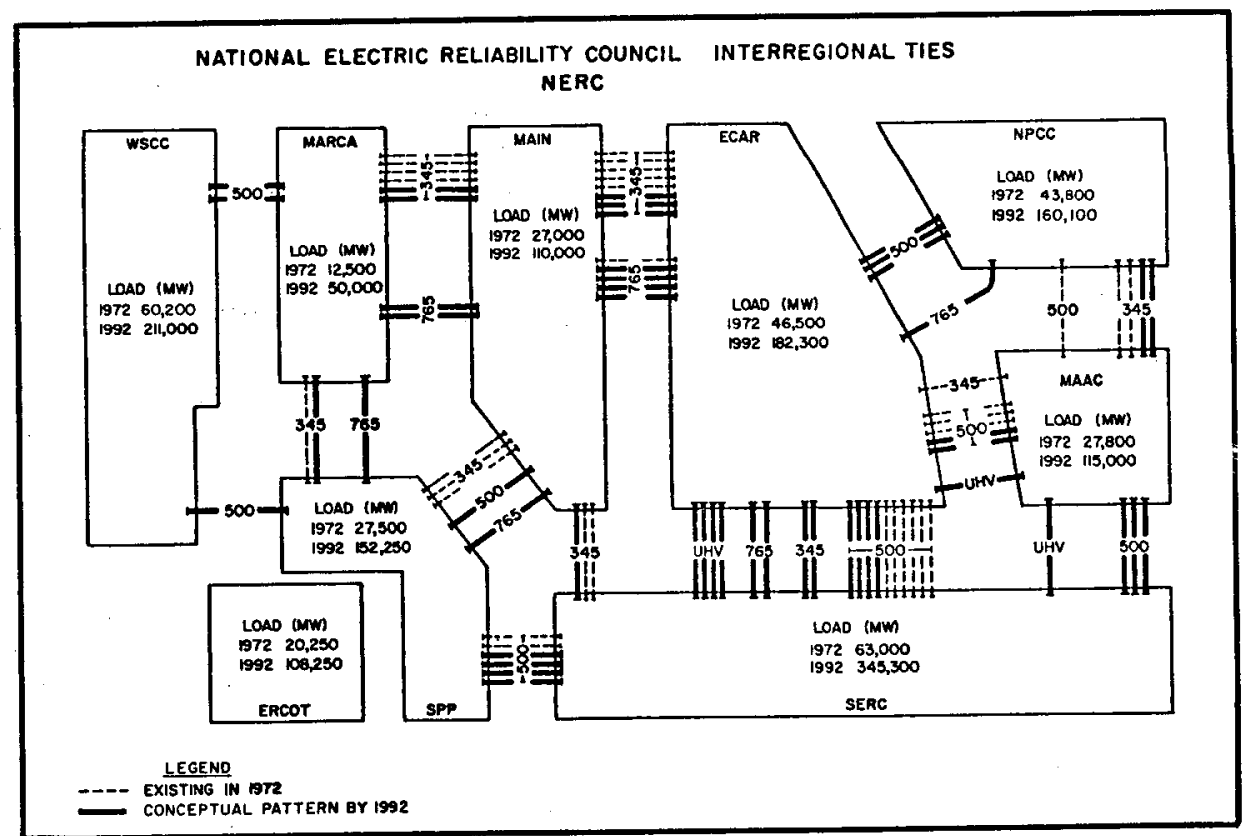

Source: National Electric Reliability Counc11 (Princeton, N.J., Apri1 1973).

Figure 4.4.1 


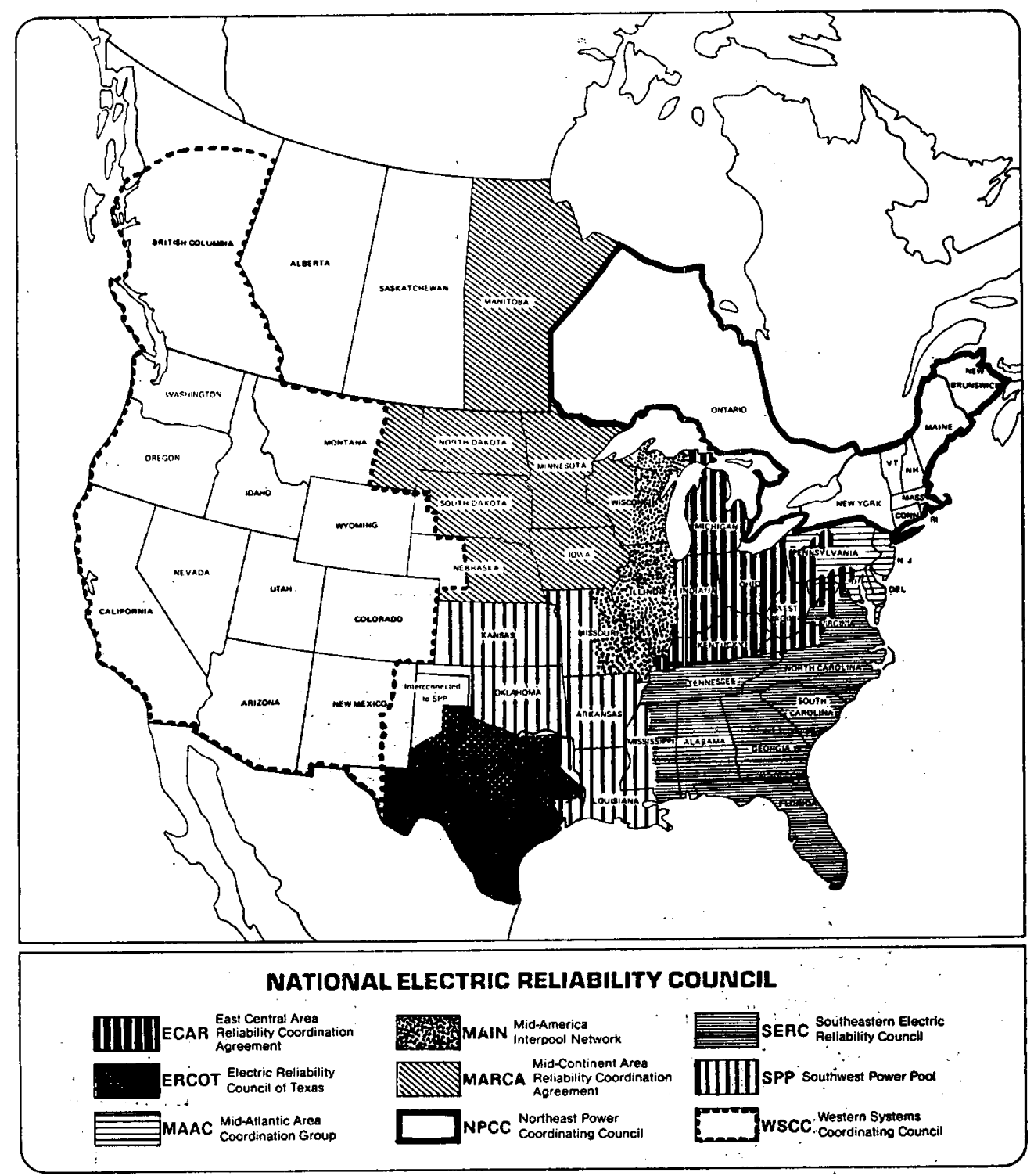

SOURCE: NATIONAL ELECTRIC RELIABILITY COUNCIL (PRINCETON, N.J., APRIL 1973).

Figure 4.4.2 


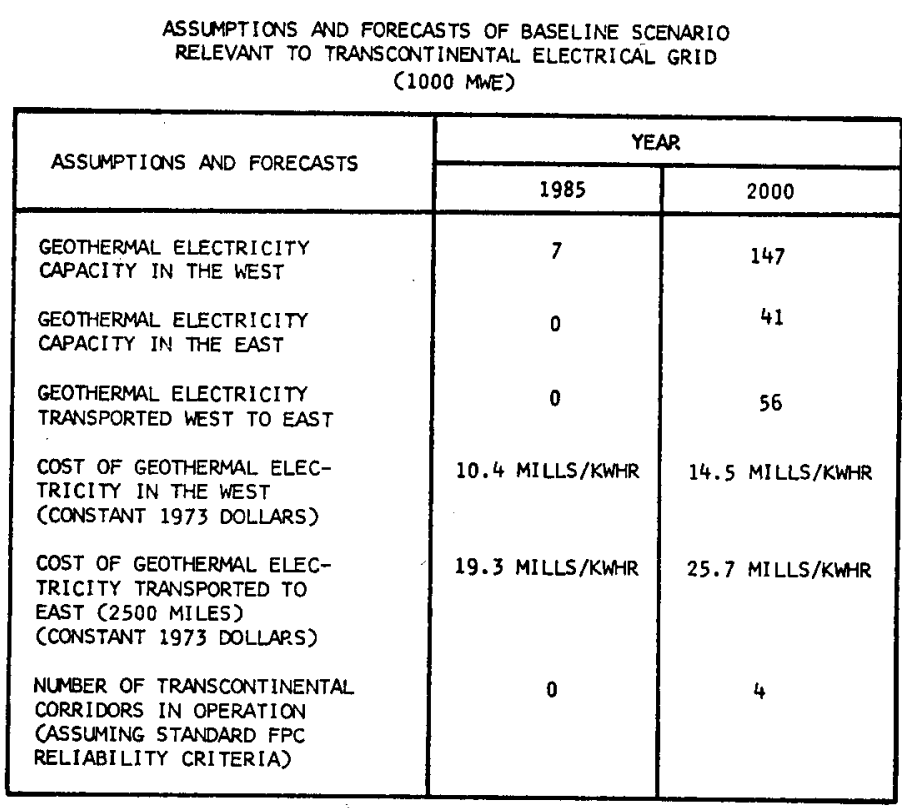

Ffgure $4 \cdot 4 \cdot 3$
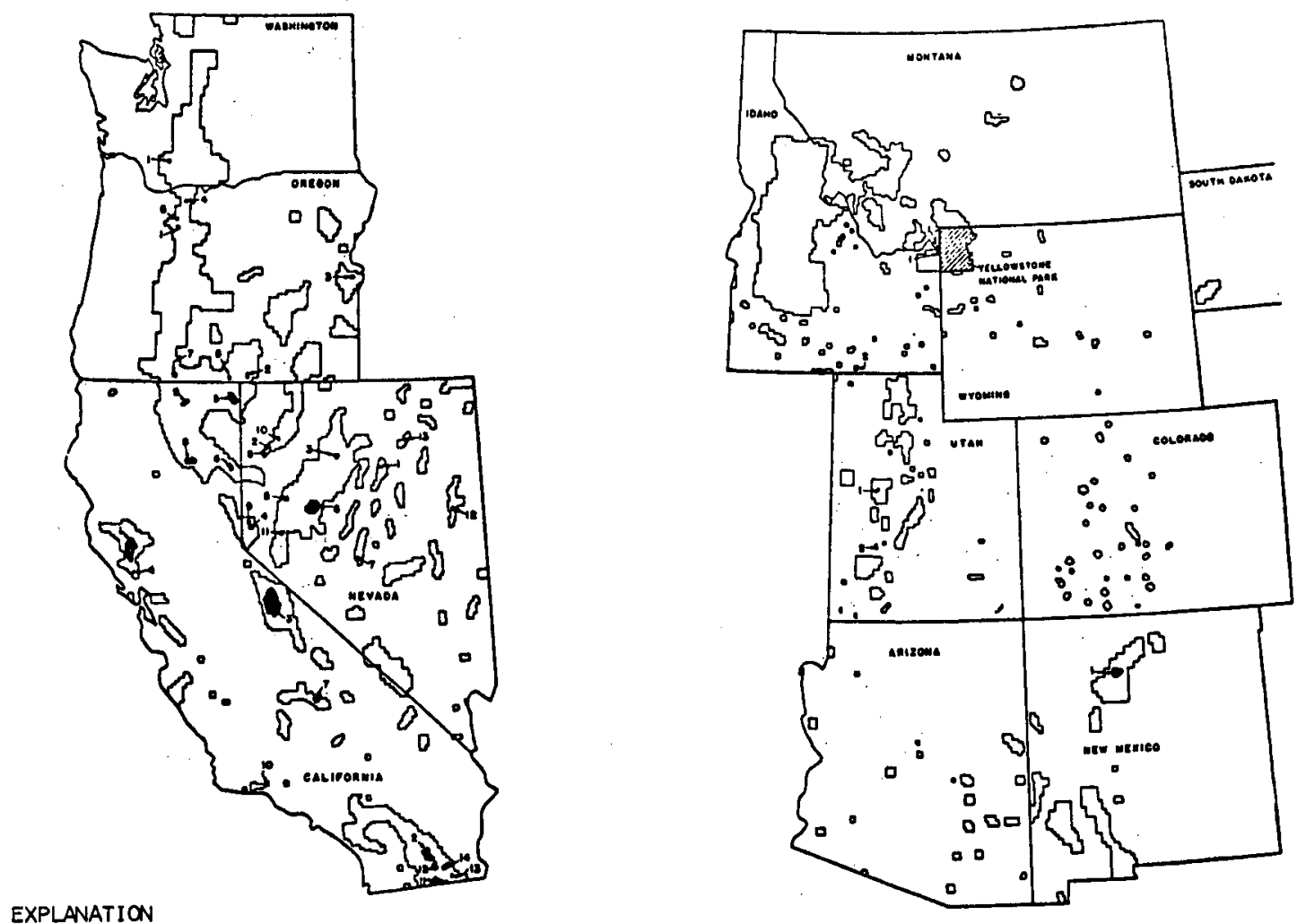

KNOWN GEOTHERMAL RESOURCE AREAS

AREAS VALUABLE PROSPECTIVELY

F1gure 4.4.4 MAP OF THE WESTERN UNITED STATES SHOWING LANDS CLASSIFIED FOR GEOTHERMAL RESOURCES EFFECTIVE DECEMBER 24, 1970 
fields. Then it will be transmitted the required long $\mathrm{d}^{\circ}$ aces at high voltages in a few transmission cor$r$ to the consuming centers. It is important to keep in mind that the presently visuallzed large consuming centers west of the Rocky Mountains are the large cities and their local environs: San Diego, Los Angeles, San Francisco, Portland, Seattle, Phoenix, Albuquerque, El Paso, Salt Lake City, Denver, and BolsePocatello. of course, there is considerable consumption in the other parts of the western territory, but these are the focal point consuming centers. Figure 4.4.1 gives the projected 1992 demand of this region as 211,000 megawatts, and the FPC estimates the year 2000 demand at 480,000 megawatts. It is estimated that in the 1990-2000 time frame, demand by the State of Calffornia alone will be 100,000-150,000 megawatts. [14] Therefore, it seems plausible that the amount of geothermal energy postulated in this study for the period 1985-2000 can be accommodated and consumed in the western load centers. For example, the simulation base run indicates that of the 147,000 megawatts generated in the West in 2000, approximately 90,000 megawatts will be consumed in this area; this would constitute about 19 percent of the total western load.

\section{Development of Large Power Complexes at Western Coal} Flelds

The increasing demand for electricity has led to consolidation of very large coal generating plants near the western coal regions. There are huge coal flelds located in Wyoming-Montana and in the New Mexico-

Arlzona four corners area. More than half of the coal
In the United States 1s located west of the MIssissippi River, and most of that is in these two thinly populated regions. Maps of these areas showing the coal deposits and proposed power plant locations are shown In Figures 4.4.5 (below) and 4.4.6. Both of these projects are at the serious planning phase and have partially started. $[5,6]$

The southwest energy system now has about 6000 megawatts of power plants in operation or under construction from the four corners area of New Mexico and Arizona to the Colorado Rfver. The final plans for this complex of generating plants is to achieve a capacity of 30,000 megawatts by 1990 . There is sufficient coal at the proposed sites to generate this capacity for well over 200 years. Since these power plants are located in a relatively isolated desert, the electricity which they generate will be transwitted to the consuming centers which are most of the cities named previously in this section. For example, the largest consumer would be the C1ty of Los Angeles, hundreds of miles away.

The north central power system is centered around the tiny city of Gillette, Wyoming. There are vast coal deposits in this area which can be mined easily. In 1970 , consuming power companies in the Mid West, and in Wyoming and Montana, began a study of large capacity power plants in this region which would transmit the electric1ty to mid-western consuming centers: Minneapolis-St. Paul, Omaha, Des Moines, Kansas City, and St. Louis. Also, some of the electricity would be used in the immediate area. Their present plan (1971) is to generate 10,000 megawatts for use in the western

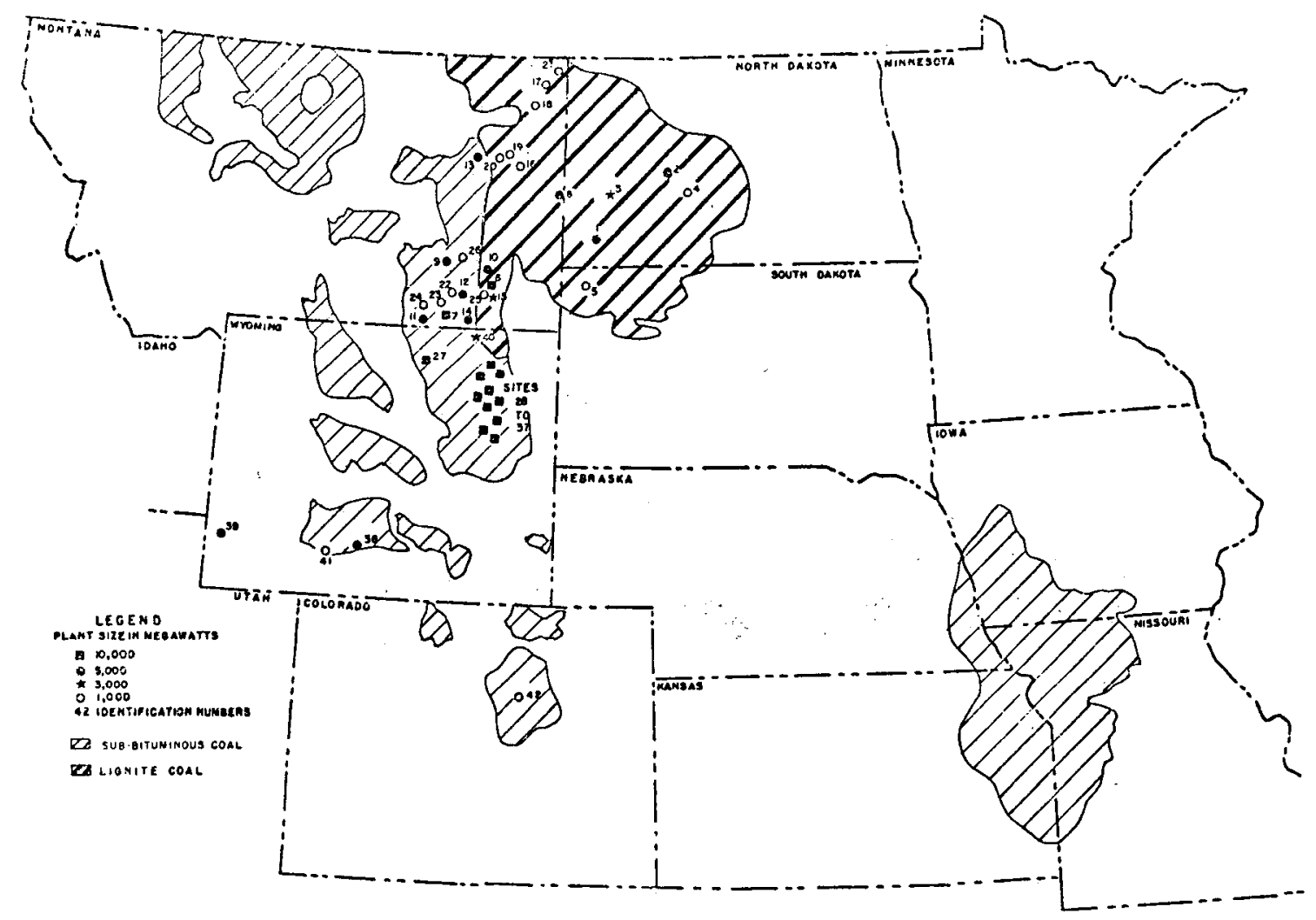

Figure 4.4.5 LOCATION AND POWER GENERATION POTENTIAL OF STRIPPABLE COAL DEPOSITS IN NORTH CENTRAL POWKR STUDY AREA 


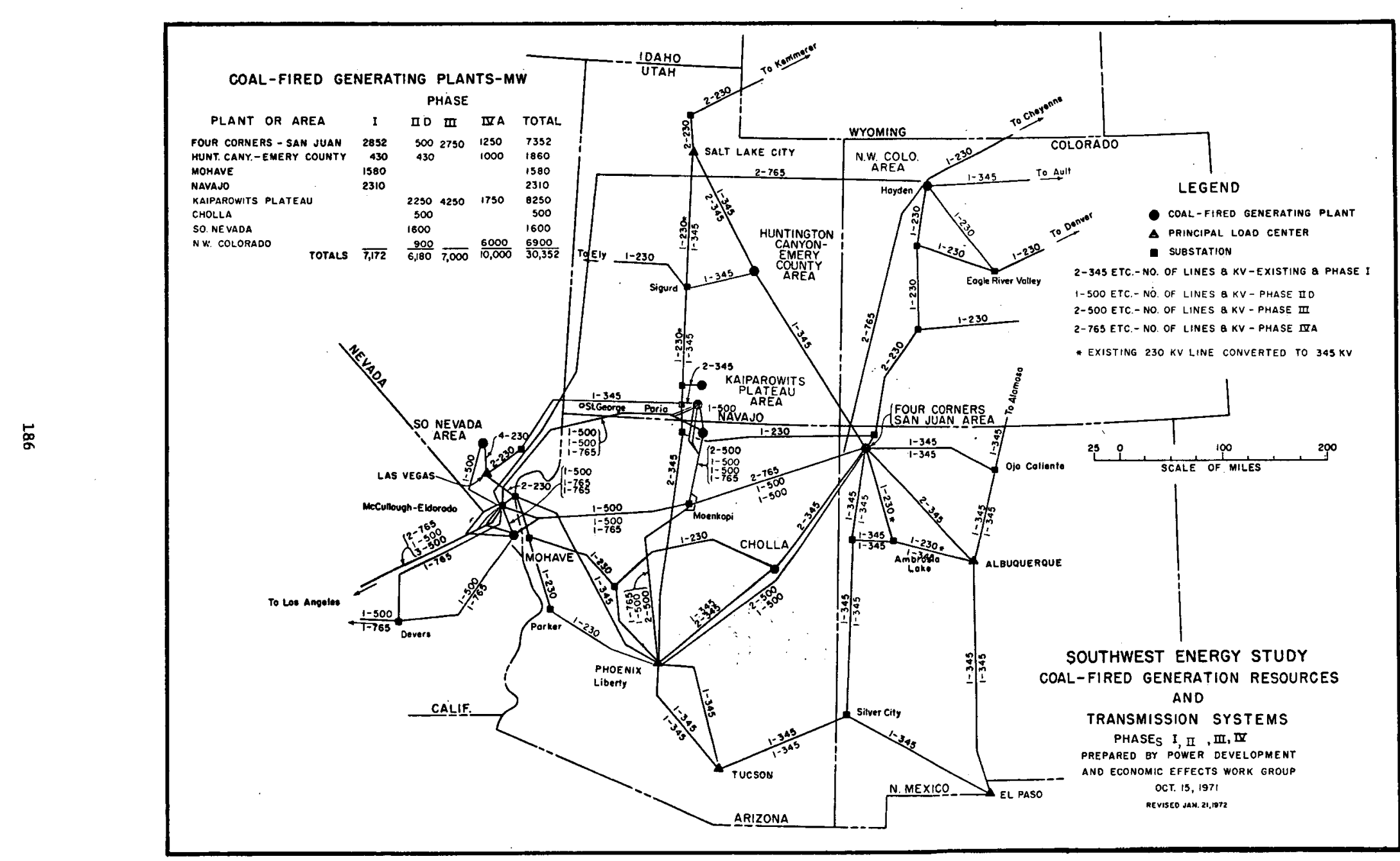

Source: [6] 
area and 40,000 megawatts for transmission to the amed mid-western cities. The plan calls for transitting this electricity along four corridors containing a total of fourteen $765 \mathrm{kV}$ AC 1ines. Twelve would be in active use and two would provide the required system redundancy.

The important point to be made for this study is that the suggestion for generating very large amounts of geothermal energy for transmission to West Coast and mid-western consuming centers must be taken as a serlous future possibility. The electrical industry has already started implementing similar systems based on the Rocky Mountain area coal deposits. The amounts of geothermal energy which might be generated in the West and transmitted to the Mid West and East are of the same order of magnitude as those contemplated for the coal mine-mouth generating plants now being planned. Therefore, the development of the high voltage transmission grids required for the geothermal electricity can and probably will be blended with those for the coal based electricity.

\section{Effect of Export Electricity on Transmission Grids}

The huge amounts of geothermal energy likely to be available for export, coupled with projected coal electricity, will have profound effects on the development of the national transmission grid. In this study, these various possible impacts were defined by constructing an impact relevance tree. The first two levels of this impact relevance tree are shown in Figure 4.4.7, and the entire relevance tree is given in Appendix $D$.

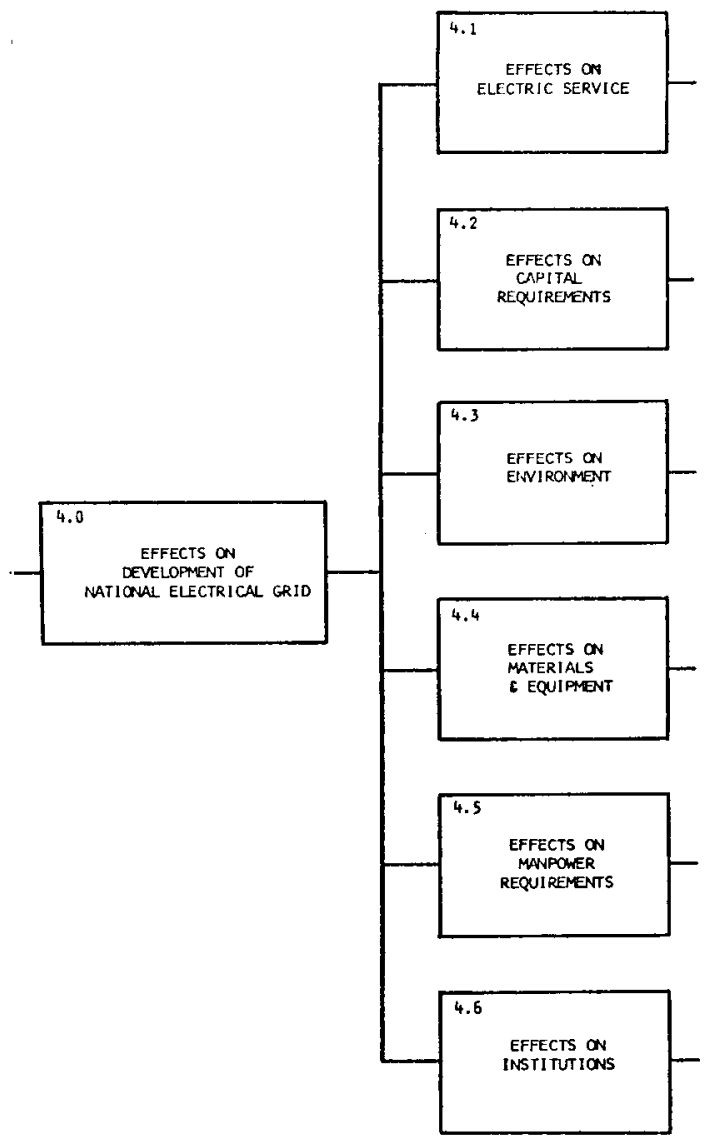

Figure 4.4 .7
Effects on the Technology of Electricity Transmission Lines

The demand for efficient transmission of higher power levels will bring an increase in transmission voltage. Increased voltages have, in the past, allowed greater power transmission per line, thus minimizing right-ofway costs and associated environmental impacts. Voltages now used and planned have upper limits of $765 \mathrm{kV}$ $\mathrm{AC}$ and $800 \mathrm{kV} \mathrm{DC}$. Such lines can carry a few thousand megawatts at reasonable costs. Transferring larger amounts of power (of the order of 10-15 thousand $\mathrm{MW}$ per line) would require an Increase in voltage to 1000-2000 $\mathrm{kV}$, a technological development assumed in the next 15-20 years. (See Figure 4.4.8)

There are important developments in transmlssion technology abroad also. The new Russian five-year plan objectives include development of new equipment for $1500 \mathrm{kV} \mathrm{DC}$ and for $1150 \mathrm{kV} \mathrm{AC}$ for transporting power from Asian coal fields over $1500 \mathrm{~km}$ to Moscow, the lines having a 6000 wWe capacity per circuit. In the future, Siberian hydroelectric power will be brought to Moscow over $4000 \mathrm{~km}$ 1ines. [7]

Increase in transmission voltage is dictated by transmission line economics. In general, transmission ine construction costs increase with increasing voltage. The line-carrying capacity, however, also increases with increasing voltage, and there is a minimum cost for transmitting power per unit of distance for the transmission of a given amount of power. Figure 4.4 .9 shows this variation of cost with distance for several high voltage lines, both $\mathrm{AC}$ and $\mathrm{DC}$.

It may be seen from Figure 4.4.9 that the transporting of larger amounts of power over large distances will probably be done with DC transmission 1ines. A compar1son of the economics of DC transmission with AC transmission may be characterized as follows: [8]

1. Construction of the transmission line overhead or underground is less expensive for DC lines. At present, DC line capital costs are approxlmately 35 percent lower than for comparable AC lines.

2. DC transmission terminal stations are appreciab1y more complex and expensive than their AC counterparts, both for Inttial costs and operating and maintenance expenses.

3. On comparable rated lines, transmission losses for DC lines will be less.

4. DC transmission cable capacitles are not limited by reactive charging currents.

5. Modern DC lines do not add appreclably to the short circult capacity requirements of their recelving buses.

6. The asynchronous nature of DC lines may be an asset in some situations in that there are phasing problems with AC interties. This is now severely limtting long distance AC power transmission.

The rights-of-way have to wide enough to accommodate transmisston towers carrying cables spaced 50-100 feet apart. For 500-765 kV AC lines the total transmission right-of-way width ranges from 250-350 feet, depending on the tower design and the terrain. A future high voltage $D C$ line will require 50-60 percent less width, only 150-200 feet. The AC towers vary from 105-160 


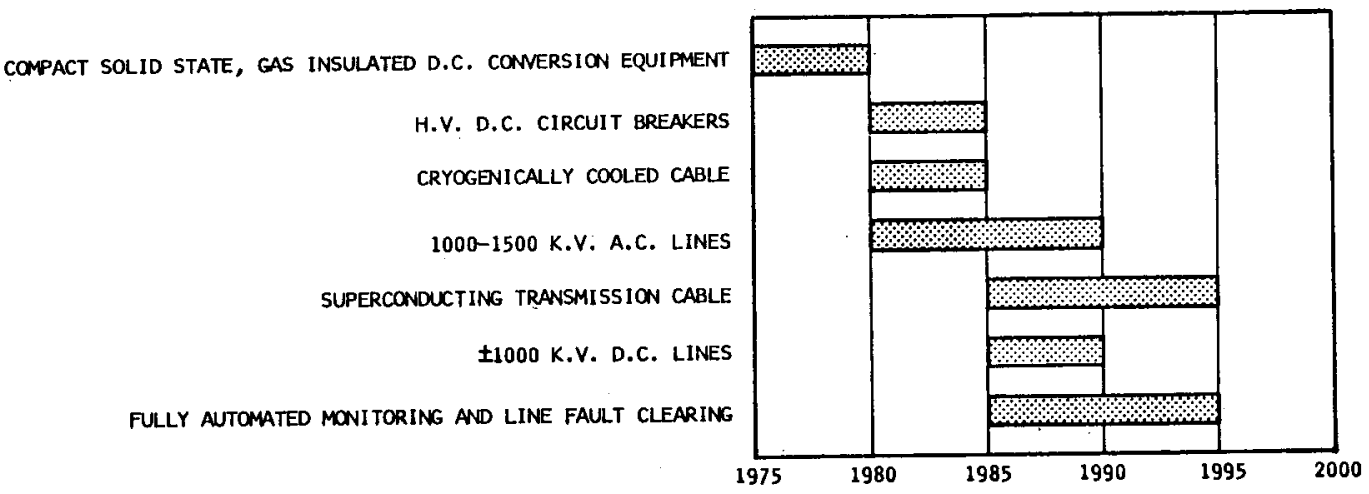

Figure 4.4.8 FUTURE DEVELOPMENTS IN TRANSMISSION TECHNOLOGY

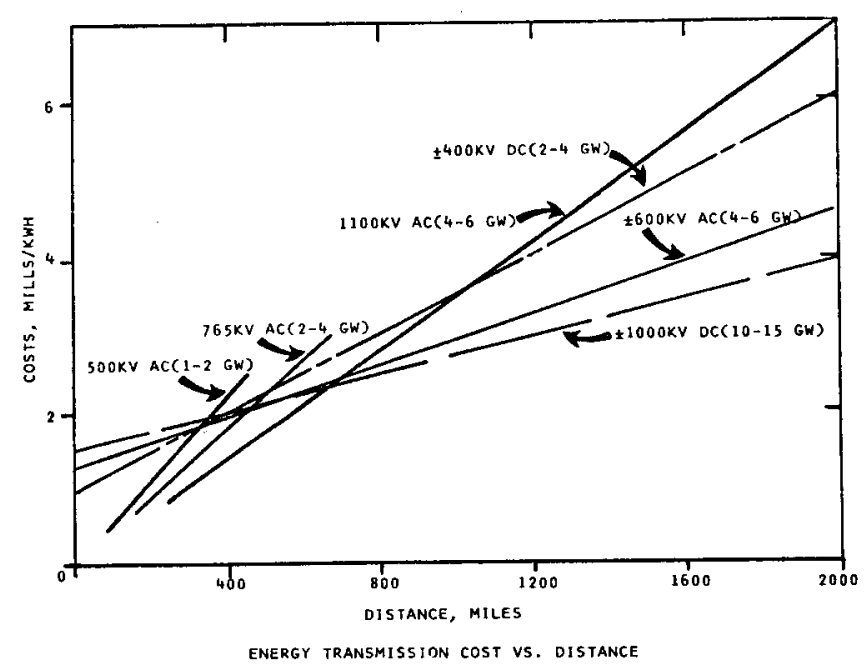

SOURCE: FROM INFORMATION SUPPLIED INFORMALLY BY G. BRUER OF GENERAL ELECTRIC CO. AND R. F. LAWRENCE OF WESTINGHOUSE ELECTRIC CORP. (THE FIGURES IN PARENT
OF A SINGLE LINE.)

Figure 4.4.9 
feet $\mathrm{h} 1 \mathrm{gh}$ and the $\mathrm{DC}$ towers vary from 100-125 feet. [9] (unm) a primary motivation for developing the national grid is improvement of system rellability, the system advantages for DC power transmission indicate that If substantial amounts of electrical power are to be transferred from western coal and geothermal electrical resources, $D C$ transmission will probably be the medium. At present, the longest DC line in the United States is the Northwest-Southwest Pac1fic Intertie running 846 miles, from The Dalles, Oregon, to Los Angeles. This 1s a $\pm 400 \mathrm{kV}$ DC line having a capabllity of approximately $1440 \mathrm{MW}$. In this case, there are also two 500 $\mathrm{kV}$ AC circuits running in parallel with the DC 1ine. Both the $\mathrm{AC}$ and DC lines together provide some redundancy so that a necessary level of reliability can be maintained for the system.

The amounts of power which may be transferred from geothermally produced electric generation in the Weat will be not only a function of the specific costs of delivery (including both generation costs and transmission line costs), but will be quite dependent on total system reliability. To prepare for the contingency of the 1088 of a Itne which carries a large amount of power, there will have to be either alternative transmission paths for power or alternate local sources of power which may be used for an emergency. The ability to provide for such an eventuality will be a limiting factor in the amount of power which can be transmitted over any single line.

The caveat on system rellabllity notwithstanding, delivery of large amounts of power from geothermal electric resources in the West to mid-western and-eastern points in the national grid may be economically feasible. As an example, three corridors might be developed by the year 2000 running parallel to transmission links which are likely to have been developed by that perlod of time. One might run east through Minneapolis to Chicago, the second to Kansas City and St. Louls, and a third to Dallas, Houston, and New Orleans. (If substantial amounts of geopressured geothermal resources are developed along the Gulf reglons, such inputs could be fed Into the New Orleans terminal:) Each corridor could contain $+1000 \mathrm{kV}$ DC lines running about 2600 miles and capab̄le of carrying 10,000-15,000 megawatts. The scenario of the development of these lines $1 \mathrm{~s}$ 11lustrated in Figures 4.4.10 and 4.4.11. These graphe show the timing for Installing the various sized lines and the costs. The transmission costs over such a distance would be about 4 mills per kilowatt hour (see F1gure 4.4.9). This cost Includes line losses, estimated to be about 13 percent of total power transmitted for a Iine operating at full capacity.

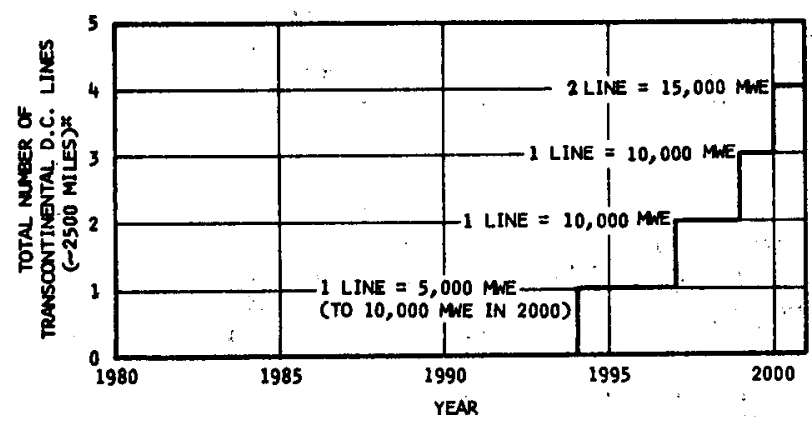

MASSUNES THAT SUFFICIENT REDUNDANY IS DEVELOPED IN EN REGIONAL INTERCONECTED GRID:

PIgure 4.4.10 DEVELOPMENT OP GEOTHERMAL POWER TRANSMISSION CORRIDORS TO THE MID WEST

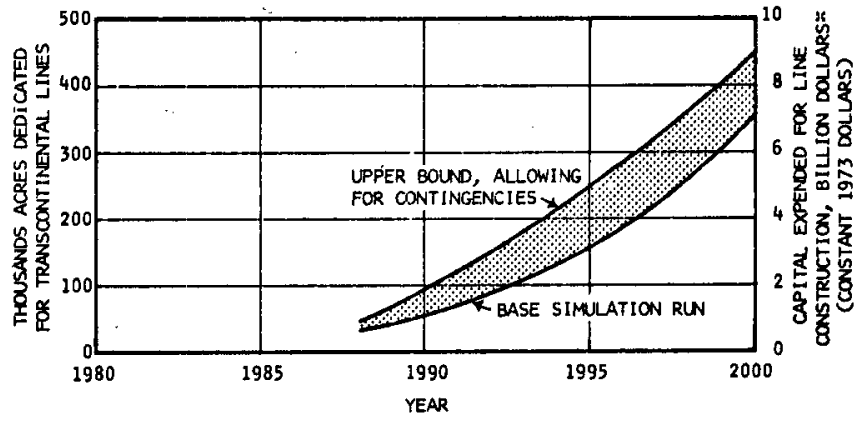

'INCLUES TERMIALS, EXCLLOES RIGTT-OF-WAY COSTS. RIGHT-OF-WAY
COSTS AT \$7TI/ACRE' WOULD ADO ABOUT $5 \%$ TO THE CONSTRUCTION COSTS. CONSTRUCTION TIME IS 6 YEARS.

Figure 4.4.11 DEVELOPMENT OF GEOTHERMAL POWER TRANSMISSION TO MIDWEST-LAND AND CAPITAL REQUIREMENTS. ASSUMES 200 FEET RIGHT-OF-WAY AND 2500 MILES LINE LENGTH.

The power transmitted along these three corridors would be equal to about 10 percent of the profected generatIng capacity for the two FPC regions in which the power would be recefved (the West Central Region and the South Central Region). Entering the grid at these points, power may be ultimately distributed further east, thus distributing the burden of rellability (related to the percentage of power delivered from geothermal resources to the local generating capacity) throughout large portions of the Midwest and eastern grids.

In planning the U.S. transmission network, changes in voltage level are seldom dictated by short-term growth predictions. When studies are limited to only a few years, the results usually show that the lowest capital requirements are obtained by remaining at existing voltage levels. It is only when studies for the transfer of large blocks of power are profected far enough into the future that new Ines at higher voltages may be jusified on a present worth basis. If the Judgments simulated by the model described in Section 3.5 are correct, the potential Mid West and East Coast markets for western geothermal electricity will be an 1mpetus to Increase voltages for the economical transregional transmission of electricity.

\section{Transmission of Hydrogen Produced from Geothermal Power}

The nature of the growth of transcontinental transmission of geothermal energy also involves other important fuel technological considerations. It may prove efficlent to transmit the energy in the form of hydrogen-that 1s, geothermally produced electrictty would be used to electrolyze water [10]; the hydrogen produced by this process would be pumped over long distances to be used as a fuel at the end of the pipeline.

In considering the synergism of geothermal energy and the hydrogen energy economy, a critical question ar1ses: What is the cost of hydrogen produced from the power? In Figure 4.4.12 the cost of hydrogen produced by the electrolysis of water, using advanced technology now foreseen, is given as a function of power costs in mills per kilowatt hour. These data Indicate hydrogen can be produced by electrolysis, using geothermal electricity, for a manufacturing cost of \$2-4 per million Btu. [11, 12] 
COST OF HYOROGEN PRODUCED FROM GEOTHERMAL' POWER

\begin{tabular}{|c|c|c|}
\hline AUTHHOR & $\begin{array}{l}\text { POWER COST } \\
\text { (MILL/KWH) }\end{array}$ & $\begin{array}{l}\text { HYDROGEN COST } \\
\text { (\$/MILLION BTU) }\end{array}$ \\
\hline GREGORY [11] & $\begin{array}{l}4.0 \\
7.0 \\
9.1\end{array}$ & $\begin{array}{l}1.50 \\
2.50 \\
2.95\end{array}$ \\
\hline LOTKER, FEIN, SALZANO & 10.0 & 4.20 \\
\hline \multicolumn{3}{|c|}{$\begin{array}{l}\text { (BOTH REFERENCES ASSUME REASONLBLY POSSIBLE FUTURE } \\
\text { IMPROVEMENTS ARE MADE IN WATER ELECTROLYSIS TECH- } \\
\text { NOLOGY OVER TTE PRESENT TECHNOLOGY IN THE NEXT } 10 \\
\text { YEARS.) }\end{array}$} \\
\hline
\end{tabular}

Pigure 4.4.12

This 1s higher than the present prices for natural gas In the western Untted States, but, of course, these supplies are now severely limited. The projected future manufacturing costs for gas from coal gasification are somewhat lower than these figures using 1972 coal prices. However, with the price of coal and oil shale rapidiy escalating, gas produced by gasification from both of these sources w111 probably be in the range of $\$ 1.50-3.00$ per million Btu in the near future. [13] Therefore, hydrogen produced from geothermal energy sources in the West may be potentially cost competitive with synthetic. fuel gas manufactured from the other avallable, fuels.

Since geothermal energy wells should be operated continuously at full capactiy, there will be excess offpeak geothermal energy which can be channeled off to the production of hydrogen. This hydrogen, of course, can be transported either as a gaseous fuel or can be converted into synthetic natural gas, synthetic o11, or methanol. (It has been well established that methanol is a good constituent of automobile fuel.) Since the Bast w1ll also require a fuel $\mathrm{mtx}$ of electricity, fuel gas, and liquid fuels, probably it w111 be desirable to convert some of this export geothermal electricity to :hydrogen and methanol for transport to the Bast. It has been pointed out by Gregory [11] and others [14] that over long distance it is cheaper to transport gaseous hydrogen or liquid fuels than electr1c1ty.: Therefore, a combined geothermal energyhydrogen economy, jointly producing electricity, fuel gas, and liquid fuel for export east of the Rocky Mountains, appears to be an interesting alternative.

Bffect of Geothermal: Energy and Transmission Grid Growth. on Electric Service in the West, and East of the Rocky. Mountains

Coupling geothermal energy development with a national grid will have beneficial results for electricity consumers. In the load centers. The most noticeable effect to them would be to help limit the cost of electric1ty and enhance 1ts avallability. It was previously shown in.this study that the cost of geothermal electricity 18 on the low end of the generation range compared to other fuels avallable to a power company. The role of the development. of the trangmisaion grid, therefore, is to -make this large potential supply of geothermal energy avaliable to remote consuming centers. As this development takes place toward the year 2000 , this w11l be noted first in the western consuming centers. After 1985-1990, according to the base s1mlation, (see FIgure 4.4.13), the large transmisston, lines will be bullt for transmitting geothermal energy

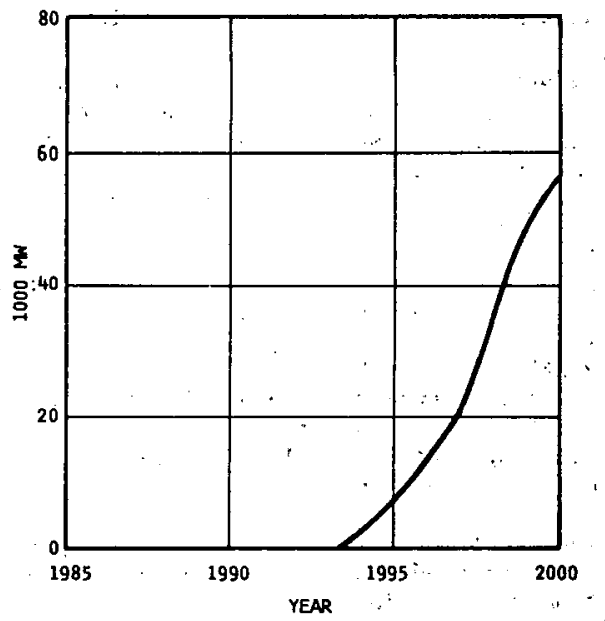

Figure 4.4.13. GEOTHERMAL ELECTRIC POWER TRANSMITTED TO THE EAST

(DATA FROM MODEL, BASE CÁSE)

east of the Rockies. At that time, the mid-western consuming centers will start to benefit also from the avallability of the low-cost geothermal energy. For them, this will probably a.lso be mixed with similarly low-priced electricity from the mountaln states' coal generating plants. [5] However, as pointed out in Section 4.1, the cost-dilluting effects of geothermal electricity are small: if the accelerated program is. realized and geothermal electricity were to cost 75 percent of the national average, the net effect would be a reduction in average cost of only. 3 percent.

One of the chief reasons, as mentioned before, for bullding transmission grids is to assure and, if possible, increase the rellability of the electrical supply to the consumer. [1] This is one of the major responsibilities of a power company. Transmission of 5-20 percent of a consuming center load from geothermal fields will increase the local system rellabllity in at least two, ways. F1rst, it will make the local energy fuel mix more diverse by adding another fuel. Second; a portion of the total energy comes from an outside distant source not subject to the vagarles of local weather or soctal disturbances. Utility executives contacted during this study Indicated the desirability of both of these points in Improving the rellability of their local system.

Purchase of 5-20 percent of the local power supply from an outside source w111 have an important effect on the construction of local power plants. It is obvious that there will be a decreasing need for constructing local power plants. Th1s will alleviate the acute problem of finding local power plant sites. Simultaneously, it will decrease considerably the amount of local pollution which might be caused by the local power plants.

\section{Effects on Institutions}

The effects of geothermal electriclty transmission and importation on utility administration and institutional arrangements will be to make the management task more complex, because local power compantes will now have to deal with an outside power source and transmission controller. The company operating the geothermal power plant probably will be different from the company controlling the transmission 1ines. Therefore, administration will Involve two other groups and, thus, w1ll become more complicated. However, this is not a selfdefeating situation, because the equipment (computer controlled) and administrative training of the power industry is being developed and Improved so that in th 
ture it can deal with these arrangements in a routine ner.

The concomitant development of geothermal generating plants distant from the consuming centers and long distance transmission lines will have a strong effect on the load center power companies. Traditionally, the load center power companies have grown gradually, and their chlef mission has been to supply cheap, reliable power to their local customers.

The local power companies get their income from the 10cal customers only; and their return is based, in part, on their invested capital. Furthermore, the power companies are regulated by the several state power commissions as to their business activities. This pattern of development has served the country and industry well. The construction of distant geothermal power plants and high voltage transmission lines are activities which will be new to the regular business of power companies; furthermore, these activities are likely to be outside the local power company service region and probably in other states. This will make the regulation of a power company very complicated.

The present method for determining charges to local consumers takes the entire capital investment of the power company (the rate base) and determines a fair return on this. However, in the future, if the power companies make investments for transmission lines outside of their territory, it is uncertain as to how much of this investment should be borne by the local consumer and how the rate base would be affected.

Nevertheless, the construction of transmission lines for transregional shipments of large amounts of electrical power is occurring and w111 undoubtedly grow in the future. In the case of the Pacific intertie which runs from the Dalles, Oregon, to Los Angeles, California, the cost for construction was shared by the several user utilities, principally Los Angeles Water \& Power Department and the Bonneville Power Authority, and included several other municipalities and the Southern California Edison Company. Most of this line $(800 \mathrm{kV} \mathrm{DC})$ is built on federally owned land. Construction from Los Angeles to the Nevada-Oregon border was done by the Los Angeles Water \& Power Division, while the northern remainder was constructed by the Bonneville Power Authority. Acquiring rights-of-way presented no insurmountable problems. While rightsof-way may have been facilitated by federal participants, utlifies, particularly in the West, have often built transmission lines to accommodate electricity generated outside of their own territory.

The ralsing of capital for the building of transregional lines, however, might be difficult to allocate among all of the utilities drawing power from the grid. In the North Central Power study several methods for doing this have been studied but no satisfactory method was decided upon. [5] This is due to the complicated nature of both the consumption and the generation of the electricity. The loads fluctuate daily and seasonally, and are also affected by changing comercial and industrial activities in a particular consuming center. All of this adds up to a variable usage of the transmission line by an individual load center. This being the case, it is clearly difficult to allocate fixed capital charges to a particular load center.

Therefore, the raising of capital for the building of transregional lines might be difficult to allocate among all of the utilities drawing power from the grid. If foint and cooperative efforts among utility comnanies for the necessary transregional factlities are mpractical, it may be necessary to consider forming an independent transmission company which could provide common carrier service in the same fashion as a gas pipeline company now does. Since power dispatching would have to be under the control of regional consumer utility groups and of generating companies, the responstbility for control of such a line would have to be worked out very carefully. This, of course, is exactly the situation for a common carrier gas pipeline company, which gathers gas from various gas fields owned by other companies and then transmits it to consuming center companies. An interstate electrical transmission company might be private but probably would be regulated by the Federal Government to ensure equitable distribution of costs of the transported power among the user utilities. Since the organizational and institutional methods for this exist in the natural gas and oil pipeline companies, it is reasonable to predict that such private transmission companies may be formed in the future.

Th1s trend w111 be encouraged by the construction of some of the planned electrical generating complexes in the West, such as the two coal studies previously discussed, and, of course, western geothermal flelds. A high voltage electrical transmission line cannot be constructed economically on a small scale. It must be built on a large scale, costing a large amount of money, or not at all. For example, a line going from geothermal fields to the Mid West would cost a minimum of approximately $\$ 1$ billion. Therefore, it is not possible for such a system to grow gradually. It is a large enterprise and w11 have to be handled accordingly. Since much of the required transmission rightof-way land is already government owned, it seems possible that a specially created federal agency for building and operating the transmission lines should be considered.

Placing the financing, construction, and operation of these spectal interregional high capacity transmission lines in the jurisdiction of a government body or a government-private company can have benefits to the consuming center utilities. It will relleve them of the responsibility for financing, constructing, and operating transmission lines which are out of their territory. (Obtaining the financing of multi-billion dollar transmission lines will be particularly onerous for private companies in the future due to money scarcity and high interest rates.)

The whole question of environment and environmental impacts due to the transmission lines can probably best be handled by a government agency. This agency not only would have the responsibility for reliable economic operation of the lines, but would also be responsible for conserving the environment in the best interest of the citizens.

The development of 1ndependent transmission line operating companies would be a strong departure from the present business methods in the electric utilities business. It would enable new companies to go into the electrical generating business. Several non-utility compantes have already shown. a strong interest in not only operating the geothermal wells but in generating the electriclty themselves. However, they have not been able to make ouitable business arrangements for delivering and selling their power to a load center. Construction and development of a common carrier transregional electrical transmission grid will enable nonutility companies to generate electricity in geothermal fields and to transmit power through the common carrier to a load center with whom they can arrange a sultable contract. This could bring a great deal more flexibility into the electrical generating capacity of the West, and ensure a more equitable, rational, reliable, and 
economic electric service to the consuming centers.

A single transmission-line agency, properly constituted, would also help simplify the problem of overlapping jurisdictions and responsibilities among current organizations. At present many regulatory agencles assert authority over transmission line locations and construction. Federally, the Federal Power Commission has the right to require licensees to construct and locate their lines in accordance with regulations concerning environmental factors. The Environmental Protection Agency does likewise. The U.S. Department of the Interior and the U.S. Department of Agriculture have the authority to impose conditions concerning location, construction, maintenance, and line use practices, of any portion of the transmission. Ines occupying public lands under their furisdiction. Some of the conditions which are now, and in the future, imposed by these agencles cover liabllity for forest fires, construction, clearing, rehabilitation, maintenance practices, access road, and specific line location in relation to surrounding terrain or unusual geologic or historical features. In addition, the Bureau of Public Roads may require transmission line facilities to be located away from interstate and scenic highway systems, and also may reject proposed highway crossings.

Since the full development of geothermal energy transmission lines will cover such a wide part of the country, it is appropriate to review the government agencies and commissions who may have regulatory jurisdiction over the siting and construction of these transmission lines.[16]. The list follows:

1. Local (City and County)

C1ty Council

Planning Commission

Board of Supervisors

Zoning Board

Flood Control Districts

County Road Department

Conservation and Development Commissions

2. State

Regulatory Commission

Water Quality Control Agency

Department of Forestry

Department of Fish and Game

H1ghway Commission

Lands Commission

Water Agency

Department of Conservation

Department of Beaches and Parks

River Commission

Power Plant Siting Committee

3. Federal

Department of the Interfor Bureau of Land Management Bureau of Indian Affairs Bureau of Sports Fisherles and Wildife U.S. Fish and Wildife Service National Park Service

Department of Agriculture Untted States Forest Service

Federal Power Commission
Department of Transportation

Federal Aviation Administration

Federal Highway Administration Bureau of Public Roads

Department of Defense

Department of the Army

United States Corps of Engineers

Environmental Protection Agency

The Effect of Geothermal Energy Transmission Lines on Power Economics

The construction and operation of high voltage transmisston lines for conveying geothermal energy from the production field to the consuming centers is clearly going to be a large enterprise. Although it is difficult to talk about transmlssion lines in general, the projects do have a common method of attack. Each transmission line project involves the following stages:

Planning and environmental impact analysis

Route selection

Rights-of-way acquisition

Design

Construction

Maintenance

Operation

The cost of a 1-2 milion volt DC line in the time period 1985-1995 is estimated to be \$1-1.5 billion (1973 dollars) for $2500 \mathrm{miles}$. Such a line is projected to have a capacity of 5-15,000 megawatts. The transmission cost of the geothermal energy dellvered hy such a line. is estimated at 7.5 mills per kilowatt hour in 1980 (lower voltage) and $4 \mathrm{mills}$ per kilowatt hour in 1995 (h1gher voltage) (1973 dollars). This is predicated on the technological improvements occurring from now to 1995, as discussed previously.

This assumes a line cost of $\$ 250,000$ per mile, exclusive of rights-of-way costs, and a cost of the inverterconverter terminal of $\$ 25$ per $\mathrm{kW}$. F1gure 4.4.11 shows the expected cumulative capital costs which are consistent with the scenario of the development of geothermal power for export to the East. Th1s indicates that by the year 2000 about $\$ 4-6$ billion (1973 dollars) exclusive of rights-of-way will be required for bullding the eastward export transuission lines.

The transmission economics presented above check closely with those made for the North Central Power study to 1970. [5] That system (as shown in Figure 4.4.14) involves 14 lines in four corridors carrying 40,000 megawatts from Gillette, Wyoming to the Mid West consumIng centers. A capital cost of $\$ 5$ billion (1970 dollars) was estimated for construction finishing in 1975. Th1s was based on the use of $765 \mathrm{kV} \mathrm{AC}$ lines; twelve lines would be in use, with two for reliability redundancy. The average transmission length would be 700 miles, with the furthest distance from Gillette, Wyoming, to St. Louls, Missourl, an alrline distance of 815 miles, but a 1000 mile line distance. Such a system was designed to carry 40,000 megawatts, with 9000 MWe being delivered to St. Louls. The estimated time of construction was five years. In the present time of high interest rates, this, of course, is a very important cons sideration. Figure 4.4 .15 presents their estimated transmission unit costs based on varying amounts of electricity transmitted. This is important because it shows the advantages to be obtained in transmitting larger amounts of electricity through a few corridors. 

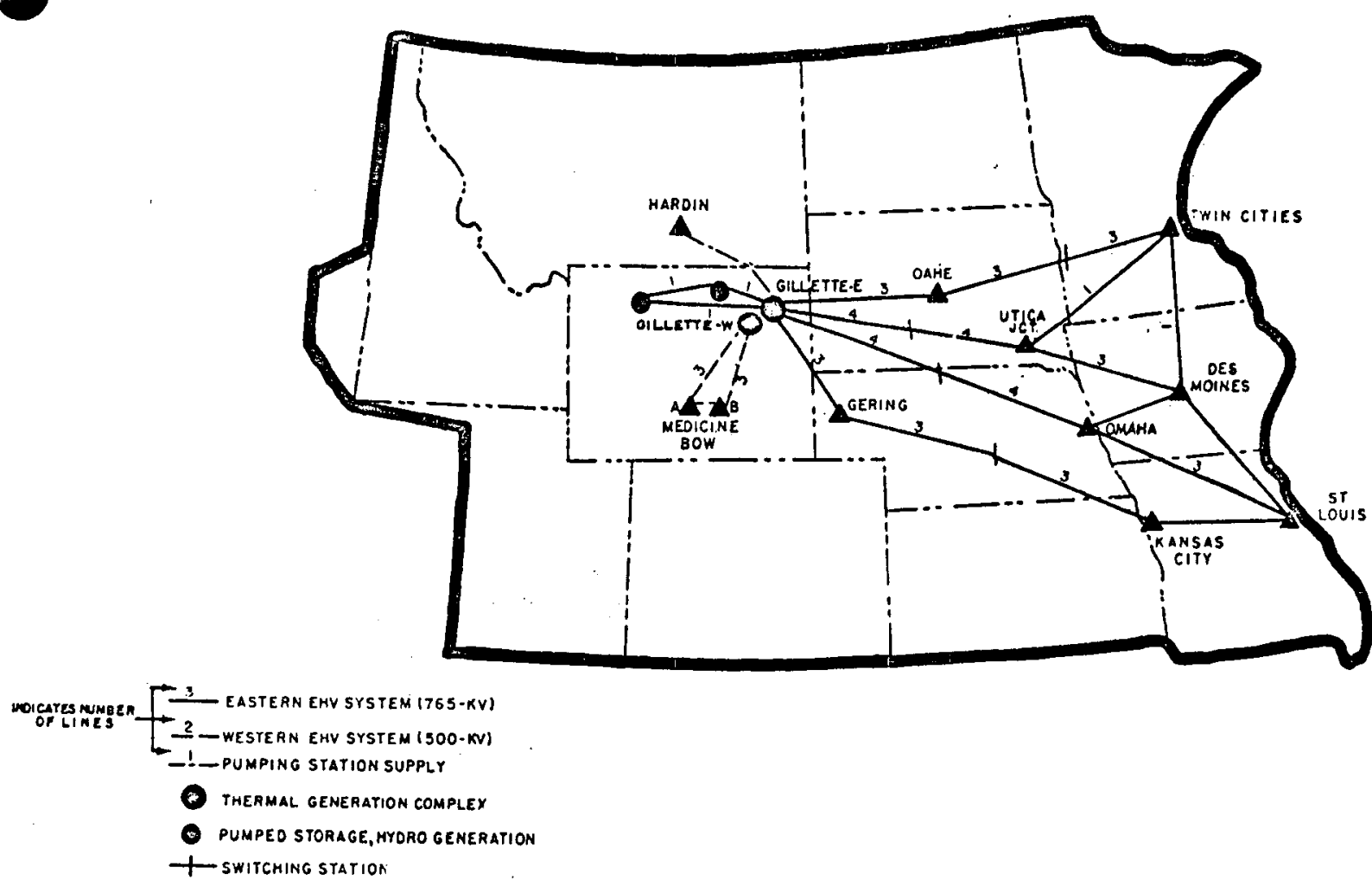

a switching and transformation substation

Figure 4.4.14 TRANSMISSION SYSTEM-ULTIMATE DEVELOPMENT DEVELOPMENT LEVEL - 10,000 MW WEST, 43,000 MW EAST

TERN SYSTEM

ESTIMATED TRANSMISSION COSTS

1975 PRICE LEVEL

(IN MILLIONS OF, DOLLARS)

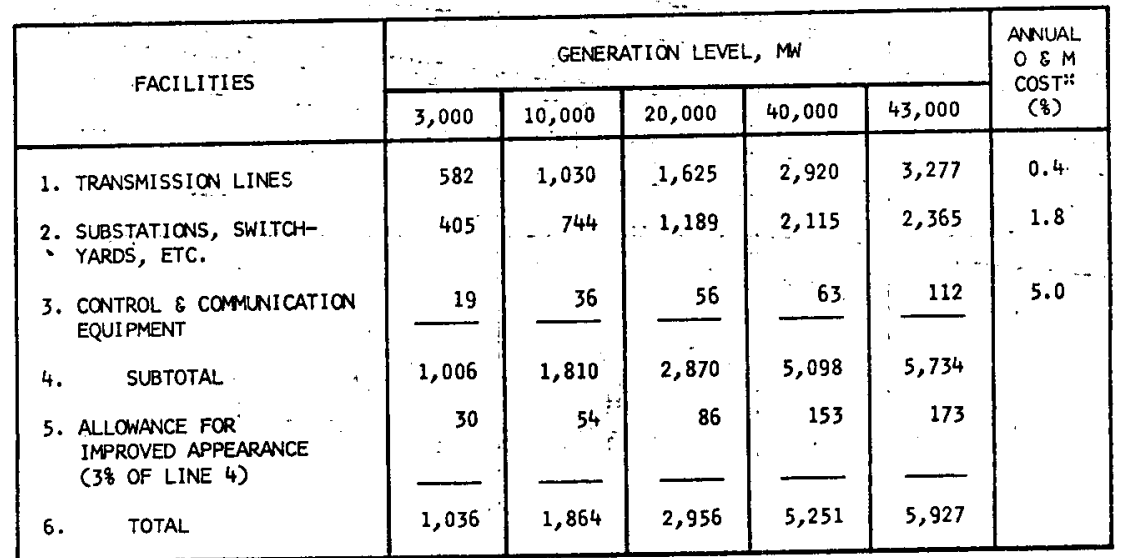

xPERCENTAGE OF TOTAL INVESTMENT

F1gure 4.4.15 
Figure 4.4.16 presents the North Central Power study operating cost estimate. The costs listed at Gillette are for the manufacturing costs at the plant, while the costs listed at the varfous consuming centers, for example, St. Louls, gives the combination of the plant manufacturing costs plus the transmission costs. Subtraction of one from the other shows that delivery of 9000 megawatts to St. Louis over about 1000 line miles was estimated at $3.5 \mathrm{mills}$ per kllowatt hour for a 14 percent annual fixed charge rate. (This is a normal charge for an investor-owned utility.)

Both the capital costs and operating costs estimates for the North Central Power study are very close to those calculated above for the transmission of geothermal energy in the new high, voltage DC lines. Therefore, they act as a good check on the estimates made in this study. The important conclusion to be reached from this discussion is that the long distance transmission of geothermal energy is economically competitive and will be so in the future development of power In the West and Mid West.

\section{Effects on Environment}

The environmental consequences of overhead lines fall largely in the domains of visual impact and land use conflicts. In part, transcontinental lines will run through some areas not usually accessed by the public, and obtaining environmentally acceptable rights-of-way for these segments may not be a serlous problem. The guidelines prepared by the Working Committee on Ut11ities, those accompanying FPC Order 414, and a 1970 report of the Departments of the Interfor and Agriculture on environmental criterla for transmission systems, show a sensitivity to the esthetic treatment of overhead transmission 1ines. Criteria particularly relevant to transcontinental lines include: [15]

1. Scenlc recreational, historic areas should be avolded where possible.

2. Heavily timbered areas, steep slopes, and proximity to main highways should be avoided. where possible.

3. Long views of transmission lines perpendicular to highways down canyons and valleys, or up ridges and hills are particularly undesirable. The line should approach and cross these areas diagonally.

4. Transmission facilities should be located with a background topography and natural cover where possible.

5. Where access roads are required they should be curved or run diagonally across the right-of-way to minimize their visual impact.

Compliance with these criteria in certain instances may be easier if existing rights-of-way are expanded or where joint use with another kind of facllity is possible. The Federal Power Commission urges such developments where they are feasible.

The effort to lessen the 1mpact on the landscape and open spaces and to minimize urban land requirements for transmission lines, will bring about joint use of air space and multi-purpose rights-of-way in the future. [16] For example, presently there are many miles of transmission lines along rallroad rights-ofway; these networks can be used more extensively in the future. This could lead to more railroad electrification which would be a highly destrable economic development.

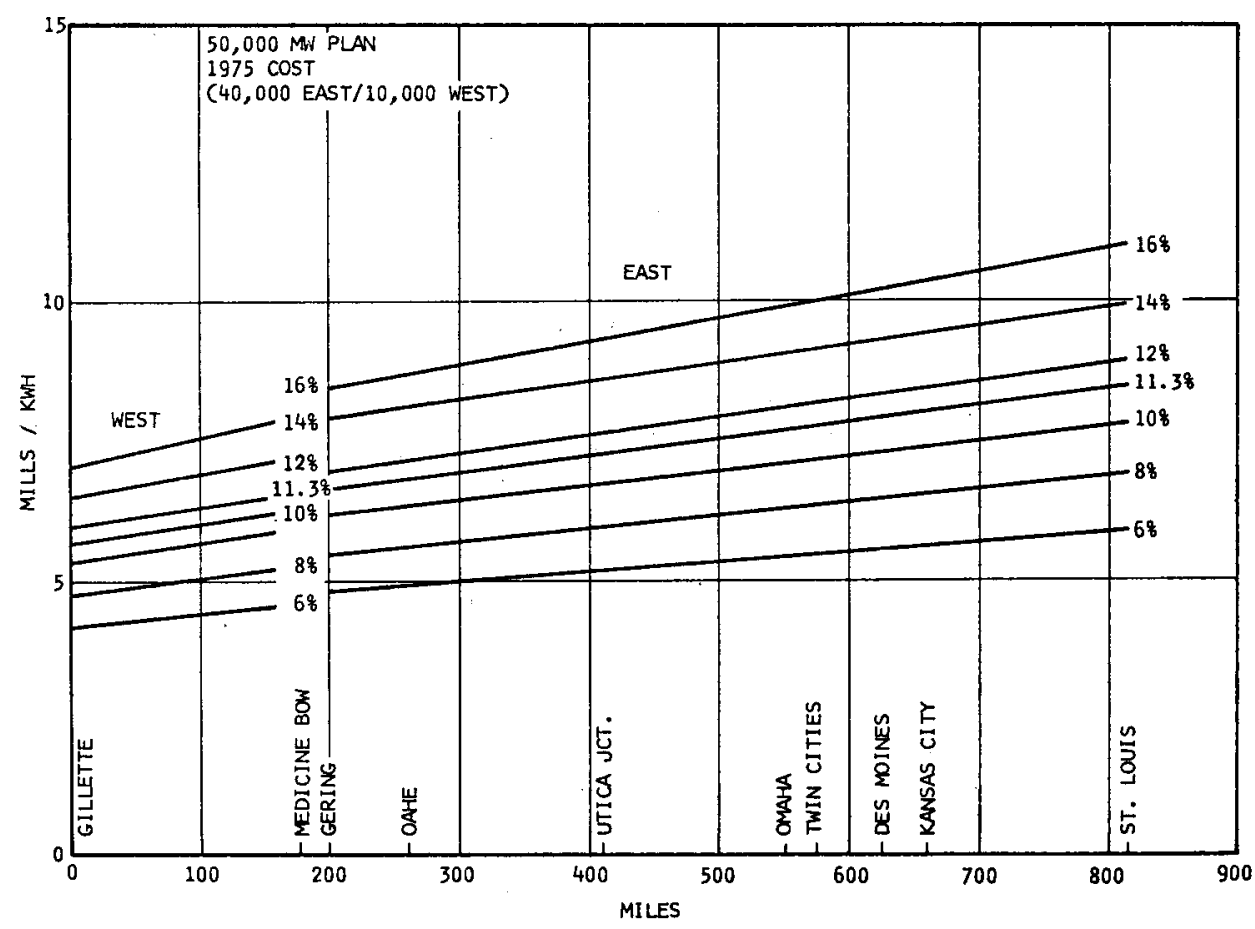

FIgure 4.4.16 TOTAL PARTICIPATION COSTS FOR VARIOUS FIXED CHARGE RATES 
' second dual purpose use would Involve the use of flood trol channels which are particular1y important in the est. Many flood control channels are artifictal concrete-1ined structures that lend themselves to joint usage for utility corridors. Jolnt use of air space, by bullding over flood control channels, should be used in the future, if possible.

A third dual usage method Involves highways and freeways. Experience has indicated that new. freeways of ten follow existing transmission lines rights-of-way without serious impalrment of environmental values. Government agencles and utilities in the future should consider the mutual benefits of foint use of such air space.

These varlous multi-purpose corridors are recelving serious consideration now and will most probably be developed in the future. For example, the North Central Power study advocated foint utilization of rights-ofway when desirable, but pointed out that the decision in this regard should be made at state and national levels. [5] One concept which they proposed would be to have corridors one mile apart, and also used for highways, railroads, overhead transmission lines, underground transmission lines, gas lines, oil lines, communication 1ines, water lines, parks, etc. Minor feeder corridors at shorter intervals could be used as needed.

The new and future designs of transmission lines are such that it is not necessary to fence the right-ofway. This means that the bulk of the right-of-way can remain in the common land-use pattern. . For example, some of these secondary use purposes can be cultivation of nursery stock, gardening, general agriculture, pasture, and various recreational purposes such as hiking trails, bicycle paths, snowmobile routes, parks, golf courses, equestrian trails, and so forth. [16]

The question of land requirements for a national transmission grid for geothermal energy can cause some anxiety. However, estimates of the land requirement may be obtained by looking at the two cases of coal mine power plant development. The southwest energy development in New Mexico-Arizona, Utah, Colorado, proposes the generation of 30,000 megawatts electric at several locations in these states and then transportation of the electricity to the major load centers as far away as Los Angeles. This will require a complete network of new transmission lines ranging from $230 \mathrm{kV}$ AC to $765 \mathrm{kV} \mathrm{AC}$ lines. The destgn study for this project indicates that some of these lines can be grouped in common transmission corridors. The total amount of corridor lengths required by 1990 for the completion of this project has been estimated at 3350 miles.

The North Central Power study is a more centralized system than the previous one. It generates 40,000 megawatts electric at Gillette, Wyoming, and then transmits it to mid-western consuming centers ranging from the Twin Cities to Kansas City and St. Louls. The 14 transmission lines are grouped into four corridors which have a total length of 2859 miles.

Averaging the results from these two examples, but giving slightly more welght to the Southwest Energy Study because $1 t$ would more closely resemble the geothermal situation, approximately 110 miles per 1000 MWe would be required for transmission corridors in a grid transporting geothermal energy east of the Rocky Mountains. Th1s uses technology which elther has been developed or will be developed in the next ten years. With the newer type of technology being developed and discussed in the previous section, this amount of land ill probably be decreased because each line will carry much heavier load.
Land usage for construction of the inverter-converter terminals will be of minor importance. One of the 1440 megawatt terminals, built in 1970 for the Pacific Intert1e, required 21 acres of land. [2] This included space for the service bullding, all of the electrical gear, service roads, and employee parking areas. Advanced technology 18 expected to reduce land requirements significantly. The first high voltade DC transmission line to be contracted for since the bullding of the Pacific Intertie will be constructed by General Electric Company for the Minnesota Power and Light Company. Th1s line, rated at 500 megawatts, will run a distance of 456 miles from a mine-mouth power project to Duluth, Minnesota. Unlike the Pacific Intertie terminals, which use mercury arc conversion equipment, this project will employ thyristor tubes and special solid state terminal circuitry. It 18 estimated that these terminals will require only one-third of the land needed for a comparable mercury arc installation. [9] For extremely high power densities, future term1nals may use gas insulated transformers in conjunction with cooling towers. Such advances in technology may reduce the acreage required by the electrical gear for a terminal to less than 1 acre per thousand megawatts. [9]

The mid-western and eastern terminals of intercont1nental transmission lines will probably be located near urban load centers; where the 1mpact of their size on existing land patterns will be important. Attention will have to be given to colors, structural design, and landscape in an attempt to provide minimum visual dissonance.

\section{Trend Analysis}

There are, of course, many assumptions and imponderables in the analyses fust presented. A more quantitive analytical method, Trend Impact Analysis (TIA), was used in this section to study the multi-effects of several future events on the transmittal of western geothermal electricity to the M1dwest and the East. (TIA is described in detall in Appendix F.) Figure 4.4.17 lists nine future events which will have an 1mportant influence on electricity transmission. These events were selected by the study team from a longer list derived from the interview sequences and many interviews with experts.

The resulting TIA curves are presented in Figure 4.4.18. Note that the curve marked history is the base case derived from the simulation model. The three curves labeled lower, center, and upper quartile, are the TIA curves predicting the combined effects of the impacts in Figure 4.4.17.

The net effect of these predicted future events wlll be a substantial increase in geothermal electricity exported to the Mid West. These curves are not meant to be actual forecasts but instead show the trend effects of the major events impacting on the baseline curve. The effect of the events would be $a \pm 4$ to 10 percent change In geothermal electricity tranamission starting In 1992.

These results show the powerful effects which may be obtained by government policies which would encourage these future events. 


\begin{tabular}{|c|c|c|c|c|c|c|c|c|}
\hline \multirow[b]{2}{*}{ POTENTIALLY IMPORTANT EVENTS } & \multicolumn{3}{|c|}{ PROBABILITY/YEAR } & \multicolumn{5}{|c|}{ I MPACT. } \\
\hline & 1980 & 1990 & 2000 & $\begin{array}{l}\text { VEARS TO } \\
\text { FIRST } \\
\text { IMPACT }\end{array}$ & $\begin{array}{l}\text { YEARS TO } \\
\text { MAXIMMM } \\
\text { IMPACT }\end{array}$ & $\begin{array}{l}\text { MAXIMUM } \\
\text { IMPACT }\end{array}$ & $\begin{array}{l}\text { YEARS TO } \\
\text { STEAOY } \\
\text { STATE } \\
\text { IMPACT }\end{array}$ & $\begin{array}{l}\text { STEAOY } \\
\text { STATE } \\
\text { IMPACT }\end{array}$ \\
\hline $\begin{array}{l}\text { Competition for capital hinders bullding of energy } \\
\text { facilities }\end{array}$ & .3 & .4 & .5 & 0 & 5 & -10 & 5 & -10 \\
\hline $\begin{array}{l}\text { Environmental pressures retard development of } \\
\text { transreglonal transmission lines. }\end{array}$ & .3 & .4 & $.5^{\prime}$ & 0 & 5 & -25 & 10 & -10 \\
\hline Low-1oss transmlasion technology is developed & 0 & .3 & .5 & 3 & 6 & +5 & 10 & +7 \\
\hline $\begin{array}{l}\text { Creation of a new transcontinental transmission utillty . } \\
\text { partially government owned. }\end{array}$ & 0 & .5 & .8 & 1 & 5 & +10 & 3 & +10 \\
\hline $\begin{array}{l}\text { F1rst operation of western mine mouth coal plants at } \\
5,000 \text { wWe. }\end{array}$ & .6 & .7 & .9 & 0 & 5 & +15 & 5 & +15 \\
\hline $\begin{array}{l}\text { Imported fuels heavily taxed by govemment and revanue } \\
\text { used to stimulace indigenous fuel development. }\end{array}$ & .4 & .8 & .8 & 1 & 3 & +10 & 5 & +15 \\
\hline Public acceptance of an energy conservation ethic. & .4 & .8 & .8 & 3 & 5 & -20 & 5 & -20 \\
\hline $\begin{array}{l}\text { National effort to develop an electriclty economy } \\
\text { based on U.S. fuels -uranfum, geothermal, solar, } \\
\text { coal, shaie, etc. }\end{array}$ & .4 & .8 & .8 & 5 & 10 & +15 & 10 & +15 \\
\hline $\begin{array}{l}\text { Mid-western agricuiture increase for world food } \\
\text { supply requires } 50 \% \text { wore electriclty input. }\end{array}$ & .7 & .9 & .9 & 1 & 5 & +5 & 10 & +5 \\
\hline
\end{tabular}

Figure 4.4.17 IMPACTS ON WESTERN GEOTHERMAL ELECTRICITY TRANSMITTED TO THE MID WEST AND EAST

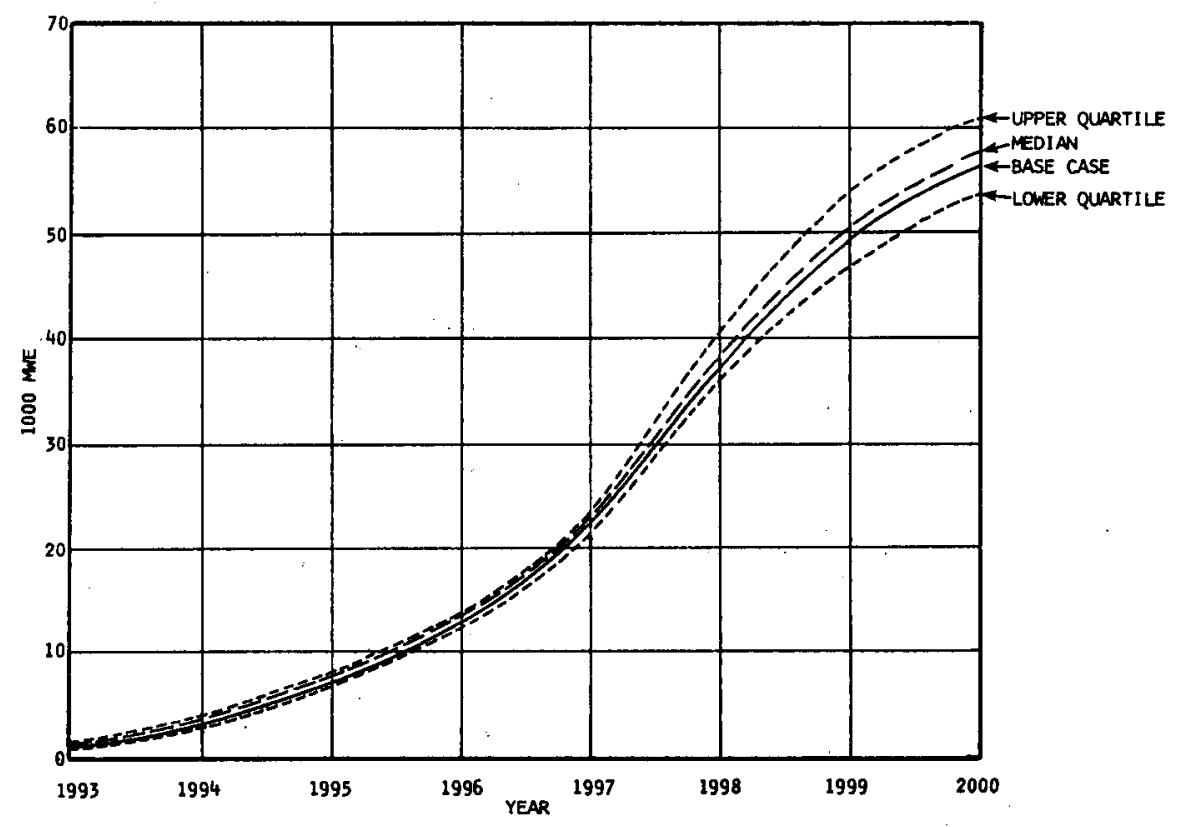

F1gure 4.4.18 CROSS COUNTRY ELECTRIC TRANSMISSION 
Review of Overall Adequacy and Reliability of the North American Bulk Power Systems (Third Annual Revision) (Princeton, N.J.: National Electric Reliability Council, 1973). See also 1970 National Power Survey, Part I, below.

[2] 1970 National Power Survey, Part I (Washington, D.C.: Federal Power Commission, 1971), pp. I-1314

[3] U.S. Department of the Interfor, Final Environmental Statement for the Geothermal Leasing Program, Vo1. I (Washington, D.C.: 1973).

[4] Mooz, W. E., and C. C. Mow, California's Electric Quandary: I Estimating Future Demands, R-1084-NSF/ CSRA (Santa Monica, Calif.: The Rand Corporation, September 1972).

[5] North Central Power Study: Report of Phase I, Vol. I, II (BIllings, Montana: U.S. Bureau of Reclamation, October 1971).

[6] Southwest Energy Study, draft (Washington, D.c. U.S. Department of the Interior, Apr11 1972).

[7] Bureau of Reclamation, Report of United States Delegation Visit to the Soviet Union, July 24August 6, 1972 (Washington, D.C.: U.S. Department of Interior, Electric Power Transmission and Power Generation Facilitles, U.S.-USSR Exchange Agreement).

[8] 1970 National Power Survey, Part. I (Washington, D.C.: Federal Power Comission 1971), pp. I-13-17.

[9] Brewer, G. D., "HVDC Transmission, An Overview of Solid State Technological Advances," Transmisston, Vol. 6 (February 1974), pp. 3-6.

[10] Maslan, F., and T. J. Gordon, "Geothermal Energy As a Resource in a Hydrogen Energy Economy," the Hydrogen Economy Miaml Energy Conference, University of Mami, March 18, 1974

[11] Gregory, D. P., "A Hydrogen-Energy Distribution System," summary, Project IU-4-6 for the Amertcan Gas Association (June 1972).

[12] Lotker, M., E. Fein, and F. J. Salzano, "The Hydrogen Economy-A Utllity Perspective," IEEE Power Engineering Society Winter Meeting, Jánụary 27,1974

[13] Linden, H. R., "SNG in the U.S. Energy Balance," Chilton's GAS Magazine (July 1973).

[14] Hotte1, H. C., and J. B. Howard, New Energy Technology--Some Facts and Assessments (Cambridge, Mass.: The MIT Press, 1971).

[15] 1970 National Power Survey, Part I (Washington, D.C.: Federal Power Commission, 1971), Pp. I-12-17.

[16] Western Systems Coordinating Counc11, Environmental Guidelines (December 3, 1971). 


\subsection{Regulatory and Institutional Impacts}

\section{Introduction}

A program designed to encourage the development of geothermal resources w111 require changes in existing regulations and institutions to meet the spectal requirements of the emerging geothermal industry. The issues which will drive these changes relate to the encouragement of exploration and development, assuring a market for the geothermal steam or hot water, and accomplishing the required research and development in a timely manner. More particularly, the issues include the need for:

1. Establishing an approprlate legal classification of geothermal resources.

2. Resolving uncertainties assoclated with avallabllity of government-owned lands for development.

3. Refining the regulations associated with land acquisition and tenure.

4. Mitigating environmental concerns and reducing complexity assoctated with the administration of environmental regulations.

5. Providing incentives which will encourage utility companies to utilize geothermal steam.

6. Diversification of utilities.

7. Transmission of geothermally derived electricity over long distances.

8. Assuring the availability of adequate capital.

9. New leglslation.

The Impacts flowing from the resolution of these issues are displayed in the top level of the relevance tree in FIgure 4.5.1; the detailed relevance tree is included in Appendix $D$.

\section{Legal Classification of Geothermal Resources}

Mineral Reservations. Federal and many state laws fa to specify whether geothermal resources should be classed as water, minerals, or something new in and of themselves (sui generis). By failing to define geothermal resources precisely, several significant uncertainties were created which will impede the development of the resource. Various homestead acts reserve mineral rights to the United States. The definition of the resource contained in current laws does not clarify the rights of landowners and the Unfted States in these cases.

Acquisition of Rights. The current broad definition of geothermal resources leaves open the possibility that these resources could be claimed under the provision of state laws which govern the acquisition of water rights on unreserved federal lands. While this approach is unlikely to be successful, ambiguitles should not be permitted to persist. The current federal law also excludes ofl, hydrocarbon gas, and helium from the definition of geothermal resources by-products; yet, in the case of geopressured resources, it is not uncommon to extract large quantities of dissolved natural gas with the geothermal fluids. The developer of geopressured zones may obtain a mineral lease as well as a geothermal lease. This complicates the development process. Without a clear definition of geothermal flulds vis-a-vis the mineral and water laws, complex regulatory and legal Issues seem certain to arise; the time required for the courts to resolve these issues will be long, and the effect will be to delay the development of the resource.

Tax Treatment. The taxation of geothermal resources is a problem which has not yet been resolved. Geothermal developers would like to obtain the favorable tax treatment both under federal and state law which is given to oll and gas developers. The depletion allowance and deductions which permit write-off of intangible costs associated with drilling and developing wells have not yet been applied to geothermal developers. In the single test case in California (U.S. vs. Reich) the geothermal resource was held to be depletable and, hence, the tax write-off was allowed; however, the Court of Appeals IImited the applicability of the case specifically to the facts of The Geysers area. Developers of geothermal resources in other areas are not certain at this time whether they may claim the depletion allowance and deduct their intangtble drilling expenses. There is 1ikely

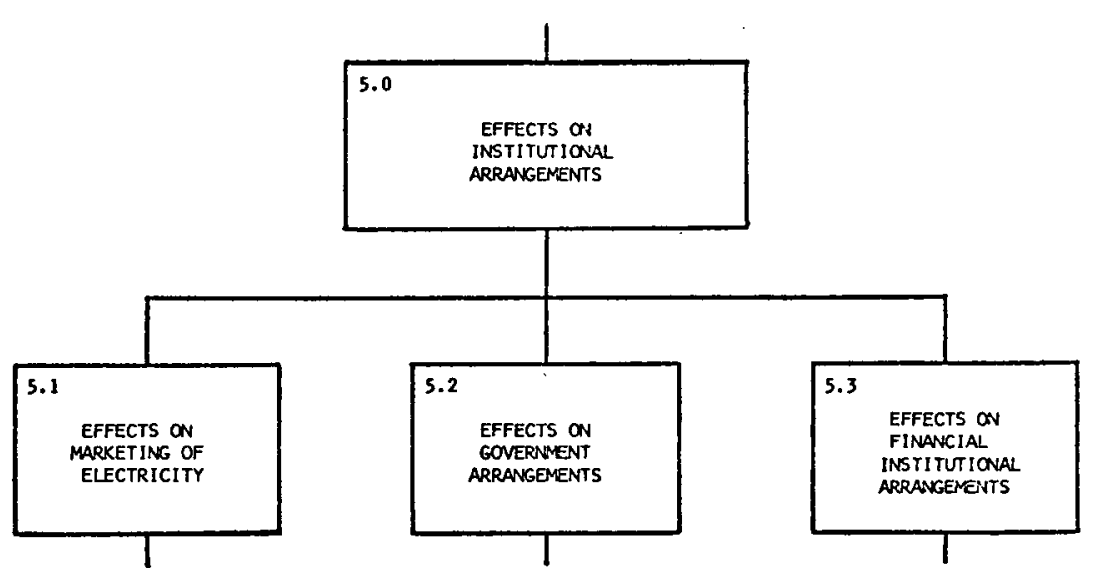

Figure 4.5.1 
to be considerably more litigation with respect to letion allowance and expense deduction. The probis not 1imited to the federal tax laws; there are state, business, income, and franchise taxes which also depend on the characterization of the resource as a gas. Federal legislation is required to define an appropriate method of taxation or subsidy; otherwise, uncertainty will prove inhtbiting.

\section{Specifying Use of Lands for Development}

Excluded Lands. The federal geothermal statute excludes large parts of the federal domain from geothermal development. While the intent is to protect the public domain from undue exploitation, it is not entirely clear that some of these areas, such as wildlife management areas, and various other kinds of open preserves, could not be made available for geothermal development wholly consistent with the purposes for which those lands are presently reserved or withdrawn. As additional information about the location of geothermal resources develops, attention should be given to the possibility of removing some of the statutory exclusions as to the areas available for geothermal development and determining whether or not the lease of these lands for development could not be put at the discretion of the Secretary of the Intertor.

Acreage Limitations. The present acreage limitations may prove an undue restriction to the development of geothermal resources. It is too early to tell whether the 1 imitations of slight1y more than 25,000 acres per lessee per state will be a substantial barrier. Careful attention should be paid as the resource is developed to the requirements for economically large developments. While this issue is politically sensitive, it appears that developers acting together cooperatively can control acreage which is substantially in excess of what an individual developer can control. For example, in one recent geothermal non-competitive lease application situation, numerous members of the same family applied for hundreds of thousands of acres of land. Careful study should continue as to whether or not these acreage limitations are realistic.

Administrative Discretion To Withdraw Lands from Geotherma1 Development. A point made repeatedly by geothermal industry representatives at congressional hearings was that the Secretary of the Interior and other agencies responsible for management of federal lands had virtually unrestricted discretion to withdraw lands from development for any purpose to protect some other function of the department or use of the lands. Depending upon how this discretion is exercised, its effect on geothermal development may be elther large or insignificant. However, it would appear as a matter of principle that when lands are classified as KGRA' $s$ or noted by the USGS as potentially valuable for geothermal development, there should be some 11mitation upon the discretion of the Secretary of the Interfor to remove these lands from further development. At a minimum some procedure should be avallable for public notice and hearing so that interested spokesmen can appear and express their support or opposition for the Secretary of the Interfor's dectsion.

Multiple Uses of Public Lands. Present federal land use pollcy is governed by the multiple-use principle; that is, a series of uses should be permitted upon a single tract of public land if the land is suitable for those uses. While this is a desirable princtple generally, in specific instances geothermal development may be curtailed because of the requirement of accomodating other uses of the public domain. While ( it is not proposed that geothermal development be given priority over other uses of land, some reconsideration should be made of relative priority in light of the current long-term energy shortage which this country is facing, and that some system of priority for energy development should be considered as an integral part of multiple land use policy.

\section{Land Acquisition and Tenure}

Exploration Rights. The federal law, unlike state laws, does not provide for protection of the discovery of geothermal resources by prospectors or explorers. The prospector receives no preferential treatment for his discovery. If he makes a discovery on non-KGRA land, in theory he can apply for a non-competitive lease of the lands. However, if another interested party files a lease application with respect to those lands within the appropriate filing period, the Secretary of the Interfor may determine (and, in fact, his regulations and policy statements indicate that he will determine) that a competitive interest is found to exist. Upon a finding of a competitive interest, the land would be reclassified from non-KGRA to KGRA land, thereby depriving the prospector of right to lease the land non-competitively and throwing the lands open for the normal competitive bidding process. This policy of pushing all bidding toward competitive bidding and not protecting exploration rights is 1ikely to have a negative effect on prospecting.

Bonus Bidding. Compounding the problem for the small developer or prospector is the bonus bidding system. This system requires that a lease be given to the highest responsible bonus bidder, that is, the person who bids the largest cash bounty for the right to lease the property. The requirement that this money be put up in advance of development tends to inhibit the participation of small firms because they may not have the cash to compete with large firms in the bonus bidding process. Furthermore, even if small firms attempt to compete actively in the bonus bidding process, they may find their capital depleted by the requirement of paying to the government large sums of money in advance which would otherwise be devoted to the development process. While the intent of the bonus bidding system--to produce the largest cash revenue immediately for the federal government--is laudable, it may in the long run discourage development and perhaps produce less net revenue for the government than a non-bonus bidding system tied to higher royalties. The early bldding on California geothermal leases (January 1974) indicates that the large energy firms have dominated the bonus bidding process.

Public vs. Private Development. The federal government must consider whether there are to be different policles regarding the development of publicly owned resources by private or public organizations. The issue has been enjolned by the American Public Power Association commenting on the Department of the Interior's Geothermal Leasing Program: "APPA is concerned that the Department of the Interior's proposed leasing regulations do not provide safeguards to prevent monopolistic control of publicly owned geothermal resources. Specifically, there are not adequate provisions to assure that publicly owned electric utilities, most of which are small, or other competitors in the energy market are able to get access to geothermal resources on fair non-discriminatory term. [1]'

APPA has requested that the regulations recognize the public interest intent of the Geothermal Act by stating that the federal antitrust policles will apply in weighing bids for geothermal resources. The organization has observed that for decades the Department of the Interior 
has been administering power marketing programs which require preference in the sale of energy from federal projects be given to public agencies such as publicly owned electric utilities.

Lease Terms. There was considerable discontent expressed at congressional hearings about the relatively short Initial lease terms provided by federal law. The time period specified was considered to be too short to permit development of the properties. On the other hand, the relatively rigorous development requirements were intended to ensure that the land was put into.production and not held back for speculation. It is too early to tell whether the primary lease term is too short. However, some states have adopted considerably longer initial lease terms and therefore consideration to revising the term should be given after careful study of the actual performance of the present leasing system.

Renegotiation Rights. The Secretary of the Interior is given certain rights to renegotiate both lease terms and conditions as we 11 as rents and royalties. There is a possibility that the renegotiation process could be used to remove certain geothermal lessees with whom the Secretary of the Interior has various agreements. The statute seems to indicate that failure to arrive at a suitable renegotiated lease will result in termination of the existing lease. While it is not anticipated that the Secretary of the Interior will be permitted by the courts to act in an arbitrary or capriclous manner, the fact that there is a possibility of dispute and termination in the negotiation process may inhibit persons from investing substantial amounts of capital in what turns out to be a risky venture largely beyond the control of the private developer.

\section{Administration of Environmental Regulations}

Trade-0ffs with Development. As noted in Section 4.8, environmental impacts associated with geothermal development can be divided into two categories: those whIch have important local but temporary significance (e.g., emission of odorous gases, notse, and so on) and those which have potentially lasting significance (e.g., contamination of groundwater supplies, selsmicity, and subsidence). Clearly, some of these Impacts must be prevented and the regulatory process must Identify them a priorl; other 1mpacts, while temporarily disturbing, could be permitted if the need to develop this new energy resource is seen as pressing. In the case of temporary impacts, controlling mechanisms could range from Indemification by government for damages caused by geothermal exploration and development (If such activities are viewed as high priority) to self-insurance by the geothermal operators.

The recent congressional action with respect to the Alaska pipeline and strip mining indicates that there has been reassessment of trade-offs between environmental protection and energy requirements. As geothermal development proceeds, environmental protection requirements should be reviewed to forge the most appropriate relationship between geothermal energy development and environmental protection. This relationship must be sensitive to the following factors: the type of geothermal resource; local conditions, needs, and desires; permanence of the Impacts; need and method for indemification; and national energy situation.

Administrative Complexity. There are three distinct areas in which regulation seems to be required: land use; environmental affairs; and the production and development of the geothermal resource itself: As described in Sections 2.4 and 3.3 , the admintstrative process is extremely complex. One reason for this complexity is that each agency involved views the world from the perspective of its own charter and, despite the fact that the regulatory areas overlap and interact, compromise and accommodation are difficult. One approach to the streamlining of the administrative process would be to initlate "one-stop" geothermal licensing. This may be possible only in the long run. In the shorter run, efforts must be made to coordinate the various regulatory responsibilities both at the state and federal level to ensure that the important values embodied in the regulatory process are preserved and to reduce the burden on the geothermal developer to obtain the approvals necessary to initiate and develop projects.

\section{Incentives for Utility Companies To Buy Steam}

Geothermal energy will become an important source of energy in the United States if the utility companies buy it. Therefore, the interface between geothermal development and utility company use is probably the key area for the construction of incentives.

The economic risk involved in exploration and development of geothermal fields will probably limit direct investment by investor owned utilities. They may be expected to purchase steam from geothermal developers for use in generating plants located near the producing fields. To encourage purchase of the resource, the developers will probably be required to guarantee the longevity of the steam supply for a period comparable to the write-off time for the generating plant, normally 30 years. In this way, the utility is protected against the high risk involved in resource development (the early demise of the field), and can maintain its favorable position as an economically conservative industry with a regard to needed capital investment.

Municipally owned utilities, on the other hand, may have greater fiscal flexibility than either investor owned utilities or cooperatives. The municipality may be able to provide capital for geothermal ventures without serlous effects on its bond rating.

A particularly powerful Incentive will be to provide government "resource insurance," that is, insurance against the risk of early depletion. This would permit the resource developer to offer 30 years worth of steam, or its fiscal equivalent, to his only potential customer, the utilities. Leglslation has already been passed by the U.S. Senate to guarantee loans made to geothermal developers (The National Energy Research and Development Pollcy Act of 1973, S. 1283, would allow the Secretary of the Interior to guarantee loans for profects up to $\$ 25$ million). By coupling such a loan program to some kind of private insurance against early depletion of the resource, both exploration and sale would be encouraged. One without the other is vacuous.

\section{Diversification of Utilities}

While most geothermal exploration and development will probably be Initiated by organizations other than utilities, this will not be true in all instances. Furthermore, the case is certain to arise in which a geothermal developer wishes to ut1lize the resource for the generation of electricity rather than for selling steam. These situations create Important Impacts. 
Under current SEC regulations, a ut1lity holding comiy would probably not be permitted to develop geoermal resources for sale to others. Utillties which are not classed as holding companies might not be so constrained. Nevertheless, it is not yet clear how the various state public utility comissions would treat geothermal investments made by utility companies

The situation would become even more complex if the geothermal resources were used for purposes other than providing energy for the generation of electricity; e.g., water for agriculture, heat for space heating and air conditioning, and the production of chemical and minerals from geothermal brines.

\section{Transmission of Geothermally Derived Electricity}

In order to meet 1 ts load commitments satisfactorlly, a utility system must have a high degree of rellability. System rellabllity is achleved not only by using components of high rellability but also by providing for interchanges between adjoining systems in the case of an emergency. Because geothermal resources may be located outside a major utility's own area and at a large distance from any existing load center, electricity may be transported by transmission lines jointly owned by several utilities taking advantage of a geothermal site. Thus, an outcome of geothermal development could be the bullding of transmission lines which increase system interconnections.

Joint ownership of transmission lines may follow the patterns set by the Pacific Intertle. As described in Section 4.4 this DC IIne is owned by a group of pub11cly and privately owned utilities, including Southern California Edison Company and the muntcipality of Los Angeles. Electricity is generated at the federal Bonneville hydroelectric project in Oregon and Washington. Much of this line, over 800 miles long, is on federal land. The line 1tself was built by the Los Angeles Department of Water and Power up to the Californla-Nevada-Oregon borders; the rest of the line to the Bonneville power project was built by the federal government. While contractual agreements among the particlpating utilities are complex, the benefits of foint ownership do result in the economtc explot tation of Bonneville power as far as Los Angeles, Calif.

The possiblitty of moving large amounts of power over dedicated transcontinental lines was discussed in detail in Section 4.4

Because of the amount of capital required, the land use problems involved, and the complex utility and regulatory interface issues, a new institution w111 probably be required to do this. There are several alternative degigns for this ingtitution:

1. Cooperative arrangements among utilities along the route, extending by a considerable degree regional power distribution pools which currently extst in many parts of the country.

2. A federal agency such as the Bonneville Power Administration.

3. A single private venture, viewing itself as an energy transportation company, in a manner analogous to a gas pipeline company.

4. A quas1 pub11c organtzation modeled after the Comunications Satellite Corporation. of or merge with the organizations which w111 transport energy from mine-mouth coal-fired generating plants now starting to be built in the West (Wyoming, Montana, and New Mexico) for power transmission to the Mid-West and the Pacific coast.

By the time dedicated transcontinental 1 ines are in place, it is expected that the interconnected grid between regions of the country will be sufficlently developed to provide necessary system redundancy. The superimposition of transcontinental ilnes dedicated to "wheeling" large amounts of power from west to east w1ll require careful coordination between the transcontinental lines and the lower voltage interconnected grid. The national transmission agency may have to take on some responsibility for "dlopatching." Th1s means closer tying together of all of the utilities in the country and should result in increased benefits in terms of system rellability and load balance.

Assuring Avallability of Capital [2]

Figure 4.5 .2 is a schemat1c of the possible monetary flow for geothermal resource development for the production of electricity. The activity of the federal government in terms of R\&D and loan guarantees can be regarded as an investment to be returned to the taxpayting consumer in the form of the benefits of geothermal power.

The rate of monetary flow will be modulated by the connections shown by dashed lines in Figure 4.5.2. That is, these activities act as values in controlilng the monetary flow. While the confidence level in geothermal resources will increase with government geothermal R\&D efforts and thus have 1mpact on the rate of capital flowing into geothermal investments, the primary stimulant to this flow can be expected to be government guarantees for loans. These guarantees may be made to banks or other financlal institutions who lend money for development of geothermal resources. Currently proposed legislation (e.g., The National Energy Regearch \& Development Pollcy Act of 1973) states, that such guarantees may be made "against $108 s$ of princlpal or interest on loans made... to qualifled borrowers for the purpose of acquirIng rights in geothermal resources and performing explorat Ion, development, and construction and operation of factifties for the commerclal production of energy from geothermal resources."

Capital. Inflow will be stimulated by increasing confidence in the viab111ty of developed geothermal resources, and to this end federal government R\&D can be expected to contribute heavily, particularly in the areas of resource exploration, assessment of fleld longevity and productivity, and power demonstration. Two pleces of legtalation discussed more fully under New Leglolation could accomplish these government contributions.

The competitive position of geothermal energy vis-a-via foseil fuels and nuclear power could be further influenced by several federal mechanisms if additional legislation were proposed and passed. These influencIng mechantsms could include federal subsidles, similar to agriculture subsidies, and federsily underwritten resource insurance. Th1s latter w11l allow developers to guarantee steam production or monetary equivalent over the lifetime of the power plant to utilities who Invest in generating and transmltting facilities at geothermal fields, and could provide the needed assurances for capital investments.

Another Influencing mechaniom could be the application of a salutary income tax depletion allowance and an annual deduction of current drilling costs. These have 


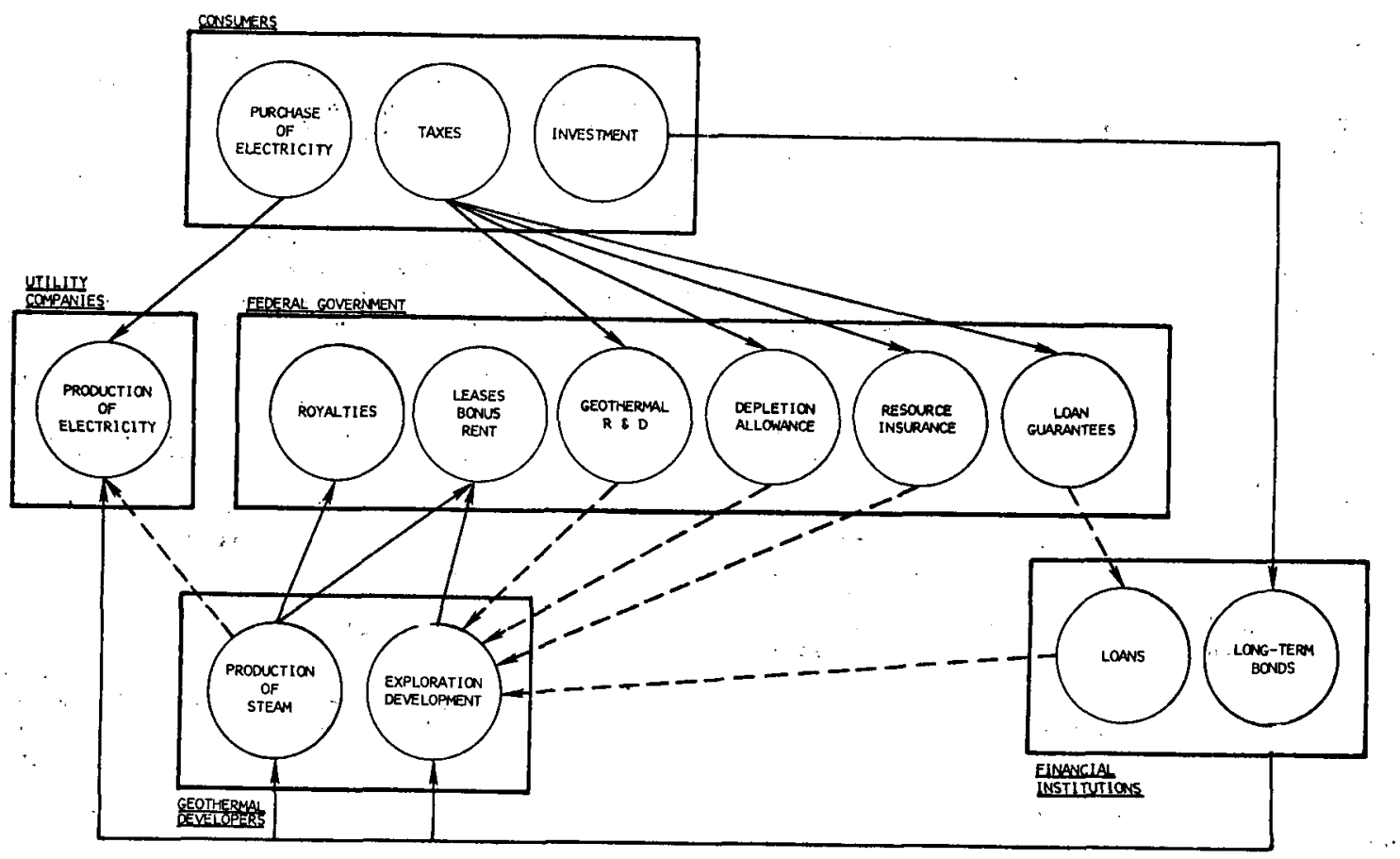

NOTE: DASHED LINES INDICATE FACTORS WICH MOQULATE MONETARY FLOW.

F1gure 4.5.2 FINANCIAL FLOW

been discussed earller, especially in: Section 2.5 under U.S. v8. Refch; The Geysers test case: It seems that until the geothermal industry enjoys these advantages, capital flow will be unable to become well establighed.

Th1s is one role which the federal government could play in the early years in the development of geothermal resources which is not indicated in Figure 4.5.2. In order to encourage the substitution of geothermal energy for fossil fuels in the production of electricity, the government could Indemify utillties for certain losses Incurred when plans for fossil plants have to be aborted. Because of the long leadtime necessary in the rate of development of geothermal resources, some utilities may not be in position to switch to geothermal energy without incurring losses in the preconstruction phase of the planning for new fossil fuel generating plants. Where it is In the public interest (in terms of environmental Impacts, for example) the federal government could reimburse the utility for such losses. To encourage phasing out of older fossil plants, rapld depreciation write-off may also be allowed. Of course, such relmbursements would require the recipient to reinvest in geothermal development.

Ventures in which utilitles foin with either ofl companies and/or drilling companies can be expected to become a popular vehicle for ralsing necessary cap1tal. These joint ventures represent the complementary interests of utilities and resource developers. In such arrangements, the participation of a regulated monopoly may provide the confidence needed to encourage investments in resource exploration. The rise of foint ventures on a large scale may require new tax and regulatory procedures, so that advantage can be taken of both utflity-type financing and of federal subsidies for exploitation of geothermal resources.

\section{New Leg1slation [2]}

Congress has been working on several pleces of legislation in 1973 and 1974. The major b111 is Energy Research and Development Administration (ERDA, formerly S.2744) now labelied HRI1510; ERDA is a compromfse b111 from both Houses in its final stages of preparation. Its purpose is to ensure that all energy technologies recelve falr consideration for national priorities and to expedite the United States' program of energy selfsufficlency in ten years. ERDA establishes an interagency coordinating committee.

Specific to geothermal energy, ERDA transfers geothermal administration from NSF to the ERDA committee. A related b111, S.1283, :mentioned ear1ler, contains geothermal loan guarantees and provides an incentive for accelerating geothermal exploration. S1283 may efther become an amendment to ERDA or be passed as a separate b111.

It seems almost certaln in the 11ght of U.S. energy needs that coordination of geothermal $R \& D$ must be handled by an objective agency such as the one established by ERDA. Geothermal R\&D planning is current1y being conducted by a federal interagency panel for geothermal energy research consisting of the National Sclence Foundation, the Atomic Energy Commission, the Department of the Interfor, and the Department of Defense. As the geothermal program develops, these groups may have divergent and conflicting interest. If the legislation mentioned above is passed, this committee will be replaced by the ERDA committee.

An interesting point here is that while some legislation has been Introduced by congressmen from states with RGRA's (Washington, Sen. Henry Jackson), other legislation has been Introduced by those with no.RGRA's 
(Connecticut, Ribicoff). The introduction in the " at two years of at least four bills that affect thermal energy is indication of Congress' concern development of geothermal energy as well as other included novel energy sources.

\section{REFERENCES}

[1] Final Environmental Statement for Geothermal Leasing Program, Vo1. 4 (Washington, D.C.: U.S. Department of the Interior, 1973), p I. 134 .

[2] See pp. 25 and 71 for a discussion of the recently enacted Geothermal Energy Research, Development and Demonstration Act of 1974 (P.L. 93-410, Appendix J) which Eandates coordination of geothermal $R \& D$ and authorizes a loan guarantee and interest assistance program.

The following reference, not numbered in the text, was used as background for this section.

Final Environmental Statement for Geothermal Leasing Program, Vo1. 4 (Washington, D.C.: U.S. Department of the Interior, 1973), p: CD-45. 
4.6 Effects on Regions, Cities and Buildings

\section{Introduction}

When geothermal energy is used to produce electricity, its special effects on reglons, cities, and buildings is slight; when it is used directly as a source of heat, it can affect reglons, cities and dwellings in several ways. The top two levels of the relevance tree which structures and displays the various primary and secondary impacts are presented in Figures 4.6.1 through 4.6.5 shown on the following page.

In order to set the stage for this review of Impacts, It is useful to list some of the characteristics of geothermal energy which will largely determine its effect on urban areas and bulldings:

1. The basic resource is not exportable as such; its utility diminishes rapidly as the attempt is made to convey the heat more than 10-20 miles from the point of extraction. This, naturally enough, leads to the construction of heat-utilizing facilities, be they electrical generating plants, hot houses, industrial plants, swiming pools, or district heating services, near the geothermal wells.

2. The geothermal resources are found in widely differing physical elrcumstances-in relatively close proximity to existing communttles and developed regions and, at the other extreme, in utterly wild and desolated land. It occurs in undulating, foothill country, in flat basins and valleys, in proximity to deserts, and in heavily forested areas. The terrain variations in themselves create conditions which will affect the development and utilization of the geothermal resource. In turn, the variations in setting will impact upon the way in which the resource is used, both locally and regionally.

3. In Investigating the impacts of geothermal energy on regions and bulldings, it would be well to remember that the longevity of each field is not yet well known, nor can 1 yet be estimated a prior1. Compared to the lifespan of human settlements, greater than 100 years, the duration of a field might be short, less than 100 years. If a settlement is designed to rely on geothermal energy, and that source "dries up", then a back-up, perhaps a redundant source of energy, will be required.

4. Geothermal energy is of relatively small scale, at least in electrical generation terms. It appears that electrical generation will be accomplished through the use of a large number of approximately 100-200 megawatt generating stations scattered throughout a geothermal region; compare this to the 1100 megawatt steam and nuclear plants currently in vogue. Each well field and generating station will be, in comparative terms, relatively small in scale, both physically and as to direct spaclal impact. This relates to cooling towers, the generating stations and wellheads themselves, collection piping, and a11 other dependent features.

5. While the scale of physical installations assoclated with geothermal energy is small, the amount of land used 1 s by no means negligible. If one assumes that 1000 acres is required to support a $100 \mathrm{MWe}$ plant, and that 190,000 MWe are developed by the year 2000 , some $1,900,000$ acres would be devoted to geothermal purposes.
This is about 2700 square miles, or roughly the area of the State of Delaware. While this nuts ber seems large, only about 10 percent of the land is physically disturbed by the installation for geothermal extraction and electrical generation, Including rights of way for access roads and transmission lines within the leased site.

6. Some of the physical environmental impacts discussed in Section 4.8 will determine, to a large extent, the impacts of geothermal energy on communities and bulldings. For example, patterns of use of geothermal energy w111 be determined to some extent by the malodorous odor of hydrogen sulfide emitted during the exploratory and operational phases of geothermal energy; the physical hazards associated with exploration, and the sonic effects of geothermal development. Physical hazard will be limited to the immedlate environs of the exploratory sites, permanent well points, steam or hot water 1 ines, and generating stations; the noise pollution effects can be considered important within the boundarles of a single well field tract and may be disturbing within one half mile of the periphery of the active wells and generating facilities.

7. The impact of transmission lines upon geothermal reglons must be considered. The amount of land visually affected by transmission lines may be greater, perhaps by as much as an order of magnitude, than the total area dedicated to the use of transmission lines. Geothermal phenomena of ten tend to occur in areas of scentc diversity and even though the use of hot springs as medicinal facilities and health spas is now out of fashion, the continued use of such resources for tourism and recreation clearly must be taken into account. The early spas have tended to establish recreational tourist zones around them in areas of hot springs, as, for example, at Clear Lake, Hot Springs, White Sulphur Springs, etc. Another factor which should be taken into account relative to high lines is that in all likelihood they will not only go from generating station to the nearest point of load, but will tend to develop an interconnected grid from each generating station into its sister installations throughout the geothermal regions. Therefore, each generation station might have emanating from it not one, but perhaps as many as three or four transmisston lines for interconnecting to other geothermal stations and to the general reglonal power grid, thus proliferating the amount of land visually affected by geothermal activity.

It should be noted also that geothermal resources of ten occur in areas which are water deficient, both with respect to present and future water resource needs. The dividing line between water surplus and water deficiency areas In the United States roughly bisects the Great Plains, with the entire western half of the country, with local exceptions, being in a water-scarce condition. In terms of development of geothermal resources themselves and of competing energy and general water requirements, the water deficiency condition is a very strong factor in determining the energy outcome and general outcome, in public policy terms, of geothermal exploitation.

Before providing more precise impacts on cities and bulldings, it will be useful to review the experience of three geothermally active cities: ReykJavik, Iceland; Klamath Falls, Oregon; and Rotorua, New Zealand. All three clties use geothermal energy directly as a source 


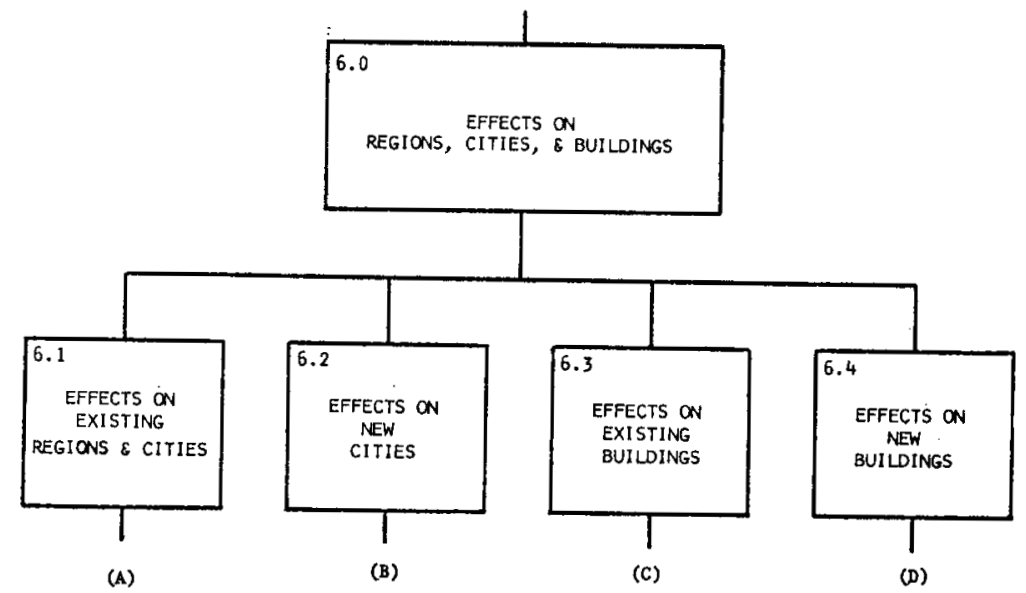

Figure 4.6.1

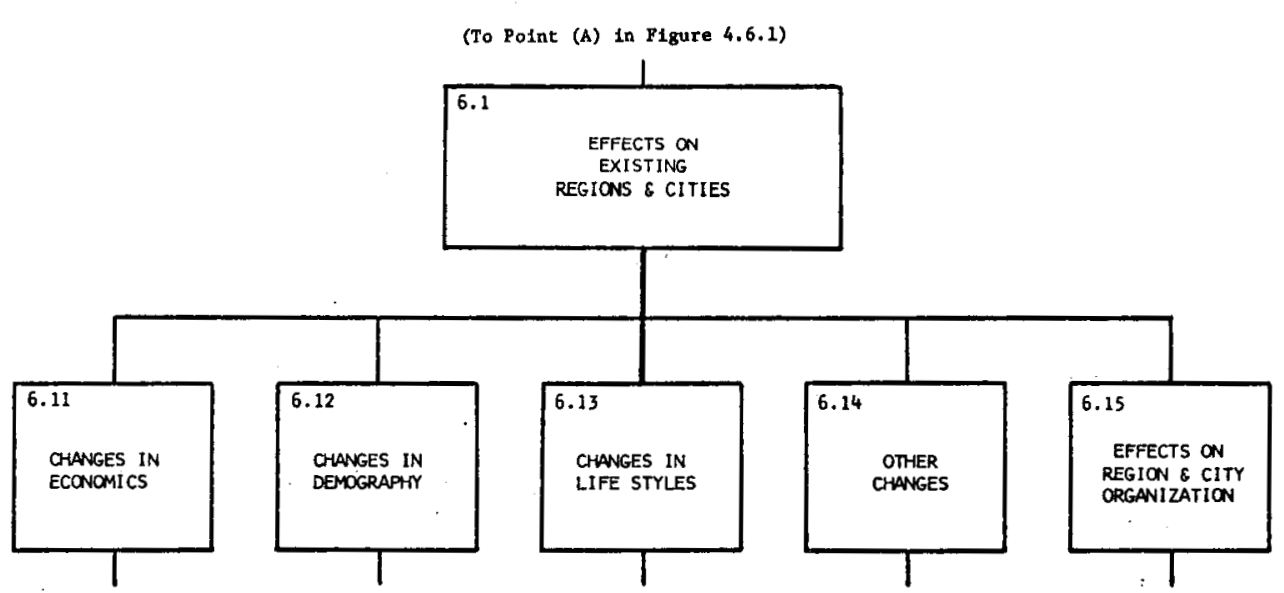

FIgure 4.6 .2 


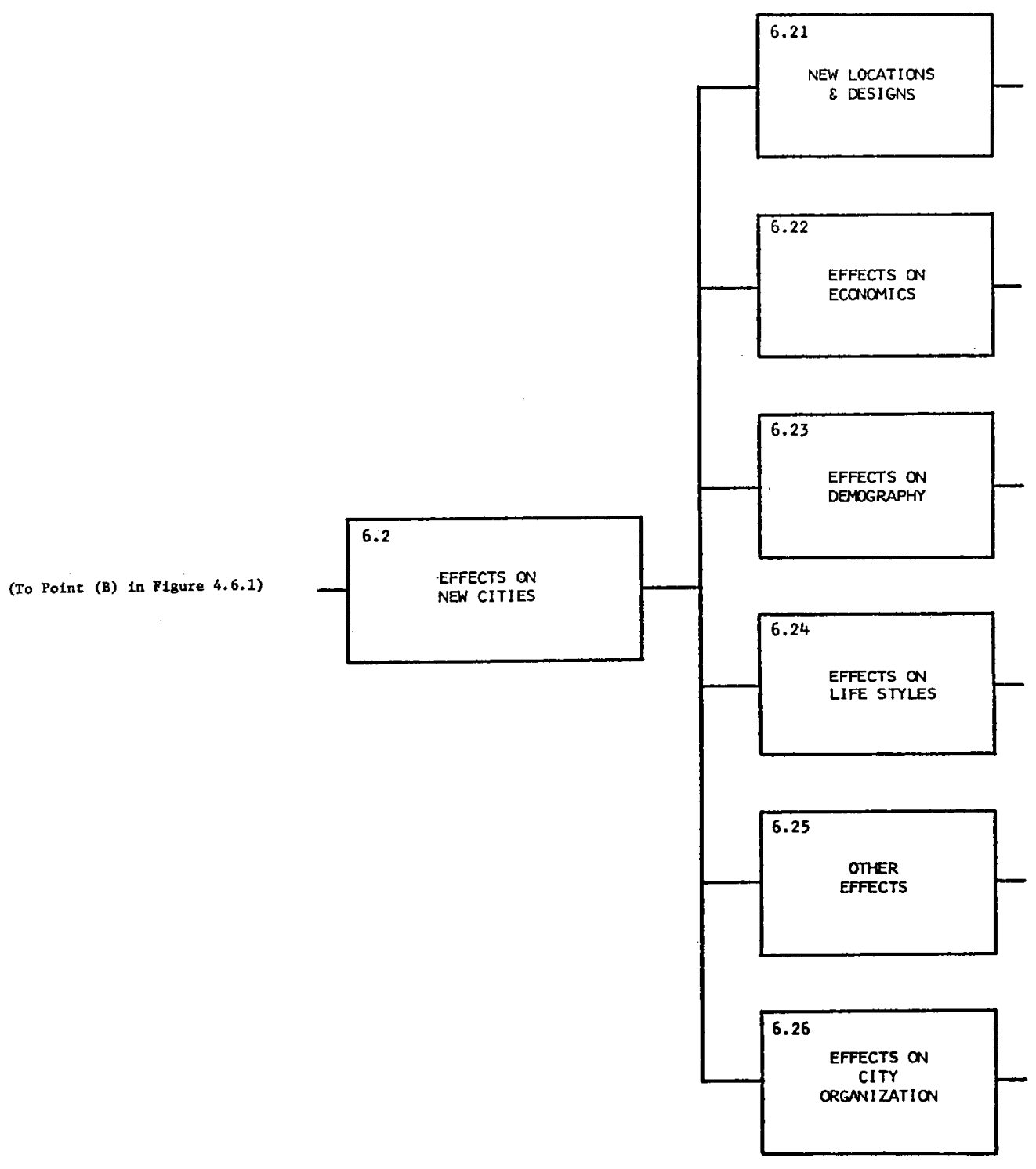

F1gure 4.6.3

of heat. These case studies are presented below.

\section{Reykjavik, Iceland}

The brochure distributed by Reykjavik to describe its use of geothermal energy begins:

When a visitor approaches Reykjavik on a bright, st111 winter day, by ship or by alrplane, he will first of all notice the absence of smoke rising from its chimeys. The dark cloud he $1 \mathrm{~s}$ accustomed to see hanging over citles is nowhere to be seen, the air is fresh and clear... The wholesome air is due to the geothermal resources hidden under the city and its vicinity, and the inftiative of its citizens in utilizing $1 t$.

Reykfavik has not always been a smokeless city. Those who remember Reykjavik in the $30^{\prime} \mathrm{s}$ and $40^{\prime} \mathrm{s}$ recall, that sometimes on still days in winter, the cloud of smoke over the city was so black that the town was hardly visible. But under this depressing cloud, people were planning the utilization of the heat they knew to be under the clty.

Iceland is Indeed an Ideal place for this development. The climate requires that houses be heated 90 percent of the time. Except for peat and 1ignite, no fossil fuel sources are Indigenous to the country. The Atlantic rift fortunately runs through Iceland and is manifested by many hot springs and geothermal steam fields.

Exploitation of the geothermal resource near Reykjavik began in the mid-1920's when hot spring water was used to heat hothouses for the growing of vegetables. [1] A
hot spring commonly used by Reykjavik 1nhabitants for washing clothes was tapped in 1928 and soon thereafter 
(To Point (c) in Figure 4.6.1)

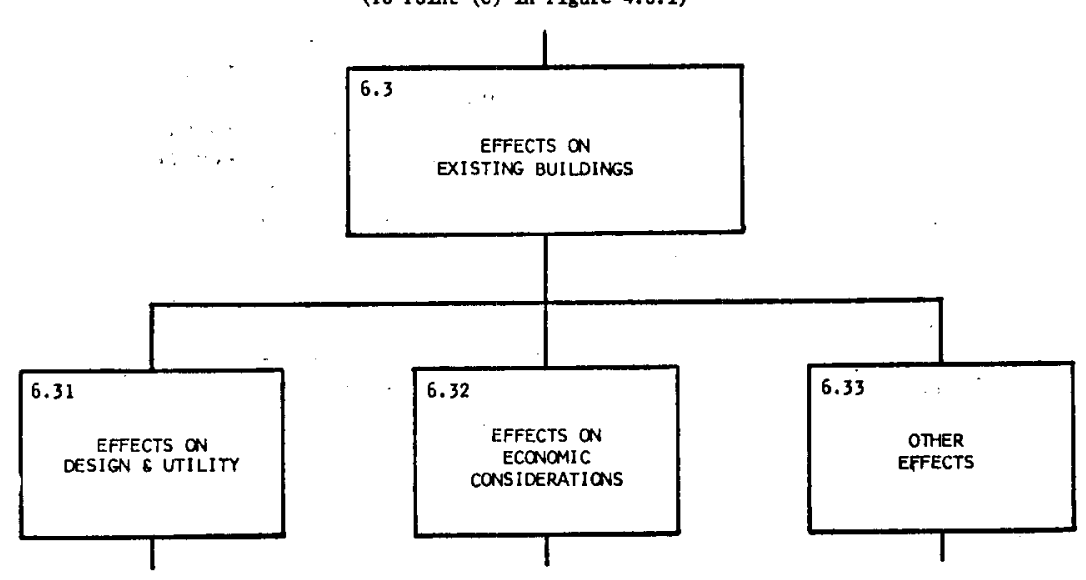

Figure 4.6 .4

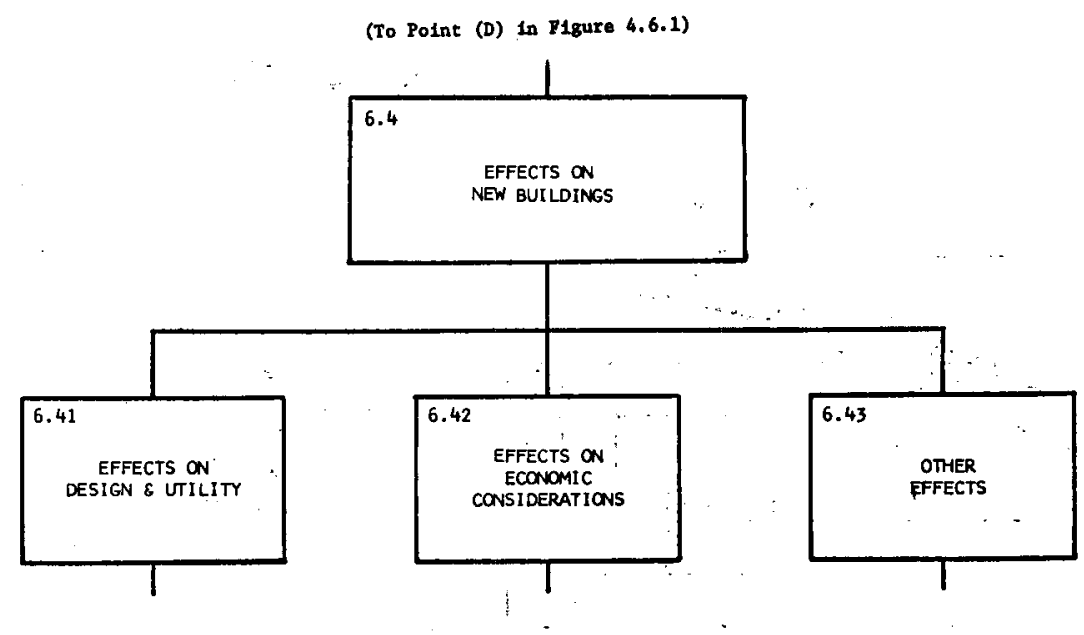

F1gure 4.6 .5 
$190^{\circ} \mathrm{F}$ water, flowing at a rate of 220 gallons per minute, was piped a distance of two miles to the town's newly bullt swimming pool, a hospltal, two school houses and 70 residential houses near the swiming pool. SatIsfactory results with this first experiment led to the search for other natural heat sources near the town.

Today, the Reykjavik District Heating Service derives its energy from three major thermal flelds as follows:

\begin{tabular}{|c|c|c|c|}
\hline F1eld & Quantity & & Temperature \\
\hline $\begin{array}{l}\text { Reyktr } \\
\text { ReykjahIto } \\
\text { Reykjavik }\end{array}$ & $\begin{array}{l}3900 \text { GPM } \\
2000 \text { GPM } \\
4700 \text { GPM } \\
2800 \text { GPM }\end{array}$ & c. . . & $\begin{array}{l}180^{\circ} \mathrm{F} \\
187^{\circ} \mathrm{F} \\
260^{\circ} \mathrm{F} \\
218^{\circ} \mathrm{F}\end{array}$ \\
\hline
\end{tabular}

The fields at Reykir have now ylelded over 300 million cubic meters of water over a period of 35 years without any drop in temperature or decrease in the rate of production.[2] The service in Reykjavik has expanded rap1diy. In 1963 only 60 percent of the population of the city enjoyed district heating; by the end of 1971 , 96 percent of the population utilized geothermal heat sources. Figure 4.6.6 shows the more than fourfold growth in geothermal energy production in Iceland since 1960 .
In Reykjavik, the hot water distribution system is handled by a municipal agency and is considered to be a normal public service roughly paralleling cold wate supply and sewerage services. The system is designed around a mintmum outside temperature of $14^{\circ} \mathrm{F}$. When the temperature drops below this figure, additional energy is supplied from hot water storage tanks and by operating oll-fired peak demand heating plants. After the hot water is circulated in homes for space heating, the users in Reykjavik are permitted to extract the remalning heat for swimming pools or small greenhouses. The delivered heat from geothermal sources is relatively inexpensive compared to other fuels, as the following table shows [2]:

\begin{tabular}{lc}
\hline \multicolumn{1}{c}{ Heat Source } & Price (\$ per million Btu) \\
\hline & \\
District geothermal heating & 1.04 \\
Night electricity & 1.33 \\
Fuel oil & 1.73 \\
\hline
\end{tabular}

Hot water from the remote geothermal sites is transmitted to the city through 14 inch diameter steel pipes lald in concrete conduit about ten miles long. Both single and double pipe distribution is used; the double pipe system allowing for the return of expended water. In the double pipe system, the waste water is mixed with

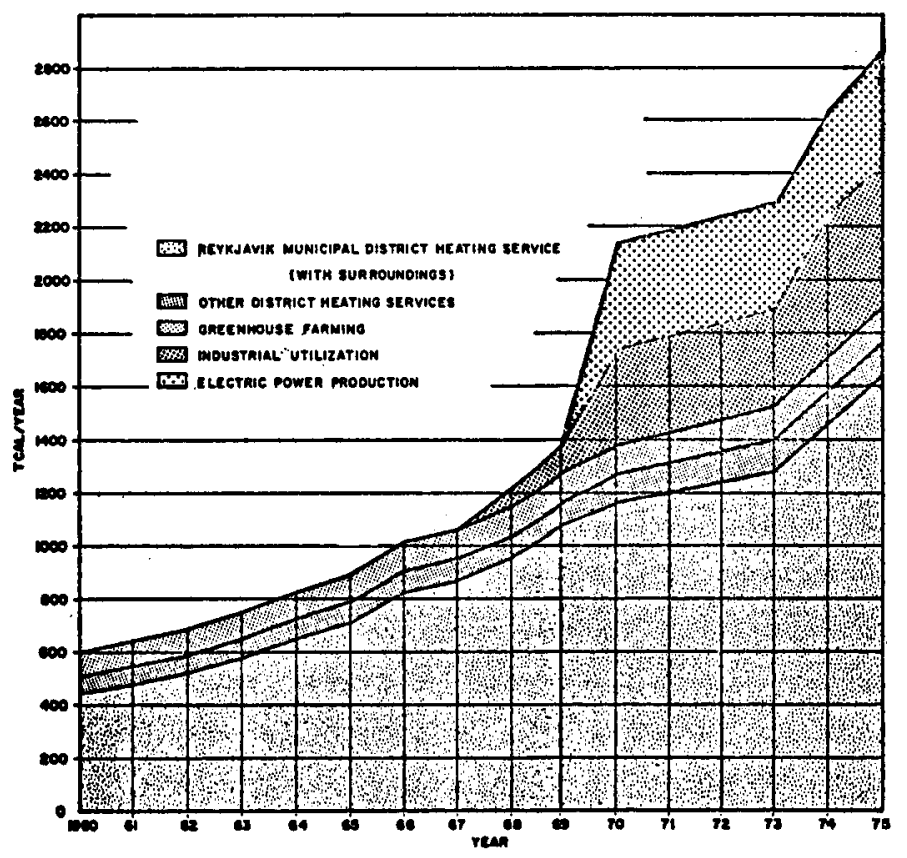

Source: E1nars8on, Svelnn S., "Geothermal Distr1ct Heating," Geothermal Energy, UNESC0, 1973, p. 125 .

F1gure 4.6.6 GROSS PRODUCTION OF GEOTHERMAL ENERGY IN ICELAND (ABOVE $40^{\circ} \mathrm{C}$ )

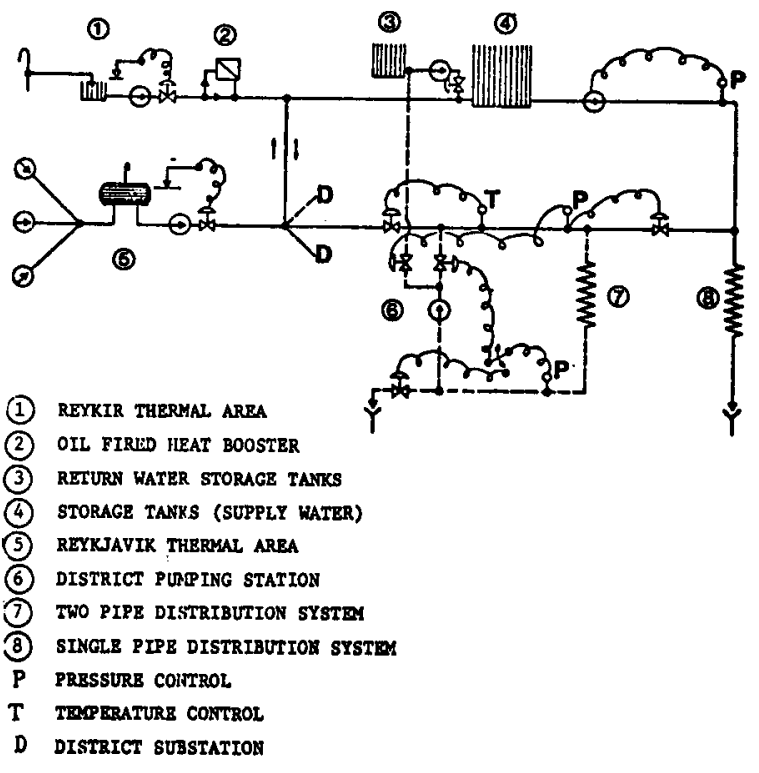

Source: E1narsson, Svelnn S., "Geothermal Diatrict Heat1ng," Geothermal Energy, UNESCO, 1973, p. 130 .

F1gure 4.6.7 SCHEMATIC DIAGRAM OF REYKJAVIK HOT WATER SYSTEM 
incoming supply water to capture a measure of the wasted heat. In the main supply lines and street disribution pipes, various forms of insulation are used to decrease the heat loss. These include: turf, lava slag, rock wool, aerated concrete or foamed plastics. The final distribution lines to the homes themselves are insulated with rock wool, felt, polyurethane foam, or high density polyethylene foam. The heat $108 \mathrm{~s}$ in the distribution system is estimated to be approximately 11 percent. Figure 4.6 .7 presents a schematic of the Reykjavik hot water distribution system.

The Impact of geothermal heat on buildings is demonstrated in the following quotation:

Since about 1930 elementary and secondary boardIng schools in the rural areas of Iceland have, whenever possible, been sited at locations where geothermal energy is avallabie. In these centers the school bulldings and living quarters for the pupils and staff are geothermally heated. They are also as a rule equipped with a swiming pool, and are self-supplying with vegetables (tomatoes, cucumbers, cauliflower, etc.) grown in their own hothouses. There are now many such schools in various parts of the country and quite of ten they are used as tourlst hotels during the sumer holidays. Quite of ten these centers have formed the nuclei of new service communities in the rural areas. [2]

\section{Klamath Falls, Oregon}

Early settlers in Klamath Falls area used the Indigenous hot springs and boiling mud pots in the flat rolling hills for cooking figh and game. By 1915 a greenhouse had been built near one of the hot springs and by 1928 a natatorium had been build to exploit the presumably therapeutic capabilities of hot springs in the area. While the original hot springs have disappeared, probably through lowering of the water table, two natural thermal displays still exist near the city: one is a spring which emits water at a temperature of $165^{\circ} \mathrm{F}$ with a flow rate of at least 100 gallons per minute, and the other is a spring located near Upper Klamath Lake. [3]

By 1967 more than 350 wells had been drilled serving more than 450 houses, several apartiments, six schools, a number of businesses and commercial firms, and the Oregon Technical Institute. The depth of the we11s ranges from 100 feet to almost 2000 feet; these wells produce water in the temperature range of from $140^{\circ} \mathrm{F}$ to $235^{\circ} \mathrm{F}$.

As contrasted to the Reykjavik case, users of geothermal heat in Klamath Falls tap the resource themselves. In most instances, a well is drilled to a satisfactory depth and 18 cased to the bottom and perforated. $A$. long single return pipe coll is inserted into the casing. The wellhead is then sealed. The coll within the casing is connected to space heating radiators. The coil is filled with domestic water and, if the system is small, circulated by thermal forces. For large systems, for example involving two or more houses, a pump provides more rapid circulation. This system avoids any problems which might occur due to deposition of solids.

Where Reykjavik provides an example of a centrally controlled large-scale geothermal space heating system, Rlamath Falls provides an example of a small-scale, Individually explofted geothermal heating system.

\section{Rotorua, New Zealand}

In many ways the geothermal activity at Rotorua lies between the extremes of Reykjavik and Klamath Falls: from the standpoint of resource size, effect on the city and its buildings and the institutional arrangements in effect, Rotorua represents a middle ground.

The first use of the geothermal resources in the Rotorua area probabiy occurred hundreds of years ago when the Maoris utilized the local hot springs and pools for heating of their homes and cooking. The earliest European domestic use of the resource occurred before the turn of the century when colls of steel pipe were inserted into the hot pools; municipal water under pressure was circulated through the coils in order to obtain a hot water supply. The earliest sha1low wells were bored fust before World War II; scarcity of foss 11 fuels, lack of reliability of the national electric power grid, and the high cost of electricity led to the initial expansion of the use of geothermal resources.

A fine example of the 1mpact of the use of geothermal resources in building design can be found in the Queen Elizabeth Hospital, built in 1942 as a military hosp1tal, and later converted to the National Hospital for Rheumatic Diseases. [4] In this hospital a physiotherapy pool uses geothermal fluids; the hospital is heated by geothermal sources; sterilizers and kitchen cooking equipment are designed to use geothermal steam; hydrotherapy and alkaline and acid geothermal therapeutic baths are also avallable.

After the War, geothermal exploitation was accomplished by small groups of property owners who organized into supply districts. By 1970 there were 650 wells drilled to depths of greater than 200 feet; perhaps 300 more exist at lesser depths.

Layout of the city is such that most businesses and residences there can be provided with geothermal heat from within the city's own boundaries; tourist locations also apparently have adequate heat reserves. Industry In Rotorua is not very extensive; it includes a veneer factory, a timber drying kiln, a mushroom farm, and a commercial tomato operation (1970). Geothermal ground is still left in areas ideal for industrial expansion and it is apparently the intent of the city to guard these areas for future use.

The flrst ten thousand million Btu per year of geotherma! heat is free to industrlal users in New Zealand; consumption over that amount costs $3 \mathrm{c}$ per million Btu, payable to the Crown. All private domestic use is completely free.

Rotorua now has placed into effect a series of new regulations which cover private use of geothermal energy. Property owners wishing to drill for geothermal fluid must first obtain a license; licenses will not be issued if the existing wells in the neighborhood may be endangered. Some areas of the city have had wells discharge dangerous gases; permits for drilling in nearby sites are no longer approved. Owners are liable for any damage which their geothermal drilling or operations may cause.

The new regulations also require that wellheads be kept outside of bulldings so as to prevent the accumulation of hydrogen sulfide or other leading gases. These regulations have had the effect of encouraging the drilling of community wells in suburban neighborhoods. Expended fluids are disposed of simply by dumping them into 
soakage pits located in porous strata near the surface. The method has apparently been quite satisfactory. [5]

The ancient Maori steam cooking technique has been adapted to modern geothermal cooking in the Rotorua area. The Maoris soaked straw mats in water, wrapped the food to be cooked in these mats, covered them with heated stones, and covered the stones with sand to trap the steam. The modern geothermal steam cooking devices are known as Hangis. A New Zealander describes the use of these cooking devices as follows:

Modern Hangis are constructed from metal or concrete. A discharge pipe is taken from a well through the Hang1; by judicious throttling of a control valve on the outlet pipe, flash steam will enter the Hangi through holes drilled in the p1pe and fill the Hangt with steam under atmospheric pressure. Food cooked in Hangis is excellent and at steam atmospheric pressure, food is never overcooked or spolled. Many hotels and hostels use this method of cooking. Hangls are a1ways constructed when geothermal fluid is available near Maori meeting houses where it is frequently necessary to cook large quantities of food for tribal gatherings. Hangls are found to be cleaner, more convenient, and economical than the conventional type of stove for fire. After use a Hangi can be washed out with a jet from the geothermal supply. Simllar types of Hangis are frequently used to cook food for livestock. [5]

The new Tourist Hotel in Rotorua employs a geothermally powered air conditioning and domestic hot water system. The afr conditioning system here is unique and may be a prototype for applications elsewhere. The air conditioning system employs a 130 ton lithium bromide absorption unit which is capable of absoprtion of approximately 2.3 million Btu per hour.[6] Individual air conditioning units with separate heat transfer coils and fans are provided in each room. The system functions through the use of a buffer heat exchanger; the $300^{\circ} \mathrm{F}$ geothermal brine transfers heat to clean water which enters the absorption refrigeration cycle at $250^{\circ} \mathrm{F}$.

Cooling water for the absorption comes from a nearby stream. Most of the components are currently commercially avallable. A review of the system design and the experfence to date in Rotorua suggests that the general design principles could be expended perhaps even to the level of providing district cooling. (The lithium bromide absorption alr conditioning unit is of American manufacture.)

In the paragraphs which follow impacts on existing regions and cities, new regions and cities, existing buildings, and new buildings are reviewed.

\section{Effects on Existing Regions and Cities}

Water Deficiencles. The scenario described in Section 3 calls for the development of at least 190,000 MWe of geothermal electricity in the United States by the year 2000. Most of this energy is produced in the West. Some is exported, but most is used indigenously. As argued elsewhere, low cost energy, particularly low cost electricity, will bring new industry to the area and affect the development of existing and new urban communitles. This growth in development, triggered by low cost energy, may be on a collision course with the avallability of process and potable water in the West. Not only is low cost energy likely to increase industrial and potable water demands, but the production of energy Itself will require water. Given the fact that

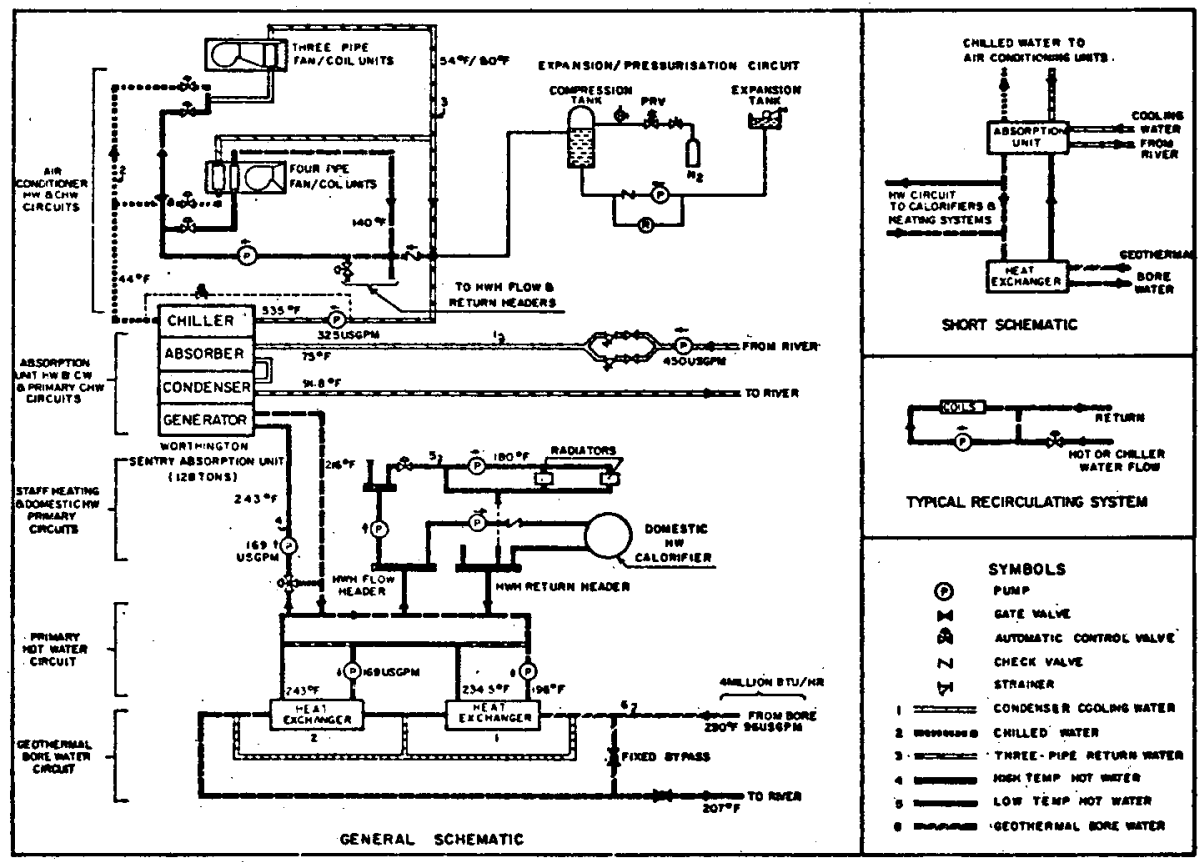

Source: EInarsson, Svelnn, "Geothermal District Heating," In H. Christopher H. Armstead (ed.), Geothermal Energy: Review of Research and Development (Paris: UNESCO, 1973), p. 132 .

FIgure 4.6.8 PIPING SCHEMATIC - ROTORUA INTERNATIONAL HOTEL 
the western states contain not one but at least five p tble forms of new energy development, o1l, oil sumul, natural gas, coal, and solar, as well as geothitrmal, the demands upon reglonal water resources for any of these, much less all of them, will be substantial and probably cannot be met except by importation. On the positive side, however, is the fact that geothermal requires next to the least in the way of water input of any of these five forms; the only one being better would be solar energy, which may be a dry process. Figure 4.6.9 below summarizes the water requirements of water resources regions of the West through the turn of the century as estimated by the Water Resources Counctl in 1968. [7] Note that by the year 2000 approximately two and a half times as much water will be required for withdrawals as in 1965 and one and a half times as much for consumptive use.

Because of the concern about water, it may be necessary to look to geothermal sources, not only for heat and electricity, but potentially for water as well. As mentioned in Section 2, the Department of the Interior has begun experimentation in this direction in the Salton Sea area of Californla. Clearly, the production of usable water for agricultural or industrial purposes from geothermal brines would have a most beneficlal effect.

Impact on Regional Lifestyle. The effect of geothermal development and indeed of al1 energy development upon western reglonal character, regional Iffestyle, and regional choices, is considerable and potentially overwhelming. The dichotomy of opinion which seems to have arisen between the States of Montana and Wyoming over the pace of coal resource development is an intraregional argument 1 ikely to be repeated and magnified over the next decades. As geothermal resources and other forms of energy production rise in demand nationally, people of the western states fear pressure will be applied on that region to export at any cost to the region. The national will could be imposed on the region, irrespective of the region's attitudes and desires. They fear that the wide open spaces will be full of smokestacks, high lines, and people.

This fear does not seem to be fustified in the case of geothermal development. Figure 4.3.8 showed that almost all KGRA's are located in countries with a density of under 50 persons per square mile. They are widely scattered, however, and except in the few cases where unusually large resources are found, most installations will probably be of moderate size. These are not labor Intensive and are not likely to attract any sizeable infusions of population, particularly when limited to power production only. The effect will be more to bolster existing lifestyles than to introduce disruptive elements.

Air Quality Issues. The Colorado Basin states as a whole and many other of the microclimates within the western states are inversion prone. Therefore, it is likely that this air entrapment effect, the water deflciency effect and the percelved threats to future iffestyle may cause settIng upper 1 imits on regional developuent and growth based on air and water quality standards. This would be done irrespective of the abundance of energy resources within these western states. From the standpoint of air quallty, geothermal resources ought to be considered for the satisfaction of regional base load power requirements, augmented by solar energy, in priority over other energy forms, in order to preserve the purtty of western airsheds. The clean air lessons of Reykjavik should be persuasive here. In short, the impact of geothermal energy on development in the West may be to remove a limit (polluted a1r) which might have otherwise existed. The effect on air pollution of replacement of 35,000 MWe of coal-fired plants and 41,000 MWe of nuclear plants is displayed in Figure 4.6.10 on the following page.

Thus the development of the base case geothermal electricity would prevent a significant amount of air pollution from coal and nuclear power plants. Further, geothermal space heating could displace even larger amounts of coal, oil, and gas, leading to greater savings from air pollution.

Outdoor Recreation and Tourism. Geothermal locations lie near almost all of the major National Parks, national recreation areas, and national monuments in the West. Therefore, the 1mpact of energy could be to bend the regional character. Without adequate planning, geothermal energy could impact adversely on important outdoor recreation and tourfsm resources. The most vistble element of geothermal development will be the proliferation of high tension transmission lines as well

\begin{tabular}{|c|c|c|c|c|c|c|}
\hline \multirow{3}{*}{ REGION } & \multicolumn{3}{|c|}{ WI THDRAWALS } & \multicolumn{3}{|c|}{ CONSUMPTIVE USE } \\
\hline & \multirow{2}{*}{$\begin{array}{l}\text { USED } \\
1965\end{array}$} & \multicolumn{2}{|c|}{ PROJECTED REQUIREMENTS } & \multirow{2}{*}{$\begin{array}{l}\text { USED } \\
1965\end{array}$} & \multicolumn{2}{|c|}{ PROJECTED REQUIREMENTS } \\
\hline & & 1980 & 2000 & & 1980 & 2000 \\
\hline MISSOURI & 19,344 & 23,264 & 27,876 & 10,554 & 13,160 & 14,979 \\
\hline RIO GRANDE & 7,289 & 8,330 & 9,510 & 4,403 & 4,676 & 4,991 \\
\hline UPPER COLORADO & 4,017 & 5,675 & 6,575 & 1,982 & 2,700 & 3,100 \\
\hline LOWER COLORADO & 6,913 & 8,497 & 8,428 & 3,448 & 4,075 & 4,645 \\
\hline GREAT BASIN & 5,115 & 7,055 & 7,550 & 2,253 & 3,299 & 3,562 \\
\hline COLUMBIA - NORTH PACIFIC & 29,631 & 41,407 & 90,135 & 10,521 & 13,581 & 17,325 \\
\hline CALIFORNIA & 37,300 & 56,290 & 120,510 & 20,944 & 29,205 & 32,660 \\
\hline TOTAL & 109,609 & 150,518 & 270,584 & 54,105 & 70,696 & 81,262 \\
\hline
\end{tabular}

SOURCE: WATER RESOURCES CONCIL, (1968). [7]

Figure 4.6.9 ESTIMATED WATER USE AND PROJECTED REQUIREMENTS, WESTERN WATER RESOURCES REGIONS (MILLION GALLONS DAILY) 


\begin{tabular}{|c|c|c|}
\hline POLLUTANT & $\begin{array}{l}\text { DISCHARGE/DAY : }: \% \\
\text { PER } 1150 \text { MWE PLWT }\end{array}$ & $\begin{array}{l}\text { DISCHARGE / DAY } \\
\text { PER 25, }\end{array}$ \\
\hline \multicolumn{3}{|l|}{ COAL-FIREO PLANT } \\
\hline - SULFUR OR $\mathrm{SO}_{2} *$ & 150 TONS & 4600 TONS \\
\hline $\begin{array}{l}\text { - NITROGEN OXICES AND } \\
\text { OTHER GASEOUS EFFLLUENTS }\end{array}$ & 60 TONS & 1800 TONS \\
\hline - PARTICULATES: $:$ & 9 TONS & 270 TONS \\
\hline \multicolumn{3}{|l|}{ NUCLEAR PLANT } \\
\hline $\begin{array}{l}\text { - TRACE AMOUNTS OF } \\
\text { RADIOACTIVE SUBSTANCES }\end{array}$ & $\begin{array}{l}\text { A FEW HUNDRED- } \\
\text { THIOUSANDTHS OF A } \\
\text { GRAIN CONTAINING } \\
2 \text { CURIES OF COM- } \\
\text { PARATIVELY LONG- } \\
\text { LIVED RADIOACTIVITY }\end{array}$ & $\begin{array}{l}\text { ABOUT A THOU- } \\
\text { SANDTH OF A } \\
\text { GRAIN CONTAIN- } \\
\text { ING } 75 \text { CURIES } \\
\text { OF COMPARATIVE- } \\
\text { LY LONG-LIVED } \\
\text { RADIOACTIVITY }\end{array}$ \\
\hline
\end{tabular}

"ASSUUING USE OF STACK GAS DESULFURIZATION SYSTEM. ::ASSUMING USE OF HIGHLY EFFICIENT PRECIPITATION AND SCRUBBERS. X\%:TYPICAL PLANT DATA PER UTILITY INDUSTRY SOURCES.

Figure 4.6.10 POSSIBLE AIR POLLUTANTS ELIMINATED BY SUBSTITUTION OF GEOTHERMAL POWER PLANTS FOR 35,000 MWe OF COAL-FIRED PLANTS AND 41,000 MWe OF NUCLEAR PLANTS IN YEAR 2000

the general creep of urbanization and Industrial deve1opment. It is hard to escape the conclusion that, in common with other forms of energy development, geothermal activity within these scenic preserves or in areas adjacent to them can have an effect which some will view as detrimental. Therefore, a clash of interests between those who feel they guard the appearance of the countryside and those who favor development seems likely. Clearly the developers of geothermal resources will have to be sensitive to their impact on the regional environment and $f$ ind ways of minimizing or making their effects beneficial. One could imagine that the development of geothermal resources would open new areas to recreational use and that expended geothermal waters could provide a new recreational resource in the form of new health spas or fishing sites.

Ethnic Lifestyles. There is little doubt that the ability of the Indian populations to maintaln ethnic integrity, to hold to traditions, and to keep influence over their youth in coming generations; will be impacted by energy-intensive activity throughout the western states. While this can be a positive factor with respect to alleviating poverty and by creating a base of employment in many areas contiguous to Indian lands, this progress w111 not be without a price in respect to the Indian heritage.

Prime Agricultural Lands. Similarly, highly productive agricultural lands of the Imperlal Valley and the NapaSonoma vineyard areas, for instance, and the grazing lands of the undeveloped high country, will all be impacted by energy development, thereby reducing the possibility for maintaining the agricultural and, hence, cultural diversity and the distinct regional character of certain parts of the West. It is becoming Increasingly evident to students of land use that natural systems and patterns of land use based upon natural process only, that is, farming, ranching, grazing, silviculture, etc., can always be outbid in the free market by any form of land development, Industrlal process, energy-based development, or mineral extraction. Any and all of these can set a higher mark for the land price than can the economic activity based upon natural process only. This $1 \mathrm{~s}$ most certainly true for unmodified existing natural systems, which have no percelved "market" value.

\section{Effect on Existing Close-In Communities}

The Exploratory Phase. Aside from the obvious envit mental impacts of noise, noxious odors, and the appearance of high tension lines, geothermal energy is likely to bring land speculation to close-in communities. A quote from the Environmental Impact Statement, on the Clear Lake-Geysers area, states that "much of the private land which is under lease would have the value of approximately $\$ 100$ per acre if it had no geothermal potential. Sonoma County tax records indicate that one 200-acre parcel (of geothermal potential) adjacent to The Geysers resort had a land value of $\$ 16,400$ per acre. The tax on this parcel yields Sonoma County over $\$ 93,000$ per year." [8] Taxation for possessory 1nterest in undeveloped leases will be another factor affecting the local close-1n communities. That is, the local taxing authority, with regard to geothermal potential, will tend to place assessed value upon lands with geothermal potential in mind. Both the taxing aspect and the speculative aspect will cause land price inflation once geothermal probability has been established.

The increase in land value fueled by geothermal prospecting will be good for those willing to sell or lease their land for those purposes, bad for those seeking to buy land for other purposes, and bad for those keeping their land, particularly if kept for scenic or other low intensity purposes. The market price for geothermal land can outbid the grazing, forestry, and cropland price structure hands down.

The increase in taxation related to anticipation of geothermal development is bad for "keepers," and bad for sellers and buyers, unless the sale or lease is related to geothermal prospecting.

On the other hand, the general population will benefit by an increase in the local tax base. This will lead to Increased and higher quality public services such as education, health, police, and welfare. This effect will certainly improve these aspects of the public living environment.

The Operational Phase. Communities close to geothermal resources will attract new industry. This impact is discussed in Section 4.2. Growth of new industries will have concomitant effects on community population and economics. It is difficult to forecast whether such Impacts will be considered desirable or undesirable within the communties involved. Some will see this growth as an intrusion into their privacy; others will see it as a dynamic and necessary step into the 21 st century and a general improvement of their present life.

The pace of geothermal development w111 not unduly alter the character and rate of development of any established large close-1n city, but 1ts 1mpact will be more strong1y felt in smaller communities. The gradual, incremental activities of wellfields and generating plant activity may not próvide sufficient impetus in itself to make feasible the regional hospital, the community college, or the group cultural activities which characterize the mature, larger community, without special planning.

The change in regional character 11kewise will be gradual, except in presently uninhabited or very sparsely inhabited environments, where the new activity will create an Immediate and long-term radical change.

Terminal Operations. The Individual welifield will one day go cold; its generating plant will fall idle. The time span is conjectural but is likely to be no less than 20 years and maybe more than 100 . In the life of a 
communtty, 100 years is not so very long. closing of .. ividual geothermal fields will undoubtedly 1mpact negatively upon close-1n communities, not as sudannly as Cripple Creek but as Inexorably as Appalachla, except to the extent that other wellfields (eventually themselves depleted) or other energy modes take over to hold the line, to provide fobs, taxes, and energy, the acknowledged bloodstream of modern 1ife. These thoughts give rise to questioning whether the leasing program should not make explicit provision for a continuity of energy avallability to existing close-in communities, which logic Indicates to be the first and last served by the KGRA in or near which it sits.

This could take the form of a cluster of timed-release leasing tracts over which the close-In community had some control as to the date for development. In a loose way, th1s 18 analogous to the h1storical forest preserves controlled in the adjoining hinterland by European capital cities, forests such as Paris' Bots de Boulogne and 0s10's Nordmarken.

The close-in community ought also have protection as to the restoration of the derellct wellfleld (which the leasing regulations opeak to) and also to settlement growth options for the fallow acreage (which they do not). Now 18 the time to start planning for all of these eventualities.

\section{Effects on New C1t1es [9]}

Economic Base. The number of $f$ obs provided by the prototypical geothermal installation is, in itself. Insuffictent to provide a large enough work base to Justify development of a new community composed of wage earners dependent upon the geothermal activity and 1 ts multiplier effect. Assuming that the geothermal Installation employs 150-200 workers and that these workers have an economic multiplier of 2 , the communitles supported w111 total between 1000-1300 persons. The 250 households thus created could not Justify the application of the Title VII procedures of the National housing Act, and a proposal so based would fall the Job opportunity and economic viability tests of the Department of Housing and Urban Development under the New Communttles Review Process. If, however, the geothermal activity supplements another activity, such as outdoor recreation or tourfsm, which In itself is usually economically marginal, both would be strengthened measurably and the viabllity threshold might be reached. For example, this is a strong poss1bility for the Mono Long Vailey KGRA in east central California. This is a beautiful mountalnous resourt aree now. Development of the geothermal potential will give ali year employment opportunities and economic strength leading to expanded recreational activities. [8]

It is significant to note that all the new towns so far approved under the New Communfties Act (TItle VII) are located in the central city and the suburbs, and none 1s beyond the present outer 11mits of suburbla. One proposal, Brter H111, was a scant 60 miles from P1ttsburgh and yet falled the economic test in the period following pre-application approval, due largely to the work base question.

Lopgevity. As with the existing close-in community, the nee town which depends wholly or partiy on a specific geothermal Installation will be concerned with the longevity of that wellfleld. It will be even more critical for a new community. 1inked to a geothermal source to have assurance as to a relatively long certainty of supply because the new town is in essence an entrepreneurial venture. Ne1ther the government as puarantor, nor a financial institution a mortgagor or equity partner, would be willing to give thelr backing on such an uncertain situation based on energy fob base of a 30-100 year varlable longevity. The National Housing Act Title VII government backed bonds are 50 year obligations. The financial communfty will require assurances of at least that long a time in the economically viable life of a new geothermal based community. So the unproven longevity of American geothermal sources constitutes a probable block to linking new town development to them, at least directly, attractive as that may be on other grounds. Some spectal government guarantee might be required to effectuate a marriage of a geothermal new town to a willing financial backer.

Leasing of Federal Lands. Since KGRA's have a high probabllity of occurring on federal land, another new avenue of governmental sponsorship of new communities could be explored, and that is the leasing of federal lands for a new town. This is unprecedented to date, and would be enormously attractive because of the favorable effect on financial requirements of leasing as aginst land aggregation by purchase in fee simple. The financial breakeven time for a new town runs from 10 to 30 years. Therefore the financlal load of land assemblage and inftial development is extremely heavy, especially for private entrepreneurs. (This is one of the chief reasons for the paucity in new town creations in the United States.) If federal land could be based as a complete package for a 99 year minimum, with renewal, the Initial financial feasibility for a new geothermal supported town could be greatly enhanced.

At the end of that road there would be another interesting question--what would happen at the ultimate end of the lease term? Would the Federal Government own a new town or would the land have to finally pass into state jurisdiction and become a normal incorporated municipality?

Cultural Maturation. Cultural maturation of communities is a relatively slow process, based primarily on population growth levels but also paced by the sequence of concerns which require coumunity attention and whtch the communtty marketplace can afford at vartous point in 1 ts growth cycle. Housing and minimal conventence shopping are succeeded by elementary schools, more shopping, and a church or two. High schools come later, as do clinics and, still later, hospitals. A rule of thumb on medical service indicates that a hospital bed must be supported by from 250-400 people and even a minimal hospital requires a service population of say $12,000-20,000$. Public libraries and pubilc gardens are further along in a town's life cycle, as are museums, theaters, and community colleges. These sequences are 1llustrative only but border on the norm. A community requires quite a number of decades to accumulate the cultural assets which are equated with the full round of communal life and to create the kind of town that w111 satisfy 1ts clt1rens' normal requirements for cultural adequacy. Therefore If geothermal energy 18 to be at the base of a town's being, provision for longevity by reservation of future wellfields would seem to be a requirement of pub11c pollcymaking. Enough t1me, greater than 50 years, must be allowed for 1n order for the new geothermal communty to achieve a well balanced social and cultural maturity.

New Locations and Destgns; What Would Be the Geographic Considerations Involved in Selecting a site for a Geothermel C1ty? Proximity to the geothermal resource so thet the heat contained in the geothermal fluids could be used directly as well as for the generation of electricity is a prime consideration. In addition, it would be hoped that the geothermal fluids would be of 
sufficlent purity so that they could furnish potable, Industrial, and agricultural water for the communtty. The community would be served by existing or future transportation systems and would be close enough to existing industrial sites (or could serve as a future location for industry) so as to provide an appropriate and adequate job base.

Idaho, Oregon, and Washington, for Instance, might provide such sites since the agricultural and lumber industries located there offer possibilities for immediate use of process heat. Likewise there are valuable mineral resources throughout the West which may be explofted economically with nearby geothermal energy. Some of these are: (a) coal--Wyoming, Montana, Utah, New Mexico, Colorado, Arizona; (b) o1l shale--Colorado, Wyoming, Montana; (c) phosphate rock--Idaho, Wyoming, Colorado; (d) copper--Montana, Utah, Arizona; (e) potassium fertilizer-New Mexico; (f) vartous other metal ores--all western states; (g) aluminum ores (dawsonite)--Colorado, Utah; and (h) magnesium, potassium, 11thlum, chlorine, bromine--Great Salt Lake, Utah, Imperial Valley, California.

In the design of the new clty, important lessons can be learned from Reykjavik, Rotorua, and Klamath Falls. The geothermal fluids would be extracted by a district service organization; it would furnish energy for district heating and cooling as well as for the generation of electricity. In addition, the low grade heat remaining after primary use of the geothermal fluids could be used for greenhouses, aquaculture, swimming pools, health spas, and the like. If the city is 10cated in a semi-arid region, and the geothermal fluids can be processed to form water acceptable for agricultural uses, the surrounding countryside can be made fertile and productive.

\section{Effects on Existing Buildings}

Heating. There is likely to be little effect of geothermal energy on existing bulldings within communities which are distant from geothermal sources; for buildinge in communities close to geothermal sources, the introduction of inexpensive forms of heat could, in some few instances, lead to the conversion of fosstl fuel space heating systems to geothermal heating systems. Conversion appears to be quite simple and requires only the substitution of geothermal heat for fossil heat (if the geothermal heat is of high enough quality). It will be easiest for existing hot water heating systems. As for atr conditioning, the conversion would be much more complex and probably would not be practical unless district air conditioning were introduced.

The prospects for district heating by recaptured geothermal waste heat are quite attractive. Even there, direct use of: the geothermal heat for space heating is many times more thermally efficient In end use than by converting, to electricity, the problem being one of bringing the demand to the source.

Prototypical cases for geothermal district heating would Include:

1. Taking the hot brines from the steam separator tinto the district heating loop, which would extract in the order of $50-$ $60^{\circ} \mathrm{F}$ in temperature drop, returning it to the generating system as condenser water then running to the reinjection wells, or
2. Taking the hot water from the end of the condenser water cycle plus, the waste by-pass water, running $1 t \cdot$ through the district heating lines and then to reinjection wells.

The first approach would provide initially higher water temperatures to the district heating system, but would require double piping in the sense that it is assumed that the bullding complex to be heated is some distance away from the wellfield so as to avold its hazard, nolse, and odor. The second has the logic that the hot waste water must be reinjected to, the bearing stratum at some distance from the operating wellfield in any event so that the mains piping for district heating is in large measure already provided as part of the normal generating cycle.

The assumptions underlying a prototypical case might be of these kinds:

Assume: - Hot water of $185^{\circ} \mathrm{F}$ entering the system

- a $55^{\circ} \mathrm{F}$ drop within the district heating cycle

- $130^{\circ} \mathrm{F}$ water into the relnjection wells

- a mild winter climate

- therefore the heating requirement would approximate 30 Btu per square foot per hour, of a typical residence of 1500 square feet.

The equation for hot water gallonage would be:

$\frac{30 \times 1500}{55^{\circ} \Delta \mathrm{T} \times 8.34 \times 60 \text { minutes }}=1.63 \mathrm{gpm}$ (8ay $2 \mathrm{gpm}$ )

A rule of thumb therefore would be $2 \mathrm{gpm}$ per residence for residential district heating. Considering the tremendous gallonage of utilizable hot waste water, it can be assumed that any hot water geothermal generating plant could supply district heating for a very sizeable community.

The cost/benefit ratio for ouch a case would be based upon comparing it to space heating utilizing alternate fuels, residual oll being the obvious measuring stick.

The formula would be:

Annualized full cost of residual oll space heating = Annualized full cost of district heating

Where: 1. Annualized full cost of residual o11 space heating is aggregate of oll-fired heating plus fuel cost

2. Annualized full cost of distinct heating is distribution system plus pumping cost plus price of heat, if any

To test this out, assume a district heating system of 1000 dwelling units. The savings in capital cost for elimination of the o11-fired boller (or furnace) plus oll tank plus cost of oll would be avallable for financing the district heating system.

Assume: - Average savings in first cost, $\$ 1000$ per dwelling 
- Average annual fuel oil cost (1973 prices) per dwelling, $\$ 400$

- A constant of .108 write-off of 8 percent for 20 years

The first cost money contribution, assuming a cost/ benefit ratio of 1.0 , available for the district heating system would therefore be $\$ 12,962$ per dwelling, or $\$ 12,962,000$ for 1000 dwelling units.

To appreciate the order of magnitude of such a fund, assume for the moment that half of the total would be avaliable for piping, the other half for heat charges, pumping cost, etc. Assume also that the average flow in the primary district heating loops would be half of the connected full demand (i.e., a diversity factor of 2), therefore the matns piping sizes would be in the order of 10-12 inches. Piping of these sizes would cost on the order of $\$ 50$ per installed lineal foot. So, for illustrative purposes, if the entire system were of these large sizes (which it would not be), it could finance $24-1 / 2$ miles of piping. In actuality, since the average pipe size would be considerably less counting secondary loops, a figure twice as large is more likely. In that event, if all dwelling units were detached houses, they could be spaced about 500-600 feet apart, ranged on both sides of streets. Considering also that the operating fund wight be spread over, say, the 20-year write-off period, the money avallable for use charges, pumping cost, maintenance, and sinking fund for system replacement, would be $\$ 325$ per dwelling unit per annum, a tidy sum, particularly since the waste water should be free of charges. All this approximate arithmetic tends to indicate that the economics of district heating by geothermal waste heat would appear to be very attractive indeed. The savings in o1l by the use of geothermal energy depend on the annual load factors. The following figures are reported[2]:

\section{Cherkest (USSR) \\ Reykjavik (Iceland) \\ Paratounka (USSR)}

Caspillok (USSR)
The Reykjavik district heating system thus saves about 150,000 tons of 011 annually that would have had to be Imported, and the annual cost of heating for the customers is only 60 percent of the cost of heating with oll. This is for a community of 72,000 people.

District Cooling. If district heating by geothermal waste heat appears attractive, then the economics of geothermal cooling appears even more attractive, particularly as compared to cooling by electric drive evaporative condenser systems.

The heat requirement for absorption system space coolIng averages between 14 and 17 pounds of steam per ton hour of refrigeration, or its equivalent in hot water whtch is 14,000-17,000 Btu. The cooling effect, 1.e., 1 ton of refrigeration, equals $12,000 \mathrm{Btu}$. Thermal efficiency of absorption chillers ranges therefore from 70-85 percent, as compared to the thermal efficlency of $4-1 / 3$ to $8-1 / 3$ percent for space cooling by electric drive systems powered by geothermally-produced power, roughly a tenfold better average benefit in end use and nearly twentyfold in the extreme. (Remember that the geothermal power plant efficiency is only 10-14 percent.)

At the present time, absorption chillers work best, all things considered, at about 500 ton capacity. As these are relatively sophisticated machines, several machines should be grouped together to facilitate professional operation, to provide service through reserve capacity Juring maintenance shut-downs and breakdown of Individual machines; 100-ton units are about the smallest on the market. Unt11 recently, maximum input temperatures of $220^{\circ} \mathrm{F}$ plus were required to operate these machines, but now efficlent operation can be assured with $170^{\circ} \mathrm{F}$ plus input temperatures, thus bringing absorption cooling into the realm of possibility for recaptured waste heat from geothermal electric generating plants.

There is also current interest on the part of the equipment manufacturers in producing small unftized absorptive chillers, say $2-10$ tons, as a resynthesized version of the old gas-fired household refrigerator. If these become available, then the spectrum of space cooling by geothermal waste heat can be extended to the detached residence or other small detached bullding. Until then, dwellings and other building uses would have to be clustered, so as to be supplied by the larger absorptive units.

Chilled water travels even less well than hot water due to the narrow usable range of temperatures in which $1 t$ operates to provide space cooling, normally only $4^{\circ} \mathrm{F}$, $44-48^{\circ}$. The minimum temperature safely attainable is $40^{\circ}$, as below this the danger of freeze-up due to operator error or mishap is too high. The maximum temperature to achleve dehumidification of the conditioned air is $55^{\circ} \mathrm{F}$. So the distance for transport of chilled water itself must be very short, in the hundreds of feet, to stay within usable range even with the best of modern pipe Insulations.

A heat exchanger would have to be Interposed between the hot brines or other corrosive geothermal waste waters and the absorption units, but these are of very high effictency also.

A further intersting facet of geothermal space cooling (and geothermal district space heating also, for that matter) is that the district cooling system can be deslgned for peak load and operate at any load below the peak without concern for fuel consumption bulk pricing, or other such concerns related to fossil fuel use or fossil-derived electricity. This is because the amount of hot water would be constant, the withdrawal of heat could vary widely according to demand, and the resultant temperature leaving the systen would be of no real concern as the water is to be reinjected into the earth in any event; it is simply to be used as a heat resource en passant.

In those geothermal areas in which the climate required no space heating, the district cooling system would need to be designed within the distance limitations imposed by the design criteria for chilled. water. However, where space heating and cooling are required in alternation, the district piping system would supply either effect with equal efficiency, thus helping the amortization of the capital cost of the distribution system, if the distance limitations for cooling are respected. The capital cost. for the condenser cycle of electric drive central air conditioning equipment would be roughly equal to the cost of a heating plant. Therefore, the economics of district cooling would be roughly analogous to the figures cited for district heating. The operating cost aspect, on a Btu basis, would be even more favorable for geothermal over fossil fuel cooling than for district heating, as compared to electrically powered systems, because of the overall lower effictencles of the latter. There is a compelling case for further research into the district space heating and cooling aspects of geothermal energy, both with respect to waste heat recapture and direct use. 


\section{Effects on New Dwellings}

If geothermal electriclty has the effect of greatly lowering the cost of electricity, then electric space heating becomes much more practical. However, if new buildings are designed for energy conservation, the price of electricity becomes less critical. As outlined above, the really exciting prospect lies in the use of geothermal energy as a direct source of space heating and as an energy source for absorptive alr conditioning.

The availability of large amounts of moderate temperature hot water together with low cost electricity are on excellent circumstances for the increased application of heat pumps. The heat pump has very good efficiency for this type of application and therefore yields good energy economics. Since it is available in single house size units and may heat or cool as desired, the heat pump should find wide new use in new Unfted States geothermally heated dwẽllings. The western seasonal climate variations usuaily require both heating and cooling. Einarsson[2] reports such installations in Iceland, USSR, and New Zealand. In regions where geothermal fluids are relatively accessible and ubiquitous; it is not at all impractical to envision small sized systems which can serve single buildings (as in the case of the Queen Ellzabeth Hospital and the International Hotel in Rotorua, New Zealand). In such places the evolution of geothermal services might well parallel municpal water and sewer services. At first everybody "digs their own." Then, as the community grows, municipal services are provided to improve convenience, safety, health standards, economics and community regulation.

\section{REFERENCES}

[1] Bodvarsson, G., and S. S. E1narsson, "Geothermal Energy for Domestic and Industrial Heating," Proceedings of the Conference of Icelandic Engtneers, Reykjavik, Iceland, 1964.

[2] Einarsson, S. S., "Geotherma1 District Heating," Geothermal Energy (Paris: UNESCO, 1973), p. 124.

[3] Peterson, Norman V., and Edward A. Groh, "Geothermal Potential of the Klanath Falls Area, Oregon, A Preliminary Study," The Ore Bin (November 1967); and J. B. Koen1g, 'Geothermal Exploration in the Western United States," Geothermics, Special Issue 2, UN Symposium (1970), p. 2 .

[4] Burrows, W.; "Geothermal Energy Resources for Heating and Associated Applications in Rotorua and Surrounding Areas," Geothermics, Special Issue 2, UN Symposium (1970), p. 1662 .

[5] Cooke, W. L., "Some Methods of Dealing with Low Enthalpy Water in the Rotorua Area of New Zealand," Geothermics, Special Issue 2, UN Symposium (1970), p: 1670.

[6] Reynolds, G., "Cooling with Geothermal Heat," Geothermics, Special Issue 2, UN Symposium (1970), p. 1658 .

[7] The Nation's Water Resources (Washington, D.C.: Water Resources Council, 1968).
[8] U.S. Department of the Interfor, office of the Secretary, Final Environmental Statement for the Geotherma1 Leasing Program, Vo1. II (November 1973), p. V-84.

[9] Lunde, Frithjof M., and Valentine A. Lehr, Geotherma1 Energy--Regiona1, Community, Cultural and Construction Industry Considerations, report to The Futures Group, Inc., Glastonbury, Conn. (New York: Warner, Burns, Toan, Lunde, architects, 1974). 


\subsection{Impacts on International Relations}

\section{Croduction}

Geothermal energy, occurring as it does around the world, will potentially impact on our foreign policy and forelgn relations in several ways. First, most directly, it offers opportuntties to provide technological assistance to nations endowed with this energy source but unable to develop 1t. Indirectly, if other nations develop this source of energy, there w11 be an effect on world fuel demand, and to the degree that geothermal energy can substitute for other forms of energy, fuels which might have otherwise been consumed by these nations will be avallable on the world market. If geothermal energy is abundant, there could be an effect on world crude ofl prices, shipping, storage, refining, and so forth.

It is possible to conjecture about the posstble effects of geothermal energy on military operations both on land and under the oceans. Certainly, under some unique circumstances, geothermal sources could provide power for military installations. But beyond this, the knowledge of geology and geophysics derived from commercial deep-drilling development could Improve the ablitty to detect underground explosions. These and other such Impacts are discussed in more detall in this section.

F1gures 4.7.1-4.7.4 present the top level of the relevance tree of Impacts in this area; Appendix D presents the complete tree.

\section{Formation of Geothermal Areas}

Where are geothermal resources most 11kely to be found in the world? FIgure 4.7.5 shows the "ring of fire" in which geothermal resources seem to be concentrated.

The study of plate tectonics and the continental drift theory provides some insight into this configuration. New fundamental concepts in earth sclences dealing with the formation and placement of continents were advanced and largely accepted within the last decade. This "continental drift" theory holds that the present continents were part of a single land mass more than 200 million years ago. The outer shell of the earth, the 1ithosphere, Is divided into several "plates," most of which bear one or more continents. Probably driven. by thermil convective forces within the earth, the plates spread from deep sea ridges and small ocean basins at rates which are usually in the range of 1-10 centimeters per year on each side of the axis. This is an exceedingly fast rate in geologic terms; .taking an average differential rate of 10 centimeters per year; two plates would have separated by 10;000. kilometers in 100,000 years. ThIs simple computation Indicates that not only are plates "born" at indersea ridges, they must also flow back into the earth elsewhere. These "subduction" zones are located at deep sea trenches. The continents float with plates; however, because the continents are light, they are not consumed as the plates leave the 11thosphere. They can, however, divide at the ridges, and hence oceans can appear across them. This general Idea of the motions of the plates and continents has been largely confirmed through analysis of core samples obtained from drillIng in the ocean floor by the Jolnt Oceanographlc Institution for Deep Earth Sampiing project. The most recent samples were taken from ridge crests; older sediments were Identifled on elther side of the ridges, and age increased with depth.

The relevance of plate tectonlcs to geothermal energy and to geothermal energy's impact on international relations is clear: the geography of plate ejection at subduction largely determines which nations are likely to have active geothermal regions. The relationship between plate motion and geothermal activity has been discussed by Sir Edward Bullard as follows:

The areas of downgoing plates contain a large proportion of the geothermal areas of the world. Many of these are around the Pactfic, and Include Indonesia, the Philippines, Japan, the Aleutians, and the Andes. The New Zealand geothermal area 18 a southward extension of the Tonga Trench and is probably assoctated with a sinking plate. Other areas where similar phenomena occur are the Caribbean, the Aegean and the Scotia Arc which runs between the southern tip of South America and Graham Land. There are some 1mportant geothermal areas whose positions in this scheme are not clear. The Mediterranean is an area in which very complicated events are in progress. Africa is moving northward and colliding with southern Europe and the Middle East. In the collision the plates have become fragmented and directions of motion have changed. It is probably that the main, north-going African plate is going down and being consumed beneath the Cretan Island Arc, but It is not clear what is happening in Italy; It 1s possible that there is a small downgoing plate moving in from the west. Another area of doubt $1 \mathrm{~s}$ in the mountain states of the U.S.A. The continent has moved westward away from Europe and has probably overrun 1ts own westward boundary trench and also part of a mid-ocean ridge. It is also possible that California is a continental fragment that had 1ts origin somewhere to the west and has collided with the rest of the U.S.A. In view of these complexities, which are typical of continental geology, it is difficult to say what is the origin of the geothermal activity in northeast Callfornia and Nevada. It is clear that it is connected with the great outpourings of lava but 1t 18 not clear what 18 the origin and history of these....

In spite of doubts about the meaning of geothermal phenomena in some areas, the suggestion that there are two main environments for igneous activity is a useful unifying concept in considering the phenomena. For any particular example it ls useful to isk:. 'Is this a place where the crust 18 splitting and new material is being added to the plate in the form of basaltic lavas and intrusions, or is it a place where the plate is being destroyed and melted and andesitic lavas are working their way to the surface? [1]

\section{Geothermal Energy and GNP}

The countries which lie within the world's geothermal regions are 1isted in Figure 4.7.6. This figure also includes certatn parameters which are germane to foreign pollcy aspects of geothermal energy: In particular, the amount of energy consumed and the amount of energy produced by these nations in terms of equivalent coal tonnage, as well as the ratio of these two parameters which 


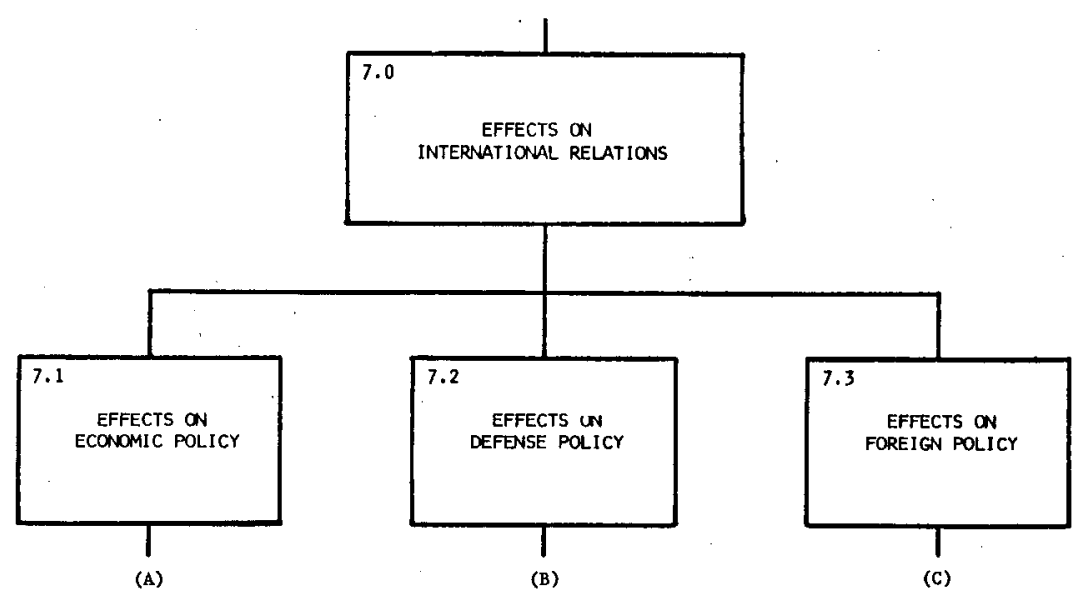

FIgure 4.7 .1

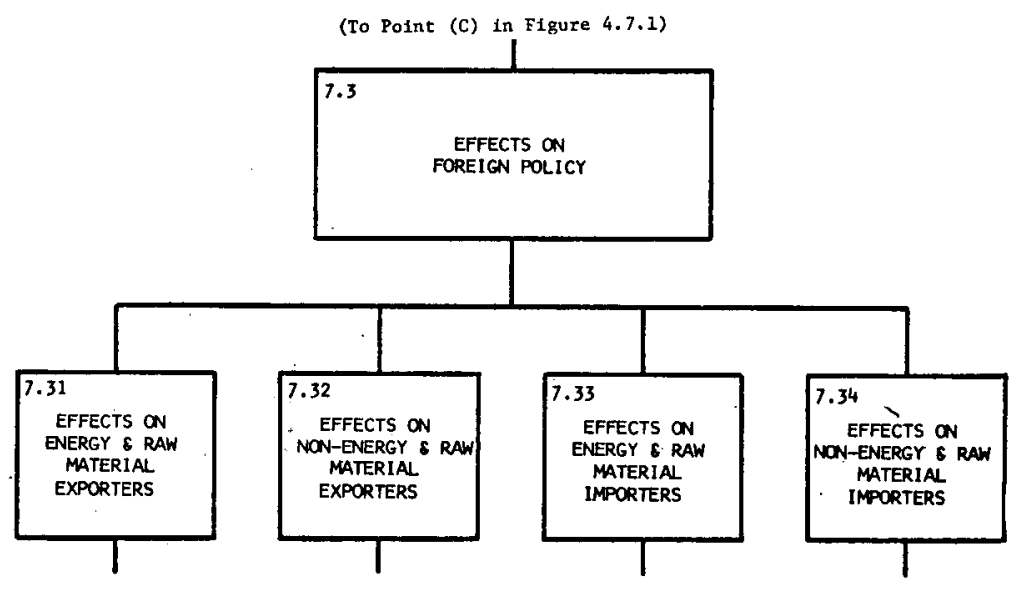

Figure 4.7 .2 


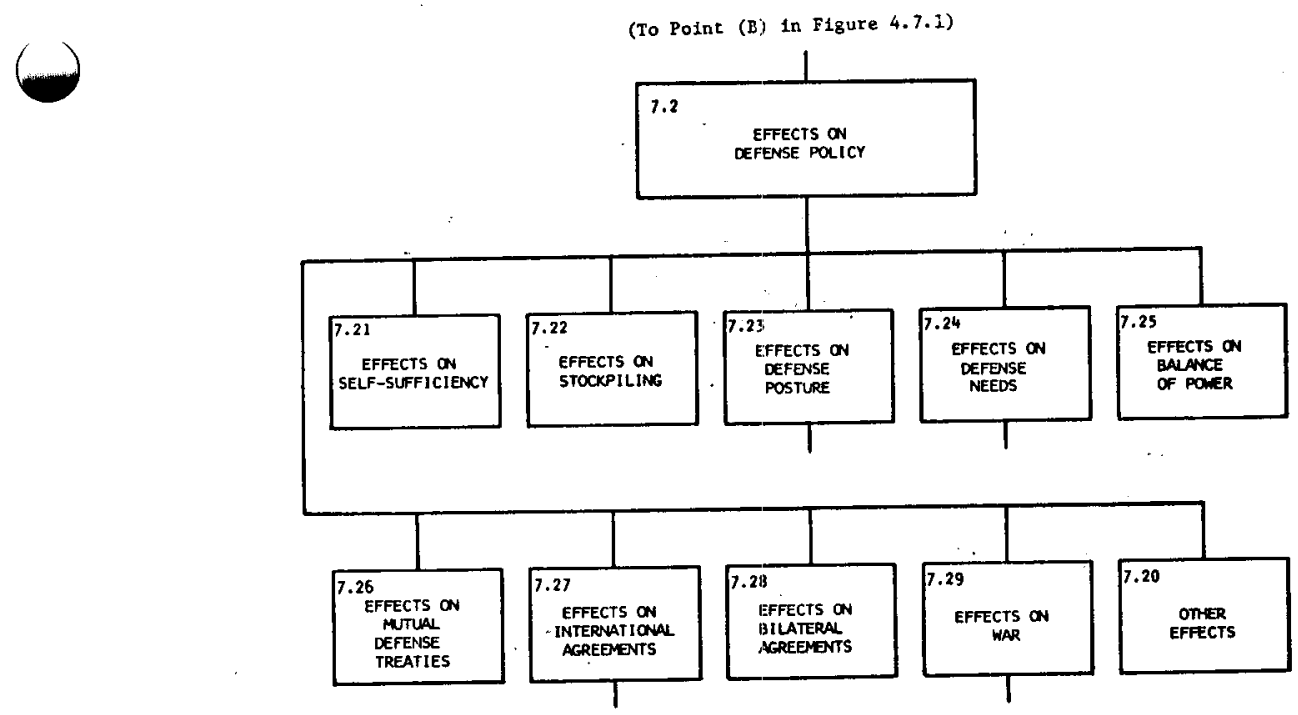

F1.gure 4.7 .3

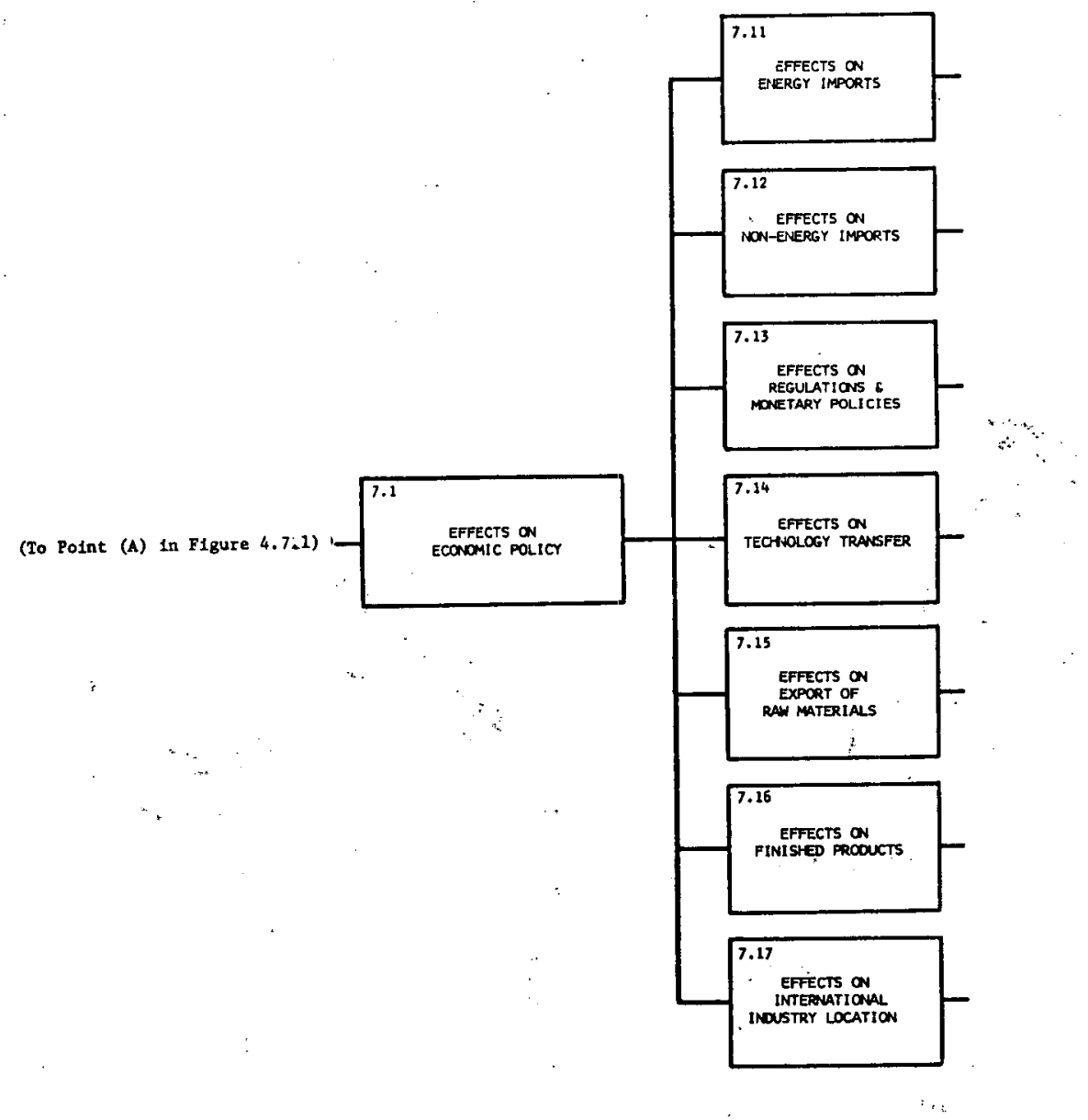

Pigure 4.7 .4 


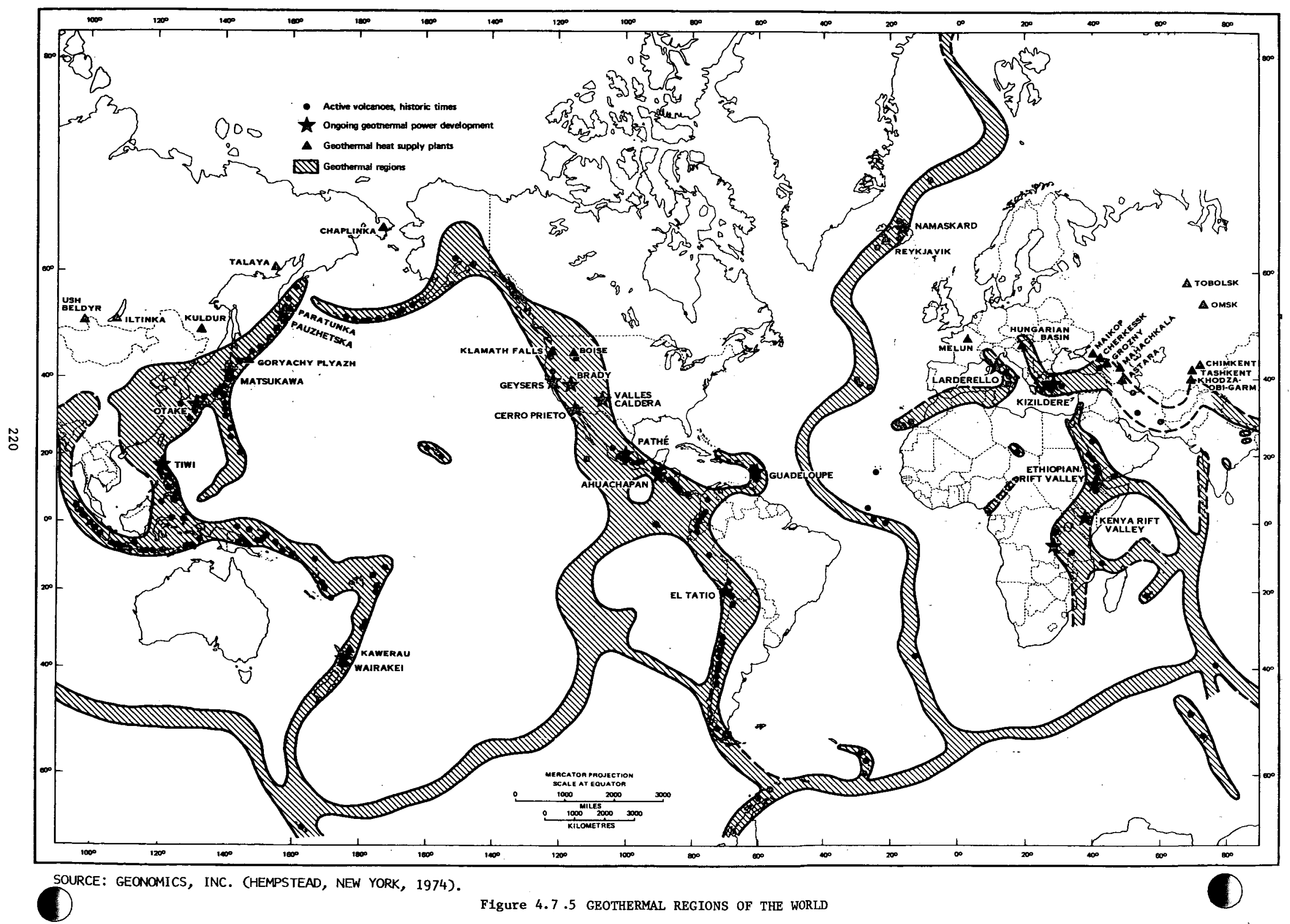




\begin{tabular}{|c|c|c|c|c|c|c|c|c|}
\hline REGION AND COUNTRY & $\begin{array}{c}\text { POPULATION } \\
\text { (THOUSANDS) } \\
1969\end{array}$ & $\begin{array}{c}\text { GNP } \\
\text { (MILLIONS } \\
\text { US DOLLARS) } \\
1969\end{array}$ & $\begin{array}{c}\text { GNP PER } \\
\text { CAPITA } \\
1959\end{array}$ & $\begin{array}{c}\text { ENERGY } \\
\text { PRODUCTION } \\
\text { (MIL. METRIC } \\
\text { TONS - COAL } \\
\text { EQUIVALENT) } \\
1969\end{array}$ & $\begin{array}{c}\text { ENERGY } \\
\text { OONSLMPIION } \\
\text { (MIL. METRIC } \\
\text { TONS - COAL } \\
\text { EQUIVALENT) } \\
1969\end{array}$ & $\begin{array}{c}\text { CONSUMPTION } \\
\text { PER CAPITA } \\
1969\end{array}$ & $\begin{array}{l}\text { GEOTHERMAL } \\
\text { DEVELOFMENT }\end{array}$ & $\begin{array}{l}\text { FRACTION } \\
\text { INDIGENOUS } \\
\text { PRODUCTION } \\
\text { OF } \\
\text { CONSUMPTION }\end{array}$ \\
\hline AFRICA & & & & 383.4 & 100.9 & 291 & & \\
\hline ALGERIA & 13,349 & 3,675 & 275 & 62.2 & 6.3 & 470 & & .99 \\
\hline BURUNDI REPUBLIC & 3,475 & 188 & $=\$ 4$ & - & .03 & 9 & & 0 \\
\hline EGYPT (ARAB REPUBLIC OF) & 32,501 & 6,100 & 188 & 17.26 & 7.18 & 221 & & 2.40 \\
\hline ETHIOPIA & 24,769 & 1,612 & 65 & .03 & .57 & 23 & $x$ & .05 \\
\hline KENYA & 10,506 & 1,431 & 136 & .04 & 1.56 & 148 & $x$ & .03 \\
\hline MALAWI & 4,398 & 272 & 62 & .01 & .18 & 41 & & .06 \\
\hline MOROCCO & 15,050 & 3,108 & 207 & .71 & 2.93 & 195 & & .24 \\
\hline MOZAMBIQUE & 7,376 & 1,549 & 21.0 & .31 & 1.24 & 169 & & .25 \\
\hline RHODESIA & 5,090 & 1,303 & 256 & 3.74 & 2.87 & 564 & & 1.30 \\
\hline RWANDA (REPUBLIC OF) & 3,500 & 262 & 75 & .01 & .12 & 268 & & .08 \\
\hline SOMALI DEMOCRATIC REPUBLIC & 2,730 & 175 & 6.4 & 0 & .07 & 27 & & 0 \\
\hline SUDAN & 15,186 & 1,725 & 11,3 & .02 & 1.52 & 100 & & .01 \\
\hline TANZANIA & 12,926 & 1,245 & 96 & .04 & .74 & 58 & & .05 \\
\hline TUNISIA & 5,027 & 1,162 & 231 & 4.84 & 1.25 & 248 & & 3.87 \\
\hline UGANDA & 8,360 & 1,122 & 11.8 & .09 & .50 & 53 & & .18 \\
\hline ZAIRE (REPUBLIC OF) & 915 & 183 & 2000 & .42 & 1.39 & 81 & $x$ & .31 \\
\hline ZAMBIA & 4,170 & 1,667 & 4010 & .44 & 2.14 & 509 & & .20 \\
\hline AMERICA, NORTH & & & & 2140.5 & 2375.2 & 10,585 & & \\
\hline CANADA & 21,089 & 68,710 & 3260 & 188.1 & 185.4 & 8,794 & & 1.01 \\
\hline UNITED STATES & 203,213 & 947,805 & 4664 & 1952.4 & 2189.4 & 10,774 & $\mathbf{x}$ & .89 \\
\hline AMERICA, CENIRAL \& CARIBBEAN & & & & 342.5 & 121.5 & 1,009 & & \\
\hline BRITISH HONDURAS & 120 & 49 & 41.0 & -- & .06 & 483 & & 0 \\
\hline COSTA RICA & 1,685 & 821 & 487 & .10 & .56 & 331 & & .18 \\
\hline DOMINICAN REPUBLIC & 4,174 & 1,272 & 305 & .01 & .97 & 232 & & .01 \\
\hline EL SALVADOR & 3,390 & 945 & 279 & .06 & .53 & 156 & $x$ & .11 \\
\hline GUADELOUPE & 323 & 174 & 540 & -- & .16 & 483 & $x$ & 0 \\
\hline GUATEMALA & 5,014 & 1,645 & 328 & .02 & 1.17 & 234 & & .02 \\
\hline HAITI & 4,768 & 405 & 85 & -- & .15 & 31 & & .02 \\
\hline HONDURAS & 2,495 & 646 & 25,9 & .02 & .57 & 230 & & .04 \\
\hline MARTINIQUE & 329 & 229 & 690 & -- & .17 & 518 & & 0 \\
\hline MEXICO & 48,933 & 29,370 & 6000 & 53.4 & 51.1 & 1,044 & $x$ & 1.05 \\
\hline NICARAGUA & 1,915 & 728 & $38: 0$ & .04 & .63 & 328 & & .06 \\
\hline PANAMA & 1,417 & 917 & 647 & .01 & 1.91 & 1,348 & & .01 \\
\hline PUERTO RICO & 2,754 & 4,468 & 1622 & .02 & 8.45 & 3,068 & & 0 \\
\hline AMERICA, SOUTH & & & & 67.2 & $107 . \dot{6}$ & 696 & & \\
\hline ARGENTINA & 23,983 & 19,860 & 828 & 31.45 & 37.03 & 1,544 & & .85 \\
\hline BOLIVIA & 4,804 & 901 & 188 & 2.66 & 1.05 & 218 & & 2.53 \\
\hline CHILE & 9,566 & 6,156 & 64.4 & 7.43 & 11.58 & 1,210 & & .64 \\
\hline COLOMBIA & 20,463 & 6,181 & 30.2 & 19.77 & 12.10 & 591 & & 1.63 \\
\hline ECLADOR & 5,890 & 1,644 & 279 & .33 & 1.59 & 270 & & .20 \\
\hline PERU & 13,172 & 5,124 & 38.9 & 5.98 & 8.20 & 623 & & .73 \\
\hline VENEZUELA & 10,035 & 9,639 & 961 & 256.2 & 21.6 & 2,153 & & 11.86 \\
\hline ASIA - MIDOLE EAST & & & & 824.1 & 64.1 & 636 & & \\
\hline IRAN & 27,892 & 9,110 & 327 & 219.9 & 15.7 & 562 & & 14.60 \\
\hline IRAQ & 9,150 & 2,693 & 294 & 98.0 & 5.83 & 623 & & 16.81 \\
\hline ISRAEL & 2,822 & 4,729 & 1676 & 3.57 & $\quad 6.08$ & 2,154 & & .59 \\
\hline JORDAN & 2,217 & 575 & 259 & $\because$ & .68 & 308 & . & 0 \\
\hline LEBANON & 2,700 & 1,435 & 531 & .11 & 1.82 & $\Rightarrow 689$ & 。 & .00 \\
\hline SALOI ARABIA & 7,520 & 2,790 & 388 & 197.0 & 5.44 & 755 & & 36.21 \\
\hline SYRIAN ARAB REPUBLIC & 5,866 & 1,600 & 273 & 2.98 & $: \quad 2.80$ & 477 & & 1.06 \\
\hline TURKEY & 34,375 & 13,016 & 380 & 11.23 & 15.85 & 461 & $x$ & .71 \\
\hline
\end{tabular}

F1gure 4.7 .6 


\begin{tabular}{|c|c|c|c|c|c|c|c|c|}
\hline REGION AND COUNTRY & $\begin{array}{c}\text { POPULATION } \\
\text { (THOUSANDS) } \\
1969\end{array}$ & $\begin{array}{c}\text { GNP } \\
\text { (MILLIONS } \\
\text { US DOLLARS) } \\
1969\end{array}$ & $\begin{array}{c}\text { GNP PER } \\
\text { CAPITA } \\
1969\end{array}$ & $\begin{array}{c}\text { ENERGY } \\
\text { PRODUCTION } \\
\text { OMIL. METRIC } \\
\text { TONS - COAL } \\
\text { EQUIVALENT) } \\
1969\end{array}$ & $\begin{array}{c}\text { ENERGY } \\
\text { CONSLMPTION } \\
\text { (MIL. METRIC } \\
\text { TONS - COAL } \\
\text { EQUIVALENT) } \\
1969\end{array}$ & $\begin{array}{c}\text { CONSUMPTION } \\
\text { PER CAPITA } \\
1969\end{array}$ & $\begin{array}{l}\text { GEOTHERMAL } \\
\text { DEVELOPTENT }\end{array}$ & $\begin{array}{l}\text { FRACTIQN } \\
\text { INDIGENF } \\
\text { PRODUCT } \\
\text { OF } \\
\text { CONSUPTION }\end{array}$ \\
\hline ASIA (EXCEPT MIDDLE EAST) & & & & 235.8 & 486.0 & 437 & & \\
\hline AFGHANISTAN & 16,516 & 1,400 & 85 & 2.89 & .43 & 26 & & 6.72 \\
\hline BURMA & 26,980 & 1,990 & 74 & 1.04 & 1.55 & 58 & & .67 \\
\hline INDIA & 536,984 & 47,670 & .89 & 88.4 & 103.76 & 193 & & .85 \\
\hline INDONESIA & 117,610 & 12,070 & 104 & 52.3 & 11.4 & 98 & & 4.59 \\
\hline JAPAN & 102,321 & 166,394 & 1626 & 59.19 & 289.4 & 2,828 & $x$ & .20 \\
\hline NEPAL & 10,845 & 868 & 80 & .01 & .12 & 11 & & .07 \\
\hline PAKISTAN & 126,740 & 16,510 & 129 & 5.59 & 11.80 & 93 & & .47 \\
\hline PHILIPPINES & 37,158 & 8,138 & 219 & .28 & 9.68 & 261 & $x$ & .3 \\
\hline TAILAN (REPLBLIC OF CHINA) & 13,800 & 4,770 & 340 & 6.32 & 12.06 & 874 & & .52 \\
\hline EUROPE & & & & $541.9 *$ & $1245.5^{\times}$ & $3,525 x$ & & \\
\hline$\overline{\text { BULGARIA }}$ & 8,434 & 8,540 & 1013 & 16.04 & 29.45 & 3,491 & & .54 \\
\hline CZECHOSLLVVAKIA & 14,418 & 26,010 & 1804 & 77.43 & 88.24 & 6,120 & & .88 \\
\hline FRANCE & 50,320 & 140,050 & 2783 & 61.79 & 177.17 & 3,518 & $x$ & .35 \\
\hline GREECE & 8,835 & 8,395 & 950 & 2.46 & 10.16 & 1,150 & & .24 \\
\hline HUNGARY & 10,295 & 11,280 & 1096 & 21.99 & 29.73 & 2,888 & $x$ & .74 \\
\hline ICELAND & 203 & 383 & 1870 & .11 & .70 & 3,453 & $x$ & .16 \\
\hline ITALY & 53,170 & 82,330 & 1548 & 25.31 & 129.24 & 2,431 & $x$ & .20 \\
\hline POLAND & 32,555 & 34,900 & 1072 & 150.21 & 131.92 & 4,052 & & 1.14 \\
\hline ROMANIA & 20,010 & 16,010 & 800 & 56.47 & 52.58 & 2,628 & & 1.07 \\
\hline YUGOSLAVIA & 20,351 & 12,296 & 604 & 19.89 & 25.29 & 1,243 & & .79 \\
\hline OCEANIA & & & & 57.5 & 69.8 & 3,901 & & \\
\hline NEW GUINEA & 1,715 & -- & - & -- & .17 & 105 & & 0 \\
\hline NEW ZEALAND & 2,777 & 5,326 & 1918 & 3.17 & 7.28 & 2,623 & $x$ & .44 \\
\hline CHINA (PEOPLE'S REPUBLIC OF) & 746,460 & - & - & 387.8 & 392.2 & 505 & & .99 \\
\hline U.S.S.R. & 240,567 & 285,710 & 1188 & 1138.6 & 1010.2 & 4,199 & $x$ & 1.13 \\
\hline
\end{tabular}

XEXCEPT EASTERN EUROPE.

SOURCES: STATISTICAL YEARBOOK, 1970 22ND EON. (NEW YORK: UNITED NATIONS, 1971); HANOBOOK OF INTERNATIONAL TRADE AND DEVELOPMENI STATISTICS, 1972 (NEW YORK: UNITED NATIONS, 1972).

Figure 4.7 .6 (Cont.)

Is a measure of energy self-suffictency of the various countries. This ratio is plotted against GNP per capita for each country in Figure 4.7.7. Several inferences can be drawn from this figure:

- All countries within the geothermal zone which have GNP per capita greater than $\$ 1500$ per person have Indigenous geothermal projects.

- Those countries within the geothermal zone which have a low ratio of energy produced to energy consumed more frequently have geothermal projects.

The locus formed by the points representing the countries of Ethiopia, Zaire, Turkey, Mexico, and the USSR Is Interesting indeed. All countries with geothermal projects fall below this 1ine; none fall above. One can imagine an explanation for this situation: at a given GNP per capita level the country with the worst energy balance $1 \mathrm{~s}$ more likely to pursue the development of its geothermal resources. For conventence the EthIopia-USSR I1ne on Figure 4.7.7 is called the "selfsufficiency threshold" in the discussion which follows.
A11 other things being equal, countries 11kely to pursue important-scale geothermal projects on their own are those lying within the world geothermal region which also have relatively high GNP per capita and fall below the self sufficiency threshold. These countries are:

$$
\begin{aligned}
& \text { Israel } \\
& \text { Czechoslovak1a } \\
& \text { Puerto Rfco }
\end{aligned}
$$

Countries 11kely to pursue important-scale geothermal projects with moderate external assistance are those lying within the world's geothermal region which have mid-range GNP per capita ( $\$ 500-1500$ per capita) and fall below the self-suffictency threshold. These countries include:

$\begin{array}{ll}\text { Panama } & \text { Poland } \\ \text { Lebanon } & \text { Hungary } \\ \text { Chile } & \text { Bulgaria } \\ \text { Yugoslavia } & \text { Greece } \\ \text { Argentina } & \text { Martinique } \\ \text { Romania } & \text { Guadeloupe }\end{array}$

Countries which are within the world geothermal region, which have relatively low GNP per capita (less than $\$ 500$ 


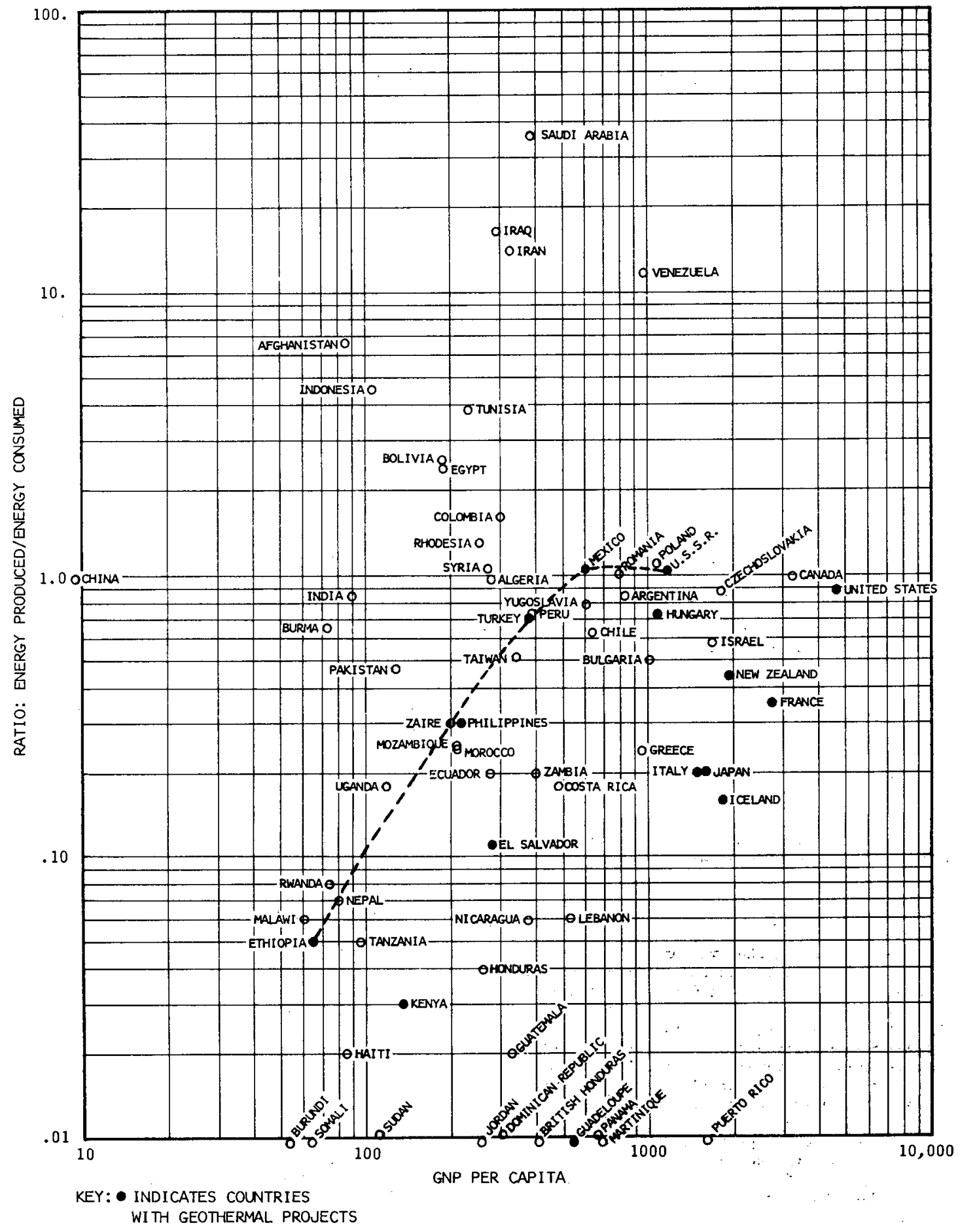

F1gure 4.7.7 GNP PER CAPITA VS. RATIO OF ENERGY PRODUCED TO ENERGY CONSUMED FOR SELECTED COUNTRIES WITH GEOTHERMAL POTENTIAL (1969 DATA) 


\begin{tabular}{|c|c|c|c|c|}
\hline \multirow{3}{*}{ YEAR } & \multicolumn{3}{|c|}{ A M OUN T OF } & \multicolumn{1}{c|}{ E N E R G Y } \\
\cline { 2 - 5 } & \multicolumn{2}{|c|}{ MNE } & \multicolumn{2}{c|}{$\begin{array}{c}\text { ANWUAL MILLI INS OF BARRELS } \\
\text { OF OIL EQUIVALENT }\end{array}$} \\
\cline { 2 - 5 } & BASE & ACCELERATED & BASE & ACCELERATED \\
\hline 1973 & .40 & .40 & 4.21 & 4.21 \\
1976 & .73 & .73 & 7.68 & 7.68 \\
1979 & 3.59 & 4.10 & 37.78 & 43.15 \\
1982 & 4.82 & 9.26 & 50.73 & 97.46 \\
1985 & 6.58 & 19.50 & 69.25 & 205.24 \\
1988 & 13.39 & 36.79 & 140.93 & 387.21 \\
1991 & 24.68 & 59.74 & 259.76 & 628.76 \\
1994 & 54.67 & 96.94 & 575.40 & 1020.29 \\
1997 & 108.33 & 158.44 & 1140.17 & 1667.58 \\
2000 & 188.11 & 249.22 & 1979.85 & 2623.04 \\
\hline
\end{tabular}

FIgure 4.7.8 OПL EQUIVALENT OF GEOTHERMAL ENERGY

per person) and which fall below the self-sufficiency threshold, are clearly countries which might benefit greatly from technological assistance. These countries include:

$\begin{array}{ll}\text { Sudan } & \text { Tanzania } \\ \text { Dominican Republic } & \text { Costa Rica } \\ \text { Guatemala } & \text { British Honduras } \\ \text { Honduras } & \text { Haiti } \\ \text { Nicaragua } & \text { Burundi Republic } \\ \text { Zambia } & \text { Somali Democratic } \\ \text { Ecuador } & \text { Republic } \\ \text { Mozambique } & \text { Jordan } \\ \text { Morocco } & \text { E1 Salvador } \\ \text { Nepal } & \text { Ethiopia } \\ \text { Kenya } & \end{array}$

Several countries lie on the border of the selfsufficlency frontier and their further development is 1ikely to increase their interest in geothermal projects within the next few years. These countries include:

$\begin{array}{ll}\text { Malawi } & \text { Peru } \\ \text { Rwanda } & \text { Pakistan } \\ \text { Uganda } & \text { Indonesia }\end{array}$

Now some specific impacts in the area of international relations will be reviewed in detall.

\section{Impact of Geothermal Energy on Trade}

If Instead of developing geothermal energy in the United States, the United States substituted petroleum and petroleum products for the production of electricity and for space heating, all other things being equal, the amount of ofl required would be on the order of 2000-2600 million barrels per year. Figure 4.7.8 presents the ofl equivalent of geothermal energy used in the production of electricity, both for the base case and for the accelerated program case.

To put these numbers in perspectlve, the U.S. petroleum supply from domestic sources was about 9.2 million barrels per day in 1973, and total consumptIon was 17 million barrels per day. of this, 6.1 million barrels per day were Imported and 1.7 million barrels per day came from natural gas liquids. Assuming that the Alaska North Slope brings in from 2 to 2.8 million barrels per day and that offshore petroleum production brings in between 1.6 and $2: 7$ million barrels per day by 1980 , a reasonable expectation of the domortic oil produced ranges from 8.9 to 13.6 million

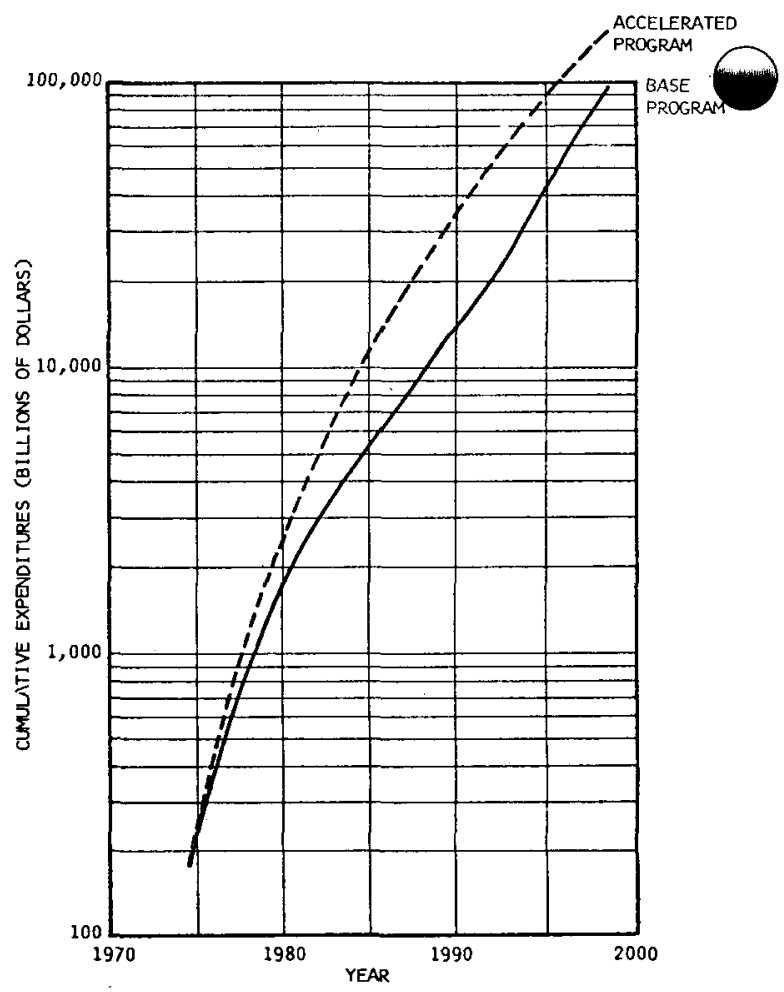

Figure 4.7.9 IF THE FORECASTED AMOUNT OF GEOTHERMAL ELECTRICITY WERE PRODUCED BY OIL COSTING $\$ 10 / \mathrm{BBL}$, IT WOULD HAVE REQUIRED THE CUMULATIVE EXPENDITURES SHOWN HERE

barrels per day [2]. Assume for the moment that the upper estimate is correct for 1980 and that this figure, through new discoveries and improvements in secondary recovery techniques, remains constant unti1 the end of the century. The barrels of oil equivalent which geothermal energy represents is about 1 percent of domestic production by 1980 and about 40 percent of domestic production by the year 2000. Had that ofl been purchased overseas at a cost of $\$ 10 / \mathrm{bbl}$., its cumulative cost by the year 2000 would have been about $\$ 100$ billion for the base case and $\$ 160$ billion for the accelerated program (assuming \$10/bbl.). (F1gure 4.7.9.)

As pointed out in Section 3.6 and illustrated in Figure 3.6.3, it is unlikely that geothermal energy will substitute for petroleum as a fuel for the generation of electricity; geothermal energy is much more likely to substitute for coal and nuclear sources in the world envisioned.

\section{Effect on Coal Exports}

Figure 4.7.10 summartzes the effect of various geothermal programs on demand for coal for the production of electricity. By the year 2000 an "accelerated" geothermal program can have the effect of lowering the requirement for coal by 278 million short-tons in that year. This amount of coal would presumably be available for conversion into other forms of fuel or for export.

Our coal exports are extremely important to other countries. For example, the United States normally exports about 10 percent of its total coal production (e.8., 50- 
COAL FOR ELECTRICITY

(1000 MWE)

\begin{tabular}{|l|c|c|c|c|}
\multicolumn{5}{c|}{ (1000 MWE) } \\
\hline PROGRAM & 1976 & 1985 & 1994 & 2000 \\
\hline NO GEOTHERMAL & 176.3 & 307.30 & 569.05 & 787.18 \\
\hline BASE & 176.3 & 305.05 & 550.82 & 695.00 \\
\hline ACCELERATED & 176.3 & 303.13 & 534.93 & 671.37 \\
\hline
\end{tabular}

COAL FOR ELECTRICITY

MILLIONS SHORT TONS (240 TONS/MNH)

\begin{tabular}{|l|c|c|c|c|}
\hline \multicolumn{1}{|c|}{ PROGRAM } & 1976 & 1985 & 1994 & 2000 \\
\hline NO GEOTHERMAL & 424 & 739 & 1368 & 1893 \\
\hline BASE & 424 & 734 & 1324 & 1671 \\
\hline ACCELERATED & 424 & 729 & 1286 & 1615 \\
\hline
\end{tabular}

TONS OF COAL "SAVED" OVER NO GEOTHERMAL CASE (MILLIONS SHORT TONS)

\begin{tabular}{|l|c|c|c|c|}
\hline \multicolumn{1}{|c|}{ PROGRAM } & 1976 & 1985 & 1994 & 2000 \\
\hline NO GEOTHERMAL & 0 & 0 & 0 & 0 \\
\hline BASE & 0 & 5 & 44 & 222 \\
\hline ACCELERATED & 0 & 10 & 82 & 278 \\
\hline
\end{tabular}

Figure 4.7.10

million tons out of 545 million in 1968). About half of our exports go to Japan; in 1971 we shipped 25 million tons to that, country. Coa1 accounts for 23 percent of the totall energy consumed In Japan and our coal exports provided 6 percent of that total. By the year 2000 Japan's energy demand w11l probably have Increased by a factor of 3 to 4; because of the growing scarcity and increasing costs of petroleum, Japan will undoubtedly put more rellance on other energy sources including indigenous geothermal; nuclear, and imported coa1. By developing geothermal energy in the United States our country w111 be in a better position to meet the demands of other developed countries for coal.

If 1 t is assumed that coal costs will average \$15 per ton between now and the end of the century (this is probably a very conservative estimate), a total of between $\$ 13$ and $\$ 20$ bilition of favorable trade can be reallzed through the export of coal displaced by geothermal power. The cumulative income from the export of displaced coal is presented in FIgure 4.7.11; in the year 2000 the coal exported in the "accelerated" program would bring about $\$ 4$ billion Into the Untted States. (For comparison, exports of goods and services in 1972 totaled $\$ 73$ billion.)

\section{Geotherma1 Energy and Wor1d Food}

It is possible that geothermal energy can, In small measure, help alleviate the world food problem. There are several reasons why the food situation in the near future may be worse than in the recent past.

- World population is currently ápproaching 4 biliton and world population growth rate exceeds 2.2 percent per year.

- Many demographers and soclologlsts expected that as the affluence of riationg grew, their

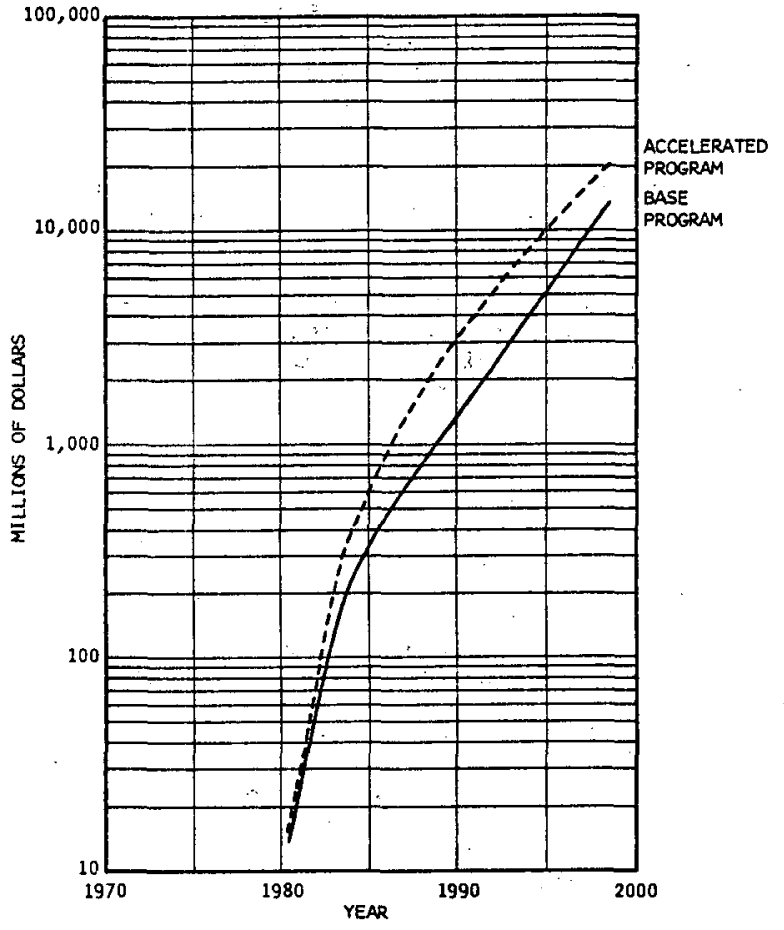

Figure 4.7.11 CUMULATIVE INCOME REALIZED THROUGH COAI EXPORTATION (IF THE FORECASTED AMOUNT OF GEOTHERMAL ELECTRICITY IS PRODUCED, IT WILL PARTIALLY SUBSTITUTE FOR COAL. IF DISPLACED COAL IS EXPORTED, THE CUMULATIVE INCOME [AT \$15/TON] WOULD BE INCREASED AS SHOWN.)

birth rates would fall. However, in some instances this has not proven to be the case.

- Eighty-five percent of the grain exported in the world comes from North America. Because of this concentration, a climatic disturbance could have extremely deletertous consequences.

- The "green revolution" whIch significantly" increased yields in several countries, including Mextco; the PhIlippines, and Japan, requires more intensive use of fertllizers and Insecticides.' With the Increasing costs of petroleum-derived raw materials and competition for these raw materlals, countries which have come to rely on energyintensive agriculture may be hard pressed: to find or afford suffictent agricultural chemicals.

- As levels of affluence rise in the world, food shtfts from more basic cereals to less efflclent forms of protein. Th1s w111 place an additional burden on grain production. For example; a cow ralsed for beef consumes 7 grams of proteln for every $u$ gram of proteln produced.

- Several technologies have been proposed for increasing ylelds and for manufacturing synthetic proteln; however, these do not promise to be avallable in sufficlent time to alleviate world hunger on a large scale. 
- The basic problem is an economic one: The hungry nations are ones that can least afford to pay for needed food or agricultural improvements.

What can geothermal energy do? Some of the potential agricultural applications of geothermal energy have already been described in Section 4.2. For the most part, these were applications whlch had some measure of attractiveness for entrepreneurs in the United States. However, there are additional applications of geothemal energy which could well be-important in Increasing the avallability of food in developing nations. Some of those applications are described be10w.

In the most general sense, geothermal energy can be used for heating, drying, distillation, refrigeration, and de-icing; in addition, the geothermal fluids themselves could prove useful. Dragone and Rumi have described their plans to bulld low-cost modular greenhouses using geothermal waters as the primary heat source [3]. They Intend to use polyethylene pipes for the heating of soil and a simple heat exchanger in which natural steam is used to heat the closed loop greenhouse water to the desired temperature. If such Bys tems could be made Inexpensively enough, perhaps through the use of vinyl plastic covering over structural plastic frames, developing countrles might use geothermally heated hothouses for raising certain fruits and vegetables, and perhaps most importantly, for the initial cultivation of tree seedilngs. Lindal estimates that in temperate climates fossil fuel costs represent 15-20. percent of the price of food grown in greenhouses.. Where geothermal energy can be substituted, greenhouse farming: can be economical [4]. Hungary had 400,000 square meters of greenhouses by the end of 1969 and planned to double this figure in the early $1970^{\prime} \mathrm{s}$. Iceland by 1970 had 110,000 square meters; the USSR, 20 million square meters [5]. Japan and New Zealand also have hothouses which are warmed by geothermal:energy

Inexpensive hothouse technology would be most important to countrles and regions which have geothermal resources and which lie outside of the tropical or temperate zones; for example, Alaska, Canada, Japan, and the Soviet Union.

It is possible that food productivity could be increased in the northern temperate regions of the world through soll warming. Boersma reported that corn sllage ylelds Increased by 45 percent, tomatoes by 50 percent, soybean:a1lage by 60 percent, and buss beans by 39 percent compared to ylelds in untreated Bo11 [6].

Geothermal water can be mixed with cooler surface waters to achleve a desirable temperature for hatchIng and ralsing fish. In both. Iceland, where salmon are ralsed to the smolt stage, and Japan, where eels are bred $1 \mathrm{n}$ an inland hatchery, this technique has proven effective. $\therefore$ Some other agricultural uses of geothermal energy include:

- Heating animal buildings such as cattle otalls, milking rooms, p1g sties, and chtcken houses.

- Providing heat to speed blodegradation of animal wastes.

- Washing and drying of wool.

- Producing dried milk, casein, and sucrose.
- Drying of fish meal and timber.

- Canning of food.

- Evaporation in sugar refining.

- Producing fresh water through distillation.

- Drying of organic materials such as fish stock, seaweed, grass, vegetables, etc.

- Refrigerating to reduce spoilage of vegetables and fruit.

\section{Weapons Implications}

Section 2.4 discusses the Interests of the Department of Defense. In geothermal energy for providing sources of rapidly mobile power in approprlate regions of the world. It is doubtful whether drilling and winning of geothermal flulds could ever be routine enough to have tactical Importance.

There are other areas, however, in which geothermal resources potentlally have strateglc Impilcations. Valfells has pointed out that geothermal steam represents an ideal raw materlal for producing heavy water [7]. The light water moderated pressurlzed reactor and the bolling water reactors beling used in the United States and elsewhere require enriched uranium as a fuel. Nonnuclear nations can obtain enriched urantum for power production through the IAEA, but unless these nations Intend to develop an enrichment Industry, which is quite expensive, they must remain dependent on other nations for their supply of fuel. If heavy water is used as a moderator, natural uranium can be used in a power reactor. This. may lead some nations in this direction if heavy water can be obtained inexpensively. (Indeed, Canada, India, and Argentina are doing this now.) One of the outputs of a heavy water reactor is plutontum, which can be used in fast-breeder reactors or, given the appropriate technology, in weapons.

Using a $\mathrm{H}_{2} \mathrm{~S} / \mathrm{H}_{2} \mathrm{O}$ isotope exchange process with geothermal steam supplying the process heat, heavy water can be produced at a savings of $10-15$ percent over other methods.

There is another possibility which seems extremely Improbable, but because of its importance should be mentioned when considering the international implications of the development of geothermal energy, the use of earthquakes as a weapon, which has been described by Gordon J. F." MacDonald, formerly of President Johnson's Sclence Advisory Committee. He wrote:

The use as a weapons sytem of the strain energy instability within the solid earth requires an effective triggering mechanism. The scheme for pumping water seems clumsy and easily detectible. On the other hand, if the strain pattern in the crust can be accurately determined, the phased or timed release of energy from smaller faults, designed to trigger a large fault at some distance, could be contemplated. This timed release could be activated through small explosions and thus it might be possible to use this release of energy stored In small faults at some distance from a major fault to trigger the fault.... [8]

Knowledge of how to detect, irack, and work with underground faults as required by the evolution of geothermal energy, particularly the hot dry rock form of the 
ragource, leads in this improbable direction. These ski11s and the new technology which they engender, probably Improve the ability to detect deep underground nuclear explosions.

\section{Relations with 011 Producing Countries}

It is an interesting fact that most important oil producing countries are also on the list of countries lying within the geothermal zone. Iran, Iraq, Saudi Arabla, Indonesta, Venezuela: All of these countries have geothermal potential. The development of these resources will probably take place under circumstances different than those in other countries. The central question here is how can geothermal resources be useful in the extraction and processing of petroleum? The literature is poor in this area even though high temperature steam and electricity can be used effectively in the refineries.

The notion of using hot geothermal brines as an energy source for secondary petroleum recovery should not be overlooked. Where both deposits occur in juxtaposition, it might be possible to lower the viscosity of petroleum and Increase the pressure on the deposit by introducting heated geothermal brines into the petroleum fleld.

The development of these spectal technologies could be the focus of technology transfer programs.

\section{Summary}

In summary, then, the most important impacts on international relations brought about by geothermal energy are:

1. The opportunity for forging new alliances on the basis of technology transfer.

2. The decreasing U.S. dependence on 1mported energy sources.

3. The U.S. ability to export more coal as a result of the domestic substitution of geothermal energy for coal in the generation of electricity.

4. The use of geothermal energy to improve, to a small degree, world agriculture.

5. The possibility, far downstream, of geothermal energy technology providing insight into a new form of strategic weaponry and underground nuclear explosion detection.

\section{REFERENCES}

[1] Bullard, Edward, "Basic Theorles," Geothermal Energy: Revlew of Research and Development (Par1s: UNESCO, 1973).

[2] Adelman, M., et al., "Energy Self-Sufficiency: An Economic Evaluation," Technology Review (May 1974).

[3] Dragone, G., and 0. Rum1, "P1lot Greenhouse for the Utilization of Low-Temperature Waters," Geothermics (Pisa: CNR, 1970), p. 918.

[4] Lindal, B., "Industrial and other App1ications
[5] The USSR figure was quoted by $G$. Dragone and 0 . Rumi in "Pflot Greenhouse for Utilization of LowTemperature Waters," Geothermics (P1sa: CNR, 1970), and was in reference to Anton Juk, AA., "Use of Geothermal Waters in Agriculture (in Russia)" (Moscow: USSR Academy of Sciences, 1963).

[6] Boersma, L., "Warm Water Utilization," Conference on Beneficial Uses of Geothermal Discharges (New York State Department of.Conservat1on, 1970).

[7] Valfells, A., "Heavy Water Production with Geothermal Steam," Geothermics (P1sa: CNR, 1970), p. 896 .

[8] MacDona1d, Gordon J. F., "How To Wreck the Environment," in Nigel Calder (ed.), Unless Peace Comes (New York: Viking Press, 1968), p. 196.

\section{of Geothermal Energy," Geothermal Energy (UNESCO, \\ of Geothermal
1973), p. 143.}




\subsection{Effects on the Enylronment}

Geotherma1 energy has been halled as a "clean" energy source by some advocates and has been recommended as an environmentally desirable alternative source of power. Geothermal energy produces no radloactive wastes, generates no products of combustion, and has no requirement for extraction of fuel, with 1 ts secondary Impacts. Nevertheless, development of geothermal energy resouxces has the potential for altering the environment in several ways. Some of these may be of the nutsance varlety, but others may be more serfous and lasting. For example, while geothermal installations can be nolsy and potentlally unsightly, improper design or operation might result in other more serlous impacts such as emission of noxious

gases, land surface subsidence, alteration of groundwater characteristics, or seismic instability. The interplay between such environmental considerations and program elements is explored in this section.

Figure 4.8.1 below illustrates the spectrum of primary and higher order environmental impacts which may result from the development of geothermal resources. While only a single branch of the tree is presented, all major geothermal sources were included in this study.

To aid in identifying potentially major environmental impacts, a series of matrices were constructed using a technique based on that of Leopold, et al. [1] The matrix is constructed using two checklists: (1) major activities involved in geothermal resources development--such as exploration, production drilling and testing with parallel fleld development operations, plant construction, and operation; and (2) pertinent aspects of the environment.

The first dimension of the matrix, i.e., operations pertinent to field development, plant construction, and operation of a geothermal system, 1nvolves the following five "Major Activity Groups."

Exploration. Field development naturally begins with an exploration phase, which consists of geological studies, test drilling, and small-scale access provision. Elements of this group include:
- Mapping and field studies

- Driliing and construction

- Test drilling (shallow and small diameter)

- Temporary roads and traffic

- Equipment operation

- Abandonment (temporary or permanent).

Production Drilling and Testing. Where field development 1s.to proceed beyond the exploration phase, or where existing field capacity is to be expanded, a production well drilling and testing phase is conducted. (Parallel field development activities carried out at the same time comprise a separate phase.) Specific well-related elements include:

- Well drilling and construction (production and reinjection)

- Well st1mulation

- Accidental blowouts

- We11 testing/venting/ponding/reinjection.

Parallel Field Development Operations. A number of concomitant activities also take place either for new field developments or expansion of existing fields:

- Land clearing and road construction; vehicular trafific

- Gathering systems (pipeline) construction

- Equipment activities

- Service living quarters

- Water, sewage, temporary electricity, and other supporting services development.

Plant Construction. Construction of a power plant is considered a separate phase of activity, 1nvolving an integrated set of activities:

- Structures and improvements

- Vehicular traffic/equipment activities

- Special construction activities as required, such as blasting

- Electric transmission systems construction

- Supporting services, such as water lines, labor camp factlities, etc.

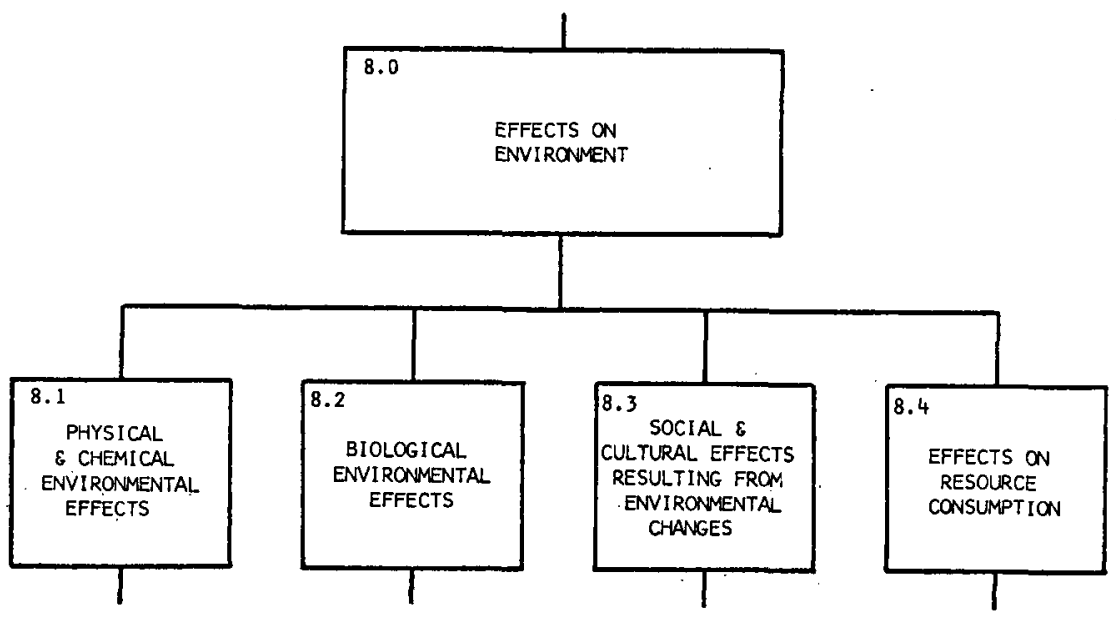

Figure 4.8.1 
Fr1-scale Operation. A number of elements characterhormal operational activities at a geothermal

d/power plant complex, These include:

- Cooling tower operation

- Venting (during short-term outages)

- Wellhead bleeding

- Reinjection

- Recharge, stimulation, and redrilling

- Corrosion and scale control

- Gaseous, liquid and solid waste discharge and/or removal

- Work force movement

- Abandonment

The second dimension of the matrix involves "Aspects of the Environment" and includes the following:

Physical and Chemfical. Physical impacts upon the land, water, and air resources have been considered, even though the exact nature of the secondary consequences to 1 ife systems from these disruptions w111 vary from site to site. In addition, when disturbances in a1r quality or regional seismic stability occur, the exact importance or extent of damages to plant and animal itfe (including man) is rarely definable in a quantitative manner. These disruptions may be regarded as potential environmental impacts to man even though thefr effects can only be generalized. Particular impact areas include:

- Air quality

- Noise

- Water quality--surface

- Water quality-groundwater

- Soils and eroston

- Land subsidence

- Seismicity.

Biological. Potential impacts upon the aquatic and terrestrial biota have been considered. Special attention has been given to life cycle and habitat disruptions, and potential hazards to rare and unique species and/or ecosystems in the following areas:

- Terrestrial flora and fauna

- Wetlands and marshes

- Aquatic flora and fauna.

Social and Cultural. Potential 1mpacts upon human well-being were considered here as well as el'sewhere in this impact analysis (see Sections 4.2, 4.3, and 4.6, particularly). In particular, the environmental impacts were taken to include:

- Land use consistency/water use consistency

- Scenic/aesthetic

- Safety

- Services burden (implying potentlal for economic and fiscal impacts to less populated regions).

Given such a matrix of. geothermal activities versus potential environmental impacts areas, the five types of resources were reviewed in the following sequence: (1) vapor-dominated systems; (2) liquid-dominated systems; (3) hot dry rock; (4) geopressured zones; and (5) magma systems.

\section{Vapor-Dominated Systems}

a development of vapor-dominated systems, even in iminary stages such as exploration, production drilling and testing, may involve potentially major environmental impacts (see Figure 4.8 .2 on the following page). In these and 1ater stages, impacts of potentially major importance are nolse, noxious gas emissions (e.g., hydrogen sulfide, sulfur dioxide, ammonia, radio-nuclides), and potential pollution of surface and subsurface waters. The disruption of previously undeveloped areas by activities associated with the development of geothermal energy is also a potentially sensttive Issue.

\section{Physical and Chemical Impacts.}

Afr Quality. The release of toxic substances to the atmosphere is of concern to many scientists, many of whom urge further research in controlling gaseous and particulate emissions. A summary of gaseous products known to be associated with various geothermal systems is presented in Figure 4.8 .3 on the following page. Hydrogen sulfide is of special concern because of its offensive odor and extreme toxicity. nther toxic substances such as boron, fluorides, and selenium which can be carried from the cooling towers as "drift-loss" can also contaminate surrounding land areas. Significant amounts of hydrogen sulfide exist in most vapor-dominated systems and control of its emission is needed, Special concern is warranted where hydrogen sulfide is released into areas which experfence frequent air stagnation or temperature inversions. In these areas hydrogen sulfide might reach severe nuisance or even toxic levels, especially near the facility itself.

The toxic level for man is .002 percent $\mathrm{H}_{2} \mathrm{~S}$ in air, by volume. At the Geysers (Calffornia) the level of $\mathrm{H}_{2} \mathrm{~S}$ in undiluted geothermal steam is .033 percent and at Lardere1lo, Italy, 049 percent. The U.S. Department of the Interior calls $\mathrm{H}_{2} \mathrm{~S}$ "the most prominent environmental hazard" and says, "although removal of noxious gases is chemically possible using various techniques, the ecoñomic justification of such systems remains to be established."[2] No deaths of plant personnel from $\mathrm{H}_{2} \mathrm{~S}$ poisoning are mentioned. In any of the 11terature reviewed for this report.

At the Pacific Gas and Electric Company's Geysers power station, prototype hydrogen sulfide gas scrubbers are under development and are expected to be operational within two to three years. Inttial research indicates 70-90 percent of cooling gas $\mathrm{H}_{2} \mathrm{~S}$ emissions can be economically removed and that the necessary control technology will be developed, within the next 12 years (see Section 3.3). Promlsing technlques include reacting the hydrogen sulfide with appropriate oxidizing agents, or utilizing a closed-loop process in which the energy can be extracted without releasing the contaminants at the surface. However, until such research is suffictently advanced and the needed equipment is operatlonal, noxious gas emissions at geothermal'sites will continue to be a major environmental consideration. In their geothermal environmental impact statement, [2] the USDI reported as follows on other constituents of the geothermal gases:

On ${ }^{2}$ the basis of volume percent In und Isturbed geothermal steam; ammonia $\left(\mathrm{NH}_{3}\right)$ would appear to present the second greatest hazard, being 5 times the toxic level in steam at The Geysers and over 6 times the toxic level in steam at Larderello. Ammonia, however, is 11ghter than air and 1s inot concentrated locally. Ammonia is readily soluble in water (as in airborne water droplets) forming anmonium hydroxide $\left(\mathrm{NH}_{4} \mathrm{OH}\right)$. It $1 \mathrm{~s}$ therefore rapidly returned to earth as rainfall where it readily is combined with soll materials and plant 


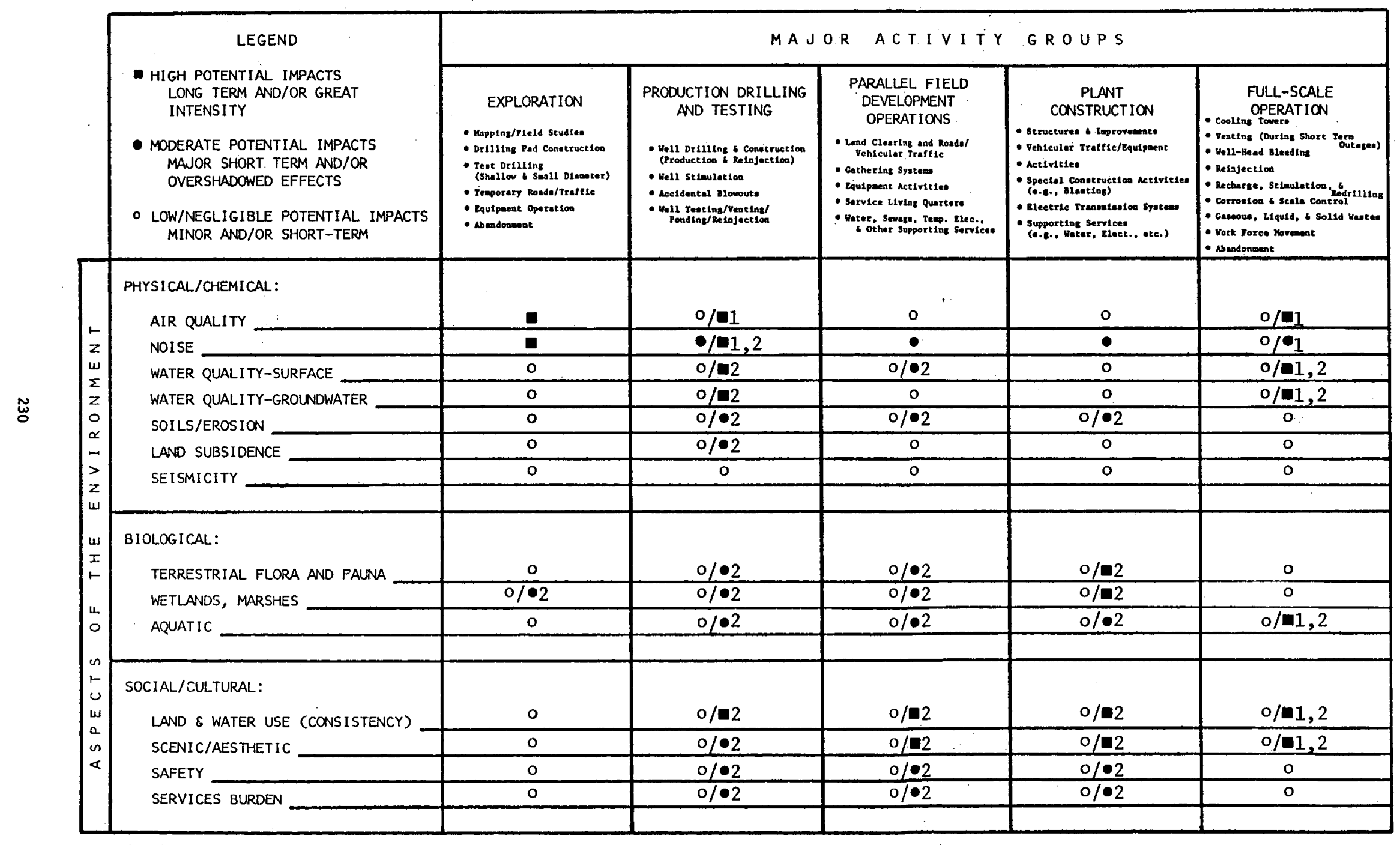

\footnotetext{
$1=$ TECHNOLOGY DEVELOPMENT $2=$ SITE DEVELOPMENT
} 


\begin{tabular}{|c|c|c|c|c|}
\hline 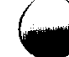 & $\begin{array}{c}\text { GEYSERS* } \\
\text { Cal1forn1a }\end{array}$ & $\begin{array}{l}\text { LARDERELLO* } \\
\text { Italy }\end{array}$ & $\begin{array}{l}\text { MATSUKAWA** } \\
\text { Japan }\end{array}$ & $\begin{array}{l}\text { NAMAFJALL } * * * \\
\text { I celand } \\
\end{array}$ \\
\hline $\mathrm{H}_{2} \mathrm{O}$ & 98.045 & 98.080 & 99.87 & 99.43 \\
\hline $\mathrm{CO}_{2}$ & 1.242 & 1.786 & 0.18 & 0.18 \\
\hline $\mathrm{H}_{2}$ & 0.287 & 0.037 & 0.01 & 0.19 \\
\hline $\mathrm{CH}_{4}$ & 0.299 & & & 0.01 \\
\hline $\mathrm{N}_{2}$ & 0.069 & 0.0105 & & 0.05 \\
\hline A & & & 0.03 & \\
\hline $\mathrm{H}_{2} \mathrm{~S}$ & 0.033 & 0.049 & & 0.14 \\
\hline $\mathrm{NH}_{3}$ & 0.025 & 0.033 & & \\
\hline $\mathrm{H}_{3} \mathrm{PO}_{4}$ & 0.0018 & 0.0075 & & \\
\hline \multicolumn{5}{|c|}{ 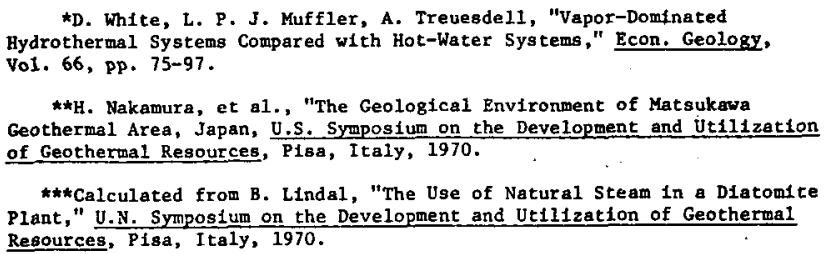 } \\
\hline
\end{tabular}

SOURCE: Office of the Secretary, U.S. Department of the Intertor, Final Environmental Statement for the Geothermal Leasing Program, Vol. 1

FIgure 4.8.3 EXAMPLES OF GASES ASSOCIATED WITH VARIOUS GEOTHERMAL SYSTEMS IN VOLUME PERCENT

acids, which are beneficial as natural fert1lizer.

Carbon dioxide in undiluted geothermal steam would not present a danger, as the noncondensable gas fraction vented into the atmosphere would act as a single gas and component separation would not take place. Adequate ventilat1on w11l prevent any danger from this gas.

Methane $\left(\mathrm{CH}_{4}\right)$ is a natural product of organic decay. It is present at about one-fifth the toxic level in The Geysers steam and normally could not collect to toxic concentrations, since it is lighter than air....

Bortc acid is present throughout the natural environment and comprises about .026\% of the volume of sea water, a slightly higher con-. centration than boric acid in.the geothermal steam at The Geysers, but less than that found in the steam at Larderello, Italy. Boric acid is found in higher concentrations in some hot springs and has been extracted commerclally from bedded ar1d lake deposits, and from saIine lake brines in San Bernadino County, California. It 18 doubtful that this compound as an aerosol would present a health or safety problem at geothermal area if geothermal brines are disposed of properly.

Mercury is a known constituent of some geothermal fluids and may be present in oufficient quantities to pose a health hazard at some locations. High concentrations of mercury have been found in areas of hot springs, mud volcanoes, and in brines from a petroleum fleld in California, a1though recent work by Barnes and others (1973), has indicated that mercury deposits in northern Calffornia could not have originated by deposition of mercury from present thermal waters....

Because of mercury's tendency to vaporize, the atmosphere near ore deposits may contain as much as $.02 \mathrm{mg} / \mathrm{m}^{3}(2.4 \mathrm{ppb})$ atmosphere by rain. The mercury content of this rainwater averages $0.2 \mathrm{ppb}$. The mercury from other sources generally is held tightly in organic and inorganic materials in the upper 2 inches of solls. Mercury apparently is removed from surface waters in large part by absorption on clays and on hydrous oxides of iron and manganese, and also by algae and plankton. Also, the presence of sulfide and reducing conditions w11l concentrate mercury in the sediments.

Higher concentrations of mercury are likely to occur in underground waters because of longer and more intimate contact of water with mineral grains, and other factors. Limited sampling of oil field brines and petroleum from California showed them to contain from 1000 to $500,000 \mathrm{ppb}$ mercury. Hot springs range generally from undetectable levels of mercury to $3.2 \mathrm{ppb}$; however, one measurement of $20 \mathrm{ppb}$ has been recorded. Vapors lssuing from fumaroles and steam condensates from hot springs have been shown to contain up to $130 \mathrm{ppb}$ mercury. Condensable steam from the McKinley steam field at Castle Rock Spring, Lake County, California, near the Geysers steam fleld, contains from 1 to $3 \mathrm{ppb}$ mercury. This $1 \mathrm{~s}$ below the maximum level of mercury constdered safe for drinking water which has been proposed by the U.S. Public Health Service at $5.0 \mathrm{ppb} . .$.

Although mercury is not considered as essentlal food materlal for organisms, methyl mercury, being soluble in water, is aval1able for incorporation into the body tissues of organlams in the aquatic environment and secondarily into terrestrial predators, such as man. The concentration of mercury by living things may accumulate by way of the food chain, or by direct assimilation frotn the surrounding medium. In any event, if It accumulates in sufficient concentration in Ifving tisgue, it can become extremely toxic. Aquatic organisms, as we11 as man, w1ll concentrate mercury within their bodies only when the intake rate exceeds the elimination rate. This will result in a bulldup with time to the extent that accumulated mercury can become toxic and, eventually, lethal....

As a result of the Japanege and other experiences, a tentative upper limit of $\mathbf{5 . 0}$ ppb of mercury in drinking water has been proposed by the U.S. Public Health. Service. This maximum is thought to be safe for human health when total probable mercury 
intake rates of physiological processes and excretion rates are taken into account. The Food and Drug Administration has declared that f1sh and other foods that contain more than $500 \mathrm{ppb}$ mercury are unflt for human consumption.

During production testing, considerable monitorIng and analytical work will be necessary and required to determine the quantity of mercury vapor and other potentially toxic substances present in geothermal fluids at each field, to evaluate the potential hazard which 1 ts presence may create, and to establish the control measures to be imposed to assure meeting environmental and public health and safety requirements.

Radium and radon are known to be assoclated with certain geothermal manifestations, particular $1 y$ hot springs..... Radium precipitates from solutions under oxidfdizing conditions with carbonates, iron, and perhaps silicates, and if present in hot-water geothermal systems may accumulate in the scale that builds up in wells and pipelines. Ordinarily, it is very doubtful that a buildup of radium in scale, would be greater than that associated with natural tufas and sinters around hot springs and geysers; however, Its presence in pipeline scale could conceivably pose a health and safety hazard around steam transmission pipes and power plants after several years of operation.

Radon, a gaseous radloactive decay product of uranium, has a halflife of 3.82 days and, being gaseous, will escape into the atmosphere through any natural or artificial opening. A small amount of radon would be a component of the noncondensable gas fraction of the steam; however, it ordinarily would pose no health and safety hazard as it would be dispersed into the atmosphere with a very short halflife. About 122 tons of radon gas escape to the atmosphere dally on a worldwide basis from natural sources, and buildups of radon gas are quite conmon where it becomes trapped beneath air inversion layers in the atmosphere. If inversion conditions were prevalent for an extended period of time over a geothermal area, the resultant buildup of radon gas would add only slightly to man's total radiologlcal burden from other natural sources such as rocks and soils. However, monitoring will be required at each lease site to assure public health and safety protection.

No1se. Nolse is an unavoldable adjunct in the developopment of all geothermal systems. Ambient noise levels are increased by truck and other traffic, by steam ventIng, well drilling, and by other plant activities. Driling activities and venting of compressed air and steam have been the principal sources of nolse in vapordominated geothermal ffelds. Excessive nolse levels may adversely affect the health and safety of humans in the area of a geothermal plant and may disrupt wildlife population distributions and breeding patterns. Recent research has produced a considerable improvement in the control of nolse associated with the development and operation of geothermal plants. The effectiveness of mufflers, such as those being tested at Cerro Prieto, Mexico, and The Geysers in California, have indicated significant progress toward reducing nolse to the levels specified in. the current guldelines. [2] It is predicted that adequate solutions to noise problems will be avallable and installed within 5 years (see Section 2.3). A summary of noise levels at The Geysers is presented in Figure 4.8.4.

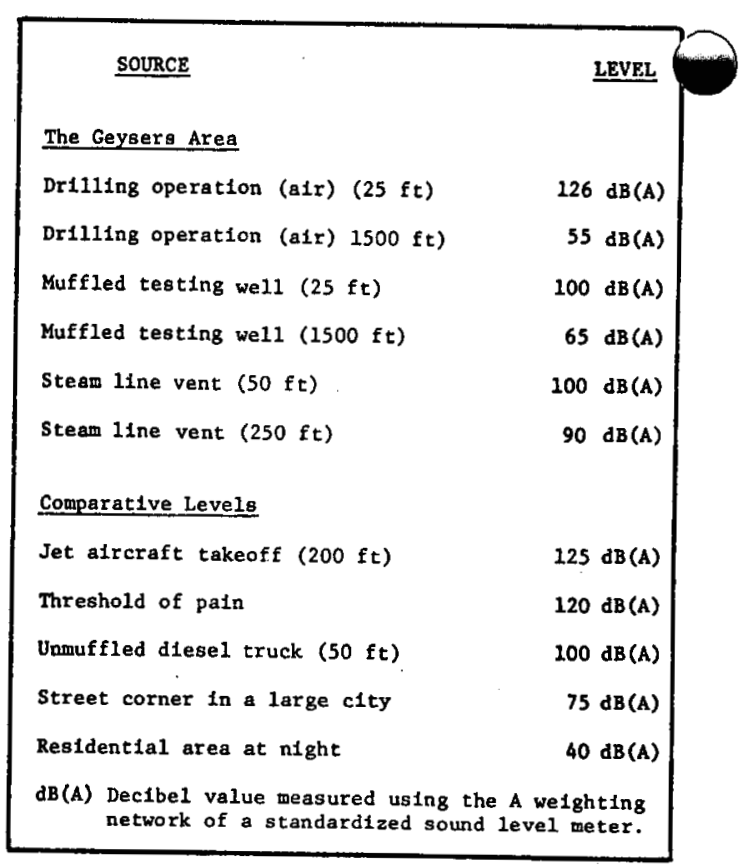

SOURCE: U.S.D.I., 1973, P. III-24.

Figure 4.8.4 COMPARISONS OF NOISE LEVELS BETWEEN THE GEYSERS GEOTHERMAL AREA AND OTHER NOISE SOURCES

Water Quality-Surface and Groundwater, Solls and Erosion, Land Subsidence, and Selsmicity. While temporary alterations of surface water, groundwater, and so11 quality may occur during the exploration, dril1ing, testing, and plant construction phases, these Impacts are expected to be minor if kept under control. The high boron content of the geothermal fluids at The Geysers has required reinjection of flutd wastes rather than their release into surface streams. Based on past experience at The Geysers, Impacts such as land subsidence and seismictiy may pose relatively few problems at vapor-domfnated flelds, although specific site evaluation for these problems will be necessary.

\section{Blological Impacts}

Terrestrial Flors and Fauna, Wetlands, Marshes, and Aquatic. Since the fuel cycle for geothermal power is centralized at the field site, and does not require such support activities as mining, fuel processing and transportation, biological impacts should be restricted to the vicinity of the plant and well sites and along transmission line corridors. Some unknown factors, however, do exist regarding the nature of the impacts on local biota. A finite area of habitat will be pre-empted by the facilities, and increased human activities may create additional nolse, disturbances, and barriers to animal movement and migration. In addition, some damage to spectes of plants and antmals could occur through the possible release of toxic industrial materials through the destruction of very spectalized habitats (such as alplne meadows), and through the release of toxic gases to the atmosphere. [3] These factors clearly need study in selected vapordominated geothermal areas, In order to determine the procedures needed for adequate protection of blota inthe affected regions. 
nsistency. Major social and cultural impacts concern problems of 1 and use consistency, aesthetics and safety. Alteration of land use is a potentially serious consideration which requires specific site evaluation. A relatively large land conmitment of approximately $0.5-1.0$ square miles will be required to support a 100-500 MWe vapor-dominated power plant. The geographical regions with the greatest number of Known Geothermal Resource Areas (KGRA's) are located primarily in undeveloped regions of the western United States. These same wilderness areas, however, are also among the more environmentally sensitive. Land use conflicts are therefore likely to exist within many of the KGRA regions, Challenges to industrial use of ten develop where such land use is not so designated prior to development. Compatible multiple use, where possible, may be one of the only methods to satisfy both environmental and industrial interests, but adequate planning methods and long term commitments are often necessary, before compatible use can be developed. (See Section 4.6, for example.) As with many large utility projects, safety considerations may limit multiple use, particularly for those activities involving public access.

Scenic and Aesthetic. Aesthetic impacts may be particularly troublesome where unspoiled areas are likely to be developed. With importance often placed on aesthetic quality in these areas for recreational purposes, impacts due to the removal of vegetation and soil cover during road building and plant construction, and the net visual impact of the plant, wells, and collector pipelines will all require consideration. The impacts affect not only the site of the geothermal development but attendant areas as well, such as linear corridors occupied by access roads and power transmission lines. The extent of the visual impact will vary, depending on the size of the plant, topography, vegetative cover, and proximity to populated areas or major travel routes. As the size of the facilities increases, the potential for adverse impact will also increase.

Safety. One of the environmental hazards experienced in test drilling in particular is a well blowout, during which vapor and/or hot water escape uncontrolled from the well. Such occurrences are present in ofl and gas drilling as well, but have the additional hazard of fire. Control is difficult but possible and blowouts are expected to be infrequent. A blowout can cause noise, waste of the resource, air contamination, surface and ground water pollution, and the potential for bodily injury to field crew.

The U.S. Department of the Interior in their Final Environmental Statement for the Geothermal Leasing Program provided historical data on the subject of potential blowouts.[2] At Wairakei, New Zealand, approximately 100 wells were drilled during "the pioneer years"; two of these were abandoned because of blowouts during drilling and another blew out after some years of service. There was no loss of life. Safety measures have been introduced at the Wairakei fields and these measures have proven generally effective. [4]

After the production drilling was completed at Wairakei in 1964, extensive exploratory drilling took place elsewhere in New Zealand. Seventy-eight wells were drilled, and although in several cases the bores reached pressure prematurely, there were no notable blowouts. [5] Equipment was not damaged nor were there personnel injuries.

At Lardare1lo, Italy, blowouts are handled routinely, T) are viewed as a "nolsy, difficult part of the regular operations, requiring highly competent drill crews, and are not considered serious mishaps that could cause pollution or have other adverse effects." It is not unusual to experience rapld uncontrolled releases or blowouts of steam and water during drilling when the hydrostatic head inside the well falls below the external pressure of the steam. The crews at Lardarello have developed techniques to cope with these occurrences and to bring such wells under control. [6]

At The Geysers fields, three blowouts had been reported by February 1973. One of these blowouts which was "attributed to a combination of inadequate casing and minor landsliding, has been a continuing noisy nuisance since 1957. A loss of $\$ 125,000$ per year is attributed to this wastage. It is estimated that this blowout, during the past 15 year period, has emitted more than 9 million tons of steam and about 4000 tons of hydrogen sulfide, 5000 tons of ammonia, and 6000 tons of methane to the atmosphere."[2]

In January 1970 a well blew out through a nearby fissure after a period of heavy rains. This blowout was controlled within ten days by injecting cement into the casing. In January 1973 a minor landslide occurred after a heavy period of rain; apparently this landslide ruptured the casing of the well and the steam explosion followed which formed a crater 50 feet in diameter. While control measures have not yet been succesful, the U.S. Department of the Interior expects that this blowout will be controlled.

At Cerro Prieto in Mexico, two blowouts have occurred, one of which was apparently caused by "mechanical failure due to vibrations in the wellhead equipment." The blowout was controlled by directional drilling and cement injection.

The second blowout was attributed to "improper casing cementation and wellhead construction." It lasted for approximately four months and was first manifested as a large crater emitting water and steam about 300 feet from the well. Within several days there was a violent blowout around the wellhead itself.

In summary, the U.S. Department of the Interior feels that, "although blowouts can be expected to occur, the probability of a significant blowout at any particular location can be greatly reduced as a result of technological refinements, drilling control measures, and increased operating experience."[2]

\section{Liquid-Dominated Systems}

Hot water systems are thought to be thermally driven convective systems in which meteorfc water percolating down an inclined aquifer is heated by a deep, local heat source and driven upward. Where this upwelling penetrates the surface, hot springs, geysers, and other thermal phenomena occur. These geothermal reservolrs frequently contain high concentrations of salts, trace metals, and a variety of other often undesirable contaminants.

Major problems of both pressurized hot water and steamflashed systems involve the handling and disposal of the often saline geothermal fluids (see Figure 4.8.5 on the following page): These fluids are of ten highly corrosive and can seriously pollute surface streams and aquifers if improperly confined, treated, or dispersed. The primary disposal method being constdered is reinjection of the spent fluids into the geological formation. 


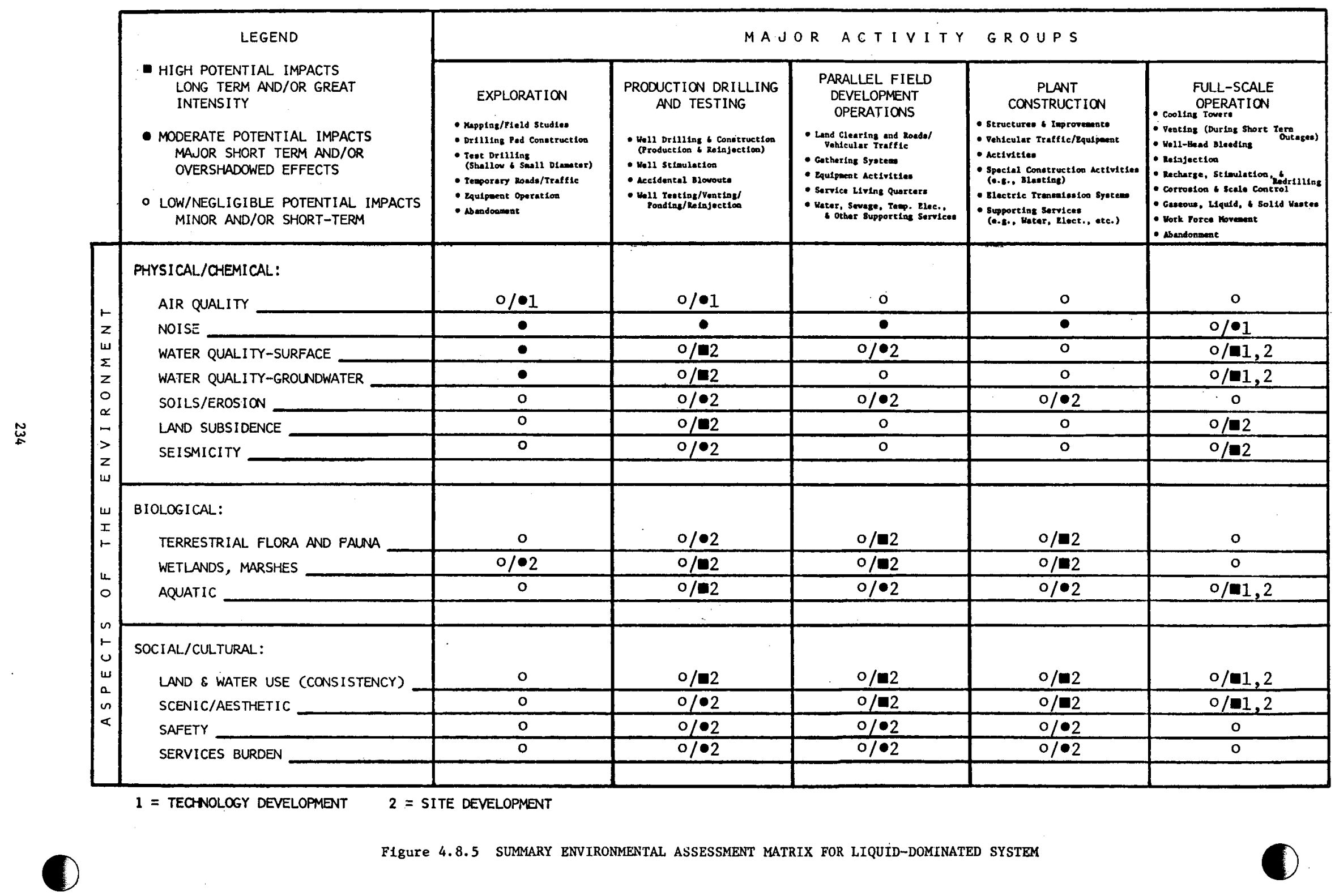


Quality. Minor we11 blowouts could lead to a1r quality problems during exploration and production drilling and testing phases. Potential for dust and related construction problems can exist as well as those problems delineated earlier for vapordominated systems.

Notse. Noise levels may be as significant a problem in the operation of liquid-dominated resources as in vapordominated systems.

Groundwater Quality. Groundwater contamination from leakage, spillage, or pollution of penetrated freshwater aquifers, are potentially serious problems, particularly during the production drilling and testing phase. Where disposal of spent thermal fluids is to take place through reinjection, it must be demonstrated that usable groundwater will not be contaminated and that precipitation of solids, which would clog passages and restrict flow, will not occur. If percolation of brines from holding ponds is allowed to occur, the potential for groundwater quality alterations is significant and constitutes a potentially major impact.

Land Subsidence. The problem of land surface subsidence, as a result of prolonged geothermal fluid withdrawal from shallow geothermal formations, is a potentially major impact of the development of water-dominated systems in areas such as Calffornia's Imperial Valley. Much of the current knowledge on the causes and effects of: subsidence has been derived from the exploitation of 011 and gas resources and from intensive pumping of groundwater. [7] If large quantities of fluids are removed from an underground reservoir which has an unconsolidated overburden, the land surface may slowly collapse and sink. This may change the surface topography enough to threaten the operation and structural integrity of nearby facilities, such as irrigation systems and earthen dams.[8] Records indicate however, that subsidence is relatively unusual [9], and has only been noted at one geothermal field, Wairakei, New Zealand. There, the subsidence occurs in part of the geothermal field itself.

The best known method of preventing subsidence is by injection of fluids, usually waste water, back into the underground reservolr. Based on experience in the Imperial Valley in southern Californla, Dutcher, Hardt, and Moyle [10], report that subsidence can be minimized or prevented by ef ther natural or artificial recharge. This requirement for injection fluid is potentially serious in locations where water would have to be imported from outside the area to supplement the spent geothermal flulds [9].

At present there is no reliable technique for predicting the potential for subsidence in advance. Monitoring of fluid pressure and land surface changes must be initiated before actual water extraction takes place. Development of pre-exploratory monitoring programs will be a major requisite for an environmentally sound geothermal development program.

The Bureau of Land Reclamation will monitor possible land subsidence in its East Mesa, Imperial Valley project. For this purpose they are setting up a very elaborate system of benchmarks. These will be used to measure subsidence and lateral movement.[11] On the issue of reinjection, the USDI has said in its environmental impact statement (1973):

Deep wel1 injection is the emplacement of wastes within the earth, usually below the water table and beneath a confining stratum which serves to 1solate the wastes from potable water supplies or other valuable or potentially valuable resources. The feasibility of injecting liquid wastes deep within the earth is suggested by the enormous volume of subsurface fluid storage space. The earth, however, contains little empty space so waste 1iquids may have to be accommodated by compressing or displacing existing fluids (including injections into depleted reservoirs) or by compressing or deforming the surrounding strata.... The possible adverse effects of high pressure waste injection include the displacement of saline waters distant from the injection site, the fracturing of geologic strata that could result in pollution of high quality zones, the migration of wastes and native fluids along existing or created fractures, the upward transfer of pollutants along well cast gs, and even the gross readjustment of the surrounding strata. The injection of fluids within the earth is concerned not only with hydrostatics but involves also the distribution of the initial pressure increases and their effects on the surrounding rock matrix. Chemlcally unstable wastes may produce heat and pressure after being injected, and these wastes may react with the flutds and minerals of the injection horizon, changing the permeability or strength of the surrounding strata. DeterminIng the compatibility of the waste solution and the fluids and minerals of the injection horizon requires careful study. The identification of strata where injection may be feasible may be difficult.

Currently there are two distinct types of deep well injection practiced in the United States. The flrst, and by far the largest in terms of number of wells and volume of fluids injected, is the return of brines and other fluids to the aquifers from which they were extracted. This is a common practice in the oil and gas industry, where 9 million barrels per day[12] of wastes are injected through many thousands of we1ls in the oil-producing states. Another type of deep well injection: is that involving liquid industrial (including geothermal), municipal, or low-level radioactive wastes. Currently a minor practice compared to the reinjection of brines; however, the number of industrial and municipal waste injection: wells is increasing rapidly.

Brine reinjection has been practiced by the petroleum industry for over 50 years, both in waterflooding for the secondary recovery of cill and as a means of disposal of the brines associated with the production of oil. Ideally, the brines are reinjected into the strata from which they were produced, not only disposing of great volumes of liquid material but also preventing land subsidence and facilitating greater ofl production. In the reinfection of oil-field brines, the most difficult problems are expected to be associated with confining the flutds to the desired strata....

Seigmicity. Major and minor faults are common in many of the areas with geothermal potentlal (e.g., Imperlal Valley of California). Exploration of the exact loca- 
tion and activity of these faults and related seismic activity is another task which should precede the development of geothermal energy flelds. Evaluation must be specific for each site.

of particular concern is the effect of the injection of fluids on seismic activity. Although experience and research on this problem is limited, available tnformation Indicates that selsmic activity can be induced by Increasing hydrostatic pressure in subterranean flulds near a fault [10]. Since future goethermal developments in this country are expected to dispose of waste water by reinjection into the geothermal reservoir or other strata, consideration of possible selsmic effects is required [8]. Seismlc occurrences triggered by injection of flutds can be minimized by avoiding the more tectonically active sites. This may severely restrict the development of some promising geothermal resources, since geothermal reservoirs tend to be found in seismically active areas.

Relevant data on the relationship between seismicity and liquid injection were accumulated in a study by Raleigh and others [13] near Denver, Colorado. Routine injection of fluids in a deep disposal well $(12,000$ feet) was carried out for 18 months (March 1962September 1963), then halted for a similar duration. The cycle was repeated over a period of years, during which seismic activity was continuously monitored. The frequency of local earthquakes was found to increase during periods of liquid injection, and to decrease to prior levels when injection ceased. [14] Although it was pointed out that the experiment had no control, and that the earthquakes might have occurred even if injection had not occurred, a causal relationship between seismic activity and injection of fluids was strongly indicated.

The science of earthquake prediction is still in the very early states of development, but researchers express hope for progress in the near future. Work in this country and in the Soviet Union Indicates that it is 1ikely that the time and place of some earthquakes will be predictable within the next five years (see Section 3.3).

The USDI has suggested that the tapping of geothermal energy may reduce the probability of large earthquakes:

The association of earthquakes with geothermal areas is not surprising, as active tectonism or intrusion would provide the conditions necessary for geothermal phenomena. The role of fluid pressure changes in triggering earthquakes is not as well known, but the possibility of generating earthquakes by large withdrawls or reinjections of geothermal fluids cannot be ruled out as a potential environmental Impact. To date, earthquakes assoclated with fluid pressure changes have been small and not disastrous, and some evidence indicates that seismic activity associated with geothermal areas is a continuous process tending to relleve regional stresses, thus reducing the probability of large earthquakes. [2]

\section{Blological, Soctal, and Cultural Impacts}

Blological impacts and social and cultural impacts of liquid-dominated systems are similar to those already discussed for vapor-dominated systems.

\section{Hot Dry Rock Syscems}

The most readily accessible hot dry rock systems con of relatively shallow pockets of impermeable hot dry rock overlying a magma intrusion chamber or other heat source at depths in excess of 50,000 feet. The diffusive flux of heat from the interior of the earth keeps these rock deposits at median temperatures of $580^{\circ} \mathrm{F}$ or more. It appears that this heat source could be exploited for power production, when deep drilling technologies become avallable.

To tap this resource, wells will have to be drilled to depths of 15,000-20,000 feet or more and relatively large volumes of fractured rock will have to be created at the bottom of the wells. Water would then be injected into the fractured zone through one well and withdrawn through another. The heated fluid could be utilized in more or less typical generating equipment to produce electricity.

Three methods are potentially available for rock fracturing to produce the underground heat exchange volume: (1) hydraulic fracturing by injection of fluids under pressure, (2) use of chemical or nuclear explosives, and (3) thermal stressing. Nuclear fracturing will require extensive and special feasibility analysis in application to hot dry rock technology and is not considered further in this assessment. Aspects of the environmental impacts of this technique are reviewed in Kruger \& Otte.[15] Figure 4.8.5 on the following page summarizes the environmental impacts which appear to be associated with hot dry rock systems.

\section{Physical and Chemical Impacts}

Alr Quality. Some very small release of natural radioactfve elements, as gases and in solution, may result from the fracture of rock masses. The amounts emitted depend on the geologic. and hydrologic conditions and cannot be predicted at this time. However, present evidence indicates that such releases will probably be well within the standards presently prescribed for the nuclear power Industry.

Potential air emisstons problems described for the two previous geothermal technologies do not appear to be as severe for the hot dry rock systems.

Surface Water Quality. Surface water quality will not be affected if the circulating fluids are well contained in a closed cycle. During construction activities, however, care must be taken to avoid contaminating streams and other surface water sources with wind- or waterborne sediment and drilling spolls.

Since, 1n this technology, fluids are introduced into a subterranean heat exchange chamber and returned to the surface in a closed cycle, problems inherent in storage or disposal of contaminants will be minimal. If fluids become saturated with minerals in the fractured rock chamber, scaling of equipment and clogging of the fractured zone could result. Acceptable control methods will have to be developed to prevent these problems.

The mafor water-related problem is one of consumptive water 1oss. An external source of suitably pure water must be found to supply the water to be injected into the subterranean fractured zone and to be used in the cooling system. This water requirement will increase as the volume of the fractured zone increases due to thermal contraction of the rock and cracking of the rock. The commitment of the large volumes of water required to operate a dry hot rock based power plant could conflict with other beneficial uses, such as agricultural or communtty water supplies, and produce a number of Iong-term secondary Impacts. 


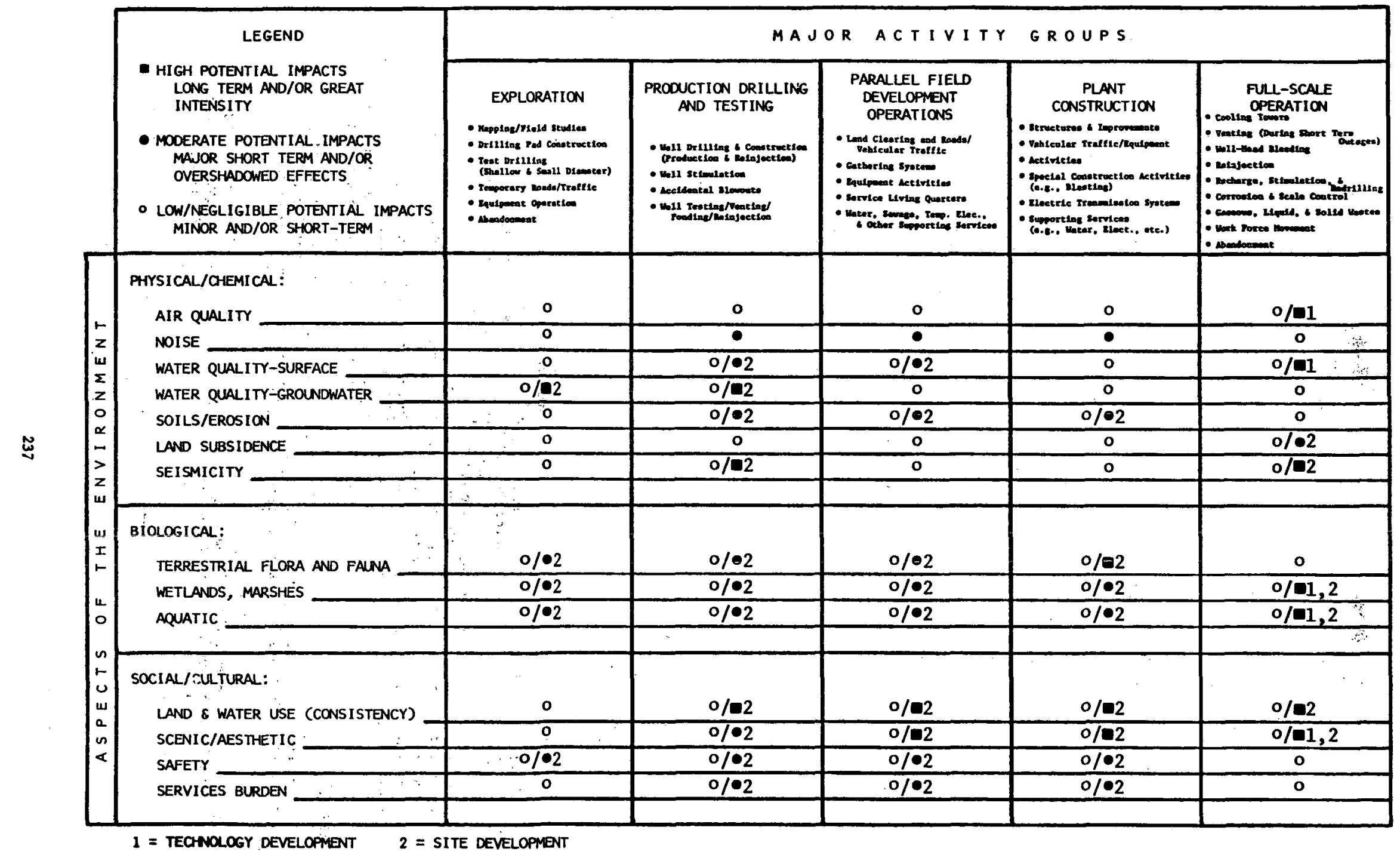

FIgure 4.8.6 SUMAARY ENVIRONMENTAL ASSESSMENT MATRIX FOR HOT DRY ROCK SYSTEM 
Groundwater Quality. Aquifers will not be adversely affected where exploration and development activities are well planned, regulated, and conducted. If care' is not taken, however, the mixing of water from 1 ow and high quality aquifers could take place.

Subsidence. Subsidence is unlikely during the development and operation of hot rock geothermal reservoirs, since the majority of the subsurface modification occurs at great depths and in solid rock strata.

Seismiclty. As in the case of the 1iquid-dominated technology, selsmicity is of concern. Since the heat exchange process typically takes place at great depths, the chances for passing through a previously undetected minor fault are real, and thus the possibility of triggering seismic activity must be considered. What will be needed is a means for 1dentifying inappropriate deep underground conditions from surface manifestations (in other words, an 1mprovement in geologlcal omn1science) or from instrumentation which, functioning underground, could produce accurate three-dimensional fault maps.

\section{B1olog 1ca1 Impacts}

Terrestrial Flora-and Fauna. The effects of any development of the blota vary greatly with the type of habitat affected. Any reasonably detalled assessment therefore will depend upon the site being considered.

In general terms, an area of habitat will; be lost which corresponds to the size of the development. The acceptability of the environmental cost depends on the avallability and use of the remaining habitat of the same type. Given the blological diversity of the United : states and the potentially large area available for the development of hot dry rock systems, prior planning should minimize the environmental costs to be borne by terrestrial biota. Aside from the direct taking of terrestrial habitat, Impacts of a secondary nature, e.g., waste streams, human activity around the site and nolse, can be controlled by proper siting and design features. In addition to habitat avallability, planning must be adjusted to accommodate breeding grounds, migrating routes, and endangered species or ecosystems.

\section{Socta1 and Cultural Impacts.}

Land Use Consistency." With the probability that hot dry rock resources are available under the entire United States, it is likely that power facilities could be developed near urban, Industrial, or other high power use areas. It is anticipated that a $100 \mathrm{MWe}$ power plant could occupy only about $1 / 5$ square mile of surface area, reducing the potential for land use conflict to essentially the same level as a conventional thermal power plant. (See Section 4.6.)

\section{Liquid and Solid Wastes}

In this technology; extraction and disposal of flutds is avolded; the only wastes are those which emanate from cooling towers.

Safety. Safety primarily concerns the well-betng of the work force, as well as others in the area; who can be affected by the Increased activity assoctated with the resource development. $\therefore$ General safety could be a problem if blowouts occur, but with proper precautions, unsafe conditions can be minimized or avolded.

\section{Geopressured Zones Systems}

The Inventory of potentlal geopressured regions is far from complete. One promising area of the United States
In which geopressured zones nave. been identified 1s the Louistana-Texas Gulf. Coast area, a belt of land 35-75 miles wide along the coast from the Rio Grande River to the Mississippi Delta (a distance of approximately 800 miles). Jones [16] reported that the geopressured belt extends far out beneath the Gulf Continental Shelf, and occurs at some depth beneath the main deltaic sand series in Miocene and Pliocene (Neogene) sèdiments everywhere Gulfward from the' innermost zone of growth faults.

Since 1953, when the classic description of geological aspects of abnormal reservoti pressures was published [1.7], additional data on geopressured reservolrs have been acquired, especially regarding production-engineering characteristics and methods of early detection and pressure estimation.

The technology and environmental impacts involved in developing geopressured reservoirs are similar to those known for the exploration and development of natural gas or petroleum reservoirs (see Figure 4.8.7.) Determination of the hydrodynamic characterfstics of the aquifer zones and monitoring of activities are needed to avold possible major, impacts, such as seismiclty, land.subsidence, surface or groundwater contamination. As in other energy technologies, land use patterns and aesthetic considerations must also be examined.

The withdrawal of geothermal fluids from stacked aquifers would commit approximately 50 square inlles of the geopressured strata for each $100 \mathrm{MWe}$ power' plant. This precludes the dense clustering of oower plants which might occur over a liquid-dominated reservolr. It also places rather severe restrictions on the maximumipotentlal capacity of any one plant. However, only a small surface area would be required for the above-ground installation, minimizing aesthetic and land use conflicts. If it should be necessary to construct extensive holding ponds or percolation fields for spent geothermal fluids, land use conflicts could be considerably greater, however.

\section{Physica1 and Chemical Impacts}

Air Quality. The emission of gases and debris is to be expected only when an accidental blowout occurs. When procedures and precautions known to other technologies are applied at the earliest stages, air emissions from such accidents can be prevented. In normal operation, the methane known to occur in unusually high concentrations in geopressured fluids w111 be flash separated and burned, or collected for transmission elsewhere.

Noise: Drilling and pumping activitles can result in high notse levels. Mufflers and other notse suppression devices similar to those being deyeloped for yapordominated systems will probably prove applicable.

Surface Water Quality. An Important and related consideration to the explottation of geopressured therinal waters has been the potential effect of discharging spent flulds to surface waters. The known range of salinities for the Gulf Coast geopressured aquifers is quite broad, from 1000 ppm to 300,000 ppm. [16] Those waters with the lowest concentrations are at the threshhold of U.S. Public Health Service Itmits for total dissolved solids. (IDS) in drinking water, whtle those at the higher end of the range are nearly 9 times the concentration of sea water. The release to surface water of the large volumes of geopressured fluids required to drive a power plant would require careful management to prevent large scale ecological damage to estuarine coastal areas and the commercial and sport hing 


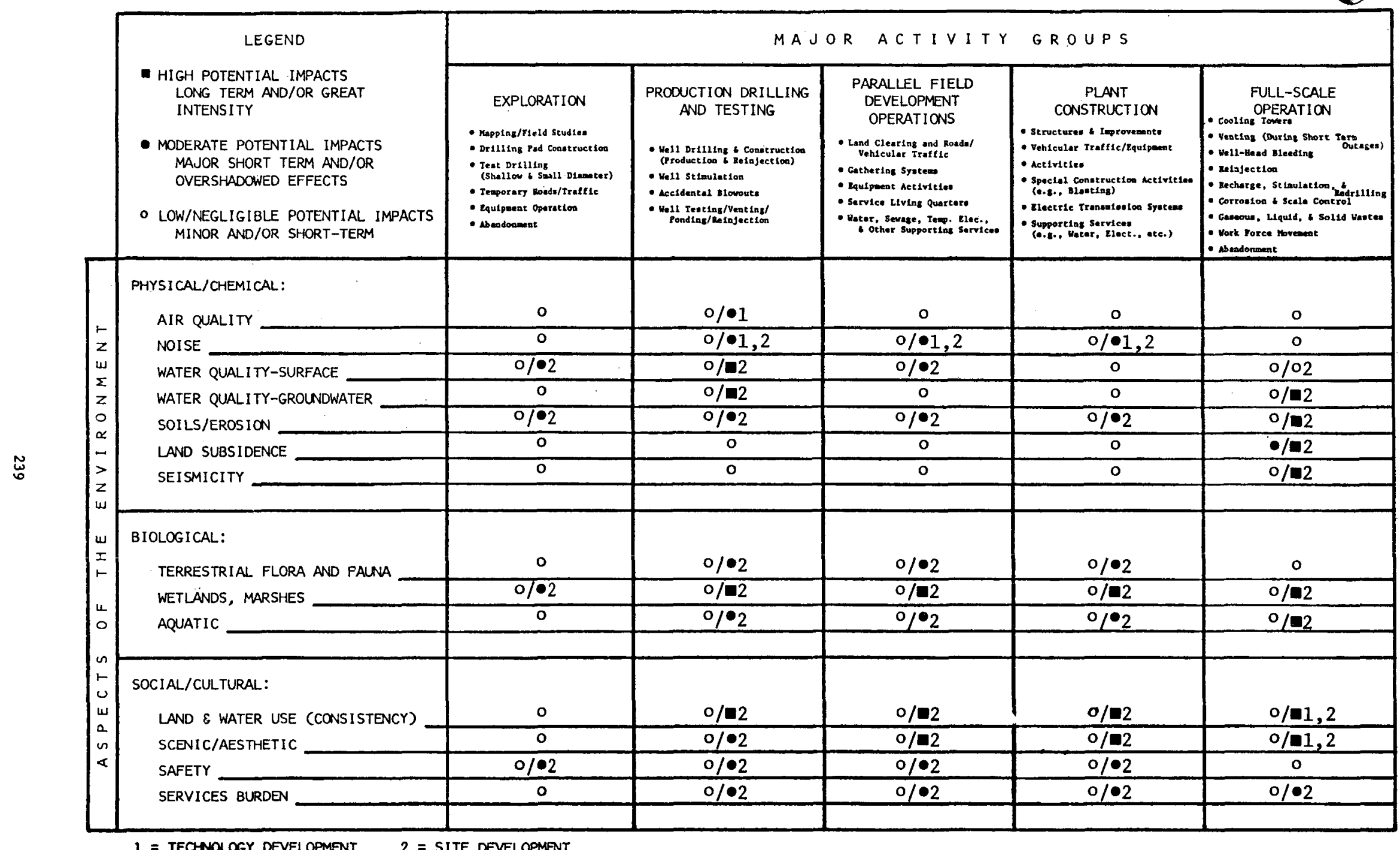

F1gure 4.8.7 SUMMARY ENVIRONMENTAL ASSESSMENT MATRIX FOR GEOPRESSED ZONE SYSTEM 
fisheries they support. It is questionable whether water with a salinity much above 35,000 ppm should be discharged even into the open ocean in the volumes being considered or indeed, if the ambient salinity of the receiving water should ever be exceeded.

Groundwater Quality. The hydrology of artesian aquifer systems in the Texas-Loulsiana Gulf region has been well documented $[16,18,19]$. When hydrologic characteristics of geopressured zones are being evaluated, information concerning the salinity of water in the aquifers is often very helpful. Precise information on geotemperature regimes is of critical concern, however. Dickenson notes that abrupt changes in temperature can occur over short ranges, which are hydrologically critical to the geopressure regime [17]. Thus, adequate information concerning geopressured zones may not be available to determine the relationship between the removal of large quantities of geopressured fluids and the impacts already mentioned such as ground or surface water contamination, seismicity, or land subsidence. These effects must be carefully considered as the technology develops.

Subsidence. Subsidence may prove to be a major $\mathrm{im-}$ pact in geopressured systems, since very large volumes of water are extracted from the reservoir. The best known method of retarding subsidence, reinjection, may not be feasible since it would consume a major portion of the energy generated from the fluid. The subsidence of the coastal area could change the high tide contour and result in the inundation of low lying regions. Irreversible property damage and changes in the coastal ecology could result.

Seismicity. Although known geopressured zones are generally not in seismically active areas, data are not yet avallable to evaluate the probability of induced seismicity. In the geographic areas where ut1lization of geopressured regions is being considered, reinjection of fluld wastes, if undertaken, is expected to be into aquifers shallower than the thermal formations. Raleigh points out that the Gulf Coast and Mid-Continent areas are relatively inactive tectonically and, except under extreme conditions, appear to hold little potential for artifically induced earthquakes. [13] Nevertheless, injection wells should be located at a safe distance from large faults. Raleigh concludes that if injection into the basement rock near large population centers is planned, even in these tectonically fnactive areas, selsmic monitoring of the infection wells seens advisable.

\section{Blological Impacts}

Baseline biological descriptions of areas suspected to offer potential for exploration must be developed. D1s ruptions to wildlife habitats, particularly in areas where this technology is under intense investigation, must be given high priority for study. The areas of the United States where geopressured resources regions exist are used extensively by migratory waterfowl. Disturbance of wetlands which serve as rich habitat for native fauna should be avoided as much as possible. The potential for the disruption of salinfty regimes is high with this system and could seriously damage coastal habitats. The potential damage to local estuarine ecosystems from the excessive discharge of highly saline geothermal fluids could also have far-reaching effects. Modification of the ambient salinity ranges could eliminate intolerant plant species or modify their distributions. Many of the Gulf's economically important fin fishes and crustaceans are totally dependent on the rich, shallow, highly productive estuaries as nursery grounds for the young. As such, estuarine wetlands are essentially a limited resource requiring continued preservation from development or extensive changes. Hence activities associated with the exploitation of geopres sured regions must be governed by sensitive concern fa the blological setting.

\section{Magma Systems}

A fifth source of geothermal energy is the magma which forms the molten core of the earth. It may be feasible, when high temperature alloys are developed, to extract heat from near-surface intrusions of magma, generally associated with volcanically active areas. A heat exchange loop could be inserted into the molten material through a well. Fluid circulated through the loop could then be vaporized and used to drive vapor turbines at the surface.

Major technological problems center on developing heat resistant materials for use in constructing the heat exchange loop and on safe drilling into a magma chamber for the insertion of the loop. Blowouts of magma and gases would pose major safety hazards. Exploration and identification of potential magma reservoirs is also required.

Virtually no information has been published on magma resources, technology, or environmental problems and solutions. For this reason, the preparation of an environmental assessment matrix for this resource was not undertaken. The fund of basic knowledge on magma systems must be materlally advanced before their 1mpacts can be assessed.

\section{Summary of the Issues}

If geothermal technology is developed under existing economic constraints, the evolution of pollution control technology will probably keep pace. Adequate environmental rules and regulations are presentiy on the books to ensure only nuisance level impacts if all leasing, pollution control, and monitoring procedures are literally applied. Most states have promulgated amblent air quality standards which of ten exceed federal standards. A summary of air quality standards of states with geothermal potential is presented in Appendix I. Except for accidents, such as blowouts, geothermal sources should not exceed these limitations for more than short periods of time. Hydrogen sulfide emission from steam and hot water sources can be reduced to safe levels by natural disperston and dilution or, if necessary, by a scrubbing apparatus expected to be avallable shortly.

Contamination of surface water by geothermal operations is a potentfal problem, but with careful study it should be possible to avoid unanticiprted or irreversible consequences.

Selsmictity and subsidence are possible geothermal issues of considerably more concern. As much information as possible should be developed about these issues on a theoretical basis. When deep injection is to take place in areas where faults are 1ikely or possible, or when reinfection is possible, seismicity and subsidence should become primary foci of environmental impact analyses.

The extensive geothermal provinces which have been 1dent1fied to date are predominantly of the 11quid-and-vapordominated reservoir type. These resource types are expected to produce a major portion of the geothermal power output in the future. Therefore, under a crash program, it could be assumed that rather large tracts in the arid sections of California, Washington, Oregon, Nevada, Arizona, New Mexico, and others would be thoroughly explored and when sultable reservoirs were discovered, developed 
into multiple unit power generating complexes with i rconnecting transmission lines. The intermingling hese plants with mineral extraction plants, water reclamation units, and other related industries could result in refinery-type complexes, with interconnecting pipelines, buildings, water holding ponds, and cooling towers which might, in some areas, cover several square miles. Of course, high voltage transmission lines would be Installed in these developments also. Based on the forecast energy development assumptions, a maximum of approximately 1500-2500 square miles of surface will ultimately be required to accomodate the development of all of these geothermal and ancillary facilities. Developments of this total magnitude could result in a varlety of effects as discussed previously.

Although the indications are that the environmental impacts created out of the development of geothermal energy are not of major significance when compared to other energy forms, it is desirable to evaluate these possible environmental impacts in a summary manner, as presented in Figure 4.8.8, "Evaluation of Important Envirnnmental Impacts." The relative signiflcance of these impacts was based on the numerical key as shown in the figure. The numbers in the figure represent the consensus opinion of the study team and the panel of consultants.

The two most important environmental impacts were judged to be contamination of surface and subsurface waters and seismicity. It is no coincidence that these two impacts are also fudged to be the most important in the Department of the Interior environmental statement for the geothermal leasing program. Many of the points made in this study are derived from those made in the Department of the Interior environmental impact statement.

The Impacts listed in the figure summarize the discussion of this section. The welghtings given to the columns on lasting qualities and timing indicate the importance of making adequate and timely plans at the beginning of the geothermal energy development. By doing this it appears that environmental disruption can be kept to a minimum while the geothermal resource can be a valuable domestic energy component.

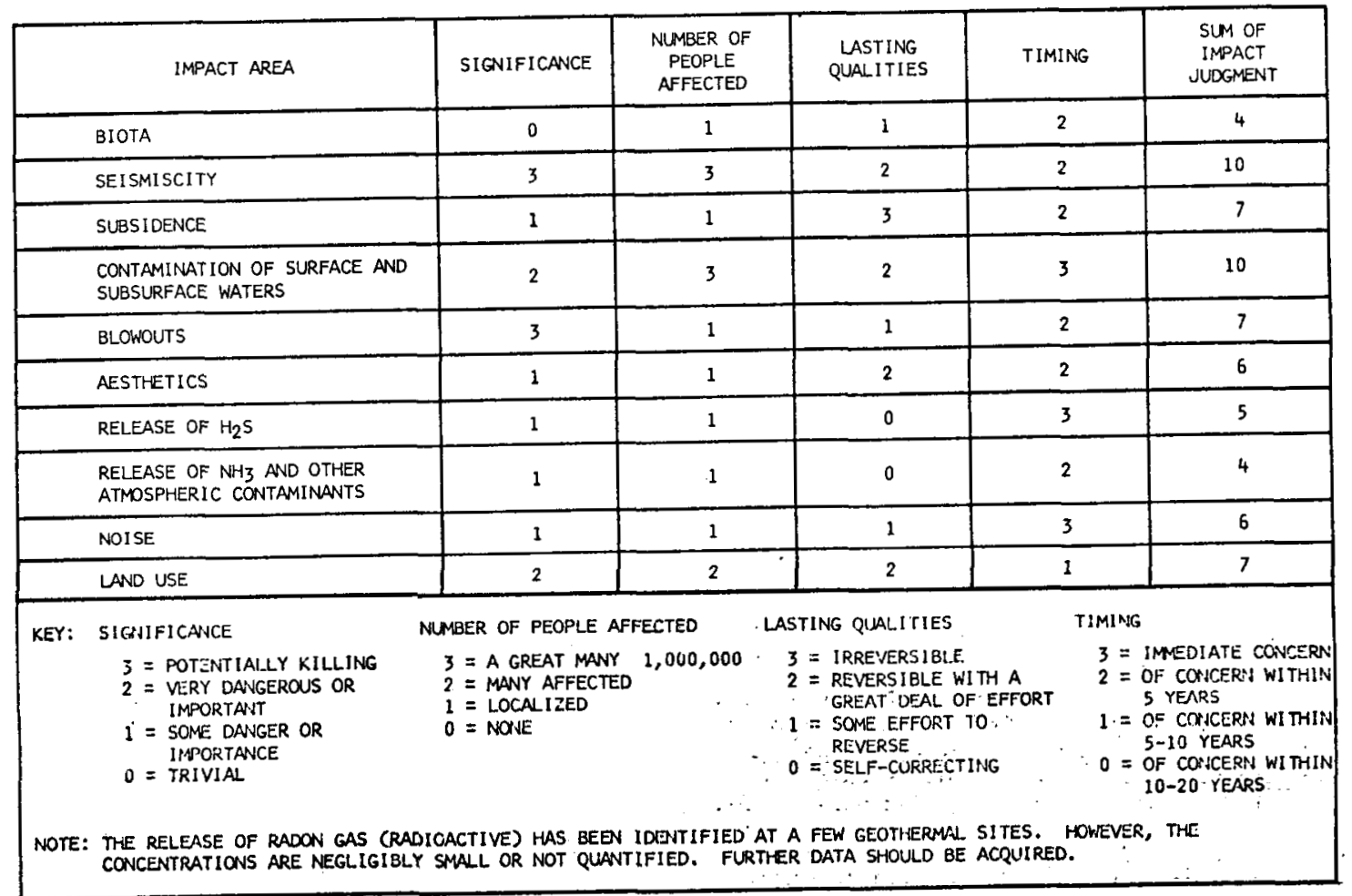

FIgure 4.8.8 EVALUATION OF IMPORTANT ENVIRONMENTAL IMPACTS 
REFERENCES

[1] Leopold, I. B., et a1., A Procedure for Evaluating Environmental Impact, U.S.G.C. Circular 645 (Washington, D.C.: 1971).

[2] U.S. Department of the Interior, office of the Secretary, Final Environmental Statement for the Geotherma1 Leasing Program, Vol. I, II, III, and IV (Washington, D.C.: October 1973).

[3] Hicke1, W. J., "Geothermal Energy: A Special Report," Geothermal Resources Research Conference (Seattle, Wash.: Battelle Seattle Research Center, September 1972).

[4] Bolton, R. S., "Blowout Prevention and Other Aspects of Safety.in.Geothermal Steam Drilling, Proceedings of the Untted Nations Conference on New Sources of Energy, Rome, Vol. 3, Geothermal Energy (1968), pp. 78-88.

[5] Stillwell, W. B., "Drilling Practices and Equipment in Use at Wairakei," United Nations Symposium on the Development and Utilitization of Geothermal Resources, Pisa, Italy, Vol. 2, Part 1, Geothermics-Spectal Issue (1970), pp. 714-724.

[6] Cigni, v., et al., "Completion of Production We11s," United Nations Symposium on the Development and Utilization of Geotherma1 Resources, Pisa, Italy, Vol. 2, Part 1, Geothermics--Special Issue 2 (1970), Pp. 757-763.

[7] Poland, J. F., and G. H. Davis, "Land Subsidence Due to Withdrawal of Fluids," Engineering Geology, Vol. 2, pp. 187-269.

[8] Peck, D. L., Assessment of Geothermal Energy Resources (Washington, D.C.: Committee on Energy [Research and Development Goals], Federal Council for Science and Technology, Panel on Geothermal Energy Resources, September 25,1972 ).

[9] Goldsmith, M., Geothermal Resources in California: Potentials and Problems, E.Q.L. Report 5 (Pasadena, Calff.: California Institute of Technology, Environmental Quality Laboratory, December 1971), pp. 30-31.

[10] Dutcher, L. C., W. F. Hardt; and W. R. Moyle, Jr., Preliminary Appraisal of Groundwater in Storage with Reference to Geothermal Resources in the Imperla1 Valley Area, California (Washington, D.C.: U.S. Geologic Survey Circular 649), p. 51.

[11] Bureau of Reclamation, "Geothermal Resource Investigations, Imperial Valley, California-Development Concepts," 1973.

[12] "Crack Down on 011 Fleld Pollution," Petroleum Englneer, Vol. 39, No. 7 (July 1967), pp. 33-36.

[13] Raleigh, C. B., Earthquakes and Fluid Injection, Memoir 18 (Washington, D.C.: U.S. Geologic Soclety Publication authorized March 17, 1972 [The Rangely Research Project], Implications, American Assoclation of Petroleum Geologists), pp. 278-279.

[14] Healy, J. G., et a1., "The Denver Earthquakes," Sclence, Vol. 161 (1968), pp. 1301-1310.
[15] Kruger, P., and C. Otte (eds.), Geotherma1 En (Stanford University Press, 1973).

[16] Jones, P. H., "Hydrodynamics of Geopressure in the Northern Gulf of Mexico Basin," Journal of Petroleum Technology, Vol. 21 (1969), Pp. 803-810.

[17] Dickenson, G., "Reservolr Pressures in Gulf Coast Louislana," AAPG Bullet1n, No. 37 (1953), pp. 410-432.

[18] Jones, P. H,, "Geological Hydrodynamics--A Possible Key to the Hydrology of Certain Aquifer Systems in the Northern Part of the Gulf of Mexico Basin, XXII International Geological Congress (1968), pp. 113-125.

[19] Jones, P. H., "Geothermal Resources of the Northern Gulf of Mexico Basin," Geothermics, Speclal Issue 2 (1970), pp. 14-26. 
5. EVALUATION OF IMPACTS

It is probably appropriate at this point in the report to pause and review the tasks which have been described and those which remain. A plausible path for the evolution of geothermal energy in the United States was developed recognizing technologlcal, political, economic, regulatory, institutional, and environmental impediments. This description was bullt from a careful review of the state-of-the art and employed judgments derived in interviews and synthesized in a simulation model. The model was used to examine the effects on fuel mix of some potential pollcies and sensitivity to changes in inttlal assumptions. Using judgments obtained in the interviews and derived from the 11terature as a starting point, primary impact areas were defined and relevance tree impacts were constructed. The purpose of the relevance trees was to describe essentially all important higher-order Impacts. Est1mates of direct consequences flowing from geothermal growth were made using the simulation model and other analysis techniques. The study team then chose secondary and tertiary Impacts for elaboration and forecasts of selected indicators assoclated with these impacts were made using the model where that was possible, trend impact analysis, and other more conventional approaches. These steps have been described in previous sections of this report.

Among the problems which remain are:

1. Who will be affected by the impacts and how deeply?

2. What policies are avallable to improve these impacts?

3. What level of improvement can be expected?

These questions form the focus of the work reported in this section.

The impact relevance trees provide a source of statements about the consequences of geothermal energy, should it develop. The study team reviewed these statements together with quantitative projections of Indicators associated with the impacts (Chapter 4) and the responses of the socio-economic interview pane1 (Appendix C) In order to form a subset of potentially significant impacts. Figure 5.1.1 on the following page presents this 11st. To be clear about the nature of the entries on this 11st, each 1 tem should be read with the following preamble:

If geothermal energy develops, in a manner similar to that described by the simulation model, then it is plausible to expect that an important direct or indirect consequence of that development will be....

The technological and impact relevance trees, and the ilterature (particularly the comments submtted in response to the Environmental Impact Statement 1ssued by the Department of the Interfor) were reviewed in order to comp1le a list of groups likely to affect or be affected by geothermal energy. It was our objective here to be as complete as possible without overstating the obvious (In the end, everyone, to some small measure, w1ll be affected by geothermal energy). The 11 st of Interest groups is presented in Figure 5.1.2.

Four matrices were then constructed in which interest groups head the columm and impact statements, the rows. Each cell of the matrix contains a number depicting the study team's judgment about how a particular interest (joup would be affected should a particular impact be realized. The coding for these fudgments was as follows:

$$
\begin{aligned}
+8 & =\text { pre-emptive positive Impact } \\
+4 & =\text { major positive Impact } \\
+2 & =\text { Important positive Impact } \\
+1 & =\text { slight positive Impact } \\
0 & =\text { no Impact } \\
-1 & =\text { slight negative impact } \\
-2 & =\text { Important negative Impact } \\
-4 & =\text { major negative impact } \\
-8 & =\text { pre-emptive negative impact }
\end{aligned}
$$

The criterfa used in evaluating the signiflcance of a particular impact for a particular group were:

1. The percentage of the group affected--the most signiflcant impact would be the one which affected the highest percentage of the group beling considered.

2. The severity of the effect--the most significant impact would be the one which would have the most deleterfous or favorable consequences.

3. The reversibllity of the effect-the most serfous impact would be one which was on an essentially Irreversible path.

4. Responsibility for correcting or obtaining the impact--the most important impact would be one for which no responsible institution exists.

Thus an Impact judgment of -8 represented a case in which a large percentage of the group being considered was affected very badly, the effect noted appeared to be essentially irreversible, and the responsibility for correcting the situation was not clearly established. An Impact judgment of +8 represented a case in which a large percentage of the group was affected very beneficlally, the evolutionary path ylelding the benefits appeared to be essentially irreversible, and institutional arrangements seemed to be well enough in place to ensure the achlevement of the benefit. Figure 5.1.3 displays a sample value matrix and the complete matrix is presented in Appendix G.

It is worthwhlle elaborating on the nature of the entries in the matrix. So that the results of this analysis can be properly interpreted, two cases will be cited as examples:

1. The fudgments provided to simulate 1mpacts on the Department of the Interior (Group 2) were as follows :

a. Impacts percelved as having a very positive affects $(+8$ to +4$)$ were

32. Increased geothermal R\&D for the environment.

33. Increased geothermal exploration and production of exploration equipment.

37. Increased geothermal R\&D exploration.

85. Decreasing rate of depletion of ofl.

b. Impacts perceived as having somewhat positive affects $(2$ to +3.9$)$ were:

29. Changes in manpower, funding, and 
1. PEWER THAN EXPECTED GASNFIRED ELECTRIC GENERATION PLANTS.

2. pemer than expected nucleap pLints.

3. FENER THAN EXPECTEO COAL-FIRED PLANTS.

4. FEWER THAN EXPECTEO OIL-FIRED PLANTS.

3. LOWER THAW EXPECTED FRICE FOR GASOLINE.

6. LOWER THAN EXPECTED PRICE FOR COAL.

7. LOWER thaN EXPECTED PRICE FOR heATING AND FELL OIL.

8. LOWER THAN EXPECTED PRICE FOR JET FUEL.

9. LOWER THAN EXPECTED PRICE FOR ELECTRICITT.

10. LOWER THAN EXPECTED PRICE FOR URANILM.

11. LOWER THAN EXPECTED PRICE FOR NATURAL GAS.

12. Delayeu deVElopNent of tar SANDS aNo OIL SHale.

13. DELAYED DEVELOPNENT OF SOLAR EVERGY.

14. DELAYEO DEVELOPTMENT OF NUCLEAR FUSION.

15. DELAYED DEVELOPMENT OF BREEDER REACTOR.

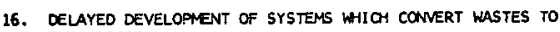
ELECTRICITY.

17. DELAYED DEVELOPMENT OF COAL GASification AND Liquefaction.

18. ImProvement IN ENVIRONMENTAL CONSIDERATIONS OF BUSINESSES THAT USE GEOTHERMAL ENERGY FOR ELECTRICITY.

19. FAVORABLE ECONOMIC CONSIDERATIONS FOR BUSINESSES THAT USE GEOTHERMAL ENERGY FOR ELECTRICITT,

20. INCREASED MANPOWER, TECHNOLOGY, AND MATERIAL REQUIREMENTS STEMMING FROM BUSINESSES FORMED AROUND THE USE OF GEOTHERML ELECTRICITY.

21. C-AANGES IN TME INSTITUTIONAL-SOCIAL SETTING AS A RESULT OF THE CREATION OF NEW BUSINESSES THAT USE GEOTHERMAL ELECTRICITYY:

32. GHANGES IN MUNPOWER, FUNDING, AND REO POLICY AS A RESULT OF THE RISE OF BUSINESSES THAT USE GEOTHERMAL ELECTRICITY.

23. MOVEMENT OF BUS INESSES THAT USE GEOTHERMAL ELECTRICIT, HEAT, OR MINERALS INTO GEOTHERMAL REGIONS.

24. MOVEMENT OF BUSINESSES THAT USE GEOTHERML ELECTRICITY, HEAT, OR MINERALS OUT OF EXISTING LOCATIONS.

25. GHANGES IN ENVIRONVEYTAL CONSIDERATIONS OF BUSINESSES THAT USE GEOTHERMAL SOARCES FOR HEAT OR MINERALS.

26. FAVORABLE ECONOMIC CONSIDERATIONS FOR BUSINESSES THAT USE GEOTHERMAL SOLRES FOR HEAT OR MINERALS.

27. INCREASED MANPOWER, TECHNOLOGY, AND MATERIAL REQUIPEMENTS INCREAING FROM SUS TESSES FORMED AROUD TIE USE OF

28. OUNGES IN THE INSTITUTIONAL-SOCIAL SETTING AS A RESULT OF THE CREATION OF NEW BUSINESSES THAT USE GEOTHERALL HEAT OR MINERALS.

29. GHANGES IN MANPOWER, FUNOING, AND RED POLICY AS A RESULT OF THE RISE OF NEW BUSINESSES THAT USE GEUTHERMAL HEAT.

30. OMIT.

31. OMIT.

32. INCREASED GEOTEERML REO FOR THE ENIRONMENT.

33. INCREASED GEOTHERMAL EXPLORATION ANO PROOUCTION OF EXPLORATION EQUIPMENT.

34. INCREASED PROOUCTION OF GEOTHERMAL HEAT EXTRACTION equiPMENT ANo services.

35. INCREASED GEOTHERMAL: FIELD OPERATIONS EQUIPMENT ANO SERVICES.

36. INCREASED GEOTHERMAL LEGAL, ANO ADMINISTRATIVE SUPPORT PROFESS LONS AND SERVICES.

37. INCREASED GEOTHERMAL RLO EXPLCRATTON.

38. IMPRCVEMENTS IN GNP OVER A "NOWGEOTHERMAL WORLD."

39. IMFROVEMENTS IN INFLATION OVER A "WON-GEOTHERMAL WDRLD."

40. IMPRONENENTS IN GOVERVMENT INCONE OVER A "NON-GEOTHERMAL WORLD."

41. DIMINISHED GOVERNENT SPENDING COMPARED TO A "NOWGEOTHERMAL WORLD."

42. USE OF AGRICULTURAL ANO FOREST LANDS FOR DEVELOPPENT OF CEOTHERMAL INSTALLATIONS.

43. RELOCATION OF LOCAL POPULATION IN ORDER TO ACCOMOOATE gegotireral installations.

44. USE OF LAND FOR NEW INOUSTRIES WHICY MOVE TO AREAS IN WHIOH GEOTHERMAL INSTALLATIONS ARE MADE.

45. USE OF RECREATION, PARK, AND WILEERNESS AREAS FOR GFOTMERHAL INSTALLATIONS.
46. CREATION OF NEW OPPCRTUNI TLES, FOR CRINE CE,G., DESTROYING GEOTHERMAL WELLS).

47. CHANGES IN RECREATIONAL PATTERNS.

48. INCREASED FINDING FOR ELEMENTARY AND SECONDARY EDUCATION AS A RESULT OF CHANGES IN THE TAX BASE NEAR GEOTHERMAL INSTALLATIONS.

49. CREATION OF NEW PROFESSICNS ANO, HENEE, NEW DEMANOS CN higher education.

50. DIMINISHED COST OF ELECTRICITY AS A RESULT OF THE INTRODUCTION OF A TRANSCONTINENTAL GRIO.

51. IMPROVED ELECTRIC RELIABILITY AS A RESULT OF THE INTRODUCTION OF A TRANSCONTINENTAL GRID.

52. NEW RESPONSIBILITIES ANO INTERFACES FOR EXISTING UTILITIES AS THE RESULT OF THE INTRODUCTION OF A TRANSCONTINENTAL GRID.

53. NEN RESPQNSIBILITIES AND INTERFACES FOR PURLIC UTILITY COMISSIOHS AS THE RESULT OF THE INTRODUCTION OF A TRANSCONTINENTAL GRID.

54. INCREASED NEED FOR CAPITAL TO FINANCE A TRANSCONTINENTAL GRID.

55. DEDICATION OF SEVERAL TRZNSCONT INENTAL CORRIDORS FOR THE CONSTRUCTION OF A TRANSCONTINENTAL GRID.

56. DEVELOPMENT OF LOW-LOSS TRANSMISSION SYSTEMS.

57. INCREASEO DEMAND AND COMPETITION FOR MATERIAL USED IN THE CONSTRUCTION OF A TRANSCONT INENTAL GRID.

58. GRONTH OF MWNPOWER FOR TEE CONSTRUCTION AND OPERATION OF A TRANSCONTINENTAL ELECTRICAL GRID. $\therefore$

59. CREATION OF A NEW FEDERAL INSTITUTION FOR REGULATION OF TRUASCONTINENTAL TRANSMISSION.

60. REVISION OF EXISTING VILLITY COMPANY GENERATION AND TRANSMISSION PLANS.

61. REVISION OF FEDERAL LEASING, TAX, ANO LAND-USE REGULATIOAS.

62. ESTABIISHMENT OF NEW FECERAL REGULATORY BOOIES FOR GEOTHERMAL ENERGY,

63. REVISION OF STATE LEASIN:, TAX, AND LAND USE REGULATIONS.

64. ESTASLISHHENT OF NEW STATE REgULATORY BOOIES.

65. INCREASING CAPITAL DEMAND FOR CEOTHERMKL DEVELOPNENT.

66. PROVISION Of THE THRUST FOR THE CREATION OF NEW CITIES.

67. Allowance of CERTAin existing cities to develoo MuDepanoer souRCES OF ENERGY.

68. DIMINISHENT OF THE MOUNT OF IMPORTED ENERGY.

69. PRovision of A NEW FOCUS FOR INTERMATIONAL TECHOLOCY tonasfer programs.

70". EXPORTING OF MINERALS DERIVED FROM GEOTHERHAL SOURCES.

71. DIMINISHED AMOUNT OF STOCXPILED ENERGY MATERIALS.

72. A MAJOR UNITED MAIIONS PROGRAM FOR ALDING THE DEVELOPMENT OF CERTAIN CONTRIES.

13. THE DEVELOPRENT OF NEW KINDS OF WEAPONS.

74. LOWERED OEPEENEENCY OF CERTAIN MATIONS (E.G., JAPAN) ON PETROLELM.

75. DIMINISHED AIR QUALITY NEAR GEOTHERMAL INSTALLATIONS.

76. INCREASED NOISE NEAR GEOTHERMAL INSTALLATIONS.

77. DIMINISHED WATER QHaLITY NEAR geOTHERMAL INSTALLATIONS.

78. INCREASED SOIL EKOSION NEAR GEOTMERMAL INSTALLATIONS.

79. INCREASEO POSSIBILITH OF LAND SUESIDENCE NEAR GEOTHERMAL INSTALLATIONS.

80. INCREASED POSSIBILITY OF SEISMICITY NEAR GEOTERMAL INSTALLATIONS.

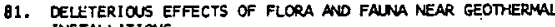
INSTALLATIONS.

82. deleterious effects on wetlanos ano marsies near cEOTERMAL INSTALLATIONS.

83. DELETERIOUS EFFECTS ON AQUATIC FLORA AND FAINA NEAR geotizkmal installations.

B4. INCREASING RATE OF DEPLETION OF CEOTERMAL RESOURCES.

85. Decreas ING Rate OF DEPLETION OF OlL.

86. DECREASING RATE OF DEPLETION OF COAL.

87. DECREAS ING RATE OF DEPIETION OF GAS.

88. DECREASING RATE OF DEPLETION OF LRANIUM.

89. INCREASING INDEPENDENCE OF THE WNITED STATES ON FOREIGN INDIGEVOUSLY THRCUCH THE USE OF CEOTLERMA MINERAL. 

1. U.S. GOVERNMENT INTERNATIONAL INTERESTS
27. SOLAR ELECTRICITY
2. DEPARTMENT OF THE INTERIOR
28. GEOTHERMAL EXPLORATION INDUSTRY
3. ATOMIC ENERGY COMMISSION
4. NATIOLAL SCIENCE FOUNDATION
29. GEOTHERMAL DRILLING INDUSTRY
30. GEOTHERMAL OFERATING INDUSTRY
5. FEDERAL ENERGY AGENCY
31. MANUFACTURERS OF GAS-FIRED PLANTS
6. DEPARTMENT OF DEFENSE
32. MANUFACTURERS OF COAL-FIRED PLANTS
7. U. S. CONGRESS
33. MANUFACTURERS OF OIL-FIRED PLANTS
8. STATE ENERGY AGENCIIES OF STATES WITH GEOTHERMAL. ENERGY
34. MANUFACTURERS OF NUCLEAR PLANTS
9. STATE ENERGY AGENCIES OF STATES WITHOUT GEOTHERMAL ENERGY
35. BUSINESSES THAT BENEFIT FROM THE USE OF GEOTHERMAL HEAT
10. UTILITY COMPANIES IN GEOTHERMAL REGIONS
11. UTILITY COMPANIES OUTSIDE OF GEOTHERMAL REGIONS
12. UTILITY COMPANIES AFFECTED BY TRANSCONTINENTAL GRID
13. NATURAL GAS EXTRACTION INDUSTRY
14. MUTURAL GAS PROCESSING INDUSTRY
15. NATURAL GAS STORAGE, TRANSPORTATION, AND DISTRIBUTION INDUSTRY
16. URANILM EXTRACTION INDUSTRY
17. URANIUM PROCESSING INDUSTRY
18. URANIUM STORAGE, TRANSPORTATION, AND DISTRIBUTION INDUSTRY
36. BUSINESSES THAT BENEFIT FROM THE USE OF GEOTHERMAL ELECTRICITY
37. BUSINESSES THAT BENEFIT FROM THE EXTRACTION OR USE OF GEOTHERMAL MINERALS
38. BUSINESSES THAT SUPPLY THE GEOTHERMAL INDUSTRY
39. THE FINANCIAL COMMNITY
40. ANTI-NUCLEAR ORIENTED ENVIRONENTALISTS
41. DNIIRONMENTALISTS AT LARGE
42. GROUPS OF HOMEOWNERS NEAR GEOTHERMAL INSTALLATIONS
43. UNITED NATIONS
44. DEVELOPING COUNTRIES WITH GEOTHERMAL ENERGY RESOURCES
19. COAL EXTRACTION INDUSTRY
20. COAL PROCESSING INDUSTTRY
45. DEVELOPING COUNTRIES WITHOUT GEOTHERMAL ENERGY RESOURCES
21. COAL STORAGE, TRANSPORTATION, AND DISTRIBUTION INQUSTRY
46. FOREIGN COUNTRIES WITH LARGE ENERGY SUPPLIES (E.G., OPEC)
22. PETROLEUM EXTRACIION INDUSTRY
23. PETTROLEUM PROCESSING INDUSTRY
24. PETROLEUM STORNGE, TRANSPORTATION, AND OISTRIBUTION INDUSTRY
47. SUPPLIERS OF GOOOS AND SERVICES FOR TRANSCONTINENTAL TRANSMISSION LINES
48. MAYORS OF CITIES NEAR GEOTHERMAL ENEREY SOURCES
49. EPA
50. RESEARCH COMMNITY IMVLVVED IN GEOTEERMAL RESEARCH

26. SOLAR HEATING INDUSTRY

F1 gure 5.1.2 INTEREST GROUPS 


\begin{tabular}{|c|c|c|c|c|c|c|c|c|c|c|c|}
\hline \multirow[b]{2}{*}{ IMFACTS } & \multicolumn{11}{|c|}{ INTEREST GROUPS } \\
\hline & 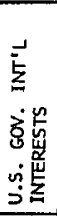 & 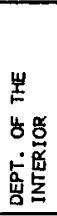 & 岁 & $\frac{4}{2}$ & 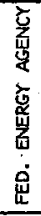 & 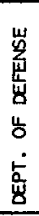 & $\begin{array}{l}\text { 岁 } \\
\text { 营 } \\
8 \\
8 \\
\dot{3}\end{array}$ & 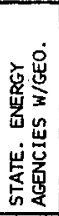 & 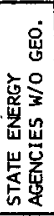 & 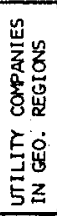 & 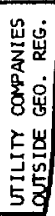 \\
\hline $\begin{array}{l}\text { FEWER THAN EXPECTED GAS-FIRED } \\
\text { ELECTRIC GENERATION PLANTS }\end{array}$ & & & & & & & & & & & \\
\hline $\begin{array}{l}\text { FEWER THAN EXPECTED NUCLEAR } \\
\text { PLANTS }\end{array}$ & & & -6 & & -1 & & 1 & & & & \\
\hline $\begin{array}{l}\text { FEWER THAN EXPECTED COAL-FIRED } \\
\text { PLANTS }\end{array}$ & & & & & & & & & & & \\
\hline $\begin{array}{l}\text { FEWER THAN EXPECTED OIL-FIRED } \\
\text { PLANTS }\end{array}$ & 1 & & & & & & & & & & \\
\hline $\begin{array}{l}\text { LOWER THAN EXPECTED PRICE FOR } \\
\text { GASOLINE }\end{array}$ & 2 & 1 & & & 4 & & 4 & 3 & 3 & & \\
\hline $\begin{array}{l}\text { LOWER THAN EXPECTED PRICE } \\
\text { FOR COAL. }\end{array}$ & & -1 & & & 4 & & 2 & 3 & 3 & & \\
\hline
\end{tabular}

Figure 5.1.3 SAMPLE VALUE MATRIX

R\&D polfcy as a result of the rise of new businesses that use geothermal heat.

70. Exporting of minerals derived from geothermal sources.

71. Diminished amount of stockpiled energy materials.

74. Lowered dependency of certain nations (e.g., Japan) on petroleum.

86. Decreasing rate of depletion of coa1.

87. Decreasing rate of depletion of gas.

88. Decreasing rate of depletion of urantum.

c. Impacts perceived as having somewhat negative affects $(-2$ to -3.9$)$ were:

12. Delayed development of $t a r$ sands and oil shale.

42. Use of agricultural and forest lands for development of geothermal installations.

43. Relocation of local population in order to accommodate geothermal installations.

55. Dedication of severa1 transcontinental corridors for the construction of a transcontinental grid.

61. Revision of federal leasing, tax, and land-use regulations.

62. Establishment of new federal regulatory bodies for geothermal energy.

75. Dimintshed afr quality near geothermal installations.

76. Increased noise near geothermal installations.

77. Diminished water quality near geothermal installations.

78. Increased soil erosion near geothermal installations.

81. Deleterious effects on flora and fauna near geothermal installations.

82. Deleterious effects on wetlands and marshes near geothermal installations.

83. Deleterious effects on aquatic flora and fauna near geothermal installations.

84. Increasing rate of depletion of geothermal resources.

d. Impacts percelved as having very negative affects $(-4$ to -8$)$ were:

45. Use of recreation, park, and wlderness areas for geothermal installations.

79. Increased possibility of 1and subsidence near geothermal installations.

80. Increased possibility of seismlcity near geothermal installations. 
2. The judgments provided to simulate impacts on the financial communtty (group 39) were

a. Impacts perceived as having a very positive affect $(+8$ to +4$)$ were:

None

b. Impacts percelved as having somewhat positive affects $(+2$ to +3.9$)$ were:

5. Lower than expected price for gasoline.

6. Lower than expected price for coal.

7. Lower than expected price for heating and fuel oil.

9. Lower than expected price for electricity

10. Lower than expected price for uranium.

33. Increased geothermal exploration and production of exploration equipment.

34. Increased production of geothermal heat extraction equipment and services.

35. Increased geothermal fleld operations equipment and services.

39. Improvements in inflation over a "non-geotherma1 wor1d."

40. Improvements in government income over a "non-geothermal world."

54. Increased need for capital to finance a transcontinental grid.

65. Increasing capital demand for geotherma1 development.

68. Dimfnishes the amount of imported energy.

70. Exporting of minerals derived from geothermal sources.

74. Lowered dependency of certain nations (e.g., Japan) on petroleum.

c. Impacts perceived as having somewhat negative affects $(-2$ to -3.9$)$ were:

12. Delayed development of tar sand and ofl shale.

17. Delayed development of coal gasification and liquefaction.

84. Increasing rate of depletion of geothermal resources.

d. Impacts percelved as having very negative affects $(-8$ to -4$)$ were:

None.

The four matrices prepared cover the following circum- stances: Case 1, norma1; Case 2, crash; Case 3, normal, with heavy emphasis on reducing environmental impacts; and Case 4, identical with Case 3 but with the addition of policies which diminish land-use impacts. In each case the artthmetic manipulation was the same:

1. A weight of unity was assigned to each Impact statement for Case 1; where different weights were appropriate for the other cases, these new weights were assigned. The wefghts are presented in Appendix $\mathrm{H}$.

2. Both positive and negative impacts affected every group. The relative strength of each impact was computed for each group by taking the columnwise sums of the products of impact weights and, first, the positive impact relevance numbers. These sums constituted a "positive figure of merit." Then a "negative figure of merit" was computed for each interest group. These sums indicated, relatively, how the selected impacts seem likely to affect the groups considered, both favorably and unfavorably.

3. The horlzontal sum of the products of relevance numbers and the weight of each impact statement constituted a "figure of merit" for each impact statement.

4. A rank ordering of the positive and negative figures of merit for each interest group indicated which groups were likely to be most beneficlally or detrimentally affected.

5. A rank ordering of the Impacts by their figure of merit indicated which impacts were 11kely to be seen as most beneficlal or detrimental.

Figure 5.1 .4 below illustrates the computation, and Figures 5.1.5 and 5.1.6 following both display the net scores for groups most significantly affected and the most important impacts for the four cases considered.

\begin{tabular}{|c|c|c|c|c|c|c|}
\cline { 3 - 7 } \multicolumn{2}{c|}{} & \multicolumn{5}{|c|}{ INTEREST GROUPS } \\
\hline IMPACTS & WEIGHT & $\begin{array}{c}\text { GROUP } \\
1\end{array}$ & $\begin{array}{c}\text { GROUP } \\
2\end{array}$ & $\begin{array}{c}\text { GROUP } \\
3\end{array}$ & $\begin{array}{c}\text { GROUP } \\
4\end{array}$ & $\begin{array}{c}\text { GROUP } \\
5\end{array}$ \\
\hline 2 & 1.2 & 3 & 0 & 0 & 2 & 8 \\
\hline 3 & 1.3 & 0 & 5 & 3 & 0 & -3 \\
\hline 4 & .7 & 2 & 3 & 5 & 0 & 0 \\
\hline
\end{tabular}

TO COPPUTE "POSITIVE FIGURE OF MERIT" FOR THE FIRST INTEREST GROUP

$$
\mathrm{FOM}_{4}=1.2 \times 3+2 \times 1.7=
$$

TO COMPUTE "NEGATIVE FIGURE OF MERIT" FOR THE FIRST INTEREST GROUP:

FOM $=1.5 \times 3=$

TO COMPUTE FIGURE OF MERIT FOR THE FIRST IMPACT:

FOM $_{\text {IMPACT } 1}=1.2(3+2+8)=$

F1gure 5.1.4 SAMPLE COMPUTATION 


\begin{tabular}{|c|c|c|c|c|c|c|c|c|c|c|c|c|}
\hline \multirow{3}{*}{ GROPS } & \multicolumn{3}{|c|}{ CASE 1} & \multicolumn{3}{|c|}{ CASE 2} & \multicolumn{3}{|c|}{ CASE 3} & \multicolumn{3}{|c|}{ CASE 4} \\
\hline & \multicolumn{3}{|c|}{ BASE CASE -2000} & \multicolumn{3}{|c|}{ CRASH CASE - 2000} & \multicolumn{3}{|c|}{ EFFECTIVE EN. POLICIES } & \multicolumn{3}{|c|}{$\begin{array}{l}\text { EFFECTIVE EN. }{ }^{6} \\
\text { UND USE POLICIES }\end{array}$} \\
\hline & $\begin{array}{c}\text { NET } \\
\text { INPACTS }\end{array}$ & $\begin{array}{c}\text { POSITIVE } \\
\text { SCORE }\end{array}$ & $\begin{array}{c}\text { NEGATIVE } \\
\text { SCORE } \\
\end{array}$ & $\begin{array}{c}\text { NET } \\
\text { IMPACTS }\end{array}$ & $\begin{array}{c}\text { POSITIVE } \\
\text { SCORE }\end{array}$ & $\begin{array}{c}\text { NEGATIVE } \\
\text { SCORE } \\
\end{array}$ & $\begin{array}{c}\text { NET } \\
\text { IMPACTS }\end{array}$ & $\begin{array}{c}\text { POSITIVE } \\
\text { SCORE } \\
\end{array}$ & $\begin{array}{c}\text { NEGATIVE } \\
\text { SCORE }\end{array}$ & $\begin{array}{c}\text { NET } \\
\text { IMPACTS }\end{array}$ & $\begin{array}{c}\text { POSITIVE } \\
\text { SCORE }\end{array}$ & $\begin{array}{l}\text { NECATIVE } \\
\text { SCORE }\end{array}$ \\
\hline 39. TEE FINANCIAL COMMNITY & 460 & 550 & -90 & 539 & 652 & -113 & 475 & 550 & -75 & 475 & s5o & -75 \\
\hline $\begin{array}{l}\text { 1. U.S. GOVERNENT INTER- } \\
\text { NATIONAL INTERESTS }\end{array}$ & 420 & 590 & -170 & 483 & 689 & -206 & 420 & 590 & -170 & 435 & 590 & -155 \\
\hline $\begin{array}{l}\text { 38. BUSINESSES THAT SUPPLY THE } \\
\text { GEOTERHAL INDUSTRY }\end{array}$ & 410 & 520 & -110 & 647 & 788 & -141 & 525 & 600 & -75 & 535 & 600 & -65 \\
\hline 30. GEOTHERMAL OPERATING INDUSTRY & 350 & 750 & -400 & 503 & 984 & -481 & 550 & 850 & -300 & 540 & 840 & -300 \\
\hline $\begin{array}{l}\text { 50. RESEARCH COMMNITY IMOLVED } \\
\text { IN GEOTHERMAL RESEARCH }\end{array}$ & 340 & 340 & 0 & 478 & 478 & 0 & 420 & 420 & 0 & 420 & 420 & 0 \\
\hline 28. GEOTHERMAL EXPLORATION INDUSTRY & 320 & 730 & -410 & 477 & 970 & -493 & 515 & 830 & -315 & 515 & 820 & -305 \\
\hline 7. U. 5. CONGRESS & 310 & 780 & -470 & 333 & 897 & -564 & 370 & 790 & -420 & 417 & 790 & -373 \\
\hline 43. UNITED NATIONS & 290 & 450 & -160 & 385 & 569 & -184 & 330 & 450 & -120 & 330 & 450 & -120 \\
\hline $\begin{array}{l}\text { 47. SUPPLIERS OF GOODS AND SERVICE; } \\
\text { FR TRASCONTINENTAL } \\
\text { TRAUSMISSIOUI LINES } \\
\end{array}$ & 240 & 280 & -40 & 258 & 298 & -40 & 240 & 280 & -40 & 200 & 240 & -40 \\
\hline 29. GEOTHERMAL DRILLING INDUSTRY & 230 & 720 & -490 & 361 & 950 & -589 & 435 & $\mathbf{B 2 0}$ & -385 & 435 & 810 & -375 \\
\hline $\begin{array}{l}\text { 44. DEVELOPING COUNTRIES WITH GEO- } \\
\text { THERMAL ENERGY RESOURCES }\end{array}$ & 220 & 280 & -60 & 247 & 319 & -72 & 250 & 280 & -30 & 250 & 280 & -30 \\
\hline $\begin{array}{l}\text { 37. EUSTINESSES THAT. BEIEFIT FROM } \\
\text { TEE EXRACTION OR USE OF } \\
\text { GEOHERMAL MINERALS }\end{array}$ & 210 & 410 & -200 & 262 & 505 & -243 & 320 & 470 & -150 & 333 & 458 & -125 \\
\hline 5. FEDERAL ENERGY AGENCY & 130 & 620 & -490 & 178 & 758 & -580 & 290 & 700 & -410 & 300 & 700 & -400 \\
\hline $\begin{array}{l}\text { 48. MAYORS OF CITIES NEAR GEO- } \\
\text { TRERMAL ENERGY SOURCES }\end{array}$ & 60 & 590 & -550 & 72 & 694 & -622 & 240 & 660 & -420 & 336 & 656 & -320 \\
\hline
\end{tabular}

Figure 5.1.5 SCORES FOR GROUPS WHICH PERCEIVE MOST POSITIVE NET BENEFITS FROM GEOTHERMAL ENERGY

\begin{tabular}{|c|c|c|c|c|c|c|c|c|c|c|c|c|}
\hline \multirow{3}{*}{ GROUPS } & \multicolumn{3}{|c|}{ CASE I } & \multicolumn{3}{|c|}{ CASE 2} & \multicolumn{3}{|c|}{ CASE 3} & \multicolumn{3}{|c|}{ CASE 4} \\
\hline & \multicolumn{3}{|c|}{ BASE CASE - 2000 } & \multicolumn{3}{|c|}{ CRASH CASE - 2000} & \multicolumn{3}{|c|}{ EFFECTIVE ENV. POLICIES } & \multicolumn{3}{|c|}{$\begin{array}{l}\text { EPFECTIVE EV. } \\
\text { LA:D USE POLICIES }\end{array}$} \\
\hline & $\begin{array}{l}\text { NET } \\
\text { INPACTS }\end{array}$ & $\begin{array}{l}\text { POSITIVE } \\
\text { SCORE }\end{array}$ & $\begin{array}{l}\text { NEGATIVE } \\
\text { SCCRE }\end{array}$ & $\begin{array}{l}\text { NET } \\
\text { INPACTS }\end{array}$ & $\begin{array}{l}\text { POSITIVE } \\
\text { SCORE }\end{array}$ & $\begin{array}{l}\text { NEGATIVE } \\
\text { SCORE }\end{array}$ & $\begin{array}{l}\text { NEET } \\
\text { IMPACTS }\end{array}$ & $\begin{array}{l}\text { POSITIVE } \\
\text { SCORE }\end{array}$ & $\begin{array}{l}\text { NEGATIVE } \\
\text { SCORE }\end{array}$ & $\begin{array}{l}\text { NET } \\
\text { IMPACTS. }\end{array}$ & $\begin{array}{l}\text { POSITIVE } \\
\text { SCORE }\end{array}$ & $\begin{array}{l}\text { NEGATIVE } \\
\text { SCORE }\end{array}$ \\
\hline 41. ENIRONENTALISTS AT LARFE & -790 & 710 & -1500 & -993 & 841 & -1834 & -420 & 810 & -1230 & -262 & 810 & -1072 \\
\hline 49. EPA & -370 & 380 & -750 & $-45 s$ & 446 & -901 & -135 & 503 & -635 & -77 & 500 & -577 \\
\hline $\begin{array}{l}\text { 42. GROUPS OF HONEOMNERS NEAR } \\
\text { GEOTERMAL INSTALLATIONS }\end{array}$ & -180 & 470 & -650 & -219 & 562 & -780 & 100 & 530 & -430 & 180 & 524 & -344 \\
\hline $\begin{array}{l}\text { 12. UILLITY COMPANIES AFFECTED BY } \\
\text { TRANSCONFINENTAL GRID }\end{array}$ & -80 & 200 & -280 & -66 & 224 & -290 & -80 & 200 & -280 & -60 & 200 & -260 \\
\hline 26. SOLAR HEAJING INOUSTRY & -40 & 150 & -190 & -73 & 170 & -243 & -60 & 150 & -210 & -64 & 146 & -210 \\
\hline 2. DEPARIMENI OF THE INIERTOR & -30 & 450 & -480 & 29 & 598 & -569 & 176 & 530 & -354 & 239 & 530 & -291 \\
\hline .27. SOLNR ELECTRICITY & -30 & 190 & -220 & -60 & 218 & -278 & -70 & 170 & -240 & -74 & 166 & -240 \\
\hline $\begin{array}{l}\text { 46. FOREIGN CONTRIES WITH LARGE } \\
\text { ONERGY SUPPLIES (E.G., OPEC) }\end{array}$ & 0 & 290 & -290 & -6 & 328 & -334 & o & 290 & -290 & 0 & 290 & -290 \\
\hline 3. ATOMIC ENERGY COMISSION & 0 & 260 & -260 & -28 & 311 & -339 & 10 & 270 & -260 & 10 & 270 & -260 \\
\hline 34. MHAFACTURERS Of NUCLEAR PLANTS & 0 & 160 & -160 & -28 & 184 & -212 & 0 & 160 & -160 & 0 & 160 & -160 \\
\hline
\end{tabular}

Figure 5.1.6 SCORES FOR GROUPS WHICH PERCEIVE MOST NEGATIVE NET BENEFITS FROM GEOTHERMAL ENERGY 
In drawing conclusions from this analysis, It is Imporint to recognize that values of the interest group re interpreted by the study tean and were not furnished directly by the Interest groups themselves. Furthermore, the kinds of judgments required by. the value matrix are extremely difflcult to make and involve subtle guesses about what w111 be Important to people between the present and 25 years from now. Nevertheless, the approach followed provided a systematic way for considering some of the myrlad factors Involved in public pollcy formulation in the fleld of geothermal energy. Some of our conclusions from this analysis (which are demonstrated primarily in Figures 5.1.5 through 5.1.8) are:

1. While many groups would see a "crash" geothermal program (Implemented In the absence of concomitant environmental and land use policies) as beneficlal, other groups would see such activity as extremely detrimental. Among the groups most threatened by a crash program are: environmentalists at large, the Environmental Protection Agency, and groups of homeowners near geothermal Installations.

2. Furthermore, such a "crash" program has the property of promoting turmoll among groups at interest. Th1s can be demonstrated by computing the standard deviations of the net Impact in both the Case 1 normal program and the Case 2 crash program. The standard deviation Is a measure of the distributions of attitudes toward the 1mpacts; a smaller deviation would mean a greater unanimity of opinion about the desirability or lack of desirability of the 1mpacts. The standard deviation increases by 50 percent between Cases 1 and 2 .

3. Case 3 involved consideration of the Impact of effective environmental pol1cles on the perceived desirability of the Impacts considered. In general, the positive consequences of the Impacts were seen to improve and the negative

\begin{tabular}{|c|c|c|}
\hline No. & IMPACT STATEMENT & SCORE \\
\hline 32 & INCREASED GEOTHERMAL RED FOR THE ENIRONMENT & 61 \\
\hline 39 & $\begin{array}{l}\text { IMPROVEMENTS IN INFLATION OVER A 'NON- } \\
\text { GEOTHERMAL WORLD" }\end{array}$ & 57 \\
\hline 9 & LOWER THAW EXPECTED PRICE FOR ELECTRICITY & 55 \\
\hline 38 & $\begin{array}{l}\text { IMPROVEMENTS IN GNP OVER A "NON-GEOTHERMAL } \\
\text { WORLD" }\end{array}$ & 51 \\
\hline 40 & $\begin{array}{l}\text { IMPROVEMENTS IN GOVERNMENT INCOME OVER A } \\
\text { "NON-GEOTHERMAL WORLD" }\end{array}$ & 50 \\
\hline 85 & DECREASING RATE OF DEPLETION OF OIL & 44 \\
\hline 87 & DECREASING RATE OF DEPLETION OF GAS & 42 \\
\hline 37 & INCREASED GEOTHERMAL RED EXPLORATION & 37 \\
\hline 68 & DIMINISHENT OF THE AMOUNT OF IMPORTED ENERGY & 36 \\
\hline 23 & $\begin{array}{l}\text { MONEMENT OF BUSINESSES THAT USE GEOTHERMAL. } \\
\text { ELECTRICITY, HEAT, OR MINERALSS INTO } \\
\text { CEOTHERMAL REGIONS }\end{array}$ & 35 \\
\hline
\end{tabular}

FIgure 5.1.7 IMPACTS WHICH ARE LIKELY TO BE PERCEIVED AS HAVING GREATEST POSITIVE CONSEOUENCES consequences were seen to be less detrimental. Among the groups which would percelve environmental policies as most helpful are: environmentallsts at large, homeowners near geothermal Installations, the Environmental Protection Agency, the Department of the Inter1or, the geothermal drilling industry, the geothermal operating Industry, the geothermal exploration Industry, and mayors of cities near geothermal energy sources.

4. Implementation of effective environmental programs also lowers the level of disagreement among groups as measured by the standard deviation of Judgments about the severity of the Impacts.

5. In Case 4 1t was assumed that effective land use pollcies would be implemented in addition to the environmental policies considered in Case 3. Th1s 1mproved the situation even further, particularly for U.S. Congress, the Department of the Interfor, mayors of cities near geothermal sources, environmentalists at large, the Environmental Protection Agency, and groups of homeowners near geothermal installations.

6. Furthermore, the assumptions of Case 4 also have the effect of further reducting disagreement among groups about the desirability of geothermal energy as evidenced by a further decrease in the standard deviation of judgments about the severity of Impacts.

7. A review of the events seen as having potentlally the greatest negative consequences shows that among the environmental factors considered the potential for selsmicity and subsidence should demand the greatest attention.

8. Two of the most negative impacts were not attacked by the policies considered in Cases 3 and 4 . These are: the delay in the

\begin{tabular}{|c|c|c|}
\hline No. & IMPACT STATEMENT & SCORE \\
\hline 80 & $\begin{array}{l}\text { INCREASED POSSIBILITY OF SEISMICITY NEAR } \\
\text { GEOTHERMAL INSTALLATIONS }\end{array}$ & -70 \\
\hline 79 & $\begin{array}{l}\text { INCREASED POSSIBILITY OF LAND SUBSIDENCE } \\
\text { NEAR GEOTTERMAL INSTALLATIONS }\end{array}$ & -68 \\
\hline 13 & DELAYED DEVELOPMENT OF SOLAR ENERGY & -41 \\
\hline 84. & $\begin{array}{l}\text { INCREASING RATE OF DEPLETION OF GEOTHERMAL } \\
\text { RESOURCES }\end{array}$ & -37 \\
\hline 46 & $\begin{array}{l}\text { CREATION OF NEW OPPORTUNITIES FOR CRIME } \\
\text { (E.G., DESTROYING GEOTHERMAL WELLS) }\end{array}$ & -34 \\
\hline 75 & $\begin{array}{l}\text { DIMINISHEO AIR QUALITY NEAR GEOTHERMAL. } \\
\text { INSTALLATIONS }\end{array}$ & -31 \\
\hline 43 & $\begin{array}{l}\text { RELOCATION OF LOCAL POPULATION IN ORDER } \\
\text { TO ACCOMMOATE GEOTHERMAL INSTALLATIONS }\end{array}$ & -29 \\
\hline 45 & $\begin{array}{l}\text { USE OF RECREATION, PARK, AND HILDERNESS } \\
\text { AREAS FOR GEOTHERMAL INSTALLATIONS }\end{array}$ & -29 \\
\hline 76 & INCREASED NOISE NEAR GEOTHEPAAL INSTALLATIONS & -29 \\
\hline 77 & $\begin{array}{l}\text { DIMINISHED WATER QUALITY NEAR GEOTHERMAL } \\
\text { INSTALLATIONS }\end{array}$ & -29 \\
\hline 42 & $\begin{array}{l}\text { USE OF AGRICULTURAL AND FOREST LANDS FOR } \\
\text { DEVELOPNENT OF GEOTHERMAL INSTALATIONS }\end{array}$ & -27 \\
\hline
\end{tabular}

FIgure 5.1.8 IMPACTS WHICH ARE LIKELY TO BE PERCEIVED AS HAVING GREATEST NEGATIVE CONSEQUENCES 
development of solar energy, and the crea-

$\therefore$ - tion of new opportuntites for crime (e.g., destroying geothermal wells): Both of

these Impact areas should probably be given attention in any comprehenglve geothermal program.

9. Among the most beneficial impacts are, not unexpectedly, impacts assoclated with

económics, particularly Inflation, gross

national product, and government income.

In addition, the ability for geothermal

energy to supplant Imported energy sources

appears high on the 11st. 
d. One fairly effective in-situ liquid sampler has been developed which is capable of going to approximately $1000 \mathrm{ft}$.

THE TECHNICAL INQUIRY

This appendix has three major sections. The first presents a summary of the comments recelved from the technical respondents during in-person and telephone interviews (and in some cases by written questionnaires) about the nature of technical impediments likely to affect the evolution of geothermal energy. Comments of one interviewee will not necessar11y correlate with those of another. The second section presents a copy of the forms used during the inquiry. The third part of this appendix summarizes the method used to synthesize the responses pertinent to the extent of geothermal resources in the United States.

\section{Resource Exploration and Appratsal}

Impediment No. A1: Need for downhole sampling proedures for the purposes of recovering representative in-situ geological samples of solids, liquids, or gases. At best, thermal I.R. will be $10-50$ percent improved over the status in Crash 1985.

\section{Present 1973}

Sampling procedures for the purposes of recovering representative in-situ geological samples of solids, 1iquids, or gases are divided into two basic groups: those conducted during drilling operations and those conducted after well completion.

Sampling during drilling can be partially characterized as follows:

a. Solids samples (cores) can most conveniently be retrieved during drilling. These are required to determine physical variations in rock types (such as poros1ty and permeability).

b. Bulk chemical composition is often difficult to determine because soluble fractions and clays are usually washed away by the drilling fluid (water or drilling mud).

c. "Slim holes" (2-3" diameter) yield more useful data because they do not disturb the sample to nearly the same extent as production drilling. Slim holes are practical to an approximate maximum depth of $3000 \mathrm{ft}$.; their sole purpose is to galn information. Sifm hole technology was developed for minerals exploration.

Sampling after well completion can be partially characterized ag follows:

a. Solids sampling is almost imposstble to perform after well completion because the well casing prevents it and present samplers are not capable of scooping solid samples from the wall of an unlined hole.

b. Liquid sampling of ground water at moderate depths is conducted in order to acquire baseline data against which to compare future composition of groundwater in order to monitor possible contamination.

c. Samplers can be sent to the bottom of a hole to retrieve an in-situ liquid sample under no-flow conditions, or a "grab" sample can be taken at the wellhead while the we11 is flowing. e. A sma11 submersible pump has been suggested as an effective sampling device.

f. There is strong need for better ways to sample fluids and gases.

Norma1 1985:

No real change in solids or liquid sampling techniques will occur because of lack of economic impetus for private industry. Good downhole solids and liquid samplers will be developed in 12 years. No real additional progress will be made for dril1-stem test equipment beyond the 1973 level.

Norma1 2000:

Surface sampling will not change or Improve in 12 or 27 years under the "normal" regime for lack of economic incentlve to prlvate industry. Good downhole samplers will be readily available off-the-shelf.

Crash 1985:

Surface sampling will not experience apprectable further development, although good downhole solids samplers will be readily available off-the-shelf. A downhole sample pump w111 be avallable in less than 12 years. Development of an adequate downhole solids sampler w111 require two years. In lieu of industry, the government will start solids sampling after production drilling is complete.

Crash 2000:

No forecast made.

Impediment No. A2: Lack of a practical technlque for conducting gross exploration; 1.e., remote thermal I.R. scanning from Earth Resources Satellite.

\section{Present 1973:}

Two individuals felt that the statement of the impediment should not have included reference to thermal I.R. or to any other specific technique.

It was generally agreed that thermal infra-red scanning Is ineffective for the purpose of conducting gross geothermal exploration. Minimum heat flow that can be detected 18 at least 10 times greater than the necessary minimum value for exploration. Instrumentation explicltly for this purpose is not Included in the Earth Resources Satellite Program. Microearthquake location techniques may become a gross exploration candidate. One individual regards the lack of an effective gross exploration method as a serious impediment to the fast exploration of U.S. geothermal resources. Another individual thinks such a technique is neither practical nor necessary since the same result can be achleved by conducting a comprehensive mapping program using presently-available uncorrelated information; funds should be spent on this method, not on thermal I.R.

\section{Norma1 1985}

Remote therma1 I.R. Is unlikely to be a practical method. The scientific conmunity w11 have assessed other promising techniques for reconnaissance-type exploration, but the impediment will still be unresolved.

One authority thinks that the funds and technical expertise should be spent Instead on compiling a comprehensive set of geological/heat-flow/surface manifestation maps 
of the entire United States, based on existing uncorrelated data; this data should be expanded by further extensive surface and sub-surface physical measurements. This program should employ three to four teams (two people each) working independently and simultaneously for four to five years, supported by funding of $\$ 500,000 /$ year for the first two years.

\section{Normal 2000:}

Remote thermal I.R. may be somewhat Improved, but is still impractical. Satellite detection probably will remain an order of magnitude behind airplane surveys. Other methods are being developed, but the impediment 1s still unresolved. Or, problem will have been essentially solved if virorous mapping program was initiated and carried forward.

\section{Crash 1985:}

Will speed up whole program and will achieve same level of understanding five years sooner than under the Normal 1985 regime.

\section{Crash 2000:}

At best, thermal I.R. will be $10-50$ percent improved over the status in Crash 1985.

Impediment A3: Need for correlation of geophysical data with actual observed data.

\section{Present 1973.}

With respect to the geopressured zones, geophysical exploration techniques applied in the Northern Gulf of Mexico Basin complement one another very well indeed, and yield definitive information on subsurface conditions to depths of $25,000 \mathrm{ft}$. or more; therefore, the impediment as stated does not apply here, in the opinion of one respondent.

It was generally agreed that fairly good correlations already exist between sets of data obtained from different geophysical measurement methods. However, one authority characterizes the present situation as confused and unsatisfactory. He stated further that the magnetic, gravimetric, and magneto-telluric methods have not been satisfactory, whereas heatflow, deep electric reststivity and general geological techniques have produced the best results. The real impediments are (1) the lack of correlation between physical data obtained from a given measurement technique and actual fact at depth, and (2) the lack of dissemination of privately-held data (see Impediment A5).

Three respondents declined to make forecasts.

\section{Normal 1985:}

There w111 be considerably improved correlation and interpretation capability, particularly for electric surface resistivity and selsmology, but the measurements and the correlative efforts will still be a research tool for preliminary exploration. Geophysical measurements and interpretation will be available as services from ofl field service companies and universities. Required inputs w1ll include funding from the government to drill experimental holes at the level of \$4 million/year from now until 1985.

Norma1 2000:

emote temperature sensing methods will not be fruitful.
Porous fluld-filled regions will be well mapped. Geophysical measuring and interpretation services will avallable on a routine commerclal basis. The geoth Industry will have sorted out and accepted the effective methods, and abandoned the ineffective methods. Required inputs will include governmental support rate of $\$ 2$ million/year through 2000 for university-type scientific research.

\section{Crash 1985:}

Crash 1985 will be the same as for Normal 2000; however, with less. scientific understanding and with some gaps In the basic knowledge, A highly developed, competently operated information exchange center (geothermal data center) is an absolute must. (See Impediment No. A5.)

\section{Crash 2000:}

No program required.

Impediment No. A4: Lack of understanding of the inferential signiflcance of a geothermal profile (identity and concentration of constituents).

\section{Present 1973:}

Inferential significance of geochemical profile is already fairly well understood; the difficulty lies in the fallure of industry to apply the known technology. A chemical proftle is needed to predict formation characteristics. It is important in determining the hydrology and porosity, and can be used to determine producibility. It is also the key to assessing the economically recoverable mineral values. The geochemical profile for each field should be determined before the conversion system is designed. In terms of downhole solution chemistry, measuring pressure, as well as temperature, is critical. (See also Impediment No. A1.)

Impediment No. A5: Lack of a geothermal data exchange center to receive, store, process, and disseminate existing and future resource and reservoir data.

\section{Present 1973:}

Most data are gathered by private companies and are not available for public release because of the "proprietary" nature of the data. Private companies of ten thwart the flow and transfer of information internal to their own organizations by isolating the various investigative groups within their organization and maintaining secrecy between them. The industry urgently needs feedback of data from exploration programs (both suczesses and failures) to a centralized data bank so it $\$ 11$ be avallable for general dissemination and correlation.

\section{Normal 1985 and 2000 :}

No real change will occur without substantial government action to overcome inate interests of private industry in this regard.

\section{Crash 1985}

Under a crash program, such a publicly-available data bank might be effected through the medium of governmentsponsored drilling programs, or the government could buy the information from private companies through a "revolving fund" (high risk money, sometimes called "bottomhole money"), under a "crash" program one required input would be the allocation of approximately 
$\$ 10 \mathrm{million} /$ year for 12 years of federal funding for jeation of a highly-developed information exchange hter (geothermal data center) with two or three very competent people to run $1 t$.

\section{Crash 2000:}

Three million dollars/year for the next five years would be required to enlarge and maintain the information exchange center.

Impediment No. A6: Lack of coherent, verified, dynamic reservoir models.

\section{Present 1973:}

This impediment is not considered to be on the critical path. Not enough drilling done to date; Insufficient drilling has falled to yield enough information on which to base a model. A concerted, well-financed program of scientific data recovery must be inst1tuted.

\section{Normal 1985 and 2000:}

Private companies will not initiate the necessary programs of scientific data recovery because it is difficult to demonstrate that this kind of investment is recoverable, let alone profitable.

\section{Crash 1985 and 2000:}

A crash program heavily supported by government fundIng is the only way that the required information w111 be developed.

Impediment No. A7: Need for 1mprovement in procedures, equipment, and data interpretation of the various geophysical exploration and appraisal techniques.

\section{Present 1973:}

The presently avallable techniques for making geophysical measurements are essentlally laboratory methods which have been adapted to field use and are often cumbersome, time-consuming, and require the use of trained personnel. Therefore, acquisition of data 18 an expensive and drawn-out affalr. In one Individual's opinion, what is needed are greatly Improved techniques, procedures, and Instruments which will reduce both required tine and required costs. Another authority stated that even with research programs to develop 1mproved techniques for ... data acquisition, such as instruments and procedures, only marginal 1mprovements can be obtained, and funds will be much better spent on information transfer (see Impediment No. A5) and on actual data correlation.

\section{Normal and Crash, 1985 and 2000:}

No forecasts were made.

Impediment No. A8: Lfmited avaliability of dri1l rigs for deep to very deep drilling $(25,000 \mathrm{ft}$. and greater)

\section{Pregent 1973:}

Geothermal drilling to date has not exceeded the $10,000 \mathrm{ft}$. depth. The few existing ultra-deep wells are gas wells. The need, expertence, and planning of deep, hot, igneous, wide-diameter geothermal wells are lacking. There are only eight to twelve rotary drill rigs In the United States today that are capable of drilling to depths greater than $25,000 \mathrm{ft}$. The geothermal industry can expect strong and Increasing competition from the deep ofl and gas well drilling industry. Current drill rig production lead time is three to five years. Geothermal drilling requires specially modified petroleum Industry equipment. At the present time there is a shortage of trained personnel, an acute shortage of tubular goods (drill steel and well casing), and there is keen competition for drill rigs of all capabilities. The geothermal Industry occupies a poor competitive position because of present lack of continuity of the drilling work (The Geysers is an exception), i.e., no long-term drilling contracts of two to three years in the same general location. (See also Impediment No. B13.)

\section{Normal 1985:}

A larger number of geothermal wells within the 10,000 $\mathrm{ft}$. and maybe the $15,000 \mathrm{ft}$. realms (and possibly a few deeper ones) w111 have been drilled. There are rigs avallable today to go to $30,000 \mathrm{ft}$.; but what will be most needed are investors and/or sponsors, A thorough systems analysis and planning of all the components of deep geothermal development appears needed most. Deep capacity drill rigs may not be the answer.

\section{Normal 2000:}

It is hoped that we will have found more rewarding ways to penetrate the deep earth than to place blind, deeppoint shots from the surface. Deep penetration technology w111 no doubt be avallable. Possibly it will cater to multiple users, similar to space stations or computers, on a cost-sharing basis. Required inputa w111 include systems analysis and planning of deep dr111Ing and other deep penetration methods, as well as total user and requirements analysis. It may be found that the ofl and gas drilling requirements are only partially applicable to the inputs required for deep geothermal penetration.

\section{Crash 1985:}

By way of performance, we will have just completed or w111 be about to complete substantial deep geothermal power capability. There will be sufficient availability of equipment to support this performance capability. The required inputs to achleve the above performance and avallability will include:

(a) Administrative priority program and sponsorship of systems and performance-oriented entities.

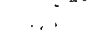

(b) National dedication on a "put man on the moon" level.

(c) Immediate systems engineering conducted on a $\$ 10 \mathrm{million} /$ year level by a dedicated contractor.

\section{Crash 2000:}

Specialized dri11 rigs for many applications, including ultra-deep, non-tapering geothermal drilling, will be available (If this application is still warranted). Several different types of deep penetrators, In addition to drill rigs, w11l be avallable. Their integratIon into the system w111 probably have occurred. Required Inputs will Include continued activity as 
suggested under Crash 1985 above, centered in industry, and administered in a very benefit-oriented and reward-oriented, multi-agency program. Even presentday drill rigs may be part of this program.

Impediment No. A9: Lack of generalized, coherent regional geological models (static).

\section{Present 1973:}

This is not a critical path impediment at this time. It is not considered an impediment at all for the geopressured zones. However, there are many geological cases which have not been verffied by the drill bit.

\section{Normal 1985:}

Wi11 be able to guide exploration to areas of several hundred square miles of regional geothermal potential. Research and exploration results will be avallable to the trade through literature, seminars, etc. General geological, geophysical and hydrological studies of the United States will be needed. Large manpower input may be necessary for geologic mapping and geochemical studies, etc. Industry.w1ll need more examples of actual geothermal areas which have been located and represented as a model.

\section{Norma1 2000:}

Will be able to guide exploration to areas of a few tens of square miles, perhaps even directly to reservolr areas.

\section{Crash 1985:}

Will be able to guide exploration to areas of a hundred square miles or so, having reglonal geothermal potential. Required inputs will include training of earth scientists in numbers necessary for the short-term timespan, and greater ability to disseminate information in the short-term timespan. Rapid feedback of information will be required. Drilling, recording, and publishing of many test cases is necessary.

\section{Crash 2000:}

Will be able to guide exploration to areas of a few tens of square miles, perhaps even directly to reservolr areas.

\section{Reservoir Development}

Impediment No. B1: Lack of practical, broadly-applicable technique for very deep drilling (1.e., below $25,000 \mathrm{ft.}$ ) and very hot drilling (1.e., greater than $800^{\circ} \mathrm{F}$ ).

\section{Present 1973:}

No proven capability extsts at.present. No broadlydefined need or program to get below $25,000 \mathrm{ft}$. depth or above $800^{\circ} \mathrm{F}$ has manifested itself; therefore no associated Industrial activity and development has occurred. Most current geothermal energy developments do not consider exploitation of deep, very hot format1ons because of the lack of drilling technology and energy extraction technology.

The major factor in this impediment is the high temperature. At the present time, the limiting temperature appears to be $600^{\circ} \mathrm{F}$ (not $800^{\circ} \mathrm{F}$ ) for the following reasons: a. Compounded drilling fluids ("mud") begin to break down chemically and physically at about $600^{\circ} \mathrm{F}$. UntIl now, there has been no compeliling reason to break through this temperature 1imit. Baroid, Inc. and Amaco Research (Tulsa, Oklahoma) are currently developing higher temperature drilling fluids.

b. The water in casing cements bolls out of the cement at $600^{\circ} \mathrm{F}$. A $700^{\circ} \mathrm{F}$ setting cement ts now being developed.

c. Data measuring and recording instrument packages (logging tools) generally fail when subjected to temperatures above $500^{\circ} \mathrm{F}$.

Divergence of opinion appears here. Two sets of opinIon are presented below and they are labelled (1) and (2) respectively.

\section{Normal 1985:}

(1) Research will generally be directed toward the temperature and depth goals, proof-of-concepts development, and limited field demonstrations. Very deep drilling will still be extremely expensive. Laboratory data and modest field demonstration may possibly be available. No commercial equipment will be avallable. Avallability of experimental equipment will be limited by what manufacturers are willing to do on spectal orders. Lead time is therefore a function of funding which comes from the government or private industry. Needed inputs w111 require that:

a. R\&D efforts be funded at $\$ 3$ million/year (which is roughly close to current national level from all sources).

b. If present interest and levels of effort at Los Alamos Scientific Laboratory and Battelle National Laboratory in hot dry rock geothermal R\&D continue, there will be modest interest and support for research into new drilling techniques which can surmount the high temperature and very deep drilling problems.

(2) There will not be any substantial change from the present situation.

Broadly applicable techniques will not come either from the geothermal community itself or from the hydrocarbon industry because both are specialized. Required Inputs will include:

a. A massive $R \& D$ program to break through the present temperature barriers.

b. Substantial government participation, possibly through a government/private industry consortium.

c. Broadly applicable techniques stimulated by appropriate program definition and incentives. The inputs should be aware of demanding only bigger and better drill rigs. What $1 \mathrm{~s}$ needed $1 \mathrm{~s}$ b1gger and broader thinking, and posstbly comblnations and atages of ways to get into deep and hot rock, similar to the ways we managed to climb into orbital altitude and beyond. 
Normal 2000:

A new commerctal source will become available for drill. bits and associated heavy-duty. drill rigs capable of making holes to depths of $40 ; 000$ ft. into formations having temperatures greater than $800^{\circ} \mathrm{F}$. Avallability will perhaps consist of one big demonstration in the field. Required inputs would Include:

a. Demonstration of the energy extraction têchnology for hot dry rock to prove this as a practical energy resource at the lower temperature levels $\left(430^{\circ} \mathrm{F}\right)$. Then the potential of very hot rock resources for expanded electric power production will generate the 1mpetus for the development of a hightemperature drilling technology to the stage of commercial field equipment.

b. Approximately \$25-75 million investment by industry.

(2) Drflling and rock penetration have a long history. So, unless new stimul1 are created, this 1mped1ment will not change much in another 15 years. The avallablilty and required inputs will be the same as for Normal 1985. Additional required inputs will include

a. Not only combinations oi users, but combinations of sponsors; governments that are willing to share space satellites may be wlling to co-sponsor new technology development for ultra-deep penetration.

Crash 1985:

(1) The following forecasts make this basic assumption: The potential of the hot dry rock extraction process has been recognized early to be a major contributor to the nation's electrical energy generating capacity and higher temperature chemical process needs. Therefore; the demand for a drilling technology to tap the heat from high-temperature rocks (approximately $800^{\circ} \mathrm{F}$, $700^{\circ} \mathrm{K}$ ) is generated.

In terms of performance, the impediment technology will have achleved the following:

Stage 1: Commerclally-avallable hole-making assemb1y for $800^{\circ} \mathrm{F}\left(700^{\circ} \mathrm{K}\right)$ service and asso-

clated (automatic) rig with $20,000 \mathrm{ft}$. $(6 \mathrm{~km})$

depth capability up to 12 in. $(300 \mathrm{~mm})$ diameter

at a reliable rate of $3 \mathrm{ft} / \mathrm{hr} \cdot(1 \mathrm{~m} / \mathrm{h})$. (Optimum strategy. In upper, cooler formations may dictate use of high penetration rates avallable $\therefore$; with conventional rotary b1ts and rigs.)

Stage 2: Commerclally avallable hole-making assembly for up to $1260^{\circ} \mathrm{F}\left(1400^{\circ} \mathrm{K}\right)$ service and assorted (automated) ultra-heavy duty $\mathrm{rfg}$ with $40,000 \mathrm{ft}(12 \mathrm{~km})$. depth capability; up to $0.5 \mathrm{~m}$ (20 in.) diameter at a rellable rate of $1 \mathrm{~m} / \mathrm{h}(3 \mathrm{ft} / \mathrm{h})$.

Equipment ava1lab111ty will be:

Stage 1: $10 \mathrm{rIgs}$ completing 50 pairs of GTE holes in established thermal anomalies.

Stage 2: One rig to provlde final demionstration of capability.

The required inputs for the above development will Include:
Stage 1:

(1) Supporting R\&D programs to develop four best approaches (Including rock melting) to develop, the required new hole-making assemb1y (1es).

(2) Establishment of commercial sources for fabrication.

(3) Design and fabrication of special rigs.

(4) Cost of approximately $\$ 40 \times 10^{6}$ to choose hole-making contender(s).

(5) Establishment of production facilities for new "drill bit" production.

Stage 2:

(1) Based on selected hole-making technology in Stage 1, scale up in size and extended depth capability.

(2) Additional $\$ 20 \times 10^{6}$ for Räb.

(3) Adaptation of ultra-deep $\mathrm{IIg}_{\mathrm{g}}$ to the new hardware.

(4) Demonstration of practical field performance.

(2) In terms of performance, broadly applicable techniques would have contributed to ultra-deep geothermal development, just as Mercury, Gemin1, and Apollo contributed, toward the moon landing. With respect to avallability, there is an abundance of talent and of Ideas which are hidden in the many speciallzed industries and agencies. Required inputs Include Immediate systems engineering by a dedicated contractor on a $\$ 10$ million a year level, backed by adminlstrative priority and sponsorsh1p. The "Rapid Excavation" program of the Department of Defense and the Interfor was an attempt in this direction.

\section{Crash 2000:}

(1) In terms of performance, the following would obtain:

a.: Use of Stage 1 technology and riga for

a.:. extensive deveiopment of high-temperature

$\therefore$, (hIgh efficiency) power plants.

b. Significant contribution ( 5 percent) of Stage 2. technology to U.S: electrical

,... power production demands.

c. Commerctally avallable hole-making assembly for up to $2060^{\circ} \mathrm{F}$ ( $\left(1400^{\circ} \mathrm{K}\right)$ service, with assoctated rig for $60,000 \mathrm{ft} .(20 \mathrm{~km})$ depth capab1lity; Stage 3.

Equipment avallability wili be:

a. Approximately 1000 of the Stage 2 based units.

b. Approximately .40 . Stage 3 systems.

The required Inputs for the above development will include:

a. Additional $\$ 100 \times 10^{6}$ for R\&D to perfect 
Stage 3 technology.

b. Extension of $\mathrm{rig}$ production, drill steam and casing mill, and machinery manufacturIng facllities. Problems foreseen are:

(1) Temperature 1imits on the downhole assembly, drilling fluids, and instrumentation.

(2) Handling of $\mathrm{hlgh}$ temperature returns at surface complicates surface equipment, e.g., ROP, drill mud cooling, pumps, swivels, hoses, packing sand lubricants.

(3) Corrosion damage, accelerated by high temperatures.

(4) Drill mud troubles.

(5) Cementing and completion.

(2) In terms of performance, broadly appllcable techniques may have added a new dimension to life, by $2000 \mathrm{AD}$. With respect to avallability, there w1ll be no problem; construction, transportation and related Industrles will be well-developed and capable. The required inputs include:

a. Continued activity as required under Crash 1985.

b. Awareness of the international and multilateral nature of this impediment which may lead to large-scale international cooperation.

It 1s belleved, however, that without drastic action by the U.S. Government in its role as the leader of world technology, very I1ttle, if anything, will happen with regard to this 1tem, even by the year 2000 .

Imped1ment No. B2: Present acute shortage of tubular goods (drill steel and well casing) wh1ch are essentlal to drilling and casing operations.

\section{Present 1973:}

Geothermal drilling operations must compete with 011 and gas drilling operations, both domestic and forelgn, for tubular goods, 1.e., for dr1ll steel and well casing. Fabrication plants have been able to keep up with the demand unt11 recently. However, the shortage has now become acute, and 18 due to a rapidly increasing domestic and forelgn demand. Forelgn buyers prefer U.S. casing and drill pipe because it is cheaper than foreign fabricated tubular goods because of the devaluation of the U.S. dollar. This situation 18 not being relleved because price control under Phase IV prevents ralsing the domestic price any higher; therefore, a very substantial fraction of the supply is flowing out of the country.

(At the writing of the Appendix, November 1973, price controls on steel were still in effect.)

In the United States alone, there are 85-100 of fshore drill rigs being built at any one time. Each of these requires approximately $40,000 \mathrm{ft}$. of drili steel (two complete strings).

Prior to development of the shortage, normal delivery t1me was 30-60 days from date of placement of an order. Now (November 1973), however, dellvery is being quoted from 18-24 months from date of placement of order, with a present slippage rate of 2-3 months per calendar month.

\section{Normal and Crash 1985:}

The near-term situation is extremely fluid and is strongly Influenced by the general worldwide demend for ofl and gas, the forelgn value of the dollar, and the future course of the federal price control program. In this kind of situation, significant changes can occur very rapid1y, and 12 years 18 much too long a time for which to make predictions. However, it can be said with certainty that geothermal drilling will have a hard time competing for a long time to come. To effectlvely relleve the shortage domestically w111 require that we:

a. Get rld of price control (Phase IV, etc.).

b. Restrict exportation of dri11ing-type tubular goods.

c. Introduce government enforced priority or allocation system for tubular goods.

Impediment No. B3: Lack of demonstrated method for continuous recovery of energy from hot dry rock reservolrs.

\section{Present 1973:}

No scheme has yet been demonstrated. Recovery of energy from hot dry rock is just an "idea" at present; 1t Is st111 in an embryonic state. Approximately o1x man-months of effort have been expended to date on this concept by the USGS. A paper is presently belng written by USGS which includes a numerical solution. B1g technological problems remain to be solved. Inftial results from the laboratory and fleld experiments are very encouraging.

A diversity of opinion exists with respect to the future prospects of the hot dry rock concept. Two sets of opinion are given below and they are labelled (1) and (2) respectively.

\section{Normal 1985:}

(1) If the present funding is expanded and the research programs are continued unt11 1980, commercial feasibility will be demonstrated with a 50-150 MWe power plant by 1985 . By 1978 the power plant w11l have demonstrated continuous energy recovery for the western United States with the concept still being developed in the eartern United States. Required Inputs to demonstrate this recovery are:

a. \$5 million/year for energy extraction methods development.

b. \$5 million/year for heat machines (novel heat engines and processes).

c. \$10 million/year for small demonstration plants (two required).

d. \$3 million/year for multiple-use demonstration plant.

(2) Industry w111 have developed high-temperature drilling technology. The first experimental hot dry rock aystem w11l be in operation, possibly a 10 wive unit, but the entire concept will still be experimental. Massive engineering problems remain to be solved. Required inputs would include the expenditure of $\$ 50$ million over 12 years, not including the conversion systems. 


\section{Normal 2000:}

Hot dry rock will be widely used for generation of electric power and thermal energy. Auxilfarles will be highly developed, including alr heat exchangers for low thermal pollution. The concept will be commercially perfected and will be avaflable throughout the world. Decentralized plants will be in common use. Required inputs include continued funding at the $\$ 10$ million/year level in order to demonstrate varlous other types of geological systems such as deep sedimentary basins and shales.

(2) Will be producing a large (?) amount of power.

\section{Crash 1985:}

(1) Two million MWe will be on line in the western United States, with a binary cycle in the eastern United States. Multiple-use systems will be demonstrated in Alaska and in the northeastern United States. Commercial systems will be routinely avatlable almost anywhere in the United States. Required Inputs w11l include:

a. A funding level of $\$ 40 \mathrm{million} / \mathrm{year}$ to support four parallel developmental programs for different geological systems and heat flow patterns (or \$50-60 militon/ year for higher acceleration of the program).

b. Very strong encouragement by government and positive action by private companies to conserve fuel and reduce pollution.

(2) Hot dry rock systems will have completed an experimental slant-hole with a set of parallel fractures as an initial experiment to prove fracturing methods; this can be completed in three years for $\$ 10$ mil1ion. In four more years, the system can have a slant-hole with a set of fractures in a real heat-bearing site for possibly $\$ 50$ million. Total time required for both above steps is seven to eight years.

Crash 2000:

(1) Many thousands of MWe will be on line, i.e., a significant contribution to electric power generation in the United States. The hot dry rock system will be carrying a substantial heating and alr conditioning load in the United States, Including nearly all new growth. Avallability will be unlimited in terms of technical development. Required inputs w111 Include:

a. Continued funding of demonstration plants at the $\$ 20-40 \mathrm{million} / \mathrm{year}$ level.

b. Demonstrated feastbility of system for adverse (not most favorable) geological sys tems.

c. Considerable advancement in drilling the technology, including increased drilling depths and reduced drilling costs.

(2) Hot dry rock systems will be supplying a major part of the electric power for the Western United States.

Impediment No. B4: Lack of demonstrated method for continuous recovery of energy from magma reservoirs.

\section{Present 1973:}

One Individual stated that it would be a waste of national effort and funds to consider magma seriously as a practical source of energy.
Norma1 1985:

Unwiling to make further forecasts except as follows.

Norma1 2000:

Possibly there will be a 10 MWe experimental unit; this will be just a scientific curiosity.

Crash 1985 and 2000:

According to same individual, no public funds should be spent In developing the concept of energy extraction from magma during the time frame under consideration.

Impediment No. B5: Non-existence of a demonstrated, practical down-hole heat exchanger of sufficlent capacity to be useful in large-scale energy extraction operations.

\section{Present 1973:}

There is no current development in terms of electric power generation.

Normal 1985:

Within two years, a system (Van Huisen concept) wil1 be full-scale tested in the Imperial Valley, California. If this system is proven to be feasible, 2000 MWe will be installed in the Imperial Valley. Required inputs will include:

a. Sufficient private risk capital to carry out a demonstration installation and test.

b. Adequate source of cooling water, or other satisfactory heat rejection schemes exist.

c. Control of deposition of dissolved so11ds on exterior of heat exchanger can be achieved by judicious management of well production.

Normal 2000

If demonstrated as being economically attractive, further development w111 be aggressively pursued by private Industry. Ten thousand MWe will be constructed In the Imperial Valley alone, and there may be additional development elsewhere.

\section{Crash 1985}

There 111 be no appreciable acceleration of demonstration of technical or economic feasibility over what will occur under the "normal" regime. Ten thousand MW will be installed sooner, with possibly $15,000-$ 2C,000 MW by 1985 .

\section{Crash 2000}

The industry will have established reservoir stimulation techniques which will open up tight or otherwise unproductive formations, permitting widespread application of this system of heat extraction. The downhole heat exchanger will be widely applicable to other geological systems.

Impediment No. B6: Lack of effectlve method for InhibitIng and correcting solids deposition in the producing formation and in the production casing.

A diversity of opinion exists with respect to the 
present and future status of this Impediment. Two sets of opinion are given below and are labelled (1) and (2) respectively.

\section{Present 1973:}

(1) Presently the hydraulic, chemical, and thermal mechanisms are quite well understood, but are often ignored in the interest of maximizing short-term economic gain.

(2) Calcium carbonate deposition has been a major problem; however, its deposition mechanism is well-known. It may become a greater problem in lower temperature brines. Silica deposition is a problem at temperatures of $240^{\circ} \mathrm{C}$ and higher, and is a major problem at $280^{\circ} \mathrm{C}$ and above. The silica deposition mechantsm is still not fully understood. No information is avallable on silica or calclum carbonate deposits in the formation. Field studies and laboratory studies on the kinetics and solubilities are much needed, as well as work on inhibiting scale formation.

\section{Norma1 1985}

(1) Close control of well production rates is required to avoid well drawdown, causing flashing and subsequent deposition in the formation which may be irreversible, or at least expensive to correct. The downhole heat exchanger will be the solution in some cases. The necessary technology for effectively removing this impediment is available today; it's simply a question of putting it into practice by judictous well production management. One required input is that the effects of mechanical pumping must be well understood and carefully applied.

(2) Work wil1 continue to be done by private industry on silica deposition with very little work being done by the universities. A good possibility exists of a breakthrough within 12 years. No work w111 be done to determine effects on the formation, although this is much needed. A required input for solving the silica deposition problem will be good field studies with strong laboratory support. For the calctum carbonate deposition problem, 1ittle or no work will occur in the United States, unless unforeseen need occurs; some forelgn work will continue. Th1s respondent considers himself not qualifled to discuss correction of existing deposits. For their prevention, artificial stimulation by acldizing, formation fracturing, or other means may be helpful.

\section{Norma1 2000:}

This would simply be a continuation of developments achleved in the previous 12 years. Additional time would not markedly change the level of development of the technology.

\section{Crash 1985:}

More funds should be put into fleld studies; at least four professionals should be working on solubility and rate studies. Professtonals should start looking at the chemtcal engineering aspects of calcium carbonate deposition. The required funding input would possibly be $\$ 250,000 /$ year to start, with reduced funding after that. Concerning deposition effects in the formation, investigators should get enough thermo-chemical data (collection and evaluation) on an accelerated basis; the technology for dolng this already exists.
Crash 2000:

Such a program would not be required.

Impediment No. B7: Non-existence of proven deepwe11 pumps (for geothermal applications at $500-700^{\circ} \mathrm{F}$ ).

\section{Present 1973:}

Electric cable and motor windings presently available for $300^{\circ} \mathrm{F}$ operation on a routine basis, but at reduced useful life and increased maintenance costs. Electric insulation is temperature-ifimited. One experimental air-cooled electric motor has been operated continuously at $500-700^{\circ} \mathrm{F}$. The present pump manufacturing workload is very heavy.

\section{Normal 1985}

Electric motors and pumps will be capable of continuous operation at $500^{\circ} \mathrm{F}$, but with reduced useful $11 \mathrm{fe}$ and higher malntenance costs. Availability will be limited on1y by capacity to manufacture the units. On a relative scale, the demand for pumps will be far less for the geothermal industry than for the o1l and gas industry, and this individual is certain that the manufacturers will be able to meet the relatively low demand which will be imposed by the geothermal sector. The ability to predict ofl and gas pump business is essential to predicting pump business in general. Required inputs will include:

a. A strong demonstrated demand (need).

b. Development of Improved lubricants, such as silicones, etc.

c. Development of high-temperature electric insulation for cables and motor windings.

d. Development of high-temperature bearings and seals.

\section{Normal 2000}

This would simply be a continuation of developments achleved in the previous 12 years. Additional time would not markedly change the level of development of the technology.

\section{Crash 1985:}

There will be no apprectable improvement in the technology for at least $1-1 / 2$ years; the work w111 be mostly experimental and developmental. A crash development program would be effective but would be much more inefficlent (expensive and wasteful) than the "normal" development program. The crash development program would achieve the same results as under "normal," but sooner. The required inputs would include:

a. A priority system must be established to allocate materials, manufacturing facilities, and personnel.

b. Sufficient capital must be made avallable.

c. Skilled labor must be trained.

\section{Crash 2000:}

A crash program beyond 12 years (1985) is not necessary. 
Impediment No. B8: Lack of knowledge and experience with ( rvoir fluid recharge.

This impediment is inherent in Impediments B6, B10, B12, $\mathrm{B} 15, \mathrm{D} 1, \mathrm{D} 3$, and $\mathrm{D} 7$, and is considered to be redundant to them. Therefore, no interview was conducted directly on it

Impediment No. B9: Lack of knowledge and experlence concerning effectiveness of field stimulation methods on vapor- or 1iquid-dominated flelds.

This impediment is inherent in Impediments B12, B15, and $\mathrm{B} 16$, and is considered to be redundant to them. Therefore, no interview was conducted direct1y on 1 t.

Impediment No. B10: Unknown effects on the producing formation resulting from reinjection of solids-bearing liquid wastes (cooling tower blowdown or flash tank bitters).

\section{Present 1973:}

Damage to the producing formation from this cause, if any, has not been investigated and therefore is essentially unknown. Liquid wastes can be cleaned up (pretreatment) before disposal on the surface or reinjection. It is essential to know the geochemical profile of the liquid wastes, the undisturbed liquids in the formation, and the solids in the reinjection zone, espectally with respect to calcium carbonate, silica, clays, and zeolltes. There is too 11ttle thermo-chemical data presently ava11able to permit prediction of the effects on the formation caused by relnjection. The small amount of avallable data is not well characterized with reference to temperature and pressure. It will be necessary to collect much new thermo-chemical data, and to develop new computer models with inputs which characterize the various geological systems, 1.e., the chemical composition of liquids and sollds which are already in place. We must also do modeling of solution/solution reaction dynamics. Experimental drilling should be conducted in which core sampling is done before reinjection and some years after reinjection, to assess the extent of buildup on the formation. It may be necessary to pre-treat before reinjection.

\section{Norma1 1985:}

Evaluation of thermo-chemical data will occur primarily in the university laboratorles. Ten to fifteen percent of the needed data will be collected and evaluated in the next 12 years. Computer modeling will continue, part1cularly with respect to liquid wastes other than from geothermal sources. Private Industry will work on pre-treatment preparatory to reinjection, but little or no work w111 occur on treatment instead of reinjection, because industry will not pay the.price. Very little if any core drilling to Investigate possible. formation damage will be done in the next 12 years.

\section{Normal 2000:}

Approximately 25-30 percent of the data of geothermal interest will be evaluated in 27 years. Possibly some core drilling for damage verification will have been. done In 27 years.

\section{Crash 1985:}

Seventy-five percent of the required data will be collected in the next 12 years. Types of data required w111 include phase equilibrium and solubility values. Working computer models would be fully developed we11 within 12 years (possibly in two years). Investigators will be able to predict almost all geological/chemical systems with few exceptions. Pre-treatment could be solved in 12 years for all types of geological/chemical systems; silica and calcium carbonate systems must be solved first. Required Inputs will include:

a. Two professionals plus one computer technician full time to evaluate thermo-chemical data, to be supported by $\$ 150,000 /$ year over a 12-year period.

b. Necessary budget funds for core drilling to assess the effects of reinjection.

c. $\$ 1.5$ million/year, the maximum aount that could be spent well.

\section{Crash 2000:}

A crash development program beyond 1985 will not be necessary.

Impediment No. B11: Lack of knowledge of thermal stressfield induced in a hot dry rock formation by massive Injection and withdrawal of cold water.

\section{Present 1973:}

Occurrence of thermal stress cracking of the formation is not essential to the hot dry rock energy extraction system. Theory is poorly developed for rock; calculations are not convincing. This lack of knowledge is not considered to be an impediment in terms of laboratory experiments. Restuls of laboratory experiments are encouraging. These experiments include casting concrete blocks, cooling them as a function of time, and observing crack propagation. Later experiments will use granite blocks.

Field experiments have not yet been performed, but successful performance is not considered to be a major impediment.

A diversity of opinion exists with respect to the future prospects of this impediment. Two sets of opinion are given below and they are labeled (1) and (2), respectively.

\section{Normal 1985:}

(1) The problem can be effectively solved in approximately five years.

(2) Engineering usefulness will be demonstrated convincingly. Thermal stress cracking will be applied as a technique for rock fracturing, and will be as avallable as the hot dry rock systems themselves. Required inputs will include:

a. - Government-funded support of the development of hot dry rock systems.

b.. Substantial university-type rock mechanics experiments with a research funding level of approximately $\$ 5$ million/year.

Norma1 2000:

(1) Theory will be fully confirmed by actual practice.

(2) Thermal stress cracking will be well understood, and will be available wherever hot dry rock geological systems are being worked. Required inputs include: 
a. Rock mechanics studies continue but on a diminished scale.

b. Research funding continues at the rate of $\$ 5$ million/year for two to three years.

\section{Crash 1985:}

(1) Problems completely soluble in approximately two years. Required inputs will include:

a. Two to three people working in the laboratory plus two people doing theoretical work for one year on an $\underline{1_{n}}$ situ field experiment.

b. Total program costing approximately $\$ 1$ million.

(2) Engineering usefulness wil1 be demonstrated convincingly, and complete understanding of mechanics and theory will exist. The availability will be the same as for all hot dry rock. Required input will include a funding level of $\$ 10$ million/year for support of sophisticated computer studies and large-scale field experiments.

\section{Crash 2000:}

The mechanism will be fully understood and economic advantage will be taken of same. This technology will have found other uses, possibly in earthquake control. Required Inputs will include:

a. Some scientific support by university investigation.

b. Funding of approximately $\$ 1$ million/year.

Impediment No. B12: Lack of confirmed understanding of cause/effect relationship between fluid injection into the formation and occurrence of earthquakes.

NOTE: Impediments $\mathrm{B} 12$ and D5 are stated identically, but from two different points of view. Impediment No. B12 Is concerned with possible damage or destruction of the wells, gathering system, or power plant proper resulting from a severe induced earthquake. On the other hand, Impediment No. DS is concerned with the untoward environmental effects on the surrounding area and populace resulting from a severe induced earthquake.

\section{Present 1973:}

This is incorrectly phrased as an "Impediment." The mechanism is better understood than is generally believed. It is presently being studied intensively by the U.S. Geological Survey. Field experiments are very advanced at this time. State-of-the-art of locatIng earthquakes is also far advanced, 1.e., with a network of inexpensive seismic stations. A present impediment is the inability to predict the magnitude of earthquakes. Based on results of recent field experiments by Dr. B. C. Raleigh (USGS) in the oil fleld near Rangely, Colorado, triggering earthquakes by injection of fluids into the formation can be avoided by not injecting where the pressurized fluid can communicate with active seismic faults.

A diversity of opinion exists with respect to the future prospects of this impediment. Two sets of opinion are given below and they are labeled (1) and (2), respectively.

\section{Normal 1985:}

(1) Seismologists will be able to predict the time and place of earthquakes within the next five years, based on research work by Russian investigators and by Dr. B. C. Raleigh.

(2) The mechanism will be well understood. Developers will probably be able to avoid active fault zones and thereby avoid triggering earthquakes. The state of public knowledge and understanding will make the general use of this knowledge routinely available. Required inputs will include:

a. Continuation of the USGS experiments as welI as programs such as the geological probing by the Los Alamos Scientific Laboratory.

b. Malntenance of a federal funding level of $\$ 2-4$ million/year.

\section{Norma1 2000:}

(2) The entire subject will be very well understood, and its techniques will be routinely applied. Required inputs will include:

a. Continued monitoring of seismic signals in developed geothermal systems.

b. Drilling and hydrofracture experiments conducted in regions of tectonic imbalance (high seismic stress flelds) to determine how much release can be achieved (earthquake contro1).

c. Research funding of $\$ 5 \mathrm{million} /$ year maintained to the year 2000 .

\section{Crash 1985}

(2) Entire subject will be we11 understood and seismic occurrences (earthquakes) will be routinely controlled. Required inputs will include:

a. A large amount of drilling and fracturing conducted in a wide varfety of genlogical formations.

b. Very heavy funding maintained, possibly \$15-20 million/year.

\section{Crash 2000:}

(2) Seismologists will be using fluid injection to contro1 earthquakes on a fairly routine basis. They anticipate driling holes along faults and injecting flulds on a scheduled basis to cause continuous release of inter-block shear stresses.

Required funding level is unknown.

Impediment No. B13: Limited avallability of drillrigs for deep to very-deep drilling (i.e., below 25,000 ft.) and very hot drflling (i.e., greater than $800^{\circ} \mathrm{F}$ ).

\section{Present 1973:}

Geothermal drilling must compete with ofl and gas drilling operations for the available drill rigs, skilled personnel, and tubular goods (drill steel and well casing). At present, there is a shortage of trained personnel, an acute shortage of tubular goods, and keen competition for drill rigs of all capabilities. Present geothermal drilling technology depends completely upon the ofl and gas industry developed drilling equipment. Deep drilling requirements Imply an extended geothermal drilling development beyond present trends which today requires only relatively shallow (approximately 5,000-10,000 ft.) steam and ho 
water wells. There are only elght to ten drill rigs in United States capable of drilling to depths greater 25,000 ft. Current drill rig production lead time is three to five years. The geothermal industry has a poor competitive position because of present lack of continuity of the drill work, 1.e., it cannot provide long-term drilling contracts of two to three years in the same general location. (See also Impediment No. A8.) The three largest drill rigs avallable in the United States today were developed in response to U.S. AEC drilling requirements.

\section{Normal 1985:}

The near-term altuation is otrongly influenced by the general demand for gas and oil in the United States and the forelgn value of the U.S. dollar. In terms of performance, drill rig capability will be extended to $40,000 \mathrm{ft}$., with ability to handle normal geothermal gradient temperature problems (i.e., less than 392$514^{\circ} \mathrm{F}$ ). Present trends in ofl and gas exploration and production demands Indicate deeper capabilities w111 evolve in the drilling compantes serving the ofl and gas industry. Very few drill rigs of this capability will exist. Avallability of drill rigs, trained crews, and tubular goods for geothermal w11l depend on the geothermal Industry's ability to attract these essential Items with higher prices and long-term contracts. Required inputs will include:

a. Government-ordered prioritles for drilling equipment.

b. 50 percent depletion allowance for steam (geothermal).

c. Continuity of work (1.e., two to three year drilling contracts), or the ability to pay premfum prices for a one- or two-hole drillIng effort.

A diversity of opinion exists with respect to the future status of this 1mpediment. Two sets of opinion are given below and are labelled (1) and (2) respectively.

\section{Normal 2000:}

(1) Th1s is much too long a time period to make a prediction, but it looks like the geothermal 1ndustry will have a hard time competing with other drilling interests for a long time to come.

(2) Drill rig depth performance will not be significantly extended beyond that for normal 1985, but some additional capability in hole size, economy, and olight improvement in high temperature performance equipment can be expected. In termis of avallability, perhaps a few $(<10)$ drili rigs will be dedicated to deep geothermal driling. Required linputs w111 Include a continuing (but modest) expansion of exploration and production activities in deep steam and hot water geothermal reservolrs; this would support the dedication of some drill rigs to these ventures.

\section{Crash 1985:}

(1) This 1 s essentially the same situation as for Normal 1985, except geothermal now has the dollar leverage with wh1ch to compete w1th the 011 and gas Industry for dr1lling equipment and crews. Required Inputs w111 include:

a. Government-enforced prior1ty or allocations systems for drill r1gs, tubular goods, etc.

b. Vigorous and sustalned crew recrufting and training program.

c. Ending of price control (Phase IV, etc.).
(2) The forecasts for Crash 1985 are premised on the assumption that drilling 1nto hot dry rock formations to exploit the resulting artificial systems is technically feasible. In a 12-year crash program this drilling requirement is implicit. The following goals w111 be set:

Developing the relatively shallow ( $<15,000 \mathrm{ft}$.) low-grade heat $\left(390^{\circ} \mathrm{F}\right)$ resources, to satisfy the projected U.S. demands for 1985 for the following:

(1) Electr1c power 0.5 percent

(2) Space heating 0.5 percent

(3) Industrial process heat 1.0 percent.

With the usual conversion efflciencies, this will require $200,000 \mathrm{MW}$ (thermal) of installed capacity. Th1s in turn requires 1000 pairs of holes at 105/8" dlameter, each pair delivering $200 \mathrm{MW}$ (therma1). Thus, this plan is essentially limited to 1000 locations in the western United States and areas of high geothermal gradients (thermal anomalles). The downhole assemblies can handle the $390^{\circ} \mathrm{F}$ environment.

\section{The forecasta are:}

Industry will be able to dr11l 15,000 ft. holes of 10-5/8" diameter into approximately $390^{\circ} \mathrm{F}$ 1gneous rock at $20 \mathrm{ft} / \mathrm{h}$. This can be accomplished by using 30 medium-sized (e.g., National Model $110-M$ or equivalent) 011 and gas drilling rigs with suitable modifications for present geothermal dri11ing.

Required Inputs will include:

a. Intiating production of modifled rigs at approximately $10 \mathrm{rigs} /$ year, i.e., $\$ 20 \mathrm{million} / \mathrm{year}$.

b. Inttlating required drill rig specifications and publishing firm driling contract projections and total market picture.

Crash 2000:

(1) Declined to make a forecast.

(2) The forecasts for Crash 2000 are premlsed on the following assumptions:

a. A nationwide explo1tation goal. This assumption is necessary in order to forecast the technical feasibility and developed technology of the hot dry rock concept. Particular emphasis should be placed on the eastern otates and midcontinent.

b. Development of deep, approximately 40,000 ft., resources at $480^{\circ} \mathrm{F}$ to sat isfy the profected U.S. demands for the year 2000 for the following:

(1) Electr1c power 0.5 percent.

(2) Industrial process heat 5.0 percent.

(3) Space heating 10.0 percent.

This requires approximately $2 \times 10^{6}$ of installed capacity. This in turn requires approximately 10,000 palre of holes at 12 " 
(300 $\mathrm{mm})$ diameter, each palr producing. approximately $200 \mathrm{MW}$ (therma1).

The forecasts are:

Industry will be capable of drilling 40,000 ft. holes, 12" In diameter, Into rocks at $4 \mathrm{ft} / \mathrm{hr}$.

In terms of availability, industry will be capable of :

a. Producing 1000 ultra-heavy-duty rotary drill rigs (approximately 20,000 rig years of drilling!), which are upgraded versions of the present ultra-deep drill rigs.

b. Producing drill rigs at approxtmately 100 rigs/year.

The required Inputs w11l include:

a. $\$ 30$ million R\&D effort over the next three. to five years.

b. Improved dr111 pipe strength/welght ratio and drill pipe handling capability, doubled average drilling rate, and reduced friction loss of drilling flulds.

c. Significant expansion of drilling machinery manufacturing facilities.

d. Extension of mill capabilities in drill string and casing production.

e. Cost of rIgs estimated at $\$ 5$ million each (total 1s \$5 billion); cost of drilling program at $\$ 10$ million per hole (total $\$ 200$ b1111on); or an investment of approximately $\$ 101$ per installed $\mathrm{kW}$ (thermal).

Impediment No. B14: Lack of an inexpensive, portable two-phase mass flow meter.

No interviews were conducted on this impediment because it was judged to be of very minor importance.

Impediment No. B15: Lack of coherent, verified, dynamic reservoir models.

\section{Present 1973}

This impediment is not considered to be on the critical path. Not enough drilling done to date; Insufficlent drilling has falled to yield enough information on which to base a model. A concerted, wel1-financed program of scientific data recovery must be instituted.

Normal 1985 and 2000 :

Private companies w111 not Initiate the necessary programs of scientific data recovery because it is difficult to demonstrate that this kind of investment is recoverable, let alone profitable.

\section{Crash 1985 and 2000:}

A crash program heavily supported by government funding is the only way that the required information will be developed.
Impediment No. B16: Lack of long-term case history data on which fịeld longevity predictions can be -ined.

Present 1973: .

The situation is very serious. We need to correlate geophysical signatures with reservoir characteristics at depth (see Impediment No. A3), and to develop test methods that allow prediction of reservoir longevity without waiting until the field is exhausted. The only data avaliable at present is on The Geysers, Walrakei, and Larderello for over a few years. Declines in pressure and fluld changes have been noted, but with no real Idea of the ultimate significance as yet.

\section{Norma1 1985:}

Impediments ${ }^{-}$w11 still be serlous becauge we need at least ten years to get a good Idea of fleld performance. We will be able to predict the behavior of a vartety of types of fluld reserves for at least five years in advance. The information will be made avallable through dissemination of data and models in the 1iterature and throughout the trade. Required inputs will include:

a. Data placed in the public domain." Information on individual well records from flelds developed by private companles are required to be made public.

b. Better technology developed for measurements of mass flows of geothermal fluids.

c. Theoretical research conducted on fluid behavior in geothermal systems, including the effects of two-phase fluld flow in the formation.

\section{Normal 2000:}

The situation w111 have improved; it w111 be a lot better, but it still won't be completely overcome. Industry will be able to predict the behavior of a varlety of types of fluld reservoirs $10-20$ years in advance. The avallability of information and the required inputs are the same as for Normal 1985 .

\section{Crash 1985:}

Th1s is st111 a serious impediment for the geothermal industry. Starting right now, it will take an add1tlonal ten years to develop field operating experience. We will be able to, predict the behavior of a variety of types of fluld reservolrs for at least five years In advance. Money will not help much here, except to enlarge the number of reservolrs being explotted for a short time. The avallability of information and required Inputs will be the same as for Normal 1985, with additional required inputs as follows:

a. Specific demonstration facilities on the varlous geothermal resource types.

b. A concerted, directed federal program.

Crash 2000:

The impediment will be essentially removed. The industry w111 be able to predict behavior of a varlety of types of fluid reservolrs for 10-20 years in advance. Statistical information will be better, avallability of information and the required inputs will be the same as for Normal 1985, with the additional required inputs of continued experimentation and eval nation using pilot. 
facilities and accumulation, compilation, and publica$t^{t-n}$ of data from production facilities.

\section{Energy Conversion}

Impediment No. C1: Non-existence of a large-scale demonstration electric power plant for liquid-dominated resources of medium to low thermal quality.

\section{Present 1973:}

No one has seriously destgned a 50-100 MWe unit. No technical impediment exists on the binary process, although no expander of this size has yet been built. (Roto-Flo Corporation has given the Ben Holt Company assurance that they can build single 75-MW hydrocarbon expanders for use in a binary cycle.) All other components are available now. The only real technical impediment is the knowledge of how to control (or live with) the scaling problem. There is no demonstrated technology for this problem yet. Scaling tendency of typical brines is not known. Possibly it can be overcome by multi-stage flash and steam clean-up. Employing multi-stage flash will permit construction of binary plants of any size. Very likely, a substantial number of reservoirs can be produced this way. Control of scaling in the heat exchanger has yet to be proven. Scale formation is likely to be a problem in the majority of cases, with some exceptions. (See also Impediment No. C4.) . Plans exist for a smallscale demonstration plant to be built in five years, plus three years of testing, for a total of eight years. Siting reconnaissance studies for this demonstration plant are underway.

A diversity of opinion exists with respect to the future status of this impediment. Two sets of opinion are given below and are labelled (1) and (2) respectively.

\section{Normal 1985:}

(1) There will be ten units of 50 MWe each, plus one unt of $100 \mathrm{MWe}$, plus $50,000 \mathrm{MW}$ proved reserves for 50 years. In terms of availability, we can produce flve units/year of 50-100 MWe each, depending on the marketability of the power. Required inputs will include:

a. $\$ 50$ million in R\&D, plus a 50 man-year effort.

b. $\$ 30$ million in federal assistance, plus a 3000 man-year effort.

c. $\$ 70$ million public utility funds, plus a 6000 man-year effort.

(2) A commerclally rellable 50 MWe untt will be in operation in six years, and a $100 \mathrm{MWe}$ unit w111 be in operation in less than 12 years. These installations will be located at the technically and economically most favorable sites, 1.e., the "high-grade" sites will be developed first. In terms of availability, there will be no limit except the ability of industry to furnish the hardware. Required Inputs will Include:

a. The general solution of the scaling problem, which w111 require an approprlate R\&D program.

b. Development of a large-scale expander of proven capability.
Normal 2000:

(1) Forty plants having 1000 MWe capacity each w 111 have been built, with proved reserves for 100 years. In terms of availability, industry can build and man five plants/year having 1000 MWe capacity each. Required inputs wil1 include:

a. $\$ 9$ billion invested capital.

b. Plant manufacturing capability shared by other types of power plants.

(2) The upper 1imit of unit size is $100 \mathrm{MWe}$ due to limitations of the field. We cannot get the advantage of economy of scale. The distance to transport the fluid in the fleld is a limitation. Industry will stay with relatively small unfts, having more sophisticated design, higher efficiencles, and lower capital costs. These plants can be designed for 15 percent plant efficlency. The availabllity will be the same as for the first 12 years, except the so-called "total flow" expander may have been proved out and with slightly improved efficlency. Required inputs will include:

a. Improved hardware and thermodynamics.

b. Competition which will eliminate the less viable candidate systems.

Crash 1985:

(1) Demonstration electric power plant of the following descriptions will have been built:

a. Four hybrid plants of 200 Me each.

b. Fifteen plants of 5 Me each.

c. Five plants of $100 \mathrm{MWe}$ each.

d. Two deep well installations of 50 MWe each.

Avaflability will be based on industry's capacity to produce flve plants of $200 \mathrm{MWe} /$ year. Required Inputs will include:

a. \$6 billion of capital invested in manufacturing facilities and the above power plants.

b. 50,000 man-years of effort.

(2) Possibly a commerclally rellable 50 MWe unit will be in operation within three years. Development time will be compressed due to ready avallability of capital. Avallability of plant will be the same as for Normal 1985, except sooner.

\section{Crash 2000}

(1) Installed capacity will equal 25 percent of the national needs, or a $300,000 \mathrm{MWt}$ national inventory of geothermal reserves, plus attendant minerals extraction. Industry w1Il have the abllity to produce $10,000 \mathrm{MWe} /$ year of plant capacity.

Required Inputs will include:

a. $\$ 80$ billion capital investment in utilities.

b. Necessary personnel to build and operate the plants.

c. Greatly enlarged manufacturing facilities. 
Impediment No. C2: Lack of demonstration electric power plant (of any size) for conversion of energy from heavy-brine reservoirs.

\section{Present 1973:}

There has been some previous but mostly negative experience, plus some hopeful plans, plus two trials of plant components which are not yet doing well. San Diego Gas \& Electric's 10 MWe binary unit was never built; instead, tests were conducted to identify the scaling problem. If the binary process is to be used, It will be necessary to heat-exchange with the steam. Separation and scrubbing can remove particulates and a11 silica. Therefore, the use of hypersaline fluid does not pose a serious problem in a direct or binary system after clean-up of the steam. A big problem which is seen is the precipitation of solids out of the residual brines (after flash).

A diversity of opinion exists with respect to the future status of this impediment. Two sets of opinton are given below and are labelled (1) and (2) respectively.

\section{Norma1 1985:}

(1) There will be one unit of 20 MWe capacity, plus one unit of $50 \mathrm{MWe}$ capacity. Three to five years of operating experience will demonstrate the excessive cost, unless the sale of recovered minerals will subsidize the operating expenses. One required input will be $\$ 30$ million plus a 2000 man-year effort.

(2) A 50 MWe demonstration plant will be in operation, and w111 probably use standard state-of-the-art

equipment. Avallability of generating capacity is just a function of Industry's capacity to produce and install the required equipment. Required inputs will include:

a. The demonstration of a feastble technique for steam clean-up.

b. The demonstration of a technique for handling and disposing of precipitated solids.

\section{Normal 2000:}

(1) Five units of 200 MWe capacity each will have been built. Avallability will be limited only by industry's ability to bulld; however, there will be 11ttle need, except to expand mineral extraction capability. It will be required to invest $\$ 300 \mathrm{~m} 111$ ion.

(2) Not applicable because demonstration was achleved by 1985 .

\section{Crash 1985:}

(1) Five untts of 200 MWe capac1ty each w111 have been built, plus a reserve will have been established In the Buttes area of the Imperial Valley. Required inputs w11 include $\$ 1000$ million plus the man-years to match.

(2) Same as for Norma1 1985, except sooner.

\section{Crash 2000}

(1) Crash program beyond 1985 is not justifiable on any basis.

(2) Crash program not necessary because goals have been achieved by 1.985 .
Impediment No. C3: Non-existence of a proven prime mover capable of continuous operation on a predomi nantly liquid two-phase fluid.

Three different developers of such prime movers were interviewed. Their views concerning their candidate concepts are given below, and are identified as (1), (2), and (3), respectively. ([1], Leonard J. Keller of The Keller Corporation; [2], Roger S. Sprankle of Hydrothermal Power Company, Ltd.; and [3], Winston H. Bishop of General Ener-Tech, Inc.)

(1) No demonstrated capability yet. A prototype KROV (Keller Rotating Oscillating Vane) engine is presently being bullt. Test plans call for a full range of mechanical and performance tests by personnel from M.I.T.

(2) Several people are proposing such engines but none are yet in comnercial operation. Hydrothermal Power Company has accumulated approximately 1000 hours of operation on direct extraction from high-energy brine, employing a helical-screw type expander.

(3) To date, bladeless turbine generators for operation on geothermal brines have not been built in any size. However, considerable development experience has been accumulated by General Ener-Tech, Inc., in bladeless turbines utilizing superheated steam, and also in various hot gas applications in ranges from $3 \mathrm{hp}$ to $1600 \mathrm{hp}$. Additionally, General Ener-Tech has developed several two- and three-phase pumps in performance ranges to $1000 \mathrm{gpm}$ which also utilize this principle.

Currently undergolng development testing is a $250 \mathrm{hp}$, $300 \mathrm{gpm}, 500 \mathrm{psig}$ geothermal reinjection pump which is scheduled for testing on one of the Imperial Valley, California, wells.

\section{Normal 1985:}

(1) There should be several 1000 MWe plants operating in the United States and Japan. Units should be shelf items in sizes up to 15 MWe. Units will be available in $200 \mathrm{MWe} / \mathrm{unit}$ at the rate of $10 \mathrm{units} / \mathrm{year}$ Required inputs will include:

a. $\$ 5$ million spent on R\&D funding during first three years.

b. Selection between the binary and flash cycles made on the most feasible basis.

c. \$5 million made avallable for test, evaluation, and revision.

d. Establishment of sufficient manufacturing facilities.

(2) In five years, the industry will have a 5-10 MWe, two-stage, portable or semi-portable, continuous duty machine, requiring only an annual shutdown for routine malntenance. Avallability will be restricted only by the manufacturing industry's abllity to pröduce them. This is estimated at 200 units/year. Required inputs include:

a. Upgrading the current capactty of manufacturing facilities.

b. A strong demand for this type of primemover expressed by the geothermal industry.

(3) In terms of performance, commerclally-rellable 
cycles will be made on the most feasible basis.

c. \$5 million is made available for test, evaluation, and revision.

d. Establishment of sufficient manufacturing facilities.

(2) In five years, will have a 5-10 MWe, two-stage, portable or semi-portable, continuous duty machine, requiring only an amual shutdown for routine maintenance. Availability will be restricted only by the manufacturing industry's ability to produce them. This 1 s estimated at 200 untts/year. Required inputs include:

a. Upgrading the current capacity of manufacturing facilities.

b. A strong demand for this type of prime-mover is expressed by the geothermal industry.

(3) In terms of performance, commercially-rellable bladeless turbine generators in sizes of $1-10$ Me will be developed In one to two years. High-speed alternators in the $3600 \mathrm{rpm}$ range are now avallable. The bladeless turbine already has had significant development, and the short lead time is further supported by the relative simplictty of the device.

By use of the 10 MWe unit in multiples, geotherma1 power plants of 10-50. MWe size can be avallable by 1975. Units of larger size do not appear to be practical due to reasons of IImfted well output and diverse locations of the wells.

In terms of availability, production capability of 10 MWe units at the rate of 20 units per year within three years is feasible.

Required inputs will include:

a. \$1.5 million R\&D over the next year and a half.

b. Moderate enlargement of faciltties and equipment capability.

Normal 2000:

(1) Standardized untts w111 be clearly established in terms of equipment options. Short delivery tImes after order will be routine on all equipment.

Required Inputs w111 include:

a. Manufacturing fac1lities bullt as required.

b. Architectural and engineering firms estab-. lished to carry out the design and construction.

(2) The situation is too volatile for a prediction: However, there are certain specific problems which must be overcome, as follows:

a. Electric utility companies must change their operating philosophies, rate structures, etc.

b. The effluent disposal problem-must be solved.

c. Construction of a demonstration plant by private industry must be accomplished.
(3) This question is probably not realistic, since it Implies that the longer time will produce largersized plants in $50 \mathrm{MWe}$ and up. While there may be reasons for developing turbine generators of larger than 10 MWe on a selective basis, which is entirely feasible, these applications would probably be limited to isolated installations except possibly in the areas of geopressure systems.

\section{Crash 1985}

(1) Equipment w111 be proven and standardized with 100,000 MWe capacity in operation. In terms of availability, industry will have the capacity for production and installation of an additional 50,000 $\mathrm{MWe} /$ year. Required Inputs Include:

a. $\$ 50 \mathrm{million}$ spent on R\&D in the first five years.

b. \$10 milion for accelerated testing and standardization.

c. A concerted program to establish sufficiently large manufacturing facilities.

d. Adequate training program for engineers and engineering companies.

(2) Same as for Normal 1985, except sooner.

(3) In terms of performance, again, 1-10 MWe units used in multiples to 40-50 MWe seem to have merit as optimum-sized plants. In terms of avallability, 100 units/year production capab1lity is reasonable within three years. Required inputs will include:

a. \$4.5 million R\&D program over the next two and a half years.

b. Substantial enlargement of production equipment and facilities.

Crash 2000:

(1) Completely optimized and standardized designs are avallable. Avallability of plants Iimited only by the avaflability of the resource.

(2) Crash program beyond 1985 is not needed.

Impediment No. C4: Lack of effective method for preventIng scale deposits on internal surfaces of mechanical equipment, 1.e., heat exchangers, pipes, turbines, etc.

\section{Present 1973:}

Medium to low-temperature brines with salinity comparable to seawater have given 11ttle trouble worldwide. Little or no trouble has been experienced with hightemperature brine except heavy brines at the Buttes (Imperial Valley, California). Little trouble has been encountered at Cerro Prieto with normal bilnes. Some partially effective methods for preventing scale deposits do exist, and other novel methods, such as low adhesion surfaces and chemical injection control, are currently under development. Corrective steps presently avallable

include use of duplex ( 100 percent backup) equipment (very expensive), mechanical reaming and chipping, and use of chemical solvents. 
Normal and Crash 1985:

Except for probably rare heavy brines, problems will be designed away. Designs and treatments will be available. Required inputs will include $\$ 2$ million in $R \& D$ plus three years of operation in several plants.

Norma1 and Crash 2000:

So little work has been done to date, it is difficult to make a prediction.

Impediment No. C5: Lack of sufficient empirical data on which to base the economical selection of plant construction materials.

Present 1973:

Sufficient data are now available to provide useful life at present power costs. Means of protection are also available.

\section{Norma1 1985}

Important problems w111 be solved and costs w111 be low. There will be widely avallable designs, for a price. Required inputs include $\$ 2$ million in $R \& D$.

Normal 2000 :

Not applicable.

Crash 1985:

Same as in Normal 1985, except in much more detail. Necessary information will be widely available in the open files. Required inputs include $\$ 10$ million for R\&D.

\section{Crash 2000:}

Not applicable.

Impediment No. C6: Lack of demonstration electric power plant of any size for conversion of energy from geopressured zones.

Present 1973:

This is a serious impediment to the development of the geopressured resources. However, at the present time, there is no known plan to construct such a plant.

Norma1 1985:

Within six months to one year after removal of certaln legal impediments, private industry will start to build a demonstration plant in the State of Texas having a minimum of 200 MWe capacity; this would effectively remove the Impediment. A required input would be leglslative action by the State of Texas to classify geothermal water as natural groundwater, Instead of as a mineral, as it is presently classified.

\section{Crash 1985:}

It is highly probable that the federal government will undertake construction of a demonstration plant at a geopressured site if a crash program is instituted. For this to occur, however, would require a direct endorsement by the highest levels of authority within the U.S. Geological Survey.

Impediment No. C7: Lack of demonstration electric power plant of any size for conversion of energy from magma.

While this impediment is of major Importance to the development of magma resources, the problem is very remote time-wise, and hence is receiving little or no attention. Therefore, no interviews were conducted on this impediment.

Impediment No. C8: Lack of demonstration electric power plant of any size for conversion of energy from hot dry rock.

\section{Present 1973:}

This is a serious impediment to the development of the hot dry rock resources; however, at the present time, there is no known firm plan to construct such a plant.

\section{Norma1 1985:}

A 10 MWe demonstration plant w11 be built at the Los Alamos Scientific Laboratory test site, possibly by 1978. This will probably be a joint venture by the federal government and private industry. A required Input would be the successful completion of present experiments at LASL with positive demonstration of the feasibility of the heat recovery method.

\section{Crash 1985}

The experimental effort will be extended to a broader base to Include possibly two more sites. The demonstration plant will be constructed approximately one year sooner than under the "normal" program. 


\section{Environmental Technology}

diment No. D1: Necessity of developing practical techniques for preventing groundwater contamination.

\section{Present 1973}

This has not yet been shown to be an impediment. The severity of the potential impediment is a function of the type of geothermal reservolr, its hydrological setting, and the means employed for flutd recharge or disposal of geothermal fluids.

\section{Norma1 1985:}

Performance is unlimited. The need is to show that it Is possible to recharge at an acceptable rate at the appropriate depth and stratum and still prevent contamination of any groundwater aquifers which are likely to be used as a water supply source. Three million dollars should suffice for field and modeling studies in areas deemed as having potential for contamination.

Norma1 2000:

Same as for Normal 1985; not an impediment.

\section{Crash 1985:}

Same "need to show..." as for Normal 1985. Th1s can be expedited by continuous observations of on-going or demonstration geothermal flelds. The estimate of required funding is increased to $\$ 4$ milition.

Impediment No. D2: Necessity of developing techniques for effectively controlling harmful or nulsance gaseous emissions $\left(\mathrm{H}_{2} \mathrm{~S}, \mathrm{CH}_{4}\right.$, ammonia, etc.).

\section{Present 1973:}

$\mathrm{H}_{2} \mathrm{~S}$ emission is the only real problem at present. $\mathrm{H}_{2} \mathrm{~S}$ is present in substantial amounts in both steam and hot water we1ls. Research to control $\mathrm{H}_{2} \mathrm{~S}$ emissions from power generating units with an open cycle, wet cooling tower, and dry steam, as at The Geysers, is essentially complete. Demonstration at the prototype and operational levels is scheduled for 1974. Control of $\mathrm{NH}_{3}$ and $\mathrm{CH}_{4}$ emtssions is not necessary at The Geysers.

\section{Norma1 1985:}

$\mathrm{H}_{2} \mathrm{~S}$ emissions control equipment will be completely operational within two to three years at The Geysers; commerciaily rellable equipment will be instailed on Units No. 11 and 14. The entire problem w111 be completely solved for both steam and hot water wells in less than 12 years. Two basic approaches to a solution are presently being pursued, as follows:

a. Process solution: Chemically reacting the $\mathrm{H}_{2} \mathrm{~S}$ in the flow stream by Introducing an appropriate reagent. Th1s approach permits rétro fitting existing plants.

b. Engineering solution: "Selecting a different power cycle, such as binary, in which the gas is not released to the atmosphere; it is always contained.

Research on methods to control $\mathrm{H}_{2} \mathrm{~S}$ emtssions at the wellhead would be valuable.
Al1 equipment for control of $\mathrm{H}_{2} \mathrm{~S}$ will be read1ly available, as required. Each geothermal site is unique, and the local physical and chemical cond1tions will determine the applicability of the avallable solutions at any given site. Required inputs will include:

a. Continuation of present experimentation and development by private industry.

b. Approximately $\$ 1.5$ million to be spent in 1974 (already funded by private industry).

Normal 2000:

Not applicable; problem already solved.

\section{Crash 1985 and 2000:}

The problem will be completely solved for both ateam and hot water wells in five to ten years by private industry. Widespread adoption of the binary process w111 largely clrcumvent the problem. A crash program is not required.

Impediment No. D3: Necess1ty of developing broadly applicable techniques for liquid and solld waste disposal.

\section{Present 1973:}

D1sposal of liquid" condensate by reinjection has already been demonstrated and is commerclally rellable at The Geysers. Dlsposal of solid waste 18 now being investigated at The Geysers and a solution is expected during 1974 .

\section{Normal 1985}

Techniques for disposal of both 11quid and solid wastes w11l be fully developed and commerclally reliable. ReInjection wells for disposal of 11quid wastes will be in routine use at The Geysers. Disposal of solld wastes may require landf 111 sites. Research to develop worthwhile uses of elemental sulfur produced by the $\mathrm{H}_{2} \mathrm{~S}$ emissions abatement processes would be valuable. Required Inputs w11 include less than $\$ 2$ milition in the next three years for demonstration of landf111 site development and monttoring. Th1s will be funded by private industry.

Impediment No. D4: Necessity for developing practical and effective techniques for nolse control during initial drilling and testing operations, as well as during operating life of the plant.

$$
\text { Present 1973: }
$$

Noise emlsslons from the power plants proper are already within acceptable limits; this is no problem for the power plant. Techniques and equipment to control notse emtisions from the power generating unfts themselves are already demonstrated, commercially avallable, and in use at The Geysers plant. The notse problem exists only for high-pressure ateam wells during drilling and clean-out blow, which to due to the use of compressed atr as a drilling fluid, and the uncontrolled release of the natural steam. At present, drilling muffiers are in an experimental stage of development oniy: Cleanout blow lasts from 6-48 hours, depending on the characteristics of the well. For hot water systems, noise 18 not a problem at the well during drilling, because driliting mud is used instead of 
compressed air, and there is no uncontrolled release of the geothermal flutd.

\section{Normal 1985:}

Adequate muffiers and nolse suppression techniques w1ll be designed, built, and in test within three years. The nolse problem at the wells w1li be completely solved within five years. The avallability of effective techniques and equipment will be limited only by industry's capacity to manufacture commerclally avallable mufflers and other noise suppression devices. Required inputs will Include continuation of the present experimentation and development work by private Industry.

Norma1 2000:

Not applicable.

\section{Crash 1985:}

Noise problem at the wells w11l be solved in less than five years. W11l require $\$ 1-5$ million in public funds.

Crash 2000:

Not applicable.

Impediment No. D5: Lack of conf1rmed understanding of cause/effect relationship between fluid injection into the formation and occurrence of earthquakes.

\section{Present 1973:}

This 1s" Incorrectly phrased as an "Impediment." The mechanism is better understood than is generally believed. It 1s presently beling studied intensively by the U.S. Geological Survey. Fleld experiments are very advanced at this time. State-of-the-art of locating earthquakes 18 also far advanced, 1.e., with a network of Inexpensive selsmic stations. A present Impediment 18 the inability to predict the magnitude of earthquakes. Based on results of recent fleld experiments by $D r$. B. C. Ralelgh (USGS) in the ofl fleld near Rangely, Colorado, triggering earthquakes by injection of fluids Into the formation can be avolded by not injecting where the pressurized fluld can communicate with active selsmic faults.

A diversity of oplnion exists with respect to the future prospects of this 1mpediment. Two sets of opintion are given below and they are labelled (1) and (2) respectively.

\section{Normal 1985:}

(1) Selsmologists will be able to predict the time and place of earthquakes within the next five years, based on research work by Russian Investigators and by Dr. B. C. Rale1gh.

(2) The mechanfsm w111 be we11 understood. Developers will probably be able to avold active fault zones and thereby avold triggering earthquakes. The atate of public knowledge and understanding w11l make the general use of this knowledge routinely avallable. Required inputs will include:

a. Continuation of the USGS experiments as we11 as programs auch as the geological probing. by the Lo8 Alamos Sclentific Laboratory.

b. Maintenance by a federal funding leve] of $\$ 2-4$ million/year.

\section{Norma1 2000:}

(2) The entire subject w11l be very well understo and 1 ts techniques will be routinely appiled.

Required Inputs will include:

a. Continued monitoring of selsmic signals in developed geothermal systems.

b. Drilling and hydrofracture experiments are conducted in regions of tectonic imbalance (high seismic stress fields) to determine how much release can be achieved (earthquake contro1).

c. Research funding of $\$ 5$ million/year is maintained to the year 2000 .

Crash 1985:

(2). Entire subject w111 be well understood and seismic occurrences. (earthquakes) will be routinely controlled. Required 1nputs will Include:

a. A large amount of drilling and fracturing conducted in a wide variety of geological formations.

b. Maintenance of very heavy funding, possib1y \$15-20 milition/year.

Crash 2000:

(2) Selsmologiats will be using flutd injection to control earthquakes on a fairly routine basis. They anticipate drilling holes along faults and infecting fluids on a scheduled basis to cause continuous release of inter-block shear stresses. Required funding level is unknown.

Impediment No. D6: Necessity to develop a design safety code dealing with hazards to workers and the public wh1ch are specific to the geothermal industry (such as prevention of well blowout).

\section{Present 1973:}

The 1ndustry's present knowledge 1s good. Actual practlce is fatr, considering the general level of safety regulation enforcement.

\section{Normal 1985:}

Safer codes w111 have been adopted. 'Safe practices w111 be well known and widely adopted. Required inputs will Include:

a. \$1 million for technique studies to select safe methods.

b. \$3 million for public and industry information campalign.

c. \$2 m1111on for legal work (legislation).

d. \$10 million for enforcement.

\section{Normal 2000:}

An excellent safety record w111 be well-established; this w1ll be at least as good as for chemlcal plants. Routine regulation and enforcement of the codes will be required. 


\section{Grash 1985:}

as for Normal 1985, except sooner and three times as $\cos t 1 y$.

Crash 2000:

Not applicable.

Impediment No. D7: Necessity of developing predictive, preventive, and corrective techniques for dealing with land subsidence consequent from geothermal fluid withdrawal.

\section{Present 1973:}

This has not yet been shown to be an impediment. The severity of the potential impediment is a function of the type of geothermal resource, as follows:

a. Deep dry steam (vapor-dominated): Not a 1ikely impediment.

b. Shallow hot water (1iquid-dominated): Greatest potential for impediment.

c. Geopressured zones: Not a 11kely Impediment.

d. Hot dry rock: Not a likely impediment.

Norma1 1985:

Performance and avallability for (a) above are unlimited. The rate of recharge of hot water should be sufficient to reduce the impediment to an acceptable level. If supplementation of the local water supply is part of a system objectlve (1.e., a net withdrawal of fluids), closer monitoring must be conducted. There may be possible trade-offs between supplementing a water supply and accepting some subsidence. It must also be recognized that land surface subsidence can be a plant operation problem (e.g., well casing fallure) as well as an environmental problem. Required inputs would 1nclude $\$ 1$ million to determine extent of subsidence (if any) during production.

Norma1 2000:

Same as for Normal 1985.

Crash 1985:

Performance and availability are unlimited. The only apparent impediment may be the impaired ability to recharge all or a signiffcant fraction of the hydrothermal fluids produced with lower quality substitute water or other waste fluids. Funding should be raised to $\$ 2$ million to provide a larger observational network, or observations at additional sites.

Crash 2000:

No need for a crash program in this time perfod.

Impediment No. D8: Necessity for reconciling design of gathering systems and balance of plant with preservation of local aesthetic values.

Present 1973:

There is an awareness of the desirability of preservIng local aesthetic values, but there is little evidence of intention of official, uniform, and fair enforcement.

\section{Norma1 1985 :}

There will be non-uniform, ambiguous, and indefinite codes, with only nominal enforcement. Required inputs will include $\$ 20$ million total in public funds supporting a 1000 man-year effort.

\section{Normal 2000:}

There will be good codes and enforcement, with falr enforcement and compliance. Required inputs will include $\$ 50$ million in public funds.

\section{Crash 1985:}

There will be good but non-uniform codes; they will be understood and enforced. The codes will be widely available but often arbitrarily enforced. Required inputs will include:

a. $\$ 200$ million for fees and wages.

b. $\$ 500$ million for subsidies and inducements.

Crash 2000:

Not applicable. 


\section{Bechtel Corporation \\ Engineers - Constructiors}

Filly Beate Sliec

San Francisco, Calitornia 94119

Bechtel Job No. 10571

October 12, 1973
Dear

As you will recall from our recent phone conversation. Bechtel Corporation is currently involved in the conduct of a study entitled "Technology Assessment of Geothermal Energy Resources Development". This work is being performed in association with The Futures Group. Inc. of Glastonbury, Comnecticut, under contract to the National Science Foundation. One of the primary purposes of this study is to search systematically for forecasts pu technological developments in geothermal energy and assess the probable significance of such developments. The results of the study may well be used to inform public policy-makers and in the allocation of $R \& D$ funds, etc.

Toward that end, we are interviewing experts in various as pect of the geotlacrmal industry. The purpose of the interviews is to solicit candid opinion regarding the present status and the possible future development of certain aspects of geothermal technology under an as sumed set of conditions.

The issue of geothermal resources appraisal, in terms of location, magnitude, and qunlity, stands out as pivolal in determining the potential of gcothermal cucrgy. We recognize that the appraisa of geothermal resources requires extensive surveys which have not yet been performed; nevertheless, resource estimates have appeared in the literature. In this series of interviews, we intend to talk with you and other experts in the field to explore current

\author{
October 12, 1973 \\ Page 2
}

views of the extent to which the appraisal of geothermal resources can be improved. With this in mind, we would like to solicit your input to the study and we seck your cooperation in the conduct of such an interview. In view of the central nature of the is sue of resources appraisal to geothermal development, we sincerely hope that you can address yourself to the questiuns. Information contributed may be on an anonymous basis, at your option. Participants in the interview will receive a summary of the output of the interviews.

In anticipation of the interview., we have enclosed the following:

- A Resource Appraisal Forecast form which indicates the data we believe is needed, along with a definition of essential terms.

- A Geothermal Technology Forecast form, along with its definition of essential terms.

It might be helpfil if you would look over the forms and jot down a few notes in anticipation of our next phone call. If, upon reviewing the questionnaires, you feel it necessary to clarify any of the questions, please phone us at any tinc. Mr. L. O. Beaulaurier (415-764-5914) or Mr. J. W. Hankin (415-764-4081) of our staff will be contacting you during the week of October 22 to discusa the interview and to solicit your replies.

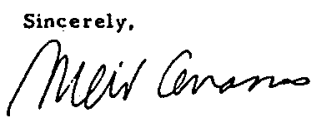

M. Carasso

Project Manager Geothermal Technology Assessment Study

MC:sam

Enclosures

\section{Geothermal Technology Assessment Study RESOURCE APPRAISAL FORECAST}

DEFINITION OF TERMS

In the attached form we have asked for your opinion on the expected developments that you can foresee in relation to specific items that impede development of geothermal energy. We ask that you consider each item in terms of "normal" and "crash" development.

By "Normal Development" is meant that geothermal technology continues to develop on the same basis that it is presently developing, without externally-applied stimuli.

By "Crash Development" is meant that geothermal technology develops under the stimulus of a declared national policy backed by massive governmental support, in which cost is virtually no impediment.

"Reserves" and "Resources": We hope you will use the definitions proposed by Dr. V. E. McKelvey, Director of the United States Geological Survey (attached is a copy of a portion of his paper on this subject). However. (attached is a copy of a portion of his paper on this subject). How
please feel free to use sny other definitions you feel are needed. 


\section{EXCERPTED FROM:}

McKelvey, V.E. "Mineral Resource Estimates and Public Policy." Appearing in U. S. Mineral Resources, U. S. Geological Survey Professional Paper 820. GPO, Washington, D.C., 1973.

\section{CONCEPTS OF RESLRVES IVD RESOURCES}

The focus of most of industry's concern over the extent of mineral resources is on the inayrnizude of the supplies that exist mow or that e:tll te developed in the near term, and this is of public interest also. Many other policy decisions, however, relate to the much more difficult question of potential supplies, a question that to be answered properly must take account both of the extent of undiscorered deposits as well as deposits that camnot be produced profitably now but may become workable in the future. Unfortunately, the need to take account of such deposits is often overlooked, and there is a widesprend tendency to think of potential resources as consisting mercly of materinls in known deposits producible under present economic and technologic conditions.

In connection with my own involvement in resource appraisal, I have been developing over the last several years a system of resource classification and terminology that brings out the classes of resources that need to be taken into account in appraising future supplies, which I believe helps to put the supply problem into a useful perspective. Before describing it, however, I want to emphasize that the problem of estimating potential resources has several built-in uncertainties that make an accu. rate and complete resource inventory impossible, no matter how comprehensive its scope.

One such uncertainty results from the nature of the occurrence of mineral deposits, for most of them lie hidden beneath the earth's surface and are diffcult to locate and to examine in a way that yields accurate knowledge of their extent and quality. Another source of uncertainty is that the specifications of recoverable materials are constantly changing as the advance of technology permits us to mine or process minerals that were once too low in grade, too inaccessible, or too refractory to recovery profitably. Still another results from advances that make it possible to utilize materials not previously visualized as usable at all.

For these reasons the quantity of usable resources is not fixed but changes with progress in science, techuology, and exploration and with shifts in economic conditions. We must expect to revise our estimates periodically to take account of new development. Even incomplete and provisional estimates are better than none at all, and if they differentiate known, undiscovered, and presently uneconomic resources they will help to define the supply problem and provide a basis for policy decisions relating to it.

The need to differentiate the known and the recoverable from the undiscovered and the unecononic requires that a resource classification system convey two prine elenesits of infornation: the degree of certainty about the existenes of the ninterials and the eronomic feasibility of recovering then. These two elements have been recognized in existing terminology, but only incompletely. Thus as used by both the mining and the petroleum industries, the tern reservies generally refers to exonomically recoverable material in identified deposits. and the term resources includes in addition deposits not yet discovered as well as identified deposits that 
cannot be recovered now (for example, Blondel and Lasky, 1956).

The degree of certainty about the existence of the nuaterials is described by terms such as proved, probable, and possible, the terms traditionally used by industry, and measured, indicated, and inferred, the terms devised during World War II by the Geological Survey and the Bureau of Mines to serve better the broader purpose of national resource appraisal. Usage of these degree-of-certainty terms is by no means standard, but all their definitions show that they refer only to deposits or structures known to exist.

Thus, one of the generally accepted definitions of possible ore states that it is to apply to deposita whose existence is known from at least one exposure, and another definition refers to an ore body sampled only on one side. The definition of inferred reserves agreed to by the Survey and the Burean of Mines permits inclusion of completely concealed deposits for which there is specific geologic evi. dence and for which the specific location can be described, but it makes no allowance for ore in unknown structures of undiscovered districts. The previous definitions of both sets of terms also link them to deposits ninable at a profit; the classification system comprised of these terms has thus neglected deposits that might become minable as the result of technologic or economic developments.

To remedy these defects, I have suggested that existing terminology be expanded into the broader framework shown in figure 4 , in which degree of certainty increases from right to left and feasibility of economic recovery increases from bottom to top. Either of the series of terms already used to describe degree of certainty may be used with reference to identificd deposits and applied not only to presently minable deposits but to others that have been identified with the same degree of certainty. Feasibility-of-recovery categories are designated by the terms recoverable, paramarginal, and sulmaryinal.

Paramarginal resources are defined here is those that are recoverable at prices as much as 1.5 times those prevailing now. (I $\mathrm{am}$ indehted to $\mathrm{S}$. $\mathrm{P}$. Schweinfurth for sugresting the prefix para to indicate that the materials described are not only those just on the margin of economic recoverability, the common economic meaning of the term marginal.) At first thought this price factor may seem to be unrealistic. The fact is, however, that prices of many mineral commodities vary within such a range from place to place at any given time, and a price elas-

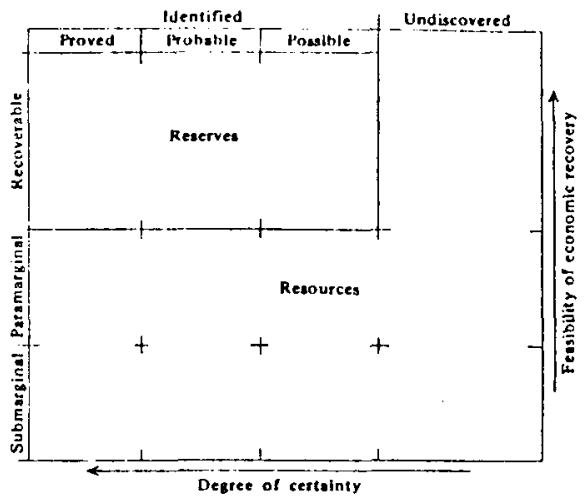

Fintre 4-Classification of mineral reserves and resources. Degree of certainty increases from right to $1 \mathrm{cft}$, and feasibility of economic recovery increases from bottom to top.

ticity of this order of magnitude is not uncommon for many commodities over a space of a few years or even months, as shown by recent variations in prices of copper, mercury, silver, sulfur, and coal. Deposits in this category thus become commercially available at price increases that can be bome with out serious economic efrects, and chances are that improvenents in existing technology will make them available at prices little or no higher than those prevailing now.

Over the longer period, we can expect that technologic advances will make it profitable to mine resources that would be much too costly to produce now, and, of course, that is the reason for trying to take account of submarginal resources. Again; it might seem ridiculous to consider resources that cost two or three times more than those produced now as having any future value at all. But kecp in mind, as one of nany examples, thit the cutolt grade for copper has been reduced progressively not just by a factor of two or three but by a factor of 10 since the turn of the century and by a fuctor of about 250 over the history of mining. Many of the fuels and minerals being produced today would once have been classed as submarginal under this definition, and it is reasonable to believe that continued technologic procress will create recoverable reserves from this category. 
Bechtel Corporation

Engineers-Constructors

Fifty Beale Street

San Francisco, Calitornia

Mall Adoregs: P. O. Box 3985, Sen Franoisco, CA 9a119

Bechtel Job No, 10571

December 7, 1973

Dear Dr.

As you will recall from the recent phone conversation with Mr. L. O. Beaulaurier, Bechtel Corporation is currently involved in the conduct of a study entitled "Technology Assessment of Geothermal Energy Resources Development". This work is being performed in association with The Futures Group, Inc, of Glastonbury, Connecticut, under contract to the National Science Foundation. One of the primary purposes of this study is to search systematically for forecasts of technological developments in geothermal energy and assess the probable significance of such developments. The results of the study may well be used to inform public policy-makers and in the allocation of $R \& D$ funds, etc.

Toward that end, we are interviewing experts in various aspects of the geothermal industry. The purpose of the interviews is to solicit candid opinion regarding the present status and the possible future development of certain aspects of geothermal technology under an assumed set of conditions.

We would like to solicit your input to the study and we scek your cooperation in the conduct of such an interview. Participants in the interview will receive a summaxy of the output of the interviews.

In anticipation of the interview, we have enclosed a set of questions concerning the present and possible future status of a particular impediment to the development of geothermal technology. Also
December 7, 1973

Page 2

enclosed are definitions of essential terms. It might be helpful if you would look over the questions and jot down a few notes in anticipation of our next phone call. If, upon reviewing the questionnaires, you feel it necessary to clarify any of the questions, please phone us at any time. Mr. L. O. Beaulaurier (415-764-5914) of our staff will be contacting you about December 12 to discuss the interview and solicit your replies.

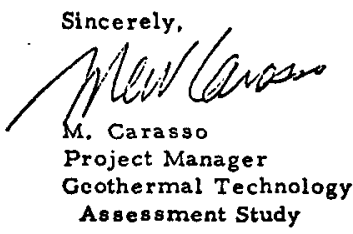

MC:sam

Enclosures 
In the attached form we ask for your opinion on the expected developments that you can foresee in relation to specific items that impede development of geothermal energy. We are asking what can be accomplished, i.e., what is technically possible, aside from political, competitive, and environmental considerations, etc. We ask that you consider each item in terms of a "normal" and "crash" development.

By "Normal Development" is meant that geothermal technology continues to develop on the same basis that it is presently developing, without externallyapplied stimuli.

By "Crash Development" is meant that geothermal technology develops under the stimulus of a declared national policy backed by massive governmental support, in which cost is virtually no impediment.

In order that we may codify your forecasts of the future status of the items which impede development of geothermal energy, it is necessary to specify "performance" and "availability" criteria such as shown in the example below. We ask that the forecasts be given, as much as possible, in quantitative terms of these criteria over future periods of time. Under "required inputs", please give your opinion regarding capital, manpower, research breakthroughs, etc., which will be necessary in order to realize the forecast.

\section{EXAMPLE}

Basis: CRASH Development

Item: Lack of a bladeless turbine

What do you think the status of this item can be in 12 years (by 1.985)?

Performance: Commercially reliable $200-\mathrm{MW}$ unit

Availability: Production capability of 20 units per year

Required inputs: (1) $\$ 3$ million $R \& D$ effort over the next three years.

(2) Substantial enlargement of manufacturing facilities 
Control No.

imped. Forms:

GEOTHERMAL TECHNOLOGY ASSESSMENT STUDY

JOB NO. 10571

IASK 5 INTERVIEW SEQUENCE

(BASIC FORM)

1. Interview
a. Date:
b. Time:
c. Phone $\square \quad$ Mail $\square \quad$ In Person $\square$ at

2. Interviewer:

3. Interviewee

a. Name:

b. Position

c. Phone No. : , , ,

4. Organization

a. Name:

b. Type business:

c. Address

5. Topic

a. R, T, Level

b. Name:

JOB 10571

TASK 5 INTER VIEW SEQUENCE

Control No.

PAGE 2

6. Impediments (R.T. Level \& Name)

a.

b.

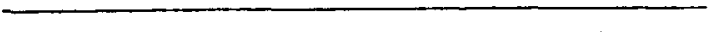

c.

d.

7. Interviewer Confidence Level
a. Knowledgeability:
12345
b. Objectivity:
12345

Low High

Geothermal Technology Assessment Study Job No. 10571, Task 5

GEOTHERMAL TECHNOLOGY FORECASTS

1. Impediment:

2. Present Status of Impediment?

3. NORMAL: Assume that the geothermal technology will continue development on an "as is" basis (present trend or norrnal basis).

a. What do you think the status of this item can be in 12 years (by 1985), in terms of:

Performance?

Availability?

Required inputs?

Job No. 10571

Geothermal Technology Forecasts

Page 2

b. What do you think the status of this item can be in 27 years (by 2000), in terms of:

Performance?

Avallability?

Required inputs?

4. CRASH: Assume that the geothermal technology will be developed on a "crash" basis (expedited basis) in which cost is not an inhibiting factor.

a. What do you think the status of this item can be in i2 years (by 1985), in terma of:

Performance?

Avallability?

Required inputs?
Control No.:

R. T. Level: 
Jou No. 10571

Geothermal Technology Forecasts

Page 3

b. What do you think the status of this item can be in 27 yoars (by 2000), in terms of:

Performance?

Avallability?

Required inputt ?
Control No.

R. T, Level:

Geothermal Tochnology Alsosoment Study

RESOURCE APPRAISAL FORECAST

Control No.

R. T. Level

\section{CRASH DEVELOPMENT}

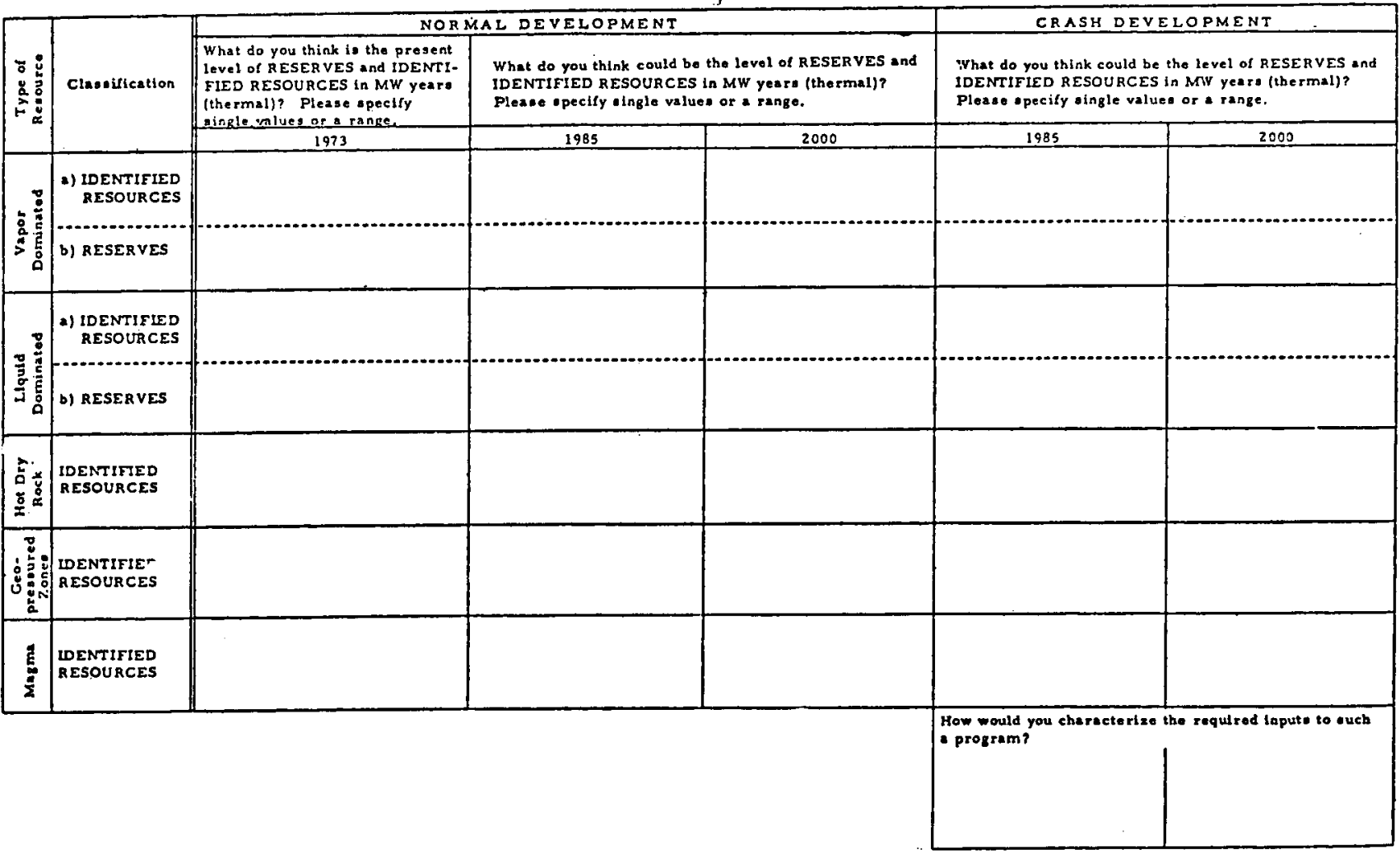




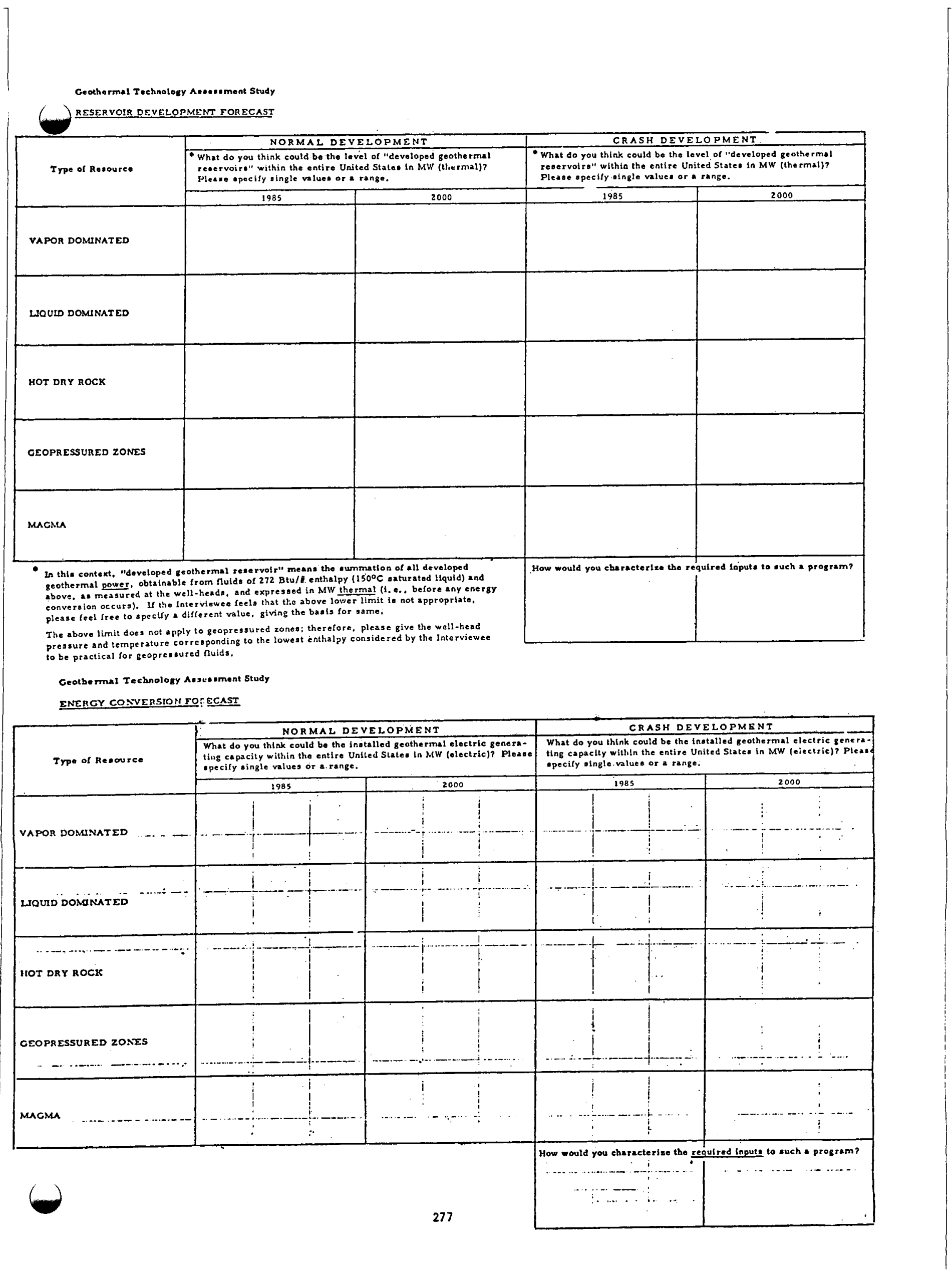




\section{Resource Estimates}

\section{Treatment of Uncertainty}

Analysis of results from the interview sequence indicates that any at rempt to achieve a consensus in describing the potential of geothermal energy by a single deterministic value would have probably falled, with the exception of a few specific cases. A range of forecasts has been obtained both for the technological subsystems and for electric power throughput from geothermal energy systems. In the treatment of results, this range of throughput forecasts will be presented in various forms:

(1) Full range (all data).

(2) Midrange, calculated by eliminating forecasts which led to extreme points of full range, and

(3) Median, calculated by integrating median subsystem forecasts.

The median values are calculated for convenience of results presentation. The two range forecasts refilect better the present state of knowledge. A sample diagram which fllustrates this treatment of uncertainty is illustrated in Figure A.4, which depicts the year 2000 results for 1iquid-dominated resources under normal program emphasis. The estimates of Identified liquid-dominated resources range from 16-1200 GWe resource equivalent. The forecasts for technological capability to develop and convert this resource base range from $15-100$ GWe. The total range of throughput forecasts of technologically feasible levels of 1iquid-dominated geothermal energy resources development, after comparing the two sets of forecasts, is 15-100 GWe capac1ty. The mIdrange is calculated by dropping the two estimates which led to the extreme points of the range forecast. In both cases, this is the development/conversion forecast rather than a resource forecast. The midrange is found now by integrating a forecast of 16-1200 GWe resource equivalent and a forecast of $100 \mathrm{GWe}$ development/conversion capability to get a midrange forecast of 16-100 GWe. The fact that the midrange is very close to the range indicates that both the lowest and highest forecasts are quite close, or, as In the case of the highest estimate here, identical to other estimates. The median forecast is found by comparing the median resource equivalent forecast of 300 GWe with the median development/conversion capability forecast of 100 GWe and selecting the limiting condition of 100 GWe, as Figure A.4 shows.
Geothermal Technology Forecasts, 1973-2000

Generation of geothermal electric power forecasts volves integration, via the methodology described in Section 3, of the forecasts obtained in the technical interview sequence. This section describes the resulting forecasts of technologically feasible levels of geothermal energy resources development for 1973 , 1985 , and 2000 , for a normal and a crash development program emphasis, by resource type as well as for all resource types combined.

1973 Situation: The current level of installed geothermal electric power capacity in the United States 1s $0.396 \mathrm{GWe}$, all of the vapor-dominated resource type, and is located in California. It has been assumed that this value approximately represents the current capability of industry for reservoir development and energy conversion, and no further attempt has been made to solicit estimates from the experts on this question for 1973 .

Estimates of the various experts on the current levels of geothermal resources which can be categorized as "identified" are summarized in Figure A.5 following. The uncertafnty regarding even the current level of geothermal resources is large, as exemplifled by a range of resource equivalent estimates from 9-4100 GWe. However, most of the uncertainty concerns the level of hot dry rock resources. The range of estimates for the remaining four resource types is equivalent to 9-97 GWe, which remains considerably above the amount of existing geothermal-electric capacity of 0.396 GWe.

The technological factors which have restricted geothermal energy resources development to such a negligible amount up to the present time are:

1. The present state of knowledge of the geothermal resources in the United States is skeletal, fragmentary, uncoordinated, and largely undeveloped.

2. Development of vapor-dominated reservoirs and of liquid-dominated reservoirs of moderate salinity has reached the level of technological feasibility, but energy extraction methods have not yet been demonstrated for high-salinity brines nor for hot dry rock, geopressured, or magma resources.

3. Technology for conversion of geothermal energy for vapor-dominated and moderatesalinity liquid-dominated geothermal systems

LIQUID.DOMINATED RESOURCES, YEAR. 2000, NORMAL PROGRAM

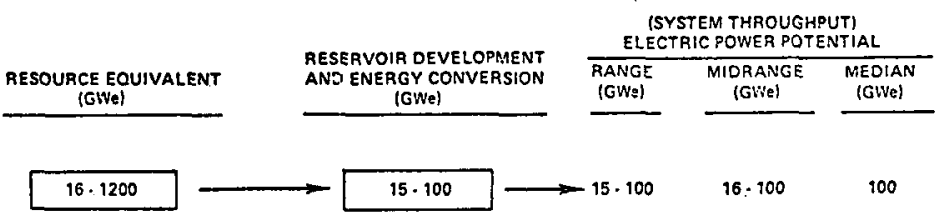

Figure A.4 


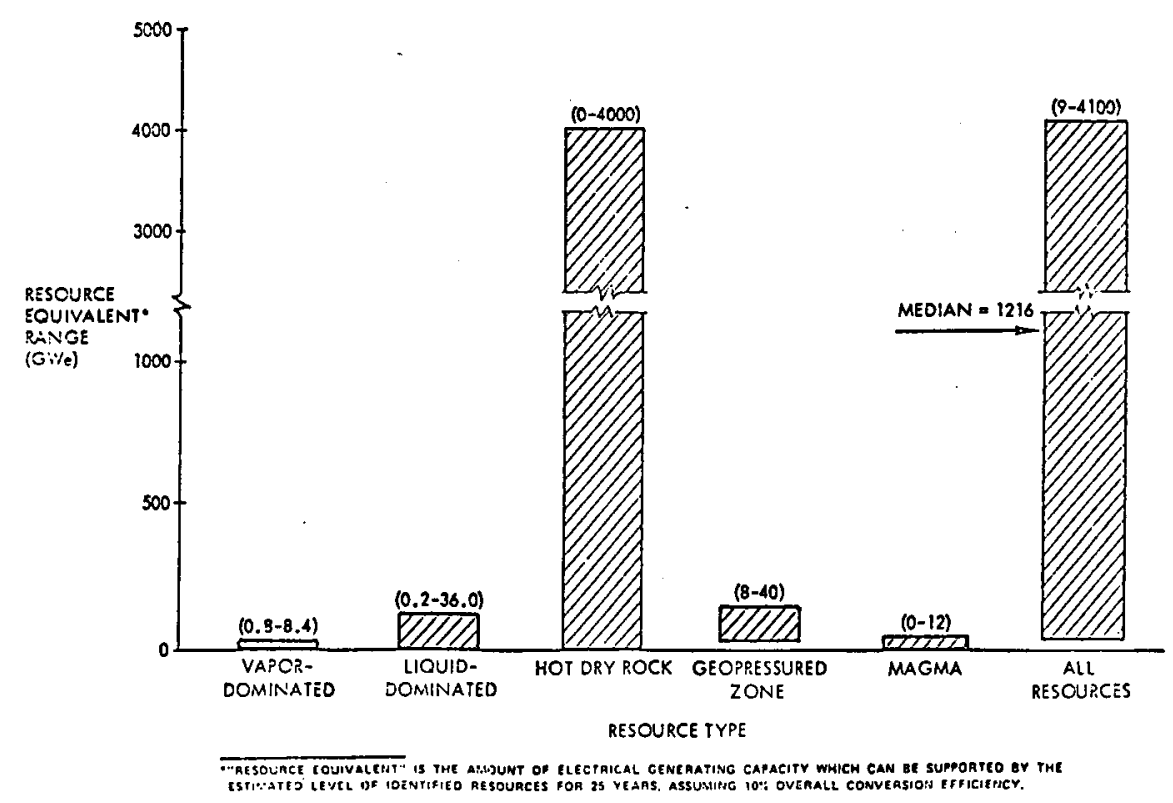

Figure A. 5

is also far advanced, but conversion processes and equipment for high-salinity and for moderate-to-low temperature liquiddominated systems, as we 11 as for geopressured and magma systems, are not yet technically feasible.

Geothermal Technology Forecasts--Summary of 1985 Results: Forecasts of technically feasible geothermal development levels for 1985 are derived in Figures A.6 and A.7 for normal and crash program emphasis, respectively. The results are summarlzed in Figure A. 8 which plots the throughput ranges for all resources. Under a normal program the forecasted throughput potential ranges from 5-24 GWe, while the midrange is 9-11 GWe. The median forecast is $10 \mathrm{GWe}$. These forecasts include comparable contributions from vapordominated, liquid-dominated, and geopressured zone resources, with a small amount of hot rock development. Ut1lization of magma resources is essentlally zero. In this short-term time frame, the industry's development/conversion capability appears to be a-more 11miting factor in nearly all cases than the level of identifled resources. However, there exists great uncertainty regarding the level of resources which. could be 1dentified by 1985 , so that it is unclear whether enhancement of development/conversion capability would stgnificantly increase system throughput.

Figure A.7 on the following page derives the system throughput for 1985 under crash program assumptions. The median forecast for technologically. feasible levels of geothermal energy resources development increases from $10 \mathrm{GWe}$ to $35 \mathrm{GWe}$ if spurred by a large influx of research and development efforts: of thls tötal, the largest potentlal contributions are to be expected from liquid-dominated and hot diry rock resources. Forecasted development of magma resources remalins negligible. The total range of throughput forecasts is 12-144 GWe, with a midrange of $27-40 \mathrm{GWe}$. (The high estimate of 144 .We in the range includes one expert's forecast of 100 GWe of geopressured-zone resource development, whtch assumes the existence of a mechanism which can utilize the chemical energy of the methane as well as the thermodynamic energy content of the fluid. If not, his estimate would be reduced by approximately two-thirds to $33 \mathrm{GWe}$, and the range narrowed to 12-77 GWe.) The limtting factor again appears to be Industry's capability to develop and convert resources which are forecasted to be identified, although the uncertainty regarding the resource level remains great.

Resource Type: Vapor-Dominated 1985

Normal development: A11 three of the interviewees queried on the resource exploration and appraisal question estimate that the level of Identified vapordominated resources with normal program emphasis will be Inadequate to support a substantial level of generating capacity. ' The highest resource estimate is equivalent to 14.4 GWe capacity. The view of three other experts questioned on the subject of development and conversion of the resource is that the development of vapor-dominated resources w111 be slightly lower in 1985 , with the highest of the three forecasting a capability to install 5 GWe capacity. Combination of the median estimates for resource appralsal and for development/conversion results in a forecast of $3 \mathrm{GWe}$ of electricity from vapor-dominated resources by 1985 , with -reservolr development/energy conversion capability and the level of identified resources equally limiting constraints.

Crash Development: Under conditions of a crash program, one of the three experts felt that the Identifled vapordominated resource base could be considerably expanded to a level sufficlent tó support $120 \mathrm{GWe}$ of generating capactity, while the other two experts forecasted no significant increase in identifled resources. On the question of development/conversion capability, the three experts agreed that a crash program would not be adequate to'significantly increase this capability by 1985 , with the most optimistic. forecast of $10 \mathrm{GWe}$ capacity. 


\begin{tabular}{|c|c|c|c|c|c|}
\hline \multirow[b]{2}{*}{ TYPE OF RESOURCE } & \multirow[b]{2}{*}{$\begin{array}{l}\text { RESOUACE EQUIVALENT } \\
\text { (OWVE) }\end{array}$} & \multirow{2}{*}{$\begin{array}{l}\text { AESERVOIR } \\
\text { OEVELOPMENT } \\
\text { AND ENEROY } \\
\text { CONVERSION (GW, }\end{array}$} & \multicolumn{3}{|c|}{$\begin{array}{l}\text { (SYSTEM THAOUGHPUT) } \\
\text { ELECTRIC POWEA POTENTIAL }\end{array}$} \\
\hline & & & $\begin{array}{l}\text { RANGE } \\
\text { (GWe) }\end{array}$ & $\begin{array}{l}\text { MIORANGE * } \\
\text { (GWe) }\end{array}$ & $\begin{array}{l}\text { MEDIAN * } \\
\text { (GWOI }\end{array}$ \\
\hline VAPOR - DOMINATED & $2 \cdot 14,4$ & $1.8 \cdot 5.0$ & $1.5 \cdot 5.0$ & $2.0 \cdot 3.0$ & 3.0 \\
\hline LIOUID - DOMINATED & 8.1200 & $2.6 \cdot 7.0$ & $2.6 \cdot 7.0$ & 3.5 & 3.5 \\
\hline HOT ORY ROCK & $2.4 \cdot 60,000$ & $0.0 \cdot 1.5$ & $0.0 \cdot 1.5$ & 1.0 & 1.0 \\
\hline GEOPRESSURED ZONES & $16 \cdot 80$ & $1.5 \cdot 10.0$ & $1.5 \cdot 10.0$ & 3.0 & 3.0 \\
\hline MAGMA & 0.12 & $0.0 \cdot 0.1$ & $0.0 \cdot 0.1$ & 0.0 & 0.0 \\
\hline TOTALS & & & 8.24 & 9.11 & 10 \\
\hline
\end{tabular}

F1gure A.6

GEOTHERMALL TECHNOLOGY FORECASTS, CRASH, 1985

\begin{tabular}{|c|c|c|c|c|c|}
\hline \multirow[b]{2}{*}{ TYPE OF RESOURCE } & \multirow[b]{2}{*}{$\begin{array}{l}\text { AESOUACE EOUIVALENT } \\
\text { (GWW) }\end{array}$} & \multirow{2}{*}{$\begin{array}{l}\text { RESERVOIR } \\
\text { OEVELOPAIENT } \\
\text { AND ENERGY } \\
\text { CONVERSION (OW.) }\end{array}$} & \multicolumn{3}{|c|}{$\begin{array}{l}\text { (SYSTEM THROUGHPUT) } \\
\text { ELLECTRIC POWER POTENTIAL }\end{array}$} \\
\hline & & & $\begin{array}{l}\text { RANGE } \\
\text { (GWE) }\end{array}$ & $\begin{array}{l}\text { MIOAANGE - } \\
\text { (GWVe) }\end{array}$ & $\begin{array}{l}\text { MEDIAN * } \\
\text { (GWE) }\end{array}$ \\
\hline VAPOR - DOMINATED & $2 \cdot 120$ & $2.0 \cdot 10.0$ & $2.0 \cdot 90.0$ & $2.0 \cdot 4.0$ & 3.5 \\
\hline LIQUID-DOMINATED & $16 \cdot 1,200,000$ & $7.5 \cdot 26.0$ & $7.5 \cdot 26.0$ & $10.0 \cdot 20.0$ & 96.7 \\
\hline HOT DAY ROCK & $20 \cdot 60,000$ & $0.05 \cdot 5.0$ & $0.05-8.0$ & 5.0 & 3.0 \\
\hline OEOPAESSUREO ZONES & $16.200^{\circ}$ & $3.0 \cdot 100$ & $3.0 \cdot 100$ & 10.0 & 10.0 \\
\hline MAGMA & 0.12 & 0.0 .2 & 0.0 .2 & 0.0 .05 & 0.05 \\
\hline TOTALS & & & 12.142 & 27.40 & 35 \\
\hline
\end{tabular}

F1gure A.7

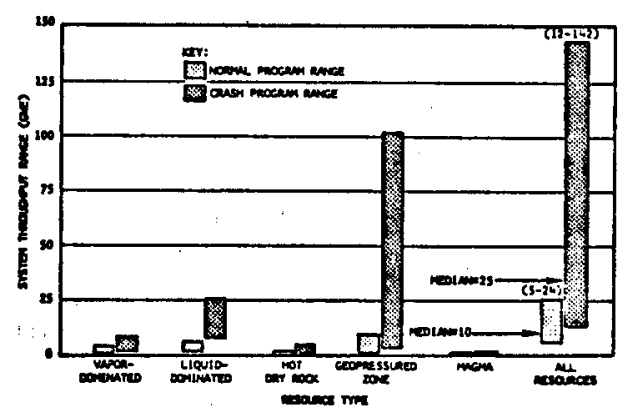

F1gure A.8

The median estimate for maximum electric power contribution of vapor-dominated resources by 1985 with a crash program 183.5 GWe, with development/ conversion only slightly more limiting than the level of Identifled resources, which could have supported 5 GWe. In the judgment of the experts, a crash program in geothermal energy development would heve negligible Impact by the year 1985 on the utilization of vapor-dominated resources, due both to resource level 1imttations and to such technological impediments as shortage of tubular goods essential to drillIng operations and to lack of experfence with reservoir fluld recharge, among others.

\section{Resource Type: Liquid-Dominated 1985}

Norma1 development: There is a significant difference of opinion among the three resource experts on the level of resources which can be identifled by 1985 under normal program emphasis, with estimates ranging from 8-1200 Gwe resource equivalent. The middle estimate is closer to the low than the high of this range. However, the $81 \mathrm{~g}-$ nIficance of this uncertainty pales in light of the fact that none of the three development/conversion experts feels that industrial capability to develop the resource w11l be even as high as the lowest resource level forecast, with major technological impediments in the form 
of a shortage of tubular goods essential to drilling operations and limited availability of drill rigs ca(um of drilling below $25,000 \mathrm{ft}$. The range of forwasts is $2.6-7$ GWe, with a midrange and median value of 3.5 GWe.

Under conditions of a crash research and development program, forecasts of industry development/conversion capability increase approximately by a factor of 3, and forecasts of identified resource level increase by up to 3 orders of magnitude (factor of a thousand). While considerable uncertainty still exists among the three resource experts (resource equivalent ranges from $16-1,200,000 \mathrm{GWe}$ ), two agreed that the resource base is adequate to support more than 200 GWe of electric generating capacity. Reservoir development and energy conversion capability remain an apparently more limiting constraint to liquid-dominated resource utilization, with estimates ranging from 7.5-26 GWe. While the Task 5 assessment concluded that no major impediments blocked development of the resource, minor impediments to reservoir development and energy conversion include a shortage of tubular goods and lack of experience with fluid recharge, among others. The midrange throughput forecast for this reservoir type is 10-20 GWe, with a median value of 16.7 GWe, which is an increase from 3.5 GWe in the normal program case.

\section{Resource Type: Hot Dry Rock}

Normal development: The geothermal experts agreed that hot dry rock will remain a largely undeveloped resource in 1985 under normal program Incentives. The highest of these forecasts for development/conversion capability is a mere $1.5 \mathrm{GWe}$. On the other hand, the quantity of hot rock resources identified by 1985 may prove to be extremely large. One of the experts forecast a virtually limitless resource potentfal of $15 \times 10^{9}$ MWt-years, adequate to support $2000 \mathrm{GWe}$ of generating capacity for 750 years. A second expert felt that the identified resource base might well be large, but expressed some uncertainty, forecasting a resource equivalent of 40-40,000 GWe. However, the third interviewee was much more pessimistic about the level of resources which would be identified by 1985 , with a forecast equivalent to only 2.4 GWe capacity. Even this low estimate is greater than any of the development/conversion capability forecasts, however.

Crash development: A crash program effort in geothermal hot rock is not adequate to significantly increase its electric power potential in the 1985 time frame, according to the consensus of the experts. With this resource, the problem remains one of inadequate technological development/conversion capability to put to use an apparently large resource base. Two of three experts interviewed felt that a crash program would increase the development/conversion industry capability a slight amount to $5 \mathrm{GWe}$. The third person forecasted no improvement, except perhaps for a small 0.05 GWe experimental facility. The 1dentified resource estimates increased somewhat and remain significantly greater than can be developed in this time frame. The median 1985 electric power from hot rock forecast increased from 1 GWe with normal program emphasis to 5 GWe with crash program emphasis.

A significant conclusion from these forecasts is that any crash program in hot rock development should emphasize the reservoir development/conversion aspects of energy production, including the demonstration of the feasibility of present concepts.

\section{Resource Type: Geopressured Zones 1985}

Normal development: Three of the four experts questioned on the quantity of geopressured zone resources which can be identffled by 1985 under normal program emphasis agreed that the resource base is less than that necessary to support 80 GWe of electrical generating capacity for 25 years. But the development/conversion capability appears to be a more limiting constraint, with the most optimistic forecast at $10 \mathrm{GWe}$. (This most optimistic estimate assumes a contribution of approximately 67 percent derived from utilization of the chemical energy of the methane in the geopressured-zone fluid.) The median forecast is for a development/conversion capability of only 1.5 GWe by 1985 , although the median resource forecast could support up to 20 GWe.

Crash development: Three of the four experts questioned felt that a crash program would not significantly affect the 1985 level of identified resources, but the remainIng person stated that the resource would be adequate to support more than 100 GWe for 50 years. The median resource equivalent estimate increased slightly to 42 GWe. Two of the three development/conversion capability forecasts are less than or equal to $10 \mathrm{GWe}$, but one forecast increased greatly to 50-100 GWe.

Combinfing all resource and development/conversion forecasts gives a range for geopressured-zone system throughput of 3-100 GWe for 1985 under crash program conditions. Reservolr development/energy conversion capability forecasts limit both extreme points of the range. After eliminating the two extreme forecasts, a midrange throughput of 10 GWe $1 \mathrm{~s}$ gotten, still limited by development/conversion.

\section{Resource Type: Magma 1985}

All five experts who discussed resource appraisal and/ or development/conversion capability for magma agreed that even under crash program conditions, magma could contribute at most a negligible amount of electric power to the UnIted States' energy system by the year 1985. The most optimistic forecast is for 0.2 GWe capab1lity by 1985, and the median forecast is a mere $0.05 \mathrm{GWe}$, assuming crash program emphasis. The nonexistence of the essential high temperature technology is the critical constraint to magma development.

\section{Conclusions for 1985 Geothermal Electric Power Poten-} tial (System Throughput)

Perhaps the major conclusion from the investigation is that most experts agree that 1985 is too soon to expect significant contribution to electric power supply from geothermal resources, even under the conditions of a crash development program. The major subsystem which impedes the timely development of geothermal energy in this time frame appears to be the industry capability to develop the resources and convert them to electricity, rather than the level of identified resources, although there is large uncertainty as to how much expansion geothermal resources could support above and beyond the forecasted system throughputs. The 1985 impact of a crash program is to Increase the total potential throughput range from 5-24 GWe to 12-144 GWe, the midrange from 9-11 GWe to $27-40$ GWe, and the medtan from 10 GWe to 35 GWe. The greatest 1mpact of a crash program in the 1985 time frame 18 forecast to be seen in development of liquid-dominated and to a less degree geopressured-zone resources, with some impact on hot rock resource development, and negligible impact on vapor-dominated and magma resources. 
Geothermal Technology Forecast--Summary of 2000 $\underline{\text { Results }}$

Forecasts of technologically feasible levels of geothermal energy resources development for 2000 are derived in Figures A.9 and A.10 for normal and crash program emphasis, respectively. The results are summarized in Figure A.11 which plots the throughput ranges for all resources. Under a normal program the system throughput forecasts range from 25-600 GWe, with a midrange of 55-200 Gwe, and a median of $200 \mathrm{GWe}$. Half of the median contribution comes from 1iquid-dominated resources, with approximately 25 percent due to each of hot dry rock and geopressuredzone resources. Negligible potential for development is expected both for vapor-dominated and magma resources. In the case of the most optimistic forecasts, hot dry rock plays the dominant role, contributing two-thirds of the total 600 GWe.

Analysis of the normal program subsystem forecasts indicates uncertainty as to which subsystem most limits geothermal development potential in this time frame. For example, the most pessimistic combination of resource forecast' indicates a level of identified resources of only 50 GWe for 25 years. On the other hand, two of the three experts interviewed agree throw hot dry rock resources are virtually inexhaustible that 11quid-dominated resources are quite large (greater than $200 \mathrm{GWe}$ for 25 years). For the other three resource types, the level of 1dentified resource and industry development/conversion capability appear to be approximately equally 11miting. A review of the Task 5 report indicates that there are no major technological impediments remaining in the year 2000 which would block development, but several minor impediments remain in the resource exploration and appraisal and the reservoir development subsystems.

Figures A.9 and A.10 11lustrate the expected impact by the year 2000 of normal and crash geothermal programs, respectively, on the various resource types. The median forecast for technically feasible levels of geothermal resources development increases from 200 GWe to 770 . Gwe, which $1 \mathrm{~s}$ about 40 percent of projected U.S. demand for installed generating capacity in the year 2000. The major Impact of the crash program would be seen as increasing the leve 1 of posstble development of 11quiddominated resources, according to the median forecasts, and also a significant increase in the potential for hot rock utilization.

GEOTHERMAL TECHNOLOGY FORECASTS, NORMAL, 2000

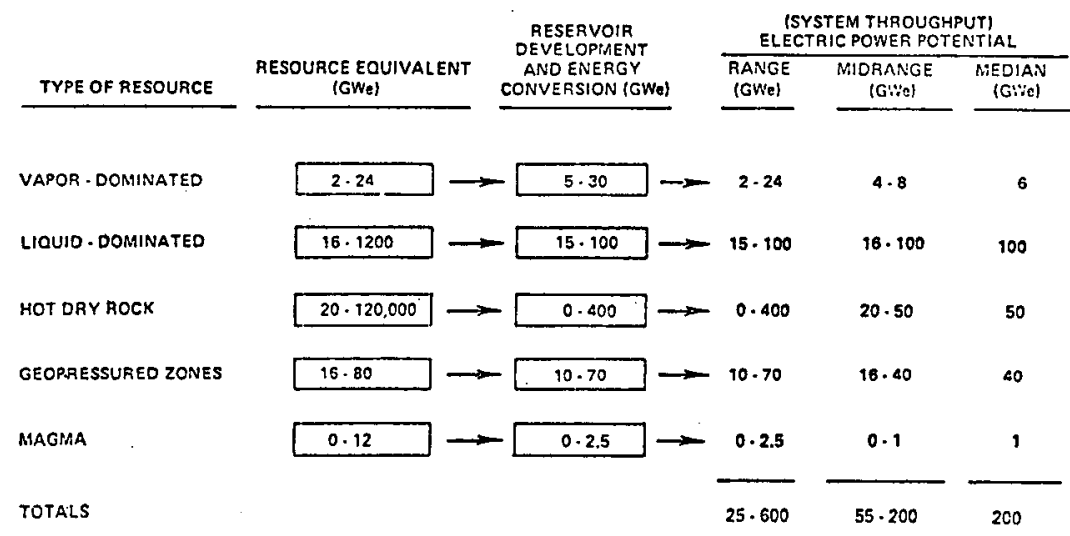

Figure A.9

\section{GEOTHERMAL TECHNOLOGY FORECASTS, CRASH, 2000}

\begin{tabular}{|c|c|c|c|c|c|}
\hline \multirow[b]{2}{*}{ TYPE OF RESOURCE } & \multirow[b]{2}{*}{$\begin{array}{l}\text { RESOURCE EQUIVALENT } \\
\text { (GWe) }\end{array}$} & \multirow{2}{*}{$\begin{array}{l}\text { RESERVOIR } \\
\text { DEVELOPMENT } \\
\text { AND ENERGY } \\
\text { CONVERSION (GWE) }\end{array}$} & \multicolumn{3}{|c|}{$\begin{array}{l}\text { (SYSTEM THROUGHPUT) } \\
\text { ELECTRIC POWER POTENTIAL }\end{array}$} \\
\hline & & & $\begin{array}{l}\text { RANGE } \\
\text { (GWe) }\end{array}$ & $\begin{array}{l}\text { MIDRANGE } \\
\text { (GWC) }\end{array}$ & $\begin{array}{l}\text { MEDIAN } \\
\text { (GIV)) }\end{array}$ \\
\hline VAPOR - DOMINATED & $2 \cdot 180$ & $6 \cdot 100$ & $2 \cdot 100$ & 6.15 & 10 \\
\hline LIOUID - DONINATED & $40 \cdot 1,200,000$ & $45 \cdot 1000$ & $40 \cdot 1000$ & $45 \cdot 500$ & 500 \\
\hline MOT DRY ROCK & $200-12,000,000$ & 0.2000 & 0.2000 & 200 & 200 \\
\hline GEOPRESSURED ZONES & $16 \cdot 320$ & $20 \cdot 500$ & $16-320$ & $20 \cdot 80$ & 54 \\
\hline MAGMA & $4-12$ & 0.10 & 0.10 & 2 & 2 \\
\hline TOTALS & & & $55 \cdot 3430$ & 270.800 & 770 \\
\hline
\end{tabular}

Figure A.10

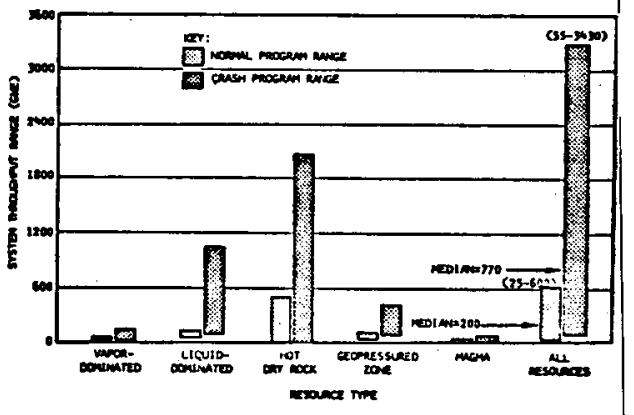

Figure A.11

SUMMARY OF SYSTEM THROUGHPUT RANGES, YEAR 2000 
Together these two resources account for 90 percent of he $770 \mathrm{GWe}$

the range of 2000 crash program forecasts is 55-3430 GWe, which indicates that considerable uncertainty exists among the experts. An investigation of Figure A. 10 points out that this uncertainty holds both for the level of identified resources and for industry's development/conversion capability. However, elimination of the extreme points of the forecasted range yields a much narrower midrange of 270-800 Gwe.

\section{Resource Type: Vapor-Dominated 2000}

Normal development: There is consensus among experts that, under normal program emphasis, the potential of vapor-dominated resources is insignificant in geothermal energy utilization in the year 2000. The most optimistic identified resource forecast is 24 GWe for 25 years, and the median system throughput forecast is only $6 \mathrm{GWe}$, limited by resource availability rather than industry's technological capabilities to develop the resource.

Crash development: Incentives of a massive R\&D program prompted one expert to expect significantly more resources to be identified and a concomitant greater level of electric power capacity installed, for a total throughput of 100 GWe. However, due to resource limitations most experts foresee little potentlal of vapordominated resource utilization, as shown by the midrange throughput value of $6-15 \mathrm{GWe}$, and a median throughput forecast of $10 \mathrm{GWe}$.

\section{Resource Type: Liquid Dominated 2000}

Normal development. The majority of respondents think that 100 GWe of electric power capacity utilizing liquiddominated resources can be installed by the year 2000 under normal progran conditions. Two of the three resource experts stated that the level of identified resources in the year 2000 could be greater than 100 GWe for 50 years, and two of the three development/ conversion experts forecasted a 100 GWe industry capability. However, the third expert in each area was more pessimistic, forecasting a resource equivalent of 16 GWe and a development/conversion capability of 1530 GWe.

Crash development. All experts agreed that a crash program could significantly increase the potential for liquid-dominated resource utilization by the year 2000 . Resource estimates increased by factors of 2-1000 and development/conversion forecasts increased by factors of 2-10. In each of the two subsystems, though, forecasts of the most pessimistic expert remalned at least an order of magnitude below those of the other two experts. The most pessimistic system throughput forecast was twice the median, equal to 50 percent of projected U.S. installed capacity in 2000 . In both the median and high forecasts, development/conversion capability rather than identified resources limits total throughput, but results do not justify a firm conclusion regarding this question.

\section{Resource Type: Hot Dry Rock 2000}

Normal development. There exists a great disparity among experts' forecasts of hot dry rock utilization in the year 2000 as compared with the range of forecasts in other resources, under normal program conditions. The uncertainty stems from the facts that:
1. Hot rock resources have, unt11 recently, recelved little exploration and appraisal effort:

2. The technology for development/conversion of hot rock resources has not been demonstrated on a large scale.

Two of the three resource experts forecast a virtually inexhaustible supply of identifled resources, but a third predicts a very low level of 20 GWe for 25 years. In the reservoir development/energy conversion subsystem, forecasts of technologically feasible levels range from $0-400$ GWe. Resulting system throughput forecasts range from $0-400 \mathrm{GWe}$, with a midrange of $20-$ $50 \mathrm{GWe}$, and a median of 50 GWe. Each of the three development/conversion forecasts are more limiting than the corresponding resource forecast.

Crash development. Forecasts made under the assumption of crash program emphasis remain widely divergent, for the reasons described in the previous paragraph. The most pessimistic resource expert increased his forecast by an order of magnitude to 200 GWe for 25 years, but a pessimistic development/conversion expert forecast virtually no impact on his normal case prediction of 0 GWe installed. The other two development/conversion experts increased their forecasts by factors of 4-5. Resulting throughput forecasts for 2000 crash program case are a range of $0 \mathrm{GWe}-2000 \mathrm{GWe}$, with a median value of $200 \mathrm{GWe}$.

\section{Resource Type: Geopressured Zones 2000}

Normal development. The forecasts of three of the four experts indicate that the level of identified resources of geopressured-zone resources limits the potential of this resource type to a lesser role than liquiddominated and hot rock resources in the U.S. electric power economy of the year 2000 under norma 1 conditions. The development/conversion forecasts are similar to the resource forecasts. The resulting throughput range is 10-70 GWe, with a midrange of $16-40 \mathrm{GWe}$, and a median of 40 GWe. These throughput forecasts are slightly lower than those for 11quid-dominated and hot dry rock resources under normal program assumptions, but the level of identified resources is a much more ilmiting factor for the geopressured-zone resource case.

Crash development. The dominant view is that the level of identifled resources will limtt geopressured-zone resource utilization to less than 80 GWe for 25 years, although one expert forecasts Identified resources at least four times higher. The median throughput forecasts is a resource-1imited $54 \mathrm{GWe}$, only slightly greater than the normal case median.

\section{Resource Type: Magma 2000}

The consensus among the experts is that magma offers no significant potential for electric power production in this century, with the most optimistic throughput forecast only 10 GWe with a crash program.

Conclustons for 2000 Geothermal Electric Power Potent1al (System Throughput)

While there exists great uncertainty among various geothermal experts, the results tend to suggest that a rather large and perhaps virtually inexhaustible resource base exists and can be identified both for hot dry rock and 1iquid-dominated resources. Vapor-dominated systems 
appear to be resource-limited, and also geopressuredzone systems to a lesser degree. Regarding the capability of Industry to develop existing resources and convert them to electric power, there is again considerable uncertainty. A majority of experts

interviewed felt that liquid-dominated, hot dry rock, and geopressured-zone resources could be exploited sufficiently to install a total of at least 200 GWe from all geothermal resources under normal conditions and 770 GWe for crash program conditions. In both cases liquid-dominated resources are forecast to contribute 50 percent or more of these totals.

R\&D efforts of a crash program emphasis should enhance the development of liquid-dominated and hot dry rock resources, while the impact on the development of other resource types is forecast to be minor. 
Append 1X B

TECHNOLOGICAL RELEVANCE TREES

One of the major research tools used in this study is the relevance tree. In concept, a relevance tree 18 a hierarchical structure in which entires at each successive level in the aggregate describe completely the next Immediate level above. A relevence tree describes a domaln and theoretically, at least, describes it completely. In the technologlcally-orlented tasks associated with this study, two relevance trees were constructed: the first dealt with geothermal energy and was designed to describe the elements of geothermal energy down to the component level. It was used to provide a framework for impediment evaluation: in esence it was a check list which helped ensure that important system aspects were not overlooked. Pigure B.I shows the levels of the tree, followed by the tree Itrelf.
B.1 shows the levels of the tree and 18 followed by the tree Itself.

In effect the geothermal tree was a detalled elaboration of the one branch of a technological relevance tree describing energy as a whole. The format for this tree is the same as for the geothermal tree, through Level $V I$, as shown in Figure B.1. The final portion of this Appendix contains the general energy tree 1tself (pages 330 through 355$)$. The tree provided visibility into technologies other than geothermal for the production of electriclty, as well as an orderly framework for impediment evaluation. The level of detall obtained in limiting the energy tree to five levels and the geothermal tree to $81 \times$ levels, was oufficlent for purposes of the study. Additlonal work in further expansion of either tree may be rewarding, however, in defining more detalled technological requirements.

\section{FIGURE B.1 - ENERGY TECHNOLOGY RELEVANCE TREE}

OBJECTIVE: Define the availability of technology associated primarily with the production of heat and electrical power from natural resources.

\section{RELEVANCE INTERROGATION:}

Level I

Level II

Level III

Level IV

Level $\mathrm{V}$ (Geothermal)

Level VI (Geothermal)
What natural resources are available?

What primary energy forms can be developed from these natural resources?

What major technologies are associated with the development of these energy forms?

What applied technological areas are involved in these major technologies?

What systems, processes, or methods are involved in these applied technological areas?

What major components comprise these systems and processes, or what specific techniques are used in these methods? 
1. THE GEOTHERMAL RELEVANCE TREE

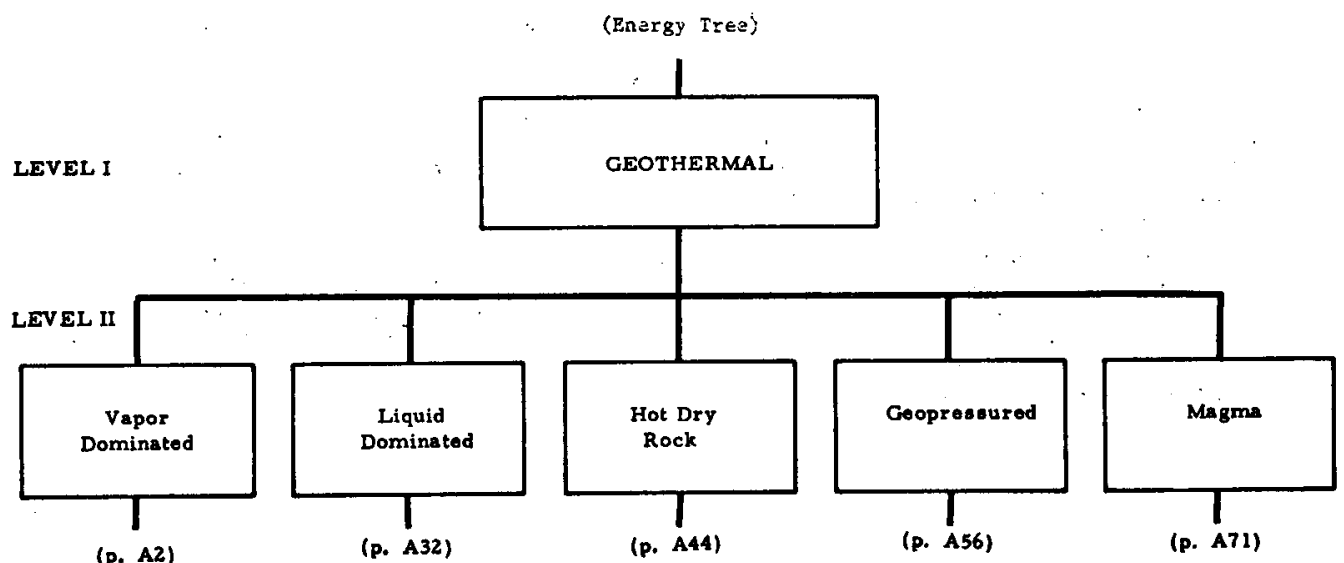

Al

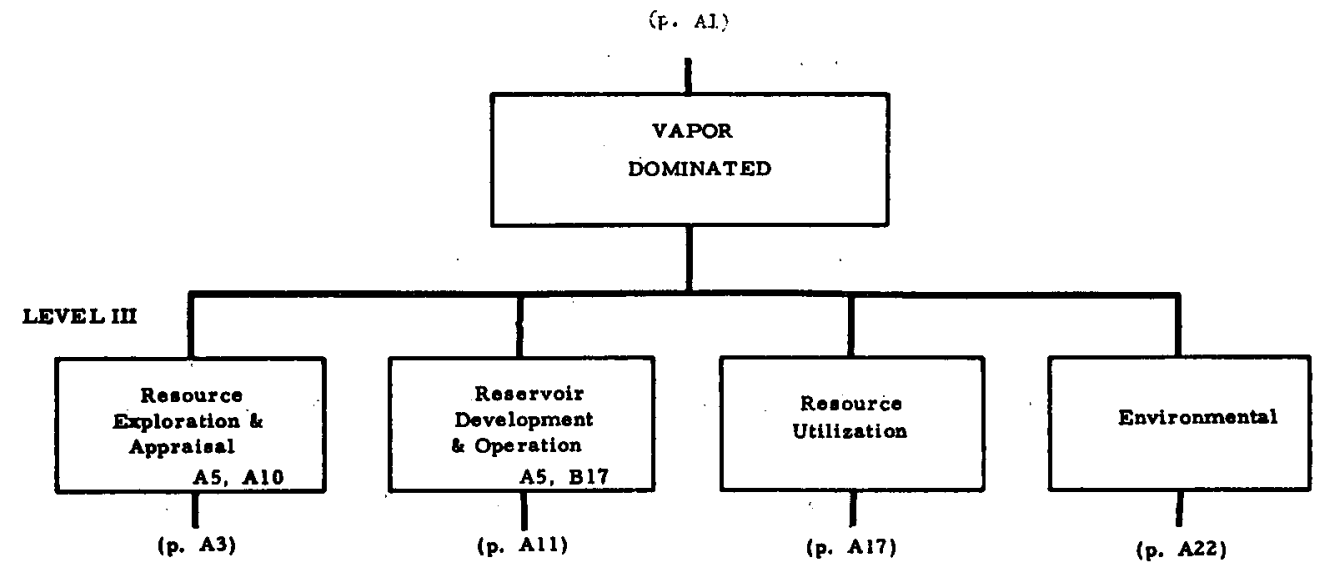

12 


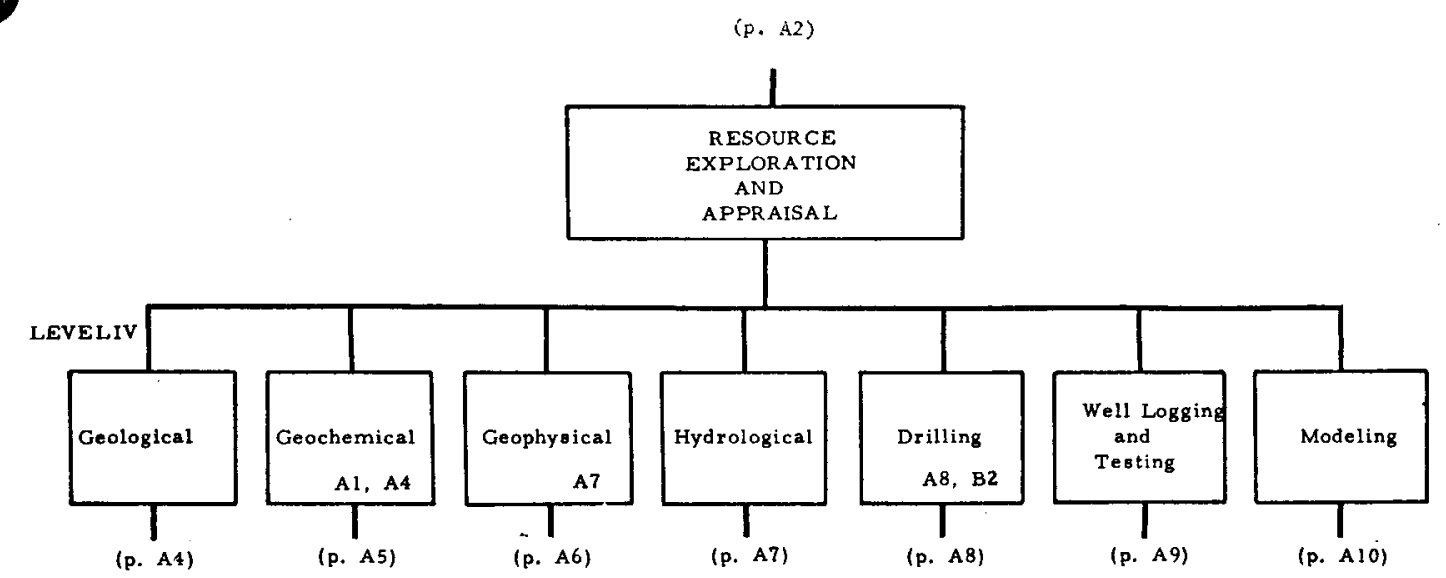

A3

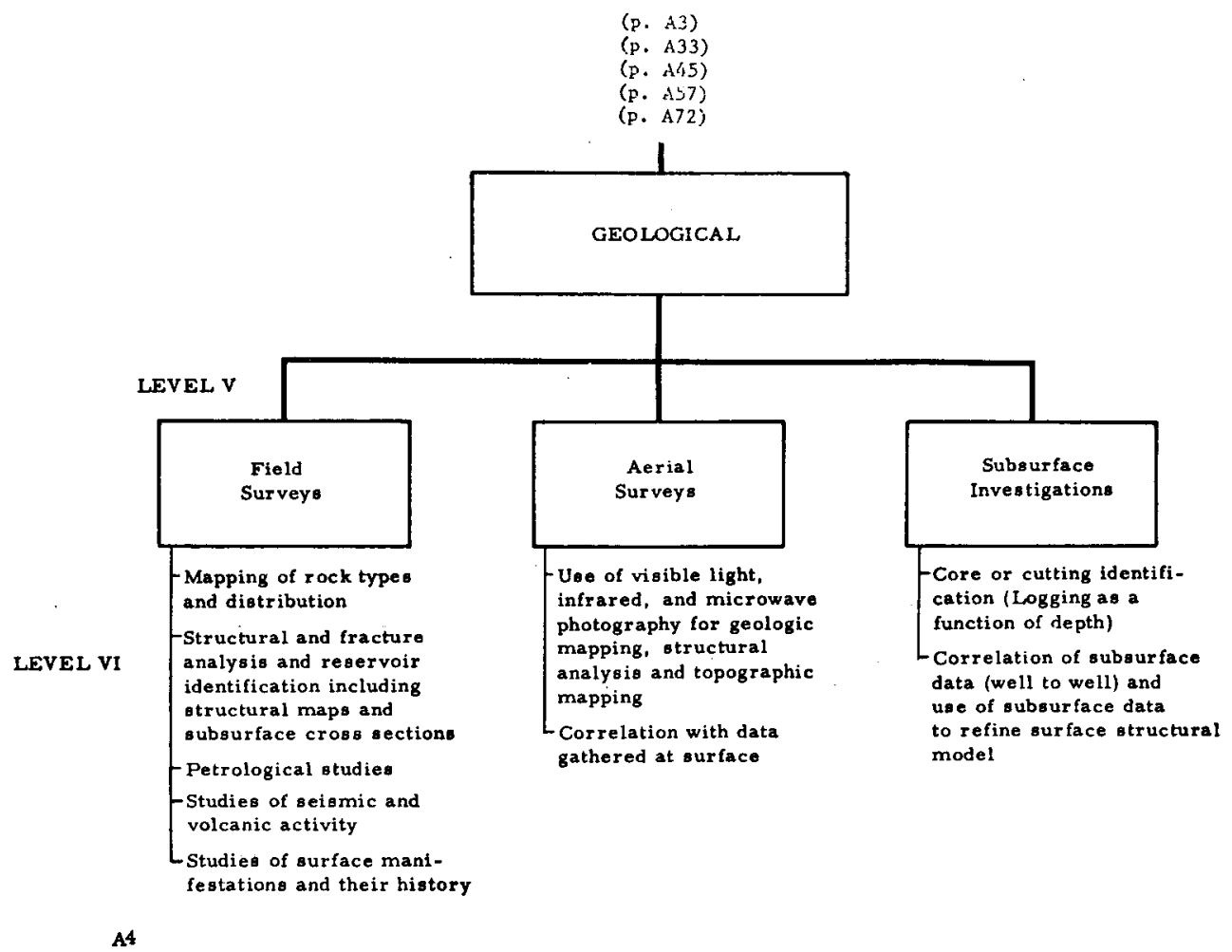




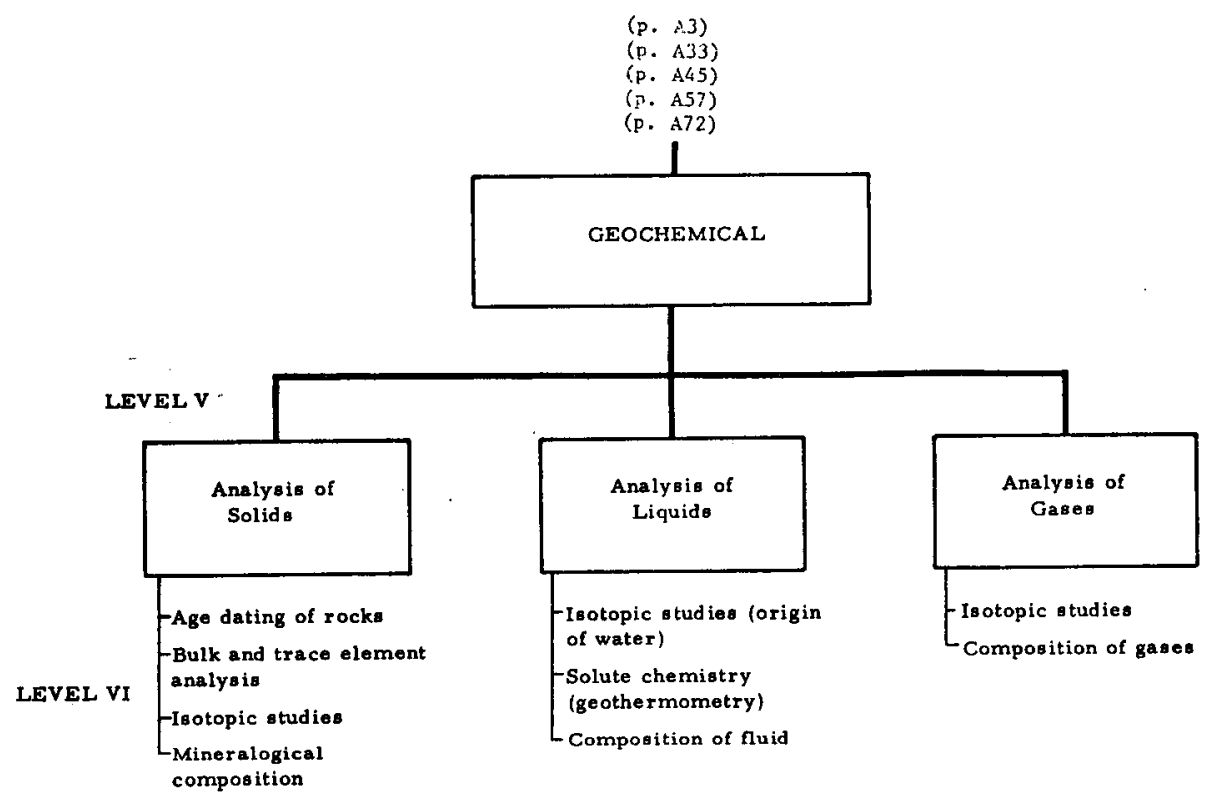

A5

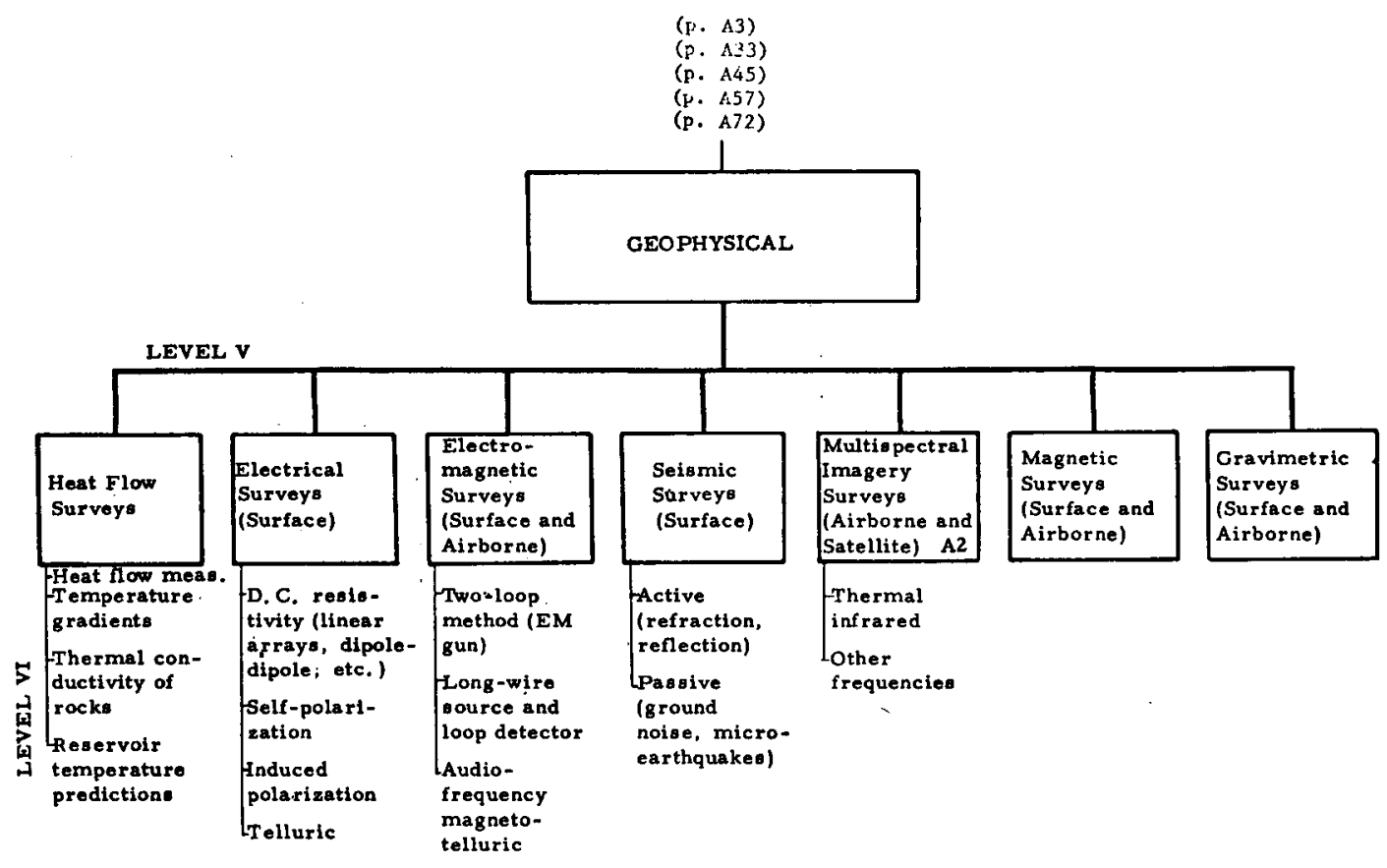

A6 


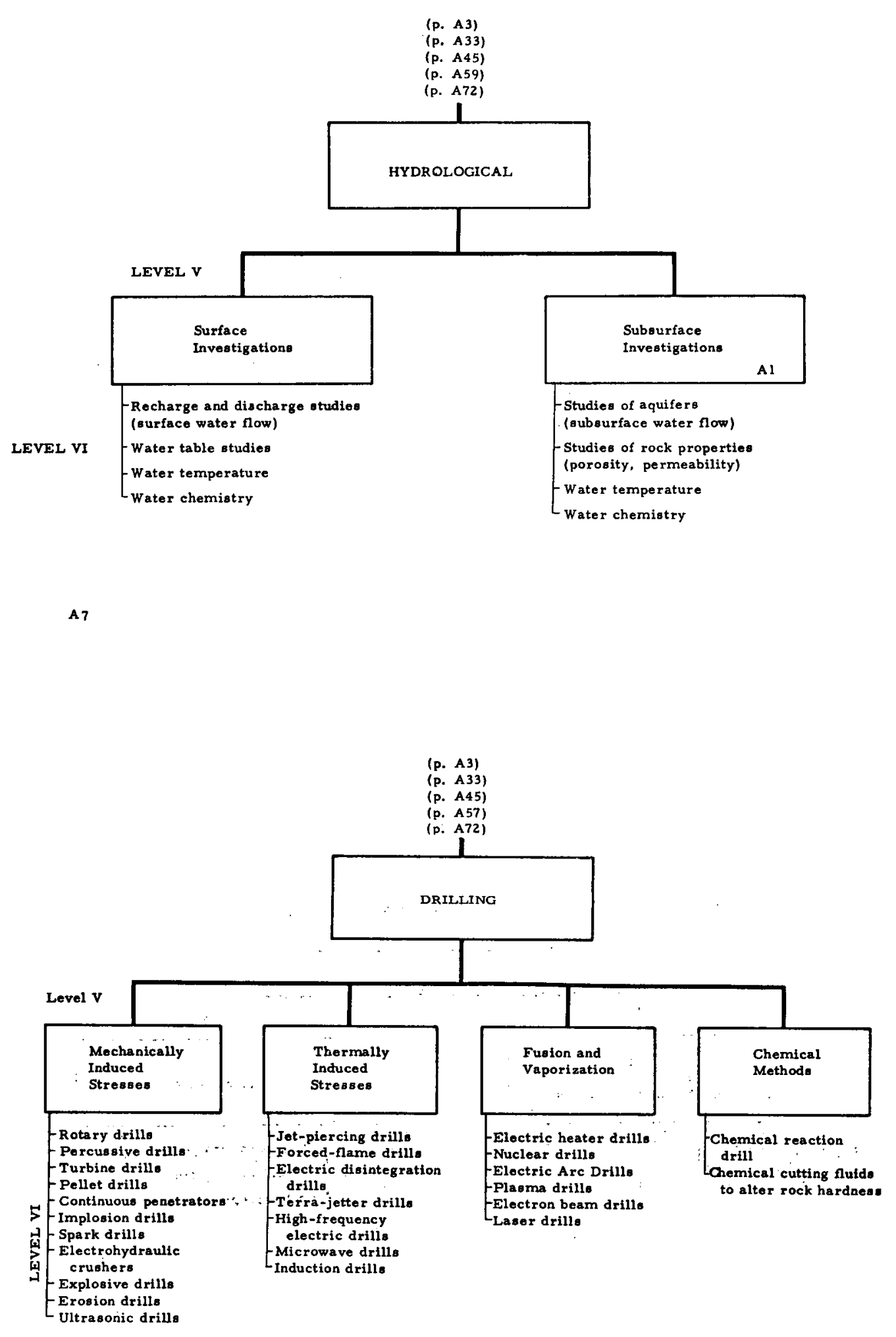

A 8 


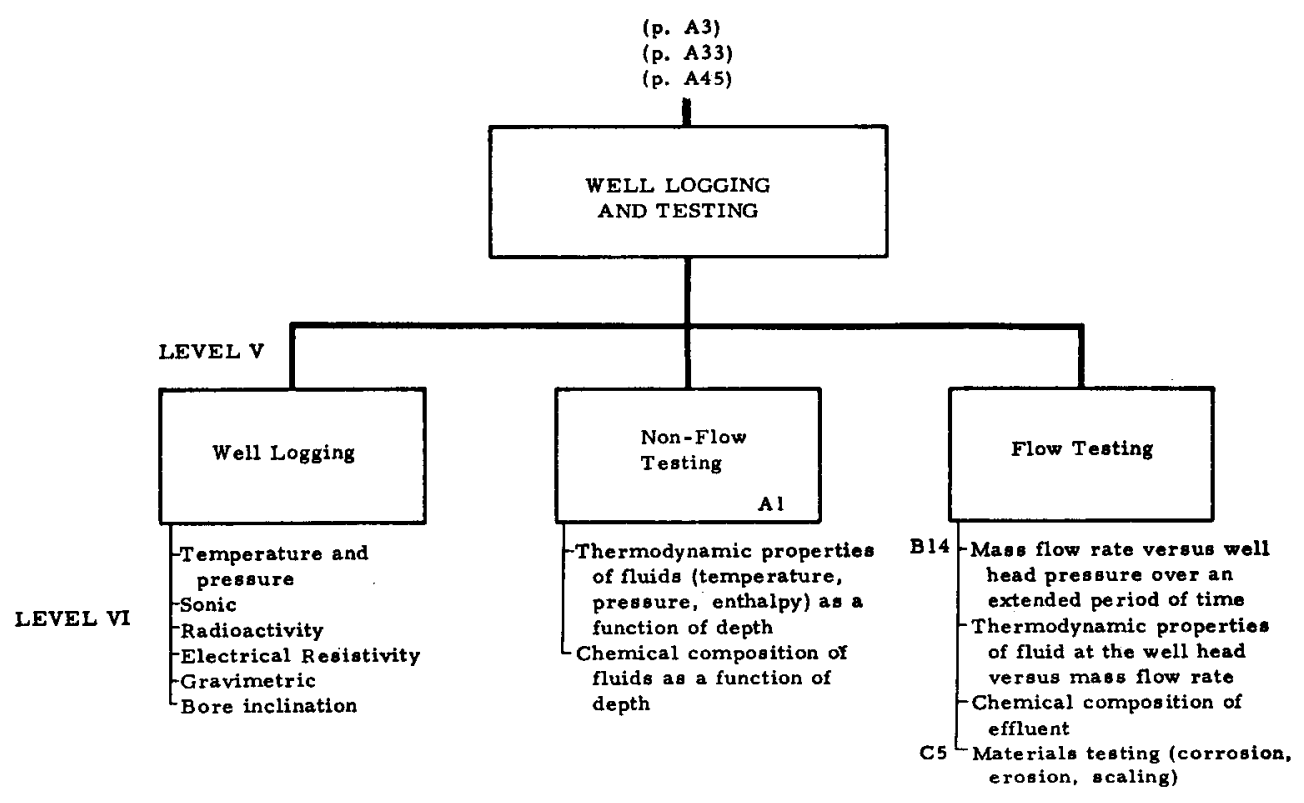

A9

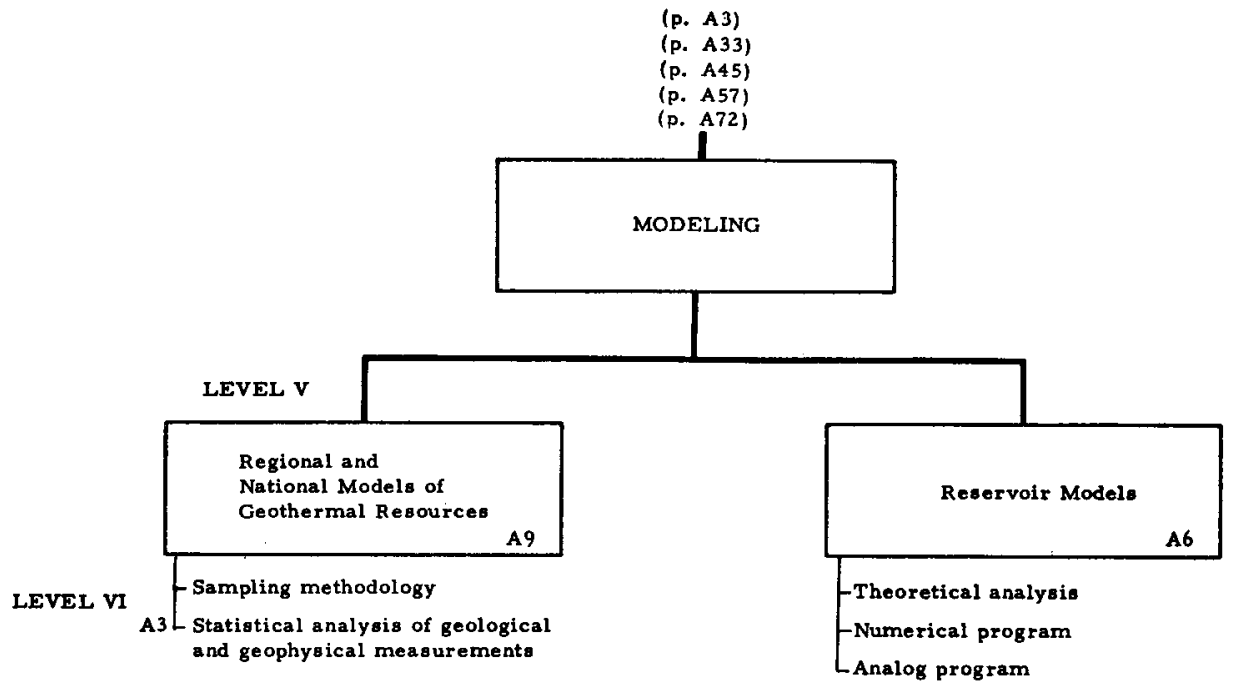

Alo 


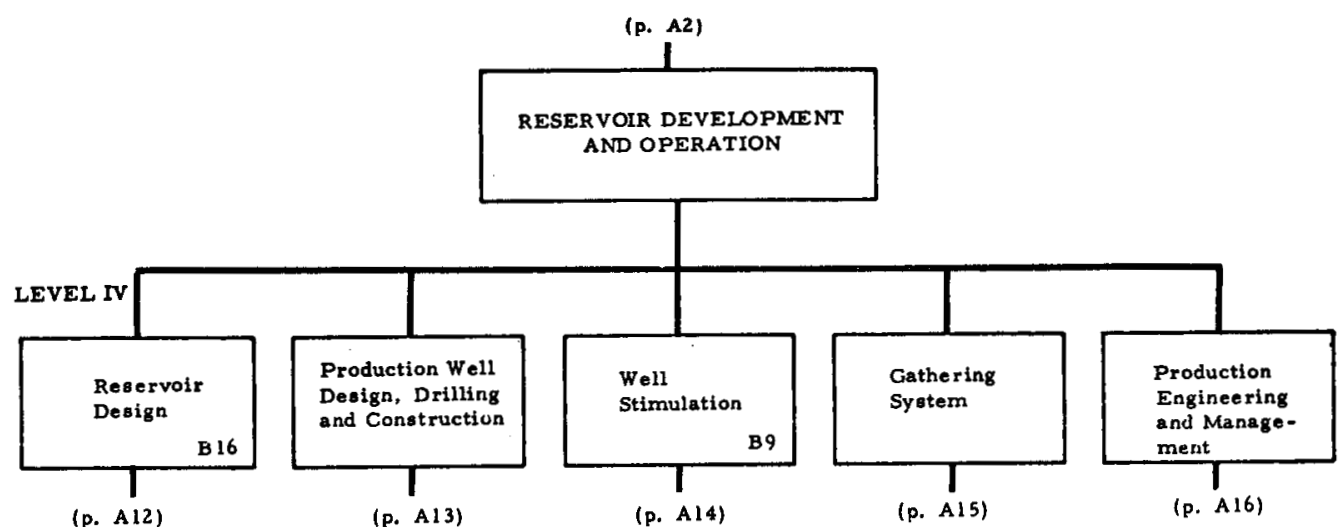

Al 1

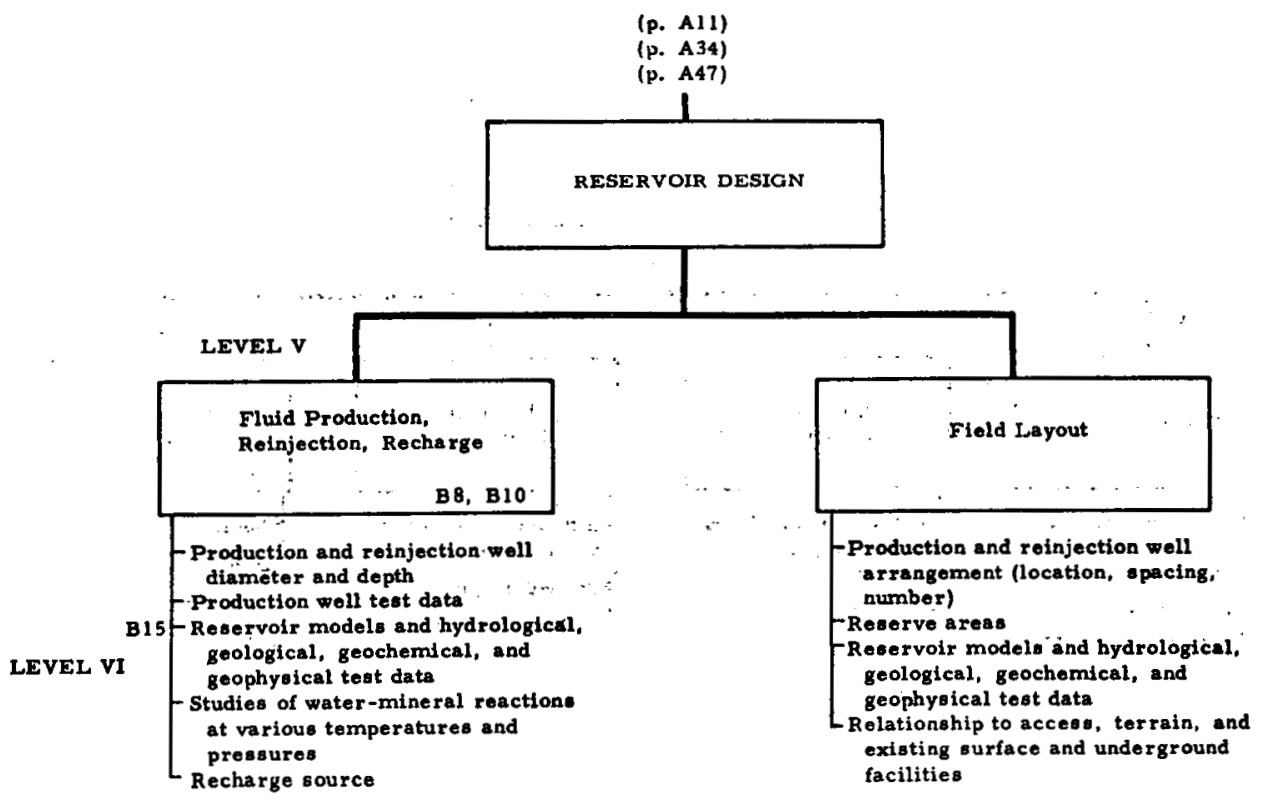

A.12 


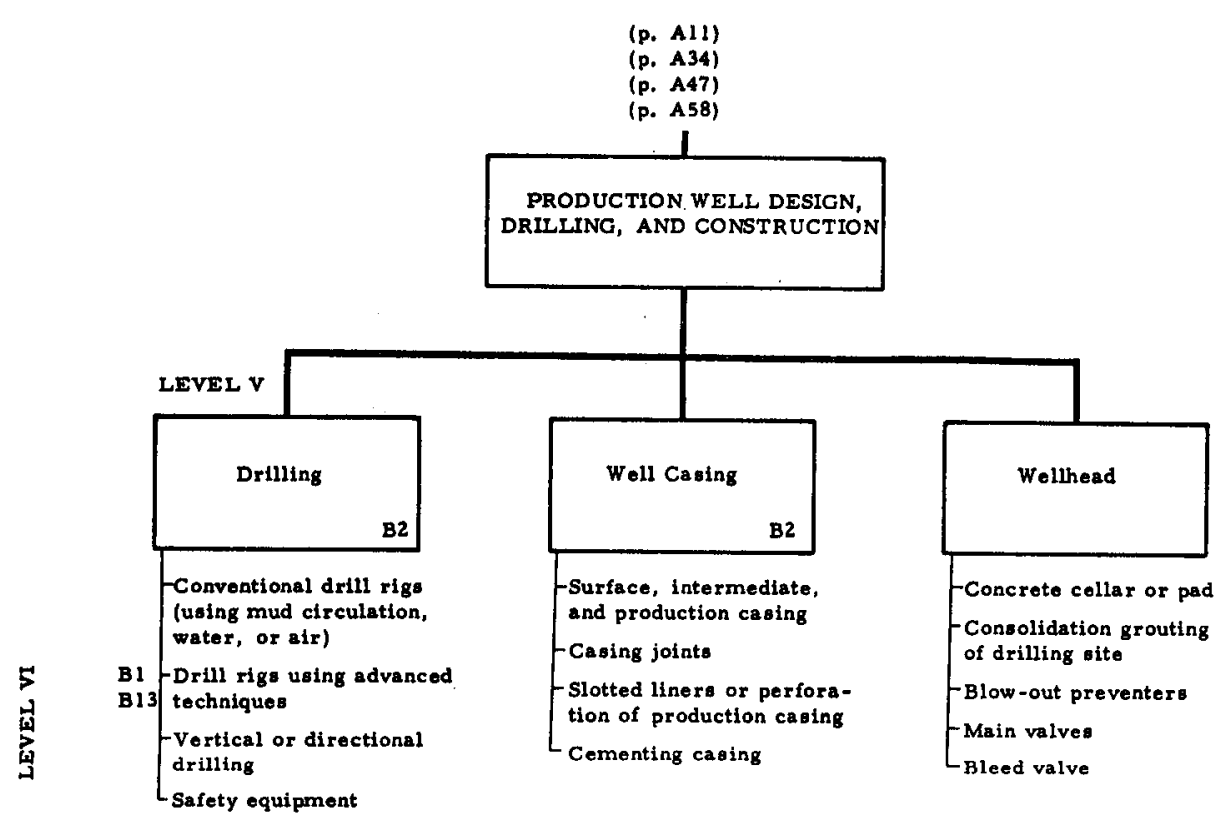

A. 3

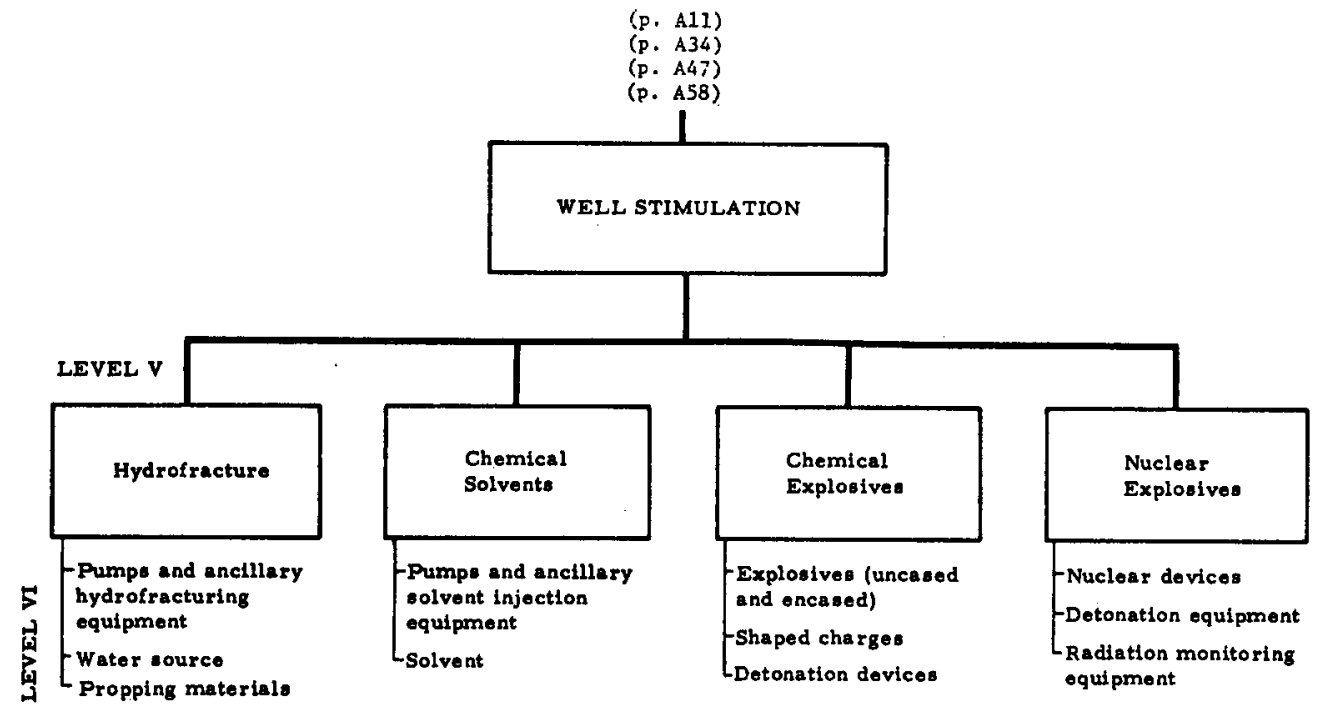




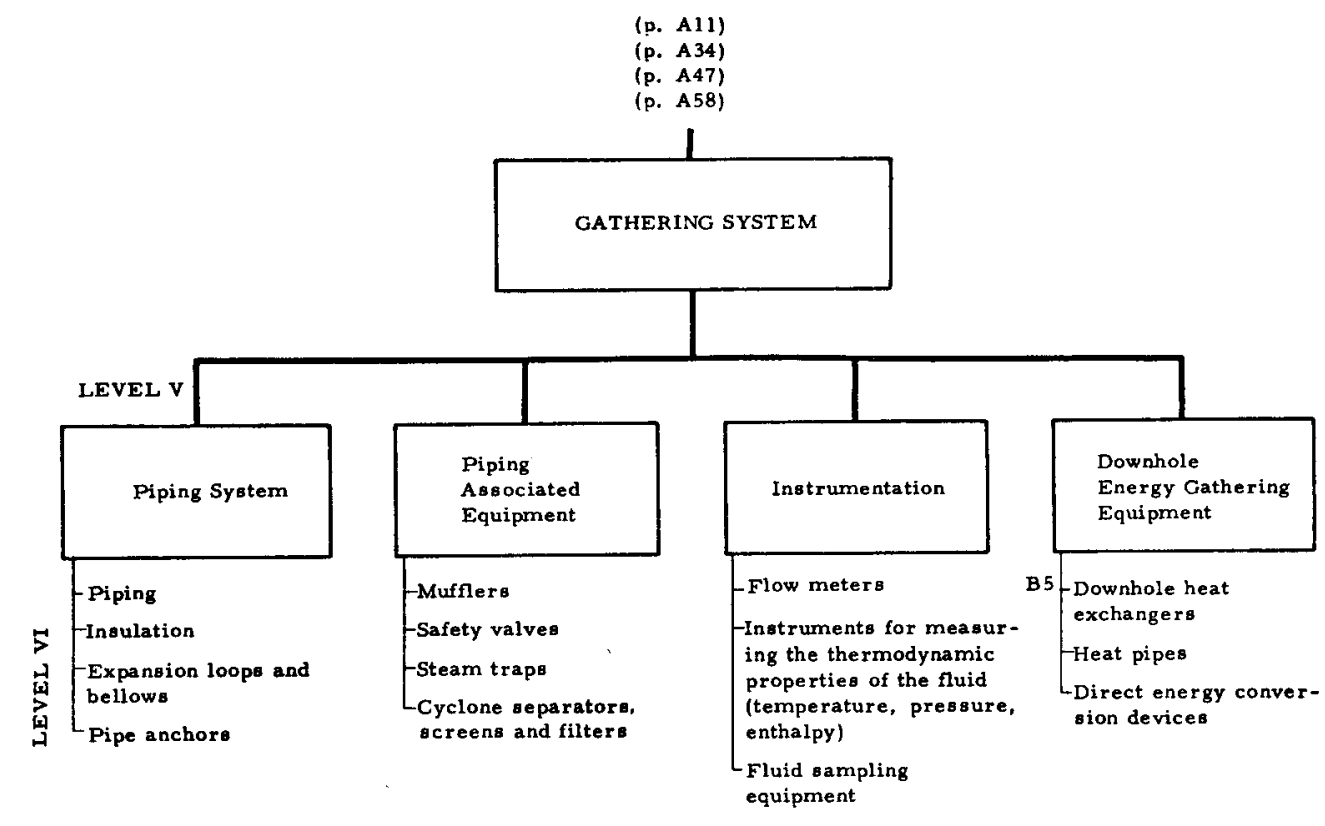

A15

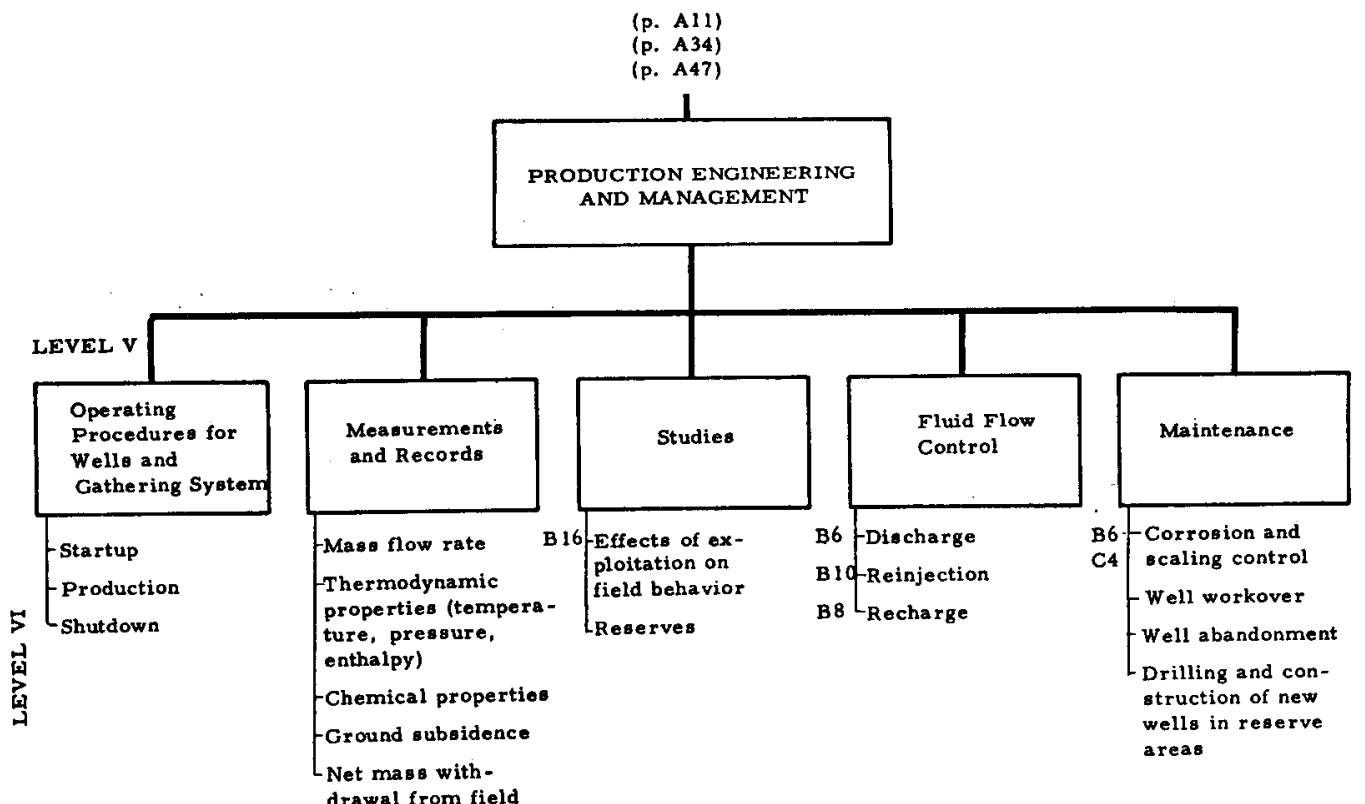

A16 


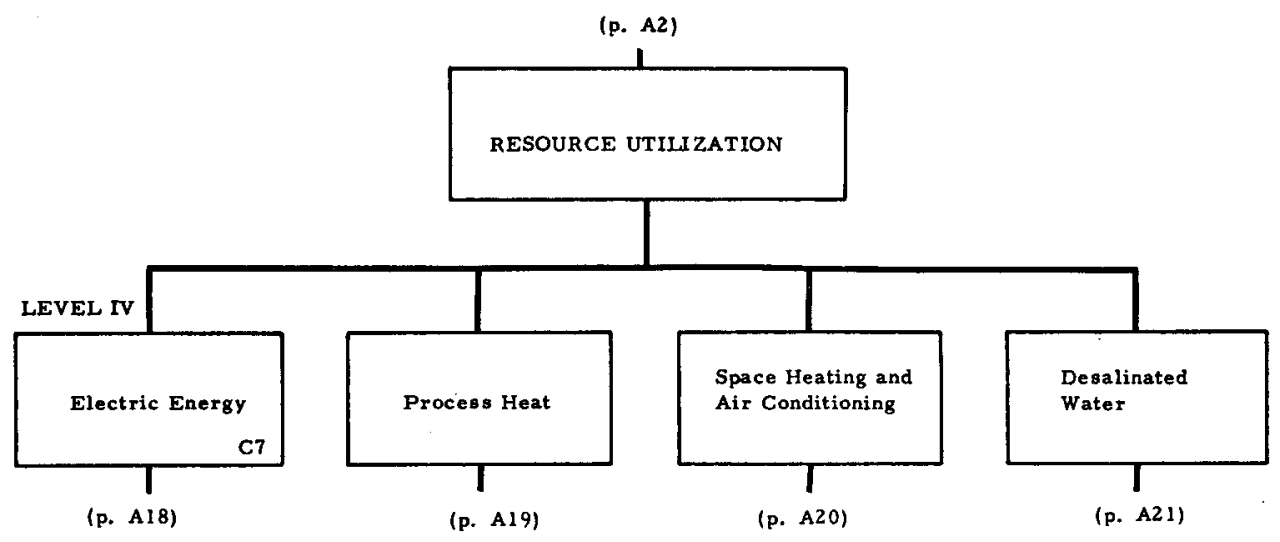

A17

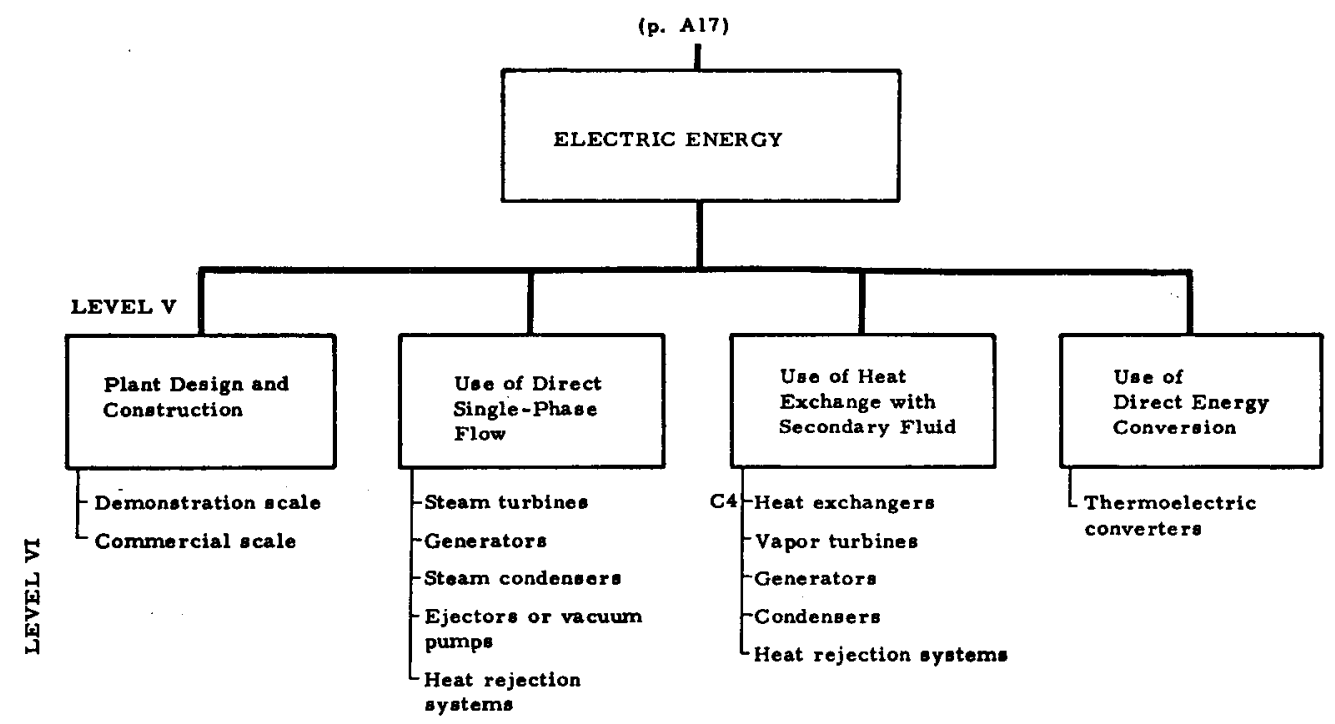

A18 


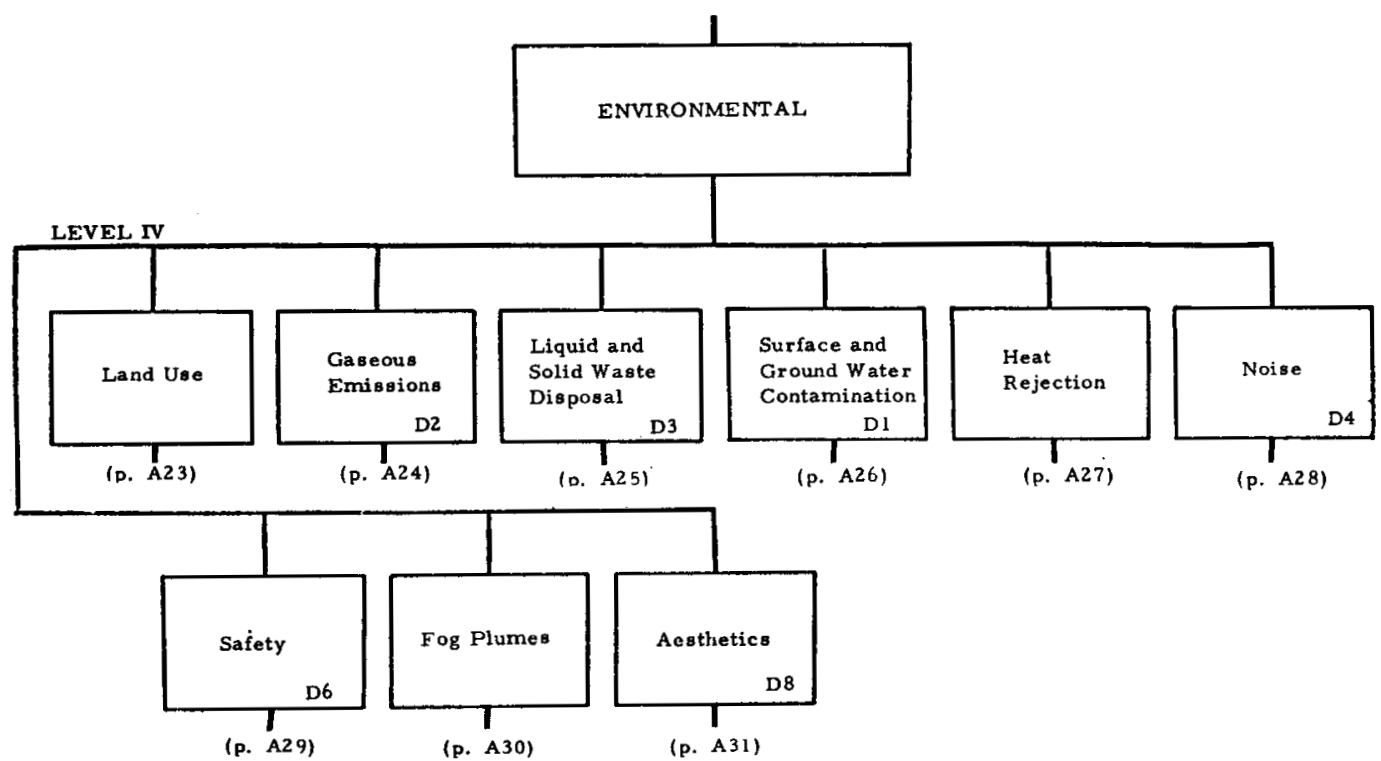

A22

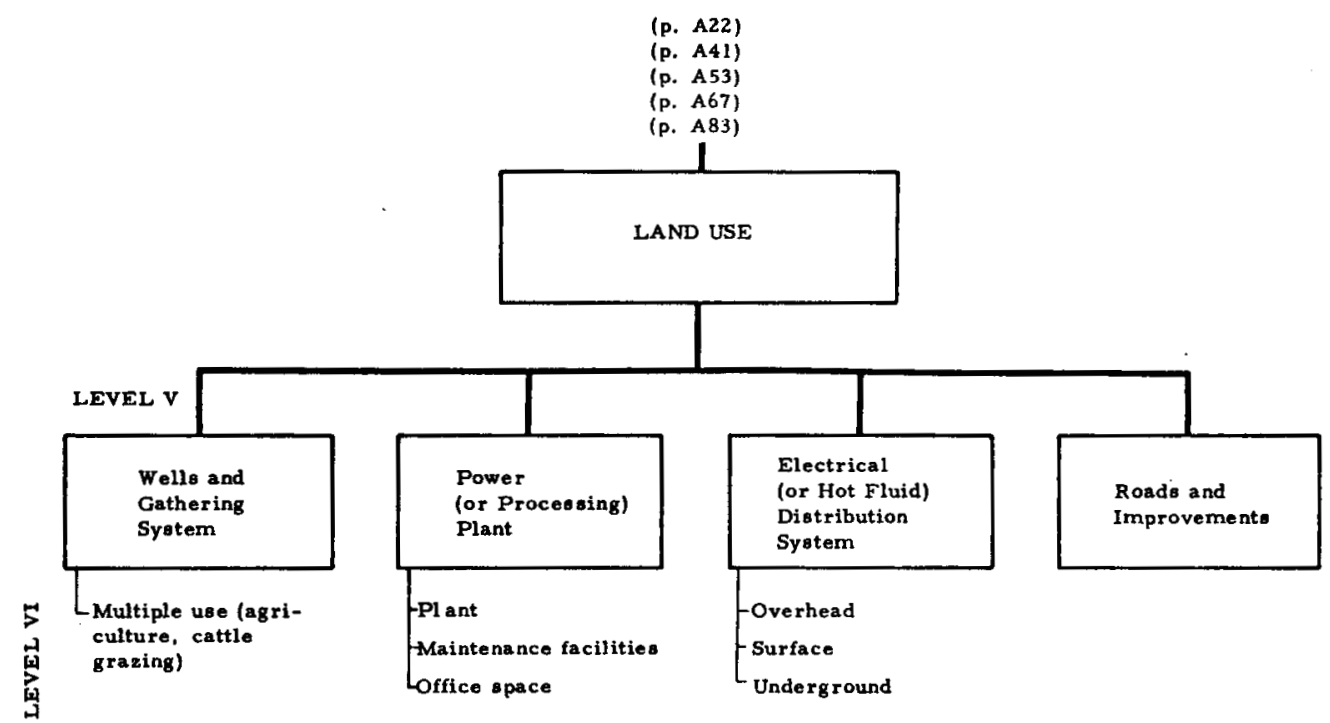




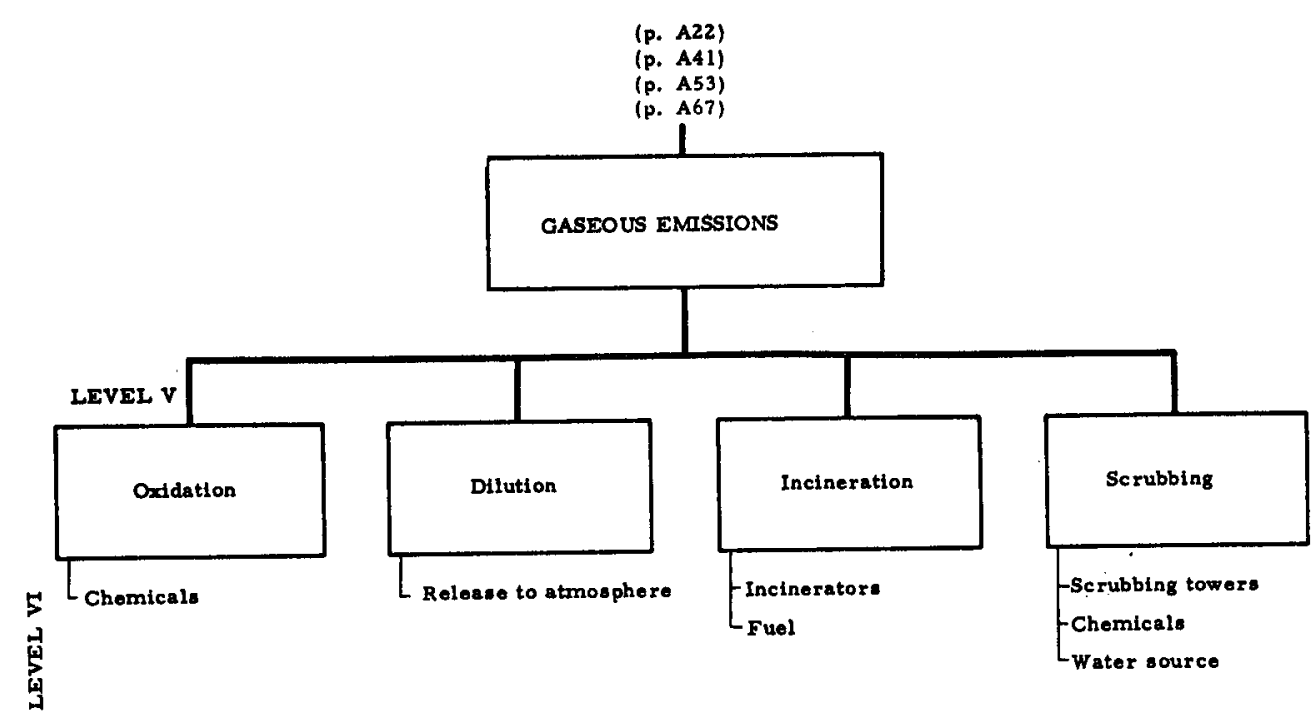

A24

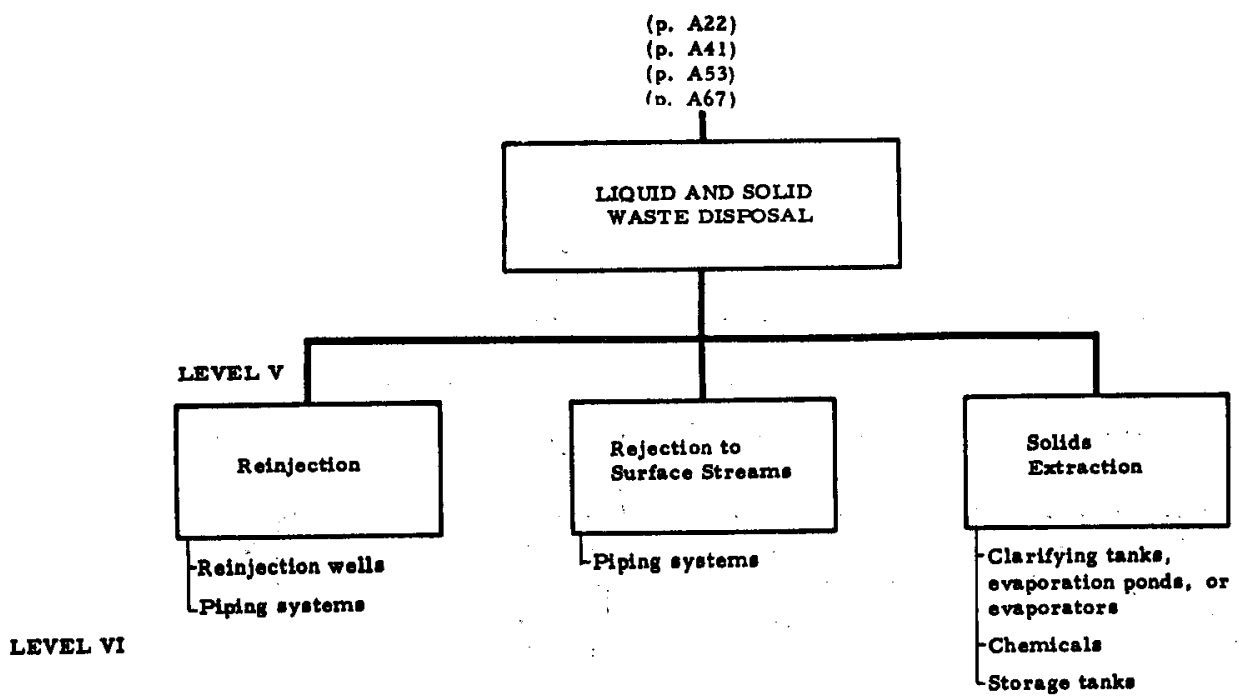

A25 


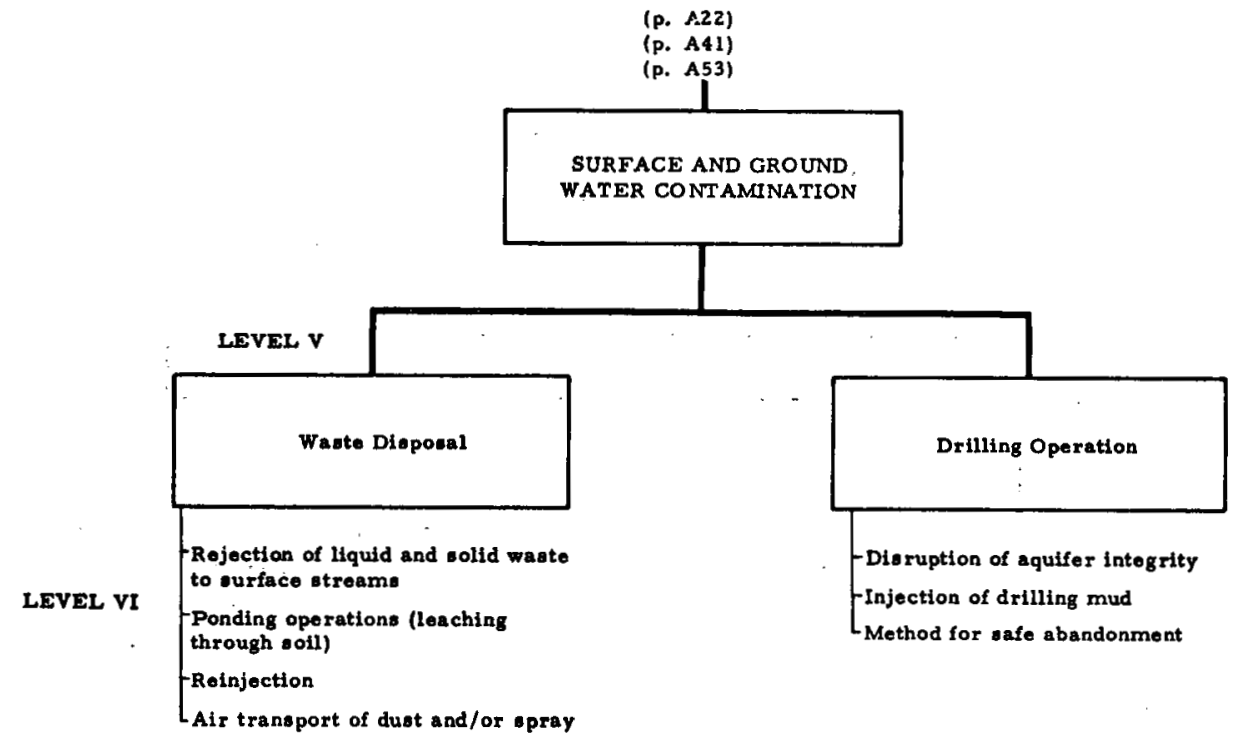

A26

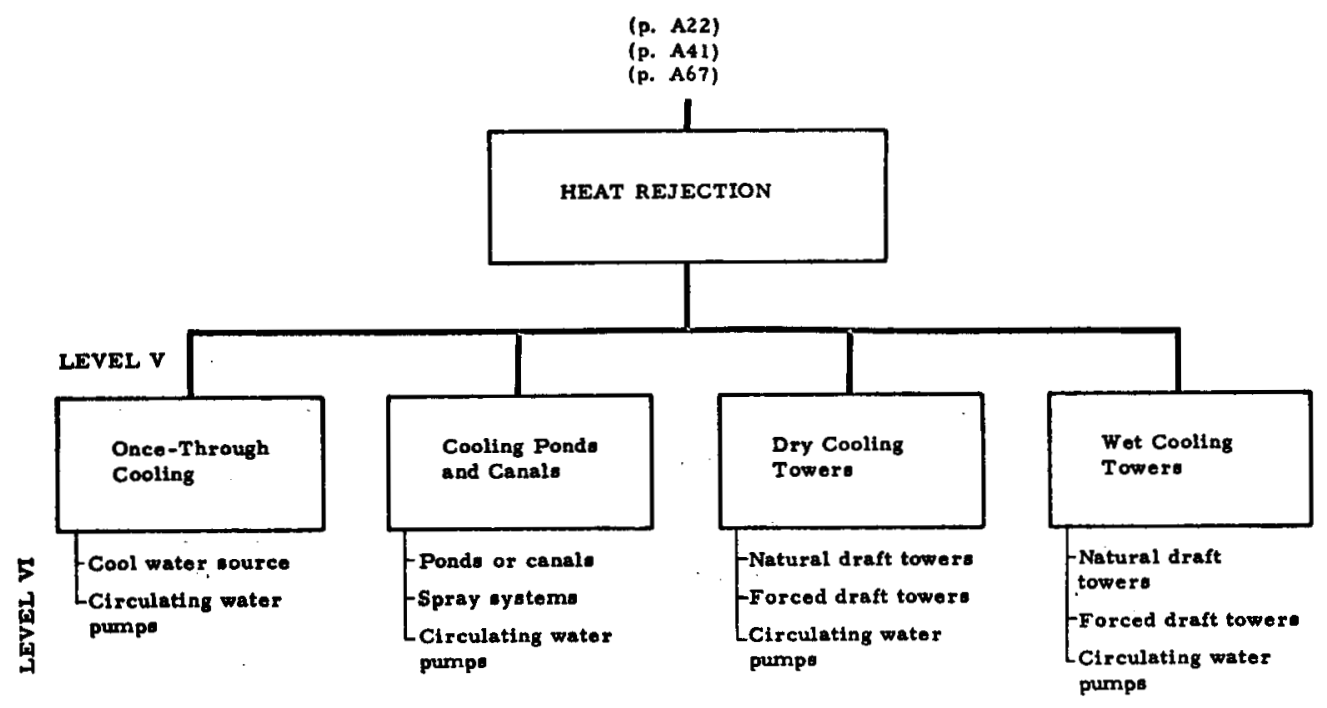

$\mathbf{A 2 7}$ 


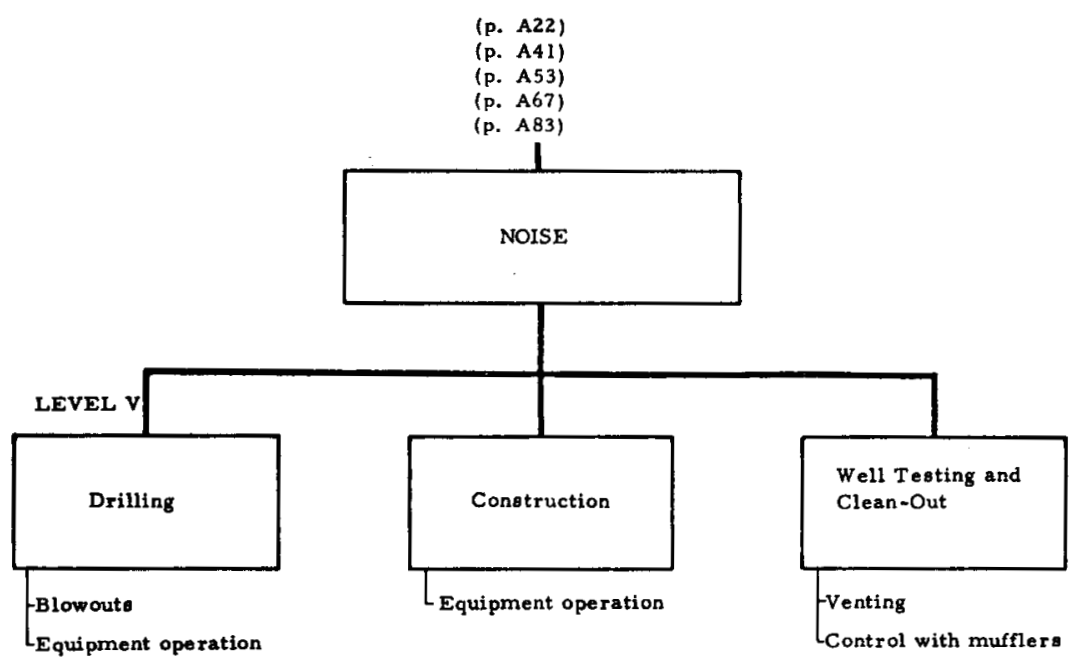

A28

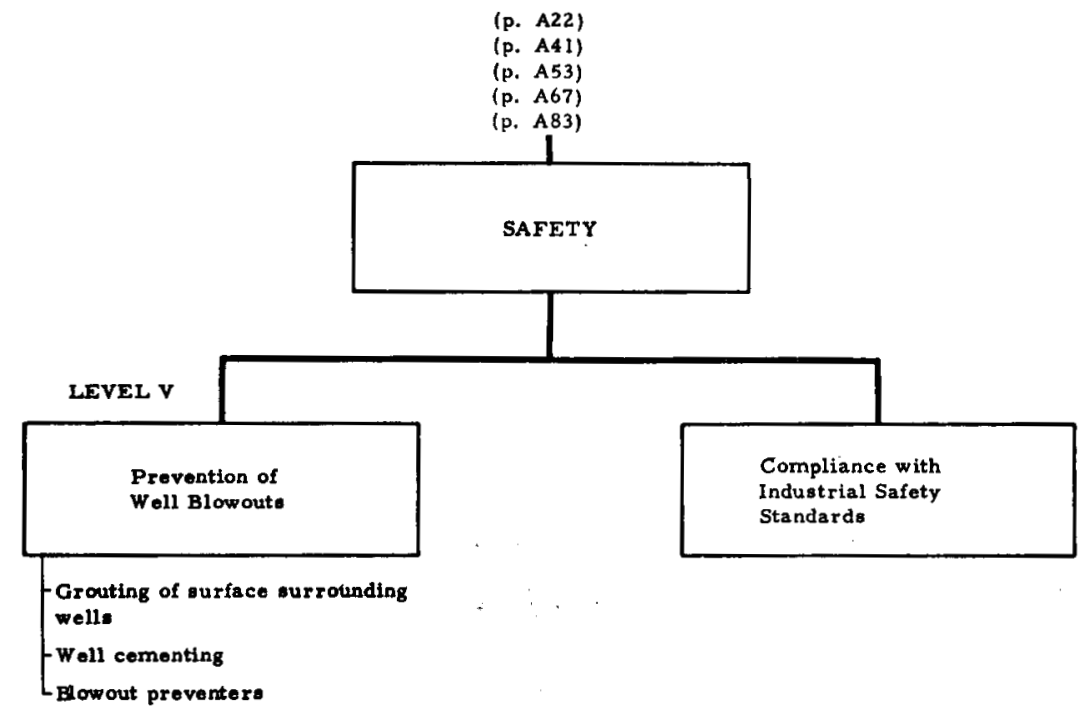

A29 


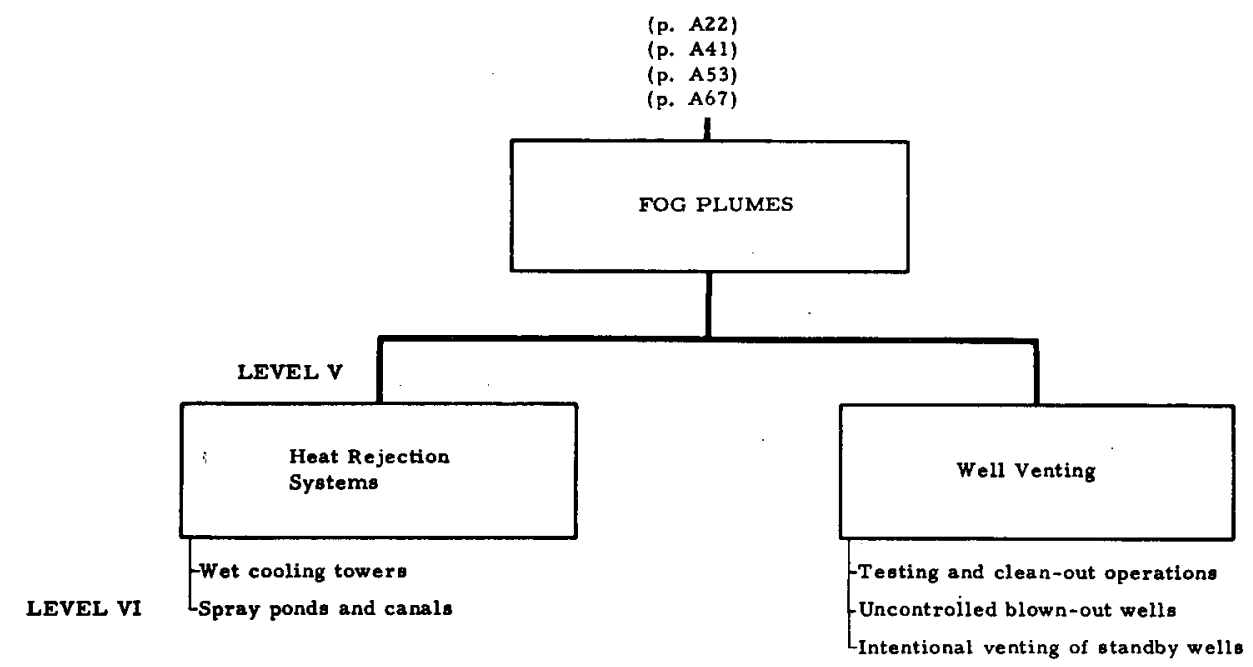

A30

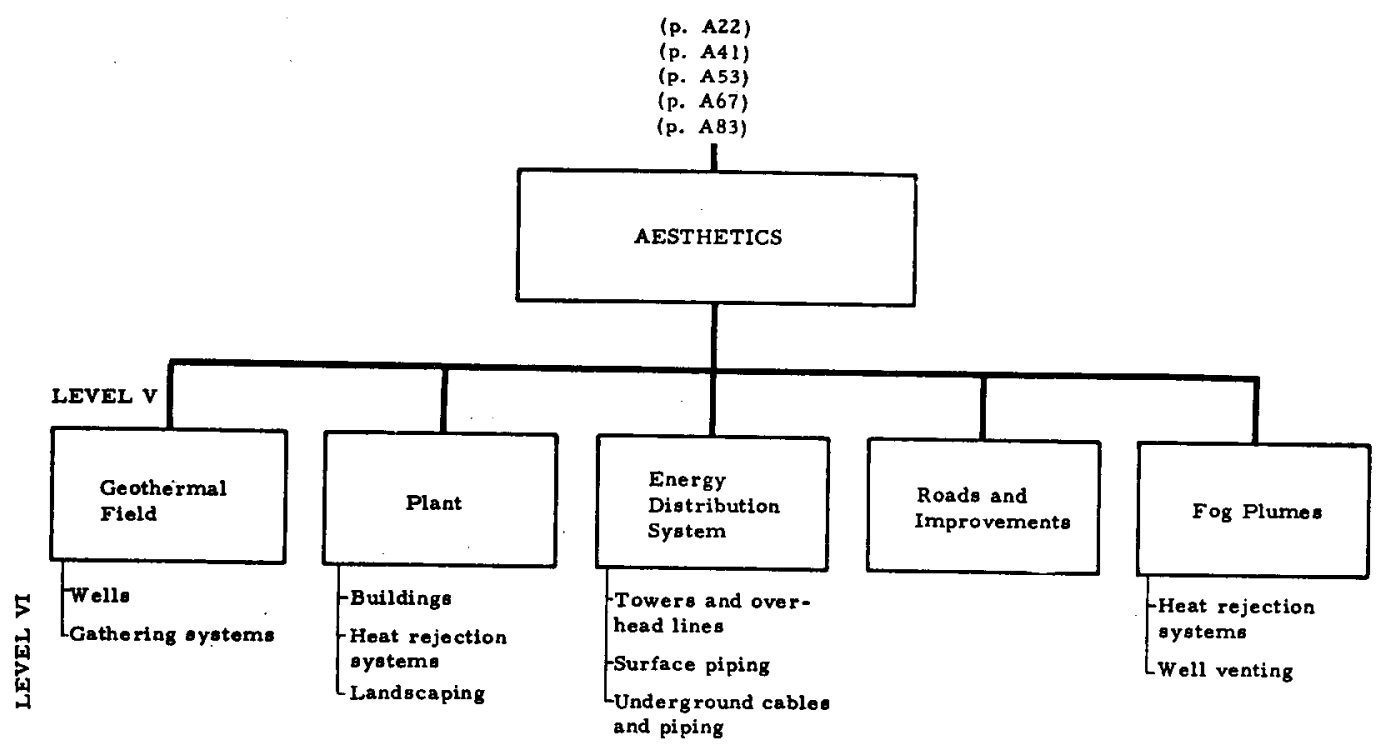

A31 


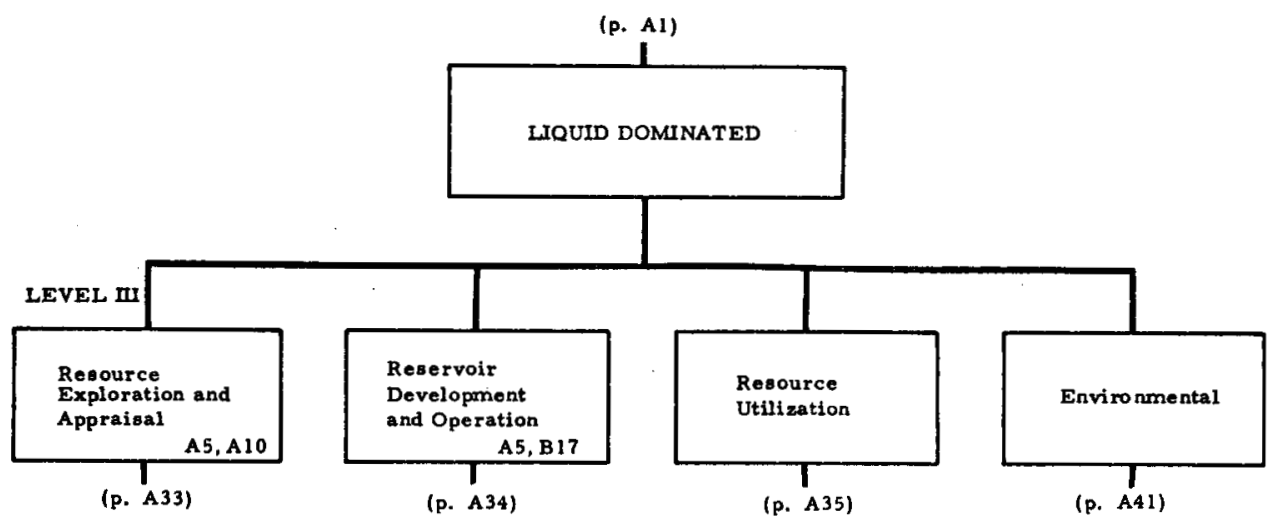

A 32

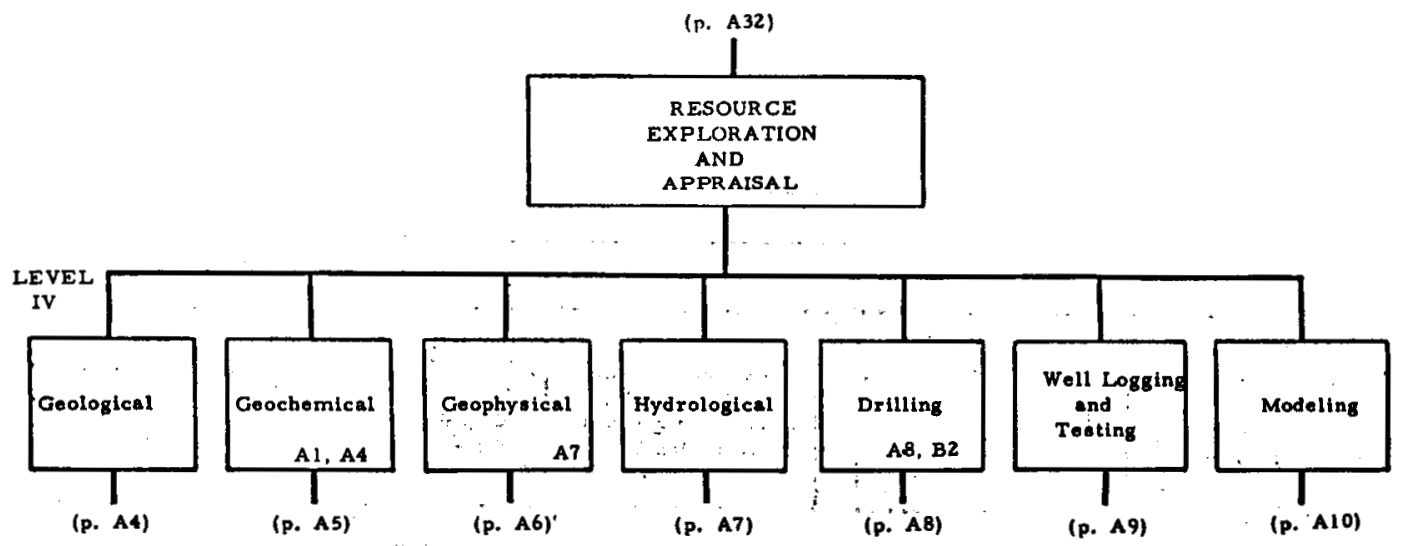

A33 


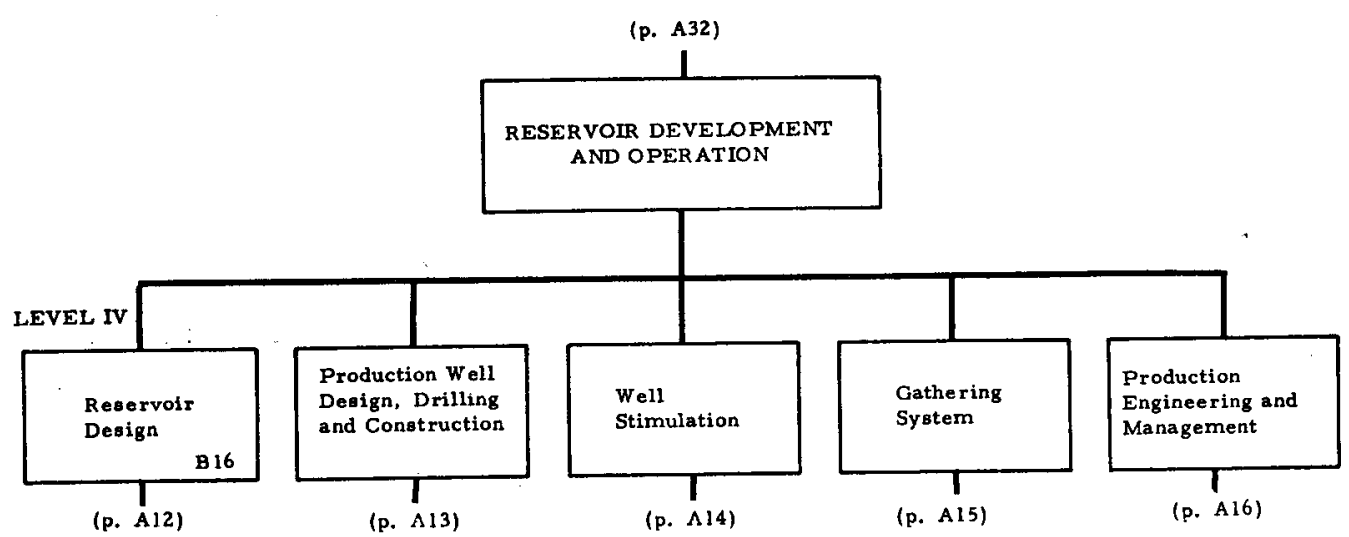

A34

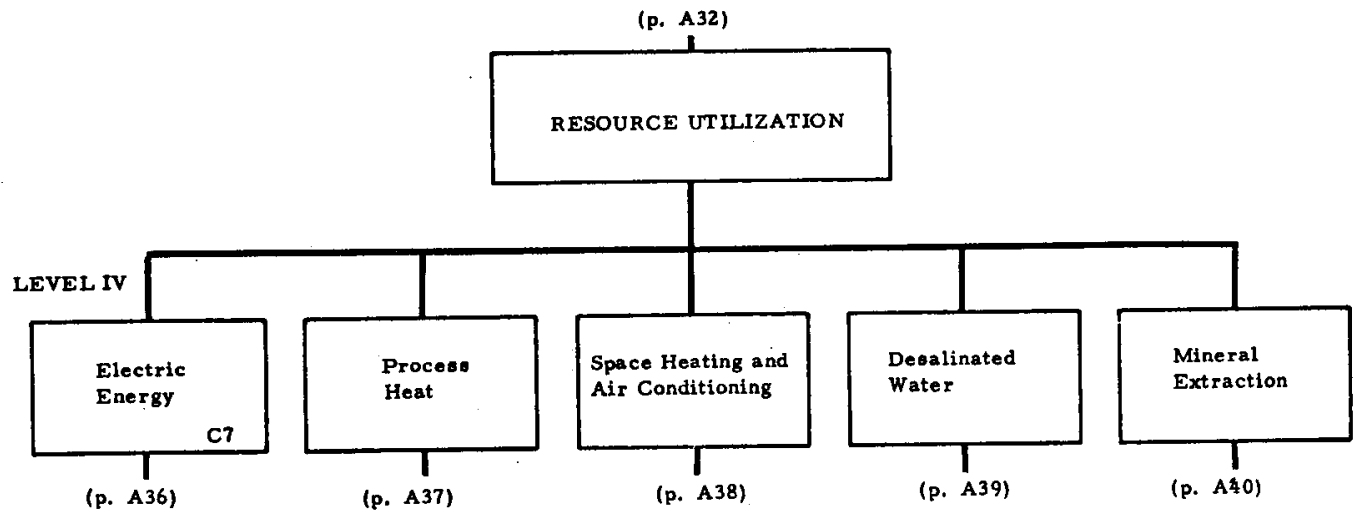

A.35 


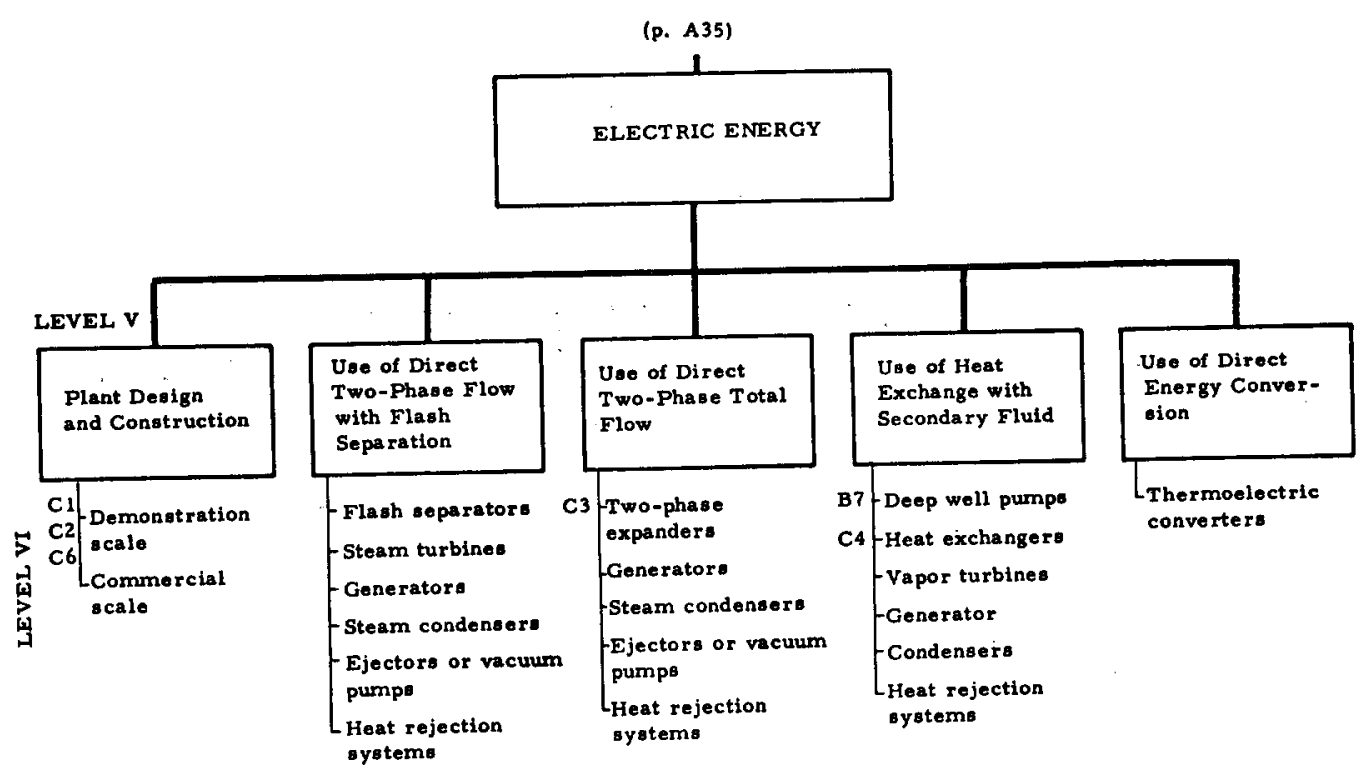

A36

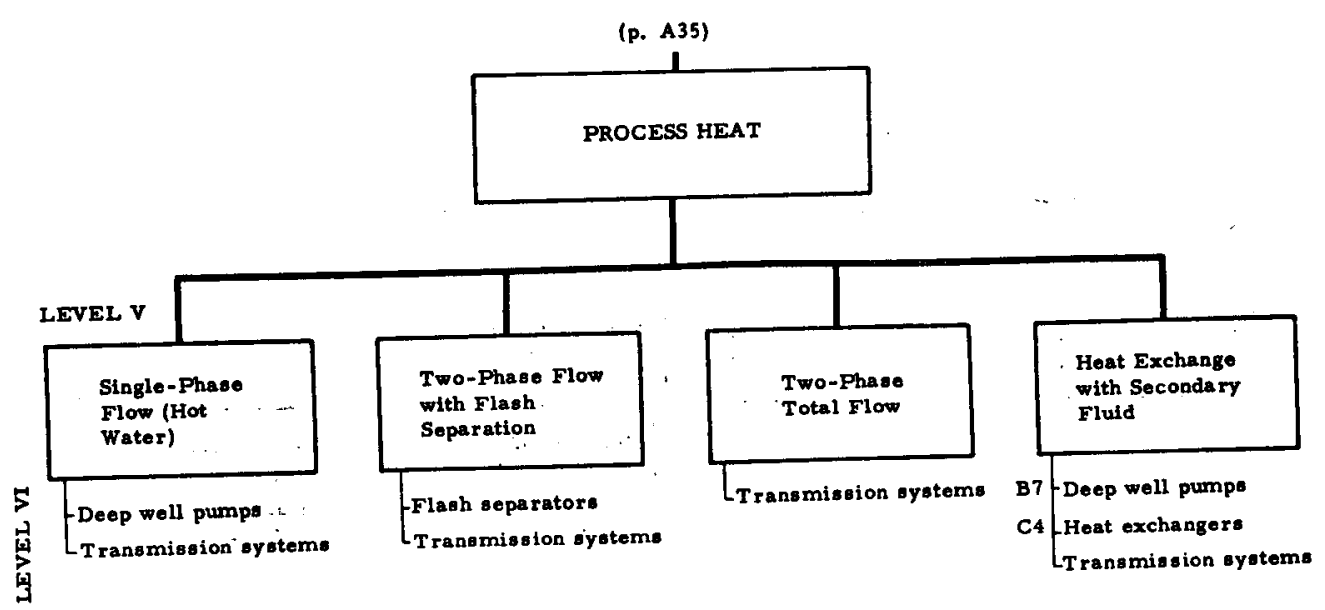

A 37 
(p. A35)

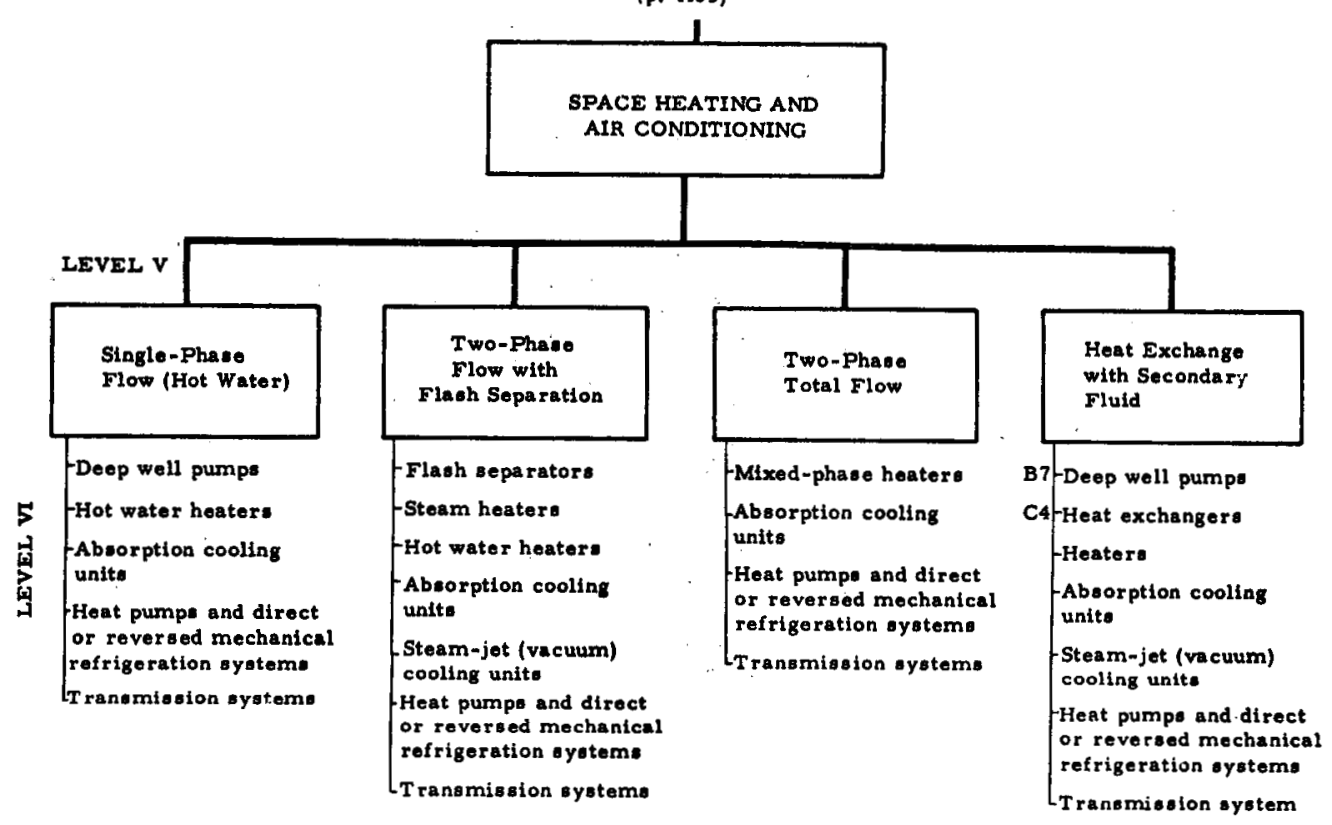

A38

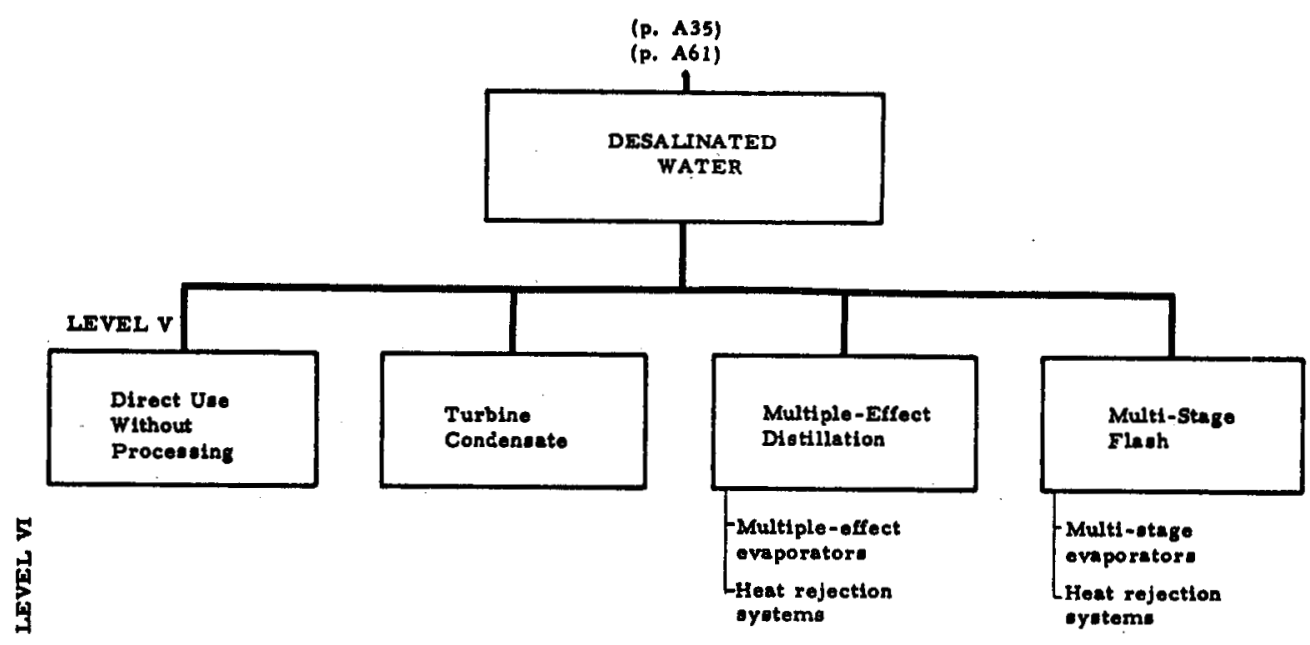

139 


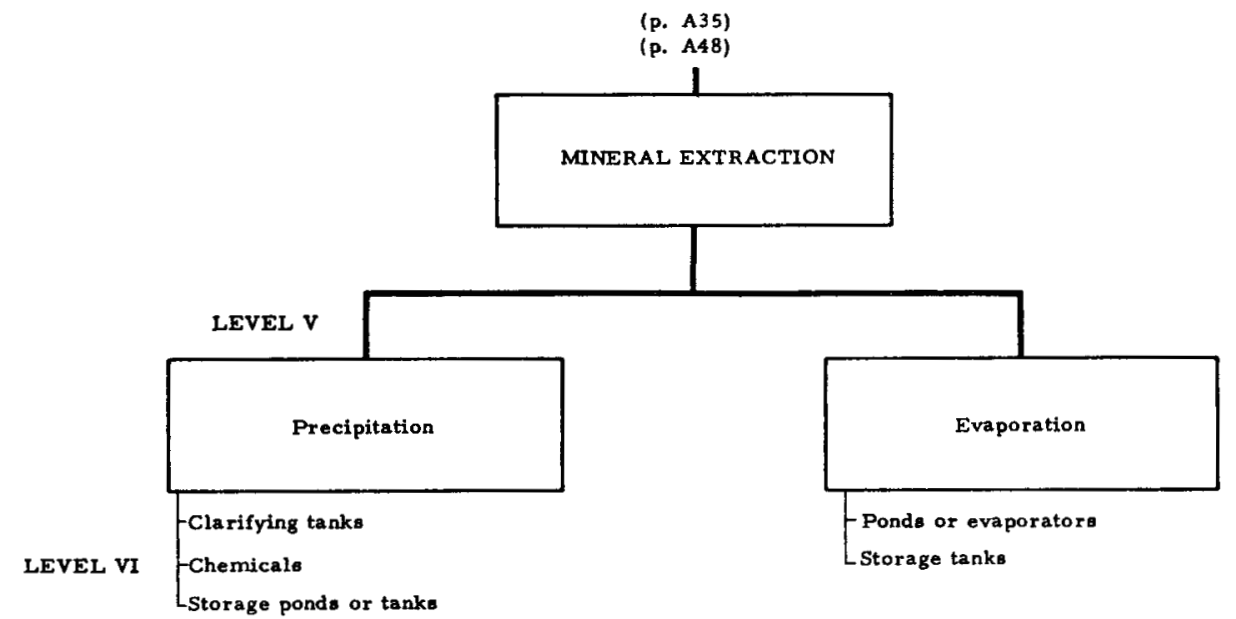

A40

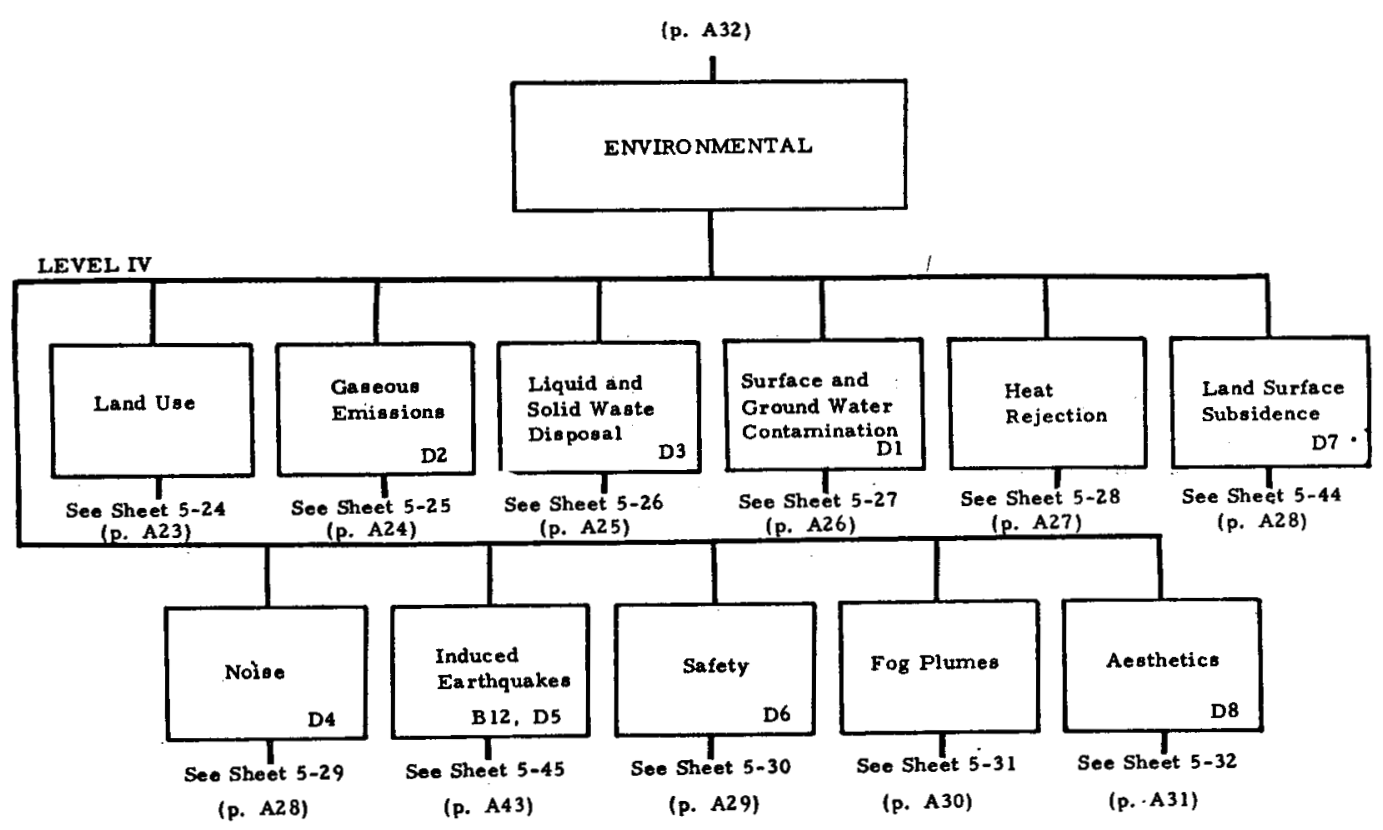

A41 
(p. A41)

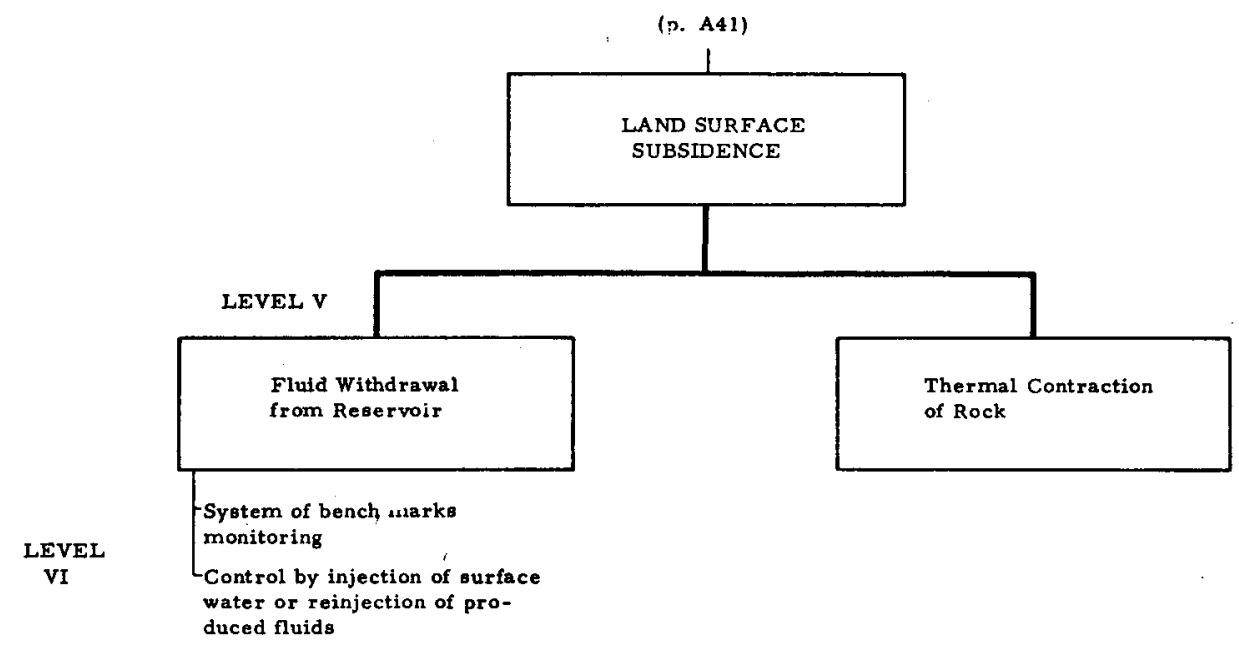

A42

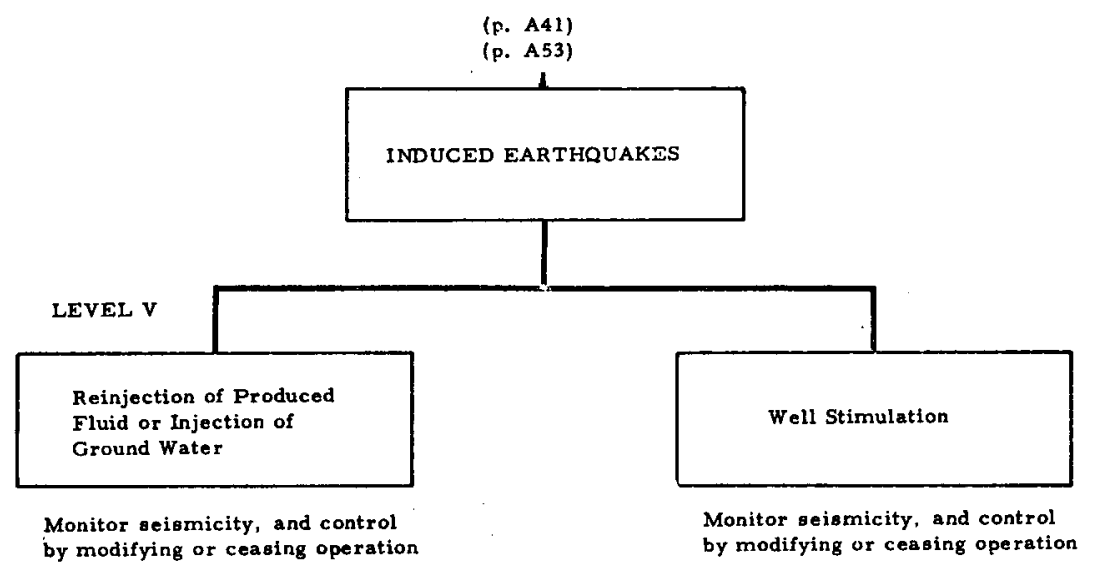

A43 


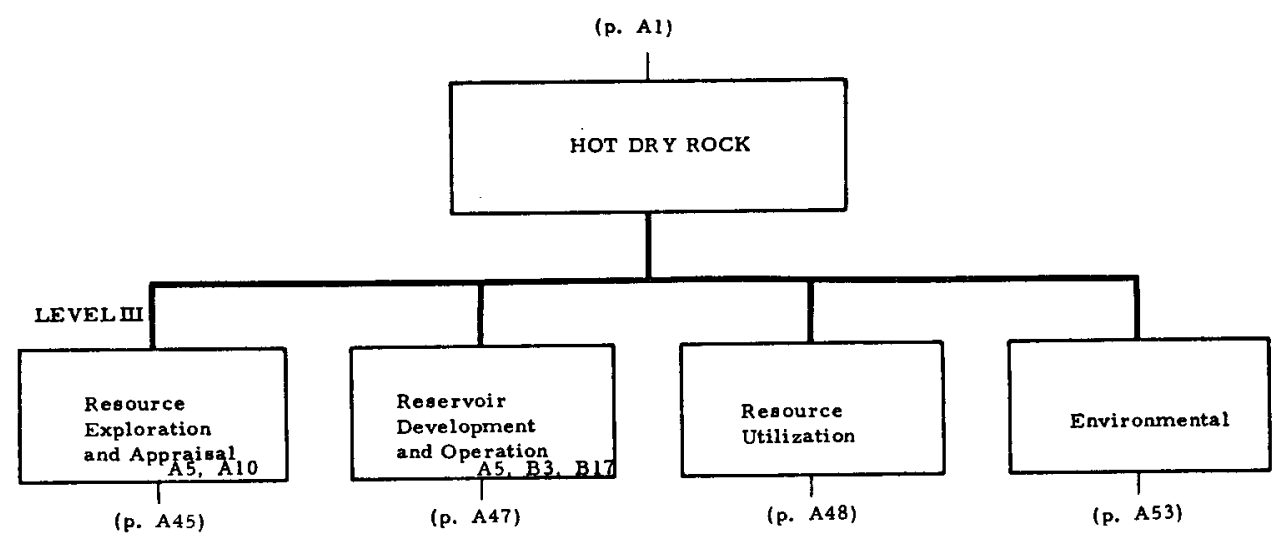

A44

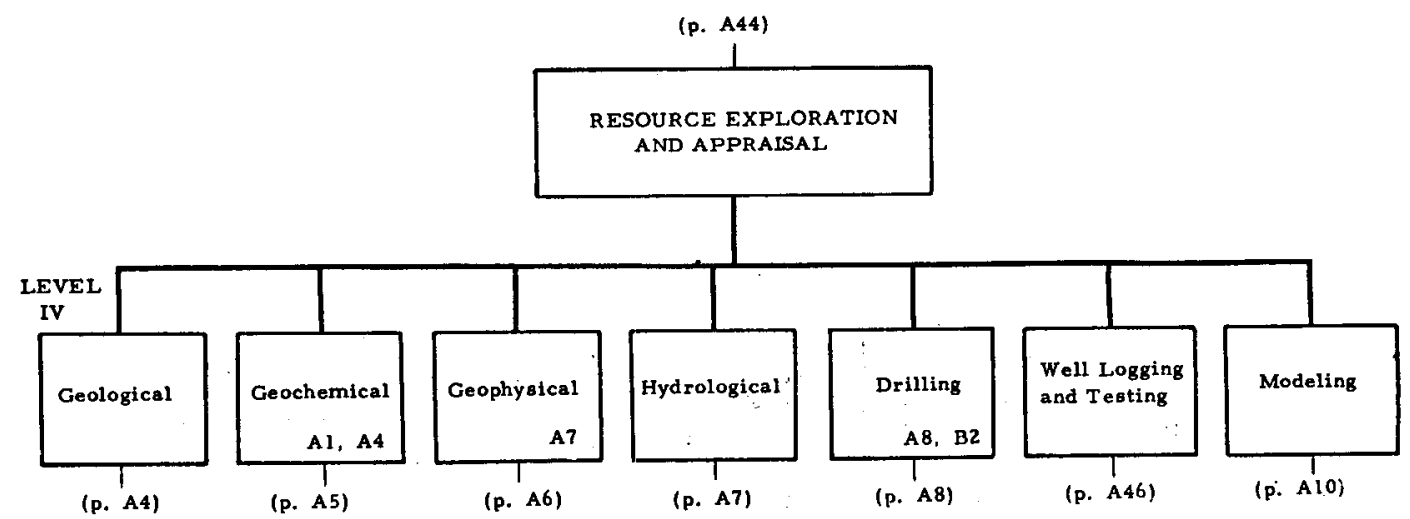

A45 

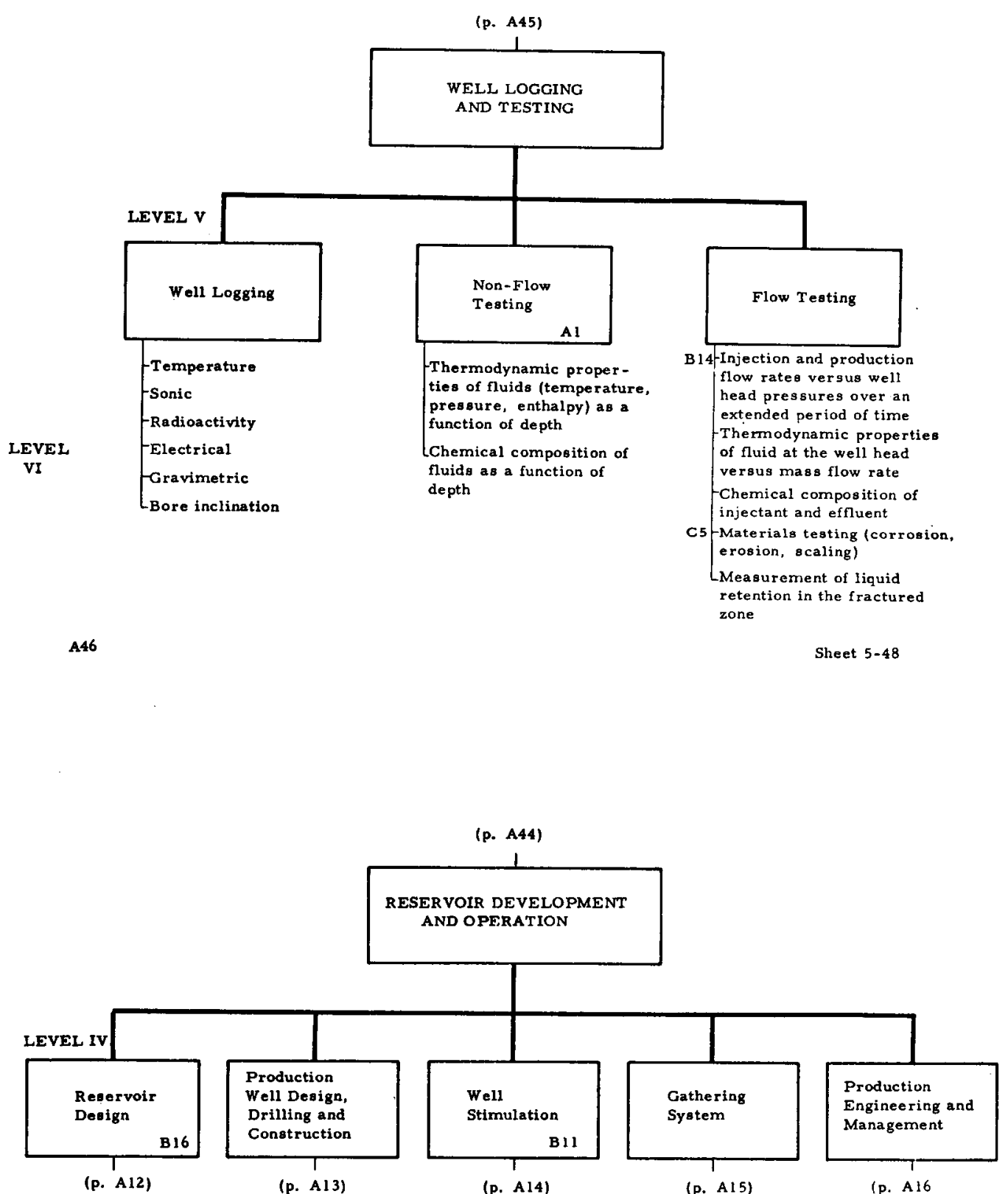

A47 


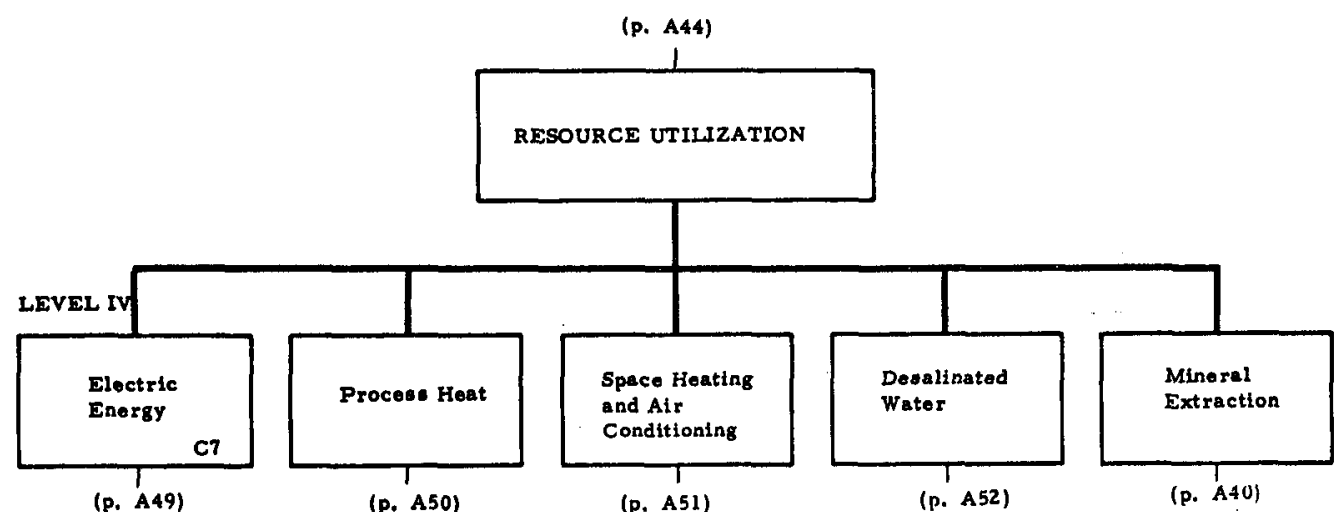

A48

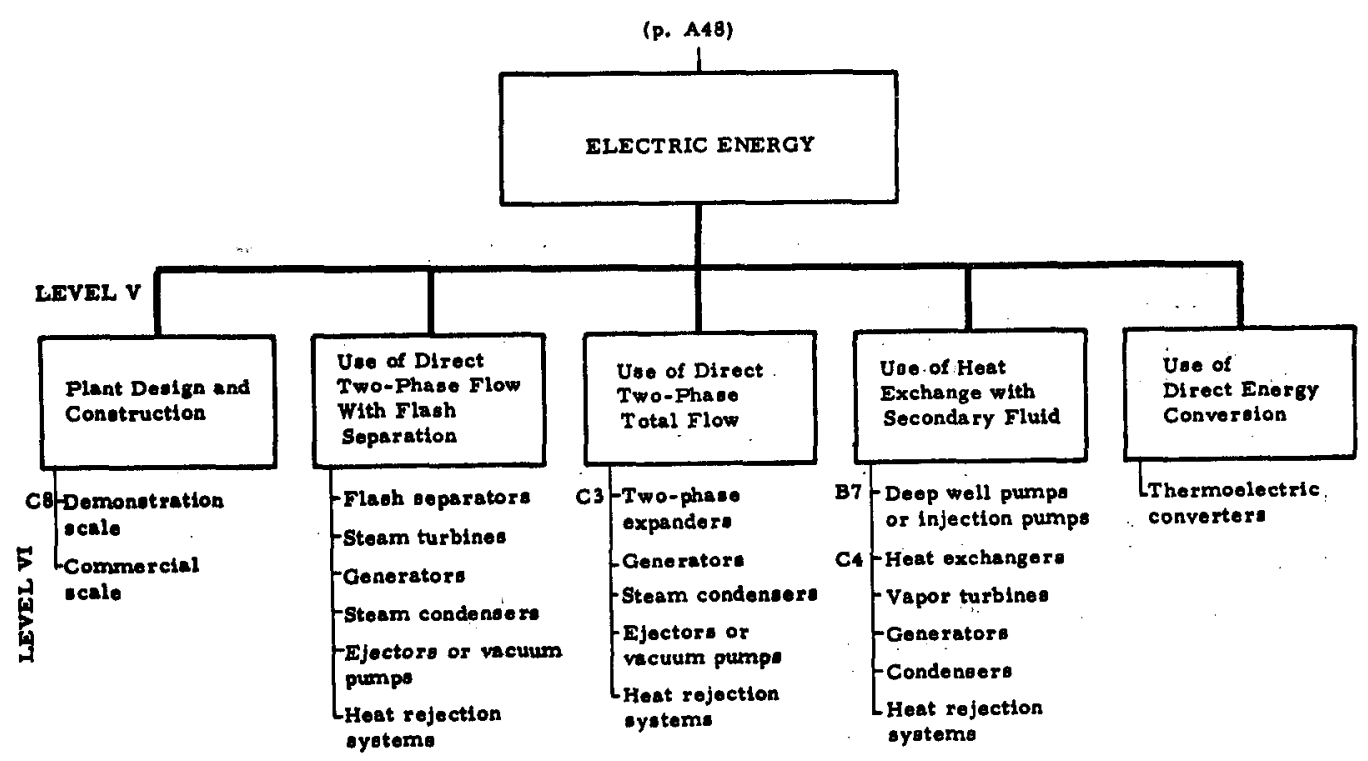

49 
Sheet 4-62 (p. A48)

PROCESS HEAT

\section{B7 Deep well pumpe or}

injection pumps
Transmiesion syster

Single-Phase

Single-Phase
Flow (Liquid)

7

Transmieston systems

Flash separatora

Transmission oystems

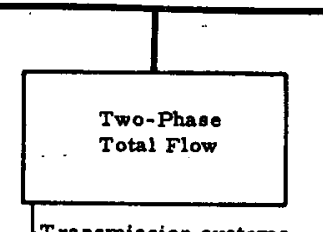

Transmisaion systems

B7 -Deep well pumps or

injection pumps

C4 Heat exchangers

Transmission systems

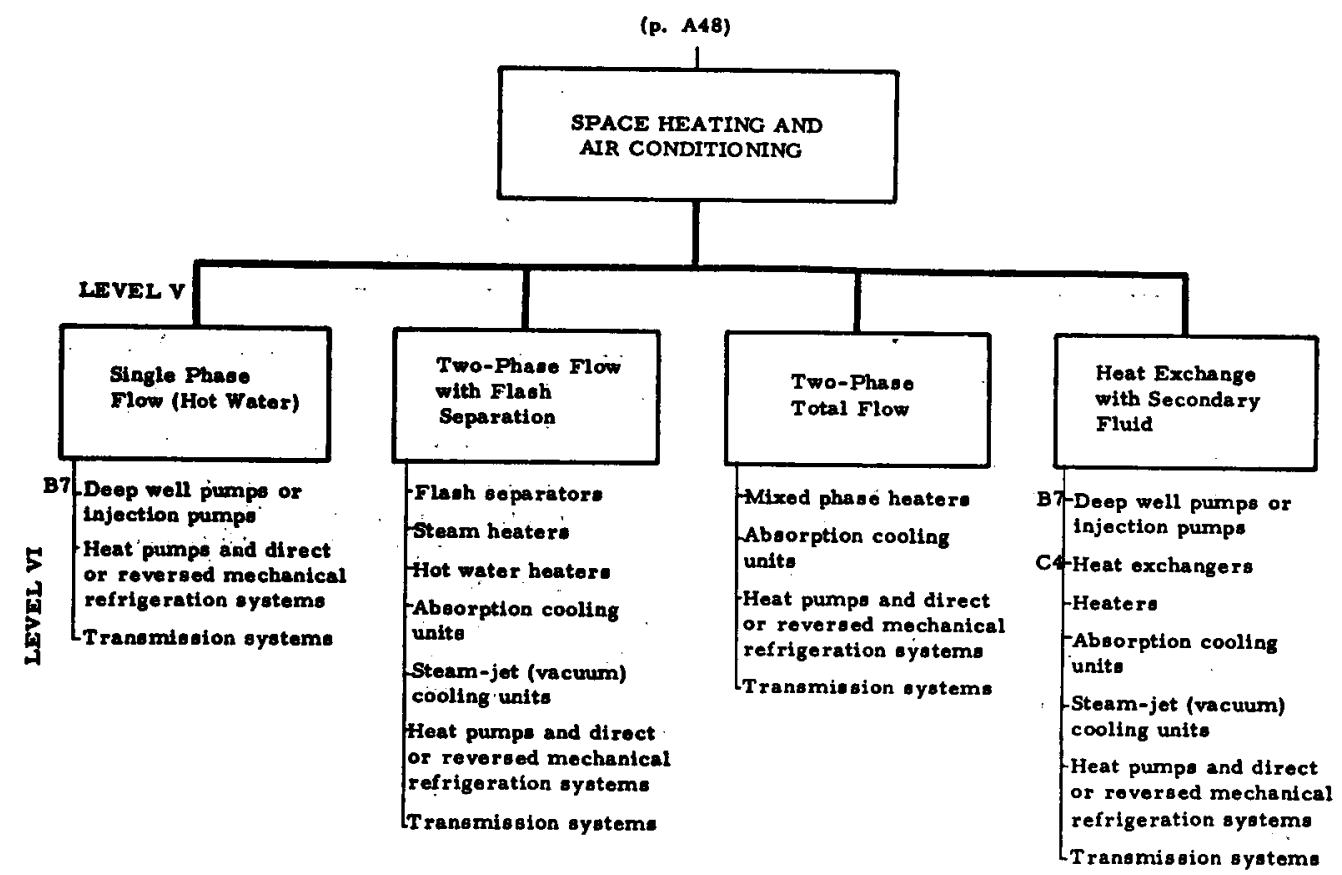

A51 


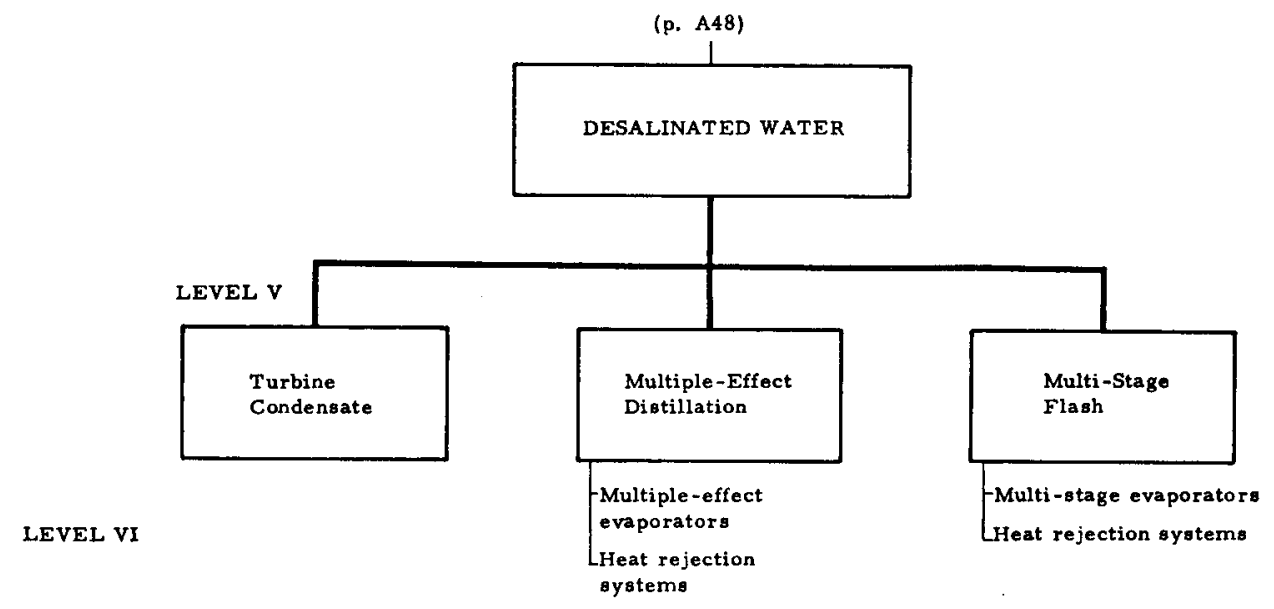

A52

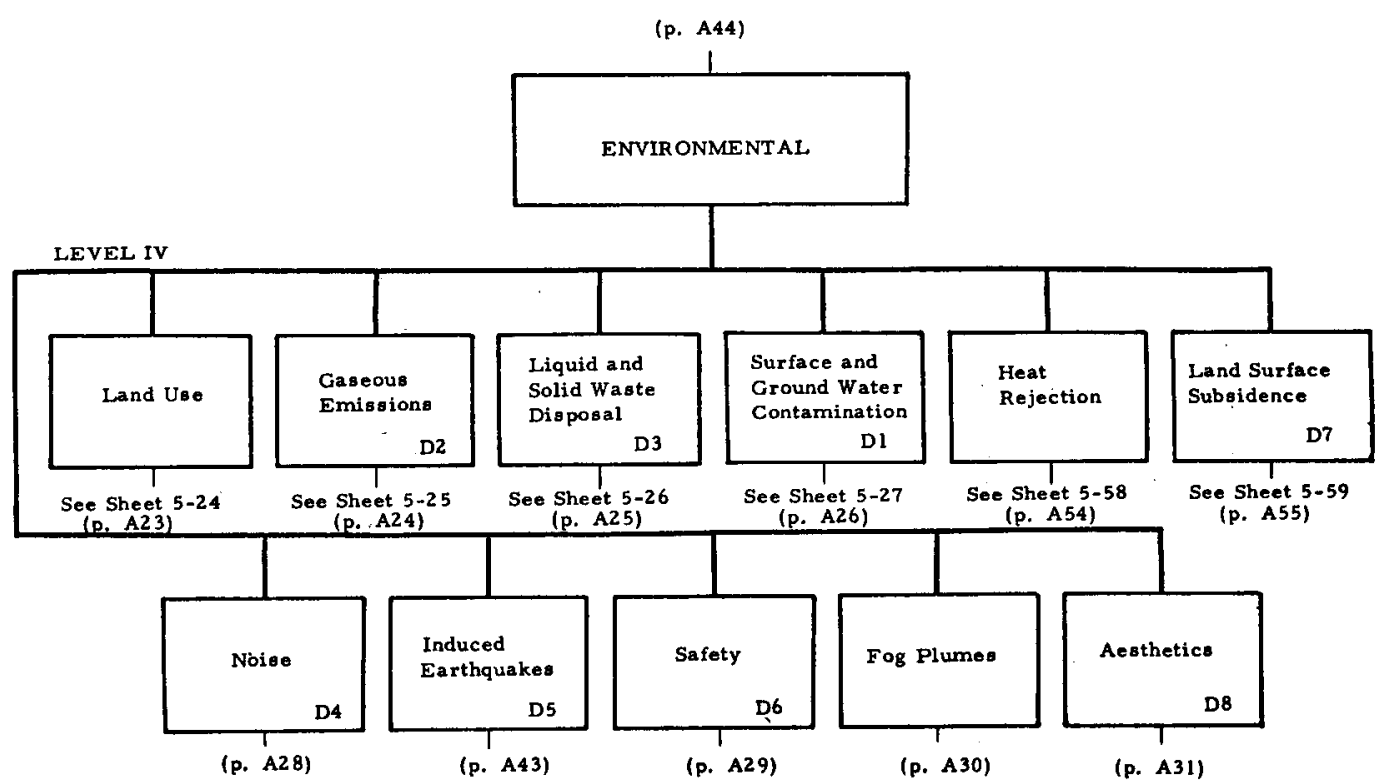

A53 


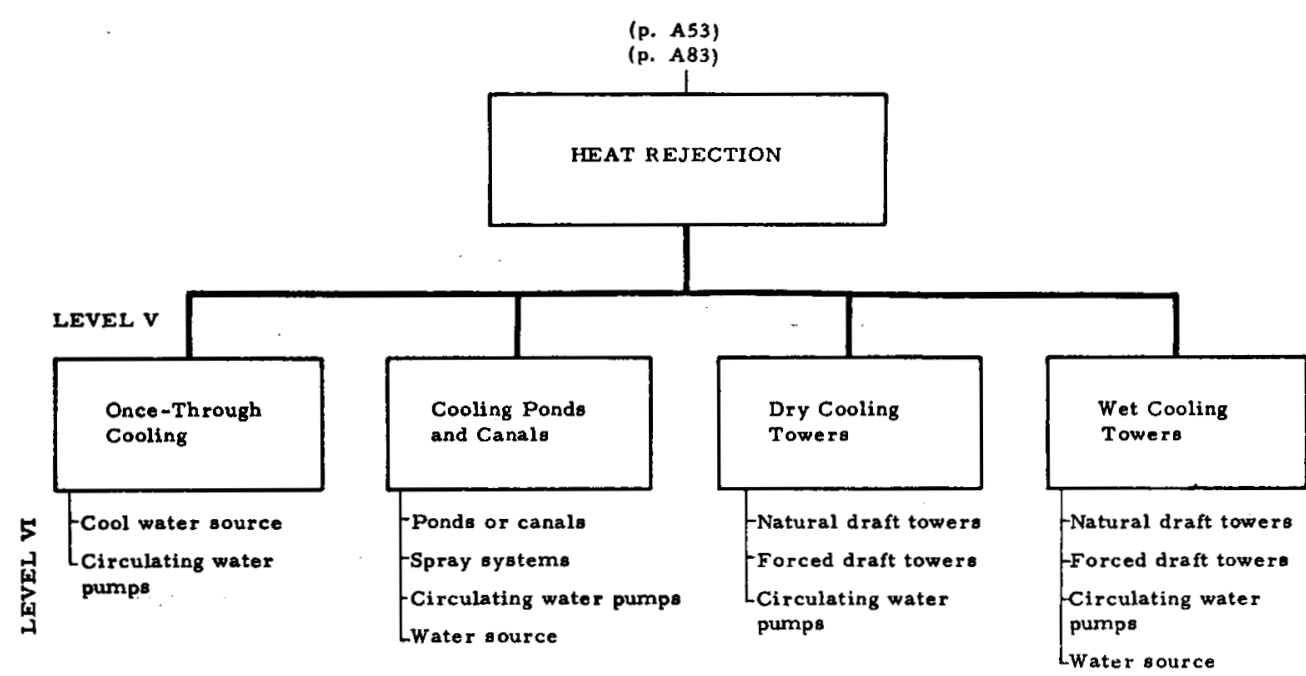

A54

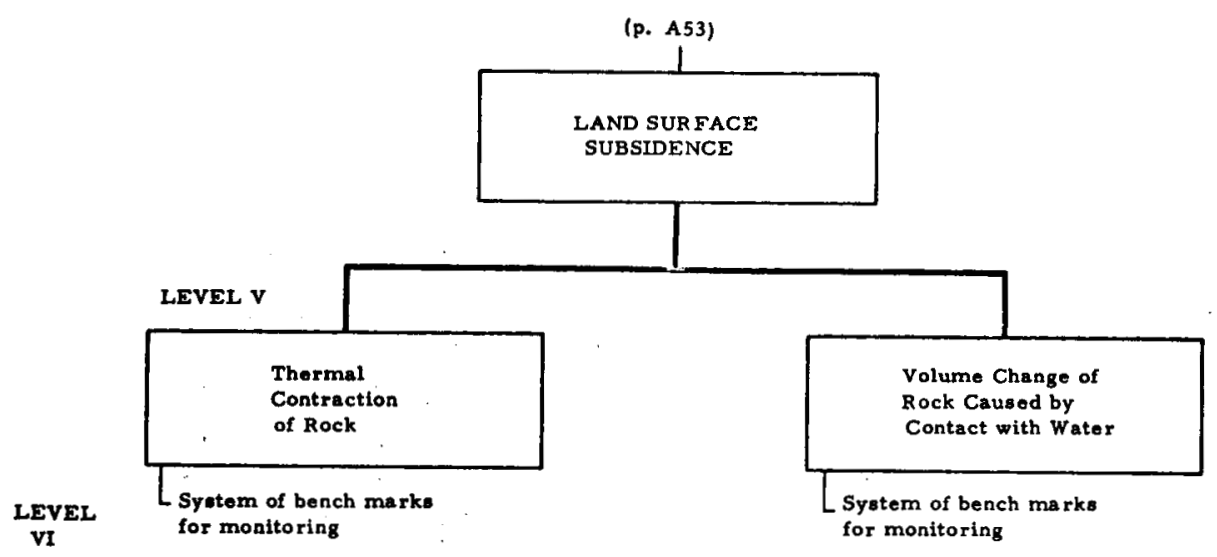

A 55 


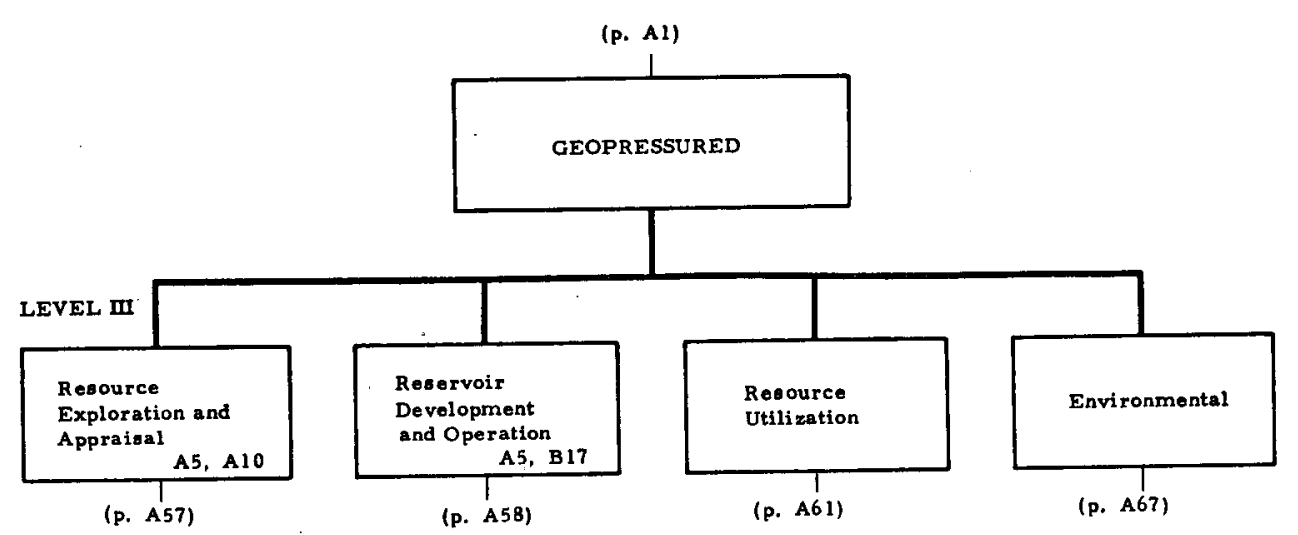

A56

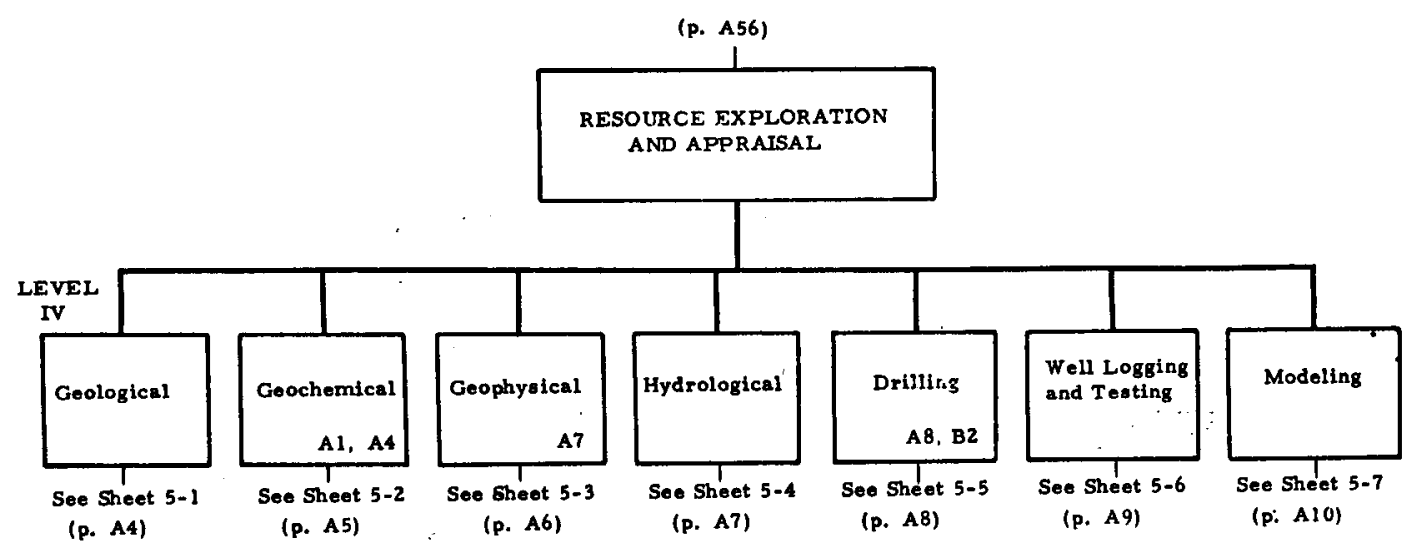

A. 57 


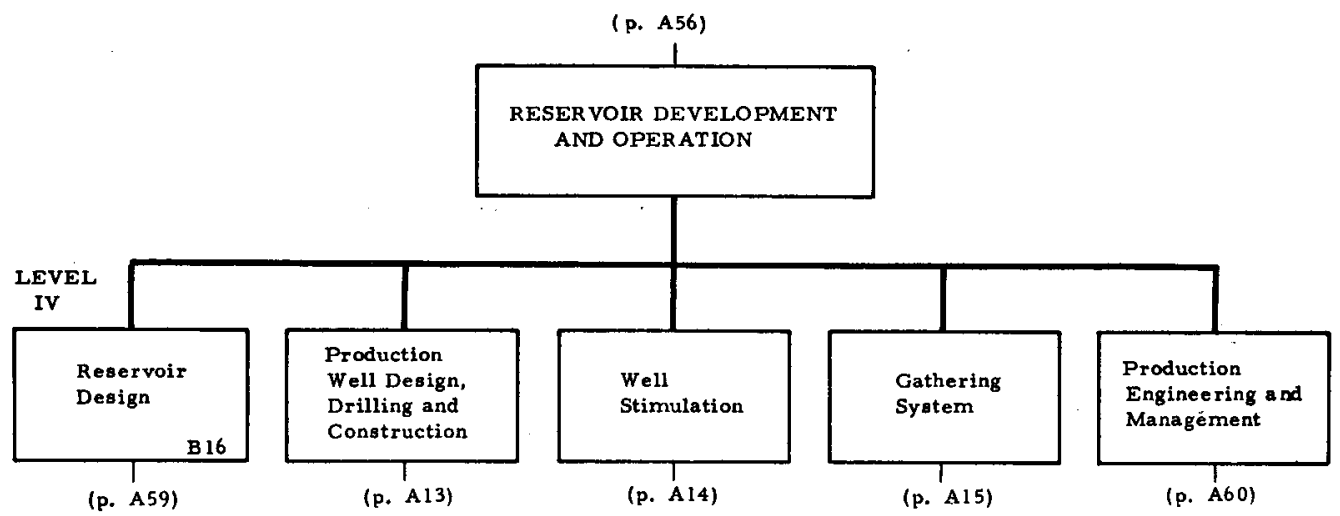

A 58

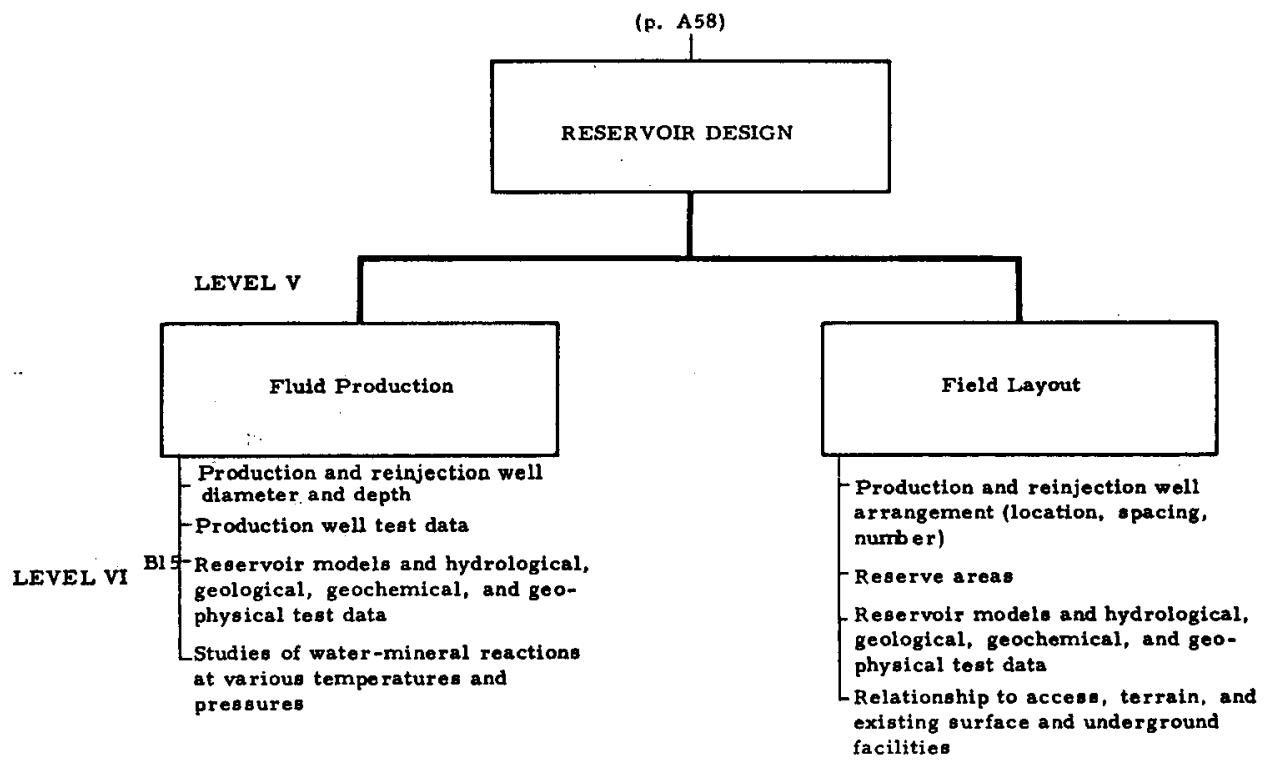

A59 


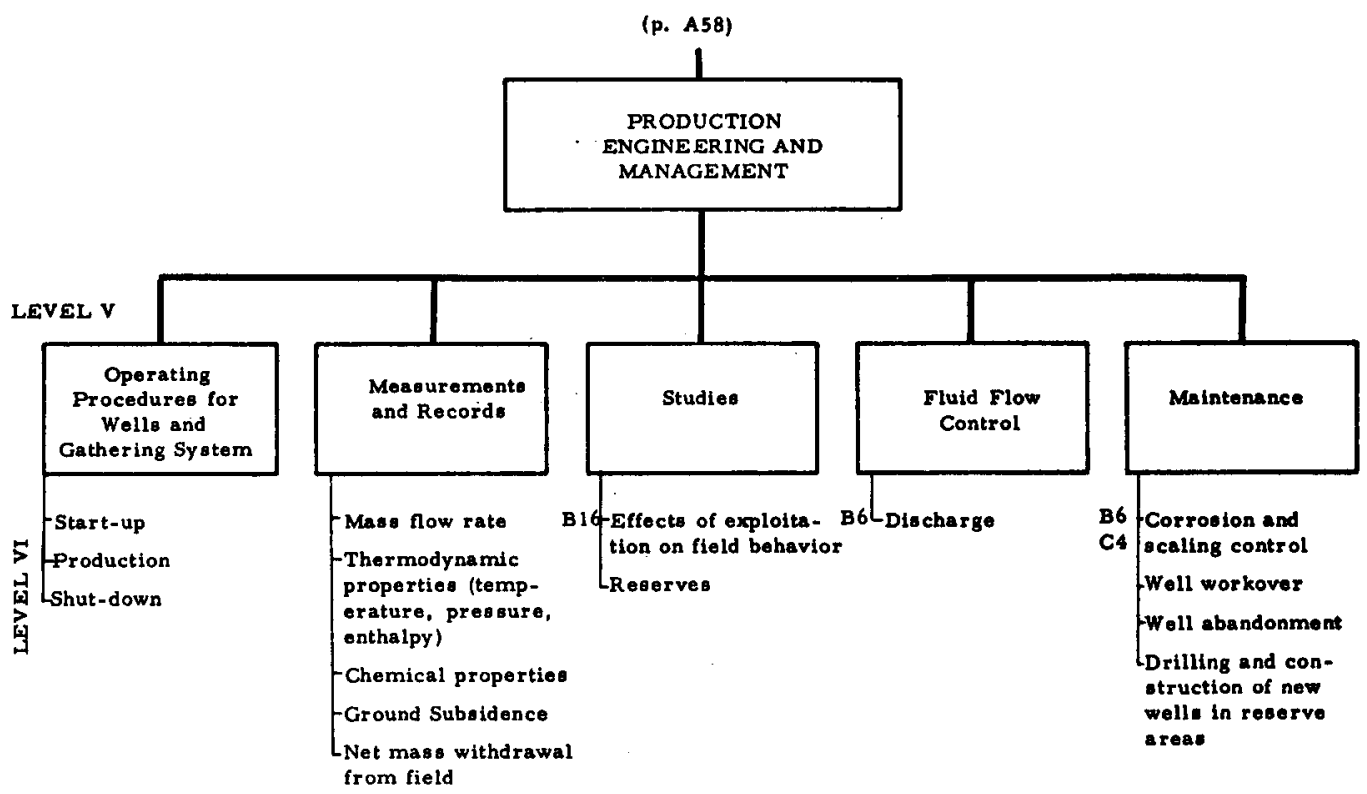

A60

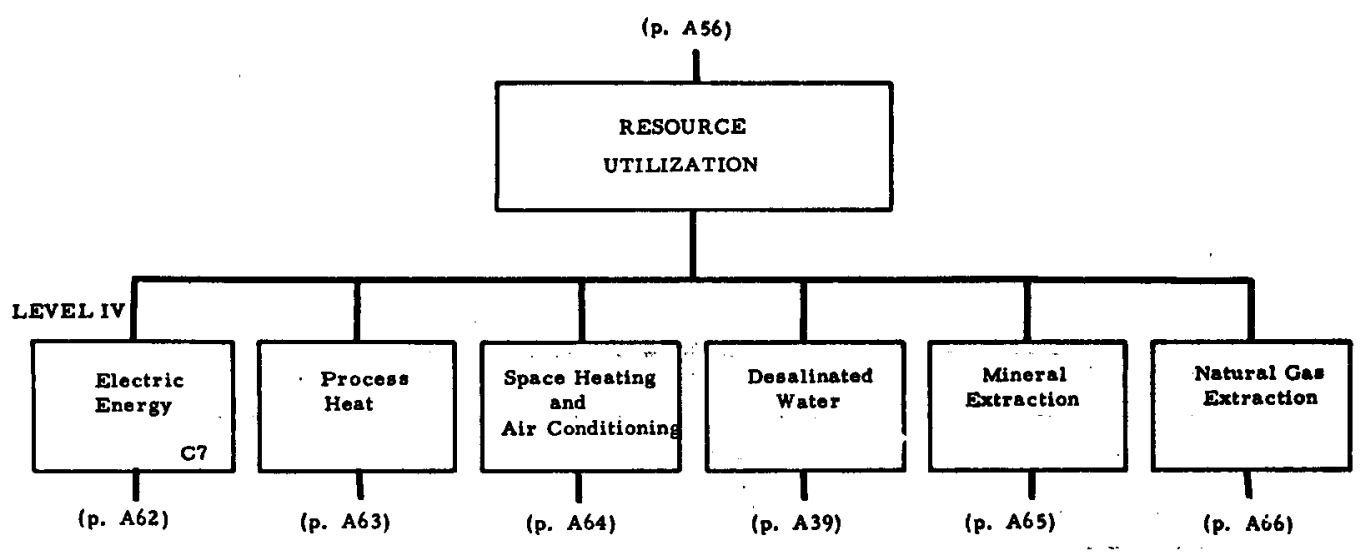

A61 


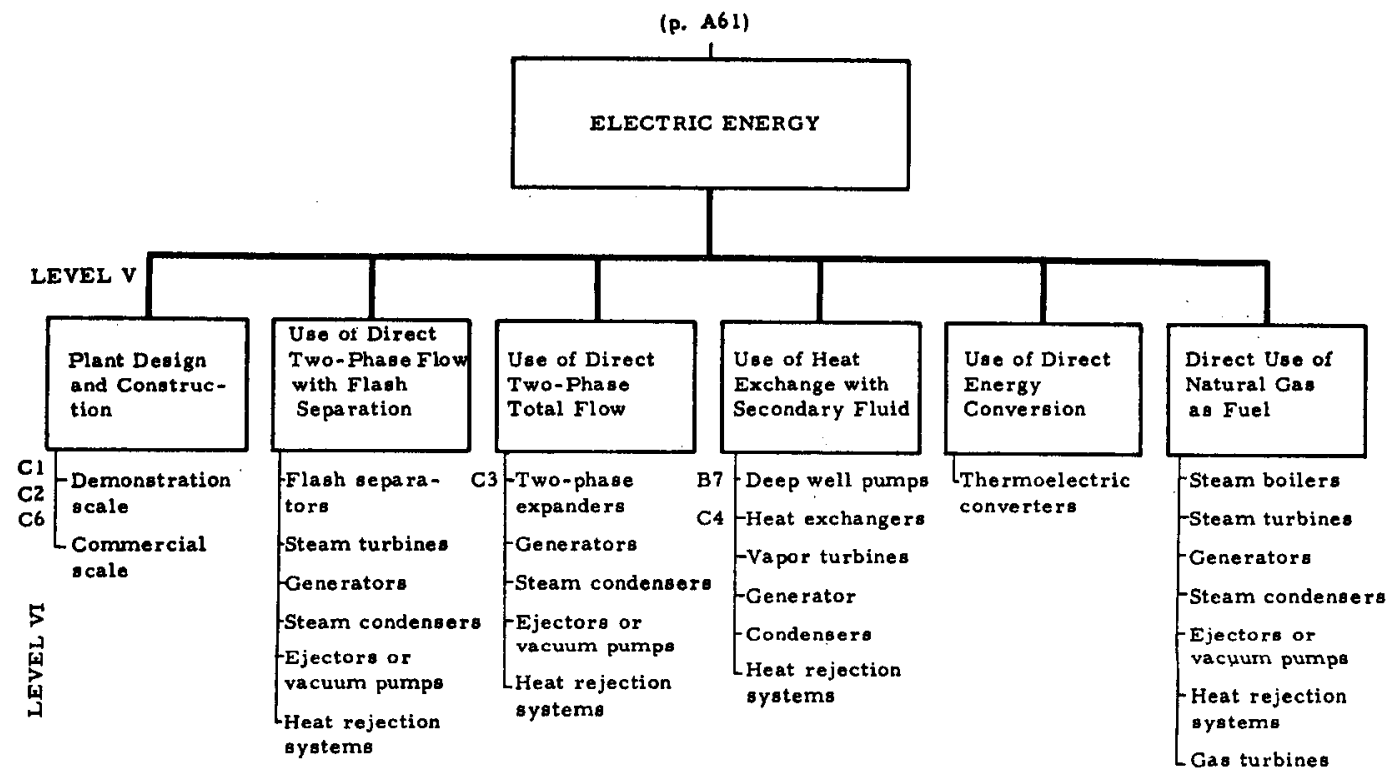

A62

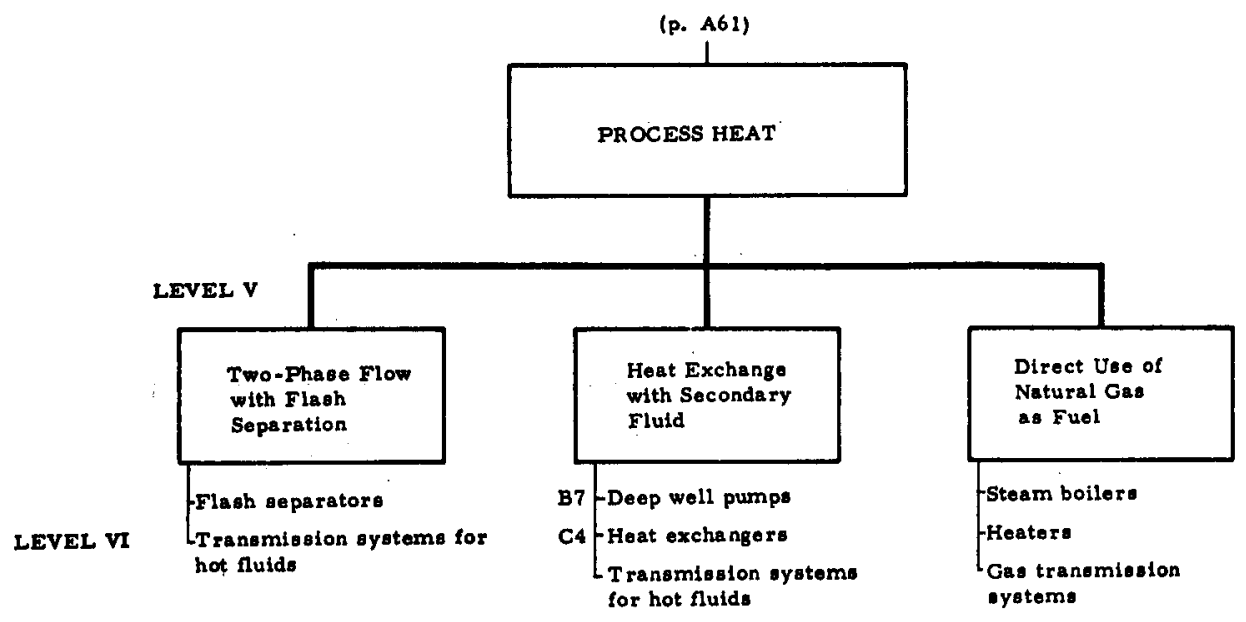




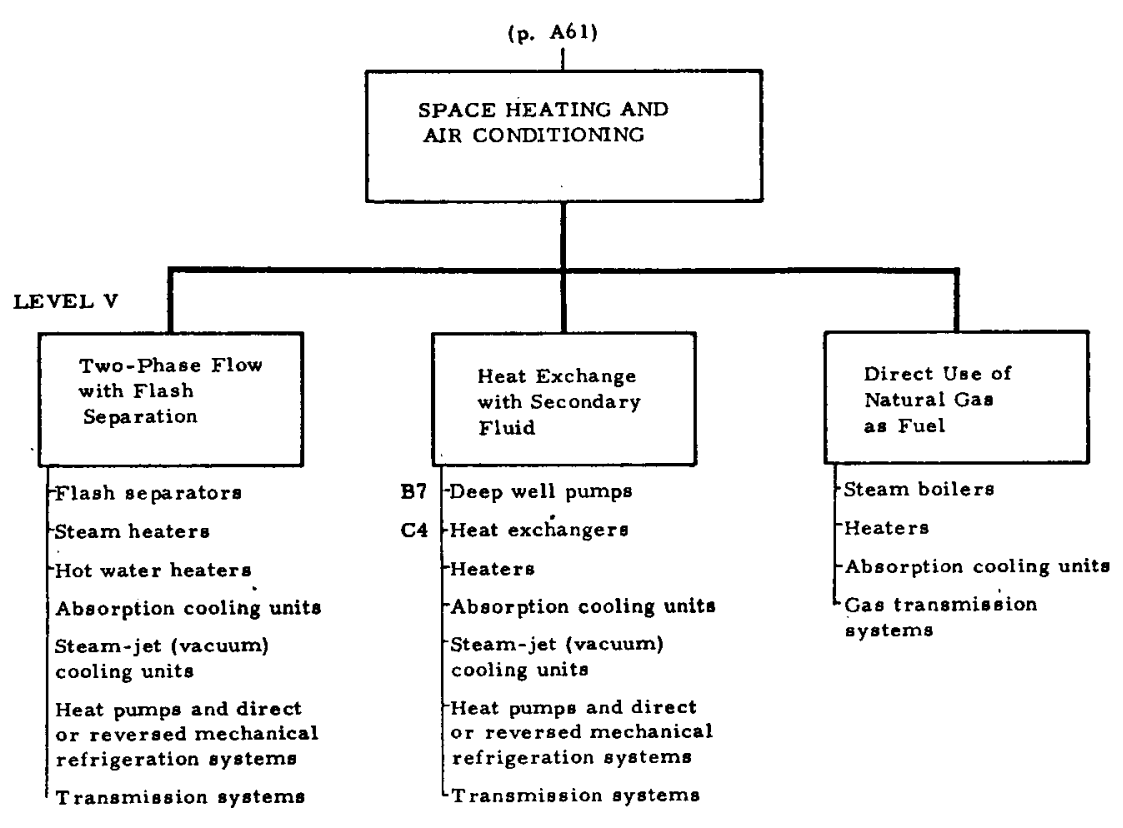

A64

(p. A61)

MINERAL

EXTRACTION

LEVEL VI

-Chemicala.

Storage ponds or tanks 

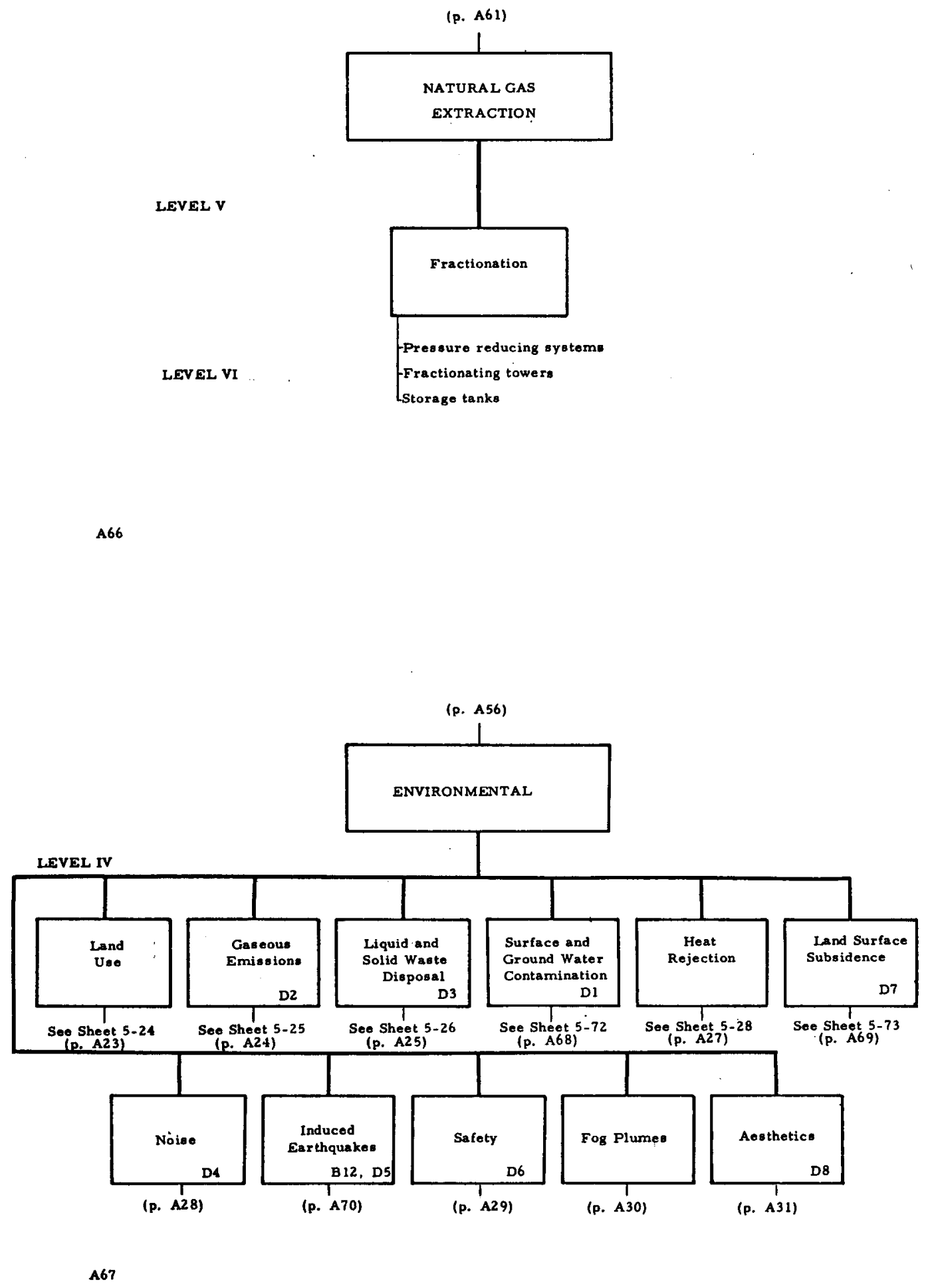


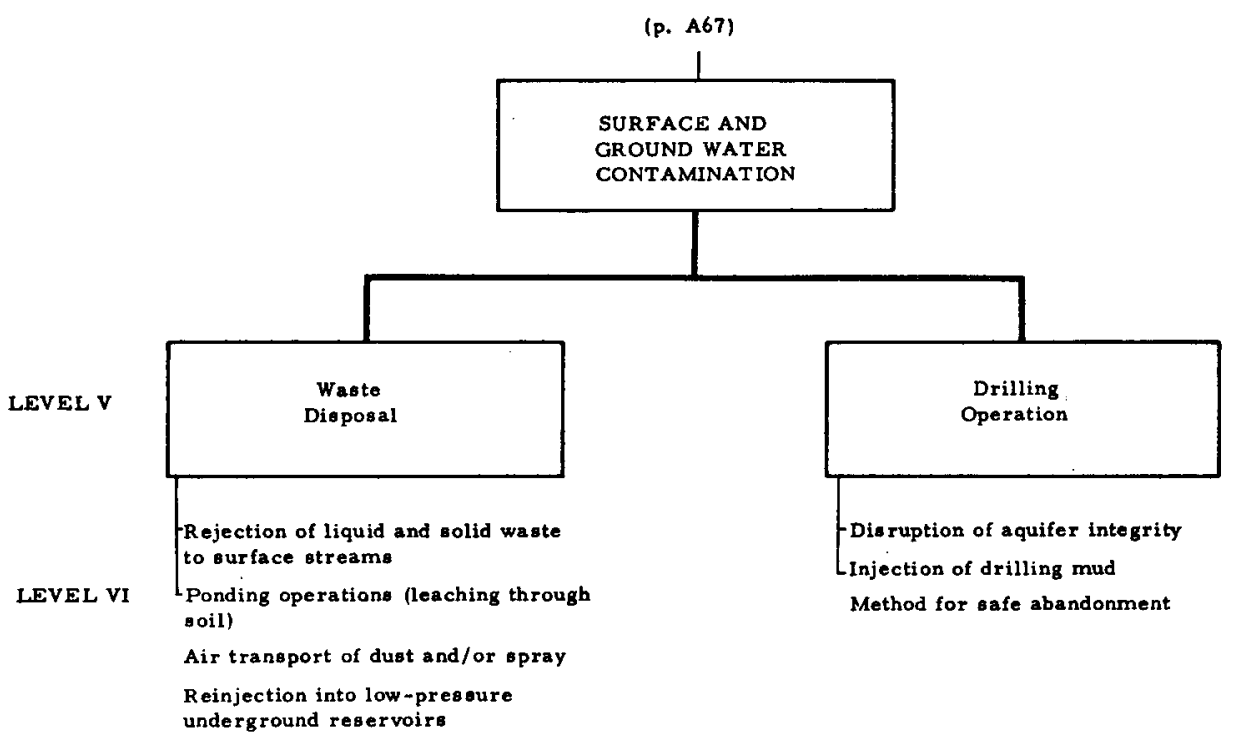

A68

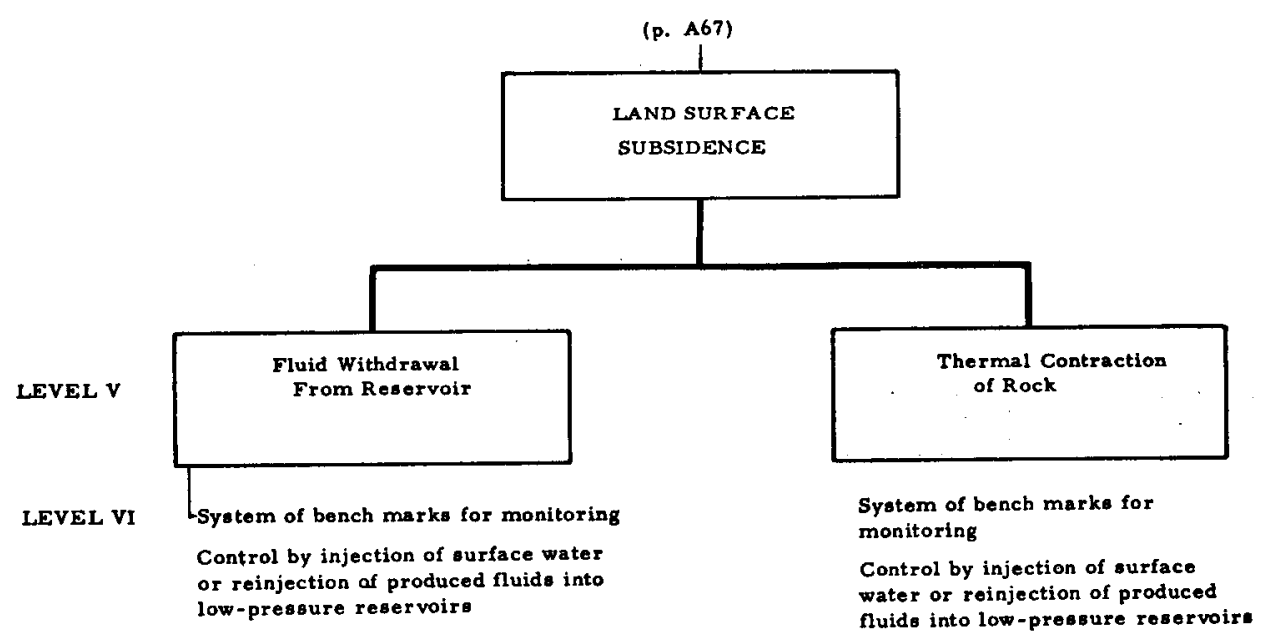

A69 


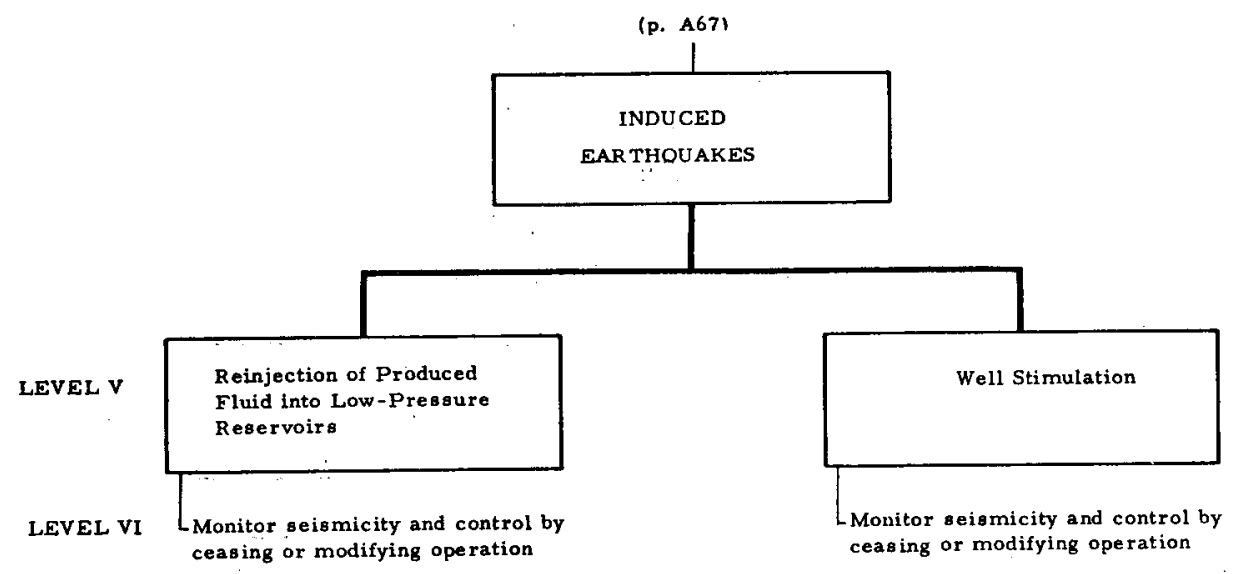

A70

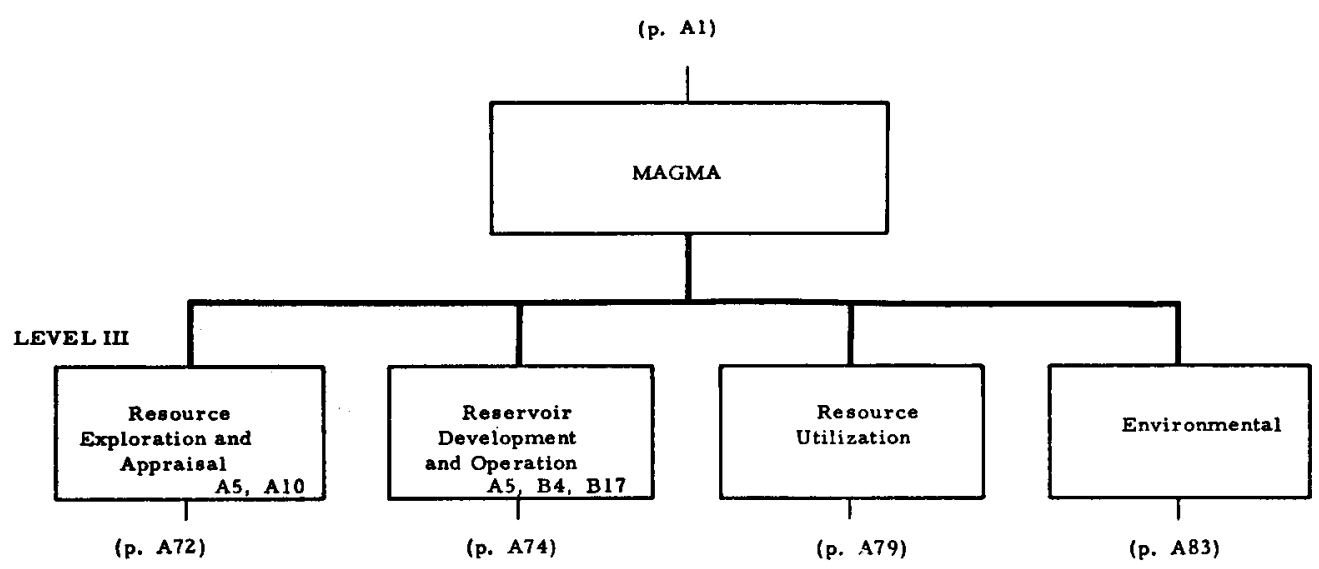

A71 


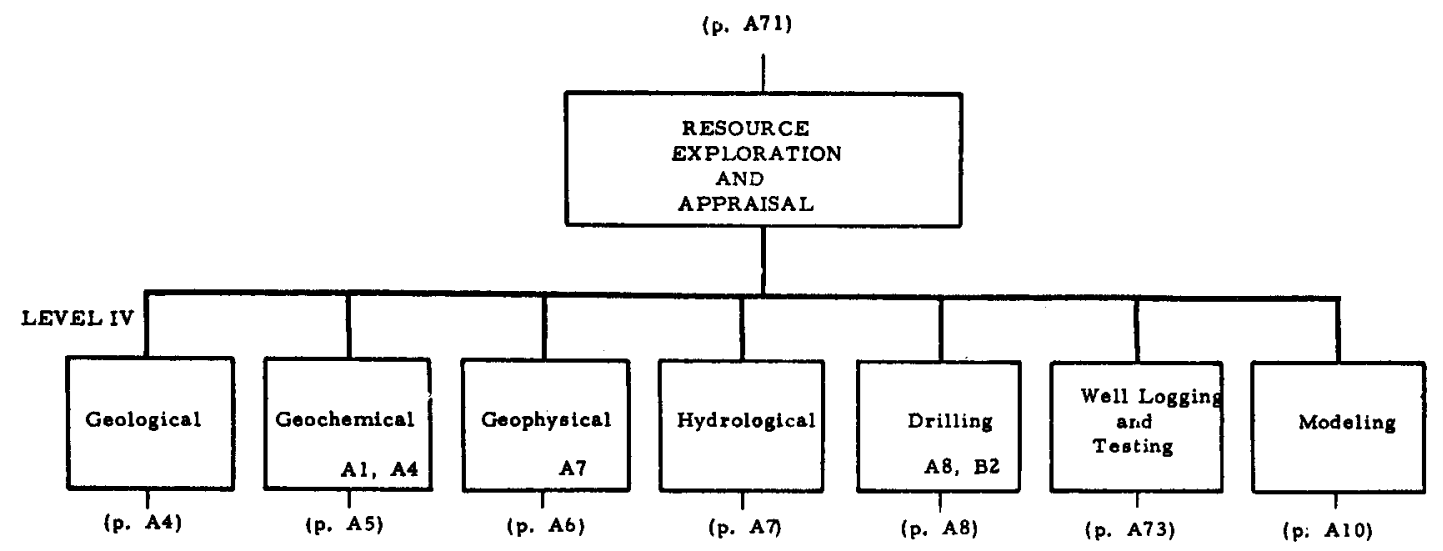

A72

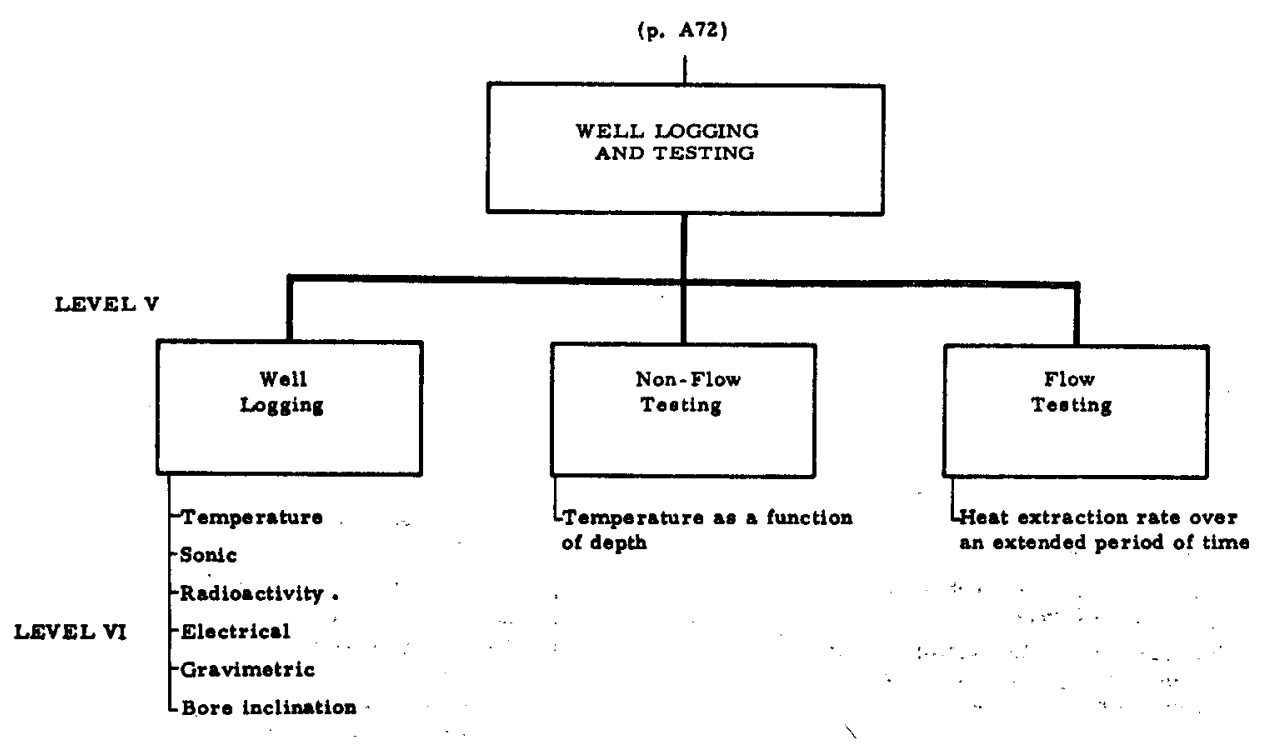

A73 


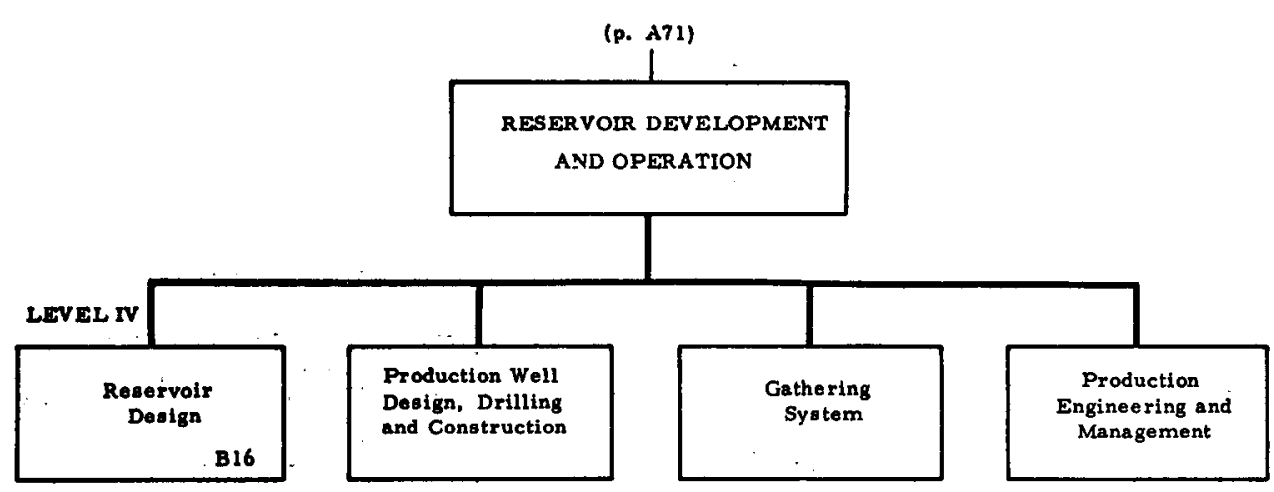

A74

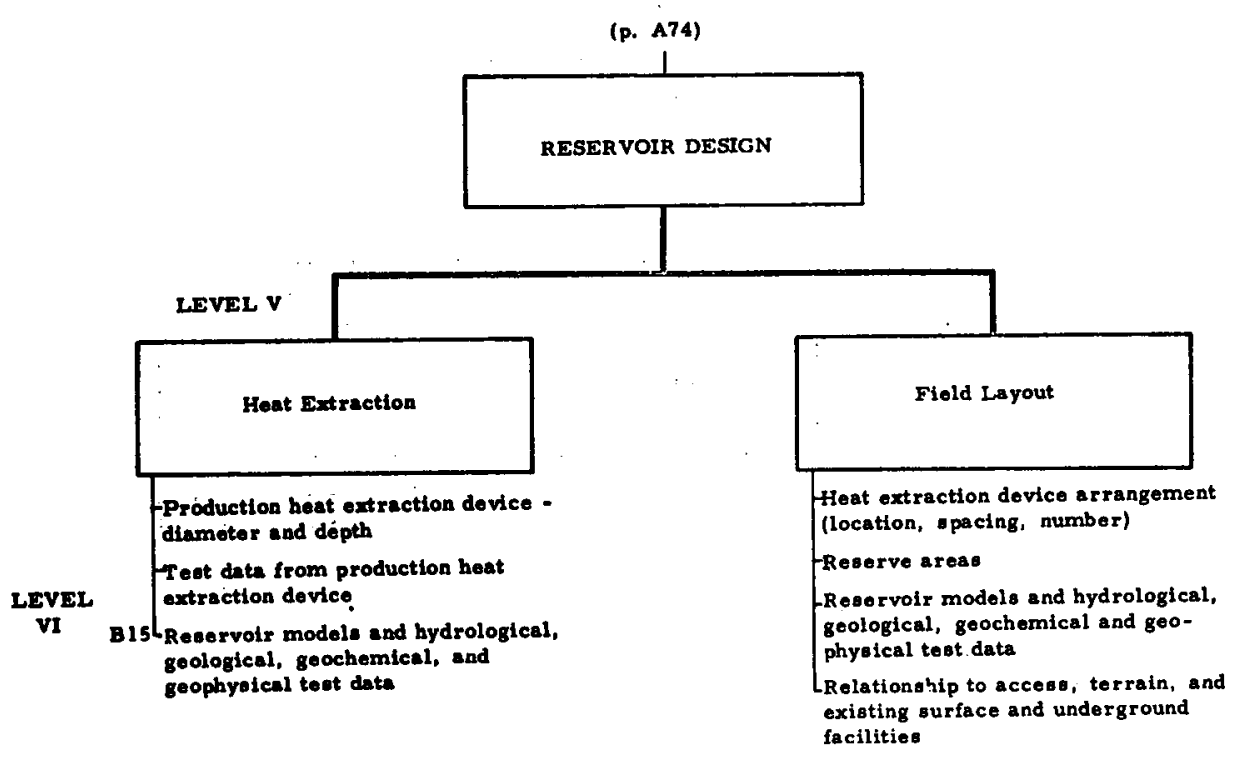

A75 


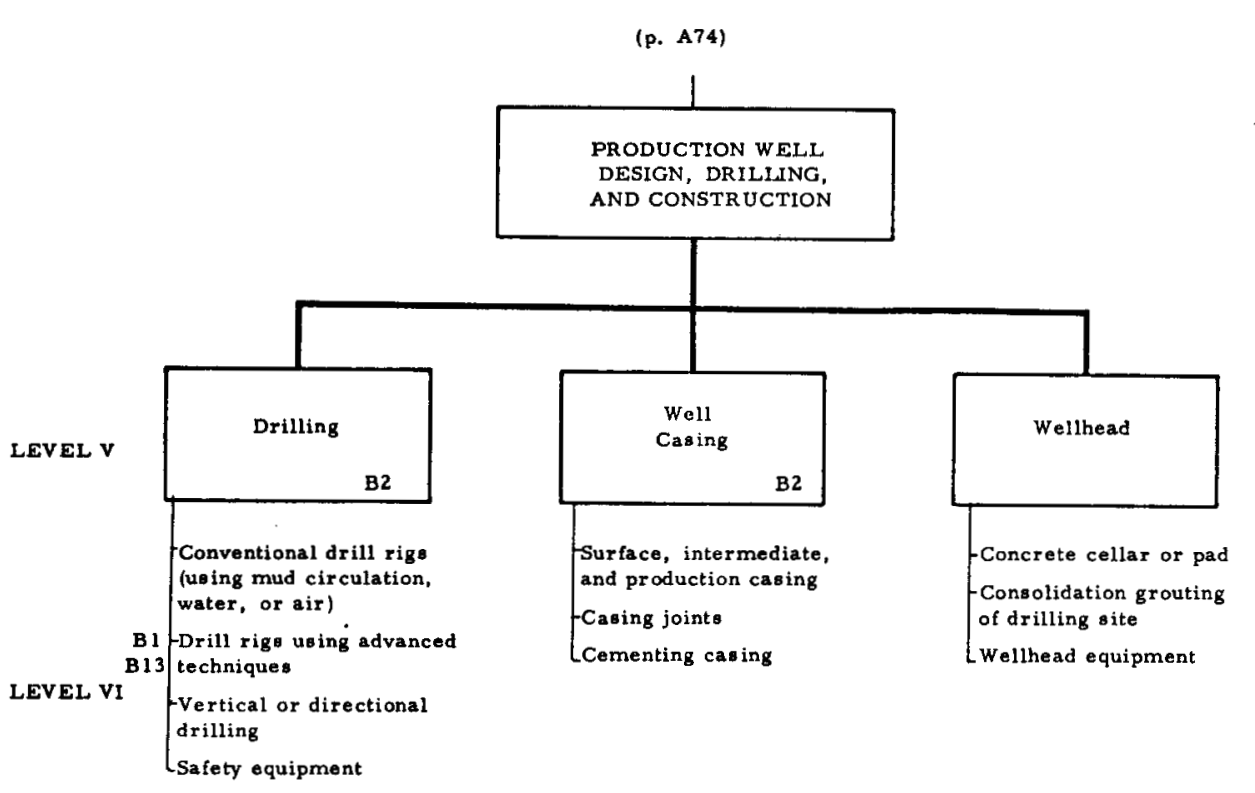

A76

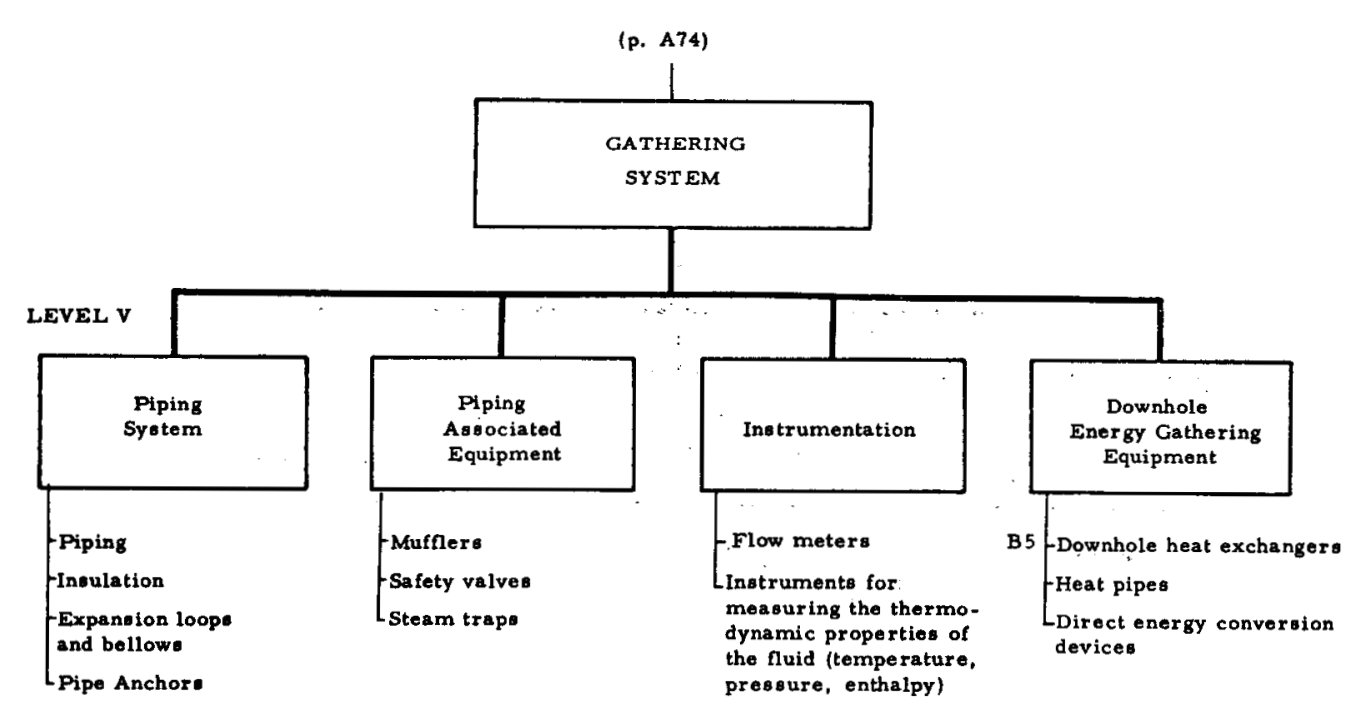

A77 


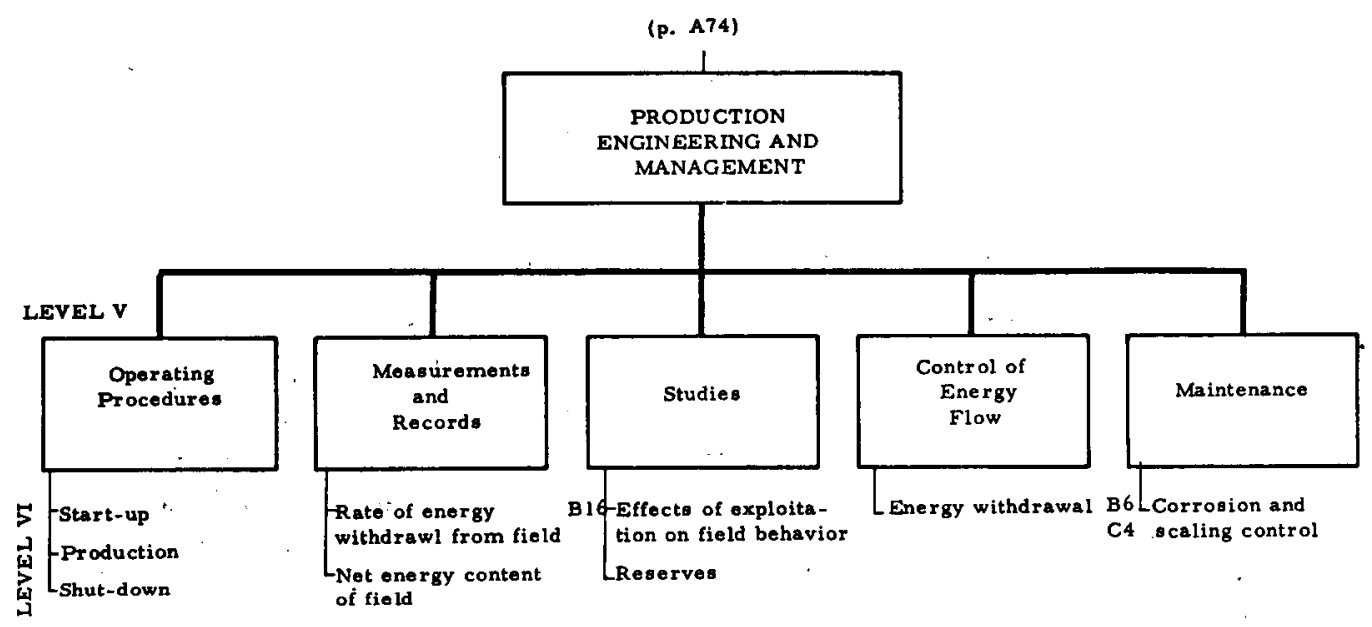

A78

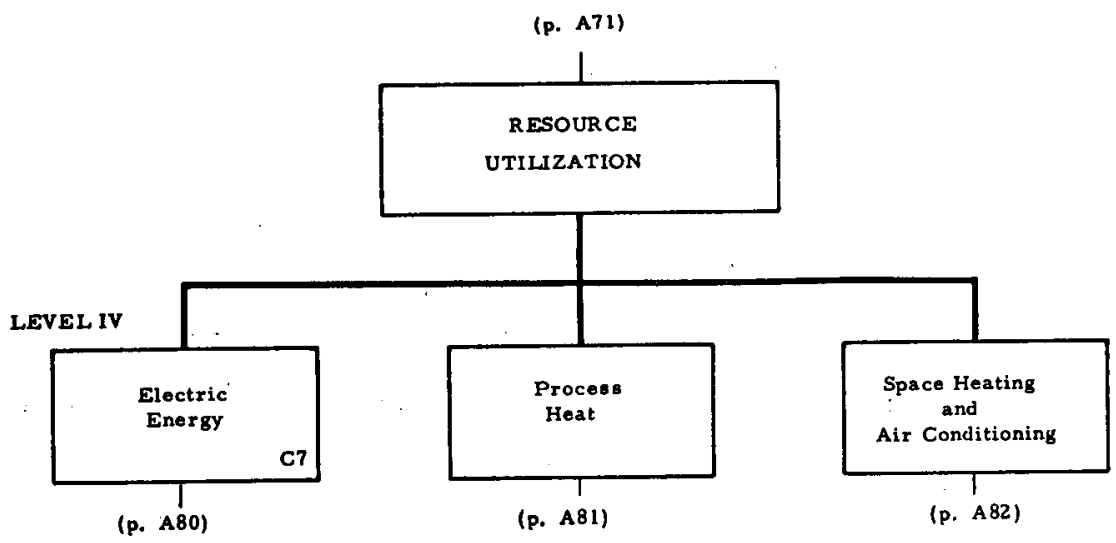

A79 


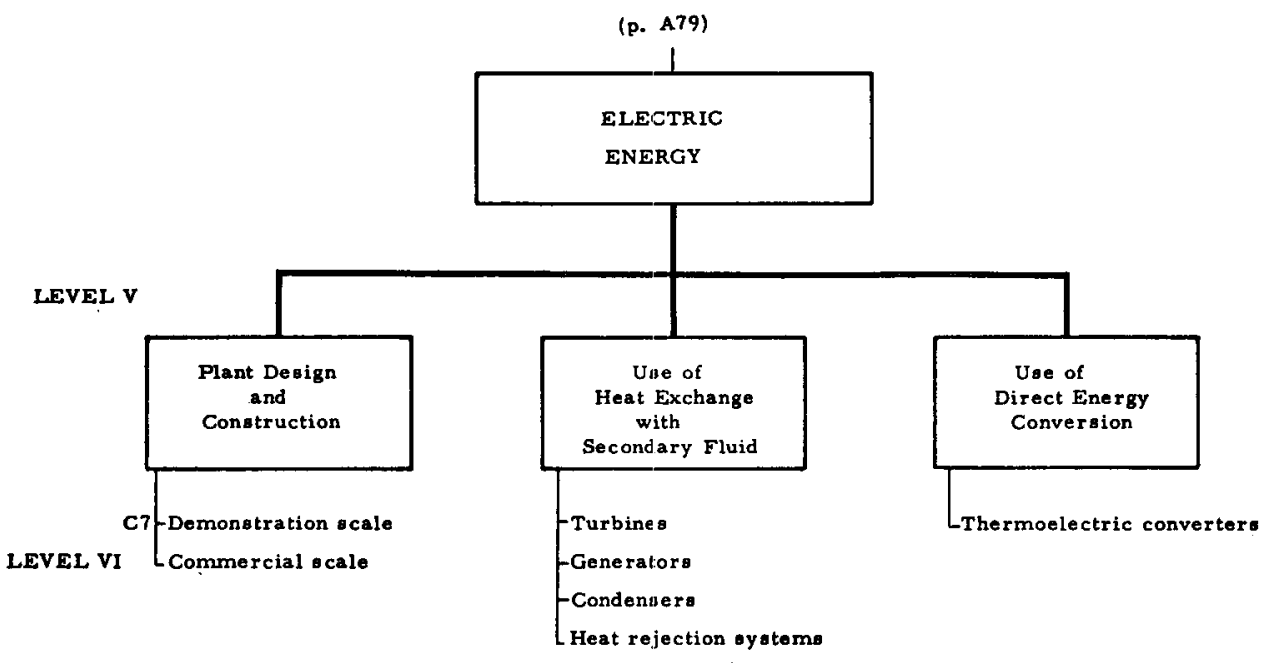

A80

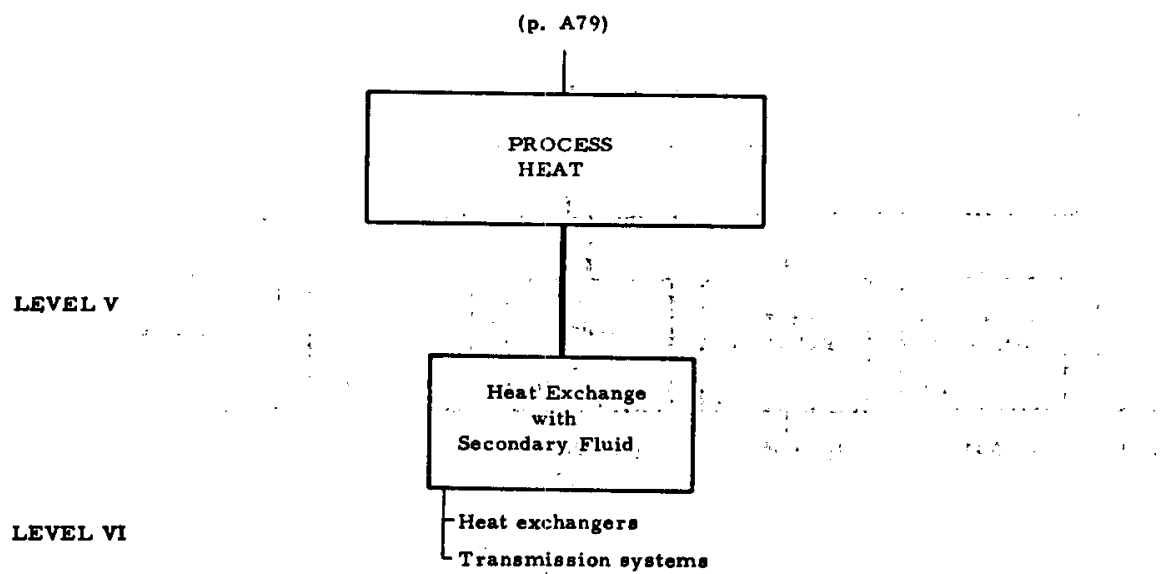

A81 


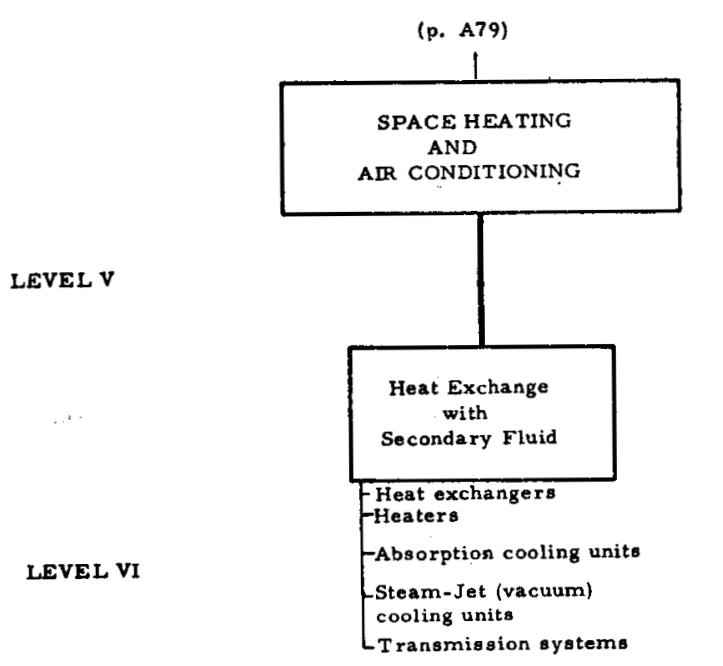

A82

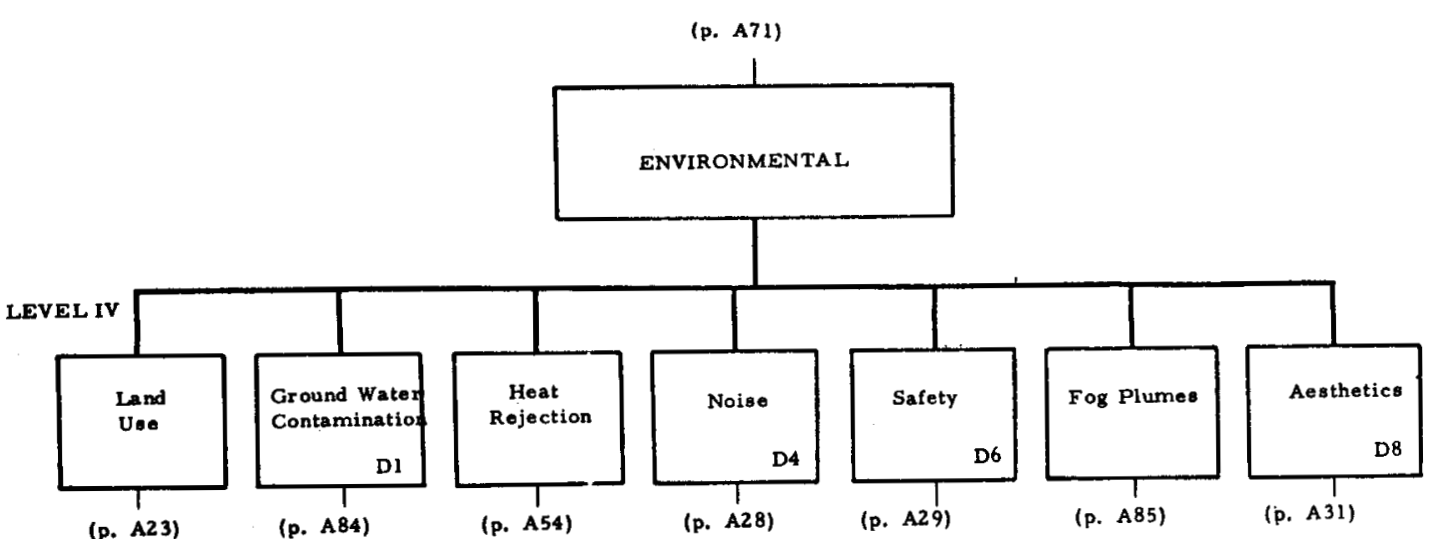

A83 


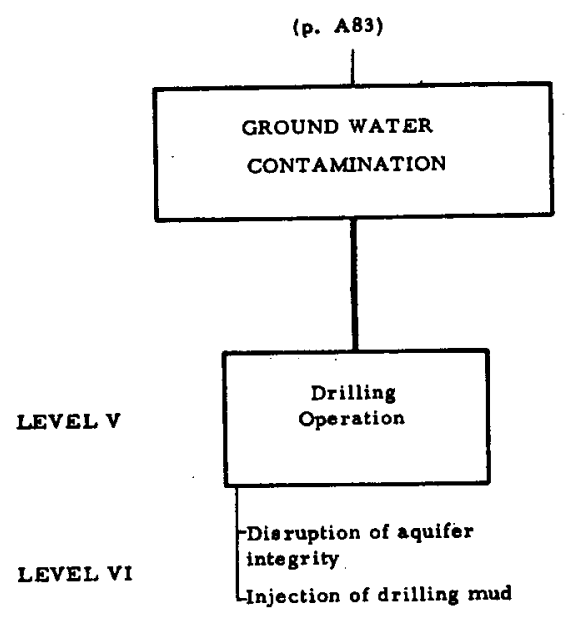

A84

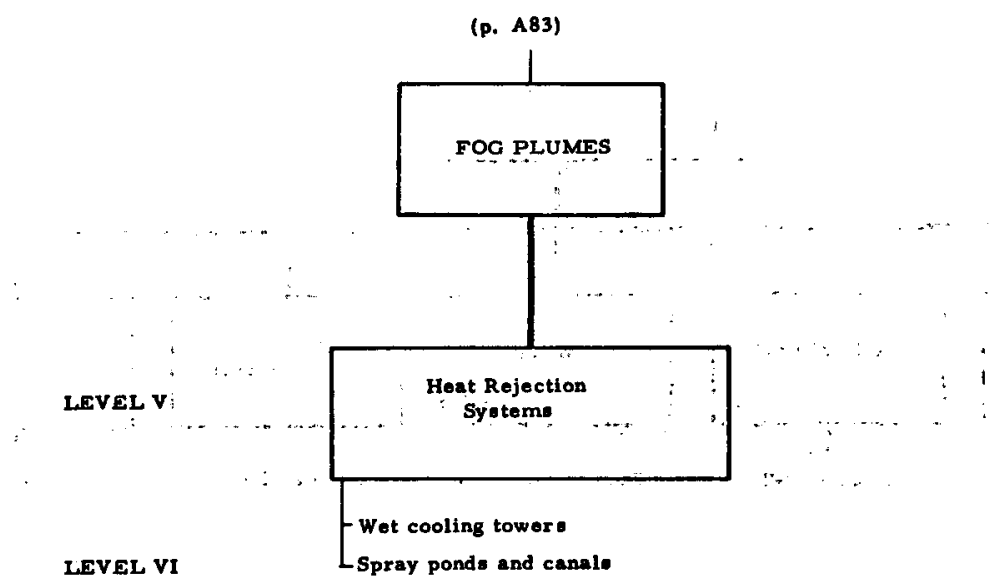

A85 
2. THE ENERGY RELEVENCE TREE

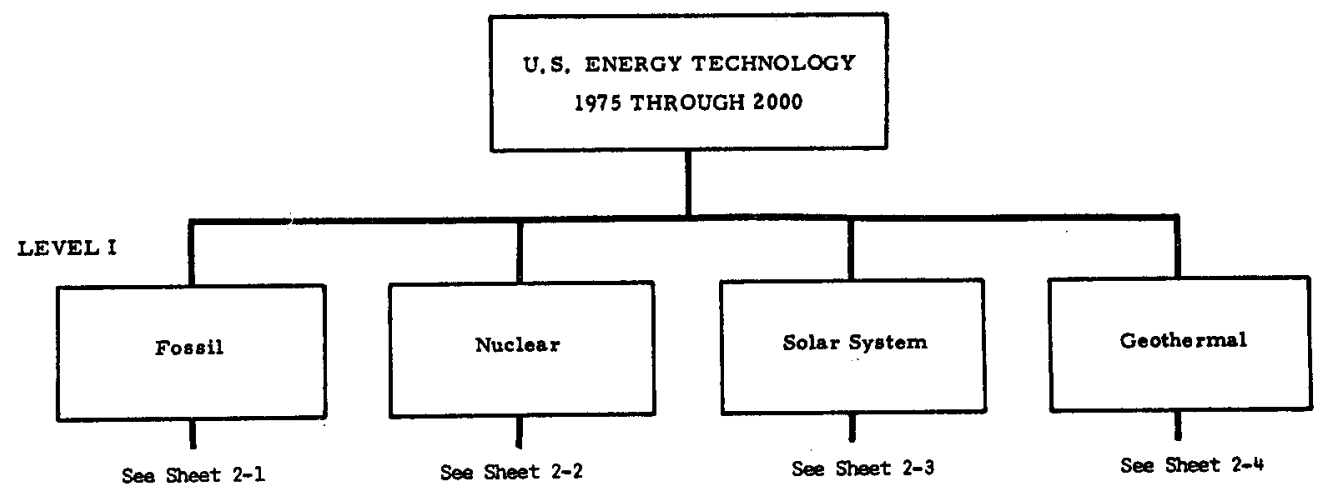

SFIEET 1

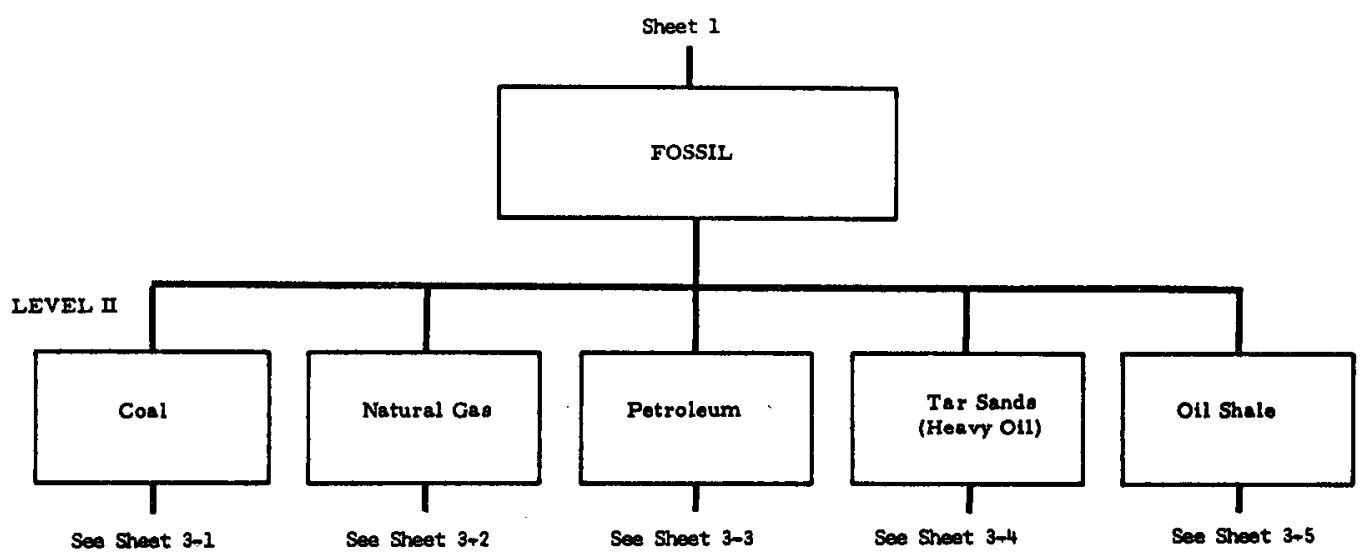

SHEET 2-1 


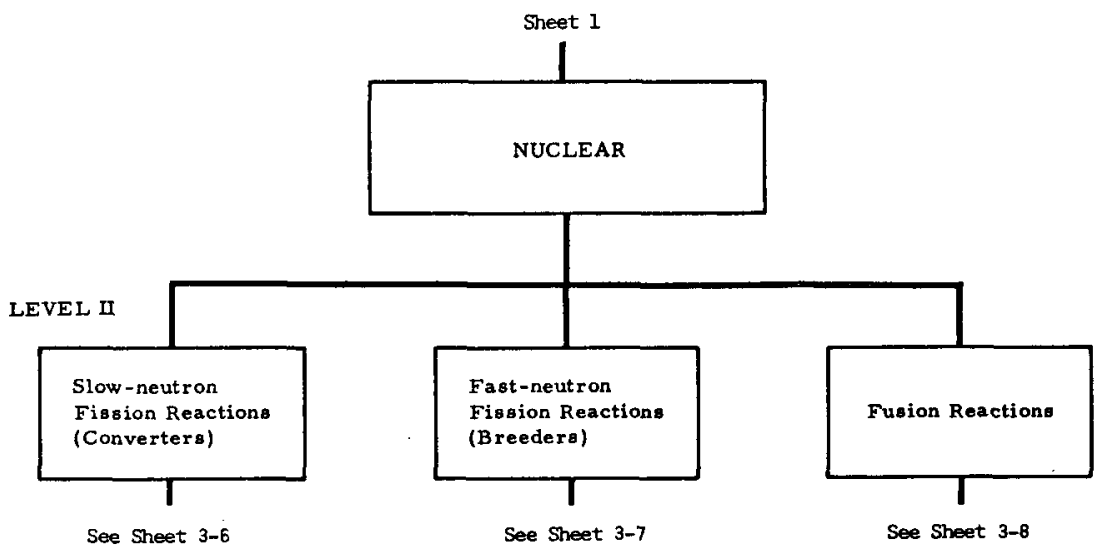

SHIET 2-2

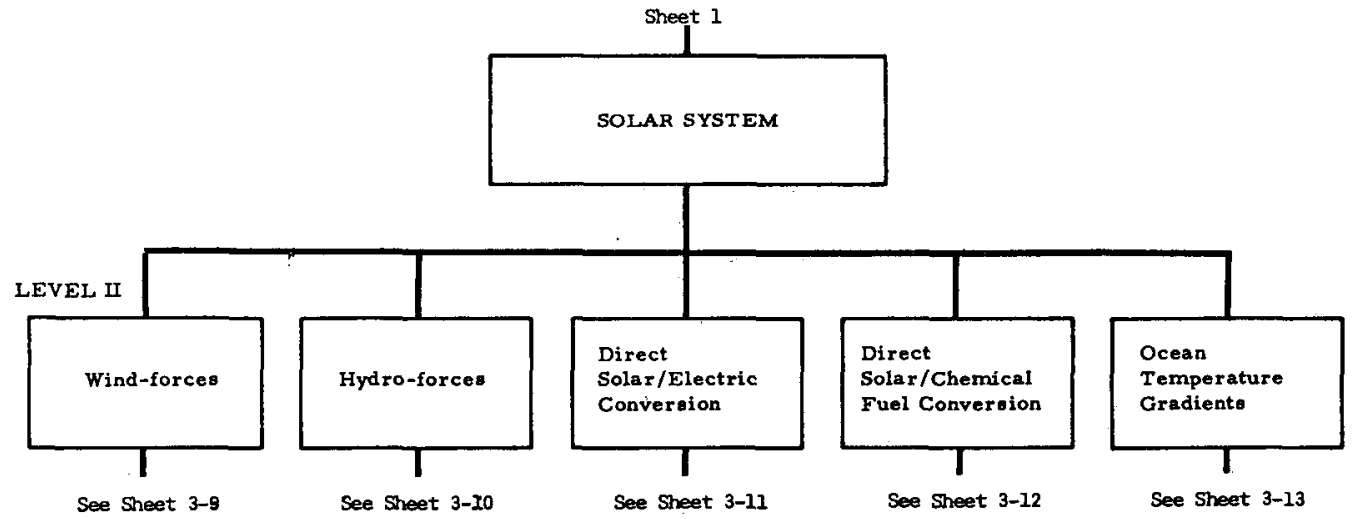

SHEET 2-3 
GEOTHERMAL ENERGY TECHNOLOGY TREE

(5hown at the beginning of Appendix B.)

SHEET 2-4

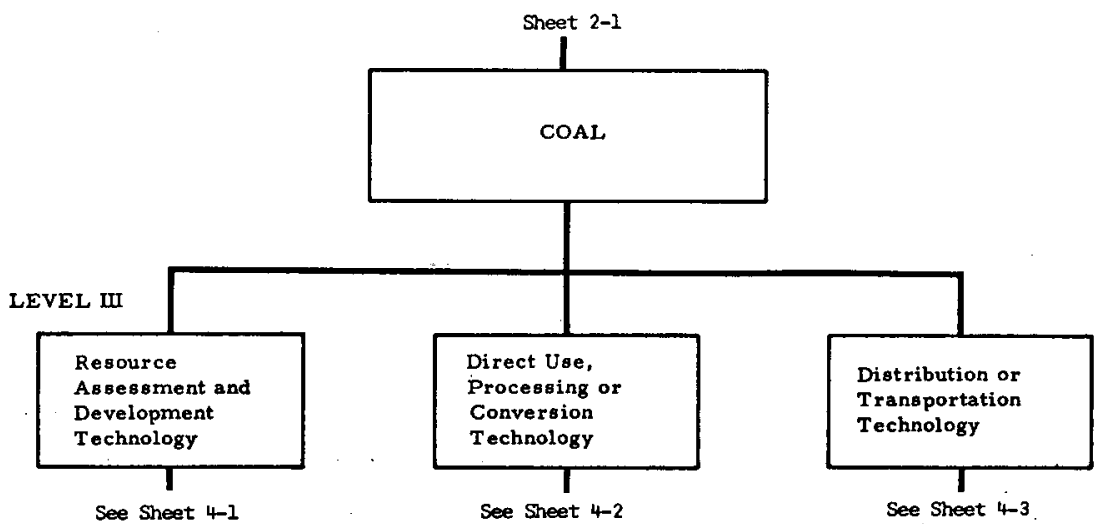

SHEET 3-1 


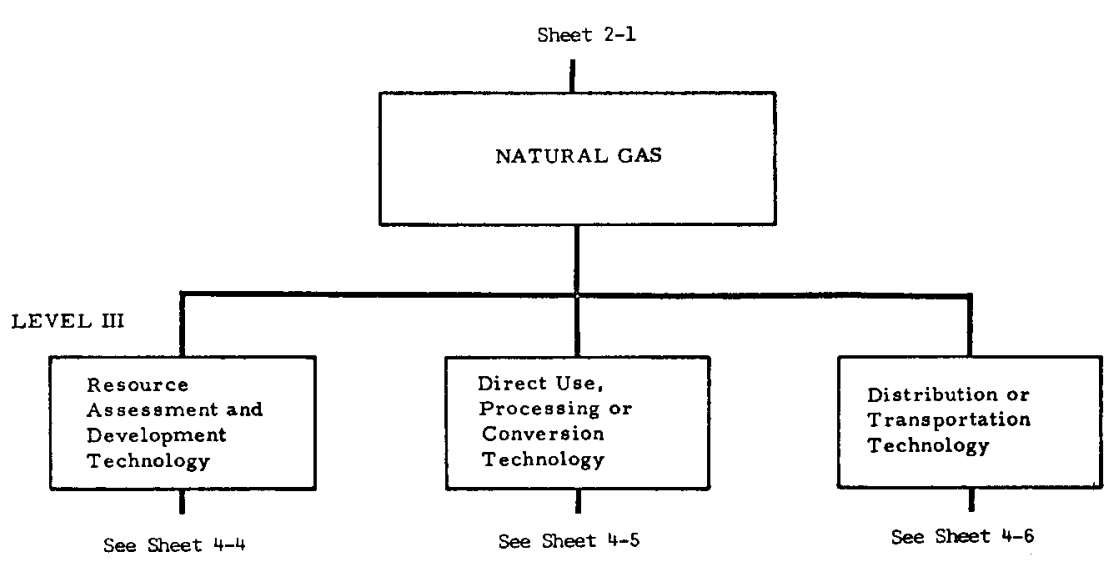

SHEET 3-2

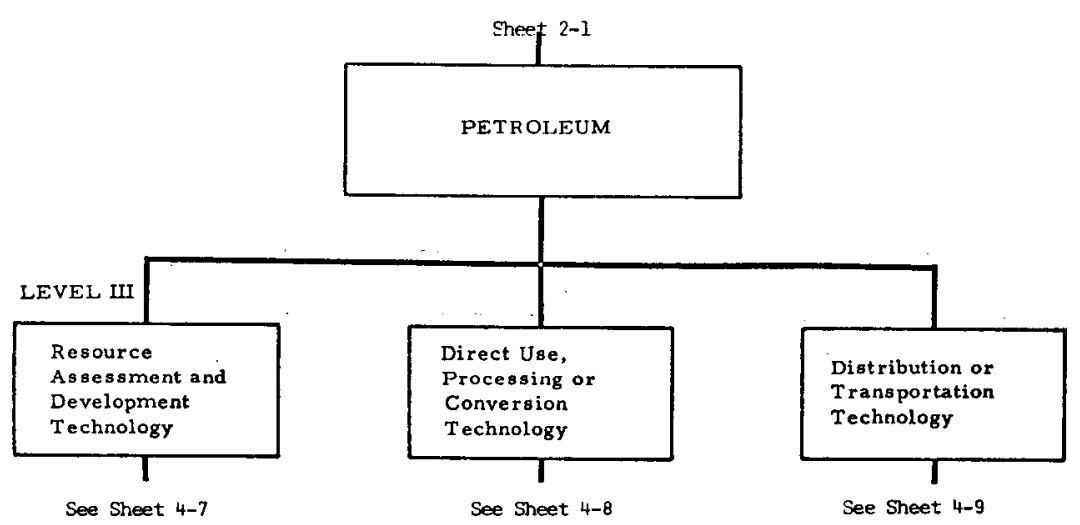

SHEET 3-3 


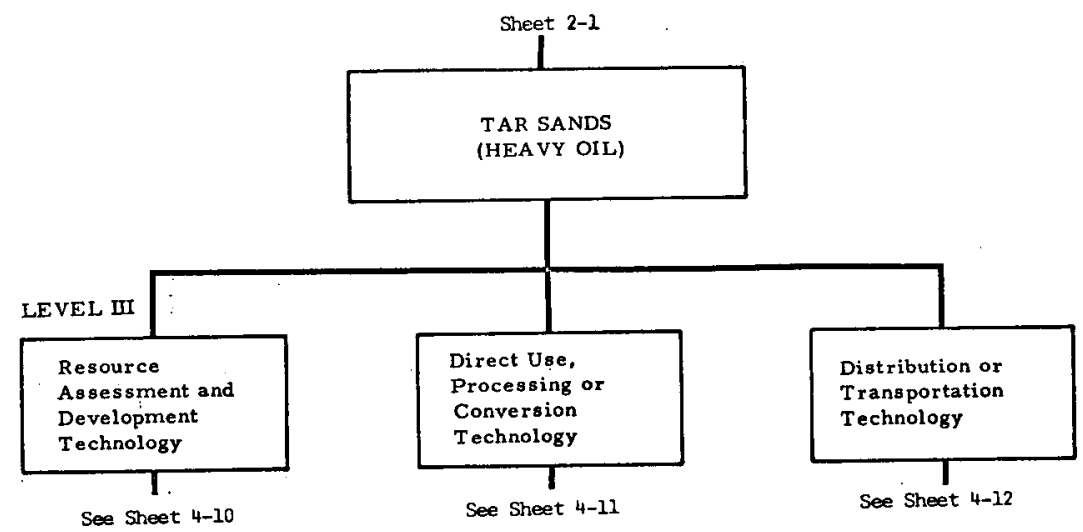

SHEET 3-4

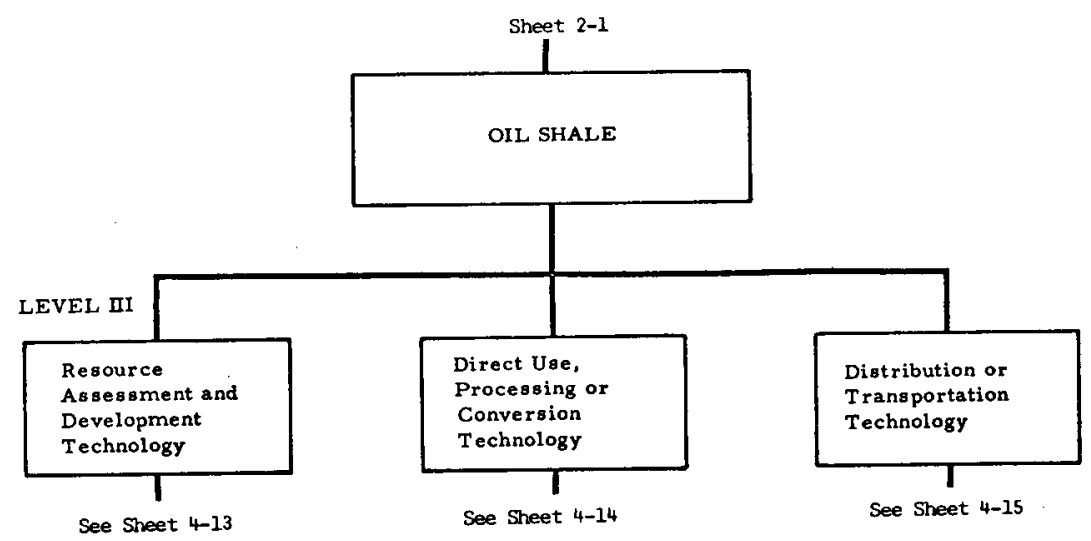

SHEET 3-5 


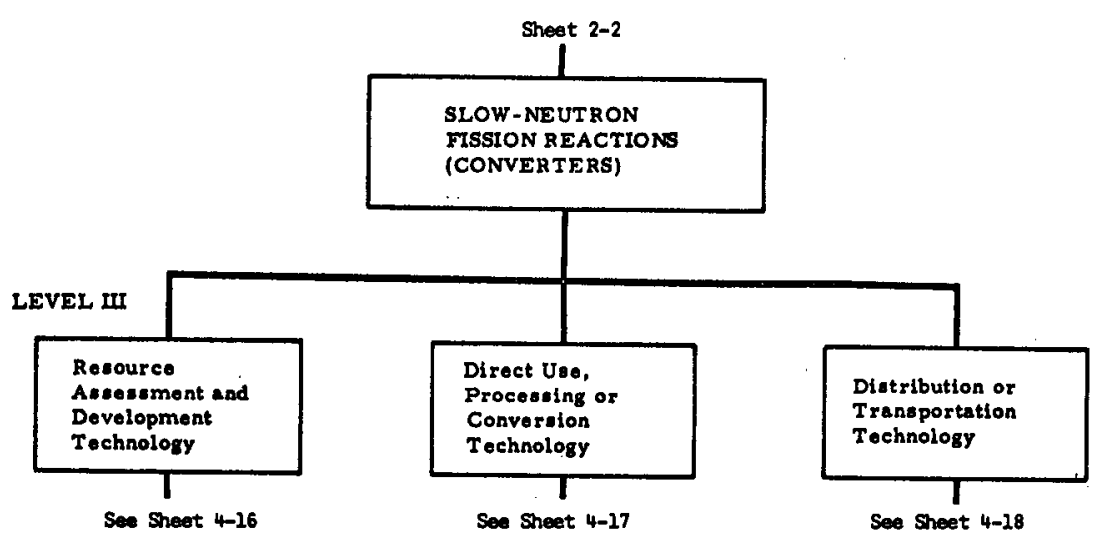

SHEET 3-6

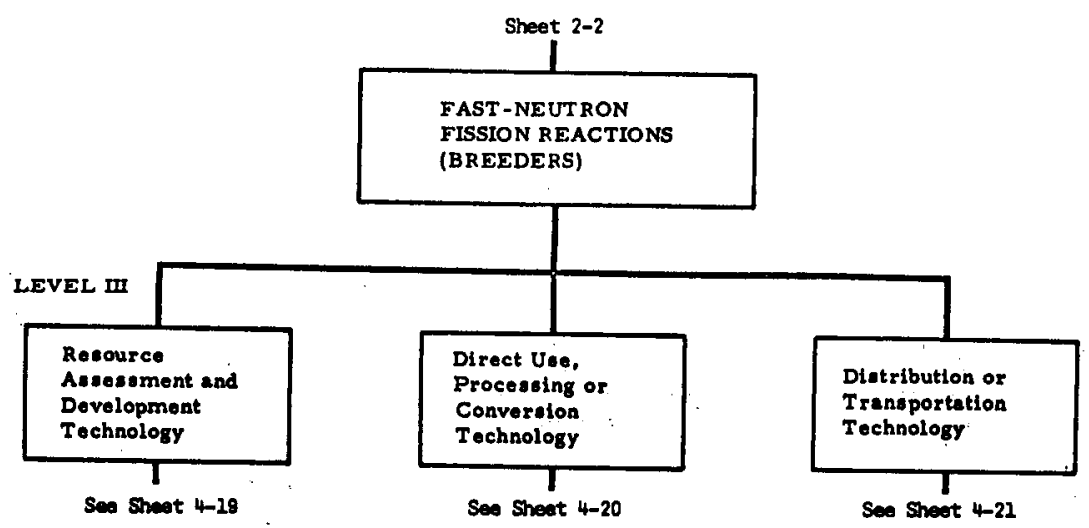

staxix 3-7 


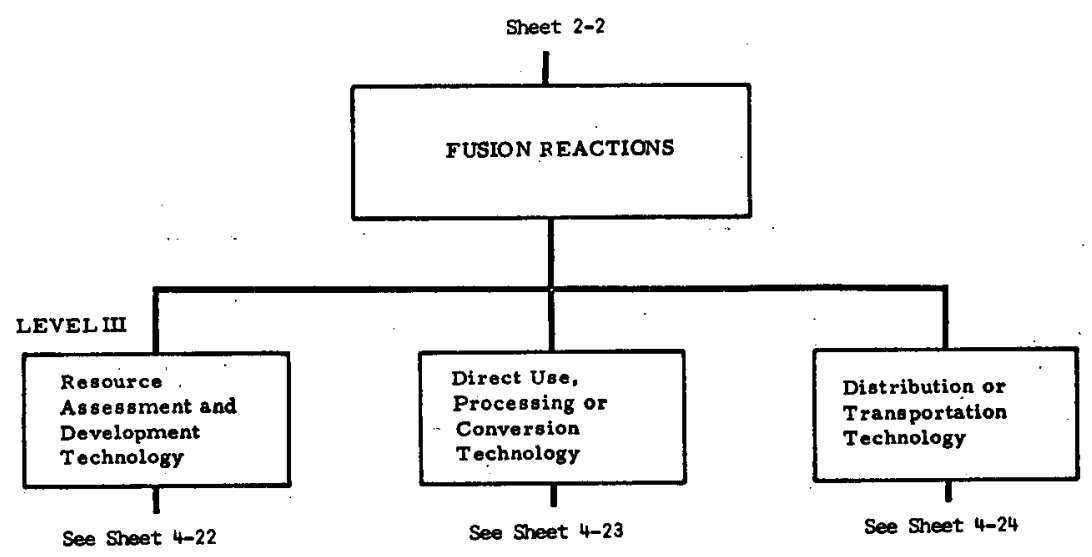

SHEES 3-8

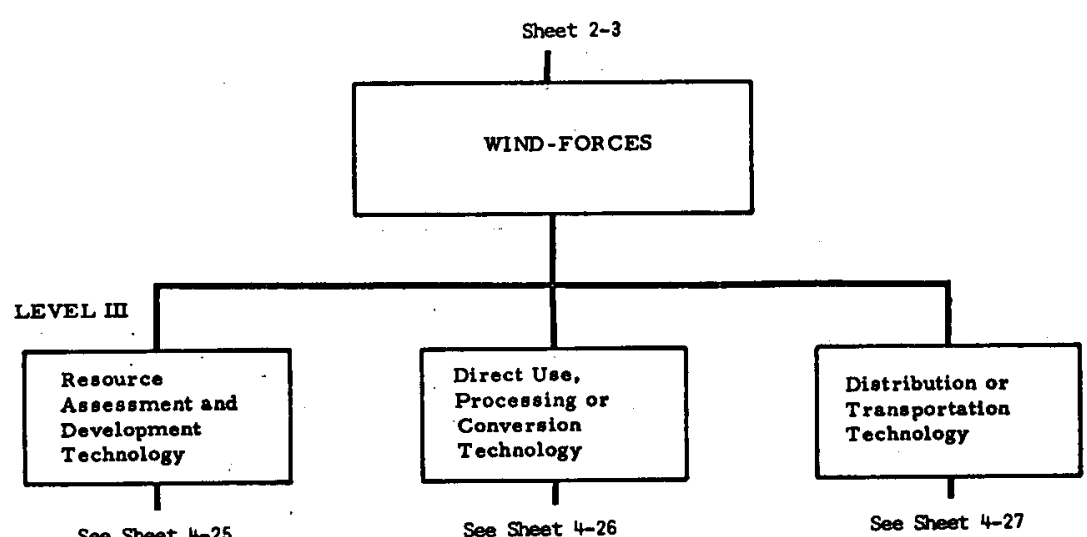

SHEET 3-9 


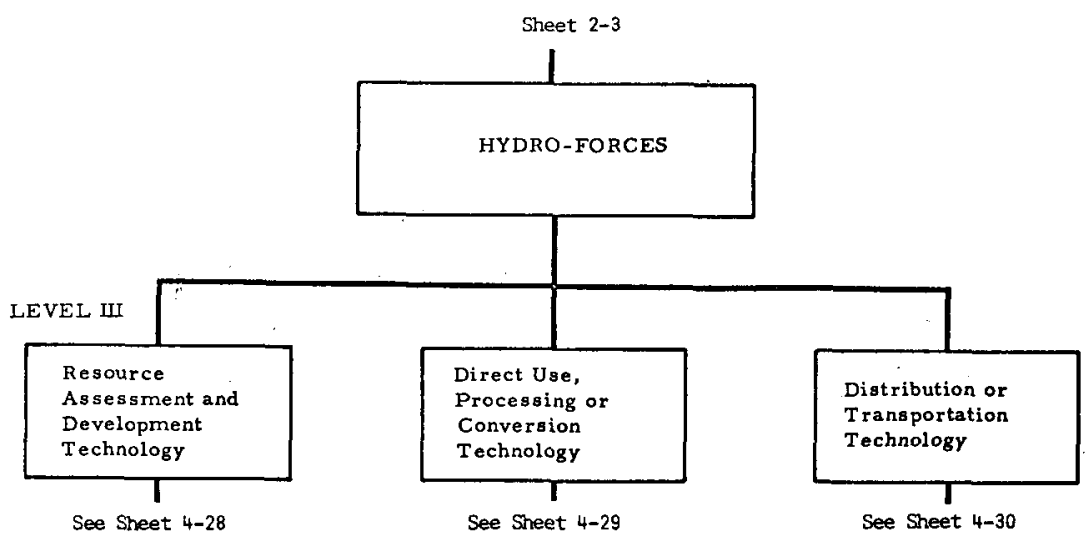

SHEET $3-10$

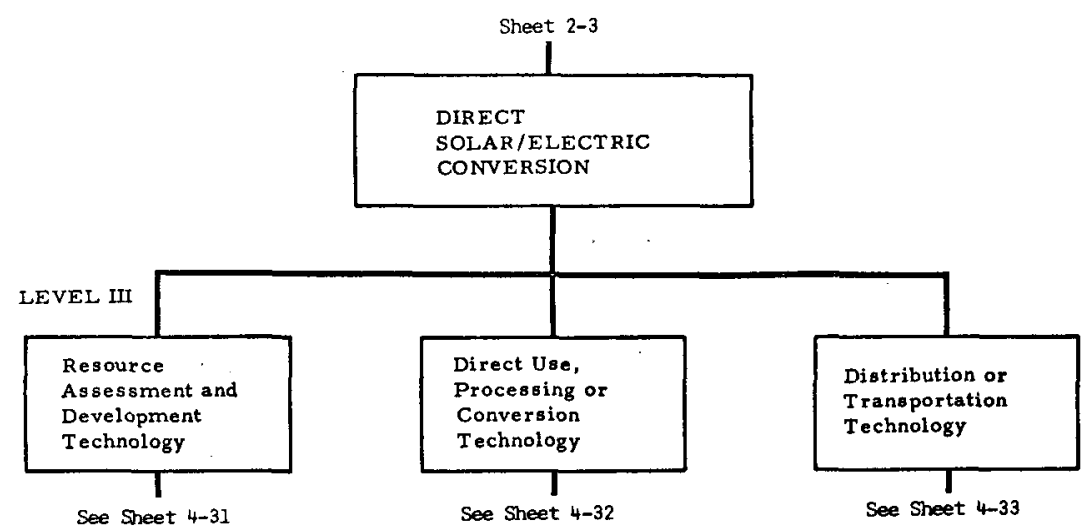

SHEET 3-11 


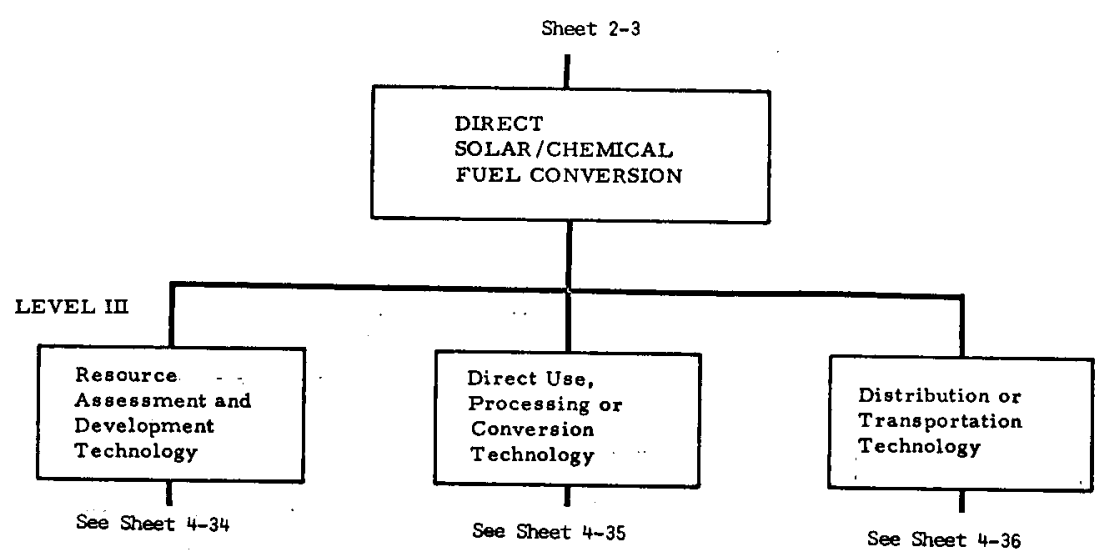

SHEET 3-12

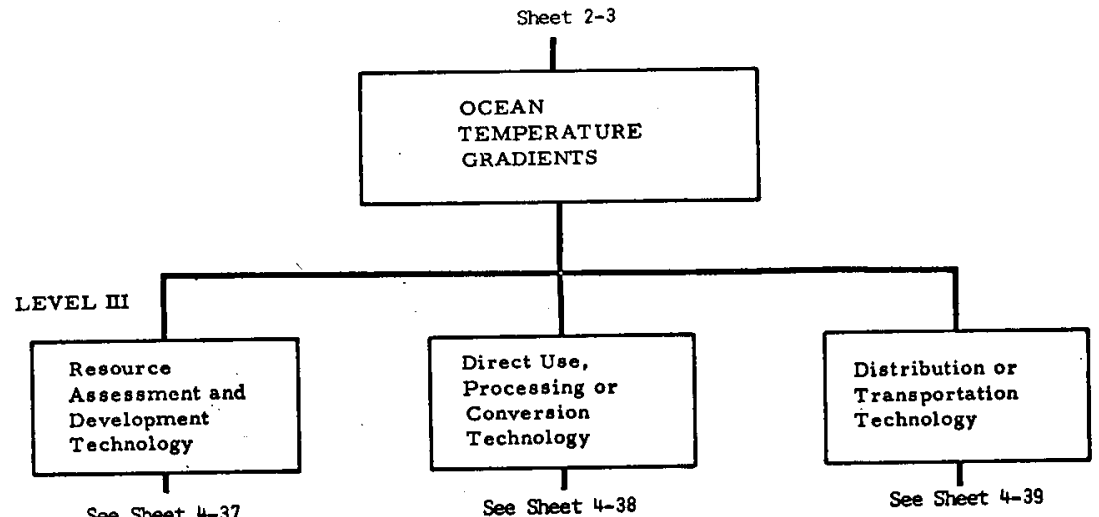

Sheet 3-13 


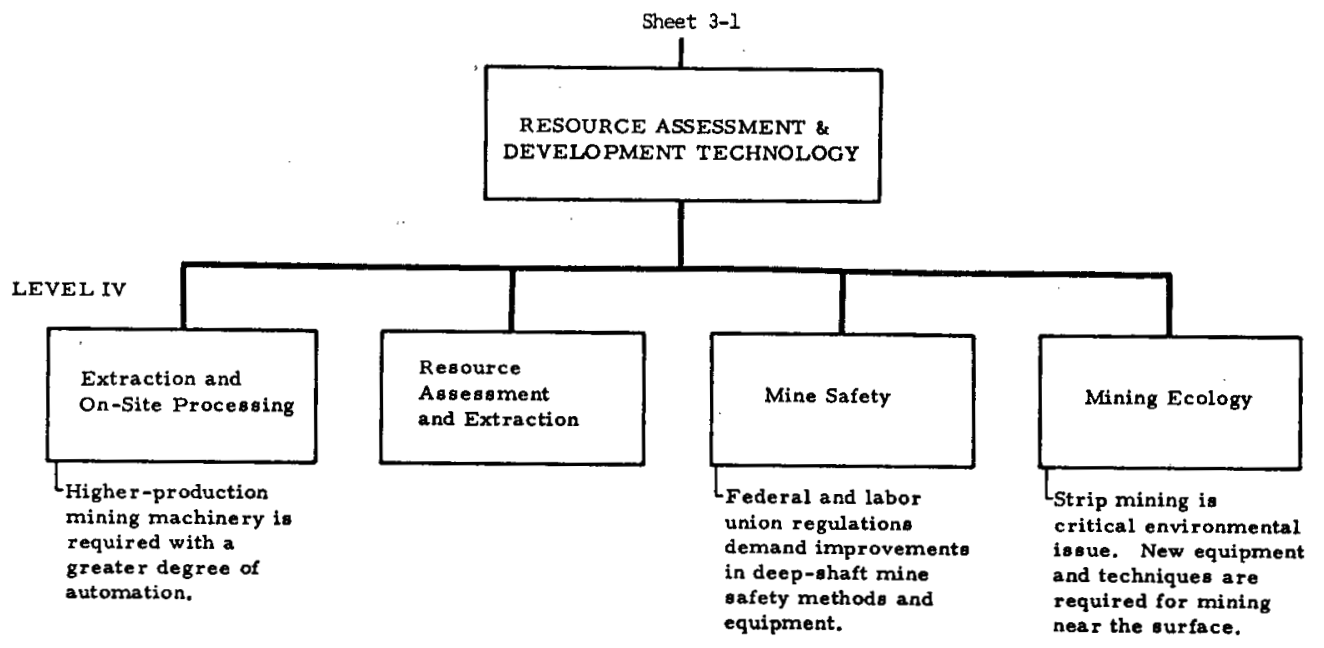

SHEET 4-1

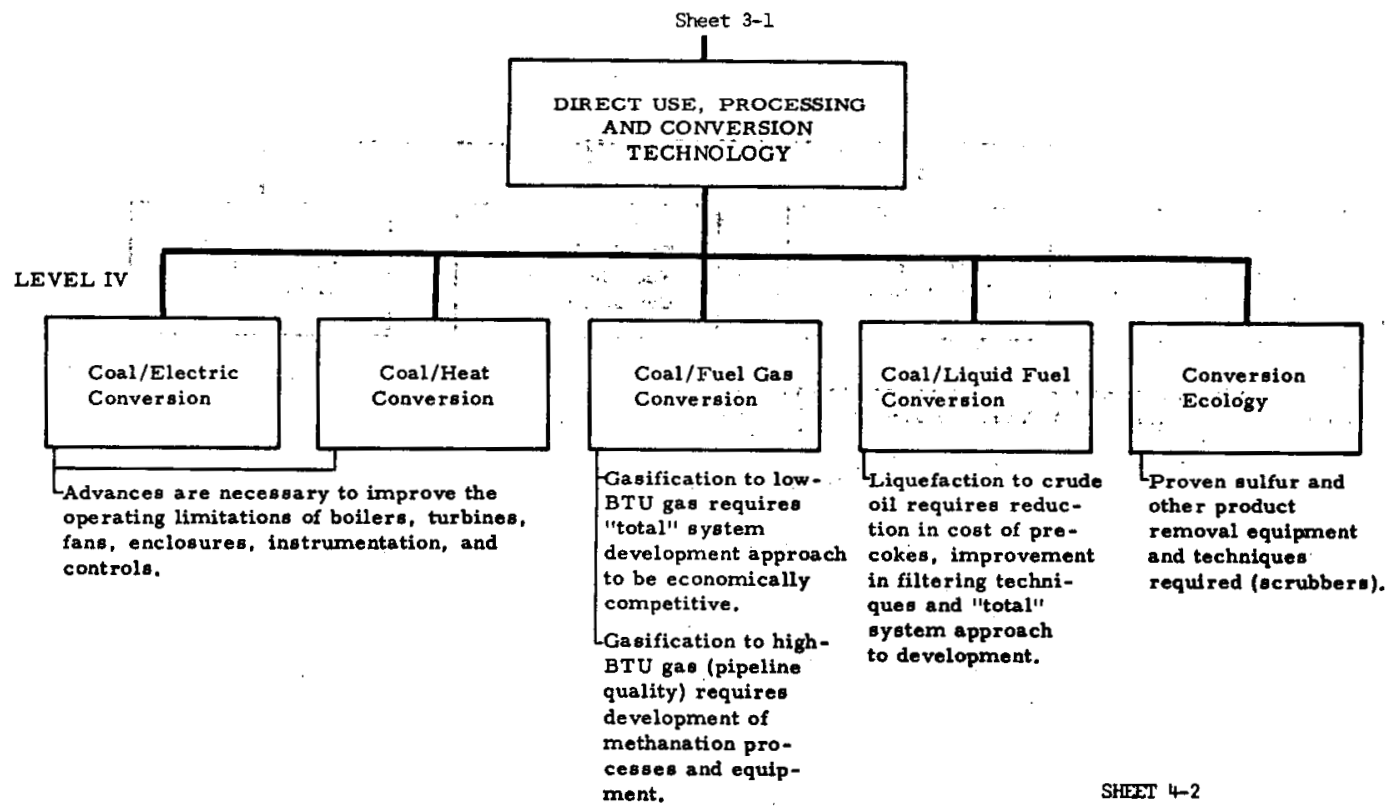




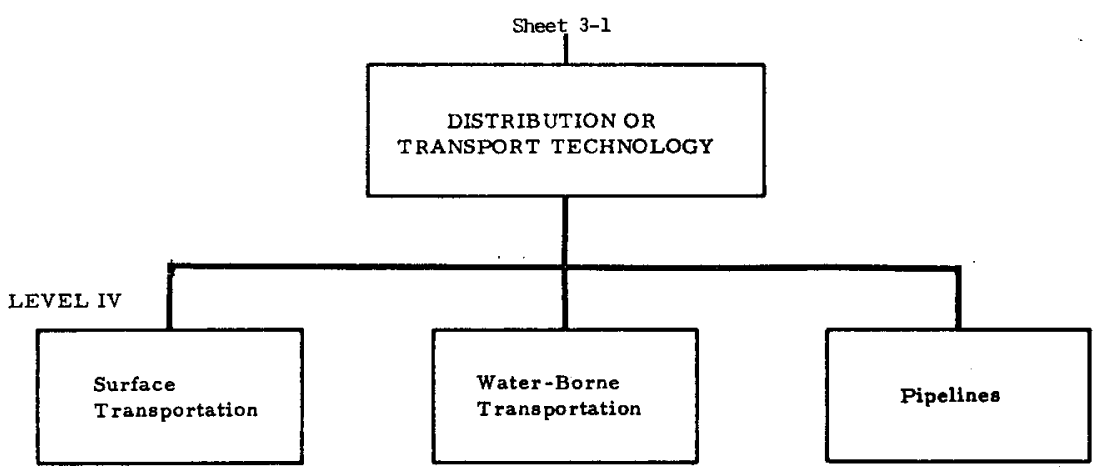

SHEET 4-3

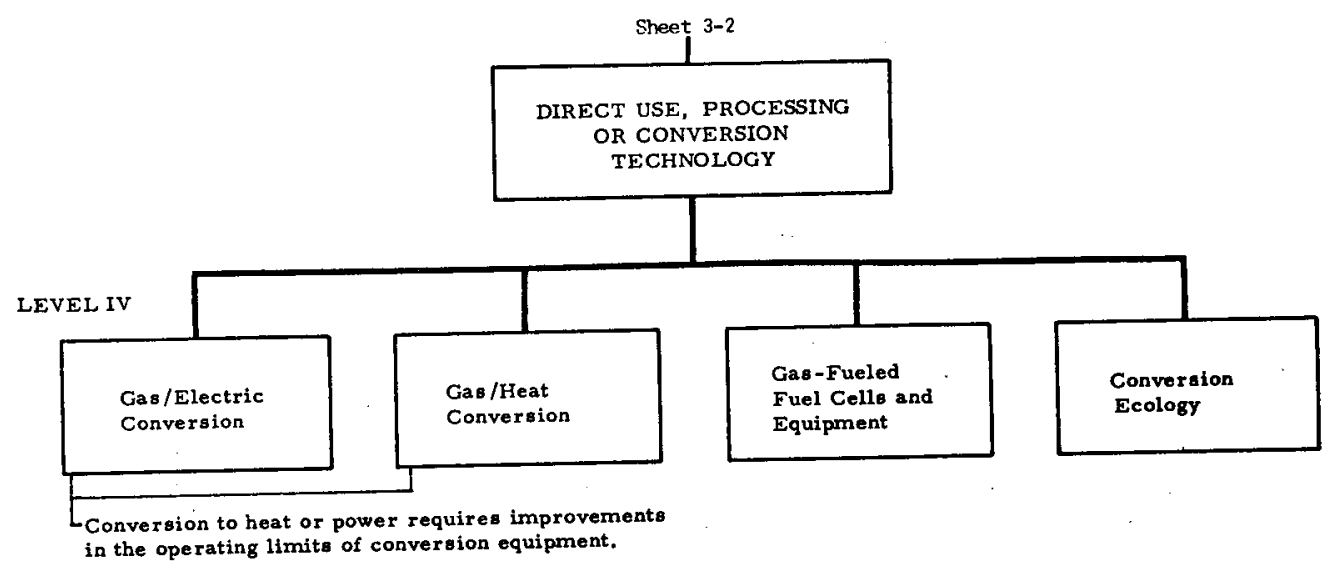

SHEET 4-5 


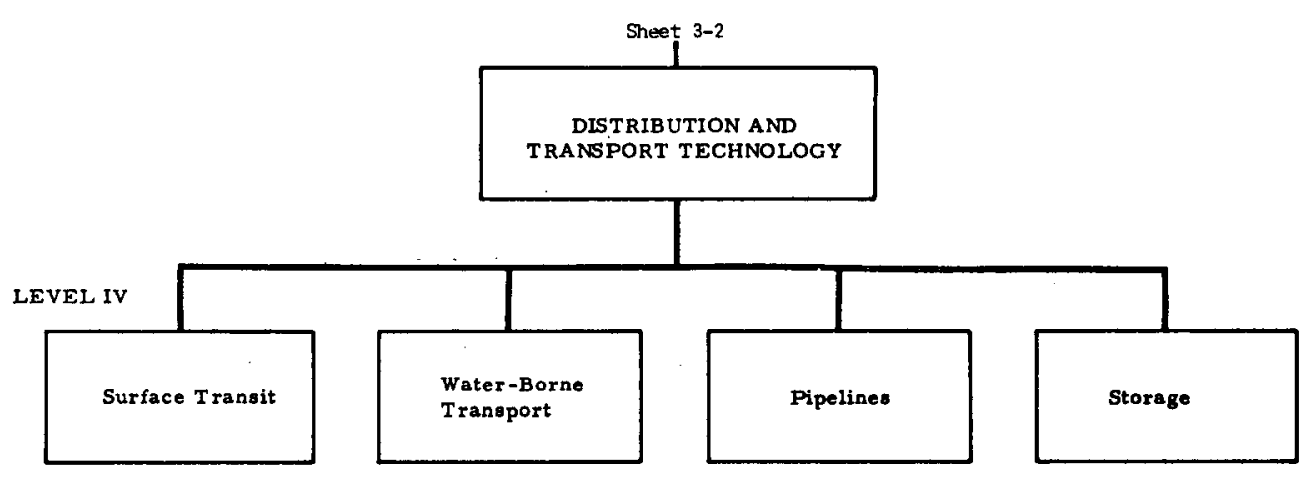

SHEET 4-6

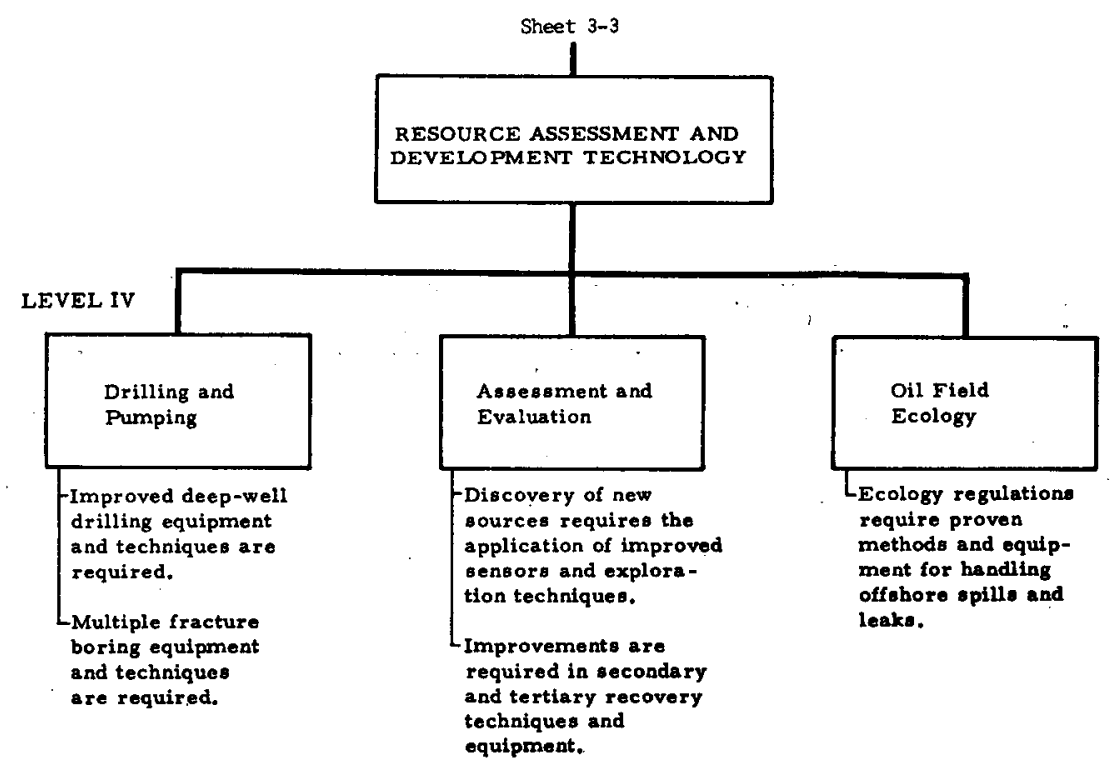

SHEसT 4-7 


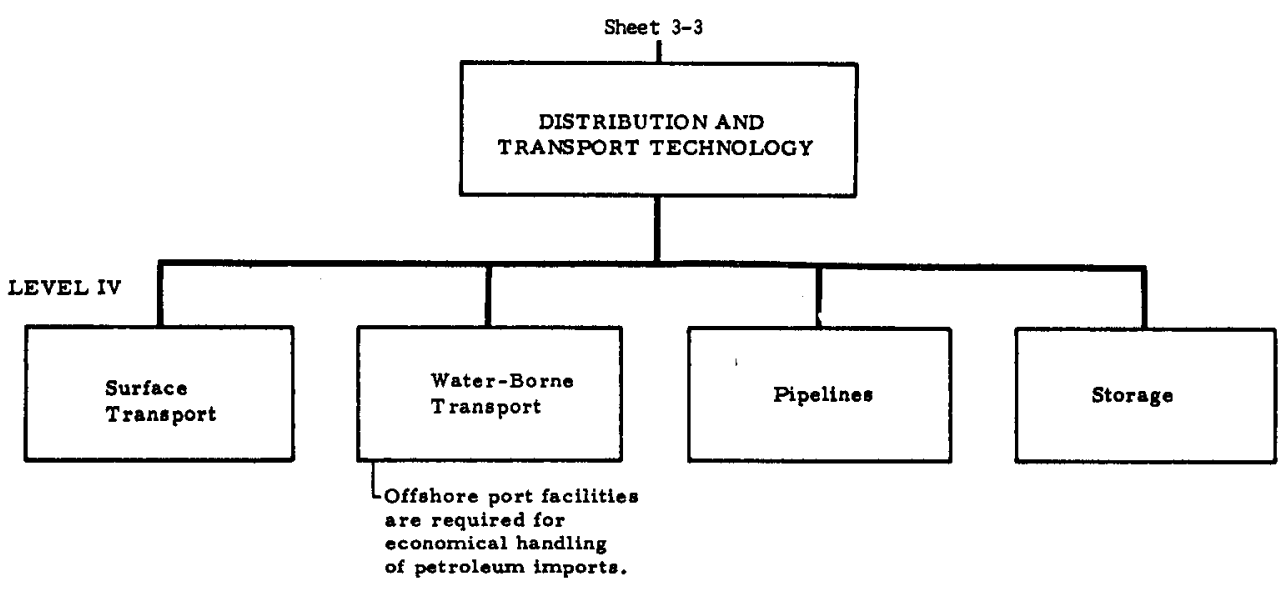

SHEET 4-8

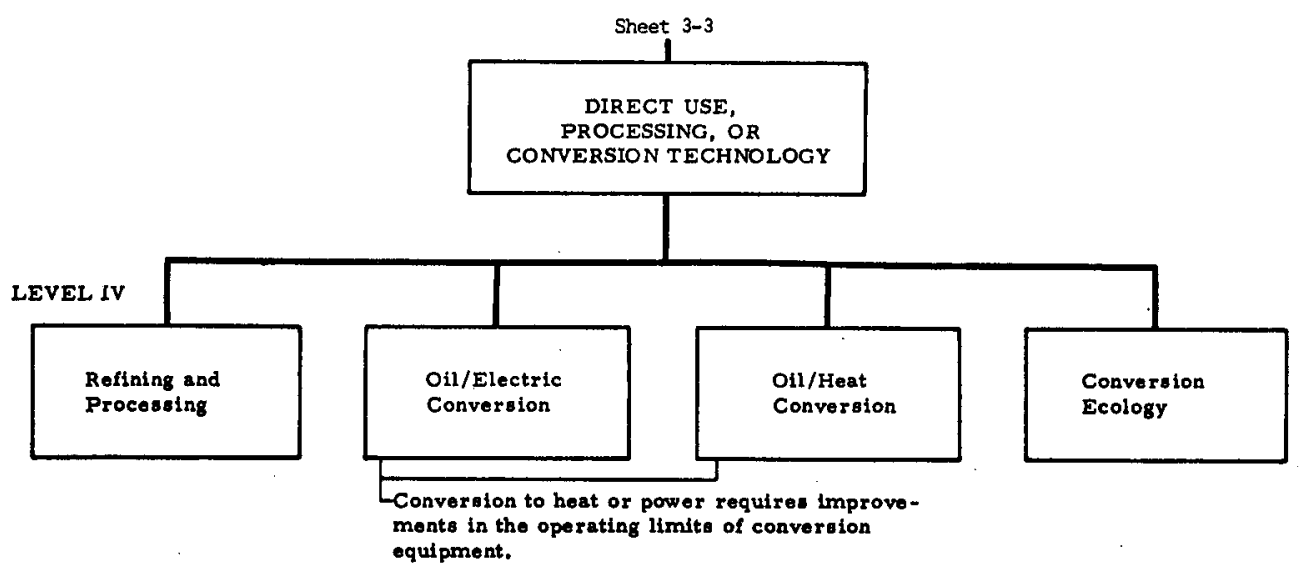

SHEET 4-8 


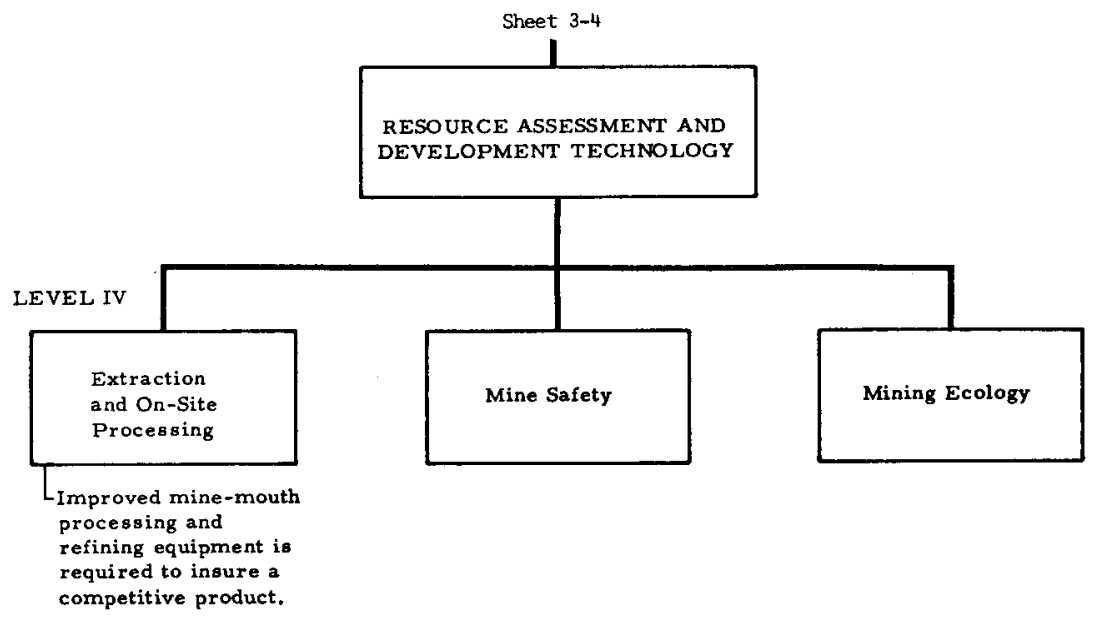

SHEET 4-10

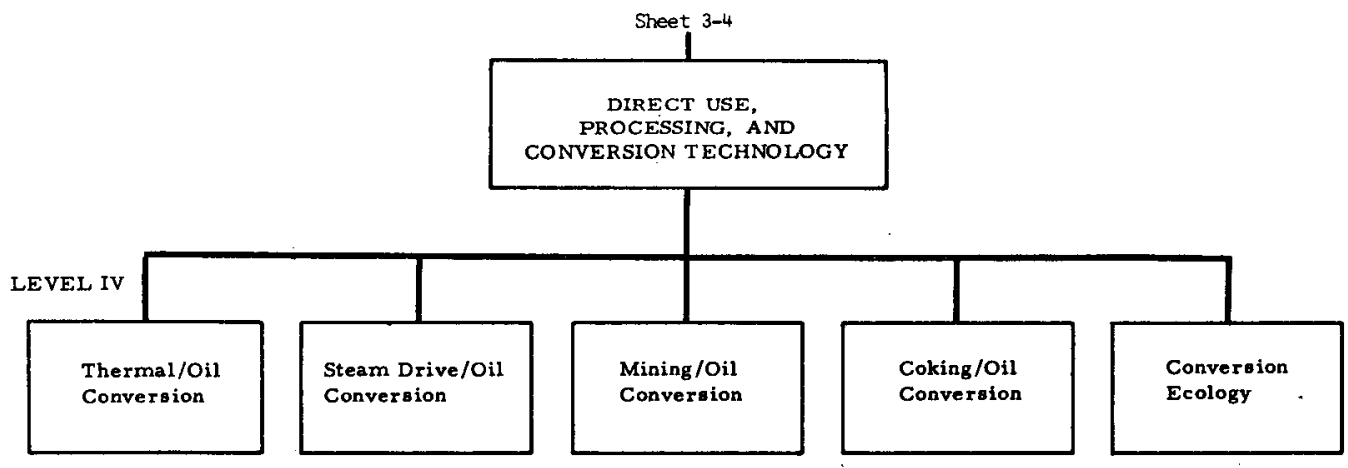

SHEET 4-11 


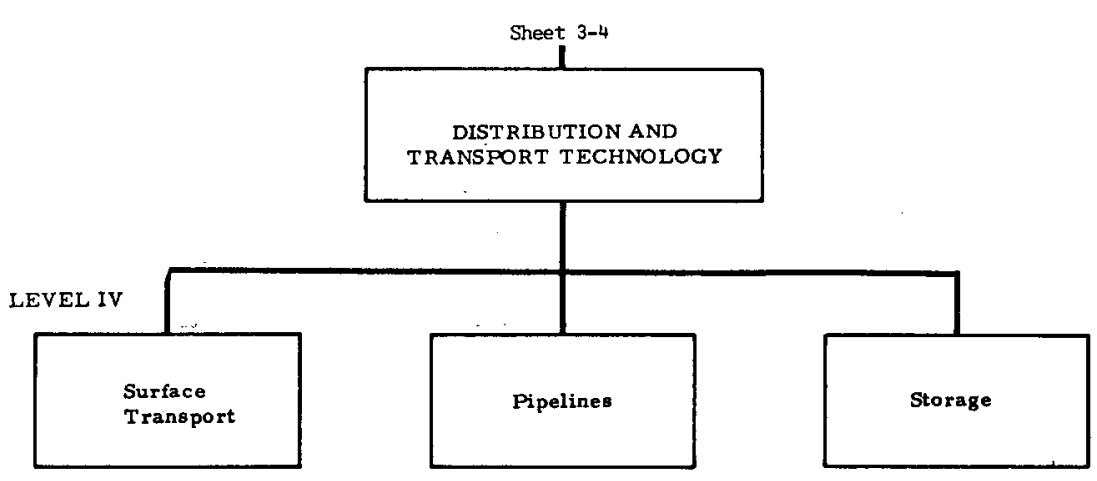

SHIEET 4-12

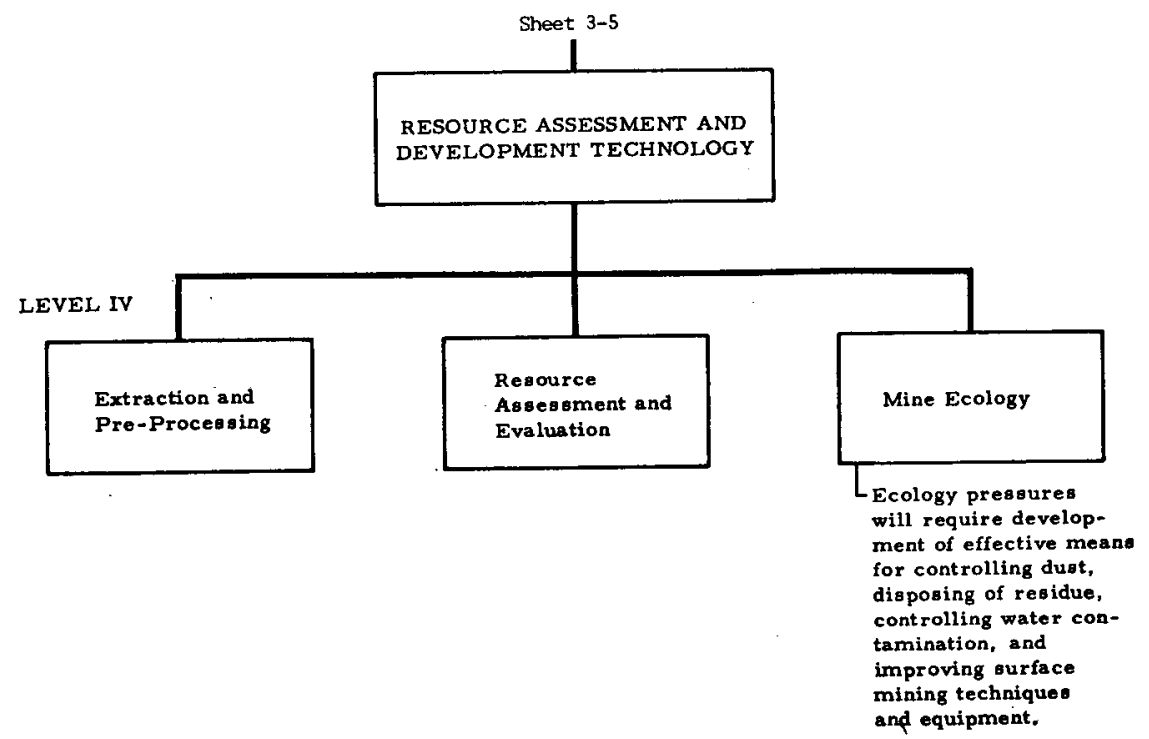

SHEET 4-13 


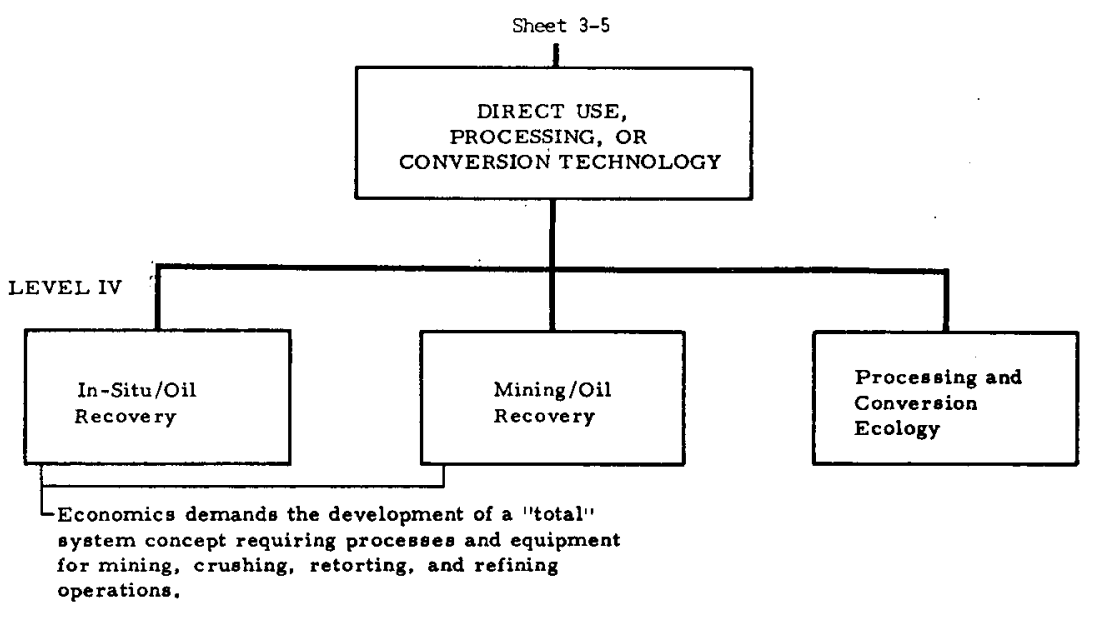

SHEET 4-14

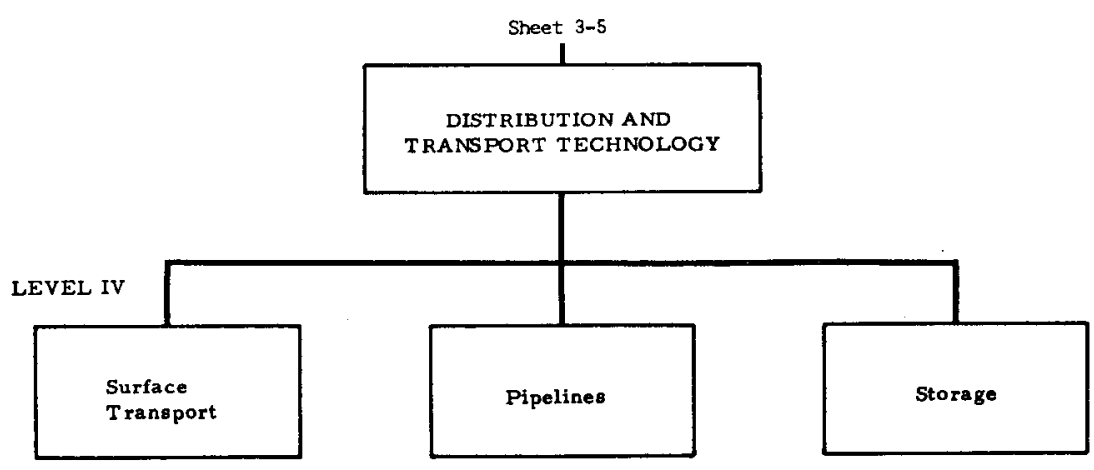

SHEET 4-15 


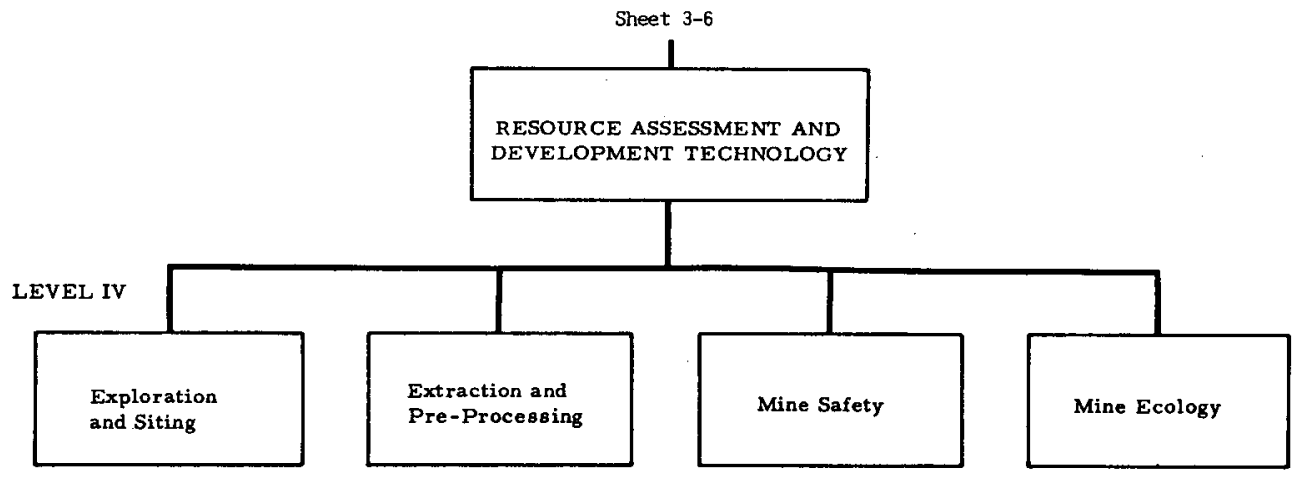

SHEET 4-16

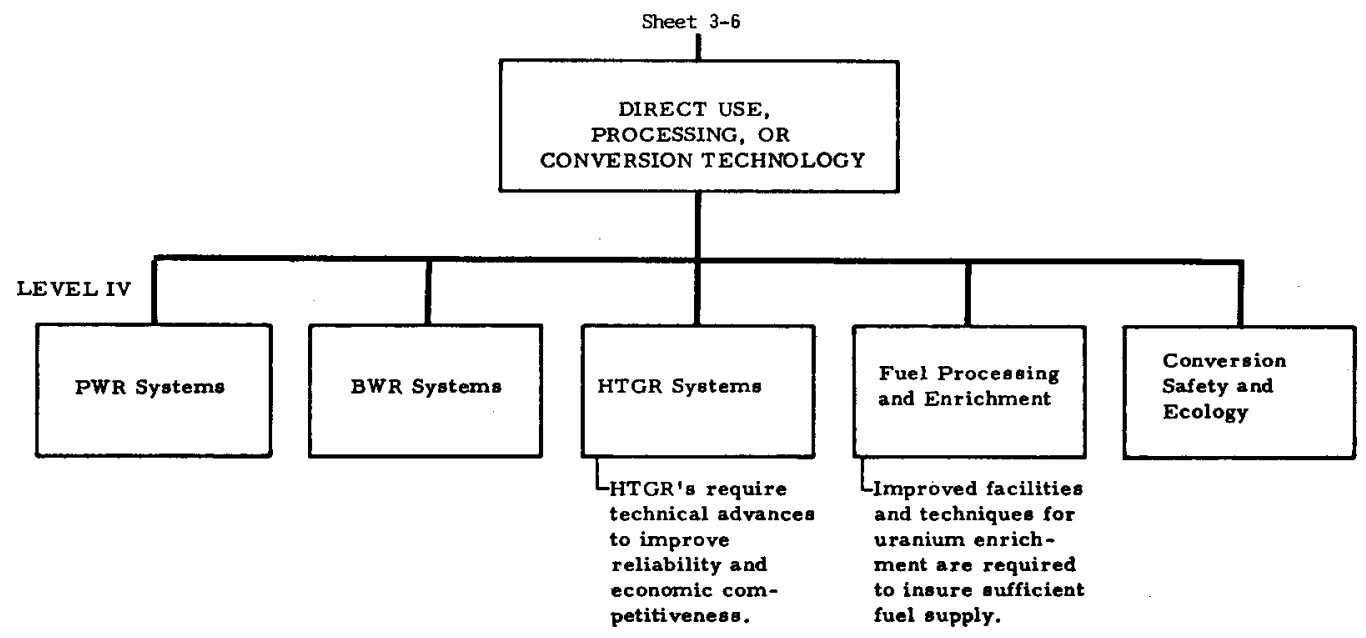

SHaET 4-17 


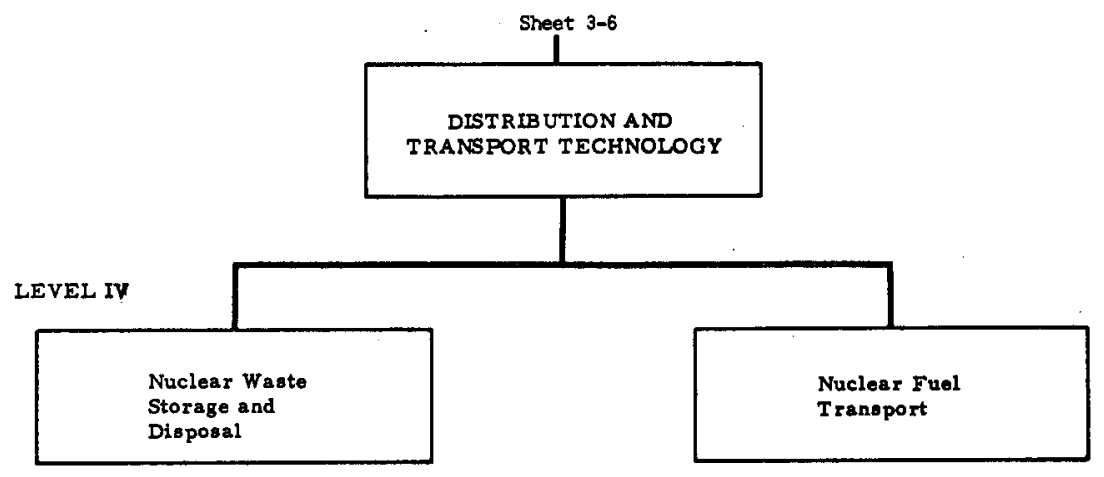

SHIXIT 4-18

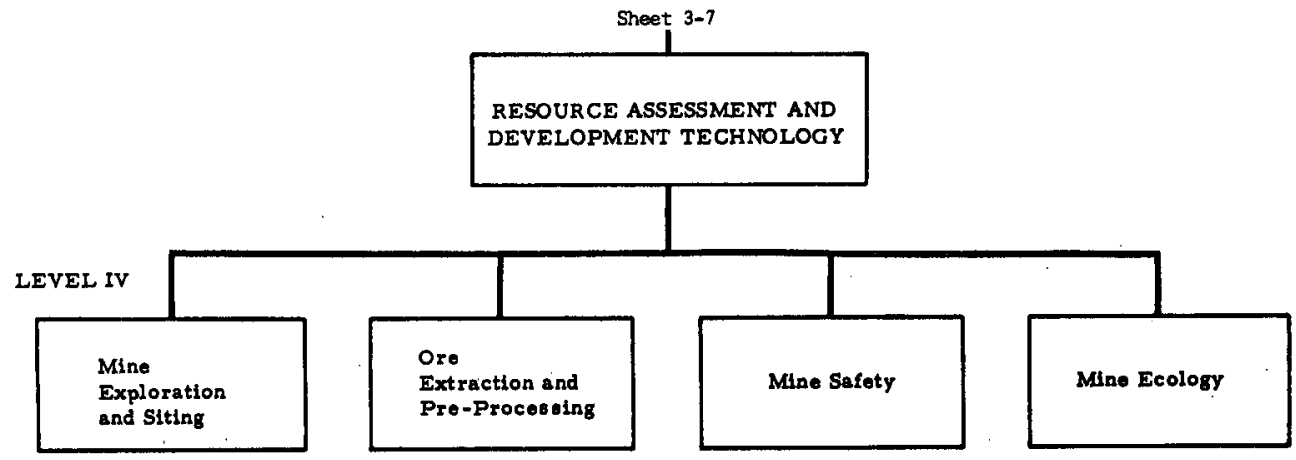

StI2XT 4-19 


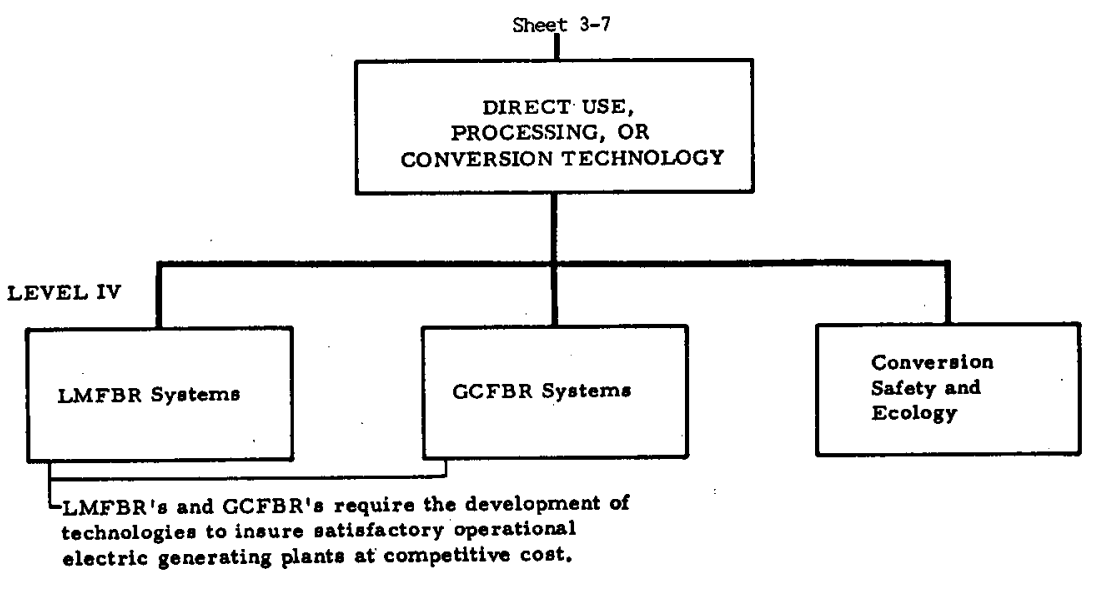

SFEXT 4-20

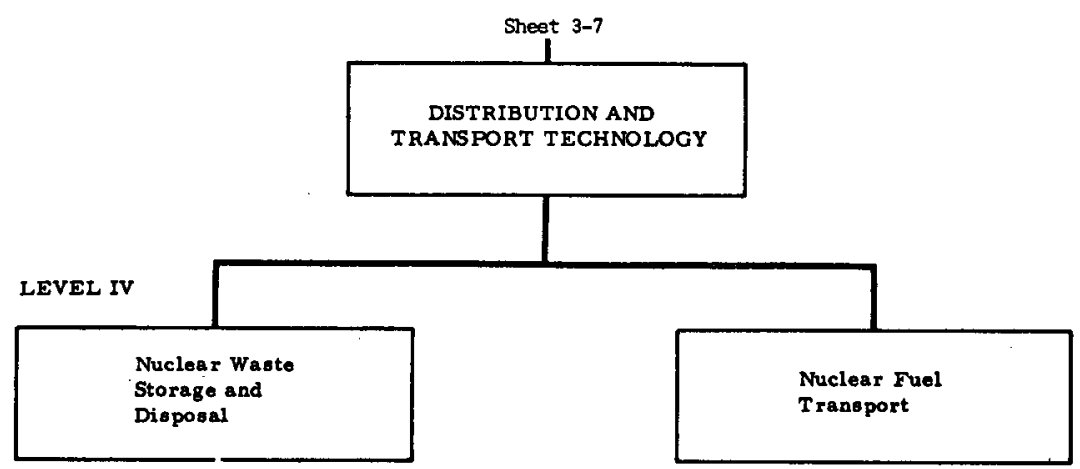

SHFET 4-2I 


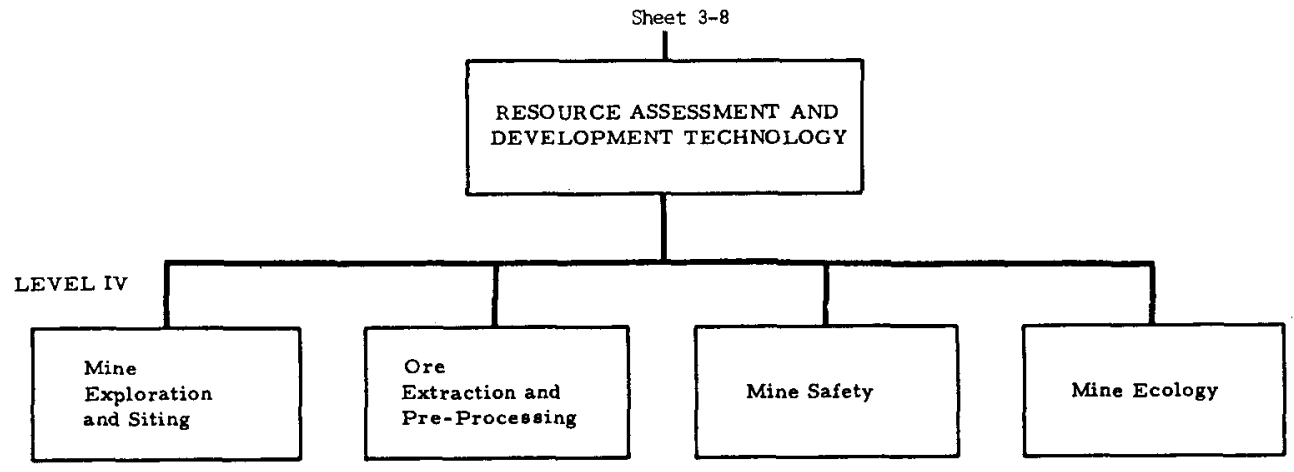

SHEET $4-22$

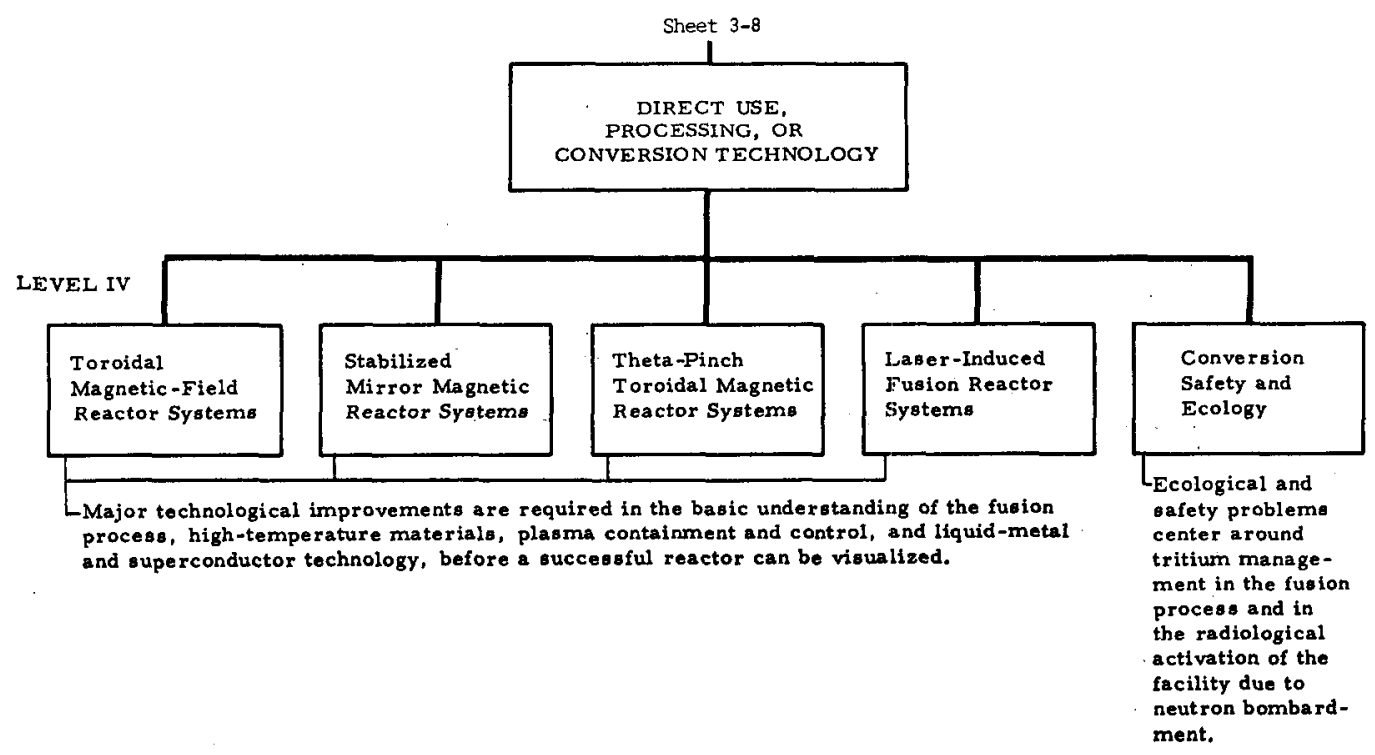

SHEET 4-23 


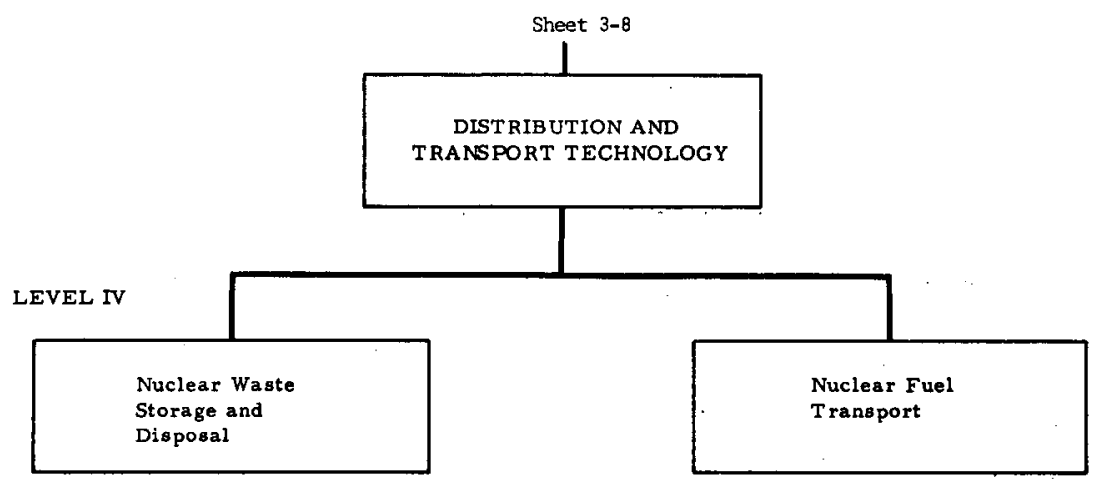

SHEET 4-24

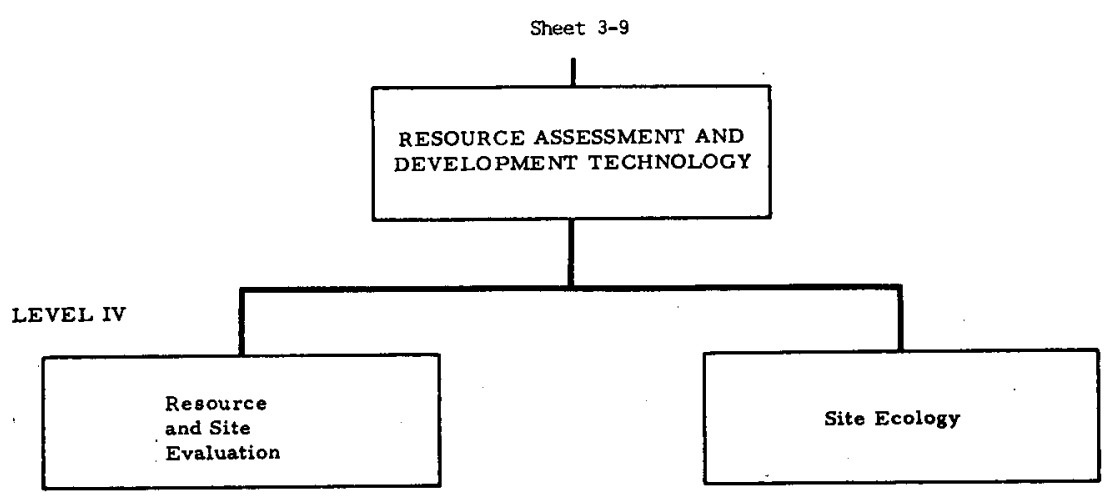

SHEET 4-25 


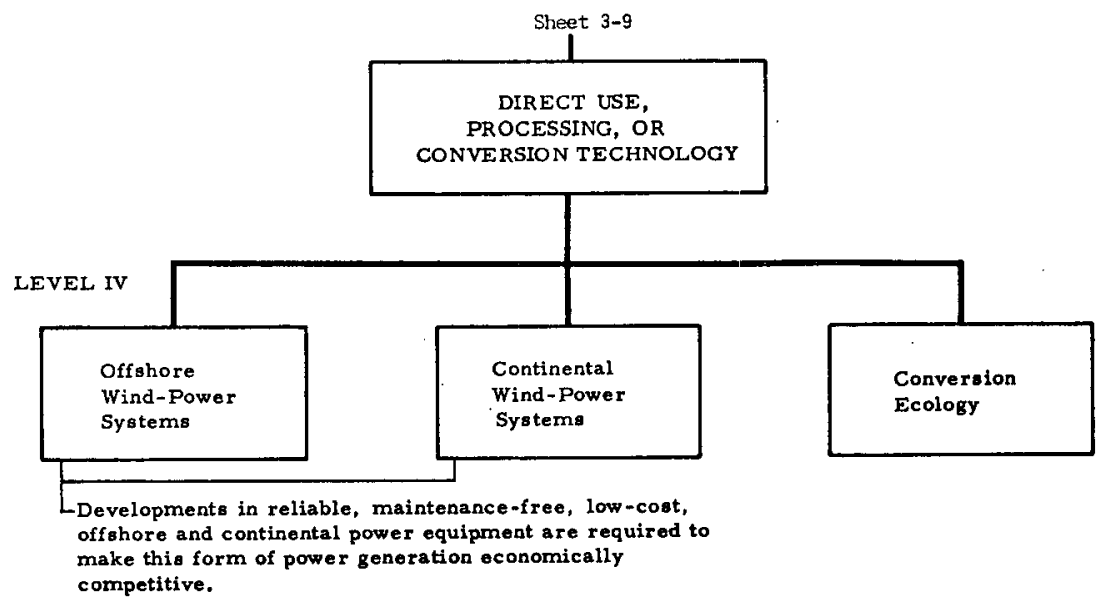

SHEET $4-26$

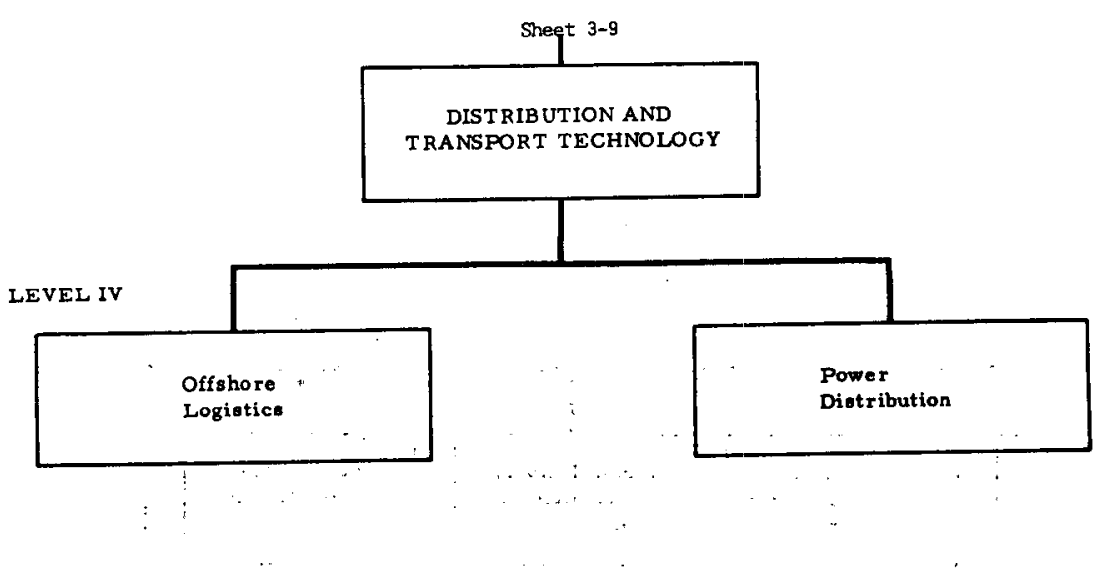

SHEET $4-27$ 


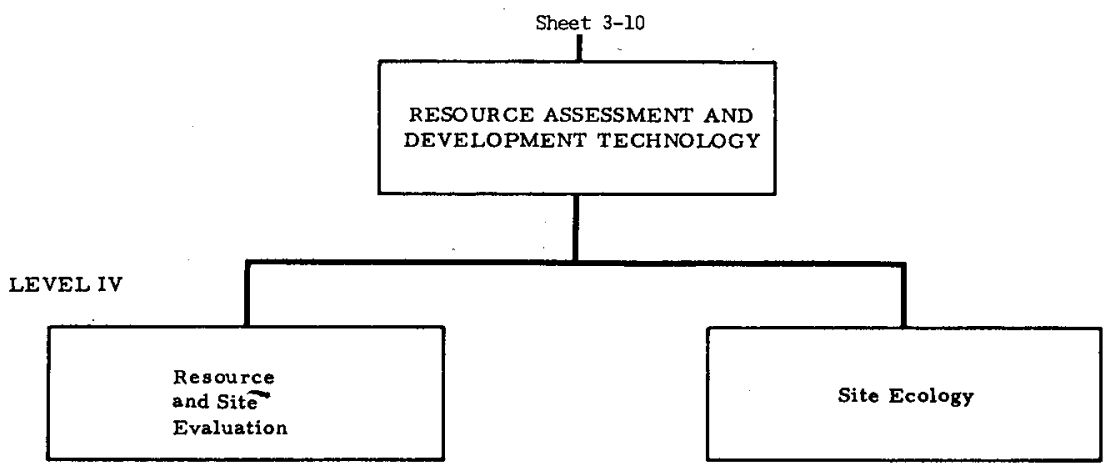

SHEET 4-28

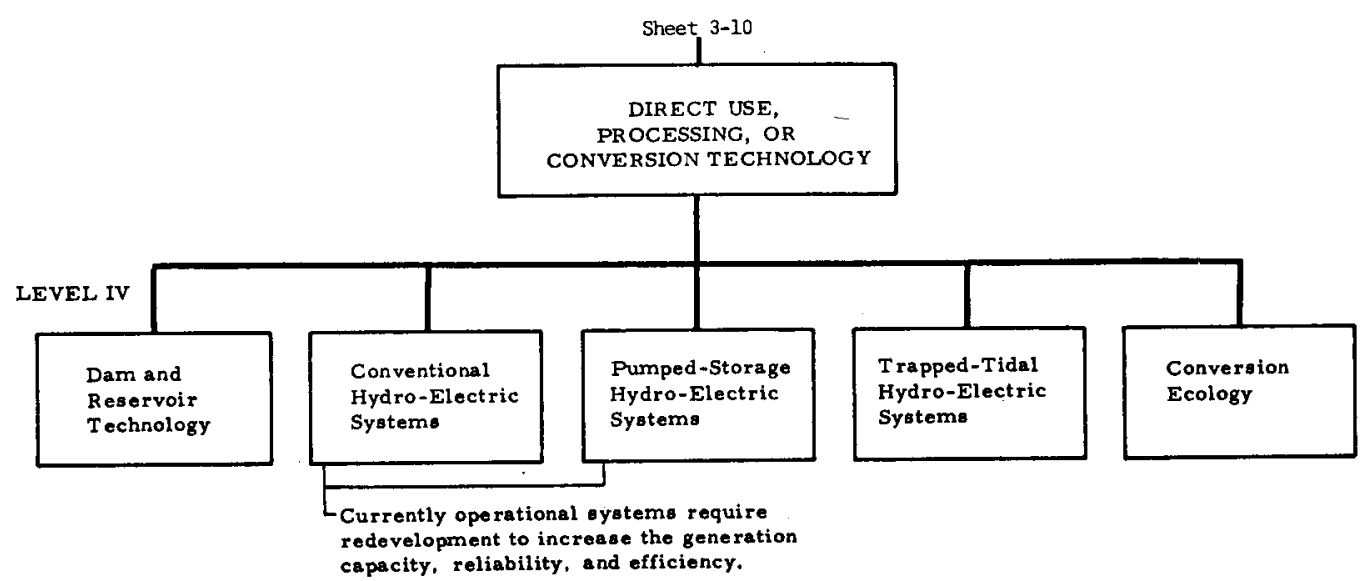

SHEET 4-29 


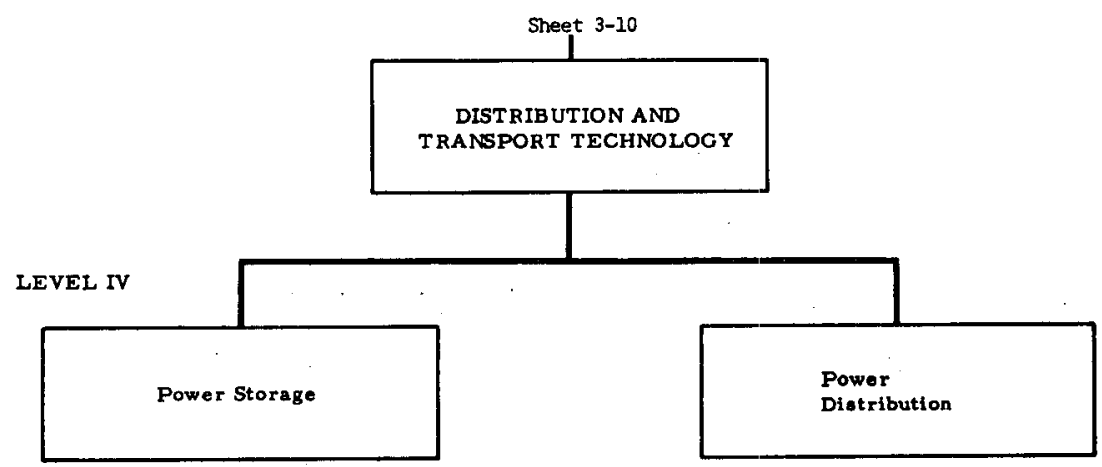

SHEET 4-30

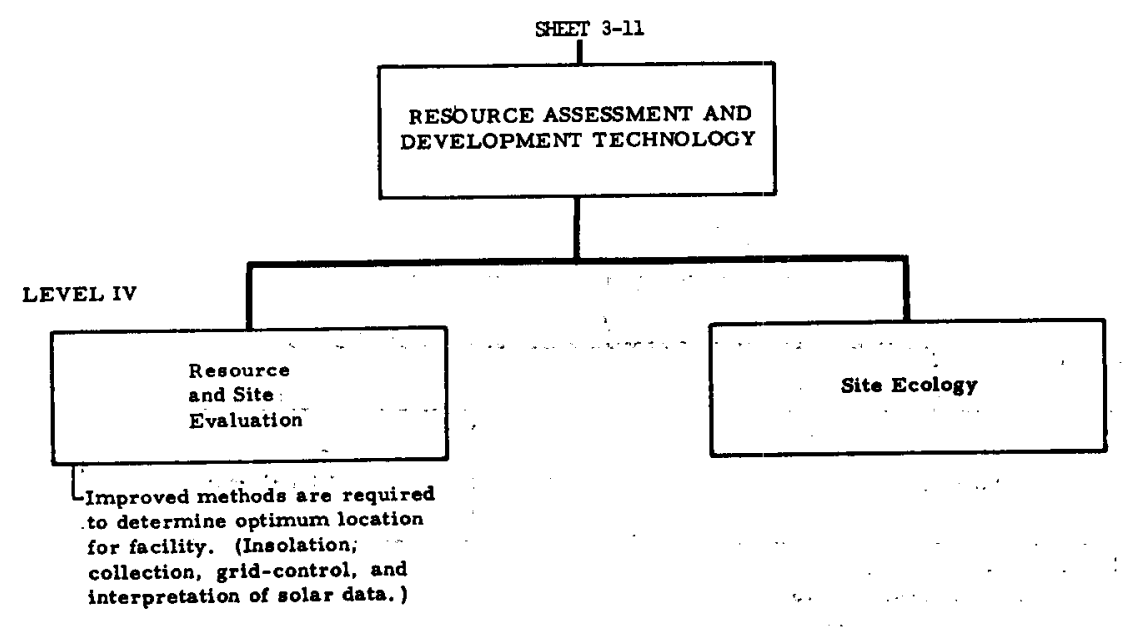

SHIDET 4-31 


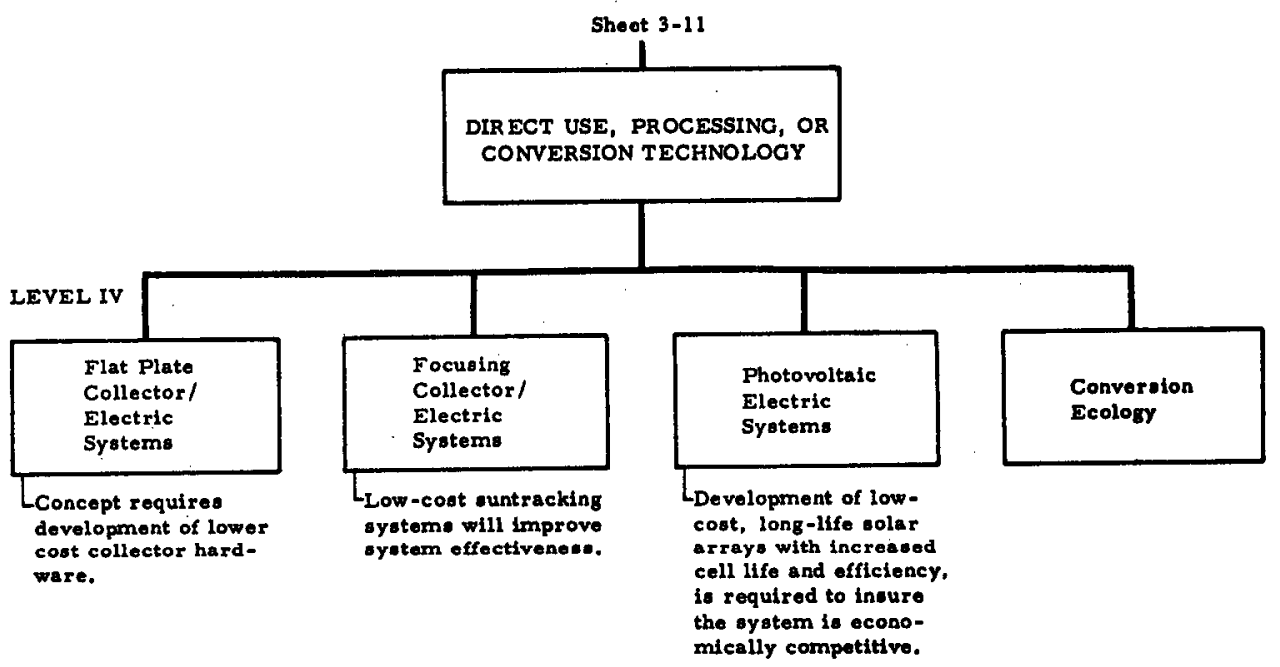

SHEET 4-32

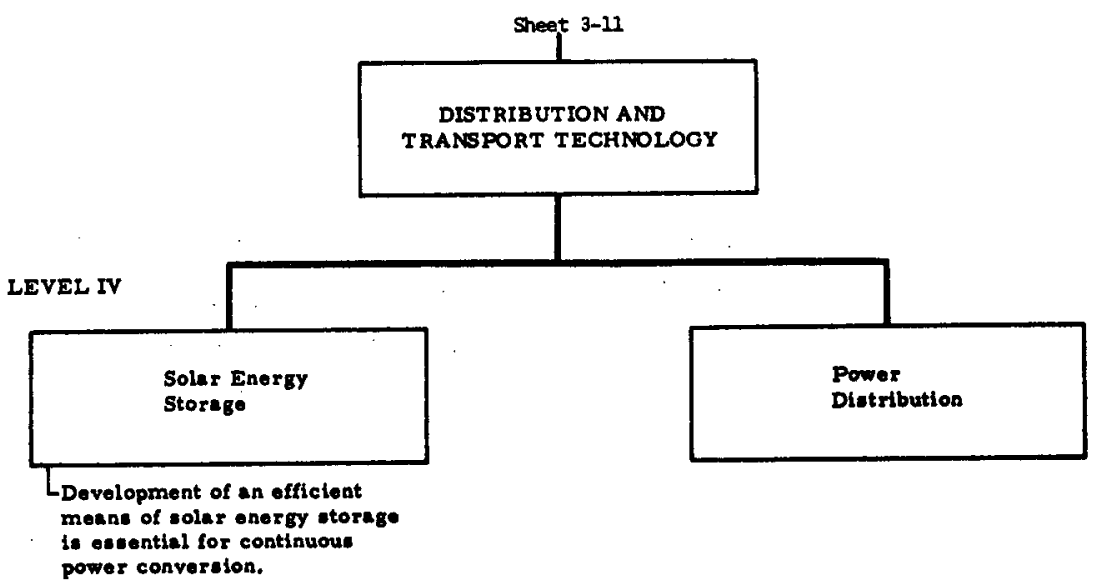

SHIXEI $4-33$ 


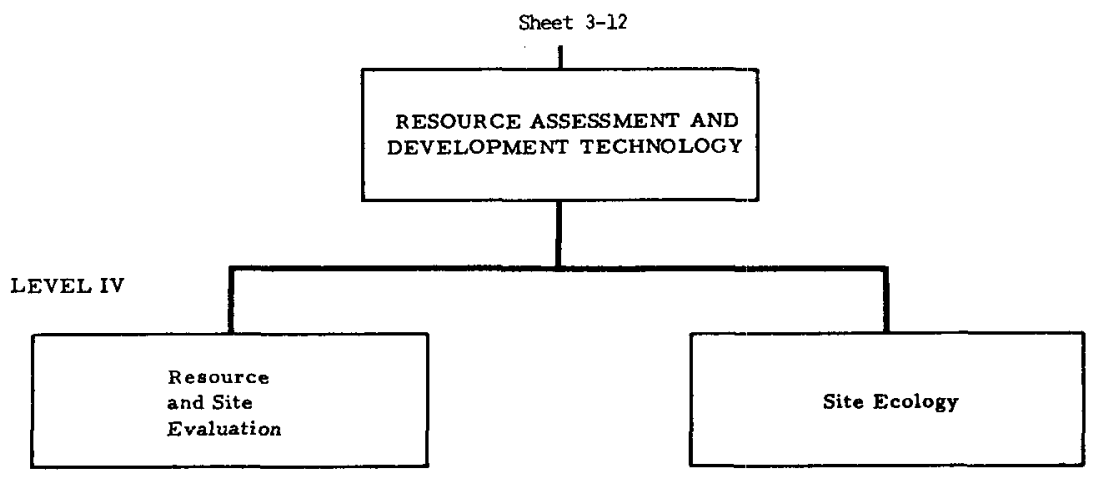

STEET $4-34$

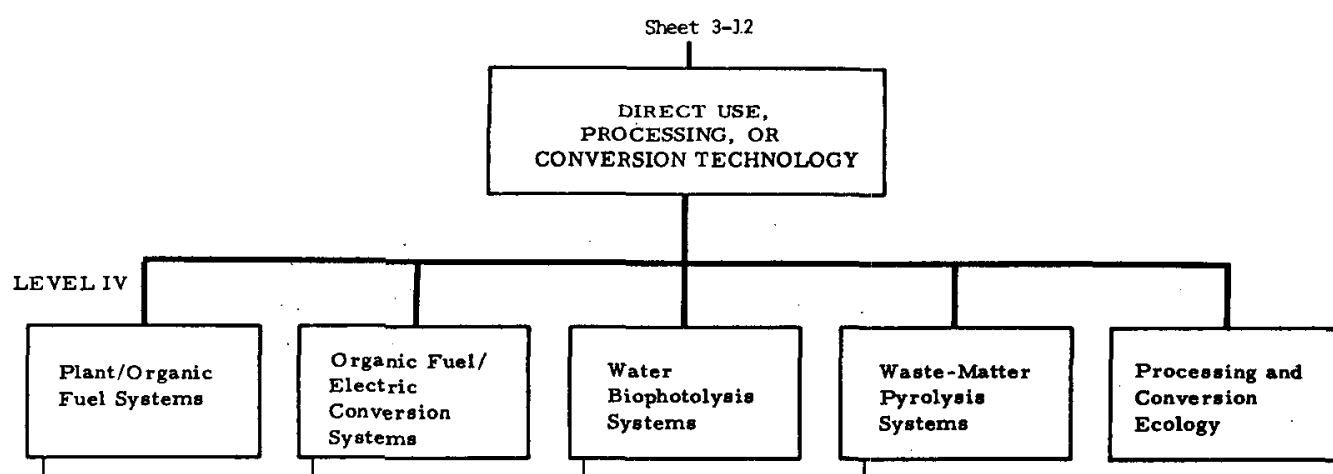

- Conversion methods require development of an efficient, economical process.

Loverall system economic feasibility requiree demonstration (from raw wource material

collection to by-product utilization after conversion).

SFIFET 4-35 


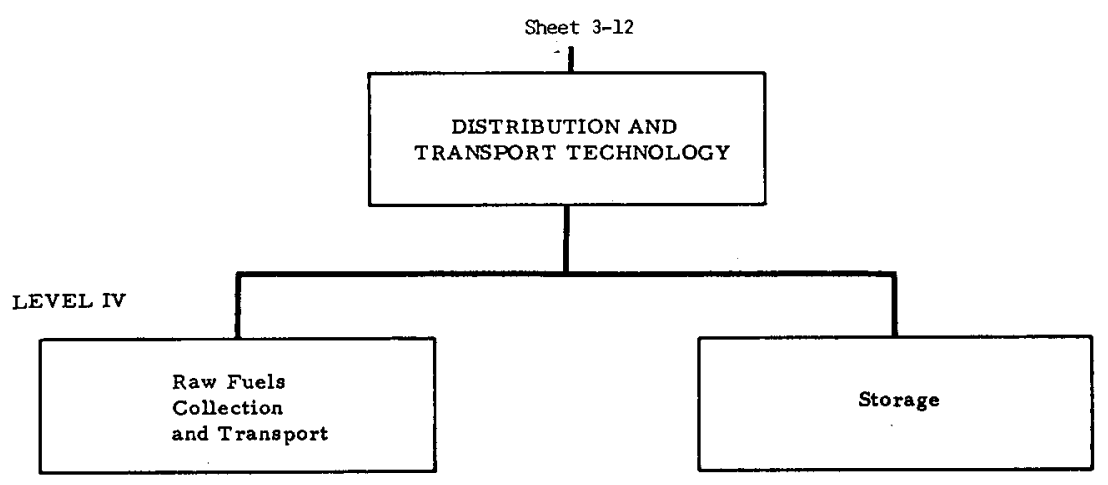

SHEET 4-36

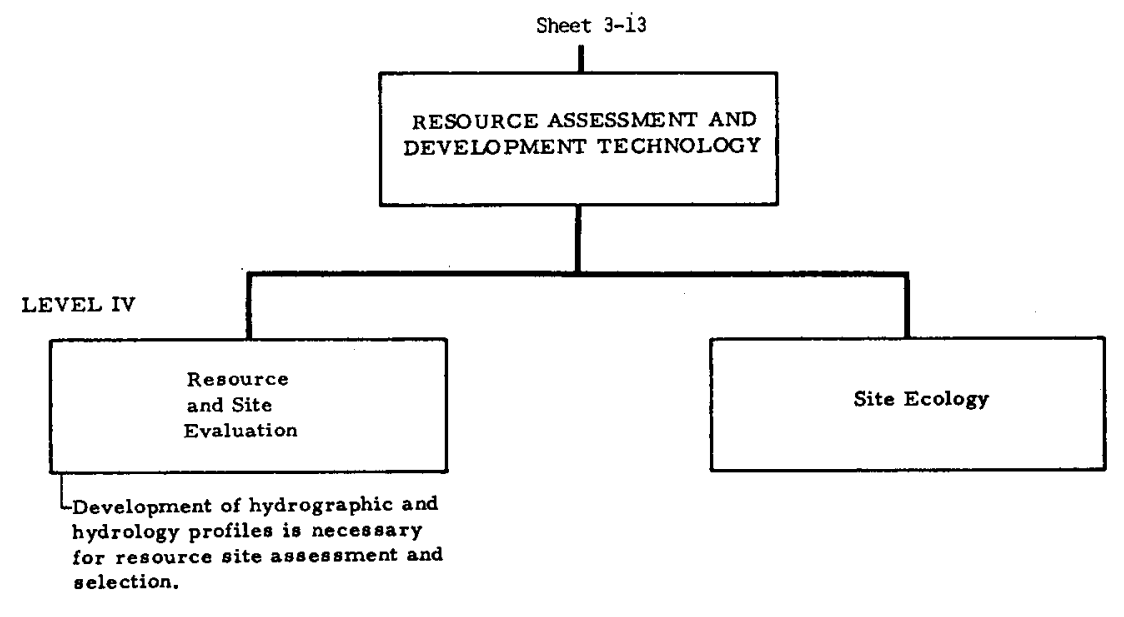

SHEET $4-37$ 


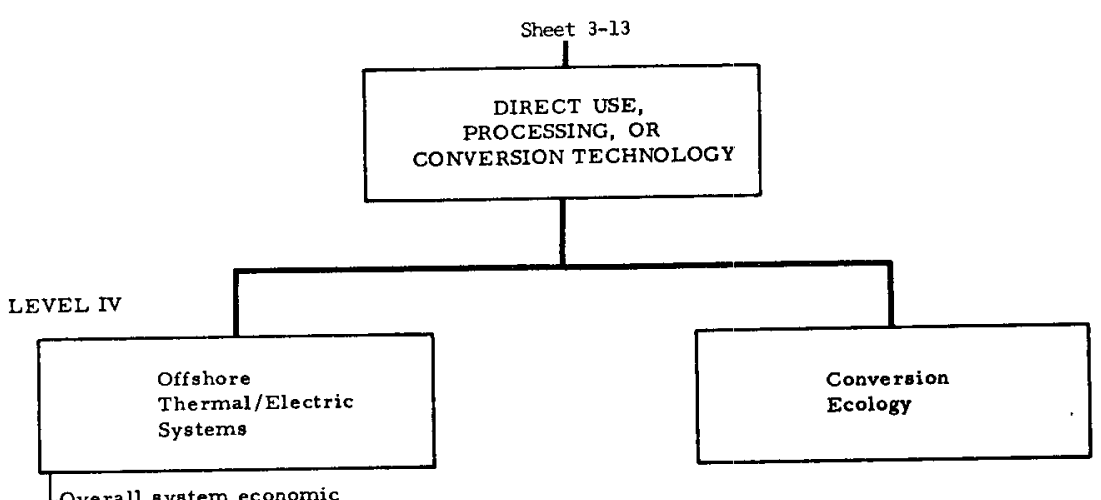

Overall system economic

feasibility requires demonstration (including the development

of a commercially-feasible low -

temperature-gradient generating

plant).

SHEET 4-38

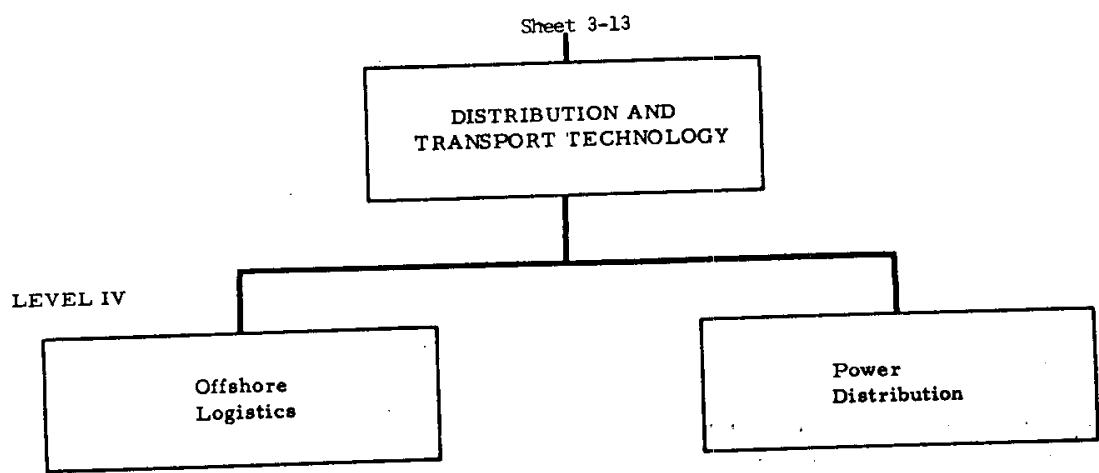

SHEET 4-39 
Appendix C

SOCIAL AND POLITICAL INTERVIEWS AND FINDINGS

\section{Int roduction}

This section of the report provides detailed information about the social and polftical interviews summarized In Section 3.2. It includes a description of the participants, the interview sequence, interview materials, and a compilation of individual responses to the impact matrix and accompanying comments.

\section{The Social and Political Interview Panel}

The members of this panel were selected as knowledgeable representatives of a range of interest groups participating in or affected by the development of geothermal energy. The names and affiliations of the participants are listed in Section 3.2.

In the compilation of opinions on which forms the major part of this appendix, responses are 11sted by participant numbers which refer to broad interest group connections but do not 1dentify each individual. This preserves the anonymity of specific answers while permitting evaluation of their importance and validity in relation to areas of expertise and points of view.

\section{The Interview Sequence}

A. Introduction. The interviewer described the role of The Futures Group in conducting the study and the general objectives of the overall study. He then outlined the specific purposes of the interview:

1. To collect the views of varfous interest groups regarding the probable future course of geothermal development and the subsequent impact of this development on their specific group, on other interest groups, and on the nation as a whole.

2. To identify and define various policles which might be implemented to mitigate or Improve potential impacts of geothermal development.

\section{B. Scenario Discusston.}

1. The respondent was asked to review the "normal" and "crash" scenarios, which in most cases had been malled to him prior to the interview.

2. He was asked to comment on their contents in general and/or in detall.

3. He was asked to present his own appralsal of the course of development and his underlying assumptions.

4. The interviewer directed the discussion to areas of the respondent's expertise or particular interest.

\section{Impact Matrix}

1. The respondent was given a deck of cards containing 36 possible impacts of the development of geothermal energy.
2. A matrix was laid out in front of the respondent by means of heading cards.

3. The respondent was asked to make two independent judgments regarding each impact in accordance with his own version of the development scenario and to place the card in the corresponding matrix square. The heading cards across the top of the matrix defined a scale of desirability for the nation as a whole:

$$
\begin{aligned}
& \text { Very desirable } \\
& \text { Desirable } \\
& \text { Neutral } \\
& \text { Undesirable } \\
& \text { Very undesirable } \\
& \text { No opinion }
\end{aligned}
$$

The heading cards along the left side of the matrix defined a probability scale:

$$
\begin{aligned}
& \text { Almost certain } \\
& \text { Very likely } \\
& \text { As probable as not } \\
& \text { Very unlikely } \\
& \text { Almost Impossible } \\
& \text { No opinion }
\end{aligned}
$$

4. The respondent was encouraged to discuss the nature of the impacts as he proceeded with the card sort, and to explain the assumptions underlying his judgments. Matrix placement and accompanying comments were recorded by the interviewer.

5. If time permitted, the scale of desirability alone was laid out and the respondent was asked to reclassify the impact cards from the point of view of his own self-interest as contrasted to the national interest assumed above. An alternative approach utilized was to ask if there was any area of impact which, if judged from the respondent's own or professional point of view, might be in conflizt with any judgments made from a national point of view.

\section{Conclusion}

1. The respondent was asked to suggest any additional impacts of geothermal developments which he could foresee.

2. He was asked to describe policies which he would like to see Implemented in the fleld of geothermal development.

\section{Interview Material--Scenarios}

Normal Development of Geothermal Energy. The energy crisis of 1973 necessitates a changing pattern of input fuels for electricity generation. Shortages of low-sulfur oil and natural gas preclude the continuing substitution of these fuels for coal. Nuclear energy supplies are less than anticipated because of siting problems and long lead times involved in nuclear plant construction. Appropriate environmental accommodations are made allowing coal to fill the generating gap until additional nuclear plants become operative by the mid-1980's. By the early $1980^{\prime} \mathrm{s}$ oil supplies are available from shale, tar sands, and Alaska, but are primarily used for transportation, heating, and petro-chemicals rather than for electricity generation. 
By 1974 intensive prospecting for geothermal resources 1p.rinderway, spurred by the open leasing of federal

Supported by venture capltal, ut1lity developfunds, and governmental pilot profects, exploration for geothermal steam and hot water resources begins in the western regions. This exploration, spurred by new developments for assessing the resource longevity of flelds, Indicates that most Identifled geothermal resources are liquid-dominated hot water systems. Potential development of these hot water resources, however, is slowed due to difficulties with high brine content. It 181978 before any commercially viable plants utilizing hot water are operative.

Legal and Institutional 1mpediments are gradually removed during the mid- to late $1970^{\prime} \mathrm{s}$. By $1980 \mathrm{geo-}$ thermal resources are treated as unique and statutes are clear regarding what can be developed and in what manner. Specific guidelines are Instituted to assure that the physical sites of geothermal systems are developed in a manner compatible with existing land use patterns.

Due to the large risk factor, substantial capital outlay involved, and long lead times which characterize geothermal developments, it becomes evident that private InItlative must be oupplemented by federal incentive programs (tallored depreclation allowances, investment guarantees, and/or production subsidies). Federal and state policles regarding geothermal resource development are coordinated and most conflicts resolved.

As hot water systems are being developed, work commences on possible utilization of hot dry rock resources. In the $1970^{\prime} \mathrm{s}$ research efforts focus on hydraulic fracturing and also on possible selsmic effects of fluid infection Into hot dry rock.

By 1985 there is an electrical output capability of about 7500 megawatts from geothermal energy in the West. of this total, 3000 is from dry steam, 3500 from hot water, and 1000 from hot dry rock. This accounts for 6 percent of the generating capacity of the West. The only other significant geothermal production is on the Gulf coast where geopressured flelds produce some 3000 megawatts.

The it1lization of geothermal resources proceeds rapldly since it has cost and environmental advantages over coal and In many Instances over nuclear powered plants as

we11. The growth of nuclear development slows somewhat in the West as geothermal power is clearly demonstrated as a practical energy source.

As the year 2000 approaches, geothermal energy is a major factor in the West and a minor; though significant, factor in the Gulf states. Prospecting for geothermal reserves in the East begins, spurred by new advances in drilling and resource locating technology.

By the year 2000 geothermal resources supply over onethird of the generating capacity of the West. Of this total of 140,000 megawatts, 6000 are from dry steam, 100,000 from hot water, and 34,000 from hot dry rock. Plans to export electricity from western regions await the development of additional capacity and adequate transmission technology.

Other uses of geothermal energy befng implemented on a relatively large scale include space heating and atr conditioning, supplying 1rrigation water from desal1nated wastes, and provision of minerals recovered from fluld wastes. Some geothermal systems are mult1purpose, combining electrical generation with one or more of the above-mentioned uses.
Crash Development of Geothermal Development. After the opening of federa1 lands for leasing in 1974, interest In geotherma1. energy intensifies. Congress, spurred by an awareness of private Industry interest, acts to stimulate geothermal development through a variety of measures. By 1975 and 1976 leglelation is passed which coordinates federal research and development activities on geothermal. energy and, in addition, funding and guarantees for new programs are passed. Since it has been demonstrated that private industry is unable or unwllling to bear all early rlsks of geothermal development, the federal government funds entire projects for mapping, exploration, and the development of hot water, hot dry. rock, and geopressure technology. To hasten the development of commerclally feasible resources (steam and hot water), the federal government utilizes loan guarantees to private industry and actually particlpates with some utflities and municipalities in joint pilot profects.

The combined actions of federal, state, and local agencles are successful in preventing duplication of effort by establishing standardized procedures regarding the development and defintition of geothermal resources. A national data bank for geothermal information is established by 1977 to facilitate orderly research and exploration.

These programs, plus additional federal activity in granting depreclation allowances and Instituting manpower training projects, have a significant effect on the pace of development of steam, hot water, and geopressure resources. Exploratory techntques advance rapidiy and the scale deposit problem is solved by 1980.

Most major technical Impediments to the development of hot water reservoirs have been removed by 1985 . In addition, hot rock and geopressure technology is developing rapidly, espectally in the area of deep drilling techniques (comerctal rigs are avallable for depths up to 30,000 feet and temperatures of $\left.800^{\circ} \mathrm{F}\right)$. Despite the lack of adequate fleld longevity data some regional utflities have been encouraged through feder:al Incentive programs to base a large part of their new capacity on geothermal energy. Th1s Increased utilization is encouraged since geothermal energy has been shown to have cost and environmental advantages over coal and in many Instances over nuclear powered plants as well. Production has reached a level of 35,000 megawatts: 3500 in steam; 16,500 in hot water, 5000 in hot dry rock, and 10,000 in geopressure.

Wh1le further development of steam and geopressure resources 1s 11mited by the extent of these resources, hot water and hot dry rock resources have been 1dentifled in very substantial quantities. Whether these resources are to be fully developed depends on the possibility of exporting excess electricity from the West to other reglons. In other areas increased demand for electricity is being met through the construction of additional nuclear plants, since fossil and synthetic fuels are largely reserved for other uses. As the use of nuclear power Increases 80 'do the perceived environmental problems of siting, safety, and wastes. In dealing w1th these problems the cost of nuclear power rises and it becomes cost-compet1tive to transport electricity from geothermal development via $\mathrm{h} 1 \mathrm{gh}$ voltage transmission lines from the West to the rest of the country.

After a prolonged national debate whlch welghs the advantages of more abundant energy versus possible environmental damage, Congress procla1ms a national polfcy to promote this tranguission of geothermal electriclty. In addition, legislative action 
provides funding and incentives to minimize any undesirable environmental and economlc effects of this policy.

By the year 2000 the geothermal industry is a major source of income in western reglons. Formerly 1solated areas are now populated as jobs open at geothermal plants and surrounding industries. Geothermal generating capacity in the West totals 660,000 megawatts: 10,000 in steam, 500,000 in hot water, and 150,000 in hot dry rock. The Gulf Coast states are supplied with 50,000 megawatts from geopressured resources, while hot rock resources utilized for space heating provides the equivalent of 50,000 metawatts in other regions. This crash program, which has elfminated major constraints and accelerated geothermal development, results in geothermal energy supplying about one-third of the electricity produced in the Untted States.

\section{Interview Materlal--Impact Liat}

1. Alr pollution due to electric generation in western regions reduced.

2. Land subsidence disrupts agricultural production.

3. Nolse from geothermal systems disrupts Iand use patterns (i.e., wildilfe withdral hab1tation, residential, agriculture, etc.)

4. Increased seismlc activity in western regions due to fractures and fluid withdrawal.

5. Localized climatic modification in areas where vapor-dominated geothermal systems are developed.

6. Development and construction of nuclear power plants slowed markedly in western reglons.

7. Contaminetion of water tables in many local1ties by geothermal wastes.

8. Previously inaccessible areas opened for recreational use.

9. The development of agriculture in previously unfarmed areas stimulated by the avallability of Irrigation water from desalinated geothermal wastes.

10. Rev1talization of the drilling Industry.

11. Other primary energy sources (o11, coal, and natural gas) freed for use other than the generation of electricity.

12. Exclusion of small firms from geothermal development.

13. Large Integrated companies dominate the deve1opment of geothermal resources.

14. Reduced needs for imported petroleum Improve the U.S. balance of trade.

15. The construction of transcontinental transmission lines requiring new rights of way.

16. Tax revenues and royalties from geothermal developments provide the basis for tax reductions In municipalities and states in western regions.
17. Increased Industrial development due to the availability of low-cost.electricity:

18. Implementation of ant1poverty programs based upon municipal development and administration of geothermal resource areas.

19. Alteration or modification of home construction techniques to utilize geothermal potential for space heating.

20. The construction and development of new towns near geothermal resource systems.

21. Commercial market for minerals and mineral salts extracted from geothermal 11quids.

22. Eastern electricity demand met in part by electricity exported from western geothermal developments.

23. Ifving standards improve.

24. Energy intensive Industries located in the East migrate to western reglons.

25. Real GNP growth higher, than it might have been without geothermal power.

26. Population migration from East to West simulated.

27. Shortage of skilled manpower.

28. Slowdown in the growth of the synthetic fuel Industry.

29. Increased government regulation of resource development by private enterprise.

30. Despotlation of land by coal strip mining essentially terminated.

31. Recreationa1 space in western states reduced.

32. The state of geological science advanced markedly.

33. Multi-purpose 1ndustrial/agricultural complexes developed in West.

34. Natural gas supplies Increased.

35. Creation of tax shelters for investment in geothermal developments.

36. Formation of many new federal, state, and munlctpal agencies to oversee geothermal resource development. 
Interviow Mater 1al-- Impace Matrdx

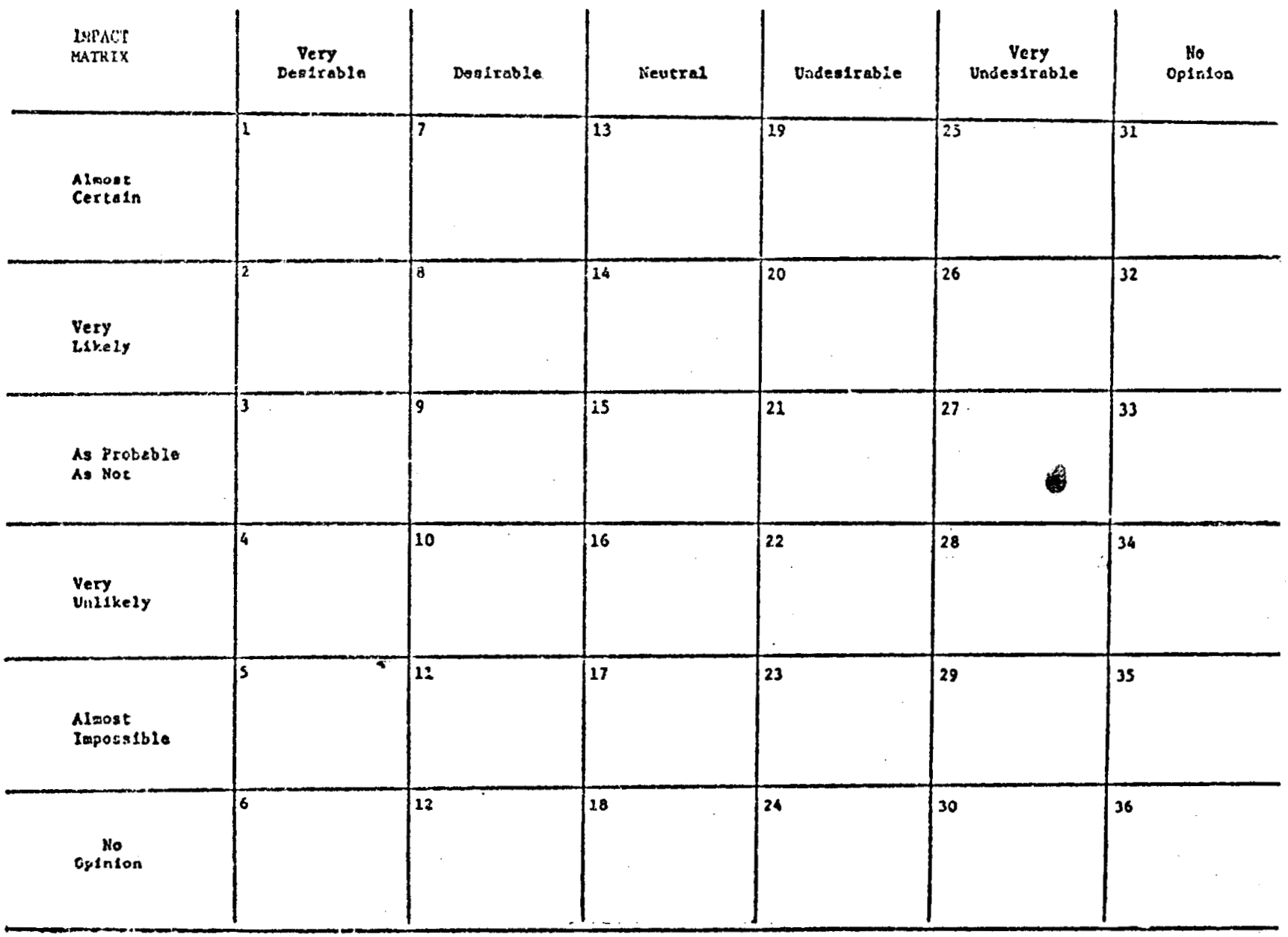


Interview Material--Compilation of Individual Responses to Impact Matrix

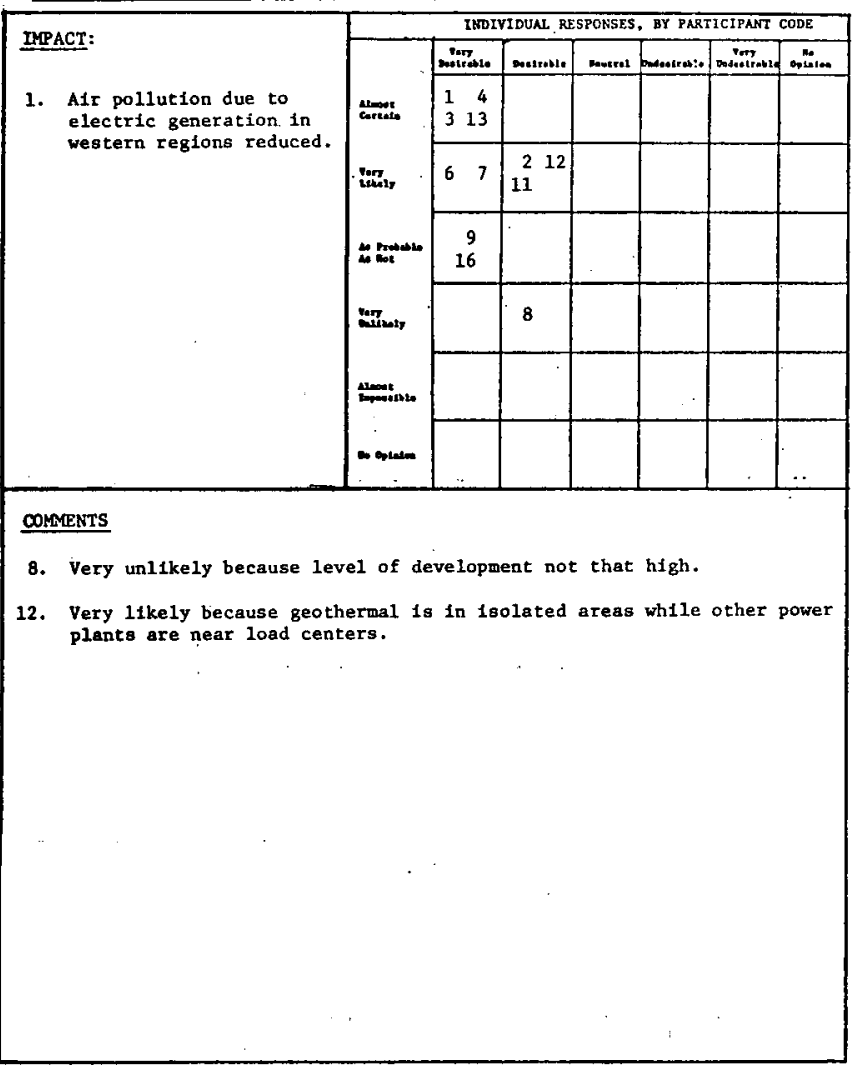

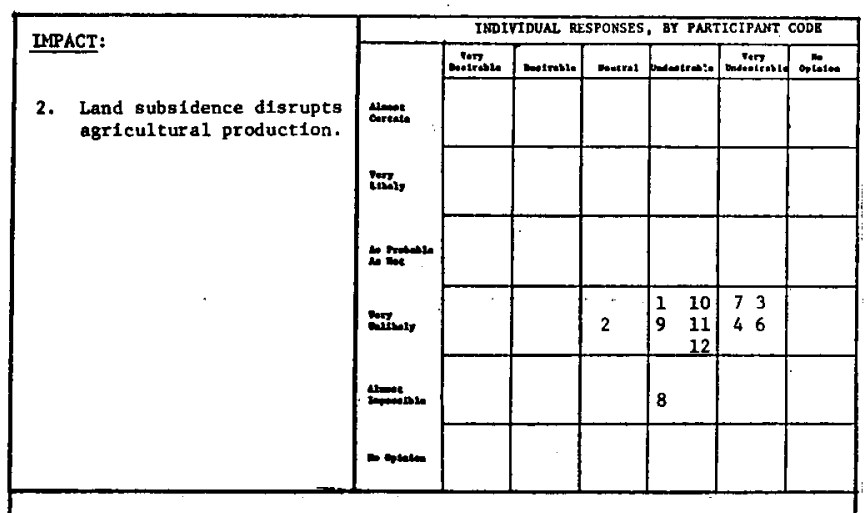

COMMENTS

3. Will be watched for--1f evidence of occurrence, work will stop. If due to loss of pressure, relajection will help.

4. Will be prevented by reinfection--toxic fluids gust be reinjected.

9. Unlikely--wouldn't continue development of area if occurred.

10. Of no 1mportance--can be easily taken care of.

12. Depends strictly on the area. There 1s none at the Geysers. Possible In the Imperial Valley but won't happen because of constant
monitoring. Need basellne data because there are constant earthmonitoring.

16. Likely because of emphasis on Imperial valley--but not in other areas.

\section{IMPACT:}

3. Noise from geothermal systems disrupts land use patterns (i.e., wildlife habitation, residential, agriculture, etc.).

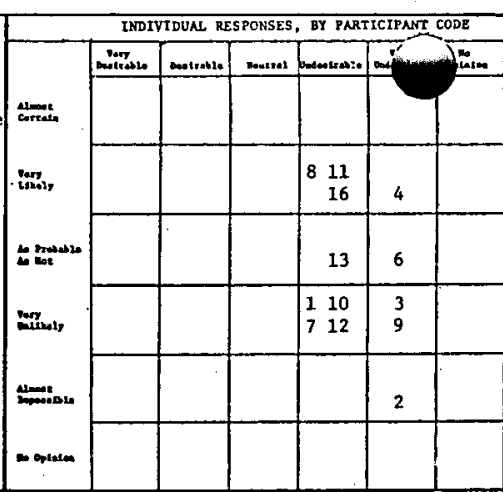

COMMENTS

4. Inherent problem.

6. Blow out control technology needs developing (at the Geysers took 2 years to bring one well which blew out under control-others no trouble).

2. Geothermal noise problems have been solved.

10. Not 1mportant; fust a siting problem. Not noisy beyond one-half mile

11. Problem can be handled.

12. Constantly working on problem--have mufflers. Producing wells are quiet.

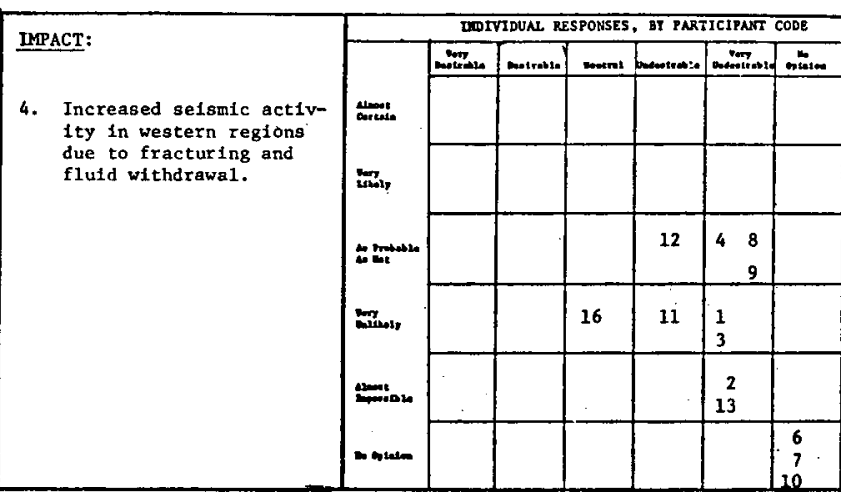

COMMENTS

1. Water would re-enter from other underground sources--nature abhors a vacuutr--only when resource is depleted on ght there be danger, but not so long as water is being withdrawn.

3. Monitoring will guide behavior--to either stop or take corrective action.

10. Nobody knows yet.

12. Unknown factor (1n Denver, storage of nuclear waste affected earthquake activity).

16. Inappropriate question. Total activity would be the same; only mode in which released would be different--3mall versus big earthquake.

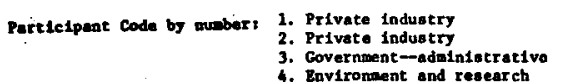

2. Private induatry
3. Government--adminiatrativo
4. Bnvironaent and resear ch 5. Public utility 7. Government-lepis lative
8. Environiment and research

\section{Public utility}

10. Governaent--Ie

12. Private industry
13. Rnvirontent and research 14. Private Induatry 16. Goverment- adain ietrative 


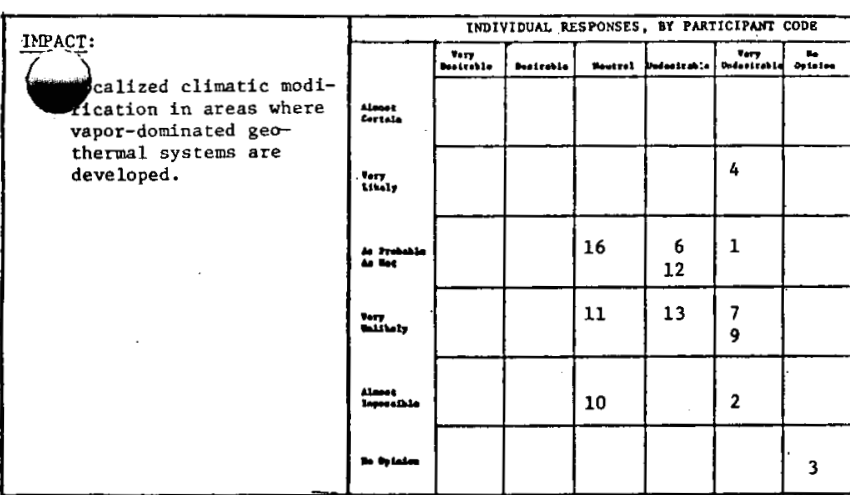

COMENTS

4. Assumes that systems are not all sealed.

6. Fogging from cooling towers, rather than from emerging steam.

12. Acknowledged problem--working on 1t. At Mammoth can see vapor clouds. Have problem at Geysers in cold weather-working it out-cooling towers give problems.

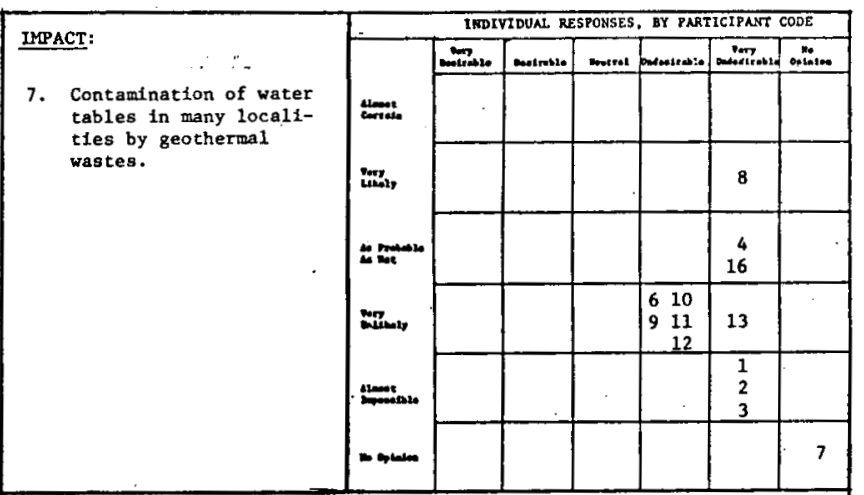

COMENTS

3. In California this 1a almost Impossible. Laws are strict enough to prevent occurrence.

8. Very likely to occur.

10. Easy to handle--one point source of contamination.

11. Can be taken care of.

12. Unlikely because of controla by regulatory bodies.

\begin{tabular}{|c|c|c|c|c|c|c|c|}
\hline \multirow{2}{*}{ IMPACT: } & & \multicolumn{6}{|c|}{ INDIVIDUAL RESPONSES, BY PARTICIPANT CODE } \\
\hline & \multirow{6}{*}{ 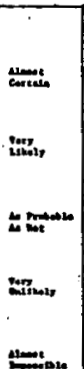 } & $\min$ & motroste & merest & •. & $\sin 10$ & antion \\
\hline \multirow{6}{*}{$\begin{array}{l}\text { 6. Development and construc- } \\
\text { tion of nuclear power } \\
\text { plants slowed markedly } \\
\text { in western regions. }\end{array}$} & & & & & & & \\
\hline & & $\begin{array}{r}1 \\
13\end{array}$ & 7 & 6 & & & \\
\hline & & & & & $\begin{array}{r}2 \\
16\end{array}$ & & \\
\hline & & 4 & $\begin{array}{r}8 \\
9 \\
\end{array}$ & 3 & 12 & & \\
\hline & & $\therefore$ & & 10 & & & \\
\hline & 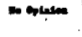 & ... & & . & &. & $\therefore$ \\
\hline
\end{tabular}

3. Sites w111 be found.

4. Giver political factors and diminishing supplies of cheap"uranium.

10. No possibility-geothermal just supplemental source.

12. Need both geothermal and nuclear to free up fossti fuels.

13. Very desirable and h1ghly 11kely--geothermal will combine with reduction of electrictity conaumption growth to reduce need for nuclear' plants.

16. Undesirab1e--will need all sources of power.

\section{IMPACT:}

8. Prevlousiy inaccessible areas opened for recreational use.

:

\section{COMENTS}

3. Geothermal areas are accessible-but not desirable.

6. Ronds would be developed to transport equipment, and people could come over them for recreation.

9. As probable as not--but odor and aolse are deterrents.

10. Not Impossible, but won't happen.

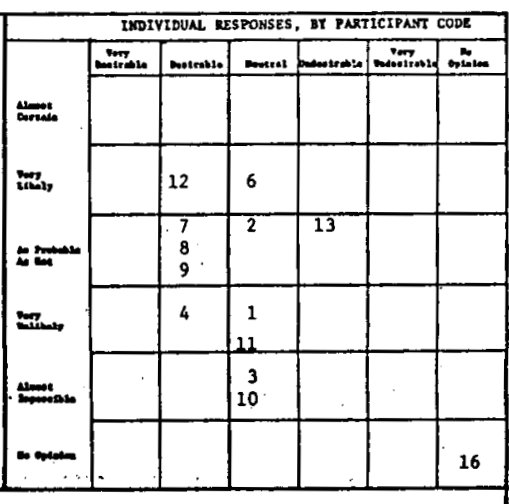

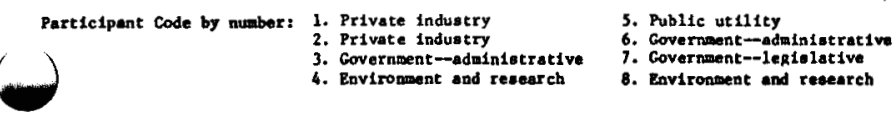

11. Covernment--1es

12. Privace industry
13. Envitonment and tesearch

14. Private 1nduetry

16. Goverment-adain Latrative 


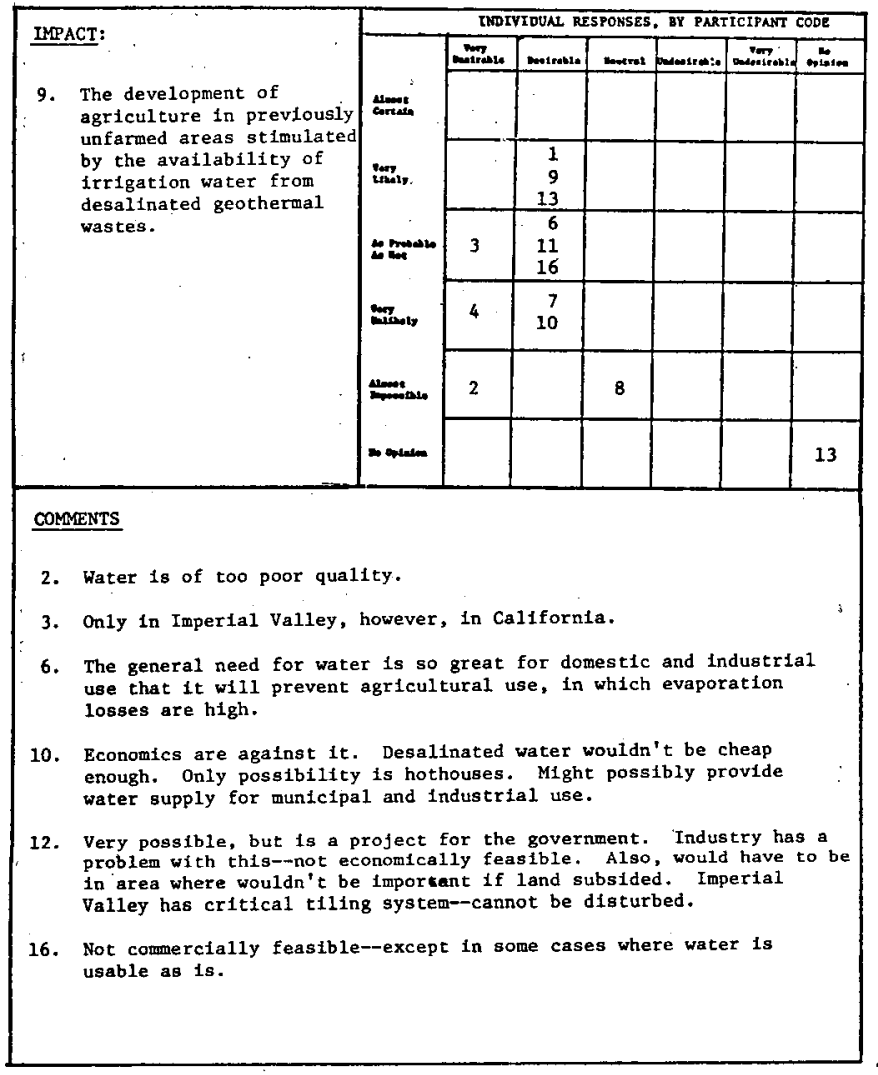

IMPACT:

10. Revitalization of the drilling industry.

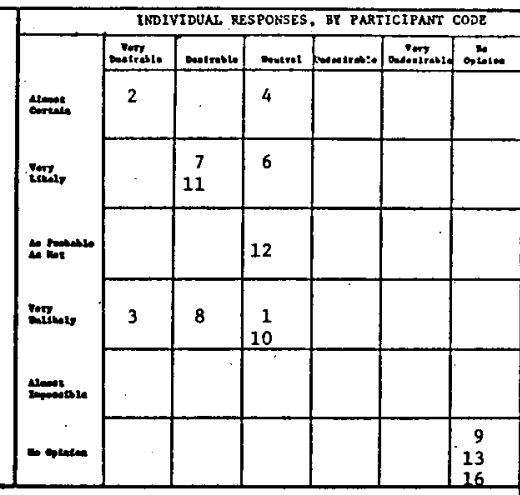

COMGNTS

1. Not enough to matter--8ome effect, though.

2. Drilling business will double or triple.

3. Not that much Increased activity due to geothermal.

6. There will be inftial shortagea in men and materlal.

10. The industry is not going downill. There will be material shortages. Offahore drilling and ofl problem alone is reviving industry-geothermal will not be much of a factor.

11. Shortage of materlal could persist for several years.

12. Shortages are not temporary unless there is a government rollback on prices of crude. Now drilling in marginal areas. If prices remaln high and the need is there, drilling will expard. Manpower avallable will now expand-during the slump there was lesa recruiting.

16. Irrelevant question--doesn't need revitalizing.

\section{Participant code by numberi 1. Private industry}

2. Private Industry

3. Governent--administrative
4. Environment and research

5. Public ut 111ty

6. Government--adminiatrative

8. Environiment and tesearch
IMPACT:

11. Other primary energy sources (oil, coal, and natural gas) freed for uses other than the generation of electrictity

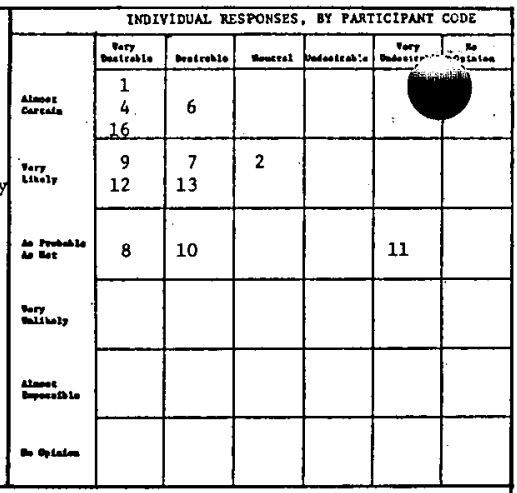

COMENTS

3. Electric demand must be met--all fuels will be required.

4. Due to less accelerated electric growth curve. Geothermal is not ouch a benign source that conservation is not needed.

6. Falrly substantial inpact on other fuels in the West:

10. Effect will be felt only after year 2000 -then geothermal may be major factor. Must stop using fossil fuels because of cumulative environmental effect.

11. Won't free that much by 2000 .

12. Geothermal supplement to free fossil fuel along with nuclear.

16. Almost certain--desperately needed.
12. Exclusion of smali firms from geothermal development.

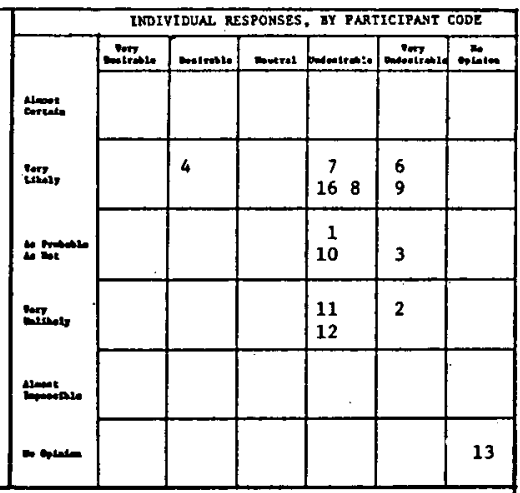

COMENTS

1. Due to their inabillty to bid on leases and their 1nability to get proper financing. Can't cospete with large companfes.

3. Not that expengive an operation. Sinail companies drilling a few wells can survive.

4. Large companies are beginning to show themselves capable of being responsive to environmental problems, while gmall companies with less resources are 1gnoring them.

6. In the beginning, small f1rms will take the b18 risks. But the only people who have the financial resources ultimately needed are large compantes.

9. Very likely that 011 and gas compantes will predominate.

10. Yes-1f not good government policy. Need financing b111s and leasing pollcy.

12. UnItkely. Sma1ler companies generste investment. O11 Industry has more wells drilled by independents than by big companies.

16. Nature of the game makes th1s very likely--need potful of money.

\section{Publie utility}

10. Covernment--le

12. Private industry
13. Rnvironment and research

15. Private Induatry

16. Coveriment-atalnietrotive 


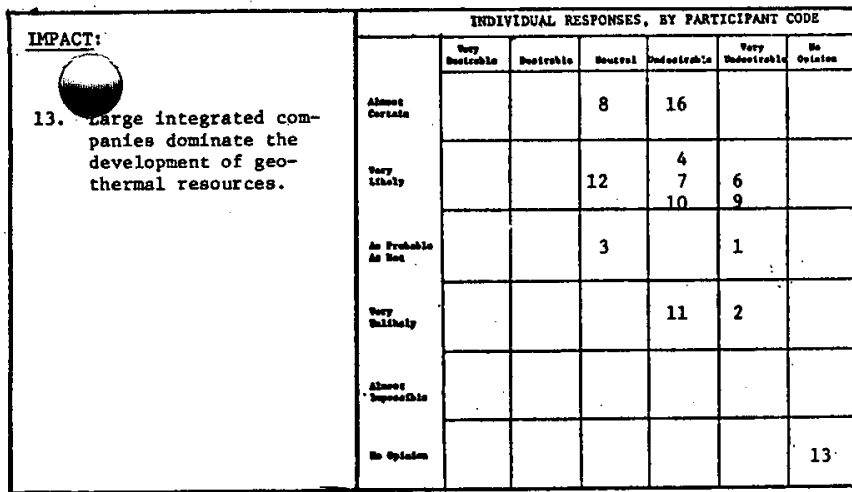

COMments

1. They do not now-but could in future. They would buy the1r way in, but not swallow small firms.

4. Fears large integrated companies.

6. Large companies w111 produce steam, manufacture chemicals, may generate electricity. Some states may make provision for nonutility electrical

10. Yes, unless conscious polictes are undertaken.

12. B18 compantes have more money and mampower. But will not necesoarily dominate exploration.

DPACT

14. Reduced needs for Imported petroleum Improve the U.S. balance of trade.

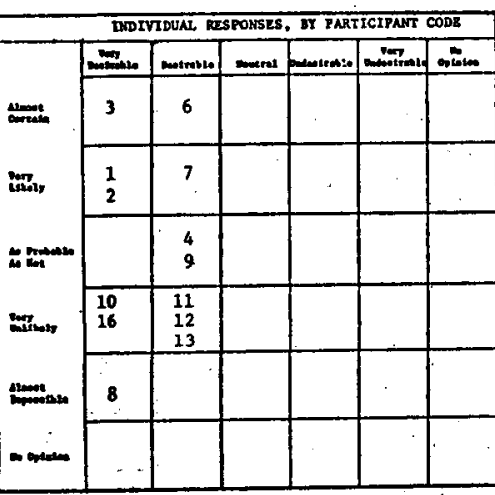

COMERTS

10. Hill result frow general energy research strategy, not geothermal alone.

11. Unilkely in timeframe.

13. Not relevant to geothermal-not a dominant factor though may help.

16. Coothermal not that signlficant a factor.

\section{DAPACT:}

15. The construction of transcontinental transmlssion lines requiring new rights of way.

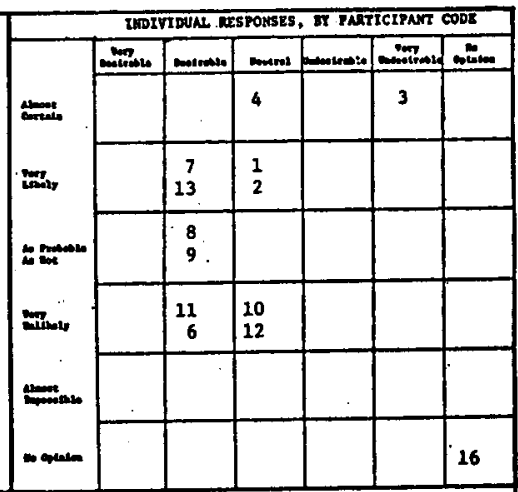

COMMENTS

3. Power w11l be exported, say from Imperial Valley.

6. Intercontinental 11 nes will be built regardlesa of geothermal to take advantage of differences in peak load times.

10. Geothermal will develop everywhere-won't move great amounts of electricity around.

9. Undesirable frow environmental point of view, but desirable from point of vies of suall companies. Ceothermel development not of magnitude to stimulate long d1atance lines--but other forces w111 be at work.

11. Wi11 happen anyway--w1 thout geothermal.

12. Unltkely-oothermal will make significant contribution to electric porer in the West and will free fossll fuel for Bast.

13. Trangmisston I1nes going in anyway-there will be a aubettution Trafe

\section{IMPACT:}

16. Tax revenues and royaltie日 from geothermal developments provide the basio for tax reduction In municipalites and 1n munctpalieteg

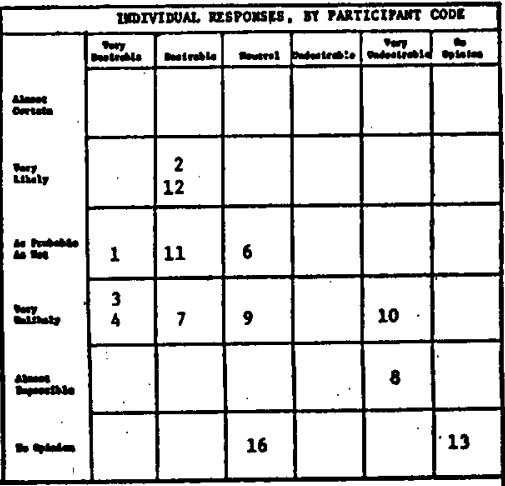

COMAENTS

3. Most geothermal sites are far from populated areas.

4. Geothermal operations w111 probably cost countles money to montor and pollce activitles.

7. Not i1kely-purpose of current b111s in Congress to think in terte of ultimate tax revenues rather than royalties.

9. Highly unlikely-most development on federal lands anyway.

10. Won't be that b1g--not Important part of economic eactor.

12. Very 11kely-most local governments eager to heve companies in their area.

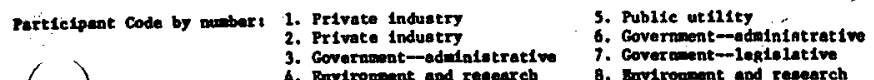

9. Public utilit

0. Governaent--leg

12. Private induatry
13. Bnvironeant and researeh

19. Private 1nduatry

16. Covernont-odndeletretive 


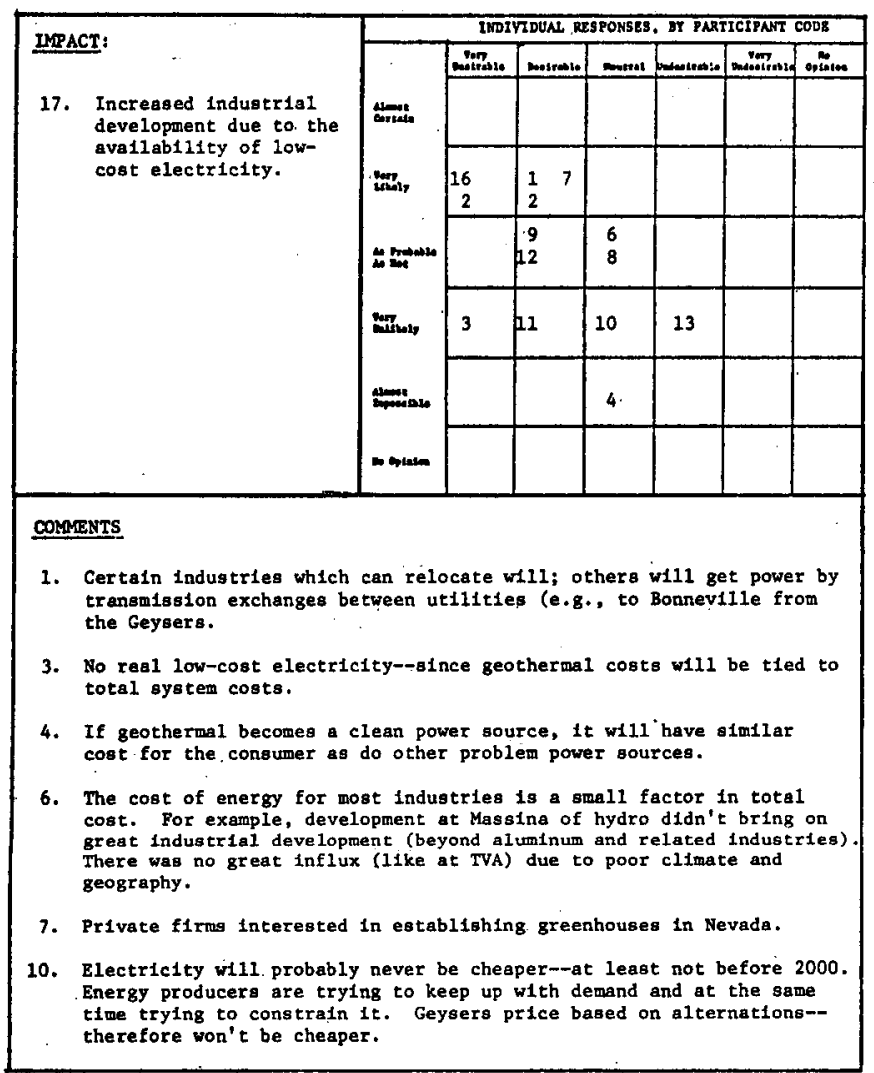

COMRENTS (Cont.)

12. Could possibly take care of an industry.

13. We will never have low-cost electrictey again.

16. Very 11kely if include process heat--used for Instances by pulp mil1s, aynthetic rubber plants. Ten percent of energy use is process steam.

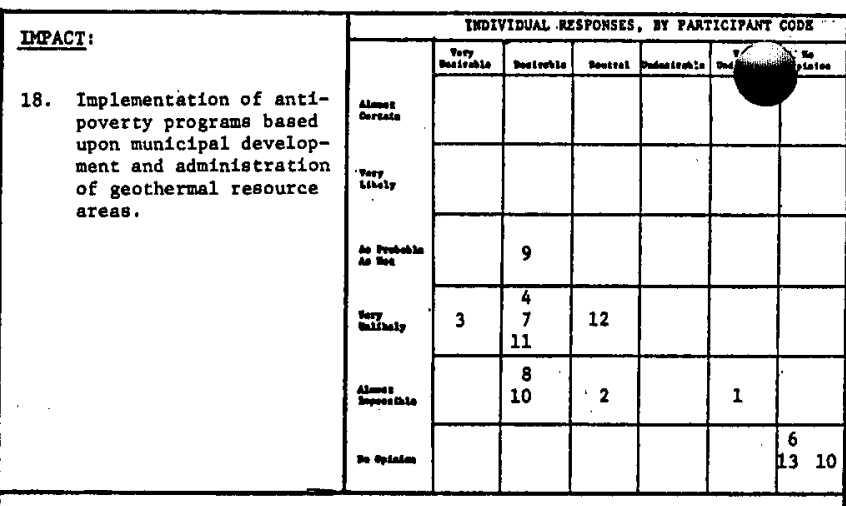

\section{COMMENTS}

1. This ties into political/social things which would interest development.

2. Munictpalities won't be Involved. Nothing spectal about geothermal-Iike oil.

IMPACT:

19. Alteration or modification of home construc tion techniques to ut11ize geothermal potential for space heating.

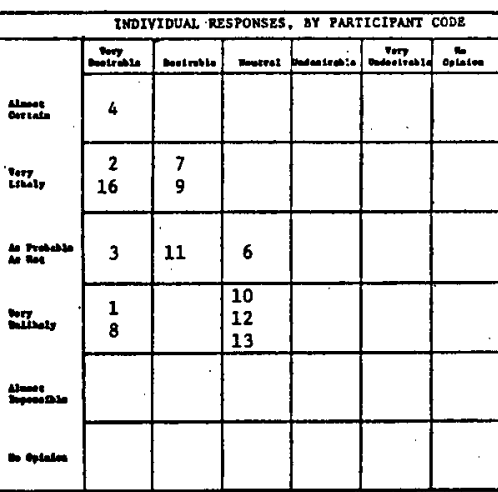

COLPENTS

3. Homes will not be bullt in areas wh1ch have resource.

2. By employing advanced concepts to derive heat from the earth In a greater varfety of locations, and perhaps nesr population centers, this impact could be significant.

10. Space heating applications will not be that big--can't move hot vater very far. Might use it for Industrial complex bullt at aite. water very far. Might use it for Industrial complex bullt at alce. as result of some deliberate 1ndustrlal attempt.

11. Locally posalble.

12. Very unlikely--hest can't be transported. Could be used for omall town. Solar more likely to have thla lmpact.

13. Unlikely--would Involve tremendous change--more likely for solar.

9. Pubile utility

10. Copornmont--10st

12. Private 1ndustry
23. Environowt and research

14. Private Induatry

16. Covernent-adain Intrative 


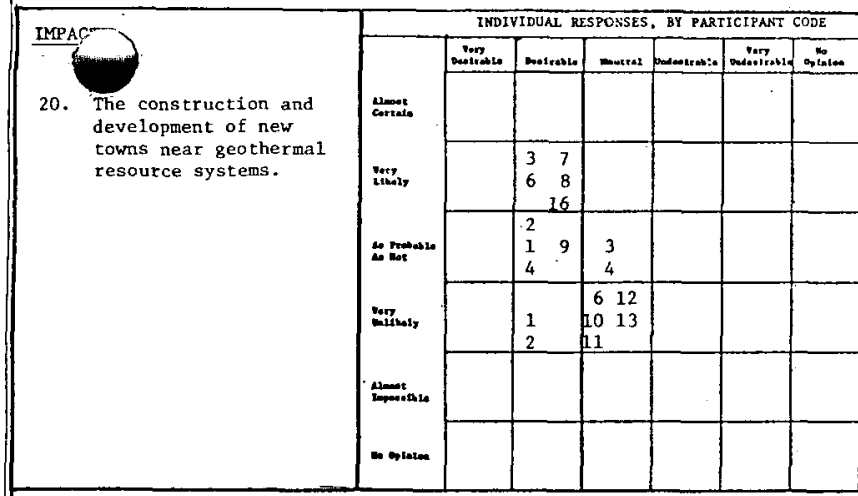

COMMENTS

1. Towns could spring up around relocated industry.

2. Some population growth, but not a big movement.

4. Only if we can't develop solar and run out of everything else. Accessibility depends on area.

7. Very likely--In Nevada plans for a transportation and warehoustng center on an Indian reservation using geothermal energy.

8. Very 11kely--geothermal could be a regional development tool-small utilities might be able to use it. Geothermal plants are small--perfect for small areas.

12. Very unllkely--doesn't cause that large a workforce.

IMPACT:

21. Comercial market for minerals and mineral salts extracted from geothermal liquids.

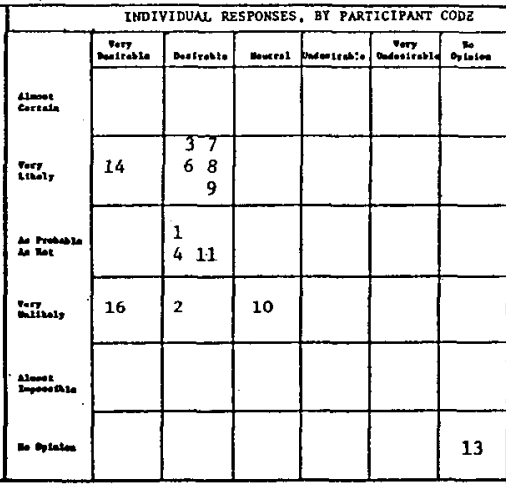

COMENTS

1. Long range. But not at all needed to make geothermal economic.

3. Imperial Valley (Morton Salt Co.) was produclng potash e $\$ 30 /$ ton. But Canadian fields underwent development e $\$ 12 /$ ton.

4. In the short term no, but perhaps for long term outlook.

6. May make a lot of difference to cost of hot water for heating. Plectric power, however, w111 be major area for geothermal heat.

11. Not in timeframe to 2000

12. There is a 11kellhood-1f market exists.

16. Unlikely to be a big piece of the action.

\section{IMPACT:}

22. Eastern electricity demand met in part by electricity exported from vestern geoth developments.

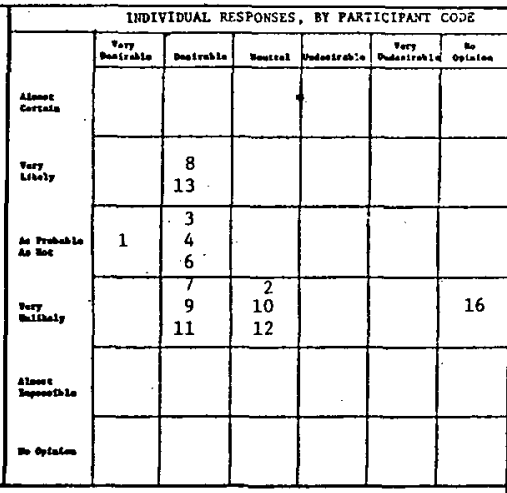

COMENTS

1. Transmission across continent possible.

3. States will not mind exporting power.

4. Much deeper drilling techniques will be needed to develop certain geothermal sources. Exporting will depend on such possible developments.

7. Very un11kely--very few proponents.

8. Will be a transcontinental line by 2000 .

10. No export from West--if hot rock successful, will develop in East.

DPACT:

23. Living standards improve.

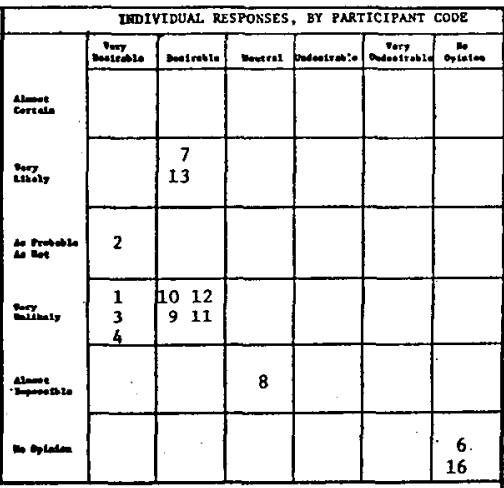

COMRENTS

1. Not much Impact.

3. Geotherwal energy is like any other source of energy-will not affect living standards any more than alternate energy sources.

4. Energy alone does not provide standard of living. There will be depletion of raw material sources in the future which geothermal will not help.

10. Not significant except on very local basis.

11. Not enough geothermal to affect living atandards.

13. Likely-but ainor effect. Would reduce nuclear pollution.
Participant Code by mumber: 1. Private Induatry 3. Government-addatnistrative 4. Enviromant and research
3. Fublic utility 6. Government-administrative 7. Govertment-1eg1slat 1 ve
9. Public utllity

10. Government--legtolative

11. Publie utility 12. Private Induetry
13. Environment and research

14. Private 1ndustry

15. Private Industry

16. Covernment- odnin1otrative 


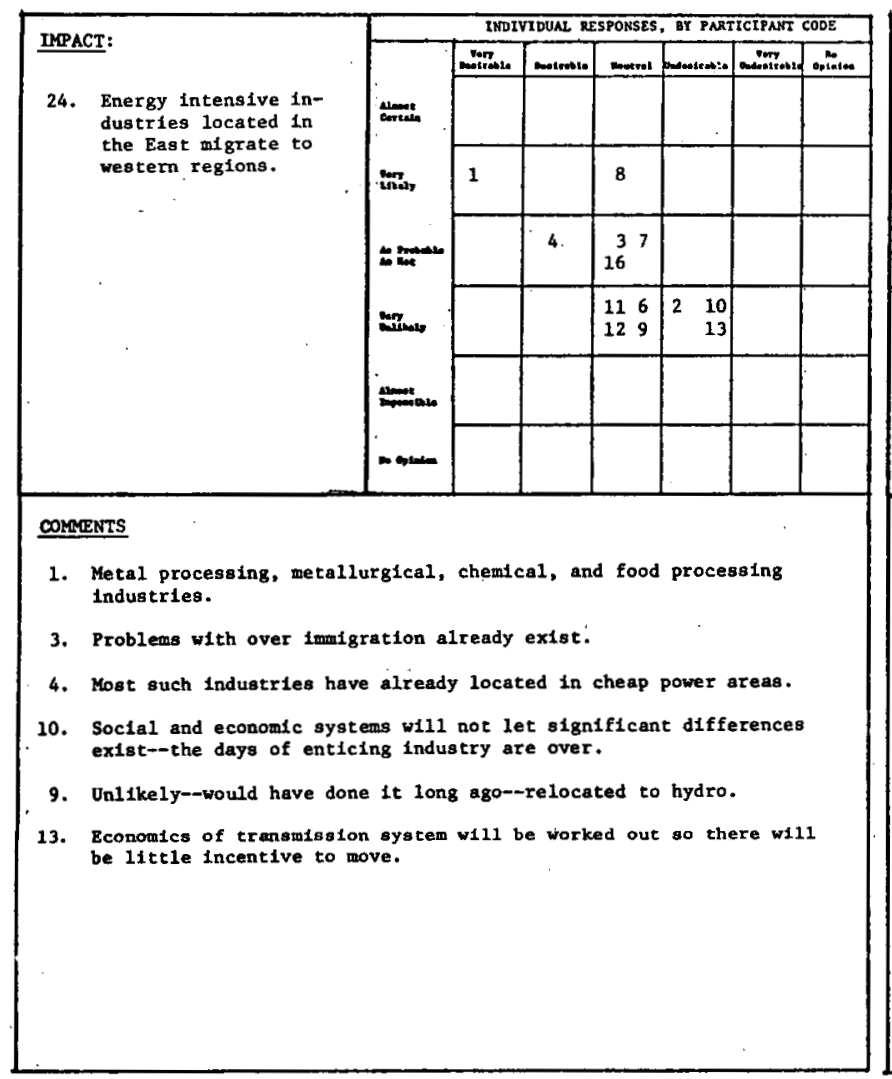

INPACr:

25. Real GNP growth higher than 1t might have been without geotheral powex. (2)

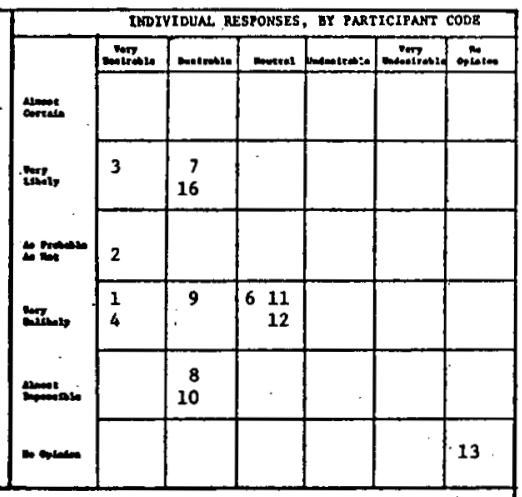

COMMERTS

1. Geothermal will have gradual lmpact but effect will balance off-long-term effect will be mall.

4. Rnergy 19 not the entire factor.

6. Energy cost with geothermal way be less than for other energy sources; this may have a negative effect on GNP.

9. Would be same--wthout geothermal would be other sources--and in addicton, demand will be cut. Sees increase in solar power, substantial increase in nuclear (although limited by terrible expenses), major developments in extraction of coal. Would be chesper to devote costa of developing breeder reactor to coal.

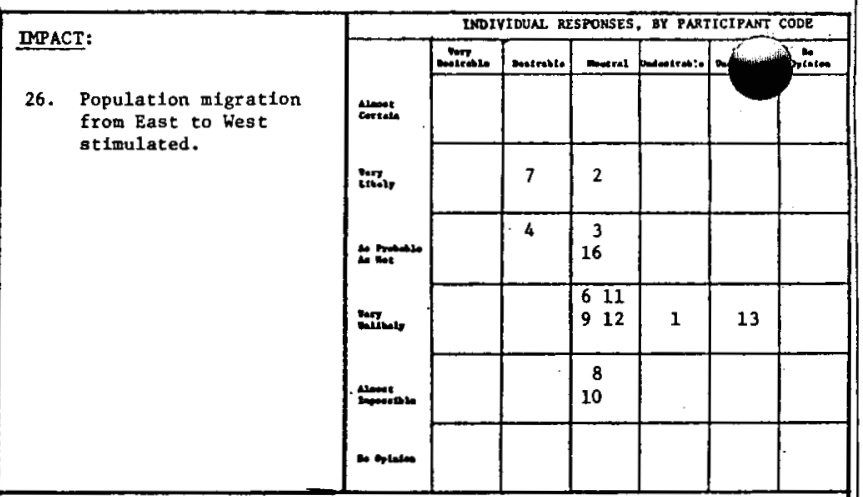

COMENTS

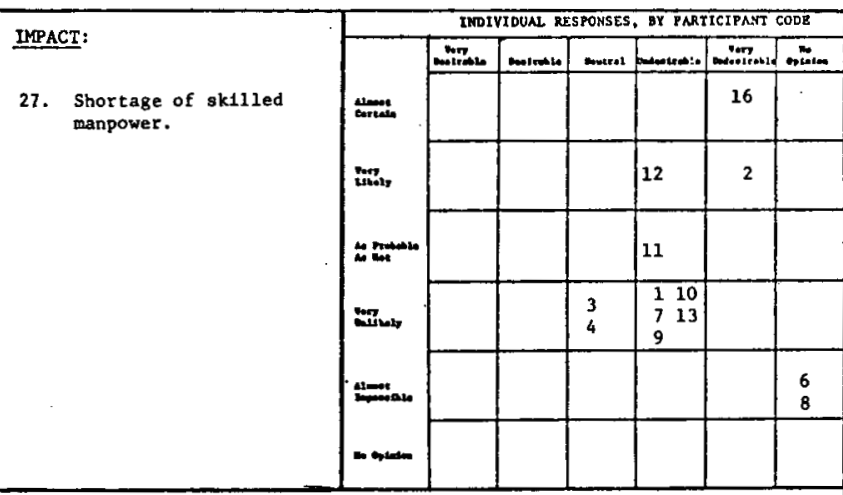

COMERTS

1. No problem for developtent.

2. Shortage in drilling exists now and will get worse. People don't like the rather dirty, difficult work.

3. Geothermal development will be held back by need for skilled labor.

4. Geothermal development will be held back more by shortages of materiala--spectfic supplies needed for energy development.

6. Not peculiar to geothermal needs--8chool enrollments are down in all mineral. fields.

7. Unlikely--will beef up state mining schools--enrollment has been dec1ining.

10. No shortage--don't need wany--not enough geothermal drilling.

12. Now great shortage, but word getting around that people are needed.

16: Almost certain shortage of geothermal experts--will be significant la In train1ng which will make development wore confused. Should support colleges with geothermal programs.

9. Publie ut111ty 13. Environment and reoearch

$\begin{array}{ll}\text { 10. Covernisent--1egiolative 14. Private Industry } \\ \text { i1. Public utility } & \text { 15. Private Induatry }\end{array}$

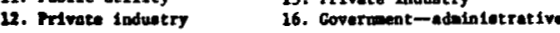




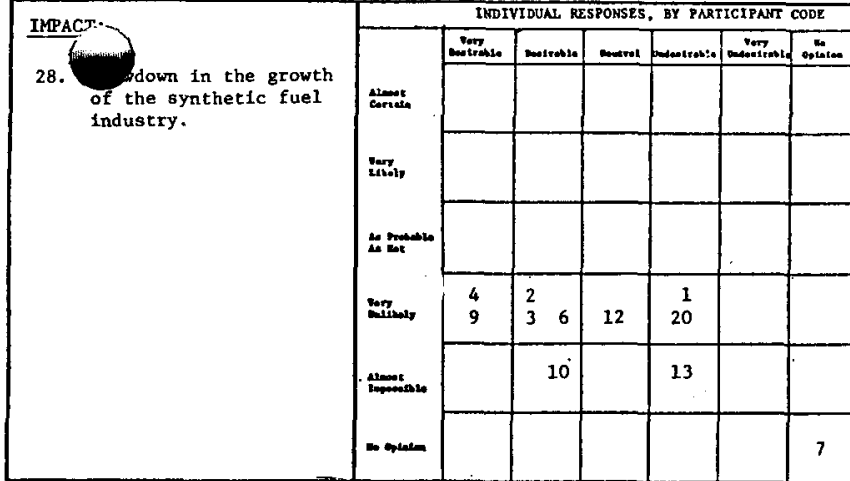

COMGNTS

1. Geothermal will not compete.

3. Need exists to expand every source of energy.

10. Absolutely no possibility--government st1mulus to coal-gas plants-growth will be staggering.

11. Undesirable development if synthetics are to be used for electricity.

12. Undestrable and unlikely--will continue to grow--we need everything.

16. Geothermal won't have any effect on this.

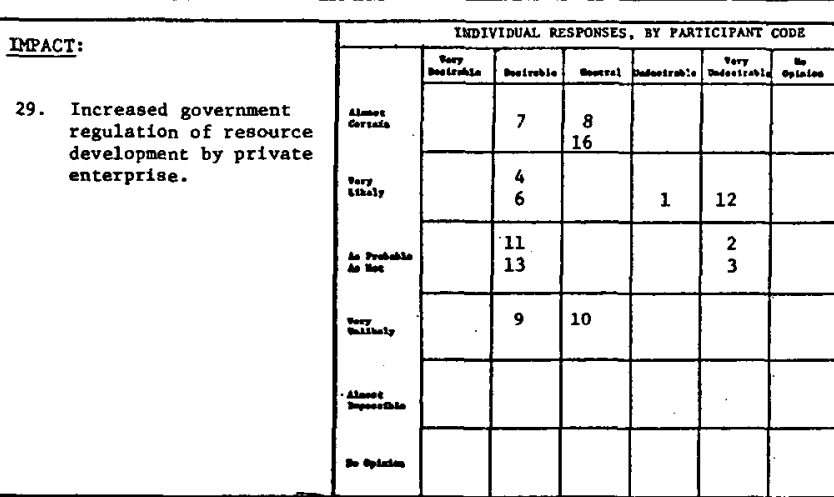

COMAENTS

1. To protect environment, fine; but not to inhibit growth. Regulation, ab now seen, will inhiblt growth.

3. Too many federal and state bills dealing with regulation--too many county ordinances.

4. Private Induatry won't regulate 1toelf. Social pressures will bring about controls due to industry's unwlilingness to do the job itself.

6. Federal goverment 1s hindering geothermal development up to now. Has tried to get maximum return on 1 ts land. It has taken too long to prepare 1mpact statements. Government now suing to reclaim minera rights, and this uncertainty will prevent speculation and development. Favor a central energy group which can look at whole problem to

balance government's role as a landlord, and Its role as an encourager of energy development. Need to make it possible for small companies to bid through staggered aystem-not have to pay entire bid amount at delivery of lease.

9. Geothermal only small factor.

10. This is the trend--but not because of geothermal.

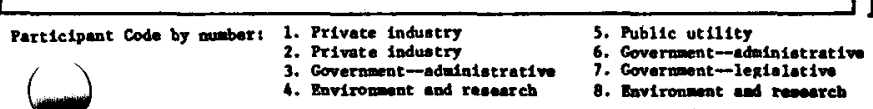

Partieipent code by number: 1. Private industry
2. Private industry

3. Government-Dduiaistrat1

Goverament--administrat1

. Coverwont-iexiolative
COMENTS (Cont.)

16. Almost certaln--desirablifty depends on kind of regulations. Need one-stop sporovel for projects. Leasing system absurd. Government needs knowledge of what activities are underway.

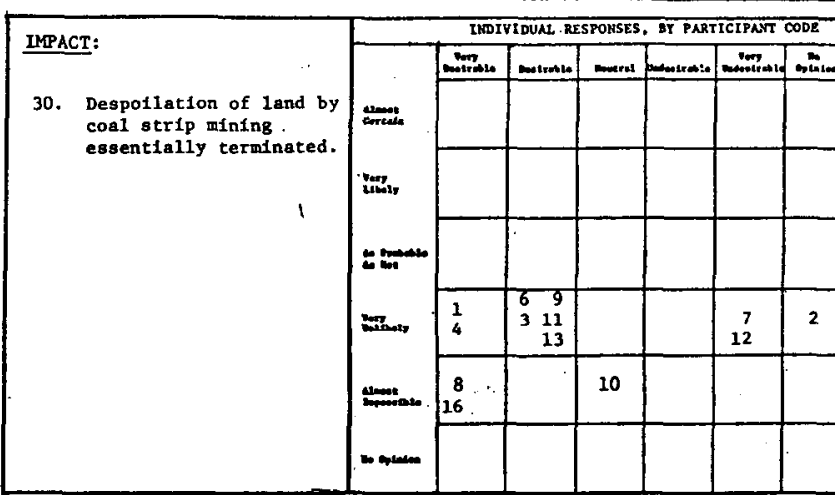

COMENTS

10. No, it is essential to get a lot of coal out.

11. Very 11kely-but geothermal will have 11ttle to do with it.

12. Undesirable and very unilkely-will develop environmentally acceptable practices. Can't see any source of energy neglecteddemand so strong that all are needed.

13. Will be teroinated regardless of geothermal-will continue to strip mine but w111 alleviate effects.

\section{Publie utility \\ 10. Covernuent--legiolative \\ 13. Epvi roment and resenrch \\ 15. Private 1nduetry} 11. Private induetry

15. Private 1aduotry
16. Covernant-adnin 1ot rative 


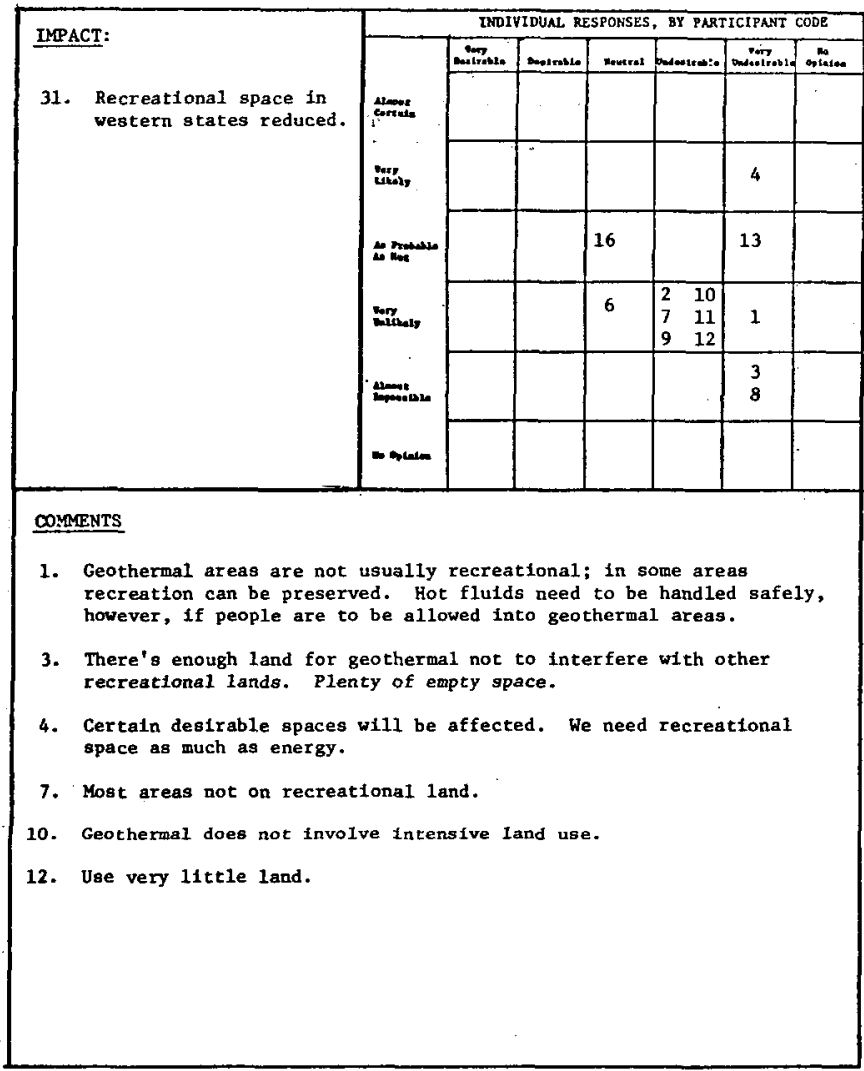

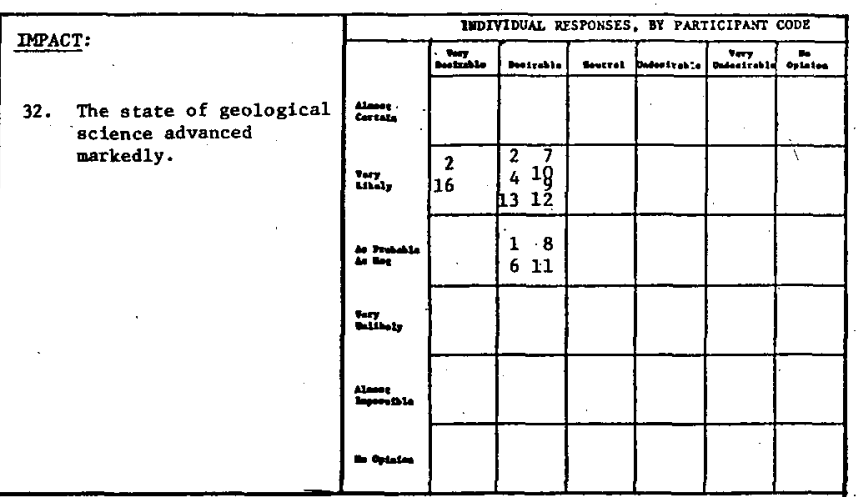

DOMENTS

3. Need for geological research. Where is heat coming from? Where is water coming from?

4. Significant things will be leamed about the crustal composition of the earth.

10. Geothermal only one of pressures to advance knowledge.

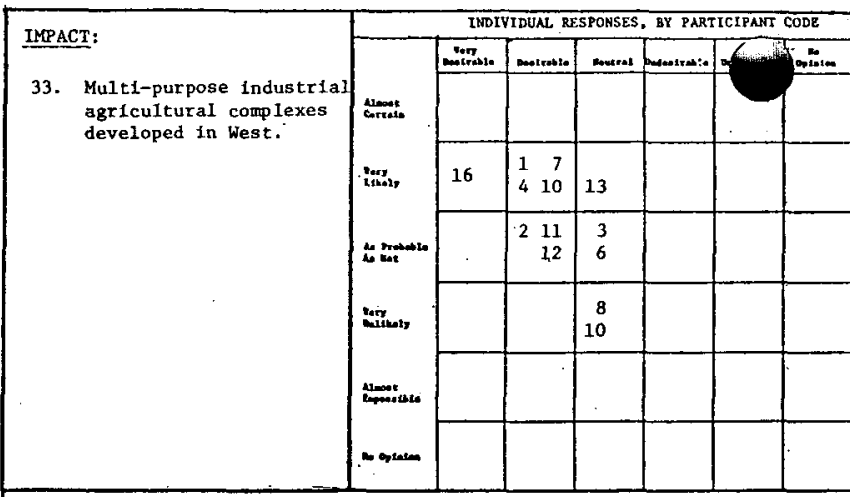

COMMENTS

3. If desalintzation problem is solved, Imperial valley could go this

6. Geothermal resources not generally in agricultural locations (Imperial Valley an exception).

10. Unlikely--not a significant water source.

12. Can be compatible with agricultural uses--grazing or crops. Cows grze at Geysers.

13. W111 develop regardleas of geothermal.

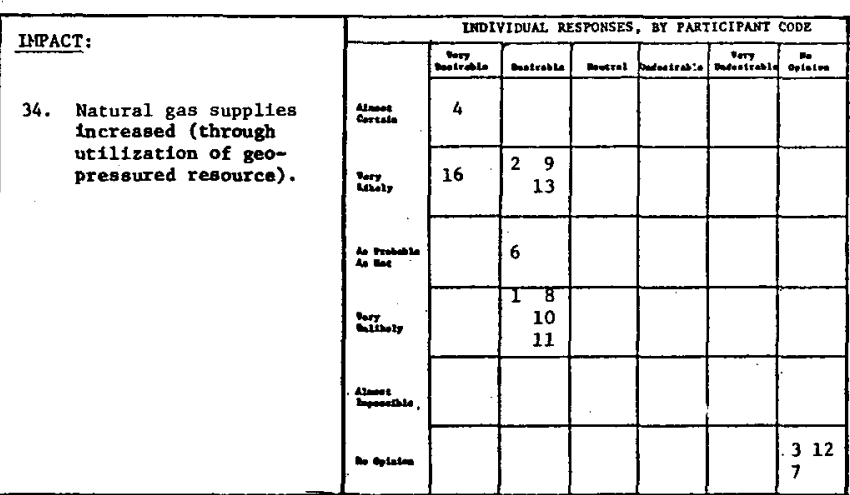

COMENTS

4. Potential effects of geopressure offshore blowouts "horrendous." Geopressure theory attractive. Marine 1 ife must be preserved, and hence fears are aroused by private industry turned. 10ose offshore.

10. Posalbly gas won't be avallable from geopressured sources--may burn it along with geothernal heat in on-site electrical plant.

11. Very inlikely in timeframe.

12. Nothing done yet in geopressure.

16. Disparity of oplnion on prospects for geopressure.

9. Public ut111ty

13. Environment and research

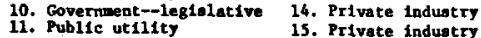

12. Private Industry 


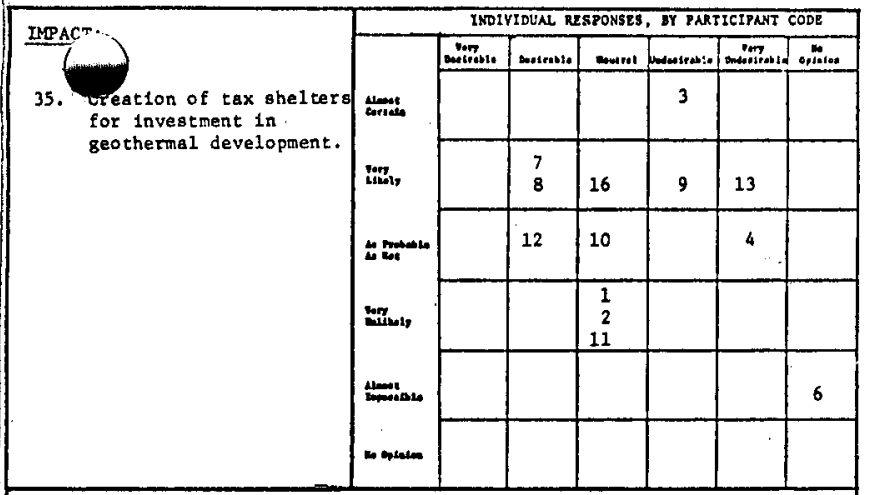

COMMENTS

1. Tax she1ter not the way to go.

3. B1g companies don't use them much. It means more regulations. It might encourage smaller companies--encourage drilling, not nece sarily discovery, aince indiscriminate activity wight result.

6. Subsid1es are generally given to "rrsong" people--they are not really productive.

10. In normal times this would be natural development--but now public attitudes are against it.

12. Tax incentives are needed for development.
IIPACT:

36. Formation of many new federal, state, and muntcipal agencles to oversee geothermal resource development.

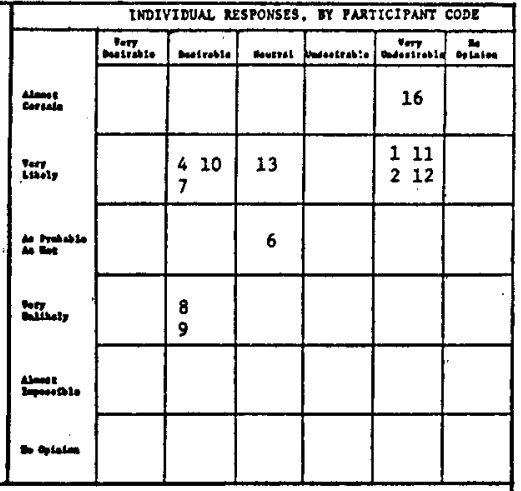

COMENTS

1. Only 50 percent of time 18 creatively used now because of th1s.

3. Constant legiolation is appearing proposing this. But there are too many against right now.

4. Desirable by necessity. Would 11ke to see reduction of number of agencles involved, but skeptical that one b1g agency can be in agencles lnulved, but akeptical that one big agency can be exploitation.

7. Degirable to have new overall agency--but not many.

10. Federal goverment has plenty of agencles. There will be overall reorganization of federal agencles-w111 take care of geothermal. reorganization of federal agencies--will take care of geothermal. (Defining geothermal as a unique resource 18 the easiest way to if follow water and mineral laws in the West will have a mess. Need new body of lsw.) Pederal Government will pre-empt environmental fleld--local agencles will have little to say--also continued state pre-emption of local federal constralnts will operate through grants.
a1r and water regulations. Reduced latitude very pronounced in whole a1r and water

12. Very 11kely but undesirable--already too many agencles. There is mors and more desire to regulate industry. Would 1ike to see trend reversed.

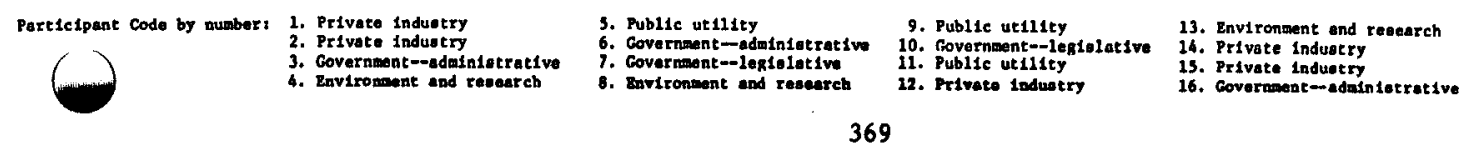


A RELEVANCE TREE OF PRIMARY AND SECONDARY IMPACTS

As pointed out in Appendix B, the use of relevance trees was important to several tasks in the study. Not only was this approach useful in exploring and describing the content of geothermal technology, it was also used to explore and describe higher order Impacts. Eight primary Impact areas constituted the top level of the tree; these elght areas are presented below. The remalnder of the tree was devoted to a detailed elaboration of the consequences within these prime impact areas.

Figure D.1 summarizes the general framework by which this analysis was conducted, and the tree itself is presented on the following pages.
OBJeCtive: Define the "IMPACt SPACE" flowing from the EVOLUTION OF GEOTHERMAL ENERGY IN THE UNITED STATES.

\section{RELEVANCE INTERROGATION}

LEVEL I WHAT ARE THE PRIMARY IMPACt AREAS?

II WHAT ARE THE PRIMARY IMPACTS WITHIN THESE AREAS?

II I WHAT ARE THE SECONDARY IMPACt AREAS?

IV WITHIN THESE AREAS, WHAT ARE THE SECONDARY IMPACTS?

$\checkmark$ WHAT TERTIARY IMPACTS FLOW FROM THESE?

F1gure D.1 IMPACT RELEVANCE TREE

D.1

GEOTHERMAL ENERGY IS NTRODUCED PER THE SCENARIO-WHAT EFFECTS WILL FOLLOW?

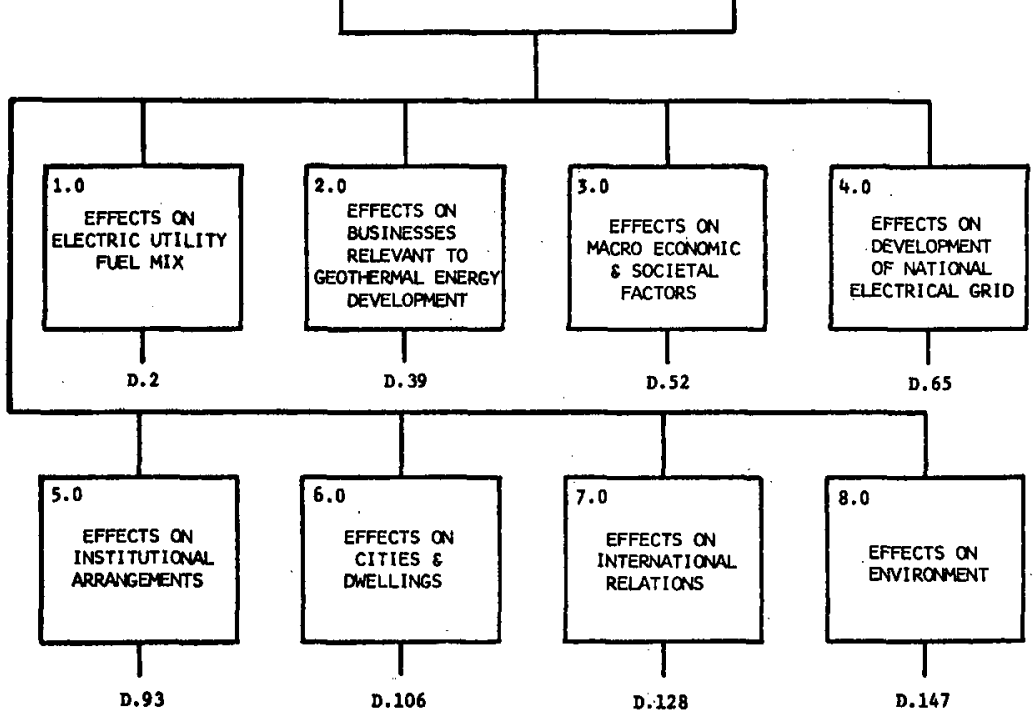



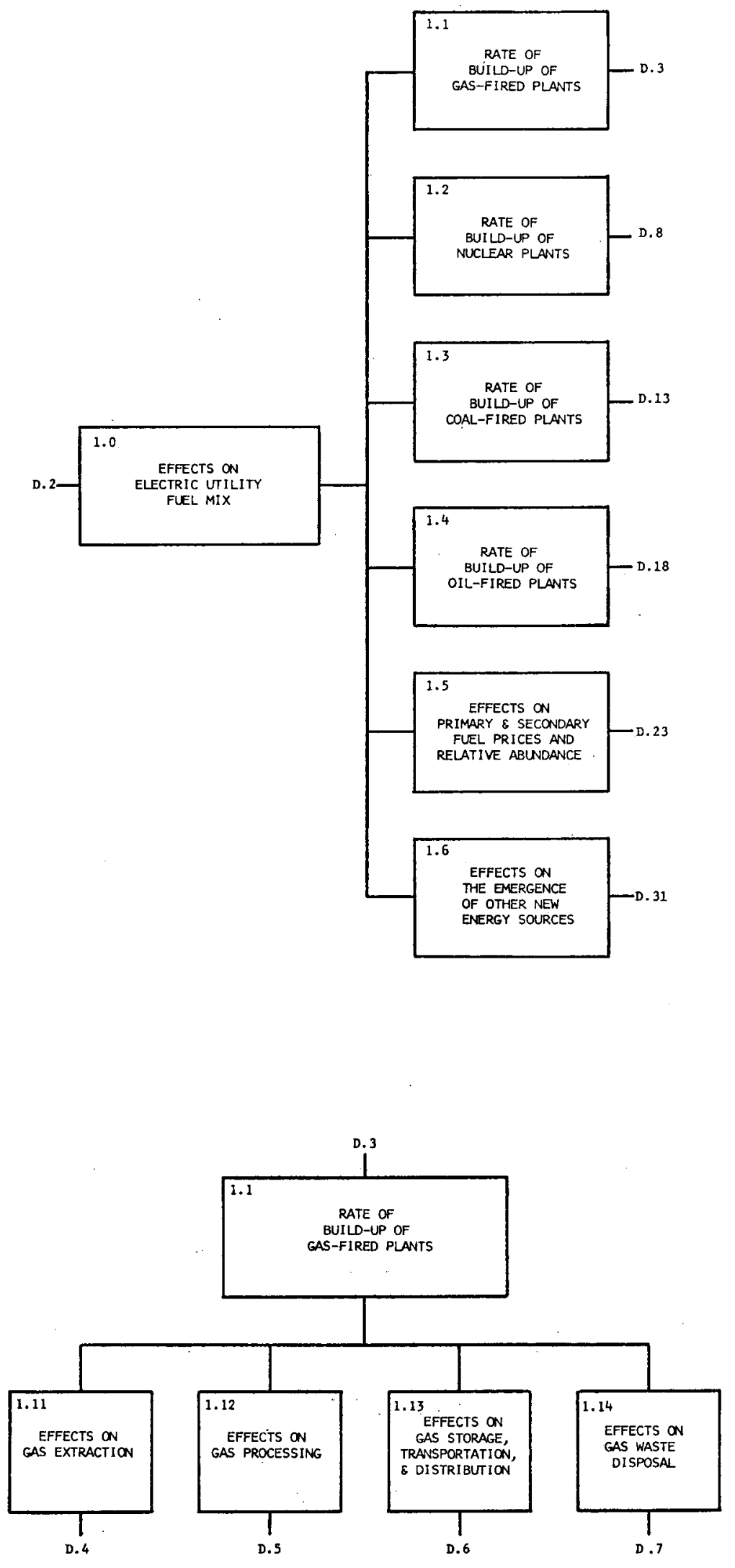

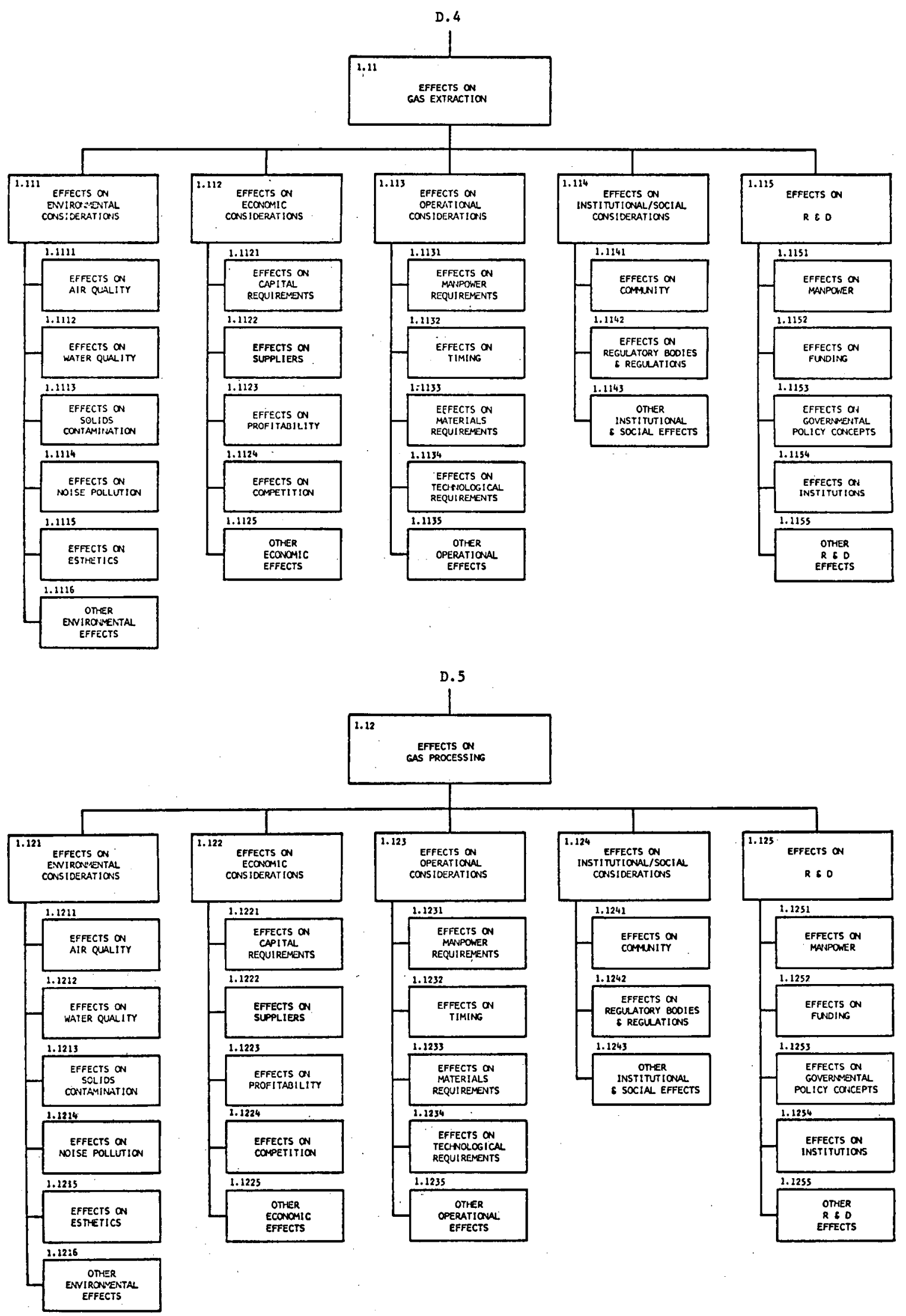


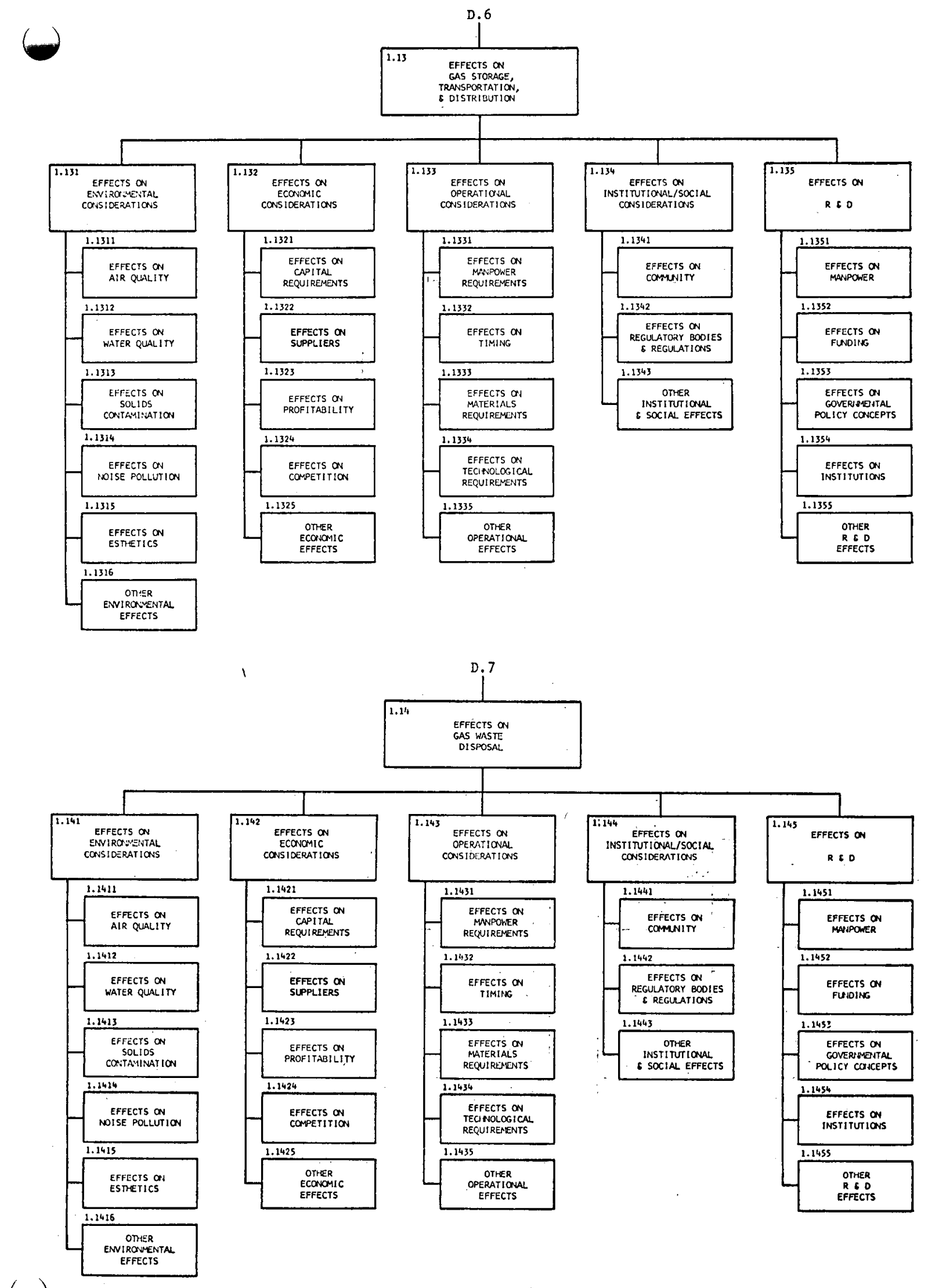



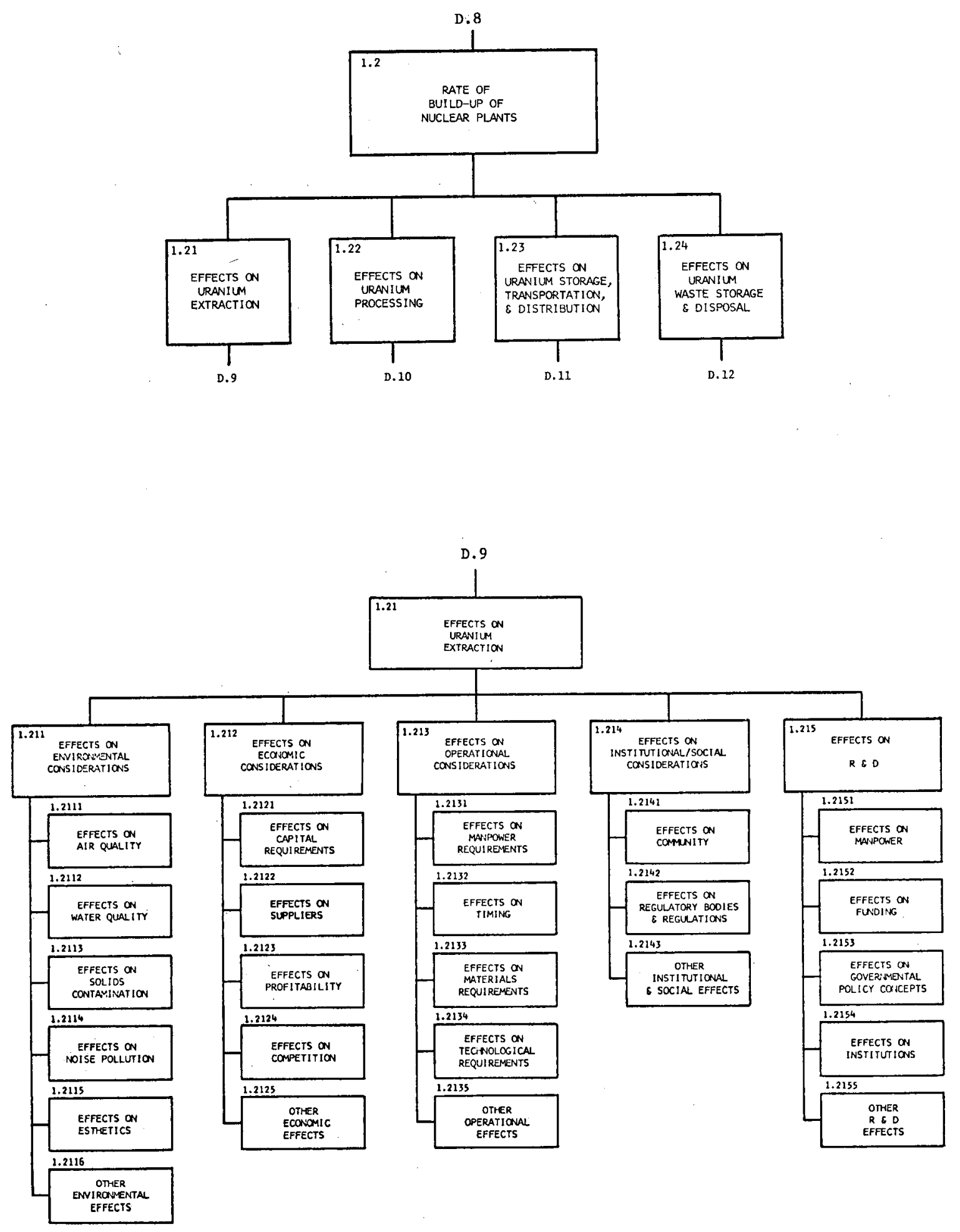


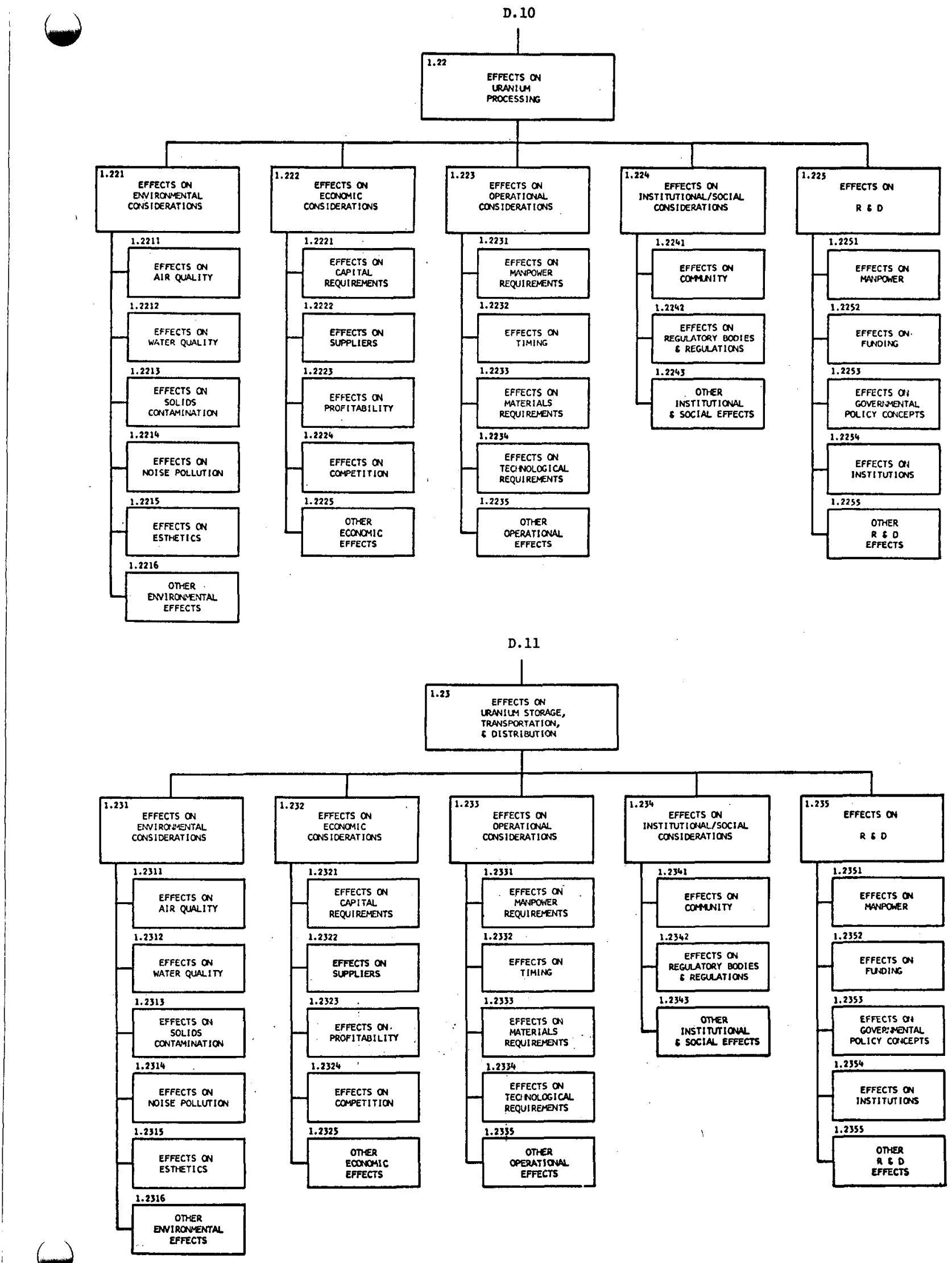



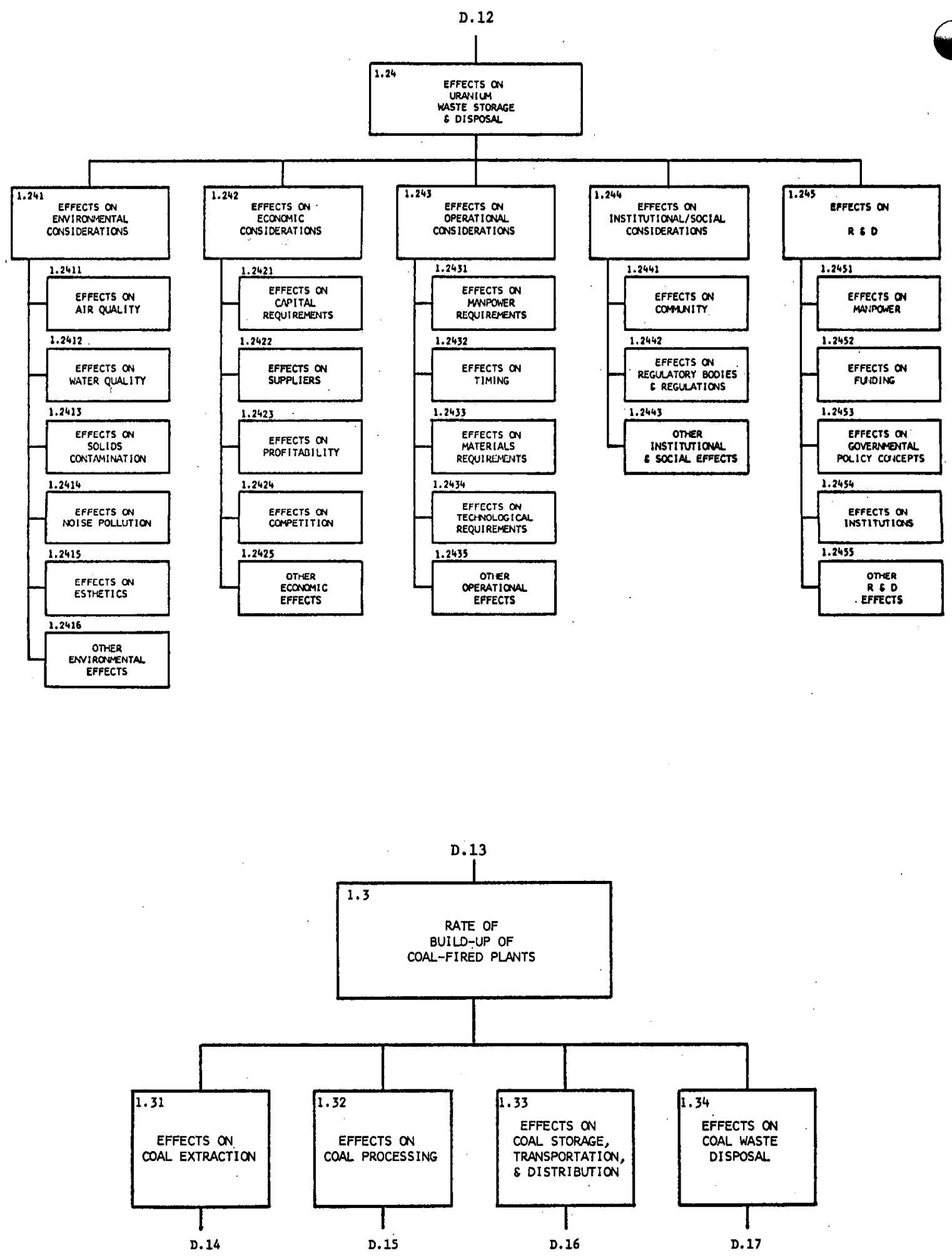

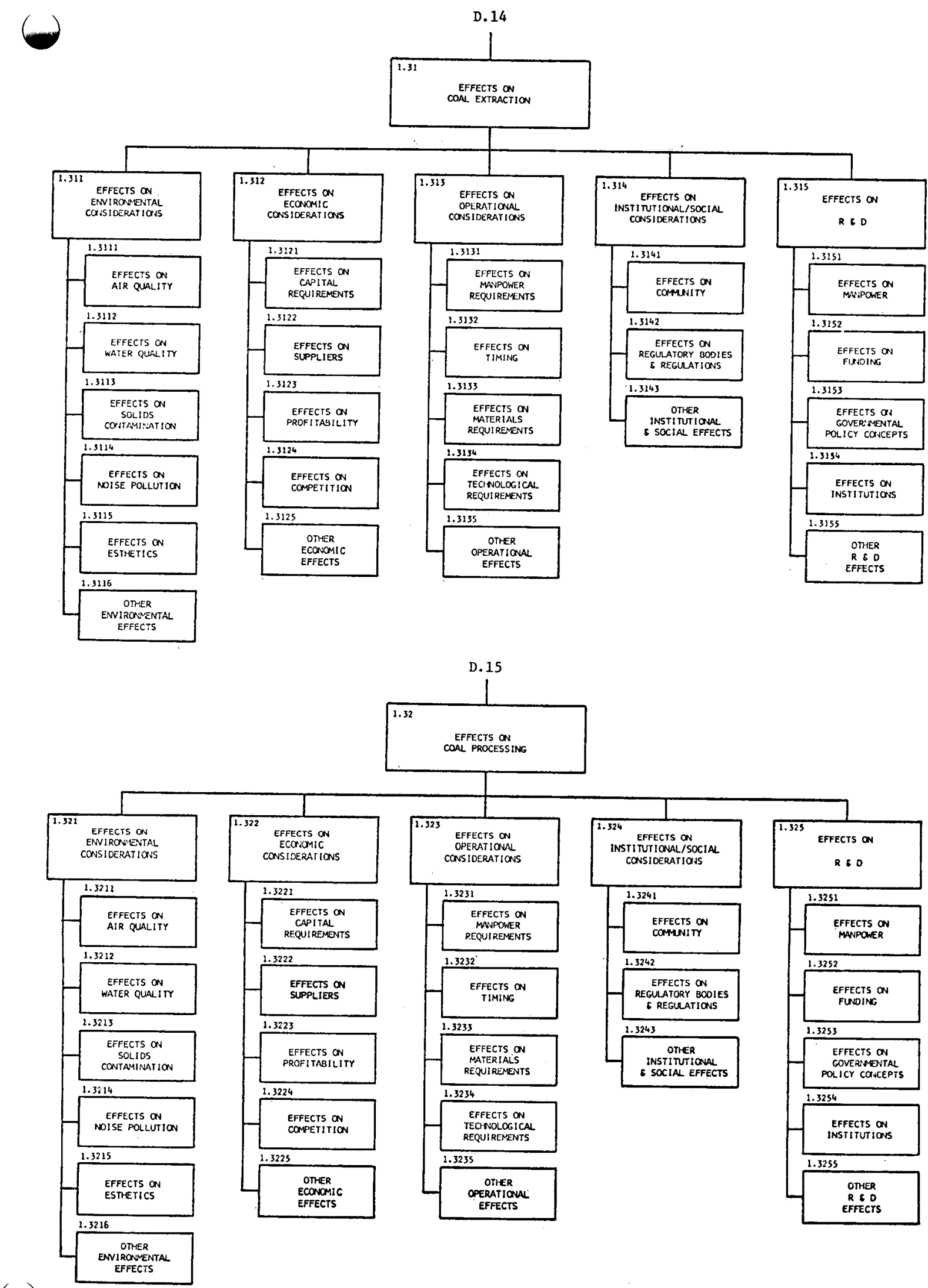

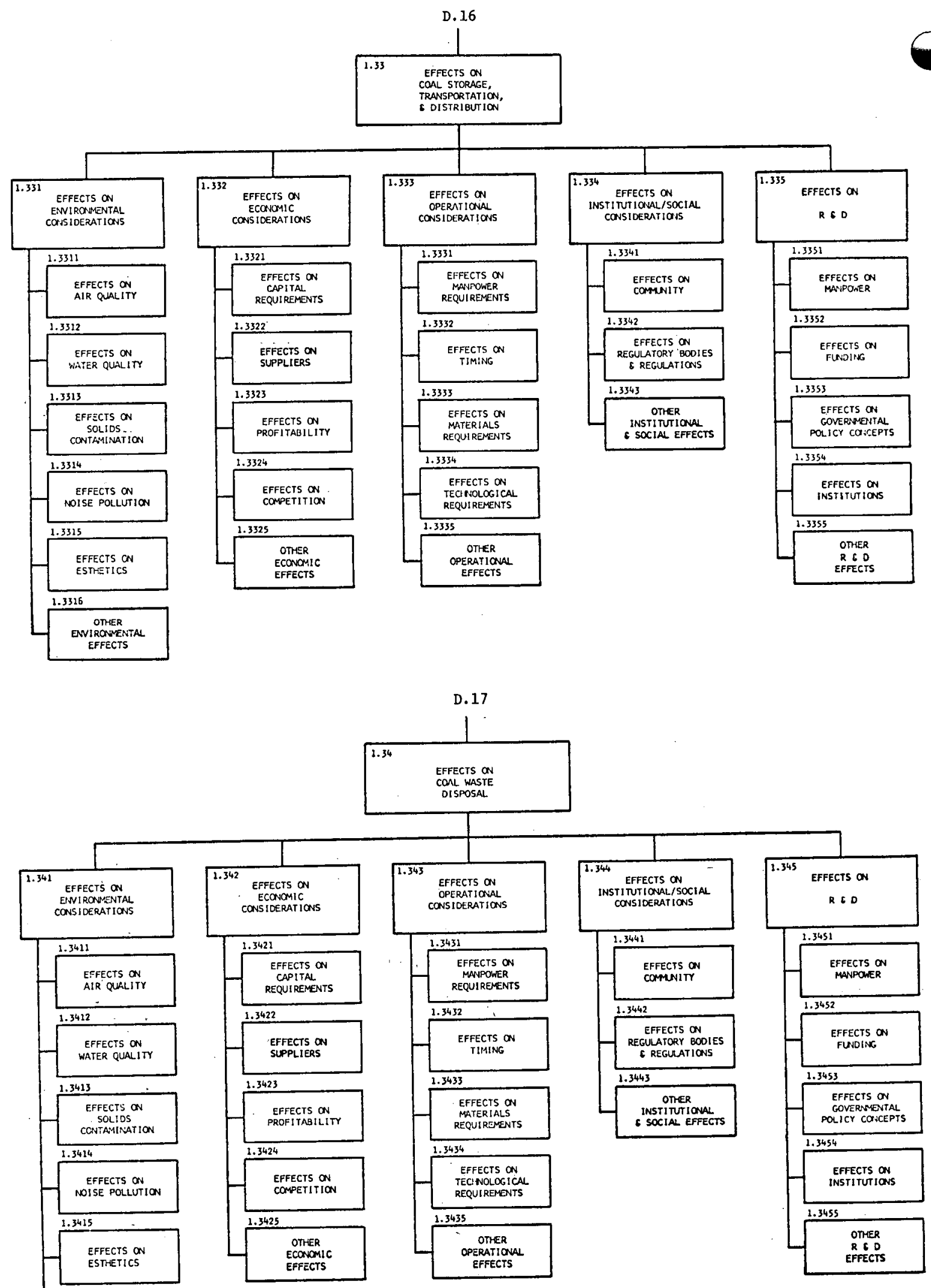

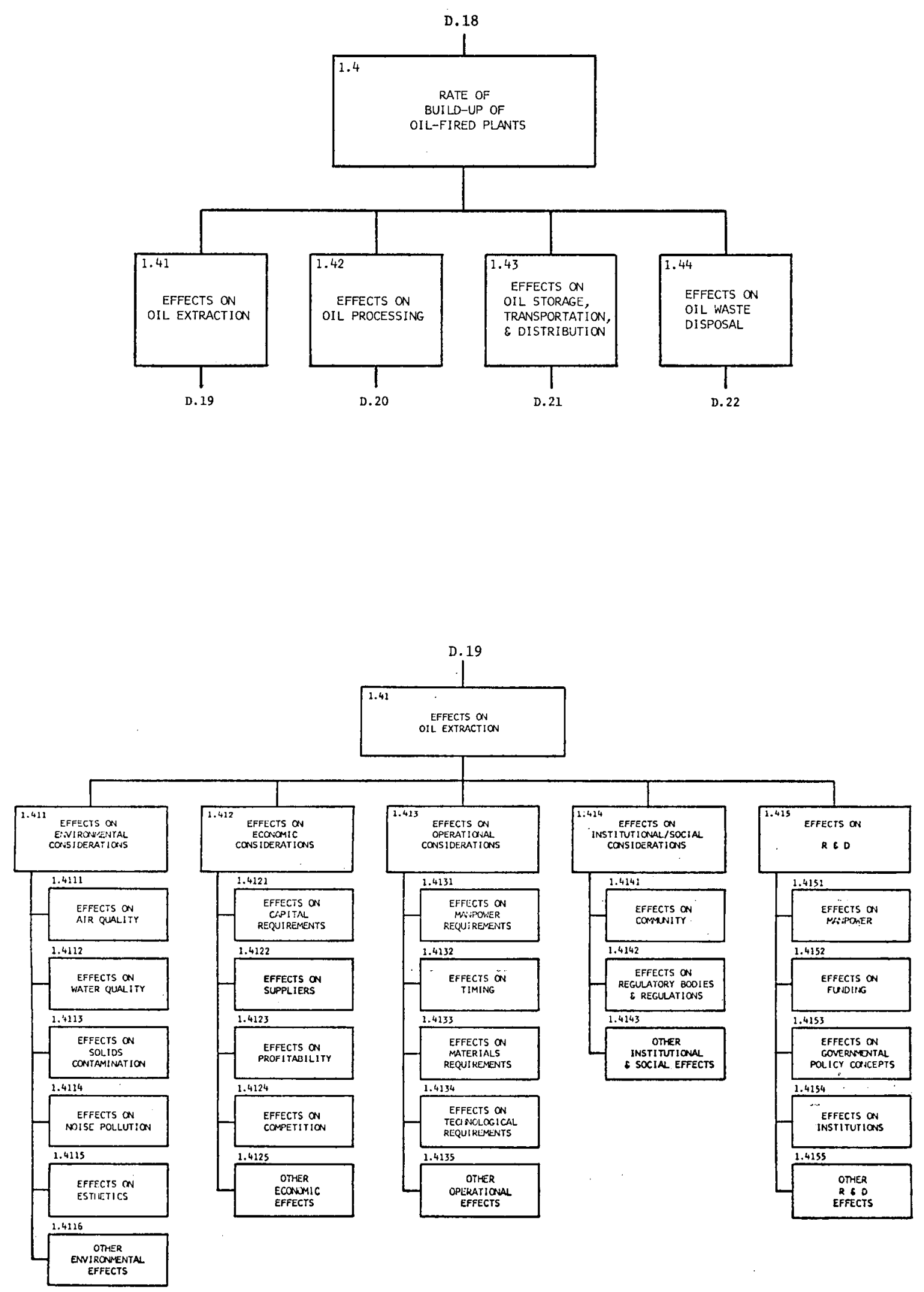

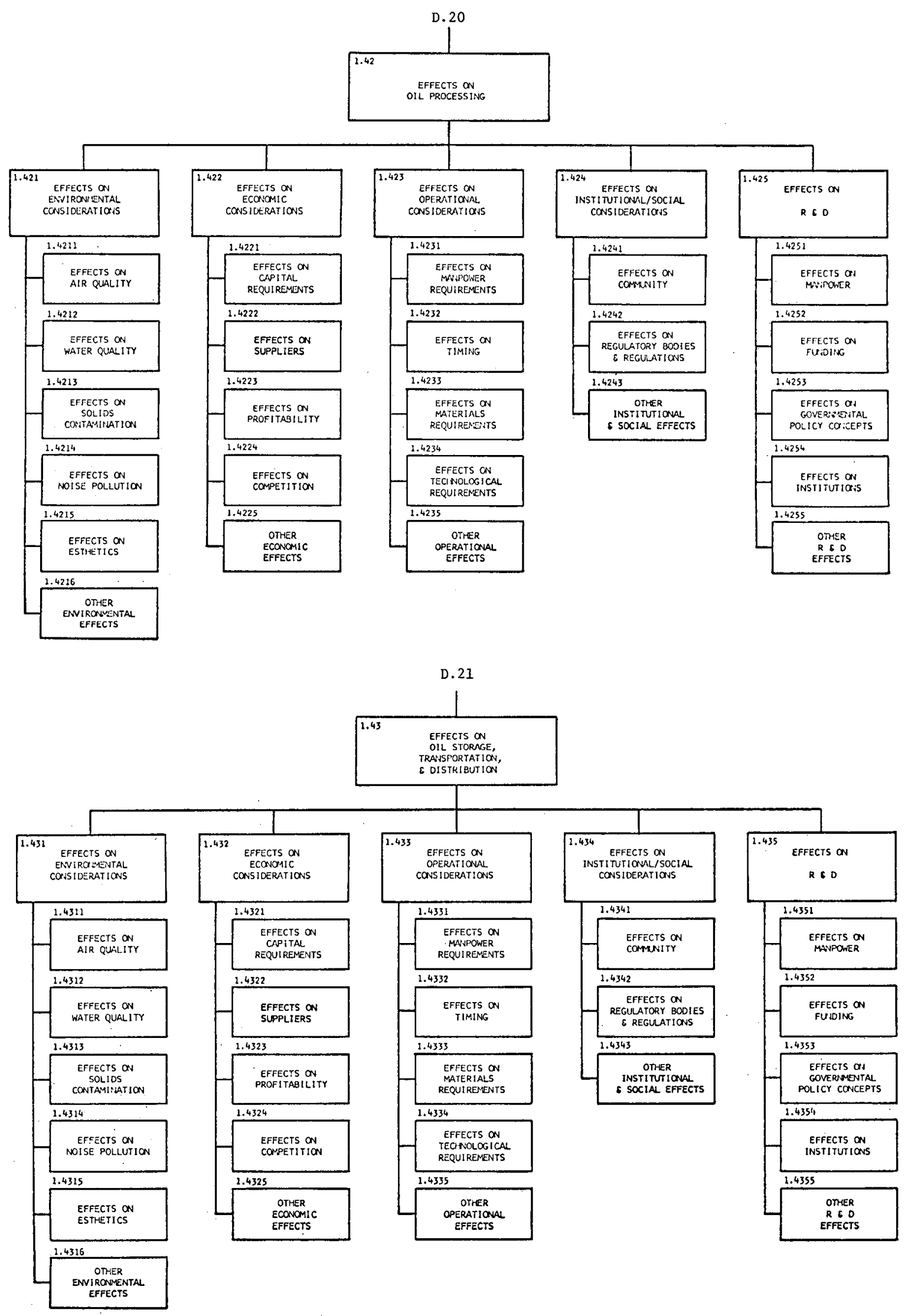


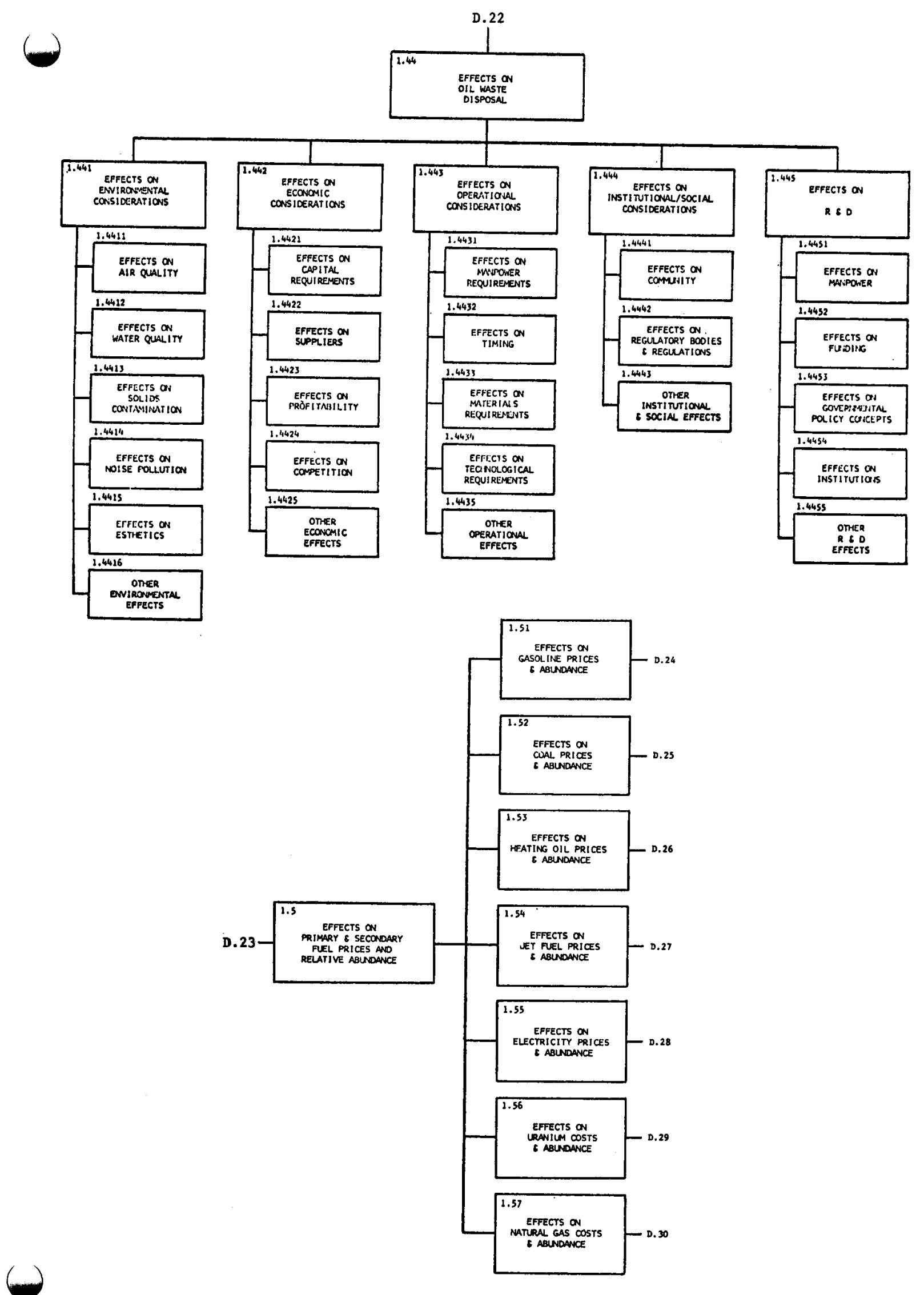




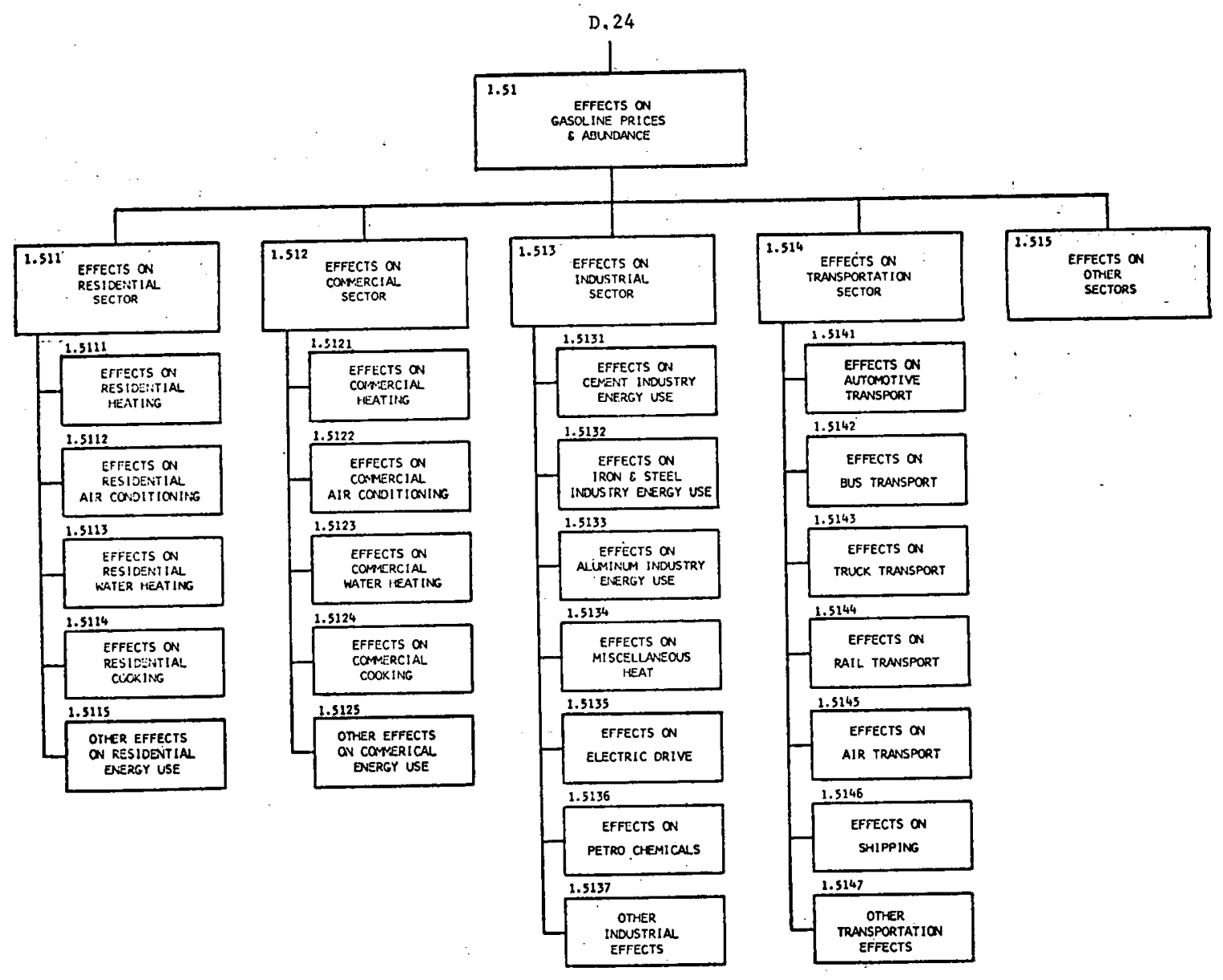




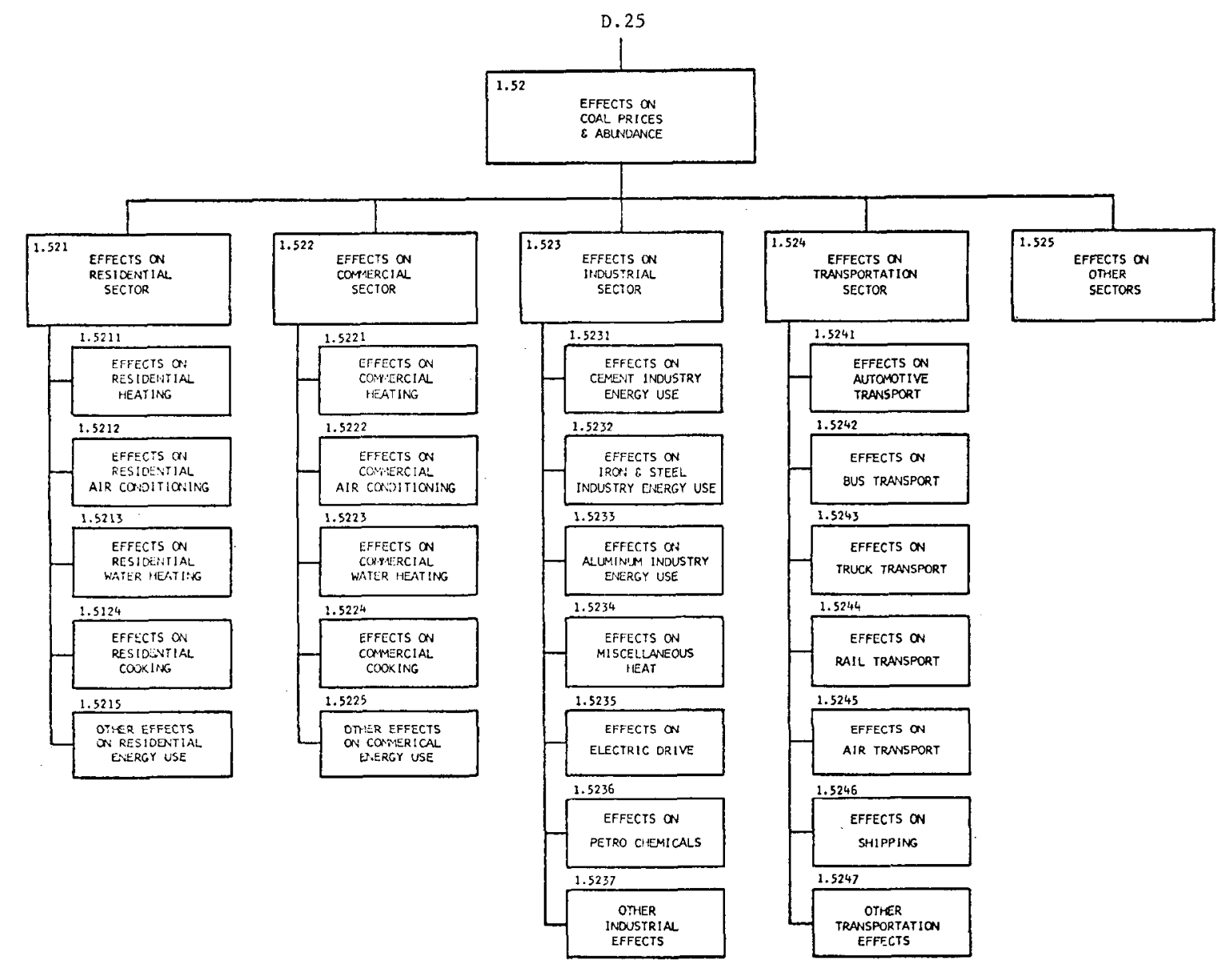




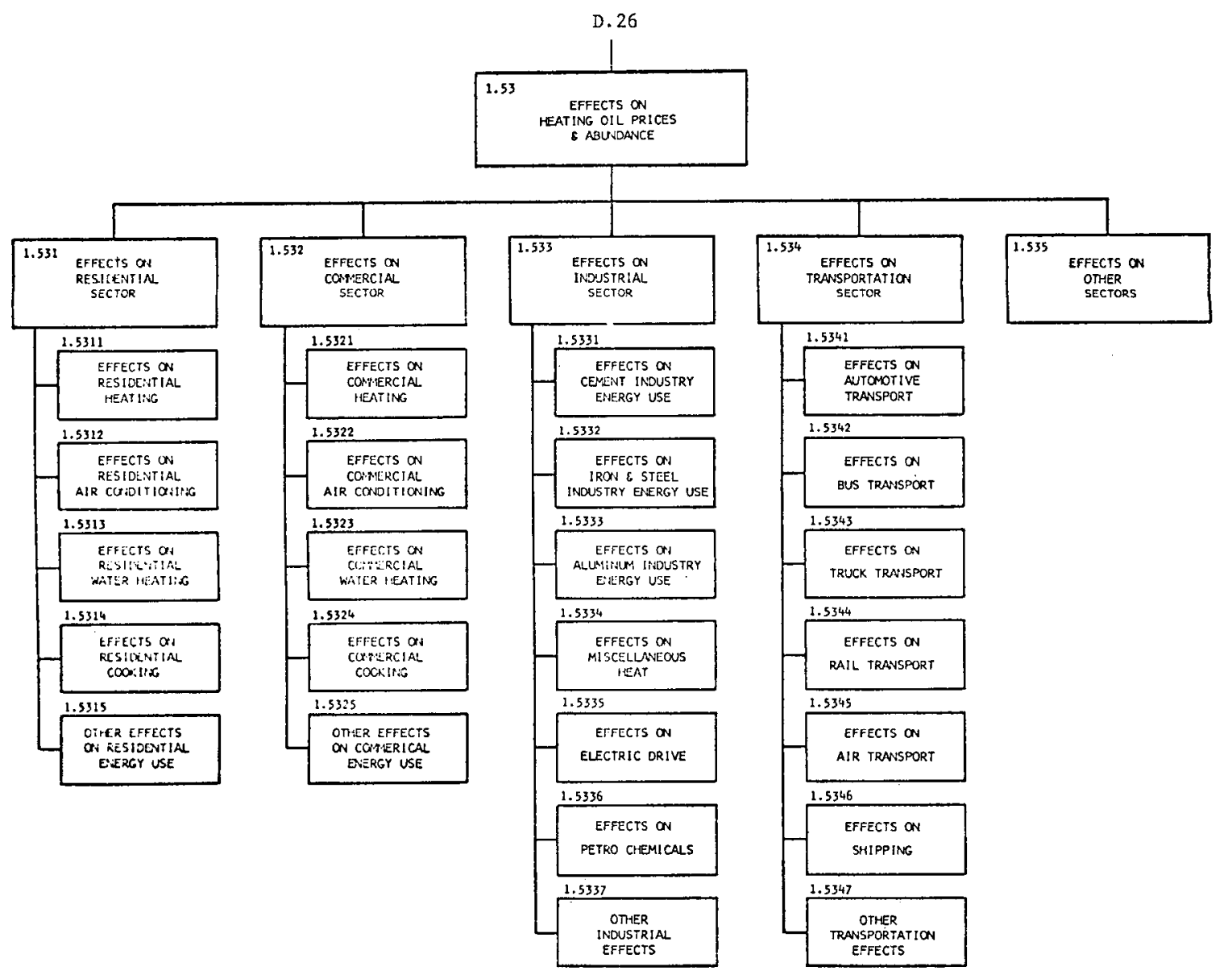




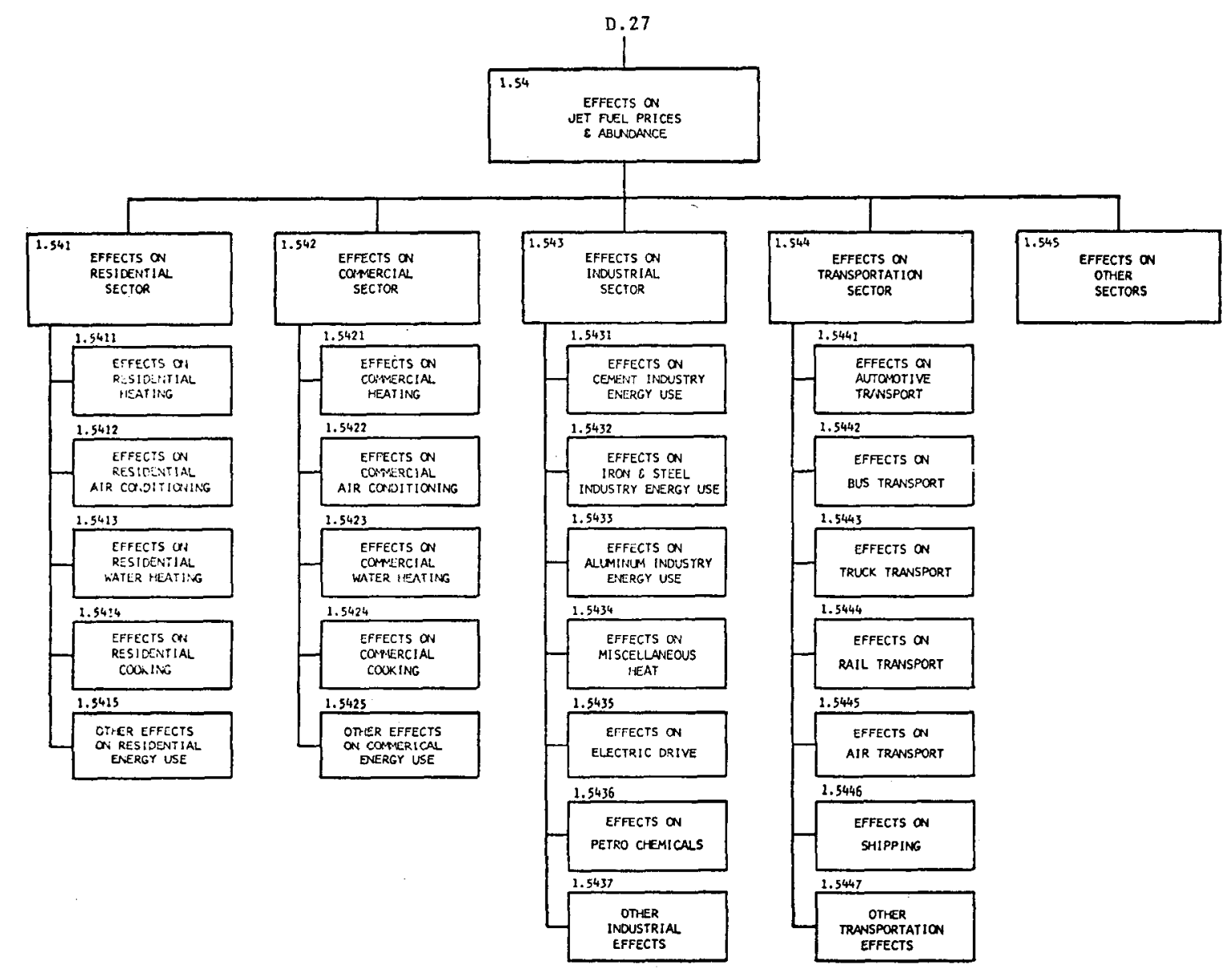




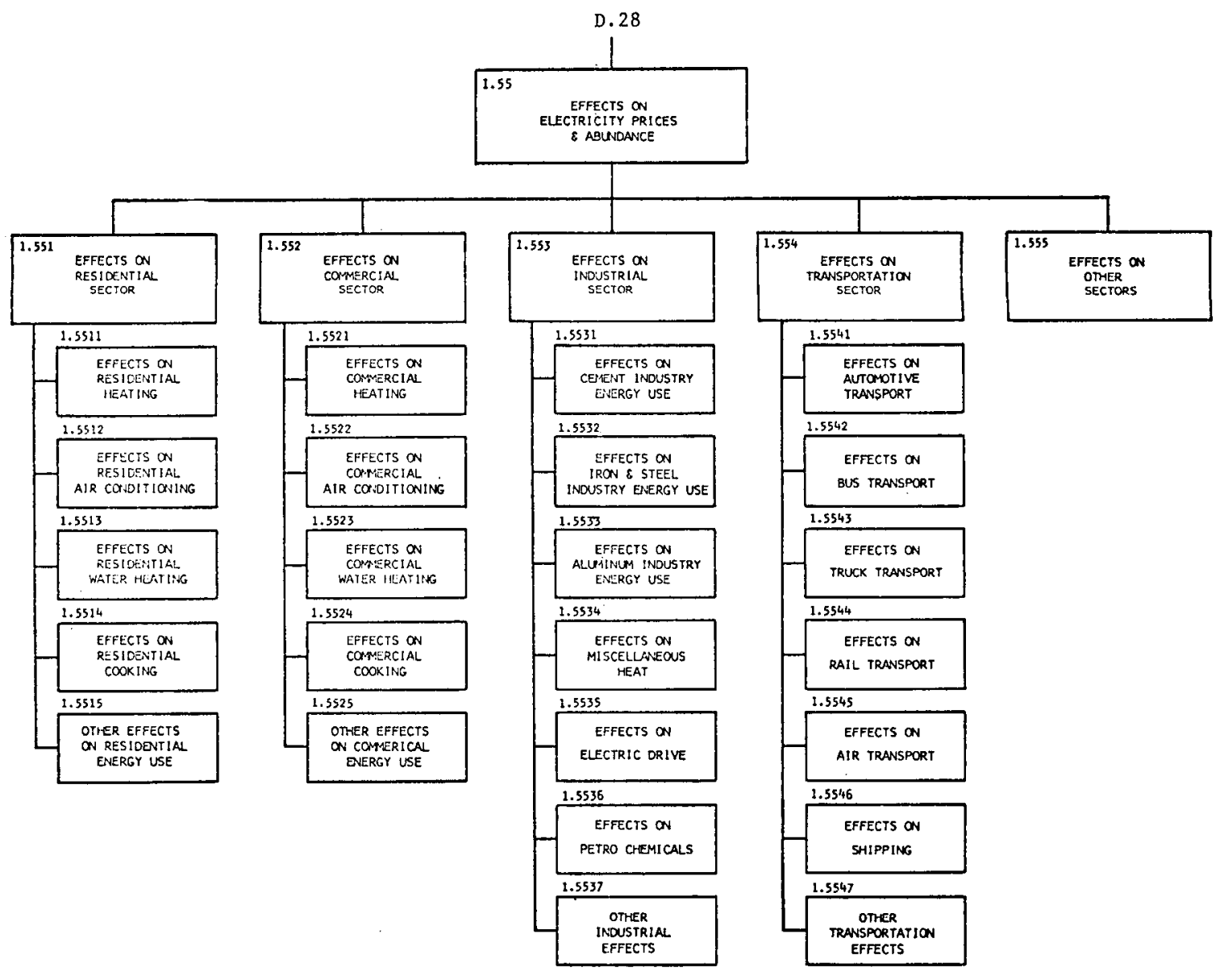




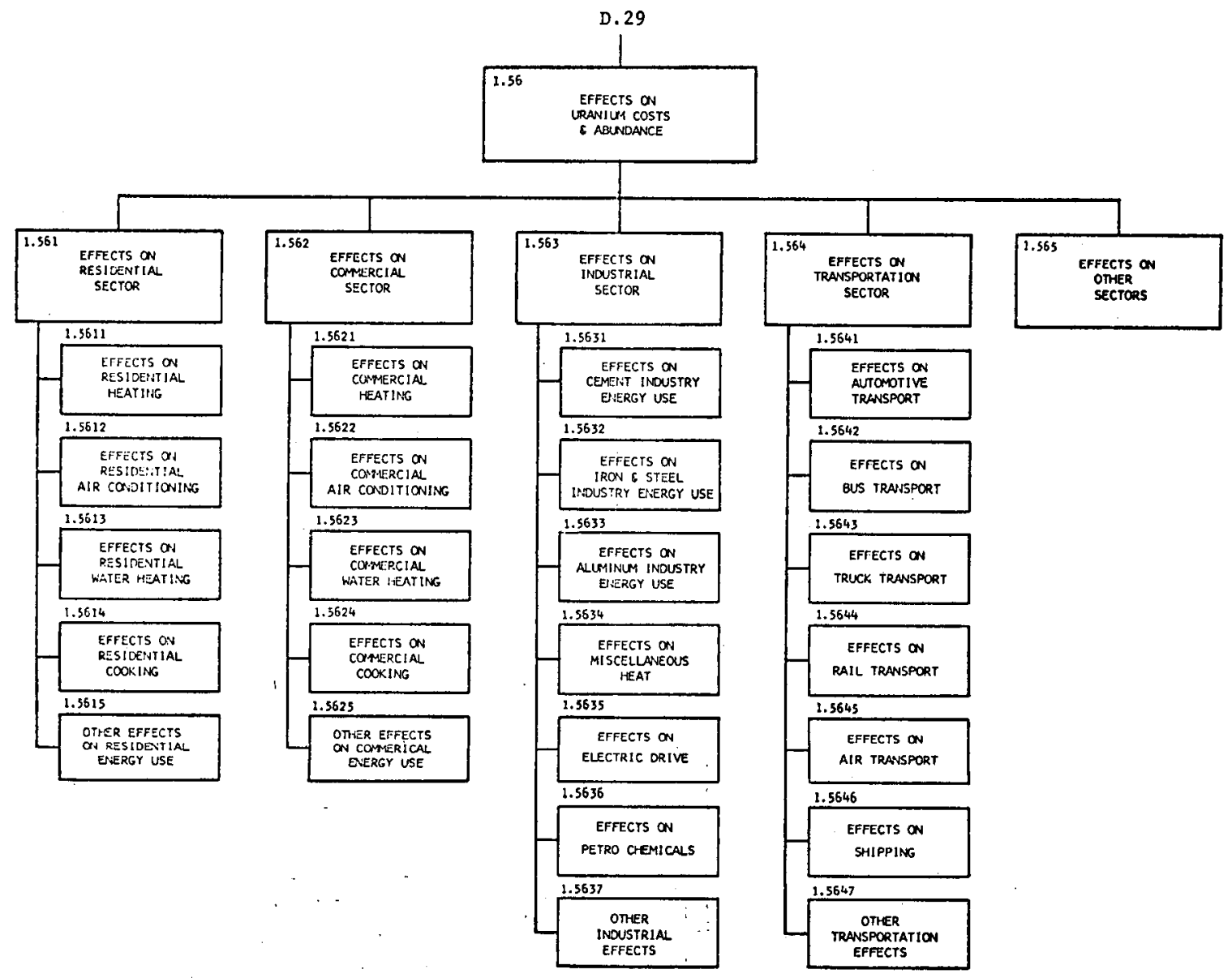




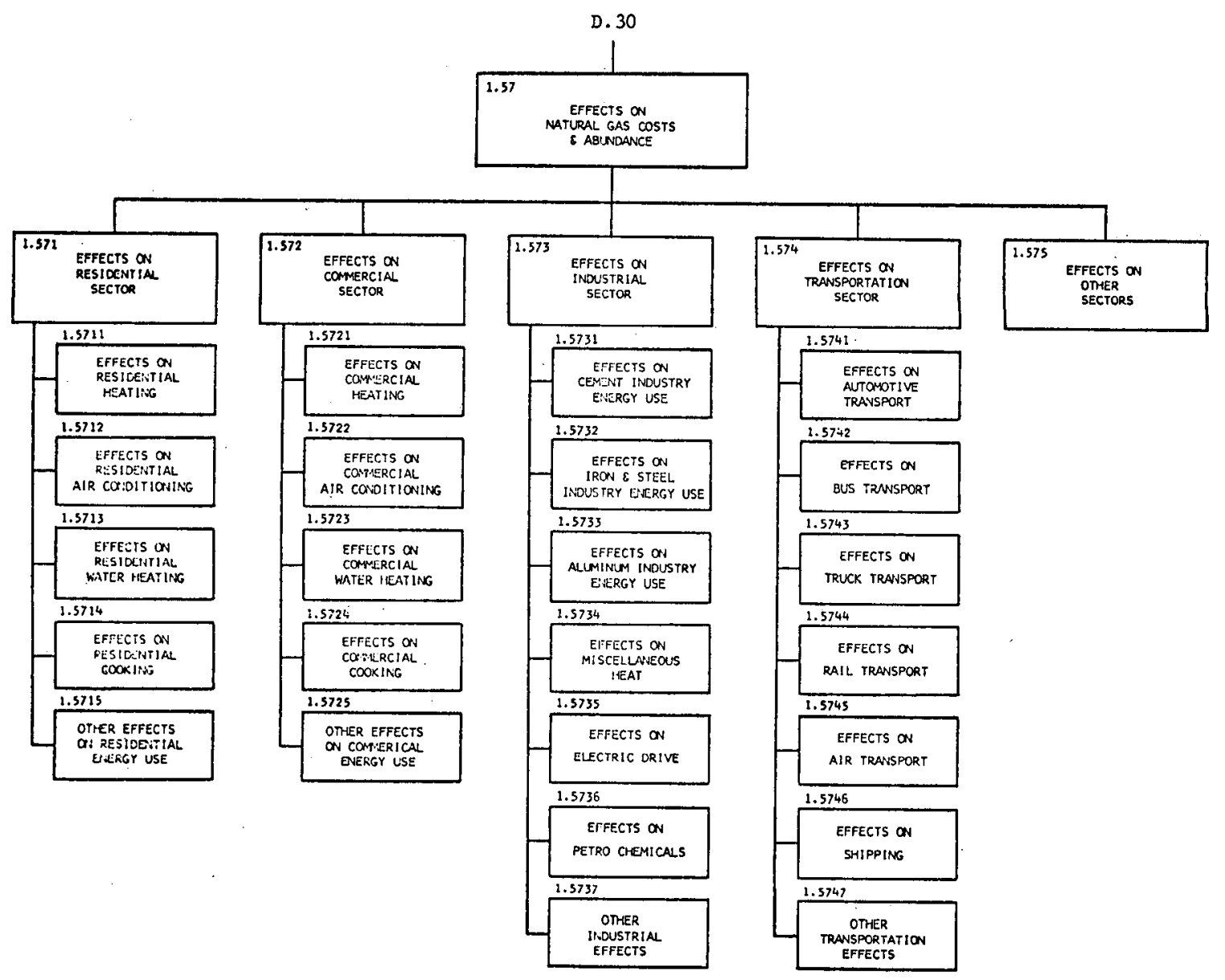




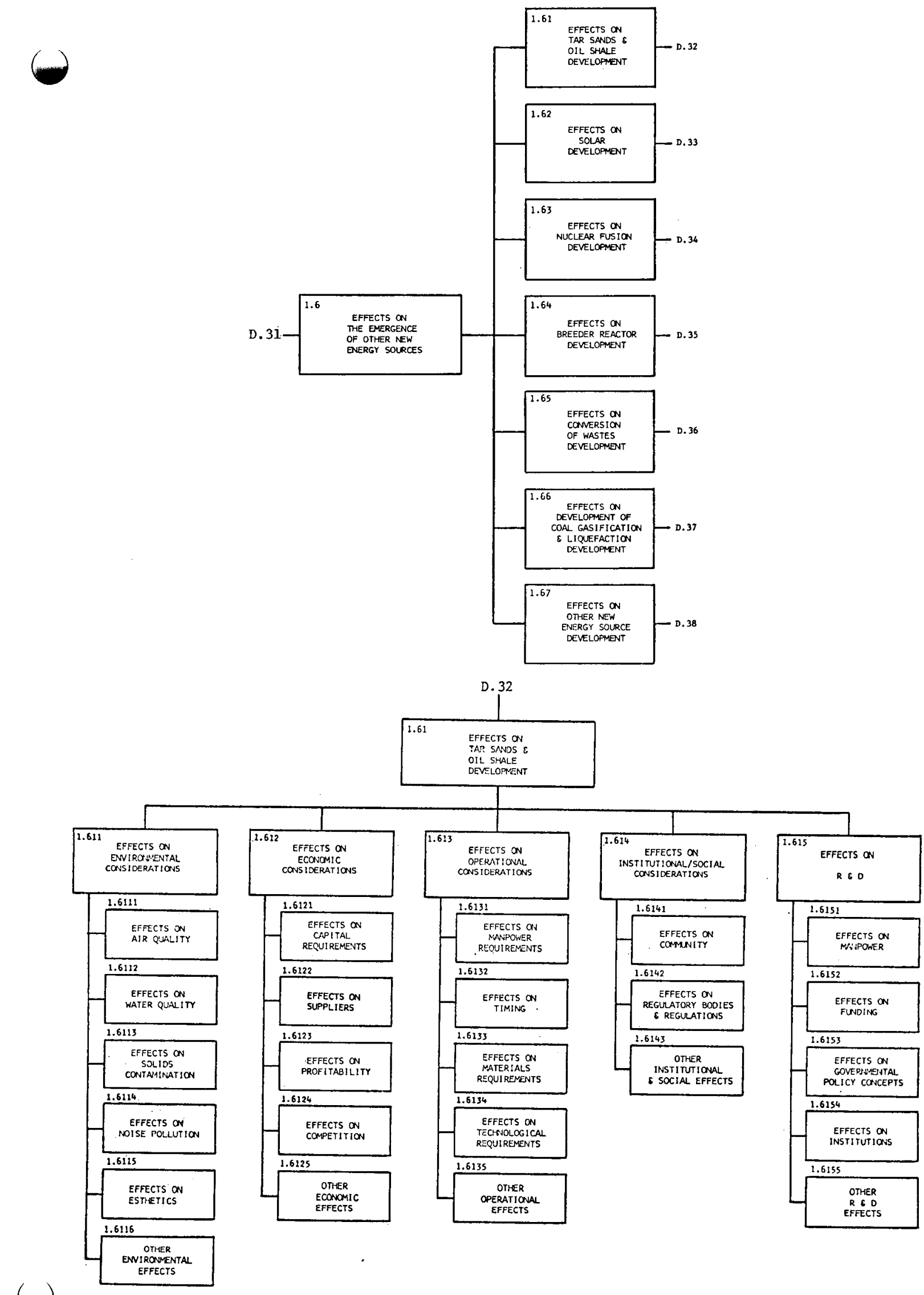



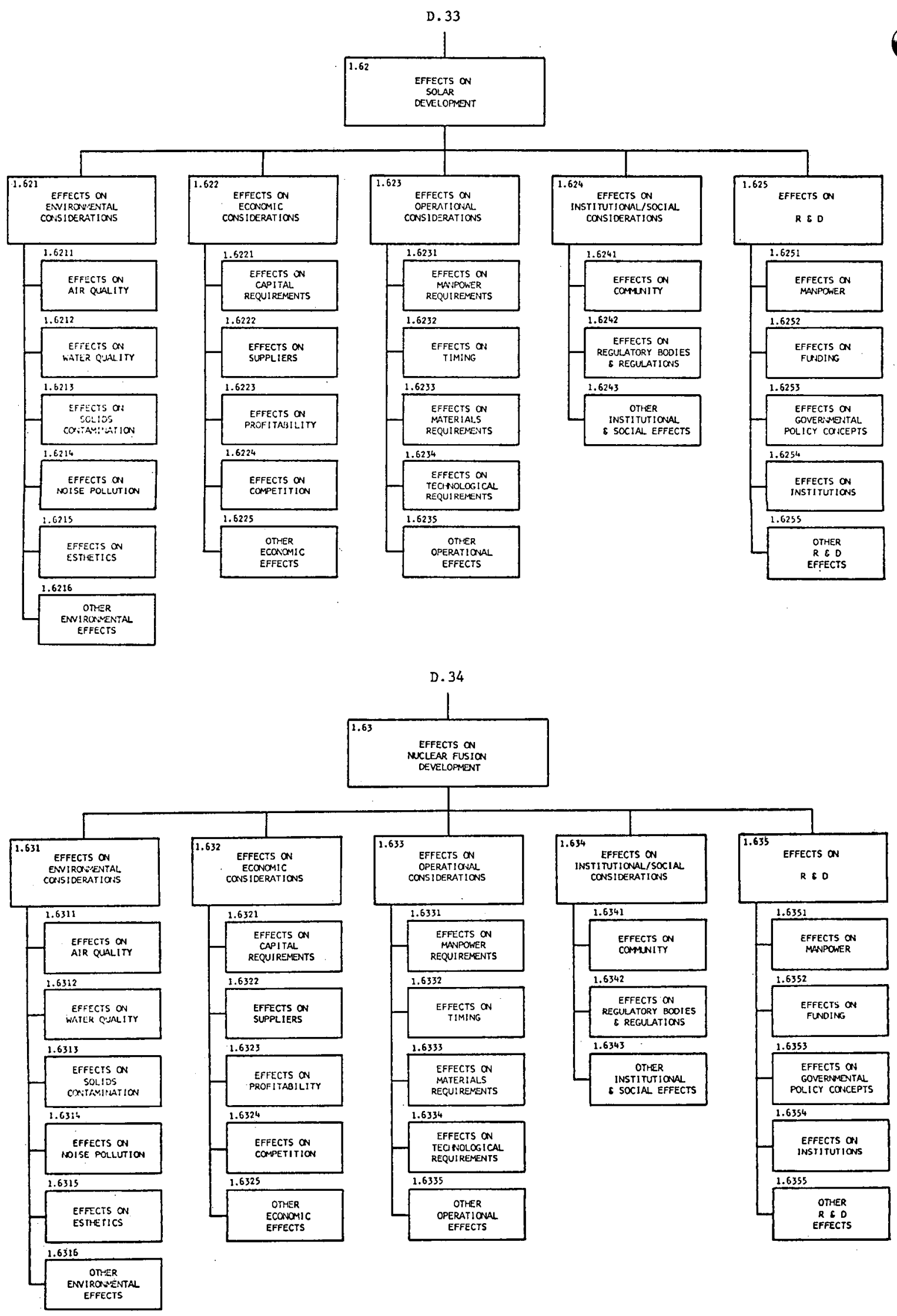


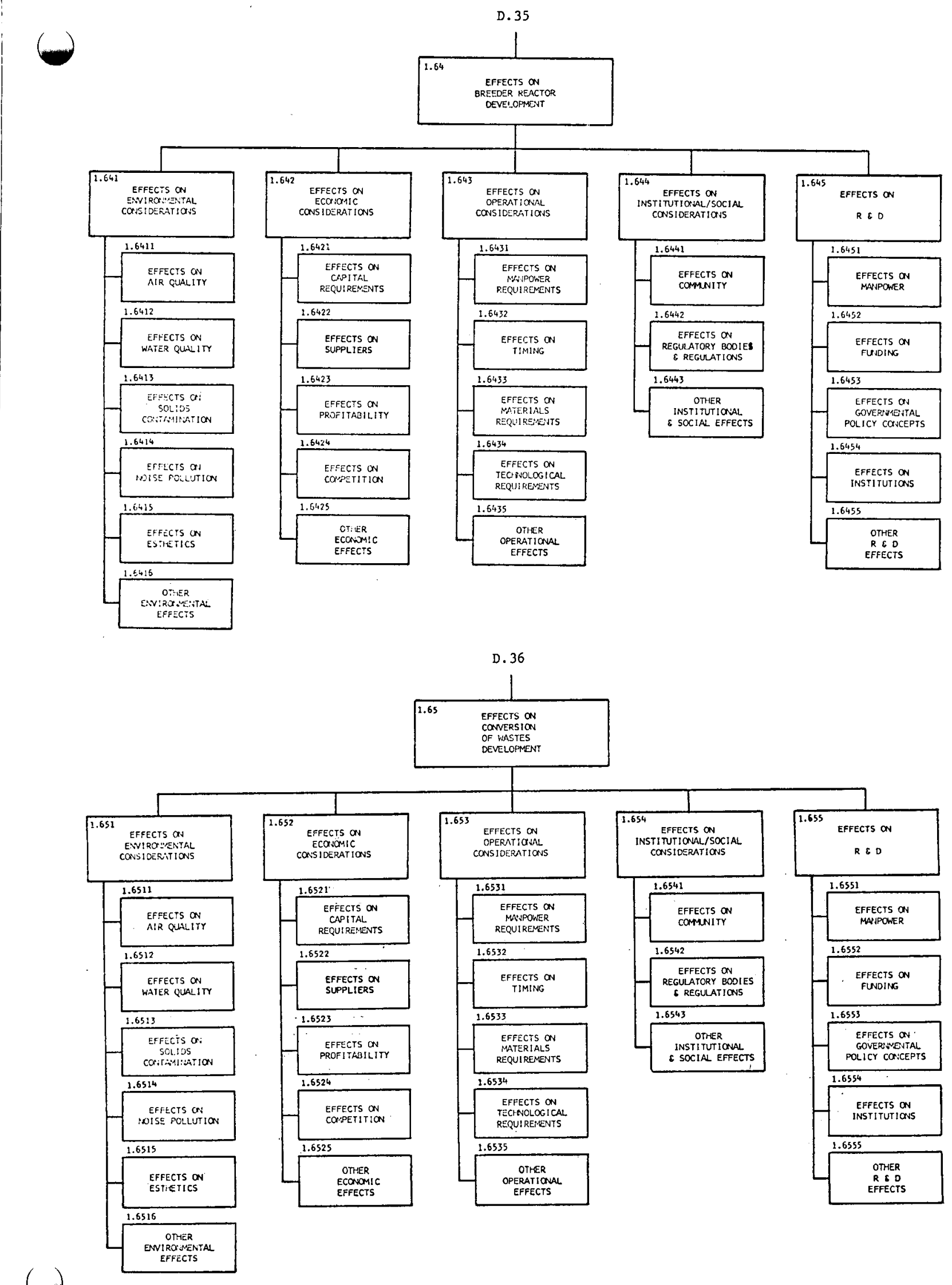



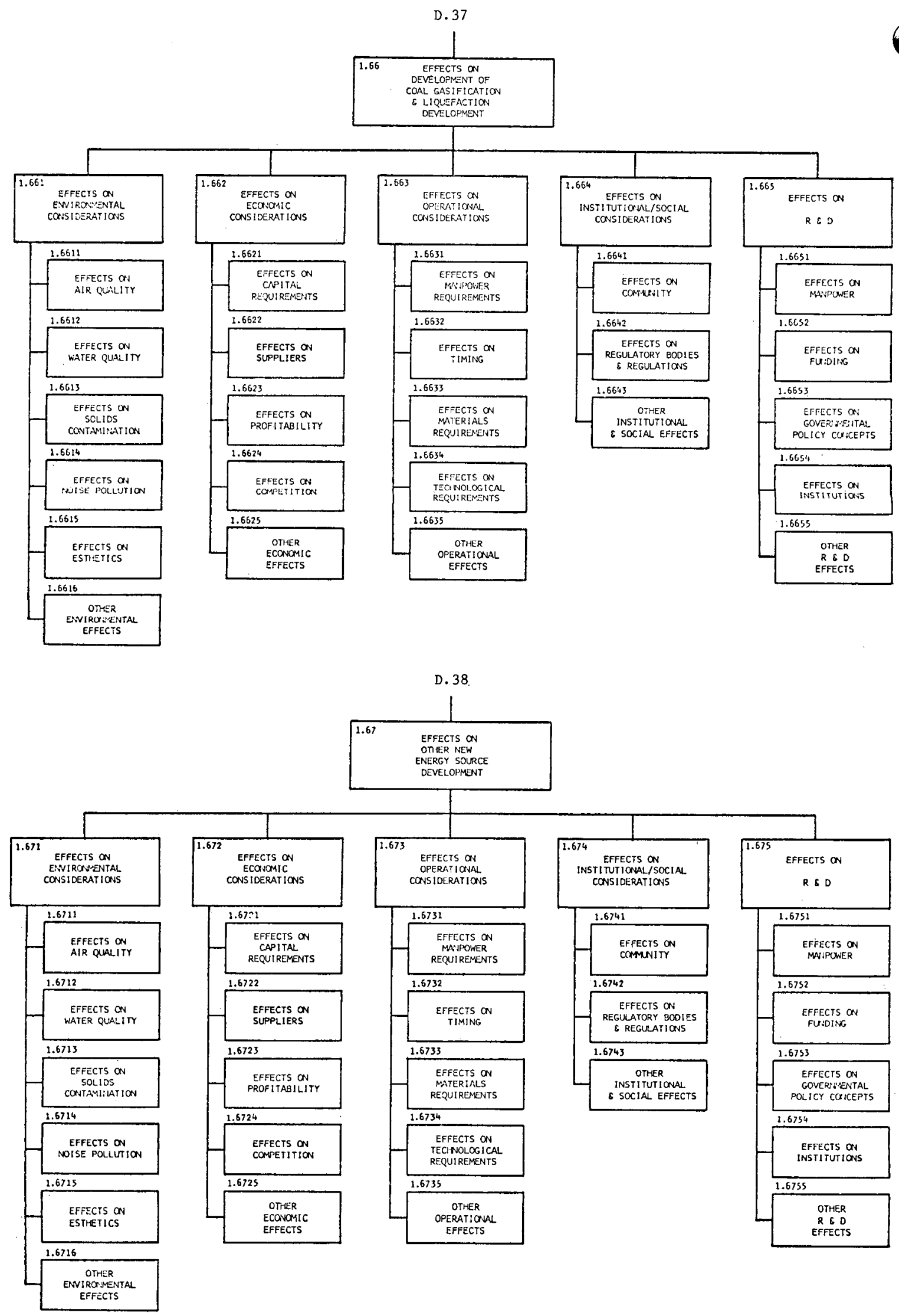

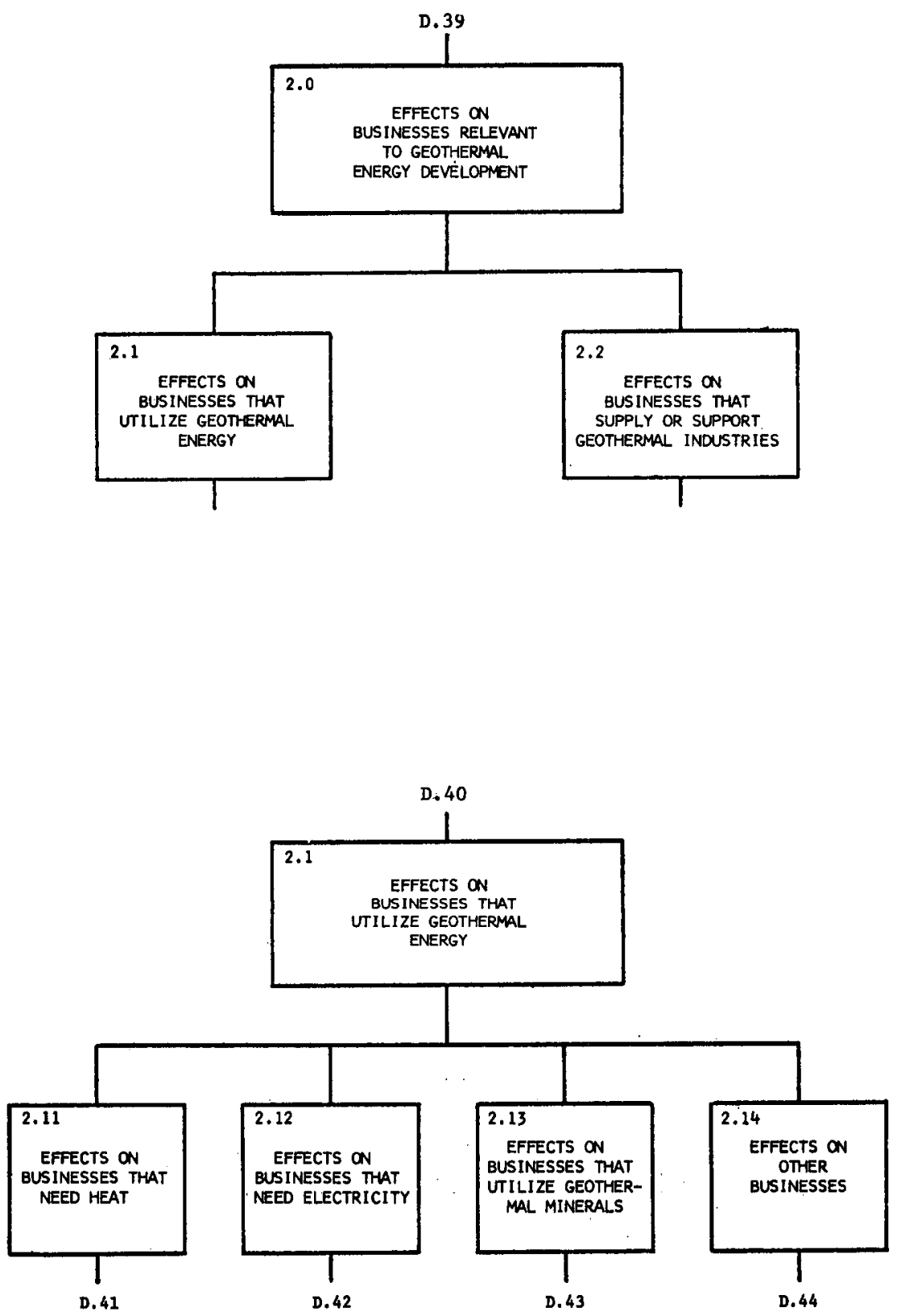


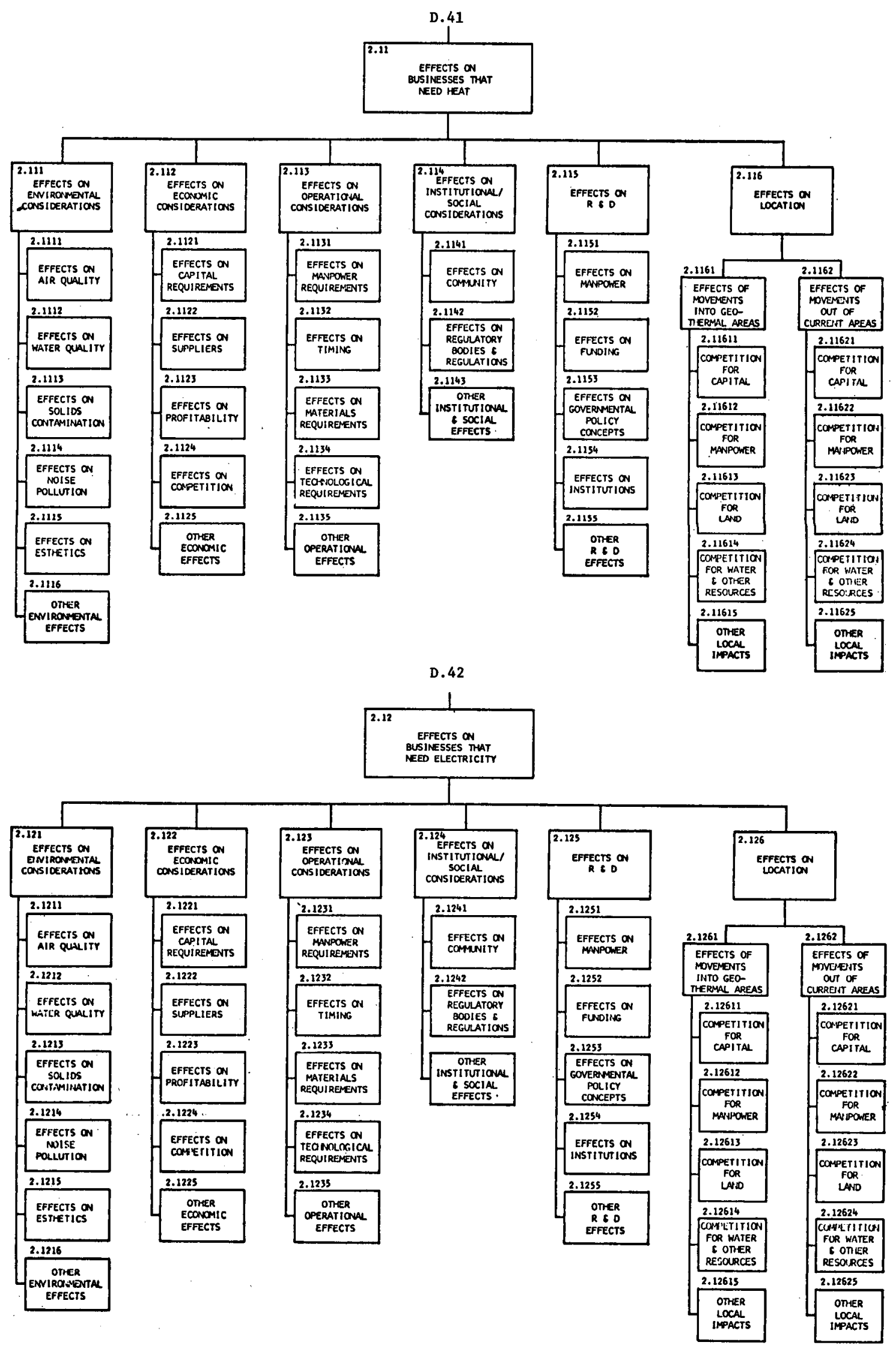



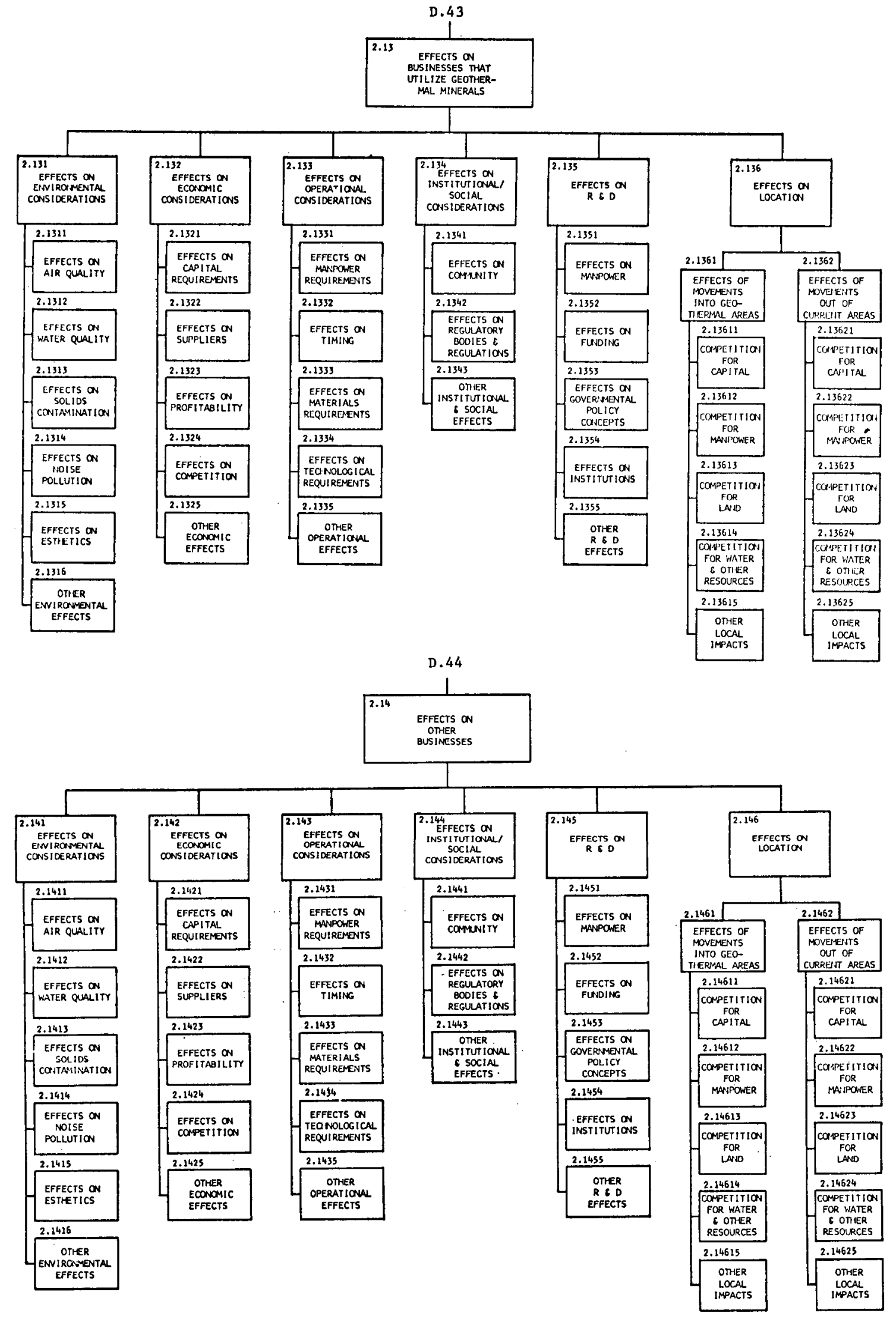


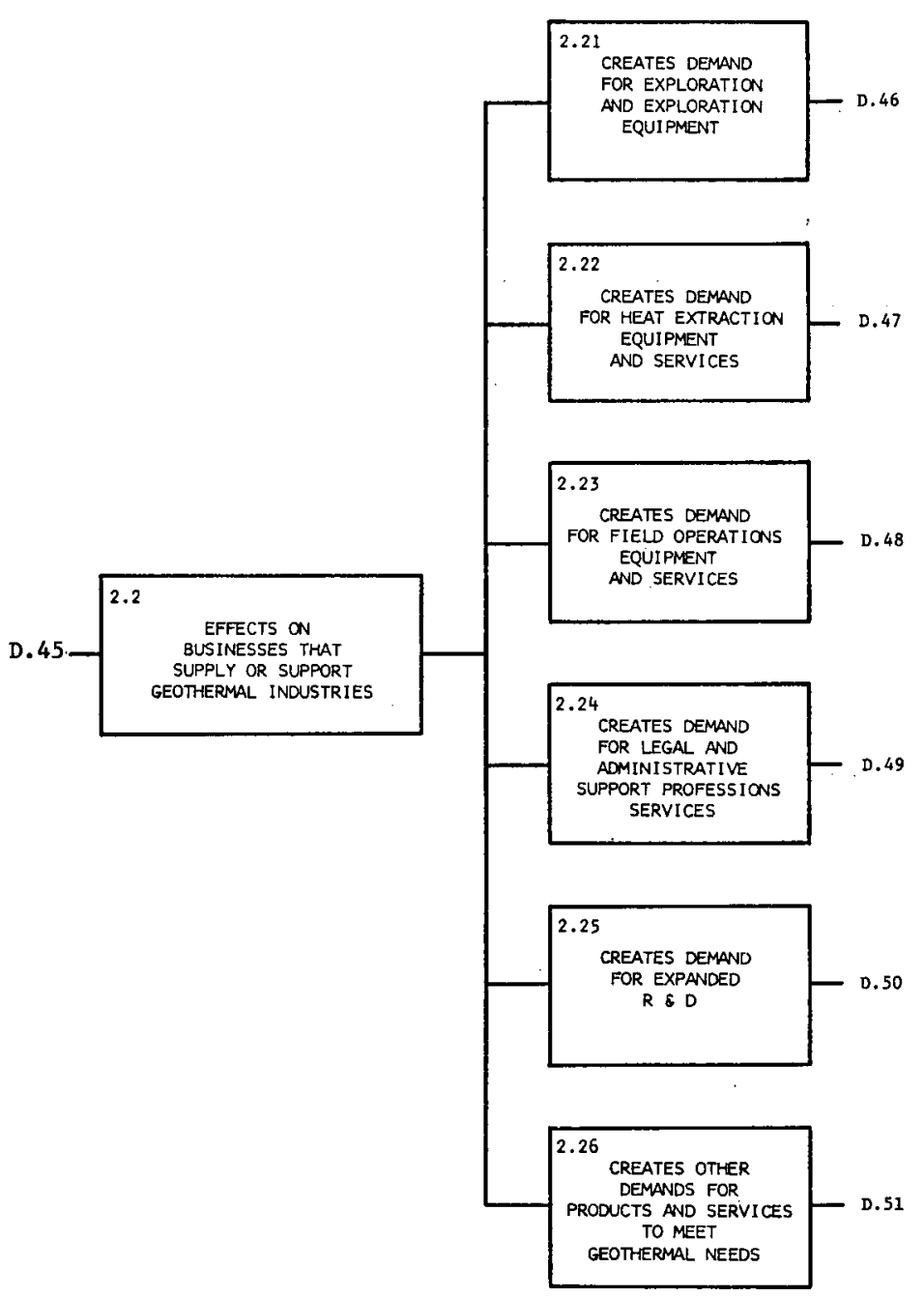



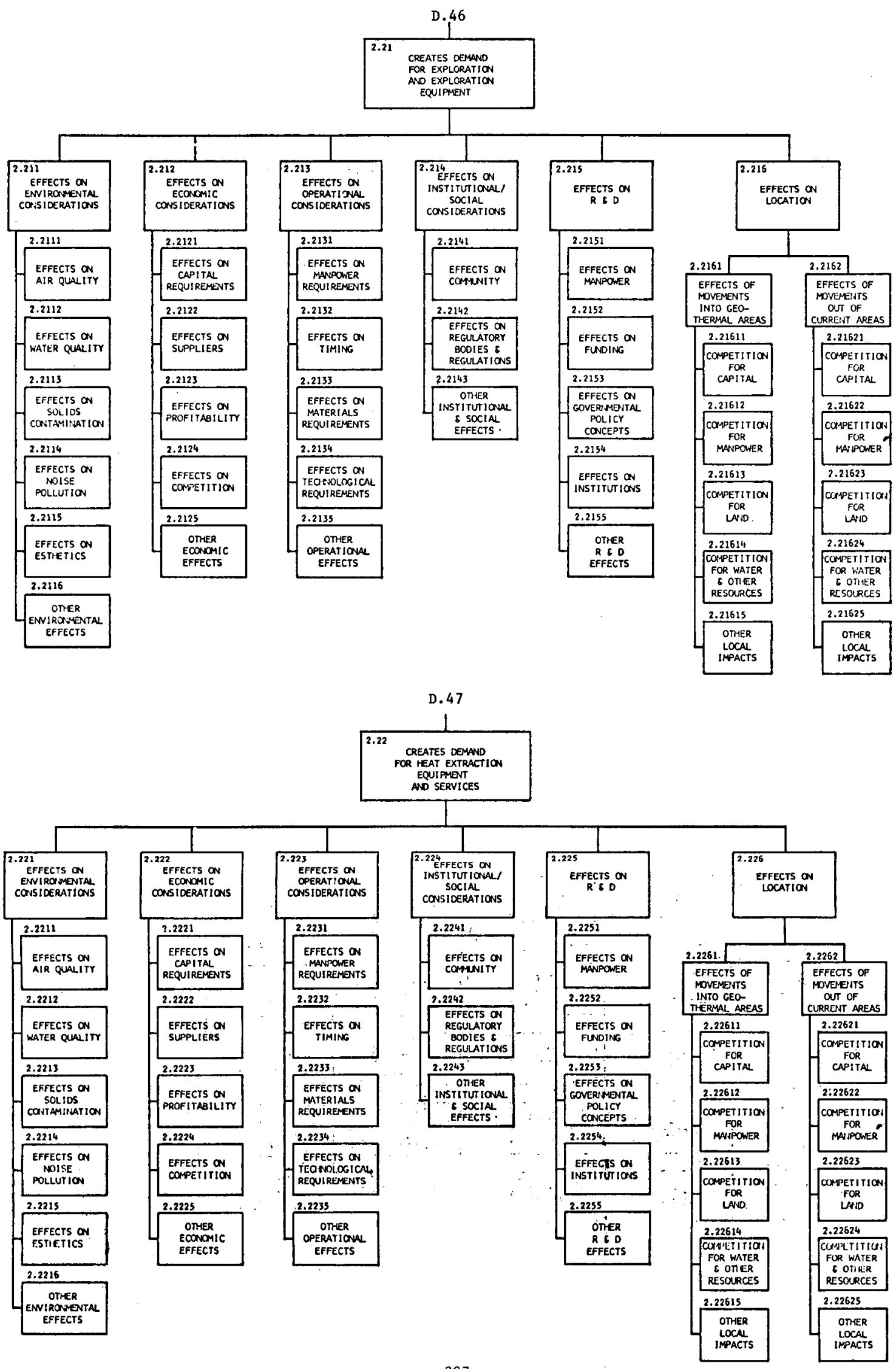

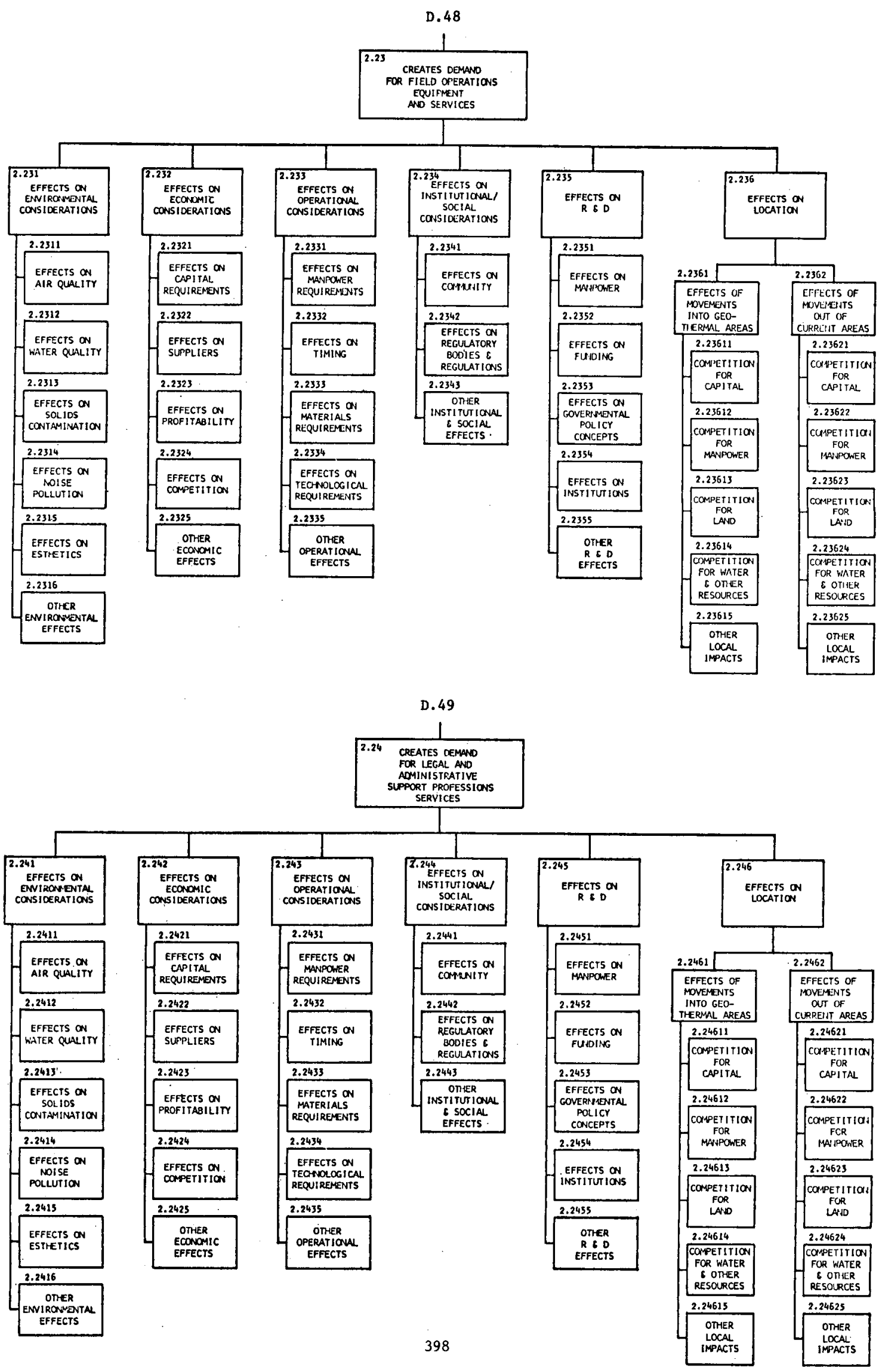

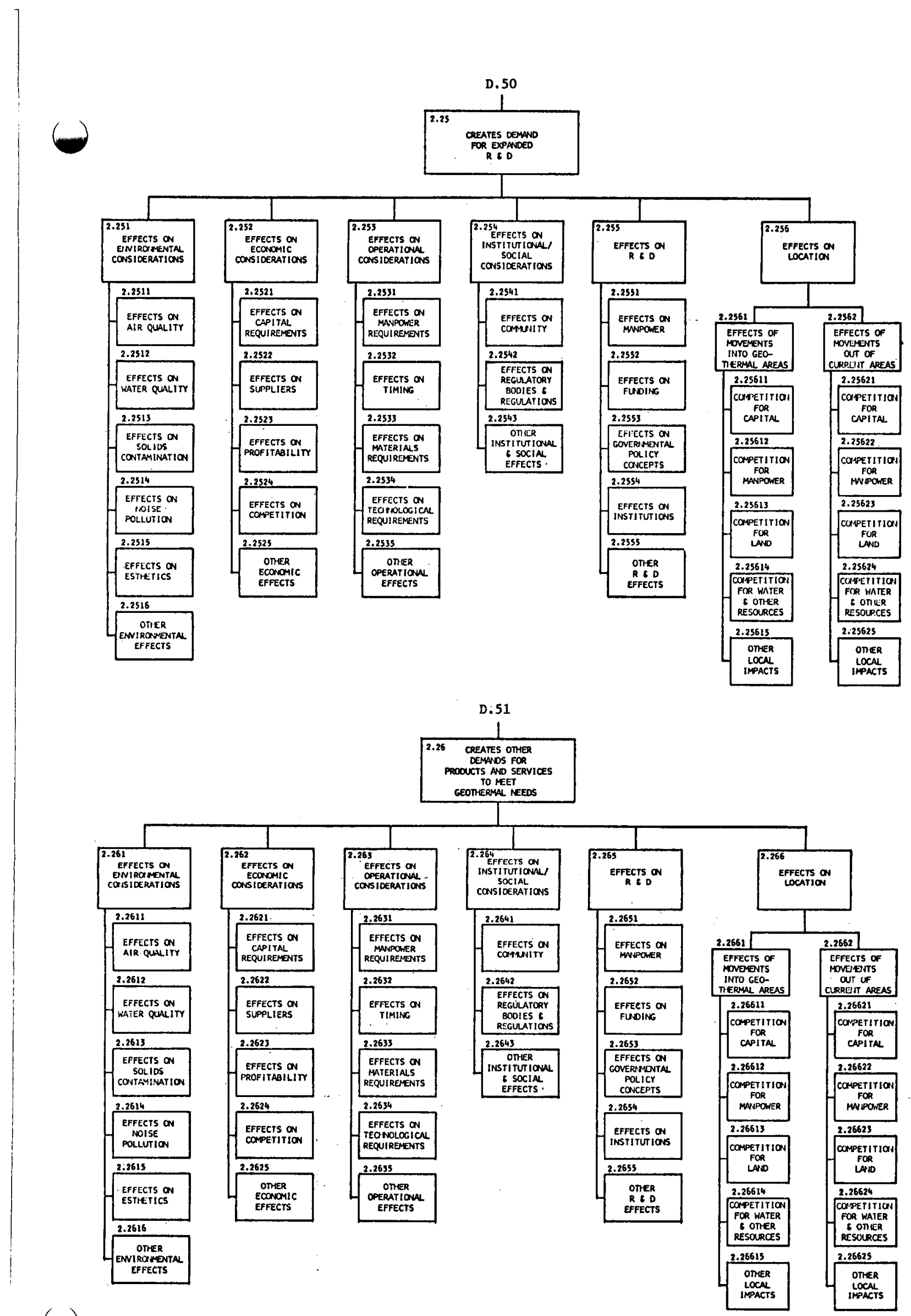

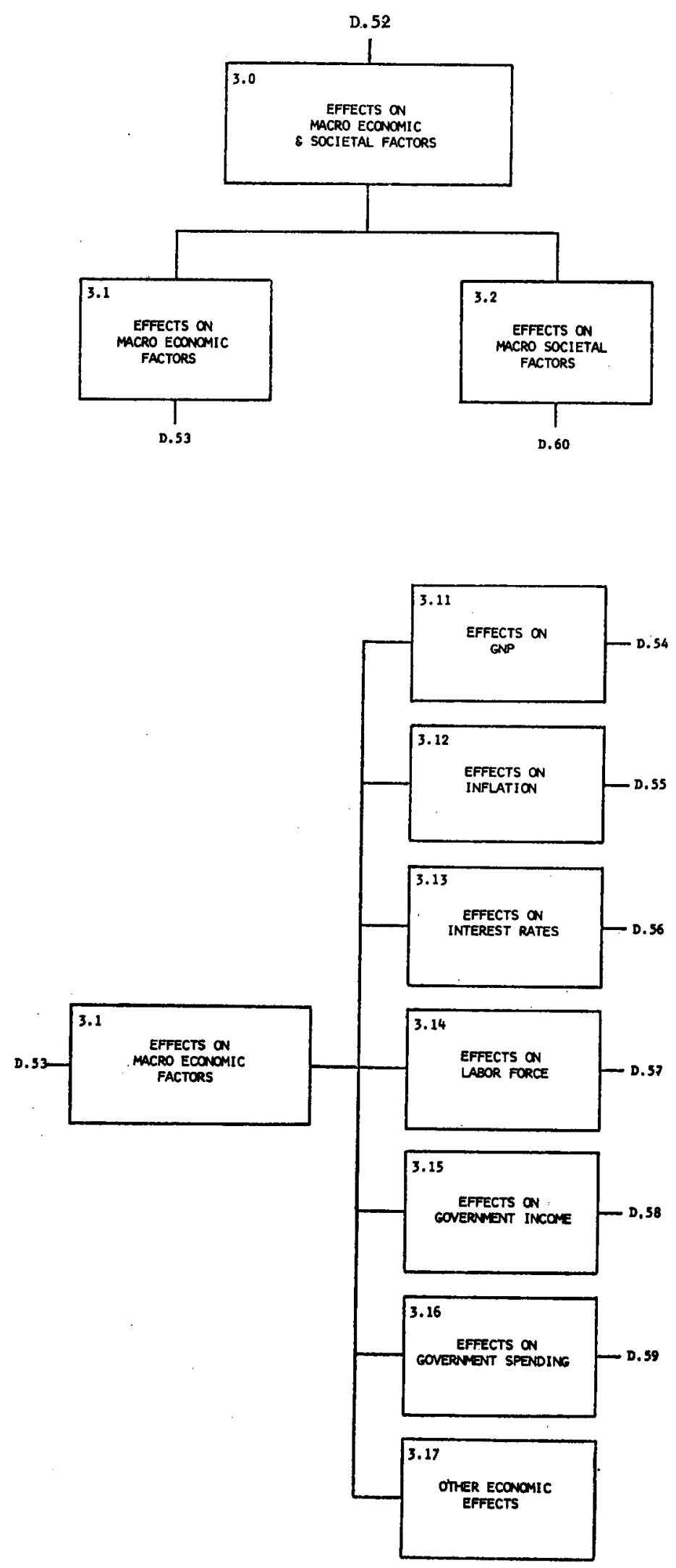

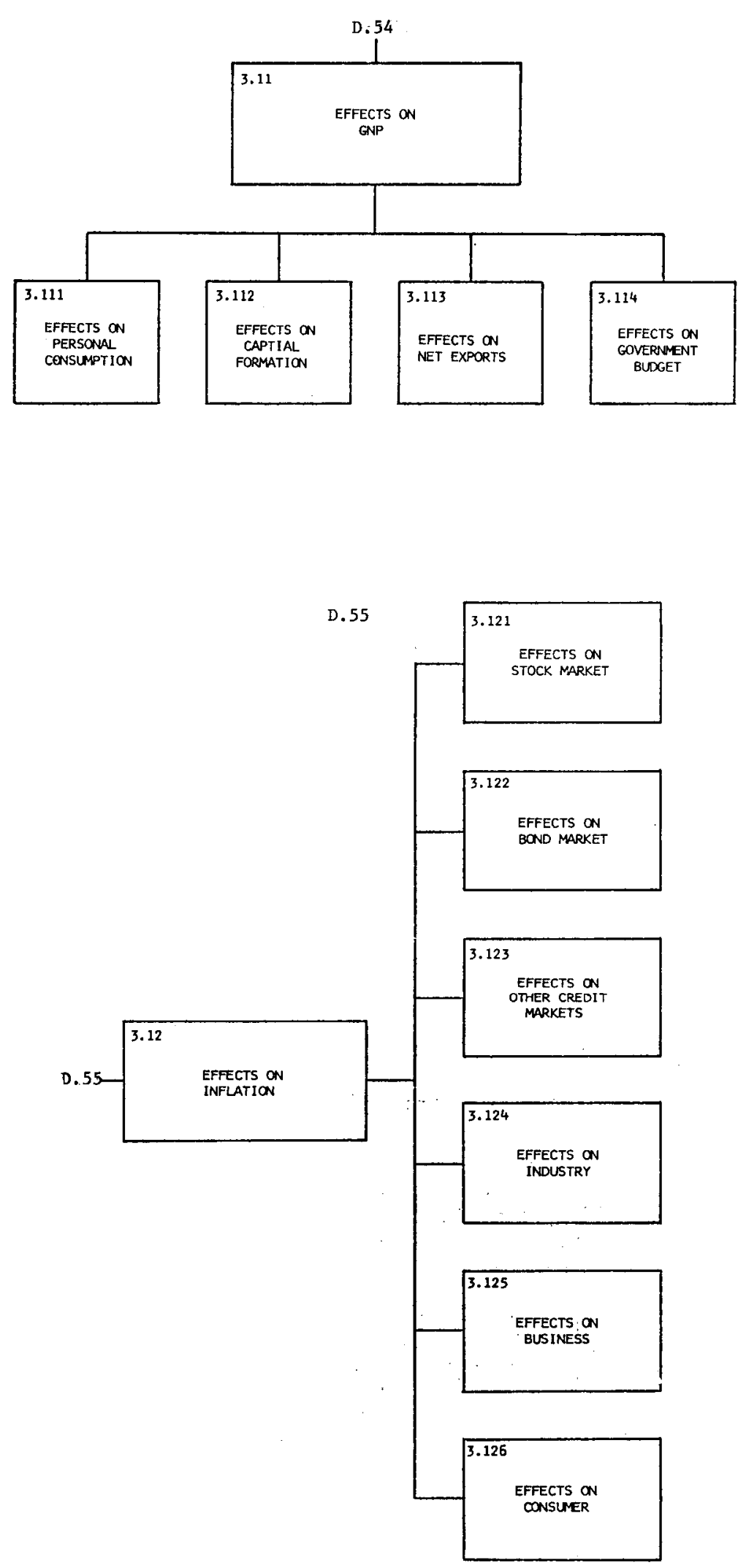


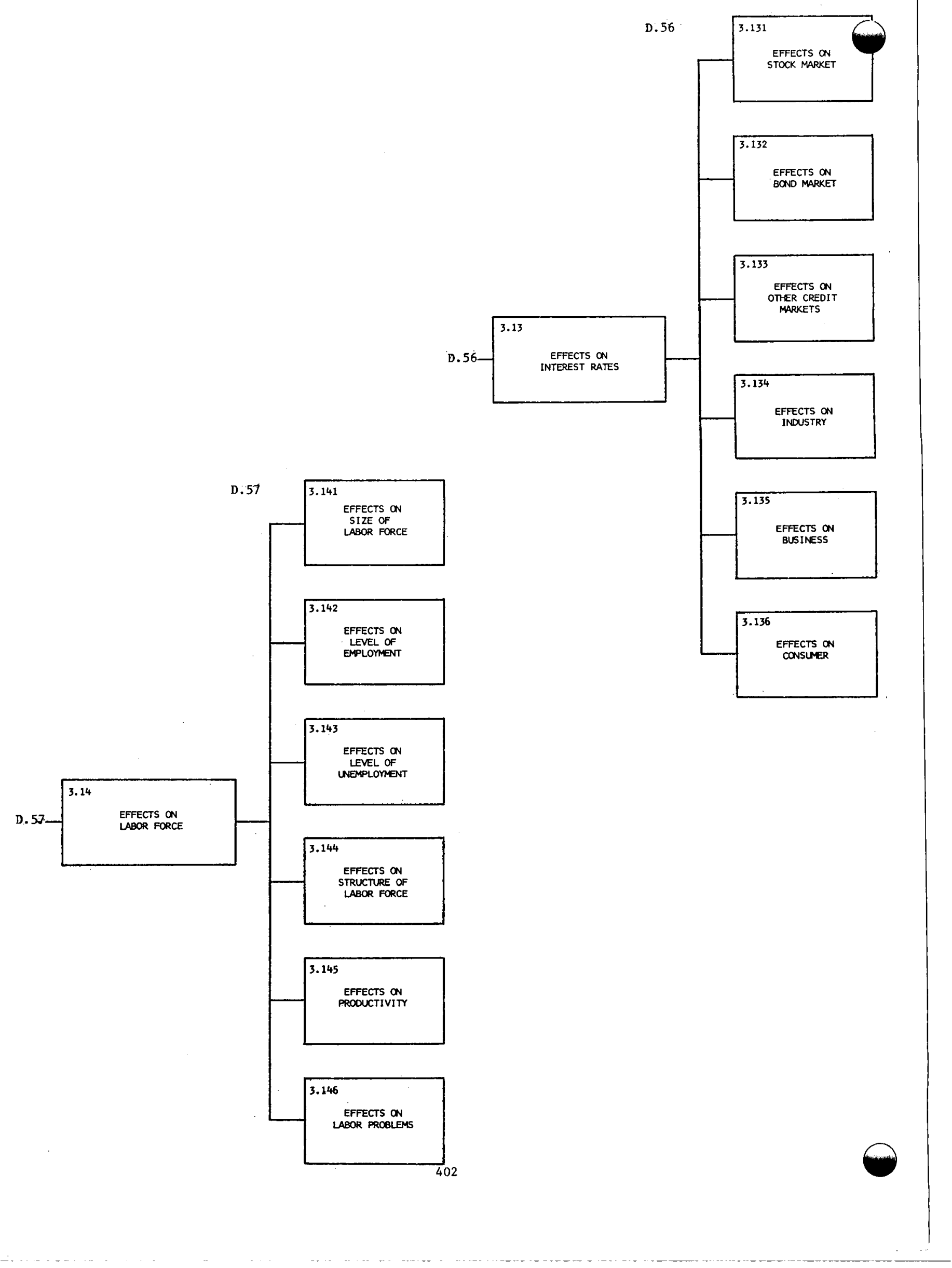



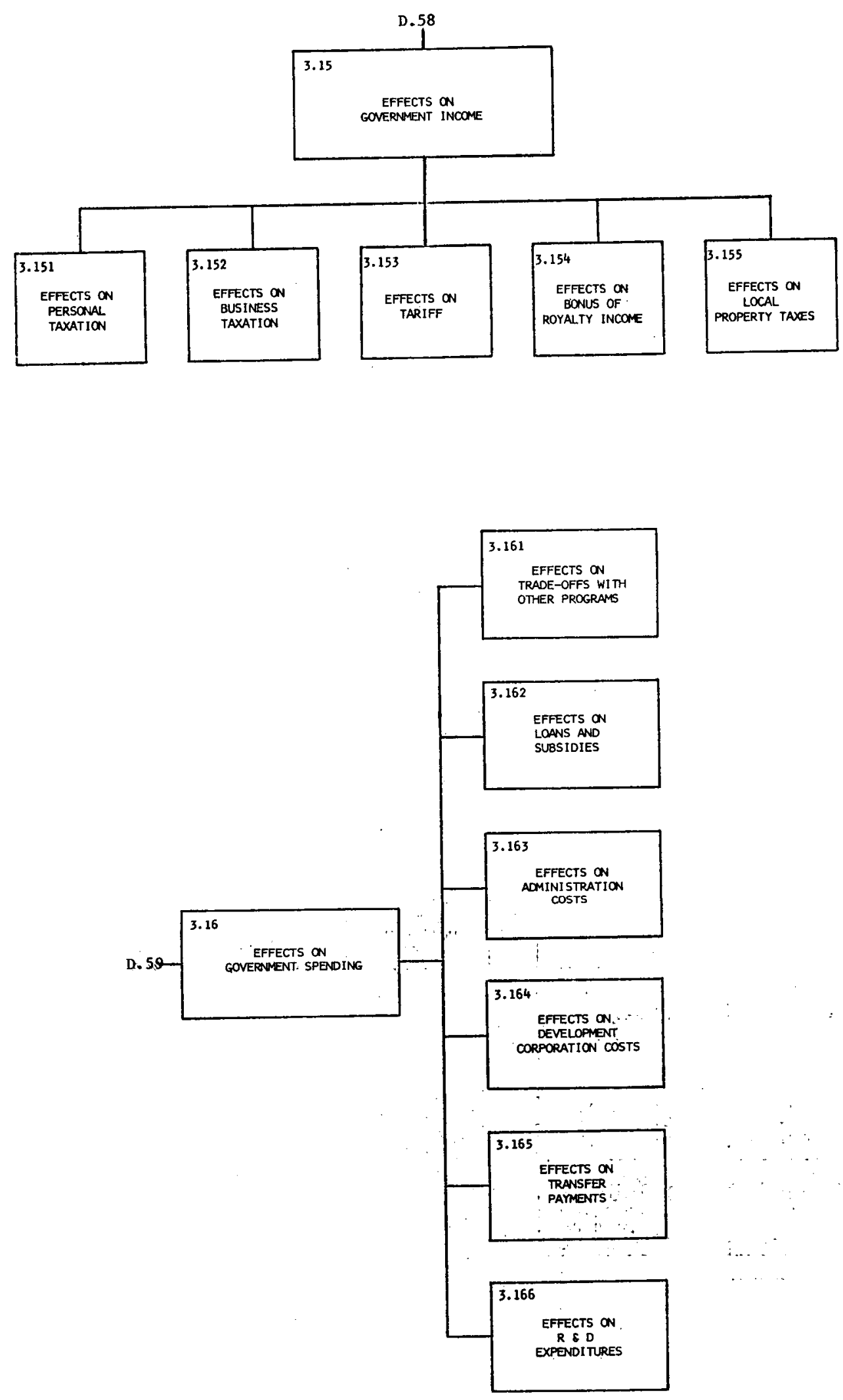



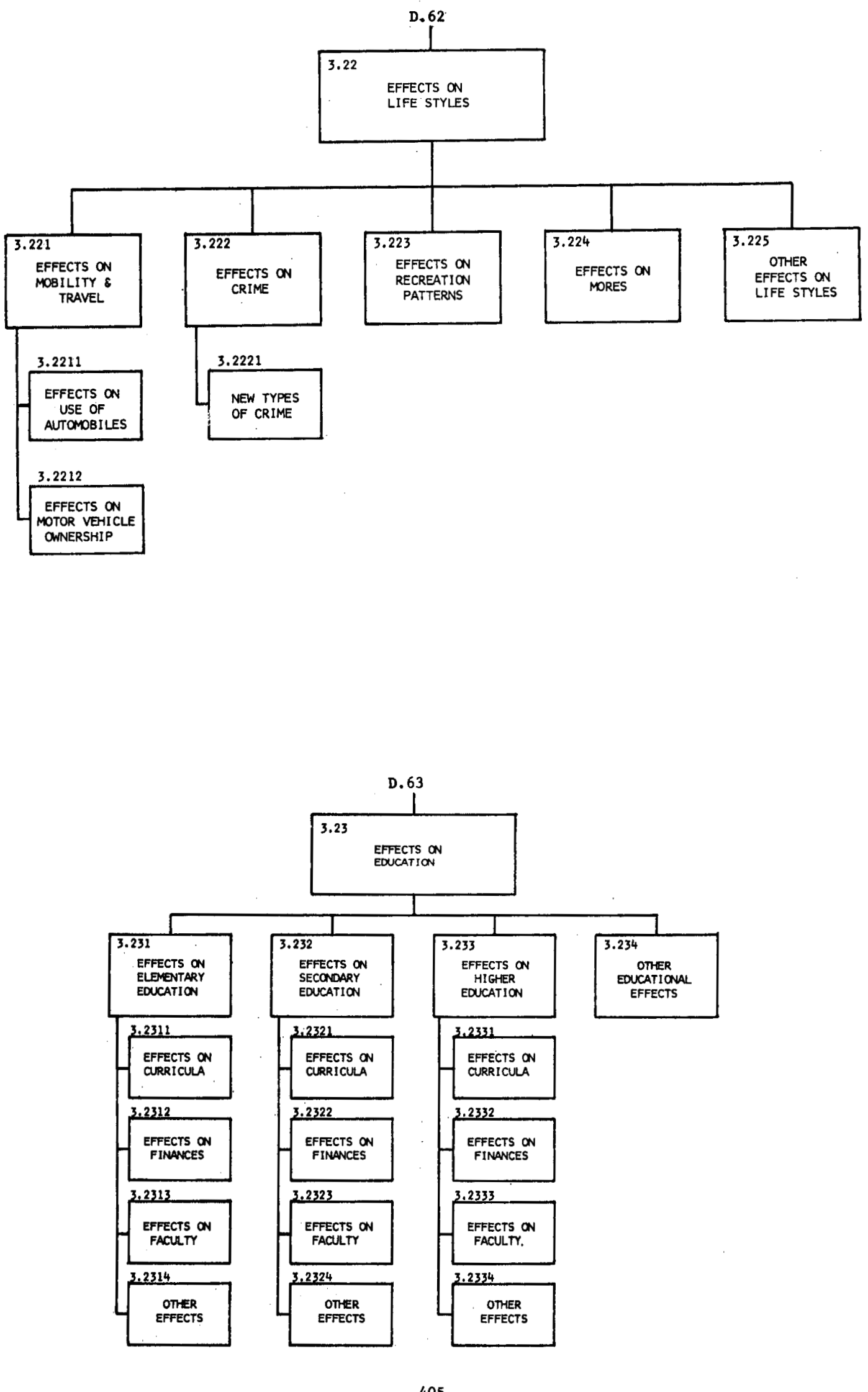

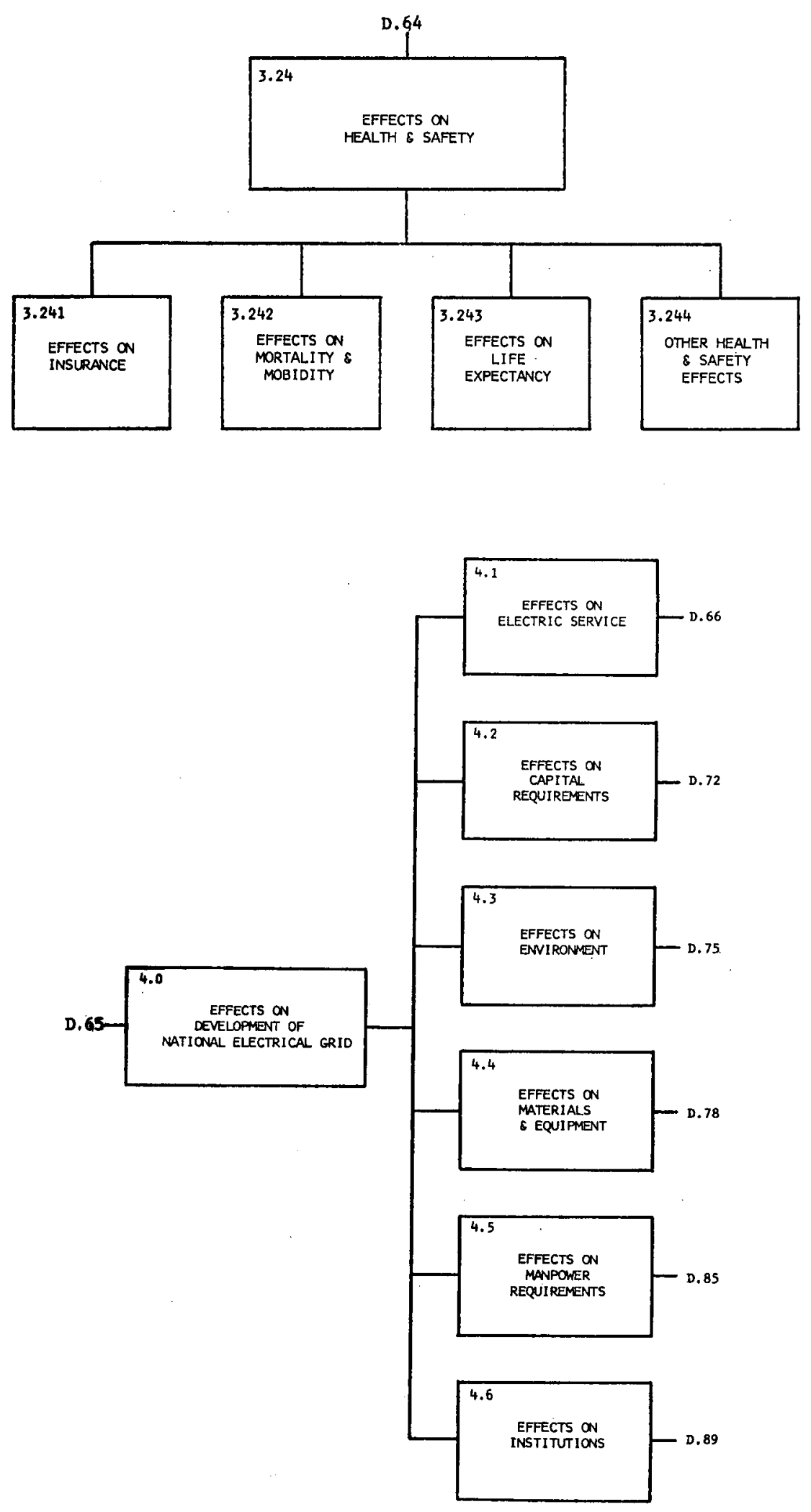

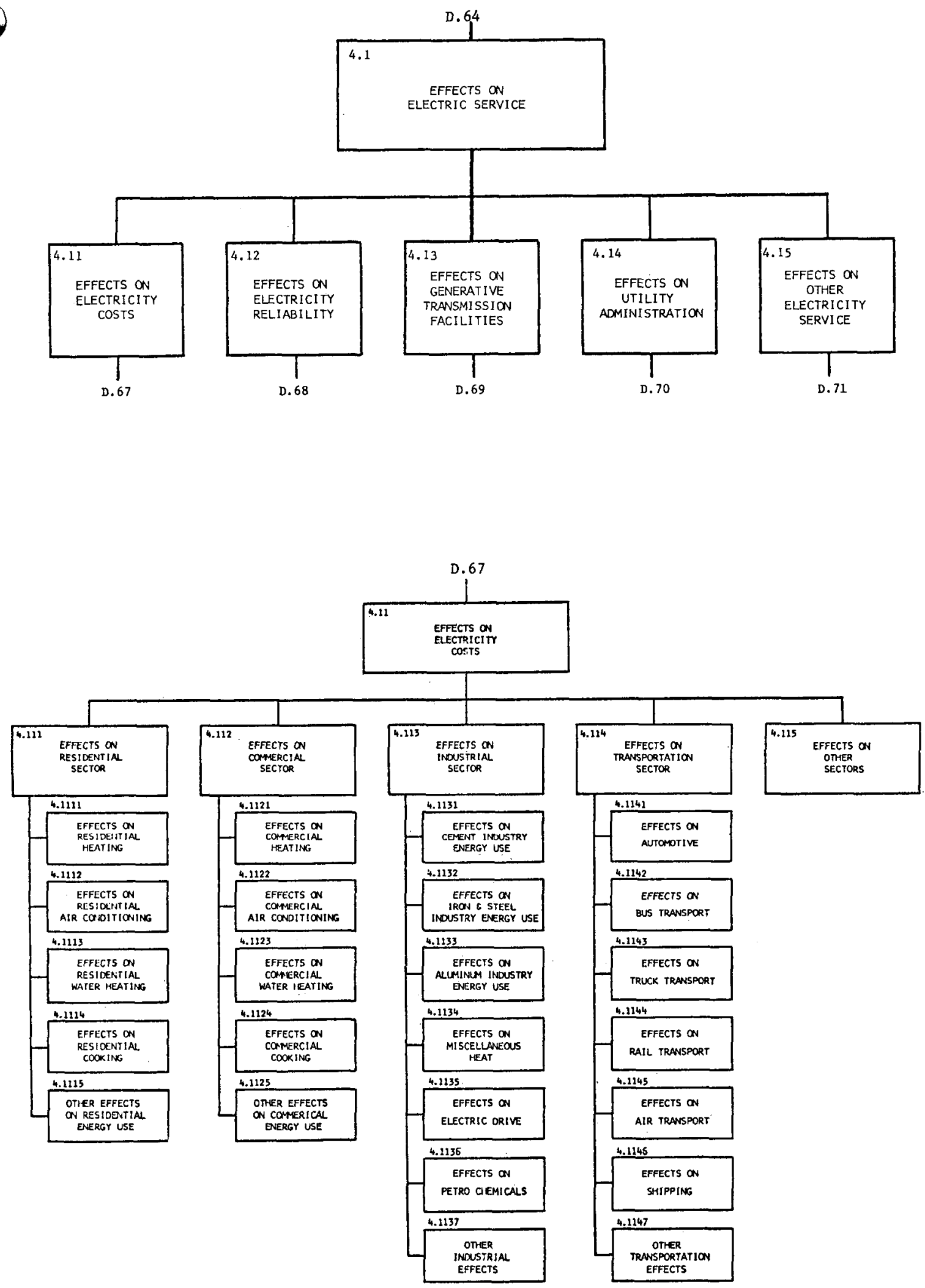


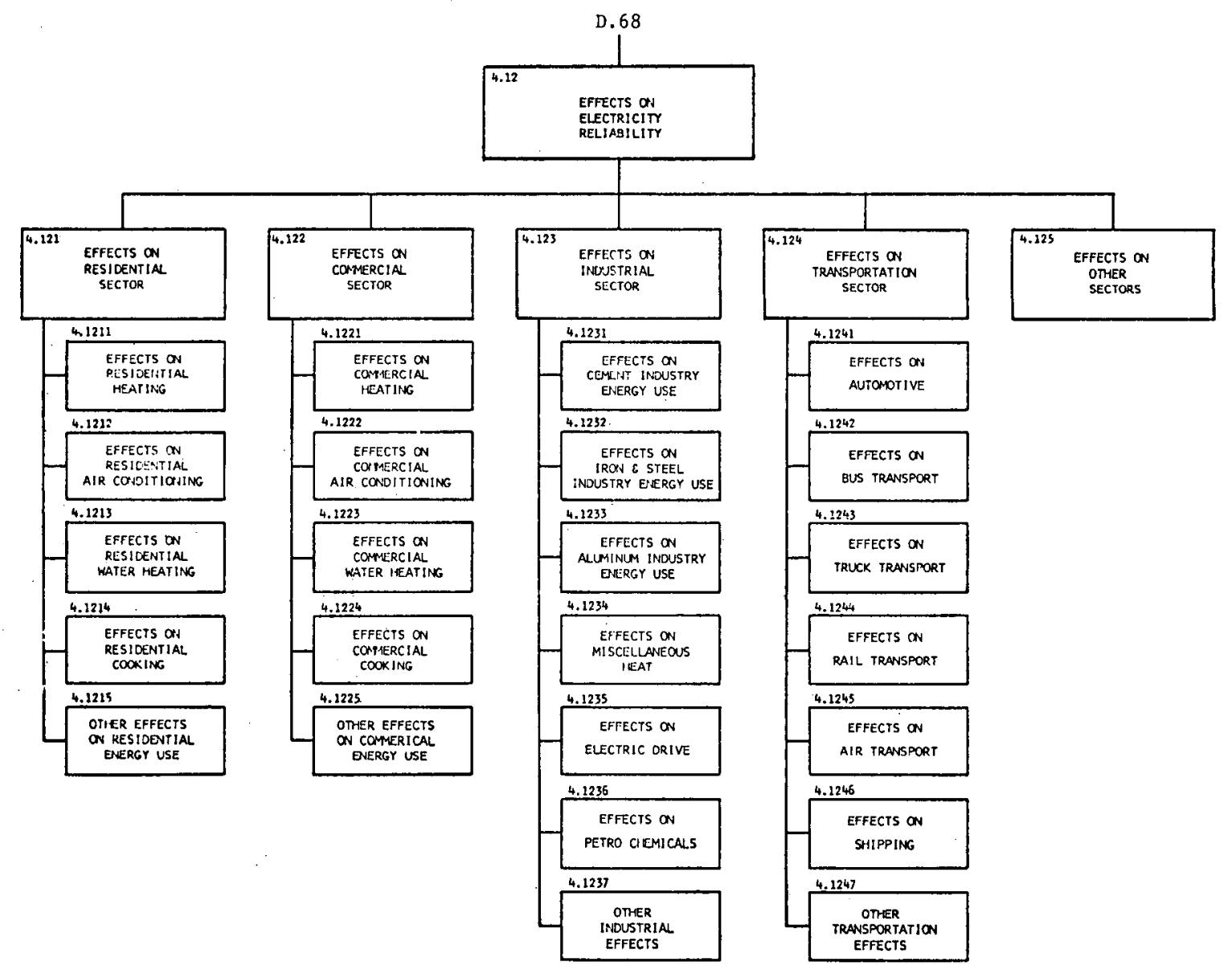




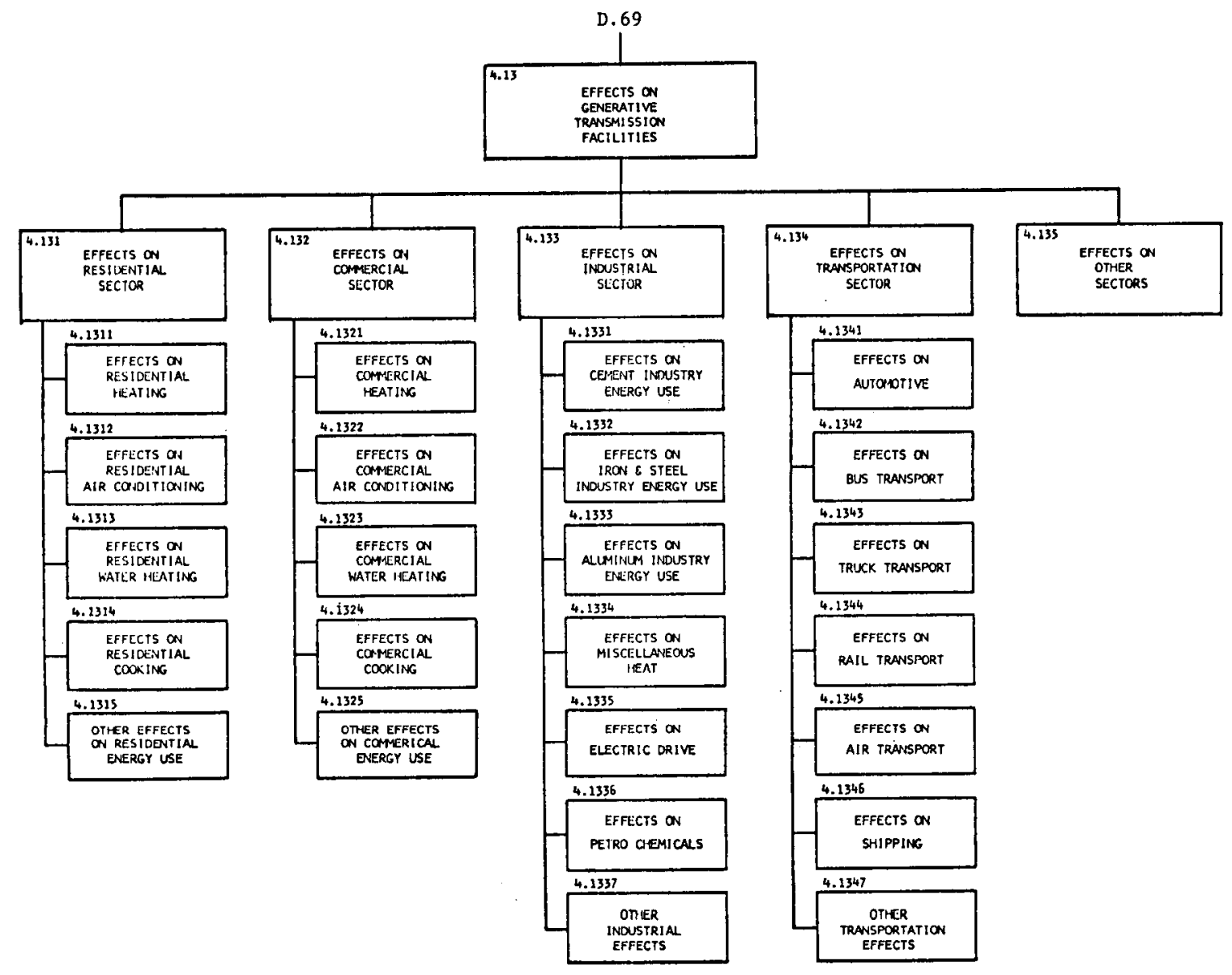




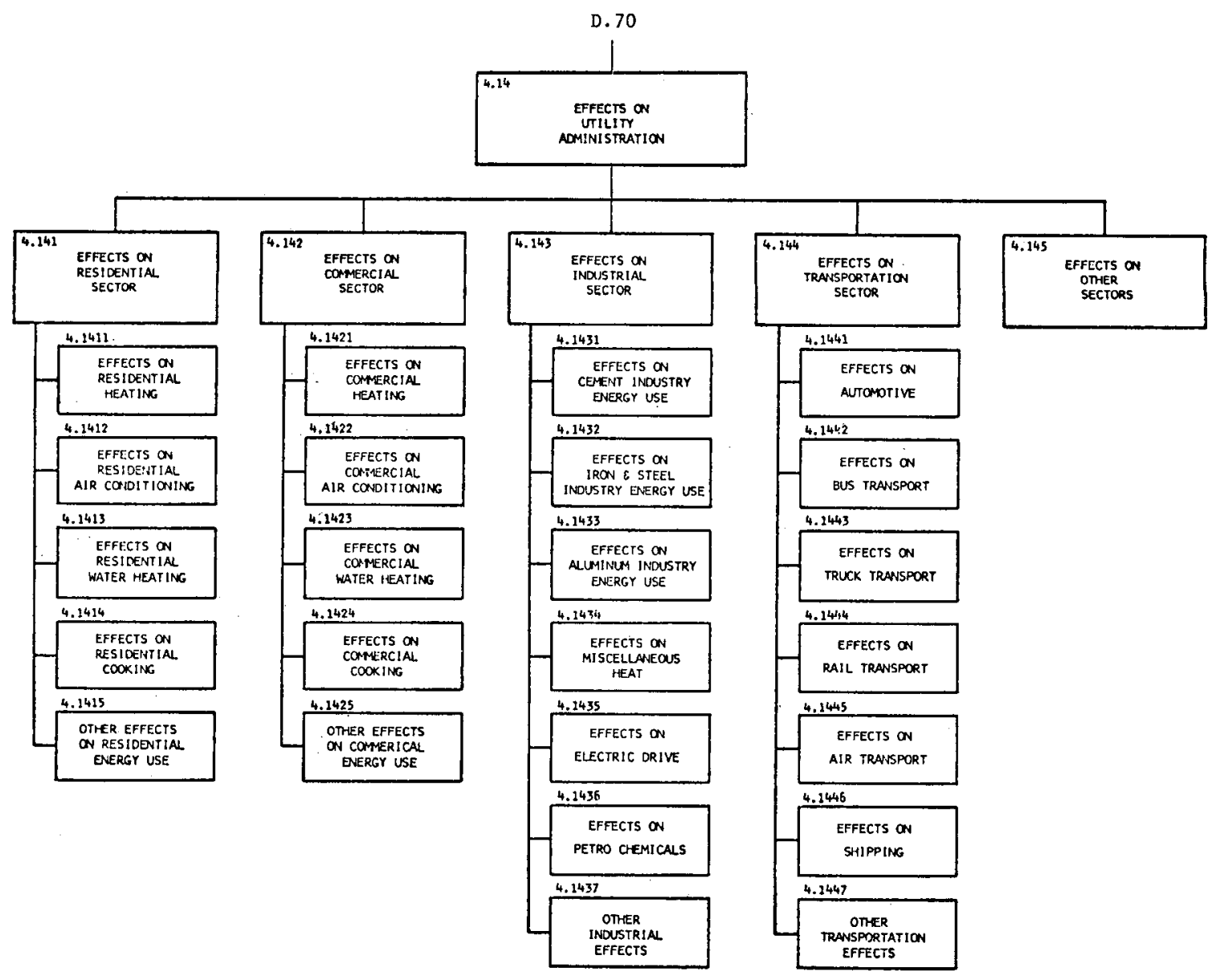



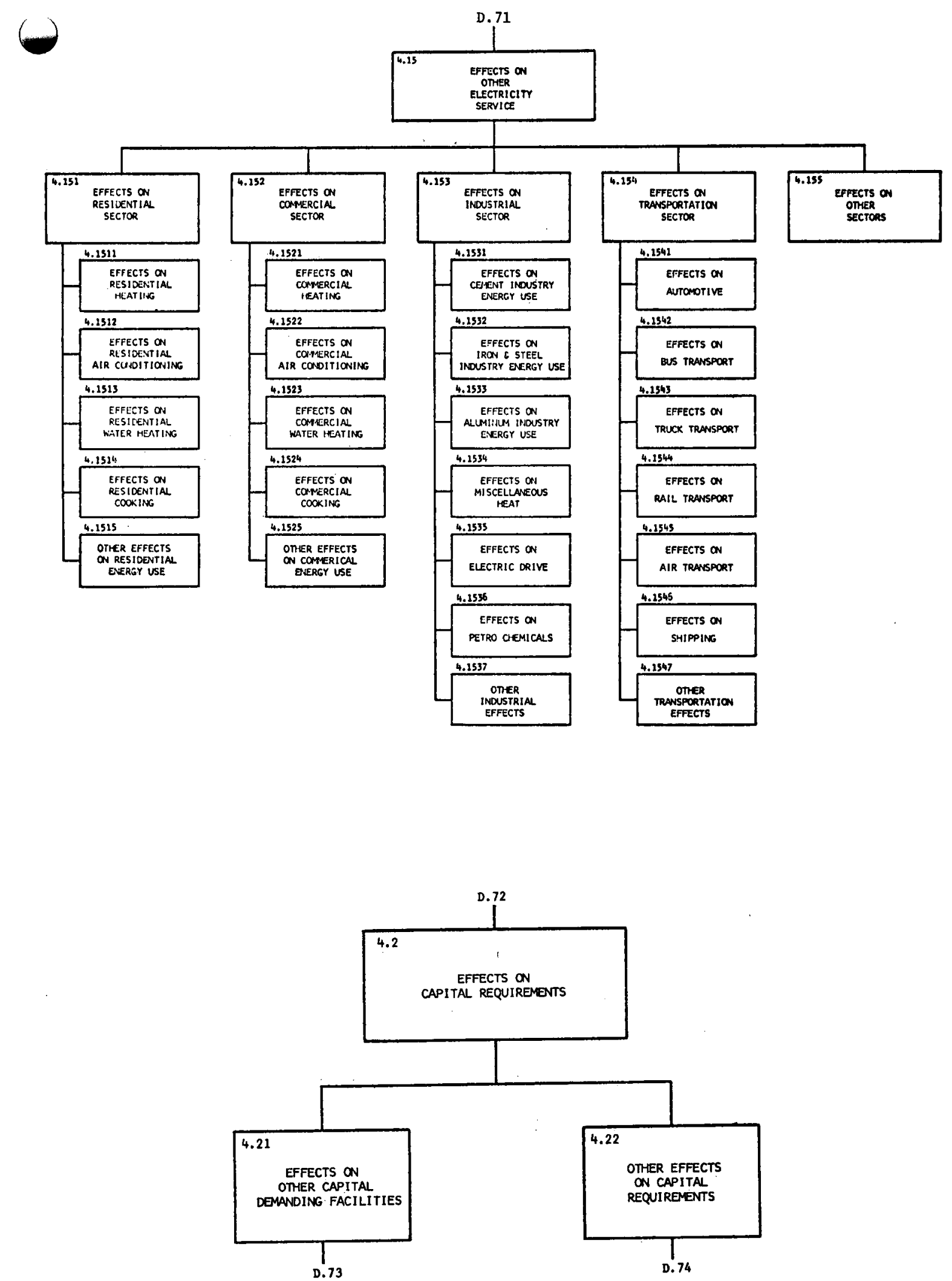

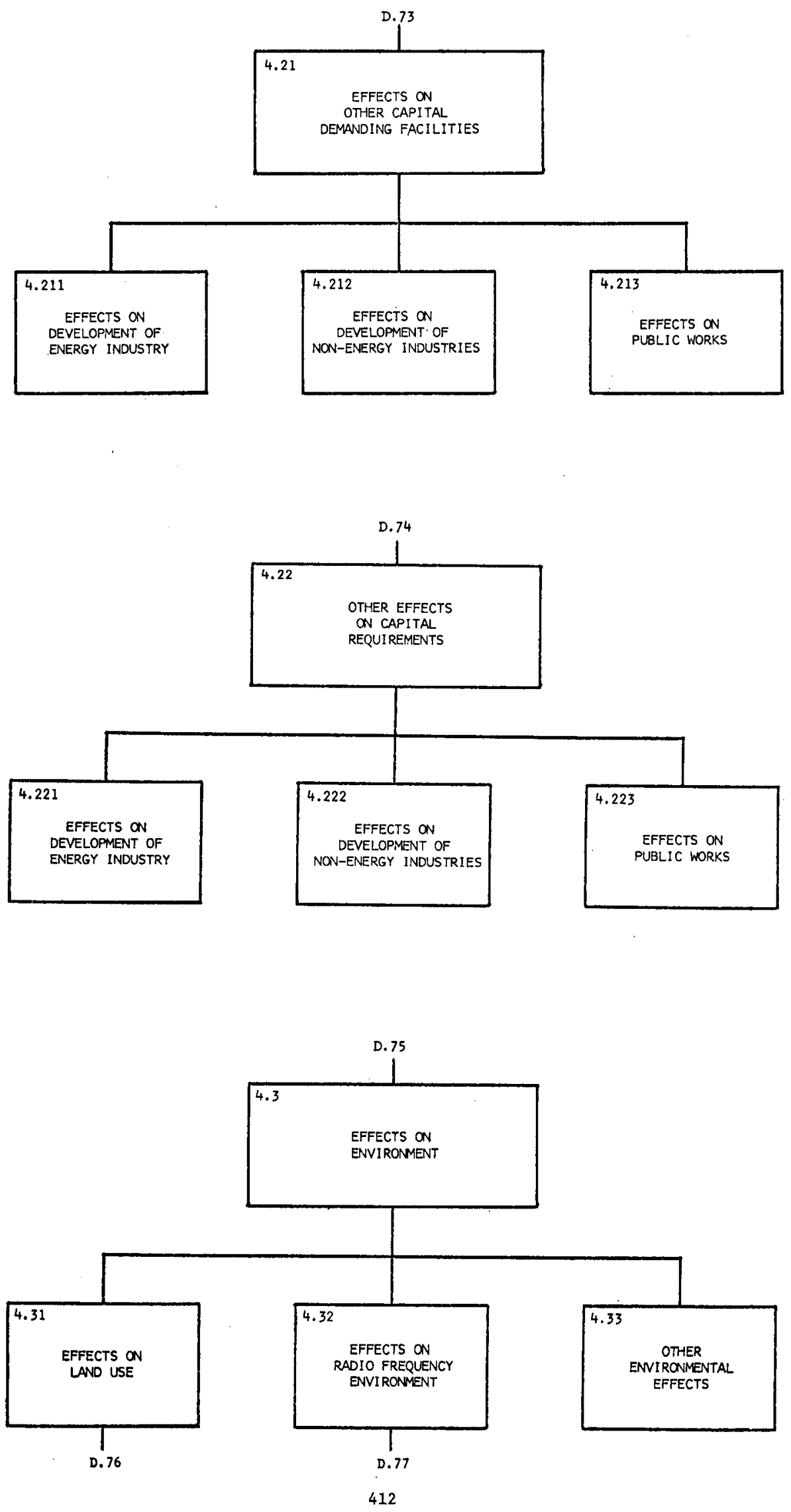

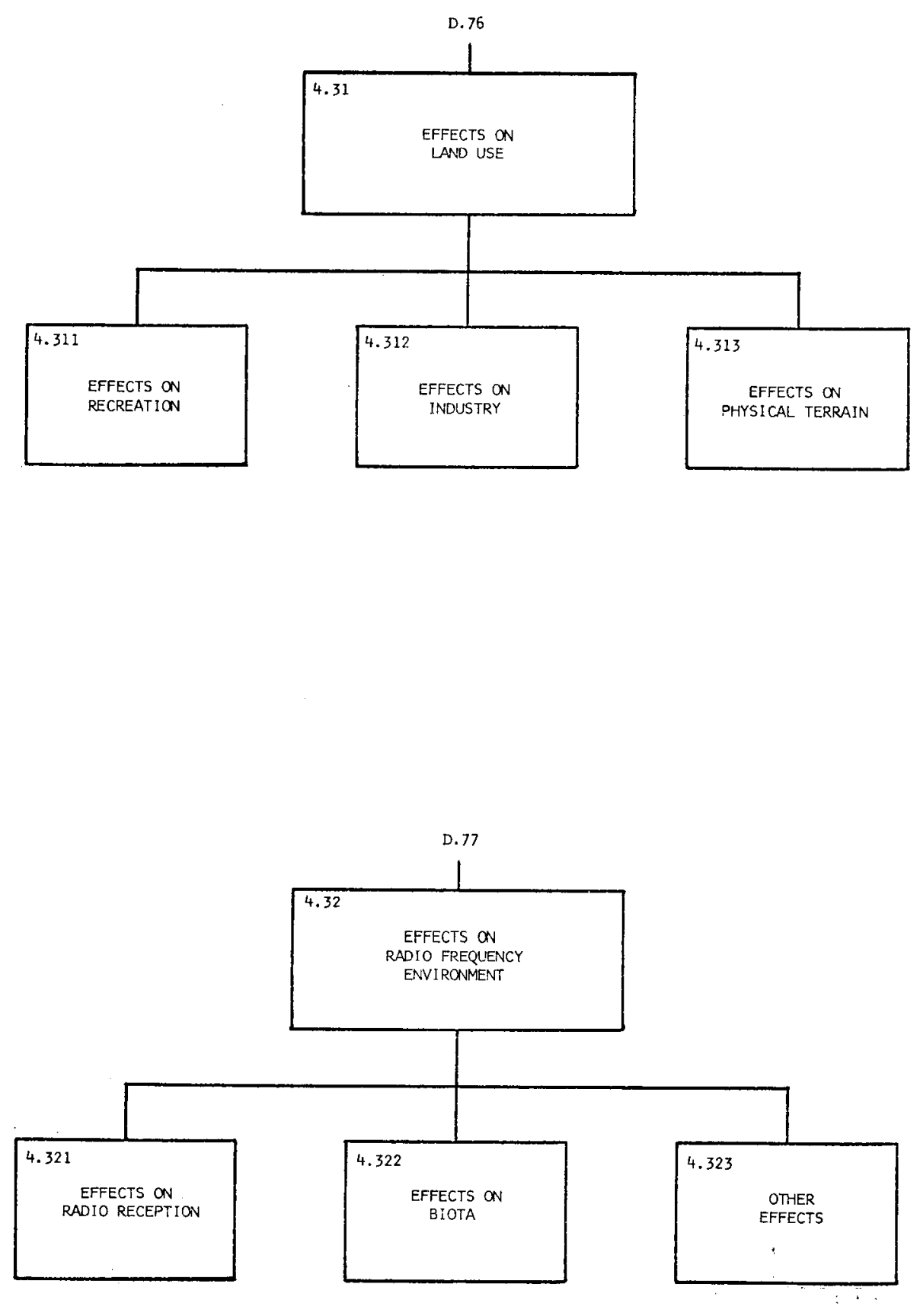

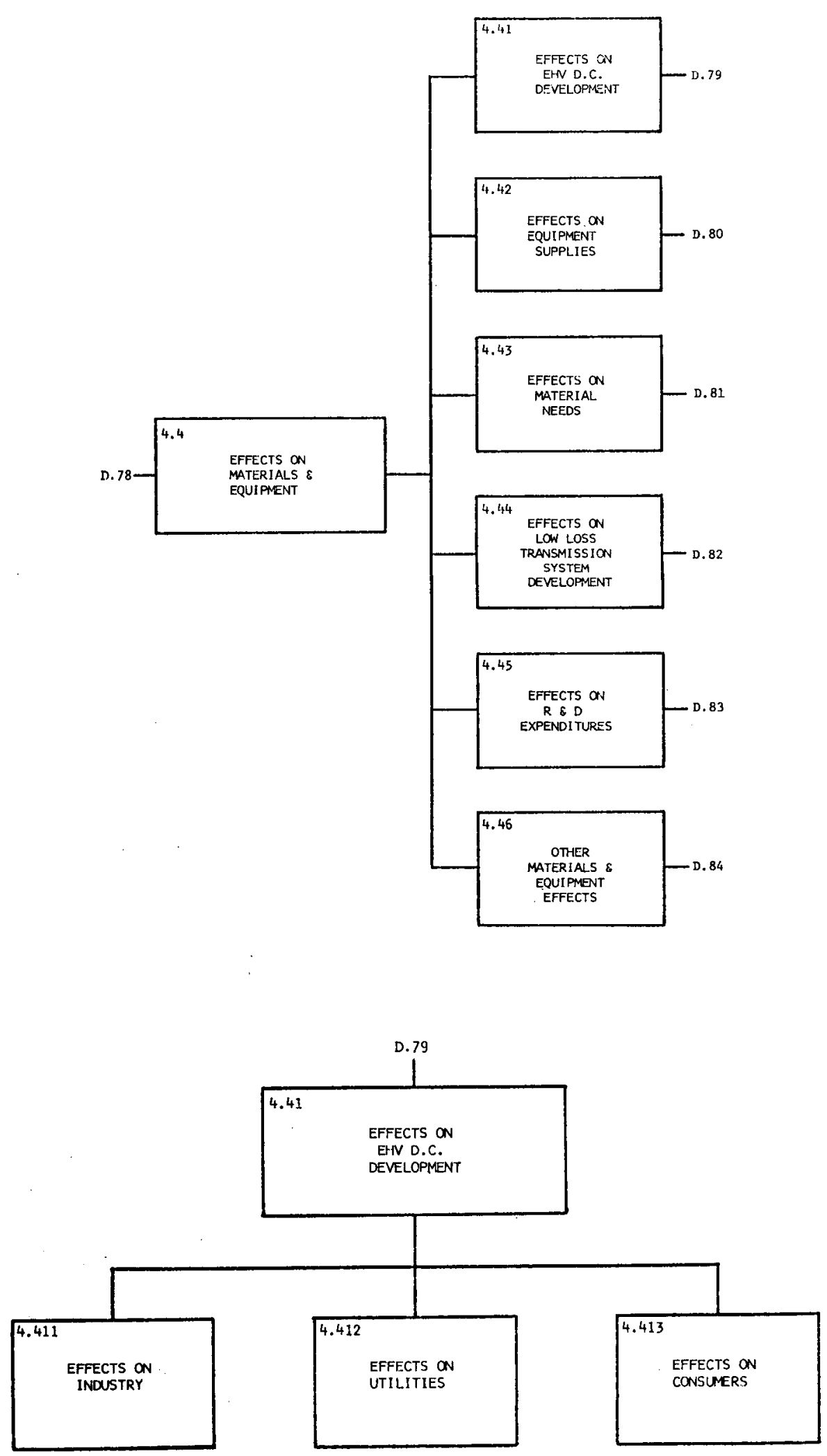

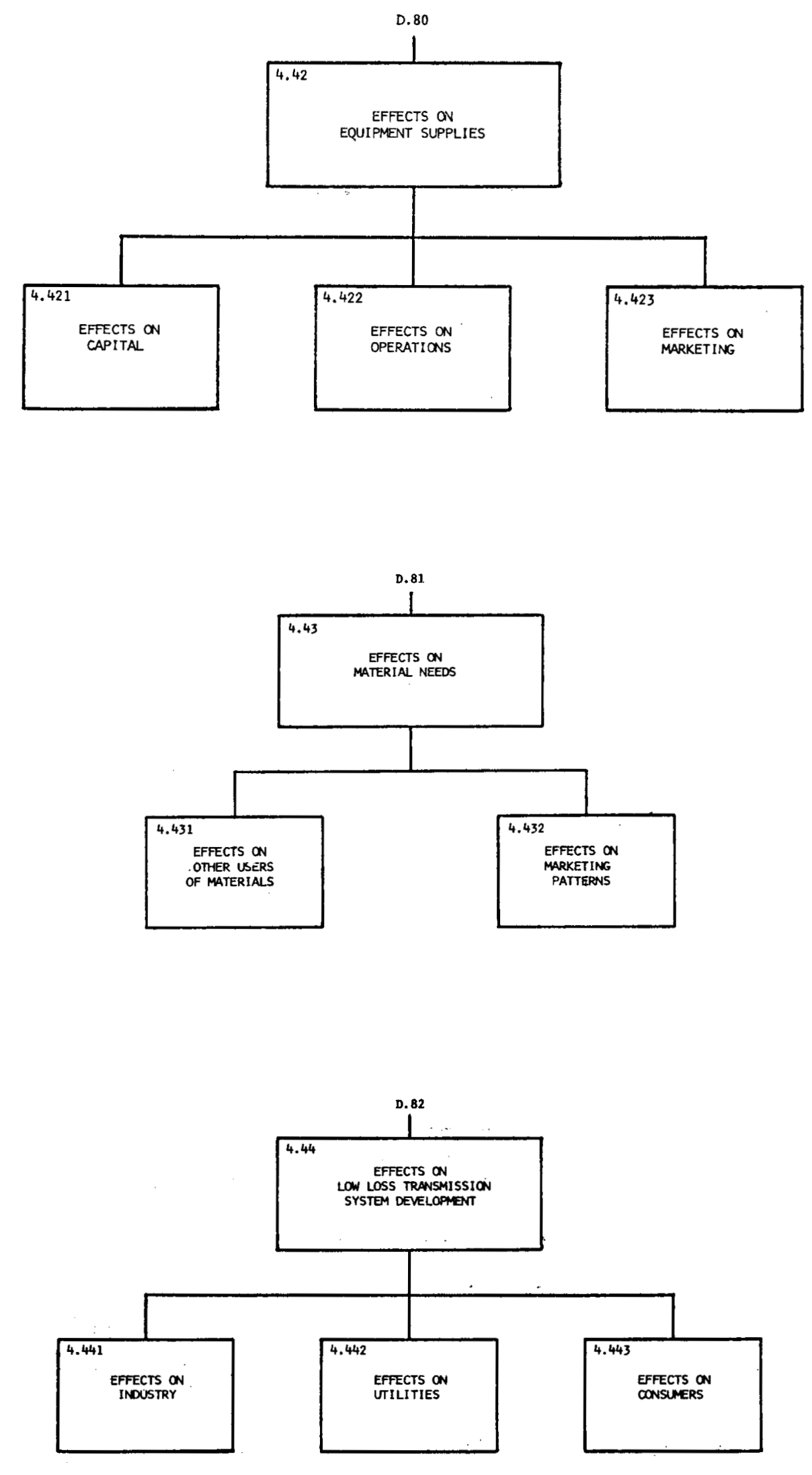

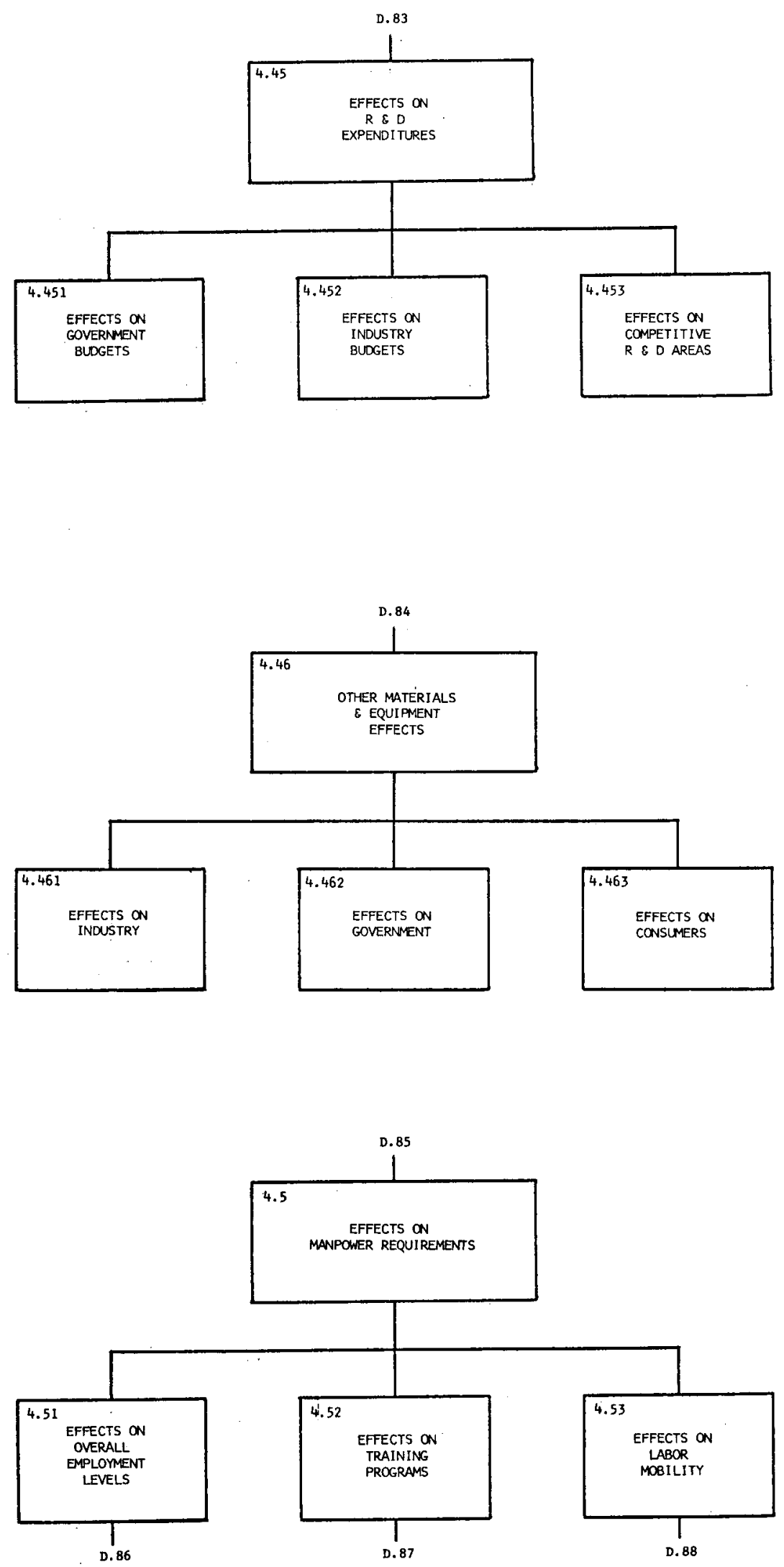

416 

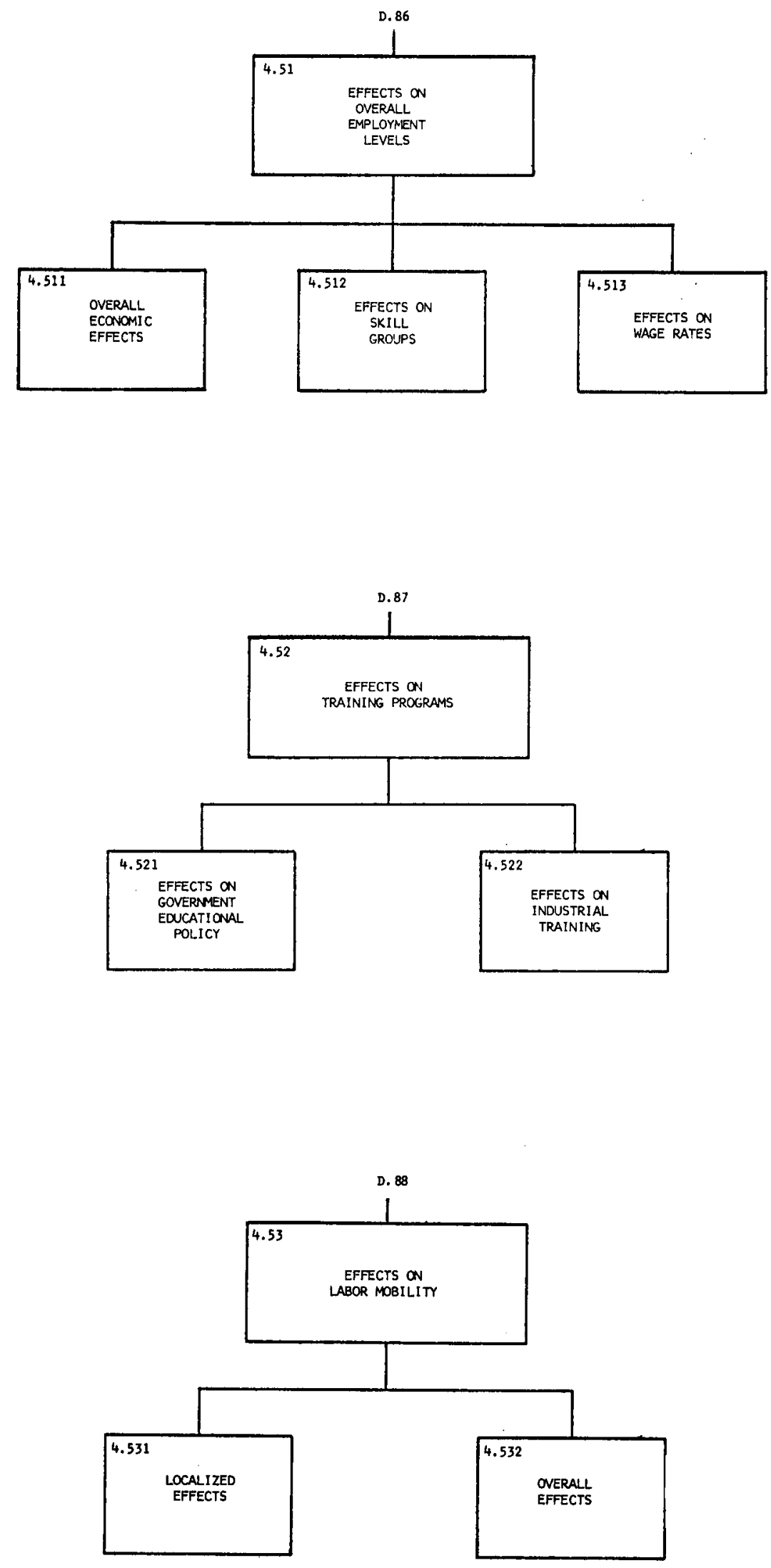

417 

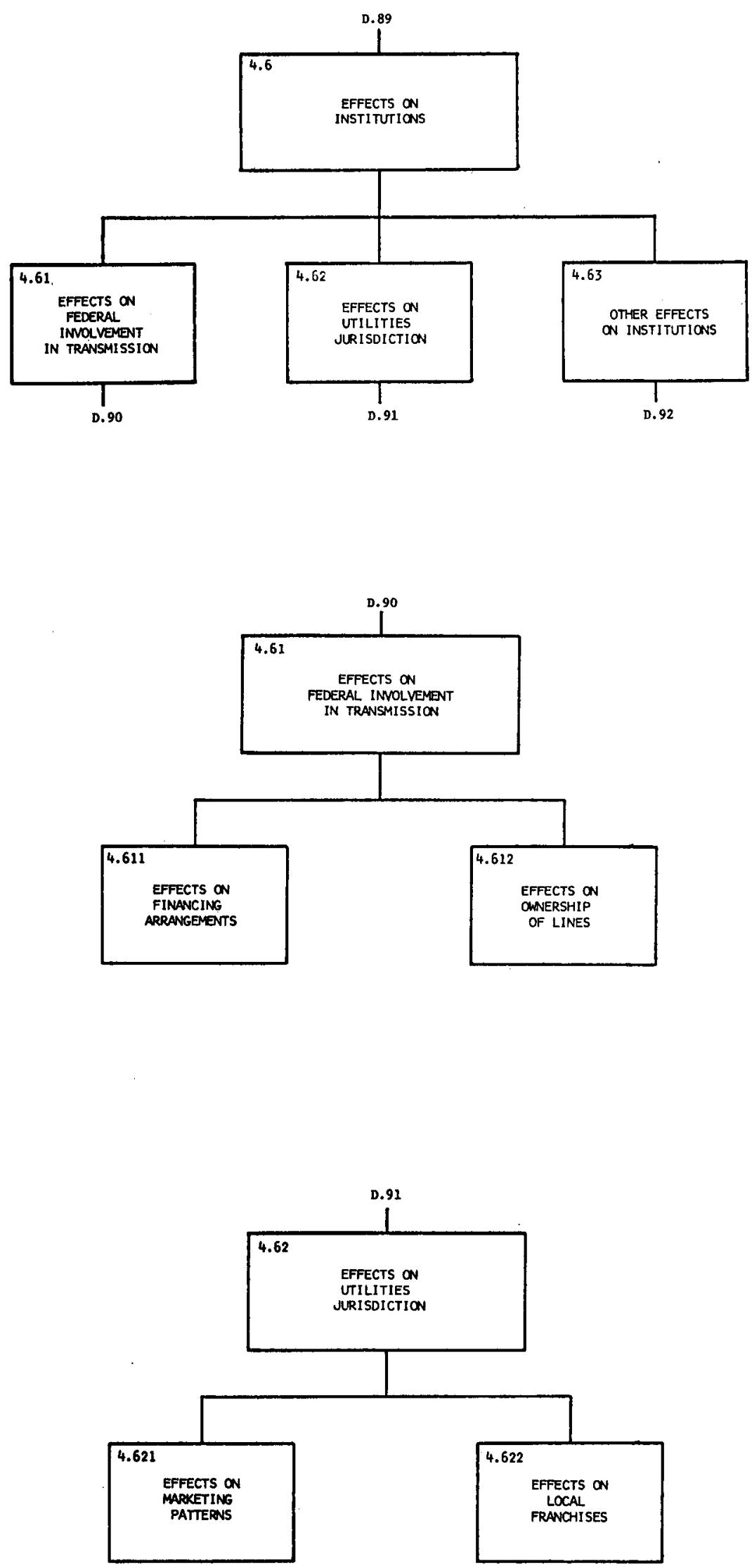

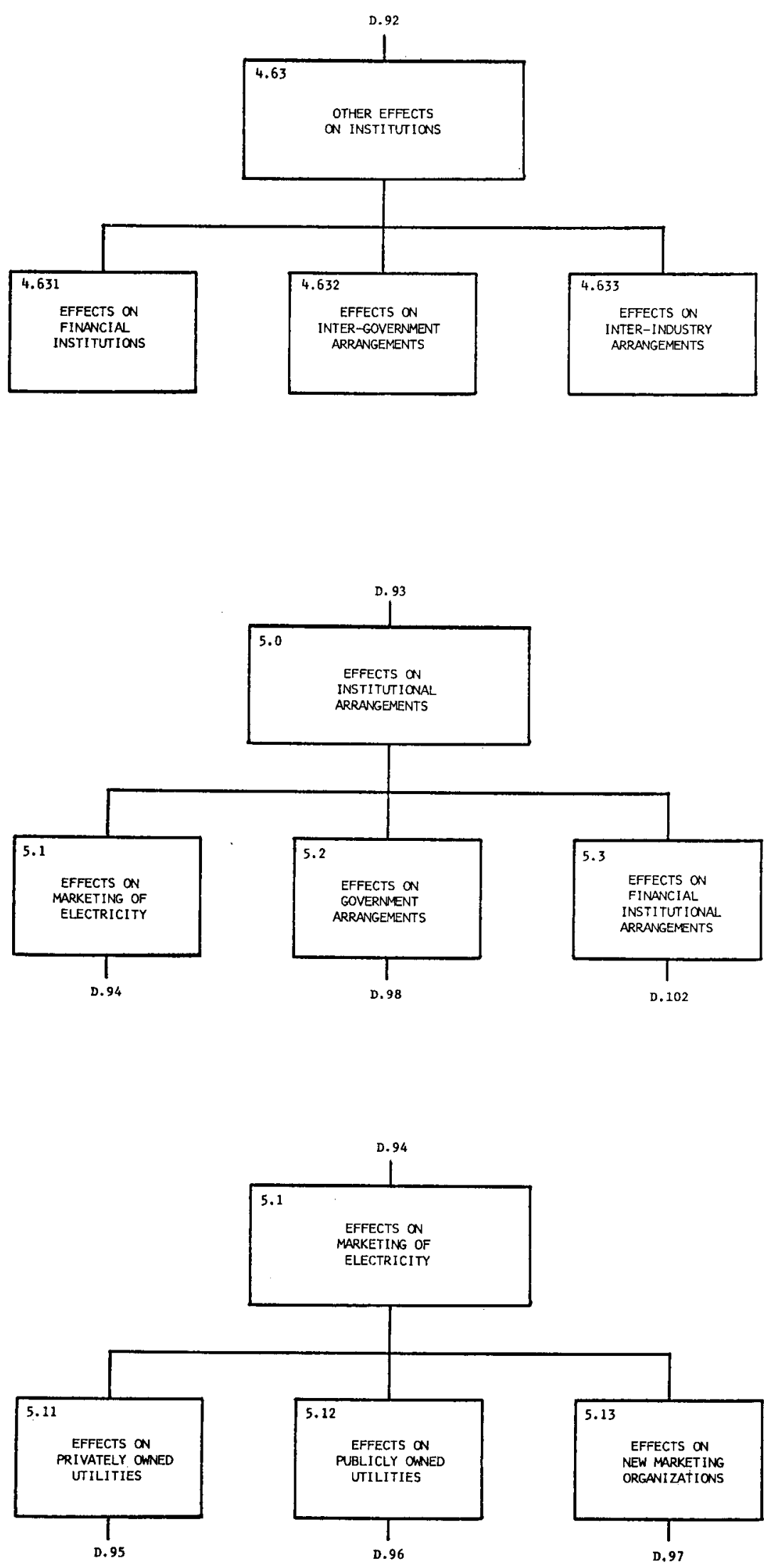


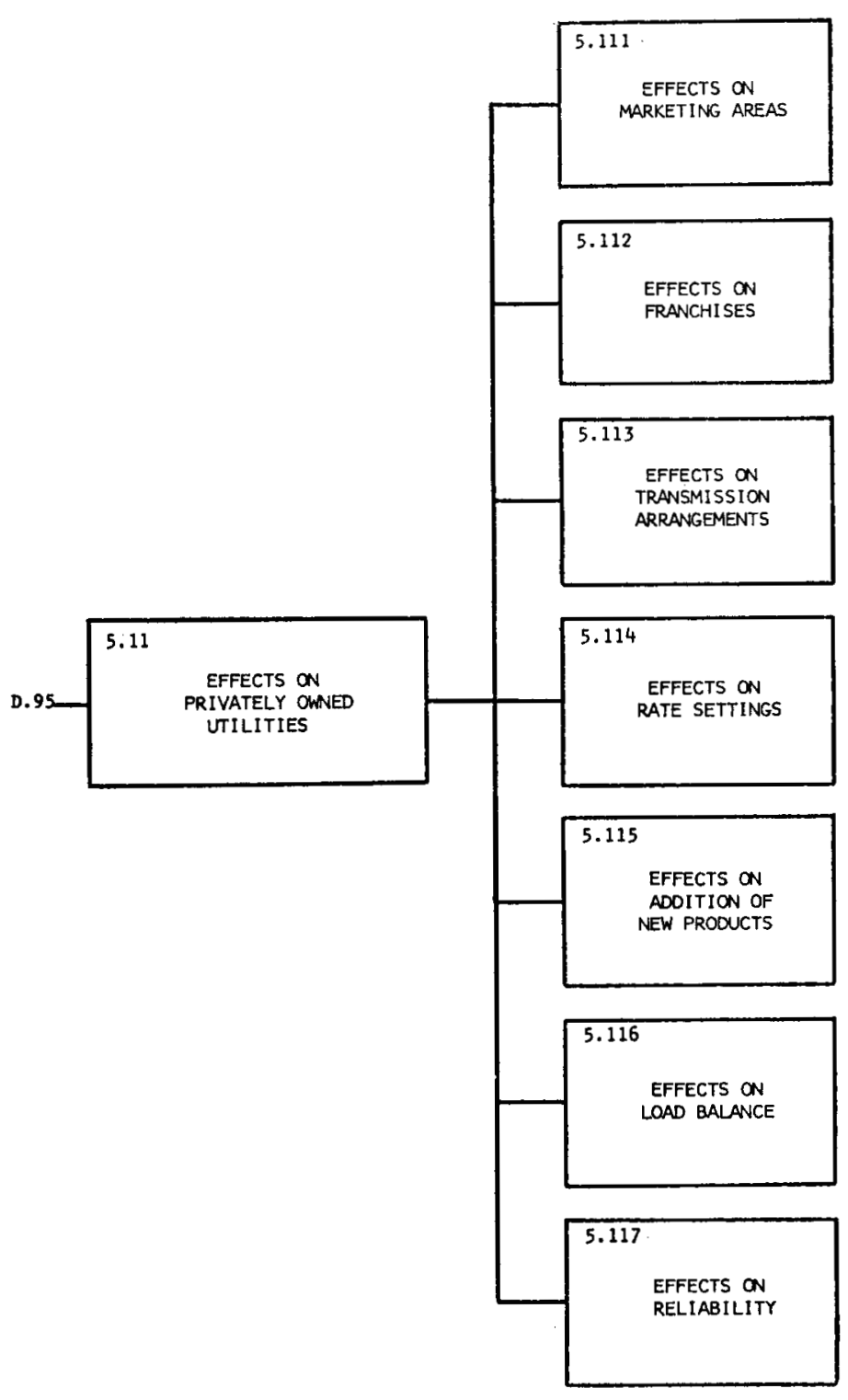




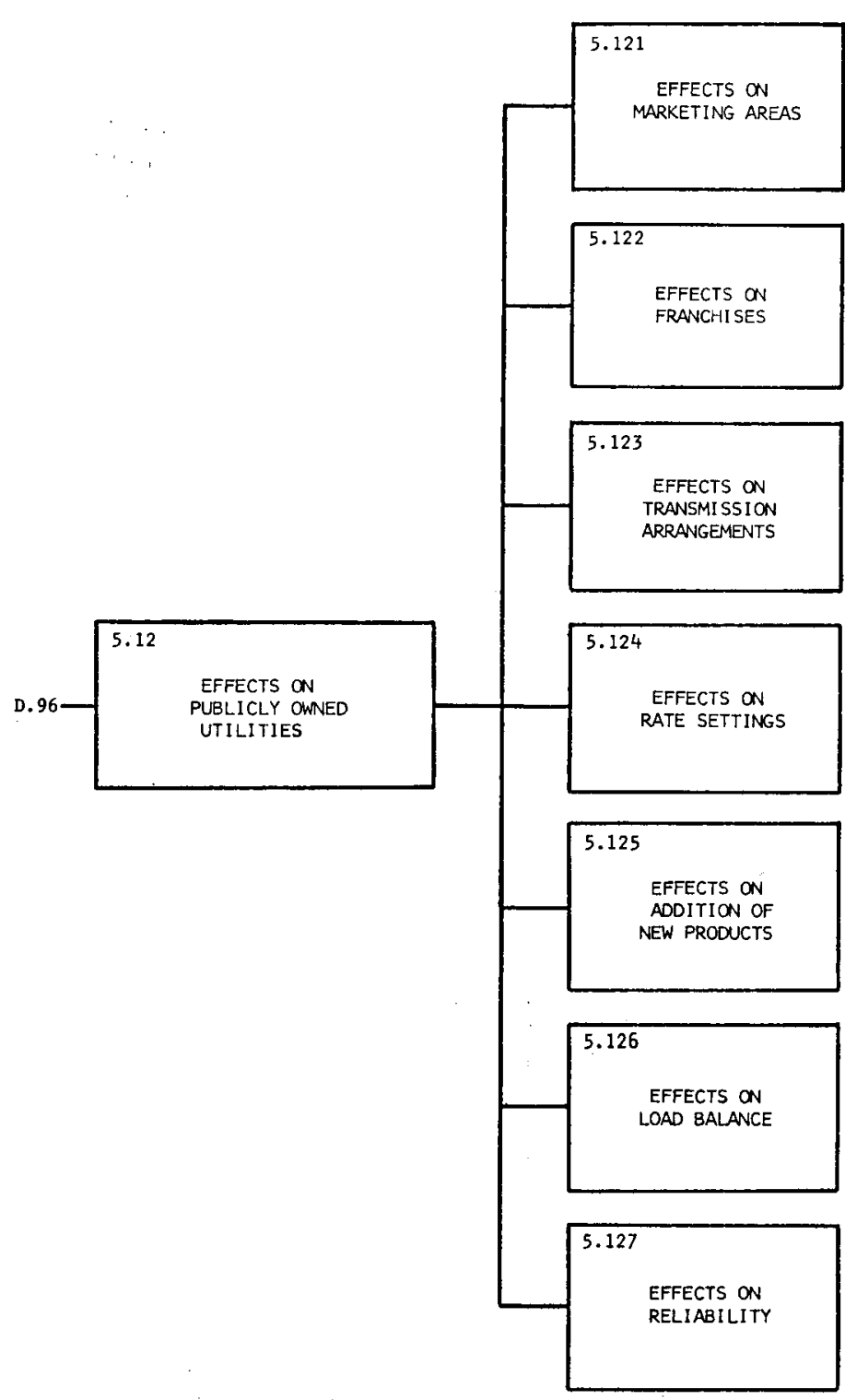




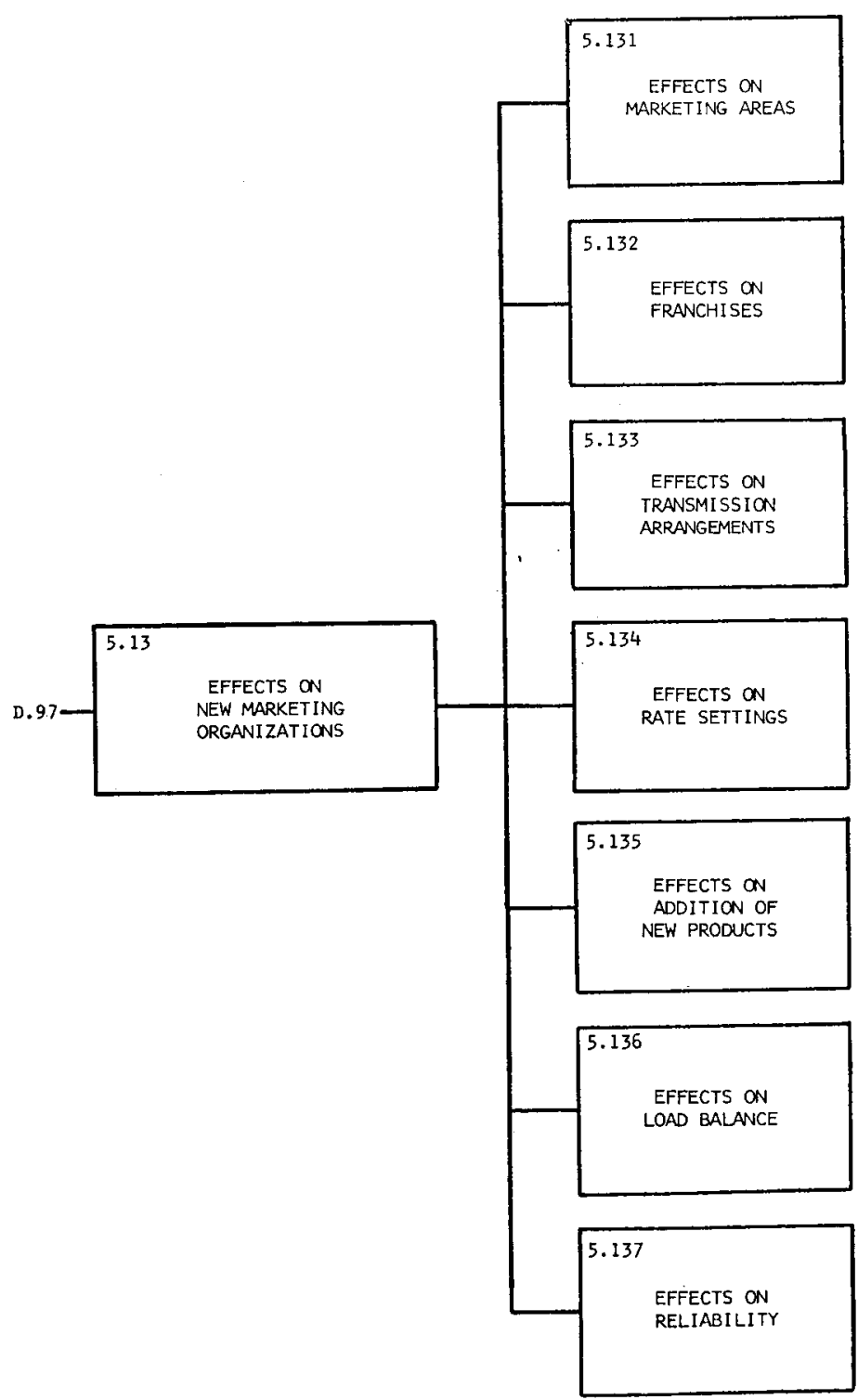



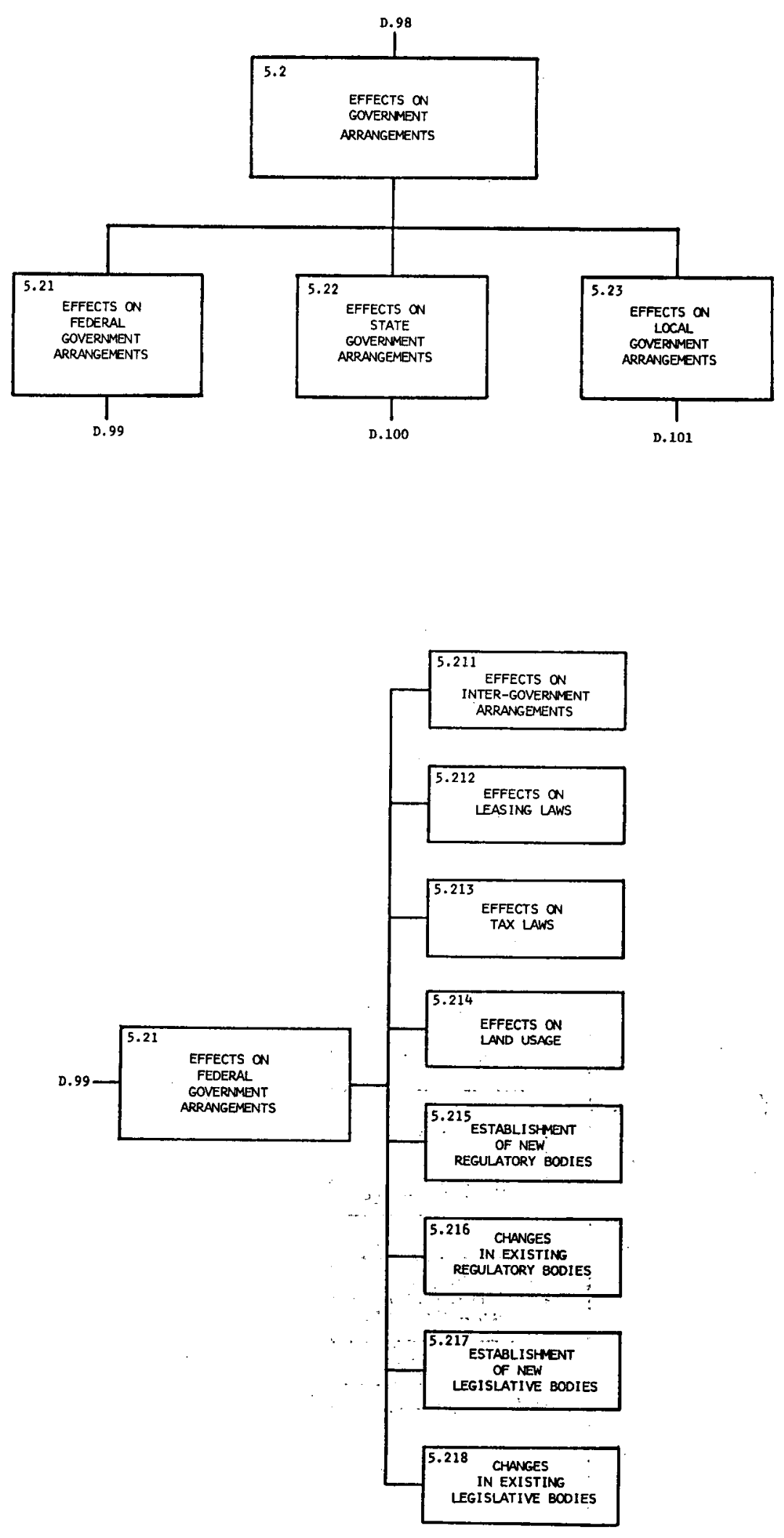


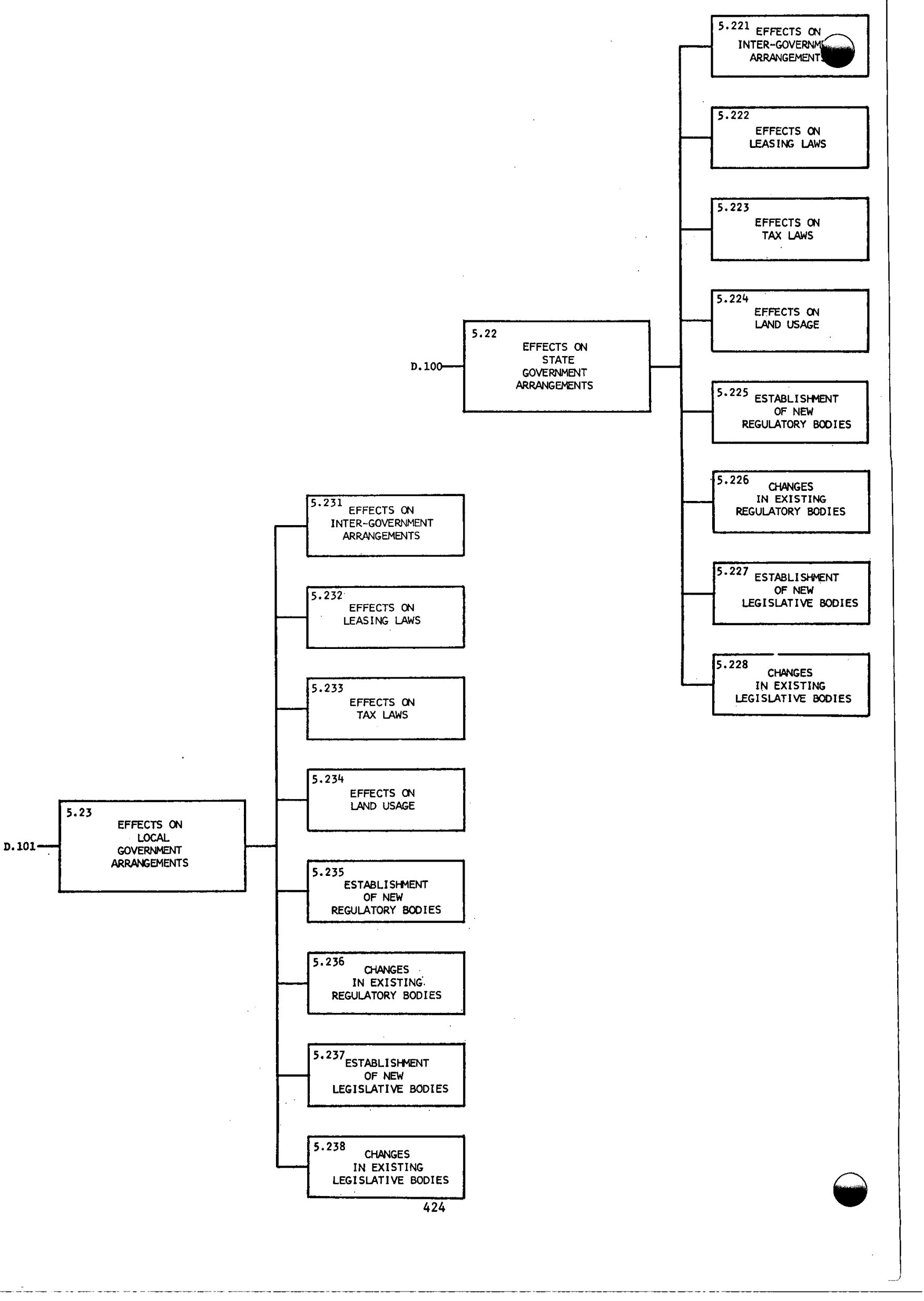



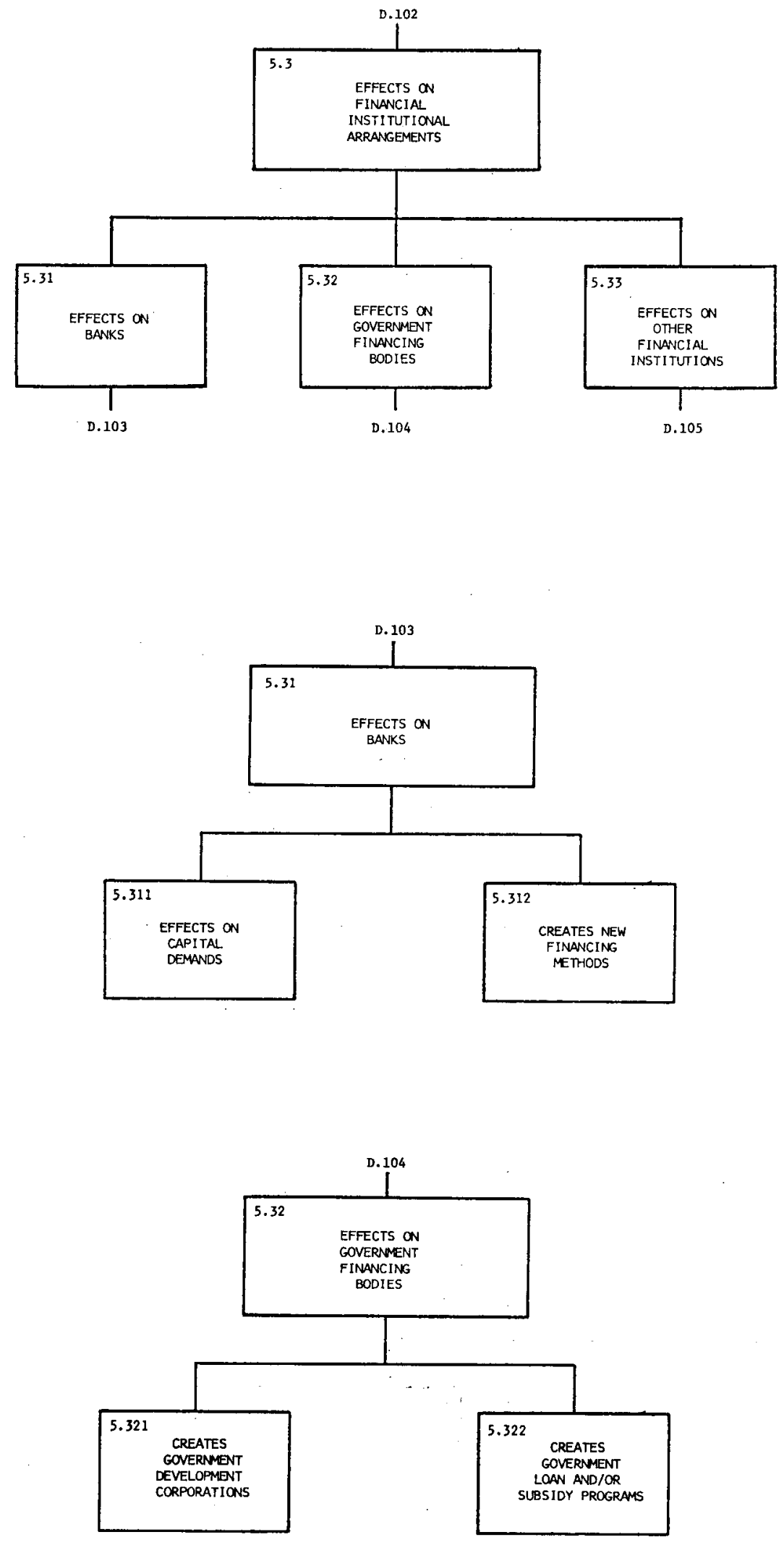

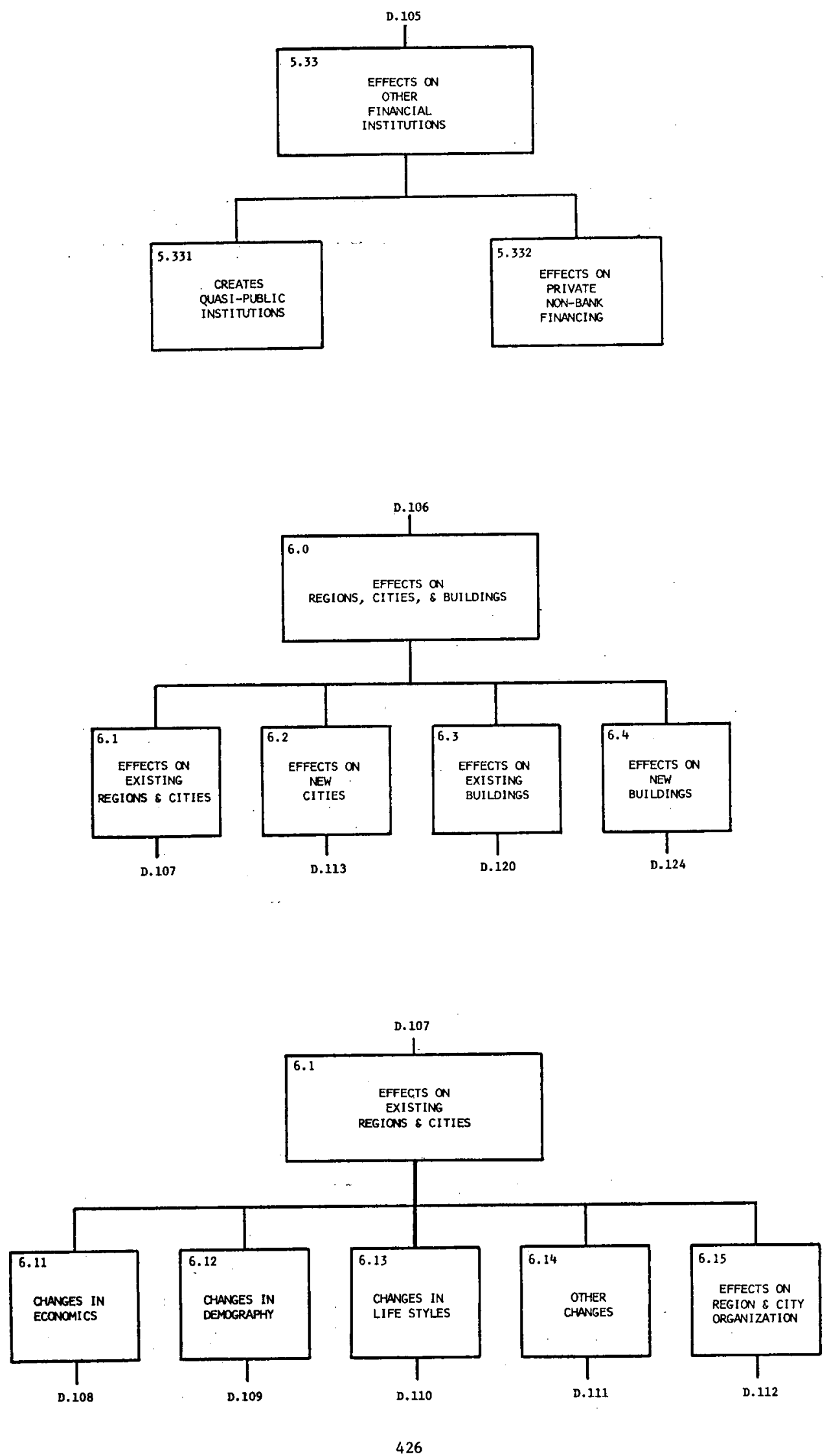

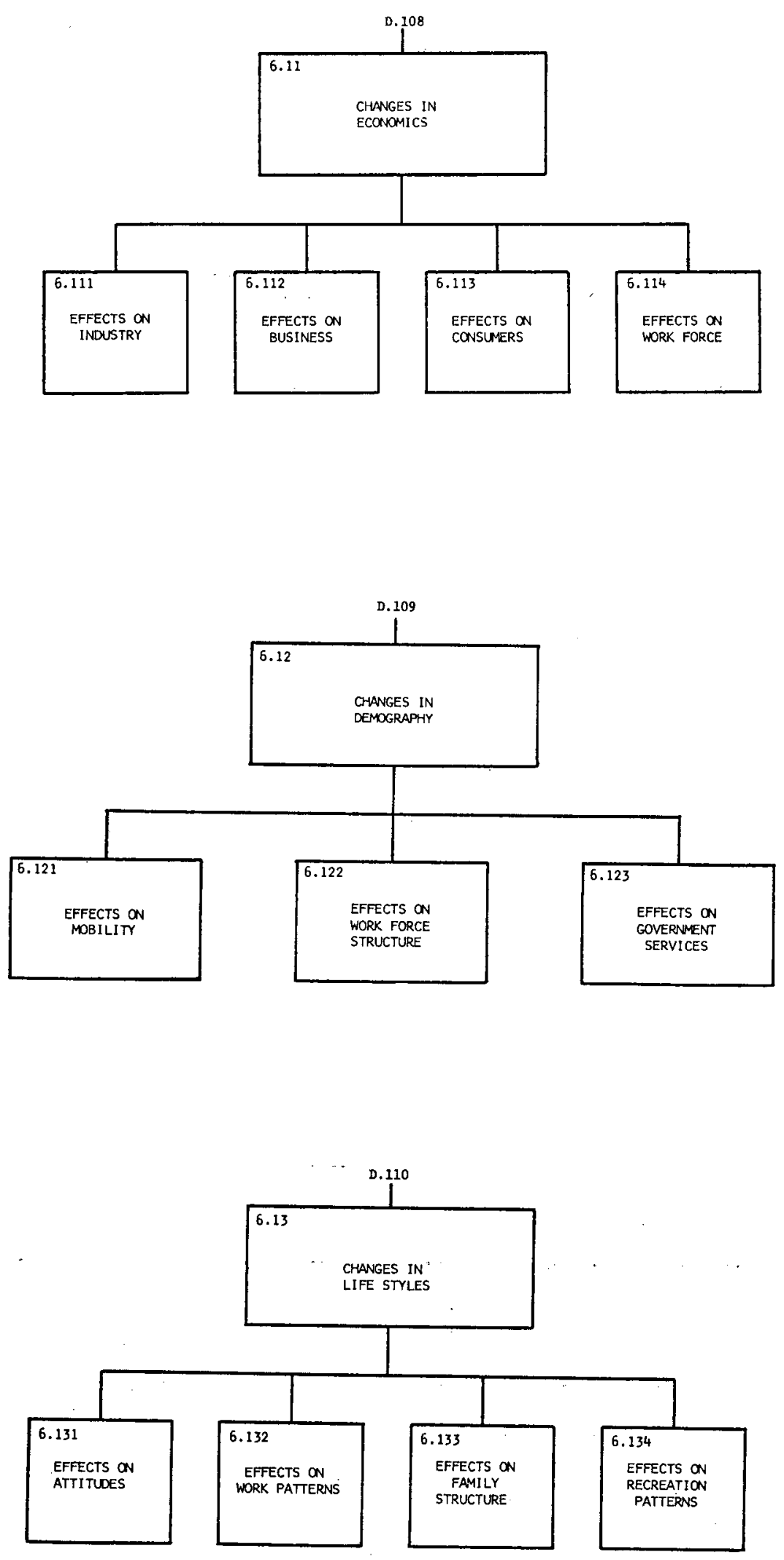

427 

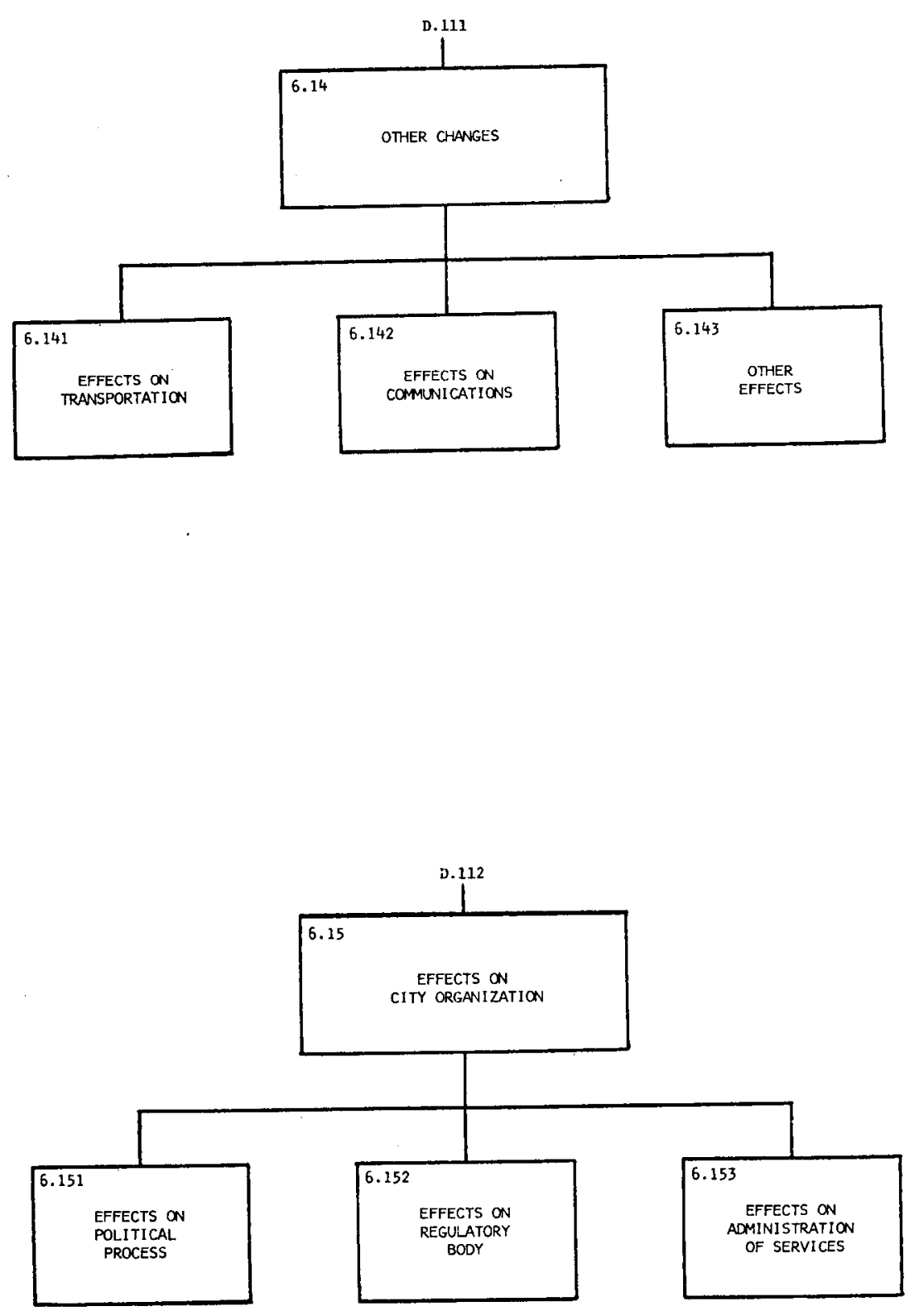

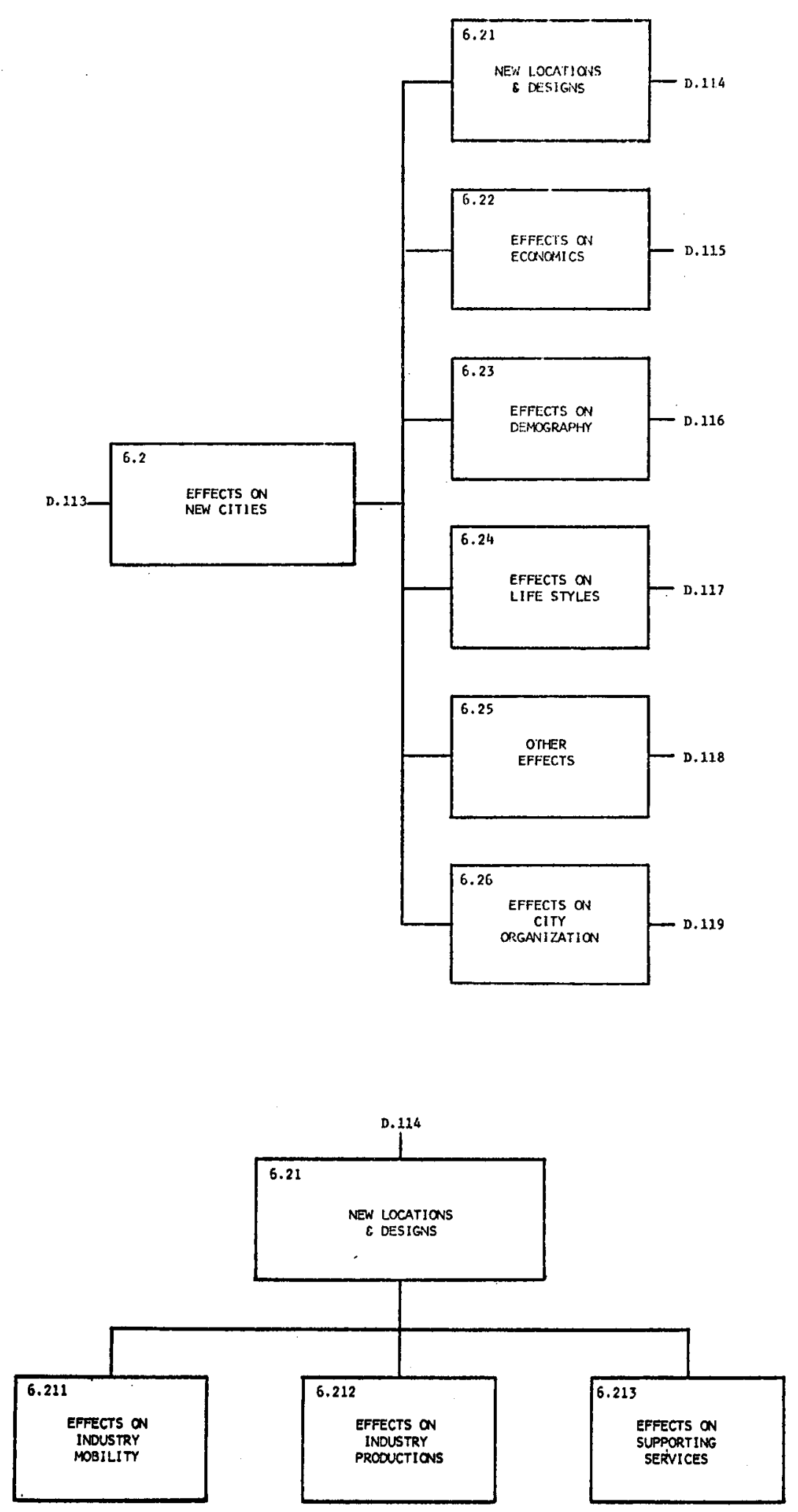

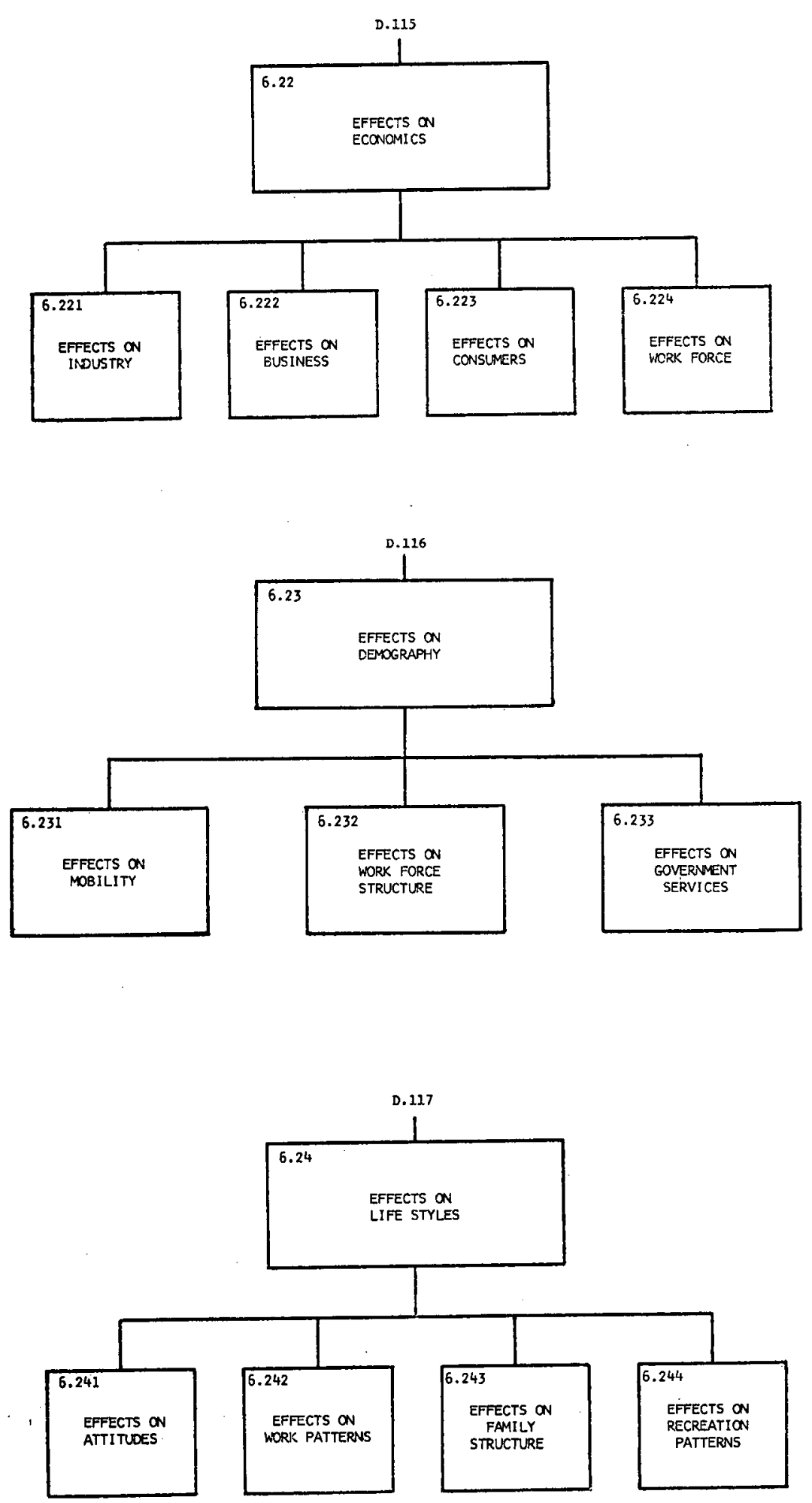

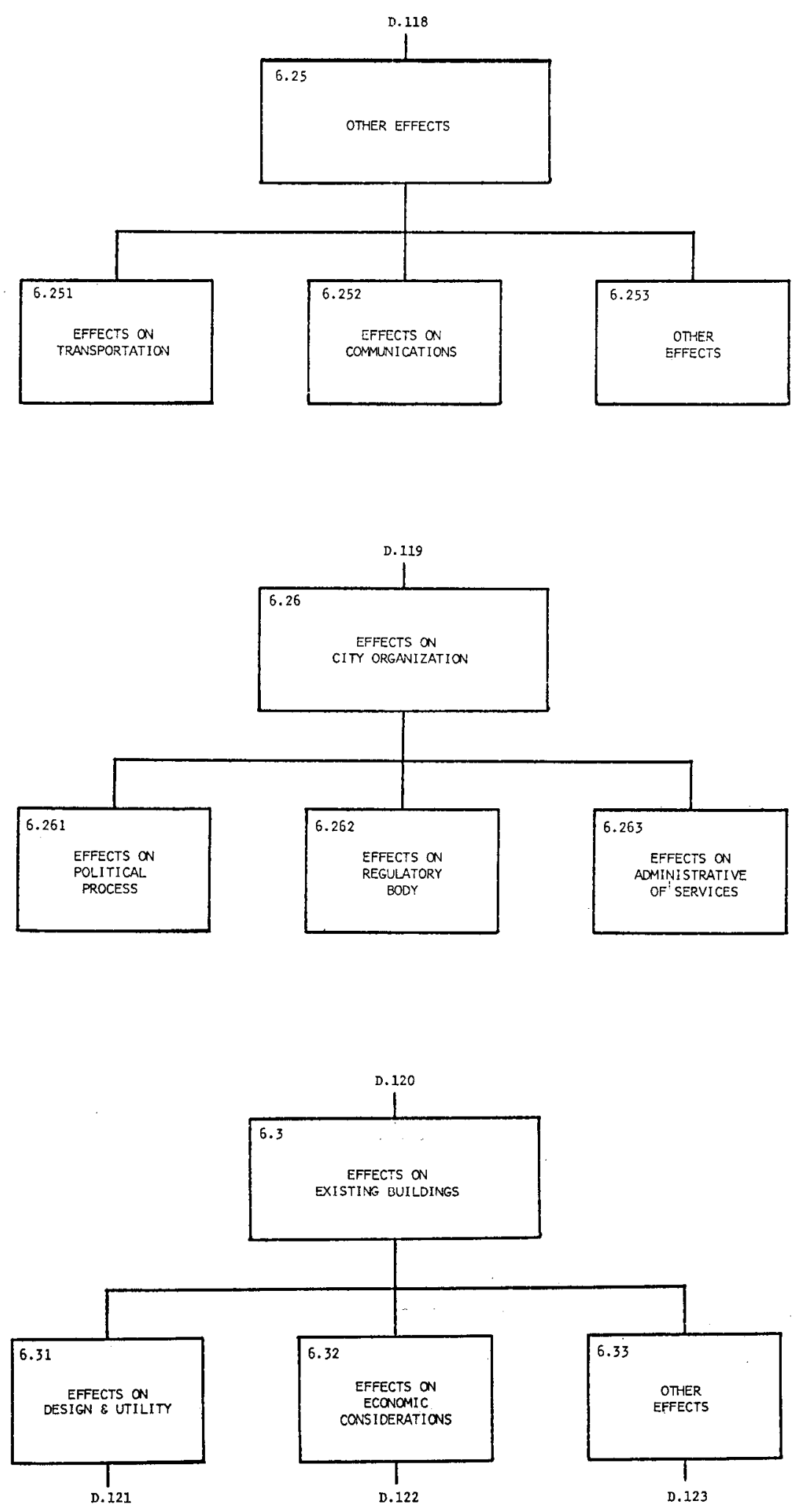

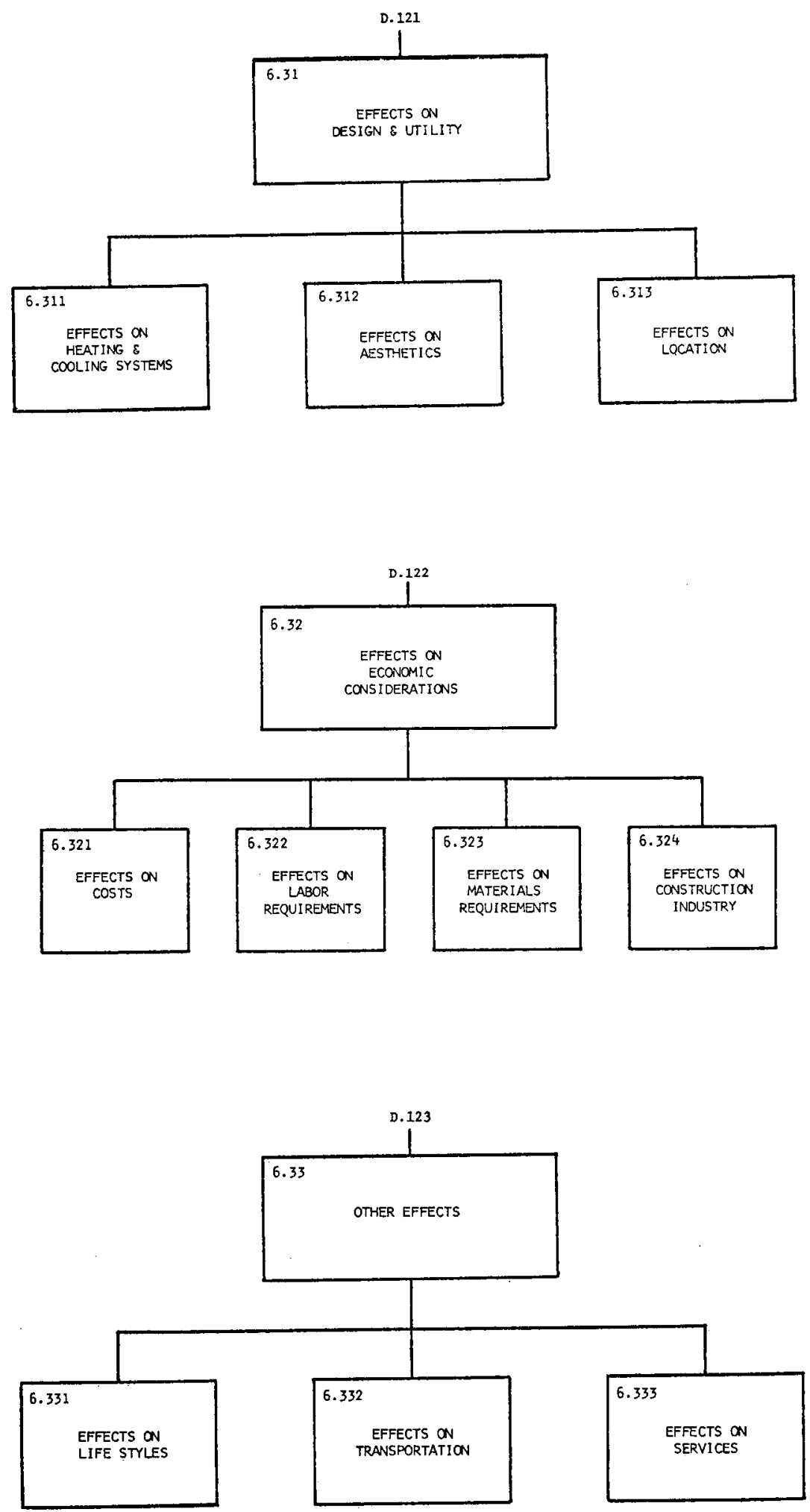

432 

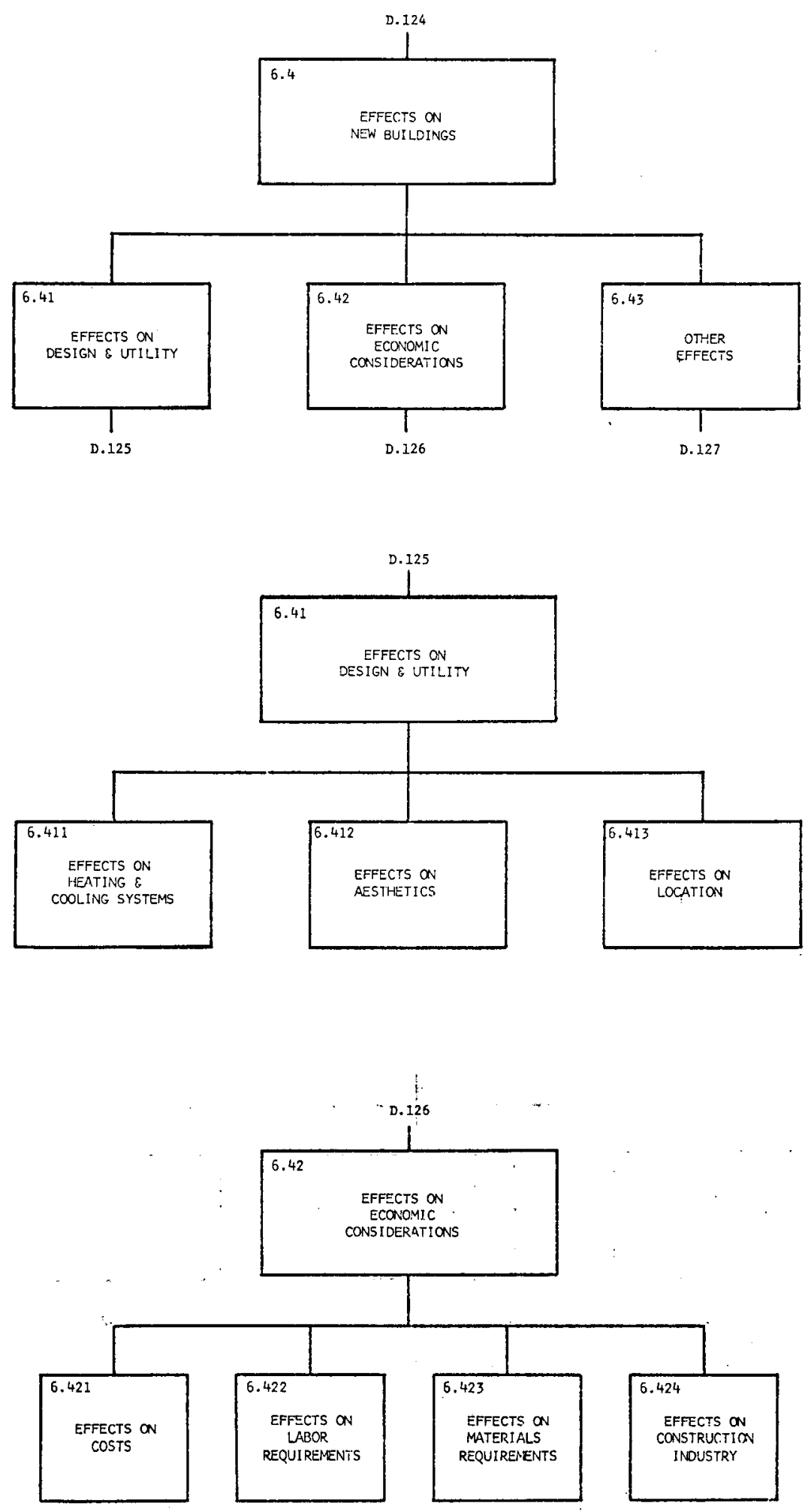

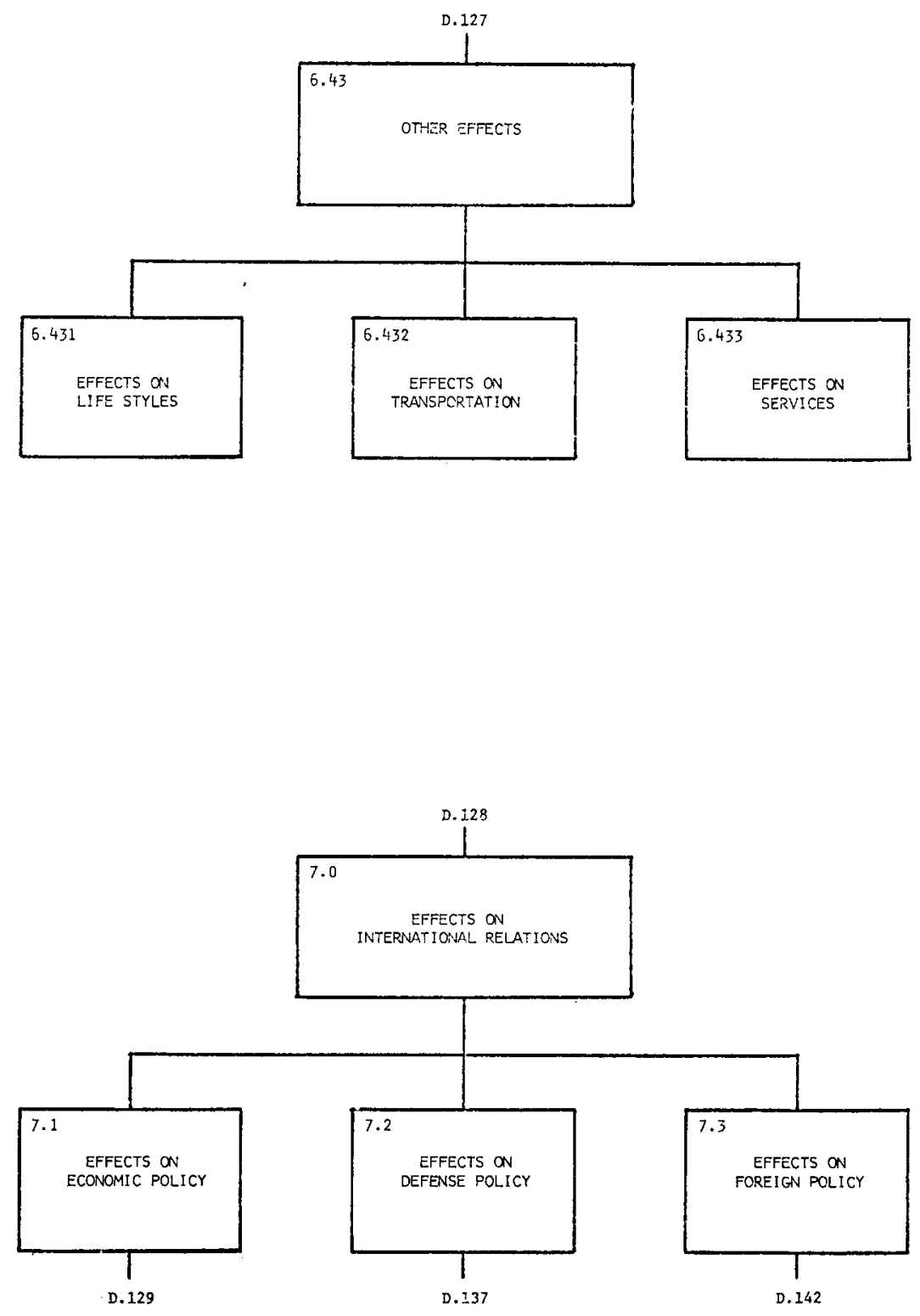

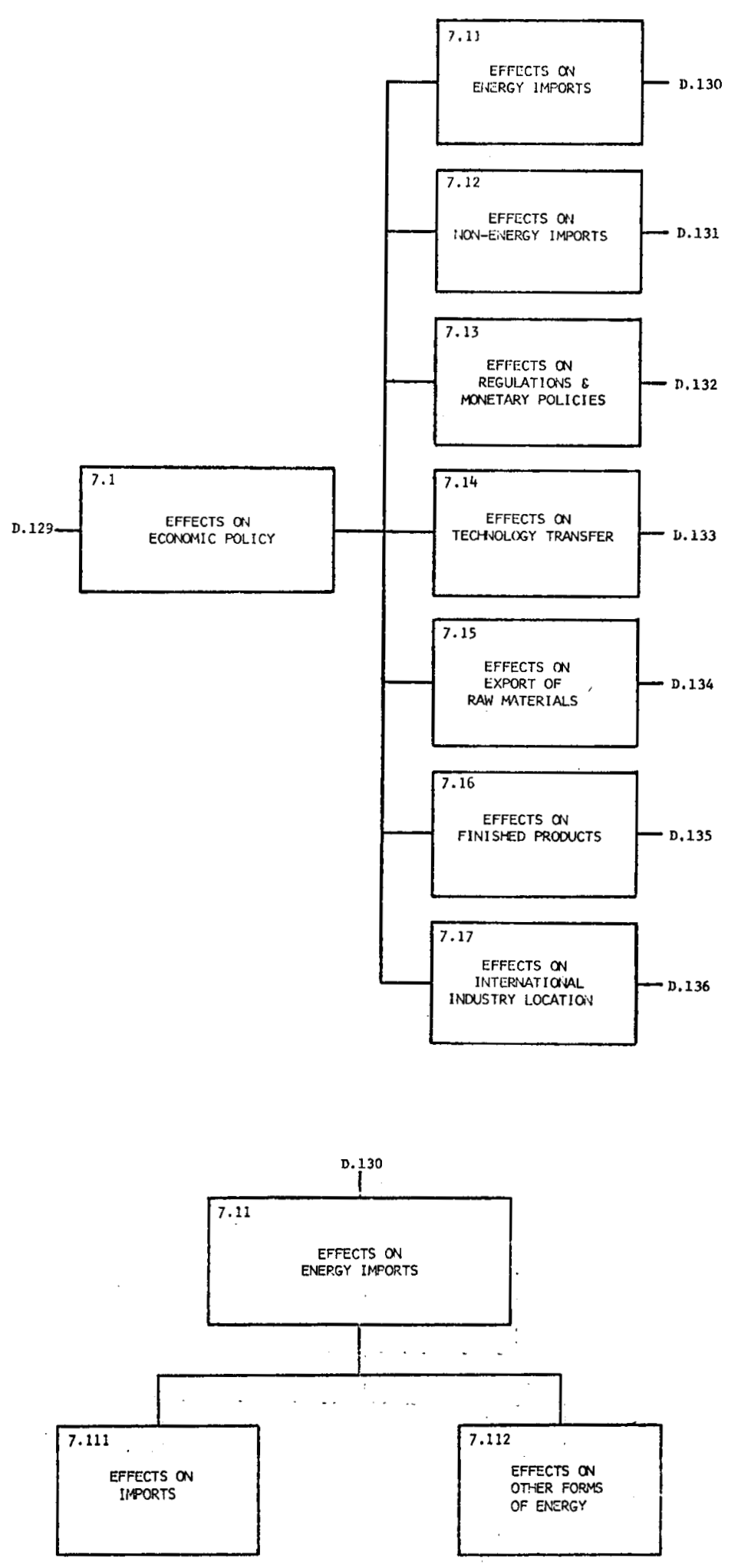

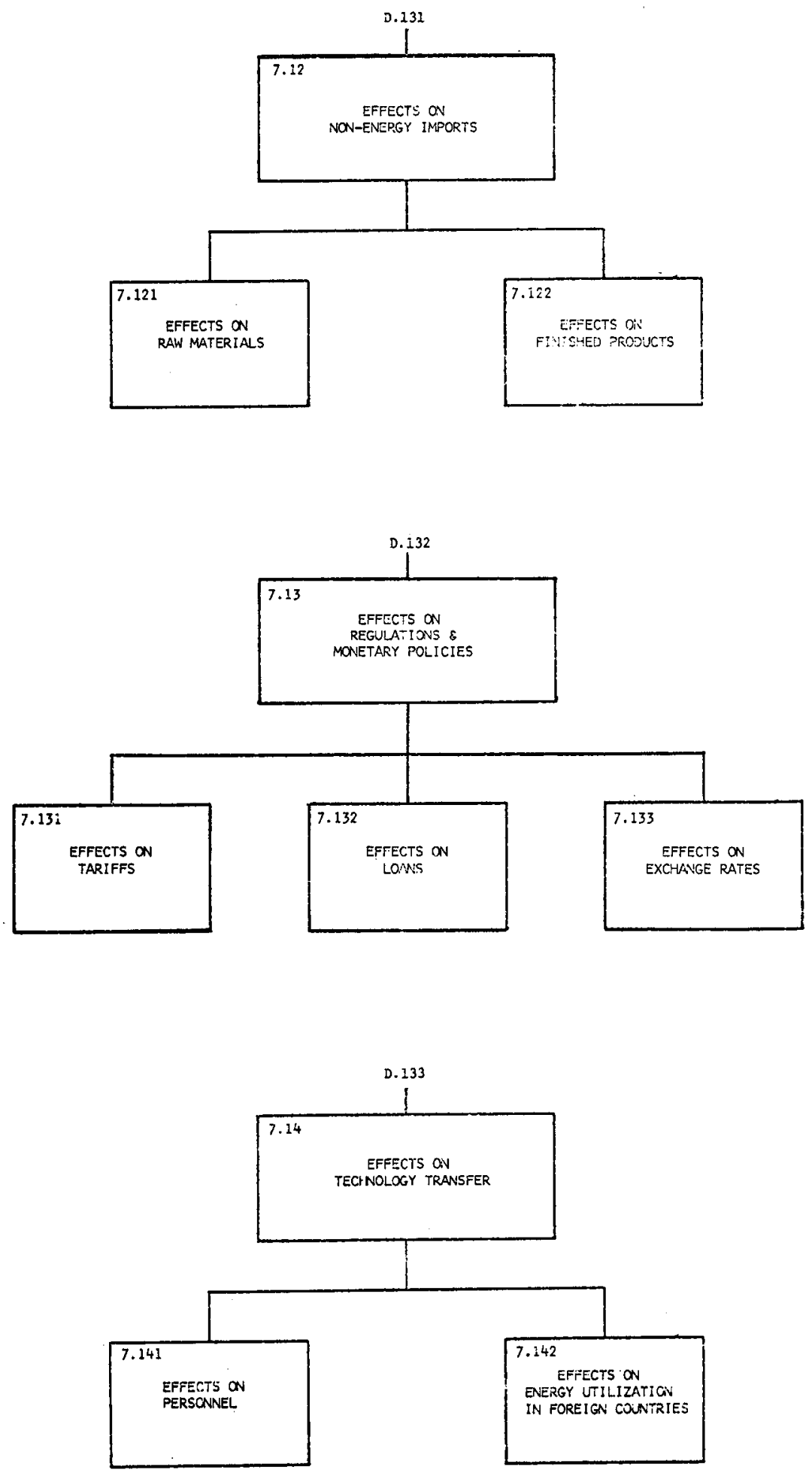

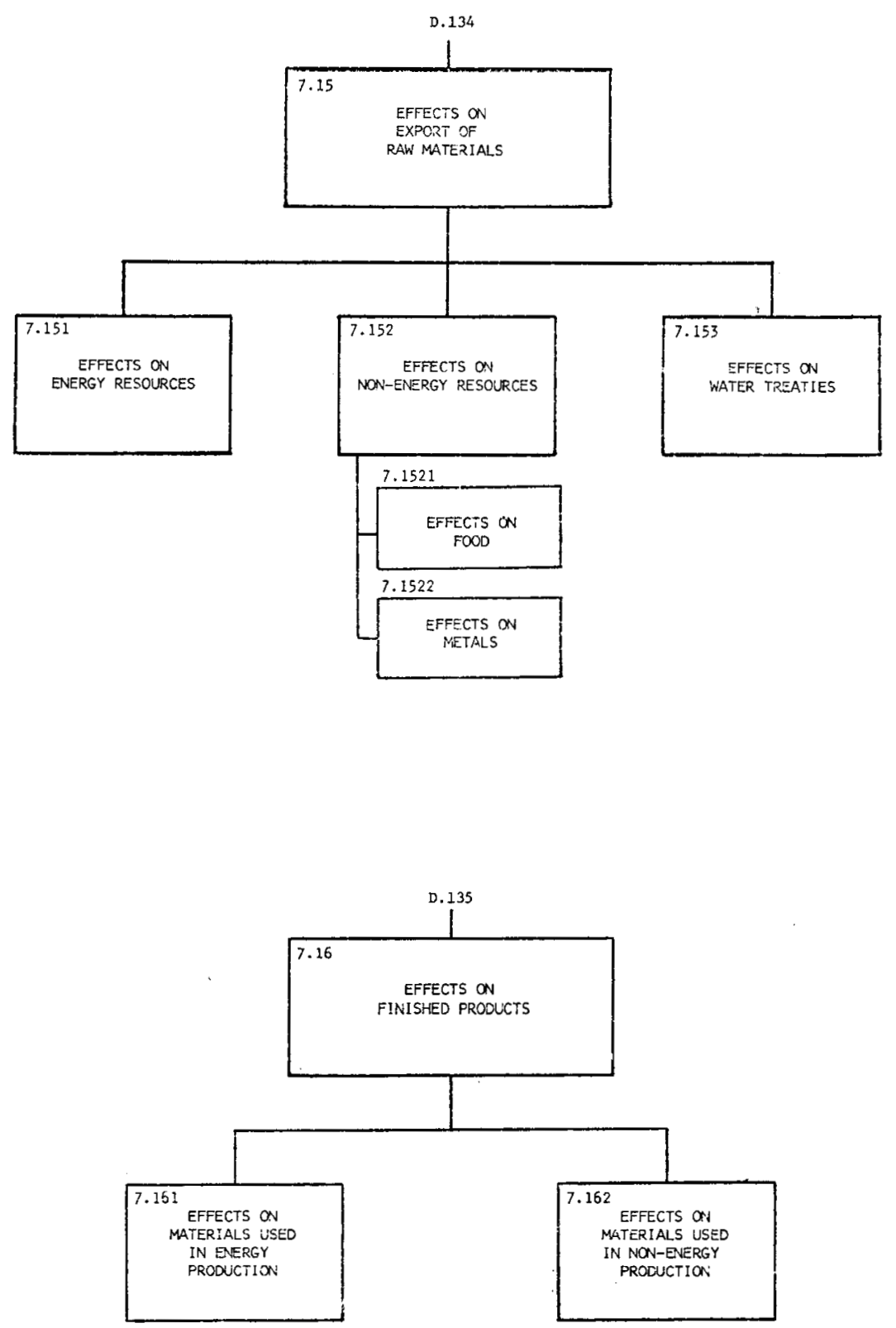

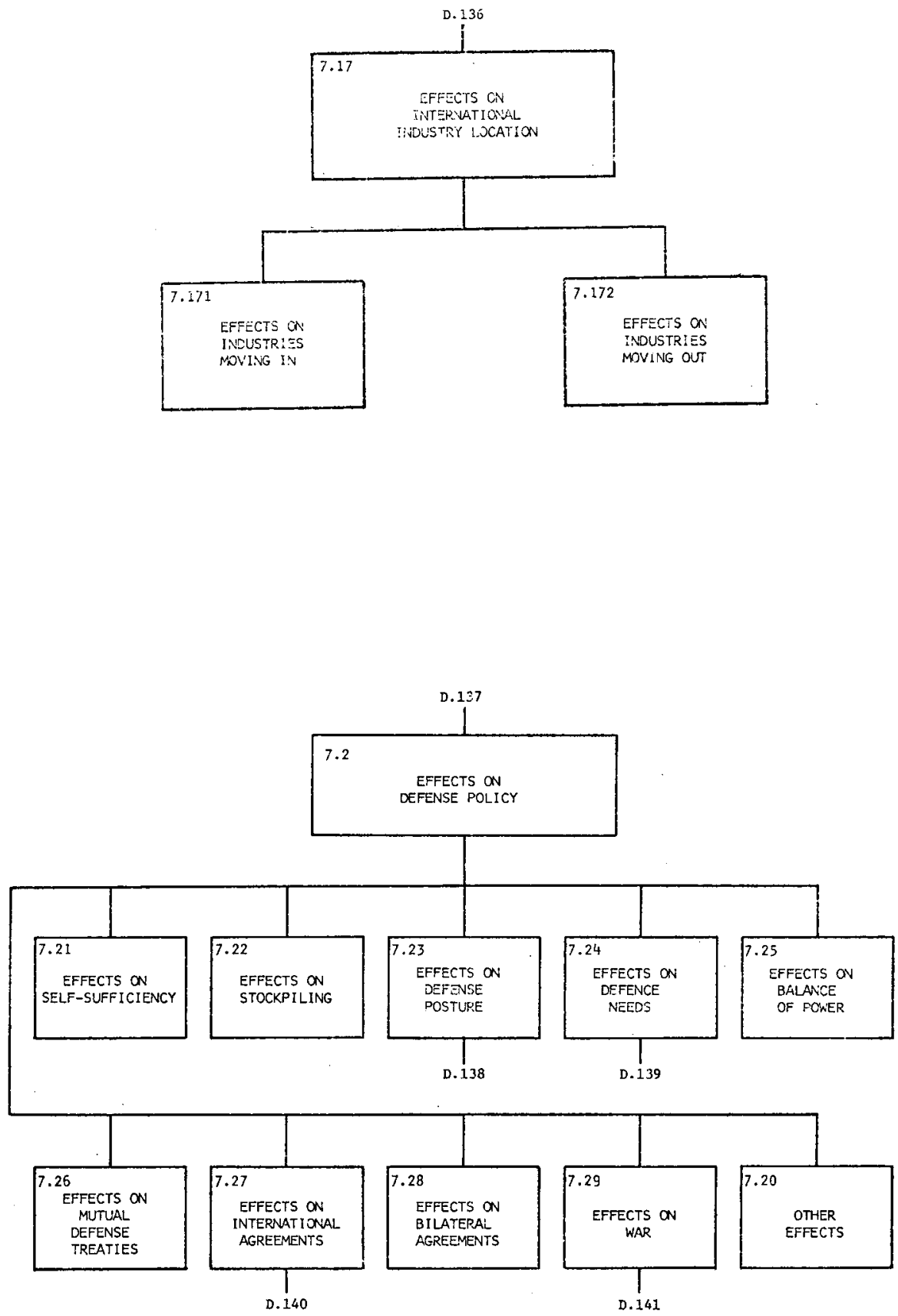

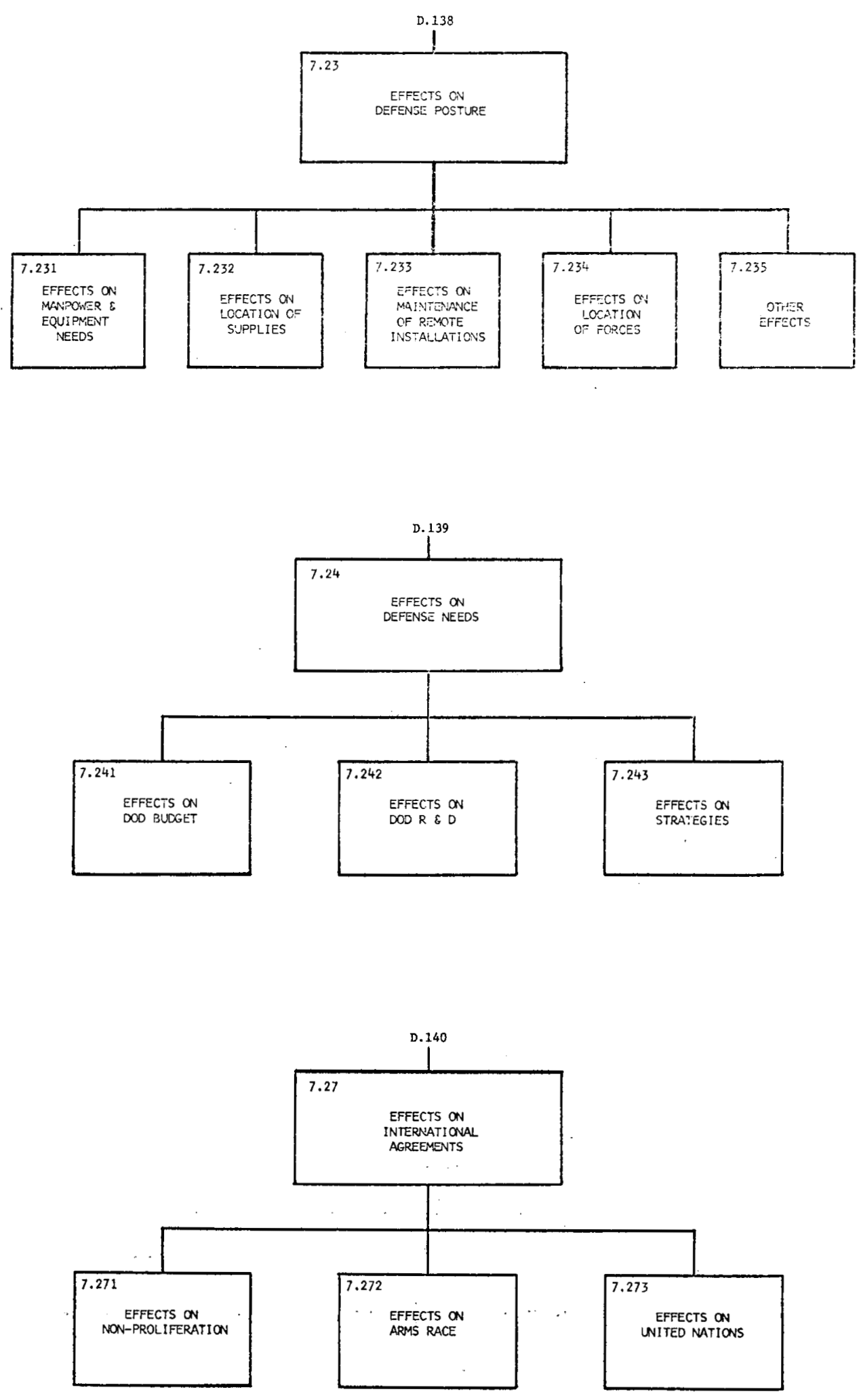

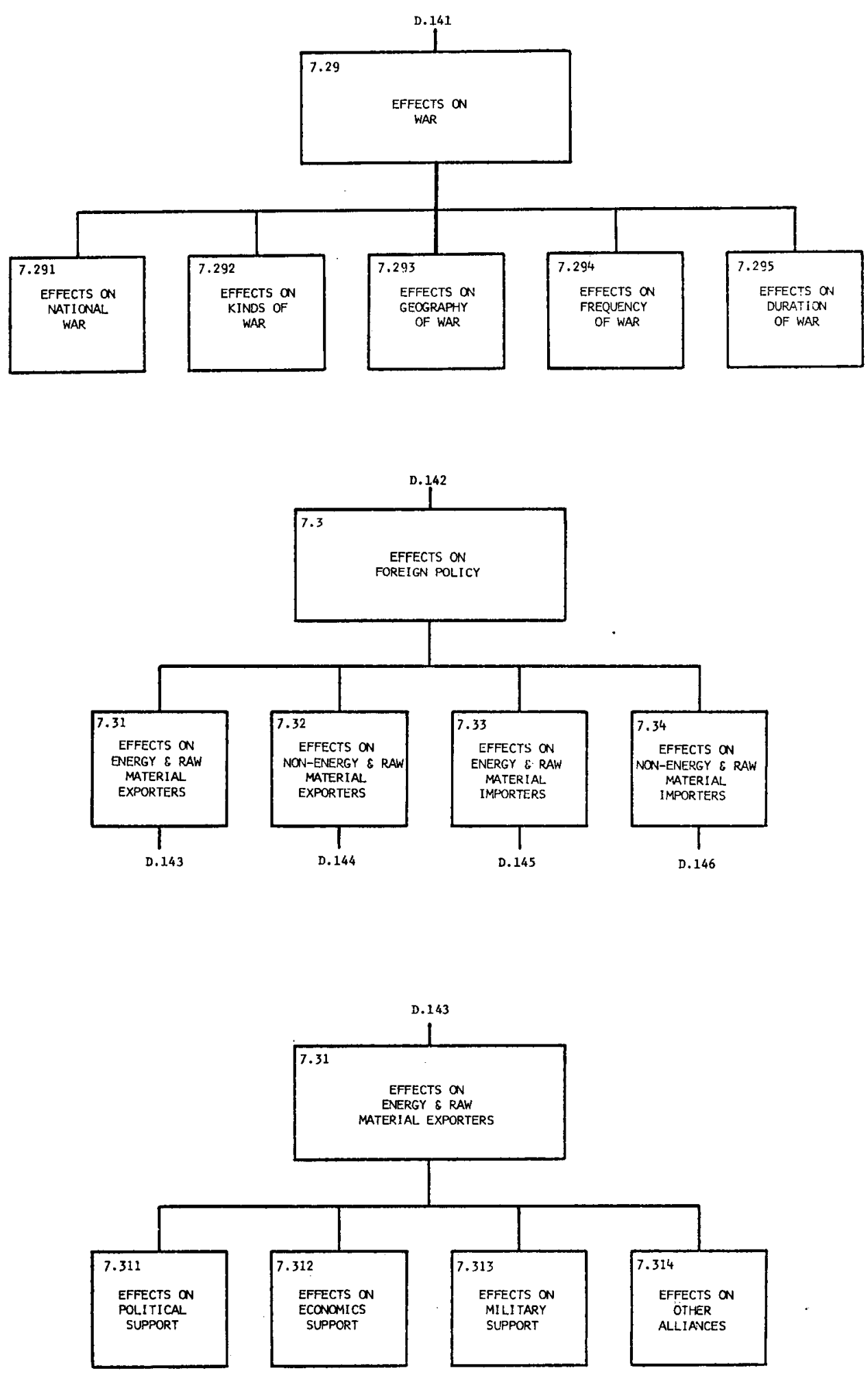

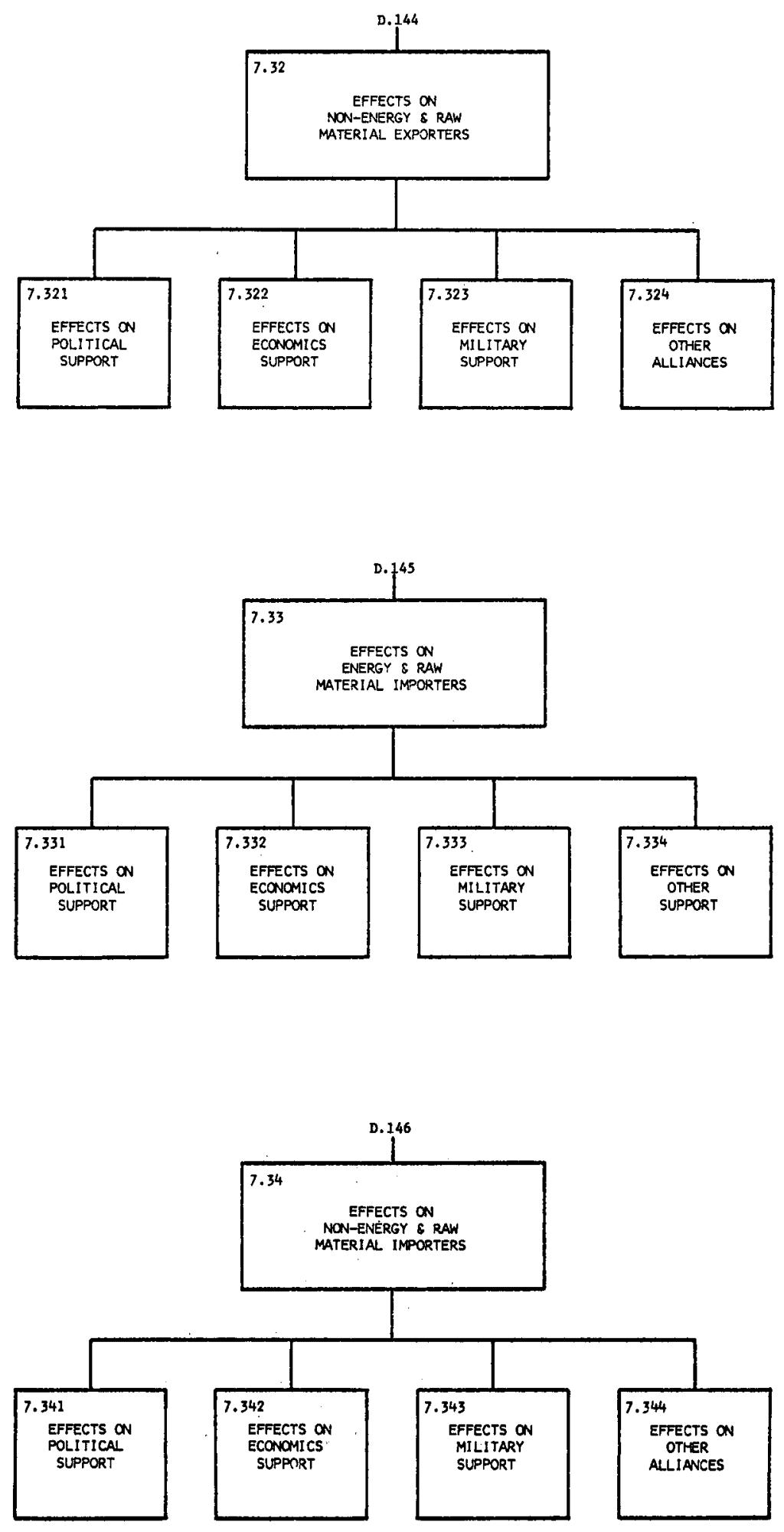

441 

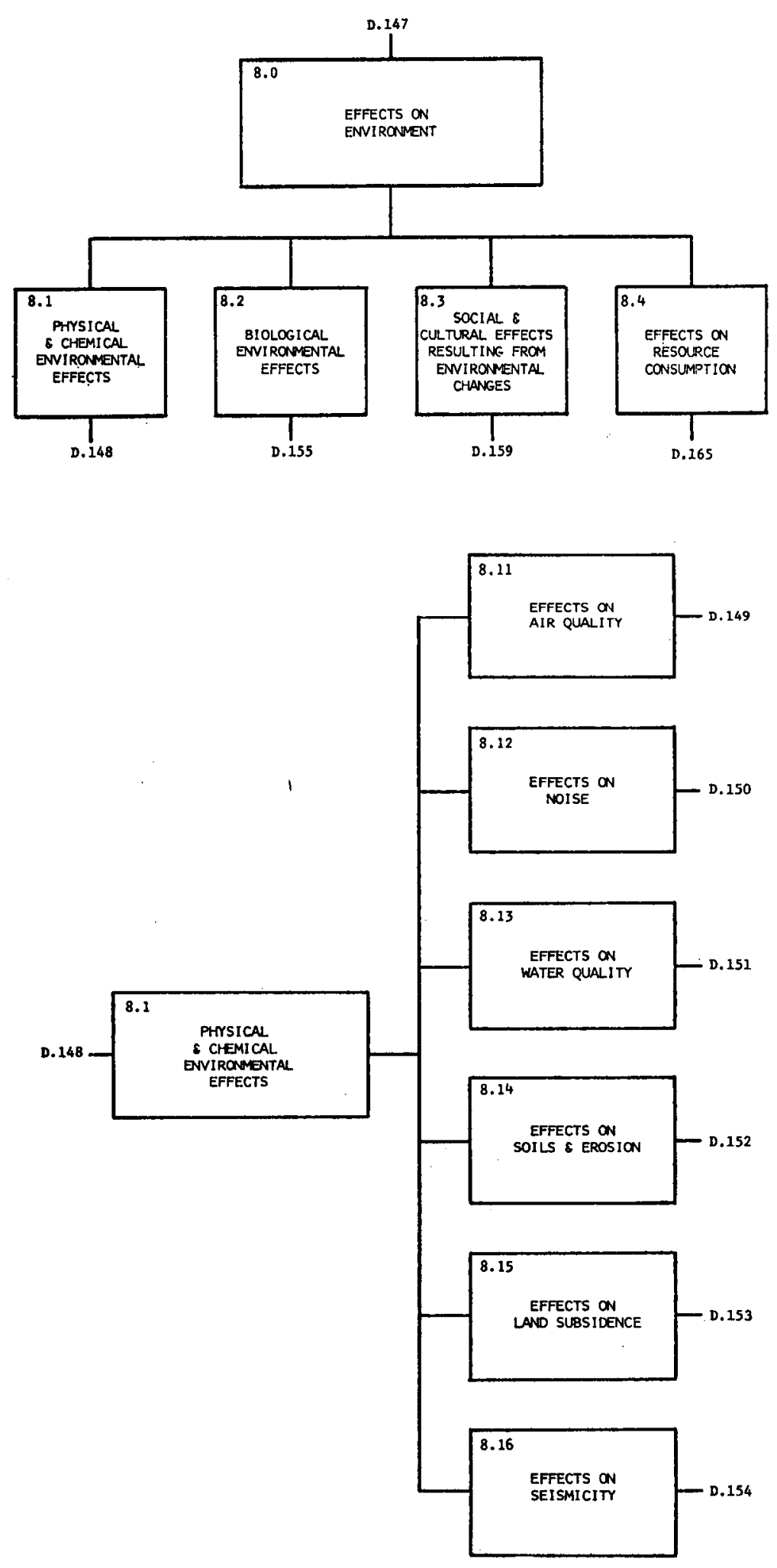

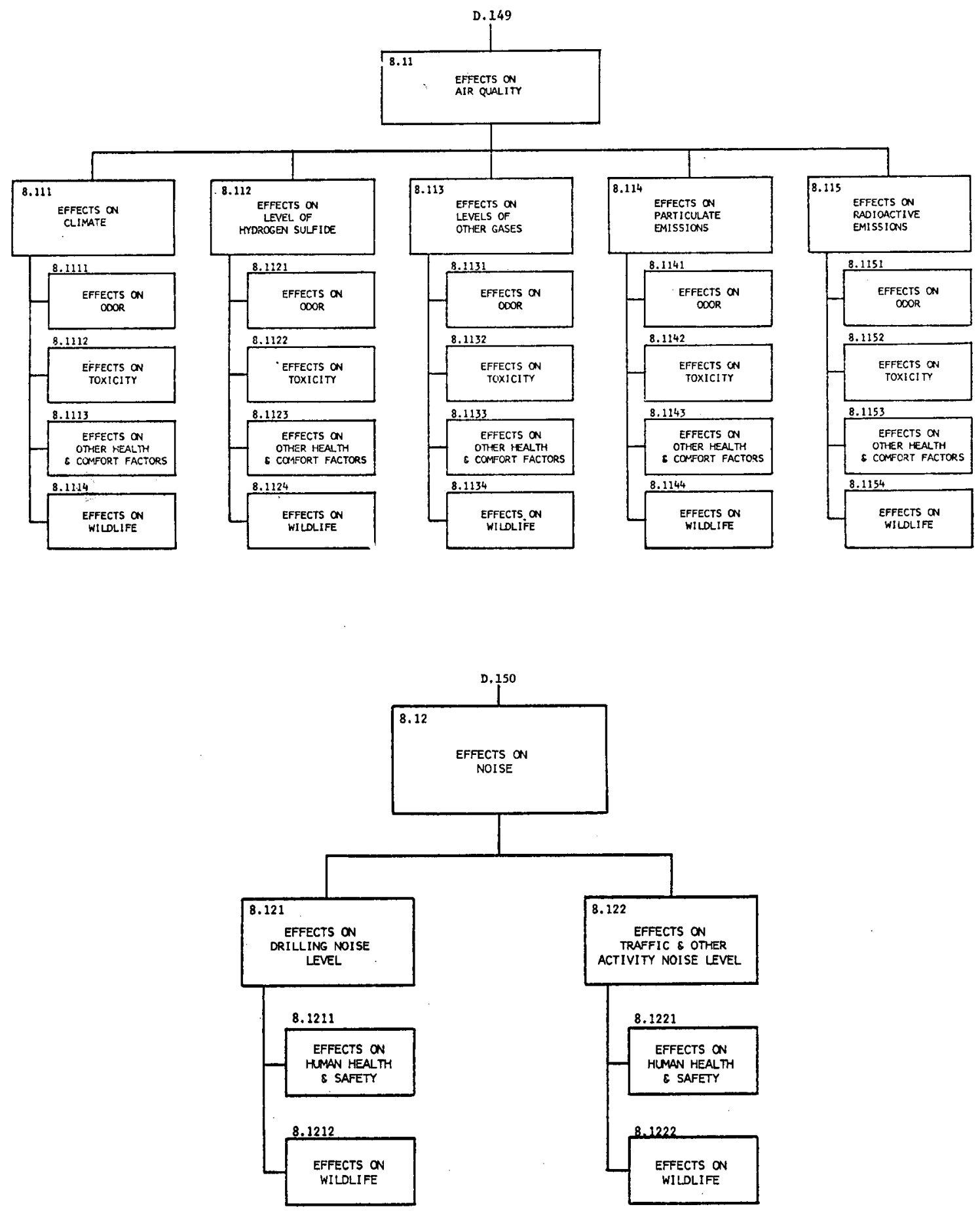

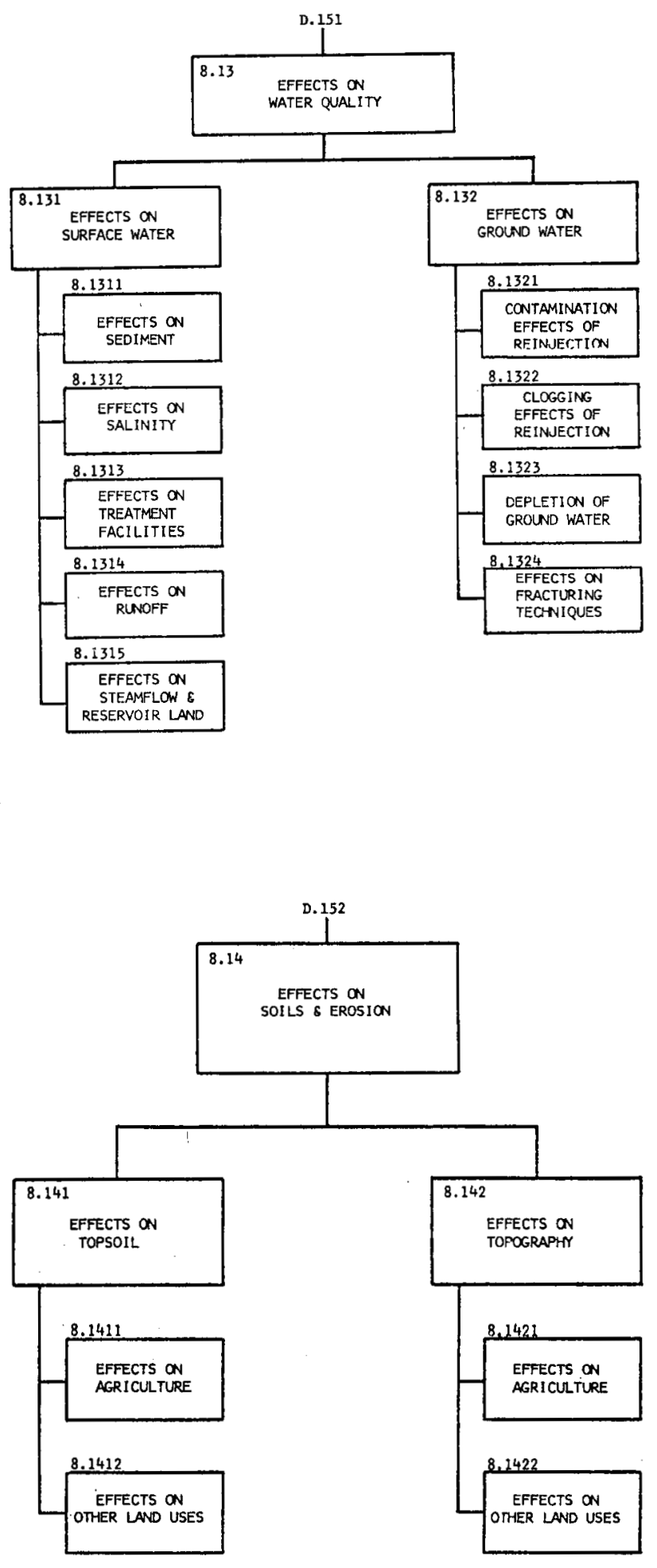

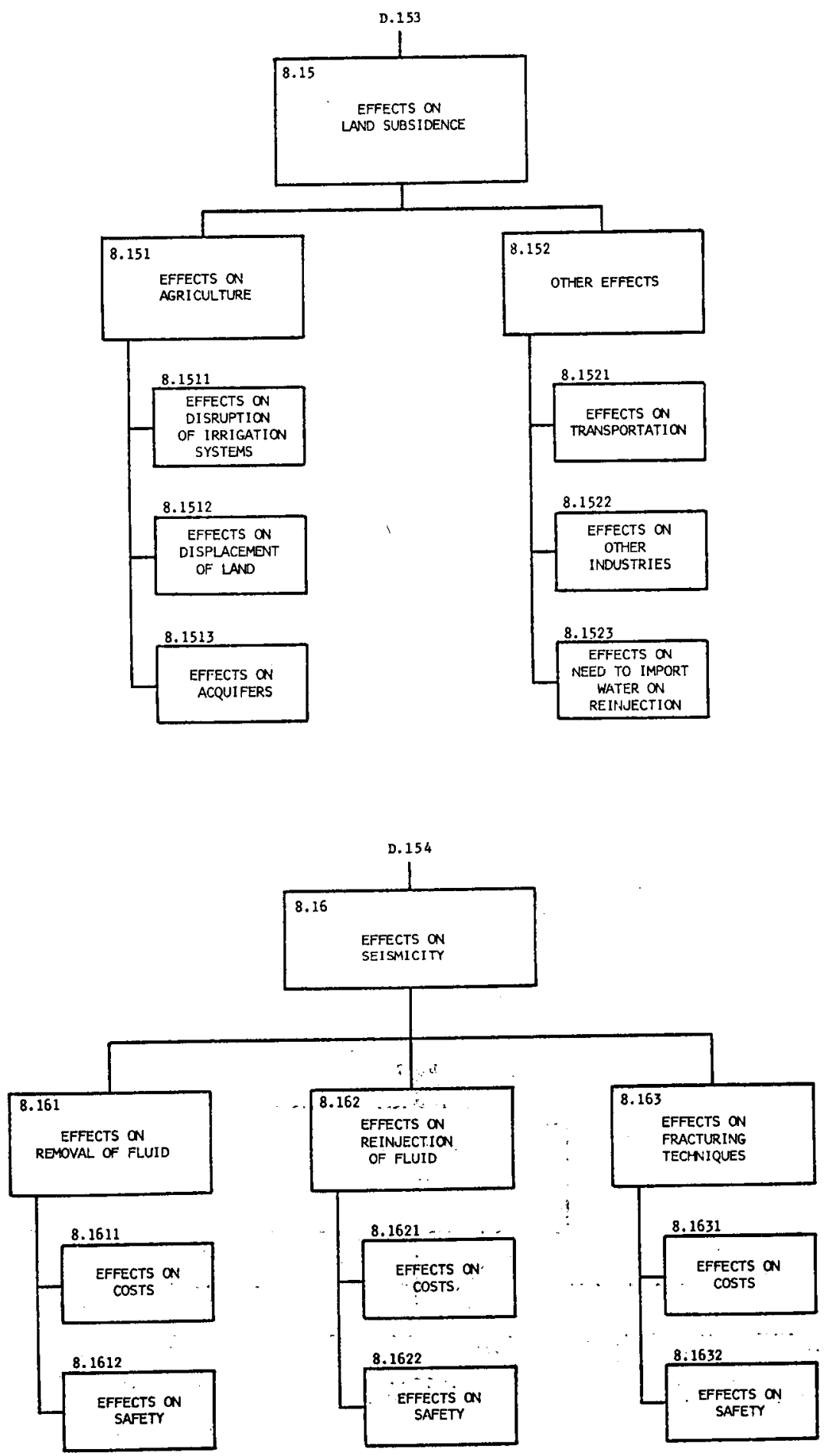

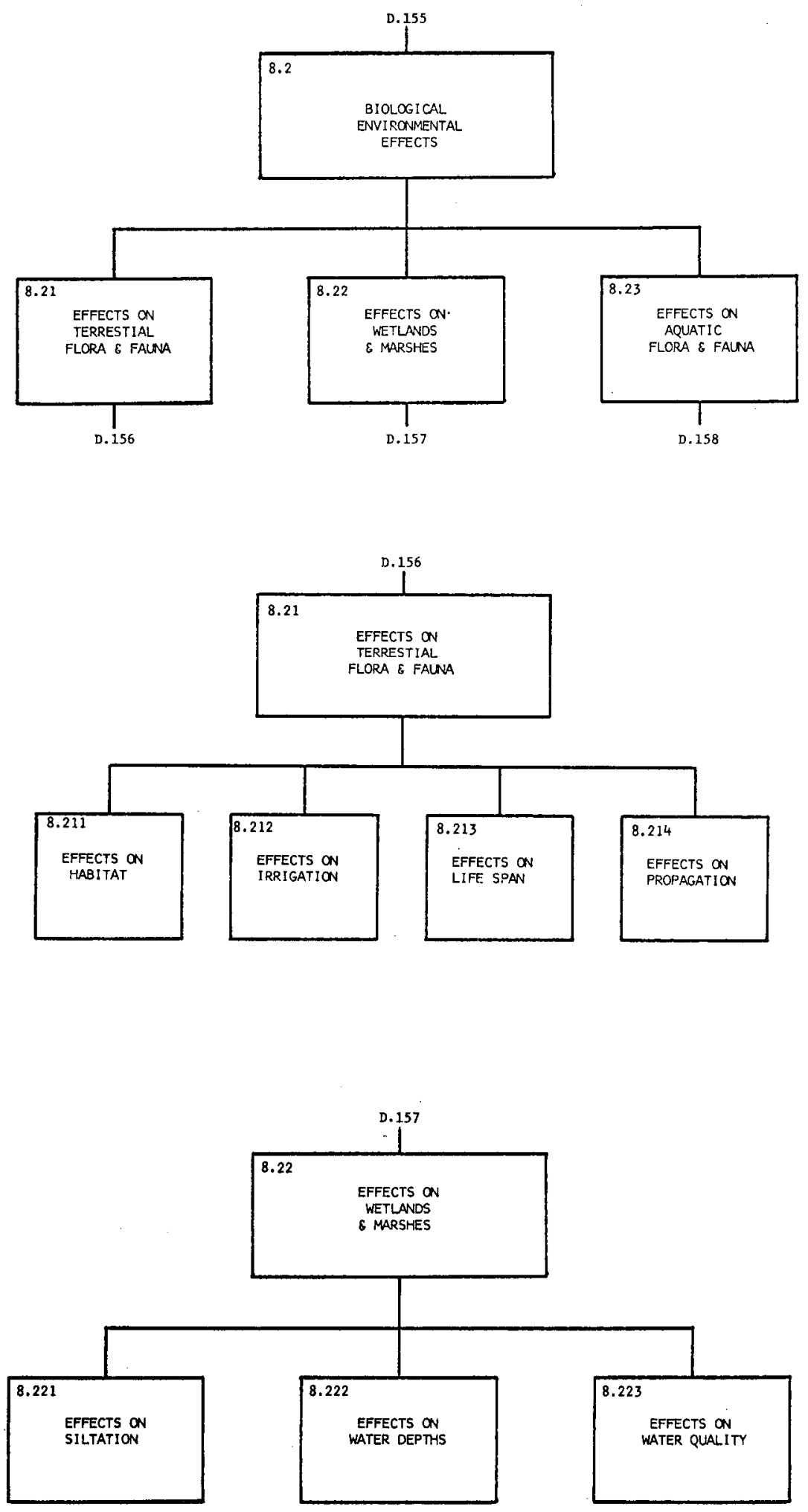

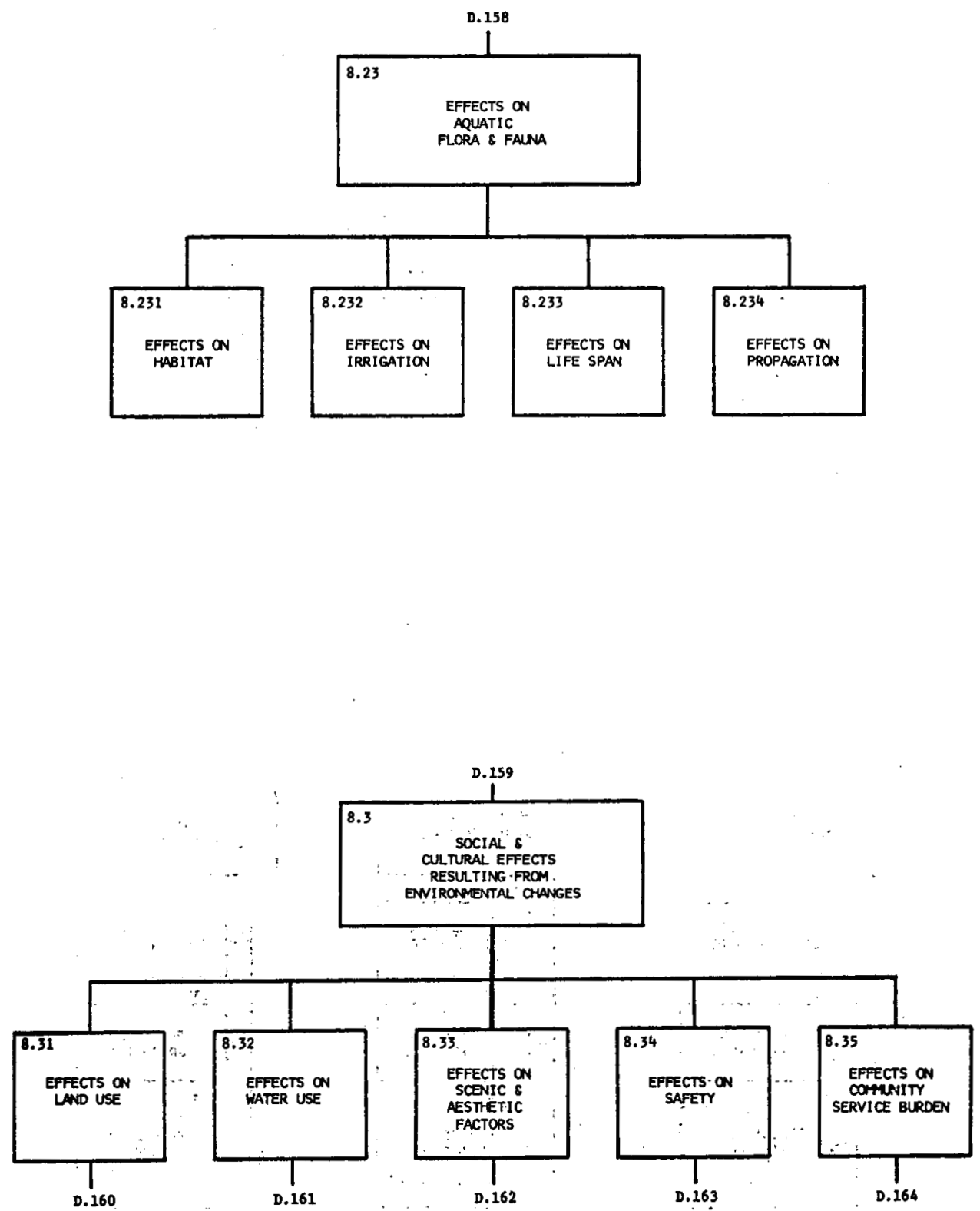

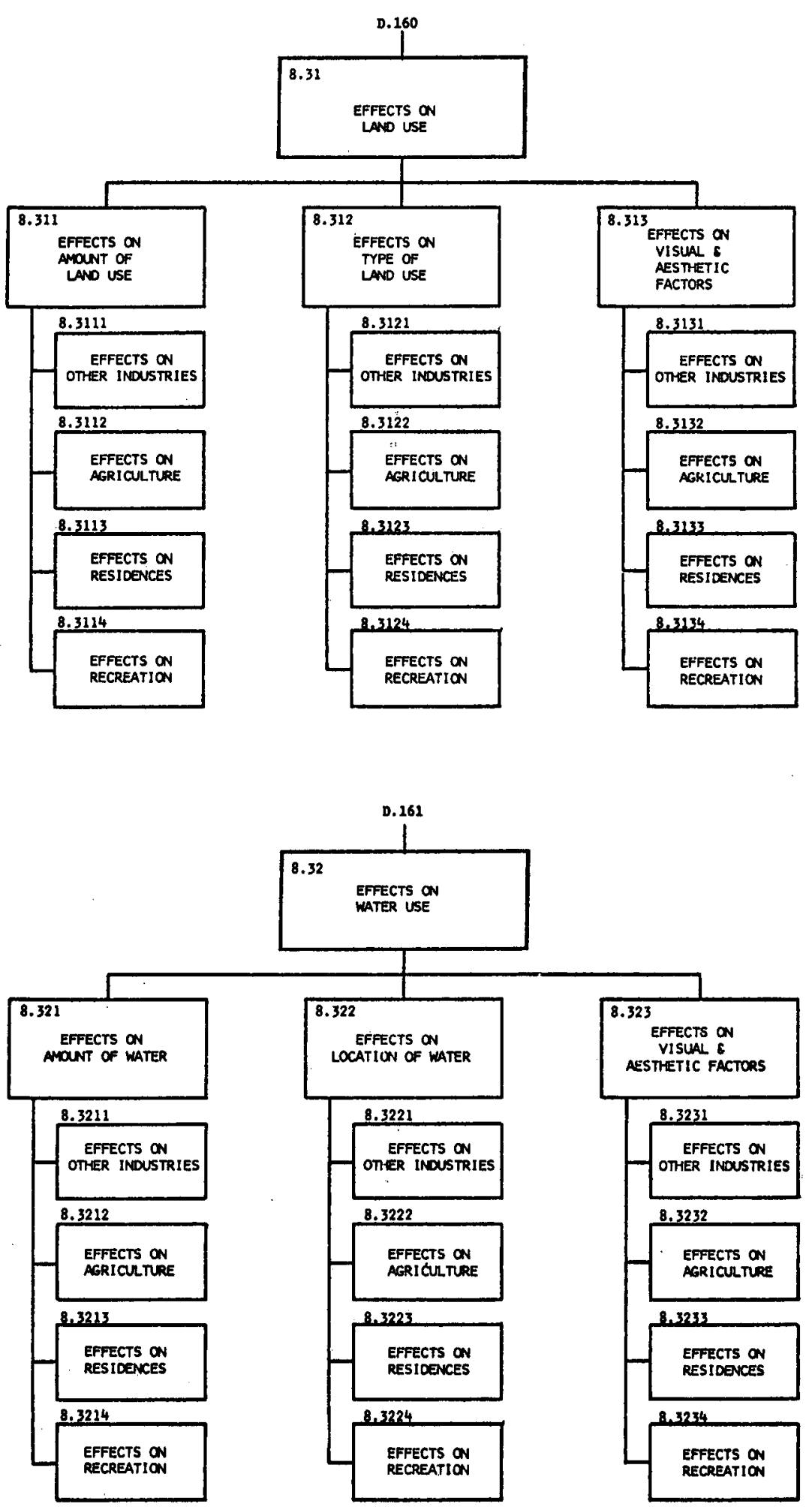

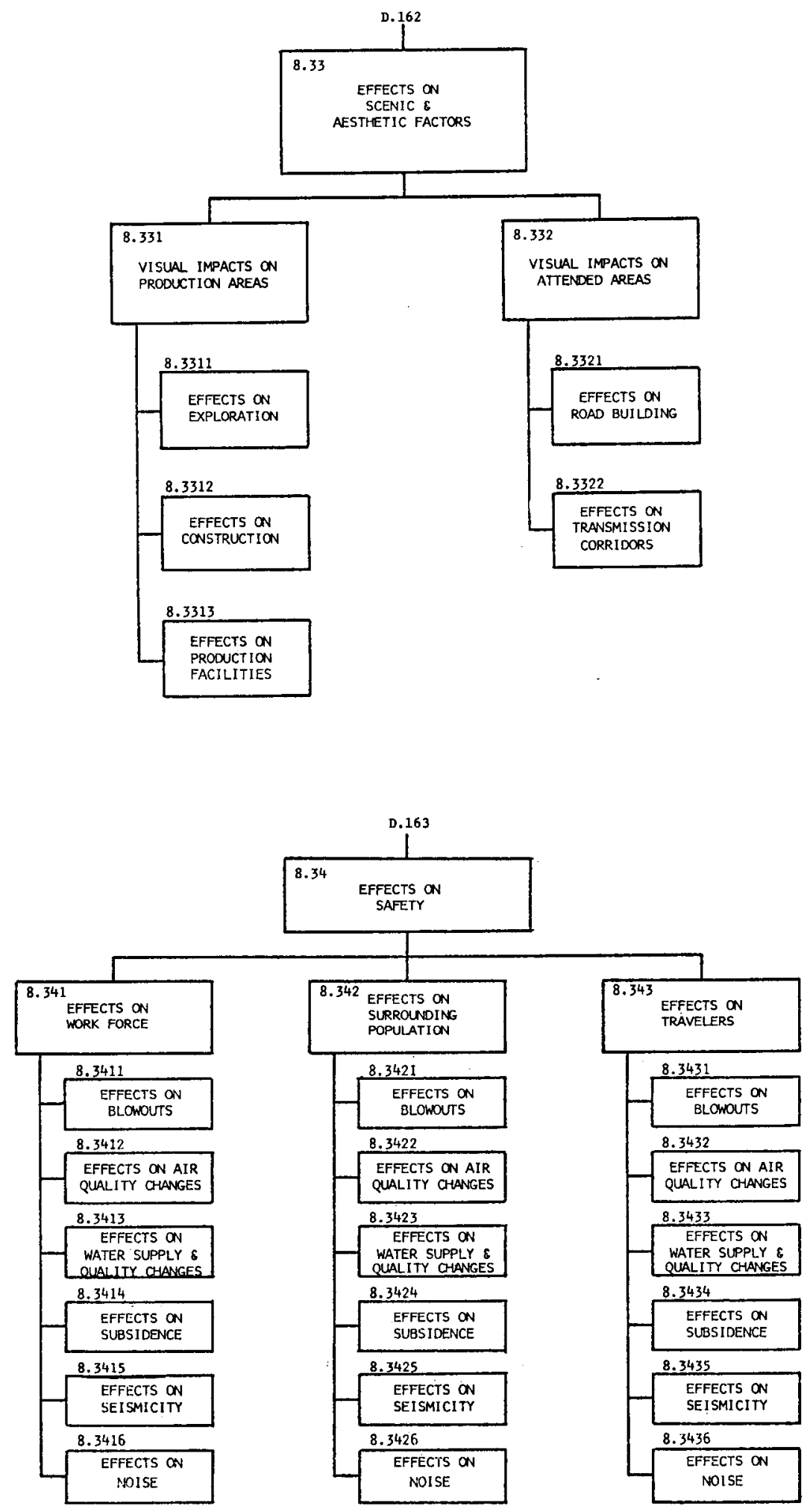

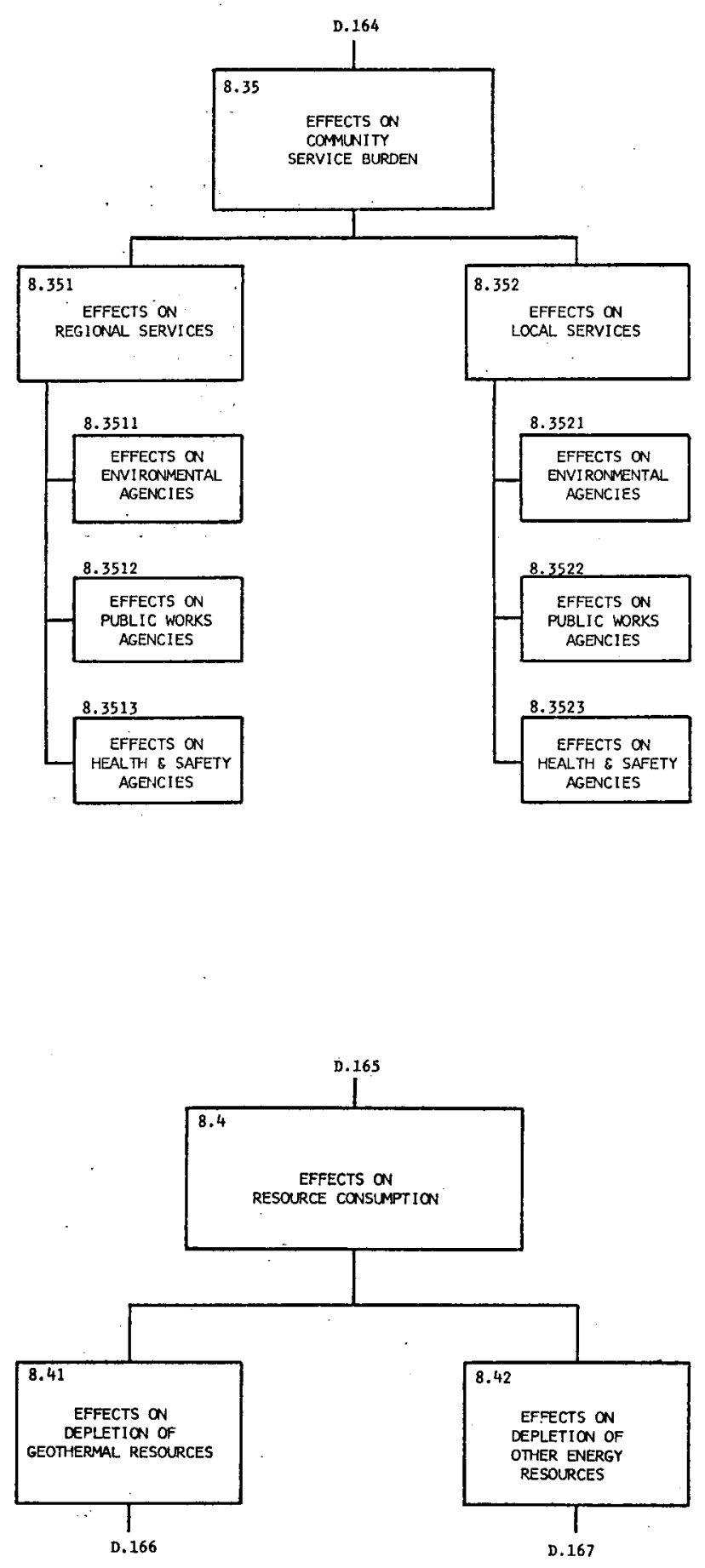

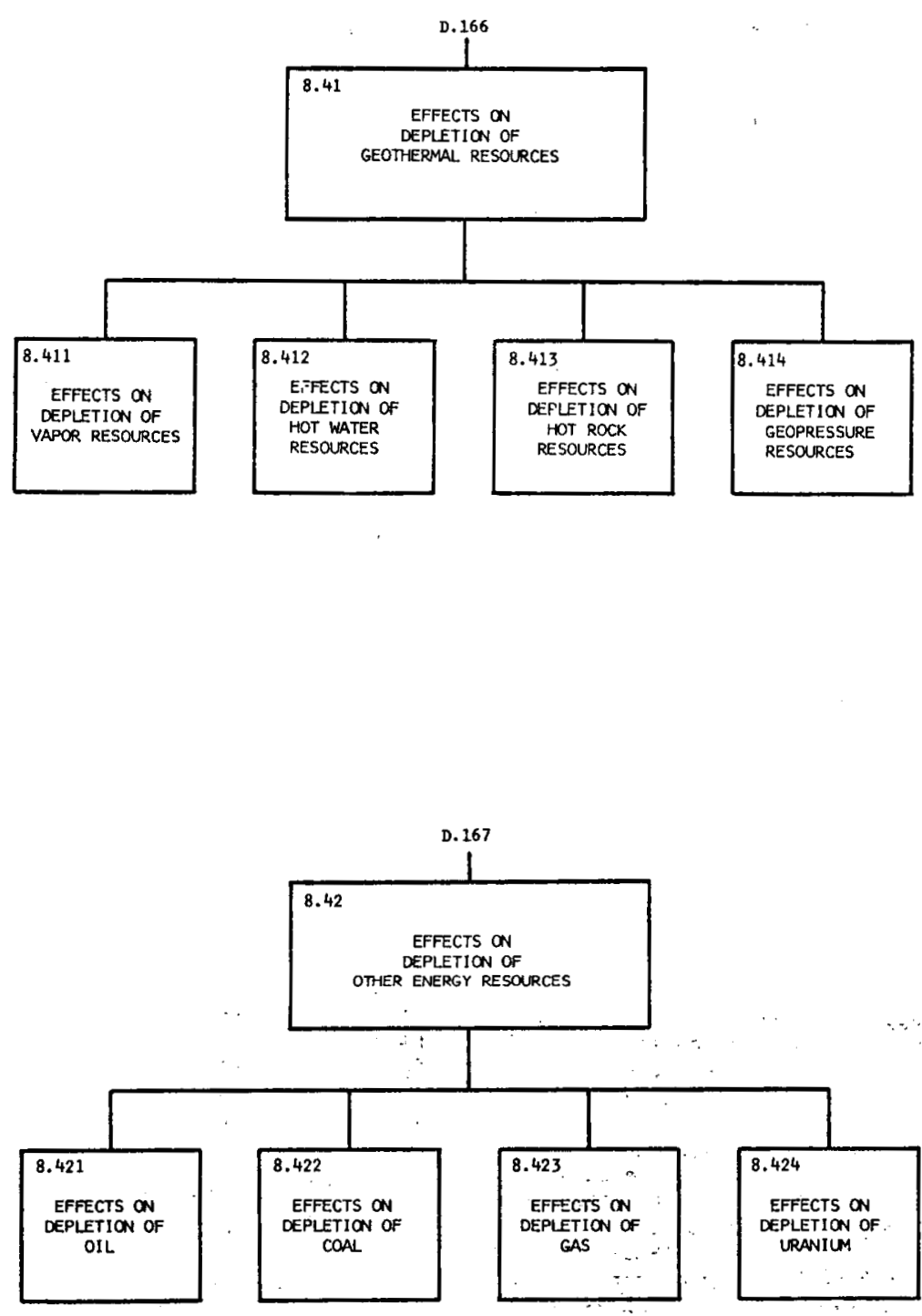


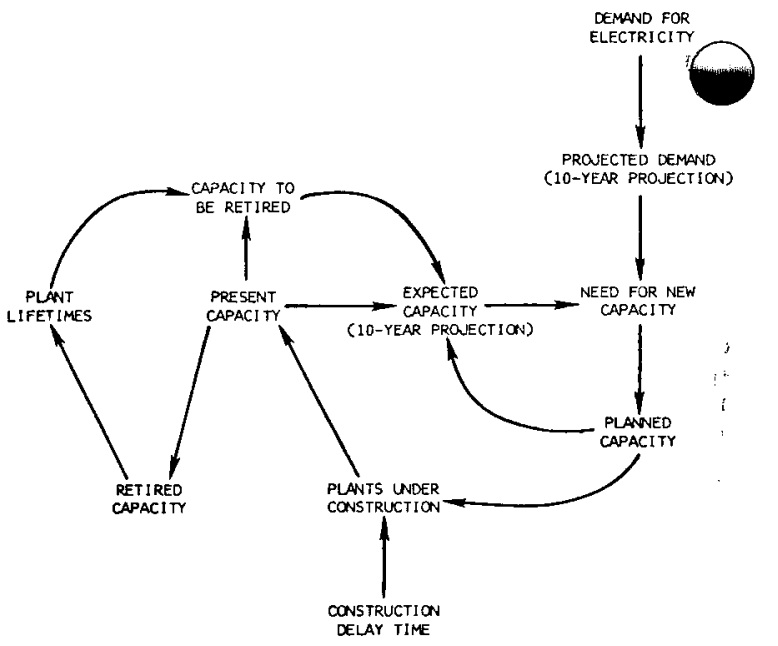

This section presents a full description of the model equations. In the first section they are discussed as they are presented. The second section contains an alphabetical listing of all the variables and constants in the model. Finally, the last section presents the model output for the various runs discussed in earlier sections of the text.

System dynamics equations, written in DYNAMO computer language, are, for the most part, simple mathematical translations of the relationships among model parameters. All vartables have a time subscript to indicate what time perfod is being referenced. System levels and auxiliary variables are subscripted either. $\mathrm{J}$, to Indcate the time period just past, or . K, to indicate the present time period. Rates of flow are subscripted either. .JK, to indicate the rate during the last time period to the present, or . KL, to Indicate the rate from the present to the next time period.

A complete treatment of the theory of system dynamics can be found In Industrial Dynamics by Professor Forrester.[1] The use of the DYNAMO language is described more fully in the DYNAMO II User's Manua1. [2]

\section{The Model Equations}

The model performs separate calculations for the western region of the United States and the rest of the country, called the East. The amount of geothermal resources avallable at any given time in the East and the West is supplied as an exogenous input to the model.

$$
\begin{array}{ll}
\text { RAW. } K=\text { TABLE (TRAW, TIME } . K, 1970,2015,15) & 1, A \\
\text { TRAW=400/7000/160000/306000 } & 1.1, T \\
\quad \text { RAW - RESOURCES AVAILABLE - WEST (MW) } & \\
\text { RAE. K=TABHL (TRAE, TIME. K, 1985, 2015, 15) } & 2, \mathrm{~A} \\
\text { TRAE }=3000 / 4000 / 80000 & 2.1, T
\end{array}
$$$$
\text { RAE - RESOURCES AVAILABLE - EAST (MW) }
$$

The amount of resources is supplied to the model through the use of a table function-a function in DYNAMO that permits tabular information to be included in a mode1. In the case of geothermal resources in the West (RAW) the function specifies that the amount of resources is a function of time--as time increases from 1970 to 2015, in steps of 15 years, the available resources increase from $400 \mathrm{MWe}$ to 7000 MWe to 306,000 MWe. These figures are based on the median estimates, developed in the technical round of interviews (Section 3.1), of the amount of geothermal resource that might be technologically exploitable. These estimates are extrapolated from the last estimate year to the year 2015 by simple straight line extrapolation.

Once the extent of the geothermal resource avallable to utility planners is known, it is necessary to calculate the amount of that resource that utility compantes will actually choose to develop into electrical. capacity. To accomplish this requires calculation of the amount of new capactty needed for any given year and the percent of that needed capacity that will be geothermal as opposed to coal, petroleum, nuclear, solar, etc. The process is deptcted in Figure 3.4.2, repeated here as Figure E.1.1. Calculations for the East are presented first.
Figure E.1.1 DETERMINATION OF PRESENT CAPACITY AND NEED FOR NEW CAPACITY

The amount of new capacity that will be needed to meet demand ten years into the future (TYCGE) is defined as the projected demand in the East minus the present and planned capacity in the East. The projected demand in the East is supplied to the model as a table function.

PTYDE . K=TABLE (TPDE, TPPT . K, 1970, 2010,5)* 1E $3 \quad 4$, A TPDE $=109 / 374.5 / 536 / 710 / 1005 / 1281 / 1558 / 2045 / 25324.1, T$ TPPT - TIME PLUS PROJECTION TIME (YRS)

TPPT $\cdot \mathrm{K}=\mathrm{TIME} \cdot \mathrm{K}+\mathrm{PT}$

$\mathrm{PT}=10$

TPPT - TIME PLUS PROJECTION TIME (YRS)

5, A

PT - PROJECTION TIME (YRS)

TPDE (the table of expected demand, shown in Figure E.1.2 for the East and the West) represents the estimates of the Federal Power Commission [3] of future demand until 1990 and a normal extrapolation of those $f_{1-}$ gures to the year 2010. The projected demand for any given year is simply the value that the demand estimate wili reach in ten years. Thus, the utilities are supplied with a perfect projection for each year. Planning is based on a ten-year projection period because the longest plant construction time in the model (nuclear) is inftially ten years.

\begin{tabular}{|c|c|c|}
\hline YEAR & EAST & WEST \\
\hline 1970 & 109 & 44 \\
2975 & 374 & 94 \\
1980 & 536 & 129 \\
1985 & 710 & 181 \\
1990 & 1005 & 255 \\
1995 & 1281 & 340 \\
2000 & 1558 & 406 \\
2005 & 2045 & 533 \\
2010 & 2532 & 660 \\
\hline
\end{tabular}

F1gure E.1.2 PROJECTED DEMAND FOR ELECTRICAL CAPACITY, EAST AND WEST (1000 MWe) 
The present and planned capactty used in determining the expected capacity is the sum of plamed capacity presently Installed capacity that will still be ine in ten years.

PAPSE . $\mathrm{K}=$ (PRCAPE . K+PLCAPE . K)

$6, \mathrm{~A}$

PAPSE - PRESENT AND PLANITE SUPPLYEAST (MW/HR)

PRCAPE - PRESENT PROJECTED CAPACITYEAST (MW)

PLCAPE - PLANNED CAPACITY-EAST (MW)

Presently profected capacity (the amount of present capactty that w11 sti11 be available in ten years) is the sum of projected capacities for each source in the East.

PRCAPE . $K=$ PRCCAPE . $K+P R P C A P E$. $K+N U C C A P E . K+$ GEOCAPE. K+SCAPE . K+PRHCAPE . K+ PRNGCAPE. K+IMPCAPE . K

7. A

PRCAPE - PRESENT PROJECTED CAPACITYEAST (MW)

PRCCAPE - PRESENT PROJECTED COAL CAPACITYEAST (MW)

PRPCAPE - PRESENT PROJECTED PETROLEUM CAPACITY- EAST (MN)

NUCCAPE - NUCLEAR CAPACITY- EAST (MW)

GEOCAPE - GEOTHERMAL CAPACITY- RAST (MW)

SCAPE - SOLAR CAPACITY- EAST (MW)

PRHCAPE - PRESENT PROJECTED HYDRO CAPACITYEAST (MW)

PRNGCAPE- PRESENT PROJECTED NATURAL GAS CAPACITY - EAST (MH)

IMPCAPE - IMPORT CAPACITY- EAST (MW)

For nuclear plants (with a lifetime of 40 years) and solar and geothermal plants (with 11fetimes of at least 30 years) and transcontinental lines (1mport capacity) there w111 be virtually no retirement of plants before the year 2000. Thus the entire capacity that is installed In any year can be expected to still be on-line ten years later. For coal, petroleum, and natural gas there will be retiring of old capacity.

$$
\begin{gathered}
\text { PRCCAPE.K=CCAPE.K* }(1-(P T * .025)) \\
\text { PRCCAPE - PRESENT PROJECTED COAL } \\
\text { CAPACITY- EAST (MW) } \\
\text { CCAPE - COAL CAPACITY- EAST (MW) } \\
\text { PT }
\end{gathered}
$$

\section{8, A}

With a IIfetime of 40 years, approximately 2-1/2 percent of total coal capacity will be retired each year. Thus, in a ten-year perlod approximately one-quarter of the present coal capacity can be expected to become obsolete. The same is true for petroleum capacity.

$$
\begin{aligned}
& \text { PRPCAPE.K-PETCAPE.K* }(1-(P T * .025)) \\
& \text { PRPCAPE - PRESENT PROJECTED PETROLEOM } \\
& \text { CAPACITY- BAST (MW) } \\
& \text { PETCAPE - PETROLEUM CAPACITY- EAST (MW) } \\
& \text { PT - PROJECTION TIME (YRS) }
\end{aligned}
$$

The Installed capacities of natural gas and hydroelectric power are not calculated in the model but are supplied as table functions. Thus, the capacity for these two sources that is expected to be on-1ine in ten years is the value those table functions w11 return in ten years.

PRHCAPE, $K$-TABLE (THCAPE,TPPT.K, 1970,2010,5)*1E3 10, A PRHCAPE - PRESENT PROJECTED HYDRO CAPACITYRAST (MN)

TPPT - TIME PLUS PROJECTION TIME (YRS)
PRNGCAPE . K=TABLE (TNGCAPE , TPPT . K, 1970, 2010,5)* IE3

PRNGCAPE - PRESENT PROJECTED NATURAL GAS

11, A

CAPACITY- EAST (MW)

- TIME PLUS PROJECTION TIME (YRS)

Total presently installed capacity is the sum of all possible sources of electricity in the East; coal, petroleum, nuclear, geothermal, solar, hydroelectric, natural gas, and Imports from the West.

PCAPE . K=CCAPE . K+PETCAPE . K+NUCCAPE . K+GEOCAPE . K+ 12 , A IMPCAPE . K+SCAPE . K+HCAPE . K+NGCAPE . K

$$
\begin{aligned}
& \text { PCAPE - PRESENT CAPACITY- EAST (MW) } \\
& \text { CCAPE - COAL CAPACITY- EAST (MW) } \\
& \text { PETCAPE - PETROLEUM CAPACITY- EAST (MW) } \\
& \text { NUCCAPE - NUCLEAR CAPACITY- EAST (MW) } \\
& \text { GEOCAPE - GEOTHERMAL CAPACITY-EAST (MW) } \\
& \text { IMPCAPE - IMPORT CAPACITY- EAST (MW) } \\
& \text { SCAPE - SOLAR CAPACITY- EAST (MW) } \\
& \text { HCAPE - HYDRO CAPACITY- EAST (MW) } \\
& \text { NGCAPE - NATURAL GAS CAPACITY - EAST (MW) }
\end{aligned}
$$

The Installed coal capacity in the East is a level that is increased by the addition of new capacity and decreased by the retirement of obsolete plants.

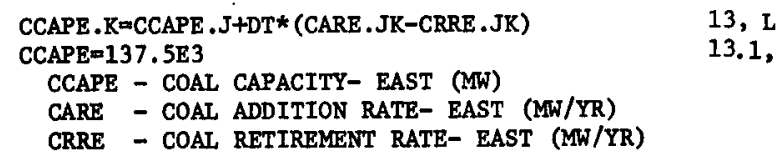

The Inttial value of coal capacity in the Bast is the 1973 value of $137500 \mathrm{MW}$. The retirement rate of coal plants to approximated by the total installed capacity divided by the average plant lifetime (assumed to be 40 years for coal plants).

$$
\begin{aligned}
& \text { CRRE . KL-CCAPE . K } / 40 \\
& \text { CRRE - COAL RETIREMENT RATE- EAST (MW/YR) } \\
& \text { CCAPE - COAL CAPACITY- EAST (MW) } \\
& \text { 14, } \mathrm{R} \\
& \text { CARE . KL=BOXC (NPCCE .K, 6, 4384, 11099,8884,11106, 15, R } \\
& \begin{array}{l}
\text { CCT } 6 \text { 6 } \\
\text { CARE - COAL ADDITION RATE- EAST (MW/YR) }
\end{array} \\
& \text { BOXC - FUNCTION THAT DELAYS VARIABLE (1) } \\
& \text { FOR A PERIOD OF VARIABLE (2) } \\
& \text { NPCCE - NEW PLANNED COAL CAPACITY- EAST (MW/YR) } \\
& \text { CCT - COAL CONSTRUCTION TIME (YRS) }
\end{aligned}
$$

The new capacity addition rate 18 a $81 x$-year delay of newly planned capacity. BOXC is a special function defined specifically for this model. It delays or saves the first argument, In th1s case NPCCE, $K$, for a certain number of years, as defined by the second argument, in this case CCT, or six years, Thus, from the time when a certain amount of new coal capacity is planned there is a delay of a1x years (the average plant conatruction time for coal) until that capacity comes on-1ine. The Inttial values in the BoxC function represent the sum of announced planned capac1t1es for electric utilities in the West. Figure E.1.3 presente the values used for Inttial capacities and planned capacities (for as many years into the future as the construction delay $t$ ime) for each of the generatIng alternatives, East and West. 


\begin{tabular}{|c|c|c|c|c|c|c|c|c|}
\hline \multirow{2}{*}{\multicolumn{2}{|c|}{ YEAR }} & \multicolumn{3}{|c|}{ EAS T } & \multicolumn{4}{|c|}{ WEST } \\
\hline & & COAL & OIL & NUCLEAR & COAL & OIL & NUCLEAR & $\begin{array}{l}\text { GEO- } \\
\text { THERMAL }\end{array}$ \\
\hline \multicolumn{2}{|c|}{$\begin{array}{l}\text { PRESENT } \\
\text { CAPAC- } \\
\text { ITIES }\end{array}$} & 137.5 & 50.4 & 12.5 & 13.2 & 6.5 & 1.6 & .396 \\
\hline \multirow{10}{*}{ 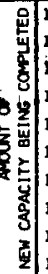 } & 1974 & 14.343 & 3.333 & 14.001 & .400 & .379 & -- & 110.0 \\
\hline & 1975 & 9.569 & 8.331 & 13.560 & 1.100 & .060 & .916 & 110.0 \\
\hline & 1976 & $i 1.106$ & 7.435 & 9.801 & 2.521 & .300 & 1.066 & 110.0 \\
\hline & 1977 & 8.884 & 7.375 & 4.952 & 1.522 & .239 & 2.183 & \\
\hline & 1978 & 11.099 & 5.553 & 11.825 & .360 & .240 & - & \\
\hline & 1979 & 4.384 & & 13.678 & & & 2.199 & \\
\hline & 1980 & & & 19.546 & & & 3.322 & \\
\hline & 1981 & & & 30.910 & & & - & \\
\hline & 1982 & & & 6.503 & & & 1.767 & \\
\hline & 1983 & & & 8.324 & & & .765 & \\
\hline
\end{tabular}

SORCE: NEW CAPACITY ADOITIOIS PLANED OR IN CONSTRUCTION AS OF JUNE 1 ,

Figure E.1.3 PRESENT AND PLANNED CAPACITIES USED AS INITIAL MODEL VALUES (1000 MWe)

The same calculations are used to define Installed petroleum capacity, petroleum retirement rate, and petroleum addition rate in the East.

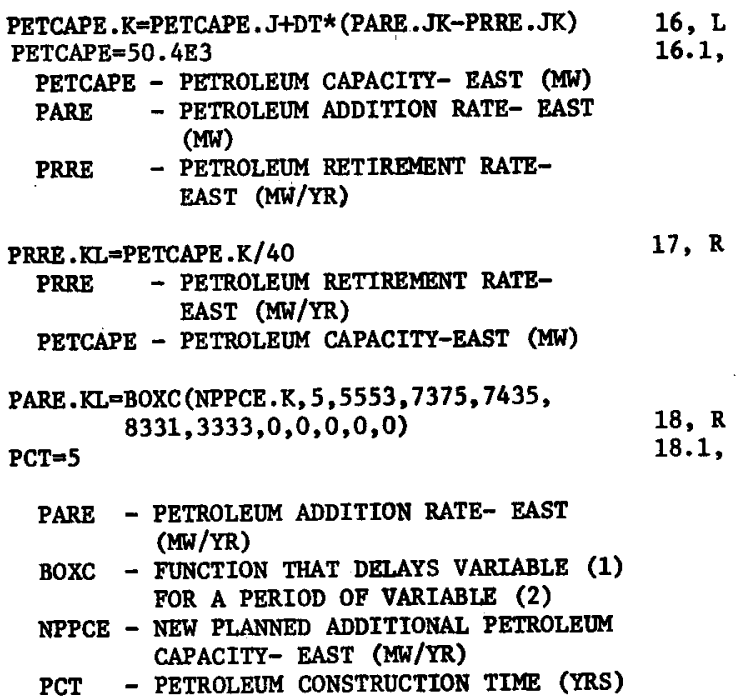

The aame calculational procedure $1 \mathrm{~s}$ also followed in calculating installed capacities for nuclear power and geothermal power. The only difference here is that the nuclear plant construction times and geothermal plant lifetimes are varlable.

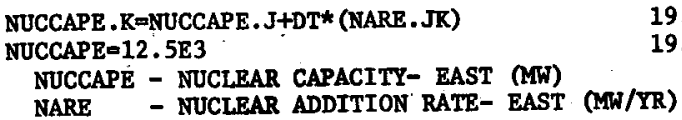

KARE . KL=BOXC (NPNCE . K, (NCT . K) , 8324, 6503,30910, 20, R $19546,13678,11825,4952,9801,13560$, 14001)

NARE - NUCLEAR ADDITION RATE- EAST (MW/YR)

BOXC - FUNCTION THAT DELAYS VARIABLE (1)

FOR A PERTOD OF VARIABLE (2)

NPNCE - NEW PLANNED NUCLEAR CAPACITYEAST (MW/YR)

NCT - NUCLEAR CONSTRUCTION TIME (YRS)

In the case of nuclear it was estimated that the average time from planning to on-line capacity is currently to years but that with streamlined regulatory procedures and standardized plants this delay would be reduced to six years by 2000 .

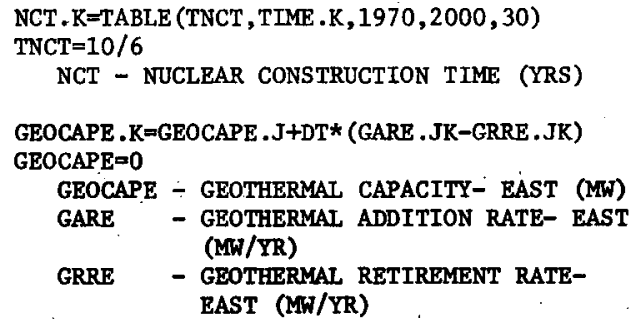

The 1ifetime of a geothermal plant built now is estimated to be about 40 years. It $1 \mathrm{~s}$ estimated that this lifetime w11 Increase because of technological advancements to 50 years by 2000 .

GRT . R=TABLE (TGRR, TIME . K, 1970, 2000, 15) TGRR $=40 / 50 / 50$

GRT - GEOTHERMAL RETIREMENT TIME (YRS)

GARE . KL $=$ BOXC (NPGCE .K, 3, 0, 0, 0, 0,0,0,0,0,0,0) 25, R $\mathrm{GCT}=3$ $25.1, \mathrm{C}$
GARE - GEOTHERMAL ADDITION RATE- EAST (MW/YR)
BOXC - FUNCTION THAT DELAYS VARIABLE (1)
FOR A PERIOD OF VARIABLE (2)
NPGCE - NEW PLANNED GEOTHERMAL CAPACITY- EAST (MW/YR)
GCT - GEOTHERMAL CONSTRUCTTON TIME (YRS)

The capacity of the transcontinental transmission Ifnes, expressed in megawatts, and the installed capacity in solar power are calculated with the same procedures already described for coal.

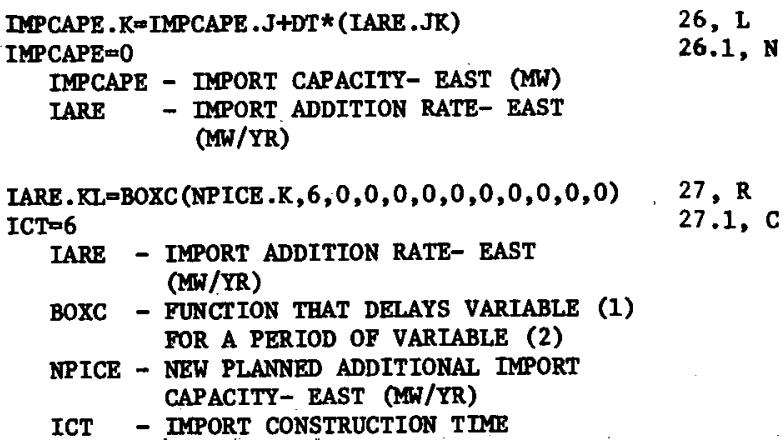


SRRE $\cdot$ KL $=S C A P E, K / S R T$

$\mathrm{SRT}=40$

(SRRE - SOLAR RETIREMENT RATE- EAST (MW/YR)

SCAPE - SOLAR CAPACITY- EAST (MW)

SRT - SOLAR RETIREMENT TIME (YRS)

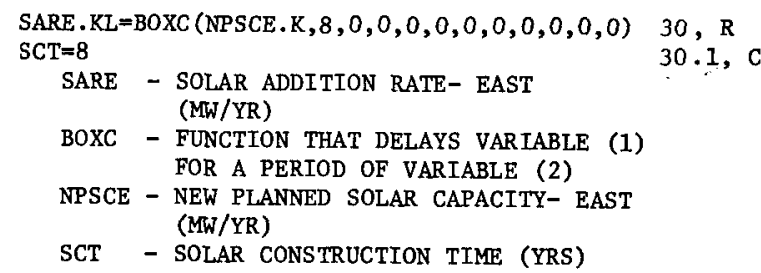

Hydroelectric and natural gas capacities in the East are supplied to the model as table functions. These projections are based, for gas, on National Electric Reliability Council [4] projections to 1982 and for hydro on FPC [3] projections to 1990 and extrapolated to 2010. These are shown in Figure E.1.4.

\begin{tabular}{|c|c|c|c|c|}
\hline \multirow{2}{*}{ YEAR } & \multicolumn{2}{|c|}{ E A S T } & \multicolumn{2}{c|}{ WE S T } \\
\cline { 2 - 5 } & $\begin{array}{c}\text { NATURAL } \\
\text { GAS }\end{array}$ & $\begin{array}{c}\text { HYDRO- } \\
\text { ELECTRIC }\end{array}$ & $\begin{array}{c}\text { NATURAL } \\
\text { MGAS }\end{array}$ & $\begin{array}{c}\text { HYDRO- } \\
\text { ELECTRIC }\end{array}$ \\
\hline 1970 & 55 & 22 & 22 & 30 \\
1975 & 43 & 21 & 19 & 35 \\
1980 & 37 & 23 & 16 & 42 \\
1985 & 30 & 25 & 13 & 47 \\
1990 & 24 & 27 & 10 & 52 \\
1995 & 20 & 30 & 9 & 55 \\
2000 & 16 & 32 & 7 & 58 \\
2005 & 14 & 34 & 6 & 61 \\
2010 & 12 & 36 & 5 & 64 \\
\hline
\end{tabular}

SOURCES: PROGRESS REPORTS OF THE REGIONAL ORGANIZATIONS TO THE EXXCUTIVE BOARD OF NAT IONAL ELECTRIC APRIL 1973); FEDERAL POWER COMMISSION.

F1gure E.1.4 PROJECTED NATURAL GAS AND HYDROELECTRIC CAPACITIES (1000 MWe)

HCAPE . K=TABLE (THCAPE, TIME . K, 1970, 2010,5)*1E 331 , A THCAPE $=21.9 / 20.2 / 23 / 25 / 27 / 30 / 32 / 34 / 36$ HCAPE - HYDRO CAPACITY- EAST (MW)

NGCAPE . K=TABLE (TNGCAPE , TIME. $K, 1970,2010,5$ )* 32, A $1 \mathrm{E} 3$

TNGCAPE $=55,42.7 / 37.1 / 30 / 24.4 / 20.4 / 16.2 / 14 / \quad 32.1$, T

NGCAPE - NATURAL GAS CAPACITY- EAST (MW)

Since nelther natural gas or hydroelectric power expected to play a large role in new capacity add1tions in the East, estimates prepared by the Federal Power Commission were used to Indicate the fraction of demand that $1 \mathrm{~s}$ met through elther of these sources.

Total planned capacity in the East is the sum of the planned capacities for each of the posstble fuels for which the model calculates capacity planning.

PLCAPE . K=PCCE. K+PPCE. K+PNCE . K+PGCE. K+ 33, A PICE. K+PSCE. $K$

PLCAPE - PLANNED CAPACITY- EAST (MW)

$\begin{array}{ll}\text { PCCE } & \text { - PLANNED COAL CAPACITY- EAST (MW) } \\ \text { PPCE } & \text { - PLANNED PETROLEUM CAPACITY- EAST } \\ & \text { (MW) } \\ \text { PNCE - PLANNED NUCLEAR CAPACITY- EAST (MW) } \\ \text { PGCE - PLANNED GEOTHERMAL CAPACITY- EAST (MW) } \\ \text { PICE - PLANNED IMPORT CAPACITY- EAST (MW) } \\ \text { PSCE - PLANNED SOLAR CAPACITY- EAST (MW) }\end{array}$

Total planned coal capacity in the East is a leve1 that is increased by new planned capactty and decreased by capacity that is actually built.

PCCE . K=PCCE . J+DT* (APCCE .JK-CARE .JK+DAPCCE1 .JK) 34;, L $\mathrm{PCCE}=49.7 \mathrm{E} 3$ $34.1, \mathrm{~N}$

$$
\begin{array}{ll}
\text { PCCE } & \text { PLANNED COAL CAPACITY- EAST (MW) } \\
\text { APCCE } & - \text { ADDITIONAL PLANNED COAL CAPACITY- } \\
& \text { EAST (MW/YR) } \\
\text { CARE } & \text { COAL ADDITION RATE- EAST (MW/YR) } \\
\text { DAPCCE1 - } & \text { DELAYED ADDITIONAL PLANNED COAL } \\
& \text { CAPACITY - EAST (1) (MW/YR) }
\end{array}
$$

The initial value of planned coal capacity is the oum of a11 reported plans for new coal capacity by utility companies in the East. The total of planned capacity is reduced by the completion of new plants, which removes them from the status of planned plants. The level of planned capacity is increased by two kinds of new capacity planning. New planning is based on profections of the capaclty gap ten years into the future. However, contracts for new coal plants need not be made ten years in advance, but since contracts for nuclear plants must be made ten years in advance (because of the Initial ten-year delay from planning to on-line capacity for nuclear) a decision not to build a nuclear plant is, in effect, a final decision to sign a contract for new coal (or some other alternative) capacity at some time in the future. Therefore, planned coal capacity in the East is increased by APCCE, planned capacity for which construction is beginning immedialy, and DAPCCE1, capac1ty for which construction will not begin immediately. (In the case of coal, construction of this capacity w111 begin in four years, so that with a six-year construction time it will be coming on-line in a total of ten years time.)

The coal capacity that w111 be contracted for 1mmediately depends upon the part of the total capacity gap that will be filled by coal and the time required to build a coal plant.

$$
\begin{array}{cl}
\text { APCCE . KLEIAPCCE.K* (CCT/PT) } & 35, \mathrm{R} \\
\text { APCCE } & \text { - ADDITIONAL PLANNED COAL CAPACITY- } \\
& \text { EAST (MW/YR) } \\
\text { IAPCCE } & \text { - INDICATED ADDITIONAL PLANNED COAL } \\
& \text { CAPACITY- EAST (MW/YR) } \\
\text { CCT } & \text { COAL CONSTRUCTION TIME (YRS) } \\
\text { PT } & \text { - PROJECTION TIME (YRS) }
\end{array}
$$

Coal capacity which w11 actually be contracted for is equal to the amount of new coal capacity that wi11 be needed in the next ten years (IAPCCE) multiplied by the ratio of the construction time for coal to the projection time (ten years).

The rest of the needed coal capacity is considered to be delayed planning.

$$
\begin{aligned}
& \text { DAPCCE } 1 \cdot \mathrm{KL}=\mathrm{IAPCCE} \cdot \mathrm{K} *(1-(\mathrm{CCT} / \mathrm{PT})) \\
& \text { DAPCCE } 1=0 \\
& \text { DAPCCE1 - DETAYED ADDITIONAL PLANNED COAL } \\
& \text { CAPACITY - EAST (1) (MW/YR) } \\
& \text { IAPCCE - INDICATED ADDITIONAL PLANNED COAL } \\
& \text { CAPACITY- EAST (MW/YR) } \\
& \text { CCT - COAL CONSTRUCTION TIME (YRS) } \\
& \text { PT - PROJECTION TIME (YRS) }
\end{aligned}
$$


Th1s delayed planning is merely the fraction of needed new coal capacity that is not immediately put on contract. This planned capacity is delayed for four years and is then added to the newly planned capacity in that year to produce the total amount of new orders (NPCCE).

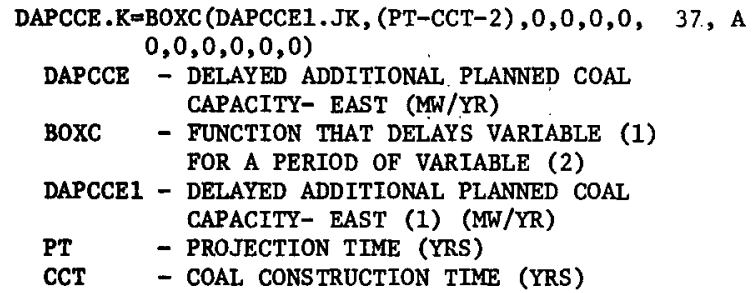

The delay time in the BOXC function (PT-CCT-2) is two years for the case of coal (10-6-2), but actually works out to be four years because of the computational sequence involved in adding this planned capacity to installed capacity. (Two rates are involved which, in this case, cause an extra two years delay.)

The fraction of the needed new capacity that is coal capacity is dependent on the coal decision factor.

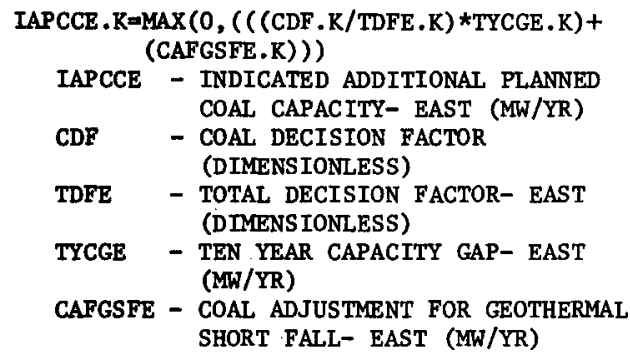

TDFE $\cdot K=C D F \cdot K+P D F \cdot K+N D F \cdot K+G D F E \cdot K+I D F \cdot K+$ SDFE.K

TDFE - TOTAL DECISION FACTOR- EAST (DIMENS IONLESS)

CDF - COAL DECISION FACTOR (DIMENSIONLESS)

PDF - PETROLEUM DECISION FACTOR (DIMENSIONLESS
NDF - NUCLEAR DECISION FACTOR (DIMENSIONLESS)

GDFE - GEOTHERMAL DECISION FACTOR- EAST (DIMENSIONLESS)

IDF - IMPORT DECISION FACTOR (DIMENSIONLESS)

SDFE - SOLAR DECISION FACTOR- EAST (DIMENSIONLESS)

This decision mechanism is present in Figure 3.4.3 which is repeated here as Figure E.1.5. It shows the dectsion process for nuclear plants.

The coal decision factor (the total desirability of new coal plants) divided by the total decision factor in the East (the sum of the decision factors for all alternatives) yields the fraction of new capacity that the utilities would like to be coal. Multiplying this fraction by the ten-year capacity gap (the total amount of new capacity needed to supply demand in ten years) gives the amount of capacity, in megawatts, that should be coal plants. This number is increased, in some cases, if the amount of that capacity gap that was allocated to geothermal energy cannot be built (because of resource limitations). In that case, the amount of the shortfall that is allocated to coal depends again on the coal dectsion factor.

\begin{tabular}{|c|c|}
\hline & NDF.K)) \\
\hline CAFGSFE & $\begin{array}{l}\text { - COAL ADJUSTMENT FOR GEOTHERMAL } \\
\text { SHORT-FALL- EAST (MW/YR) }\end{array}$ \\
\hline AFGSFE & $\begin{array}{l}\text { - ADJUSTMENT FOR GEOTHERMAL SHORT- } \\
\text { FALL- EAST (MW/YR) }\end{array}$ \\
\hline CDF & $\begin{array}{l}\text { - COAL DECISION FACTOR (DIMENSION- } \\
\text { LESS) }\end{array}$ \\
\hline PDF & $\begin{array}{l}\text { - PETROLEUM DECISION FACTOR (DIMEN- } \\
\text { SIONLESS) }\end{array}$ \\
\hline NDF & $\begin{array}{l}\text { - NUCLEAR DECISION FACTOR (DIMEN- } \\
\text { SIONLESS) }\end{array}$ \\
\hline
\end{tabular}

The amount of the shortfall allocated to coal is the total shortfall multiplied by the coal decision factor divided by the sum of the decision factors of the three fuels that are assumed to make up the shortfall: coal, petroleum, and nuclear.

The coal decision factor is based on six decision criteria: rellability, capital investment, environmental considerations, cost of electricity, fuel avallability, and construction delay time.

\section{$\mathrm{CDF} \cdot \mathrm{K}=\mathrm{RF} * \mathrm{CR} \cdot \mathrm{K}+\mathrm{CIF} * \mathrm{CCI} \cdot \mathrm{K}+\mathrm{ECF} * \mathrm{CEC} \cdot \mathrm{K}+\mathrm{CEF} * \mathrm{CCE} \cdot \mathrm{K}+\quad 41$, FAF*CFA. $K$ \\ CDF - COAL DECISION FACTOR (DIMENSIONLESS) \\ RF - RELIABILITY FACTOR (DIMENSIONLESS) \\ CR - COAL RELIABILITY (DIMENSIONLESS) \\ CIF - CAPITAL INVESTMENT FACTOR (DIMENSIONLESS)}

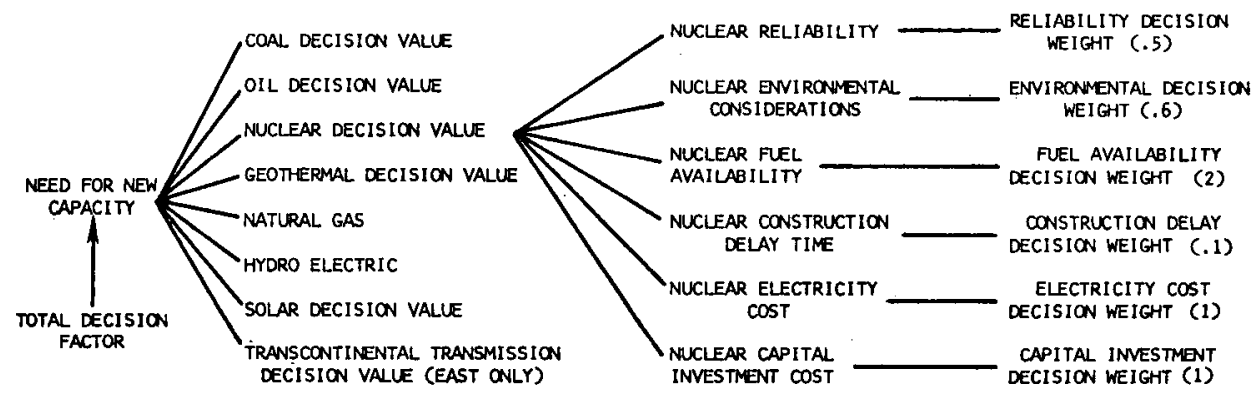

Figure E.1.5 ALLOCATION OF NEW CAPACITY 
CCI - COAL CAPITAL INVESTMENT (DIMENSIONLESS)

DECF - ENVIRONMENTAL CONSIDERATION FACTOR (DIMENSIONLESS)

CEC - COAL ENVIRONMENTAL CONSIDERATIONS (DIMENSIONLESS)

CEF - COST OF ELECTRICITY FACTOR (DIMENS IONLESS)

CCE - COAL COST OF ELECTRICITY (DIMENSIONLESS)

FAF - FUEL AVAILABILITY FACTOR (DIMENSIONLESS)

CFA - COAL FUEL AVAILABILITY (DIMENSIONLESS)

The decision process in the electric utility is assumed to rely mainly on these six criteria plus a consideration of the technology to develop the resource, Each of these factors is given a weight which corresponds to its Importance in the final decision.

$\mathrm{RF}=.5$

$\mathrm{CIF}=1$

$\mathrm{ECF}=.6$

$\mathrm{CEF}=1$

$\mathrm{FAF}=2$

$\mathrm{CDLF}=.1$

RF - RELIABILITY FACTOR (DIMENSIONLESS)

CIF - CAPITAL INVESTMENT FACTOR (DIMENSIONLESS)

ECF - ENVIRONMENTAL CONSIDERATION FACTOR

CEF - COST OF ELECTRICITY FACTOR (DIMENSIONLESS)

FAF - FUEL AVAILABILITY FACTOR (DTMENSIONLESS)

CDLF - CONSTRUCTION DELAY FACTOR (DIMENSIONLESS)

These welghts were assigned by the study team and were based on conversations with electric utility planners concerning the factors which they considered in selecting fuel $\mathrm{mix}$, and the importance of those factors to their dectsions.

The reliablilty of coal plants, when rated on a scale from 0 to 1 was assumed to go $\mathrm{frcm} .8$ in 1970 to .7 in 1985. Figure E.1.6 shows the rellability estimates for all alternatives. (A discussion of this table 1s included in Section 3.4.)

CR. K $=$ TABLE $(T C R, T T M E \cdot K \cdot 1970,2000,15)$ $\mathrm{TCR}=.8 / .7 / .7$

CR - COAL RELIABILITY (Dimensionless)

42, A

$42.1, \mathrm{~T}$

\begin{tabular}{|c|c|c|c|c|c|c|}
\hline YEAR & COAL & OIL & NUCLEAR & $\begin{array}{c}\text { GEO- } \\
\text { THERMAL }\end{array}$ & SOLAR & $\begin{array}{c}\text { TRANS- } \\
\text { CONTI- } \\
\text { NENTAL } \\
\text { GRID }\end{array}$ \\
\hline 1973 & .8 & .9 & .6 & .7 & - & 1 \\
\hline 1985 & .7 & .9 & .9 & .7 & .55 & 1 \\
\hline 2000 & .7 & .9 & .9 & .8 & .65 & 1 \\
\hline
\end{tabular}

Figure E. 1.6 ESTIMATES OF PERCEIVED PLANT RELIABILITY (THE SCALE IS FROM 0 TO 1 , WITH 1 DENOTING THE MOST RELTABLE PLANTS)

The capital Investment rating of coal is found by dividIng the actual capital investment cost expected to prevall In ten years time, expressed in dollars per k1lowatt, Into the capital costs associated with the least pensive type of capacity, geothermal.
CCI. $K=G C I C . K / C C I C . K$

43, A

CCI - COAL CAPITAL INVESTMENT (DIMENSIONLESS)

GCIC - GEOTHERMAL CAPITAL INVESTMENT COST $(\$ / \mathrm{KW})$

CCIC - COAL CAPITAL INVESTMENT COST ( $/ \mathrm{KW})$

The actual capital cost of an average coal plant was est Imated over time to the year 2010 and supplied to the model as a table function.

$\begin{array}{ll}\text { CCIC.K=TABLE (TCCIC },(\text { TIME } . \mathrm{K}+10), 1970,2010,5) & 44, \mathrm{~A} \\ \text { TCIC }=240 / 359 / 550 / 615 / 662 / 713 / 768 / 828 / 892 & 44.1, \mathrm{~T} \\ \text { CCIC - COAL CAPITAL INVESTMENT COST }(\$ / \mathrm{KW}) & \end{array}$

This estimate is also presented in Table E.1.7 where it is compared with capital cost estimates for the other alternative electrical sources.

\begin{tabular}{|c|c|c|c|c|c|c|c|}
\hline YEAR & COAL & OIL & NUCLEAR & $\begin{array}{c}\text { GEO- } \\
\text { THERMAL }\end{array}$ & $\begin{array}{c}\text { SOLAR } \\
\text { EAST }\end{array}$ & $\begin{array}{c}\text { SOLAR } \\
\text { WEST }\end{array}$ & $\begin{array}{c}\text { TRANS- } \\
\text { CONTI- } \\
\text { NENTAL } \\
\text { GRID }\end{array}$ \\
\hline 1973 & 240 & 220 & 354 & 264 & -- & -- & -- \\
1975 & 359 & 260 & 385 & 272 & -- & - & - \\
1980 & 550 & 299 & 615 & 292 & -- & -- & - \\
1985 & 615 & 332 & 734 & 315 & 3000 & 1500 & 467 \\
1990 & 662 & 358 & 791 & 339 & 2667 & 1334 & 503 \\
1995 & 713 & 386 & 852 & 365 & 2334 & 1167 & 542 \\
2000 & 768 & 416 & 918 & 394 & 2000 & 1000 & 583 \\
2005 & 882 & 447 & 989 & 424 & 2000 & 1000 & 629 \\
2010 & 892 & 482 & 1055 & 456 & 2000 & 1000 & 677 \\
\hline
\end{tabular}

Figure E.1.7 CAPITAL COST PROJECTIONS (1973 DOLLARS/KW)

The environmental impacts of coal (as percelved by the electric utility) rated on a scale from 0 to 1 (with a value of 1 representing minimal impact) are assumed to vary from .5 in 1973 to .8 in 2000 .

$$
\begin{array}{ll}
\text { CEC . K }=\text { TABLE (TCEC, TIME . K, 1970, 2000, 30) } & 45, \mathrm{~A} \\
\text { TCEC }=.5 / .8 & 45.1 \mathrm{~T} \\
\text { CEC - COAL ENVTRONMENTAL CONSIDERATIONS } &
\end{array}
$$

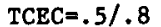

The improvement. of coal gasification technologies and stack scrubbers w111 tend to reduce the negative impacts of coal but many other problems will still remain (strip mining, for example). Figure E.1.8 presents the enyironmental impact estimates for all alternatives.

\begin{tabular}{|c|c|c|c|c|c|c|}
\hline YEAR & COAL & OIL & NUCLEAR & $\begin{array}{c}\text { TRANS- } \\
\text { GENTI- } \\
\text { THERMAL }\end{array}$ & SOLAR & $\begin{array}{c}\text { NENTAL } \\
\text { GRID }\end{array}$ \\
\hline 1973 & .5 & .7 & .9 & .75 & .8 & 1 \\
\hline 2000 & .8 & .85 & .9 & .9 & .8 & 1 \\
\hline
\end{tabular}

F1gure E.1.8 ENVIRONMENTAL IMPACTS (THE SCALE IS FROM 0 to 1 , WITH 1 DENOTING THE LEAST IMPACT ON THE ENVIRONMENT)

The total decision factor for coal is, therefore, found by multiplying the weight for each decision factor by the percelved value of that factor for these alternatives 
and suming the products for a11 six decision factors. For example, for coal in the year 2000 the total decision value is found by summing the following products:

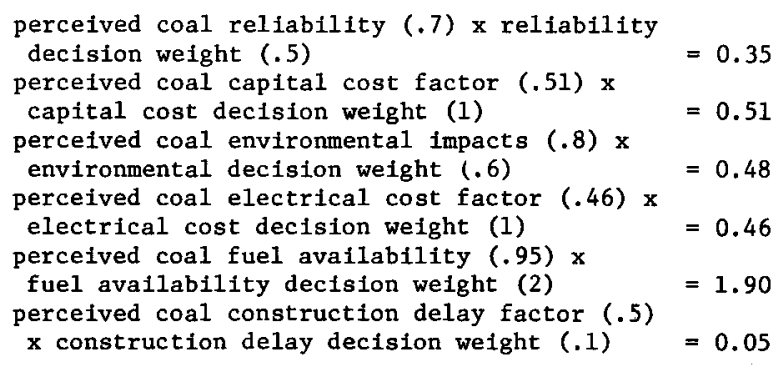

The sum of these products, 3.75 , is the total decision value for nuclear in 2000. Dividing the value by the total decision value for all possible alternatives in the year 2000, 21.6, for example, yields the amount of new capacity needs that will be met by new coal plants. In this case, one-fifth of the capacity gap will be filled with new coal plants.

The electricity cost of coal was estimated to the year 2010 and supplied to the model as a table function. The costs of electricity from each of the different sources are compared in Figure E.1.9.

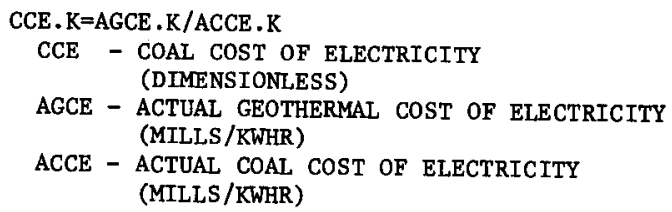

ACCE - ACTUAL COAL COST OF ELECTRICITY (MILLS/KWHR)

ACCE . $K=$ TABLE (TACCE , (TIME . K+10), 1970, 2010,5) 47, A TACCE $=117 / 18 / 21 / 23.3 / 25.8 / 28.7 / 31.8 / 35.2 / 39.147 .1 \mathrm{~T}$ ACCE - ACTUAL COST OF ELECTRICITY (MILLS/KWHR)

\begin{tabular}{|c|c|c|c|c|c|c|c|}
\hline YEAR & COAL & OIL & NUCLEAR & $\begin{array}{c}\text { GEO- } \\
\text { THERMAL }\end{array}$ & $\begin{array}{c}\text { SOLAR } \\
\text { EAST }\end{array}$ & $\begin{array}{c}\text { SOLAR } \\
\text { WEST }\end{array}$ & $\begin{array}{c}\text { TRANS- } \\
\text { CONT1- } \\
\text { NENTAL } \\
\text { GRID }\end{array}$ \\
\hline 1973 & 12 & 21 & 12 & 7 & & & 14 \\
1975 & 18 & 23 & 18 & 8 & & & 16 \\
1980 & 21 & 27 & 19 & 9 & & & 18 \\
1985 & 23 & 30 & 21 & 10 & & & 19 \\
1990 & 26 & 33 & 23 & 12 & 196 & 98 & 21 \\
1995 & 29 & 37 & 25 & 13 & 180 & 90 & 23 \\
2000 & 32 & 42 & 27 & 14 & 180 & 90 & 26 \\
2005 & 35 & 47 & 29 & 16 & 180 & 90 & 28 \\
2010 & 39 & 53 & 32 & 18 & 180 & 90 & 31 \\
\hline
\end{tabular}

Figure E.1.9 COST OF ELECTRICITY (MILLS/KWER) (CONSTANT DECEMBER 1973 DOLLARS)

Here again the actual cost is divided into the actual cost of the least expenstve electricity (geothermal, in this case) to produce an electricity cost factor between 0 and 1 .

The fuel availability of coal (defined as the perceived likelihood that a plant built today will have coal avallable for the entire 40-year Iffetime of the plant) was est1mated to be .95 , again on a scale of 0 to 1. The estimates for all fuels are presented in Figure E.1.10.

\begin{tabular}{|c|c|c|c|c|c|c|}
\hline YEAR & COAL & OIL & NUCLEAR & GEO- & THERMAL & $\begin{array}{c}\text { TRANS- } \\
\text { CONTI- } \\
\text { NENTAL } \\
\text { GRID }\end{array}$ \\
\hline 1973 & .95 & .75 & 1 & .75 & 1 & 1 \\
\hline 1985 & .95 & .4 & .95 & .75 & 1 & 1 \\
\hline 2000 & .95 & .2 & .95 & .95 & 1 & 1 \\
\hline
\end{tabular}

Figure E.1.10 PROJECTED PERCEIVED FUEL AVAILABILITY

CFA. K=TABLE (TCFA, TIME. $K, 1970,2000,30)$

$\mathrm{TCFA}=.95 / .95$

CFA - COAL FUEL AVATLABILITY (DIMEN-

48, A SIONLESS)

The construction delay factor for coal is .5 , found by dividing the delay time for coal plant construction ( 6 years) into the shortest construction delay (3 years for geotherma1).

$\mathrm{CDT}=.5$

$48.2, C$

CDT - COAL DELAY TIME

The same calculational procedures are followed in determining the planned capacities of nuclear, petroleum, solar, and imports from the West. Therefore, the equations will simply be presented here and only the differences from the coal case will be discussed.

PPCE. K=PPCE. J+ (APPCE.JK-PARE . JK+DAPPCE1.JK) $P P C E=33.5 E 3$

- PLANNED PETROLEUM CAPACITY-

49, L

EAST (MW)

PPCE - PLANNED PETROLEUM CAPACITYEAST (MW)

APPCE - ADDITIONAL PLANNED PETROLEUM CAPACITY- EAST (MW/YR)

PARE - PETROLEUM ADDITION RATE- EAST (MW/YR)

DAPPCE1 - DELAYED ADDITIONAL PLANNED PETROLEUM CAPACITY-EAST (1) (MW/YR)

APPCE . $\mathrm{KL}=$ (IAPPCE . $\mathrm{K} *(\mathrm{PCT} / \mathrm{PT})$ )

APPCE - ADDITIONAL PLANNED PETROLEUM $50, \mathbf{R}$ CAPACITY- EAST (MW/YR)

IAPPCE - INDICATED ADDITIONAL PLANNED PETROLEUM CAPACITY- EAST (MW/YR)

PCT - PETROLEUM CONSTRUCTION TMME (YRS)

PT - PROJECTION TIME (YRS)

NPPCE . K $=($ IAPPCE . K* (PCT/PT) )+DAPPCE . K

NPPCE - NEW PLANNED ADDITIONAI PETROLEUM CAPACITY- EAST (MW/YR)

IAPPCE - INDICATED ADDITIONAL PLANNED PETROLEUM CAPACITY- EAST (MW/YR)

PCT - PETROLEUM CONSTRUCTION TIME (YRS)

PT - PROJECTION TIME (YRS)

DAPPCE - DELAYED ADDITIONAL PLANNED PETROLEUM CAPACITY- EAST (MW/YR)

DAPPCE . K=BOXC (DAPPCE 1. JK, (PT-PCT-2) , 0,0,0,0, $52, A$ $0,0,0,0,0,0)$

DAPPCE - DELAYED ADDITIONAL PLANNED PETROLEUM CAPACITY- EAST (MW/YR) 


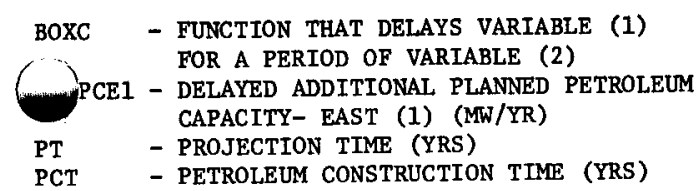

DAPPCE $1 . K L=$ IAPPCE.$K *(1-(\mathrm{PCT} / \mathrm{PT}))$

DAPPCE $1=0$

DAPPCE1 - DELAYED ADDITIONAL PLANNED PETROLEUM CAPACITY- EAST (1) (MW/YR)

IAPPCE - INDICATED ADDITIONAL PLANNED PETROLEUM CAPACITY- EAST (MW/YR)

PCT - PETROLEUM CONSTRUCTION TIME (YRS)

PT - PROJECTION TIME (YRS)

IAPPCE . KaMAX (0, ((PDF .K/TDFE.K)*TYCGE .K)+ 54, A (PAFGSFE.K))

IAPPCE - INDICATED ADDITIONAL PLANNED PETROLEUM CAPACITY-EAST (MW/YR)

PDF - PETROLEUM DECISION FACTOR (DIMENSIONLESS)

TDFE - TOTAL DECISION FACTOR- EAST (DIMENS IONLESS)

TYCGE - TEN YEAR CAPACITY GAP- EAST (MW/YR)

PAFGSFE - PETROLEUM ADJUSTMENT FOR GEOTHERMAL SHORT-FALL- EAST (MW/YR)

PAFGSFE $\cdot K=A F G S F E \cdot K *(P D F \cdot K /(C D F \cdot K+P D F \cdot K+N D F \cdot K)) \quad 55, A$

PAFGSFE - PETROLEUM ADJUSTMENT FOR GEOTHERMAL SHORT-FALL- EAST (MW/YR)

AFGSFE - ADJUSTMENT FOR GEOTHERMAL SHORTFALL- EAST (MW/YR)

PDF - PETROLEUM DECISION FACTOR (DTMENSTONLESS)

CDF - COAL DECISION FACTOR (DIMENSIONLESS)

NDF - NUCLEAR DECISION FACTOR (DIMENSIONLESS)

PDF $. K=(R F * P R \cdot K+C I F * P C I . K+E C F * P E C, K+C E F * P C E \cdot K+\quad 56, A$ FAF*PFA.$K) *$ PFAM.K

PDF - PETROLEUM DECISION FACTOR (DIMENSIONLESS)

RF - RELIABILITY FACTOR (DTMENSIONLESS)

PR - PETROLEUM RELIABILITY (DTMENSIONLESS)

CIF - CAPITAL INVESTMENT FACTOR (DIMENSIONLESS)

PCI - PETROLEUM CAPITAL INVESTMENT (DIMENSIONLESS)

ECF - ENVIRONMENTAL CONSIDERATION FACTOR (DIMENSIONLESS)

PEC - PETROLEUM ENVIRONMENTAL CONSIDERATIONS (DIMENSIONLESS)

CEF - COST OF ELECTRICITY FACTOR (DIMENSIONLESS)

PCE - PETROLEUM ELECTRICITY COST (DIMENSIONLESS)

FAF - FUEL AVAILABILITY FACTOR (DIMENSSIONLESS)

PFA - PETROLEUM FUEL AVAILABILITY (DIMENSIONLESS)

PFAM - PETROLEUM FUEL AVAILABILITY MULTIPLIER (DIMENSTONLESS)

In some cases one of the criteria Involved in the dec1glon concerning what type of capacity to build may become so important that the other criterla have little influence on the final decision. For example, if the percelved fuel availability of a particular fuel approaches zero, no new plants are going to be bullt requiring that fuel no matter how attractive it may appear under the other criteria. Therefore, certain limitations are set on some of the criterla. If the value for any particular fuel falls below certain levels that factor controls the decision. In the case of fuel availability, for example, we assumed that if the perceived fuel avallability of any fuel were to drop below .50 then no new capac1ty would be planned for that fuel. This consideration comes into play in the case of petroleum. Thus, the petroleum fuel avallability factor mult1plies the decision factor by some number that varies from 0 to 1 as the percelved avallability of petroleum varies from .50 to .60 . The petroleum decision factor may, therefore, become zero if the perceived avallability of the fuel becomes very low.

PR . K=TABLE (TPR, TTME.K, 1970,15)

$T P R=.9 / .9 / .9$

PR - PETROLEUM RELIABILITY (DIMEN-

$57.1, \mathrm{~T}$ SIONLESS)
PCI.K=GCIC.K/PCIC.K
PCI - PETROLEIM CAPITAL INVESTMENT (DTMENSIONLESS)
GCIC - GEOTHERMAL CAPITAL INVESTMENT $\operatorname{CosT}(\$ / K W)$

PCIC - PETROLEUM CAPITAL INVESTMENT COST $(\$ / \mathrm{KW})$

PCIC. K=TABLE (TPCIC , (TIME . K+10), 1970, 2010,5)

59, A TPCIC $=220 / 260 / 299 / 332 / 386 / 416 / 447 / 482$ PCIC - PETROLEUM CAPITAL INVESTMENT $\operatorname{cosT}(\$ / K W)$

PEC . K=TABLE (TPEC, TIME. $K, 1970,2000,30)$

TPEC $=.7 / .85$

PEC - PETROLEUM ENVIRONMENTAL CONSIDERATIONS (DIMENSIONLESS)

PCE. K=AGCE. $R /$ APCE. $K$ PCE - PETROLEUM ELECTRICITY COST (DTMENSIONLESS)

AGCE - ACTUAL GEOTHERMAL COST OF ELECTRICITY (MILLS/KWHR)

APCE - ACTUAL PETROLEUM ELECTRICITY COST MILLS (MILLS/KWHR)

APCE . K=TABLE (TAPCE, (TIME . $K+10), 1970,2010,5$ ) TAPCE $=21 / 22.7 / 26.6 / 33.4 / 37.5 / 42.0 / 47.1 / 52.8$ APCE - ACTUAL PETROLEUM ELECTRICITY COST (MILLS/KWTR)

PFA . K $=$ TABLE (TPFA, TMME . K, 1970, 2000,15)

TPFA $=.75 / .4 / .2$

PFA - PETROLEUM FUEL AVAILABILITY (DIMENSIONLESS)

PFAM. K=TABHL (TPFAM, PFA . $\mathrm{K}, .5, .6, .1$ )

TPFAM $=0 / 1$

PFAM - PETROLEUM FUEL AVAILABILITY MULTIPLIER (DIMENSIONLESS)

PFA - PETROLEUM FUEL AVAILABTLTTY

$\mathrm{PDT}=.6$

PDT - PETROLEUM DELAY TIME (DIMENSIONLESS)

$58, A$

$59.1, \mathrm{~T}$

$60, A$

$60.1, T$

61, A

62 , A

$62.1, \mathrm{~T}$

63, A

$63.1, T$

64, A

$64.1, T$

$64.2, \mathrm{C}$

65. L

PNCE . K=PNCE. J+DT* (APNCE. JK-NARE. JK+ DAPNCE1.JK)

PNCE $=183.6 \mathrm{E} 3$

PNCE - PLANNED NUCLEAR CAPACITYEAST (MW)

APNCE - ADDITIONAL PLANNED NUCLRAR CAPACITY - EAST (MW/YR)

NARE - NUCLEAR ADDITION RATE- EAST (MR/YR)

DAPNCE1- DELAYED ADDITIONAL PLÁNNED NUCLEAR CAPACITY- EAST (1) (MW/YR)

APNCE . KL=(IAPNCE . K* (NCT . K/PT))

$60, R$

APNCE - ADDITIONAL PLANNED NUCLEAR CAPACITY- RAST (MW/YR) 


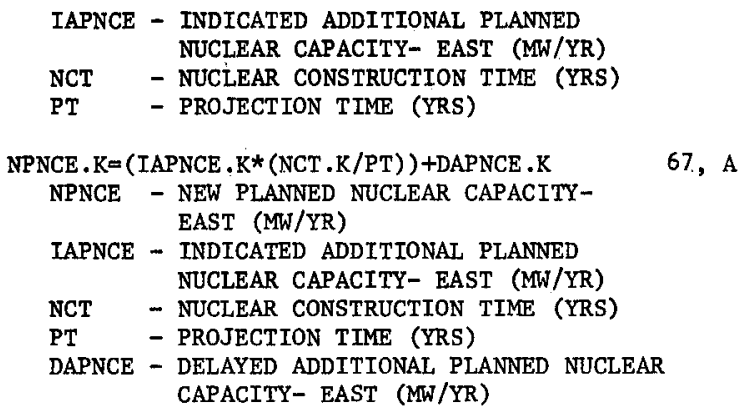

67, A

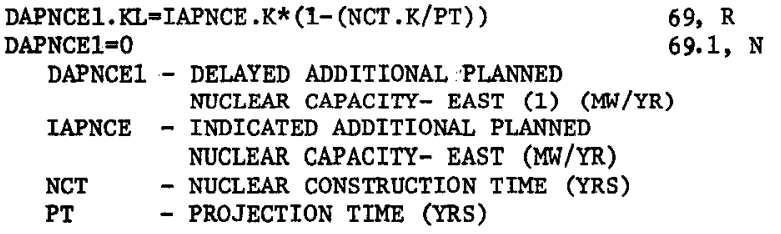

$69, \mathrm{R}$

$69.1, \mathrm{~N}$

LAPNCE . K=MAX (O, ( (NDF . K/TDFE . K $) *$ TYCGE . K $)+$ (NAFGSFE.K))

IAPNCE - INDICATED ADDITIONAL PLANNED NUCLEAR CAPACITY- EAST (MW/YR)

NDF - NUCLEAR DECISION FACTOR (DIMENSIONLESS)

TDFE - TOTAL DECISION FACTOR- EAST (DIMENS IONLESS)

TYCGE - TEN YEAR CAPACITY GAP- EAST (MW/YR)

NAFGSFE - NUCLEAR ADJUSTMENT FOR GEOTHERMAL SHORT-FALL- EAST (MW/YR)

NAFGSFE . K $=A F G S F E \cdot K *(N D F \cdot K /(C D F \cdot K+P D F \cdot K+N D F \cdot K))$

NAFGSFE - NUCLEAR ADJUSTMENT FOR GEOTHERMAI SHORT-FALL- EAST (MW/YR)

AFGSFE - ADJUSTMENT FOR GEOTHERMAL SHORTFALL- EAST (MW/YR)

NDF - NUCLEAR DECISION FACTOR (DIMENSIONLESS)

CDF - COAL DECISION FACTOR (DIMENSTONLESS)

PDF - PETROLEUM DECISION FACTOR (DIMENSIONLESS)

$\mathrm{NDF} \cdot \mathrm{K}=\mathrm{RF} * \mathrm{NR} \cdot \mathrm{K}+\mathrm{CIF} * \mathrm{NCI}, \mathrm{K}+\mathrm{ECF} * \mathrm{NEC} \cdot \mathrm{K}+\mathrm{CEF} * \mathrm{NCE} \cdot \mathrm{K}+\quad 72, \mathrm{~A}$

FAF*NFA. K

NDF - NUCLEAR DECISION FACTOR (DIMENSIONLESS)

RF - RELTABILITY FACTOR (DIMENSIONLESS)

NR - NUCLEAR RELIABILITY (DIMENSIONLESS)

CIF - CAPITAL INVESTMENT FACTOR (DIMENSIONLESS)

NCI - NUCLEAR CAPITAL INVESTMENT (DIMENSIONLESS)

ECF - ENVIRONMENTAL CONSIDERATION FACTOR (DIMENS IONLESS)

NEC - NUCLEAR ENVIRONMENTAL CONSIDERATIONS (DIMENSIONLESS)

CEF - COST OF ELECTRICITY (DIMENSIONLESS)

NCE - NUCLEAR COST OF ELECTRICITY (DIMENSIONLESS)

FAF - FUEL AVAILABILITY FACTOR (DIMENSIONLESS)

NFA - NUCLEAR FUEL AVAILABILITY (DIMENSIONLESS)
70, A

71, A

46

NR . K=TABLE (TNR, TIME $\cdot \mathrm{K}, 1970,2000,15)$

TNR=.6/.9\%..9

NR - NUCLEAR RELIABILITY (DIMENSIONLESS)

NCI . $\mathrm{K}=$ GCIC $\cdot \mathrm{K} / \mathrm{NCIC} \cdot \mathrm{K}$

NCI - NUCLEAR CAPITAL INVESTMENT (DIMENSIONLESS )

GCIC - GEOTHERMAL CAPITAL INVESTMENT $\cos T(\$ / K W)$

NCIC - NUCLEAR CAPITAL INVESTMENT COST $(\$ / \mathrm{KW})$

NCIC. $K=$ TABLE (TNCIC, $($ TIME . $K+10), 1970,2010,5) \quad 75, A$

TNCIC $=354 / 385 / 615 / 784 / 791 / 852 / 918 / 989 / 1065 \quad 75.1,{ }^{\prime} \mathrm{T}$ NCIC - NUCLEAR CAPITAL INVESTMENT COST $(\$ / \mathrm{KW})$

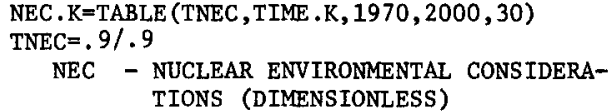

ANCE - ACTUAL NUCLEAR COST OF ELECTRICITY (MILLS/KWHR)

ANCE . K=TABLE (TANCE , (TIME . K+10), 1970, 2010,5 ) TANCE $=12 / 18 / 19 / 20.9 / 22.9 / 24.9 / 27.0 / 29.4 / 32$ ANCE - ACTUAL NUCLEAR COST OF ELECTRICITY (MILLS/KWTR)

NFA . $K=$ TABLE (TNFA . TIME . $K, 1970,2000,30)$

TNFA= $1 / .95 / .95$

NFA - NUCLEAR FUEL AVAILABILITY

73, A

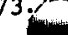

$74, \mathrm{~A}$

$$
\text { (KW) }
$$

$76, \mathrm{~A}$

$76.1 ; \mathrm{T}$ (DIMENSIONLESS)

NDT . K=GCT/NCT , K

NDT - NUCLEAR DELAY TIME (YEARS)

GCT - GEOTHERMAL CONSTRUCTION (TIME YEARS)

NCT - NUCLEAR CONSTRUCTION TIME (YEARS)

PICE . KaPICE . J+DT* (APICE . JK-IARE . JK+ DAPICE1.JK)

PICE $=0$$$
\text { DAPICE1.JK) }
$$

PICE - PLANNED IMPORT CAPACITY- EAST (MW)

APICE - ADDITIONAL PLANNED IMPORT CAPACITY- EAST (MW/YR)

IARE - IMPORT ADDITION RATE- EAST (MW/YR)

DAPICE1 - DELAYED ADDITIONAL PLANNED IMPORT CAPACITY- EAST (1) (MW/YR)

APICE $\cdot \mathrm{KL}=\mathrm{MAX}(0,(($ IDF $. \mathrm{K} / \mathrm{TDFE} \cdot \mathrm{K}) *$ TYCGE $. \mathrm{K} /$ (PT/ICT)))

APICE - ADDITIONAL PLANNED IMPORT CAPACITY- EAST (MW/YR)

IDF - IMPORT DECISION FACTOR (DIMENSIONLESS)

TDFE - TOTAL DECISION FACTOR- EAST (DIMENSIONLESS)

TYCGE - TEN YEAR CAPACITY GAP- EAST (MW/YR)

PT - PROJECTION TIME (YRS)

ICT - IMPORT CONSTRUCTION TIME

TDFE - TOTAL DECISION FACTOR- EAST (DIMENSIONLESS)

TYCGE - TEN YEAR CAPACITY GAP- EAST (MW/YR)

PT - PROJECTION TIME (YRS)

ICT - IMPORT CONSTRUCTION TIME

NPICE . K= (IDF . K/TDFE . K )*TYCGE . K* (ICT/PT) + DAPICE2.K

NPICE - NEW PLANNED ADDITIONAL IMPORT

116, A

IDF (DIMENSIONLESS)
$78, \mathrm{~A}$

78..1, T

$79, \mathrm{~A}$

$79.1, \mathrm{~T}$

$80, \mathrm{~A}$

$114, \mathrm{~L}$

$114.1, \mathrm{~N}$

$115, \mathrm{R}$ 


$$
\begin{array}{cc}
\text { TDFE } & \text { - TOTAL DECISION FACTOR- EAST } \\
& \text { (DIMENSIONLESS) } \\
\text { - } & \text { TEN YEAR CAPACITY GAP- EAST } \\
& \text { (MW/YR) } \\
\text { ICT } & \text { IMPORT CONSTRUCTION TIME } \\
\text { PT } & \text { PROJECTION TIME (YRS) } \\
\text { DAPICE2 - } & \text { DELAYED ADDITIONAL PLANNED } \\
& \text { IMPORT CAPACITY- EAST (2) } \\
& (\text { MW/YR) }
\end{array}
$$

DAPICE2 $. \mathrm{K}=\mathrm{BOXC}$ (DAPICEI.JK, (PT-ICT-2) , 0, 0,0 $0,0,0,0,0,0,0)$

DAPICE2 - DELAYED ADDITIONAL PLANNED IMPORT CAPACITY- EAST (2) (MW/YR)

BOXC - FUNCTION THAT DELAYS VARIABLE (1) FOR A PERIOD OF VARIABLE (2)

DAPICE1 - DELAYED ADDITIONAL PLANNED IMPORT CAPACITY- EAST (1) MW/YR)

PT - PROJECTION TIME (YRS)

ICT - IMPORT CONSTRUCTION TIME

DAPICE1. KL $=($ IDF $. K / T D F E . K) * T Y C G E . K *(1-$ (ICT/PT)

DAPICE $1=0$

DAPICE1 - DELAYED ADDITIONAL PLANNED IMPORT CAPACITY- EAST (1) (MW/YR)

IDF - IMPORT DECISION FACTOR (DIMENS IONLESS)

TDF - TOTAL DECISION FACTOR- EAST (DTMENS IONLESS)

TYCGE - TEN YEAR CAPACITY GAP- EAST (MW/YR)

ICT - IMPORT CONSTRUCTION TTME

PT - PROJECTION TIME (YRS)

Since at the present time there is no transcontinental electric grid, eastern utilities cannot now choose to import power from the West. Therefore the decision factor for imports is inftially set equal to zero. It becomes non-zero only when some sort of intercontinental grid is established. It was assumed in this model that planning for such a grid would commence around 1985. Thus, the import decision factor is zero until 1985, after which time it is calculated as are the decision factors for the other alternatives. There is one further Iimitation on imports of power by the East. Since the East can hardly expect a major portion of its power to be generated in the West and then delivered by a transcontinental grid, imports are limited to 5 percent of total demand. The total de cision factor for imports is, then, the indicated decision factor multiplied by a factor that ensures that the total import capacity will not exceed 5 percent of total capacity in the East.

$$
\begin{aligned}
& \text { IDF . K }=F \text { IFGE }(\text { IIDF . } K, 0, \text { TIME .K, IMPYEAR }) * \\
& \text { POSDFM. } \mathrm{K} \\
& \text { IMPYEAR }=1985 \\
& \text { IDF - IMPORT DECISION FACTOR } \\
& \text { (DTMENSTONLESS) } \\
& \text { POSDFN - POSSIBLE DECISTON FACTOR MULTI- } \\
& \text { PLIER } \\
& \text { IIDF - INDICATED IMPORT DECISION FACTOR } \\
& \text { (DIMENSIONLESS) }
\end{aligned}
$$

FIFGE is a DYNAMO function that returis the first argument if the third is greater than or equal to the fourth. otherwise the second argument is returned.

POSDFM. K=TABHL (TPOSDFM, IMPR. $\mathrm{K}, 0,0.05$, .005) TPOSDFM $=1 / 1 / 1 / 1 / 1 / .9 / .7 / .5 / .3 / .1 / 0$

120, A $120.1, \mathrm{~T}$
POSDFM - POSSIBLE DECISION FACTOR MULTIPLIER (DIMENSIONLESS)

IMPR - IMPORT RATIO (DIMENSIONLESS)

The decision factor multiplier depends on the import ratio. As this ratio approaches 5 percent the multiplier approaches zero.

The import ratio is calculated as the sum of present and planned import capacity divided by total present and planned capacity in the East:

$$
\begin{aligned}
& \text { IMPR }, \mathrm{K}=(\text { IMPCAPE }, \mathrm{K}+\mathrm{PICE}, \mathrm{K}) \text { /PAPSE } . \mathrm{K} \\
& \text { IMPR - IMPORT RATIO (DIMENSIONLESS) } \\
& \text { IMCAPE - IMPORT CAPACITY -EAST (MW) } \\
& \text { PICE - PLANNED IMPORT CAPACITY -EAST (MW) } \\
& \text { PAPSE - PRESENT AND PLANNED SUPPLY - EAST } \\
& \text { (MW/YR) }
\end{aligned}
$$

Imports are assumed to come from geothermal plants in the West. Therefore, if geothermal resources are not available in the West no new import capacity can be planned. The import decision factor is, then, equal to zero if the geothermal shortfall in the West is positive (indicating an excess of demand over avallable resources).

$$
\begin{array}{cc}
\text { IIDF. K=FIFGE } & (0, \text { IIDF1, K, GEOSFWL, JK, } 0) \\
\text { IIDF } & \text { INDICATED TMPORT DECISION FACTOR } \\
& \text { (DIMENSIONLESS) } \\
\text { IIDF1 } & \text { - INDICATED IMPORT DECISION FACTOR } 1 \\
\text { GEOSFL } & \text { (DIMENSIONLESS) } \\
\text { - GEOTHERMAL SHORT-FALL -WEST LAST } & \text { TTME PERIOD (MW/YR) }
\end{array}
$$

If geothermal resources are avallable in the West it is necessary to determine if there is enough resource to satisfy the demand for 1mported energy by the East.

$$
\begin{aligned}
& \text { IIDF1. } K=F \text { IFGE ( }(-1 \text { *GEOSFWL. JK*TDFEL.JK/TYCGE.K), 123, A } \\
& \text { IIDF2.K; (IIDF 2. } K \text { *TYCGE . K/TDFEL .JK), } \\
& (-1 * \text { GEOSFWL.JK }))
\end{aligned}
$$

The amount of new import capactty idesired by the East w111 be the total capacity gap to be: filled: (TYCGE) multiplied by the ratio of the Indicated import decision factor (IIDF2) and the total decision factor in the East (TDFEL - the total decision factor in the last time period). If this amount (the third argiment in the FIFGE function for IIDFl.K) is greater: than or equal to the amount of geothermal resources ava11-; able in the West " $(-1$ *GEOSFWL $)$ then sufficient resources are not avallable and a new declstion valueimust be calculated for imports. This new value is the first argument of the FIFGE function and was determined In the following manner

$$
\therefore \text { in on }
$$

If resources are avallable, the amount of new capactly to be planned (IAPICE)! is the total: capacity gap (TYCGE) times the ratio of the Import decision factor (IIDF2Y) to the total decision factor (TDFEL), or IAPICE=TYCGE (IIDF 2/TDFEL) 
If geothermal resources are limiting, the amount to be planned (IAPICE) is replaced by the amount actually-available (GEOSFWL) and the equation is solved for the dectsion factor IIDF2. Thus,

\section{IIDF2 $=($ GEOSFWL *TDFEL $) /$ TYCGE}

This expresston is the first argument in the FIFGE function for IIDFI. $K$. If resources are not limiting (the third argument is less than the fourth), the decision factor is simply equal to the indlcated decision factor (IIDF 2). This varlable (IIDF2) 18 calculated in the same manner that the decloton factors are computed for all other generating alternatives.

$$
\begin{aligned}
& \text { IIDF2 } \cdot \mathrm{K}=(R F * I M R \cdot K+C I T * I C I, K+E F C * I E C, K+ \\
& \text { CEF*ICE .K+FAF*IFA.K) *ILF, K } \\
& \text { IIDF2 - INDICATED IMPORT DECISION FACTOR } \\
& \text { 2. (DTMERSIONLESS) } \\
& \text { RF - RELIABILITY FACTOR (DIMENSIONLESS) } \\
& \text { IMR - IMPORT RELIABILITY (DIMENSIONLESS) } \\
& \text { CIF - CAPITAL INVESTMENT FACTOR (DIMEN- } \\
& \text { SIONLESS) } \\
& \text { ICI. - IMPORT CAPITAL INVESTMENT (DIMEN- } \\
& \text { SIONLESS) } \\
& \text { ECF - ENVIRONMENTAL CONSIDERATION FACTOR } \\
& \text { (DIMENS IONLESS) } \\
& \text { IEC - IMPORT ENVIRONMENTAL CONSIDERA- } \\
& \text { TIONS (DIMENSIONLESS) } \\
& \text { CEF - COST OF ELECTRICITY (DIMENSION- } \\
& \text { LESS) } \\
& \text { ICE - IMPORT COST OF ELECTRICITY (DIMEN- } \\
& \text {. SIONLESS) } \\
& \text { SIONLESS) } \\
& \text { IFA - IMPORT FUEL AVAILABILITY (DIMEN- } \\
& \text { SIONLESS) } \\
& \text { ILF - IMPORT LEARNING FACTOR (DIMENSION- }
\end{aligned}
$$

In order to account for the fact that many companles are slow to accept new technologles, a learning factor has been introduced into the calculations of the import decision' factor.

$$
\begin{gathered}
\text { ILF. } K=\text { TABHL (TLF } . \text { TIME } . K, 1985,1995.1) \\
\text { TLF }=0 / .04 / .10 / 18 / .30 / .50 / .70 / .82 / .90 / .96 / 1.0 \\
\text { ILF - TMPORT LEARNING FACTOR (DIMENSION- } \\
\text { LESS) }
\end{gathered}
$$

124, A

his learning factor multiplies the import decision factor by a number that is inftially zero, in the first year of planning for imports, and increases to one by the tenth year.

$$
\begin{aligned}
& \text { IMR } \cdot \mathrm{K}=\text { TABLE (TIMR, TIME .K, 1970, 2000, 30) } \\
& \operatorname{TIME}=1 / 1 \ldots \\
& \text { IMR - MPORT RELIABILITY (DIMENSIONLESS) } \\
& \text { GCIC - GEOTHERMAL CAPITAL INVESTMENT COSTS } \\
& \because \ldots \quad \text { (DIMENSIONLESS) }
\end{aligned}
$$

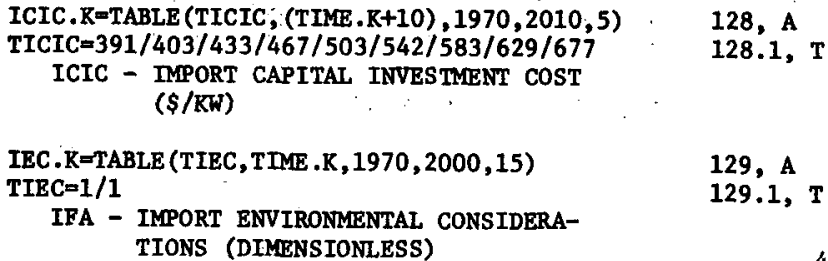

129, A

129.1, T

125, A
ICE . KaAGCE . K/AICE . K

ICE - IMPORT CAPACITY- EAST (IMW)

AGCE - ACTUAI GEOTHERMAL COST OF ELECTRICITY - EAST (MILLS/KWH)

AICE - ACTUAL IMPORT COST OF ELECTRICITYEAST (MILLS/KWH)

AICE : K=TABLE (TAIC, (TME . K+10), 1970, 2010,5)

TAICE $=14.5 / 16,3 / 17,6 / 19,3 / 21.2 / 23,3 / 25.7$ $/ 28.3 / 31.1$

AICE - ACTUAL IMPORT COST OF ELECTRICITYEAST (MILLS/KWH)

IFA.K-TABLE (TIFA, TIME . K, 1970, 2000, 15)

TIFA $=1 / 1 / 1$

IDT $=.5$

IFA - IMPORT FUEL AVAILABILITY (DIMENS IONL.ESS)

IDT - IMPORT DELAY TIME (DIMENSIONLESS)

PSCE. KøPSCE. J+DT+ (APSCE. JK-SARE. JK+ DAPSCE1.JK)

PSCE $=0$

PSCE - PLANNED SOLAR CAPACITY - EAST (MW)

APSCE - ADDITIONAL PLANNED SOLAR CAPACITY- EAST (MW)

SARE - SOLAR ADDITION RATE- EAST (MW/YR)

DAPSCE1 - DELAYED ADDITIONAL PLANNED SOLAR CAPACITY- EAST (1) (MW/YR)

APSCE . KL $=$ (IAPSCE . K $*(S C T / P T)$ )

APSCE - ADDITIONAL PLANNED SOLAR CAPACITY- EAST (MW)

IAPSCE - INDICATED ADDITIONAL PLANNED SOLAR CAPACITY- EAST (MW/YR)

SCT - SOLAR CONSTRUCTION TIME (YRS)

PT - PROJECTION TIME (YRS)

NPSCE . $K=($ IAPSCE . K* (SCT/PT) )+DAP SCE . K NPSCE - NEW PLANNED SOLAR CAPACITYEAST (MW/YR)

IAPSCE - INDICATED ADDITIONAL PLANNED SOLAR CAPACITY- EAST (MW/YR)

SCT - SOLAR CONSTRUCTION TIME (YRS)

PT - PROJECTION TIME (YRS)

DAPSCE - DELAYED ADDITIONAL PLANNED SOLAR CAPACITY- EAST (MW/YR)

DAPSCE , $\mathrm{K}=\mathrm{BOXC}$ (DAPSCE $1, \mathrm{JK},(\mathrm{PT}-\mathrm{SCT}-2), 0,0,0$, $0,0,0,0,0,0,0$ )

DAPSCE - DELAYED ADDITIONAL PLANNED SOLAR CAPACITY- EAST (MN/YR)

BOXC - FUNCTION THAT DELAYS VARIABLE (1) FOR A PERIOD OF VARIABLE (2)

DAPSCE1 - DETAYED ADDITIONAL PLANNED SOLAR GAPACITY- EAST (1) (MW/YR)

PT - PROJECTION TIME (YRS)

SCT - SOLAR CONSTRUCTION TIME (YRS)

DAPSCE1.KL=IAPSCE * K* (1-(SCT/PT $))$

DAPSCE1 $=0$

DAPSCE1 - DELAYED ADDITIONAL PLANNED SOLAR CAPACTTY- EAST (1) (MW/YR)

IAPSCE - TNDICATEID ADDITIONAT PIAANED SOLAR CAPACITY- EAST (MW/YR)

SCT - SOLAR CONSTRUCTION TDME (YRS)

PT - PROJECTION TTME (YRS)

IAPSCE . $K=\mathrm{MAX}(0,(($ SDFE . K/TDFE . K ) *TYCGE . K)) IAPSCE - INDICATED ADDITIONAL PLANNED SOLAR CAPACITY- EAST (MW/YR)

SDFE - SOLAR DECISION FACTOR- EAST (DIMENSIONLESS)

TDFE - TOTAL DECISION FACTOR- EAST (DIMENSIONLESS)
$130, \mathrm{~A}$

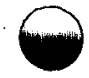

131, A 131.1, T

132, A

132.1, T

132.2 , C

133, L

133.1, N

$134, \mathrm{R}$

135, A

$136, \mathrm{~A}$

137, R

$137.1, \mathrm{~N}$

138, A 


\section{TYCGE - TEN YEAR CAPACITY GAP- EAST (MW/YR)}

Cencral station solar generating plants were estimated to first come on-line around 1995. Thus, the solar decision factor is equal to zero until 1987. In 1987 the first solar plants are planned. They come on-line in 1995 after an eight-year planning and construction delay period.

The decision factor for solar is different for the East and the West. This difference arises from the already mentioned fact that the cost of electricity and the capital costs are different for solar plants in the West and in the East. A separate decision factor is, therefore, calculated for solar for conditions prevalling in the East and for those prevailing in the West. In both cases a cost of electriclty multiplier is included in the calculation of the deciston factor. This multiplier has the effect of stopping all new planning in solar plants if the cost of electricity generated by those plants becomes extremely high. If the cost of electricity, expressed as a number from 0 to 1 (with 1 representing the least cost) falls below .06 , the total solar decision factor goes to zero.

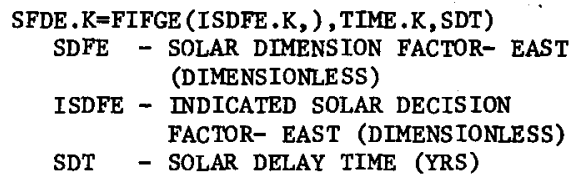

SDFW. K=FIFGE (ISDEW. $K$, ), TIME .K, SAT)

SAT $=1987$

SDFW - SOLAR DECISION FACTOR- WEST (DIMENS IONLESS)

ISDFW - INDICATED SOLAR DECISION

FACTOR (DIMENSIONLESS)

SAT - SOLAR AVAILABILITY TIME (HRS)

ISDFE $\cdot \mathrm{K}=\mathrm{PF} * \mathrm{SR} \cdot \mathrm{K}+\mathrm{CIF} * \mathrm{SCI} \cdot \mathrm{K}+\mathrm{ECF} * \mathrm{SEC} \cdot \mathrm{K}+\mathrm{CEF} *$ SCEE . K+FAF. K*SFAE . K+CDLF*SDT) *SLF. $K$ * SCEEL.K

ISDFE - INDICATED SOLAR DECISION FACTOR- EAST (DIMENS IONLESS)

RF - RELIABILITY FACTOR (DIMENSIONLESS)

SR - SOLAR RELIABILITY (DIMENSIONLESS)

CIF - CAPITAL INVESTMENT FACTOR (DIMENSIONLESS)

SCI - SOLAR CAPITAL INVESTMENT (DIMENSIONLESS)

ECF - ENVIROMMENTAL CONSIDERATION FACTOR (DTMENS IONLESS)

SÉC - SOLAR ENVIRONMENTAL CONSIDERA-: TION (DIMENSIONLESS)

CEF - COST OF ELECTRICITY FACTOR (DTMENSIONLESS)

SCEE - SOLAR COST OF ELECTRICITY - EAST (DIMENSIONLESS)

FAF - FUEL AVAILABILITY FACTOR (DIMENSIONLESS)

SFAE - SOLAR FUEL AVAILABILITY- EAST (DIMENSIONLESS)

SLF - SOLAR COST OF ELECTRICITY- EAST LIMITATION (DTMENSIONLESS)

SCEEL - SOLAR COST OF ELECTRICITY - EAST ITMITATION " (DIMENSIONLESS)

CDLF - CONSTRUCTION DELAY FACTOR (DIMENSIONLESS)

SDT - SOLAR DELAY FACTOR (DIMENSIONLESS)

$139, \mathrm{~A}$

$140, \mathrm{~A}$

$140.1, \mathrm{C}$

141, A
SEC - SOLAR ENVIRONMENTAL CONSIDERATION (DIMENSTONLESS)

CEF - COST OF ELECTRICITY FACTOR (DIMENSIONLESS)

SCEW - SOLAR COST OF ELECTRICITY- WEST (DIMENSIONLESS)

FAF - FUEL AVAILABILITY FACTOR (DIMENSIONLESS)

SFAW - SOLAR FUEL AVAILABILITY- WEST (DIMENSIONLESS)

SLF - SOLAR LEARNING FACTOR (DIMENSIONLESS)

SCEWL - SOLAR COST OF ELECTRICITY- WEST LIMITATION (DIMENSIONLESS)

CDLF - CONSTRUCTION DELAY FACTOR (DIMENSIONLESS)

SDT - SOLAR DELAY TIME (YRS)

SLF . K=TABHL (TSLF , TIME . K, $1985,1994,1$ )

TSLF $=.1 / .2 / .3 / .4 / .5 / .6 / .7 / .8 / .9 / 1.0$

SLF - SOLAR LEARNING FACTOR (DIMENSIONLESS)

SR . K =TABLE (TSR . TIME . K , 1985, 2000, 10)

TSR $=.55 / .65$

SR - SOLAR RELIABILITY (DIMENSIONLESS)

144, A

144.1, T

SCIE $\cdot \mathrm{K}=\mathrm{GCIC} \cdot \mathrm{K} / \mathrm{SCICE} \cdot \mathrm{K}$

SCIE - SOLAR CAPITAL INVESTMENT-

145, A FAST (DTMENSIONLESS)

GCIC - GEOTHERMAL CAPITAL INVESTMENT $\operatorname{cosT}(\$ K / K W)$

SCICE - SOLAR CAPITAL INVESTMENT COSTEAST $(\$ / \mathrm{KW})$

SCICE. K-TABHL (TSCICE , (TIME .K+10), 1985 , $2000,15)$

TSCICE $=3000 / 2000$

SCICE - SOLAR CÁPITAL INVESTMENT COSTEAST ( $\$ / K W)$

SCIV. K=GCIC. $\mathrm{K} / \mathrm{SCICW}, \mathrm{K}$

SCIW - SOLAR CAPITAL INVESTMENT-

WEST (DIMENSIONLESS)

GCIC - GEOTHERMAL CAPITAL INVESTMENT COST ( $/ \mathrm{KW})$

SCICW - SOLAR CAPITAL INVESTMENT' COST $(\$ / \mathrm{KW})$

SCICW. K=TABHL (TSCICW, (TIME . K+10), 1985 $2000,15)$

TSCICW $1500 / 1000$

SCICW - - SOLAR CAPITAL INVESTMENT

COST- WEST $(\$ / K W)$

146, A

$146.1, \mathrm{~T}$

147, A$$
147,
$$

SEC.K=TABLE(TSEC, TIME .K, 1970, 2000,30) : $: 149$, A TSEC=.8/.8 $\quad 149.1, T$ SEC - SOLAR ENVIRONMRNTAL CONSIDERA- $149.1, \mathrm{~T}$ TIONS (DIMENSIONLESS)

SCEE . K=AGCE . K/ASCEE . K

SCEE - SOLAR COST OF ELECTRICITY EAST (DIMENSIONLESS)

ASCE - ACTUAL GEOTHERMAL COST OF ELECTRICITY (MILLS/KWHR)

ASCEE - ACTUAL SOLAR COST OF ELECTRICITY- EAST (MIILS/KWHR)
$148, \mathrm{~A}$

$148.1, T$

a.

$150, \mathrm{~A}$ 


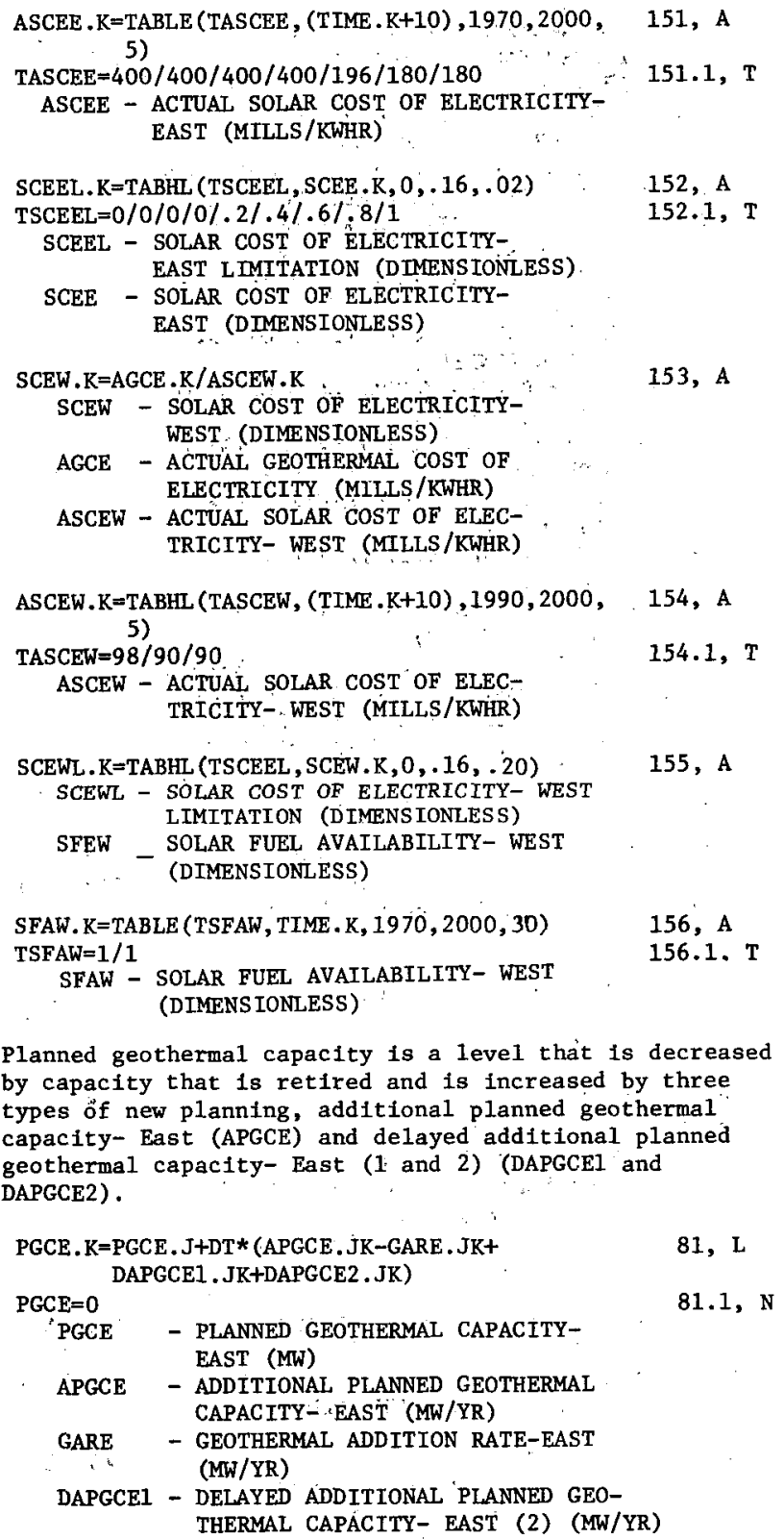

Additional planned geothermal capacity- East (APGCE) is normally equal to indicated additional planned geothermal capacity- East (IAPGCE) (which is calculated in the same way that indicated additional planned capacity is calculated for the other fuels). However, in some cases there may not be enough geothermal resources avallable to fill the demand for new geothermal capacity.

In this case, the amount of new geothermal capacity that is indicated is reduced by the ratio of the available resources (GRAFCAE) to the amount of new capacity that is desired (INPGCE). APGCE $: K L=$ IAPGCE. $K *($ MIN $(I,($ GRAFCAE $. K /$
INPGCE.$K)))$

82, $\mathrm{R}$

APGCE $=0$ $\begin{aligned} \text { APGCE - } & \text { ADDITIONAL PLANNED GEOTHERMAL } \\ & \text { CAPACITY- EAST (MW/YR) }\end{aligned}$
IAPGCE - INDICATED ADDITIONAL PLANNED GEOTHERMAL CAPACITY- EAST (MW/YR)
GRAFCAE - GEOTHERMAL RESOURCES AVAILABLE FOR CAPACITY ADDITION-EAST (MW/YR)
INPGCE - INDICATED NEW PLANNED GEOTHERMAL CAPACITY - EAST (MW/YR)

This equation ensures that new capacity additions will not exceed the geothermal resources that are avaflable.

Indicated additional planned geothermal capacity- East (IAPGCE) is equal to IAPGCE1 (the amount of new capacit that will be geothermal as indicated by the ratio of the geothermal decision factor to the total deciston factor for all types of generation) multiplied by the time necessary to construct a geothermal plant divided by the projection time.

$$
\begin{aligned}
& \text { IAPGCE } \cdot K=(\text { IAPGCE } 1 \cdot K *(G C T / P T)) \\
& \text { IAPGCE - INDICATED ADDITIONAL PLANNED } \\
& \text { GEOTHERMAL CAPACITY - EAST } \\
& \text { (MW/YR) } \\
& \text { IAPGCE1 - INDICATED ADDITIONAL PLANNED } \\
& \text { GEOTHERMAI CAPACITY- EAST (1) } \\
& \text { (MW/YR) } \\
& \text { GCT - GEOTHERMAL CONSTRUCTION TIME (YRS) } \\
& \text { PT - PROJECTION TIME (YRS) }
\end{aligned}
$$

Thus, the amount of new capacity that is needed to meet expected demand in ten years is multiplied by the ratio of the geothermal decision factor to the total decision factor for all fuels to yleld the amount of geothermal capacity that should be built during the next ten years Since it takes only three years to build a geothermal plant, it is not necessary to begin construction on the entire amount of capacity that will be needed in ten years. Rather, construction should begin immediately on only one-third of the capacity that will be needed. Construction can begin on the second third in three years and on the last third in seven years. In this manner the entire amount will be available in ten years to meet expected demand. The amount of construction tha should begin in three years (DAPGCE1) is simply the indicated total amount needed (IAPGCE1) multiplied by GCT/PT, or one-third, again adjusted for the resource availability should desired additions exceed the amount of resources available.

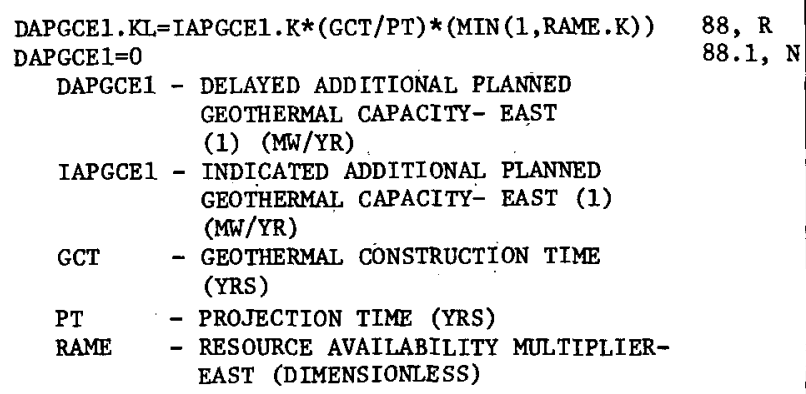


INPGCE - INDICATED NEW PLANNED GEOTHERMAL CAPACITY- EAST (MW/YR)

The fimount of construction that should begin in seven years (DAPGCE2) is the total amount needed minus what is being bullt inmediately minus what will be built in three years, again adjusted for resource avallabllity.

\begin{tabular}{|c|c|c|}
\hline \multicolumn{2}{|c|}{$\begin{aligned} \text { DAPGCE } 2 . \mathrm{KL} & =(\text { IAPGCE } 1, \mathrm{~K}-(\text { IAPGCE } 1 . \mathrm{K} * 2 * G C T / P T)) \\
& *(\text { MIN }(1, \mathrm{RAME} \cdot \mathrm{K}))\end{aligned}$} & $89, \mathrm{R}$ \\
\hline DAPGCE $2=0$ & & $89.1, \mathrm{~N}$ \\
\hline DAPGCE2 & $\begin{array}{l}\text { - DELAYED ADDITIONAL PLANNED } \\
\text { GEOTHERMAL CAPACITY- EAST } \\
\text { (MW/YR) }\end{array}$ & \\
\hline IAPGCE1 & $\begin{array}{l}\text { - INDICATED ADDITIONAL PLANNED } \\
\text { GEOTHERMAL CAPACITY - EAST } \\
\text { (1) (MW/YR) }\end{array}$ & \\
\hline GCT & $\begin{array}{l}\text { - GEOTHERMAL CONSTRUCTION TIME } \\
\text { (YRS) }\end{array}$ & \\
\hline PT & - PROJECTION TIME (YRS) & \\
\hline RAME & $\begin{array}{l}\text { - RESOURCE AVAILABILITY MULTI- } \\
\text { PLIER- EAST (DIMENSIONLESS) }\end{array}$ & \\
\hline
\end{tabular}

The total amount of new construction that w111 be beginning at any one particular time 1s, therefore, the sum of the planning from three different periods. The amount of new capacity to be begun in 1980, for example, will be the sum of new capacity planned in 1980 to begin immediately (one-third the total amount of new capacity needs allocated to geothermal) plus capacity that was planned three years earller, 1n 1977, to begin after a three-year delay plus the capacity that was planned in 1973 to begin seven years later (as long as that sum is less than or equal to the total geothermal resources avallable at that time).

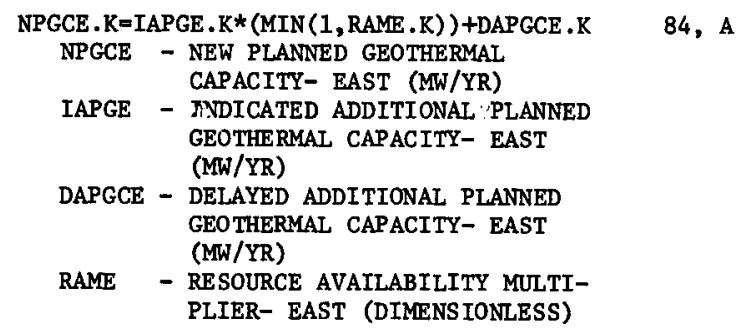

The Indicated newly planned geothermal capacity (INPGCE) is the same as NPGCE with the exception that 1t Indicates that amount of new capacity that would be planned If there were no resource restriction, wh1le NPGCE is corrected for resource restrictions, if any exist.

$$
\begin{aligned}
& \begin{aligned}
\text { INPGCE. } & =\text { MAX }(.01,((\text { IAPGCE } 1 . K *(G C T / P T)) \\
\text { +DAPGCE.K })) & 86, A
\end{aligned} \\
& \text { INPGCE - INDICATED NEW PLANNED GEO- } \\
& \text { THERMAL CAPACITY-EAST (MW/YR) } \\
& \text { IAPGCE } 1 \text { - INDICATED ADDITIONAL PLANNED } \\
& \text { GEOTHERMAL CAPACITY- EAST } \\
& \text { (1) (MW/YR) } \\
& \text { GCT - GEOTHERMAL CONSTRUCTION TTME } \\
& \text { (YRS) } \\
& \text { PT - PROJECTION TIME (YRS) } \\
& \text { DAPGCE - DELAYED ADDITIONAL PLANNED } \\
& \text { GEOTHERMAL CAPACITY - EAST } \\
& \text { (MW/YR) }
\end{aligned}
$$

DAPGCE, the amount of delayed plannting from earller years, is calculated using the BOXC delay function described earlier. The delay time used in this function for the three-year delay is expressed as PT-GCT-2, or one year, because this quantity is used in two successive rate equations in the process of evolving from planned capacity to actual capacity. These two rate equations cause an additional two-year time delay (when the solution interval of the model 1s one year) that must be corrected for in this equation. Similarly, the $s 1 x$-year delay 18 expressed as PT- $(2 * G C T)-2$.

$$
\begin{aligned}
& \text { DAPGCE . KaBOXC (DAPGCE2 . JK, (PT-GCT-2), 0, 0, 0, 0,0, 87, A } \\
& 0,0,0,0,0)+B O X C \text { (DAPGCE1. JK, (PT- } \\
& (2 * G C T)-2), 0,0,0,0,0,0,0,0,0,0) \\
& \text { DAPGCE - DELAYED ADDITIONAL PLANNED } \\
& \text { GEOTHERMAL CAPACITY- EAST } \\
& \text { (MW/YR) } \\
& \text { BOXC - FUNCTION THAT DELAYS VARIABLE } \\
& \text { (1) FOR A PERIOD OF VARIABLE (2) } \\
& \text { DAPGCE1 - DELAYED ADDITIONAL PIANNED GEO- } \\
& \text { THERMAL CAPACITY - EAST (I) (MW/YR) } \\
& \text { PT - PROJECTION TIME (YRS) } \\
& \text { GCT - GEOTHERMAL CONSTRUCTION TIME (YRS) } \\
& \text { DAPGCE2 - DELAYED ADDITIONAL PLANNED GEO- } \\
& \text { THERMAL CAPACITY- EAST (2) (MW/YR) }
\end{aligned}
$$

The resource avallability multiplier is a function of avallable resources and indicated planned capacity.

$$
\begin{aligned}
& \text { RAME . K=MIN ( (GRAFCAE. K/INPGCW.K), (MIN 85, A } \\
& \text { ((GRACAE6.K/(IAPGCE1.K*2/3)), } \\
& \text { (GRACAE9.K/IAPGCW1.K)))) } \\
& \text { RAME - RESOURCE AVAILABILITY MULTI- } \\
& \text { PLIER- EAST (DIMENSIONLESS) } \\
& \text { GRAFCAE - GEOTHERMAL RESOURCES AVAILABLE } \\
& \text { FOR CAPACITY ADDITION- EAST } \\
& \text { (MW/YR) } \\
& \text { INPGCW - INDICATED NEW PLANNED GEOTHERMAL } \\
& \text { CAPACITY- WEST (MW/YR) } \\
& \text { GRACAE6 - GRAFCAE IN SIX YEARS (MW) } \\
& \text { IAPGCW1 - INDICATED ADDITIONAL PLANNED GEO- } \\
& \text { THERMAL CAPACITY - WEST (1) (MW/YR) } \\
& \text { GRACAE9 - GRAFCAE IN NINE YEARS (MW) }
\end{aligned}
$$

RAME is the minimum of three ratios: the ratio of resources available in three years to indicated Immediate planning (which would become on-1ine capacity in three years), the ratio of resources avallable in six years to two-thirds total indicated new planning (approximately the amount that would be on-line in s1x years) and the ratio of resources avallable in nine years to total indicated new planning (the amount that would be on-line in ten years). A value less than one for any of these ratios indicates that sufficient resources are not avallable for all the new plants desired. RAME is, therefore, set equal to the minimum of the three ratios and restricts new planning to the resources avallable.

Geothermal resources available for capacity additions In three years (GRAFCAE) is a function of total resources in three years minus resources already allocated.

$$
\begin{aligned}
& \text { GRAFCAE . K=MAX (0, ((PRAE.K-GEOCAPE.K- (PGCE.K/ 9l, A } \\
& \text { GCT) )/1)) } \\
& \text { GRAFCAE - GEOTHERMAL RESOURCES AVAILABLE } \\
& \text { FOR CAPACITY ADDITION- EAST } \\
& \text { (MW/YR) } \\
& \text { PRAE - PROJECTED GEOTHERMAL RESOURCES- } \\
& \text { EAST (MW) } \\
& \text { GEOCAPE - GEOTHERMAL CAPACITY- EAST (MW) } \\
& \text { PGCE - PLANNED GEOTHERMAL CAPACITY- } \\
& \text { EAST (MW) } \\
& \text { GCT - GEOTHERMAL CONSTRUCTION TIME (YRS) }
\end{aligned}
$$

PRAE is a projection of total resources that will be avallable in three years. Subtracting from PRAE the resources that are already being used (GEOCAPE) and the planned capactity that will come on-1ine in three years (approximately one-third total plenned capacity) ylelds the amount of resources that are as yet unallocated. These resources are avallable for new planning.

Profected resources are simply the value that the geothermal resources- East estimate will reach in three years. 


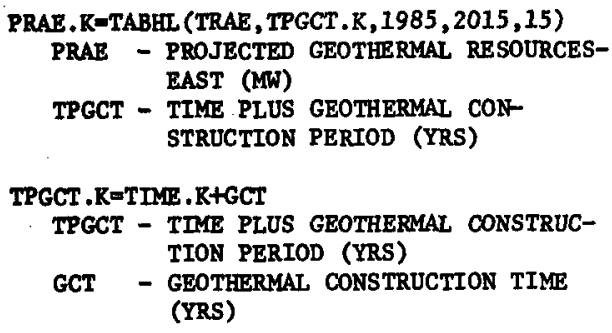

Bstimates of geothermal. resources that are avallable for new planning for capacity additions in $s 1 x$ and nine years are developed in a similar manner.

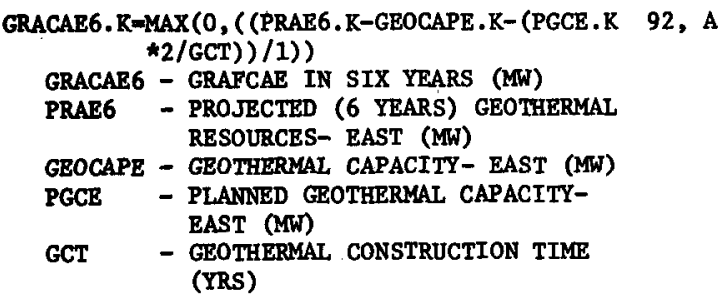

If Indicated new geothermal capacity (INPGCE) exceeds avallable resources the amount of the shortfall is calculated and allocated to other power sources. The amount of the shortfall is simply equal to Indicated new capacity planning for geothermal minus the resources avallable. Of course, when resources exceed the desire for new capacity, the shortfall 18 zero.

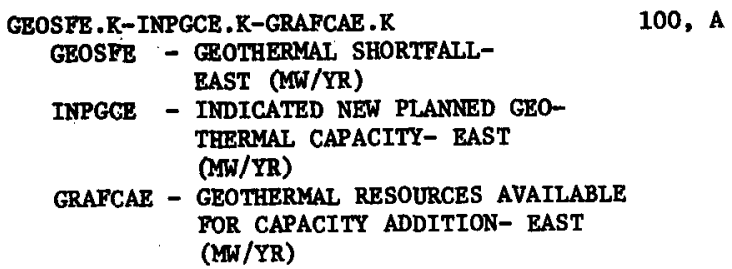

$100, \mathrm{~A}$

AFGSFE, $K=$ MAX (GEOSFE . $K, 0)$

AFGSFE - ADJUSTMENT FOR GEOTHERMAI SHORTFALL- EAST (MW/YR)

GEOSFE - GEOTHERMAL SHORTFALL- EAST (MW/YR)

101, A

The technology for geothermal in the East is not yet sufficientiy developed to make geothermal an alternative energy source at the present. It was estimated, however, that the technology might become avaflable in the mid-1980's. Thus, the geothermal dectsion factor for the East is equal to zero unt11 1985.

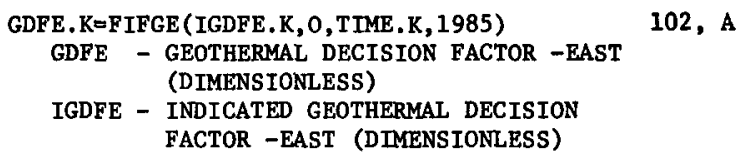

After 1985 the decision factor is a function of the $s 1 x$ decision vartables described earlier.

In order to account for the fact that many companies are unwilling to commit themselves to a new technology until that technology has been used for some time, a learning factor that has been introduced into the equation for the geothermal decision factor.

$$
\begin{aligned}
& \text { IGDFE. } \mathrm{K}=(\mathrm{RF} * \mathrm{GR}, \mathrm{K}+\mathrm{CIF} * \mathrm{GCI} . \mathrm{K}+\mathrm{ECF} * \mathrm{GEC} . \mathrm{K}+\quad 103, \\
& \text { CEF*GCE. K+FAF*GFA.K)*LFE. } K \\
& \text { IGDFE - INDICATED GEOTHERMAL DECISION FACTOR- } \\
& \text { EAST (DIMENSIONLESS) } \\
& \text { RF - RELIABILITY FACTOR (DIMENSIONLESS) } \\
& \text { GR - GEOTHERMAL RELIABIIITT (DIMENSTONLESS) } \\
& \text { CIF - CAPITAL INVESTMENT FACTOR (DIMENSION- } \\
& \text { LESS) } \\
& \text { GCI - GEOTHERMAL CAPITAL INVESTMENT } \\
& \text { (DIMENSIONLESS) } \\
& \text { ECP - ENVIRONMENTAL CONSIDERATION FACTOR } \\
& \text { (DIMENSTONLESS) } \\
& \text { GEC - GEOTHERMAL ENVIRONMENTAL CONSIDERA- } \\
& \text { TIONS (DIMENSIONLESS) } \\
& \text { CEF - COST OF ELECTRICITY FACTOR (DIMENSION- } \\
& \text { LESS) } \\
& \text { GCE - GEOTHERMAL COST OF ELECTRICITY } \\
& \text { (DIMENSIONLESS) } \\
& \text { FAF - FURL AVAILABIIITY FACTOR (DIMENSION- } \\
& \text { LESS) } \\
& \text { GFA - GEOTHERMAL FUEL AVAILABILITY } \\
& \text { (DTMENSIONLESS) } \\
& \text { LFE - LEARNING'FACTOR- EAST (DIMENSIONLESS) }
\end{aligned}
$$

The learning faotor reduces the value of the geothermal decision factor in the first few years that the technology is avallable in the East. This multiplier becomes one ten years later when the technology 18 well understood by all possible users. Thus a type of learning process is included with the introduction of new geothermal techniques.

LFE. K=TABHL (TIME, TIME. K, 1985, 1996,1) TLFE $=0 / .04 / .10 / .18 / .30 / .50 / .70 / .82$

$$
1.90 / .96 / 1.0
$$

The geothermal decision factor for the West is similar to that fust described for the East with the exception that the learning multipller begins in 1970 and reaches 1 in 1980.

$\mathrm{GDFW} \cdot \mathrm{K}=(\mathrm{RF} * \mathrm{GR} \cdot \mathrm{K}+\mathrm{CIF} * \mathrm{GCI} . \mathrm{K}+\mathrm{ECF} * \mathrm{GEC} . \mathrm{K}+$ CEF*GCE $. K+F A F * G F A . K) * L F W . K$

GDFW - GEOTHERMAI DECISION FACTOR- WEST (DIMENS IONLESS)

RF - RELIABILITY FACTOR (DIMENSIONLESS)

GR - GEOTHERMAL RELIABILITY (DIMENSTONLESS)

CIF - CAPITAL INVESTMENT FACTOR (DIMENSIONLESS) 


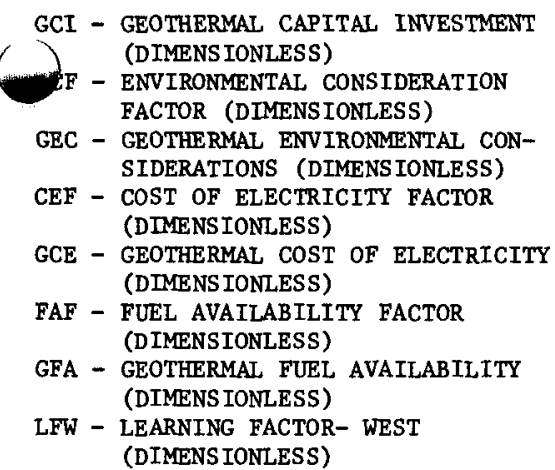

LFW. K=TABHL (TLF , TIME . K, 1970,1981, 1)

TLF $=0 / 0 / 0 / .2 / .3 / .4 / .5 / .6 / .7 / .8 / .9 / 1$

LFW - LEARNING FACTOR- WEST

(DIMENS IONLESS)

The estimates of perceived reliability, capital investment cost, environmental considerations, manufacturing costs of electricity, fuel avallability, and construction delay time that are a part of the decision factor calculations have already been discussed. The model equations for these variables are presented below.

GR $. K=T A B L E(T G R, T I M E \cdot K, 1970,2000,15)$

$107, A$

TGR $=.7 / .7 / .8$

GR - GEOTHERMAL RELIABILITY (DIMENSIONLESS)
GCT $. \mathrm{K}=\mathrm{GCIC} \cdot \mathrm{K} / \mathrm{GCIC} \cdot \mathrm{K}$
GCI - GEOTHERMAL CAPITAL INVESTMENT $\cos T$
GCIC - GEOTHERMAL CAPITAL INVESTMENT $\operatorname{cosT}(\$ / K W)$
GCIC . $K=$ TABLE (TGCIC , (TIME . $K+10), 1970,2010,5) \quad 109, A$ TGCIC $=264 / 272 / 292 / 315 / 339 / 365 / 394 / 424 / 456 \quad 109.1$, T GCIC - GEOTHERMAL CAPITAL INVESTMENT $\operatorname{cosT}(\$ / \mathrm{KW})$

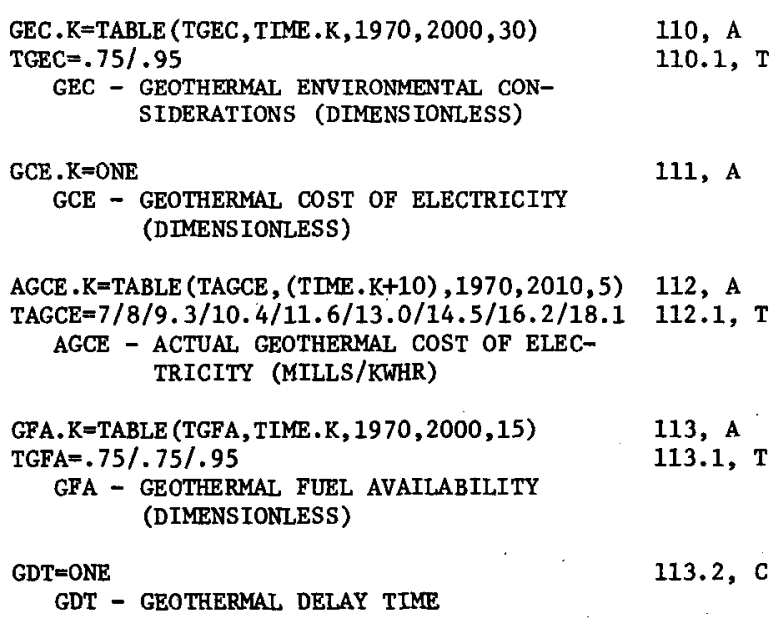

AGCE $. K=$ TABLE $($ TAGCE $,($ TIME $\cdot K+10), 1970,2010,5) \quad 112, A$ TAGCE $=7 / 8 / 9.3 / 10.4 / 11.6 / 13.0 / 14.5 / 16.2 / 18.1$ 112.1, T AGCE - ACTUAL GEOTHERMAL COST OF ELECTRICITY (MILLS/KWHR)

The equations for calculating capacities in the West are identical to those already described for the East, with two exceptions. Initial values are, of course, different for installed and planned capacities. Imports of electricity are not included as one of the alternative power sources for the West.

The rest of the calculations for the West are Identical to those already described for the East. They are therefore, presented on the following pages without further comment.

$$
\begin{gathered}
\text { TYCGW. } K=\text { PTYDW. } K \text {-PAPSW.K } \\
\text { TYCGW - TEN YEAR CAPACITY GAP- WEST } \\
\text { (MW/YR) } \\
\text { PTYDW - PROJECTED TEN YEAR DEMAND- } \\
\text { WEST (MW/YR) } \\
\text { PAPSW - PRESENT AND PLANNED SUPPLY- } \\
\text { WEST (MW/YR) }
\end{gathered}
$$

PTYDW . $K=$ TABLE (TPDW, TPPT . K , 1970, 2010,5)*1E3 TPDW=44/94/129/181/255/340/406/533/660

PTYDW - PROJECTED TEN YEAR DEMANDWEST (MW/YR)

TPPT - TIME PLUS PROJECTION TIME (YRS)

PAPSW. $K=($ PRCAPW. $K+$ PLCAPW. $K)$-IMPCAPE.$K$

PAPSW - PRESENT AND PLANNED SUPPLYWEST (MW/YR)

PRCAPW - PRESENT PROJECTED CAPACITYWEST (MW)

PLCAPW - PLANNED CAPACITY - WEST (MW)

IMPCAPE- IMPORT CAPACITY - EAST (MW)

PRCAPW. $K=P R C C A P W \cdot K+P R P C A P W \cdot K+N U C C A P W \cdot K$ +GEOCAPW. K+SCAPW. K+PRHCAPW. $K$ +PRNGCPW. K

PRCAPW - PRESENT PROJECTED CAPACITYWEST (MW)

PRCCAPW - PRESENT PROJECTED COAL CAPACITYWEST (MW)

PRPCAPW - PRESENT PROJECTED PETROLEUM CAPACITY - WEST (MW)

NUCCAPW - NUCLEAR CAPACITY- WEST (MW)

GEOCAPW - GEOTHERMAL CAPACITY- WEST (MW)

SCAPW - SOLAR CAPACITY- WEST (MW)

PRHCAPW - PRESENT PROJECTED HYDRO CAPACITY- WEST (MW)

PRCCAPW . K $=$ CCAPW. $K *(1-(P T * .025))$

PRCCAPW - PRESENT PROJECTED COAL CAPACITY- WEST (MW)

CCAPW - COAL CAPACITY- WEST (MW)

PT - PROJECTION TIME (YRS)

PRPCAPW. $K=P E T C A P W . K *(1-(P T * .025))$

PRPCAPW - PRESENT PROJECTED PETROLEUM CAPACITY- WEST (MW)

PETCAPW - PETROLEUM CAPACITY- WEST (MW)

PT - PROJECTION TIME (YRS)

160, A

$160.1, \mathrm{~T}$

$161, A$

162, A

PRHCAPW. K=TABLE $($ THCAPW, TPPT . K, 1970, 2010,5)*

1E3 CAPACITY- WEST (MW)

TPPT - TIME PLUS PROJECTION TIME (YRS)

PRNGCPW . $K=$ TABLE (TNGCAPW, TPPT . K, 1970, 2010,5) * 166, A $1 \mathrm{E} 3$

TPPT - TIME PLUS PROJECTION TIME (YRS)

PCAPW $, K=C C A P W \cdot K+P E T C A P W \cdot K+N U C C A P W \cdot K+G E O C A P W \cdot K 167, S$ + SCAPW. K+HCAPW. K+NGCAPW. $K$

PCAPW - PRESENT CAPACITY - WEST (MW)

CCAPW - COAL CAPACITY - WEST (MW)

PETCAPW - PETROLEUM CAPACITY-WEST (MW)

NUCCAPW - NUCLEAR CAPACITY- WEST (MW)

GEOCAPW - GEOTHERMAL CAPACITY - WEST (MW)

SCAPW - SOLAR CAPACITY - WEST (MW)

HCAPW - HYDRO CAPACITY - WEST (MW)

NGCAPW - NATURAL GAS CAPACITY- WEST (MW)

CCAPW. $\mathrm{K}=\mathrm{CCAPW} \cdot \mathrm{J}+\mathrm{DT}$ * (CARW.JK-CCRW.JK)

$\mathrm{CCAPW}=13.2 \mathrm{E} 3$

$168, \mathrm{~L}$

168.1 , N 
CCAPW - COAL CAPACITY - WEST (MW)

DT - LENGTH OF SOLUTION INTERVAL (YRS)

CARW - COAL ADDITION RATE- WEST (MW/YR)

CRRW - COAI RETIREMENT RATE- WEST (MW/YR)

CRRW.KL=CCAPW.K/40

CRRW - COAL RETIREMENT RATE- WEST (MW/YR)

CCAPW - COAL CAPACITY- WEST (MW)

CARW . KL=BOXC (NPCCW . K, 6, 360, 1522, 2521, 1100, $1100,400,0,0,0,0)$

CARW - COAL ADDITION RATE- WEST (MW/YR)

BOXC - FUNCTION THAT DELAYS VARIABLE (1) FOR A PERIOD OF VARIABLE (2)

NPCCW - NEW PLANNED COAL CAPACITY- WEST $(M W / Y R)$

PETCAPW . $K=P E T C A P W . J+D T *$ (PARW . JK-PRRW . JK) PETCAPW $=6.5 \mathrm{E} 3$

PETCAPW - PETROLEUM CAPACITY- WEST (MW)

DT - LENGTH OF SOLUTION INTERVAL (YRS)

PARW - PETROLEUM ADDITION RATEWEST (MW/YR)

PRRW - PETROLEUM RETIREMENT RATEWEST (MW/YR)

PRRW. $K L=P E T C A P W . K / 40$

PRRW - PETROLEUM RETIREMENT RATEWEST (MW/YR)

PETCAPW - PETROLEUM CAPACITY - WEST (MW)

PARW. $K L=B O X C(N P P C W . K, 5,240,239,300,60,379$, $0,0,0,0,0)$

PARW - PETROLEUM ADDITION RATEWEST (MW/YR)

BOXC - FUNCTION THAT DELAYS VARIABLE (1) FOR A PERIOD OF VARIABLE (2)

NPPCW - NEW ADDITIONAL PLANNED PETROLEUM CAPACITY- WEST (MW/YR)

NUCCAPW. $K=N U C C A P W . J+D T *$ (NARW . JK) NUCCAPW $1.6 \mathrm{E} 3$

NUCCAPW - NUCLEAR CAPACITY- WEST (MW)

DT - LENGTH OF SOLUTION INTERVAL (YRS)

NARW - NUCLEAR ADDITION RATE- WEST (MW/YR)

NARW . KL=BOXC (NPNCW . K, (NCT . K) , 765, 1767, 0 $3332,2199,0,2183,1066,916,0)$

NARW - NUCLEAR ADDITION RATE- WEST (MW/YR)

BOXC - FUNCTION THAT DELAYS VARIABLE (1) FOR A PERIOD OF VARIABLE (2)

NPNCW - NEW PLANNED NUCLEAR CAPACITYWEST (MW/YR)

NCT - NUCLEAR CONSTRUCTION TIME (YRS)

GEOCAPW. K=GEOCAPW.J+DT* (GARW.JK-GRRW .JK) GEOCAPW $=396$

GEOCAPW - GEOTHERMAL CAPACITY - WEST (MW)

DT - LENGTH OF SOLUTION INTERVAL (YRS)

GARW - GEOTHERMAL ADDITION RATEWEST (MW/YR)

GRRW - GEOTHERMAL RETIREMENT RATEWEST (MW/YR)

GRRW.KL=FIFGE ((GEOCAPW.K/GRT.K), 0,TIME.K, 2000) $177, \mathrm{R}$ GRRW - GEOTHERMAL RETIREMENT RATEWEST (MW/YR)

GEOCAPW - GEOTHERMAL CAPACITY- WEST (MW)

GRT - GEOTHERMAL RETIREMENT TIME

(YRS)

169, R

173, R

175, R
GARW . KL $=$ BOXC (NPGCW . $K, 2,124,106,106,0,0$, $0,0,0,0,0)$

GARW - GEOTHERMAL ADDITION RATEWEST (MW/YR)

BOXC - FUNCTION THAT DELAYS VARTABLE (1) FOR A PERIOD OF VARIABLE (2)

NPGCW - NEW PLANNED GEOTHERMAL CAPACITYWEST $(M W / Y R)$

SCAPW . K=SCAPW. J+DT* (SARW.JK-SRRW.JK)

170, R SCAPW $=0$

SCAPW - SOLAR CAPACITY- WEST (MW)

DT - LENGTH OF SOLUTION INTERVAL

SARW - SOLAR ADDITION RATE- WEST (MW)

$S R R W \cdot K L=S C A P W \cdot K / S R T$

SCAPW - SOLAR CAPACITY- WEST (MW)

SRT - SOLAR RETIREMENT TIME (YRS)

$171, \mathrm{~L}$

171.1, N

SARW . $K I=B O X C$ (NPSCW . $K, 8,0,0,0,0,0,0,0,0,0,0)$

SARW - SOLAR ADDITION RATE- WEST (MW)

BOXC - FUNCTION THAT DELAYS VARIABLE (1) FOR A PERIOD OF VARIABLE (2)

NPSCW - NEW PLANNED SOLAR CAPACITYWEST (MW/YR)

HCAPW . K=TABLE (THCAPW, TIME .K, 1970, 2010,5)*1E3

THCAPW $=29.7 / 35 / 42 / 47 / 52 / 55 / 58 / 61 / 64$ HCAPW - HYDRO CAPACITY - WEST (MW)

NGCAPW . K=TABLE (TNGCAPW, TIME . K, 1970, 2010,5)*1E3 TNGCAPW $=22 / 18.7 / 16.2 / 13 / 10.5 / 8.7 / 7 / 6 / 5$ NGCAPW - NATURAL GAS CAPACITY- WEST (MW)

PLCAPW $\cdot \mathrm{K}=\mathrm{PCCW} \cdot \mathrm{K}+\mathrm{PPCW} \cdot \mathrm{K}+\mathrm{PNCW} \cdot \mathrm{K}+\mathrm{PGCW} \cdot \mathrm{K}+\mathrm{PSCW} \cdot \mathrm{K}$ PLCAPW - PLANNED CAPACITY - WEST (MW)

PCCW - PLANNED COAL CAPACITY- WEST (MW)

PPCW - PLANNED PEIROLEUM CAPACITYWEST (MW)

PNCW - PLANNED NUCLEAR CAPACITY - WEST (MW)

$174, \mathrm{~L}$

$174.1, N$

PGCW - PLANNED GEOTHERMAL CAPACITYWEST (MW)

PSCW - PLANNED SOLAR CAPACITY- WEST (MW)

PCCW. K=PCCW.J+DT * (APCCW. JK-CARW. JK+DAPCCW1. JK) PCCW $=9.7 \mathrm{E} 3$

PCCW - PLANNED COAL CAPACITY-

DT - LENGTH OF SOLUTION INTERVAL

APCCW - ADDITIONAL PLANNED COAL CAPACITY-

CARW - COAL ADDITION RATE- WEST (MW/YR)

DAPCCW1 - DELAYED ADDITIONAL PLANNED COAI

APCCW . KL=IAPCCW. $K *(C C T / P T)$

APCCW - ADDITIONAL PLANNED COAI CAPACITY- WEST (MW/YR)

$176, \mathrm{~L}$ $176.1, \mathrm{~N}$

IAPCCW - INDICATED ADDITIONAL PLANNED

CCT - COAL CONSTRUCTION TIME (YRS)

PT - PROJECTION TIME (YRS)

$\mathrm{NPCCW} \cdot \mathrm{K}=\mathrm{IAPCCW} \cdot \mathrm{K} *(\mathrm{CCT} / \mathrm{PT})+\mathrm{DAPCCW} \cdot \mathrm{R}$

NPCCW - NEW PLANNED COAL CAPACITYWEST (MN/YR)

IAPCCW - INDICATED ADDITIONAL PLANNED

CCT - COAL CONSTRUCTION TIME (YRS)

P'T - PROJECTION TIME (YRS)

DAPCCW - DELAYED ADDITIONAL PLANIED COAL CAPACITY- WEST (MW/YR) (YRS)

WEST (MW) (YRS) WEST (MW/YR) CAPACITY - WEST (1) (MW/YR) COAL CAPACITY- WEST (MW/YR) COAL CAPACITY - WEST (MW/YR)

$178, \mathrm{R}$

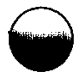

179, L

$179.1, \mathrm{~N}$

$180, R$

181, R

$182, \mathrm{~A}$

$182.1, T$

183, A

$183.1, \mathrm{~T}$

184. A

$185, \mathrm{~L}$ $185.1, \mathrm{~N}$

$186, \mathbf{R}$

187, A 
DAPCCW. K=BOXC (DAPCCWI. JK, (PT-CCT-2), 0, 0, 0,0, 188, A $0,0,0,0,0,0$ )

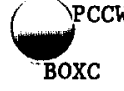

ADDITIONAL PLANNED

COAL CAPACITY- WEST (MW/YR)

- FUNCTION THAT DELAYS VARIABLE

(1) FOR A PERIOD OF VARIABLE (2)

DAPCCW1 - DEIAYYED ADDITIONAL PLANNED COAL

CAPACITY- WEST (1) (MW/YR)

PT - PROJECTION TIME (YRS)

CCT - COAL CONSTRUCTION TIME (YRS)

DAPCCW1. $K L=I A P C C W \cdot K *(1-(C C T / P T))$

DAPCCW1 $=0$

DAPCCW1 - DELAYYED ADDITIONAL PLANNED COAL CAPACITY- WEST (1) (MW/YR)

IAPCCW - INDICATED ADDITIONAL PLANNED

COAL CAPACITY- WEST (MW/YR)

CCT - COAL CONSTRUCTION TIME (YRS)

PT - PROJECTION TIME (YRS)

IAPCCW. $K=$ MAX $(0,(((C D F . K / T D F W . K) * T Y C G W . K)$ +CAFGSFW.K))

IAPCCW - INDICATED ADDITIONAL PLANNED COAL CAPACITY- WEST (MW/YR)

CDF - COAL DECISION FACTOR (DIMENSIONLESS)

TDFW - TOTAL DEMAND FACTOR- WEST (DIMENSIONLESS)

TYCGW - TEN YEAR CAPACITY GAPWEST (MW/YR)

CAFGSFW - COAL ADJUSTTENT FOR GEOTHERMAL SHORTFALL- WEST (MW/YR)

CAFGSFW. $K=A F G S F W \cdot K *(C D F \cdot K /(C D F \cdot K+P D F \cdot K$ +NDF.K))

CAFGSFW - COAL ADJUSTMENT FOR GEOTHERMAL SHORTFALL- WEST (MW/YR)

AFGSFW - ADJUSTMENT FOR GEOTHERMAL SHORTFALL- WEST (MW/YR)

CDF - COAL DECISION FACTOR (DIMENSIONLESS)

PDF - PETROLEUM DECISION FACTOR (DIMENSIONLESS)

NDF - NUCLEAR DECISION FACTOR (DIMENSIONLESS)

PPCW. K=PPCW.J+DT* (APPCW. JK-PARW. JK+CAPPCW1. JK) 192, L PPCW=. 4E3

PPCW - PLANNED PETROLEUM CAPACITYWEST (MW)

DT - LENGTH OF SOLUTION INTERVAL (YRS)

APPCW - ADDITIONAL PLANNED PETROLEUM CAPACITY- WEST (MW/YR)

PARW - PETROLEUM ADDITION RATE- WEST (MW/YR)

DAPPCW1 - DELAYED ADDITIONAL PLANNED PETROLEUM CAPACITY- WEST (1) (MW/YR)

APPCW. $K L=($ IAPPCW. $K *(P C T / P T))$

APPCW - ADDITIONAL PLANNED PÉTROLEUM CAPACITY- WEST (MW/YR)

IAPPCE - INDICATED ADDITIONAL PLANNED PETROLEUM CAPACITY - WEST (MW/YR)

PCT - PETROLEUM CONSTRUCTION TIME (YRS)

PT - PROJECTION TIME (YRS)

NPPCW. $K=($ IAPPCW. $K *(P C T / P T))+D A P P C W: K$

NPPCW - NEW ADDITIONAL PLANNED PETROLEUM CAPACITY- WEST (MW/YR)

IAPPCW - INDICATED ADDITIONAL PLANNED PETROLEUM CAPACITY- WEST (MW/YR)

PCT - PROJECTION TIME (YRS)

DAPPCW - DELAYED ADDITIONAL PLANNED PETROLEUM CAPACITY - WEST (MW/YR)

$189, \mathrm{R}$

$193, R$

194, A
DAPPCW . K $=$ BOXC (DAPPCW1. JK, (PT-PCT-2)

$$
0,0,0,0,0,0,0,0,0,0)
$$

DAPPCW - DELAYED ADDITTONAL PLANNED PETROLEUM CAPACITY- WEST (MW/YR)

BOXC - FUNCTION THAT DELAYS VARIABLE

(1) FOR A PERIOD OF VARIABLE (2)

DAPPCW1 - DELAYED ADDITIONAL PLANNED

PETROLEUM CAPACITY - WEST ( 1 ) (MW/YR)

PT - PROJECTION TIME (YRS)

189.1 , N

PCT - PETROLEUM CONSTRUCTION TIME (YRS)

DAPPCW1 . KL $=$ IAPPCW . $K^{*}(1-($ PCT $/ P T))$

DAPPCW1 $=0$

DAPPCW1 - DELAYED ADDITIONAL PLANNED PETROLEUM CAPACITY - WEST (1) $(M W / Y R)$

IAPPCW - INDICATED ADDITIONAL PLANNED PETROLEUM CAPACITY- WEST (MW/YR)

190, A PCT - PETROLEUM CONSTRUCTION TIME (YRS)

PT - PROJECTION TIME (YRS)

IAPPCW . $K=$ MAX $(0,((($ PDF . K $/$ TDFW . K $) *$ TYCGW . K $)$ +PAFGSFW.K))

IAPPCW - INDICATED ADDITIONAL PLANNED PETROLEUM CAPACITY- WEST (MW/YR)

PDF - PETROLEUM DECISION FACTOR (DIMENSIONLESS)

TDFW - TOTAL DEMAND FACTOR- WEST (DIMENSIONLESS)

TYCGW - TEN YEAR CAPACITY GAP- WEST (MW/YR)

PAFGSFW. $\mathrm{K}=\mathrm{AFGSFW}, \mathrm{K} *(\mathrm{PDF} \cdot \mathrm{K} /(\mathrm{CDF} \cdot \mathrm{K}+\mathrm{PDF} \cdot \mathrm{K}$ HNF.K))

AFGSFW - ADJUSTMENT FOR GEOTHERMAL SHORTFALL- WEST (MW/YR)

PDF - PETROLEUM DECISION FACTOR (DIMENSIONLESS)

CDF - COAL DECISION FACTOR (DIMENSIONLESS)

NDF - NUCLEAR DECISION FACTOR (DIMENSIONLESS)

PNCW. K=PNCW . J+DT* (APNCW . JK-NARW. JK+DAPNCW1. JR) 199, L PNCW $=15.7 \mathrm{E} 3$

PNCW - PLANNED NUCLEAR CAPACITYWEST (MW)

DT - LENGTH OF SOLUTION INTERVAL (YRS)

APNCW - ADDITIONAL PIANNED NUCLEAR CAPACITY- WEST (MW/YR)

NARW - NUCLEAR ADDITION RATE- WEST (MW/YR)

DAPNCW1 - DELAYED ADDITIONAL PLANNED NUCLEAR CAPACITY- WEST (1) (MW/YR)

APNCW $. K L=I A P N C W \cdot K *(N C T \cdot K / P T)$

APNCW - ADDITIONAL PLANNED NUCLEAR CAPACITY- WEST (MW/YR)

IAPNCW - INDICATED ADDITIONAL PLANNED NUCLEAR CAPACITY- WEST (MW/YR)

NCT - NUCLRAR CONSTRUCTION TIME (YRS)

PT - PROJECTION TIME (YRS)

NPNCW. $K=$ IAPNCW.$K$ * $(N C T \cdot K / P T)+D A P N C W . K$

NPNCW - NEW PLANNED NUCLEAR CAPACITYWEST (MW/YR)

IAPNCW - INDICATED ADDITIONAL PLANNED NUCLEAR CAPACITY - WEST (MW/YR)

NCT - NUCLEAR CONSTRUCTION TIME (YRS)

PT - PROJECTION TIME (YRS)

DAPNCW - DEIAYED ADDITIONAL PLANNED NUCLRAR CAPACITY - WEST (MW/YR)
196, R

$196.1, \mathrm{~N}$

197, A

198, A

199.1 , N

$200, \mathrm{R}$

201, A 


$$
\begin{array}{cl}
\text { DAPGCW1 - } & \text { DELAYED ADDITIONAL PLANNED } \\
& \text { GEOTHERMAL CAPACITY- WEST } \\
& \text { (1) (MW/YR) } \\
\text { (1) } & \text { INDICATED ADDITIONAL PLANNED } \\
& \text { GEOTHERMAL CAPACITY- WEST (1) } \\
& \text { (MW/YR) } \\
\text { GCT } & \text { - } \\
& \text { (YEOTHERMAL CONSTRUCTION TIME } \\
\text { PT } & \text { - PROJECTION TIME (YRS) } \\
\text { RAM } & - \\
& \text { RESOURCE AVAILABILITY MULTI- } \\
& \text { PLIER (DIMENSIONLESS) }
\end{array}
$$

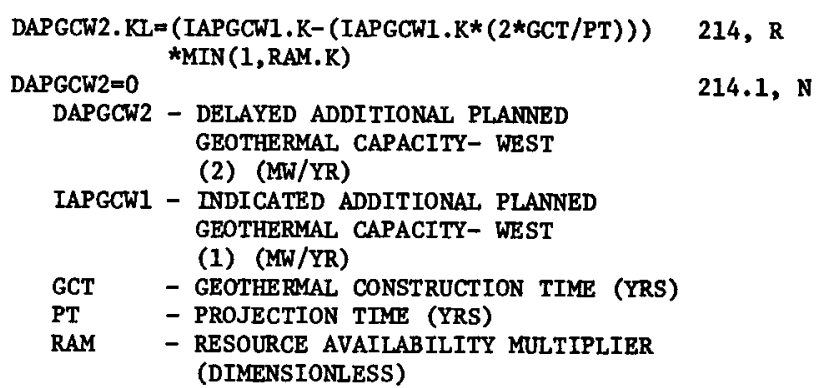

GRAFCAW.K=MAX (0, ((PRAW.K-GEOCAPW.K- (PGCW.K/ GCT) - (PICE .K/GCT))/1))

GRAFCAW - GEOTHERMAL RESOURCES AVAILABLE FOR CAPACITY ADDITION- WEST (MW/YR)

PRAW - PROJECTED RESOURCES AVAILABLE (MW)

GEOCAPW - GEOTHERMAL CAPACITY - WEST (MW)

PGCW - PLANNED GEOTHERMAL CAPACITYWEST (MW)

GCT - GEOTHERMAL CONSTRUCTION TIME (YRS)

PICE - PLANNED IMPORT CAPACITY- EAST (MN)

GRACAW6. $K=$ MAX $(0,($ (PRAW6. K-GEOCAPW. K- (PGCW. K 216, A *2/GCT) $-(P I C E . K * 2 / G C T)) / 1)$ )

GRACAW6 - GEOTHERMAL RESOURCES AVAILABLE FOR CAP ADDITIONS IN 6 YEARS (MW)

PRAW6 - PROJECTED RESOURCES AVAILABLE IN 6 YEARS (MN)

GEOCAPW - GEOTHERMAL CAPACITY- WEST (MW)

PGCW - PLANNED GEOTHERMAL CAPACITYWEST (MW)

GCT - GEOTHERMAL CONSTRUCTION TIME (YRS)

PICE - PLANNED IMPORT CAPACITY - EAST (MW)

GRACAW9. $\mathrm{K}=\mathrm{MAX}(0,($ (PRAW9. K-GEOCAPW. $\mathrm{K}-\mathrm{PGCW} . \mathrm{K}-\quad 217, \mathrm{~A}$ PICE.K)/1))

GRACAW9 - GEOTHERMAL RESOURCES AVAILABLE FOR CAP ADDITIONS IN 9 YBARS (MW)

PRAW9 - PROJECTED RESOURCES AVAILABLE IN 9 YEARS (YRS)

GEOCAPW - GEOTHERMAL CAPACITY- WEST (MW)

PGCW - PLANNED GEOTHERMAL CAPACITYWEST (MW)

PICE - PLANNED IMPORT CAPACITY- EAST (MW)

PRAW. K $=$ TABLE (TRAW, TPGCT . K, 1970, 2015, 15)

PRAW - PROJECTED RESOURCES AVAILABLE (MW)

TPGCT - TIME PLUS GEOTHERMAL CONSTRUCTION PERIOD (YRS)

PRAW6. K=TABLE (TRAW, TP2GCT . R, 1970, 2015, 15)

PRAW6 - PROJECTED RESOURCES AVAILABLE IN 6 YEARS (MW)

TP2GCT - TIME PLUS TWO GEOTHERMAL CONSTRUCTION PERIODS (YRS)

PRAW9. $K=$ TABLE (TRAW, TP3GCT.K, 1970, 2015, 15) PRAW9 - PROJECTED RESOURCES AVAILABLE IN 9 YEARS (YRS)

218, A

$220, A$
TP3GCT - TIME PLUS THREE GEOTHERMAL CONSTRUCTION PERIODS (YRS)

IAPGCW1.K-MAX (.01, ((GDFW.K/TDFW.K)*TYCGW.K)) 221, A IAPGCW1 - INDICATED ADDITIONAL PLANNED GEOTHERMAL CAPACITY- WEST (1) (MW/YR)

GDFW - GEOTHERMAL DECISION FACTORWEST (DIMENSIONLESS)

TDFW - TOTAL DEMAND FACTOR- WEST (DIMENS IONLESS)

TYCGW - TEN YEAR CAPACITY GAP - WEST (MW/YR)

DAPICE . R=BOXC (NPICE . K, (ICT-GCT-1) , 0, 0, 0,0 $0,0,0,0,0,0$ )

DAPICE - DELAYED ADDITIONAL PLANNED IMPORT CAPACITY - EAST (MW/YR)

BOXC - FUNCTION THAT DELAYS VARIABLE (1) FOR A PERIOD OF VARIABLE (2)

NPICE - NEW PLANNED ADDITIONAL IMPORT CAPACITY- EAST (MW/YR)

ICT - IMPORT CONSTRUCTION TIME

GCT - GEOTHERMAL CONSTRUCTION TIME (YRS)

GEOSFW.KEINPGCW.K-GRAFCAW.K

GEOSFW - GEOTHERMAL SHORTFALL- WEST (MW/YR)

INPGCW - INDICATED NEW PLANNED GEOTHERMAL CAPACITY- WEST (MW/YR)

GRAPCAW - GEOTHERMAL RESOURCES AVAILABLE FOR CAPACITY ADDITION- WEST (MW/YR)

(MW)
GEOSFWL. $\mathrm{KL}=\mathrm{GEOSFW} \cdot \mathrm{K}$

GEOSFWL $=0$

GEOSFWL - GEOTHERMAL SHORTFALL- WEST LAST TIME PERIOD (MW/YR)

GEOSFW - GEOTHERMAL SHORTFALL- WEST (MW/YR)

AFGSFW. K=MAX (GEOSFW.K,0)

AFGSFW - ADJUSTMENT FOR GEOTHERMAI SHORTFALL- WEST (MW/YR)

GEOSFW - GEOTHERMAL SHORTFALL- WEST (MW/YR)

PSCW.K=PSCW.J+DT* (APSCW.JK-SARW.JK+DAPSCW1.JK) 226, I PSCH $=0$

PSCW - PLANNED SOLAR CAPACITY- WEST $226.1, \mathrm{~N}$

DT - LENGTH OF SOLUTION INTERVAL (YRS)

APSCW - ADDITIONAL PLANNED SOLAR CAPACITY- WEST (MW)

SARW - SOLAR ADDITION RATE- WEST (MW)

DAPSCW1 - DELAYED ADDITIONAL PLANNED SOLAR CAPACITY- WEST (MW/YR)

APSCW.KL $=($ IAPSCW. $K *(\mathrm{SCT} / \mathrm{PT}))$

APSCW - ADDITIONAL PLANNED SOLAR . CAPACITY - WEST (MW)

IAPSCW - INDICATED ADDITIONAL PLANNED SOLAR CAPACITY- WEST (MW/YR)

SCT - SOLAR CONSTRUCTION TIME (YRS)

PT - PROJECTION TIME (YRS)

NPSCW. $\mathrm{K}=($ IAPSCW. $\mathrm{K} *(\mathrm{SCT} / \mathrm{PT}))+\mathrm{DAPSCW} \cdot \mathrm{K}$ NPSCW - NEW PLANNED SOLAR CAPACITYWEST (MN/YR)

IAPSCW - INDICATED ADDITIONAL PLANNED SOLAR CAPACITY - WEST (MW/YR)

SCT - SOLAR CONSTRUCTION TIME (YRS)

PT - PROJECTION TIME (YRS)

DAPSCW - DELAYED ADDITIONAL PLANNED SOLAR CAPACITY- WEST (MW/YR)

IAPSCW. $\mathrm{K}=\mathrm{MAX}(0,(($ SDFW. K/TDFW.K $) * T Y C G W . K))$

229, A

224, R $224.1, N$

225, A

227, $\mathrm{R}$

228, A 


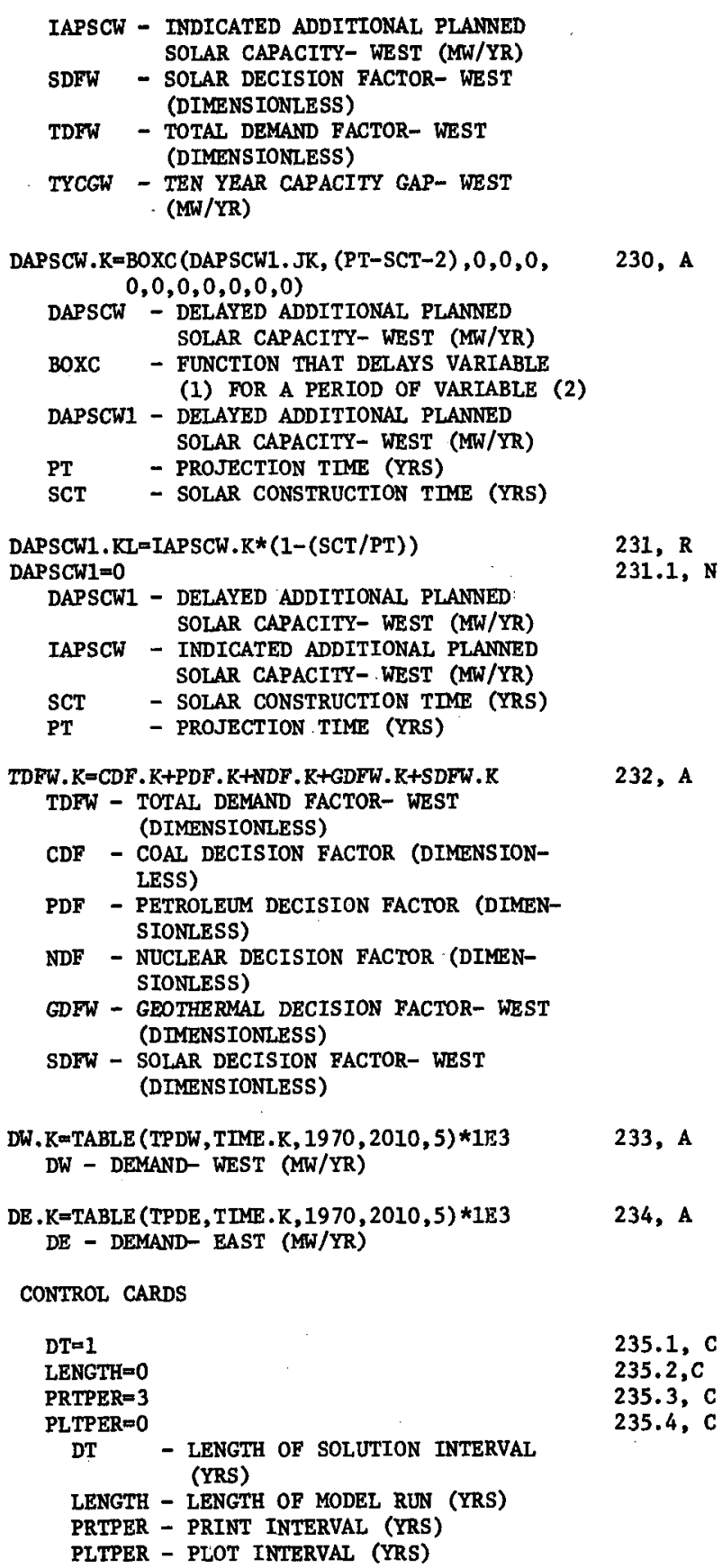

CONTROL CARDS

DTel

LENGTH $=0$

PRTPER $=3$

PLTPER $=0$

DT

- LENGTH OF SOLUTION INTERVAL

230, A

231, R

231.1, N

232, A

233, A

234, A

$235.1, \mathrm{C}$

$235.2, C$

$235.3, \mathrm{C}$

$235.4, \mathrm{C}$

LENGTH - LENGTH OF MODEL RUN (YRS)

PRTPER - PRINT INTERVAL (YRS)

PLTPER - PLOT INTERVAL (YRS) 
$T$ TNC T $=10 / 6$

GEOCAPE .K=GEDCAPE .J+DT*(GARE.JK-GRRE.JK)

GE OCAPE $=0$

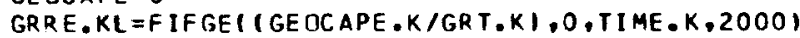

GRT . K = TABLE (TGRR, TIME,K, 1970,2000,15)

TGRR $=40 / 50 / 50$

GARE.KL $=B O \times C(N P G C E, K, 2,0,0,0,0,0,0,0,0,0,0)$

$G C T=3$

I MPC APE . K = I MPCAPE •J+DT*(IARE .JK)

IMPCAPE $=0$

I ARE, KL $=B O X C$ (NP [CE, $K, 6,0,0,0,0,0,0,0,0,0,0)$

ICT $=6$

SCAPE . $K=$ SCAPE . J+DT* (SARE .JK-SRRE . JK)

SC APE $=0$

SRRE,$K L=S C A P E \cdot K / S R T$

$S R T=40$

SARE,$K L=B O X C$ (NPSCE, $K, 8,0,0,0,0,0,0,0,0,0,0)$

$S C T=8$

HCAPE, K=T ABLE(THCAPE, TIME,K, 1970,2010,5)*1E3

THCAPE $=21.9 / 20.2 / 23 / 25 / 27 / 30 / 32 / 34 / 36$

NGCAPE,K = TABLE (TNGCAPE, TIME,K, $1970,2010,5) * 1 E 3$

TNGCAPE $=55 / 42.7 / 37.1 / 30 / 24.4 / 20.4 / 16.2 / 14 / 12$

$P L C A P E . K=P C C E \cdot K+P P C E . K+P N C E \cdot K+P G C E \cdot K+P I C E \cdot K+P S C E \cdot K$

$P C C E . K=P C C E . J+D T *(A P C C E . J K-C A R E, J K+D A P C C E L$. JK)

$P C C E=49.7 E 3$

$A P C C E \cdot K L=I A P C C E \cdot K *(C C T / P T)$

NPCCF . $K=I$ APCCE $K *(C C T / P T)+D A P C C E, K$

DAPCCE . K=8OXC (DAPCCE I. JK, $(P T-C C T-2), 0,0,0,0,0,0,0,0,0,0)$

DAPCCEI.KL = IAPCCE.K $*(1-\{C C T / P T) \mid$

DAPCCE I $=0$

IAPCCE,$K=M A X(0,(($ (CDF $, K / T D F E, K) * T Y C G E, K)+(C A F G S F E \cdot K))$

CAFGSFE.K $=A F G S F E \cdot K *(C D F \cdot K)(C D F \cdot K+P D F \cdot K+N D F \cdot K))$

$C D F, K=R F * C R \cdot K+C I F * C C I, K+E C F * C E C \cdot K+C E F * C C E, K+F A F * C F A \cdot K+C D L F * C D T$

$R F=.5$

$C I F=1$

$E C F=.6$

$C E F=1$

$F A F=2$

CDLF $=.1$

CR. $K=$ T ABLEI TCR, TIME $, K, 1970,2000,151$

$T C R=.8 / .7 / .7$

CCI $, K=I C I C, K / C C I C, K$

CCIC.K=TABLE(TCCIC, IT IME .K+101,1970,2010,5)

TCCIC $=240 / 359 / 550 / 615 / 662 / 713 / 768 / 828 / 892$

CEC . K $=$ TABLE(TCEC, TIME . K, $1970,2000,30)$

TCEC $=.5 / .8$

$C C E \cdot K=A G C E \cdot K / A C C E, K$

ACCE .K $=$ TABLE(TACCE, (T IME .K+10), 1970,2010,5)

$T A C C E=11.7 / 18 / 21 / 23.3 / 25 \cdot 8 / 28.7 / 31.8 / 35.2 / 39.1$

CFA, K = TABLE (TCFA, TIME $, K, 1970,2000,15)$

TCFA $=.95 / .95 / .95$

$\mathrm{CDT}=.5$

PPCE.K=PPCE ,J+DT*(APPCE . JK-PARE . JK+DAPPCE 1 .JK)

$P P C E=33.5 E 3$

$A P P C E, K L=(I A P P C E, K *(P C T / P T))$

NPPCE, $K=$ (I APPCE, $K *(P C T / P T))+D A P P C E, K$

DAPPCE $. K=B O X C I D A P P C E L$.JK, $(P T-P C T-2), 0,0,0,0,0,0,0,0,0,0)$

DAPPCE $1 . K L=I A P P C E, K *(1-(P C T / P T))$

DAPPCEL $=0$

I AP PCE . K =MAX $10,((P D F, K / T D F E, K) * T Y C G E, K)+(P A F G S F E, K))$

PAFGSFE,$K=A F G S F E \cdot K *(P D F \cdot K /(C D F \cdot K+P D F \cdot K+N D F \cdot K))$

$P D F, K=(R F * P R, K+C I F * P C I, K+E C F * P E C \cdot K+C E F * P C E, K * F A F * P F A, K+C D L F * P D T) *$

PFAM.K

$P R, K=T A B L E(T P R, T I M E, K, 1970,2000,15)$

$T P R=.9 / .9 / .9$

$P C I \cdot K=I C I C \cdot K / P C I C \cdot K$

PCIC.K=TABL E (TPCIC, ITIME,K+10),1970,2010,5)

TPCIC $=220 / 260 / 299 / 332 / 358 / 386 / 416 / 447 / 482$

PEC.K $=$ TABLE $(T P E C, T I M E . K, 1970,2000,30)$

$T P E C=.7 / .85$

$P C E \cdot K=A G C E \cdot K / A P C E \cdot K$

APCE,$K=$ TABLE $(T A P C E,(T I M E, K+10), 1970,2010,5)$

TAPCE $=21 / 22.7 / 26.6 / 29.8 / 33.4 / 37.5 / 42.0 / 47.1 / 52.8$

PFA, $K=$ TABLE (TPFA, TIME,K, $1970,2000,15)$

TPFA $=.75 / .4 / .2$

PFAM. K= TABHL ITPFAM,PFA.K..5, .6, . 11

TPFAM $=0 / 1$

10301

10310

10311

10320

10321

10330

10340

10341

10350

10360

10370

10380

10381

10390

10400

10410

10411

10412

10413

10414

10415

10416

10420

10421

10430

10440

10441

10450

10451

10460

10470

10471

10480

10481

10482

10490

10491

10500

10510

10520

10530

10531

10540

10550

10560

10561

10570

10571

10580

10590

10591

10600

10601

10610

10620

10621

10630

10631

10640

10641 


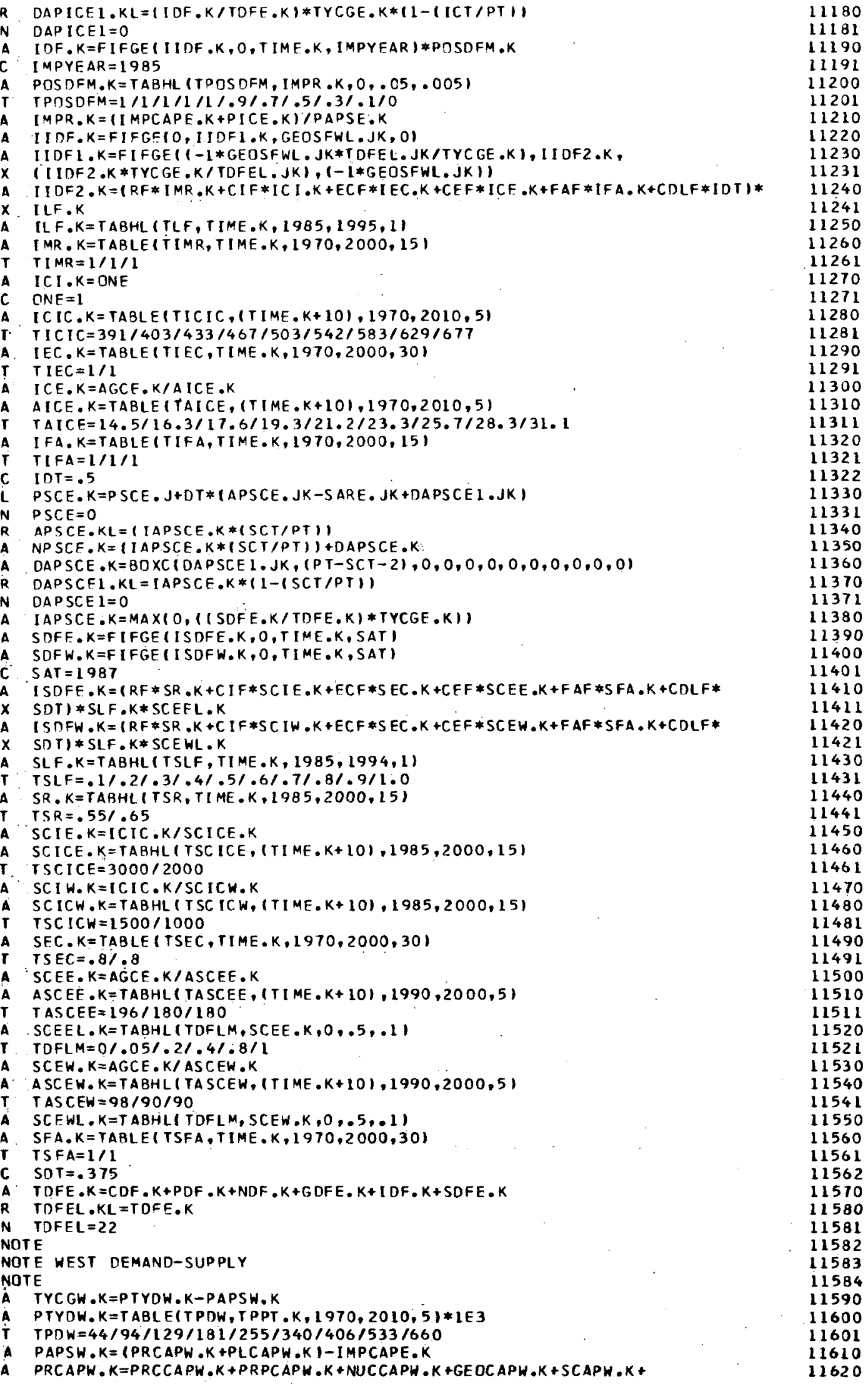

11220

11230

11231

11240

11241

11250

11260

11261

11270

11271

11280

11281

11290

11291

11300

11310

11311

11320

11321

11322

11330

11331

11340

11350

11360

11370

11371

11380

11390

11400

11401

11410

11411

11420

11421

11430

11431

11440

11441

11450

11460

11461

11470

11480

11481

11490

11491

11500

11510

11511

11520

11521

11530

11540

11541

11550

11560

11561

11562

11570

11580

11581

11582

11583

i1 1584

11590

11600

11601

11610

11620 
$X$ PRHCAPW. $K+P R N G C P W \cdot K$
$A \quad P R C C A P W \cdot K=C C A P W \cdot K * 11$

$P R C C A P W . K=C C A P W, K *(1-(P T * .025)$

PRPCAPW.K=PE TCAPW.K* $(1-(P T * .025))$

1621

PRHCAPW.K = TABLE ITHCAPH, TPPT,K, 1970

NGC APW,K

CCAPH.K =CCAPW.J+DT*(CARH.JK-CRRW.JK)

CCAPW $=13.2 E 3$

R CRRW.KL $=C C A P W \cdot K / 40$

R CARW.KL $=B O X C$ (NPCCW.K, $6,360,1522,252 \mathrm{~L}, 1100,1100,400,0,0,0,0)$

PETCAPW. K =PE TCAPH.J+DT $*$ (PARW. JK-PRRW. JK)

PETCAPW=6.5E3

PRRW.KL=PETCAPW.K $/ 40$

PARW.KL $=B$ OXC (NPPCW.K, 5,240,239,300,60,379,0,0,0,0,0)

NUCCAPW. K=NUCCAPW.J +OT*INARW.JK I

NUCCAPW $=1.6 E 3$

NARW, KL $=$ BOXC (NPNCW.K, (NCT,K), 765,1767,0,3332,2199,0,2183,1066,916, 01

GEOCAPW.K =GEOCAPW.J+DT*\{GARW.JK-GRRW.JK\})

GEOCAPW $=396$

R GRRW.KL=FIFGE ( (GEOCAPW,K/GRT,K), 0, TIME,K, 2000)

R GARW.KL =BOXC (NPGCW.K, 2,124,106,106,0,0,0,0,0,0,0)

$S C A P W \cdot K=S C A P W . J+D T *(S A R W . J K-S R R W \cdot J K)$

SCAPW $=0$

$R \quad S R R W \cdot K L=S C A P W \cdot K / S R T$

SARW. KL $=$ BOXC (NPSCW.K, 8,0,0,0,0,0,0,0,0,0,0)

A HCAPW.K=TABLEITHCAPW,TIME,K, $1970,2010,5) * 1 E 3$

THCAPW=29.7/35/42/47/52/55/58/61/64

NGCAPW.K=TABLE (TNGCAPW,TIME .K.1970,2010,5)*1E3

TNGCAPH $=22 / 18.7 / 16.2 / 13 / 10.5 / 8.7 / 7 / 6 / 5$

$P L C A P W \cdot K=P C C W \cdot K+P P C W \cdot K+P N C W \cdot K+P G C H \cdot K+P S C W \cdot K$

$P C C W . K=P C C W . J+D T *(A P C C W . J K-C A R W . J K+D A P C C W 1 . J K)$

$P C C W=9 \cdot 7 F 3$

$\triangle P C C W \cdot K L=I A P C C W \cdot K *(C C T / P T)$

NPCCW.K =IAPCCW.K*ICCT/PT)+DAPCCW.K

A DAPCCW.K = BOXC(DAPCCWL.JK, $(P T-C C T-2), 0,0,0,0,0,0,0,0,0,0)$

$R$ DAPCCWI.KL = IAPCCW.K* $(1-(C C T / P T))$

DAPCCWI $=0$

A IAPCCW.K=MAX $(0,((1, C D F, K / T D F W \cdot K) * T Y C G W \cdot K)+C A F G S F W \cdot K))$

A CAFGSFW.K $=A F G S F W . K *(C D F, K /(C D F, K+P D F, K+N D F \cdot K))$

L PPCH.K=PPCH.J+DT* (APPCW.JK-PARW.JK+DAPPCW I.JK)

$N \quad P P C H=.4 E 3$

R APPCW:KL = (IAPPCW.K*(PCT/PT)

A NPPCW.K = (IAPPCW.K *(PCT/PT ) )+DAPPCW.K

$A$ DAPPCH.K=BOXCIDAPPCWI.JK, $(P T-P C T-2), 0,0,0,0,0,0,0,0,0,0)$

DAPPCW $1 \cdot K L=[A P P C H \cdot K *(1-(P C T / P T))$

DAPPCWI $=0$

IAPPCW. K=MAX(O, ( ( (PDF. K/TOFW.K)*TYCGH.K)+PAFGSFW.K) )

PAFGSFW.K $=A F G S F H \cdot K *(P O F, K /(C D F, K+P D F, K+N O F \cdot K))$

PNCW.K=PNCW.J+DT* (APNCW.JK-NARW.JK+DA PNCWI -JK)

$P N C W=15.7 E 3$

$A P N C H, K L=I A P N C W \cdot K *(N C T, K / P T I$

NPNCH.K=IAPNCW.K* (NCT,K/PT)+DAPNCW,K

DAPNCW.K $=80 \times C$ (DAPNCW1.JK, $(P T-N C T \cdot K-1), 0,0,0,0,0,0,0,0,0,0)$

DAPNCHI.KL $=I A P N C W, K *(1-I N C T, K / P T)$

DAPNCHI=0

IAPNCW.K=MA $\times(0,(($ (NDF, $K /$ TDFW.K $) * T Y C G H \cdot K)+N A F G S F W \cdot K))$

NAFGSFH. K=AF GSFW. $K *(N D F, K /(C D F, K+P D F, K+N D F \cdot K)$

PGCH.K=PGCW.J+DT* (APGCW.JK-GARW. JK+DAPGCW1 . JK+DAP GCW2 . JK)

$P G C H=1831$

APGCW.KL $=I A P G C H \cdot K *(M I N(1$, (GRAFCAH.K/INPGCW.K $) 1)$

$A P G C W=110$

A IAPGCW,K=(I $\triangle P G C W 1, K *(G C T / P T)$

A NPGCW.K=(IAPGCH.K*IMIN(1,RAM,KI) $+D A P G C H, K+D A P I C E, K$

A RAM.K=MINI(GRAFCAH,K/INPGCH,K), (MINI(GRACAH6,K/(IAPGCHL.K\$2/3))

11630

11640

11650

11660

11670

11671

11680

11681

11690

11700

11710

11711

11720

11730

11740

11741

11750

11751

11760

11761

11770

11780

11790

11791

11800

11810

11820

11821

11830

11831

11840

11850

11851

11860

11870

11880

11890

11891

11900

11910

11920

11921

11930

11940

11950

11960

11961

11970

11980

11990

11991

12000

12010

12020

12030

12031

12040

12050

12060

12061

12070

12071

12080

12090

12100

12101

12110

INPGCW.K=MAX $(.01,($ I IAPGCHI.K*(GCT/PT) )+DAPICE $. K+D A P G C W \cdot K))$

12120

12121

12130

12131

12140

12141

12150

GRAFCAW. $K=$ MAX $(0,($ (PRAW.K-GEOCAPH $. K-(P G C H \cdot K / G C T)-(P I C E, K / G C T) / 11))$

12160 
$x \quad 1$

A GRACAW9.K=MAX (O, I (PRAW9.K-GEOCAPW.K-PGCH.K-PICE.K)/1)

12161

PRAH.K=TABLEITRAH,TPGCT,K,1970,2015,15 I

A PRAH6.K=TABLE(TRAW,TP 2GCT.K, 2970,2015,15)

A PRAW9,K=TABLE(TRAH,TP3GCT,K, $1970,2015,151$

A IAPGCWI $K=M A X(.01,(1$ GDFW.K/TOFW.K) $\$$ TYCGH.K) )

DAPICE,K $=$ BOXC (NP ICE .K, I ICT-GCT- $11,0,0,0,0,0,0,0,0,0,0)$

GE OSFW.K=I NPGCW.K-GRAFCAH,K

R GEOSFWL $. K L=G E O S F H . K$

N GEOSFWL $=0$

A AFGSFW.K $=$ MAXIGEOSFW.K, OI

$L \quad P S C H . K=P S C W . J+D T *(A P S C W . J K-S A R H . J K+D A P S C H 1 . J K)$

PSCW $=0$

R APSCH.KL $=(I A P S C H, K *(S C T / P T))$

A NPSCW.K=IIAPSCH.K *ISCT/PTII+DAPSCW.K

A IAPSCH.K=MAX(O, (ISDFH.K/TOFH.K) \#TYCGH.K)

A DAPSCW.K=BOXC (DAPSCW $1 . J K,(P T-S C T-2), 0,0,0,0,0,0,0,0,0,0)$

R DAPSCWI.KL=IAPSCH.K $\#(1-(S C T / P T))$

N DAPSCW1 $1=0$

A T TFW. $K=C D F, K+P D F \cdot K+N D F, K+G D F W \cdot K+S D F W \cdot K$

NOTE MACRO

NOTE

A DW.K=TABLE(TPDW, TIME,K, 1970,2010,51*1E 3

A DE.KETABLE(TPOE, TIME, K, 1970,2010,5)*1E3

NOTE

NOTE CONTROL CARDS

NOTE

PRINT IICCAPE,CCAPH/2IPE TCAPE,PETCAPW/3INUCCAPE ,NUCCAPH/

PRINT \&) GEOCAPE, GEOCAPH/ 5 ISCAPE, SCAPW/6I HCAP E, HCAPW/

PRINT 7 INGC APE . NGC APW/BIIMPCAPE *

PLOT CCAPW $=C, P E T C A P W=P, N U C C A P W=N, G E O C A P W=G, S C A P W=S, H C A P W=H, N G C A P W=M$

$\times(0,200 E 3)$

PLOT CCAPE $=C$,PETCAPE $=P$, NUCC APE $=N, G E O C A P E=G$, SCAPE $=S$, HCAPE $=H, N G C A P E=M$,

$X$ IMPCAPE $=I(0,800 E 3)$

C $\mathrm{DT}=1$

C LENGTHEO

C PRTPER=3

C PLTPER $=0$

RUN BASE RUN

12310

12311

12320

12321

12322

12330

12340

12341

12342

12343

12344

12345

12346

12347

12348

12349

12350

12351

12352

12353

12354

12360 


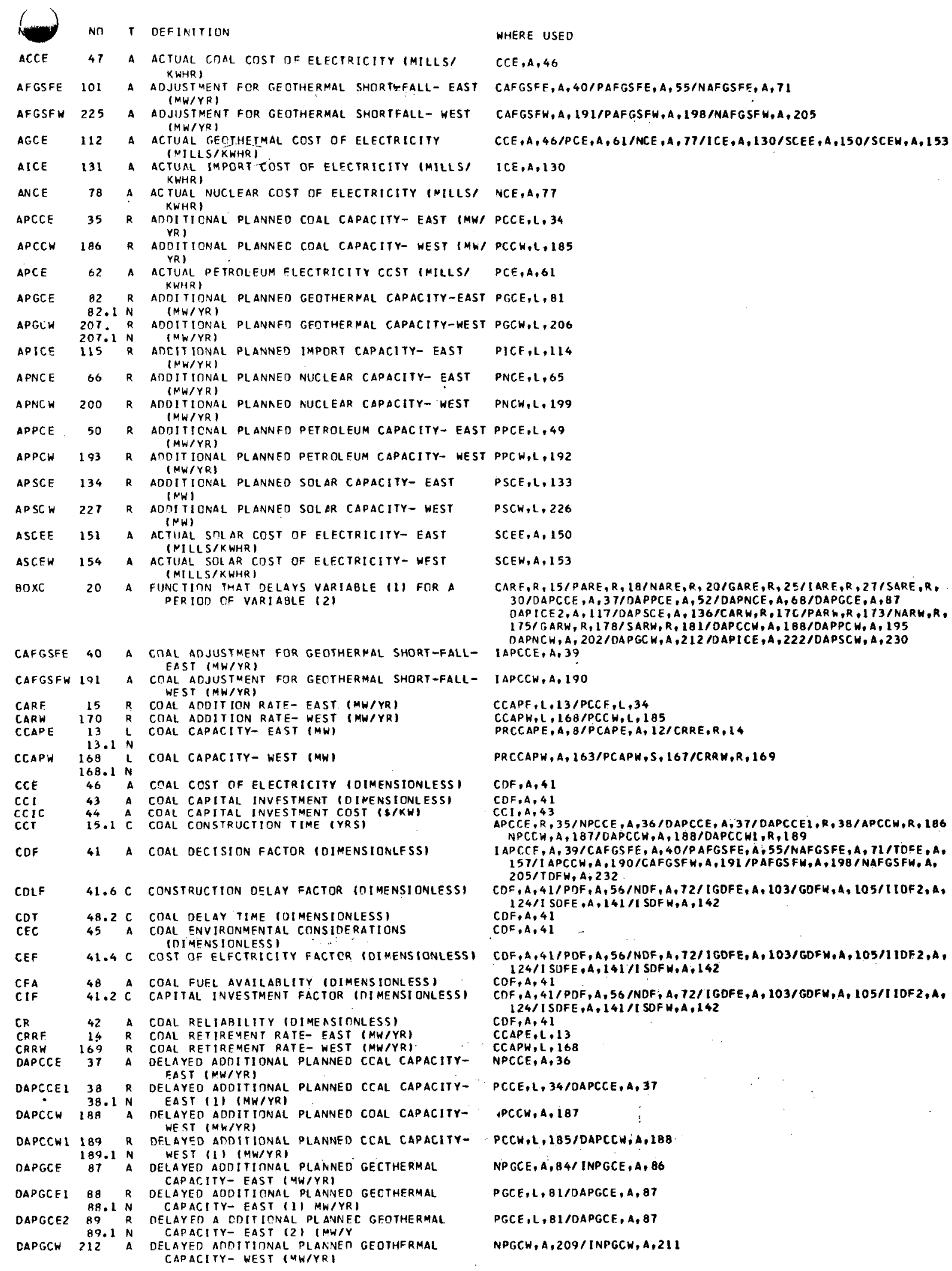




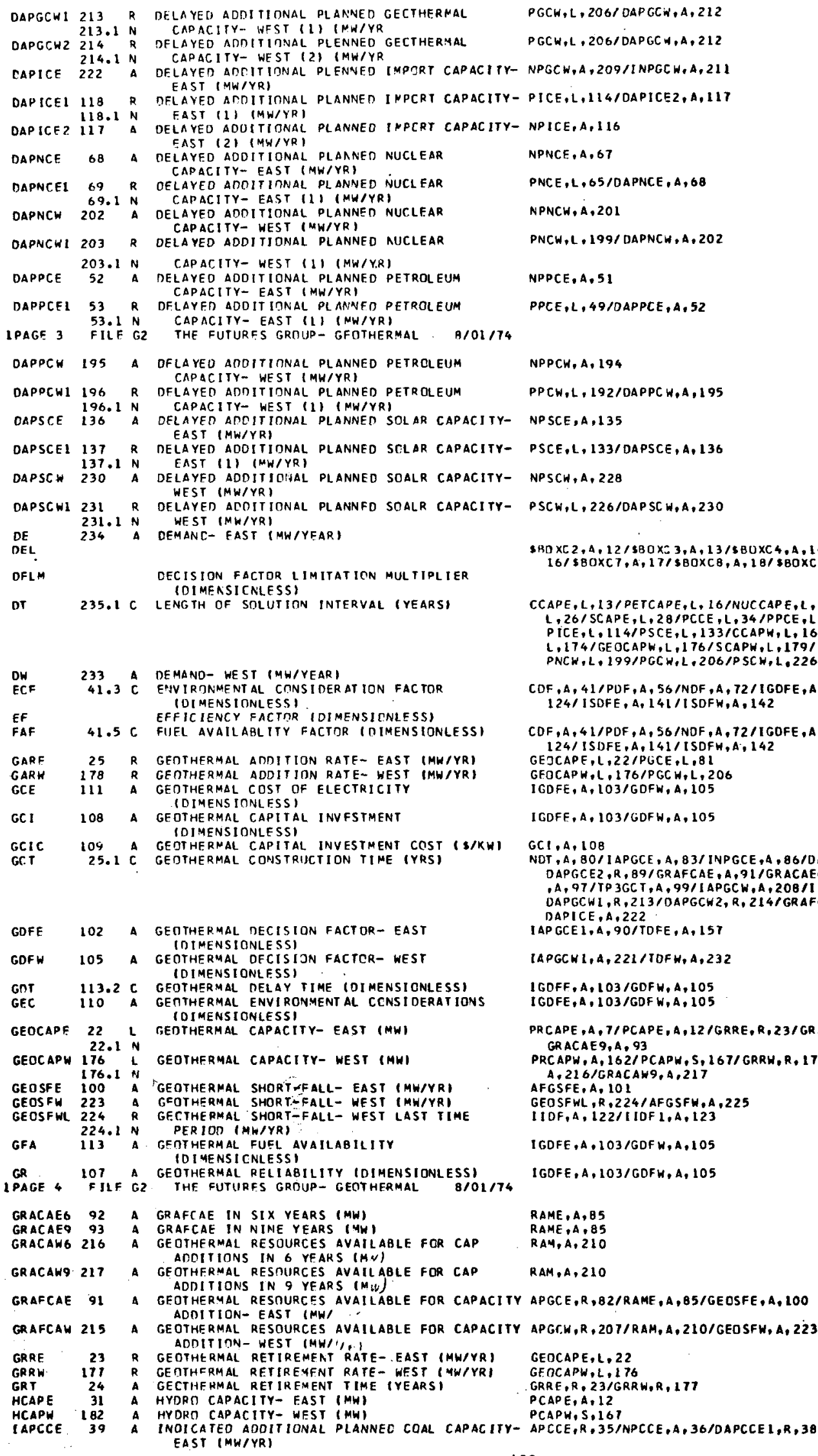




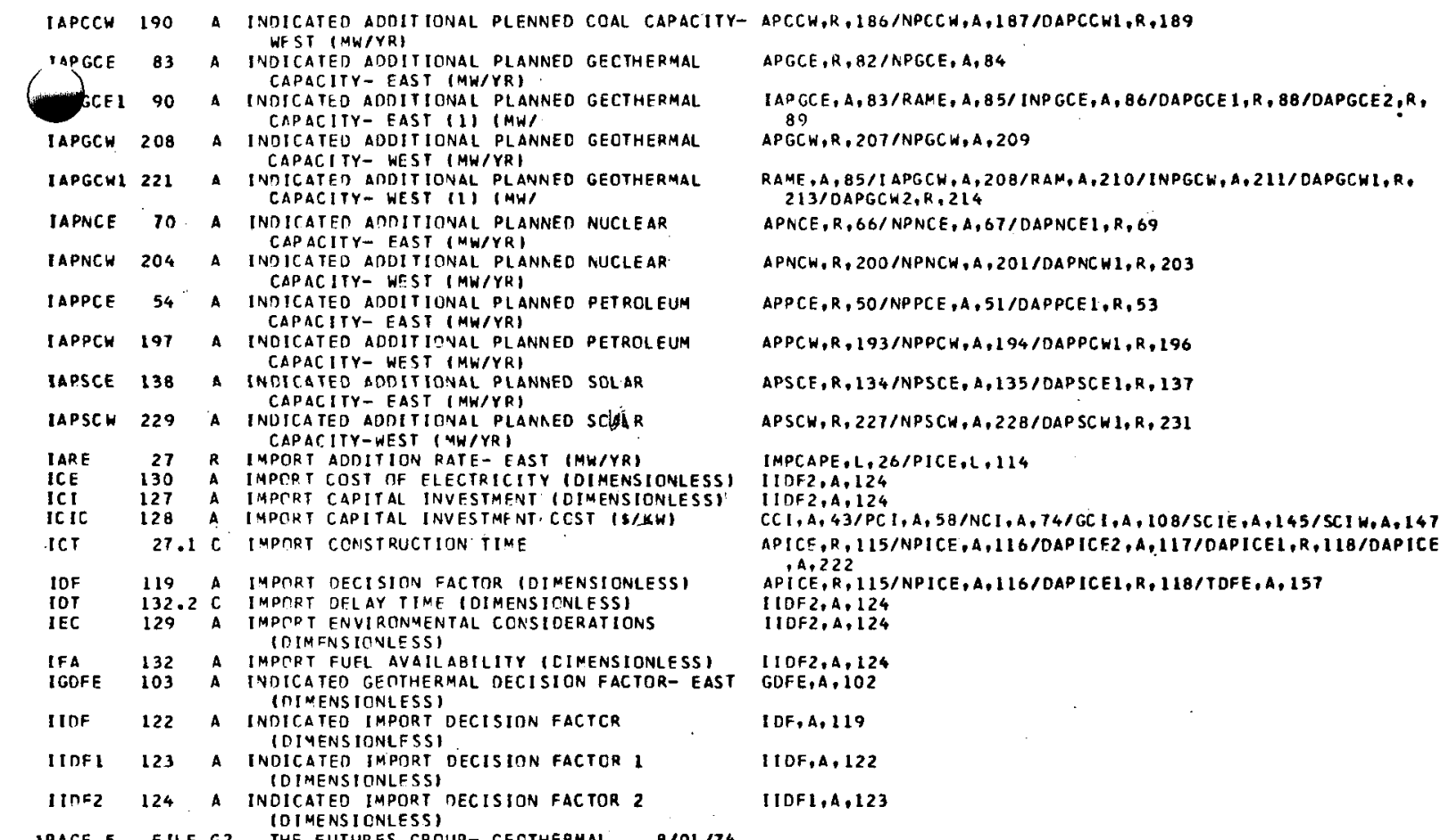

IPAGE 5 FILE G2 THE FUTURES GROUP-GECTHERMAL $8101 / 74$

\begin{tabular}{|c|c|c|c|c|}
\hline $\begin{array}{l}\text { ILF } \\
\text { IMPCAPE }\end{array}$ & $\begin{array}{l}125 \\
26 \\
26.1\end{array}$ & $\stackrel{A}{L}$ & IMPORT CAPACITY-EAST (MW) & $\begin{array}{l}\text { IIDF2, A, } 124 \\
\text { PRCAPE, A,7/PCAPE, A, 12/IMPR, A, 121/PAPSH,A, } 161\end{array}$ \\
\hline IMPR & 121 & A & IMPORI RATIO (DINENSIONLESS) & POSDFM, A, 120 \\
\hline $\begin{array}{l}\text { IMPYEAR } \\
\text { IMR }\end{array}$ & 119.1 & c & IMPORT START YEAR (YEARS) & IDF,A,119 \\
\hline & 126 & $\Delta$ & IMPCPT RELIABILITY IOIMENS IONLESSI & $\begin{array}{l}\text { IIOF2,A,124 } \\
\text { SVI, R, IO }\end{array}$ \\
\hline INYPGCE & 86 & A & $\begin{array}{l}\text { INOICATFO NEW PLANNED GEOTHERMAL CAPACITY- } \\
\text { EAST (MW/YR) }\end{array}$ & APGCE, R, $82 / G E O S F E, A, 100$ \\
\hline INPGCW & 211 & A & $\begin{array}{l}\text { INDICATED NEW PLANNEO GEOTHERMAL CAPACITY- } \\
\text { WEST (MW/YR) }\end{array}$ & RAME, A, B5/APGCH, R, 201/RAM, A, 210/GEOSFW, A, 223 \\
\hline $\begin{array}{l}\text { INTRAT } \\
\text { ISDFE }\end{array}$ & & & $\begin{array}{l}\text { INTEREST RATES IOINENSIONLESSI } \\
\text { INDICATED SOLAR DECISION FACTOR- EAST }\end{array}$ & \\
\hline ISDFE & 141 & A & $\begin{array}{l}\text { INDICATED SOLAR DECISION FACTOR- EAST } \\
\text { IOIMENSIONLESSI }\end{array}$ & SDFE,A,139 \\
\hline ISOFW & 142 & A & $\begin{array}{l}\text { INDICATED SOLAR DECISION FACTCR- WEST } \\
\text { INIMENSIONLESSI }\end{array}$ & SDFW, A, 140 \\
\hline $\begin{array}{l}\text { LENG TH } \\
\text { LFF }\end{array}$ & $\begin{array}{l}235.2 \\
104\end{array}$ & $\begin{array}{l}c \\
4\end{array}$ & $\begin{array}{l}\text { LENGTH CF NODEL RUN (YEARS I } \\
\text { LFARNING, FACTIR- EAST (DINENSIONLESS) }\end{array}$ & IGDFE, A, 103 \\
\hline LFW & 106 & A & LEARN ING FACTDR - WEST IDIMENSIONLESS) & GDFW,A, 105 \\
\hline NAFGSFE & 71 & A & $\begin{array}{l}\text { NUCLEAR AD JUSTMENT FOR GEOTHERMAL SHORT- } \\
\text { FALL- EAST IMH/YRI }\end{array}$ & IAPNCE, A.70 \\
\hline NAFGSFW & 205 & $\mathbf{A}$ & $\begin{array}{l}\text { NUCLEAR AOJUSTMENT FOR GECTHFRMAL SHORT- } \\
\text { FALL- WEST (MW/YR) }\end{array}$ & IAPNCW, A, 204 \\
\hline NARE & 20 & $\mathrm{R}$ & NUCLEAR ARTITION RATE- EAST (MW/YRI) & NUCCAPE,L, 1 9/PNCE,L, 65 \\
\hline $\begin{array}{l}\text { NARW } \\
\text { NCE }\end{array}$ & 175 & $\mathbf{R}$ & NUCLEAR ACOITION RATE- WFST (MW/YRI & NUCCAPW, L, 1 74/PNCH,L,199 \\
\hline $\begin{array}{l}\text { NCE } \\
\text { NCI }\end{array}$ & $\begin{array}{l}77 \\
74\end{array}$ & $A$ & $\begin{array}{l}\text { NUCLEAR CAST OF ELECTRICITY IOINENSIONLESSI } \\
\text { NUCLFAR CAPITAL INVESTMFNT IDIMENSIONLESSI }\end{array}$ & $\begin{array}{l}\text { NDF, A, } 12 \\
N D F, A, 72\end{array}$ \\
\hline NCIC & 75 & Á & $\begin{array}{l}\text { NUCLEAR CAPITAL INVESTMENT COST IS/KWI } \\
\text { NUCLEAR CAPITAL INVESTMENT COST }\end{array}$ & $\begin{array}{l}N D F, A, 72 \\
N C 1, A, 74\end{array}$ \\
\hline NCT & 21 & $\Delta$ & NUCLEAR CONSTRUCTION TIME (YRS). & $\begin{array}{l}\text { NARE, } R, 20 / 4 P N C E, R, 66 / N P N C E, A, 67 / D A P N C E, A, 68 / 0 A P N C E 1, R, 69 \\
\text { NDT, A, 80/NNARW,R, } 175 / A P N C H, R, 200 / N P N C W, A, 201 / 0 A P N C H, A, 202 \\
\text { OAPNCW } 1, R, 203\end{array}$ \\
\hline NOF & 12 & A & NUCL EAR DECISION FACTOR IOIMENSIONLESSI & 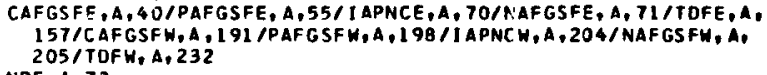 \\
\hline $\begin{array}{l}\text { NOT } \\
\text { NEC }\end{array}$ & $\begin{array}{l}80 \\
76\end{array}$ & A & $\begin{array}{l}\text { NUCL FAR DELAY TIME IDIMENSIONLESSI } \\
\text { NUCLEAR ENVIRONMENT AL CONS IOERATIONS } \\
\text { (DIMENSIONLESSI }\end{array}$ & $\begin{array}{l}N D F, A, 72 \\
N D F, A, 72\end{array}$ \\
\hline NFA & 79 & A & NUCL FAR FUFL AVAILABLITY (DIMENSIONLESS) & NDF, $A, 72$ \\
\hline $\begin{array}{l}\text { NGCAPE } \\
\text { NGCAPH }\end{array}$ & $\begin{array}{r}32 \\
183\end{array}$ & A & $\begin{array}{l}\text { NATURAL GAS CAPACITY- EAST (MW) } \\
\text { NATURAL GAS CAPACITY- WEST (MW) }\end{array}$ & $\begin{array}{l}\text { PCAPE, A, 12 } \\
\text { PCAPH, }, 167\end{array}$ \\
\hline $\begin{array}{l}\text { NPCCE } \\
\text { NPCCW } \\
\text { NPGCE }\end{array}$ & $\begin{array}{r}36 \\
187 \\
84\end{array}$ & $\hat{A}$ & $\begin{array}{l}\text { NEW PLANNED COAL CAPACITY- EAST (MW/YR) } \\
\text { NEW PLANNED COAL CAPACITY- WEST (MW/YR) } \\
\text { NEW PLANNED GEOTHERMAL CAPACITY- EAST (MH) } \\
\text { YR) }\end{array}$ & $\begin{array}{l}C A R E, R, 15 \\
\text { CARW,R, } 170 \\
\text { GARE,R, } 25\end{array}$ \\
\hline NPGCH & 209 & a & $\begin{array}{l}\text { NEW PLANNEO GEOTHERMAL CAPACITY- WEST (MW/ } \\
\text { YR) }\end{array}$ & GARW, R, 178 \\
\hline NPICE & 116 & A & $\begin{array}{l}\text { NFW PLANNED ADOITIONAL IMPCRT CAPACITY-EAST! } \\
\text { (MW/YR })\end{array}$ & IARE, R, 27 IOAPICE, A, 222 \\
\hline $\begin{array}{l}\text { NPNCE } \\
\text { NPNCW } \\
\text { NPPCE }\end{array}$ & $\begin{array}{r}67 \\
201 \\
51\end{array}$ & A & $\begin{array}{l}\text { NEW PL ANNEC NUCLFAR CAPACITY- EAST (MW/YR) } \\
\text { NEW PLANNED NUCLEAR CAPACITY- WEST (MW/YR) } \\
\text { NEW PL ANNED ADOITIONAL PETROLEUM CAPACI YY } \\
\text { EAST (MW/YR) }\end{array}$ & $\begin{array}{l}\text { NARE, R, } 20 \\
\text { NARW, R, } 175 \\
\text { PARF, R, } 18\end{array}$ \\
\hline NPPCW & 194 & A & $\begin{array}{l}\text { NEW ADD ITTONAL PLANNED PETRCLEUM CAPACITY- } \\
\text { WEST (MW/YRI }\end{array}$ & PARW, R, 173 \\
\hline $\begin{array}{l}\text { NP SCE } \\
\text { NPSCH } \\
\text { NR }\end{array}$ & $\begin{array}{r}135 \\
228 \\
73\end{array}$ & A & $\begin{array}{l}\text { NEW PLANNED SOLAR CAPACITY- EAST (MW/YR) } \\
\text { NEW PLANNED. STALR CAPACITY LEST (MW/YR) } \\
\text { NUCLEAR RELIABILITY (DIMENSIDNLESS) }\end{array}$ & $\begin{array}{l}\text { SARE, R, 30 } \\
\text { SARH,R,18L } \\
\text { NOF,A, } 72\end{array}$ \\
\hline NTCL & & & NUMBER OF TRANSCONTINENTAL LINES (LINES) & \\
\hline
\end{tabular}




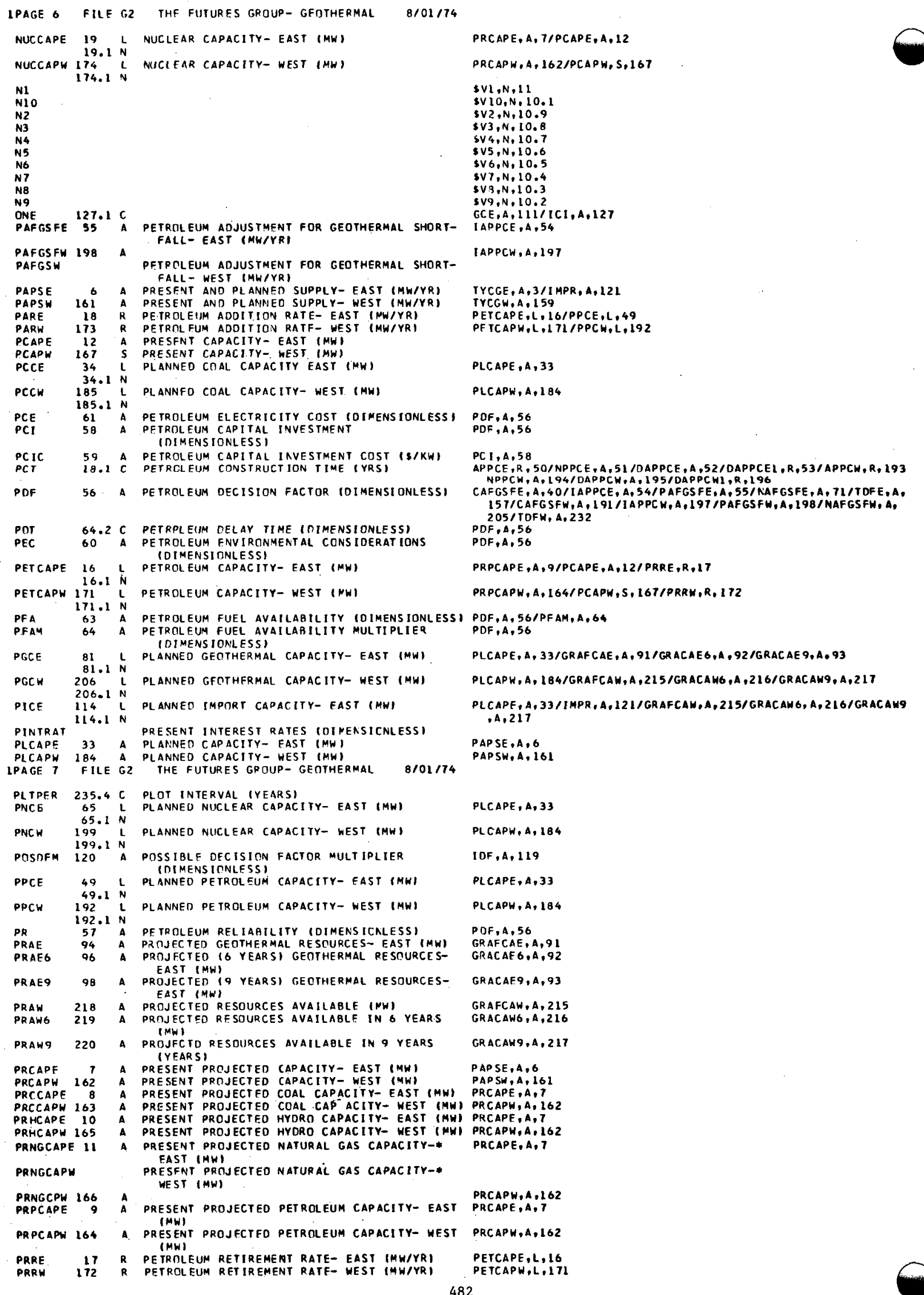




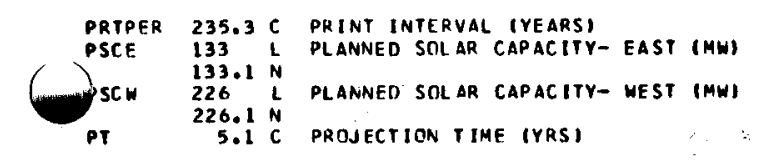

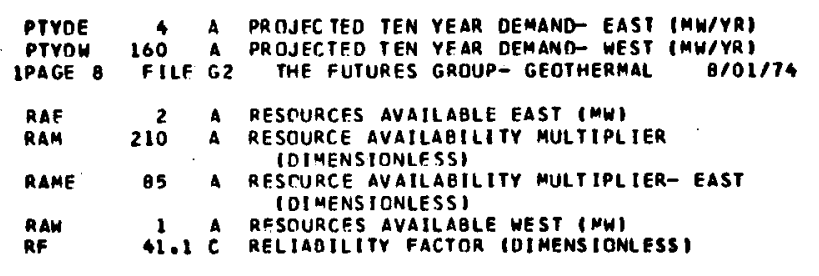

RIR
SARE RELAT IVE INTEREST RATES (DIMENS IONLESS)

SARE 30 R SOLAR ADDITION RATE- EAST (MW/YRI

SARW
SAT
140.1 C SOLAR ADNITION RATE- WEST (MW)

SCAPE 28 L SOLAR CAPACITY-EAST (MW)

SCAPW 179 L L SOLAR CAPACITY - WEST (MW)

SCEE $150.1 \mathrm{~N}$ A SOLAR COST OF ELECTRICITY- EAST

SCEEL 152 A SOLAR COST DFELECTRICITY-EASI LIMITATION

SCEH 153 A SOLAR.COST OF ELECTRICITY- WEST

SCEWL 155 A SOLAR COST OF ELECTRICITY- WEST LIMITAT ION

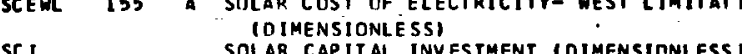

SC I

SCIC

SCICE $146 \quad A$

SCICW 148 A

$\begin{array}{lll}\text { SCIE } & 145 \\ \text { SCIN } & 147\end{array}$

SC T

SDFE

$\begin{array}{lllll}\text { SDFE } & 139 & \text { SOLAR DECISION FACTOR- EAST (DIMENSIDNLESSI } \\ \text { SDFW } & 140 & \text { A SOLAR DECISION FACTOR- WEST IDIMENSIONLESS } \\ \text { SOT } & 156.2 \text { C SOLAR DELAY TIME IDIMENSIONLESSI }\end{array}$

SEC 149 A SOLAR ENVIRONMENTAL CONSTOERATIONS COIMENSIONLESSI

SFA 156 A SOLAR FUEL AVAILAÓ́ILITY- EAST
SFAE

SOLAR FUEL AVAILABI
(DIMENSIONLESSI

SFAH SOLAR FUEL AVAILABILITY- WEST
IOIMENSIONLFSSI

SLF 143 A SOLAR LEARNING FACTMR IDIMENSICNLESSI

SR. 144 A SOLAR REL IABILITY (OIMENSIONLESSI

SRRE 29 R SOLAR RETIREMENT RATE- EAST (MW/YR)

$\begin{array}{llll}\text { SRRW } & 180 & R & \\ \text { SRT } & 29.1 & C & \\ \text { SOLAR RETIREMENT TIME (YEARS }\end{array}$

TACCE 47.1 T

TAGCE 112.1

TAICF 131.1

TANCE 78.1 T

TAPCE $62.1 \mathrm{~T}$

TASCEW 154.1 T

TCAP

TCEC $45.1 \mathrm{~T}$

TCFi. 48.1 T

IPAGE 9

TCR

TOFE

TOFEL

TOFLM

FIIE 62

TOTAL CAPACITY (MH)

$42.1 \mathrm{~T}$

158

$158.1 \mathrm{~N}$

TOTAL DECSION FACTOR- EAST (DIMENSIONLESS

TOTAL CECISION FACTOR- EAST LAST TIME

PFRIOD (OIMENSIONLESSI

TARLE OF DEC ISION FACTOR LIMITATION

TOFH 232 A TOTAL DEMAND FACTOR- WEST (DIMENSIONLESS!

rGCIC $109.1 \%$

TGEC IOG.1

TGEC 119.1

TGFA 113.1 T

TGR $\quad 24.1$ T

THCAPE 31.1 T

THCAPW 182.1 T

TICIC 128.1 T

TIEC 129.1 T
PLCAPE, A, 33

PLCAPW, A, 184

TPP T, A, 5/PRCCAPE , A, 8/PRPCAPE, A, 9/APCCE, R, 35/NPCCE, A, 36 DAPCCE, A, 37/UAPCCE $1, R, 38 / A P P C E, R, S O / N P P C E, A, 51 / O A P P C E, A$. $52 / D A P P C E 1, R, 53 / A P N C E$, $R$, 66/NP NCF, A, 67/OAPNCE, A, 68 DAPNCEI R , 69/I A PGCE, A, B3/IIMPGCE, A, 86/OAPGCE, A, BT IDAPGCEL , R, BB/DAPGCE2, R, B9/APICE, R, I15/NP ICE, A, 116/DAPICE 2,A, 117 DAPICE 1 , $R, 118 / 4 P$ SCE, $R+134 /$ NPSCE , A, 135 /DAPSCE, A, 136 OAPSCE $1, R, 137 / P R C C A P W, A, 163 / P R P C A P W, A, 164 / A P C C W, R, 186$ NPCCW, A, L BT/DAPCCW, A, LBB/ DAPCCHI,R, $189 / A P P C W, R, 193 / N P P C H$ A, $194 / 0 A P P C W, A, 195 / O A P P C W L, R, 196 / A P N C H, R, 200 / N P N C H, A$, $201 / D A P N C W, A, 202$ DAPNCWL, $203 / 1 A P G C H, 208 / 1 M P G C H, A, 211$ DAPGCW,A,212/DAPGCHI, R, 213 /OAPGCW $2, R, 214 / A P S C H, R, 227$

NPSCW, A, 228/DAP SC W,A, 230 /OAPSCWL,R, 231

TYCGE,A, 3

TYCGW,A, 159

NPGCH,A, 209/DAPCCHI,R,213/DAPGCH2,R,214

NPGCE, A, B4/DAPGCE $1, R, 88 / 0 A P G C E 2, R, 89$

CDF, A, 41/PDF, A, 56/NDF, A, 72/IGDFE, A, 103/GDFW, A, 105/II DF2, A, $124 /$ ISOFE, $A, 141 / 1$ SOFW, $A, 142$

SCAPE, L, 28/PSCE, L, 133

SCAPH, L, $179 /$ PSCW,L,226

SOFE,, $139 /$ SDF W. A, 140

PRCAPE, A, T/ PCAPE, A, 12/SRRE, R, 29

PRCAPW,A, 162/PCAPH, S, $167 /$ SRRM,R, 180

ISDFE,A, 14L/SCEEL,A, 252

ISDFE, A, I4I

ISDFW, $A, 142 /$ SCEWL, A, ISS

ISDFW, $A, 142$

SCIE, $A, 145$

SCI $1 M, A, 147$

ISOFE, $A, 141$

AP SCE, R, 134 /NPSCE, A, $135 / 0 A P S C E, A, 136 / 0 A P S C E 1, R, 131 / 4 A S C W, R$ APCE,R, $134 / N P S C E, A, 135 \%$ AP SCE,A, $136 \%$ CAPSCE $1, R$

APSCE, $A, 138 /$ TDFE, $A, 157$

ISDFE, $A, 141,1$ ISDFW, $A, 142$

ISDFE, $A, 14111$ SDF $, A, 142$

ISDFE, A, 14LI ISOFW, A, 142

ISDFE, $A, 141 /$ ISNFW, $A, 142$

I SNFE, $A, 141 / 1$ SDFW, $A, 142$

SCAPE, L, 20

SCAPW, L, 179

SRRF, R, 29/SRRM,R, 100

$A C C E, A, 47$

AGCE,A,112

AICE,A. 131

ANCE,A,7B

$A P C E, A, 62$

ASCEE,A, 151

CC IC, A, 44

CEC, $A, 45$

$C R, A, 42$

IAPCCE, A, 39\% IAPPCE, A, 54/I IAPNCE, , , 70/IAPGCE I, A, 90/APICE, R, I15/NPICE, A, 116/OAPICEL, R,LIB/IAPSCE,A, $138 / T$ DFEL, R, 150 IIDF $1, A, 123$

SCFEL, A, 152 /SCE WL, A, 155

IAPCCH, A, 190/ IAPPCH, A, 197/I APNCW, A, 204/IAPGCH1, A, 221

IAPSCW.A.229

GCIC,A, 109

$G F C, A, 110$

GFA,A, 113

GR, A, 107

GRT,A,Z4

PRHCAPH, A, 165/HCAPH, A, 102

ICIC,A, 128

IEC,A, 129 
TIFA 132.1 T
TIME

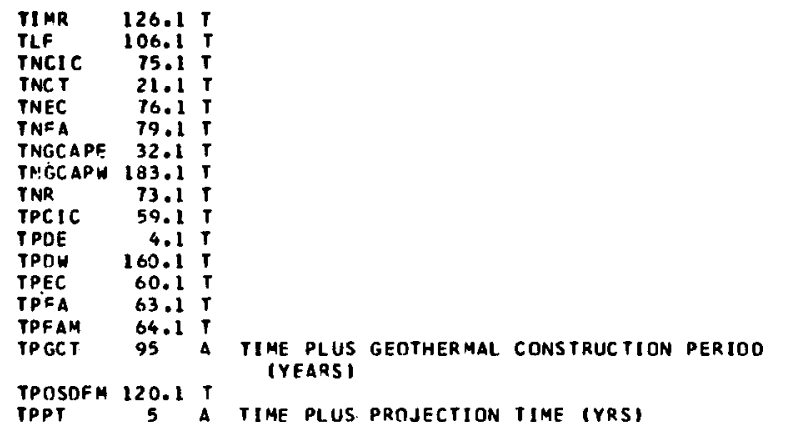

TPR 57 TPCT 97.1 A TIME PLUS TWO GEOTHERMAL CCNSTRUCTION

A PFRIONS (YEARSI

TP3GCT 99 A TIME PLUS THREE GEOTHERMAL CENSTRUCTION

$\begin{array}{lll}\text { TRAE } & 2.1 & \text { T } \\ \text { TRAW } & 1.1 & \text { T }\end{array}$

TSCICE 146.1 T

IPAGE 10 FILF G2 THE FUTURES GROUP- GECTHERMAL $8 / 01 / 7$

TSCICW 148.1 T

TSEC 149.1

TSFA $156.1 \mathrm{~T}$

TSR 143.1 T

TYCGE 3 A TEN YEAR CAPACITY GAP- EAST (MW/YR)

TYCGM 159 A TEN YEAR CAPACITY GAP- WEST (MH/YR)

$380 \times 22$

$380 \times C 3 \quad 13 A$

$300 \times 05$

$\$ B O \times C$

SAOXC 7

$\operatorname{sioxc8}$

sBoxco

s 1

svio

sv 2

sv 3

sv4

sv5

svo

s 7

sve

ve

sv9
IFA, $A, 132$

A, 2/TPPT, A, 5/NCT, A, 21/GRRE, R, 23/GRT, A, 24/HCAPE CA, $31 / N G C A P E, A, 32 / C R, A, 42 / C C$ IC, $A, 44 / C E C, A, 45 / A C C E, A, 47$

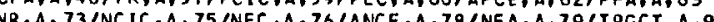
TP2GCT ,

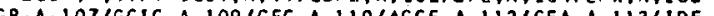
RA IFA A

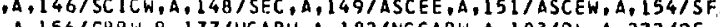
, A, 156/GRRW, R, 177/HCAPH,A, 182/NGCAPW,A, 183/0h,A,233/0E, A $A, 126$

LFE, A, 104/LFW, A, LO6/ILF,A, 125

NCTC,A,75

NCT,A, 21

NEC,A+76

NFA, A,79

PRNGCAPE, A, 11/NGCAPE, A, 32

PRNGCPW, A, L66/NGCAPH, A, 183

$N R, A, 73$

PCIC, A, 59

PTYDF, A,4 $1 D E, A, 234$

PTYDW,A, 160 /OW,A,233

PEC, A, 60

PFA, A, 63

PFAM, A, 64

PRAE, A, 94/PRAW, A, 218

POSDFM, A, 120

PTYOE, A, 4/PRHCAPE, A, 10/PRNGCAPE, A, 11/PTYOW, A, 160/PRHCAPH, A 165/PRNGCPW, A, 166

$P R, A, 57$

PRAE6, A, 96/PRAW6, A, 219

PRAE9, A, 98/ PRAK9, A, 220

RAE, A, 2/PRAE, A, 94/PRAE6,A,96/PRAE9,A,98 RAW, A, L/PRAW, A, 218/PRAW6, A, $219 /$ PRAW9,A, 220 SCICE,A, 146

$S C I C W, A, 148$

SEC, $A_{1}, 149$

SFA,A, 156

SL $F, A, 143$

$S R, A, 144$

IAPCCE, A, 39/1 IAPPCE, A, 54/IAPNCE, A, 70/IAPGCEI, A, 90/APICE, R,

$115 / N P I C E, A, 116 / 0 A P I C E I, R, 1 \mid 8 / I I O F 1, A, 123 / 1 A P S C E, A, 138$

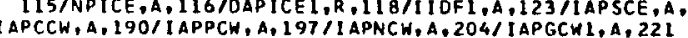

I APSC $W, A, 229$

$3 B O \times C 3, A, 13$

$B A \times C 4, A, 14$

BOXC 5, $A, 15$

$B O \times C 6, A, 16$

B

Boxce, $A, 18$

$S B O \times C 9, A, 1$

(1) $2,8,9 / \$ 80 \times C 2, A, 12$

$B O X C, A, 20$

$\$ V 3, R, B / \$ B O \times C 2, A, 12$

$S V 4, R, 7 / \$ B O \times C 3, A, 13$

$\$ V 5, R, 6 / \$ B O \times C 4, A, 14$

$S V 6, R, 5 / 5 B O \times C 5, A, 15$

$\$ V 7, R, 4 / \$ 80 \times C 6, A, 16$

\$V8, R, 3/\$80XC7,A, 17

SV9,R, $21 \$ B O \times C A, A, 18$

SV $10, R, 1 / 3 B 0 \times C 9, A, 19$ 


\title{
4. Mode1 Output
}

\author{
A. Policy Runs
}

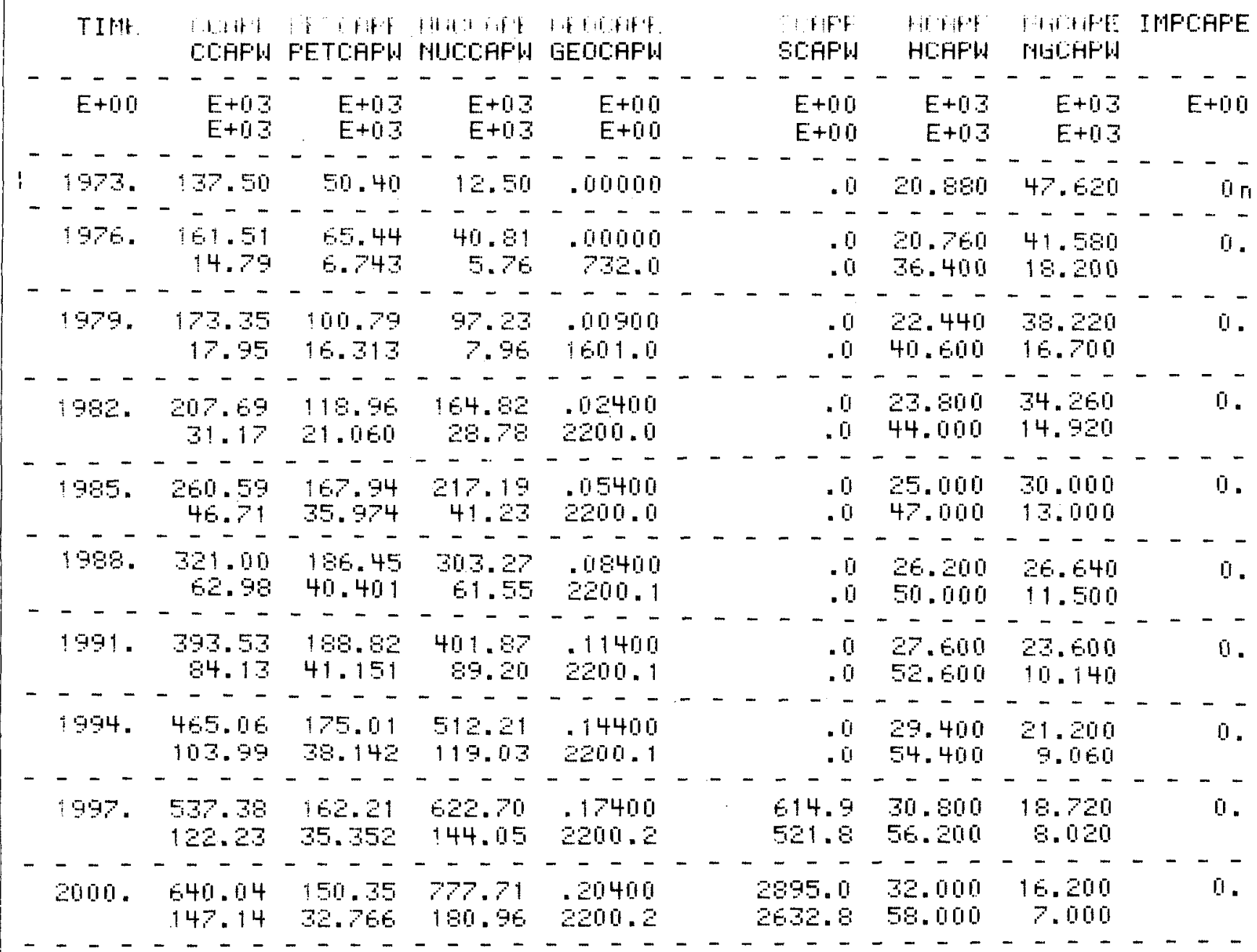

Figure E.4.1 GEOTHERMAL RESOURCES NOT DEVELOPED 


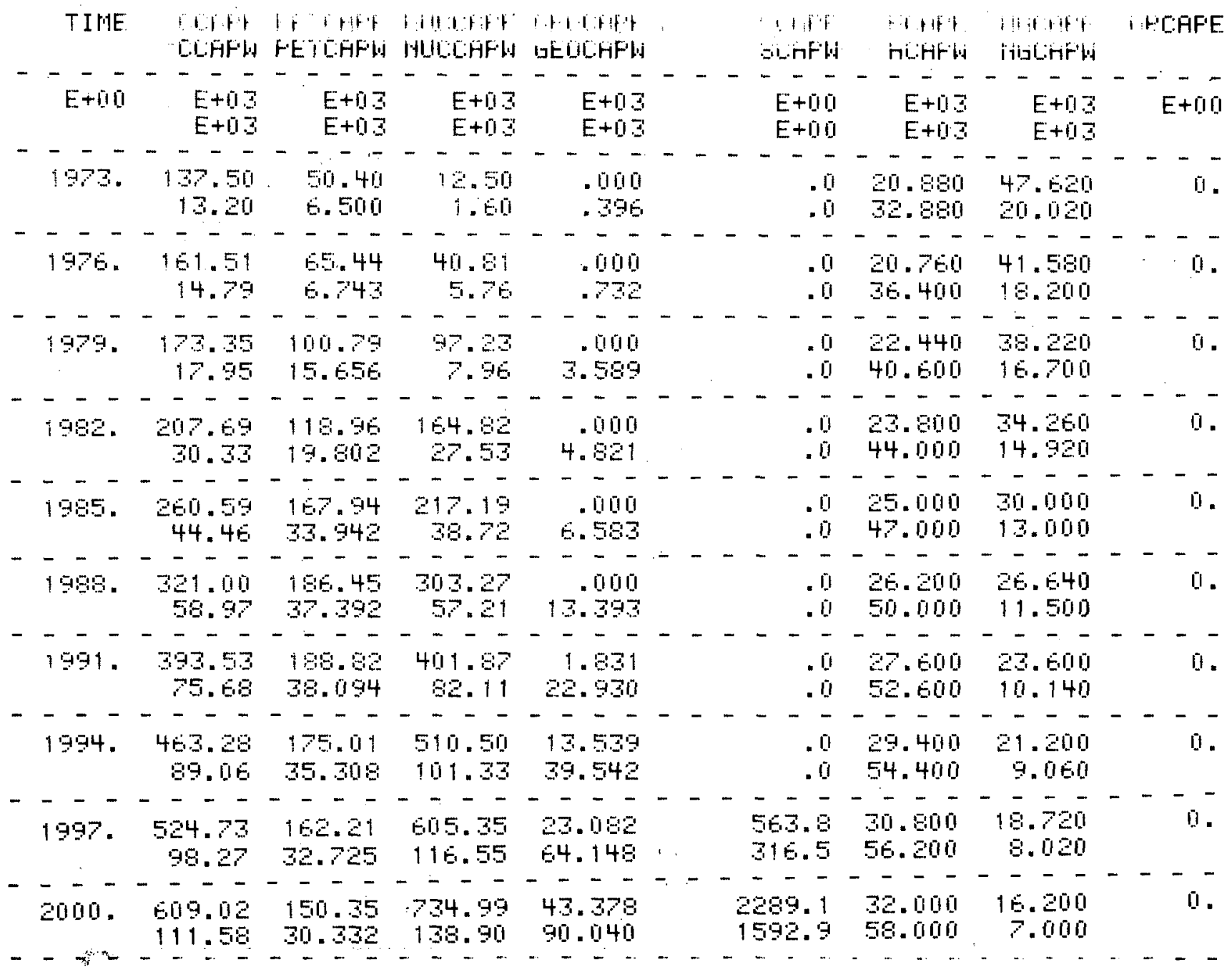




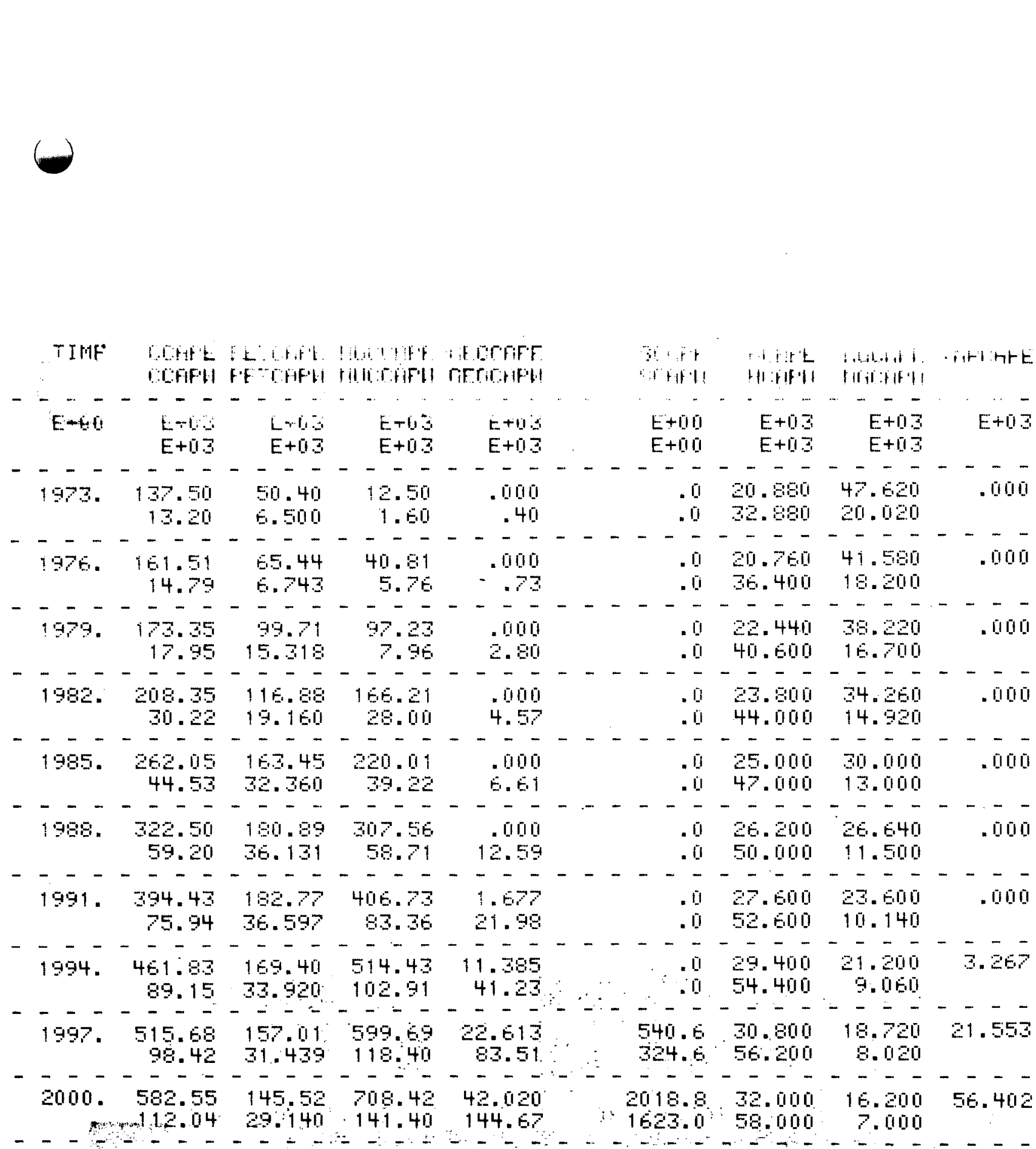

Figure E.4.3 BASE RUN 


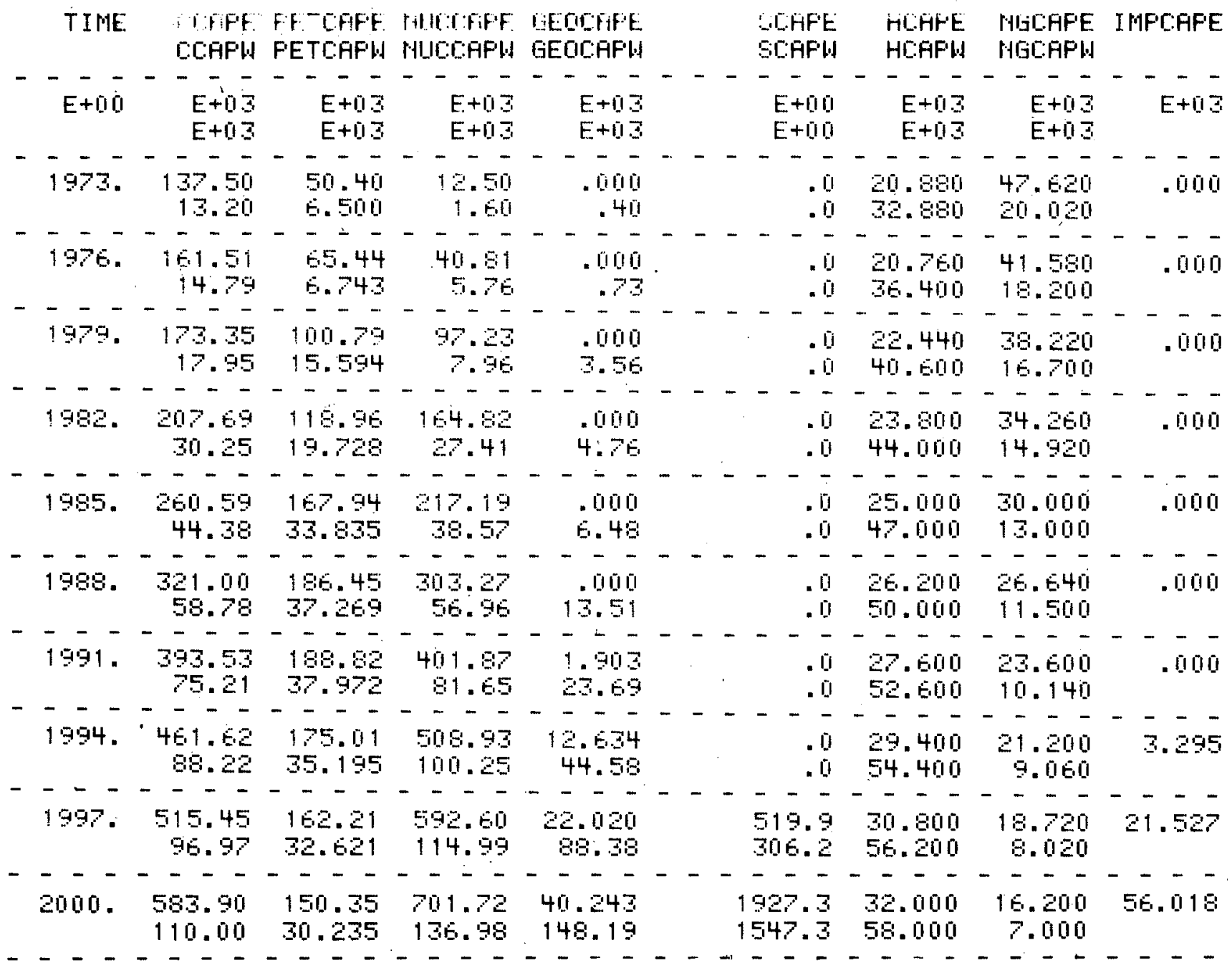

Figure E.4.4 INCENTIVES CREATED TO REDUCE PERCEIVED RISK ASSOCIATED WITH FIELD DEPLETION RATE 


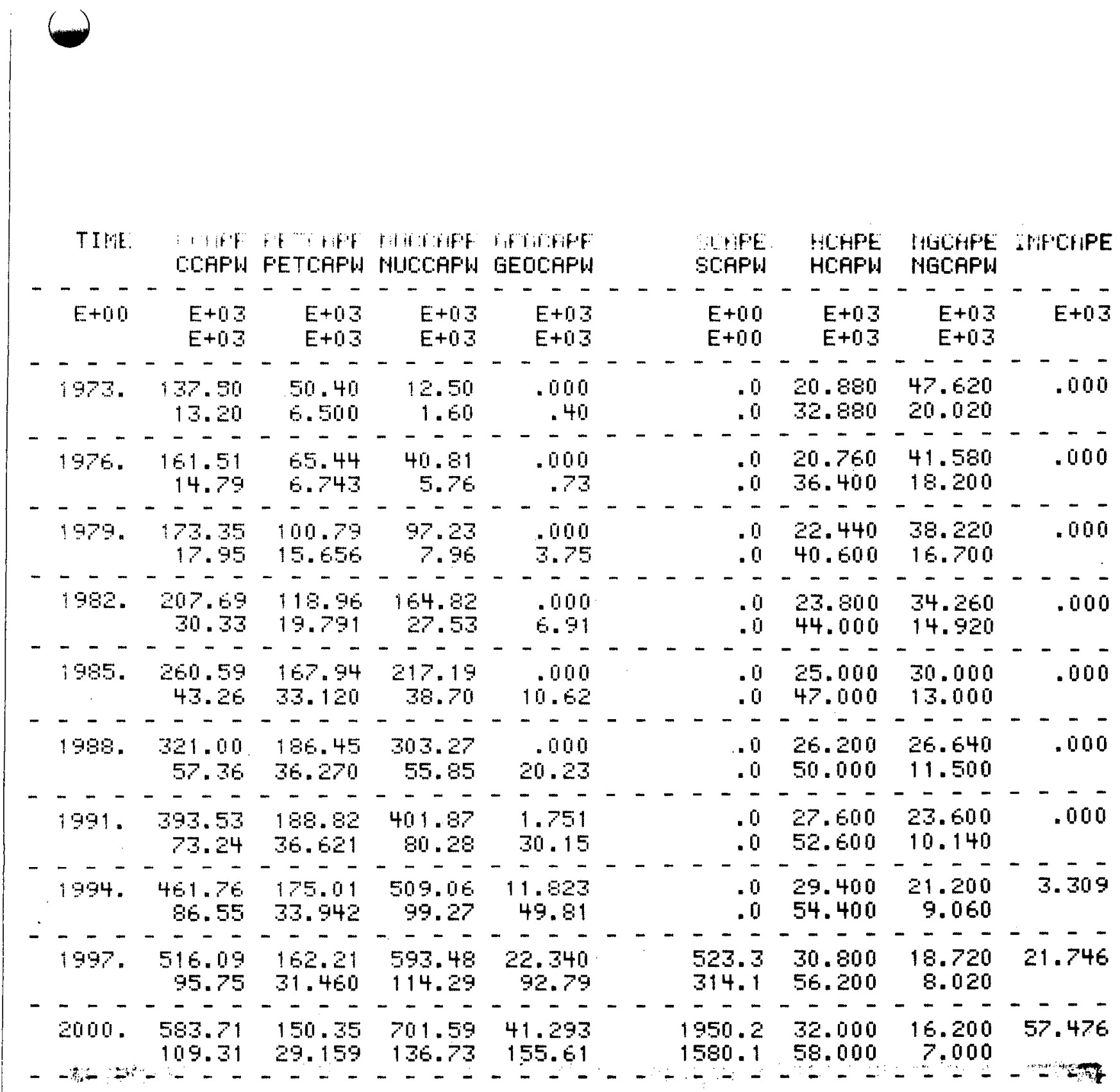

Figure E.4.5 GOVERNMENT FUNDED HOT ROCK DEVELOPMENT PROGRAM 


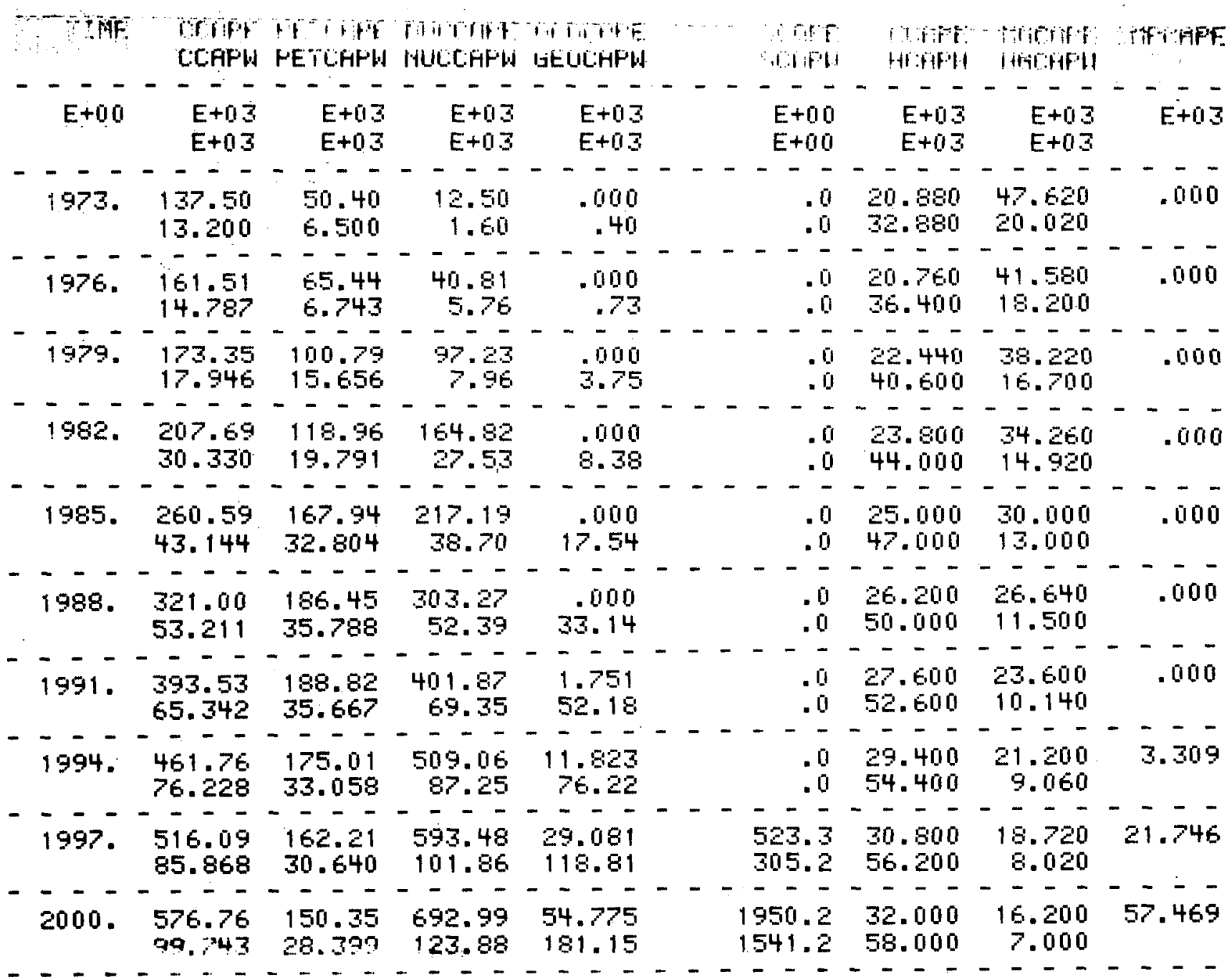

Figure E.4.6 TECHNICAL "CRASH" PROGRAM 


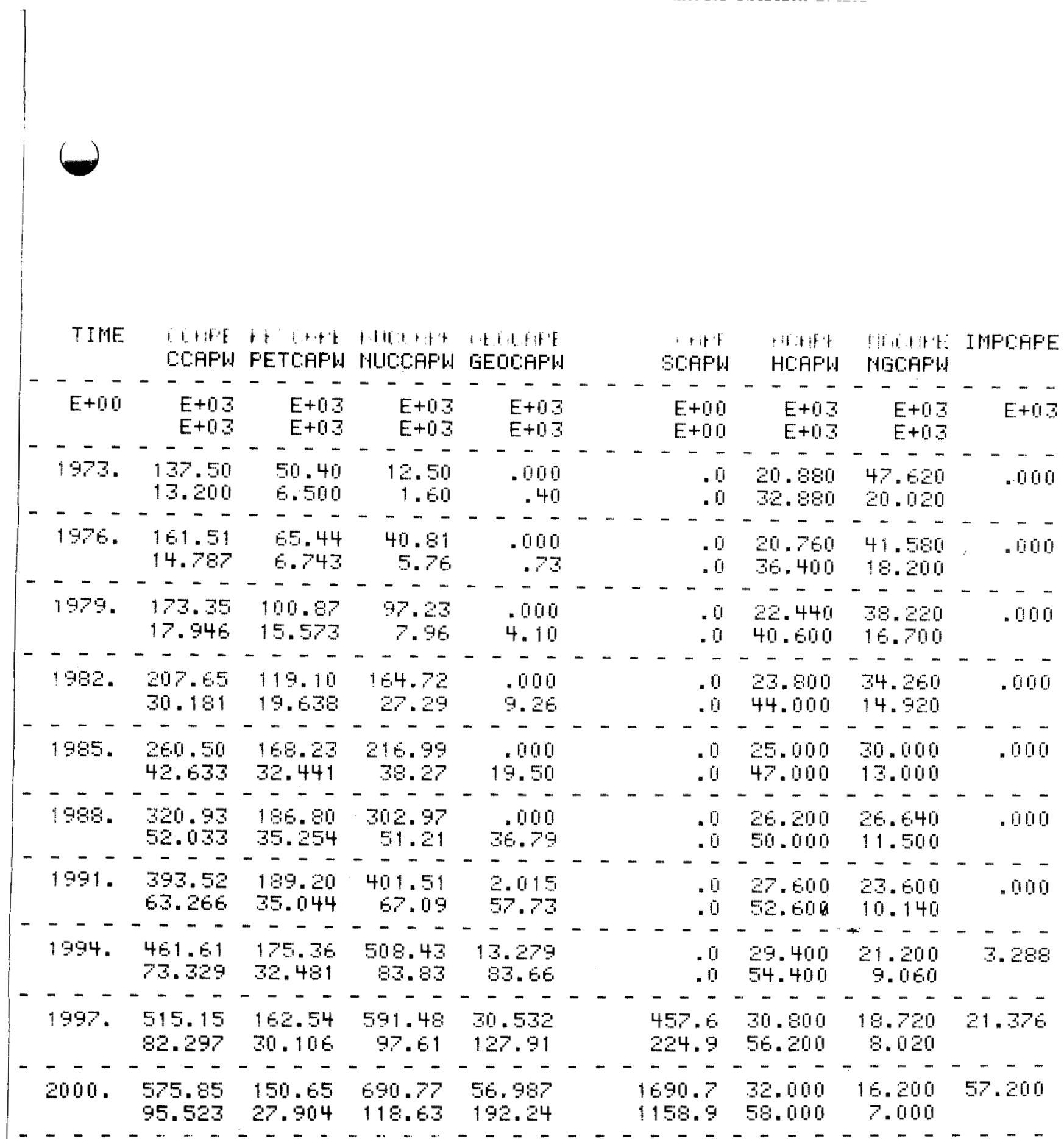

Figure E.4.7 ACCELERATED PROGRAM 


\begin{tabular}{|c|c|c|c|c|c|c|c|c|c|c|c|c|}
\hline & & $\begin{array}{l}\text { EDEFFE } \\
\text { E:E:AFW }\end{array}$ & FETI:AFW & $\begin{array}{l}\text { ITLL:LHFE } \\
\text { HILE:AFW }\end{array}$ & GEOLEFW & & & & $\begin{array}{l}\text { IIF } \\
\text { SL:FFH }\end{array}$ & $\begin{array}{l}\text { A.HFF" } \\
\text { HE:HFW }\end{array}$ & $\begin{array}{l}\text { lWit:FAF } \\
\text { HIGE:AFH }\end{array}$ & \\
\hline & $\begin{array}{r}-.-- \\
E+D D\end{array}$ & $\begin{array}{r}-\overline{-} \\
E+10 \Xi \\
E+11 \Xi\end{array}$ & $\begin{array}{r}--\overline{-} \\
E+03 \\
E+03\end{array}$ & $\begin{array}{r}---\overline{-} \\
E+n \Xi \\
E+\square \Xi\end{array}$ & $\begin{array}{r}--- \\
E+13 \\
E+11\end{array}$ & & & & $\begin{array}{r}-\overline{-} \\
E+00 \\
E+\square 0\end{array}$ & $\begin{array}{r}--\overline{-} \\
E+113 \\
E+[13\end{array}$ & $\begin{array}{r}-- \\
E+[1] \\
E+[3\end{array}$ & $-\bar{E}$ \\
\hline & - & $\begin{array}{r}-7-5 \\
13750 \\
13.501\end{array}$ & 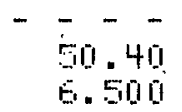 & $\begin{array}{r}-\quad-5 \\
-50 \\
-50\end{array}$ & $\begin{array}{r}-5- \\
.01010 \\
401\end{array}$ & & & & $\begin{array}{r}-- \\
.01\end{array}$ & 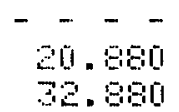 & $\begin{array}{r}-7-\overline{-} \\
47.601 \\
80.020\end{array}$ & $-\overline{-1}$. \\
\hline & - & 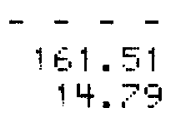 & $\begin{array}{r}--- \\
65.44 \\
5.743\end{array}$ & $\begin{array}{r}--- \\
41.91 \\
5.75\end{array}$ & $\begin{array}{r}-5- \\
11010 \\
73\end{array}$ & & & & $\begin{array}{r}- \\
. \\
.11 \\
.11\end{array}$ & 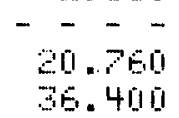 & $\begin{array}{r}-5- \\
41.550 \\
15.200\end{array}$ & $\begin{array}{r}- \\
-10 \\
.10\end{array}$ \\
\hline & $\overline{1979 .}$ & $\begin{array}{r}--- \\
173.35 \\
17.95\end{array}$ & $\begin{array}{r}-\overline{-}-\overline{0} \\
1010.16 \\
15.479\end{array}$ & $\begin{array}{r}-\quad-\quad- \\
9.23 \\
7.95\end{array}$ & $\begin{array}{r}-\quad- \\
-010 \\
20 \\
20\end{array}$ & & & & $\begin{array}{r}- \\
-1 \\
.0 \\
.11\end{array}$ & $\begin{array}{rr}- & - \\
2 & -4 \\
40.510\end{array}$ & $\begin{array}{r}-7- \\
30.201 \\
1 E .700\end{array}$ & $--\frac{-}{.111]}$ \\
\hline & $\begin{array}{l}--- \\
1982 .\end{array}$ & 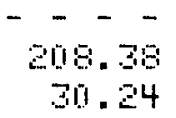 & $\begin{array}{r}---- \\
117.76 \\
19.413\end{array}$ & 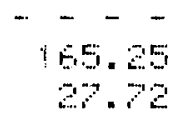 & $\begin{array}{r}-\overline{-} \\
.100 \\
4 . E 1\end{array}$ & & & & $\begin{array}{r}- \\
.0 \\
.01\end{array}$ & 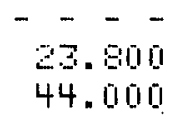 & 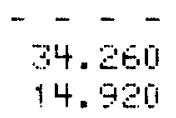 & $\begin{array}{l}- \\
.111\end{array}$ \\
\hline & - & $\begin{array}{r}-\quad-\quad- \\
261.92 \\
44.54\end{array}$ & $\begin{array}{r}--- \\
155.33 \\
32.57\end{array}$ & 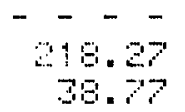 & $\begin{array}{r}- \\
-10 \\
.10 \\
\dot{B}, \bar{E}\end{array}$ & & & & $\begin{array}{r}-5 \\
.01 \\
.0\end{array}$ & $\begin{array}{r}---- \\
=5.0100 \\
47.1010\end{array}$ & 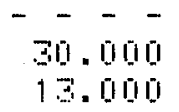 & $\begin{array}{r}- \\
.110\end{array}$ \\
\hline & 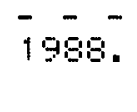 & $\begin{array}{r}- \\
322 \\
59\end{array}$ & $\begin{array}{r}-- \\
193 . \\
35.78\end{array}$ & $\begin{array}{r}- \\
305.41 \\
-9.20\end{array}$ & $\begin{array}{r}-5- \\
.0101 \\
12.56\end{array}$ & & & & $\begin{array}{r}- \\
. \\
.11 \\
.01\end{array}$ & $\begin{array}{rr}- & - \\
z E & =00 \\
50.000\end{array}$ & $\begin{array}{ccc}- & - & - \\
2 & -540 \\
11.501\end{array}$ & $-\overline{11}$ \\
\hline & $\overline{1991 .}$ & $\begin{array}{r}-7-5.50 \\
79.901\end{array}$ & $\begin{array}{r}-7- \\
195.31 \\
37.242\end{array}$ & $\begin{array}{r}-5-\overline{-} \\
405.04 \\
5.02 .07\end{array}$ & $\begin{array}{l}-5- \\
1.59 \\
=1.81\end{array}$ & & & & .01 & 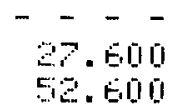 & $\begin{array}{r}-\overline{-}- \\
\overrightarrow{2} .6010 \\
10.140\end{array}$ & -7 \\
\hline & $19 \overline{94 .}$ & $\begin{array}{r}-\overline{50} \\
40.50 \\
69.10\end{array}$ & $\begin{array}{r}-7 . \\
171.75 \\
34.515\end{array}$ & $\begin{array}{r}-7.7 \\
512.79 \\
112.911\end{array}$ & $\begin{array}{r}-\overline{-} \\
17.146 \\
40.94\end{array}$ & & & & $\begin{array}{r}- \\
-01 \\
-0\end{array}$ & $\begin{array}{r}- \\
-9.400 \\
54.400\end{array}$ & 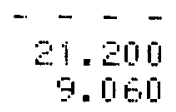 & $\begin{array}{l}- \\
\Rightarrow\end{array}$ \\
\hline & - & $\begin{array}{r}-- \\
513.53 \\
99.59\end{array}$ & $\begin{array}{r}--15- \\
159.19 \\
31.995\end{array}$ & 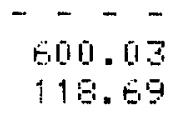 & 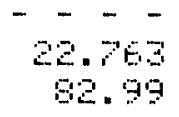 & & & & $\begin{array}{l}-- \\
5.5 .4 \\
32.51\end{array}$ & 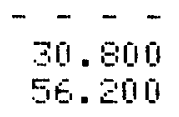 & $\begin{array}{r}-\overline{-}- \\
15,7=0 \\
G .030\end{array}$ & $\begin{array}{r}-\overline{-} \\
21.777\end{array}$ \\
\hline & $\begin{array}{l}-- \\
2000 .\end{array}$ & $\begin{array}{l}-5 \\
579 \\
112 .\end{array}$ & $\begin{array}{r}--\quad-\quad- \\
147.55 \\
29.553\end{array}$ & $\begin{array}{c}-7- \\
709 . \\
149 .\end{array}$ & 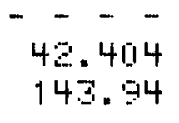 & & & & $0 \overline{7}$ & 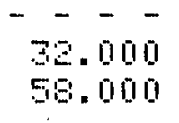 & $\begin{array}{r}- \\
16 \\
7 .\end{array}$ & $5 \overline{5}-\overline{5}$ \\
\hline
\end{tabular}




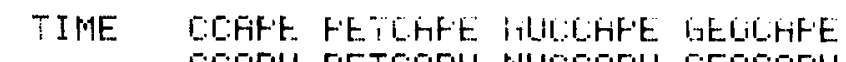
CEFFW FETEAFW HIICCAFW GEOCAFW

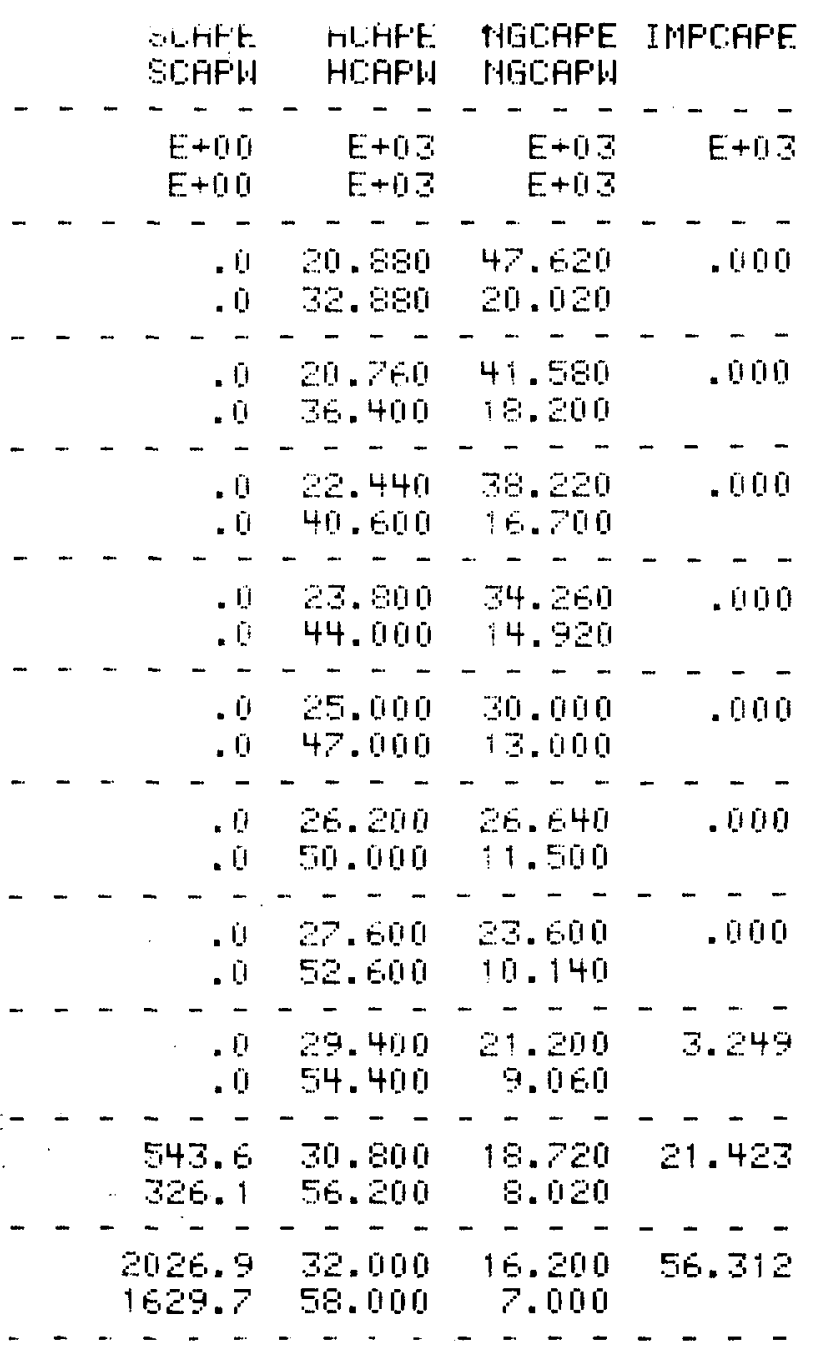
-

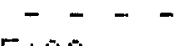
$-{ }^{-}-$

- - - - - - - - -

$E+103 \quad E+03 \quad E+103$

$-$

973.97 .511

13.20

1976. $161.5 \overline{1}$

14.79

$E+03$

$E+03$

$E+103$

511.411

6.500

$--\overline{-}-$

0.74
6.743

$-7979 .-73.35$

17.95

$9 .-\overline{4}$

15.224

$-790-20-7$

30.21

i $-\overline{-}$

19.019

$-\cdots$

-

$-$

1985.

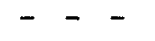

- 26.1日

1.00

.0100

.40

$411.9 !$

5.76

.00

.73

97.2

7.96

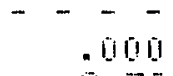

2.79

-
.000

4.55

$--\overline{1}$

$44.52 \quad 32.061 \quad 39.47$

$-$

1980. 322.72 $19.53 \quad 308.91$

$59.21 \quad 35.776 \quad 59.01$

- - -

.

5.59

- - - -

$1991 . \quad 394.69$

75.97

181.28

30.220

407.72

83.57

$-\overline{194}$

$-2-$

16.

$5+4.62$

89.19

33.57

102.92

1997.516 .75

98.44

155.73

- - -

$---$

12.61

12.01
1.599

22.08

1. .54

41.45

$-5$.

119.24

83.82

$-\quad-$

2000.584 .14

$144.34 \quad 707.67$

28.839

140.99

41.791

144.84

SLFF TLHFE THEAFE INFCAFE

CHFW HEAFW HGCAFW 


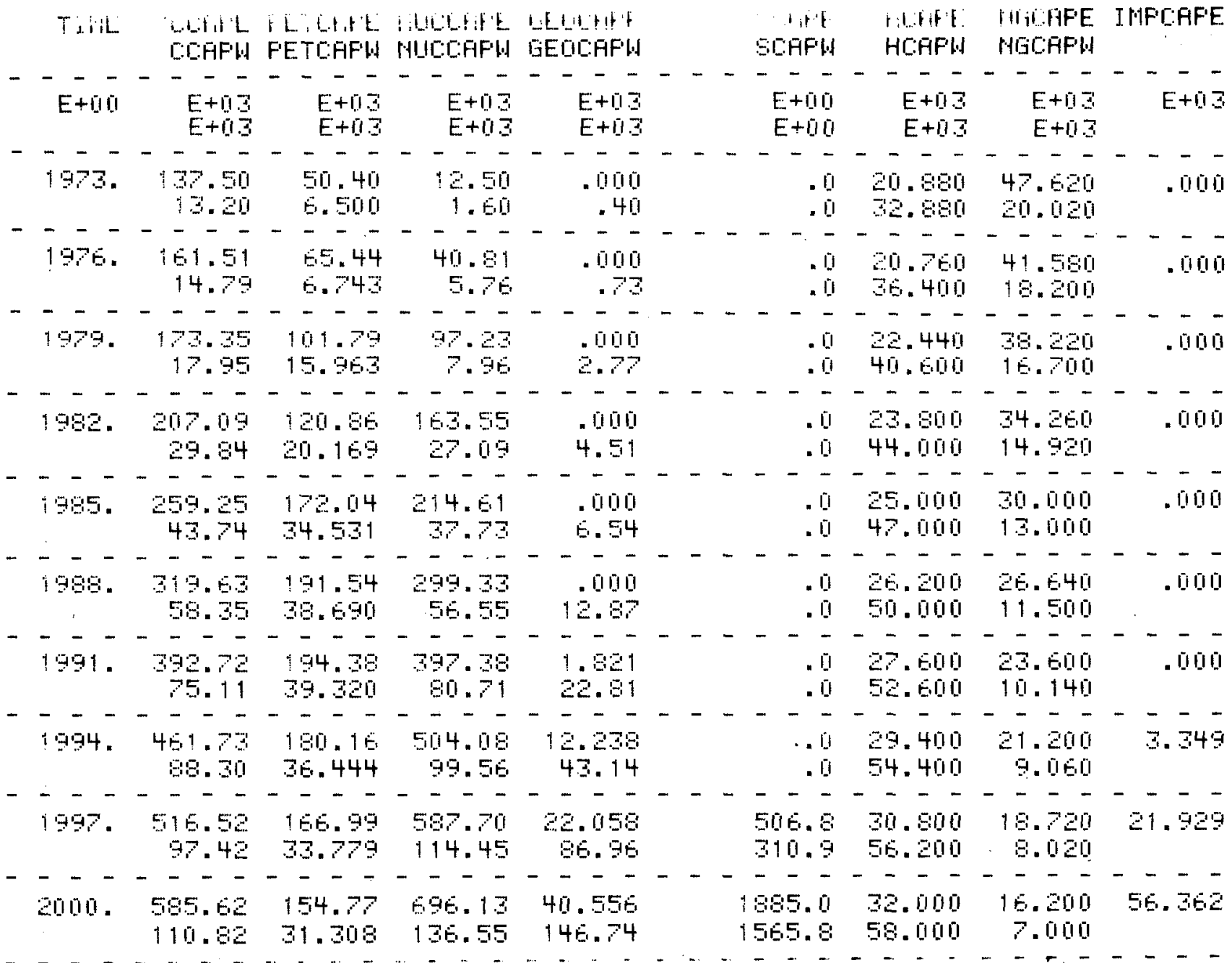

Figure E.4.10 CAPITAL INVESTMENT DECISION

WEIGHT DOUBLED ( $C I F=2)$ 


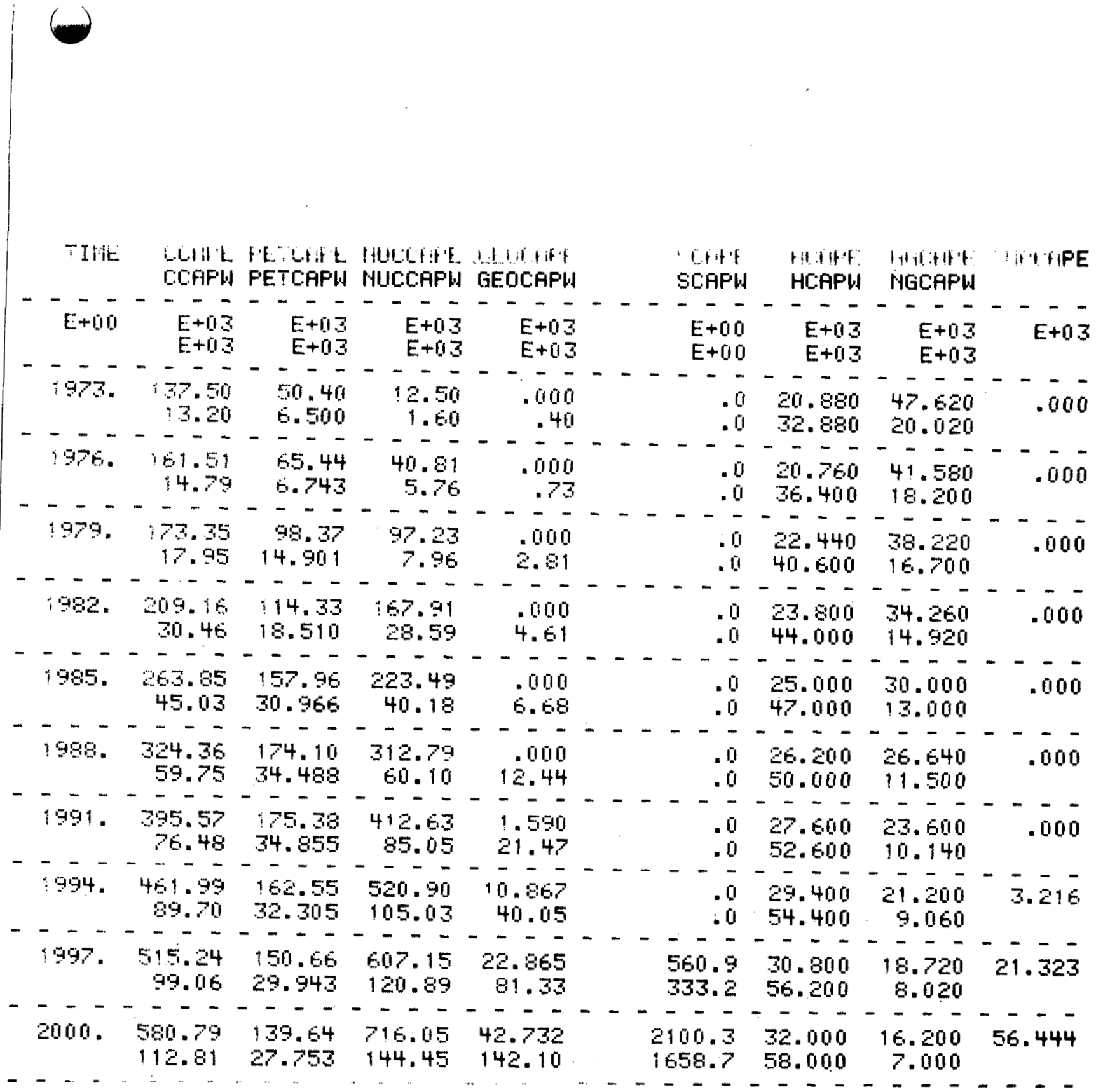

Figure E.4.11 CAPITAL INVESTMENT DECISION

WEIGHT HALVED (CIF $=.5$ ) 


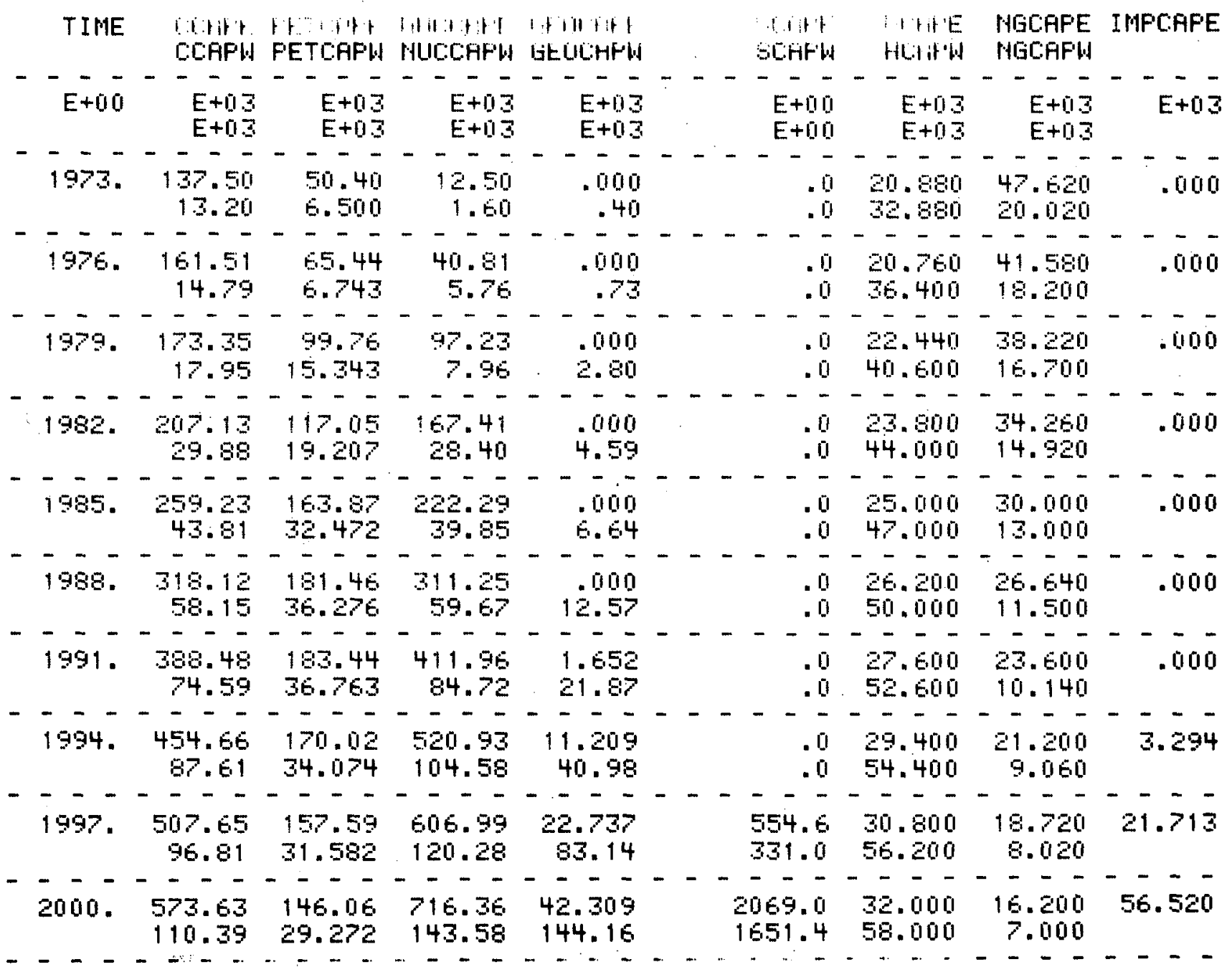

FI gure E.4.12 ENVIRONMENTAL DECISION WEIGHT

DOUBLED (ECF=1.2) 


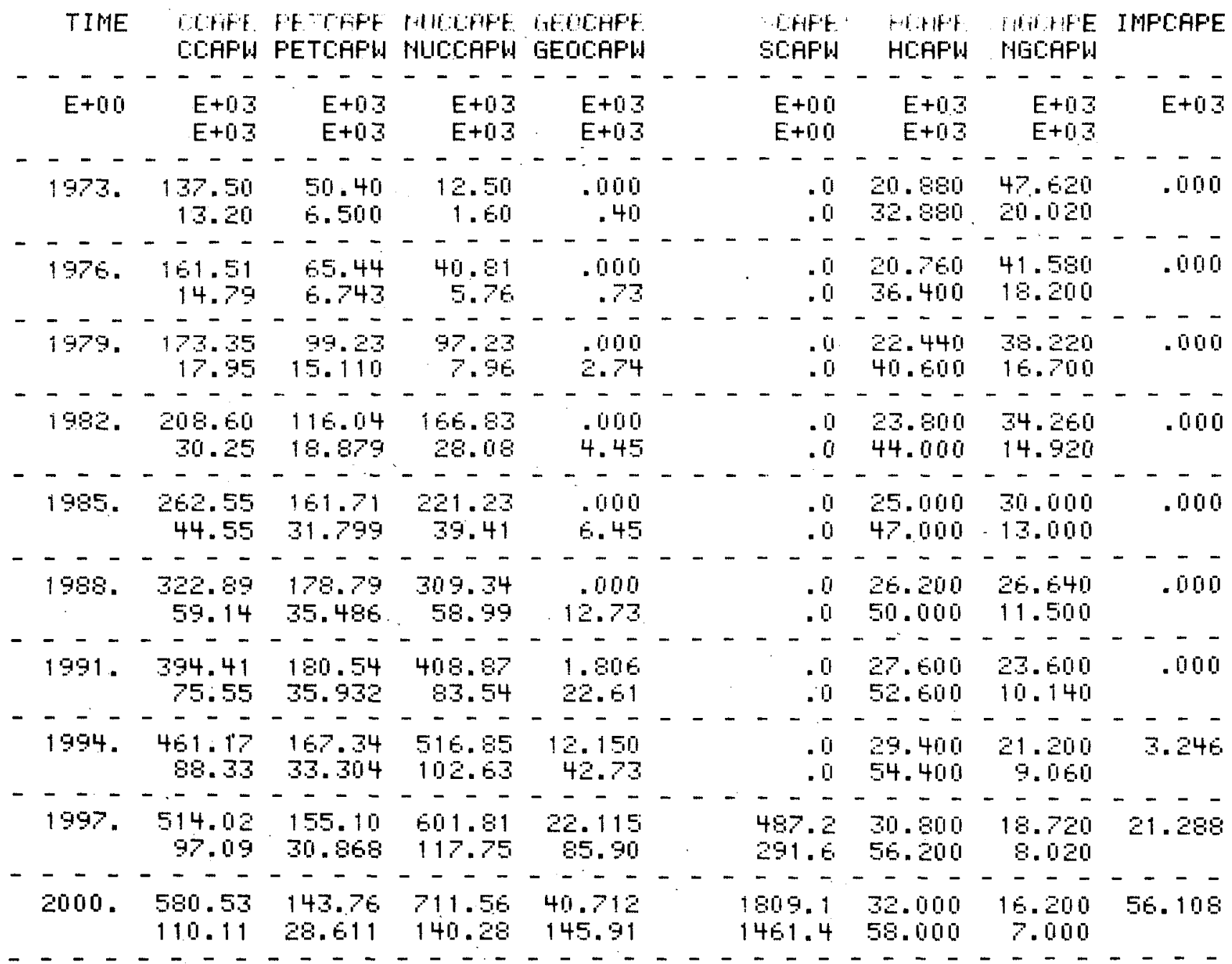

Figure E.4.14 COST OF ELECTRICITY DECISION WEIGHT DOUBLED ( $\mathrm{CEF}=2)$ 


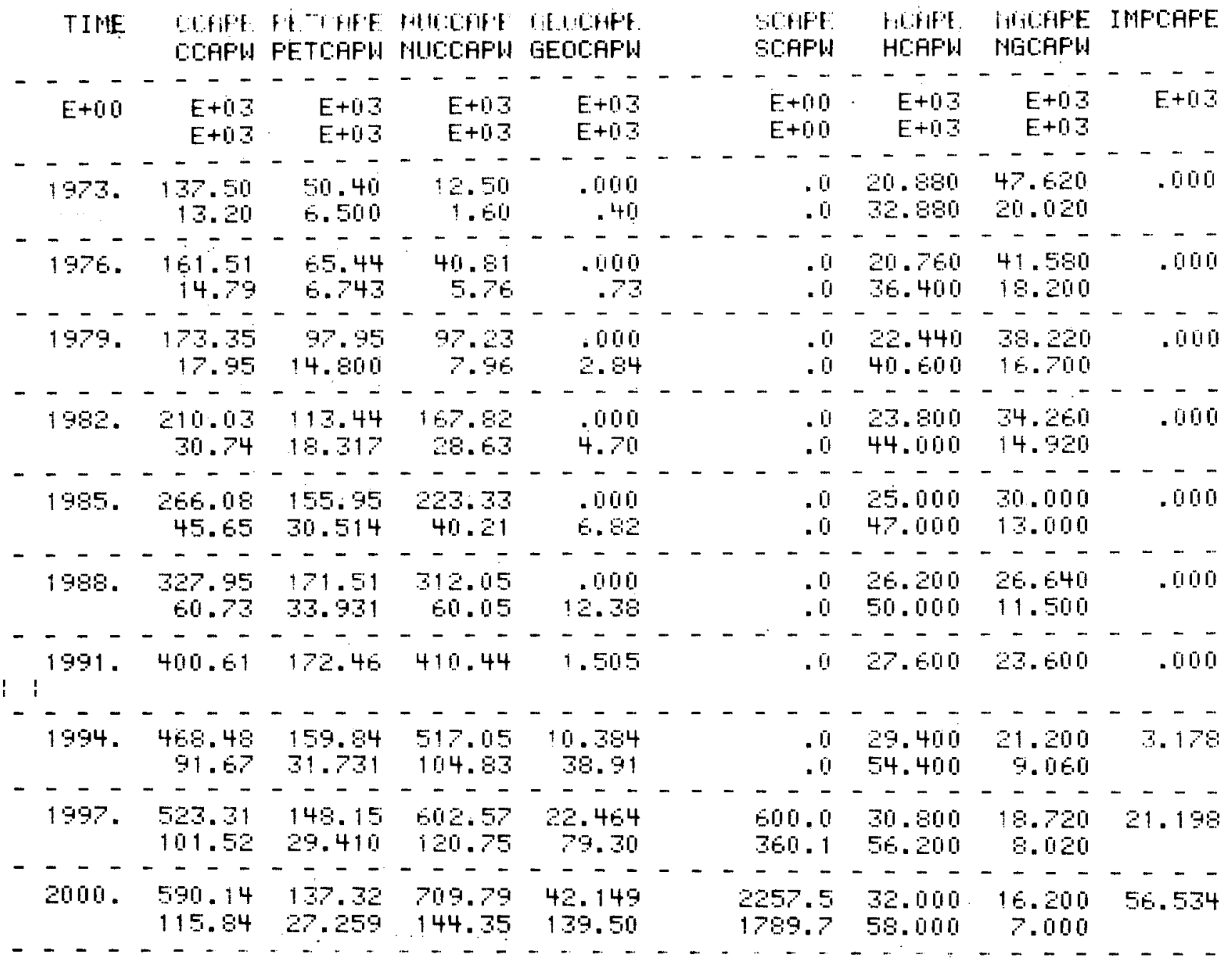

Figure E.4.16 FUEL AVAILABILITY DECISION WEIGHT DOUBLED (FAF=4) 


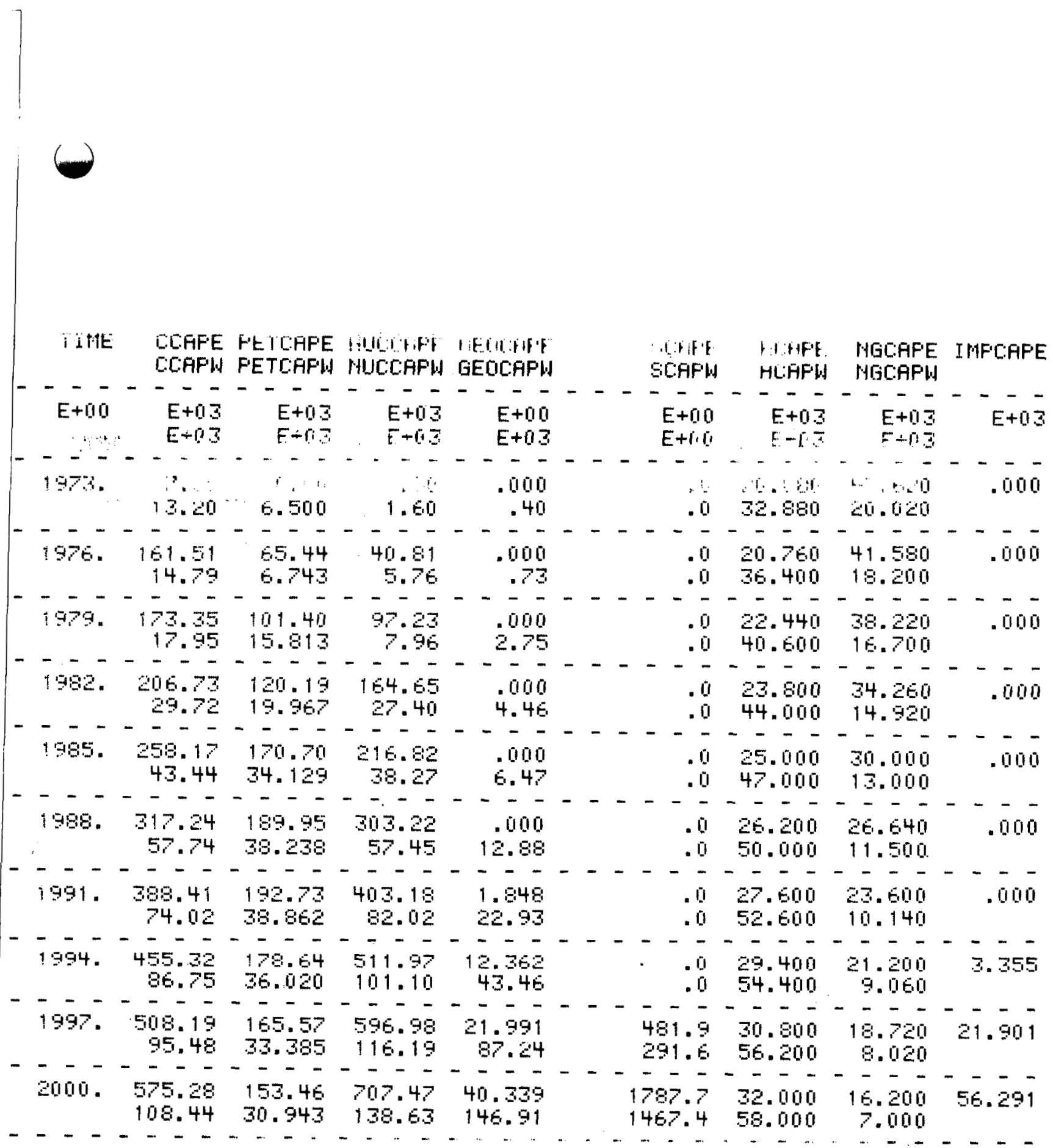

Figure E.4.17 FUEL AVAILABILITY DECISION WEIGHT HALVED (FAF $=1$ ) 


\begin{tabular}{|c|c|c|c|c|c|c|c|c|c|c|}
\hline TIME & $\begin{array}{l}\text { COHFE } \\
\text { CCAFW }\end{array}$ & $\begin{array}{l}\text { PE CAPE } \\
\text { PETCAPH }\end{array}$ & $\begin{array}{l}\text { YULCCAF } \\
\text { HUCCAP }\end{array}$ & $\begin{array}{l}\text { GEGICAPE } \\
\text { GEOCAPH }\end{array}$ & & & $\begin{array}{l}\text { SC:APE } \\
\text { SC:AFW }\end{array}$ & $\begin{array}{l}\text { HCAPE } \\
\text { HC:AFH }\end{array}$ & $\begin{array}{l}\text { MGCAPE } \\
\text { MGCAPW }\end{array}$ & IMPCAPE \\
\hline$E+-\overline{0}$ & $\begin{array}{c}-\overline{-} \\
E+03 \\
E+03\end{array}$ & $\begin{array}{r}E+03 \\
E+03\end{array}$ & $\begin{array}{r}E+03 \\
E+03\end{array}$ & $\begin{array}{r}E+03 \\
E+03\end{array}$ & & & $\begin{array}{c}-\overline{-} \\
E+00 \\
E+00\end{array}$ & $\begin{array}{r}E+03 \\
E+03\end{array}$ & $\begin{array}{r}E+03 \\
E+03\end{array}$ & $-c$ \\
\hline$\overline{1973 .}$ & $\begin{array}{r}--- \\
137.50 \\
13.20\end{array}$ & $\begin{array}{l}--\overline{-} \\
50.40 \\
6.500\end{array}$ & $\begin{array}{r}-\overline{-} \\
12.50 \\
1.60\end{array}$ & $\begin{array}{r}-7 \\
.000 \\
.40\end{array}$ & & & $\begin{array}{r}-- \\
.0 \\
.0\end{array}$ & $\begin{array}{l}--\overline{-} \\
20.880 \\
32.880\end{array}$ & $\begin{array}{l}-\overline{-} \\
47.1 \\
20.1\end{array}$ & $--\overline{0}$ \\
\hline$\overline{1978 .}$ & $\begin{array}{r}- \\
161.5 \\
14.79\end{array}$ & $\begin{array}{l}65.44 \\
6.743\end{array}$ & $\begin{array}{r}--- \\
40.81 \\
5.76\end{array}$ & $\begin{array}{r}-.0 \\
.000 \\
.73\end{array}$ & & & $\begin{array}{r}-0 \\
.0\end{array}$ & $\begin{array}{l}20.760 \\
36.400\end{array}$ & $\begin{array}{l}- \\
41 . \\
18 .\end{array}$ & $\begin{array}{r}-- \\
.00\end{array}$ \\
\hline$-\overline{-}$ & $\begin{array}{r}- \\
173.35 \\
17.95\end{array}$ & $\begin{array}{r}-\overline{97.47} \\
14.687\end{array}$ & $\begin{array}{r}-77.23 \\
7.96\end{array}$ & $\begin{array}{l}--- \\
.000 \\
2.80\end{array}$ & & & $--\overline{0}$ & $\begin{array}{l}-\overline{-} \overline{-} \\
22.440 \\
40.600\end{array}$ & $\begin{array}{l}-\overline{-}-\overline{1} \\
38.220 \\
16.700\end{array}$ & $-\overline{00}$ \\
\hline$\overline{1982 .}$ & $\begin{array}{r}- \\
211.1 \\
31.1\end{array}$ & $\begin{array}{r}-\overline{-}-\overline{1} \\
112.47 \\
10.117\end{array}$ & $\begin{array}{r}-\overline{-}- \\
167.56 \\
20.65\end{array}$ & $\begin{array}{l}--\overline{-} \\
.000 \\
4.79\end{array}$ & & & $-\overline{0}$ & $\begin{array}{r}-\overline{-}-\overline{0} \\
23.800 \\
44.000\end{array}$ & $\begin{array}{r}-\overline{-}-\overline{1} \\
34.260 \\
14.920\end{array}$ & $-\overline{0}-\overline{0}$ \\
\hline$\overline{1985 .}$ & $\begin{array}{r}-5 . \\
268.4 \\
46.3\end{array}$ & $\begin{array}{r}-\overline{-}- \\
15.32 \\
30.068\end{array}$ & $\begin{array}{r}-5-\overline{0} \\
223.05 \\
40.25\end{array}$ & $\begin{array}{r}--\overline{-} \\
.000 \\
7.01\end{array}$ & - & & $-\overline{0}$ & & $\begin{array}{c}-\overline{30} \\
13.0\end{array}$ & $-\overline{0}-00$ \\
\hline$\overline{1988 .}$ & $\begin{array}{r}-- \\
330.6 \\
61.6\end{array}$ & $\begin{array}{l}168.83 \\
33.344\end{array}$ & $\begin{array}{r}311 . \\
60.1\end{array}$ & $\begin{array}{r}-\overline{0} \\
12000\end{array}$ & & & - & $\begin{array}{l}-\overline{-} \\
26.200 \\
50.000\end{array}$ & $\begin{array}{c}- \\
26 . \\
11 .\end{array}$ & $--\overline{0}$ \\
\hline$\overline{199}$ & $\begin{array}{r}-- \\
403.5 \\
79.1\end{array}$ & $\begin{array}{r}-\overline{169} \\
1690 \\
33.613\end{array}$ & $\begin{array}{r}-5- \\
410.2 \\
85.1\end{array}$ & $\begin{array}{r}-.- \\
2.364 \\
20.27\end{array}$ & & & - - & & & $--\overline{0}$ \\
\hline 1994. & $\begin{array}{r}471 \\
93\end{array}$ & $\begin{array}{l}157.10 \\
31.155\end{array}$ & $\begin{array}{c}-\overline{-} \\
517.4 \\
105.8\end{array}$ & $\begin{array}{l}-\overline{-}- \\
9.527 \\
37.08\end{array}$ & & & .0 & $\begin{array}{l}-\overline{-}-\overline{-} \\
29.400 \\
54.400\end{array}$ & $\begin{array}{r}-5 \\
21.0 \\
9.0\end{array}$ & $\begin{array}{l}-\overline{3} \\
3.15\end{array}$ \\
\hline$\overline{199}$ & $\begin{array}{c}- \\
526 \\
103\end{array}$ & $\begin{array}{r}-\overline{145.61} \\
28.876\end{array}$ & $\begin{array}{r}--\overline{-} \\
604.2 \\
122.3\end{array}$ & $\begin{array}{r}-\overline{-7} \\
76.14\end{array}$ & & & $\begin{array}{l}-\overline{-} \\
629.5 \\
379.2\end{array}$ & $\begin{array}{l}-\overline{-}-\overline{-} \\
30.800 \\
56.200\end{array}$ & $\begin{array}{r}-\overline{-}-\overline{1} \\
19.720 \\
9.020\end{array}$ & $\begin{array}{r}-\overline{2} \\
21.24\end{array}$ \\
\hline 2000 & $\begin{array}{r}-\overline{-}- \\
592.01 \\
118.20\end{array}$ & $\begin{array}{l}-\overline{3} \\
26.7\end{array}$ & $\begin{array}{r}-\overline{1}-\overline{1} \\
146.84\end{array}$ & $\begin{array}{r}-\overline{-}-\overline{1} \\
41.106 \\
135.14\end{array}$ & & & $\begin{array}{l}-\overline{-}-\overline{8} \\
2386.5 \\
1879.8\end{array}$ & $\begin{array}{r}-\overline{-}-\overline{0} \\
32.000 \\
58.000\end{array}$ & $\begin{array}{r}-\overline{-}- \\
16.200 \\
7.000\end{array}$ & $-\overline{56} . \overline{8}$ \\
\hline
\end{tabular}

Figure E.4.18 DECISION WEIGHT SET PESSIMISTIC FOR GEOTHERMAL DEVELOPMENT 


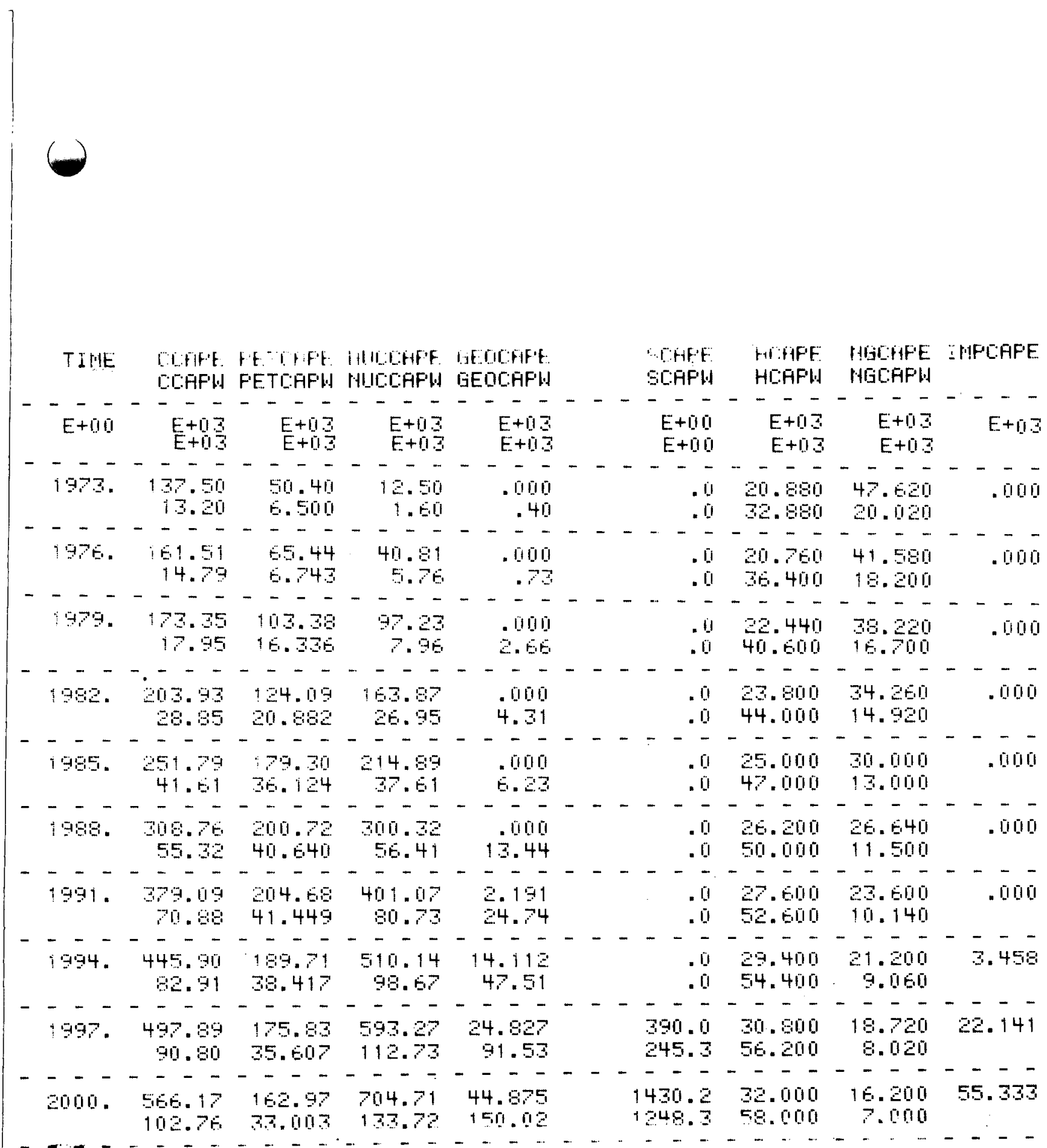

Figure E.4.19 DECISION WEIGHT SET OPTIMISTIC

FOR GEOTHERMAL DEVELOPMENT 


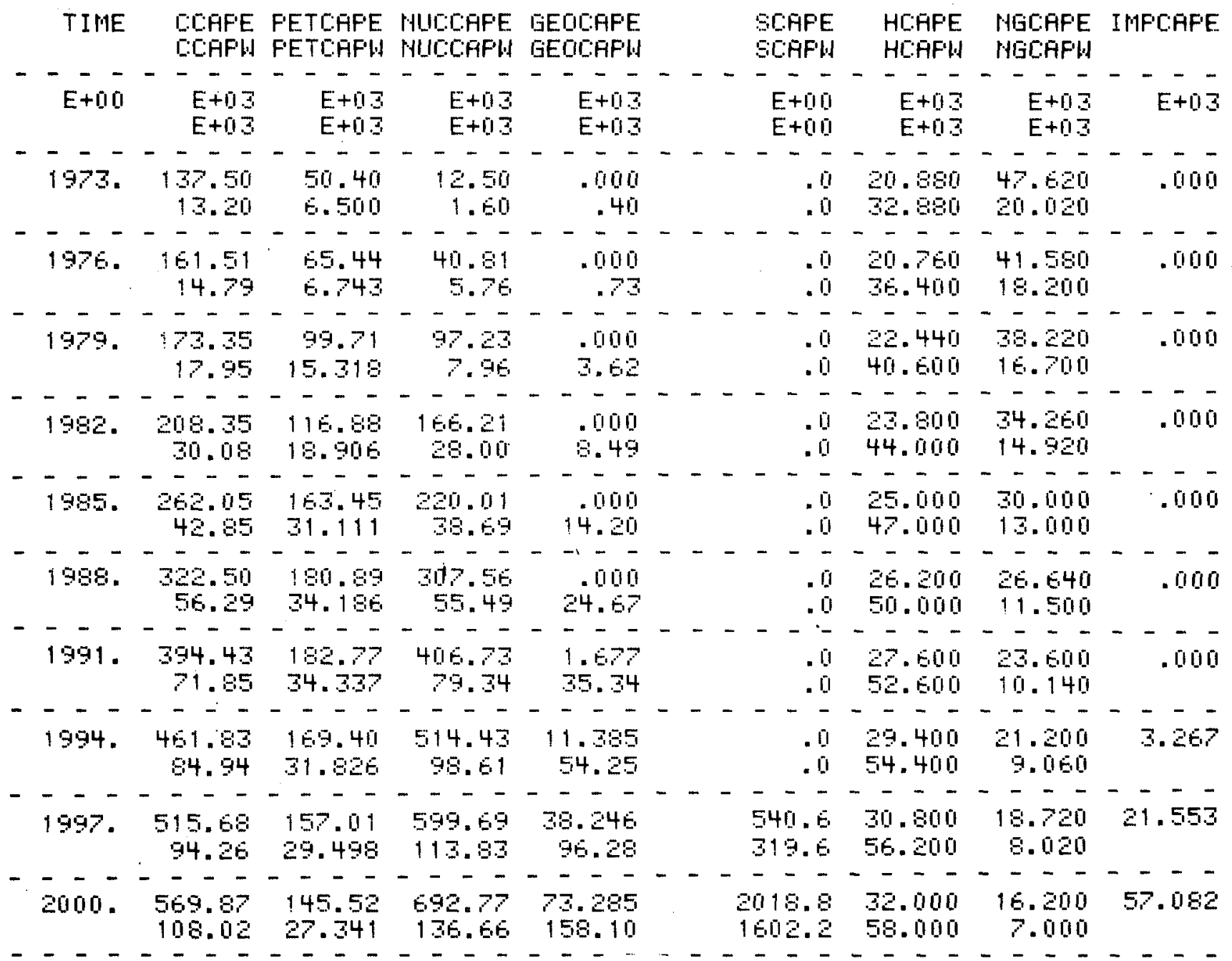

Figure E.4.20 GEOTHERMAL RESOURCES DOUBLED 


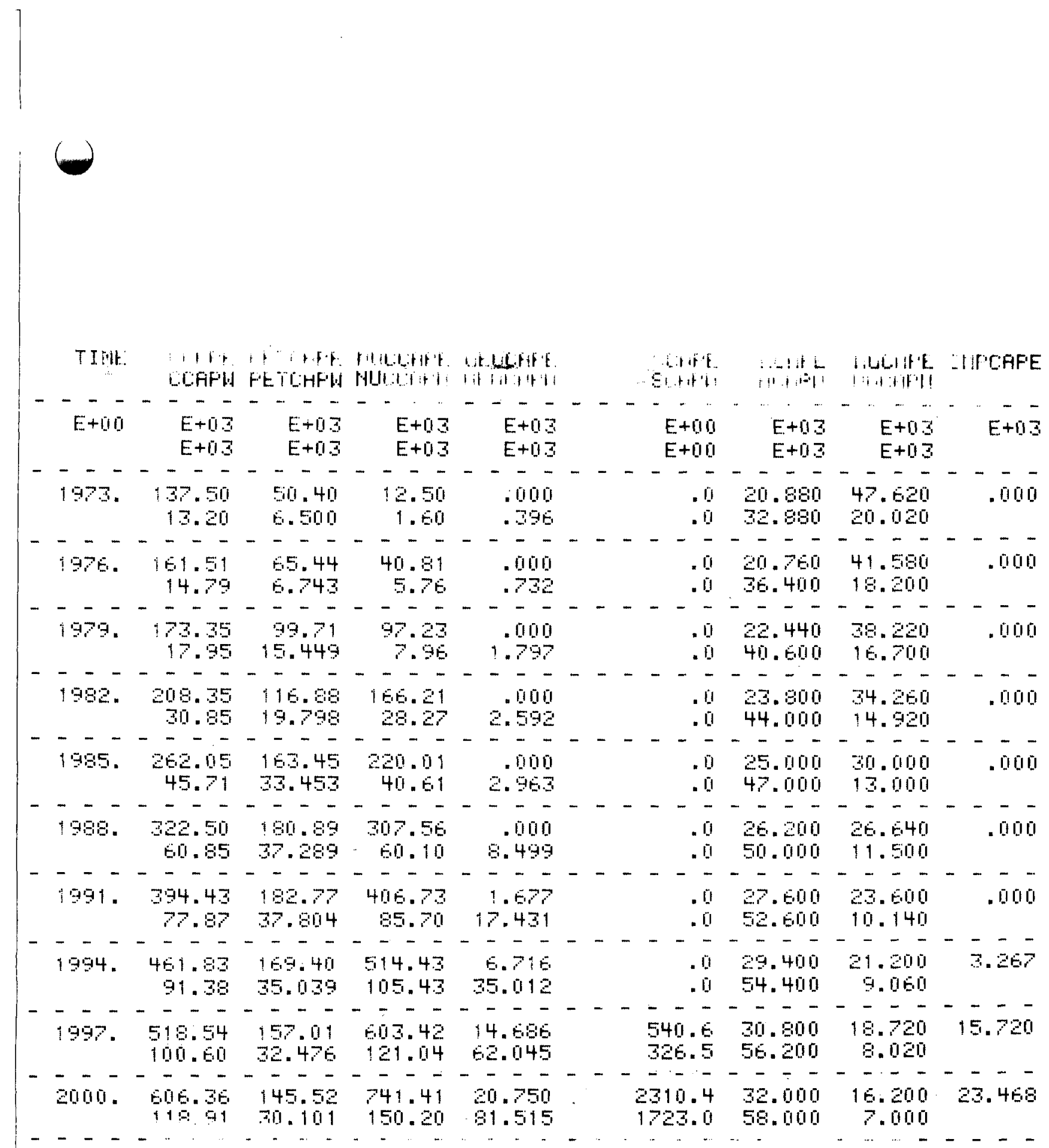

Figure E.4.21 GEOTHERMAL RESOURCES HALVED 


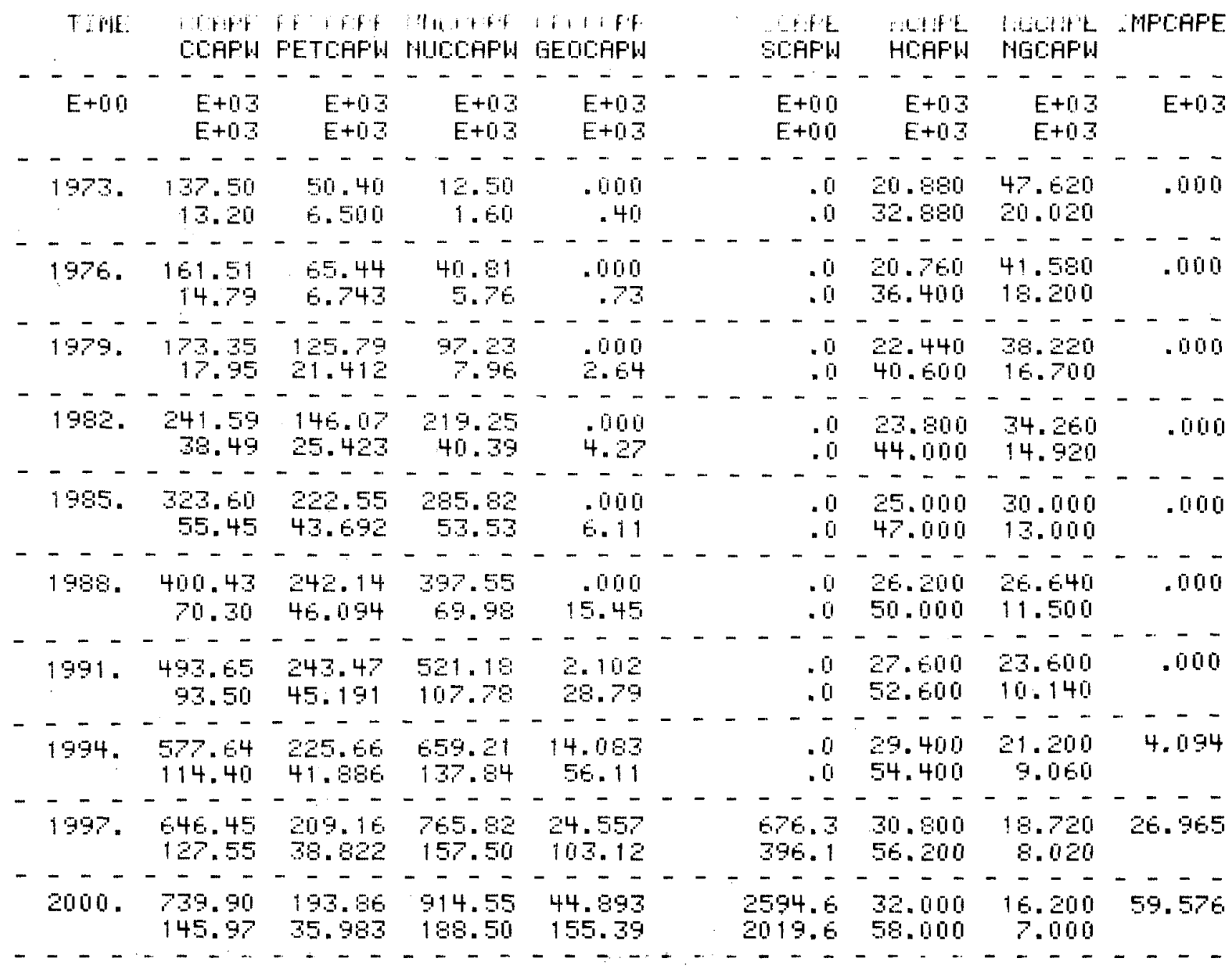

Figure E.4.22 DEMAND INCREASED BY 25 PERCENT 


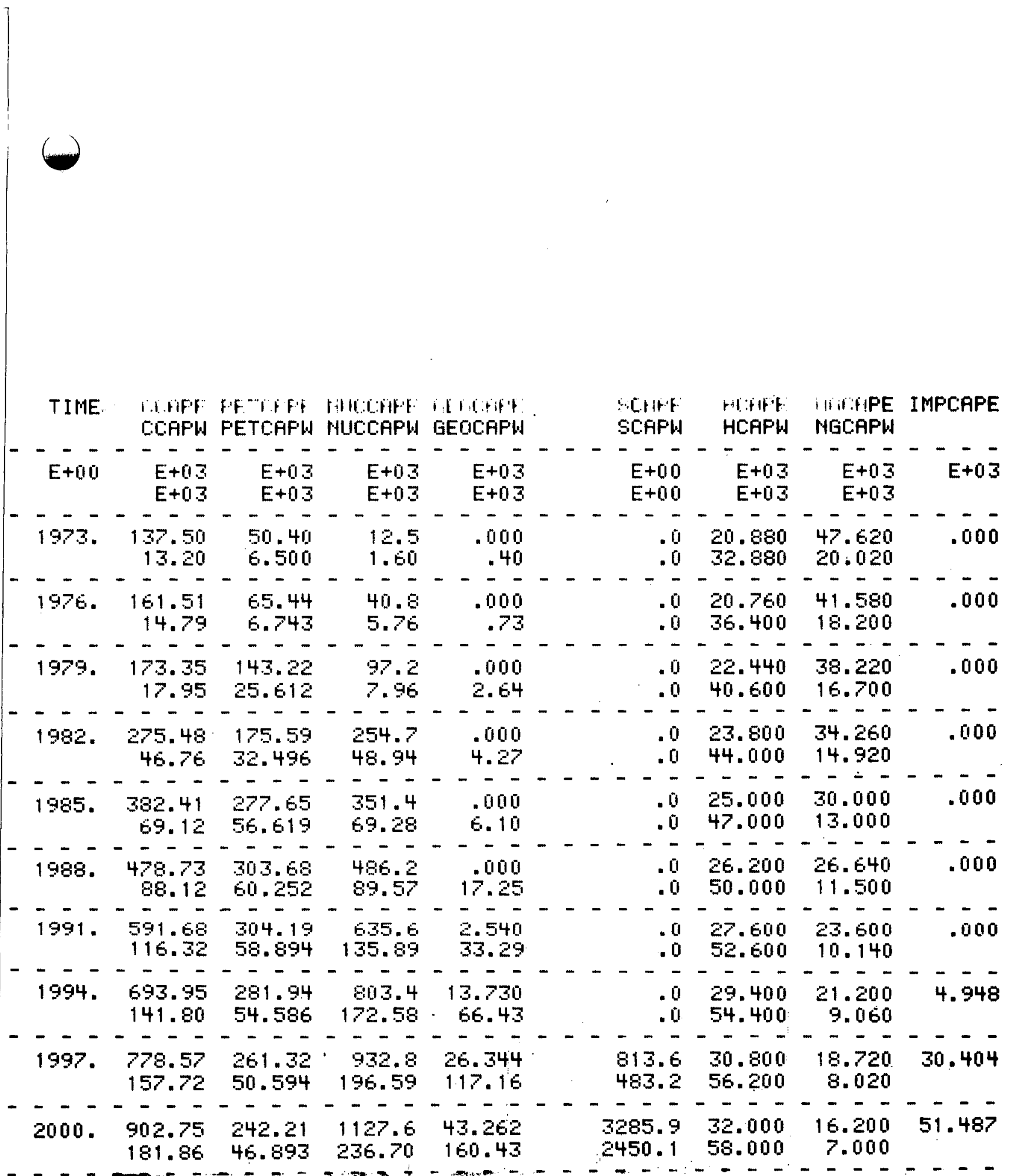

Figure E.4.23 DEMAND INCREASED BY 50 PERCENT 
TIME CEAFE FETCAFE HULCAFE GEOCAFE CCAFW FETCAFW WUCCAFW GEOCAFW

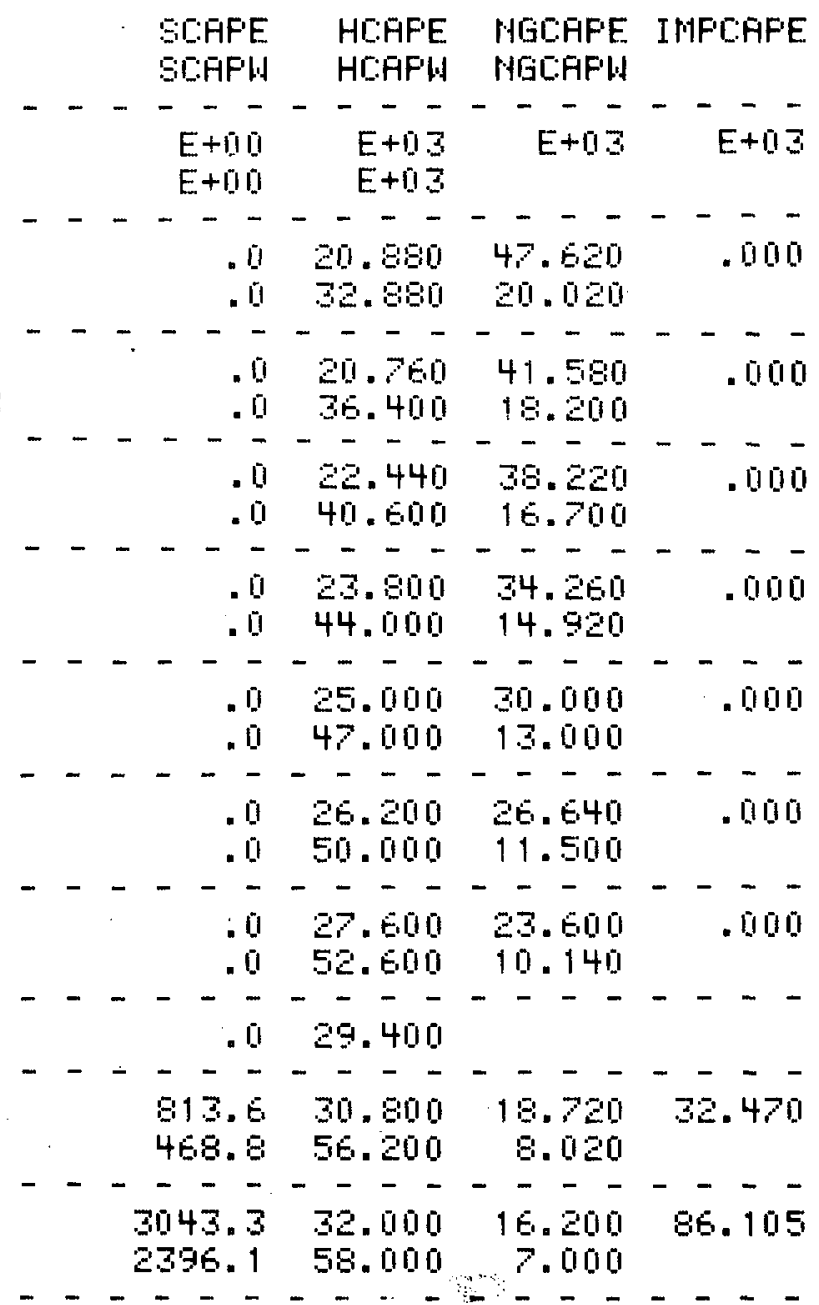

Figure E.4.24 DEMAND INCREASED BY 50 PERCENT AND

GEOTHERMAL RESOURCES INCREASED TO LIMIT

OF TECHNICAL DEVELOPMENT POLICY 


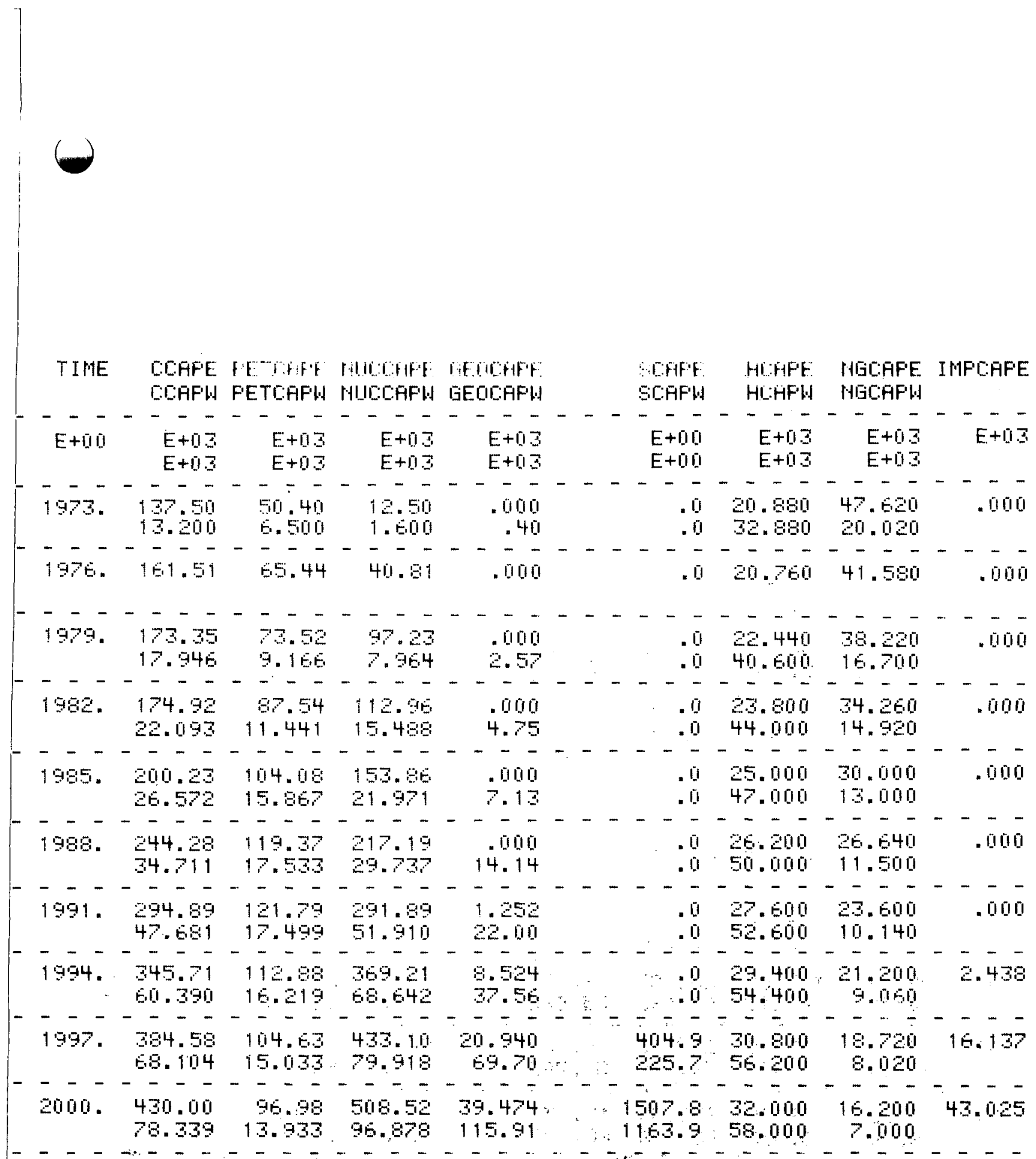

Figure E.4.25 DEMAND DECREASED BY 25 PERCENT 


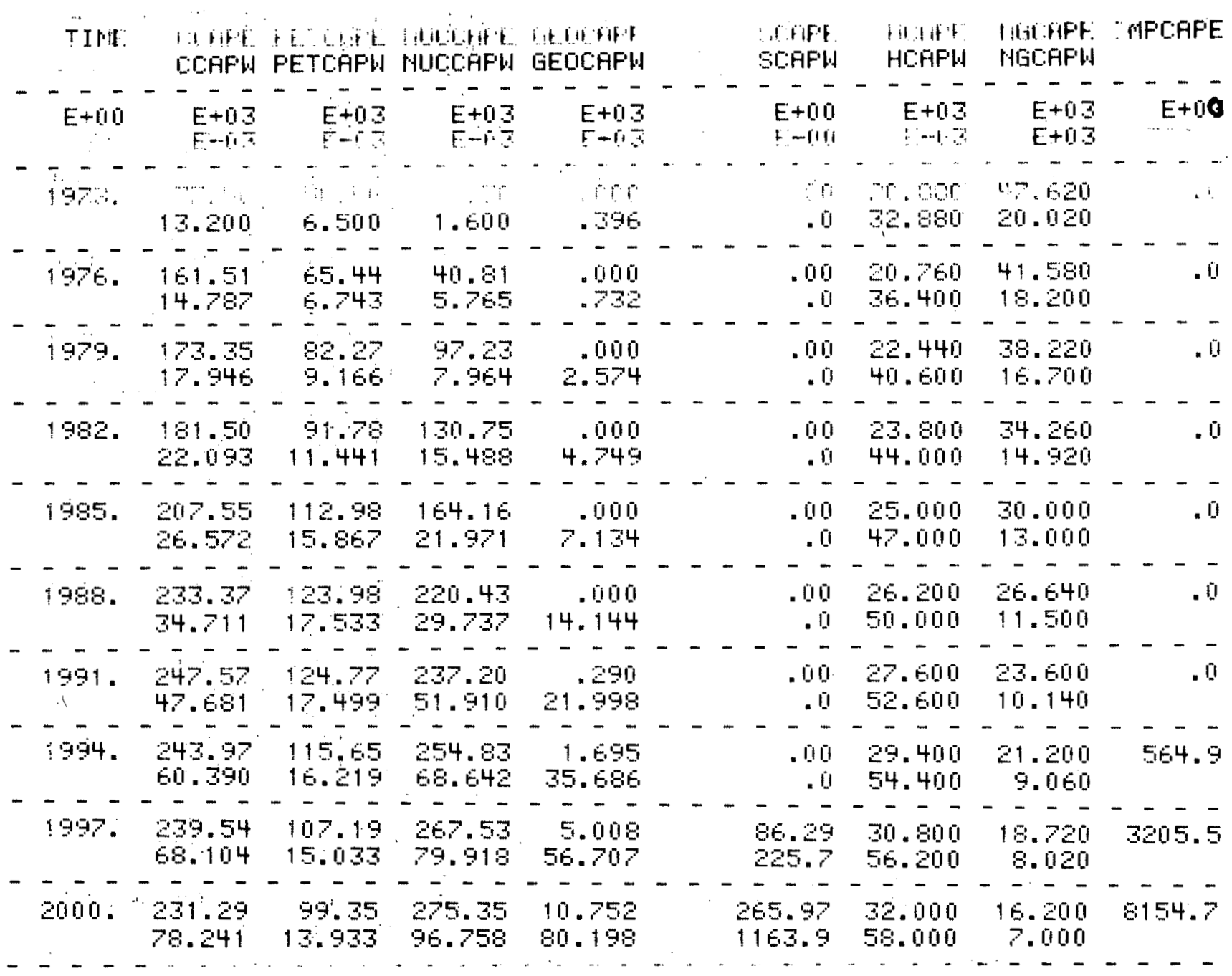

Figure E.4.26 NO GROWTH IN DEMAND AFTER 1990 


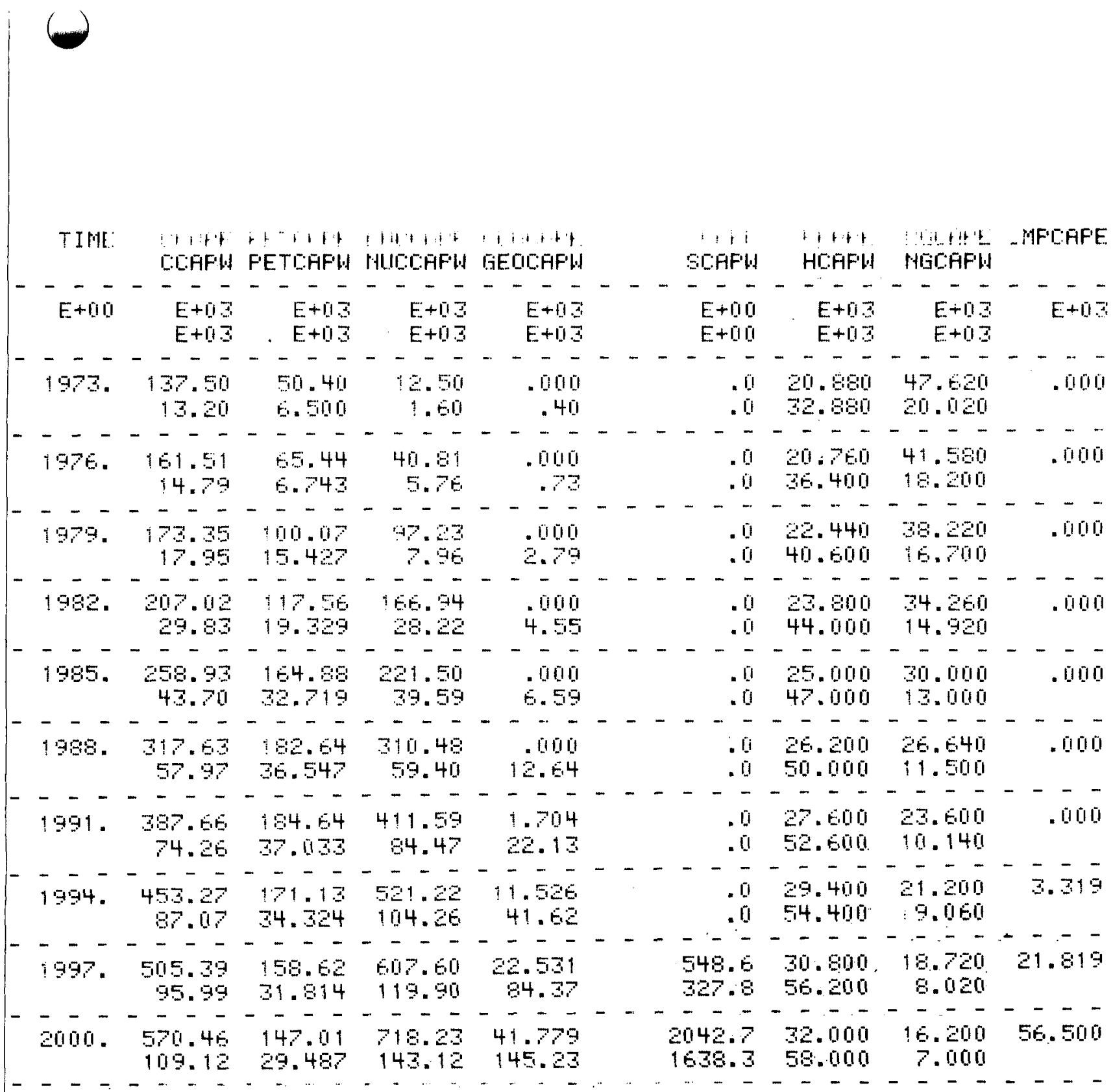

Figure E.4.27 COAL ELECTRICITY GENERATION

COSTS INCREASED BY 50 PERCENT 


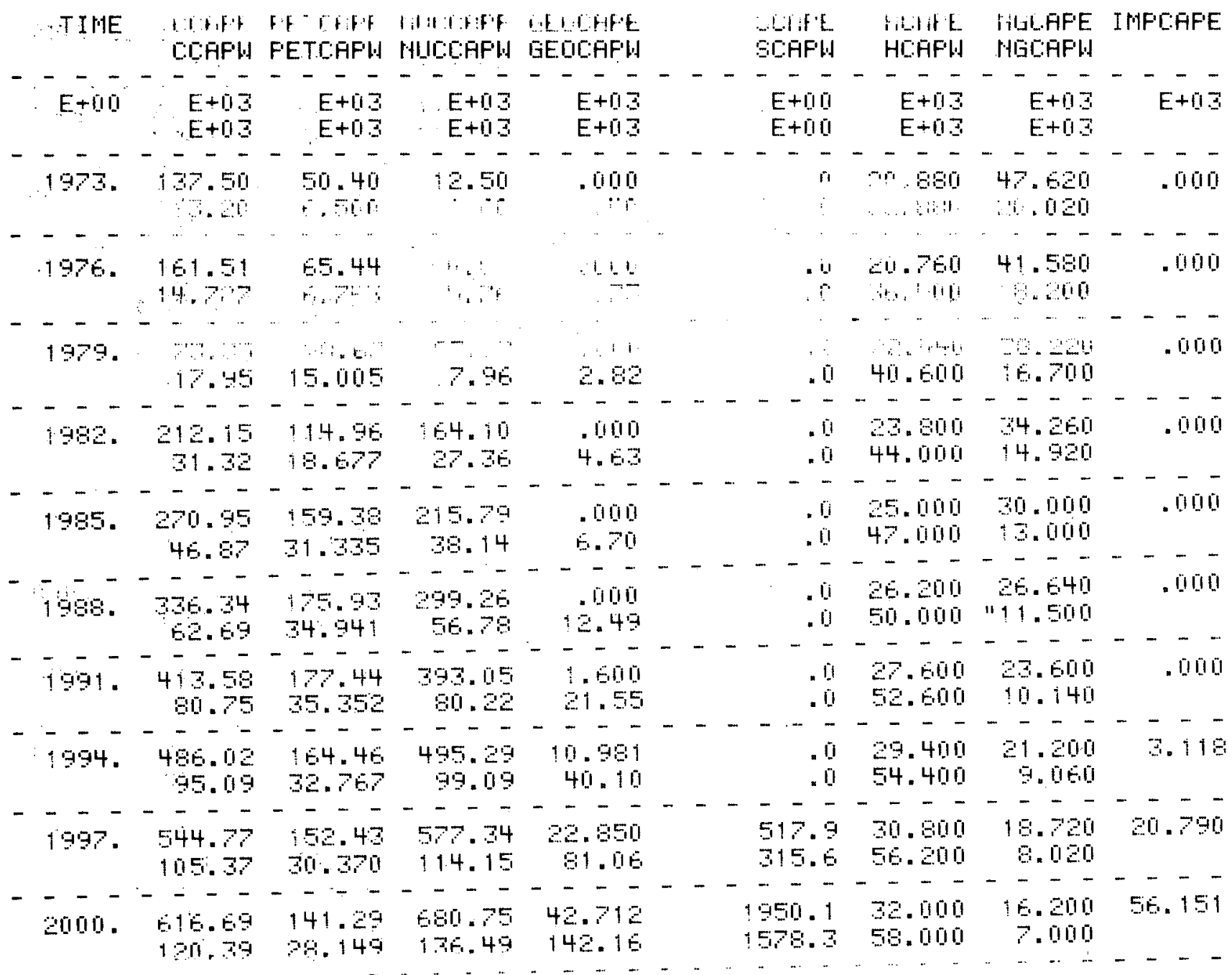

Figure E.4.28 COAL ELECTRICITY GENERATION COSTS DECREASED BY 50 PERCENT 


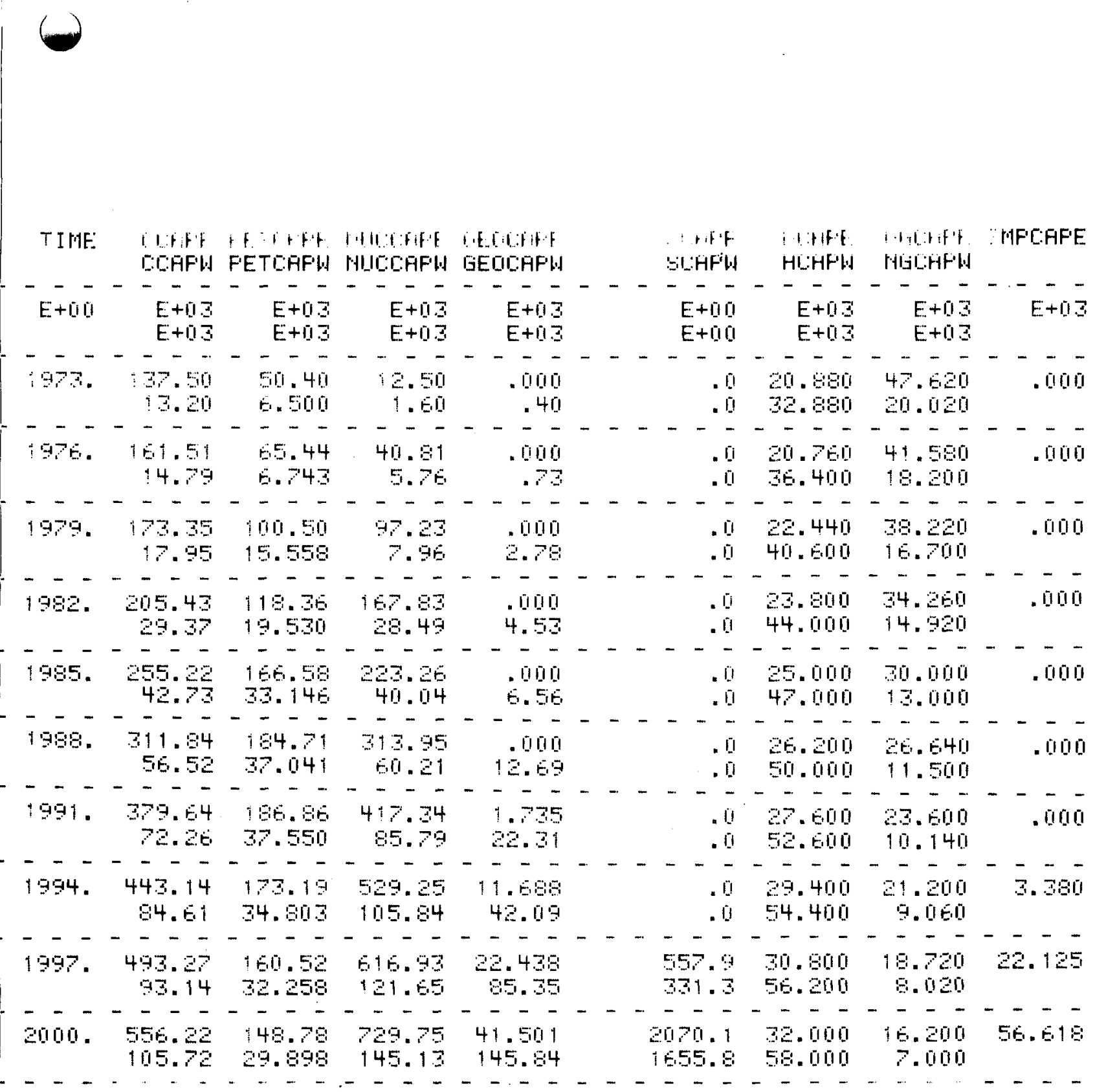

Figure E.4.29 COAL ELECTRICITY GENERATION COSTS AND CAPITAL INVESTMENT COSTS INCREASED BY 50 PERCENT 


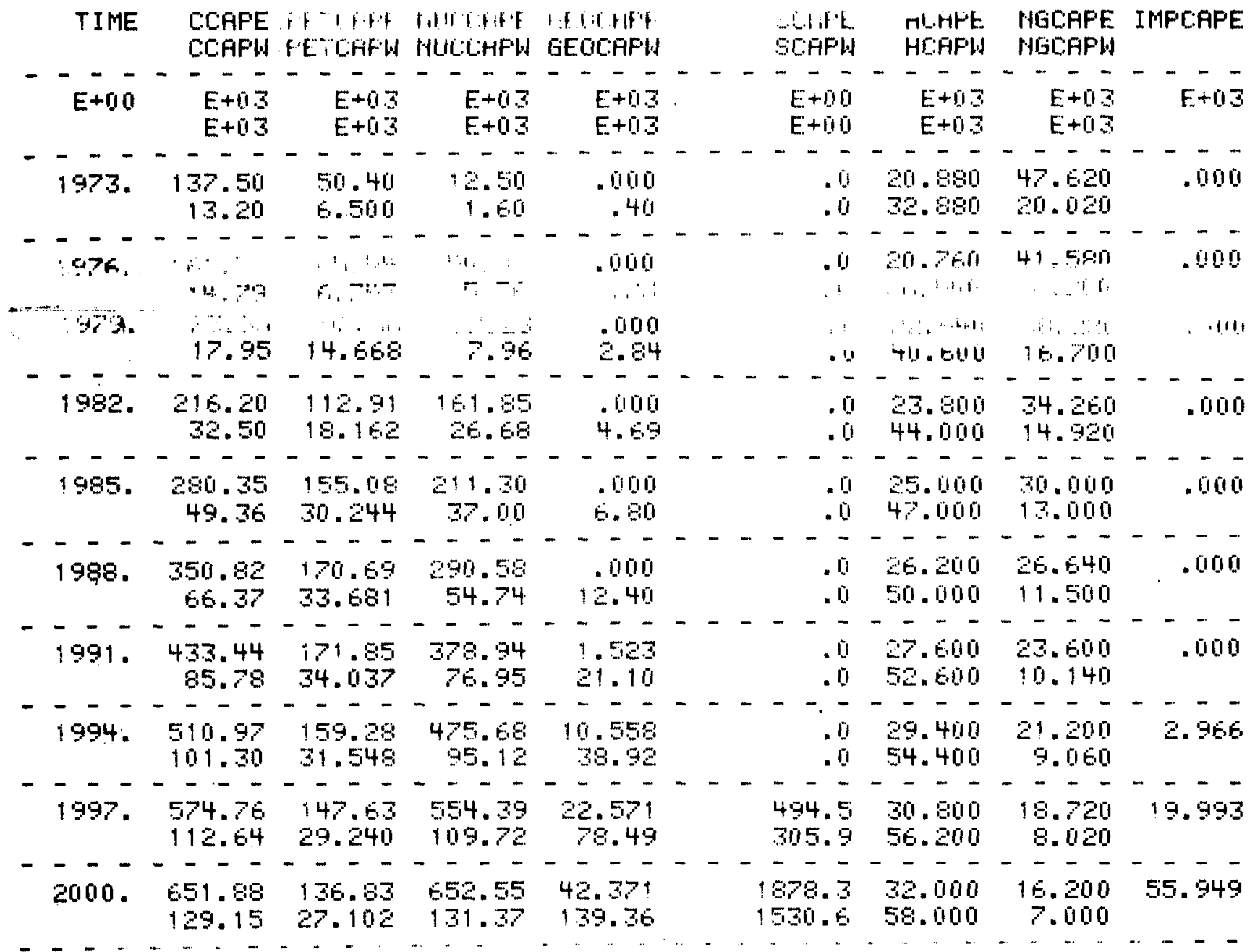

Figure E.4.30 COAL ELECTRICITY GENERATION COSTS AND CAPITAL INVESTMENT COSTS

DECREASED BY 50 PERCENT 


\begin{tabular}{|c|c|c|c|c|c|c|c|c|c|c|c|c|}
\hline & $T I$ & $\begin{array}{c}\text { IA } \\
\text { CLAFH }\end{array}$ & FETEFFW & $\begin{array}{l}\text { HCLAF } \\
\text { NUCERFH }\end{array}$ & $\begin{array}{l}\text { G } \\
\text { GEQIEFFW }\end{array}$ & & & & $\begin{array}{l}\text { SEAPW } \\
\text { SEA }\end{array}$ & $\begin{array}{c}1: t \\
\text { HCFFW }\end{array}$ & $\begin{array}{l}\text { HIL:AFW } \\
\text { MLW }\end{array}$ & IN \\
\hline & $-\bar{E}+\overline{0}$ & $\begin{array}{r}--\overline{-} \\
E+0 \Xi \\
E+0 \Xi\end{array}$ & $\begin{array}{r}--- \\
E+0 \Xi \\
E+0 \Xi\end{array}$ & $\begin{array}{r}--\overline{ } \\
E+03 \\
E+03\end{array}$ & $\begin{array}{r}E+03 \\
E+0 \Xi\end{array}$ & - & - & & $\begin{array}{c}-\overline{-} \\
E+\square 0 \\
E+00\end{array}$ & $\begin{array}{r}--\overline{ } \\
E+0 \Xi \\
E+11 \Xi\end{array}$ & $\begin{array}{r}-E- \\
E+0 \Xi \\
E+03\end{array}$ & $-\frac{-}{E+i}$ \\
\hline & $\begin{array}{l}- \\
1973 .\end{array}$ & $\begin{array}{r}--- \\
17.50 \\
13.20\end{array}$ & $\begin{array}{r}---- \\
50.40 \\
E .500\end{array}$ & $\begin{array}{r}--- \\
i=50 \\
1.50\end{array}$ & $\begin{array}{r}-5 \\
.001 \\
.40\end{array}$ & - & - & & $\begin{array}{r}- \\
-\quad- \\
.11 \\
.0\end{array}$ & $\begin{array}{r}--- \\
-10.900 \\
\text { J. Bgi }\end{array}$ & $\begin{array}{r}-\overline{-} \\
47.620 \\
20.020\end{array}$ & -5 \\
\hline & - & $\begin{array}{r}---- \\
161.51 \\
14.79\end{array}$ & $\begin{array}{l}--- \\
5.54 \\
5.743\end{array}$ & $\begin{array}{r}--5 \\
40.51 \\
5.76\end{array}$ & $\begin{array}{r}-- \\
.0010 \\
73\end{array}$ & - & - & - & $\begin{array}{r}- \\
- \\
.01 \\
.01\end{array}$ & 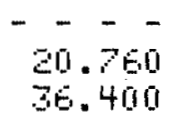 & 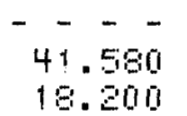 & $---\overline{0}$ \\
\hline & - & $\begin{array}{r}-75 \\
17.35\end{array}$ & $\begin{array}{r}---5 \\
98.57 \\
14.975\end{array}$ & $\begin{array}{r}-\overline{-} \\
97 . \overline{3} \\
7.95\end{array}$ & $\begin{array}{r}-5- \\
.000 \\
2.32\end{array}$ & - & - & - & $\begin{array}{r}-- \\
.0 \\
.0\end{array}$ & 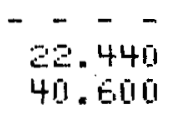 & $\begin{array}{r}-\overline{-}- \\
3 \theta .220 \\
1 E .700\end{array}$ & $--\overline{0}$ \\
\hline & -582. & $\begin{array}{r}- \\
20 E . Z 1 \\
2 G .60\end{array}$ & $\begin{array}{r}-\overline{-}- \\
14.75 \\
19.53\end{array}$ & $\begin{array}{r}-\overline{-}- \\
17.57 \\
29.47\end{array}$ & $\begin{array}{r}-- \\
400 \\
4.0\end{array}$ & - & - & - & $\begin{array}{r}-\quad- \\
.01 \\
01\end{array}$ & 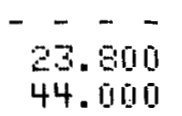 & $\begin{array}{r}-\quad-- \\
34.251 \\
14.920\end{array}$ & $\begin{array}{r}- \\
.00 \\
.01\end{array}$ \\
\hline & $-\overline{1905 .}$ & $\begin{array}{r}---- \\
25.7 .07 \\
43.30\end{array}$ & $\begin{array}{r}---- \\
156.95 \\
31.275\end{array}$ & $\begin{array}{r}--- \\
-29.71 \\
41.59\end{array}$ & $\begin{array}{r}-5- \\
000 \\
8.71\end{array}$ & - & - & - & $--\overline{1}$ & $\begin{array}{r}-\overline{-}-\overline{-} \\
25.0100 \\
47.0100\end{array}$ & $\begin{array}{r}-\overline{-}- \\
30.000 \\
13.000\end{array}$ & $\begin{array}{r}-- \\
.010\end{array}$ \\
\hline & 1988. & $\begin{array}{r}---- \\
313.32 \\
57.08\end{array}$ & $\begin{array}{r}---- \\
175.42 \\
34.819\end{array}$ & $\begin{array}{r}- \\
32.11 \\
62.43\end{array}$ & $\begin{array}{r}-0 . \\
100 \\
-42\end{array}$ & - & - & - & $\begin{array}{r}- \\
.0 \\
.0\end{array}$ & $\begin{array}{r}-\overline{-}-\bar{Z} \\
2 G \cdot \overrightarrow{0} \\
50.000\end{array}$ & $\begin{array}{l}-\overline{0} \\
\bar{E}, 50 \\
11.500\end{array}$ & -50 \\
\hline & $\begin{array}{l}- \\
1991 .\end{array}$ & $\begin{array}{r}---- \\
399.64 \\
72.77\end{array}$ & $\begin{array}{r}---- \\
17 E .66 \\
75.216\end{array}$ & $\begin{array}{r}---- \\
425.95 \\
68.65\end{array}$ & $\begin{array}{r}-- \\
1.5 E \\
21.33\end{array}$ & - & - & - & $--\overline{0}$ & 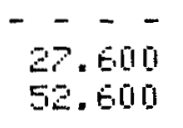 & $\begin{array}{r}-\overline{-}- \\
23.600 \\
10.140\end{array}$ & $--\frac{-}{.010}$ \\
\hline & $\overline{1994 .}$ & $\begin{array}{r}-\overline{-}-\overline{ } \\
441.49 \\
65.15\end{array}$ & $\begin{array}{r}---- \\
163.92 \\
32.64 \pi\end{array}$ & 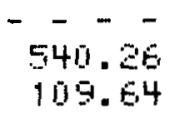 & $\begin{array}{r}-\overline{-} \\
10.703 \\
39.51\end{array}$ & - & & & $\begin{array}{r}-- \\
.01\end{array}$ & $\begin{array}{r}-\overline{-}- \\
29.400 \\
54.400\end{array}$ & $\begin{array}{r}--5- \\
21.200 \\
9.060\end{array}$ & $\begin{array}{l}- \\
3.047\end{array}$ \\
\hline & $-\overline{1997}$ & $\begin{array}{r}---\overline{-} \\
491.08 \\
93.94\end{array}$ & $\begin{array}{r}-\overline{-}- \\
151.93 \\
30.253\end{array}$ & $\begin{array}{r}--\overline{31.17} \\
125.34\end{array}$ & $\begin{array}{r}-\overline{-}- \\
22.759 \\
79.55\end{array}$ & - & - & & $\begin{array}{l}-\overline{-} \\
505.0 \\
310.1\end{array}$ & 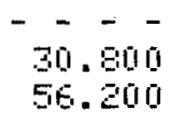 & $\begin{array}{r}---- \\
19.720 \\
8.020\end{array}$ & $\begin{array}{r}- \\
20.26\end{array}$ \\
\hline & $\begin{array}{l}- \\
2000 .\end{array}$ & -5. & $\begin{array}{r}-\overline{-}-\overline{2} \\
140.62 \\
28.040\end{array}$ & $\begin{array}{r}---\overline{-} \\
744.93 \\
151.25\end{array}$ & $\begin{array}{r}-\overline{-}-\overline{5} \\
42.533 \\
140.54\end{array}$ & - & - & & $\begin{array}{l}--\overline{-} \\
901.5 \\
1541.9\end{array}$ & $\begin{array}{r}-\overline{-}- \\
52.0100 \\
58.000\end{array}$ & $\begin{array}{r}16.200 \\
7.000\end{array}$ & -56.08 \\
\hline
\end{tabular}

Figure E.4.32 NUCLEAR ELECTRICITY GENERATION COSTS DECREASED BY 50 PERCENT 


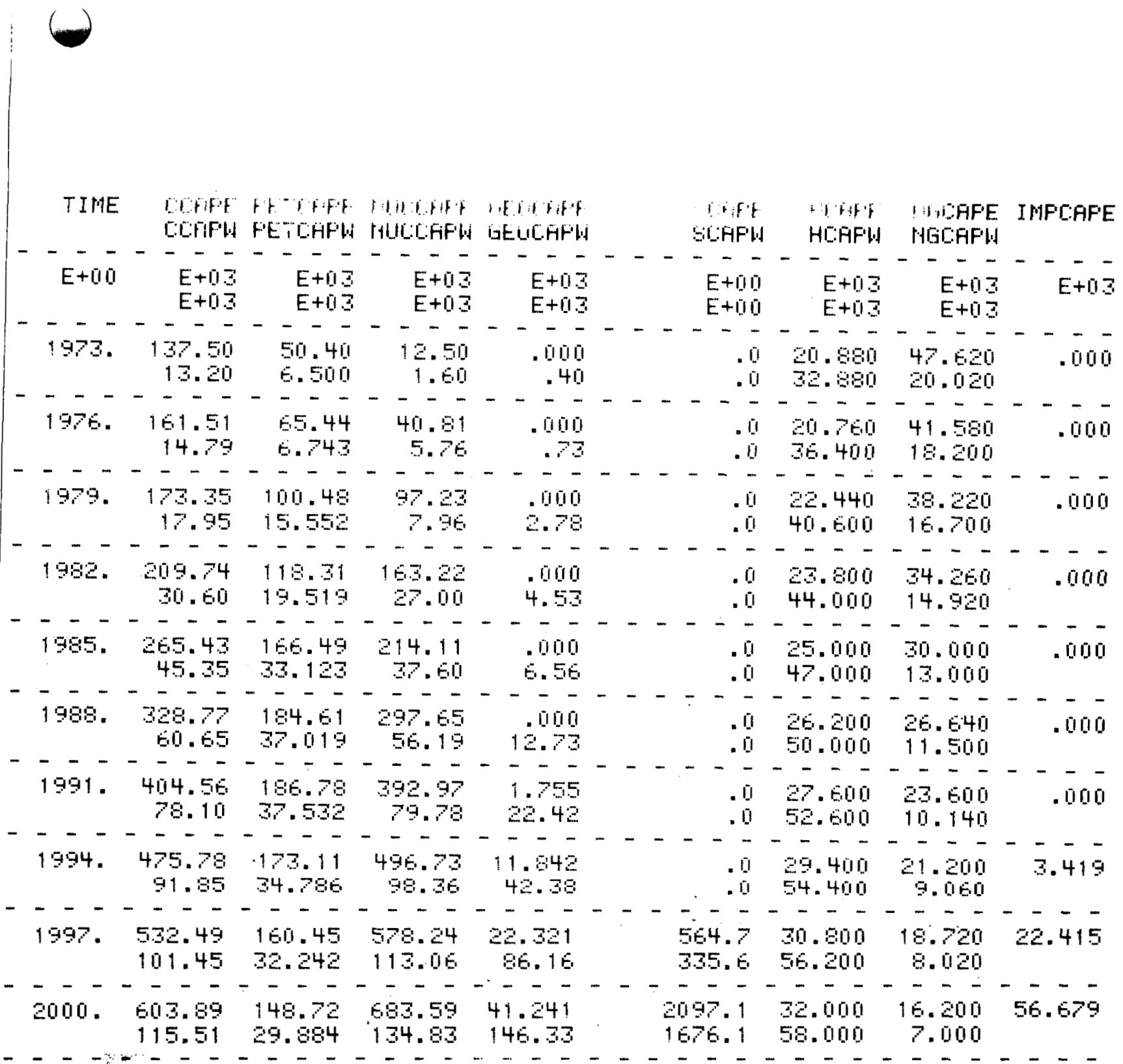

Figure E.4.33 NUCLEAR ELECTRICITY GENERATION

COSTS AND CAPITAL INVESTMENT

COST INCREASED BY 50 PERCENT 


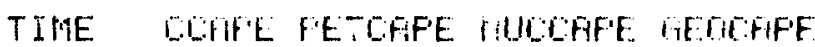
DCEFW FETCAFW HUCEAFW GEGCAFW

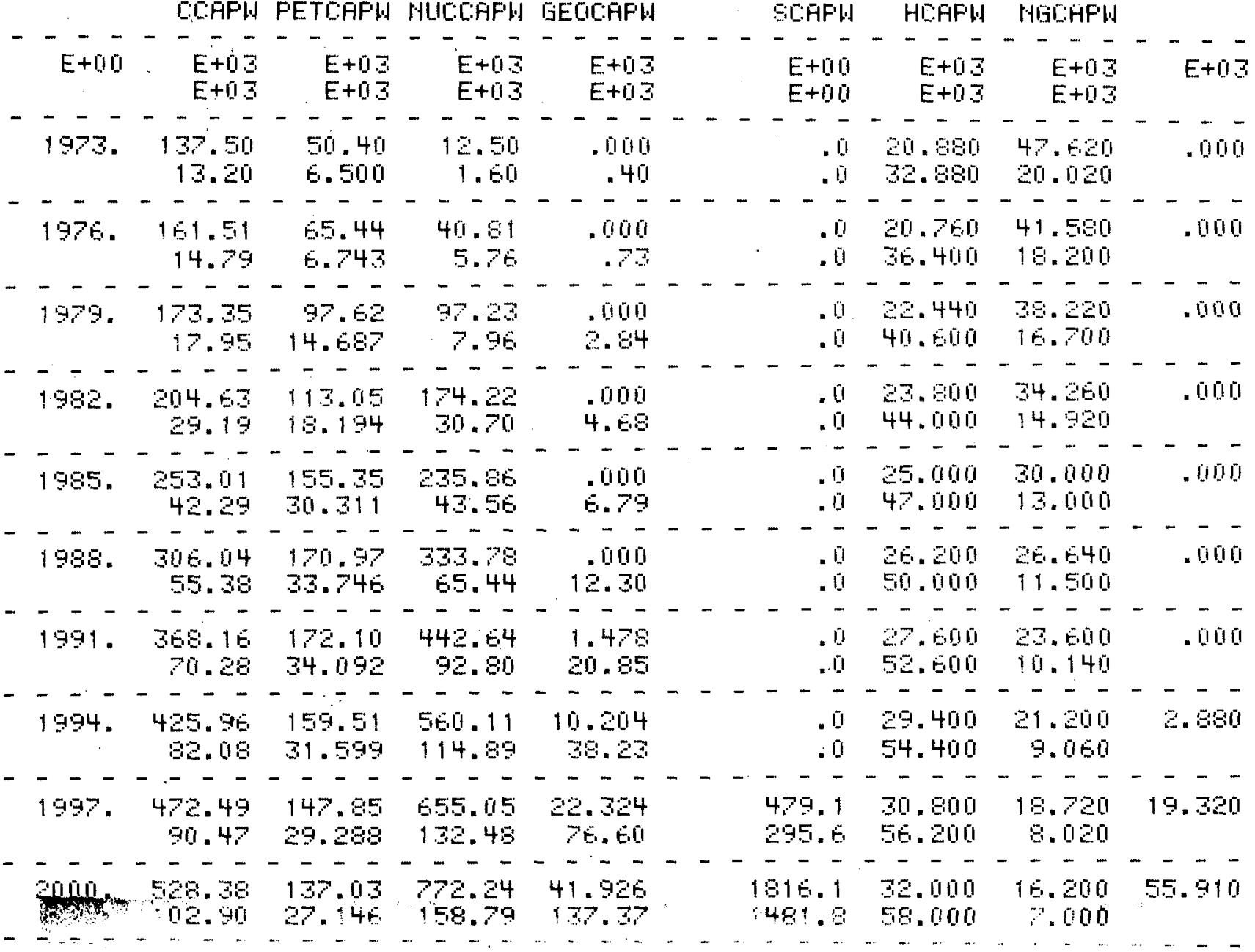

Figure E.4.34 NUCLEAR ELECTRICITY GENERATION COSTS AND CAPITAL INVESTMENT COST DECREASED BY 50 PERCENT 


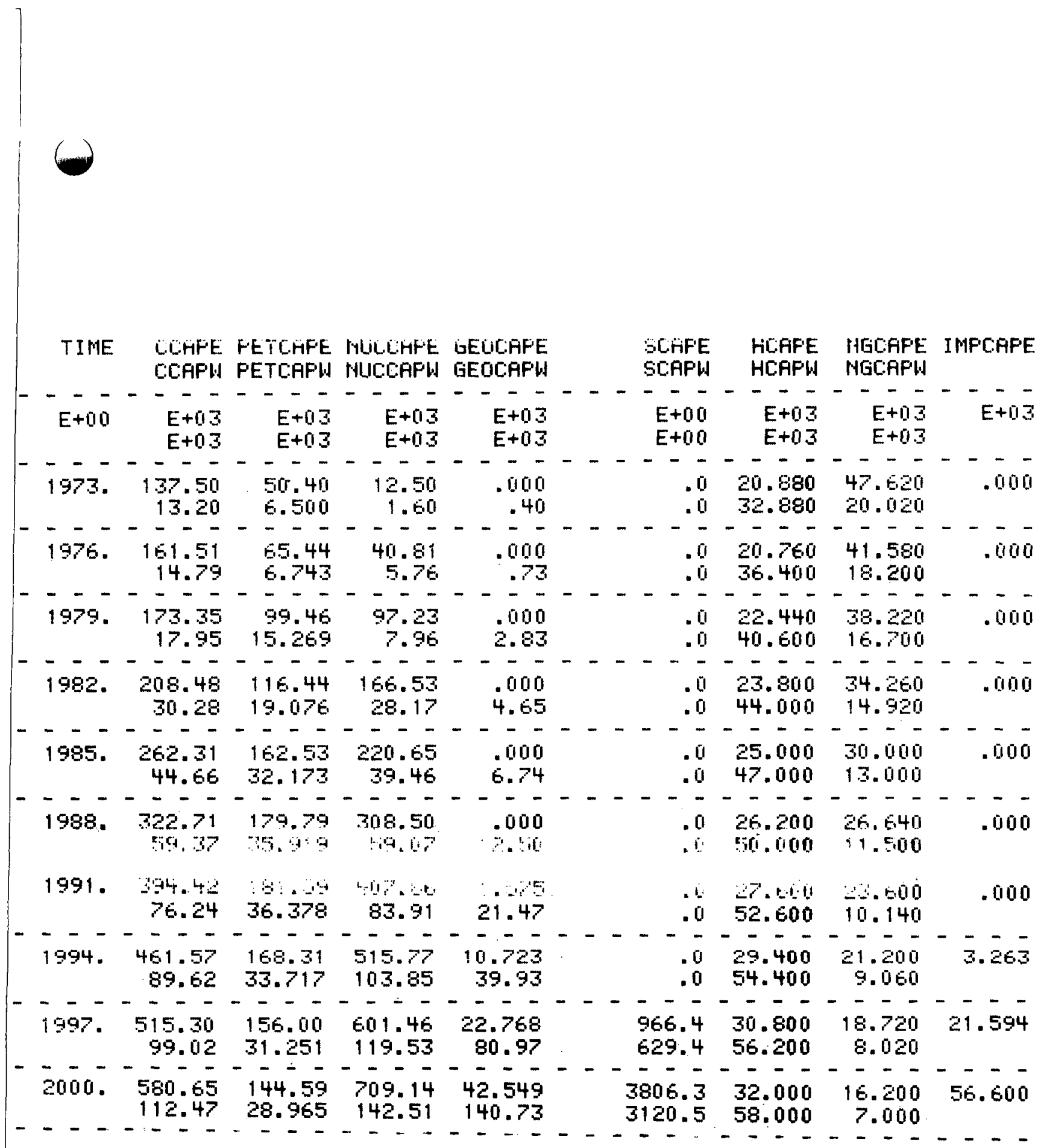

FIgure E.4.35 GEOTHERMAL ELECTRICITY GENERATION

COSTS INCRRASED BY 50 PERCENT 


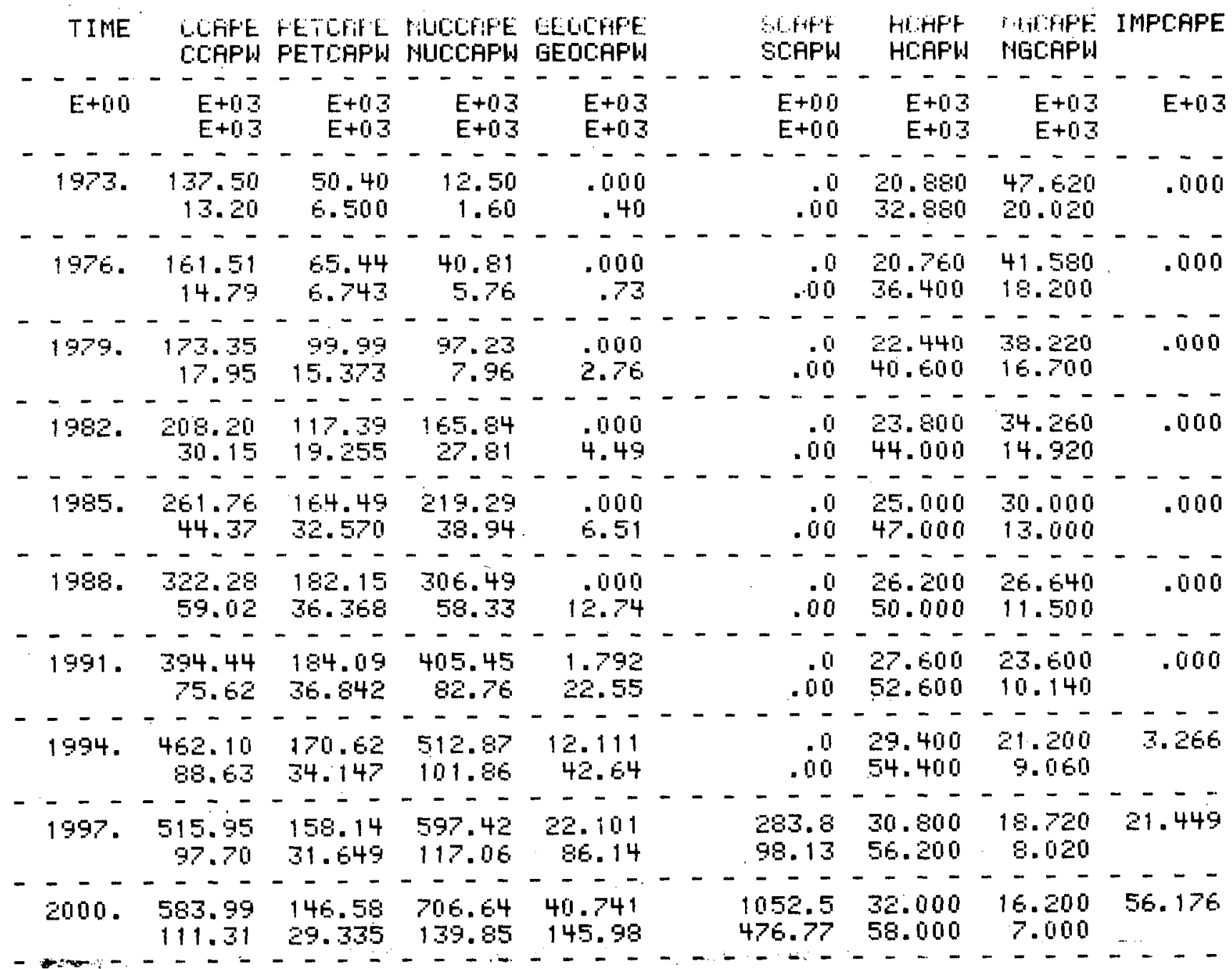

Figure E.4.36 GEOTHERMAL ELECTRICITY GENERATION COSTS DECREASED BY 50 PERCENT 


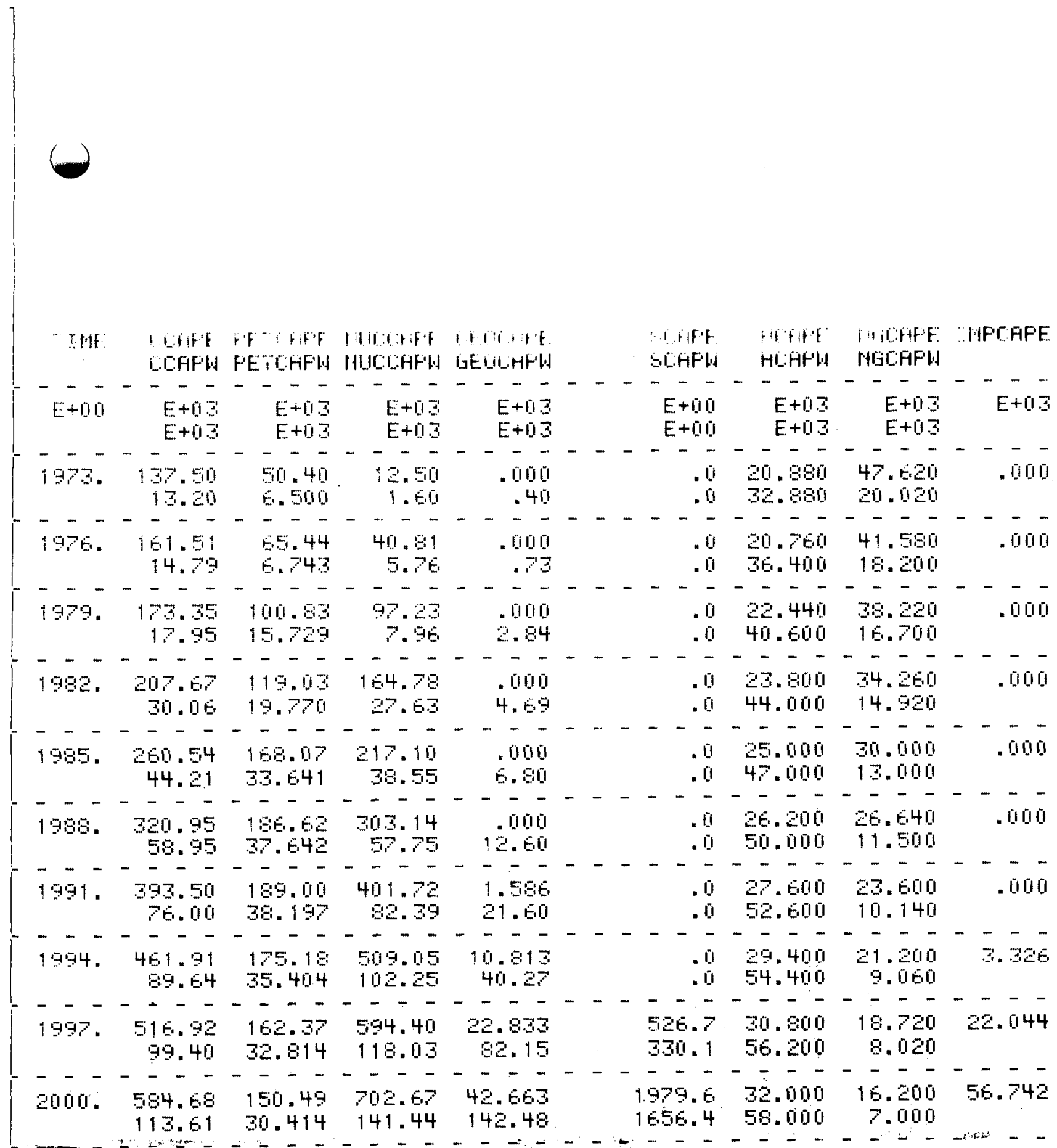

Figure E.4.37 GEOTHERMAL CAPITAL INVESTMENT COSTS INCREASED BY 50 PERCENT 


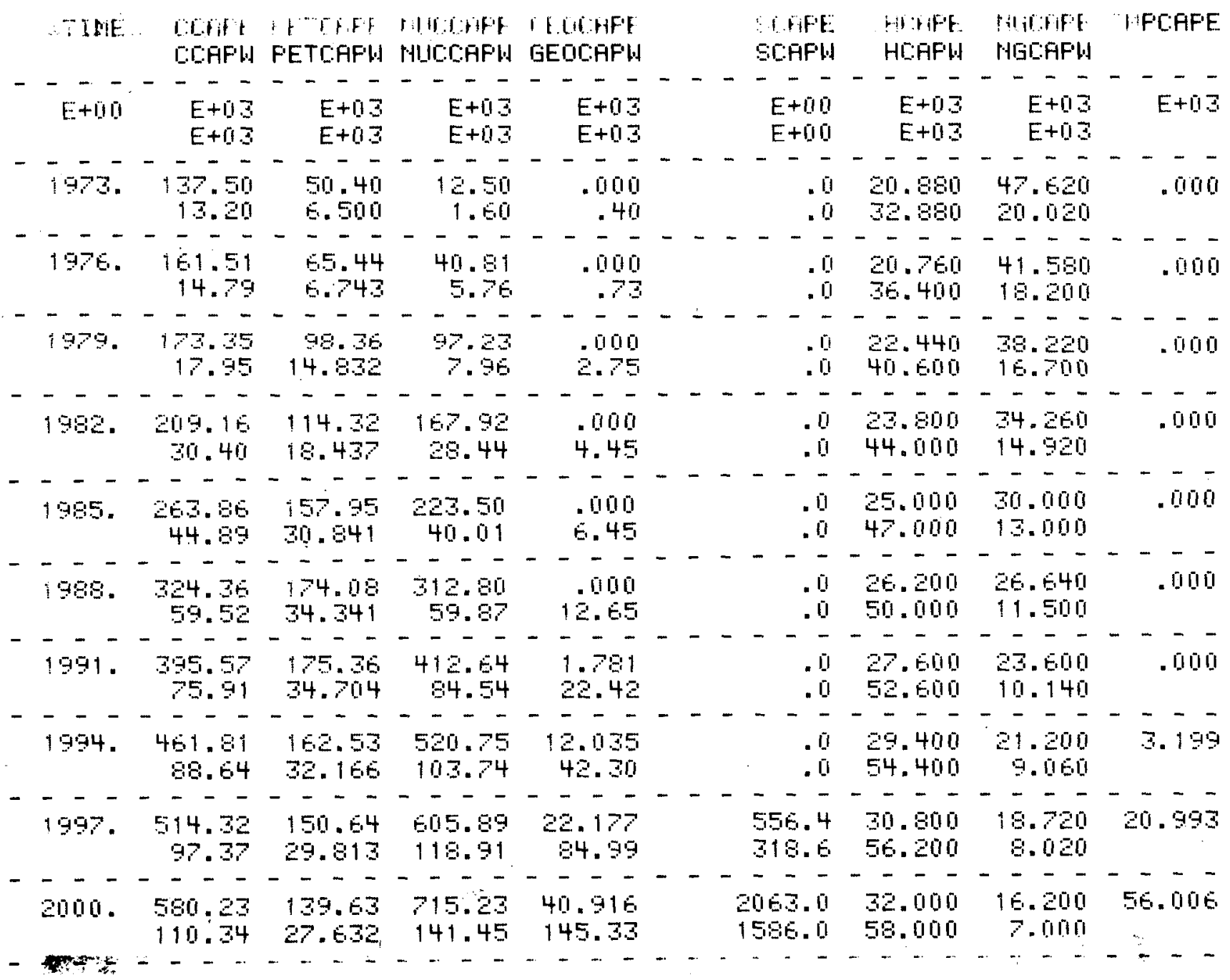

Figure E.4.38 GEOTHERMAL CAPITAL INVESTMENT COSTS DECREASED BY 50 PERCENT 


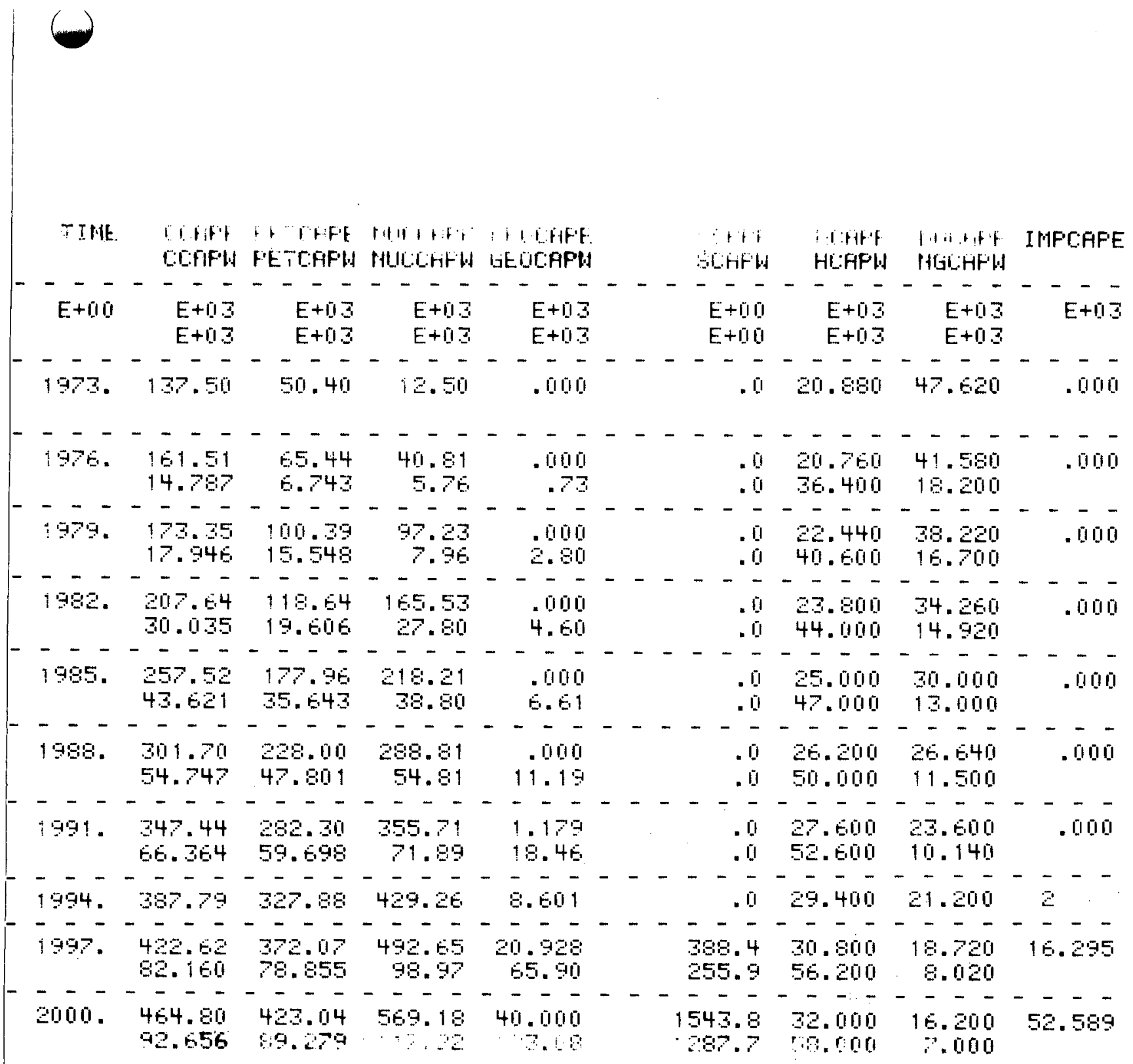

Figure E.4.39 PETROLEUM FUEL AVAILABILITY

INCREASED TO CONSTANT VALUE OF .75 


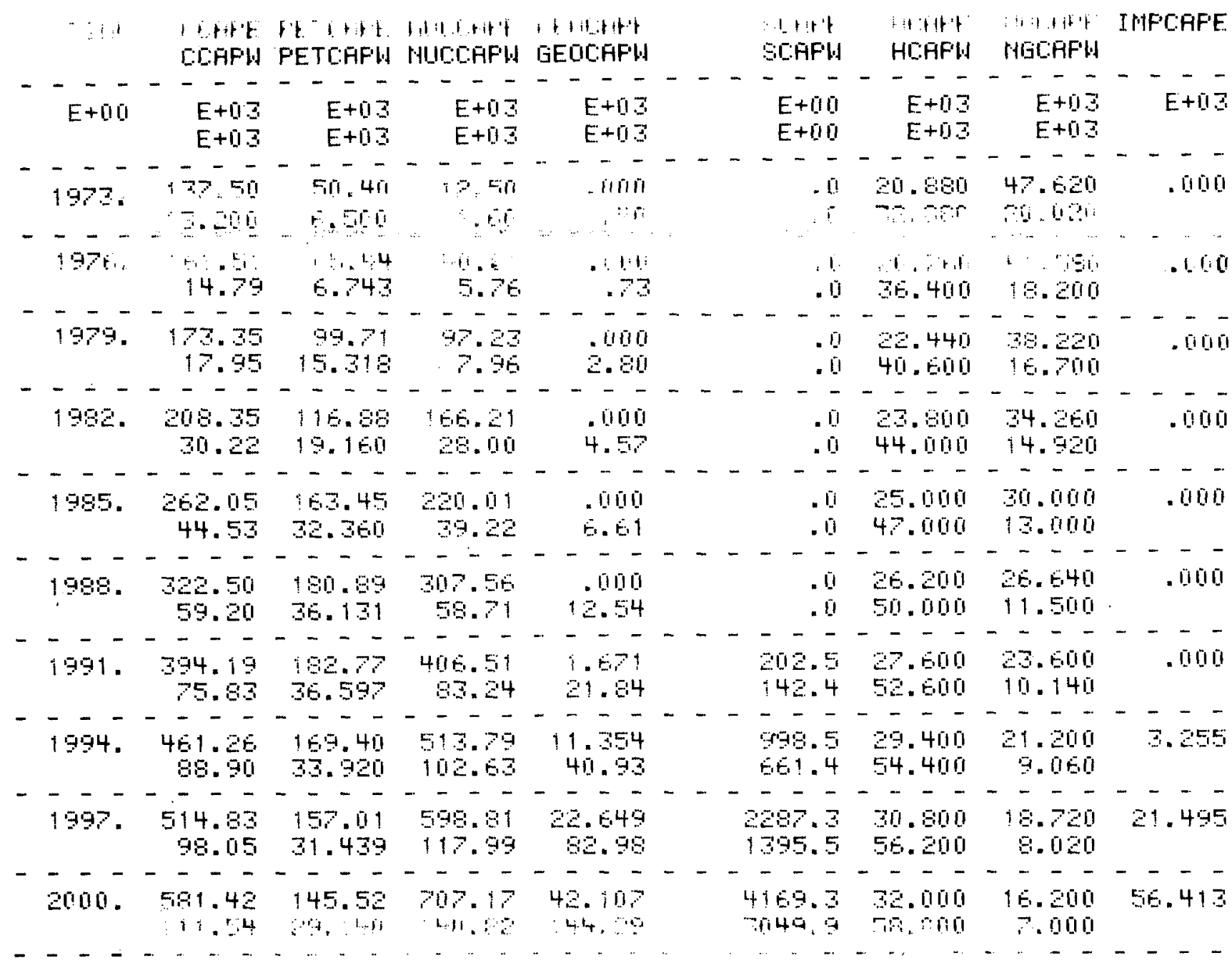

Figure E.4.40 SOLAR AVAILABILITY TIME

SET AT 1982 


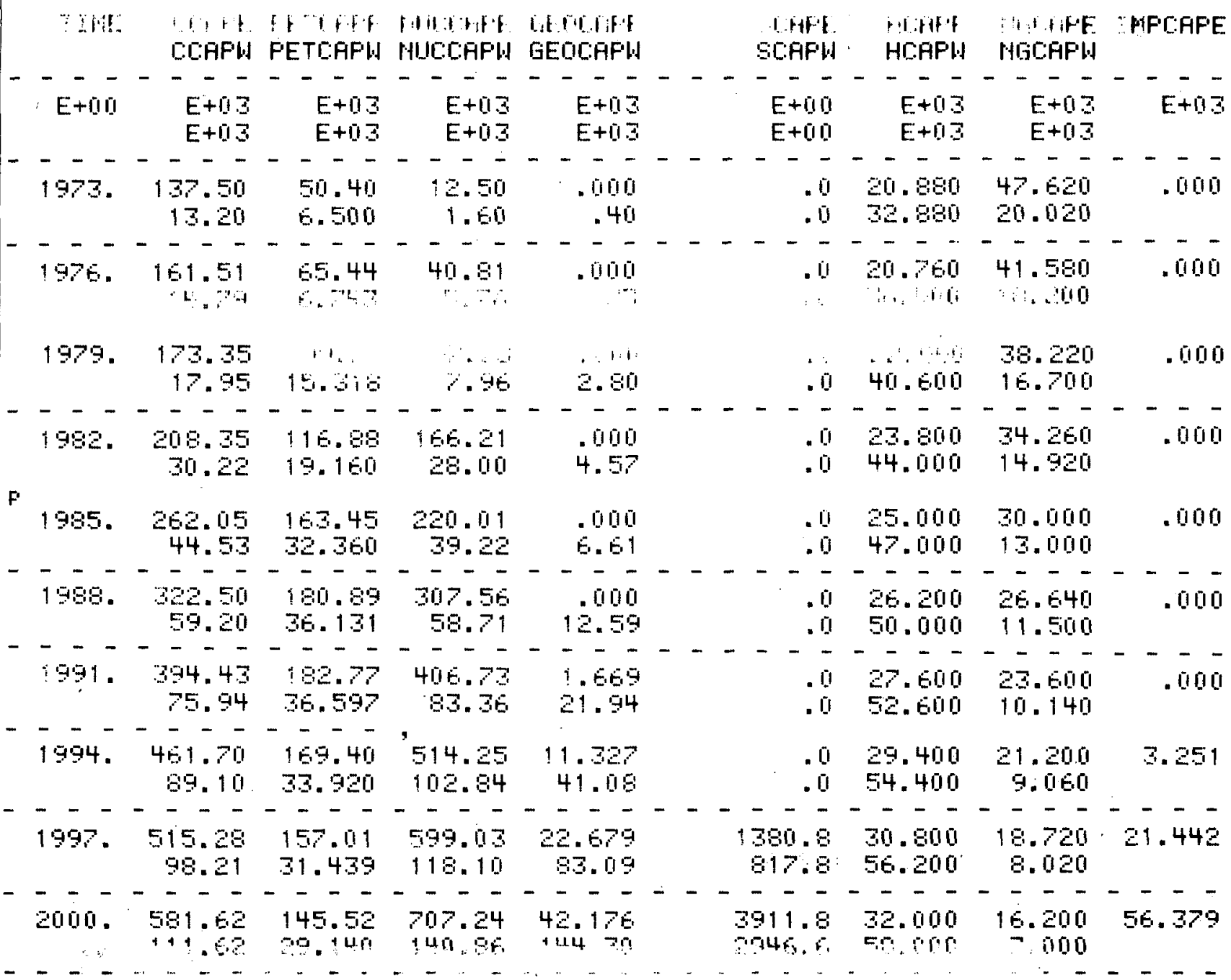

Figure E.4.41 SOLAR LEARNING PROCESS ACCELERATED 


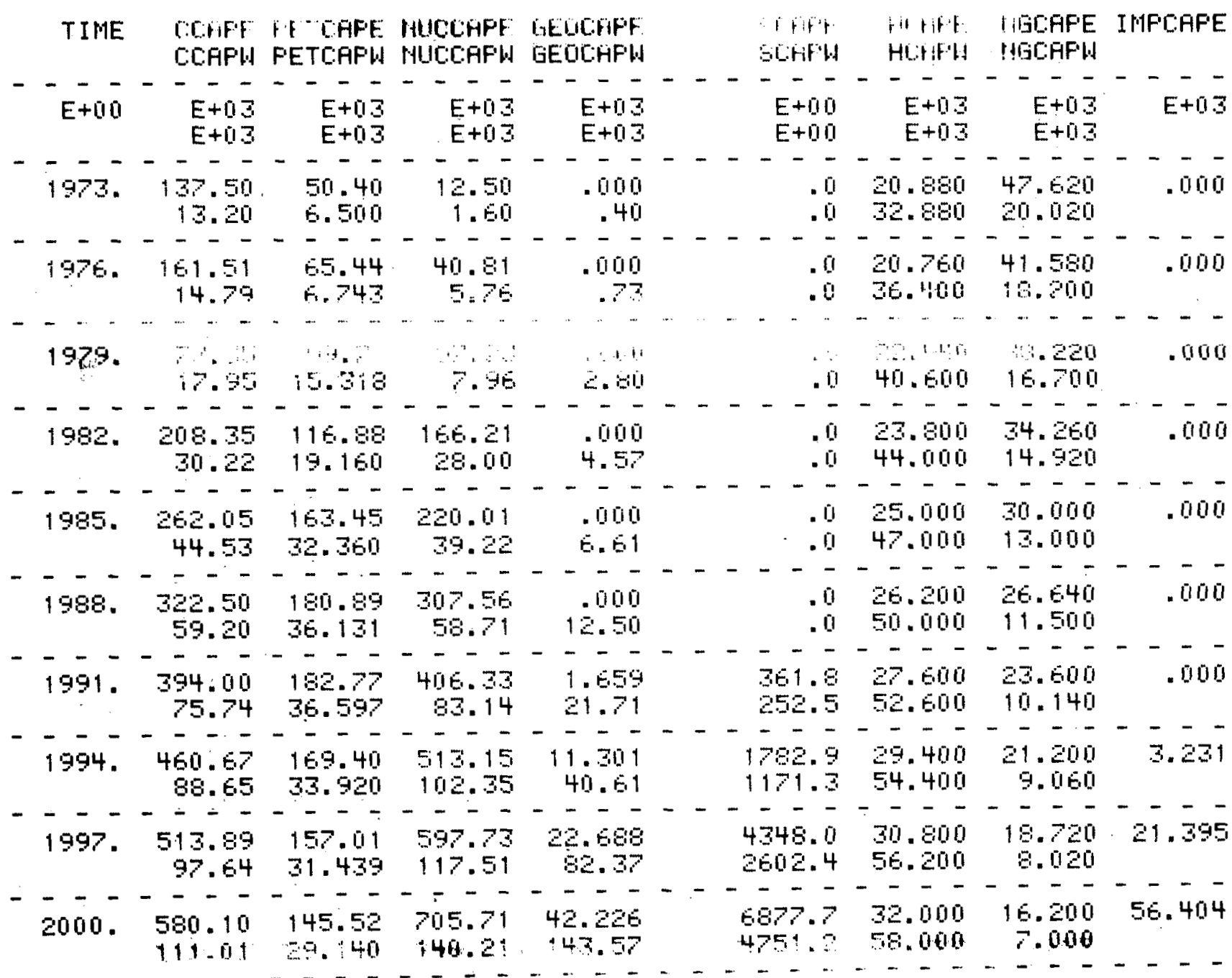

F1gure E.4.42 SOLAR AVAILABILITY TIME SET AT '1982, LEARNING PROCESS ACCELERATED, AND RELIABILITY INCREASED TO 1.0 


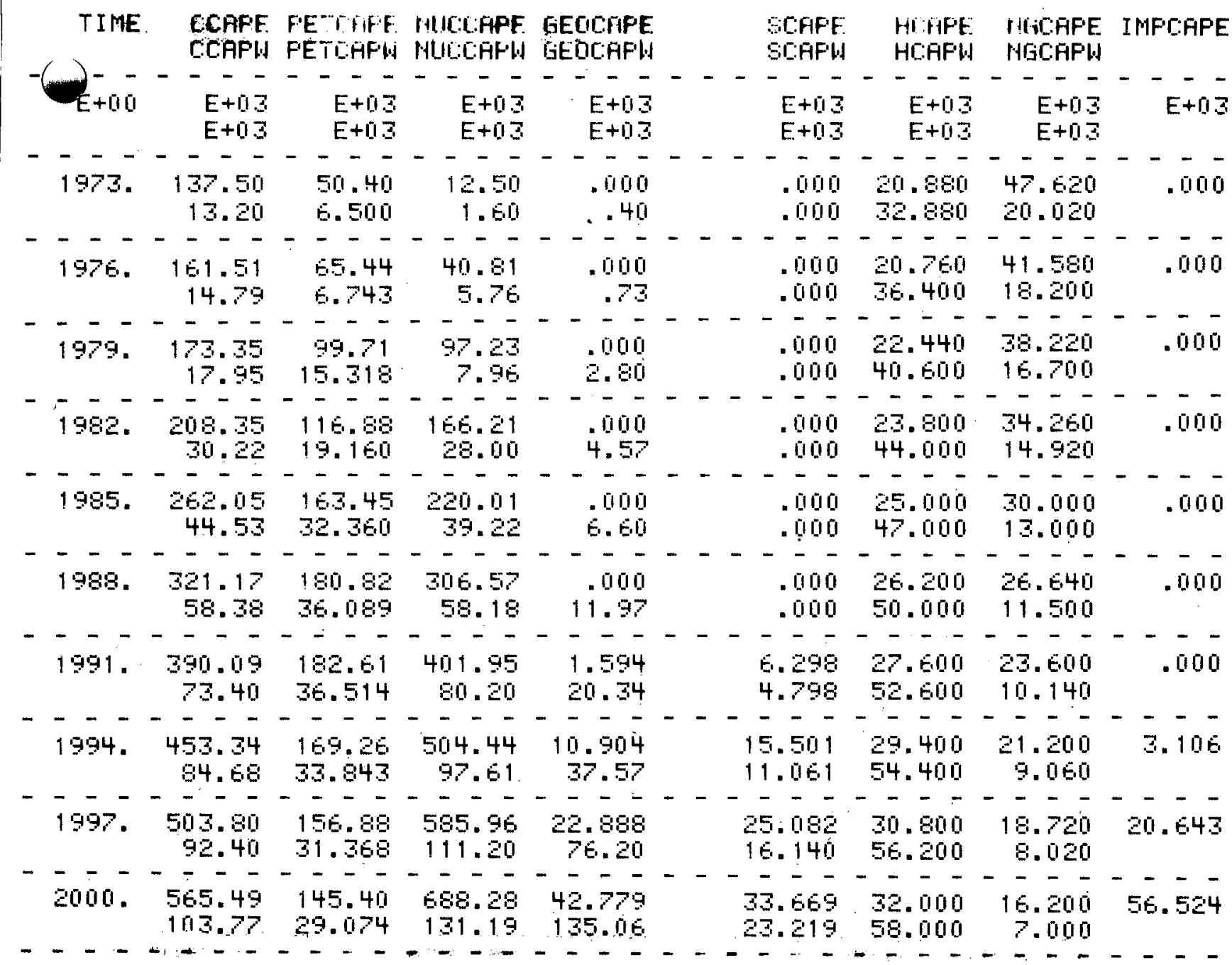

Figure E.4.43 SOLAR AVAILABILITY TIME SET AT 1980, RELIABILITY INCREASED TO 1.0 , LEARNING PROCESS ACCELERATED, ELECTRICITY GENERATION COSTS HALVED; AND CAPITAL INVESTMENT COSTS HALVED

REFEREMCES

[1] Forrester, Jay W., Industrial Dynamics (Cambridge, Mass, : Y.I.T. Press, 1961).

[2] Pugh, Alexander I., III, Dynamo II User's Manual, 4th Edition (Cambridge, Kass.: M.I.T. Press, 1973).
[3] Estimated Fossil Fuel Requirements for the Electric Utility Industry of the United States 1973-1982. Nat1onal' Electric Rellability Counc1l, Pebruary 12 , 1974.

[4] The 1970 Nat1onal Power Survey (Washingtón, D.C.: Federal Power Comp1sa1on, December 1971). 
Append1x F

Trend Impact Analysis

\section{Trend Extrapolation}

The ability to quantify various parameters and project them Into the future is an important factor in accomplishing the varlous steps in the planning process. Many techniques are and have been used to obtaln such time serles data. These range from highly judgmental, Intuitive methods to highly complex mathematical treatments. In the former case, individual estimates (genius, expert, or non-expert) or group consensus (obtalned by polling, fface-to-face conferences, Delphi conferences, or situation gaming) may be employed.

Unfortunately, both human judgment and mathematical extrapolation have their own fallibilities. Past combinations of the two have not been notably successful In combining the best features of each, while avoiding their weaknesses. A principal strength of judgment in trend extrapolation is that humans can take into account the possible impacts of unprecedented future events that may cause unique perturbations in the trends. For example, if a pharmaceutical industrialist or food manufacturer might be interested in how the discovery of a link between pancreatic cancer and the consumption of sugar would influence the trend in sales of artiflcial sweetners. This influence, however, could manifest iteself in quite novel ways, since, by its very nature, it has never been felt before. Common mathemat1cal methods of extrapolation are unable to take Into account potential future events since the past history of a trend cannot reveal how 1t would be influenced by such events.

On the other hand, subjective or unalded human judgment is usually inferior to mathematical formulas when it comes to fitting a set of points with a best-fit curve. Moreover, mathematical curve-fitting techniques are well established in theory and application. They can be readily communicated and used by others, thereby overcoming the stigma of arbitrariness or mere idiosyncrasy that attends subjective projections. At best, however, a mathematical approach simply produces a good estimate of how a trend would appear if it were not modifled by unprecedented future events.

Three examples 11lustrate how the occurrence of unprecedented events can influence a previously stable trend.

1. Until about 1955 the birth rate in the United States rose regularly and smoothly. The trend reversed dramatically in the $1960^{\prime} \mathrm{s}$ when cheap and effective contraceptives permitted the expression of new values and attitudes about ideal family size (see Figure F.1). Extrapolations based on the h1storical trend from 1950 through 1960 conslatently over-estimated the present birth. rate in the United States.

2. Figure F.2 illustrates the long-term drop in the cost of electriclty in the United States. The trend towards diminishing costs began almost with the advent of the first electricity generating system and reflected the generally unstated goal of producing cheap power. Cost was reduced through economies of scale, improved technology and operating effictency, more readily available fuels, etc. Recently, however, the cost of electricity has atabilized and begun to rise because of increasing costs of fue1, new requirements for: costly anti-pollution devices, and restrictions on the size of generating plants that end or lower savings through economies of scale. An extrapolation based on all but the latest data would have missed the recent "turn-around."

BIRTH RATE

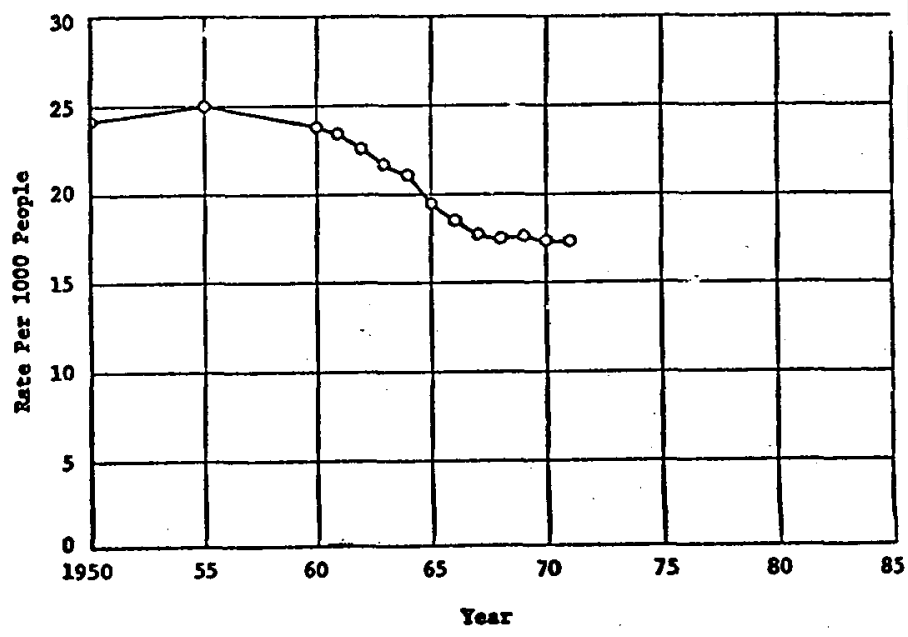

Source: 0.S. Public Health Service, pital Statistics of the United States, annual.

Figure F.1 BIRTH RATE IN THE UNITED STATES

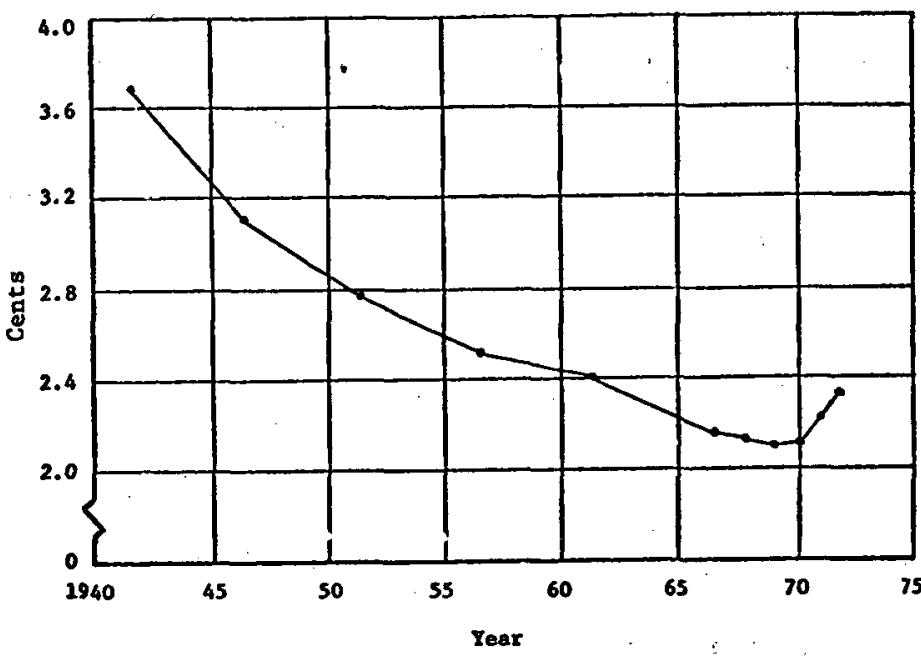

Source: Edison Electr1c Insticute, Questions and Answers About the Electric Ut1lity Industry, annual.

F1gure F.2 ELECTRICITY USED IN THE HOME AVERAGE REVENUE PER KILOWATT-HOUR 
3. The long-term trend in the United States toward the sale of automobiles of increasingly greater weight and horsepower has begun to change appreciably in recent months. This change may be the result of concern about increasing costs of gasoline, new public attitudes about conservation of the environment, or both.

Many other examples can, of course, be cited. The point is that deviations from historically-based extrapolations usually seem to reflect the impact of unprecedented events.

Trend Impact Analysis (TIA), an analytic procedure newly developed by The Futures Group, divides the task of extrapolation in such a way that humans and computers are assigned precisely the task that each does best. First, the computer extrapolates the past history of a trend. Second, the human specifies a set of unique future events and how the extrapolation would be changed by the occurrence of each of these events. The computer then uses these fudgments to modify the trend extrapolation. Finally, the human evaluates the resultant adjusted extrapolation and modifies the input data to the computer in those cases where the output appears unreasonable. Figure F.3 schematically shows this procedure.

\section{Mathematical Trend Extrapolation}

The development of a surprise-free extrapolation is the first step in the TIA process. A computer program selects the "best-fitting" curve from a set of alternative equations. This curve is then used to provide the surprise-free future extrapolation. At the option of the program user, in order to avold unreasonable extrapolations, the program can elther truncate extrapolations that fall outside upper or lower bounds, or select the "best-fitting" curve only from among those that do not give rise to extrapolations falling outside the speciffed bounds. Alternatively, the user can reject the mathematical extrapolation generated by the TIA program and supply an extrapolation developed by some other curve fitting program or one based entirely on human judgment.

Several refinements in the programming of this aspect of TIA enhances the effectiveness of the best-fit test and extrapolation procedure.

1. Although the extrapolation is usually in terms of annual estimates (at least for the work done to date by The Futures Group), the input data may be quarterly, monthly, or any other more meaningful interval.

2. It is not necessary that the data cover a continuous span of time. Data in which there are gaps are fully acceptable--the program makes use of whatever data are available, taking into account any gaps, but without being stymied by them.

3. The program does not give equal weight to all data. Rather, a year may be specified (normally the present year) for which data are to be given maximum weight. As the times to which the data refer are further removed from the year which has maximum weight, the data are given less welght.* This procedure thus takes into account the possibly lower rellability of data that are more distant in the past or, more important perhaps, the lower influence on the future of developments that have occurred progressively farther in the past. The formula chosen also makes the sum of an infinite number of weights infinite, rather than convergent, so that evey very distant years continue to have a finite contribution.

4. Since there is no guarantee that a mathematical extrapolation will give a good fit to the given data, the TIA program reports to the human user just how good the fit was,

*The weighting formula is $\frac{1}{1+\left|y-y_{0}\right|}$, where $y$ is a given

year and $y_{0}$ is the year given maximum weight. STEP 4

STEP 1

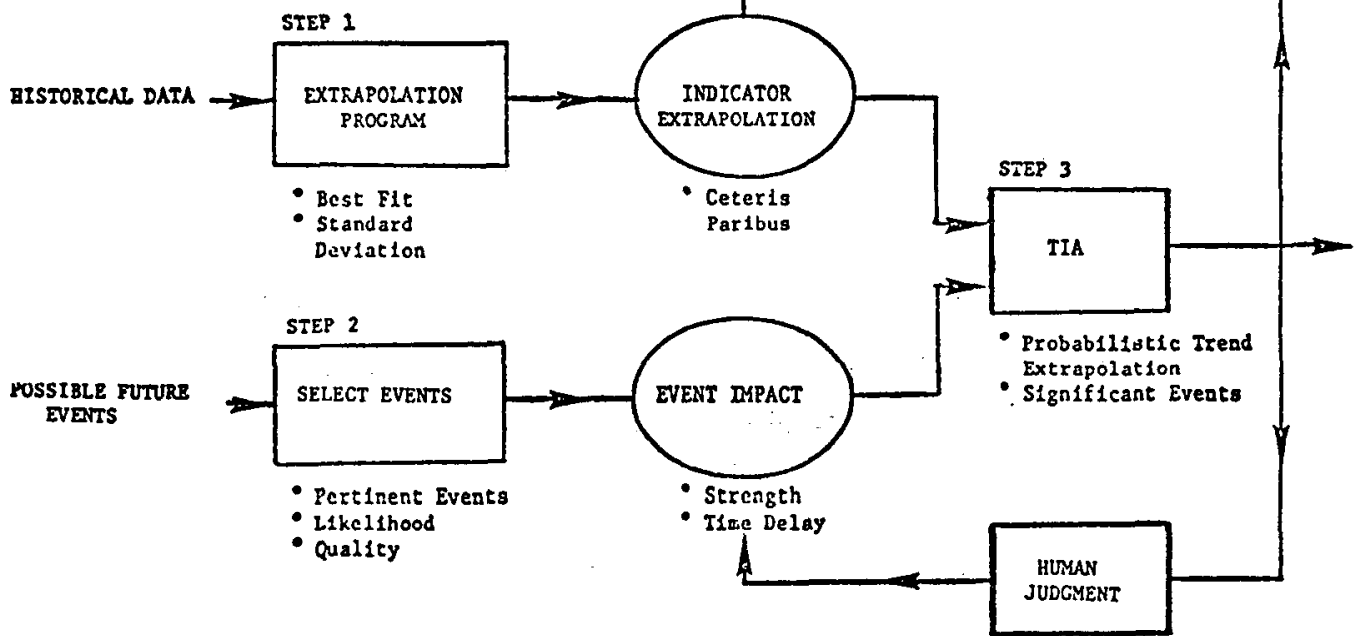

Figure F.3 TREND IMPACT ANALYSIS (TIA) 
using the same squared correlation coefficient that determines which mathematical formula should be used. As noted earlier, where judgment or analysis indicates a more realistic set of data should be used, they can be Input directly as part of the spectfied data used for subsequent steps.

\section{Human Judgments of Events Impacts}

Human Judgment and imagination are central to the second step of TIA. Here, the program modifies the surprise-free extrapolation to take into account tmportant unprecedented future events. First, a list of such events is prepared. These events should be unprecedented, plausible, potentlally powerful in impact, and verifiable in retrospect. The source of this list of events might be, typically, a literature search, a Delph1 study, or a consensus among consultants. Whatever the source, the events selected comprise an inventory of potential forces which could lead to a departure from a surprise-free future.

Several fudgments are made about each selected event. First, estimates are made of the probability of occurrence of each event as a function of time. Second, the impact of each event on the trend under study is estimated. Impacts can be specified in several ways; our procedure (Figure F.4) involves specification of:

1. The time from the occurrence of the Impacting event until the trend begins to respond.

2. The time from the occurrence of the impacting event until the impact on the trend is largest.

3. The magnitude of that largest impact.

4. The time from the occurrence of the impacting event until the impact reaches a final or steady-state level.

5. The magnitude of that steady-state Impact.
Each of the three specified times and the 1mpact magnitudes assoclated with them are taken to be completely independent. For example, the maximum impact might be positive, and the steady-state impact negative, or the steady-state Impact might be zero, meaning that the impact is only temporary. Finally, the maximum impact might be the same as the steady-state impact.

In addition, impacts can be specified in either relative or absolute units--1.e., they can be specified as percentages of the values of the trends at the time of impact, as a percentage change of that number, or they can be specified in absolute units of magnitude of the trend. For example, the impact of a particular event on the number of dentists could be specified either as 90 percent of that number, as a 10 percent decline of that number, or as a downward shift of 12,000 . The form used to record these estimates is shown in Figure F.5.

\section{Computer Processing of Impact on Extrapolated Trends}

The heart of TIA is the computer program for using these judgments to calculate the expected 1mpact of the selected events on the extrapolated trend. A closed-form procedure is used to solve this problem. The expected value, or mean, of the impact and upper and lower quartiles of the distribution of possible impacts are computed for each indicator. The expected value of the impact is computed by summing the products of the probabilities of the impacting events for each possible year times the magnitude of their 1mpact, taking into account their spectified lags. Probabilitles of events for years not specified are estimated by linear interpolation, assuming that an event has 0.00 probability at the present time. Similarly, impacts are linearly interpolated between the three specified impact magnitudes.

This approach treats the coupling among the impacts of the various events as negligible. Thus, the impact estimate is produced as the sum of independent random variables. The net result is that the variance of the Impact-adjusted forecast is the sum of the variance of the trend extrapolation (as measured by the square of the standard error of estimate) and the variances of the impacts of the associated events.

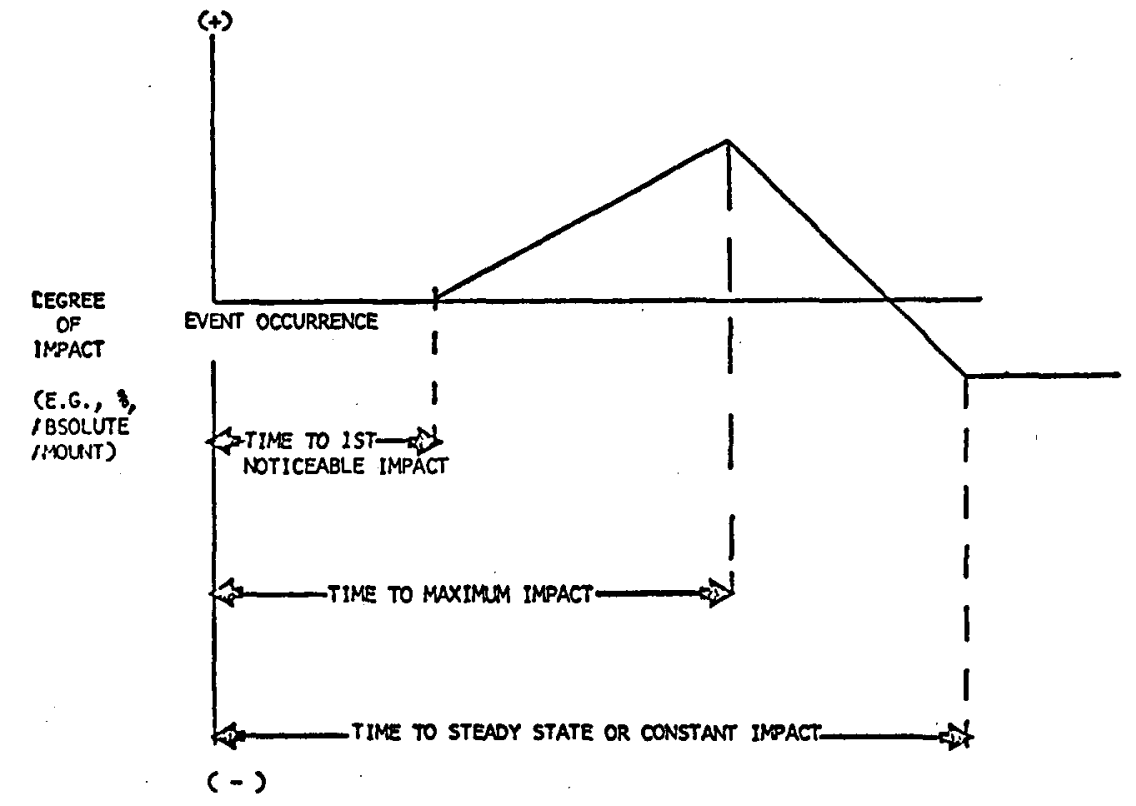

Figure F.4 EVENT IMPACT ESTTMATES 


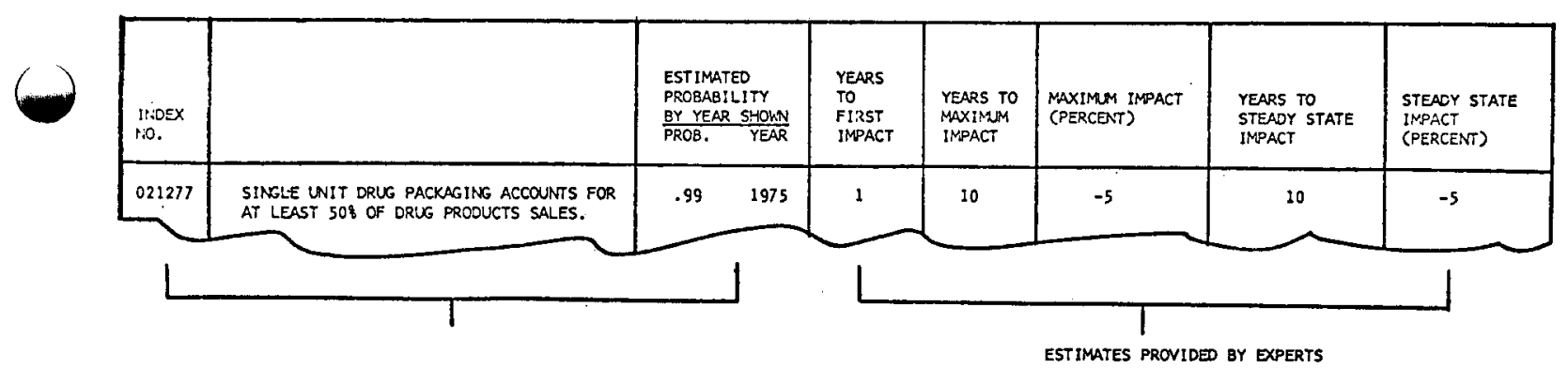

Figure F.5 FORMAT FOR EVENT IMPACTS

Thus, where $P_{y e}$ is the likelihood that event e will occur in year $y$, and $a_{y_{k}}-y, e$ is the impact that event $e^{e}$ would give rise to $\left(y_{k}-y\right)$ years after $i$ ts occurrence, the expected value of the impact in year $\underline{y}_{k}$ would be $\sum_{e} \sum_{y=y_{0}}^{y_{k}} \quad P$ ye $y_{k}-y, e$ where $y_{0}$ is the present year

(e.g., 1974). (See Figure F.6.)

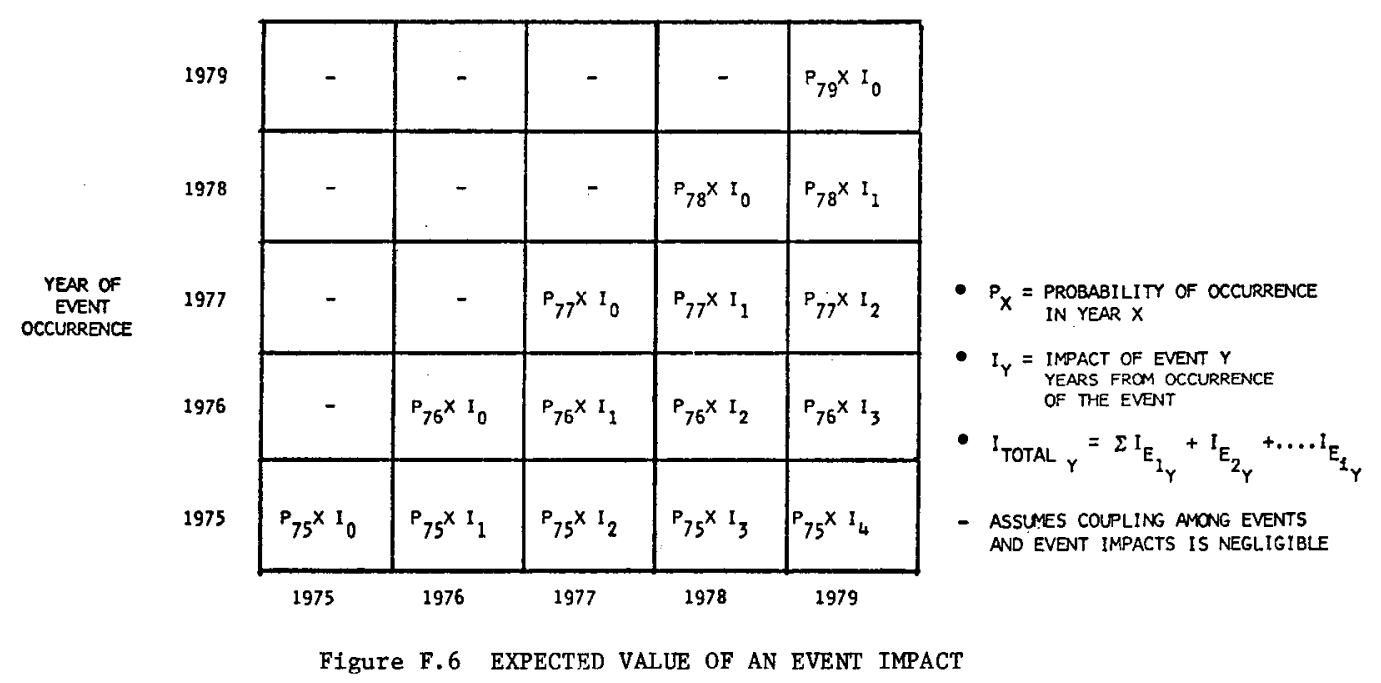


THE VALUE MATRIX

\begin{abstract}
The charts which follow present the value matrix discussed in Section 5 of the report. Potentlal Impacts of geothermal energy form the rows of the matrix, and interest groups, the columns. The relevance numbers shown within the cells of the matrix display the study team's judgments as to the significance of each Impact for each interest group.
\end{abstract}

Please refer to Section 5 for the scaling used, the impact statements, and the names of the interest groups. 


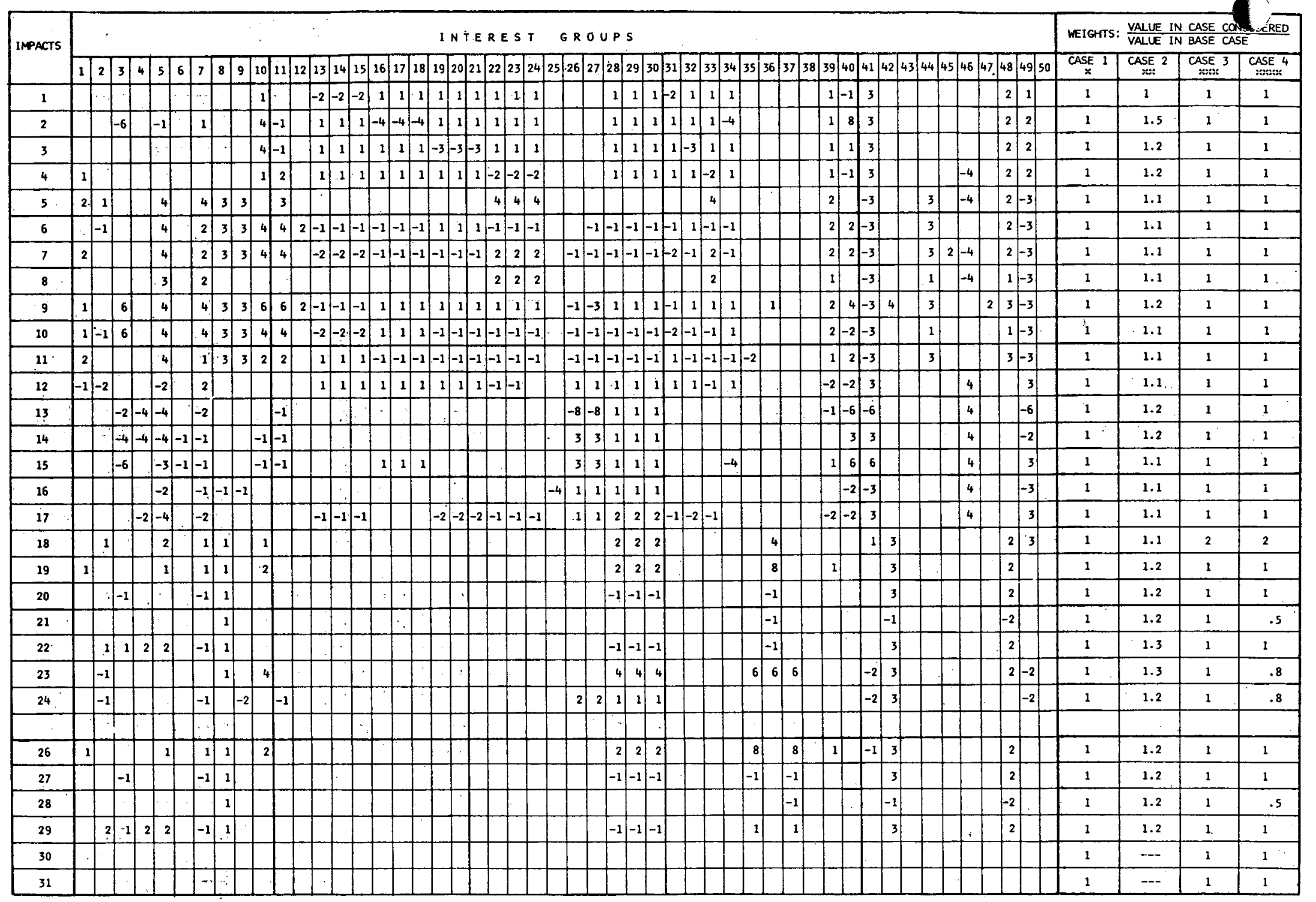

$\therefore$ BASE 2000 NORMAL.

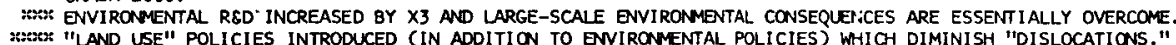




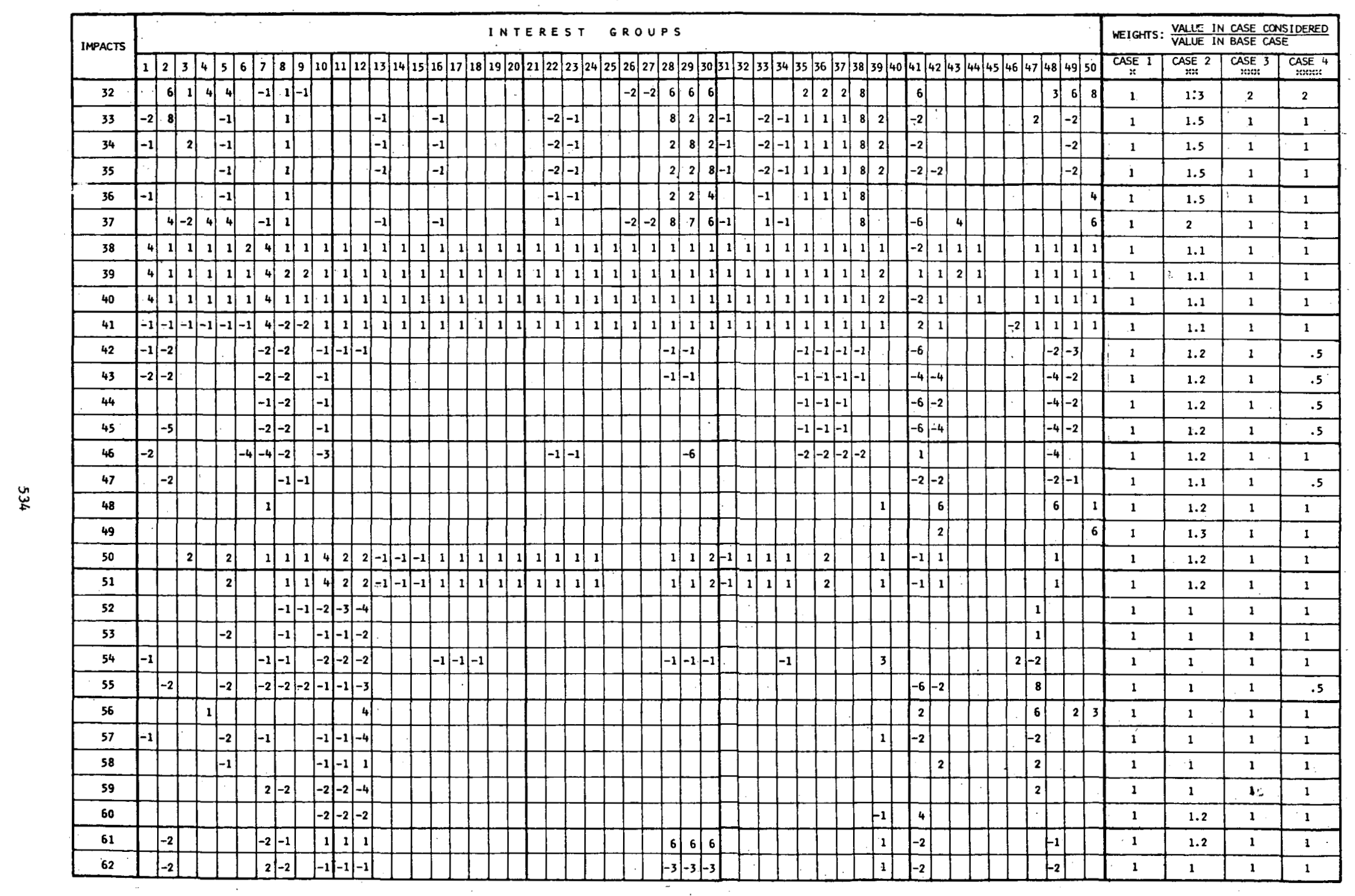

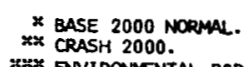

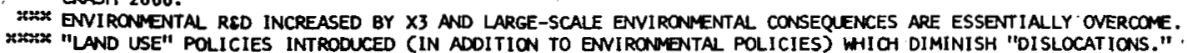


impacts

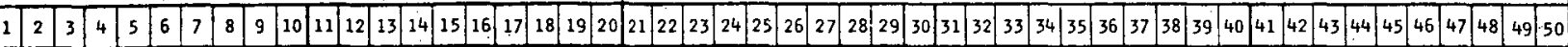

\begin{tabular}{|l|l|l|l|}
\hline CASE 1 & CASE 2 & CASE 3 & CASE 4 \\
\hline
\end{tabular}

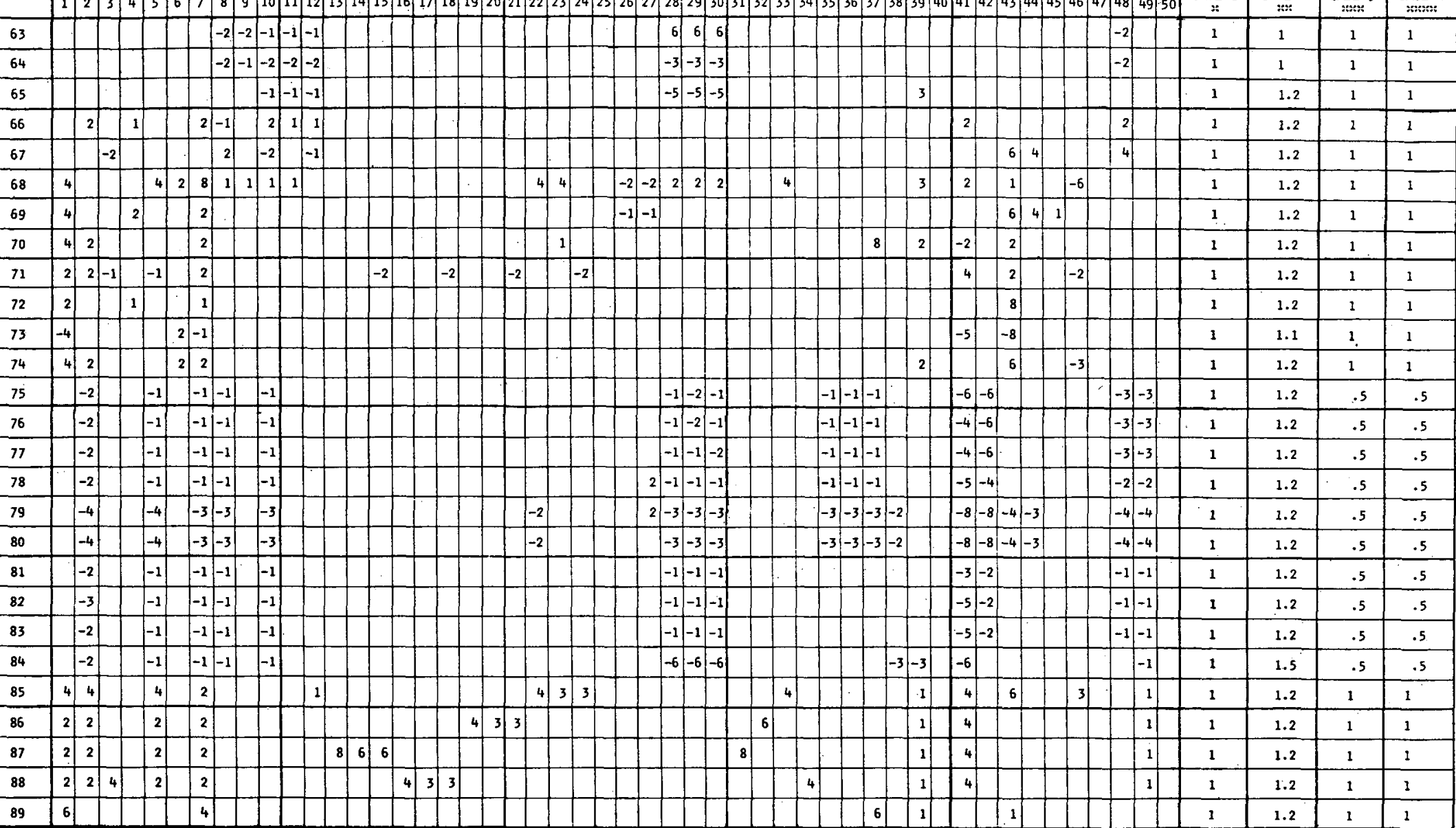

$\because$ BASE 2000 NORPMAL.

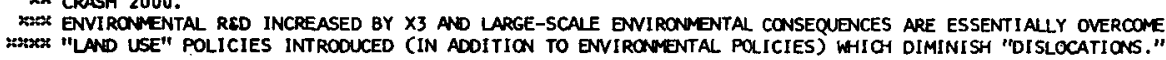


Append1x $\mathrm{H}$

STATE AIR QUALITY STANDARDS

FOR STATES WITH GEOTHERMAL POTENTIAL 


\begin{tabular}{|c|c|c|c|c|}
\hline STATE & PARTICURATES & CARBON MONOXIDE & DUST & $\mathrm{H}_{2} \mathrm{~S}$ \\
\hline Nevada & $\begin{array}{l}60 \text { micrograms } / \mathrm{M}^{3} \\
\text { annual geometric mean } \\
150 \text { micrograms } / \mathrm{M}^{3} \\
\text { maximum } 24-\text { hour con- } \\
\text { centration }\end{array}$ & $\begin{array}{l}10,000 \text { micrograms } / \mathrm{M}^{3}(9.0 \mathrm{ppm}) \\
\text { maximum } 8 \text {-hour concentration } \\
40,000 \text { micrograms } / \mathrm{M}^{3}(35.0 \mathrm{ppm}) \\
1 \text {-hour concentration }\end{array}$ & & \\
\hline Oregon & $\begin{array}{l}60 \text { micrograms } / \mathrm{M}^{3} \\
\text { annual geometric mean } \\
100 \text { mi crograms } / \mathrm{M}^{3} \\
24 \text {-hour concentration } \\
\text { for more than } 15 z \text { of the } \\
\text { samples collected fn any } \\
\text { calendar month } \\
150 \text { micrograms } / \mathrm{M}^{3} \\
24-\text { hour concentration } \\
\text { not to be exceeded more } \\
\text { than once per year }\end{array}$ & $\begin{array}{l}10 \text { mill1grams } / \mathrm{M}^{3}(8.7 \mathrm{ppm}) \\
\text { maximum } 8 \text {-hour average not to } \\
\text { be exceeded more than once } \\
\text { per year }\end{array}$ & 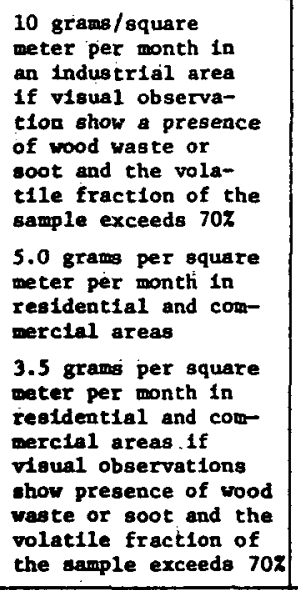 & \\
\hline Utah & $\begin{array}{l}90 \text { micrograms } / \mathrm{M}^{3} \\
\text { annual geometric mean not } \\
\text { more than } 17 \text { of the } \\
\text { aamples collected between } \\
\text { Apri1 } 1 \text { and October } 31 ; \\
\text { not more than } 5 \pi \text { of the } \\
\text { somples collected between } \\
\text { Movember } 1 \text { and March } 31 \\
\text { shall exceed a concentra- } \\
\text { tlon of } 200 \text { micrograms } / \mathrm{M}^{3}\end{array}$ & $\begin{array}{l}9 \text { ppm } \\
\text { maximum 8-hour concentration } \\
\text { not to be exceeded wore than } \\
\text { once per year } \\
35 \text { ppm } \\
\text { maximum 1-hour concentration } \\
\text { not to be exceeded pore than } \\
\text { once per year }\end{array}$ & . & \\
\hline WashIngton & $\begin{array}{l}60 \text { micrograms } / \mathrm{M}^{3} \\
\text { annual geometric mean } \\
150 \text { micrograms } / \mathrm{M}^{3} \\
\text { maxdmum } 24-h o u r \text { concen- } \\
\text { tration not to be exceeded } \\
\text { wore than once per year }\end{array}$ & $\begin{array}{l}10 \text { milligrams } / \mathrm{M}^{3} \text { (9 ppm) } \\
\text { 8-hour average concentration } \\
\text { not to be exceeded more than } \\
\text { once per year } \\
\left.40 \text { milligrams } / \mathrm{M}^{3} \text { ( } 35 \mathrm{ppm}\right) \\
\text { 1-hour average concentration } \\
\text { not to be exceeded more than } \\
\text { once per year }\end{array}$ & 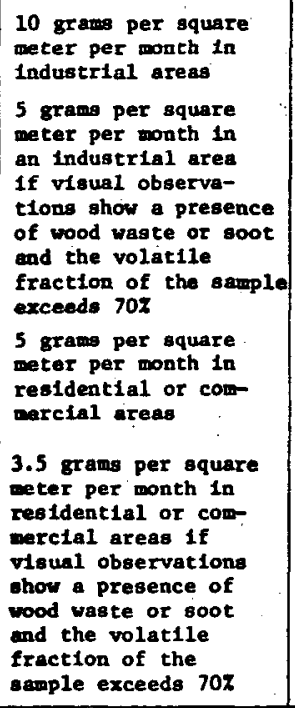 & \\
\hline Wyoming & $\begin{array}{l}60 \text { micrograms } / \mathrm{M}^{3} \\
\text { annual geometric mean } \\
150 \text { micrograms } / \mathrm{M}^{3} \\
\text { maximum } 24-\text { hour concen- } \\
\text { tration not to be } \\
\text { exceeded more than } \\
\text { once per year }\end{array}$ & $\begin{array}{l}10 \text { milligrams } / \mathrm{M}^{3}(9 \mathrm{ppm}) \\
\text { maximum } 8 \text {-hour concentration } \\
\text { pot to be exceeded more. them } \\
\text { once per year } \\
\left.40 \text { milligrams } / \mathrm{m}^{3} \text { ( } 35 \mathrm{ppm}\right) \\
\text { maximum } 1 \text {-hour concentration } \\
\text { not to be exceeded wore than } \\
\text { once per year }\end{array}$ & 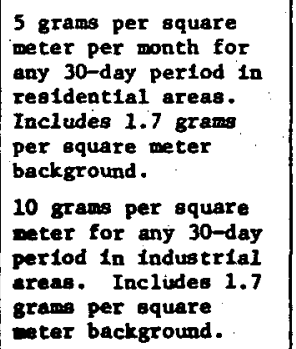 & $\begin{array}{l}70 \text { micrograms } / \mathrm{M}^{3} \\
1 / 2 \text {-hour average } \\
\text { not to be exceeded } \\
\text { more than two t1mes } \\
\text { per yeer } \\
40 \text { micrograms } / \mathrm{M}^{3} \\
1 / 2 \text {-hour average } \\
\text { not to be exceeded } \\
\text { more than two times } \\
\text { In any } 5 \text { consecu- } \\
\text { tive days }\end{array}$ \\
\hline
\end{tabular}




\begin{tabular}{|c|c|c|c|c|}
\hline STATE & : PARTICULATES & CARBON MONOXIDE & DusT & $\mathrm{H}_{2} \mathrm{~s}$ \\
\hline Alaska & $\begin{array}{l}60 \text { micrograms } / \mathrm{M}^{3} \text { annual } \\
\text { geometric mean } \\
150 \text { micrograms } / \mathrm{M}^{3} 24- \\
\text { hour maximum not to be } \\
\text { exceeded more than once } \\
\text { per year }\end{array}$ & $\begin{array}{l}10 \mathrm{mill1} \text { grams } / \mathrm{M}^{3} \text { 8-hour } \\
\text { maximum not to be exceeded } \\
\text { more than once per year } \\
40 \mathrm{~m} 1111 \mathrm{grams} / \mathrm{M}^{3} \text { 1-hour } \\
\text { max1mum not to be exceeded } \\
\text { more than once per year }\end{array}$ & & \\
\hline Arizona & $\begin{array}{l}70 \text { micrograms } / \mathrm{M}^{3} \text { annual } \\
\text { annual geometric mean } \\
100 \text { micrograms } / \mathrm{M}^{3} \text { 24- } \\
\text { hour maxlmum }\end{array}$ & $\begin{array}{l}\text { 7,000 micrograms } / \mathrm{M}^{3}(8 \mathrm{ppm}) \\
\text { 8-hour maximum } \\
38,000 \text { micrograms } / \mathrm{M}^{3}(43.5 \mathrm{ppm}) \\
90 \text { m1nute maximum } \\
6,000 \text { micrograms } / \mathrm{M}^{3}(6.9 \mathrm{ppm}) \\
\text { max1mum } 7 \text {-day average }\end{array}$ & & \\
\hline Cal1fornta & $\begin{array}{l}60 \text { mlcrograms } / M^{3} \text { annual, } \\
\text { geometr1c mean } \\
100 \text { micrograms } / \mathrm{M}^{3} \\
24 \text {-hour maximum }\end{array}$ & $\begin{array}{l}20 \mathrm{ppm} \\
\text { 8-hour maxirium }\end{array}$ & . & $\begin{array}{l}0.03 \mathrm{ppm} \\
1 \text {-hour average }\end{array}$ \\
\hline Colorado & $\begin{array}{l}45 \text { micrograms } / M^{3} \text { annual } \\
\text { arithmetic mean of all } \\
24 \text {-hour concentrations } \\
150 \text { micrograms } / M^{3} \\
24 \text {-hour maximum not to } \\
\text { be exceeded more than } \\
\text { once in a 12-monch } \\
\text { perlod }\end{array}$ & $\begin{array}{l}\text { "Not to exceed National } \\
\text { Standards" }\end{array}$ & . & \\
\hline Hewa11 & $\begin{array}{l}100 \text { micrograms } / \mathrm{M}^{3} \\
\text { average value during } \\
\text { any } 24 \text {-hour period } \\
55 \text { mlcrograms } / \mathrm{M}^{3} \\
\text { annusl artthmetic mean } \\
\text { value durtng any } 12- \\
\text { month perlod }\end{array}$ & $\begin{array}{l}10 \text { m1ll1grams } / \mathrm{M}^{3} \\
\text { average value during any } \\
\text { 1-hour period } \\
5 \text { m1lligrams } / \mathrm{M}^{3} \\
\text { average value during any } \\
\text { 8-hour perlod }\end{array}$ & & \\
\hline Idaho & $\begin{array}{l}\text { Primary } \\
75 \text { micrograms } / M^{3} \\
\text { annual geometric mean } \\
260 \text { micrograms } / M^{3} \\
\text { maximum } 24-\text { hour con- } \\
\text { centration not to be } \\
\text { exceeded more than once } \\
\text { per year } \\
\text { Secondary } \\
60 \text { micrograms } / M^{3} \\
\text { annual geome tric mean } \\
150 \text { micrograms } / \mathrm{M}^{3} \\
\text { maxdmum } 24-h o u r \text { con- } \\
\text { centration not to be } \\
\text { exceeded more than } \\
\text { once per year. }\end{array}$ & $\begin{array}{l}\left.10 \text { milligrams } / \mathrm{M}^{3} \text { ( } 9 \mathrm{ppm}\right) \\
\text { maximum } 8 \text {-hour concentration } \\
\text { not to be exceeded more than } \\
\text { once per year } \\
40 \text { mill1grams/ } \mathrm{M}^{3} \text { (ppm) } \\
\text { naximum 1-hour concentration } \\
\text { not to be exceeded more than } \\
\text { once per year }\end{array}$ & $\begin{array}{l}0.8 \text { milligrams per } \\
\text { square centimeter } \\
\text { per month not to be } \\
\text { exceeded more than } \\
252 \text { of the time }\end{array}$ & - \\
\hline Montana & $\begin{array}{l}75 \text { micrograms } / \mathrm{M}^{3} \\
\text { annual geometric mean } \\
200 \text { micrograms } / \mathrm{M}^{3} \\
\text { not to be exceeded more } \\
\text { than } 17 \text { of days a jear }\end{array}$ & $\begin{array}{l}\text { "Not to exceed National } \\
\text { Standards" }\end{array}$ & $\begin{array}{l}\text { Is tons per square } \\
\text { mlle per month, 3- } \\
\text { month everage in } \\
\text { residentlal areas } \\
30 \text { toos per oquare } \\
\text { mlle per month, 3- } \\
\text { month average in } \\
\text { heavy industrial } \\
\text { areas }\end{array}$ & $\begin{array}{l}0.03 \text { ppm } \\
1 / 2-\text { hour average } \\
\text { not to be exceeded } \\
\text { more than twlce in } \\
\text { any } 5 \text { consecutive } \\
\text { days } \\
0.05 \text { ppm } \\
1 / 2-\text { hour average } \\
\text { not to be exceeded } \\
\text { over twice a year }\end{array}$ \\
\hline New Mexico & $\begin{array}{l}150 \text { micrograms } / \mathrm{M}^{3} \\
24 \text {-hour average } \\
110 \text { micrograms } / \mathrm{M}^{3} \\
7 \text {-day average } \\
90 \mathrm{mlcrograms} / \mathrm{M}^{3} \\
30 \text {-day average } \\
60 \mathrm{~m} \text { crograms } / \mathrm{M}^{3} \\
\text { annual geometric mean } \\
\text { Aobeatos pregenting } \\
\text { particulate } \\
\text { maximum concentration } 0.01 \\
\text { micrograms } / \mathrm{M}^{3} \text { based on a } \\
30 \text {-day average }\end{array}$ & $\begin{array}{l}8.7 \mathrm{ppm} \\
8 \text {-hour average } \\
13.1 \mathrm{ppm} \\
\text { 1-hour average }\end{array}$ & . & \\
\hline
\end{tabular}


Public Law 91-581

91 st Congress, S. 368

December 24, 1970

\section{An Ant}

To autborize the Secretary of the Interlor to make dispostion of zeothermal

a) Stat, 2566

We if enacted by the Senale and House of Representatives of the linited States of 1 merica in Congress assembled. That this Act niny be citer as the "Geothermal Stram $\Lambda$ ct of 1970"

Sec. 2. As used in this Aet, the term-

(a) "Secretary" means the Sccretary of the Interior

(b) "geothemial lease" means in lease issucd under authority of this Act;

(c) "yeothicrmal steam and associnted geothermal resources" means (i) all products of geothermal processes, embracing indigenous stean, hot water and hot brines; (ii) steam and of het gises, hot water and hot brines resulting from water, gas, or other fluids artificially introduced into geothermal formations; (iii) heut or other associated energy found in peothen

and (iv) any byproduct derived from them; oil (d) and helium) which are found in solution or in association with geot ${ }^{2}$-rmal steam and which have $n$ value of less than 75 per centum of the value of the geothermial stean or are not, because of quantity, quality, or technical difficulties in extraction and production, of suflicient value to warrant extraction and production by themselves:

(e) "known geothermal resources area" means an area in which the geology, nearby discoveries, competitive interests, or other indicia would, in the opinion of the Secretary, engender belief in men who aro experienced in the subject matter that the prospects resolurces are good enough to warrant expenditures of money for that purpose.

Sec. 3. Subject to the provisions of section 15 of this Act, the Seere- Laees. lary of the Interior may issue leases for the development and utiliza. tion of geothermal stesm and associnted geothermal resources (1) in lands adninistered by him, including public. withdrawn. and acquired auds, (2) in any national forest or other lands administered by the Department of Agricult ure through the Forest Service, including public, withdrawn, and acquired lands, and (3) in lands which have been conveyed by the Inited States subject to a reservation to the Cnited Sitates

Sec. 4. If lands to be leased under this Act are within any known bude.

genthermal resonirces area, they shall be leased to the highest responsiblo qualitied bidder by competitive bidding under regulations formugivie qualitied bidder by competitive bidding under regulations formulated by the Secretary. If the lunds to bo leased are not within anj known geothermal resources area, the qualified person first making application for the lease shall be entitled to s lense of such lands with. within oute hundred and eighty days following the efiective dato of this Act:

(a) with respect to all lands which were on September 7, 1965, ubject to valid leases or pormits issued under the Mfineral Lening Act of February 25, 1920, as amended (30 U.S.C. 181 et seq), or under the Mineral Leasing Act of Acquired Lands is amended (30 U.S.C. 351,358 , , or to pxisting mining claims located on or or their successors in interest who are qualified to hold geothermal Dot of 1970 . enstar, 2567

leases shall have the right to convert sucli leases or permits or claims to penthermal leases mvering the sunic lands

(b) whre tliere nre contlicting cluins, leasus, or permits therefor embracing the same land, the person who first was issued a lease or pesmit, or who first reco

(c) with respert to all lunds which were on September 7, 1065, the subject of applications for lenses or permits uncler the sbove Acts, the applicunts mny convert tlicir applications to applications for geothermal lenses having priorities dating from the time of filing of such applications under such $A$ ets;

Goothy nimal St

Aareaces

(d) no person shall be pernitted to convert mineral leases

dustation. pernits, npplications therefor, or nining claims for more than 0,240 acres; and

(e) the conversion of leases, permits, and mining claims and applieations for lenses and permits shall lo nccomplished in accordance with regulations prescribed by the Secretary. Sio right to enniersion to a feothernial lease shall accrue to on person under this section unless such person show's to the rensonable satis. faction of the Secretary that sulstantial expenditures for the exploration, development. or production of geothermal steam have been made by the applicant who is secking conversion, on the lands for which a lense is sought or on adjoining, adjacent, or nearby Federal or non-Federn] lands.

(f) with respect to lands within any known geothermal resources area and which are subject to a right to conversion to a emthermnl lease. such lands shall be lensed by competitive bidding: Provided. That, the competitive geothermal lease shall be jssued in the person owning the right to conrersion to ceothermal lease if he makes payurent of an amount equal to the figliest bons fide birl for the coinpetitive crothermal lease, plus the rental for the first year, within llirty days after he recire written notice fmm the Secretary of the amount of the highest bid.

beave. S. Geothernial icases shall provide for-

proviaiona. (a) $\cdot$ a royalty of not less than 10 per centum or more than 15

per centum of the ainnint or value of stenm, or nny other form of hr utilized by thic lessce or rensonably stusceptible to sole or or utilization by the lessce:

(b) a royalty of not more than 5 per centum of the ralue of any byproduct derived from production under the lease and sold or utilized or renzonnbly susceptible of sale or utilization by the lessec, except that as to any byprnduct which is $n$ mineral named in section 1 of the Jtinern! Tasing Act of February 25, 1920, as

41 stat. 437. amended ( 30 UT.S.C. 181), the rafe of royalty for such mineral shall be the same as that provided in that Aet and the maximum rate of royalty for such mineral shall not exceed the maximum rate of royalty for such mineral shall

(c) payment in advance of an annial rentnl of not less than 81 per acre or fraction thereof for each year of the lease. If there is no per acre or fraction thereof for each year of the lease. If there is no well on the lensed lands capnble of producing geothermal resources in commercial quantities, the failure to pay rental on or before the anniversary date shnll terminate the lease by operation of law: Prpzinded, horreiver. That whenever the Secretnry discovera that the rental payment diue under a lease is paid tintely but the amount of tho payment is deficient becanse of an error or other reason and the defriency is nominn, as determined by the Secretary porsuant deficiency and such lease shall not automatically terminato anles 
04 STAT. 1568

the lesse fails to pay the deficimey witlin the perind prescrilsed in the notice: /reverited further. "liat, whre any lease hats been terminated zutomntically by operation of law unile this section for failure to pay rentil timely and it is shown to the sat isfaction of the Sectetiry of the Interior that the failure fo pily timely the lease rental was justiliable or not dite to a lack of reasoninble diligence, lic in lis julgment puav reinstate the lease if -

(1) a petition for reibistatement, toget her with the required

antul, is filed with the Secretury of tice lnterior; and

(2) no valid lcitsc has been issicel nifecting any of the lands in the terminated lease prior to the filing of the petition for reinstitement: and

(d) n ninimum royalty of $\$ 2$ per nere or fraction thereof in lieu of rental payable at the expiration of each lease yent for ench produring lease, commencing with the lease year beginuing on or a fter the entumencement of production in commercial quantities. For

the purpose of determining royaltins hereinder the value of any geothermit steam and byproduct used by the lessee nnd not sold
and rensonably susceptible of sale shail be determined by the Secretury, who shall take into consideration the cost of explonation nnd production and the economic value of the resource in terms of its ultimate utilization.

Sec. 6. (a) Geotheimal leases shall be for a primnry term of ten Torm.

years. If genthermal steam is procluced or utilized in conmercial quantities within this term, such lense shall contimue for so long thereafter as geothernal steam is pmoluced or utilized in commercinl quan-

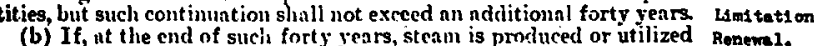

in commercial qunutities and the linuls are not needed for other purposes, the lessee sliall have a preferential right to a renewal of such poses, the lessee shial hare a preferential right to a renewal of such conditions as the Secretiry deems appropriate.

(c) Any lease for land on which, or for which under an approved Extanaton. cooperntive or unit plan of developnent or operntion, nctual drilling are being diligently prosecuted at that time shall he extended for five yenrs and so long therenfter, but not more than thirty-five years, as yenrs and so long therenfter, but not more than thirty-five Jears, as geothermal stenm is prodncec or utilized in commercinl quantities. If, in commercial quantities and the lands nre not needed for nther purin commercial quaritities and the lands are not needed for nther purposes, the lessee shall have a preferentinl right to a renewal of such the Secretary deems appropriate.

(d) For purposes of sulusection (a) of this section, proluction or ntilizntion of meothernul steam in commerial quantities shall be deemed to include the completion of one or more weils proslucing or capable of produring geothermnl steam in commercinl quantities and a bona hde sale of stuch geothermal steam for delivery to or utilization by a facility or farilities not yet instnlled but scheduled for installation not later than fiftcen yenrs

primary term of the lense. hare prodiced geothermal steam, and have been determined by the Secretury to be incapable of further commercial production and utilisation of geothermal stenm may be further extended for a period of not more tlunn five years from the date of such determination but only for $\mathrm{sn}$ long as one or more raluable byproducts are produced in commercial quantities. If such byproducts are leasable under the Jineral

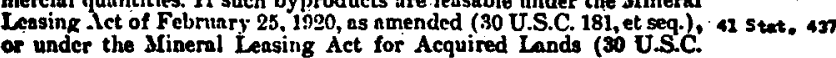

61 Stat. 913.

$35(-358)$, and the leaselond is primarily valuable for the production thercof, the lessee shatl bo entit led to convert his geothermal lease to a minerul lease under, nnd subject to all the terms and conditions of, such appropriate Act uyon application at any time before expiration of the lease extension by reason of bypmiluce production. The lessce simit be entitled to locate under the tniming laws all minerals which are not Iensable and which would constitute a byproduct if conmercinl production ot utilization of gcothermal ste:tm continuted. The lessee in order to acquire the rights liere in granted him shall complete the lncation of minernl claims within ninety days after the termination of the lease for geothermal stcam. Any such converted lense or the surface of nny mining chim located for genthernal byproducts mineral a ffect ing lands withdrawn or acnuired in aid of a function of a Federal department or agency, including the Department of the Interior, shall be subject to sucli additional terms and conditions es may be preseribed by such department or a gency with respect to the additional operations or effects resulting from sucl, conversion upon adecuate utilization of the lands for the purpose for which they are administered

(f) Minerals locatable under the mining laws of the United States in lands subject to a geothermal lease issued under the provisions of this Act which are not associated with the peothermal steam and aseociated geothermal resources of such lands as defined in section 2(c) herein stall bo locatable under said mining laws in accordance with the principles of the Mlultiple(Mineral Development Act (68 Stat. 708; found in 30 L.S.C. 521 et seq.).

Src. 7. A peothermal lease shall embrace a reasonably compret area of not more than two thousand five hundred and sixty acres, except where a departure therefrom is occasioned by an irrecular suldivision or subdivisions. No persoll, association, or corporation, exeept as otheror subdivisions. A person, association, or corporation, except as other-
wise provided in titis Act, shall take, liold, own, or control at one time, whether acquired directly from the Secretary under this Aet or atherwise, nuy direct or indirect interest in Fuderol genthermal leases in any Ste lenses acquired under tho provisions of section this Act.

Inoroese.

At any time after fifteen years from the effective date of this Art the Secretary, after public licarings, may increase this maximum liold ing in any one State by remulation, not to exceed fifty-one thousand two hundred acres.

Readjuetsont.

Src. 8. (a) Tho Secretary mny readjust the terms and conditions except as otherwise provided hereir, of any geothermal lense issued under this Act at not less than ten-year intervals berinning ten yenrs after the dnte the peothermal stenm is produced as determined by the Secretary. Each geothermal leaso issued under this Act shall provide for such rendjustment. The Secretary shall give notice of any proposed irendiustment of terms nnd conditions, and, unless the lessee files with the Secretary objection to the proposed terms or relinquishes the lease within thirty days a fer receipt of such notice, the lessee shall con-

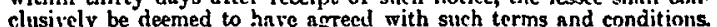
clusicly be deemed to hare agreed with such terms and conditions. the Secretary and the lessee within a period of not less than sixty days, the Secretary and tho lessee within a period of

(b) The Secretary may readjust the rentals and royalties of any geothermal lease issued under this Act at not less than twenty-year intervals beginning thirt y-five yon rs after the date geothermal steom is produced, as determined by the Secretary. In the event of any such resdjustment neither the rental nor royalty may be increased by more than 50 per centum over the rental or roynity paid during the proceding period. and in no event shall the roynty payable exceed 221/3 
Q4 STAT, 1570 en STAT. 2571

for such rearljusf ment. The Secretn ry slinlt pive notice of nny proposed Not10e.

readjust ment of rentals und royultice, nnd, unless the lesswo files with tho secretary objection to the proposed rentuls and roynlticn or relin. quivice tho lense Within thirty din's nfter receint of Bucls notice, tho lesuce shall conclisively he rliemel to luve neresd with such tenms and conditions. If the iessee files objections, and no ngreement can bo reached between the Secretnry und the lossee within a period of not

less than sixty dnys, the leuse inay be termiunted by either party.

(c) Any readjistment of the ternis nnd conditions as to use, protection, of restorution of the surfince of any lense of lands withirnwn of ner thited in the Department of the Interior mny he minde only upon notice to, nud witis elis nuprovial of, such deparinsent or ngeney.

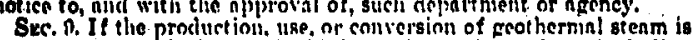

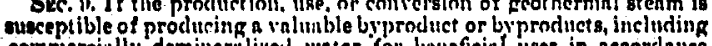
comntercially deminertizel water for letheficin uses in necordnuce

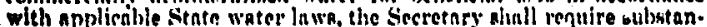
tinl beneficinl production or use thereof unless, in individunl circum. otances he modifies or vaives this requirement is the interest of coneoryation of nnturul resources or for other rensens entisfnet ory to $\mathrm{him}$. If wwever, the productinn or une of such byprodurt shall be sub. feet io the riglite of the looldars of precxisting lenkes, claims, or permite erering the same ind or tle enme minernis, if any.

Src. 10. The holder of any geothermnl lenee nt nny timo mny make and file in tho appropriate lund office a written reliniquishment of all rights under such lense or uf any legal subclivision of thic n men covered by such lense. Such relinquishment shinll be effectire ns of the dnte of its filing. Thereupon the lessee shall be relensed of ull obligntions theire-
after accruing under snid lense with respect to the lands relinquislsed, after accruing under snid lense with respect to the lands relinquislsed, but no such relinquishment sinll release such lessee, or his surety or than an obligation to drill, ncerued at the date of the relinquishment, or from the continued obligation, in accordnnce with the npplienble leaseterms and regulations, (1) to mnke pnyment of nll nerrued rentals and roynlties, $(2)$ to place all rells on the relinquished Jands in condjtion for suspension or abandionment, nnd (3) to protect or restore sub. mantially the surface and surfare resources.

Sxc. 11. The Secretary, upon applicntion by the leswee, mny authorize the lesee to suspend operations and production on $n$ pirducing lease and he mny, on his own motion, in the interest of conscrintion anspend operations on any lense but in either cnse he mny extend the lense term
tor the period of any suspension, and he may waive, suspend, or reduce the rental or royalty regured in sisch lense.

Sec. 12. Icases may be lerminnted by tho Secretary for any violntion of the regulations or lease terms after thirty days notice provided that weh violation is not corrected within tho notics period, or in the ovent the violation is such that it cannot be corrected within the notice poriod hen provided that lcsses has not cominenced in pood tnith rithin seid notico period to correct such violation and therenfter to proceed dili. pently to correct such violation. Iessee shall be entitled to a henring on the minter of such claimed vinlation or proposed terminntion of lease If request for a hearing is made to the Secretary within the thirty-day perind after notice. The period for correction of violation or.commencement to correct silch violntion of regulntions or of lense terms, a. aforesaid, ohall be extended to thirty days after the Secretary's deciaion

Yzc. 18. The Secretary may raive, suspend, of reduce the rental or rojalty for any lease or portion thereof in the intereste of ennservaton and to encourage the erreateat ultimate recovery of coothermal resourecs, if he determincs that this is neccesary to promotn dovelopment or that the lease cannot be successfully operated under the lease terms. Surrese
iand, wee. 14. Subject to the other provisions of this Act, a lesere shall be
entitled to use so much of the surface of tho land covered by hia peo. thormal lenso as may be found by the Secretnry to ie necesenry for tho production, utilization, and conserration of reothermal resources. SEc. 15. (a) Geothermal leases for lands withdrewn or ecquired in aid of functions of the Depart ment of the Interior may be issued only under such termis and conditions as the Secretary may prescribe to insure adequate utilization of the lands for the purposes for which they were withidrawh or acquited.

(b) Geothermal leases for Innds withdrawn or scquired in aid of funetions of the Department of A priculture may be issued only with the cousent of, and subject to stich terms and conditions as may bo prescribed by, thac hend of that Department to insure adequnte utilias. tion of the lands for the purposes for which they were withdrawn or cequired. Geathermal lenses for lands to which section 24 of the Fodern 41 Stat. 2075, Power Act. as amended (10 L.S.C. 818), is mpplicable, may bo issued
62 Stat. 275. Only with the consent of, and subject to, such terms and conditions as the Federal Power Commission may prescribe to insure adequate ntilizafion of sucl: lands for power and related purposes.

(c) Geviliermni leases under this Act shnil not bo isoved for lande dministered in accordence with (1) the Act of August 25,1916 (80 Stat. \$35), as amended or supplemented, (2) for lands within a national recreation are (3) for lands in a fish hetchery administered by the Secretary, wildifie refuge, wildlife range; fame range, wildlife manSccretary, willife refugc, wildife range, kame range, tild life manrement area, waterforrl production aren, or for lands arquired or reserved for the protection and conscrvation of fish nnd wildiffo that Indian trust or restricted lands, within or without the boundarie of Indian meserrations.

besene. Sec. 16. Leases under this Act mny be isened only to citirens of the olt1zonsup United States, associations of such citizens, corpomtions organized ander tho lans of the Lnited States or of any Stnte or the Mistrict municipalities.

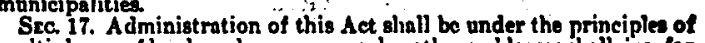
multiple use of lands and resources; nnd geothermal leases shall, insofar as feasible, allow for cocxistence of otleer lenses of the snme lands foe depositg of minernis uncler the la ws npplicnllo to them, for the locktion and production of clains under. the mining laws, and for other uses or theh other uses, howerer, glinll not unreasonably interfere with o. such other uses, however, slinll not unreasonably incerfere with or ondanger operations under any leas issed pursunnt fo this Aet, nor thall opernicions under lenses so issued unreasongly interfere with or ondanger operations under any lense, license, clajm, or permit ine pursuant to the provisions of any other Act. of any geothermal pool, field; or like area or any. part thereof: letees of any feothermal pool, feld; or like area or any. part thereof; lesects or sepa rately with others, in collectivicly adopting and operating unde cooperntive or unit plan of development or operntion of such pool, feld. certifed bv the Secretary to be necessary or advisable in the publie interext. Tha Sceretary mnv in his discretion and mith the consent o tho holders of leases inrolver, establish, Rlier, chango, revoke, and make wuch regulntione with relerence to such lenses in connecton wh ho may deem necessary or proper to secure reasonable protection of the 


\section{S4 STAT, 1572 SA STAT. 1573}

public interest. Ife may include in geot hemal lenses a provision requiring the lessee to operate under such a reasomuble cooperntive or unit plan, and he may prescribe such a pinn under which such lessee shall operate, which shall adequately protect the rights of all partics in tion of he haing the linat states. Any such plan may, in the uiscre tion of the Secretary, provide for vesting in the Secretary or any other person, committee, or Federal or State agency designated therein, authority to alter or modify from time to time the rate of prospecting and development and the qunntity and rate of production under such plan. All Jeases operated under any such plan approved or prescribed by the Secrctary shall be excepted in determining holdings or control for the purposes of section 7 of this Act.

When separate tracts cannot be independently developed and operated in conformity with an established rell-spincing or development program, any lease, or $n$ portion thereof, may be pooled with other Inuds, whether or not owned by the. United States, under a communitization or drilling apreement providing for an apportionment of production or royalties aniong the separate tracts of land comprising the drilling or spacing unit when determined by the Secretary to be in the public interest, and operations or production pursuant to such an agrcement shall ho deemed to be operations or production as to ench lease committed thereto.

The Secretary is hereby nuthorizer. on such conditions as he may prescribe, to approve opcrating, drilling, or development contracts made by one or more lessees of geothermal leases, with one or more persons, associntions, or corporntions whenever, in his discretion, the conservation of natural products or the public convenience or necessity may require or the interests of the Iinited States may be best served thereby. All lenses opernted under such approved operating, drilling, or derelopment contrncts, and interests thereunder, shall be exce.

in determining holdings or control under section 7 of this Act. : Sic. 10. Upon request of the Secretary, other Federal departments
and agencies shall furnish him with any relevant data then in their and agencios shall furnish him with any relevant data then in their posscesion or knowledge concerning or having, bearing upon fair and produced for conversion to electric power or other purpases. Data given to any department or agency as confidential under In $w$ shall not bo furnished in any foshion which identifics or tends to identify the business entity whose nctivities are the subject of such data or the per con or persons who furnished such information.

Siec 20 . All moneys received under this Act from public lands Monare. nnder the jurisdiction of the Secretnry shall be disposed of in the sam manner as moneys received from the sale of public lands. Moneys recoived under this Act from other lands shall be disposed of in the ame manner as other receipts from such lands.

8ec. 21. (a) Within one hundred and twenty days after the effective publloats on in date of this Act, the Secretary shall ranse to be published in the Poderel Reatoter. Federal Register a determination of nill lands which were included within any knonin geothermal resources aren on the effective dafe of the Act. He shall likewise publish in the Federnl Register from time to time his determination of other knox'n geothermal resources areas opecifying in each case the date tho lands were included in such area;

(b) Geothermal resources in lands the surface of which has passed from Fodnral ownership bit in which the minerals have been reserved to the Cnited States shall not be developed or produced except under eeothermal lenses made nursinnt to this Act. It the Secretary of the Interior finds that such development is immineat, or that production trom well heretofore drilled on such landa is, imminent, ho shall so report to the-Attorncy Genernl, and the Attomey Generol is inthorised and directed to institute an nppropriate proceeding in the binited States distriet contrt of the dist riet int which sich lunils are located, to quict the title of the latited states in such resonres, and if the court giner the lands intolved included the geothermal resourres, to enjoin their production othere than underich That upon all nuthoritacive judicial determination that Federal ming oral nesertiation does not include geotierinal steam and associated geothermal ressures the duties of the seeretary of tho Interior to report and of the Attomey (iene

Sre. 2*. Sothing in this Act slanll constitute nu cxpress or inplied claim or denial on the part of the Federal Governiment as to its exemption from State water laws.

Haste, Sec. 23. (n) All leases under this Act sliall le suliject to the condi. tion that the lesee will, in condicting his explorution, developnent and producing operations, use all reasomuble precantions to prevent develoned in the lands leased.

(b) Rights to develop and utilize geothermal steam nind associated geothemnal resources underlying laids owned by the Linited States may be acquired solely in accordance with the provisions of this det. Aules and Sec. 24. The Secretary shall prescribe sich rules and regulations as he may deem appropriate to carry out the provisions of this Act. Such prevention of waste, (b) development and conservation of geothermal and other natural resources, (c) the protiection of the public interest (d) assignment, sagremation, extension of ternis, relinnuishment of leascs, devefoyment contracts, unitization, pooling, and drilling ngreements, (e) compensatory royat ity agrements, suspension of operations or production, and stspension or reduction of rentals or royalties (f) the filing of surety bonds to assure compliance' with the terms of the lease and to protect. surface use and resources, (f) use of the sur. the lease and to protect. surface use and resources, (f) we of the sur. by the lessee of an active development prorram, and (i) protection of by the lessee of an active development program,

Sec. 25 . As to any lind subject to geot iermal leasing under section 3 of this. 25 . As to any lit da ws which either (a) provide for the disposal of land
(a) by patent or other form of conveyance or by grant or by operation of law subject to a reservation of any mineral or (b) prevent of restrict the disposal of such land because of the mineral cliarncter of the land shall herenfter be deemed to embrace gcothermal steam and associnted geothermal resources as a sibstance which either must be reserved or must pretent or restrict the disposal of such land, as the case may be. This section shall not be construed to affect grants, patenty or other

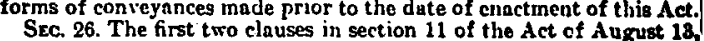

Sec. 26. The first troo clauses in section 11 of the Act of
1954 (68 Stat. 708, 716), are amended to read ns follows:

"As used in this Act, 'mineral leasing lin' 's' shall menn the Act of 30 usC 530. 30 USC 281.
30 USC 282 . 101) Act of A pril 17, 1026 (44 Stat Act of 1970 , and all Acts heretofore or hereafter enacted which are amendntory of or supplementary to uny of the foregoing Acts; 'Lensing Act minernls shall menn all mincrils whicl, upon the effective date of this Act, are provided in the mineral lensing la ws to be disposed of thereunder and nll genthermal stenm nnd nssociated geothermal resources which, upon the effective date of the Geothermal Steam Act
of 1970 , are provided in that Act to be disposed of thereunder;". 
Sro. 27. The tuited States reserves the ownership of and the right Cortain mineral extract under such rules and repulations as the Secretary may pre- Foms,

jbo oil, hydrocarbon gas, and helium from all geothermal stenn

hd associntert grothermal resources prodnced from inthds leased under

this $\mathrm{Act}$ in accordance with presently ipplicable laws: Protided, That

whenever the right to extract oil, hydrotarbon gis, and helium from

goothermal steam and associnted geothermal resuluress produced from

ouch lands is exercised pursunnt to this section, it shall be exercised

80 as to cause no stibstantinl interference with the production of gco-

Approved December 24, 1970.

1TCTSLATIVE HISTORY:

HOUSE PEPORT No, 91-1544 (Comm. in Interlor and Insular Arfal re); SEXUTE REPORA No. 91-1250 (Corm, on Interlor and Insular Arta1 m).

COMCRUSSIOML RECORD, Vol. 116 (1970):

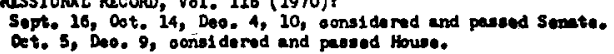

0 
GEOTHERMAI ENERGY RESEARCH, DEVELOPMENT, AND DEMONSTRATION ACT OF-1974, Public Law 93-410

93rd Congress, H.R: 14950, September 3, 1974

\section{An Atr}

To further the conduct of resenrch, development. nud demoustrutions In geothermat encrery techublogies, to estublish " Genthermall tinery condination und Manatement l'roject, to provide for the eurrying out of resenteh and devolopuent in peothermal encrgy trohmolngy, fo carry aut a jorogram of demonst rutions in ferhnologies for the utlizatiun of gothermal resources. to establish a ban guatranty program for the finanding of geothermat energy dovelopment, and for otlier purposes.

Be it enacted by the Senate and. House of Representativers of the I'nited States of America in Congress assembled.

\section{SHORT TITL:}

Srction 1. This Act may be cited as the "Geothermal Fnergy Rescarch, Jevelopment, and Demonstrition Act of 1974".

\section{FINDINGS}

Src. 2. The Congress hereby finds that--

(1) the Nition is currently suffering a critical shortage of environmentally acceptable forms of energy;

(2) the inadequate orgauimational structures and levels of funding for energy research have limited the Fation's current and future options for meeting energy needs;

(3) electric energy is a clean and convenient form of energy at the location of its use and is the only practicable form of energy in some modern applications. but the demand for electric energy in every reginn of the linited States is tuxing all of the alternative energy sonrces presently available and is projected to increase; some of the sonrces available for clectric power generation are already in short supply, and the development and use of other sources presently involve undesirable environnental impacts;

(4) the Nation's critical energy problems can be solved only if a national commitnent is made to dedicate the necessary financial resources, and enlist the cooperation of the private and public sectors, in dereloping geothermal resources and other nonconventional sources of energy :

(5) the conventional geothermal resources which are presently being used have limited total potential : but geothernal resources which are different from those presently being used, and which have extremely large energy content, are known to exist;

(6) some geothermal resources contain energy in forms other than heat: examples are methane and extremely high pressures available upon release as kinetic energy;

(7) some geothermal resources contain valuable byproducts such as potable water and mineral compounds which should be processed and recovered as national resources;

(8) technologies are not presently arailable for the (levelopment of most of these geothermal resources. but technologics for the generation of electric energy from geothermal resources are potentially economical and envirommentally clesimble, and the development of geothernial resources offers possibilities of process enerey and other nonelectric applications;

(9) much of the known geothermal resources exist on the public lands;

Geothe nnal Energy Researoh, Development, and Demonstration Aot of 1974. 30 USC 1101 note.

30 USC 1101. 
(10) Federal financial assistunce is necessary to encounge the cxtensite cxplotation, researels. and dovelopument in geothermal resomres which will bring these techmologies to the point of eommercial application;

(11) the adrancement of technology with the cooperation of private industry for the production of useful forms of energy from geothermal resonres is important with respect to the Fedcral responsibility for the general wolfare to facilitate commerce, to encouragre productive harmony letween matn and his environment, and to protect the public interest ; and

(12) the Federal Govermment should encourage and assist private inclustry through Federal assistance for the development and demonstration of practicable means to produce useful energy from geothermal resources with environnmontally acceptable processes.

\section{DHFINITIONS}

30 USC 1102.

Src. 3. For the purposes of this Act-

(1) the teim "geothermal resources" me:tns (A) all products of greothermal processes, embracing indicrenous steam, hot water, and brines, (B) steam and other gases, hot water and hot brines. resulting from water, gas, or other fluids artificially introduced into geothermal formations, and (C) any byproduct derived from them;

(2) the term "byproduct" means any mineral or minerals which are found in solution or in association with geothermal resources and which have a value of less than 75 percent of the value of the geothermal steam and associated geothermal resources or are not, because of quantity, quality, or technical difficulties in extraction and production, of sufficient value to warrant extraction and production by themselves;

(3) "pilot plant" means an experimental unit of small size used for early evaluation and development of new or improved processes and to obtain technical, engineering, and cost data;

(4) "demonst ration plant" means a romplete facility which produces electricity, hent energy, or useful byproducts for commercial disposal from geothermal resoures and which will make a significant contribution to the knowledece of full-size technology, plant opcration, and process economics;

(5) the term "Project" means the Geothermal Energy Coordination and Management Project established by section 101(a);

(b) the term "fund" means the (reothermal Resources Development Fund established by section $204(a)$; and

(T) the term "Chaiman" nuias the (hairman of the Project.

\section{TITLE I-GEO'TERMAJ, EXERGY (OORDINATION AND} MANAGEMENT PROOJECT

\section{FSTABIISIIMENT}

30 USC 1121. Srce 101. (a) There is herehy established the (ioothermal Knergy Coordination and Management P'roject.

Membership. Q9. ST:T. 1080

(b) (1) The Project shall be composed of six members as follows:

$305 \mathrm{THT} \cdot 1081$

(A) one nppoint ed by the P'resident;

(I) an . Issistant Jifector of the Sitional soience Fomdation;

(() an Assistant becretary of the Department of the Interior;

(1) an Assoriate Administrator of the Nutional . Aromantics and Space ddministration; 

and

(E) the Cencral Manager of the Atomic Finergy ('ommission;

(F) an Assistant Administmator of the Federal Enerey Administration.

(2) The l'resident shall designate one momber of the l'roject to serve as Chairumn of the Project.

(3) If the individual appointed under panagraph (1) (A) is an oflicer or employes of the Federal (iovermment. he shall receive no ndditionnl piy on uccount of his service as a member of the Project. If such indivilual is not an oflicer or emplovere of the Federal (iorernment, he shall be entitled to recoive the daily orfuivalent of the annual rute of basic pay in effect for lovel $1 V^{\circ}$ of the liscentive sichedule U.S.C. 5315) for (anch day (incheding traveltime) during which he is engaged in the act ual performane of duties vested in the p'roject.

(c) The Project shall have overall responsibility for the provision of effective management and coordination with resprect to a national geothermal energy. research, development, and demonstration program. Such program shall include-

(1) the determination and evaluation of the resource base;

(2) research and development with respert to exploration, extraction, and utilization techmologries;

(3) the demonstration of appropriate technologies; and

(4) the loan guaranty program under title II.

(d) (1) The Project shall carry out its responsibilities under this section acting through the following Federal agencies :

(A) the Department of the Interior, the responsibilities of which shall include evaluation and assessment of the resource base, including development of exploration technologies;

(B) the National Aeronautics and Space Idministration, the responsibilities of which shall include the provision of contract management capability, evaluation and assessment of the resource base, and the development of technologies pursuant to section $102(b)$;

(C) the Atomic Energy Commission, the responsibilities of which shall include the development of technologies; and

(I) the National Science Foundation, the responsibilities of which shall include basic and applied research.

(2) Upon request of the Project, the head of any such agency is authorized to detail or assign, on a reimbursable basis or otherrise, any of the persomnel of such agency to the Project to assist it in carrying out its responsibilities under this Act.

(e) The Project shall have exclusive authority with respect to the establishment or upproval of programs or projects initiated under this Act, except that the acency involved in any palticular program or project shall be responsible for the operution and andninist ration of such program or project.

\section{PROGRAM DEFINITIOIX}

Sxc. 102. (a) (1) The Chairman. acting throngh the Administrator of the National Arronaties and Space Administration, is authorized and directed to prepare a comprehensive prouram definition of an integrated effort and commitment for effectively developing geothermal energy resources. Such Arministrator. in prepuring such compre. hensive program definition, is uthorized to consult with ot her liederal agencies and non-Federul ont ities. 
Transmittal to President and Congress.

Interim reports.

Inventory schedule and objectives transmittal to President and Congress.

30 USC 1123
(2) The Chnirman shnll transmit such compurhensive pmyram definition to the President and to each llouse of the Congress. Interim reports shall be transmitted not lnter than November 30, 1974, and not Inter than Janunry 31, 1975. Such comprchensive program definition shall be transmitted as soon as possible therenfter, but in any case not. later than August $31,1975$.

(3) As part of the comprehensive program definition required by parapraph (1), the Chairman. acting through the Geological Survey, shall transmit to the l'resident and to each IIouse of the Congress a schedule and objectives for the inventorying of geothermal resources.

(b) The National Aeronautics and Sipace Administration is anthorized to undertake and carry out those programs assigned to it by the Project.

MFAOURCE INIENTORY AND ISSKGSMENT IROORAM

Src. 103. (a) The Chairman shall initiate a resource inventory and assessment program with the objective of making regional and national uppraisals of all types of geothermal resources. including identification of promising target areas for industrial exploration and development. The specific goals shall include-

(1) the improvement of geophysical, geochemical, geological, und hydrological techniques necessary for locating and evaluating geothernul resources:

(2) the devolopment of better methods for predicting the power potential and longevity of geothermal reservoirs;

(3) the determination and assessment of the nature and power potential of the deeper unexplored parts of high temperature geothermal convection systems; and

(4) the survey and assessment of regional and national geothermal resources of all types.

(b) The Chairman, acting through the Geological Survey and other ippropriate agencies, shall-

(1) develop and carry out a general plan for the orderly inventorying of all forms of genthermal resources of the Federal lands and, where consistent with property rights and determined by the Chairman to be in the national interest, of non-Federal lunds;

(2) conduct regional surveys, based upon such a general plan, using innovative geological, geophysical, geochemical, and.strataerrophic drilling techniques, which will lead to a national invencory of geothermal resources in the United States;

(3) publish and make available maps, reports, nnd other documents developed from such surveys to encourage and facilitate the commercial development of genthemnal resonrces for beneficial use and consistent with the national interest;

(4) make such recommendutions for legislation as may from time to time uppear to be necessary to make Federal leasing policy for geothermal resources consistent with known inventories of various resonrce types, with the current stnte of technologies for geothermal energy development, and with current eraluations of the environmental impacts of swch development; and

(5) participate with appropriate Federal agencies and nonFedernl entities in resen rch to develop, impirove, and test technolngies for tho discovery and evaluation of all forms of geothermal resonices, and conduct research into the principles cont rolling the location, occurrence, size, tenperuture, energy content, producibility, and economic lifetimes of geothernul reservoirs. 
Sre. 104. (a) The (hairman, acting through the appropriate Fed- 30 USC 1224. eral agencies and in comperation with non-Federal entities, shall initiate a researeh and development progrim for the purpose of resolving all major technical problems inhibitung the fullest possible commercial utilization of geothermal resources in the United States. The specific goals of such procrams shall include-

(1) the development of effective and eflicient drilling methods to operate at high temperatures in formations of geothermal interest: ;

(2) the developiment of reliable predictive methods and cont rol techniques for the production of geothemul resources from reservoirs;

(3) the exploitation of new comerpts for fracturing rock to permit recovery of contained heat reserves;

(4) the improvement of equipment and teclunology for the extraction of geothermal resources from reservoirs;

(5) the development of improved methorls for converting geothermal resources and byprosucts to useful forms;

(6) the development of inproved methods for cont rolling emissions and wastes from geothermal utilization facilities, including new monitoring methods to any axtent neressary;

(7) the development and evaluation of waste disposal control technologies and the evaluation of surface and subsurface envirommental eflects of geothermal development;

(8) the improvement of the technical apability to predict environmental inpacts resulting from the development of geothermal resources, the preparation of envirommental impact statements, and the assuring of compliance with applicable standards and criteria;

(9) the identification of social, legal, and cconomic problems associated with geothermal development (both locally and regionally) for the purpose of developing policy and providing a framework of policy alternatives for the commercial utilization of geothermal resources;

(i0) the provision for an adeguate supply of scientists to perform required geothermal research and development activities; and

(11) the establishment of a program to encourage States to establish and maintain geothermal resources clearinghouses, which shall serve to $(A)$ provide geothermal resources developers with information with respect to applicable local, State, and Federal laws, rules, and regulations, (B) coordinate the processing of permit applications, impact statements, and other information which geothermal resonrces developers are required to provide. (C) encourage uniformity with respert to local and State laws, rules, and regulations with respect to geothermal resources development, and (D) encourige establishment of land use plans. which would include zoning for geothermal resources development and which would assure that greothermal resources developers will be able to carry out development programs to the production stage.

(b) The Chaiman, actiner through the appropriate Federal agencies and in cooperation with non-Federal entities, shall implement a coordinated program of research and development in order to demonstrate the technical means for the extraction and utilization of the resource base, including any byproducts of such base, and in order to 
accomplish the goals estublished by subsection (u). Research authorized by this Act having potential apjilications in matters other than geothernal energy may be pursued to the extent thit the findings of such research can be published in a form for utilization by others.

\section{DH:MTONSTRTTON}

30 USC 1125.

Sic. 105. (a) The Clinirman, acting through the approprinte Federal agencies and in cooperation with non-Fideral entities, shall initiate a program to design and const ruct grothermal demonstration plants. The specific goals of such program shall include-

(1) the development of economical"geothermal resources production systems and components which mect environmental standards;

(2) the design of plants to produce electric power and, where upproprinte, the large-scale production and utilization of any useful byproducts;

(3) the involvement of engineers, inalysts, technicians, and managers from industry field and powerplant development, which shall lead to the early industrial exploitation of advanced geothermal resources;

(4) the provision for an adequate supply of trained geothermal cnginecrs and technicians;

(5) the provision of experimental test beds for component testing an eraluation by laboratories operated by the Federal Govremment, industry, or inst itutions of higher'education;

(6) the construction and operation of pilot plants; and

(7) the construction and operation of demonstration plants.

(b) In carrying out his responsibilities under this section, the Chairman, ncting through the appropriate Federal agencies, and in cooperation with non-Federal entitics, may provide for the establishment of one or moie demonstration projects utilizing each geothermal resource base involved. which shall inclide: as appropriate, all of the "xploration, siting. drilling. pilot plant construction and operation, demonstration plant construction and operation; and other facilities and activities which may be necessary for the generation of electric energy and the utilization of geothermal resource byproducts.

(c) The Chairman, acting through the appropriate Federal agencies, is anthorized to investigate and enter into a greements for the cooperative development of facilities to demonstrate the production of energy from geothermal resources. The responsible Federal agency may consider-

(1) conperative irreements with utilities and non-Federal governnontal entities for construction of facilities to prodince energy for rominercial disposition; and

(2) cooperative ugreements with other Federal ngencies for the constriction and operation of facilities to produce energy for direct Federal coinsumption.

(d) The responsible Federal agency antlionized to investigate the feasibility of, construct, and operate, demonstration projects without entering into cooperative airecments with respect to such projects, if the Chairman finds that-

(1) the nature of the resource the geographical location, the scale and engincring design of the fucilities. the techniques of production, or nny other significant factor of the proposal offers opportunities to make important contributions to the general 
knowledge of geothermnl resoures, the techniques of its development, or public confidence in tho technology ; and

(2) there is no opportunity for comperative ngrecments with any utility or non-Federal governmental entity willing and able to cooperate in the demonstrntion project under subsection (c) $(1)$, and there is no opporfunity for cooperative agrerments witl ot her lederal agencies under stibsection (c) (2).

(e) Before farorably considering proposals under subsection (c), the responsible Federal anency must find that-

(1) the nature of the resource, the generaphical location, the scale and engineering design of the facilities, the technigues of production, or any other significant factor of the propessil offers opportunities to make important contributions to the general knowledge of geothermal resources, the techniques of its development, or public confidence in the techmology;

(2) the development of the practical benefits as set forth in paragraph (1) are unlikely to be accomplished without such cooperative development; and

(3) where non-Federal participants are involved, the proposal is not eligible for adepuate Federal ussistance under the loan guaranty provisions of title Il of this Act.

(f) If the estimate of the Federal investment with respect to construction and operation costs of any demonstration project proposed to be established under this section exceeds $\$ 10,000,000$, no ainount may be appropriated for such project except as specifically authorized by legislation licren fter enacted by the Congress.

(g) (1) At the conclusion of the program under this section or as soon therea fter as may be practicable, the responsible Federal agencies shall, by sale, lease, or otherwise, dispose of all Federal property interests which they have acquired pursuant to this section (including mineral rights) in accordance with existing law und the terms of the cooperative agreements involved.

(2) The ngency involved shall, under appropriate agreements or other arrangements, provide for the disposition of geothermal resource byproducts of the project administered by such agency.

Federal property interests, disposal.

Project byproducts, disposal.

\section{SCIENTIRIC ANJ TECHNICAL EDUCATION}

SFC. 106. (a) It is the policy of the Congress to encourage the development and maintenance of programs through which there may be provided the necessary trained personnel to perform required geothermal research, development, and demonstrution activities under sections 103, 104, and 105 .

(b) The National Science Foundation is authorized to support programs of education in the sciences and engineering to carry ont the policy of subsection (a). Such support may include fellowships, trainceships, technical training programs, technologist training prograins, and summer institute programs.

(c) The National Science Foundation is authorized and directed to coordinate its actions, to the maxinum extent practicable, with the Project or any permanent Federal orwanization or agency having jurisdiction over the energy research and development functions of the United States, in determining the optimal selection of programs of education to carry out the policy of subsection (a). 
(d) The Pational Science Foundation is authorized to encourage, to tho maximum extent practicable international participation and cooperation in the development and maintenance of programs of education to carrying out the policy of subsection (a).

\section{TITLE II-LOAN GIIRANTIES}

\section{ESTABIISIIMENT OF IOAN GCARANTY PROGRAM}

30 USC 1141.

Terms and conditions.

Limitation.

"Qualirled borrower."
SEc. 201. (a) It is the policy of the Congress to encournge nnd assist in the commercial development of practicable means to produce useful enerery from geothermal resources with cnvirommentally acceptable processes. Accordingly, it is the policy of the Congress to facilitate such commercial development by authorizing the Chairman of the l'roject to designate an appropriate Federal agency to guarantee loans for such purposes.

(b) In order to encourage the commercial production of energy from erothermal resources, the head of the clesiernated agency is authorized to, in consultation with the Secretary of the Treasury, wuantec, and to enter into commitments to gua rantee, lenders against loss of principal or interest on loans made by such lenders to qualified borrowers for the purposes of-

(1) the determination and evaluation of the resource base;

(2) research and development with respect to extraction and utilization technolngies:

(3) acquiring rights in geothermal resources; or

(4) development, construction, and operation of facilities for the demonst ration or commercial production of energy from geothemal resources.

(c) Any guaranty under this title shall apply only to so much of the principal amount of any loan as does not exceed 75 percent of the argregate cost of the project with respect to which the loan is made.

(d) I oan grumanties under this title shall be on such terms and conditions as the head of the designated agency determines, except that a guaranty shall be made under this title only if-

(1) the loan bears interest at a rate not to exceed such annual per centum on the principal obligation outstanding as the head of the designated agency determines to be reasonable, taking into account the range of interest rates provaling in the private sector for similar loans and risks by the lnited States;

(2) the terms of such loan repuire full repayment over a period not to exceed thirty years, or the useful life of any physical asset to be financed by such lonn, whichever is less (as determined by the head of the designated arency);

(3) in the judgment of the head of the designated agency, the amount of the loan (when combined with amounts arailable to the qualified borrower from other sources) will be sufticient to carry out the project; and

(i) in the judgment of the hearl of the designated arency, there is reasonable assurance of repayment of the loan by the qualified borrower of the guaranted indebterlness.

(e) The amount of the guaranty for any loan for a project shall not exceed $\$ 25,000,000$, and the amount of the guaranty for any combinntion of louns for any single quialified borrower shall not exced $\$ 50,000,000$.

(f) As used in this title, the term "qualified borrower" menns any public or private agency, institution, association, partnership, 
corporation, political subdivision, or other legal entity which (as determined by the head of the designated ugency) has presented satisfuctory evidence of an interest in greothermal resources and is capable of performing resenrch or completing the development and production of energy in an acceptable manner:

\section{PAYMRNT OF' INTTRKST}

Six: 202. (a) With respect to any loin guandinted pursuant to this title, the heal of the designated anency is anthorized to entor into a contract to pay, and to pay, the lender for and on behalf of the borrower the interest charges which become due and payable on the unpaid balance of any such loan if the head of the desiguated agency finds-

(1) that the borrower is unable to meet interest charges, and that it is in the public interest to permit the borrower to continue to pursue the purposes of his project. and that the probable net cost to the Federal (iovermment in paying such interest will bx less than that which would result in the crent of a default: and

(2) the amount of such interest charges which the head of the designated agency is authorized to pay shall be no grenter than the amount of interest which the borrower is obligated to pay under the loan arreement.

(b) In the event of any default by a qualified borrower on a guaranteed loan. the head of the designated agency is authorized to make payment in accordance with the guaranty, and the Attorney General shall take such action as may be appropiriate to recover the amounts of such payments (including any paynent of interest under subsection (a) from such assets of the defaulting borrower us are associated with the project, or from any other surety included in the terms of the guaranty.

PFRIOD OF OUIRANTIYS AND INTERYST ASSISTANCY

Src. 203. No loan guarunties shall be made, or interest assistance contract entered into, pursuant to this title, after the expiration of the ten-calendar-year period following the date of enactment of this Act.

\section{OYOTHERMAL RFSOURCFS DHVHAIPMHNT FUND}

Sec. 204. (a) There is established in the Treasury of the United States a Geothermal Resources Developinent Fund, which shall be available to the head of the designated agrency for carrying out the loan guaranty and interest assistance program authorized by this title, including the payment of administrative expenses incurred in connection therewith. Moncys in the fund not needed for current operations may, with the approval of the Secretary of the Treasury, be invested in bonds or other obligations of, or guaranted by, the Cinited States.

(b) There shall be paid into the fund the amounts appropriated pusuant to section 304 (c) and such amounts as may be returned to the United States pursuant to section $202(\mathrm{~b})$, and the amounts in the fund shall remain available until expended, except that after the expiration of the ten-vear period established by section 203 . such umoints in the fund which are not required to secure outstanding 

Treasury.

(c) Business-type financial reports covering the operations of the

Financial reports, submittal to Congress.

30 USC 1161.

Reports to President and Congress. 30 USC 1162.

30 USC 1153. fund shall be submitted to the Congress by the hewl of the rlesignated agency ammatly upon the completion of an nppropriate accounting period.

\section{TITLE III-GENEIAI, PIROVISIONS}

\section{PROTZCHION OF kNIRONMENT}

Sac. 301. In the conduct of its activities, the Project and any participating public or private persons or agencies shall place particular emphasis npon the objective of assuring that the cnvironment and the safety of persons or property are eflectively protected: and the prorrani umler title I shall inchile such special resen re?: and development as may be necessary for the achievement of that objective.

\section{REPORTING RFQTIREMENTE}

Src. 302. (a) The Chairman of the Project shall submit to the President and the Congress full and complete anmual reports of the activities of the Project, including such projections and estimates as may be necessary to evaluate the progress of the national geothermal energy research, development, and demonst rat ion yogram and to provide the basis for as aceurate a judument as is possible concerning the extent to which the objectives of this Aet will have been achieved by June 30 , 1980.

(b) No later than one year after the termination of each demonstration project under section 105 , the Chairman of the Project shall submit to the President and the Congress a final report on the activities of the Project related to each project. including his recommendations with respert to any further legislative, administrative, and other actions which should be taken in support of the objectives of this Act.

\section{TRANSFER OF FLINCIONS}

Skc. 303. (a) Within sixty days after the effective date of the law creating a permanent Fecleril organization or agency having jurisdiction orer the energy research and development functions of the United States (or within sixty clays after the date of the enactment of this Act if the effective date of such law occurs prior to the date of the enactment of this Act), all of the research, derelopment, and demonstration functions (including the loan gruntanty program) vested in the Project under this Act, along with relited records, documents, personnel, obligations, and other items to the extent necessary or appropriate, shall, in accorlance with regulations prescribed by the Office of Management and Budget, be transferrecl to and vested in such organization or agency.

(b) Upon the establishment of $a$ permanent Federal oryanization or agency having juristiction over the cneroy research and development functions of the United States, and when all rescarch and development (and other) functions of the Project are transferred, the members of the l'roject may provide advice and counsel to the hend of such organization or agency, in accordance with arrangenents made at that time. 


\section{AOTHORIZATKONS OF APPROPRIATIONS}

Sec. 304. (a) For the fiscal years ending Juno 30, 1976, and Septem- 30 uSC 1164 ber $30,1977,1978,1279$, and 1980 , only such sums may be appropriated as the Congress may hereafter authorize by law.

(b) There are nuthorized to be approprinted to the National Acronautics and Space Administration not to exceed $\$ 2,500,000$ for the fiscal year ending June 30,1975 , for the purpose of preparing the program definition under section $102(a)$.

(c) In addition to sums authorized to be appropriated by subsection (b), there are authorized to bo appropriated to the fund not to cxceed $\$ 50,000,000$ annually, such sums to carry out the provisions of the loan guaranty program by the Project under title II.

Approved September 3, 1974.

LEGISLATIVE HISTORY:

HOUSE REPORTS: No. 93-1112 (Comp. on Solence and Astronautios). and

$$
\text { No. 93-1301 (Comm. of Conference). }
$$

SENATE REPORT No. 93-849 aooompanying S. 2465 (Comm. on Interior and Insular Affairs).

CONGRESSIONAL RECORD, Vol, 120 (1974):

July 10, considered and passed House.

July 11, considered and passed Senate, amended, in 11 eu of S. 2465 .

Aug, 20, Senate agreed to conference report.

Aug. 21, House agreed to conferenoe report.

$\mathrm{O}$ 